1 




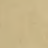







\section{GRUNDZÜGE} Vert. Pal, DER

PALÄONTOLOGIE (PA L ÄOZ O OLOGIE)

VON KARL A.VON ZITTEL

NEUBEARBEITET VON

$\begin{array}{lll}\text { F. BROILI E. KOKEN M. SCHLOSSER } & \text { M }\end{array}$

\section{ABTEILUNG \\ VERTEBRATA}

ZWEITTE VERMEHRTE UND VERBESSERTE AUFLAGE MIT 749 IN DEN TEXT GEDRUCKTEN ABBILDUNGEN
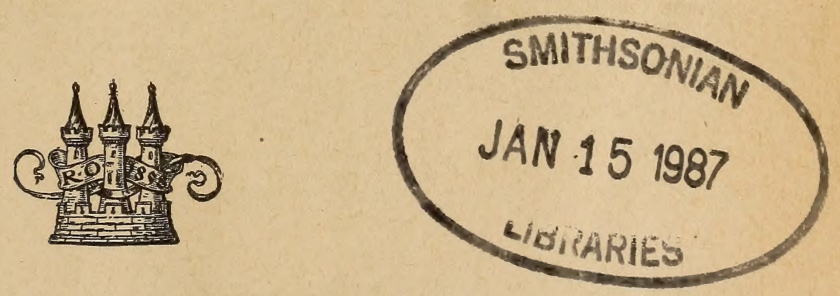

MÜNCHEN UND BERLIN

DRUCK UND VERLAG VON R. OLDENBOURG 
ALLE RECHTE VORBEHALTEN

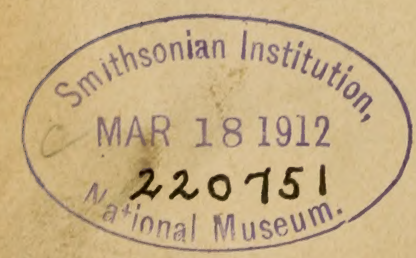




\section{Vorwort zur ersten Auflage.}

Als ich mich vor zwanzig Jahren mit dem Gedanken beschäftigte, ein auf dem Boden der neueren Anschauungen stehendes Lehrbuch der Paläontologie zu schreiben, lag es zunächst in meiner Absicht, Studierenden und Freunden dieser Wissenschaft eine kurze und übersichtliche Darstellung des Inhaltes der Versteinerungskunde zu bieten. Allein der damalige Mangel eines zusammenfassenden Kompendiums und die Schwierigkeit, aus der überaus umfangreichen, vielsprachigen und ungleichwertigen Literatur das Wichtigere herauszugreifen, veranlaßte schon nach dem Erscheinen der ersten Lieferung eine Änderung des ursprünglichen Plans, und an Stelle eines Lehrbuchs entstand das 5 Bände starke Handbuch der Paläontologie.

Was nun anfänglich beabsichtigt war, soll das vorliegende Werk bringen. Es folgt, wie fast alle neueren Lehrbücher der Paläontologie, der im Handbuch eingeschlagenen Methode der Darstellung und Anordnung des Stoffes; aber nur wenige Abschnitte konnten in einfachem Auszug wiedergegeben werden. Die Entwicklung der Paläontologie ist eine so rasche, daß sich seit dem Erscheinen des Handbuchs in den meisten Gruppen, namentlich bei den Wirbellosen, tiefgreifende Veränderungen vollzogen haben, welche eine vollständige Umarbeitung der betreffenden Teile erheischten, und auch bei den Wirbeltieren haben die letzten Jahre eine Anzahl wichtiger und unerwarteter Entdeckungen geliefert.

Eine Hauptaufgabe der Paläontologie wird stets die Erzielung einer natürlichen, den morphologischen und phylogenetischen Erfahrungen entsprechenden Systematik bilden, derselben wurde darum auch besondere Aufmerksamkeit gewidmet. Da jedoch der gebotene Raum nur eine äußerst knappe Behandlung und lediglich eine Auswahl des Wichtigeren gestattete, so wurde auf den vorhandenen 
Formenreichtum innerhalb der verschiedenen Gruppen häufig nur durch einfache Anführung von Namen ohne jede Beschreibung hingewiesen. Dadurch werden die Grundzüge auch für die Besitzer des Handbuchs einen gewissen Wert erhalten, indem sie wenigstens andeutungsweise die neueren Fortschritte und die jetzige Gestaltung des Systems zur Anschauung bringen.

Ausführlichere phylogenetische Erörterungen mußten im Hinblick auf den beschränkten Raum ausgeschlossen werden, auch wurde auf Wiedergabe oder Aufstellung von Stammbäumen verzichtet, da deren Begründung eine Fülle von Detail beansprucht, welches hier nicht gegeben werden konnte. Da jedoch eine natürliche Systematik zugleich die Verwandtschaftsbeziehungen der Organismen zum Ausdruck bringen muß, so konnte der Stammesgeschichte durch geeignete Anordnung des Stoffes und durch kurze Andeutungen über die genetischen Beziehungen der Angehörigen verschiedener Gruppen gebührende Rechnung getragen werden.

Die Versteinerungen sind in diesem Werke vorzugsweise als fossile Organismen behandelt, während ihre Bedeutung als historische Dokumente zur Altersbestimmung der Erdschichten nur in zweiter Linie Berücksichtigung finden konnte. Auf die Aufzählung oder Beschreibung einzelner geologisch wichtiger Leitfossilien wurde darum verzichtet, doch sind dieselben bei Auswahl der Abbildung nach Möglichkeit bevorzugt.

Durch Verwendung des ungemein reichen Materials an Klischees aus dem Handbuch sowie durch Herstellung einer Anzahl neuer Abbildungen, konnten die Grundzüge in ungewöhnlich reichem Maße mit Illustrationen ausgestattet werden. Der Umfang des Werkes ist dadurch allerdings, obwohl der botanische Teil ausgeschlossen wurde, in unerwünschter Weise angeschwollen; um so dankbarer muß es anerkannt werden, daß die Verlagsbuchhandlung den Preis desselben so niedrig als möglich angesetzt hat.

$\mathrm{Zu}$ besonderem Danke bin ich auch Herrn Privatdozent Dr. P o mpeckj verpflichtet, welcher mich bei Durchsicht der Korrekturbogen bereitwilligst unterstützte.

München im März 1895. 


\section{Vorwort zur zweiten Auflage.}

Auf Wunsch von Frau Geheimrat v. Zittel haben wir im Frühjahr 1910 die Neuauflage der II. Abteilung: »Vertebrata « der »Grundzüge der Paläontologie von Karl von Zittel übernommen, die in erster Auflage vor über 15 Jahren erschienen war, und zwar hat E. Koken die Fische, F. Broili die Amphibien und Reptilien und M. Schlosser die Vögel und Säugetiere durchgearbeitet.

Die Aufgabe war keine leichte, da es sich darum handelte, das viele Neue, was gerade in diesem Zeitraum über die fossilen Wirbeltiere bekannt geworden ist, in kurzer Form zusammenzufassen und mit dem früheren Material zu verschmelzen, ohne dabei jene klare Übersicht und Kürze zu verlieren, durch welche hervorragende Eigenschaft K. von Zittel in seinen Grundzügen bahnbrechend und vorbild. lich die ganze Entwicklung der Lehrmethode in der Paläontologie beeinflußte.

Die der ersten Auflage beigefügten Abbildungen wurden einer weitgehenden Revision unterzogen, dabei mußte eine große Reihe veralteter Klischees durch andere ersetzt werden, und außerdem wurde eine ansehnliche Zahl neuer Figuren aufgenommen, so daß die Gesamtzahl derselben nun 749 beträgt gegen 662 in der ersten Auflage.

Bei diesen kostspieligen Mehrungen fanden wir die weitgehendste Unterstützung der Verlagshandlung R. Oldenbourg, die überhaupt alles getan hat, um dem Buch eine vollendete Ausstattung zu geben und die Drucklegung desselben möglichst zu beschleunigen; ihr sei unser besonderer Dank ausgesprochen.

Tübingen und München im März 1911.

Die Herausgeber. 


\section{Inhalt.}

VIII. Stamm. Vertebrata. Wirbeltiere ... . . . . . S. 1.

1. Klasse. Pisces. Fische. (Bearbeitet von E. Koken) S. 3. Unterklasse Placodermi S. 26. Ordnung Anaspida S. 27. Ordnung Heterostraci S. 28. Ordnung Osteostraci S. 33. Ordnung Antiarchi S. 35. Unterklasse Elasmobranchii S. 39. Ordnung Ichthyotomi S. 41. Ordnung Acanthodi S. 46. Ordnung Selachii S. 48. Unterklasse Holocephali S. 69. Unterklasse Dipn oi \&. 73. Unterklasse Arthrodira S. 78. Unterklasse Teleostomi S. 84. Ordnung Crossopterygii S. 85, Abteilung Actinopterygii S. 89. 4. Ordnung Ganoidei S. 90. Unterordnung Chon. drostei S. 94. Unterordnung Belonorhynchidae S. 96. Unterordnung Heterocerci S. 97. Unterordnung Pycnodonti S. 102. Unterordnung Orthoganoidei S. 105. Unterordnung Lepidosteidae S. 112. Unterordnung Amioidei S. 113. Unterklasse Teleostei S. 117. Ordnung Physostomi S. 118. Ordnung Physoclysti S. 127. 1. Ordnung Impennes S. 322. Unterordnung Acanthopterygii S. 128. Unterordnung Lophobranchii S. 141. Unterordnung Plectognathi S. 142.

2. Klasse Amphibia. Amphibien. Lurche. (Be arbeitet v on F. Broili.) S. 143. 1. Ordnung Stegocephali S. 147. 1. Unterordnung Phyllospondyli S. 160. 2. Unterordnung Lepospondyli S. 162. 3. Unterordnung Temnospondyli S. 166. 4. Unterordnung Stereospondyli S. 171. 2. Ordnung Coeciliae S. 174. 3. Ordnung Urodela S. 174. 1. Unterordnung Ichthyoidea S. 176. 2. Unterordnung Salamandrina S. 176. 4. Ordnung Anura S. 177.

3. Klasse Reptilia. Reptilien. Kriechtiere. (Bearbeitet von F. Broili.) S. 179. 1. Ordnung Theromora S. 188. 1. Unterordnung Cotylosauria S. 188. 2. Unterordnung Pelycosauria S. 193. 3. Unterordnung Theriodontia S. 196. 4. Unterordnung Anomodontia S. 198. 2. Ordnung Rhynchocephalia S. 201. 3. Ordnung Lepidosauria (Squamata) S. 207. 1. Unterordnung Lacertilia (Saurii) S. 207. 2. Unterordnung Ophidia S. 218. 4. Ordnung Ichthyosauria S. 220. 5. Ordnung Sauropterygia S. 229. 6. Ordnung Testudinata S. 241. 1. Unterordnung Pleurodira S. 247. 2. Unterordnung Cryptodira S. 250. 3. Unterordnung Cheloniidea S. 252. 4. Unterordnung Trionychia S. 256. 7. Ordnung Parasuchia S. 257. 8. Ordnung Crocodilia S. 261. 9. Ordnung Dinosauria S. 273. 1. Unterordnung Theropoda S. 278. 2. Unterordnung Sauropoda S. 283. 3. Unterordnung Praedentata S. 288. 10. Ordnung Pterosauria S. 298. 1. Unterordnung Rhamphorhynchoidea S. 303. 2. Unterordnung Pterodactyloidea S. 305.

4. Klasse. Aves. Vögel. (Be arbeitet von M. S chlosser) S. 308. 1. Subklasse Sa ururae S. 316. Ordnung Archaeornithes S. 316. 2. Subklasse Ornithurae S. 317. 1. Uberordnung Odontolcae S. 317. Ordnung Hesperornithes S. 318. 2. Uberordnung Odontormae S. 318. 3. Uberordnung Dromaeognathae S. 319. 1. Ordnung Struthiones S. 319. 2. Ordnung Apteryges S. 321. 3. Ordnung Crypturi S. 321. 4. Überordnung Euornithes S. 322. Unterordnung Anacanthini S. 127. 2. Ordnung Cecomorphae S. 322. 3. Ordnung Grallae S. 322. 4. Ordnung Chenomorphae S. 323. 5. Ordnung Herodii S. 323. 6. Ordnung Steganopodes S. 323. 7. Ordnung Opisthocomi S. 324. 8. Ordnung Gallinae S. 324. 9. Ordnung Columbae S. 324. 10. Ordnung Accipitres S. 324. 11. Ordnung Psittaci S. 324. 12. Ordnung Picariae S. 324, 13, Ordnung Passeres S. 325. 
5. Klasse. Mammalia. Säugetiere. (B e arbeitet v on M. Schlosser S. 325. A. Unterklasse Eplacentalia S. 349. 1. Ordnung Monotremata S. 349. 2. Ordnung Marsupialia S. 350. 1. Unterordnung Allotheria S. 351. 2. Unterordnung Diprotodontia S. 355. 3. Unterordnung Polyprotodontia S. 358. B. Unterklasse Placentalia S. .364. 1. Ordnung Insectivora S. 364. 1. Unterordnung Zalambdodonta S. 366. 2. Unterordnung Dilamb. dodonta S. 366. 2. Ordnung Chiroptera S. 373. 3. Ordnung Carnivora S. 374. 1. Unterordnung Creodontia S. 375. 1. Tribus Acreodi S. 376. 2. Tribus Pseudocreodi S. 378. 3. Tribus Eucreodi S. 382. 2. Unterordnung Fissipedia S. 384. 3. Unterordnung Pinnipedia S. 399. 4. Ordnung Cetacea S. 401. 1. Unterordnung Archeoceti S. 405. 2. Unterordnung Odontoceti S.406. 3. Unterordnung Mystacoceti S. 409. 5. Ordnung Edentata S. 410. 1. Unterordnung Nomarthra S. 412. 2. Unterordnung Xenarthra S. 413. 1. Tribus. Anicanodonta S. 413. 2. Tribus Hicanodonta S. 418. 6. Ordnung Rodentia S. 422. 1. Unterordnung Simplicidentata S. 425.

2. Unterordnung Duplicidentata S. 433. 7. Ordnung Ungulata S. 435.

1. Unterordnung Condylarthra S. 437. 2. Unterordnung Litopterna S. 440.

3. Unterordnung Perissodactyla S. 444. 4. Unterordnung Artiodactyla S. 468.

A. Bunodontia S. 472. B. Bunoselenodontia S. 476. C. Selenodontia S. 480.

5. Unterordnung Amblypoda. S. 506. 8. Ordnung Notoungulata S. 511.

1. Unterordnung Typotheria S. 513. 2. Unterordnung Toxodontia S. 518.

3. Unterordnung Entelonychia S. 521. 4. Unterordnung Astrapotherioidea

S. 524. 5. Unterordnung Pyrotheria S. 526. 9. Ordnung Subungulata S. 528.

1. Unterordnung Embrithopoda S. 529. 2. Unterordnung Hyracoidea S. 530.

3. Unterordnung Proboscidea S. 532. 4. Unterordnung Sirenia S. 540. 10. Ordnung Primates S. 544. 1. Unterordnung Lemuroidea S. 544. 2. Unterordnung Anthropoidea S. 550 . 



\section{Stamm. Vertebrata. Wirbeltiere. ${ }^{1)}$}

Bilateral symmetris che Tiere mit einem meist metamer gegliederten, aus gleichwertigen Abschnitten zusammengesetzten Achsenskelett, welches dorsal das zentrale Nervensystem trägt. Die Anhänge des Achsenskeletts umschließen als obere Bögen das Rückenmark, als untere die Aorta. Nie mehr als zwei Paar Gliedmaßen vorhanden.

Ausscheidung von phosphorsaurem Kalk führt zur Verkalkung oder Verknöcherung des knorpligen Skeletts und zur Bildung von Skeletteilen in der Haut. Knochen und Dentin sind dem Wirbeltierstamm eigene Gewebeformen.

Die wichtigsten Grundlagen des Achsenskeletts sind die stabförmige Chorda dorsalis, ein zelliges Gebilde von gallertartiger Beschaffenheit, und das perichordale Bindegewebe, welches mit seinen Fortsätzen das Rückenmark und ventral die Aorta und die Coelomwand umgreift (öfter als skeletogenes Gewebe bezeichnet).

Die Chorda scheidet sehr bald nach ihrer Anlage eine dünne cuticulare Hülle, die Elastica externa, ab; unter dieser bildet sich eine dickere, zellenfreie Faserscheide, die Chordascheide. Sie kann sich nach innen durch eine Elastica interna abgrenzen.

Die Stützgebilde des perichordalen Bindegewebes entstehen hauptsächlich dort, wo die Myosepten sich mit diesem Bindegewebe vereinigen; sie sind wohl durch den Reiz des Muskelzugs hervorgerufen und dienen zunächst dazu, diesen Zug auf die elastische Chorda zu übertragen. Bei stärkerer Entwicklung und besonders nach ihrer Verkalkung oder Verknöcherung tritt die Bedeutung für den Schutz des Rückenmarks, für die Festigung des Coeloms und als Insertionsstützen der mächtiger und komplizierter sich entwickelnden Muskulatur in den Vordergrund. Die Entstehung dieser Bögen geht der Segmentierung der Chordascheide voran und übt meist einen bestimmenden Einfluß auf die Abschnitte, die sich in dieser bilden, aus.

Die Segmente können durch Aufnahme von phosphorsaurem Kalk verkalken oder verknöchern, indem (seltener) das Knorpel-

1) Gegenbaur, Vergleichende Anatomie der Wirbeltiere. I. II. - Grundrif der vergleichenden Anatomie. 2. Aufl.1878. - Bütschli, C., Vorlesungen über die vergleichende Anatomie. I. Leipzig 1910. 
gewebe in knöchernes umgewandelt oder (häufiger) zerstört und durch knöchernes ersetzt wird. Von außen (vom bindegeweblichen Perichondrium) dringen blutgefäßführende Kanäle in den Knorpel, auf denen Zellen (die Osteoblasten) einwandern, von denen die Abscheidung des Knochens ausgeht. Die Osteoblasten werden zum Teil von dem abgeschiedenen Knochen umhüllt (Knochenkörperchen, Lacunen), bleiben aber durch sehr feine Röhrchen (Primitivröhrchen) mit den Kanälen (Haversschen Kanälen) in Verbindung. Bei manchen Teleostiern fehlen die Lacunen, weil die Osteoblasten nicht in den von ihnen gebildeten Knochen hineingeraten. Nur ihre Fortsätze lassen sich in diesen hinein verfolgen, die demnach von den Haversschen Kanälen direkt auszugehen scheinen. Derartiger Knochen ist nicht prinzipiell von Dentin (s. unten) verschieden.

Am vorderen Ende der Wirbelsäule befindet sich bei Cranioten die das Gehirn umschließende Schädelkapsel nebst dem Visceralskelett. Das Skelett der Extremitäten besteht aus mehreren, gelenkig verbundenen Abschnitten, die je nach der Funktion der Gliedmaßen außerordentlich verschiedene Ausbildung erlangen. Es ist knorplig in der Anlage und wandelt sich bei den höheren Wirbeltieren meist vollständig in Knochen um.

Das Nervensystem besteht aus einem in Gehirn und Rückenmark gegliederten Zentralorgan, von welchem zahlreiche Nervenäste entspringen und in sämtliche Körperteile verlaufen. Das Blut wird von dem mit ein oder zwei Vorkammern versehenen Herzen zuerst nach den Respirationsorganen (Kiemen oder Lungen) getrieben, durchzieht nach vollzcgenem Gasaustausch den Körper und kehrt als venöses Blut wieder zum Herzen zurück. Speiseröhre, Magen, Darm, Leber, Nieren, Milz und Generationsorgane liegen im ventralen Teil des Körpers.

Die Haut ist häufig mit Haaren, Stacheln, Schuppen, Federn oder Knochenplatten versehen.

Man unterscheidet gewöhnlich bei den Wirbeltieren 5 Klassen: Pisces, Amphibia, Reptilia, Aves und Mammalia.

Die früher allgemein zu den Fischen gerechneten Amphioxiden werden jetzt als Acrania oder Leptocardii, die weder ein Cranium noch ein muskulöses Herz besitzen, in eine besondere Klasse und allen übrigen, den Pachycardiern mit Cranium und mit muskulösem Herz gegenübergestellt.

Unter den Pachycardiern nehmen aber wiederum die Cyclostomen eine ganz besondere Stellung ein, die in verschiedener Weise systematisch zum Ausdruck gebracht ist. Wegen des unvollkommen ausgebildeten und sehr eigenartigen Primordialcraniums und des Kiemenskeletts, das mit den Kiemenbögen der übrigen Vertebraten nur wenig Ähnlichkeit hat, werden sie besser nicht als Unterklasse der Fische, sondern als eine besondere Klasse geführt, die sich selbständig zwischen Leptocardier und die übrigen Wirbeltiere einschiebt. Dann gruppieren sich die Vertebraten in folgender Weise:

I. Leptocardii oder Acrania. Nur mit Chorda, ohne Schädelanlage. Kein muskulöses Herz. Klasse: Leptocardii. 
II. Pachycardii oder Craniota. Mit knorpligem oder ossifiziertem Schädel. Mit muskulösem Herzen.

A. Cyclostomi. Schädelanlage unvollkommen und nicht über den Nervus vagus zurückgreifend. Klasse: Marsipobranchii.

B. Eucrania. Schädel vollständig, auch die Region des N. vagus umschließend.

Anamnia $\left\{\begin{aligned} \text { Klasse: } & \text { Pisces. } \\ 》 & \text { Amphibia. } \\ 》 & \text { Reptitia, } \\ 》 & \text { Aves, } \\ 》 & \text { Mammalia. }\end{aligned}\right.$

Eine Chorda dorsalis, das für die Definition der Wirbeltiere wichtigste Organ, kommt auch den Tunicaten zu, allerdings meist nur den Jugendformen. Indessen besitzen die Appendicularien auch als erwachsene Tiere eine Chorda. Hieraus leitet man die Berechtigung ab, die Tunicaten mit den Wirbeltieren als Chordata zusammenzufassen. Über die Entstehung der Wirbeltiere gewährt die Paläontologie keine Auskunft, auch nicht über ihr Verhältnis zu den Tunicaten.

\section{Klasse. Pisces. ${ }^{1}$ ) Fische. (Bearbeitet von E. Ko ken.)}

Kaltblütige, meist ausschließlich durch Kiemen at. mende Wasserbewohner. Gliedmaßen als Flossen aus. gebildet. Haut mit Schuppen, Hautzähnen oder Knochenplatten, selten nackt. Wirbelsäule meist in einer verti-

1) Cuvier et Valenciennes, Histoire natur. des Poissons. Paris 1828-49. 22 Bde. - Agassiz L., Recherches sur les poissons fossiles. 5 Bde. in $4^{0}$ mit Atlas. Teuchâtel 1833-43. - Müller Joh., Über den Bau und die Grenzen der Ganoiden und das natürliche System der Fische. Abhandl. Berl. Akad. für 1844 (1846). Cope Edw., Classification of fishes. Trans. Amer. Philos. Soc. 1870. S. 449, und Proceed. Amer. Assoc. Advancem. Sc. 1871. S. 326. - Günther Alb., An introduction to the Study of fishes. Edinburgh 1880. - Woodward, A. Smith, Catalogue of the fossil fishes in the British Museum. Part I-IV. 1889-1901. - Pander Chr. H., Monographie der fossilen Fische des silurischen Systems des russisch-baltischen Gouvernements. St. Petersburg 1856. - Agassiz L., Monographie des poissons fossiles du vieux grès rouge. Neuchâtel 1844. - Huxley Th., Preliminary essay upon the systematic arrangement of the fishes of the devonian epoch. Mem. geol. Surv. Un Kingdom 1861. - Newberry J. S., Description of fossil fishes. Geol. Surv. Obio. Palaeontology. vol. I u. II. Columbus 1873. - Newberry J. S., Worthen and St. John, Geol. Surv. Illinois. vol. II 1866, vol. IV 1870 u. vol. VII $1873 .-$ Newberry J. S., Palaeozoic fishes of N. Amerika. Washington 1889. - Quenstedt $F$. A., Der Jura. Tübingen 1858. - Wagner A., Beiträge zur Kenntnis der in den lithogr. Schiefern abgelagerten urweltl. Fische. Abhandl. Bayer. Akad. Bd. VI 1851 und IX 1861-63. - Thiollière $V$., Description des poiss. foss. provenants des gisements coralliens du Jura dans le Bugey. Lyon. I u. II. 1854 u. 1873. Pictet E. J., Description de quelques poiss. foss. du Mont-Liban. Genève 18500. Pictet $E$. J., et Humbert A., Nouv. rech. s. l. poiss. foss. du Mont-Liban. 1866. Daris J. W., Fossil fishes of the Chalk of Mount Libanon. Trans. Roy. Soc. Dublin 1887. $4^{\circ}$. - Cope E. D., Report of the U. S. geol. Survey of the Territories. vol. II. The Vertebrates of the cretaceous formations of the West. Washington 1875. - Marck W. $v$. d., Fossile Fische etc. aus der jüngsten Kreide in Westfalen. Palaeontographica XI, XV, XXII, XXXI, XLI. 1863-94. Volta S., Ittiologia Veronese. Verona 1796. - Heckel J. J., Beiträge zur Kenntnis der fossilen Fische Österreichs I 1849. II 185̋6. Denkschr. Wiener Akad. Bd. XI. 
kalen Schwanzflosse endigend. Herz miteinfacher Kammer und Vorkammer. Entwickelung ohne Amnion und Allantois.

$\mathrm{Zu}$ den Hautgebilden gehören die Schuppen, Hautknochen, Stacheln, Flossenstrahlen und Zähne.

1. Schuppen. L. Agassiz unterschied 4 Arten von Schuppen, denen in seinem System ebenso viele Ordnungen von Fischen entsprechen.

a) Die Placoidschuppen der Selachier und Holocephalen. Es sind meist kleine rhombische Plättchen, stern-, blatt-, pfeilspitzen-, schaufelförmige oder auch konische Gebilde, die dicht nebeneinander liegen und ein rauhes Mosainkpflaster (Chagrin) bilden. Häufig haben sie auf verschiedenen Körperteilen verschiedene Form und zuweilen zeichnen sich (so bei Rochen) einzelne durch beträchtliche Größe

$a$

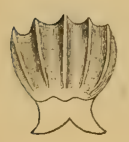

Fig. 1.

a Schuppe von Scyllium canicula. Rezent. $50 / 1$.

$b$ Schuppen von Carcharias (Prionodon) gangeticus. Rezent. Vergr.
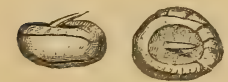

Fig. 2.

Raja antiqua. Große Placoidschuppe mit Stachel. Nat. Gr.

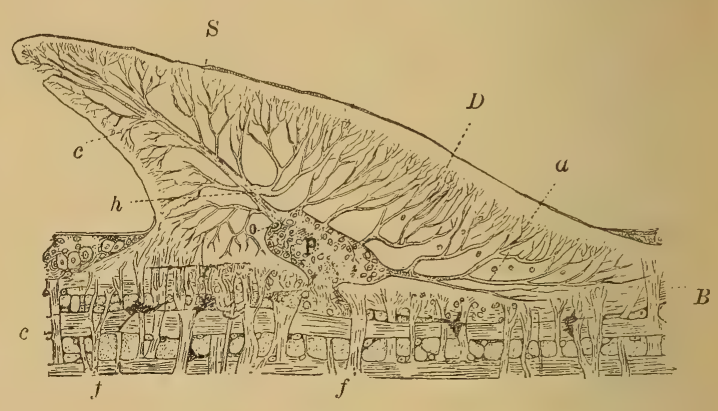

Fig. 3.

Sagittalschnitt durch eine Schuppe von Scymnus Lichia in 60 facher Vergr. (Nach O. Hertwig.) S Schmelz, $D$ Dentin, $B$ Basalplatte, $p$ Pulpa, $c$ Lederhaut, $h$ starker, nach oben verlaufender Hauptzahnkanal, $d$ horizontale Dentinkanäle, $o$ Odontoblasten, $f$ Bindegewebfasern.

aus und erscheinen als dicke, außen rauhe oder mit Stacheln bewehrte Platten. Die Placoidschuppen entstehen aus Papillen des Corium, über welche sich die basale Schicht der Epidermis hinwegzieht. Die letztere lagert Schmelz ab, während die Zellen im Innern der Papille Zahnbein (Dentin) entstehen lassen. Dazu tritt die in der Lederhaut selbst gebildete Basalplatte. Die Placoidschuppen (Fig. 1-3)

- Heckel J. J. und Kner, Neue Beiträge etc. ibid. 1861. Bd. XIX. - Zigno Ach. di, Catalogo ragionato dei pesci fossili di Monte Bolca. Atti R. Istit. Veneio di Sc. 1874. - Sauvage H. E., Mem. sur la faune ichthyol. de la periode tertiaire. Ann. Sc. géol. IV u. IX. - Baudelet, Rech. s. l. structure et le dével. des écailles des poissons. Arch. Zool. expérimentale 1873. Bd. II. - Gegenbaur, Grundzüge d. vergleich. Anatomie. 1870. - Hertwig O., Bau u. Entwickelung der Placoidschuppen und d. Zähne d. Selachier. Jenaer Zeitschr. f. Naturwiss 1874. - Úber das Hautskelett d. Fische. Morpholog. Jahrb. Bd. II, V, VII. - Hofer Br., Über den Bau und die Entw. d. Cycloid- und Ctenoidschuppen. Ges. f. Morphol und Physiol. München 1889. - Klaatsch H., Zur Morphol. d. Fischschuppen etc. Morphol. Jahrb. XVI. 1890. - Kölliker, Uber verschied. Typen in d. mikroskop. Struktur d. Skelettes d. Knochenfische. Verh. phys. medic. Ges. Würzburg. 1858. - Nickerson, The development of the scales of Lepidosteus. Bull. Mus. Compar. Zorl. 1893. XXIV. - Reißner, Uber die Schuppen v. Polypterus u. Lepidosteus. Arch. f. Anatom. Physiol. 1859. - Williamson, On the microscop. structure of the scales and dermal teeth of some Ganoid and Placoidfishes. Phil. Transact. 1849. I. 
haben demnach die Struktur der Zähne. Die in die Haut eingèsenktè Basalplatte besteht aus dichtem phosphorsaurem Kalk, der von senkrechten Bündeln von Bindegewebsfasern durchzogen ist; der sich frei erhebende Oberteil ist aus Dentin zusammengesetzt und von gröberen und feineren Kanälen durchzogen. Die dünne glänzende Rinde, welche den Dentinkern überzieht, entspricht histologisch und chemisch dem Schmelz, ist sehr hart und strukturlos.

Die Kanäle des Dentins entspringen aus einer mit Bindegewebe (des Coriums) und Zahnzellen (Odontoblasten) erfüllten Höhle (Pulpa $p$ ) und vergabeln sich nach außen in immer feinere Äste. Die einfache Pulpa kann auch durch ein Bündel größerer Kanäle ersetzt werden. Die Substanz des Dentins ist phosphorsaurer Kalk mit kleinen Mengen von Fluorcalcium und kohlensaurem Kalk.

Die Placoidschuppen fallen öfters aus und werden wie die Zähne durch Ersatzplättchen verdrängt.

b) Ganoidschuppen (Fig. 4, 5) haben durchschnittlich ansehnlichere Größe als die Placoidschuppen und bedecken meist den ganzen Rumpf. Wo sie gedrängt vorkommen, stehen sie in diagonalen Reihen, welche den sich kreuzenden

Faserrichtungen des Corium entsprechen. Rhombische Ganoidschuppen sind meist durch vorspringende Zapfen am Vorderrand, welche in eine Rinne auf der Innenseite der benachbarten Schuppe eingreifen, beweglich verbunden; rundliche Schuppen liegen dachziegelartig, mit imbrizierenden Rändern, übereinander. Dieknöcherne, von zahlreichen Kanälen durchzogene Basalplatte ist meist dick mit einer

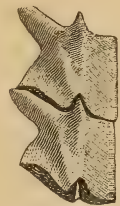

Fig. 4.

Schuppen von Polypterus Bichir Bonap. Rezent. (Nat. Gr.)
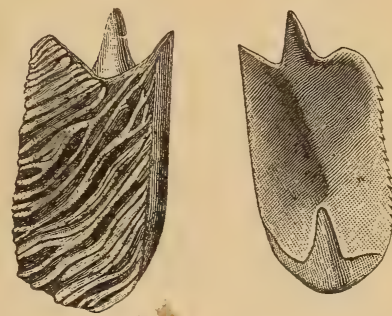

Fig. 5.

Schuppe von Cosmoptychius striatus Ag. sp. Steinkohlenformation. $a$ von außen, $b$ von innen. $3 / 1$.

glänzenden, schmelzartigen Schicht (Ganoin) überzogen, welche verschiedenartig verziert sein kann.

Nach Gegenbaur und Klaatsch ist der Ganoinbelag nicht eigentlicher Schmelz, sondern entstanden durch Konkreszenz von kleinen Hautzähnchen über der vorher angelegten Basalplatte. Er entspricht also auch dem Dentin der Placoidschüppchen. Indessen grenzt sich der Schmelzbelag häufig deutlich und charakteristisch ab (Scupin, l.c.) und kann auch wiederum ganz fehlen (Pycnodonten, Rhynchodontiden zum Teil).

Die Basalplatte zeigt namentlich bei paläozoischen Gattungen große Mannigfaltigkeit (Fig. 6, 7). Die tieferen Lagen enthalten zahlreiche Knochenkörperchen und Haversische Kanäle, die oberen sind häufig nur von feinen Dentinröhrchen durchzogen (Ostein, Osteinkanäle Scupins).

c) Die Cycloid- und Ctenoid schuppen (Fig. 8, 9) stimmen in ihrer Zusammensetzung miteinander überein. Beide sind dünn, elastisch, von rundlicher, elliptischer, vier-, fünf- oder sechsseitiger Gestalt. Sie bestehen aus einer homogenen glasigen Deckschicht aus phos- 
phorsaurem Kalk und aus einer in Alkalien löslichen, lamellar geschichteten Basis von Bindegewebesubstanz. Die Deckschicht (Hyalodentin Hofers) ist ein modifiziertes Dentin.

Die Schuppen entwickeln sich in besonderen Taschen des Corium und greifen meist dachziegelartig übereinander. Die Cycloidschuppen haben rundliche Form und einfachen Hinterrand. Bei den Ctenoidschuppen ragen am Hinterrand kleine Zacken und Zähnchen hervor, welche zuweilen in mehreren Reihen hintereinander stehen und einen ansehnlichen Teil des hinteren Feldes bedecken können. Sie haben die Zusammensetzung der Oberflächenschicht. Von dem sog. Primitivfeld strahlen meist nach vorn und nach hinten divergierende, zuweilen auch anastomosierende Linien aus, die nichts anderes als rißartige Unterbrechungen der Deckschicht sind. Durch Verstärkung und Zerteilung des Leistenreliefs der Schuppen

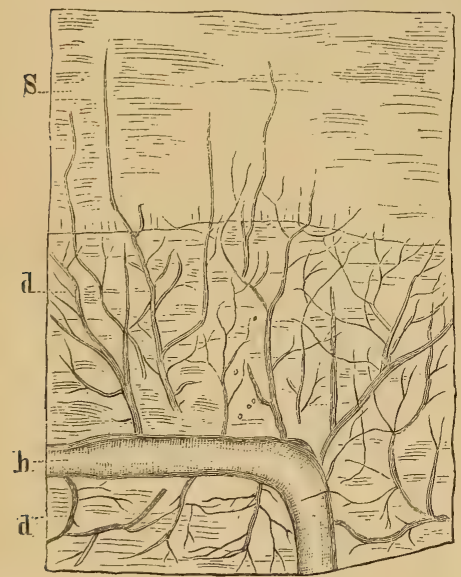

Fig. 6.

Vertikalschnitt durch die Schuppe von Lepidosteus. $30 \% /$. (Nach O. Hertwig.) $S$ Schmelz, $h$ Haversischer Kanal, d Dentinröhrchen.

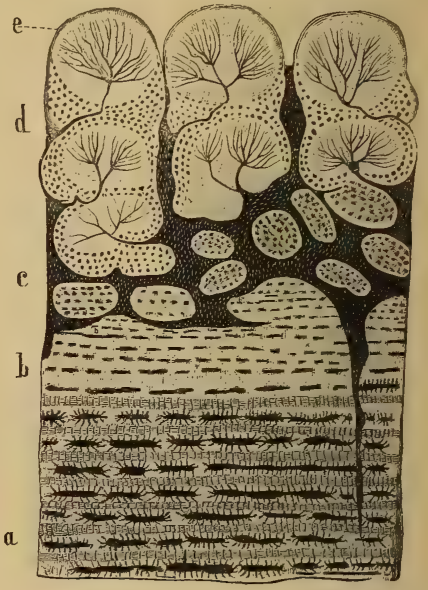

Fig. 7. Vertikalschnitt durch eine Schuppe von Glyptolepis, stark vergr. (Nach Pander.) $a, b$ Isopedinschicht mit spindelförmigen Knochenzellen, $c$ Knochenschicht mit Haversischen Kanälen, $d$ Schicht mit fein verästelten Dentinröhrchen (Kosmin), e Schmelz.

können kleine und größere Stacheln entstehen. Zuweilen ist nur ein einziger Stachel auf kleiner Basalplatte vorhanden, so daß die Form des Placoidzahns resultiert, indessen sind diese anderer Entstehung und nicht direkt homolog.

Zwischen den oberen Lamellen der Basis sind oft Knochenkörperchen nachweisbar; die tieferen șind von fibrillärer Beschaffenheit (sklerosiertes Bindegewebe) und enthalten Knochenkörperchen nur selten und nur in den untersten Lagen. Derartige Schuppen unterscheiden sich nicht wesentlich von dünnen Ganoidschuppen.

Große Knochenplatten bei Cataphracten, Plectognathen, Lopthobranchiern beruhen wahrscheinlich auf Konkreszenz schuppenartiger Anlagen.

Die Schuppen der Seitenlinie sind bei Ganoiden und Teleostiern durchbohrt und oft von etwas abweichender Form. 
Die größeren Platten, Schilder, Stacheln etc., welche teils den Rumpf, teils den Kopf vieler Fische (Placodermi, Siluridae, Accipenseridae) bedecken, bestehen entweder aus gleichmäßiger Knochensubstanz oder aus Lagen von Ostein, Dentin und Schmelz. Bei den Accipenseriden lassen sie sich von normalen Ganoidschuppen ableiten, in die sie am Schwanz oft direkt übergehen. Bei den Panzer-
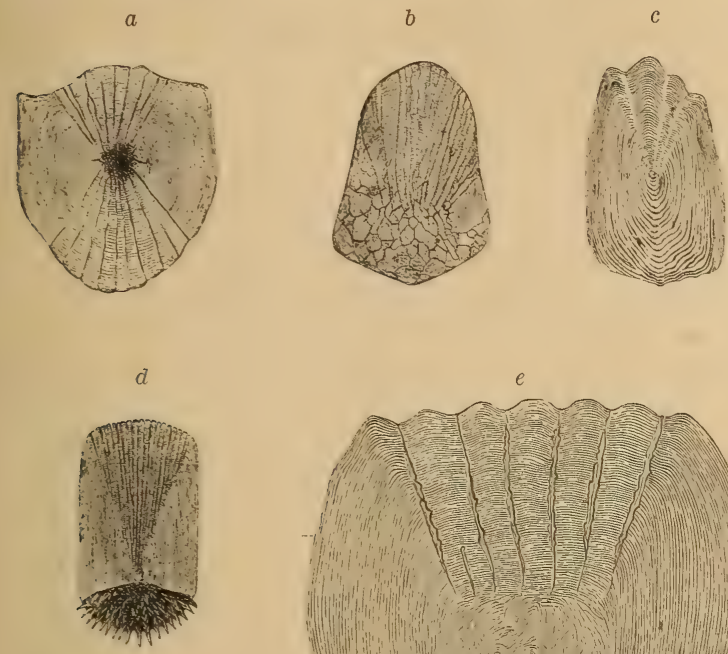

Fig. 8 .

Cycloidschuppe von

a Leuciscus,

b Mormyrus,

c Naucrates,

Ctenoidschuppe von

$d$ Solea,

e Holacanthus (stark

vergrößert.)

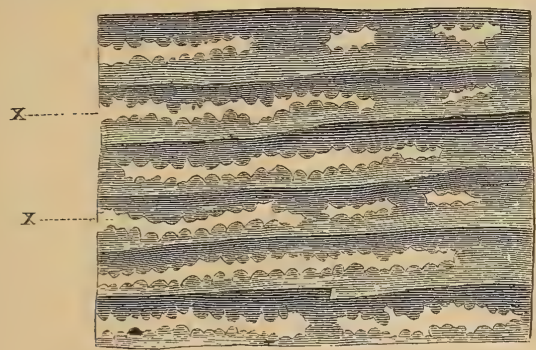

Fig. 9

Oberfläche einer Pleuronectes-Schuppe, um die Lücken $(x)$ zWischen den erhabenen konzentrischen Leistchen zu zeigen. Sehr stark vergr. (Nach Baudelot.)

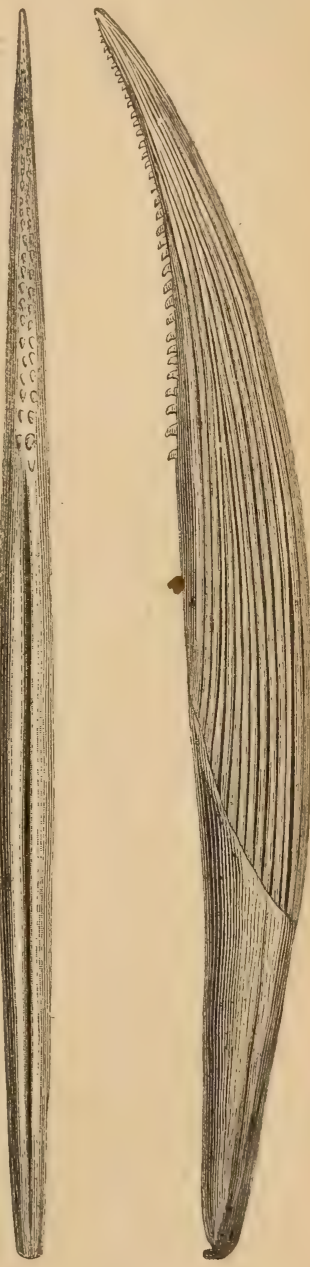

Fig. 10.

Rückenflossenstachel von Hybodus reticulatus Ag, aus dem oberen Lias von Boll.

welsen sind Zähnchen, welche den Placoidschüppchen vergleichbar sind, mit einer solchen Knochenplatte verbunden aber nicht verwachsen.

Größere Stacheln (Ichthyodorylithen) (Fig. 10) kommen am Vorderrande der Flossen oder am Kopf bei Fischen mit knorpligem Innenskelett vor (Selachier, Holocephalen). Sie stecken meist mit 
einer verlängerten Basis im Fleisch und treten gern mit einer knorpligen Platte oder Unterlage in Verbindung. Sie bestehen, wie die Zahngebilde der Placoidfische, aus Dentin mit Pulpa oder aus Vasodentin. Sie zeichnen sich oft durch reiche Verzierung (Längsrippen, Höcker, Randzähnchen etc.) aus.

Hautgebilde mesodermalen Ursprungs sind auch die äußeren Teile der Flossen (Hornfäden, Strahlen). Die Hornfäden (Ceratotrichia) sind bei den Haien elastische Fasern, bei den Dipnoern zellenhaltig. Bei den Ganoiden und Teleostiern werden die embryonalen Hornfäden später von knöchernen Flossenstrahlen verdrängt, die sich von Knochenschuppen ableiten. Sei sind aus zwei dicht aneinanderliegenden Hälften zusammengesetzt, die bei den Weichflossen durch Querteilung in zahlreiche Stückchen gegliedert werden, nach außen häufig fächerförmig zerteilt

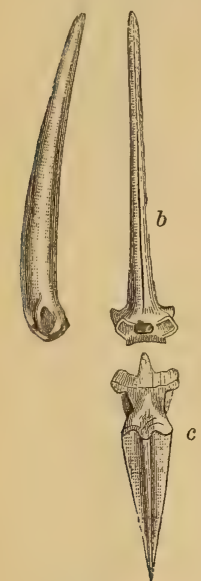

Fig. 11.

$a, b$ Flossenstrahlen aus der
Rückenflosse eines Hartflossers,

c Flossenträger. sind. Kommen harte und weiche Strahlen in einer Flosse vor, so stehen die ungegliederten voran.

Die Flossenstrahlen der unpaaren Flossen werden in der Regel von flachen, knorpligen oder knöchernen Trägern gestützt, mit denen sie gelenkig verbunden sind. Die Träger (A x on oste) (Fig. 11) gehören dem Innenskelett an. Sie schieben sich zwischen die Dornfortsätze der Wirbel und werden je nach ihrer Lage (dorsal oder ventral) als Interneuralia oder Interhämalia bezeichnet.

Bei manchen Selachiern (Pristiophorus, Raja) findet zwischen den Placoidschuppen der äußeren Haut und den Zähnen ein allmählicher Übergang statt, und da beide im wesentlichen dieselbe histiologische Zusammensetzung aufweisen und die Zähne nur bei den höheren Fischen in feste Verbindung mit den Kopfknochen treten, so müssen die Zähne. ebenfalls den Hautgebilden zugezählt werden.

Bei den Fischen können sämtliche Knorpel oder Deckknochen, welche an der Mund- und Kiemenhöhle teilnehmen, Zähne tragen. Sie gehen aus der Verkalkung von Hautpapillen hervor und bestehen aus einer frei vorragenden Krone und einer von Bindegewebe umgebenen oder mit dem Kopfskelett verbundenen Wurzel. Form und Größe sind je nach ihrer Funktion außerordentlich verschieden. Von den winzigen 》Sammtzähnchen « des Barsches zu den langen Bürstenzähnen des Wallers, zu den kräftigen Hechelzähnen des Hechtes und den gewaltigen Kegeloder Dolchzähnen von Dendrodus oder Portheus existieren alle Übergänge. Bei den Haien kommen Zähne von der Form einer einseitig abgeplatteten Dolchklinge mit oder ohne Nebenzacken häufig vor. Zum Zermalmen der Nahrung dienen teils stumpfkonische, teils bohnenförmige, kugelige oder pflastersteinartige Zähne, und bei gewissen Selachiern fügen sich die Zähne zu einem geschlossenen Mosaik aneinander. Eigentümliche schneidende Zahnplatten von ansehnlicher Größe finden sich bei Diodon und Chimaera.

Ebenso mannigfaltig wie die Form ist auch die Zahl der Zähne bei den Fischen. Während die Dipnoer, Chimaeriden und Gymno- 
donten im ganzen nur 4 bis 6 Zähne besitzen, zählen dieselben bei vielen Haien und Knochenfischen nach Hunderten.

Die Befestigung auf der knorpeligen oder knöchernen Unterlage wird in der Jugend bei fast allen Fischen durch faseriges Bindegewebe bewerkstelligt, und bei Haien und vielen Knochenfischen bleibt diese Art der Befestigung zeitlebens, so daß die Zähne nach längerem Kochen leicht von der Basis abgestreift werden können. Bei Knochenfischen und vielen Ganoiden tritt eine Verwachsung der Zahnwurzel mit dem Knochen ein, wobei auf letzterem meist eine sockelartige Erhöhung dem Zahne entgegenwächst. Ausnahmsweise findet man auch in Höhlungen (Alveolen) eingefügte Zähne. In der Regel entwickeln sich die Ersatzzähne neben den fungierenden Zähnen und schieben dieselben nach und nach aus.

Mit wenigen Ausnahmen besteht die Zahnkrone aus Dentin, Vasodentin und Schmelz, die Wurzel aus Vasodentin oder Osteodentin. Der Schmelz (Placoinschmelz) bildet eine sehr dünne, glasharte, glänzende, homogene Deckschicht, welche unter polarisiertem Licht Doppelbrechung erkennen läßt. Die Schmelzschicht schließt zu- $D$ weilen noch die äußersten Ausläufer der Dentinröhrchen ein. Sie ist aus phosphorsaurem Kalk mit etwas Fluorcalcium, wenigkohlensaurem Kalk, phosphorsaurer Magnesia und sehr geringen Mengen organischer Substanz zusammengesetzt. Das D entin (Elfenbeinsubstanz) enthält kein Fluorcalcium, viel mehr organische Beimengung als der Schmelz, ist weniger hart und löst sich in Säure langsamer auf. Das eigentliche Dentin (Fig. 12) wird lediglich von sehr feinen, nach außen verästelten Röhrchen durchzogen, die von der Pulpa oder deren Verzweigungen ausgehen und fadenförmige Verlängerungen der Zahnzellen (Odontoblasten) enthalten. Sehr häufig wird die Dentinsubstanz auch von groben, anastomosierenden Kanälen (Haversische Kanäle) durchzogen, in welchen Blutgefäße verlaufen und deren Wände mit Odontoblasten ausgekleidet sind. Von diesen groben Kanälen gehen alsdann in peripherischer Richtung feine Dentinröhrchen aus. Diese gefäßreiche Modifikation der Zahnsubstanz heißt V as o dentin (Fig. 13, 14).

Die Wurzel der Fischzähne unterscheidet sich von der Krone durch Mangel eines Schmelzüberzuges. Sie besteht entweder gänzlich aus Vasodentin, oder es kommen noch Knochenzellen mit ausstrahlenden Primitivröhrchen hinzu (Osteodentin).

Das innere Skelett der Fische (Fig. 15) zeigt, daß in den verschiedenen Ordnungen dieser Klasse fast alle Entwickelungsstadien, welche bei den höheren Wirbeltieren nur vorübergehend durchlaufen werden, als dauernde Einrichtungen im ausgewachsenen Zustand fortbestehen. Der ganze Prozeß der allmählichen Gliederung, Verknorplung: und Verknöcherung der Wirbelsäule und des übrigen Skeletts ist in den 
verschiedenen Abteilungen der Fische veranschaulicht, und namentlich die fossilen Formen aus paläozoischen und mesozoischen Ablagerungen gewähren in dieser Hinsicht die bemerkenswertesten Aufschlüsse.

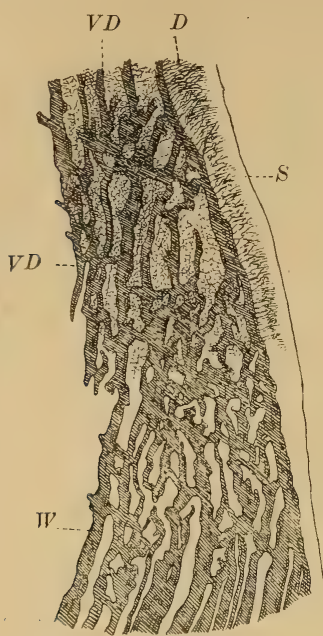

Fig. 13.

Vertikalschnitt durch einen Teil eines Hechtzahnes. (Nach Sternberg.)

Stark vergr. S Schmelz, $D$ Dentin, $V D$ Vasodentin, $W$ Zahnwurzel.

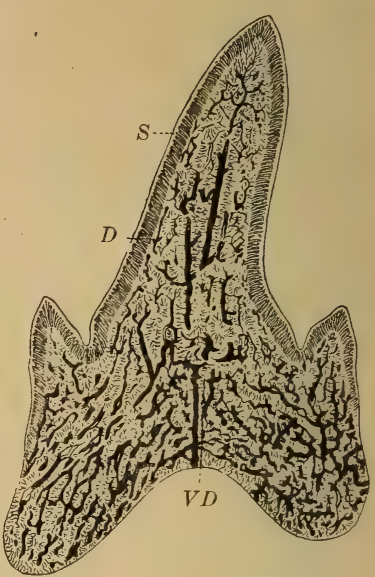

Fig. 14.

Vertikalschnitt durch einen Otodus-Zahn. Vergr.

$V D$ Vasodentin, $D$ Dentin. S Schmelz.

\section{Wirbelsäule.}

Die erste Anlage des inneren Skeletts beschränkt sich auf die Chorda dorsalis. Schon bei Amphioxus tritt hierzu ein membranöses Skelettsystem, in dem sich die in der Längsrichtung noch zusammenhängenden oberen und unteren Bogen und die myocommatischen Querlamellen unterscheiden lassen, bzw. die an den Bogenlamellen durch ihren Ansatz hervorgerufenen Gewebsverstärkungen.

Bei den Cyclostomen entwickeln sich dorsal im Anschluß an die austretenden Spinalnerven kleine Knorpelstücke (je zwei jederseits in jedem Metamer), die im Schwanz zu einer Längsleiste verschmelzen. Entsprechende ventrale Bildungen sind nur im Schwanz beobachtet.

Diese schon bei den Cyclostomen nachweisbaren oberen und unteren Bögen lassen bei den typischen Fischen die metamere Gliederung der Wirbelsäule entstehen, wobei die Chorda selbst noch häufig ungegliedert verharrt. Die Chordascheide ist verstärkt, die ursprüngliche Elastica nach außen gedrängt. Von den Knorpelstücken der Bogen geht eine Zerstörung der Elastica aus und Knorpelzellen wandern in die Scheide ein. Damit ist die metamere Sonderung auch der Wirbelkörper angebahnt, deren Ausarbeitung im einzelnen sehr verschiedene Wege geht.

Ein vollständiger Wir b el bestehtaus einem Wir b elk ör p er (Zentrum), zwei oberen, den Rückenmarkkanal umgebenden Bogenhälften (obere Bögen, Neurapophysen) und zwei unteren Bogenstücken 


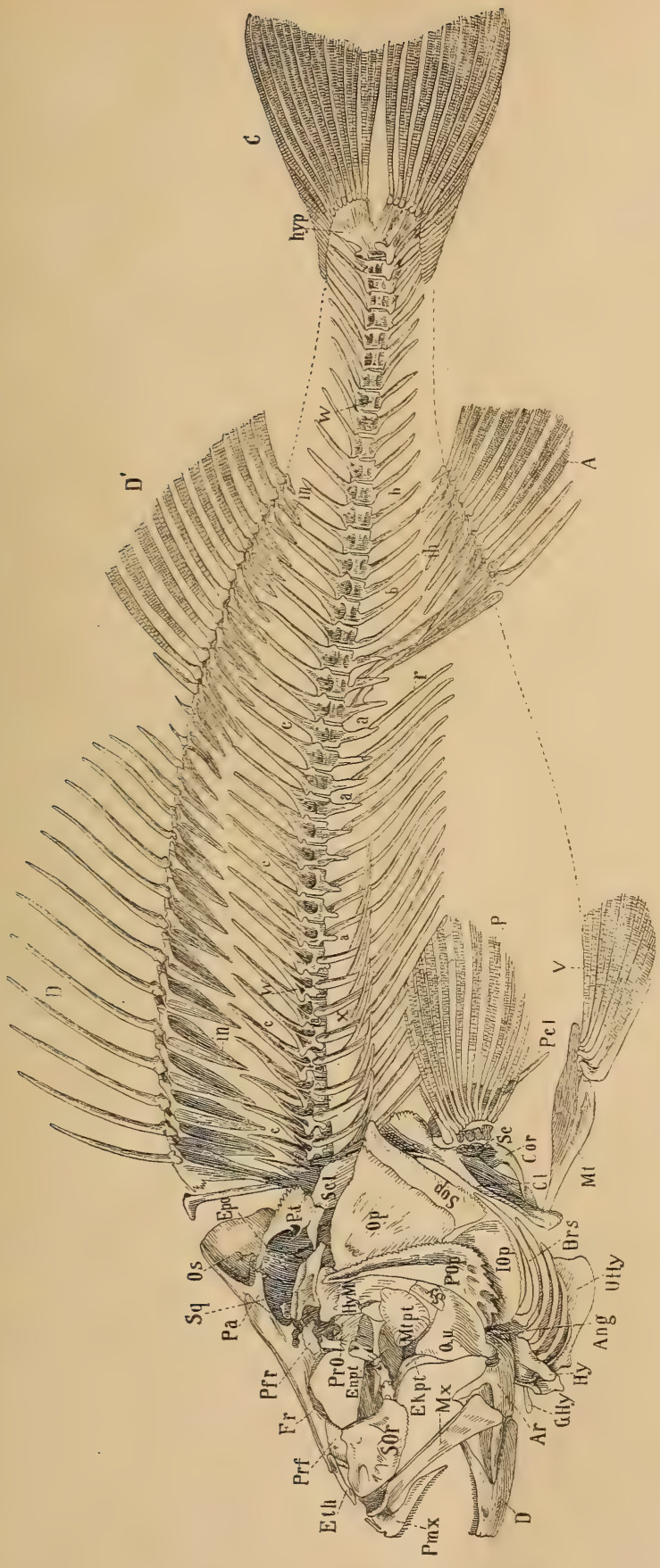

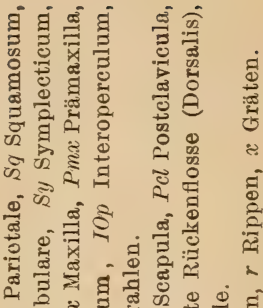

\&

ब,

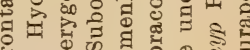

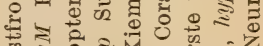

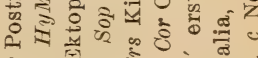

के

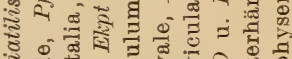

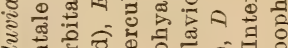

ई

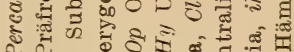

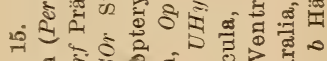

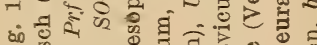

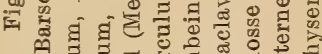

घ

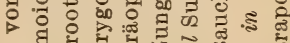

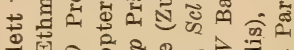

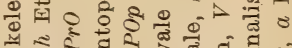

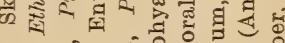

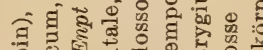

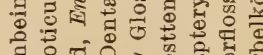

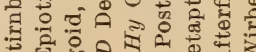

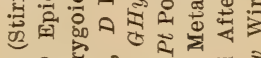

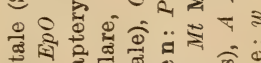
牙

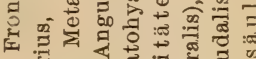


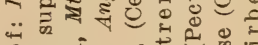

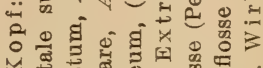

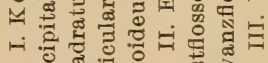

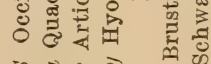

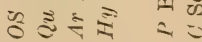


(Hämapophysen). Die oberen Bogen vereinigen sich zu einem dorsalen Dornfortsatz (processus spinosus oder spina dorsalis), die unteren können entweder in der Schwanzregion durch Vereinigung einen ventralen Dornfortsatz (spina ventralis) bilden (Fig. 18) oder sie bleiben als untere Querfortsätze (P arapophysen) getrennt.

Bei vielen mit knorpeliger Wirbelsäule versehenen Fischen (Selachier, Accipenseriden) schieben sich zwischen die oberen und unteren Bögen knorpelige Schaltstücke (Intercalaria) ein, welche die Bögen zuweilen an Größe übertreffen (Fig. 16): Es entspricht dies vielleicht dem Auftreten doppelter oberer und unterer Bogen in jedem Segment bei $\mathrm{Pe}$ tromyzon.

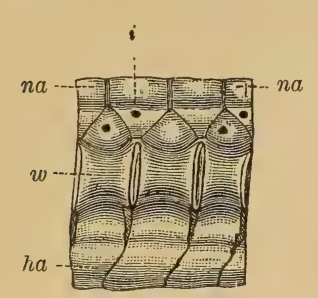

Fig. 16.

Drei Schwanzwirbel von Centrophorus von der Seite. (Nach Hasse.) $w$ Wirbelkörper, na oberer Bogen, $i$ Intercalarstück, ha unterer Bogen.

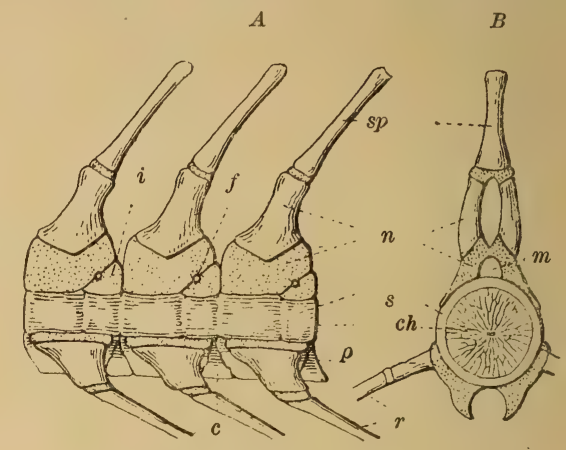

Fig. 17.

Wirbel aus der Rumpfregion des Stör. $A$ von der Seite, $B$ in vertikalem Querschnitt. $s p$. d. oberer Dornfortsatz, $n$ oberer Bogen (Neurapophyse), $p$ Parapophyse, ha unterer Bogen (Hämapophyse), $m$ Rückenmarks- (Medullar-) Kanal, ch Chorda dorsalis, s Chordascheide, $i$ Intercalaria, $r$ Rippen, $f$ Durchtrittsöffnungen der Nerven. (Der Knorpel ist punktiert, der Knochen weiß.) (Nach R. Hertwig.)

Die Wirbelcentra oder Wirbelkörper enthalten bei den Knorpelfischen meist noch einen Teil der Chorda, welche als weicher zentraler Strang die ganze Wirbelsäule durchsetzt und die Zwischenräume zwischen den einzelnen Wirbeln teilweise ausfüllt. Die knorpeligen, verkalkten oder verknöcherten Vorder- und Hinterwände der Wirbelkörper sind wie Doppelkegel tief ausgehöhlt (amphicöl) und verleihen dem Wirbelzentrum dadurch sanduhrähnliche Gestalt. Bei den Selachiern tritt meist eine teilweise Verkalkung, bei den Ganoiden und Knochenfischen eine Verknöcherung des ursprünglichen Knorpelzentrums ein. Während aber die Knochenfische meist eine vollständige Umwandlung des ganzen Wirbels mit all seinen Fortsätzen in kompakte, dentinartige Knochensubstanz aufweisen, lassen die Ganoiden, namentlich der paläozoischen und mesozoischen Ablagerungen, die verschiedensten Stadien des Verknöcherungsprozesses erkennen. Bei vollkommen verknöcherten Wirbeln legen sich die vorderen und hinteren Ränder der amphicölen Wirbelzentren dicht aneinander und sind überdies durch Ligamente verbunden, die Chorda füllt nur noch die intervertebralen Zwischenräume aus und bildet keinen kontinuierlichen Strang. Die Bögen verwachsen fest mit dem Zentrum, und am Vorderrand der oberen Bögen ragt häufig ein kurzer Fortsatz (Zygapophyse) vor, welcher sich jederseits über einen ähnlichen hinteren Fortsatz des Zentrums legt und so die Verbin- 
dung benachbarter Wirbel verstärkt (Fig. 18). In der hinteren oder $\mathrm{Schwanzregion}$ vereinigen sich die unteren Bogen zu einem ventralen Dornfortsatz (Fig. 18); in der vorderen Rumpfregion ragen die unteren Bogen als kurze Parapophysen vor und dienen beweglichen Rippen als Träger. Eigentliche Querfortsätze (Diapophysen, processus transversi), an welche sich bei den höheren Wirbeltieren die Rippen anlegen, und welche von den oberen Bogen ausgehen, kommen nur ganz ausnahmsweise (Polypterus, Pleuronectes) neben den Parapophysen vor. Bei den Cyclostomen und Chimären fehlen Rip pen vollständig, bei den Selachiern und Knorpelganoiden sind sie meist schwach entwickelt oder rudimentär. In keinem Fall vereinigen sich die Rippen auf der Ventralseite miteinander, weder direkt, noch durch das $Z$ wischentreten eines Sternums. Nicht zu verwechseln mit Rippen sind die aus verknöcherten Sehnen entstehenden Gräten;
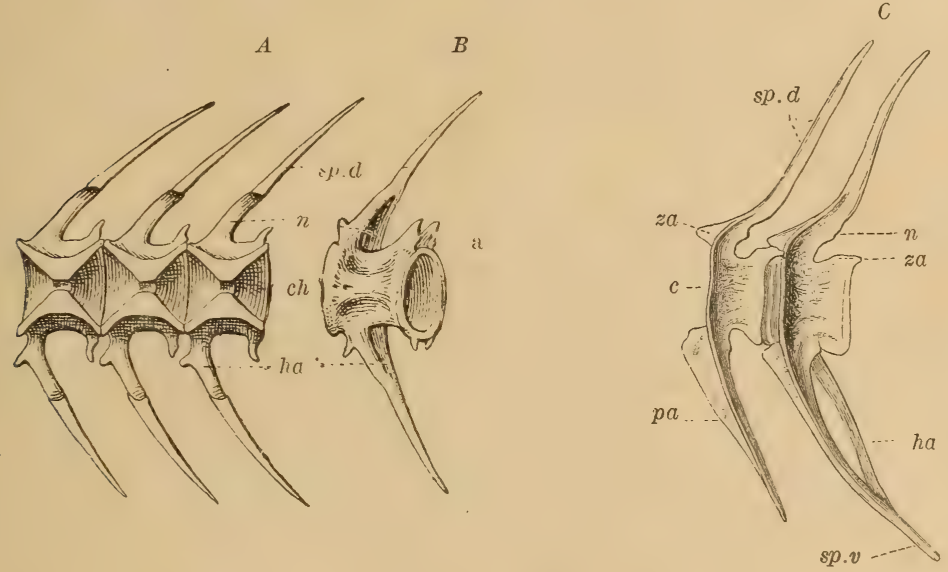

Fig. 18.

Schwanzwirbel vom Karpfen. A der Länge nach in sagittaler Richtung durchschnitten, $B$ ein einzelner Wirbel in halb seitlicher Ansicht. $C$ letzter Rumpf- und erster Schwanzwirbel. $s p$. $d$ oberer Dornfortsatz, $n$ oberer Bogen, $c h$ Chorda dorsalis, $c$ Zentrum, $z a$ Zygapophysen, $h a$ Hämapophyse. (Nach R. Hertwig.)

dünne, an einem Ende häufig vergabelte Knochenfäden, welche zwischen den Muskeln liegen und sich an die Wirbelzentren, Bogen oder Rippen anheften.

Die Zahl der Fischwirbel schwankt je nach den verschiedenen Gruppen ganz außerordentlich. Bei gewissen Knochenfischen (Ostracion) zählt man nur 15 , bei anderen 70 bis 80 , beim Aal etwa 200, bei manchen Haien 350 bis 400 .

Das hintere Ende der Wirbelsäule ist bei allen Fischen im Embryonalzustand diphycerk oder heterocerk. Im ersteren Fall verlängert sich die Wirbelsäule geradlinig bis zum Körperende und ist oben und unten symmetrisch von der Schwanzflosse umgeben. In diesem embryonalen Stadium verharren zeitlebens die Cyclostomen, Dipnoer und viele Crossopterygier (Fig. 19). Bei den heterocerken Fischen (Haien, Rochen, vielen Ganoiden) krümmt sich die Wirbelsäule hinten aufwärts und tritt vollständig in den oberen Lappen der Schwanzflosse ein, welcher sich meist verlängert und den unteren an Größe 
übertrifft (Fig. 20). Zwischen diphycerker und heterocerker Schwanzbildung gibt es vielfache Übergänge. So verlängert sich beim heterodiphycerken Schwanz die Wirbelsäule mit schwacher Aufbiegung bis zum Körperende und ist oben und unten von Strahlen umgeben; aber die Strahlen des oberen Lappen bleiben erheblich an Stärke hinter denen des unteren zurück. Zuweilen ist auch die äußere

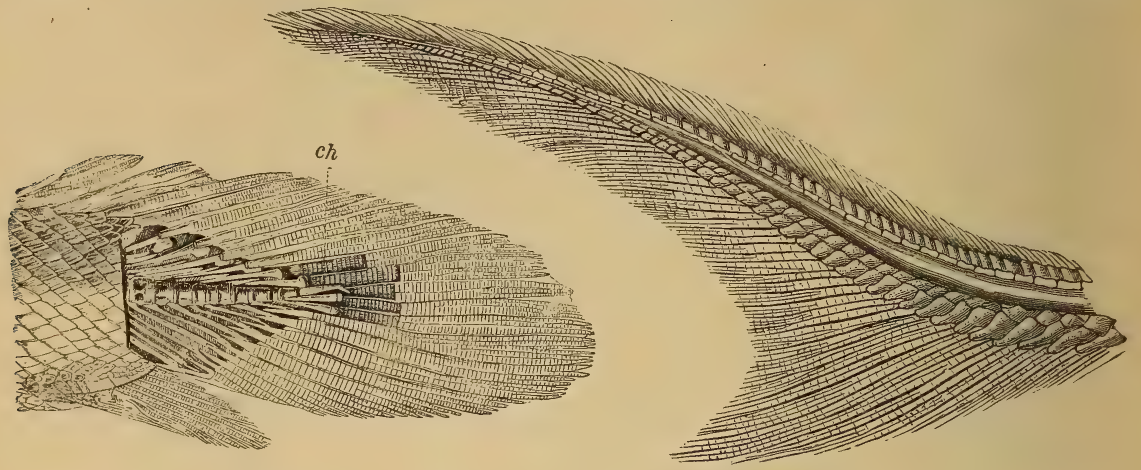

Fig. 19.

Diphycerke Schwanzflosse von Polypterus Bichir. (Nach Kölliker.)

ch hinteres Ende der Wirbelsäule.
Fig. 20.

Außerlich und innerlich heterocerke Schwanzflosse vom Stör.

Schwanzflosse aus zwei gleichen Lappen zusammengesetzt, während sich die Wirbelsäule aufwärts biegt und eine Strecke weit in den oberen Lappen eindringt (Fig. 21). Derartige Flossen sind äu(3erlich hornocerk, innerlich heterocerk. Beim hemi-heterocerken Schwanz ist der obere Lappen der äußerlich gleichlappigen Schwanzflosse noch eine Strecke weit oder auch bis zur Spitze beschuppt.

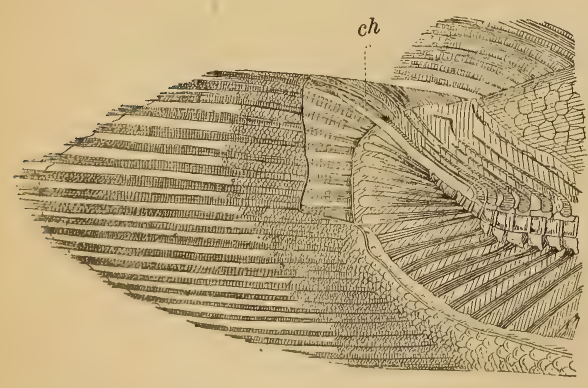

Fig. 21

Innerlich heterocerke Schwanzflosse von Amia. (Nach Kölliker.) ch verknorpeltes Hinterende der Wirbelsäule mit dem Chordastrang.

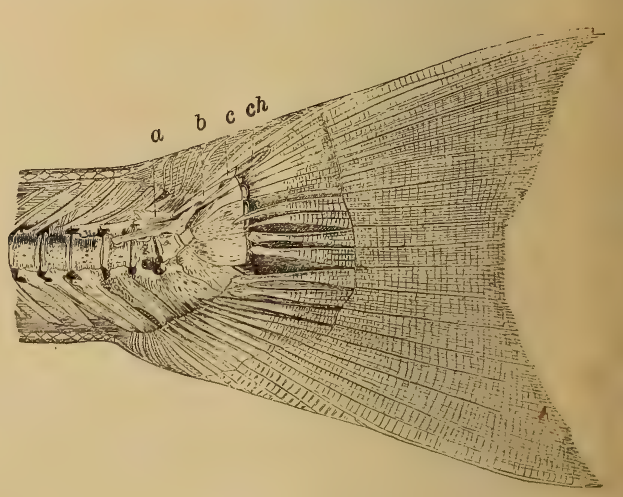

Fig. 22 .

Äußerlich homocerke (stegure) Schwanzflosse vom Lachs (Salmo Salar). (Nach Kölliker.) ch Ende der Chorda (Schwanzfaden),

$a, b, c$ obere Deckknochen des Schwanzfadens.

Bei sämtlichen Cycloid- und Ctenoidfischen ist die Schwanzflosse äußerlich homocerk (Fig. 22). Die Wirbelsäule endigt meist vor der Flosse mit einem Wirbel, an welchen sich eine breite, vertikale, fächerförmige Schlußplatte (Hypurale) anschließt, die aus der Ver- 
schmelzung mehrerer Flossenträger und Hämapophysen entsteht. Über dieser Schlußplatte liegt meist ein kurzer, knorpeliger, aufwärts gerichteter Fortsatz der Chorda oder ein schräg aufwärts gerichtetes, griffelartiges Knochenstück (Urostyl). Den homocerken Schwanzflossen liegt somit eine innerliche Heterocerkie zugrunde.

Sämtliche paläozoischen Fische haben diphycerke oder heterocerke Schwänze, hemiheterocerke Formen beginnen im Jura. Die cretaceischen, tertiären und lebenden Knochenfische haben im ausgewachsenen Zustand homocerke Schwanzflossen, durchlaufen aber in der Jugend ein diphycerkes oder heterocerkes Stadium.

\section{Schädel.}

Das embryonale Primordialcranium der Fische ist knorpelig und entwickelt sich aus der Chorda dorsalis, die eine Strecke weit in die Schädelbasis eindringt.

Bei den Selachiern (Fig. 23) besteht das Kopfskelett dauernd aus einheitlichem Knorpel, der oberflächlich mit Plättchen aus phosphorsaurem Kalk inkrustiert, seltener eine auch in die Tiefe greifende

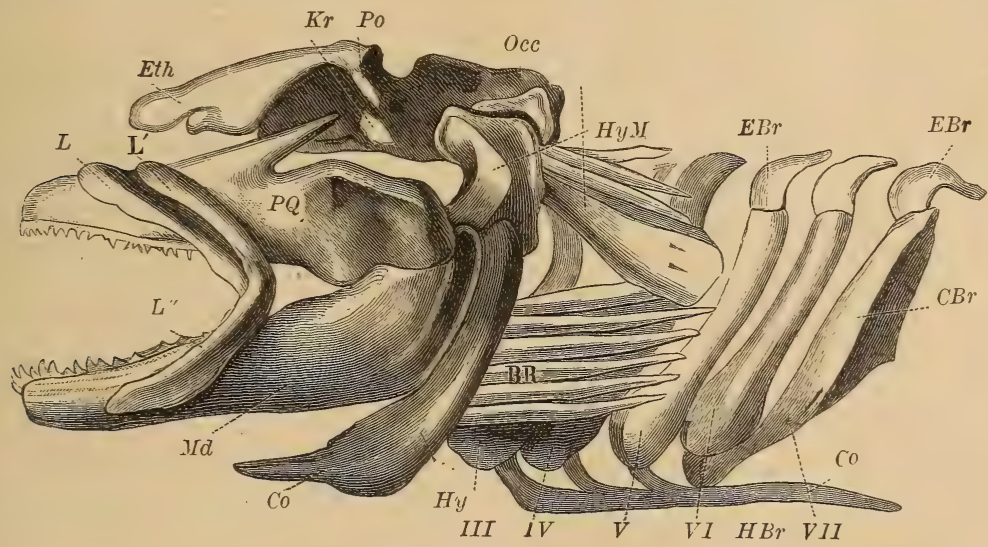

Fig. 23.

Schädel und Kiemenkorb von Squatina vulgaris. (Nach Gegenbaur.) Eth Ethmoidalregion (Rostrum), Po Postorbitalfortsatz, Occ Occipitalregion, $P Q$ Palatoquadratum, $L$ vorderer, $L^{\prime}$ hinterer, $L^{\prime \prime}$ unterer Labialknorpel, IId Unterkiefer (Yandibula), HyM Hyomandibulare, Hy Hyoideum, Co Copula des Zungenbeinbogens, III-VII Kiemenbögen (Branchialia), E Br Epibranchiale, CBr Ceratobranchiale, $H B r$ Hypobranchiale, $C 0^{\prime}$ hinterste Copula der Kiemenbögen, $B R$ Kiemenstrahlen des Hyoideum.

Verkalkung aufweist. Die Schädelkapsel enthält das Zentralnervensystem und zwar hinten die Hemisphären des großen und kleinen Gehirns, in der Mitte die Sehhügel (lobi optici), im vorderen Teil die Riechnerven; mit der Schädelkapsel vereinigen sich sehr früh die in der Anlage selbständigen Gehörorgane, Augen und Nasengruben. Das Visceralskelett besteht aus einer Anzahl verschiedenartig ausgebildeter knorpeliger Bögen, von denen der vorderste, der sog. Mandibularbogen, die Mundhöhle umrandet und sich durch Größe und Bezahnung auszeichnet. Der obere Teil, das Palatoquadratum, ist mit dem unteren, dem Unterkiefer, gelenkig verbunden; bei den meisten Haifischen ist er durch Bänder, die von seinem niedrigen, 
vorderen Fortsatze ausgehen, an den Schädel geheftet. Bei den primitiven Haien (Notidanus, Hybodus) erhebt sich das Palatoquadratum hinten zu einem viel breiteren Fortsatz, der mit dem postorbitalen T'orsprung des Schädels in gelenkartiger Fläche zusammenstößt. Der zweite Visceralbogen oder H y o i d bog en berührt ebenfalls mit seinem oberen Abschnitt, Hyomandibulare, die Gehörregion des Schädels: während sein unterer als Zungenbein, Hyoid, ausgebildet ist. Das Hyomandibulare ist bei Notidanus, Hybodus etc. ein langer, schmaler Knorpel, der sich ganz dem Hinterrand des Palatoquadratum anschmiegt; bei den meisten Haien ist es aber verkürzt und verbreitert und weiter nach hinten geschoben.

Die sog. Lippenknorpel (Fig. 23) werden häufig als präorale Kiemenbögen bezeichnet, oder als die knorpeligen Äquivalente des Maxillare bzw. Prämaxillare (unter Bezug auf Beobachtungen bei Polyodon) oder auch als neue Erwerbungen bezw. Abgliederungen. Ihr Auftreten bei älteren fossilen Formen läßt sich zu Beweisen einstweilen nicht verwerten, es ist immerhin beachtenswert, daß sie zuweilen selbst alten Formen fehlen oder sehr klein sind. Ontogenetisch treten sie später auf als die eigentlichen Visceralbogen.

Hinter den Zungenbeinbogen folgen noch fünf (selten sechs oder sieben) Visceralbögen, welche als Stützen der Respirationsorgane dienen, aus mehreren Stücken zusammengesetzt sind und ventral durch mediane Zwischenknorpel (Copulae) verbunden werden. Sowohl die Kiemenbögen als auch das Hyoideum, bei alten Formen auch das Hyomandibulare, tragen knorpelige Kiemenstrahlen. Bei den Holocephalen verschmelzen Palatoquadratum und Hyomandibulare miteinander und mit der Schädelkapsel. Der Unterkiefer wird dadurch autostyl, d. h. direkt an den Schädel eingelenkt.

Bei den Knorpelganoiden (Accipenser, Spatularia) nehmen bereits knöcherne Elemente an der Zusammensetzung des Kopfes teil. Die Schädelkapsel bleibt zwar der Hauptsache nach knorpelig, aber außen entstehen eine Anzahl Knochenplatten, welche das Cranium oben und auf den Seiten bedecken, und ebenso entwickelt sich an der Schädelbasis ein langer schmaler Hautknochen (Parasphenoid), welcher vorne bis zur Ethmoidalregion, hinten bis zum Hinterhaupt reicht. Auch am Palatoquadratum, Hyomandibulare und Unterkiefer stellen sich Knochenbelege ein, und ebenso ossifiert eine die Kiemenspalten deckende Hautfalte zu einem einfachen Kiemendeckel (Operculum). Palatoquadratum und Hyomandibulare bilden den frei beweglichen (hyostylen) Träger des Unterkiefers.

Ähnlich wie die Knorpelganoiden verhalten sich auch die Dipnoer, bei denen jedoch Palatoquadratum und Hyomandibulare mit dem Cranium verschmolzen sind (Autostylie).

Bei den Schuppenganoiden und Knochenfischen findet eine mehr oder weniger vollständige Ossifikation der Schädelkapsel und des Visceralskelettes statt. Die Verknöcherung beginnt, wie bei den Knorpelganoiden, zuerst mit Hautknochen, welche anfänglich (durch eine Bindegewebsschicht) vom Knorpelcranium getrennt bleiben. Die Bildung derErsatzknochen erfolgt phylogenetisch später und geht vom Perichondrium des Primordialschädels aus. Der Knorpel wird 
durch Knochen ersetzt (Ersatzknochen, zu diesen gehören z. B. immer die unteren und seitlichen Hinterhauptsbeine). Eine klare Scheidung beider Knochenarten ist aber dadurch erschwert, daß die Bildung von Hautknochen oft in größerer Tiefe vor sich geht und selbst den unten liegenden Knorpel ergreifen kann. Es kann auch ein Knochen gemischter Entstehung sein, indem ein Deckknochen mit der gleichfalls verknöchernden Knorpelunterlage verschmilzt. Das gilt $z$. B. öfters für das Supraoccipitale, auch für das Opisthoticum.

Am eigentlichen Cranium (Fig. 24) unterscheidet man drei Regionen (Occipital- und Gehör-Abschnitt, Orbital- und EthmoidalRegion). Die Hinterhaupts- oder Occipital-Region besteht aus vier Knorpelknochen: dem unteren Hinterhauptsbein (Occipitale basilare, Basioccipitale), welches meist noch Reste der Chorda dorsalis enthält und mit seinem tief ausgehöhlten Hinterende die Verbindung mit der Wirbelsäule herstellt, einem rechten und linken seitlichen Hinterhauptsbein (Occipitalia lateralia, Exoccipitalia), welche den größeren Teil des Hinterhauptsloches umgrenzen, oft oben mit dem Supraoccipitale sich vereinigen, und einem oberen Hinterha u p ts b e in (Occipitale superius, Supraoccipitale), das zum Schädeldach gehört, sich zwischen die davor liegenden

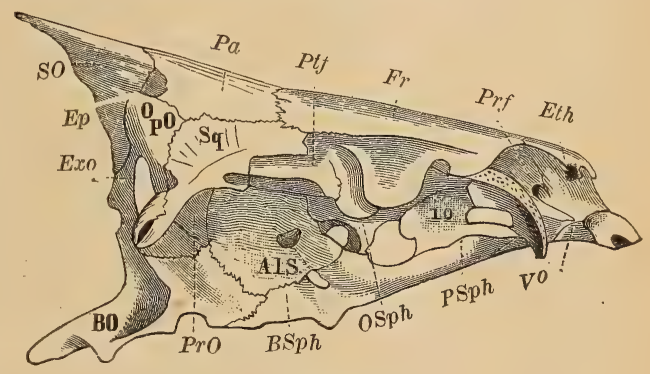

Fig. 24.

Schädelkapsel von Cyprinus carpio Lin. (Karpfen). (Nach R. O w e n.) BO Occipitale basilare, Exo Exoccipitale SO Occipitale superius, $O p O O$ Opisthoticum, $E p$ Epioticum, PrO Prooticum, $S q$ Squamosum, Als Alisphenoid, $B S p h$ Basisphenoid, OSph Orbitosphenoid, $P a$ Parietale, Ptf Postfrontale, Fr Frontale, Prf Präfrontale, Eth Ethmoideum, Vo Vomer, io Interorbitale.

Scheitelbeine einschiebt und häufig mit einer vertikalen Medianleiste oder einem hohen Kamm versehen ist.

Die Gehörkapseln werden seitlich von mehreren, unter den Gesichtsknochen vollkommen versteckten Knochenpaaren umschlossen. Man unterscheidet hier das unmittelbar vor den Occipitalia lateralia gelegene $O$ pisthoticum $\left.\left(O_{p} O\right)^{1}\right)$, das im hinteren oberen Teil an das Opisthoticum angrenzende Epioticum EpO, und das Prooticum $\operatorname{Pr} O$, welches gewöhnlich die uffnung des Nervus trigeminus umschließt. Mit diesen die eigentliche Gehörkapsel bildenden Knochen verbindet sich jederseits eine über und vor dem Opisthoticum gelegene, teils aus Hautknochen, teils aus Knorpel hervorgegangene Knochenplatte, das Squamosum Sq (Pteroticum Park., Schläfenbein), unter der sich der Kieferstiel (Hyomandibulare) einlenkt.

Die seitliche Umgebung der mittleren orbitalen Schädelregion, welche bald knorpelig oder häutig bleibt, bald mehr oder weniger vollständig verknöchert, ist äußerlich vollkommen von den Gesichtsknochen bedeckt. Man unterscheidet hier zwei Knochenpaare: das hintere unmittelbar vor dem Prooticum gelegene Alisphenoid und das vordere Orbitosphenoid; in der Mitte wachsen beide Knochenknochen.

1) Das Opisthoticum, auch Intercalare, ist bei Fischen meist ein Deck- 
paare, namentlich aber die beiden Orbitosphenoide, häufig zusammen und verschmelzen vollständig miteinander. Die Orbitosphenoide können auch ganz in einem häutigen Interorbitalseptum aufgehen. Die Grundfläche des Schädels wird durch einen Hautknochen, das lange, spanförmige Parasphenoid gebildet, welches hinten an das Basioccipitale, vorne an den Vomer anstößt.

Das Dach der beiden hinteren Schädelabschnitte wird wesentlich von Deckknochen gebildet. So schalten sich zwischen das obere Hinterhauptsbein und die beiden Squamosa zwei Parietalia (Scheitelbeine) ein, auf welche nach vorn die zwei Frontalia (Stirnbeine) folgen, die öfters zu einem einfachen großen Hauptstirnbein verschmelzen. Seitlich davon liegt vor dem Squamosum das Postfrontale (Hinterstirnbein, Sphenoticum Parker), das bei den Ganoiden zu den Haut-, bei den Teleostiern zu den Knorpelknochen gehört. Über den Augenhöhlen kommt zuweilen ein kleines Supraorbitale vor.

Die vordere Ethmoidalregion besitzt als Basis das Pflug. scharbein $V_{0}$ (Vomer), das gleichzeitig die vordere Decke des harten Gaumens bildet. Von Vomer steigt schräg nach hinten und oben jederseits ein z. T. knorpelig präformiertes, oben dermal angelegtes Vorderstirnbein (Präfrontale, Ethmoidale laterale Parker) auf, das sich mit dem Stirnbein und mit dem die Nasenkapsel oben, vorn und teilweise seitlich umschließenden Ethmoidale Eth verbindet. Eine oder mehrere kleine Deckknochen über jedem Nasenloch, welche sich zuweilen außen an das Ethmoidale anheften, werden Nasenbeine $\mathrm{Na}$ (Nasalia) genannt; das Ethmoid ist ein Ersatzknochen.

Zum Visceralsk elett gehören der Kieferapparat, die Gesichtsknochen und das Kiemengerüst. Das Hyomandibulare tritt in enge Verbindung mit dem hinteren Teil des Palatoquadratum, d. h. dem Quadratum. Daraus geht der sog. Kieferstiel (Hyomandibulare und Symplecticum und Quadratum) hervor, welcher als Träger des Unterkiefers am Schädel durch Bänder beweglich befestigt ist. Das Quadratum articuliert unten mit dem Unterkiefer und ist nach oben innig mit dem aus dem unteren Ende des Hyomandibulare hervorgegangenen Symplecticum verbunden. An das Quadratbein fügen sich nach vorn das winklig gebogene Ectopterygoid (ein Deckknochen), nach oben das Metapterygoid, nach vorne das Mesopterygoid an, dessen vorderes Ende sich mit dem Palatinum (Gaumenbein) verbindet. Letzteres ist mit seinem Vorderrand durch Knorpelbänder am Vomer und der Ethmoidalregion angeheftet, es ist ein Mischknochen, in dem ein Deckknochen und ein Ersatzknochen ver. einigt sind.

Vor dem Gaumenbein liegen jederseits zwei ziemlich große, meist mit Zähnen besetzte Deckknochenpaare; das vordere derselben, die Prämaxilla (Zwischenkiefer), stößt vor der Ethmoidalregion durch eine Symphyse mit dem korrespondierenden Knochen der anderen Seite zusammen; das hintere, die Maxilla (Oberkiefer), tritt zuweilen durch ein schmales, eingeschaltetes Jugale (Jochbein) mit dem Quadratum in Verbindung.

Jer Unterkiefer (Mandibula) besteht aus dem Gelenkstück ( $\Lambda$ rticulare, einem Ersatzknochen), einem hinteren unteren Eck- 
stück Angulare, das öfters knorpelig bleibt und dem großen, mit Zähnen besetzten Hauptstück Dentale, welches als Deckknochen den Meckelschen Knochen umhüllt. Auf der Innenseite kommt hierzu noch ein Belegknochen, das Operculare oder Spleniale, das nicht selten Zähne trägt und zuweilen (namentlich bei den Crossopterygiern) durch zwei oder mehr Knochenstücke ersetzt ist.

Eine ungewöhnlich starke Entwicklung erlangen sowohl bei Ganoiden als Teleostiern mehrere aus einer Hautfalte hervorgehende Opercularknochen. Der vorderste, das Präoperculum, ist meist eine ziemlich lange, schmale, etwas gebogene Knochenplatte, welche sich oben an das Hyomandibulare, unten an das Quadratum anheftet; dahinter liegt oben ein $\mathrm{Operculum}$ von meist ansehnlicher Grölße, ferner ein Suboperculum und als unterstes Stück ein öfters mit dem Unterkiefer zusammenhängendes Interoperculum.

Eine wechselnde Anzahl kleiner Hautknochen begrenzen als Suborbitalia bogenförmig den hinteren und unteren Rand der Augenhöhle. Das über derselben gelegene Supraorbitale $(S O r)$, sowie das Lacrimale $L$ (Tränenbein) sind kleine Hautknochen, welche in enger Verbindung mit dem Cranium stehen, aber nur selten entwickelt sind. Das schon erwähnte Präfrontale ist ein Mischknochen.

Das Kiemengerüst (Fig. 25) der Ganoiden und Teleostier unterscheidet sich nicht unerheblich von jenem der Selachier. Abgesehen davon, daß die bei letzteren dem Hyomandibulare anhaftenden Kiemenhautstrahlen hier zu Opercula r platten umgewandelt sind, und daß hinter dem Hyoideum nie mehr als fünf (selten vier) knöcherne Bögen auftreten, sind die Kiemenhautstrahlen des Zungenbo-

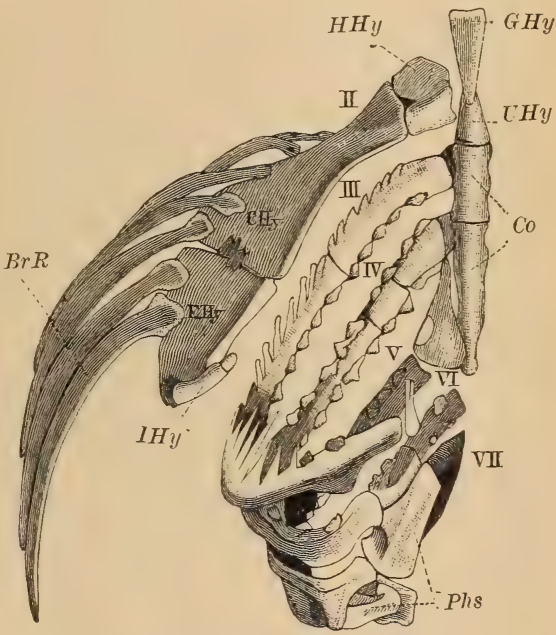

Fig. 25.

Rechte Hälfte des Zungenbeins und der Kiemenbögen rom Barsch (Perca fluviatilis). (Nach Cu vi e r.) II Zungenbeinbogen, $I I I-V I$ Kiemenbögen, IHy Interhyale, EHy Epihyale, $H H y$ Hypohyale, $G H y$ Glossohyale (Zungenbein), UHy Urohyale. Co Copulae d. Kiemenbögen, Phs obere Schlundknochen, $B r R$ Kiemenhautstrahlen. ge ns als kräftige Knochenstücke oder Blätter ausgebildet. Das Hyo ideum zerfällt in ein oberes Epihyale, ein mittleres Ceratohyale und ein kleines aus zwei Stücken bestehendes Hypohyale (Basihyale); das mediane Verbindungsstück (Copula) verlängert sich mehr oder weniger weit nach vorn als Glossohyale (Zungenbein) in die Zunge und ist bald mit Zähnen bedeckt, bald zahnlos; ein zweites nach hinten gerichtetes, zur Copula gehöriges Knochenstück heißt Urohyale. Die Kiemenbögen (Branchialia) sind gleichfalls aus je drei Stücken (Epi-, Cerato- und Hypo-Branchiale) zusammengesetzt, durch Copulae in der Mitte verbunden und ihrer ganzen Länge nach mit feinen knorpeligen Strahlen, auf der Innenseite zuweilen mit zahnähnlichen Höckern oder Stacheln besetzt. An die Epibranchialia schließen sich noch kurze, häufig Zähne tragende obere Schlund- 
knochen an. Von dem Epibranchiale des 1. Bogens aus bildet sich bei den Labyrinthfischen die knöcherne Unterlage des akzessorischen Respirationsorgans. Der letzte (5.) Kiemenbogen ist meist mehr oder weniger modifiziert und bildet die unteren Schlundknochen.

Die parigen Flossen entsprechen den Extremitäten der höheren Wirbeltiere und zwar die Brustflossen den vorderen, die Bauchflossen den hinteren.

Sowohl die Brust- als auch die Bauchflossen heften sich an ursprünglich knorpelige Bogen (Schulter- und Beckengürtel) an, die durch Ossifikation in eine verschiedene Anzahl einzelner Knochenstücke zerfallen können. Mit Ausnahme der Selachier befestigt sich der Schultergürtel am oberen Hinterhauptsbein oder am Squamosum. Er bildet bei den Selachiern (Fig. 28 A) einen ventral geschlossenen einfachen, selten, bei paläozoischen Formen, mehrteiligen, hinter den Kiemen gelegenen Knorpelbogen, dessen dorsale Enden entweder frei endigen oder sich an die Wirbelsäule anheften (Rochen); an der Insertionsstelle der Flosse ist er aufgetrieben und von Nervenlöchern durchbohrt. Bei manchen Ganoiden (Chondrostei, Crossopterygii, Heterocerci) lagern sich dem primären knorpeligen, aus zwei auch ventral gesonderten Hälften bestehenden Schultergürtel jederseits drei Deckknochen an, wovon der mittlere größte von Gegenbaur als Cleithrum, der untere als Claviculare, der obere als Supraclavicula bezeichnet werden. Letztere zerfällt zuweilen in zwei Stücke, wovon das obere Posttemporale genannt wird. Bei den übrigen Ganoiden und den Knochenfischen wird der primäre Schultergürtel sehr verkleinert. $Z_{\text {wei, durch }}$ Zackennähte an der inneren und hinteren Seite der sehr großen Clavicula befestigte Knochen, wovon der hintere der Scapula (Schulterblatt), der vordere mehr nach innen gelagerte dem Coracoid

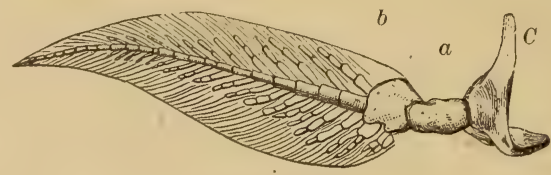

Fig. 26.

Brustflosse von Ceratodus Forsteri. Queensland.

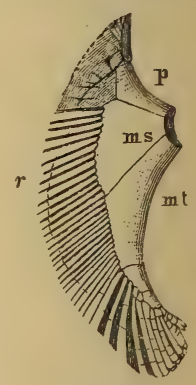

Fig. 27. Brustflosse von Squatina (ohne die áußeren Hornfäden). $p$ Propterygium, ms Mesopterygium, $m t$ Meta pterygium pterygium,
r Radien.

entspricht, bilden hier den Brustgürtel. Bei mehreren Familien (Phy s o stomen) kommt hierzu noch ein drittes, schmales, brückenförmig gegen die Clavicula sich wölbendes Spangenstück.

Der Hauptknochen des Schultergürtels der Teleostier ist immer die Clavicula, deren Größe und Form außerordentlich variiert.

Er ist nach Bütschli aus der Vereinigung von Clavicula und Cleithrum hervorgegangen, nach Gegenbaur entspricht er nur dem Cleithrum, während die Clavicula zurückgebildet ist.

Nach oben schließen sich als Belegknochen eine Supraclavicula und ein Posttemporale $(P t)$ an, hinten lagert sich ein meist schmaler akzessorischer Hautknochen, die Postclavicula an. 
Die Brustflossen selbst lassen sich im einzelnen schwer mit dem Bau der vorderen Extremitäten der höheren Vertebraten vergleichen. Nimmt man mit Gegenbaur die biseriale Flosse des Ceratodus als die der Urflosse (Archipterygium) am nächsten stehende Grundform an, so sieht man auf den größtenteils knorpeligen Brustgürtel zwei größere Knorpelstücke folgen, an welche sich dann eine lange Kette kleinerer zylindrischer oder quadratischer Glieder anreiht, von denen nach beiden Seiten Knorpelstrahlen ausgehen. Eine zentrale Achse der Brustflosse besaß auch die erloschene SelachierGattung Pleuracanthus, dagegen sind die Knorpelstrahlen bei allen übrigen Selachiern vorwiegend einreihig angeordnet. Hier verbinden sich drei größere, nebeneinander gelegene Knorpel, das $\operatorname{Pro-}$, Mesound Metapterygium, mit dem Brustgürtel und an jedes derselben fügen sich mehrere aus Knorpelstücken zusammengesetzte Radien an (Fig. 27). Am stärksten ist immer das Metapterygium ausgebildet, die beiden anderen sind häufig stark reduziert oder können sogar vollständig fehlen. Die häutige Flosse selbst ist von zahlreichen, stets paarig auftretenden Hornfäden durchzogen.

Bei den Ganoiden und noch mehr bei den Teleostiern findet eine ziemlich weitgehende Rückbildung der von den Basalstücken ausstrahlenden Radienglieder statt. Polypterus besitzt noch drei $\mathrm{Ba}$ -

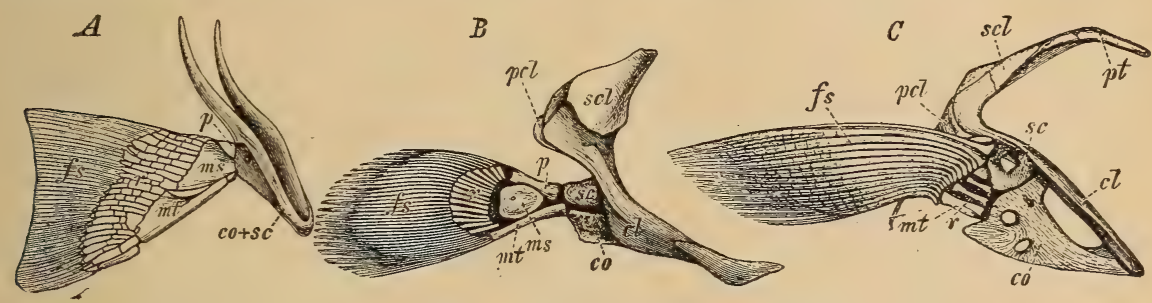

Fig. 28

Schultergürtel und Brustflosse von A Heptanchus (Selachier), B Polypterus (Ganoid), C Salmo (Teleostier). $c l$ Clavicula, co Coracoid, sc Scapula, pcl Postclavicula, scl Supraclavicula, $p t$ Posttemporale, $p$ Propterygium, $m s$ Mesopterygium, $m t$ Metapterygium, $r$ Radien der Flossenstrahlen, $f_{\varepsilon}$ äußere Flossenstrahlen.

salstücke (Figur $28 \mathrm{~B}$ ), bei den meisten übrigen Ganoiden dagegen bildet das Metapterygium fast allein die Stütze für die Flosse; Mesound Propterygium verkümmern. Dafür treten aber zwei bis drei Radien in gleiche Reihe mit den Basalstücken und verbinden sich mit dem Brustgürtel.

In gleicher Weise besteht die Basis der Brustflosse bei den Teleostiern stets aus vier bis fünf gleichartigen, abgeplatteten Knochenstücken, denen eine wechselnde Anzahl kurzer Knorpelstückchen angefügt ist. In gleichem Maße als die peripheren Teile des primären Flossenskeletts zurückgehen, entwickeln sich auf beiden Flächen der häutigen Flosse ossifizierte Flossenstrahlen als sekundäre Bildungen.

Wesentlich einfacher als der Brustgürtel ist der sog. Beckengürtel der hinteren Extremität zusammengesetzt. Er erscheint bei den Selachiern als eine paarige oder unpaare, von Nervenlöchern durchbohrte Spange, die entweder quer zur Längsachse des Körpers liegt oder einen nach vorn konvexen oder konkaven Bogen bildet. An diesen Gürtel lenken sich die zwei Basalstücke (Pro- und Meta- 
pterygium) der Bauchflosse ein, die ihrerseits wieder eine Reihe uniserialer knorpeliger Radien aussenden. Unter den Ganoiden haben sich nur noch bei Polypterus zwei kleine Knorpelstücke als Überreste eines Beckengürtels erhalten; bei allen übrigen, sowie bei den Teleostiern fehlt der Beckengürtel vollständig, dagegen erlangt das Metapterygium jederseits eine ansehnliche Größe und bildet bald als einfacher, länglicher Knochen, bald als eine in zwei Stücke vergabelte Platte den ganzen Flossenträger. Bei den Ganoiden sind die zum Flossenskelett gehörigen Radien zuweilen knöchern, bei den Teleostiern dagegen meist knorpelig, stark verkümmert, zuweilen sogar gänzlich geschwunden. Die Hautflosse selbst enthält zahlreiche gegliederte Knochenstrahlen. Eine eigentümliche Entwicklung zeigt der Beckengürtel bei den Dipnoern. Er stellt eine unpaare, vierseitige, vorn in einen langen Fortsatz auslaufende Knorpelplatte dar, an welche sich die knorpelige Achse der biserialen Flosse anheftet.

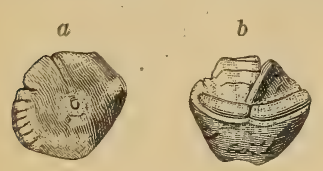

Fig. 29

Giehörknöchelchen (Otolith) eines Knochenfisches. Oligocän. Lattdorf. Nat. Gr.

$a$ von außen, $b$ von innen.

Während die Bauchflossen bei Selachiern, Ganoiden und Dipnoern stets am Bauchende stehen, rücken sie bei den Teleostiern häufig weit nach vorn und treten sogar mit dem Schultergürtel in Verbindung. Durch diese Vorwärtswanderung der Bauchflossen ergeben sich auffällige Modifikationen in der Gesamterscheinung der Knochenfische, die in der Systematik weitgehende Verwertung finden.

Neben den festen Hautgebilden und Skelettresten finden sich in gewissen Ablagerungeri oft reichlich fossile Otolith en ${ }^{1}$ ) (Gehörsteine) (Fig. 29); es sind Ausscheidungen von kohlensaurem Kalk innerhalb des Labyrinths, die bei höheren Fischen, besonders im sog. Sacculus, im Utriculus und in der Lagena des Labyrinths fest umschriebene, charakteristische Gestalt annehmen. Der Otolith des S a cculus heißt Sagitta, der in der Lagena Asteriscus, nach der Form, die sie bei Cypriniden haben. Bei diesen ist die Lagena auffallend verlängert und nebst dem Sacculus in die Schädelbasis eingesenkt; bei Panzerwelsen enthält der Utriculus den weitaus größten Otolithen, der besonders bei Arius massig ist und sich häufig findet. Bei allen anderen Teleostiern sind diese Otolithen klein, und der umfangreiche Sacculus enthält den größten Otolithen. Die der Labyrinthwand zugekehrte, dieser anliegende Seite weist einen sehr verschieden geformten Eindruck auf, den Sulcus acusticus; er ist nach den Umrissen der Macula acustica geformt, jener Stelle der Labyrinthwand, in der die letzten Ausstrahlungen des Gehörnervenastes sich vollziehen, und das wichtigste und beständigste Merkmal am Otolithen. Durch die Arbeiten von Koken, Schubert, Priem u. a. ist aus dem Studium der Otolithen besonders für die Statistik der Teleostier wertvolles Material gewonnen. Die weite Verbreitung und das hohe Alter

$\left.{ }^{1}\right)$ Bassoli G. G., Otoliti fossili terziarii dell'Emilia. Riv. Italiana di Palaeontologia, 1906. - Koken E, Uber Fisch-Otolithen etc. (Zeitschr. d. geol. Ges. 1884). Neue Untersuchungen an tertiären Fischotolithen (ebenda 1889, 1891). - Priem $F$., Sur les otolithes des poissons éocènes du bassin Parisien (Bull. soc. géol. France. 1906). - Schubert R. J., Die Fischotolithen des österr.-ungar. Tertiärs. (Jahrb. geol. Reichsanst. 1903, 1905, 1906.) 
der fossilen Gadiden, Sciaeniden u. a. ließ sich erst aus der Bestimmung der tertiären Otolithen erweisen. Auch über die Fische großer Meerestiefen (Macruriden etc.), von denen sich die Otolithen oft allein erhalten, sind Anhaltspunkte gewonnen.

Die Systematik der Fische hat sich seit Aristoteles vorzüglich auf Merkmale des inneren und äußeren Skelettes, auf die Beschaffenheit und Stellung der Flossen und auf die Respirationsorgane gestützt. Schon Artedi, Bonaparte, Lacépède, Cuvier und $\mathrm{V}$ alenciennes stellten die Knorpelfische den mit knöchernem Skelett versehenen Formen gegenüber und zerlegten beide Abteilungen wieder in verschiedener Weise in mehrere Gruppen. Auf die fossilen Fische wurde hierbei keine Rücksicht genommen, obwohl namentlich Haifischzähne, Zähne von verschiedenen Knochenfischen (Bufoniten, Cheloniten, Krötensteine, Schlangenaugen), sowie ganze Skelette aus verschiedenen Lokalitäten (Kupferschiefer von Eisleben, Solnhofen, Oeningen, Monte Bolca, Glarus) schon im 18. Jahrhundert bekannt und mehrfach beschrieben waren. Das epochemachende Werk von L. Ag assiz lieferte (1833-1834) eine vollständige Übersicht aller bis dahin bekannten fossilen Fische und suchte zugleich eine neue auf das Hautskelett begründete Einteilung der Fische in 4 Hauptgruppen: Placoidei, Ganoidei, Cycloidei und Ctenoidei einzuführen. Jo h. Müller vereinigte die zwei letzten Gruppen unter der Bezeichnung Teleostei (Knochenfische), begrenzte die Ganoiden schärfer und zerlegte die Knorpelfische in 4 Unterklassen: Leptocardii, Cyclostomi, Selachii und Dipnoi. Die neueren, wichtigeren Veränderungen in der Systematik knüpfen besonders an die Arbeiten von Cope, Jordan, Gill, Traquair, A. Smith Woodward u. a. an.

Die bisher unter der Bezeichnung Fische zusammengefaßten Formen wurden auf $3 \mathrm{Klassen}$ verteilt, die weit geschieden sind: Leptocardii, Marsipobranchii, Pisces.

Eine kurze, nur auf die allgemeinen Eigenschaften beschränkte Diagnose führt zu der Gruppierung:

I. Kein Schädel. Chorda bis zum Beginn des Kopfes reichend. Gehirn nicht deutlich differenziert. Ohne zentrales, muskulöses Herz; mehrere kontraktile Strecken der Gefäßwände ersetzen das Herz.

\section{Leptocardii.}

II. Schädel mehr oder weniger entwickelt. Chorda nicht über die Hypophysenregion hinausreichend. Herz musculös entwickelt (mindestens eine Kammer und eine Vorkammer), Gehirn deutlich entwickelt.

A. Schädel unvollkommen, kein Unterkiefer. Kein Becken, kein Schultergürtel, keine paarigen Extremitäten. Kiemen beutelförmig.

\section{Marsipobranchii.}

B. Schädel gut entwickelt, mit Unterkiefer. Schulter- und Beckengürtel vorhanden. Paarige Extremitäten vorhanden (bzw.

1) Vgl. Gill, Arrangement of the families of fishes. Smithson-Miscell. Coll. 247. 1872. S. IX. 
wieder atrophiert). Schultergürtel beider Seiten ventral vereinigt. Kiemen nicht beutelförmig.

\section{Pisces.}

Man muß aber über die hier vorgenommene Trennung noch hinausgreifen und die Leptocardier nicht nur als eine den Fischen gleichwerte Klasse hinstellen, sondern als eine Klasse, welche allen anderen Wirbeltieren isoliert gegenübersteht und zu der weder ontogenetisch noch pạläontologisch eine Brücke hinüberführt.

Prinzipielle Fragen knüpfen sich auch an die Stellung der Marsipobranchier. Es ist nicht allein der Mangel des Unterkiefers und der Extremitäten, der sie so weit von anderen Vertebraten scheidet, sondern die fundamental abweichende Bildung des Knorpelschädels und des Kiemenskeletts. Sie stehen jedenfalls den eigentlichen Fischen als Klasse selbständig gegenüber und eine Zusammenordnung mit paläozoischen Fischen ist damit, daß diese keine paarigen Extremitäten haben und den Unterkiefer vermissen lassen, noch nicht gerechtfertigt.

Nach Ausscheidung auch der Marsipobranchier (Cycliae), die fossil nicht sicher ${ }^{1}$ ) bekannt sind, lassen sich dann die Fische in folgender Weise teilen:

1) Fossile Cyclostomen. Als Palaeospondylus Gunni sind von Traquair Reste aus den Ubergangsschichten zwischen Silur und Devon (Passage beds) bekannt gegeben. Vgl. W. J. Sollas und J. B. J. Sollas: An account of the devonian fish Palaeosp. Gunni. Philos. Trans. Roy. Soc. London. Series B. Vol. 196. 1903. Die Rekonstruktion, die allein in die Lehrbücher übergegangen ist, erweckt aber

A

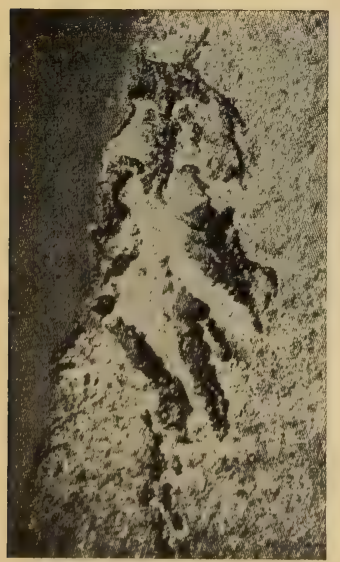

$B$

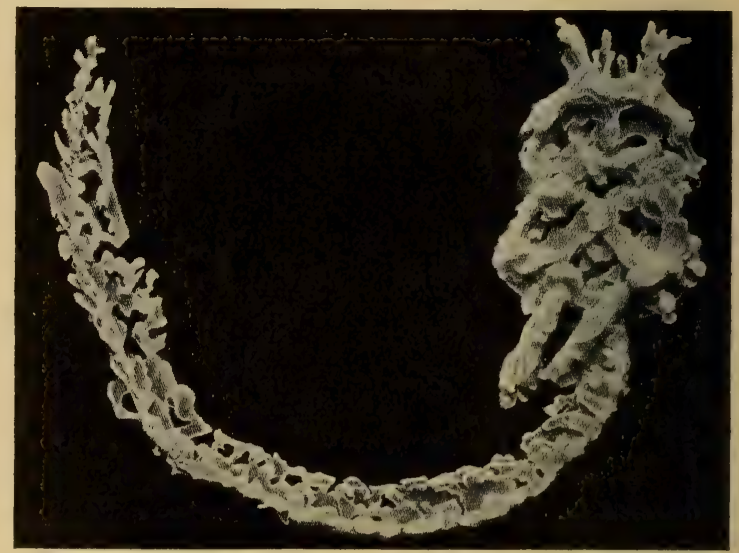

Fig. 30. Palaeospondylus Gunni Traquair.

A Abbildung eines Vorkommenstücks. Unterer Old Red Sandstone, Caithness. $5: 1$. $B$ Wachsmodell. $10: 1$. (Nach Sollas.)

eine falscho Vorstellung von dem wirklichen Erhaltungszustand, den Fig. 30 zum Ausdruck bringt; es sei auf die objektive Diskussion durch Sollas verwiesen. Die gefundenen Reste bestehen aus einer Art Kohle; fast dieselbe Zusammensetzung haben im gleichen Lager gefundenen Coccosteus.Reste. Der Schluß, daß auch das Skelett von Palaeospondylus ursprïnglich Knochen war, ist aber deswegen noch nicht berechtigt. Die Frage, wohin diese Reste zu stellen sind, ist nicht beantwortet. 
I. Unterklasse: Placodermi (Agnatha). Ohne paarige Extremitäten. Ohne Unterkiefer. Mit Hautzähnchen, welche durch Verbindung mit einer sklerosierten Unterlage oft $\mathrm{zu}$ Platten vereinigt sind.

1. Ordnung: Anaspida. Spindelförmig, heterocerk. Hautzähnchen am Kopf isoliert, am Rumpf zu Schuppen vereinigt.

2. Ordnung: Heterostraci. Flach, mit breiter Kopfregion und schlankem Schwanz; ohne Knochenzellen. Heterocerk.

Unterordnungen oder Familien: Coelolepidae, Pteraspidae, Psammosteidae.

3. Ordnung: Osteostraci. Kopfregion mit großen Platten. Die untere Lage der Platten mit Knochenzellen. Augen genähert.

4. Ordnung: Antiarchi. Kopf und vorderer Rumpf mit Platten bedeckt, welche Knochenzellen enthalten.

II. Unterklasse: Elasmobranchii.

III. Unterklasse: Holocephali.

IV. Unterklasse: Dipnoi.

V. Unterklasse: Arthrodira.

VI. Unterklasse: Teleostomi.

Diesen letztgenannten 5́ Abteilungen kommt sämtlich der Besitz von paarigen Extremitäten und Unterkiefer zu. Man könnte sie also als Gnathostomata oder Eupterygia zusammenfassen. Die Elasmobranchier und Holocephalen sind durch knorpliges Innenskelett, Entwicklung von Placoidschuppen, Mangel dermaler Knochen, Besitz von Pterygopodien miteinander verwandt, Holocephalen und Dipnoer durch die autostyle Angliederung des Kieferbogens, das Gebiß und einige andere Eigenschaften. Die Dipnoer treten aber auch in Beziehung zu den Teleostomen, wie durch einen Vergleich der älteren Dipnoer und Crossopterygier erhellt, und sind anderseits auch den Arthrodira (Coccosteus u. a.) näher verwandt. Dagegen ist die Verwandtschaft der Arthrodira mit den Placodermen (Antiarchi) nicht so nah, wie früher angenommen.

Die Anaspida, Heterostraci, Osteostraci, Antiarchi haben weder paarige Extremitäten noch Extremitätengürtel (die vorderen Anhänge der Antiarchi sind den Extremitäten anderer Wirbeltiere nicht homolog). Über den Schädel (d. h. dessen knorpelige Grundlage) der Anaspida und der Coelolepiden ist nichts bekannt; bei den Heterostraci sehen wir die in der Haut durch Konkreszenz der Hautkörner entwickelten Platten, aber nichts vom Schädel. Die Bezeichnung Agnatha für Placodermi kann nur aussagen, daß in normaler Form entwickelte, am Schädel articulierende Unterkiefer nicht beobachtet sind; morphologische Äquivalente der Unterkiefer können trotzdem vorhanden gewesen sein. Bei Pterichthys sind die zwei vor den Semilunarplatten des Ventralschildes gelegenen Stücke schon auf den knöchernen Belag eines Unterkieferknorpels beziehbar. Bei Tremataspis ist die entsprechende Region von zahlreichen Platten bedeckt, bei Drepanaspis ist weitgehende Konkreszenz in der mittleren Lage eingetreten. 
A uf die Ausdehnung und Einschränkung dieser Haut. gebilde hat die Beweglichkeit der Region unmittelbaren und formativen Einflu B. Wir sind noch nicht in der Lage, hier die progressiven Reihen von den regressiven zu sondern. Bringt man Coccosters (und Verwandte) in enge Beziehung zu den Antiarchi, wie dies wieder versucht wird (J a e kel), so ist, da Coccosteus isolierte, gelenkig dem Schädel angehängte, bezahnte Unterkiefer hat, die Stellung der Agnatha abseits des Weges und ihre Kieferlosigkeit ein regressives Merkmal. Ist der Vergleich des Palatoquadratum-Mandibular-Bogens mit Kiemenbogen berechtigt, so ist schon hieraus gegeben, daß Agnathie (Mangel eines Unterkiefers) entweder nur auf den Mangel von erkennbaren Deckknochen bezogen werden kann, was einen Rückschluß auf die nicht fossilisierbare knorplige Unterlage nicht zuläßt, oder ein unbedingt regressives Merkmal ist.

\section{Unterklasse: Placodermi.}

Die Haut ist mit kleinen Schuppen versehen, welche bei den meisten Gruppen sich mit grofien basalen, oft blättrig gebauten Platten zu umfangreichen Hautgebilden vereinigen. Ohne paarige Extremitäten. Ohne Unterkiefer.

Die Placodermen umfassen auffallend gestaltete Fische des Silurs und Devons, die zum ersten Male von Agassiz zusammengefaßt und in der Nähe der Ganoiden eingereiht wurden. Der Umfang der Abteilung ist dadurch verringert, daß die an Coccosteus sich anschließenden Formen abgetrennt und als Arthrodira neben die Dipnoer gestellt sind, nach anderer Richtung hin aber durch die Einfügung der besonders von Traquair untersuchten Anaspida und Coelolepidae erweitert. Die ursprünglich auf die starr gepanzerten Formen angewendete Bezeichnung Placodermen trägt zwar dem Aussehen eines Thelodus etc. nicht Rechnung, aber dasselbe läßt sich auch gegen die Benennung Ostracodermi anführen, die sich auch nur auf eigentliche Panzerfische bezog. Sie wurde von Cope und A. Sm. W o odward eingeführt, als die Coccosteiden zu den Dipnoern gestellt und damit den Placodermen eine ihrer bekanntesten Abteilungen genommen wurde. Es empfiehlt sich, die eingebürgerte Bezeichnung Placodermen auch nach den notwendigen Veränderungen am Umfang der Gruppe nicht fallen zu lassen, denn nach wie vor umschließen sie den Kern der alten Agassizschen Abteilung: die Heterostraci (Pteraspis und Verw.), Osteostraci (Cephalaspis und Verw.) und Antiarchi (Pterichthys und Verw.), zu denen noch Traquairs Anaspida kommen.

Die Stellung der Placodermen ${ }^{1}$ ) bei den Fischen scheint trotz der neueren Arbeiten Pattens, der sie als Peltocephalata mit Arthro-

1) Jaekel O., Uber Tremataspis und Pattens Ableitung der Wirbeltiere. (Zeitschr. geol. Ges. 1903. Protoc. S $84 \mathrm{ff}$. - Über die Organisation und systematische Stellung der Asterolepiden. (Protok. Zeitschr. geol. Ges. 1903). - Uber Tremataspis und P'attens Ableitung der Wirbeltiere von Arthropoden. (Protok. Zeitschr. Geol. Ges. 1903). - Neue Wirbeltierfunde a. d. Devon von Wildungen. (Sitz.-Ber. Ges. naturf. Freunde, Berlin. 1906). - Patten William, On the structure and classification of the Tremataspidae. (Mém. Acad. Impér. d. Sci. St.-Pétershourg. Xlll. Bil, Ni. 5. 1901. 
poden in Beziehung bringt, gesichert. Die Frage, ob die Coccosteiden (Arthrodira) scharf von den Antiarchi getrennt werden dürfen, ist wieder zur Diskussion gestellt, besonders durch Hinweise von J a ekel, dessen ausführliche Untersuchungen noch nicht veröffentlicht sind.

Die Placodermen umfassen die merkwürdigsten und zugleich ältesten Formen unter den Fischen. Sie treten schon im Silur auf. Der Mangel an paarigen Flossen ist noch wichtiger als die Agnathie, denn das Fehlen harter Unterkiefer beweist nicht den Mangel knorpelig angelegter Mandibularbögen. Wenn aus dem Alter dieser Formen gefolgert wird, daß die ältesten Fische noch keine paarigen Flossen besaßen, der Erwerb solcher sich demnach erst in der Weiterentwickelung der Fische vollzog, so muß beachtet werden, daß auch die Selachier bis zum Silur zurückreichen (Onchus) und demnach die Ausbildung der Extremitäten bei Fischen älter sein muß als die bisher gefundenen Placodermen.

\section{Ordnung. Anaspida. Traquair. $\left.{ }^{1}\right)$}

Spindelförmige Fische ohne Kiefer, Zähne, Extre. mitäten und Extremitätengürtel. Innenskelett ohne Ossifikationen. Schuppen der Haut homogen oder etwas faserig (ohne Dentin oder Knochenzellen), jedoch läßt der Erhaltungszustand keine sichere Entscheidung zu.

Familie: Birkeniidae. Traquair.

Klein, spindelförmig, mit tief ausgeschnittenem, heterocerkem Schwanz. Dorsalis weit hinten. Ohne Augen.

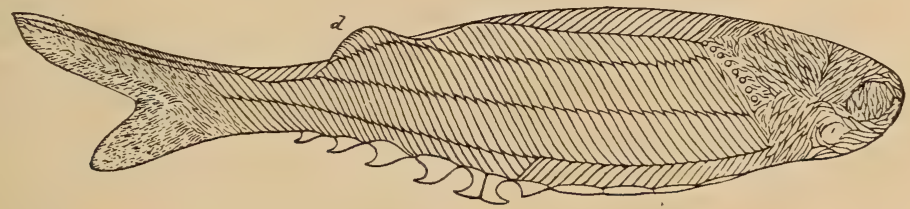

Fig. 31 .

Birkenia elegans Traq. Nat. Gr. Rekonstruktion von Traquair.

Birkenia Traqu. Schuppen des Rumpfes schmal und hoch, in mehreren Längsreihen und so angeordnet, daß die Vertikalreihen schräg von oben nach unten vorn ziehen. Der vorn breit gerundete Kopf mit kleineren Schuppen, die sich in mehrere Komplexe ordnen. Am Hinterrande des Kopfes 8 kleine, runde Löcher (? Kiemenlöcher). Bauch mit größeren Stachelschuppen. B. elegans Tr. Obersilur (Ludlow, häufig im Downtonian von Lanarkshire).

1) R. H. Traquair, Report on fossil Fishes collected by the Geol. Survey of Scotland in the Silurian Rocks of the South of Scotland (Trans. Roy. Soc. Edinburgh. XXXIX. Part III. No. 32. 1899) und Ders., Supplementary Report. ibid. Nr. 33. 1900. 
Lasanius Traqu. Lang spindelförmig. Bauch mit einer medianen Reihe großer Stachelschuppen besetzt, sonst keine Schuppen. Hinter dem Kopf 8 längliche, nach vorn und unten gerichtete Knochenstäbe, die oben scharf geknickt sind (? Kiemenkorb). L. armatus Traqu. Obersilur (Downtonian) von Lanarkshire.

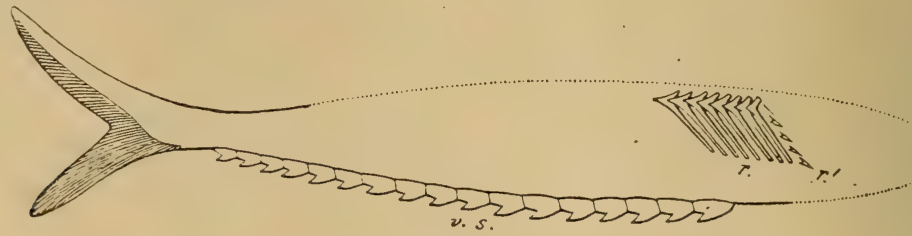

Fig. 32.

Lasanius problematicus Traquair. Rekonstruierter Umriß nach Traquair. Eingetragen sind auch die hinter dem Kopf liegenden Knochenstäbe.

\section{Ordnung. Heterostraci.}

Fische mit breitem, deprimiertem Vorderkörper und schlankem, verschmälerten Schwanz, der in eine heterocerke, öfter tief ausgeschnittene Flosse ausläuft. Augen weit voneinander getrennt an den Seiten des Kopfes. Mundspalte meist auf der Unterseite. Kiemenöffnungen unbekannt. Haut mit harten, dentinösen Schüppchen oder mit größeren Schuppen und Platten, die aus der Vereinigung der kleinen Hautschüppchen auf basalen

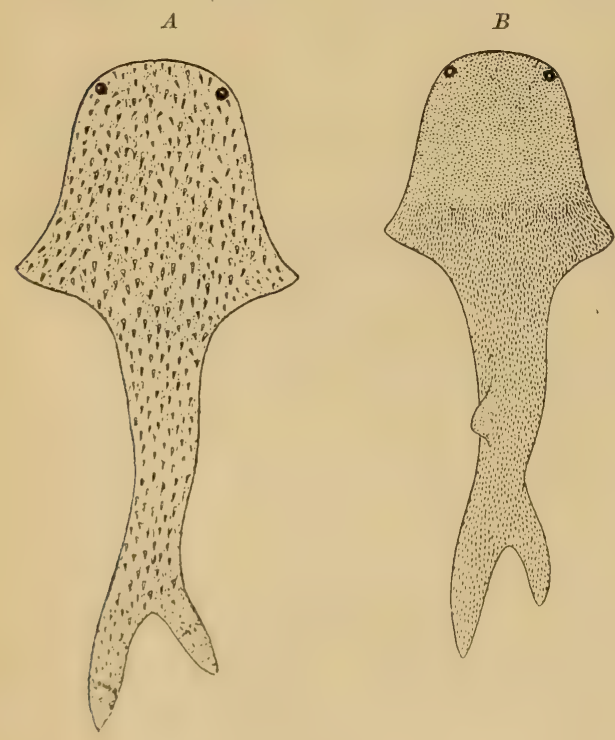

Fig. 33.

A Lanarkia spinosa Traçuair. IS Thelodus scoticus Tragurair. lieide rekonstruiert von Traquair.
Platten entstehen. Keine $\mathrm{Knochenkörperchen} \mathrm{in}$ den Platten.

Dieschärfer umschriebene, auf die Pteraspiden allein gegründete Diagnose der Heterostraci mußte nach der Entdeckung von Thelodus und Drepanaspis beträchtlich erweitert werden. Es ist aber ersichtlich, daß die drei Familien: Coelolepidae, Drepanaspidae und Pteraspidae in engerem Zusammenhange stehen. Obersilur, Devon.

Familie: Coelolepidae. Pander. ${ }^{1}$ )

Gestalt rochenartig, mit breitem, rundem Vorderteil und schmalem Körper. Der vordere Teil von flossenartigen Lappen begleitet, die nach hinten weiter heraustreten. Schwanz tief ausgeschnitten, heterocerk. Augen(?)

2) R. H. Traquair. On Thelodus Pagei Powrie sp. from the Old Red Sandstone of Forfarshire. (Trans. Roy. Soc. Edinburgh. Vol. XXXIX. Part III. Nr. 21. 1899.) 
Klein, weit voneinander getrennt. Haut mit zahlreichen kleinen Chagrinschuppen, aus Dentin mit Ganoinbelag.

Thelodus Ag., (Turinia Traquair, Coelolepis, Thelolepis, Pachylepis, Nostolepis Pander). Schuppen mit Basis und einer durch eine Einschnürung abgetrennten Krone, rund, oval oder vierseitig, zuweilen nach hinten spitzig. Unterseite meistmit einer Höhlung, die in die Pulpa führt. Kleine Dorsalis. Bei Thelodus Pagei zeichnen sich auf der dorsalen Fläche des Stückes jederseits einer medianen Einsenkung 8 flache, rippenartige Schwellen ab, welche dem Kiemengerüst entsprechen werden. Thelodus scoticus und planus Traqu., Obersilur, Schottland. Th. Pagei Powrie sp. Unteres Oldred. Die Schuppen häufig im obersilurischen Beyrichienkalk und der oberen Oeselschen Stufe.

Lanarkia Traqu. Die Schuppen bestehen aus hohlen Kegeln ohne Basis. Keine Dorsalflosse. $L$. hor rida Traqu-, spinosa Traqu., spinulosa Traqu., Obersilur, Schottland.

Familie: Gemündenidae.

Form rochenartig, mit schmalem Schwanz und breiter vorderer Scheibe. Haut mit zahlreichen Höckerchen (? Chagrin). Ein inneres Skelett der Kopfregion undeutlich unter der Haut erkennbar; segmentierte Achse.

Die Stellung dieser Familie ist unsicher; wenn das Vorhandensein eines inneren segmentierten Skeletts sich bestätigt, dürfte es sich um einen Selachier handeln.

Gemündenia Traqu. Unterdevon.

A

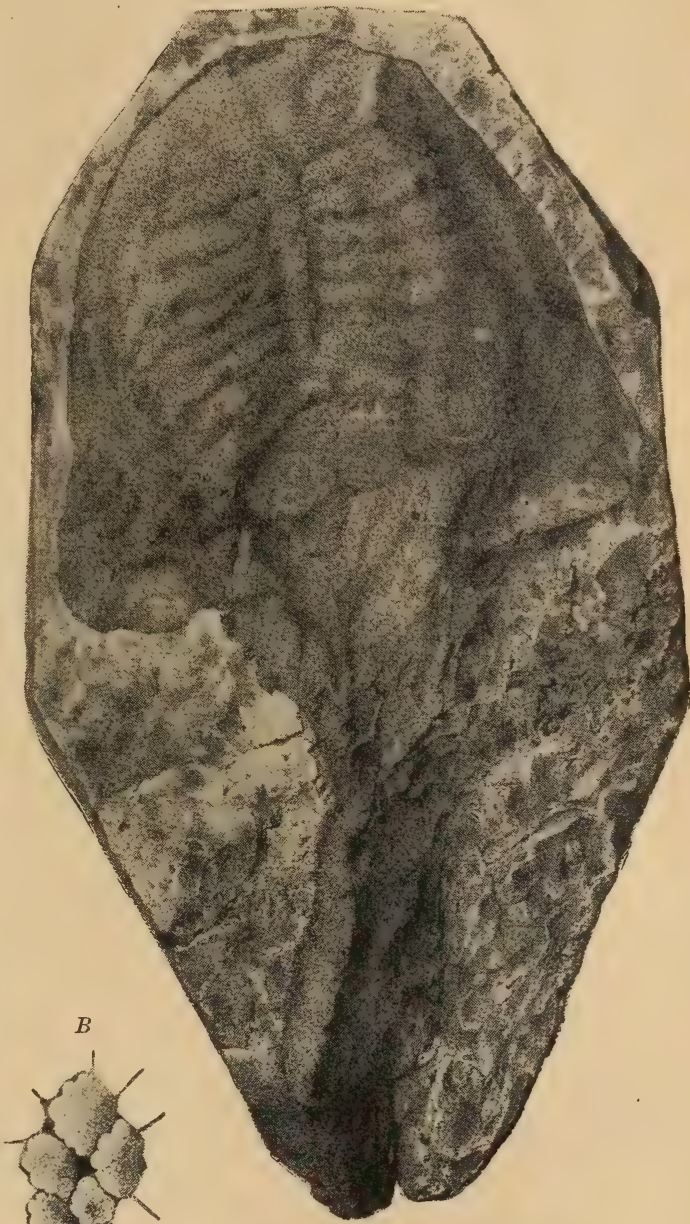

Fig. 34 .

A Thelodus Pagei Powrie. c. 1:5.

$\begin{array}{cc}C & B \text { Schuppen des Vorderrandes. } \\ C \text { Schuppen (Coelolepis-Typus) aus dem } & \text { Ludlow. (Nach Traquair.) }\end{array}$

Familie: Drepanaspidae. Traquair ${ }^{1}$.

Kopf äußerlich nicht vom Rumpf geschieden, beide in einen Panzer geschlossen, dessen Oberfläche zierliche Tuberkel trägt. Mund terminal, ohne

1) R. H. Traquair, The lower devonian fishes of Gemünden. Trans. Roy. Soc. Edinb. XL. 1903. Supplement. ibidem. XLI. 1905. 
Zühne, ohne erkennbare Kiefer. Schwanz beschuppt, dorsal und ventral mit gekielten, imbrizierenden Fulcren. Schwanzflosse heterocerk, aber nicht stark ausgerandet, mit kleinen Schuppen bedeckt, ohne sichtbare Strahlen. Keine Dorsalis. Seitenlinien nicht beobachtet. Dorsal und ventral je eine große Platte, vor der ventralen eine kleinere, welche die Mundspalte nach hinten begrenzt. An eine lange, seitliche, nach vorn zugespitzte und relativ schmale Platte legen sich vorn und hinten (ventral) noch je einige größere. Die Zwischenräume zwischen den großen unpaaren Platten der Dorsal- und Ventralseite und dem Zuge der Seitenplatten sind durch kleine, unregelmäßige Plättchen gefüllt. Die kleinen Augenlöcher (?) etwas ventral gerïckt. Anus am Ende der großen Ventralplatte. (Durch die Lage von Mund und After ist diese Seite als ventrale deutlich gekennzeichnet.) Die breite flache Form wird sich etwas ändern, wenn man die Entstellung durch Zusammenpressung korrigiert. Dann rücken auch die »Augen« auf die Seiten selbst.
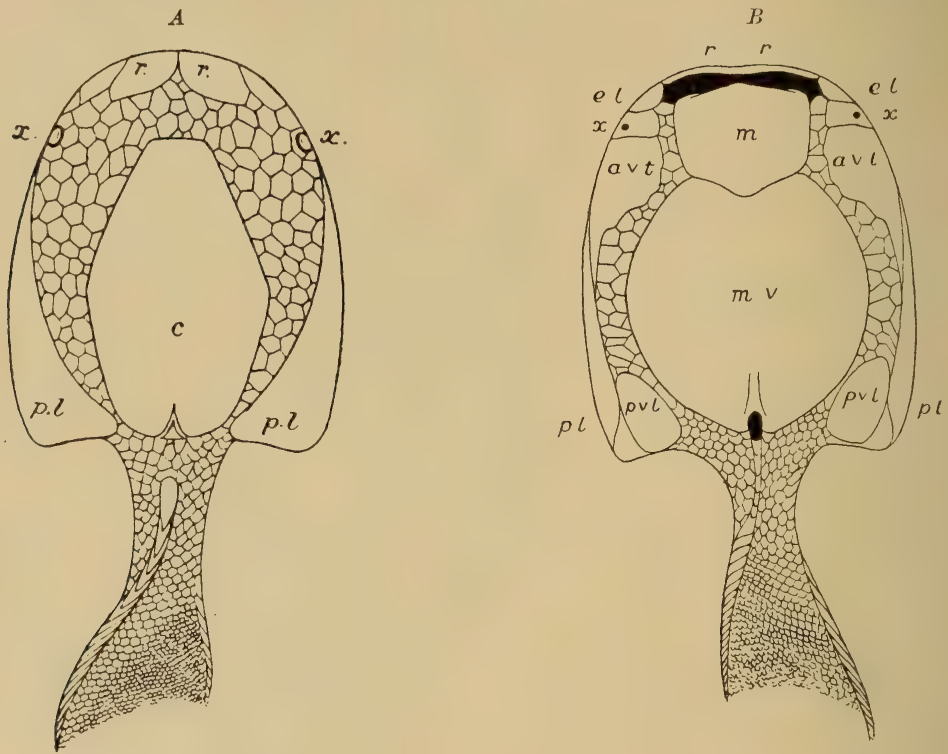

Fig. 35.

Drepanaspis gemündenensis Schlüter. Rekonstruktion von Traquair. Etwa 1:3. Die Ornamente der Platten sind fortgelassen; der Schwanz ist etwas gedreht, um die Schwanzflosse im Profil zu zeigen. A. $r$ Rostralplatten, $c$ mittlere Dorsalplatte, $p . l$ hintere Lateralplatten, $x$ wahrscheinlich Augenöffungen, $B, m, m v$ die großen mittleren Platten, $a v l, p v l$ vordere und hintere Ventrolateralplatten. $p l$ Seitenplatten (Cornua), $r$ Rostralplatten, $e l$ äußere Labialplatten, $x$ Stelle der Augen.

Drepanaspis Schlüter.

Dr. gemündenensis Schlüter. Unterdevon, Hunsrück.

Psammosteus Ag. Devon. Livland, Schottland, Spitzbergen.

\section{Familie: Pteraspidae. ${ }^{1}$ )}

Hautschüppchen zu größeren Platten und Schuppen zusammengezogen. Kopf und vorderer Teil des Rumpfes mit einem aus mehreren Stücken zusammengesetzten, selten einfachen Rückenschild und einer einfachen Ventralplatte bedeckt.

1) Alth, Al. v., Uber P'teraspis, Cyathaspis und Scaphaspis. Beiträge zur Palä(nntologie (')sterreich-Ungarns von Mojsisovics und Neumayr. II. 1886. - Claypole E. $W$., I'teraspidian fishes in the upper Silurian Rocks of North-America. ( uart. journ. geol. Soc. 1885. vol. XIII p. 48. - Dollo, L., Le Pteraspis dans l'Arlenne. (Comptes Rendus. 1903). - Drevermann, $F$., Úber Pteraspis dunensis F. Roe. sp. (Zeitschr. d. geol. Ges. 56. Bd. 1904). - Huxley Th., Úber Cephalaspis 
Jede Platte aus 3 Schichten ohne Knochenzellen bestehend. Die Mittelschicht mit maschigen Hohlrüumen und Kanälen, die außen in einer Doppelreihe von Poren münden. Die Platten sind mit zarten, emaillierten Leisten verziert, die sich den Rändern parallel ziehen. Augen klein, am Außenrand des Rückenschildes. Hinterer Teil des Rumpfes mit rhombischen Schuppen bedeckt. Schwanz unbekannt. Oberes Silur, Devon.

Von diesen sonderbaren Formen finden sich meist nur isolierte Kopfplatten, die sich durch den Mangel an Knochenzellen ${ }^{1}$ ) von den übrigen Placodermen unterscheiden. Die äußere Schalenlage besteht aus Dentin, die innere aus parallelen Lagen phosphorsauren Kalkes.

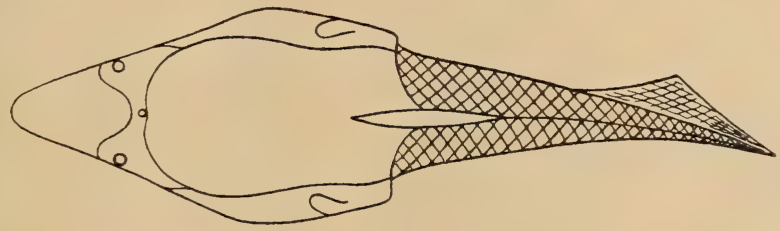

Fig. 36 .

Pteraspis rostrata Ag, von oben, Schwanz etwas gedreht. Nach A. Sm. Woodward,

Traquair und Andreae. c. $1: 3$.

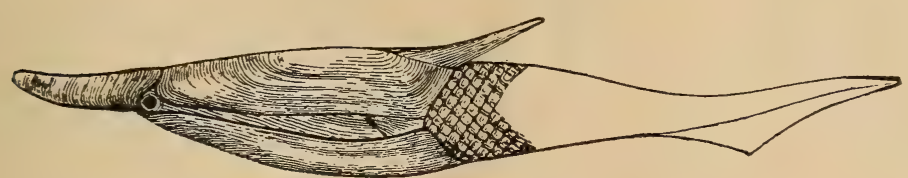

Fig. 37.

Pteraspis rostrata Ag., von der Seite, c. 1:3. Unt. Oldred (Passagebeds) von Herefordshire. Nach A. Sm. Woodward. Aus dem "Guide to the fossil Reptilia etc. ", mit Genehmigung der Trustees des British Museum of Nat. Hist.

Pter asp is Kner (Palaeoteuthis, Archaeoteuthis Roemer, Scaphaspis R. Lank.) Rückenschild vorn in eine schmale Schnauze verlängert, hinten mit einem (gelenkig befestigten) Medianstachel, aus 7 fest verbundenen Stücken bestehend. Bauchschild einfach (Scaphaspis). Die Zusammensetzung des Rückenschildes ist: ein großes Mittelschild, mit einem dreiseitigen Rostral. schild vorn und dem Dorsalstachel hinten; zwei Orbitalschilder, welche die Augen ganz einschließen und sich zum Teil zwischen Mittelschild und Rostralschild einschieben, zwei sog. Cornua, welche die hinteren Seitenecken bilden und von einem großen Loch (? Kiemenloch) durchbohrt sind. Die kleinen Augen sind von einem Augenring umgeben. Auf der Unterseite des Dorsalschildes liegt zwischen den Augen eine Grube, welche auf die Epiphyse bezogen wird. Die durch Poren nach außen mündenden

und Pteraspis. Quart. journ. geol. Soc. 1856. vol. XII p. 100, 1858 vol. XIV p. 267, 1861 vol. XVII p. 163 . - Kner, $R$., Über Cephalaspis Lloydii und Lewisii. Haidinger, Naturw. Abhandl. 1847 Bd. I. - Kunth, A., Über Pteraspis. Zeitschr. d. deutsch. geol. Gesellsch. 1872 Bd. XXIV S. 1. - Lankaster, Ray, and Powrie J., A Monograph of the fishes of the old red Sandstone. I. Cephalaspidae. Palaeont. Soc. 1868. - Lériche, M., Le Pteraspis de Liévin (Pas de Calais), Pt. Crouchi Lank. (Ann. Soc. géol du Nord. XXXII. 1903). - Lindström, G., On remains of a Cyathaspis from the Silurian strata of Gotland. (Svensk. Vet. Akad. Handl. Bihang. 21. 1895.) - Roemer, Ferd., Utber Palaeoteuthis Dunensis. Palaeontographica 1856 Bd. IV. - Woodward, Smith A., Catalogue of the fossil fishes. II: 1891. - Guide to the fossil Reptiles etc. in the British Museum. 1905.

1) Pteraspis dunensis Drevermann zeigt nach Drevermanns Angaben Knochenzellen. Zeitschr. d. deutsch. geol. Ges. 1904. S. 205. 
maschigen Kanäle der Mittelschicht sollen dermale Sinnesorgane (den Seitenlinien entsprechend) enthalten haben. Obersilur; England, Podolien, Galizien, Schweden, Petschoraland, Spitzbergen, Nordamerika. Unteres Oldred bzw. Gédinnien von Schottland, England, Nordfrankreich, Belgien, Galizien, Eifel.
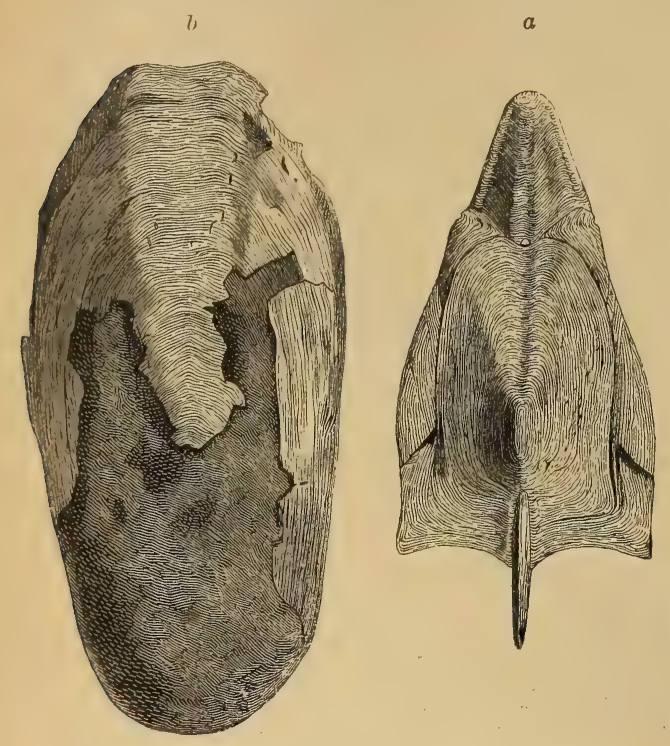

Fig. 38 .

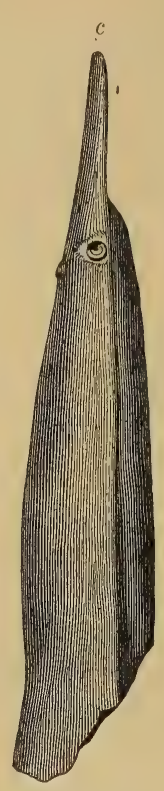

$a, b$ Pteraspis rostrata Ag. Unt. Devon, (Cornstones). Herefordshire. a Rückenschild, 1/2 nat. Gr., restauriert. b Bauchschild (Scaphaspis. Lloydii Ag.) $2 / 3$ nat. Gr. (Nach R. Lankas ter.) c Pteraspis Rückenund Bauchschild, restauriert nach einem in Galizien gefundenen Exemplar. (Nach Alth)

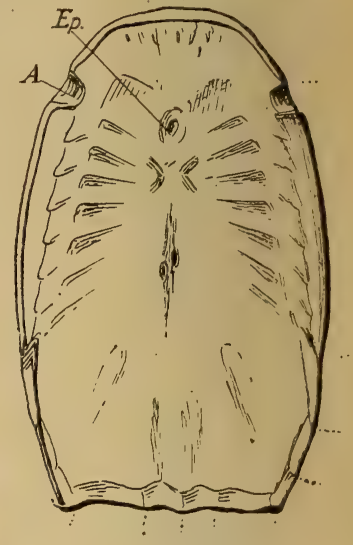

Fig. 41.

Cyathaspis integer Kunth. 1/. nat. Gr. Nach Jaekel. Die Innenfläche des Rückenpanzers eines Cyathaspis integer Kunth (Orig. - Mus. Berlin) aus obersilurischem Wenlockkalk (sog. Graptolithengestein) von Erkner bei Berlin. Vorn seitlich die Ausschnitte der Augen, median die Grube für die Epiphyse, dahinter seitlich die paarigen Eindrücke von Kiemenbögen und medianen Narben, die der rautenförmigen Grube von Cephalaspiden und Tremataspis entsprechen könnten.

Pala easpis Claypole (Holaspis R. Lank.). Rückenschild einfach, ohne Dorsalstachel. Orbita nicht ganz von der Orbitalplatte umschlossen. Unteres Oldred, Schottland. Devon, Nordamerika.

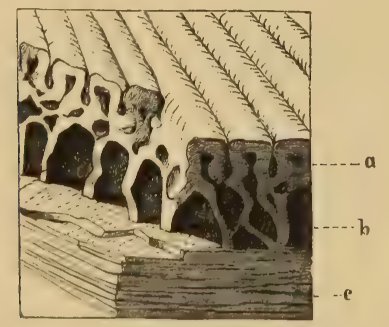

Fig. 39.

Pteraspis Lloydii Ag. sp. Ein Stück der Schale, stark vergr. $a$ obere. $b$ mittlere, $c$ untere Schicht. (Nach Ray Lankaster.)

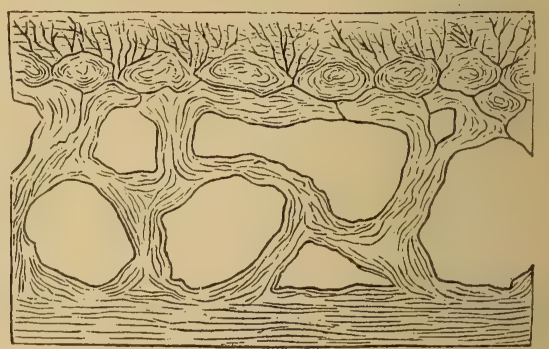

Fig. 40.

Pteraspis rostrata Ag. Vertikalschnitt durch das Kopfschild parallel einer Längsleiste. Stark vergr. (Nach Ray Lankaster.)

Cyathaspis Lank. (Diplaspis Matthew). Rückenschild vierteilig, aus einem großen Mittelstück, zwei schmalen Seitenstücken und einem unpaaren, vorn abgerundeten Rostralstück bestehend. Ob. Silur; England, Gotland. Unteres Oldred, Schottland. 


\section{Ordnung: Osteostraci. ${ }^{1}$ )}

Kopf durch ein großes, am Rande umgeschlagenes Knochenschild und meist auch durch ventrale Knochenbildungen oder Platten geschützt. Augen einander sehr genähert. Eine Dorsalflosse, Schwanz heterocerk. Rumpf mit Schuppen, von denen die auf den Flanken stehenden meist sehrhoch, die des Rückens häufig gekielt, die der Bauchseite V.förmig geknickt (oder durch ebenso verlaufende Reihen kleiner Schuppen ersetzt) sind.

Die Kopfplatten bestehen aus einer dünnen Schmelzschicht, einer darunter liegenden Osteodentinschicht (mit Knochenkörperchen oder mit Dentinröhrchen), einer mit groben Kanälen und maschigen Hohlräumen erfüllten mittleren Lage, und der basalen, an langgestreckten, spindelförmigen Knochenkörperchen reichen Isopedinschicht. Obersilur bis Oberdevon.

\section{Familie: Cephalaspidae Ag.}

Kopfschild vorn gerundet oder leicht verschmälert, hinten abgestutzt, an den Ecken in lange Stacheln (Hörner, Cormua) ausgezogen, mit sternförmigen Höckern

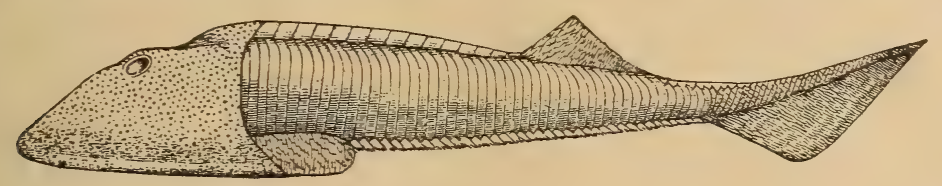

Fig. 42.

Cephalaspis Murchisoni, etwa 1:2. Unt. Oldred (Passagebeds), Herefordshire.

Nach A. Sm. Wo odw ard. Aus dem "Guide to the fossil Reptilia etc.", mit Genehmigung der Trustees des British Museum of Nat. Hist.

oder Körnchen. Die knöcherne Briiche zwischen den Augen fest mit dem Kopfschild verschmolzen. Die dorsolateralen Schuppen sehr hoch, imbrizierend, in 3 Reihen. Obersilur bis Devon.

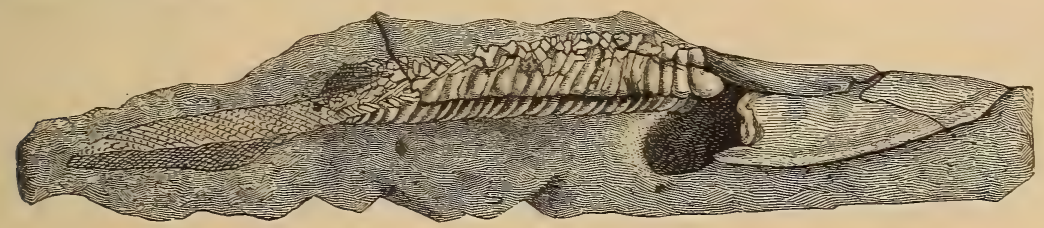

Fig. 43.

Cephalaspis Lyelli Ag. Old red. Arbroath, Forfarshire. 1/2 nat. Gr. (Nach Lankaster.)

Cephalaspis Ag. (Eucephalaspis, Hemicyclaspis, Zenaspis R. Lank). Hinterecken des Koptschildes mit mäßig langen Hörnern. Im Ausschnitt

1) Huxley Th., Uber Cephalaspis und Pteraspis. Quart. Journ. Geol. Soc. 1856. 1858. 1861. - Lankaster R. u. Powrie J., Palaontograph. Soc. 1868. A monograph of the fishes of the old red sandstone. - Rohon $\nabla$., Die obersilurischen Fische ron Oesel. Mem. Acad. Imp. Pétersbourg. 1892. Bd. 38. No.13. 1893. 40. Bd. No.5. Zur Kenntnis der Tremataspiden. Mélanges géol. et paleónt. Pétersbourg 1893. Weitere Mitteil. über die Gattung Thyestes. Bull. Acad. Imp. Pétersbourg. (气. Ser.) Bd. IT. 1896. - Rohon V.,Die Segmentierung am Primordialcranium der obersilurischen Thyestiden. Terh. russ. mineral. Ges. Petersburg 1895. - Schmidt Fr., Über Thyestes verrucosus und Cephalaspis Schrencki. Verh. russ. mineralog. Ges. Petersburg 1866. 
des Kopfrandes über ihnen tritt ein lappenartiges Gebilde auf. Es hängt mit der Mittellage des Kopfschildes zusammen ${ }^{1}$ ) und ist von gleicher zelliger Struktur, aber lockerer gebaut, daher wohl biegsam. Die äußeren Lagen (Osteodentin, Isopedin) fehlen ihm.

Nach dieser Darstellung handelt es sich nicht um eine Flosse; die Deutung als eine Art Kiemendeckel kann wohl nur auf die Funktion abstellen, nicht auf die morphologische Äquivalenz. Dorsalflosse ohne eigentliche Strahlen, aber mit zahlreichen aneinandergefügten und in Reihen stehenden Plättchen.

C. Lyelli Ag. C. Murchisoni Egerton Unteres Oldred.

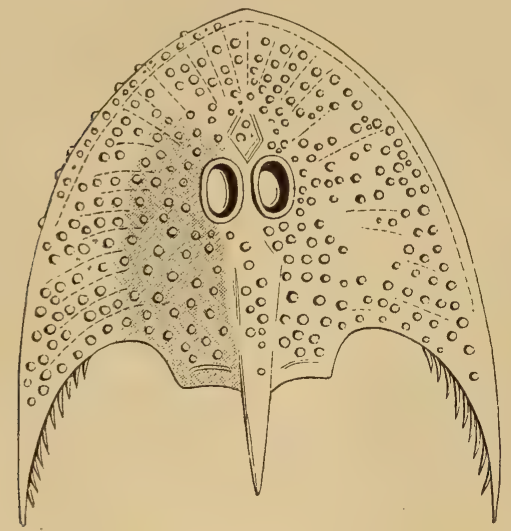

Fig. 45.

Kopfschild von Cephalaspis Agassizi Lank. Devon. Herefordshire. (Nach Lankaster.)

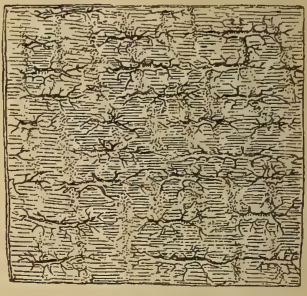

Fig. 44

Horizontalschnitt durch die innere Schalenschicht des Kopfschildes von Cephalaspis Lyelli mit Knochenkörperchen (Nach Huxley.)

Ateleaspis Traquair. Mit flachem runden Kopf, der mit sehr vielen kleinen polygonalen Plättchen bedeckt ist. Die hinteren gerundeten Ecken des Kopfes erinnern an Thelodus, die Augenhöhlen aber liegen wie bei

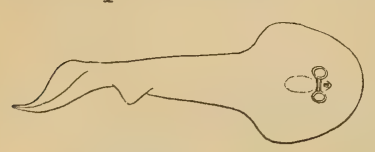

Fig. 46

Atcleaspis tessellate Traquair. Imrif nach R. H. Tracuair. ca. $1 / 5$ der nat Gr. Hörner des Kopfschildes mäßig lang. Hinter dem Kopfschild sind 3-4 Reihen dorsolateraler Schuppen fest verschmolzen zu einer dem vorderen Schild angelagerten oder mit ihm vereinigten Platte. Orbitae sehr genähert; vor ihnen liegt eine kleine frontale, hinter ihnen eine größere, flach eingesenkte Parietalgrube, mit spongiösem Boden. Die Randregion des Kopfschilds ist ̈̈hnlich gegliedert wie bei Eukeraspis; die Hohlräume waren gegen die Mittellinie offen, wie von Rohon beschriebene Steinkerne zeigen. Th. verrucsus Eichw. Obersilur, Oesel. Th. Egertoni Lank. sp. Tiefstes Oldred bzw Passagebeds, Schottland.

Didymaspis Egerton. Hörner des Kopfschilds sehr schwach, die hintere Platte ebenso groß wie das Kopfschild, mit diesem zu einem ovalen Schild vereinigt. Unteres Oldred.

1) Woodward A. Sm., Catalogue etc. II. 1891. 


\section{Familie: Tremataspidae.}

Der vordere Teil des Körpers mit einem großen Dorsalschild, das den beiden von Didymaspis entspricht. Mit ihm verbindet sich ein ventrales Schild und bedecht etua zwei Drittel der ventralen Fläche; davor liegt ein Mosaik kleiner Platten, Oralplatten, bis zur Mundspalte hin. Auf der Grenze der beiden Regionen sind eine Anzahl Löcher angeordnet, die man als Kiemenöffnungen auffaßt. Die Augen sehr genïhert; zwischen ihnen ein kleines loses Mittelstïck, nach Jaekel durchbohrt (Epiphyse). Davor eine "Frontalgrube» (mit geschlitztem Boden) und dahinter. eine größere, flache »Parietalgrube mit spongiösem Boden, deren Bedeutung ebenso strittig ist, wie die der beiden Gruben, die jederseits am Rande auftreten (mit spongiösem Boden).

Jaekel denkt an Tentakeldurchbrüche; von diesen würde aber das eine Paar hinter dem vermutlichen Kiemenapparat stehen, was diese Annahme sehr erschwert. Vermutlich handelt es sich um Haut-Sinnesorgane, die vielleicht mit dem reichverzweigten Kanalsystem innerhalb der Knochenplatten in Verbindung stehen; dies dürfte dann auch für das sog. Parietalorgan gelten. (Vgl. die Bemerkung über die internen Kanäle bei Pteraspis, die durch Poren nach außen münden.) $\mathrm{Patten}$ hat Tremataspis nach dem Material von Oesel (Obersilur) vorzüglich rekonstriert, aber mit seiner Interpretation Widerspruch gefunden. Die Kiemenöffnungen der Ventralseite sind von ihm als Ansatzstellen von Beinen gedeutet, die denen des Molukkenkrebses, Limulus, entsprechen sollen. ${ }^{1}$ ) Die Reste vermutlicher, innerer Kiemenbögen sind von Jaekel bei Cephalaspis Murchisoni beobachtet, die Eindrücke solcher auch bei Cyathaspis (vgl. Fig. 41), auf der Innenfläche des Dorsalpanzers. Hier reihen sich die älteren Beobachtungen über die inneren Hohl-
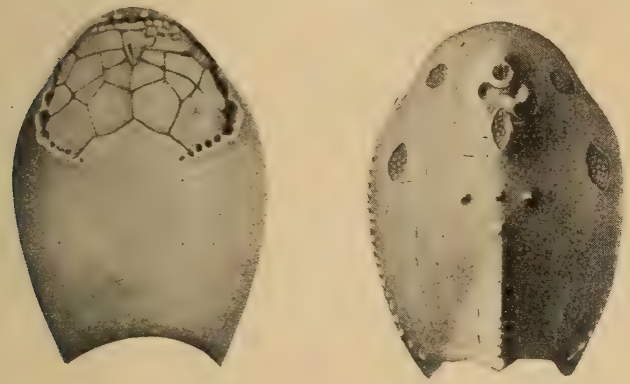
räume bei Eukeraspis (A. Sm. Woodward) und die angebliche Segmentierung des Primordialcranium bei Thyestes (Rohon) an.

Tremataspis Schmidt, Obersilur, Rotziküll auf der Insel Oesel. Tr. Schrencki Pander sp.

\section{Ordnung. Antiarchi. ${ }^{2}$ )}

Kopf und Rumpf durch einen geschlossenen Panzer von symmetrisch angeordneten, mit schrägen Rändern übereinanander greifenden und sternförmig oder höckerig verzierten Knochenplatten bedeckt. Kopfabschnitt als Ganzes am Rumpf beweglich. Augenhöhlen auf der Oberseite sehr genähert. Kopf-und Seitenplatten des Rumpfes mit dermalen Sinneskanälen. Hohle, mit Knochenplatten gepanzerte und durch

${ }^{1}$ ) Jaekel O., Über Tremataspis und Pattens Ableitung der Wirbeltiere. (Zeitschr. geol. Ges: 1903.)

$\left.{ }^{2}\right)$ Egerton Ph. Gr., On Pterichthys. Quart. Journ. geol. Soc. 1848, 1862. Miller H., Ann. Mag. Nat. Hist. 1849. S. 63. - Pander Chr. R., Die Placodermen des devonischen Systems. Petersburg 1857. - Traquair R. H., Ann. Mag. Tat. Hist. 1888. - Woodward A. Sm., Catalogue etc. II. 1891. Guide etc. 1905. S. 59. 
ein Quergelenk geteilte Anhänge sind mit dem vorderen Teil des Bauchpanzers durch ein Sperrgelenk verbunden. Bauchflossen fehlen. Der hinter dem Panzer liegende Teil des Körpers beschuppt oder nackt. Eine Dorsalflosse, mit Fulcren. Schwanz heterocerk.

Die Knochenplatten bestehen aus drei mit Knochenzellen erfüllten Schichten, von denen die mittlere von groben Kanälen und Hohlräumen durchzogen ist, während die innere und äußere dichtere Struktur besitzen.

Zwei kleine, am Vorderrand des Ventralschildes gelegenen Plättchen (Mentalia) werden als dermale Bedeckung des Unterkiefers gedeutet (nicht ohne Widerspruch).
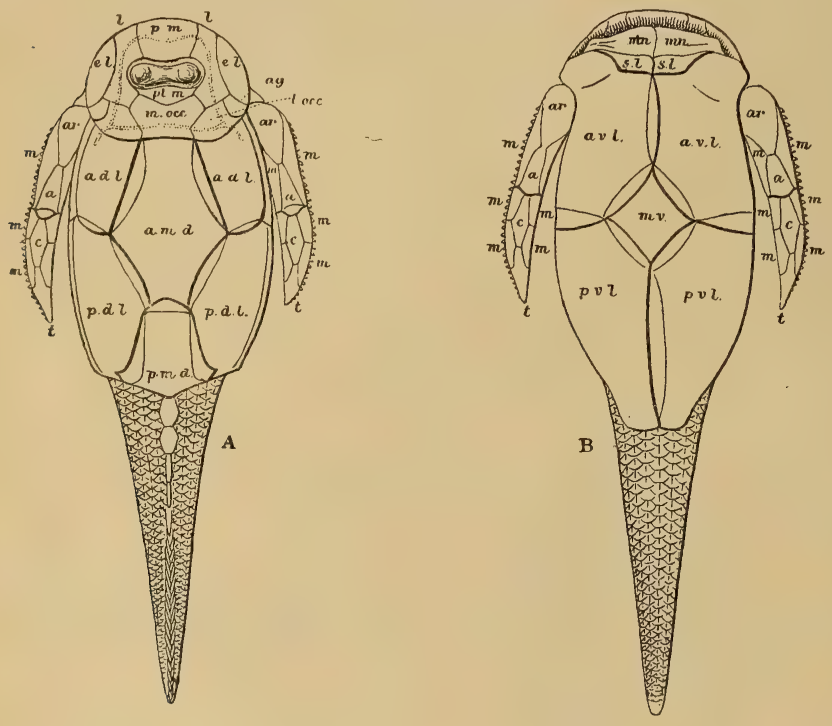

Fig. 48.

Pterichthys Milleri, Mittleres Oldred. Schottland, etwa 1:2. Nach Traquair. Aus dem "Guide to the fossil Reptilia etc." mit Genehmigung der Trustees des British Museum of Nat. Hist.

m.oce mittl. Occipitalplatte, ptm postmediane Platte, $p m$ prämediane Platte, e.l Extralateralplatte, l.occ seitl. Hinterhauptsplatte, $l$ Lateralplatte, $a g$ Angularplatte, s.l Semilunarplatte, $m n$ Mentalplatte, amd, pmd vordere und hintere dorsale Mittelplatte, $a d l ; p d l$ vordere und hintere dorsale Seitenplatte, $a v l, p v l$ vordere und hintere ventrale Seitenplatte, $m v$ mittlere Ventralplatte,

$a, c, a r, m$ Platten des „Ruderorgans". Seiten-

linien punktiert.

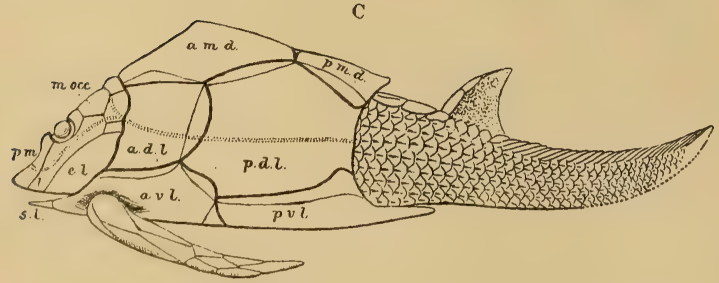

Die systematische Stellung der Antiarchi, deren wich. tigste Gattungen, Pterichthys und Bothriolepis, gut bekannt sind, wird sehr verschieden aufgefaßt. Noch Cope verglich sie mit Tunicaten wie Chelyosoma. Für ihre Stellung bei den Fischen ist maßgehend die histologische Struktur der Knochenplatten und Schuppen. Für die Stellung innerhalb der Klasse der Fische ist sie es weniger, und man kann sie nicht zum Beweis der Ansicht heranziehen, daß die Asterolepiden etc. Ganoiden seien. Die »flügelartigen * Anhänge sind nur von Wenigen mit echten Extremitäten verglichen, die sie 
nach der morphologischen Anlage auch gar nicht sein können. J a e k el, der eine nähere Verwandtschaft der Antiarchi mit Coccosteus annimmt, vergleicht sie mit den »Ruderorganen « bei diesen, und läßt sie aus den Hinterecken bezw. Stacheln des Kopfschildes von Cephalaspiden hervorgehen. Indem er aber zugleich mit den Pectoralstacheln der Störe vergleicht, die aus Strahlen der Brustflosse entstehen, sind sehr verschiedene Organe in die Diskussion hineingezogen.

Die Bildung der Anhänge und die Art des Gelenkes machen sie als Ruderorgane untauglich. Ihre Funktion mag die einer Schreckwaffe gewesen sein. ${ }^{1}$ ) Es scheint aber auch nicht ausgeschlossen, daß sie zur Anklammerung an größeren Kadavern, oder zum Festklemmen kleinerer Nahrungsobjekte gebraucht wurden.

\section{Familie: Asterolepidae.}

Pterichthys Ag. (Physichthys Meyer.) $3-20 \mathrm{~cm}$ lange Fische. Der vorn gerundete Kopfpanzer ist vom Rumpfpanzer durch zusammenhängende Fugen getrennt und gegen letzteren beweglich. In der Mitte des Kopfes eine brillenförmige Öffnung für die A ugen, welche durch eine kleine, aber dicke, isolierte Platte (os dubium Panders) getrennt werden. Auf der Unterseite dieser Platte wird eine tiefe Grube beobachtet, in welcher die Epiphyse lagerte (pineal plate A. Sm. Woodward). Die Platten des Kopfes können nicht genau mit denen anderer Fische homologisiert werden. ${ }^{2}$ ) Man unterscheidet eine mittlere Reihe mit der mittleren Occipitalplatte und der postmedianen Platte hinter, und der prämedianen Platte vor den Augen. Letztere Platte begrenzt dorsal die Mundspalte. Seitlich liegen die Lateral- und Occipitolateralplatten und, den äußeren Winkel zwischen beiden füllend, die kleine Angularplatte. Die Seitenwand wird aber hauptsächlich gebildet von der Extralateralplatte, die A. Sm. Woodward als Operculum deutet.

Der Rumpfpanzer besteht aus viel größeren Platten. Dorsal können ein vorderes und ein hinteres Rückenschild unterschieden werden, denen sich seitlich je eine vordere und hintere Seitenplatte anschließen. Ventral decken vier Platten, die sich um eine kleine mittlere symmetrisch gruppieren, den Körper. Vor den großen vorderen Ventralschildern liegen, einen breiten Ausschnitt füllend, die kleinen Semilunarplatten und vor diesen die nur locker verbundenen kleinen Mentalplatten.

An den vorderen Ventralplatten articulieren die Ruderorgane in einer ausgeprägten Gelenkgrube, welche sich in der Mitte zapfenförmig erhebt und durchbohrt ist. Der Schwanz ist mit rundlichen, imbrizierenden Schuppen bedeckt; vor der kurzen, steilen Rückenflosse decken einige größere gekielte Schuppen den Rücken. Hinter dieser liegen die Schuppen der Rückenlinie wie dicht gepackte Fulcra aufeinander.

Eine besondere Erwähnung verdienen die Kanäle der Hautsinnesorgane. Eine deutliche Seitenlinie läuft als offener Kanal über die Mitte der beiden Seitenplatten, die sich in dieser Linie öfters teilen (Jaekel), tritt in die seitliche Hinterhauptsplatte ein, gabelt sich hier und umkreist die Augenhöhle.

1) Hoffmann. Die Ruderorgane d. Asterolepidèn. (Palaeontographica 1911.) (Ausführliche Literatur über Placodermen.)

2) Jaekel hat die Ansicht ausgesprochen, daß die Platten bei Coccosteiden und bei Asterolepis dieselben Elemente darstellen und den gewöhnlichen Belagknochen im Fischschädel zu homologisieren sind. Dann enthält die mittlere Reihe das Occipitale superius, das Parietale (der kleine, die Orbita zerlegende Knochen) und das Präfrontale; die seitlichen werden Epioticum, Supratemporale, Jugale und Postfrontale genannt. (Zeitschr. geol. Ges. 1903.) 
Kiemen sind bisher nicht nachgewiesen; A. Sm. Wo od ward deutet die äußere Seitenplatte des Kopfpanzers als Operculum und nimmt damit auch eine bestimmte Lage der Kiemen an.

Hinter dem Kopf liegende Platten des Rumpfes sind mit den Deckknochen des Schultergürtels in Verbindung gebracht. So bezeichnet Jaekel die vordere Ventralplatte, an der die Anhänge gelenken, als Clavicula, die hintere als Postclavicula, die hintere Seitenplatte (nach ihm

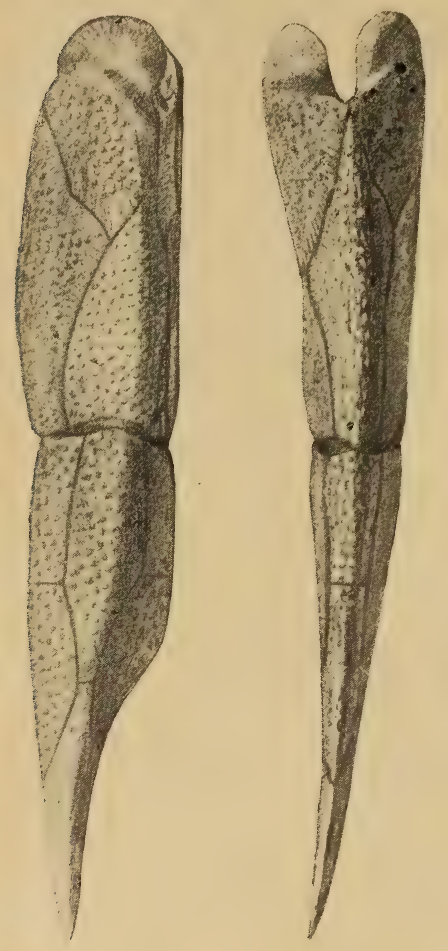

Fig. 49.

Ruderorgan von Asterolepis. Nach $\mathrm{H}$ of $\mathrm{f}$ -
mann. $1 / 2$.

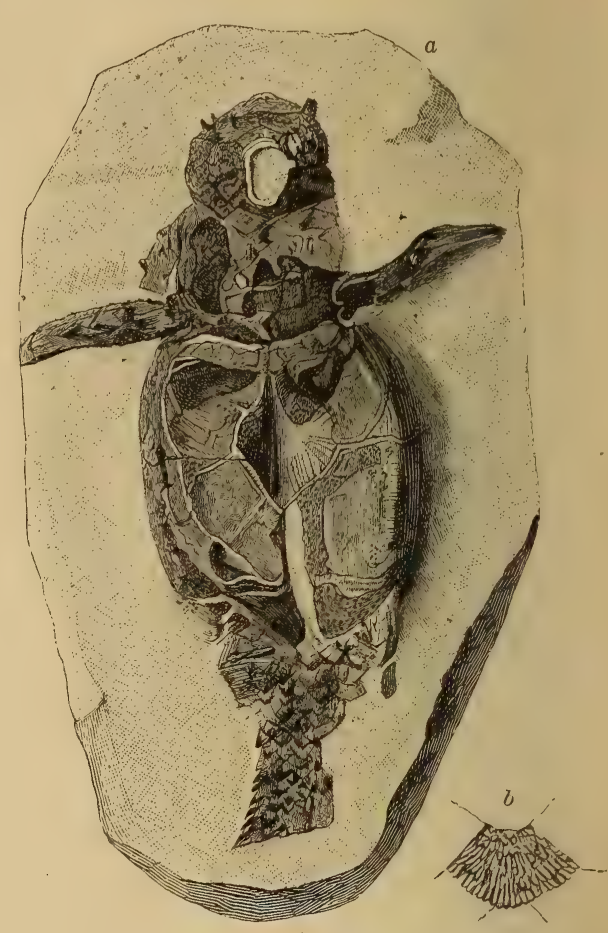

Fig. 50.

Pterichthys quadratus Egert. Old red Sandstone (Devon), Gamrie. Schottland. a Exemplar in $1 / 2$ nat. Gr., b eine Schuppe vergr. (Nach Egerton.)

zweiteilig) als Cleithrum und Supracleithrum. Demnach wäre auch erst hinter diesen letzteren die Brustflosse zu suchen, wenn sie überhaupt entwickelt war.

Die vorderen Seitenplatten, zwischen Nackenschild und Clavicula gelegen, gelten als Operculum und Suboperculum. Von einer Kiemenspalte, die sie decken sollten, ist allerdings nichts zu sehen. Man wird diese wohl besser innerhalb der Fuge zu suchen haben, die den eigentlichen Kopf vom Rumpfpanzer scheidèt. Unteres Oldred. Pt. Milleri Ag. Mitteldevon der Eifel, Pt. rhenanus Beyr.

Asterolepis Eichw. (Chelonichthys Ag., Odontacanthus Ag.) Größer als Pterichthys. Die vordere mediane Rückenplatte bedeckt mit ihren schrägen Rändern die seitlichen Platten, während sie bei Pterichthys von den dorsolateralen Platten bedeckt wird. A. ornata Eichw. Devon, Rußland. A. maxima Ag. Oberes Oldred. 
Bothriolepis Eichw. Die Anhänge sind länger als der Panzer oder mindestens ebensolang und der distale, durch das Quergelenk abgegrenzte Teil viel kürzer als dęr proximale. Schwanz wahrscheinlich ohne Schuppen. Devon, Rußland. Oberes Oldred, Schottland. Oberdevon, Kanada. (B. canadensis Whiteaves, in ausgezeichneter Erhaltung.)

Microbrachium Traquair. Unteres Oldred, Schottland.

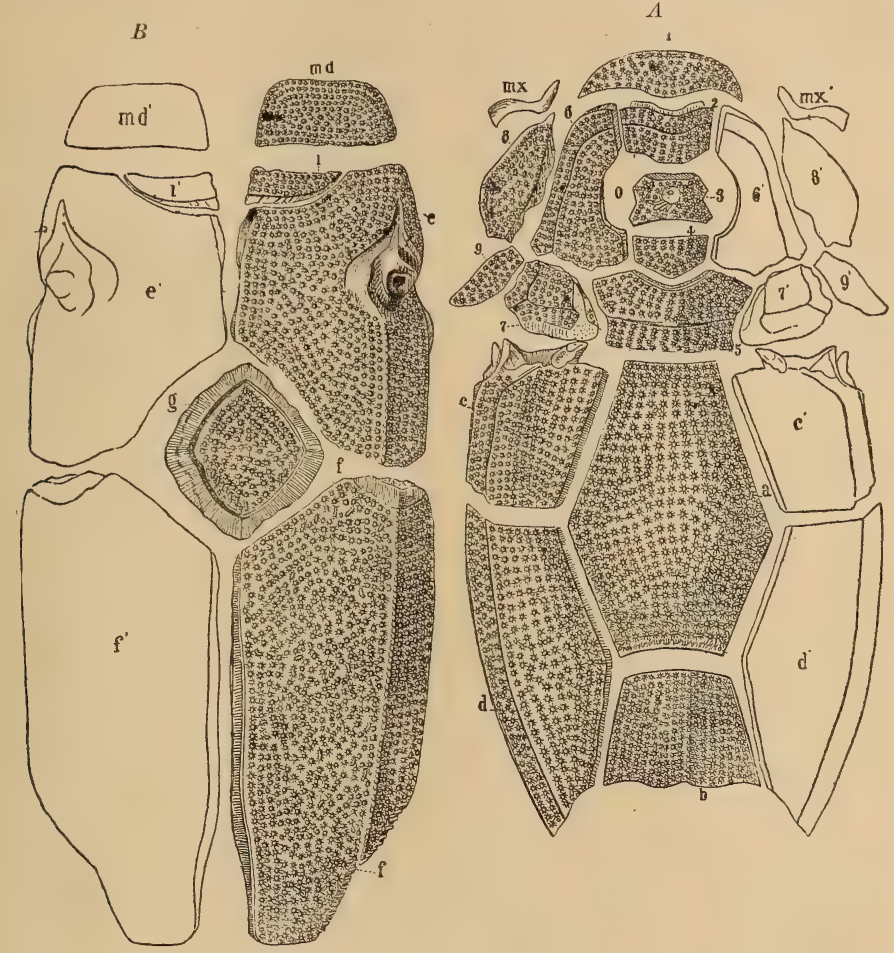

Fig. 51.

Asterolepis ornatus Eichw. aus dem alten roten Sandstein von Livland. A von der Rückenseite. $B$ von der Bauchseite. 1 os terminale. 2 os medium anticum. 3 os dubium. 4 os medium posterius. 5 os occipitale medium. 6 os posterius laterale. 7 os occipitale laterale. 8 os operculare. 9 os angulare. $m x$ Oberkiefer. $a$ vordere, $b$ hintere Rückenplatte, $c$ vordere, $d$ hintere Seitenplatte. md Unterkiefer. $i$ Thoracalplatte (os semilunare). $e$ vordere, $f$ hintere, $g$ mittlere Bauchplatte. $1 / 2$ nat. Gr. (Nach Pander.)

\section{Unterklasse : Elasmobranchii. ${ }^{1}$ )}

Fische mit knorpeligem Innenskelett, Schädel ohne dermale Belagplatten. Haut mit Placoidschuppen. Oberkieferbogen (Pterygopalatinum) nicht mit dem Schädel verschmolzen, Hyomandibulare frei. Die Kiementaschen miinden frei nach außsen, ohne Kiemendeckel. Zähne in mehreren

1) Agassiz, Poissons fossiles. Vol. III. 1843. Bonaparte C. L., Selachorum tabula analytica. Mém. Soc. Sc. nat. Neuchâtel 1839. - Davis I. W., On the fossil fishes of the carboniferous limestone of Great Britain. Transact. Roy. Soc. Dublin. Soc. 1883. Vol. I. ser. II. p. 327 bis 648. Taf. 42 bis $65.44^{\circ}$ - Hasse C., Das natürliche System der Elasmobranchier auf Grundlage des Baues und der Entwickelung ihrer Wirbelsäule. Jena 1879, Ergänzungsheft 1885. $4^{\circ}$. - Mïller Joh. und Henle J., Systematische Beschreibung der Plagiostomen. Berlin. 1841. 60 Taf. gr. $4^{\circ}$. - Jaekel O., Die eocänen Selachier von Monte Bolca. 1894. Berlin. Nötling Fr., Die Fauna des samländischen Tertiärs. Abh. geol. Spezialkarte v. 
Reihen hintereinander auf den Kieferrändern. Sehnervenfasern nicht gekreuzt, der Conus arteriosus des Herzens mit drei Reihen Klappen, Darm mit Spirulfalte, Ovarien mit nur wenigen großen Eiern. Männchen mit Pterygopodien.

Das knorpelige Skelett der. Haifische zeigt häufig eine corticale, seltener in größere Tiefe dringende Verkalkung, indem die colloide Intercellularsubstanz Kalk aufnimmt und sich Kalkplatten bilden, deren jede ein strahliges Gefüge zeigt. Die Wirbel verkalken in sehr mannigfaltiger Weise und gewähren nach Hasse gute Anhaltspunkte für die Systematik. Ihre Zahl ist bei Haien sehr hoch (bis 365).

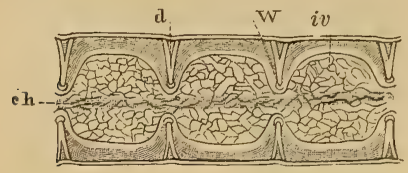

Fig. 52.

Längsschnitt durch den vorderen Teil der Wirbelsäule von Heptanchus, $w$ Einschnürung der Chordascheide, $d$ Anlage eines verkalkten Doppelkegels, $i v$ Intervertebraler mit Chorda erfüllter Raum, ch Chorda. (Nach Kölliker.)

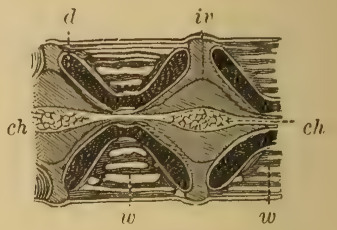

Fig. 53 .

Längsschnitt durch die tectispondyle Wirbelsäule von Squatina, $w$ Wirbelkörper mit konzentrischen Verkalkungsringen, $d$ verkalkter Doppelkegel, iv Intervertebralraum, ch Chorda. (Nach Hasse.)

Unter den lebenden Haien haben die Notidaniden die primitivste Wirbelsäule. In regelmäßigen Abständen dringen Ver-

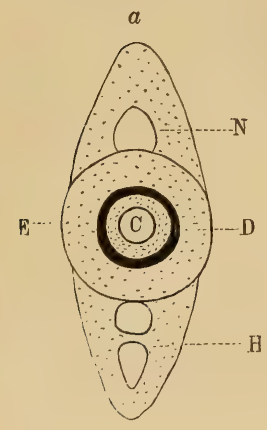

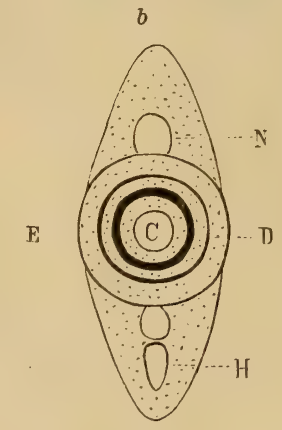

Fig. 54

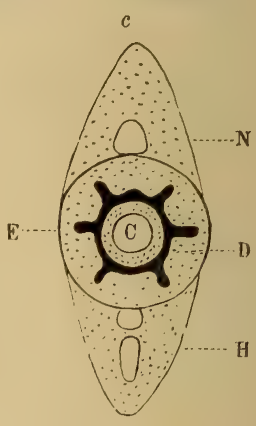

Schematischer Querschnitt durch die Mitte eines a Cyclospondylen-, $b$ Tectispondylen- und $c$ Asterospondylen-Wirbels. C Chordahöhle, $D$ zentrale Kalkringe, E Elastica externa, $N$ Neurapophyse, $H$ Hämapophyse. (Nach Hasse.)

dickungen der Chordascheide gegen das Zellgewebe der Chorda vor und bilden in der Mitte durchbohrte Scheidewände (Diplospondylie).

Die Chorda erscheint vertebral eingeschnürt, intervertebral erweitert. Durch das Auftreten der Bogenteile und ihr Eingreifen in

Preußen. Berlin 1885. - Probst, Beiträge z. Kenntnis der fossilen Fische aus der Molasse von Baltringen. Jahreshefte Ver. f. Naturk. Württemberg. 1874, 1877, 1878, 1879. - Fritsch A., Reptilien und Fische d. böhm. Kreideformation. Prag. 1878. Fauna d. Gaskohle. 2. Bd. 1889. - A. Smith Woodward. Catalogue of the fossil fishes. Part. I. 1889. Part. II. 1891. Hier ausführliche Literaturangaben. Priem E., Fitude des poissons fossiles du Bassin Parisien. Ann. de Paléontologie. Paris 1908. - Leriche M., Les poissons paléocènes de la Belgique. Mém. Mus. Hist. Nat. de Belgique. T. II. 1902. 
die Chordascheide (s. o.) wurde an diesen Stellen ein weiteres Dickewachstum der Chorda verhindert. Indem die Wirbel sich auch in longitudinalem Sinn ausdehnen, greift auch die Hemmung des Chordawachstums weiter aus. Auf diese Weise müssen amphicöle Wirbelanlagen und intervertebrale Chordaverdickungen entstehen.

Als Cyclospondyli bezeichnete Hasse diejenigen Wirbel, bei denen rings um die Chorda im Zentrum des Wirbelkörpers, in einèr faserigen Zone innerhalb des Knorpels, ein verkalkter Ring entsteht, der sich mit der verkalkten konkaven Vorder- und Hinterwand des Wirbels verbindet.

Entwickeln sich innerhalb des Wirbels noch weitere Kalkhülsen, die sich konzentrisch um die ersteren legen, so entstehen tectispondylische Wirbel, gehen von dem inneren Ringe radiale Kalkblätter oder keilförmige Verkalkungen gegen die Peripherie, so heißen die Wirbel asterospondylisch.

Neben den Wirbeln kommen am häufigsten die Hautgebilde (Placoidschuppen), Flossenstachel und Zähne vor (s. S. 4, Fig. 1 bis 3). Haifischzähne gehören zu den am längsten bekannten Versteinerungen und sind als Glossopetrae, Vogelzungen, Schlangenzungen etc. in der älteren Literatur vielfach erwähnt.

Die Form der Zähne ist sehr verschieden, häufig scharf zugespitzt mit schneidenden Seitenrändern, ein- oder mehrspitzig, öfters aber auch pflasterartig mit ebener, stumpfkonischer Krone. Sie bestehen im wesentlichen aus Vasodentin oder Dentin und Schmelz (Placoidschmelz) (s. Fig. 14) und sind stets nur durch Ligament befestigt, niemals festgewachsen.

Die Elasmobranchier zerfallen in drei Ordnungen: Ichthyotomi, Acanthodi, Selachii. Die Holocephali stehen ihnen unter allen Fischen am nächsten, sind aber doch so scharf geschieden, daß wir sie nicht als den Genannten gleichwertige Ordnung einreihen können.

\section{Ordnung: Ichthyotomi Cope (Proselachii Döderlein, Koken).}

Paarige Flossen mit langer, segmentierter Achse. Wirbel. säule ungegliedert oder nur kleine Ausscheidungen in der Chordascheide. Bogenteile wohl entwickelt, lang, flatterig. Keine Intercalarstücke. Außer der prismatischen äußeren auch noch in die Tiefe des Innenskelettes dringende Verkalkungen. Zähne mehrspitzig. Fünf Kiemenbögen.

In dem hier gegebenen Umfang umfaßt die Ordnung zwei Familien: die Pleuracanthiden und die Cladodontiden. Eine Sonderstellung der Cladodonten als Ordnung der Pleuropterygier erwies sich als unhaltbar. Manche Züge näherer Verwandtschaft scheinen die Cladodontiden auch mit den Hybodontiden $\mathrm{zu}$ verbinden, aber die Cladodontiden sind stark spezialisiert, wenn auch weniger als die Pleuracanthiden, deren anscheinend primitive Eigenschaften (archipterygiale paarige Flossen, diphycerke Schwanzflosse) sich als sekundäre Anpassungen auffassen lassen. 


\section{Familie: Pleuracanthidae. ${ }^{1}$ )}

Skelettknorpel kalkig inkrustiert, wie bei anderen Haifischen; auch wohl mit tiefer diringenden Verkalkungen. Haut olne Placoidzähnchen. Obere und untere Bögen lang, flattrig, verkalkt. Chorda persistent, ohne Wirlelanlagen ${ }^{2}$ ), gradlinig in die diphycerke Schwanzflosse auslaufend. Brustflossen mit langer, gegliederter Achse (Metapterygium), mit zahlreichen, knorpeligen Strahlen, die am distalen Ende der Achse auch auf die mediale Seite übertreten (biseriales Archipteryyium), während einige direkt an dem Schultergürtel inserieren (Propterygium). Der Schultergürtel besteht aus 2 getrennten Spangen, von denen ein Infrascapulare sich meist deutlich, ein Suprascapulare seltener absondert. Es liegt wohl zum Teil daran, daß an diesen Stellen störkster Biegung die Kalkinkrustation aussetzt. Zwei weit getrennte, dreiseitige Beckenknorpel, mit denen distal die basalen Stücke der Knorpelstrahlen articulieren; medial ist, ähnlich der Brustflosse, eine lange, gegliederte Achse ausgebildet (Metapterygium), welche bei Männchen zu den Pterygopodien hinführt. Schüdel flach, deprimiert, Mundspalte fast terminal, das Palatoquadratum in den Ausschnitt zwischen den Postorbitalfortsützen und den epiotischen Vorsprïngen (opistharthrisch) eingefügt, aber isoliert. Hyomandibulare lang, an Processus pteroticus gelenkig inseriert, mit langen Kiemenstrahlen besetzt. 5 Kiemenbögen, von vorn nach hinten an Größe stark abnehmend. Am Schüdel articuliert hinten ein kräftiger, abgeflachter,

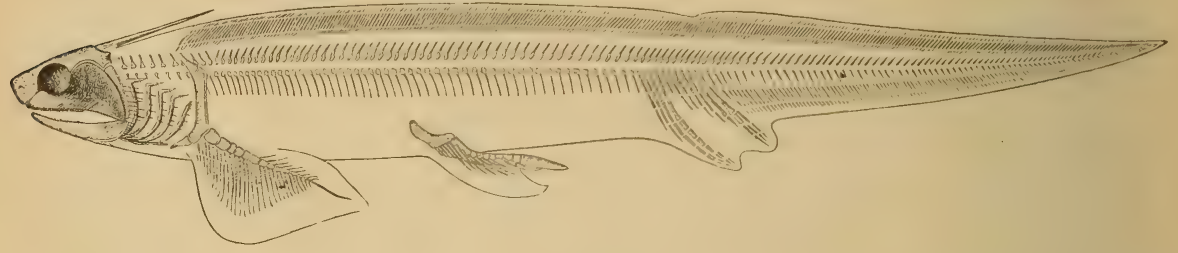

Fig. 55 .

Pleuracanthus sessǐlis Jordan sp. Abgeänderte Rekonstruktion von Jaekel. Rotliegendes, Lebach. Etwa $1 / 6$ nat. Gr.

beiderseits mit Zähnen besetzter Nackenstachel. Zühne in zahlreichen Bändern, mit zwei langen, außen zugeschürften Spitzen, zwischen denen eine kleine mittlere steht. Die Spitzen erheben sich am Vorderrande einer dickplattigen, rundlichen Wurzel. Hybodusähnliche Streifung tritt öfter auf. Der Rücken ist ganz von der langen Dorsalflosse eingenommen, die allmählich in die zugespitzte Schwanzflosse übergeht, von der sie nur durch eine kleine Einkerbung geschieden ist; knorpelige Flossenträger stïtzen in 2 Reihen die dorsalen Flossenstrahlen. Im allgemeinen kommen 2 Flossen-

1) Agassiz, L., Poiss. foss. vol. III. 1843. - Beyrich, E., Uber Xenacanthus. Monatsber. Akad. Berlin. 1848. - Brongniart, Ch., Etudes s. l. terr. houiller de Commentry. Faune ichthyol. I. 1888. - Bull. soc. géol. France. 1888. S. 546. Cope, E., Amer. Philos. Soc. Philadelphia. 1884. - Davis, J., On the fossil fishremains of the Coal Measures. I. Pleuracanthidae. Trans. Roy. Soc. Dublin. 1892. vol. IV. - Döderlein, L., Zool. Anzeiger. 1889. XII. S. 123. - Ders. in Steinmann, Elemente der Paläontologie. - Fritsch, A., Die Fauna d. Gaskohle. II. 1888/89. III. 1890. - Goldfuß $\beta$, Neues Jahrb. 1847. S. 404. - Beitr. zur vorweltl. Fauna d. Steinkohlengeb. - Jaekel, O., Uber die Organisation der Pleuracanthiden. Sitz.-Ber. Ges. naturf. Freunde. Berlin. 1895. - Neue Rekonstruktion von PI. sessilis Jord. sp. und Polyacrodus (Hybodus) Hauffianus E. Fraas. ibid. 1906 - Jordan, N. Jahrb. 1849. - Koken E., Über Pleuracanthus Ag. und Xenacanthus Beyr. Sitz.-Ber. Ges. naturf. Freunde Berlin. 1889. S. $77 \mathrm{ff}$. - Reis, O. M., Das Skelett der Pleuracanthiden und ihre systemat. Bedeutung. Abh. Senckenb. Ges. Frankfurt a. M. 1897. Woodwaard, A. Sm, Catalogue of the fossil fishes. I. 1889. S. XV ff. S. $1 \mathrm{ff}$. Hier noch spezielle Literaturangaben.

2) Die unteren Bögen bestehen zwischen Becken und Brustgürtel aus einem rippenförmigen distalen und einem selbständigen proximalen Plättchen, das auch als Differenzierung innerhalb der Chordascheide gedeutet werden kann. 
träger auf 1 Bogenpaar der Wirbelsäule. Zwei vor der Caudalflosse sich heraushebende Gruppen knorpeliger Strahlen dienten zur Stïtze etwas stärker heraustretender Flossenlappen, die man als vordere und hintere Analflosse oder als Analflosse und vordere Caudalflosse bezeichnen kann. Es liegt kein Grund vor, ihnen eine Bedeutung für die Genese der Extremitäten zuzuschreiben.

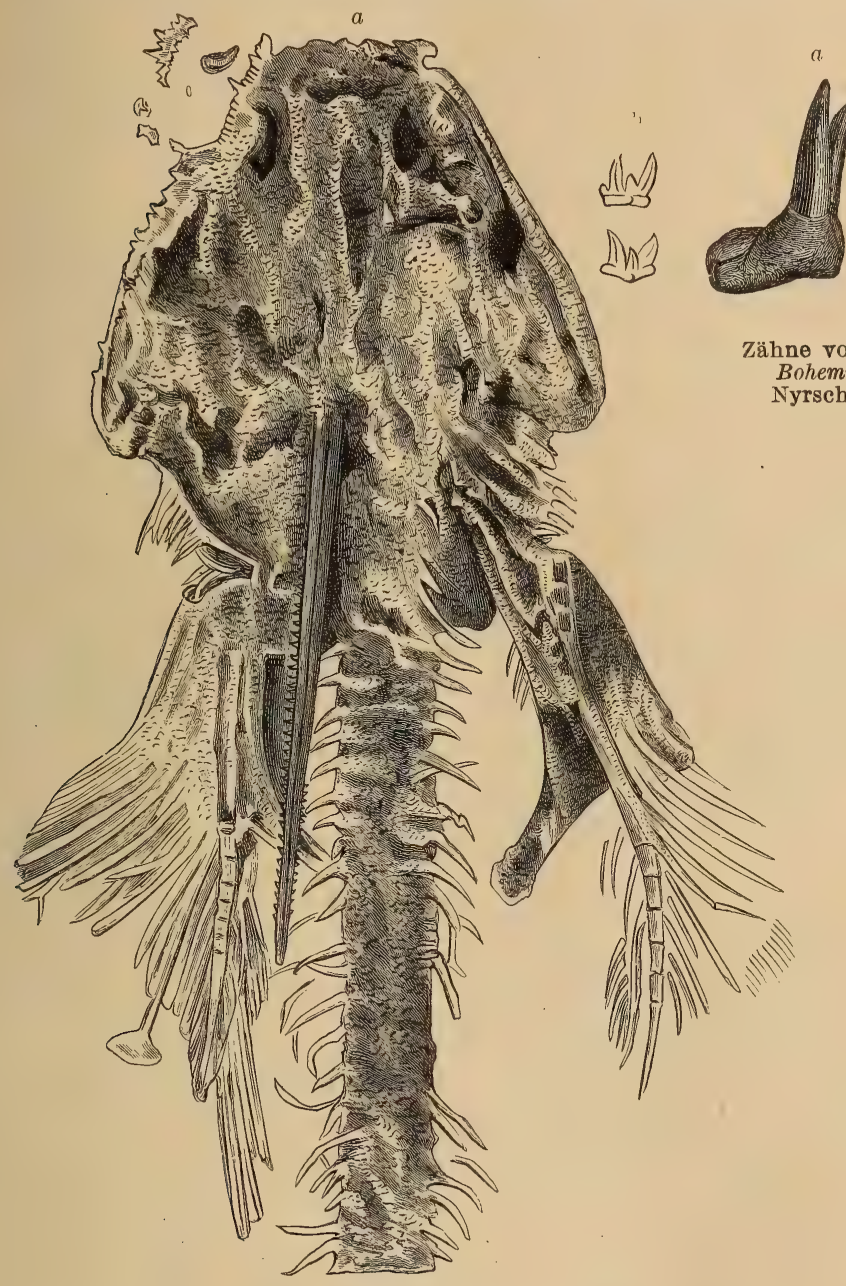

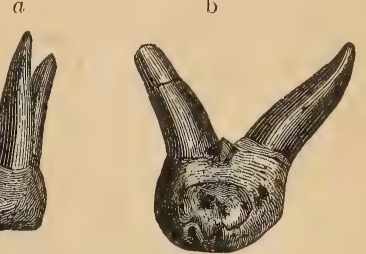

Fig. 58 .

von Pleuracanthus (Diplodus) Bohemicus Quenst. Gaskohle. yrschan bei Pilsen, Böhmen.

Fig. 56.

Pleuracanthus (Xenacanthus) Decheni Goldf. Braunau, Böhmen. $a$ Vorderer Teil des Körpers, 1/2 nat. Gr. $b$ Einzelne Zähnchen vergr. (Nach F. Roemer.)

Die wichtigste Gattung, auf die sich die Diagnose der Gruppe gründet, ist Pleuracanthus Ag., Triodus Jord., Xenacanthus Beyr., Didymodus Cope, Triacranodus Garm. Gute Skelettreste aus dem Rotliegenden von Lebach (bei Saarbrücken), Braunau und Ruppersdorf in Schlesien; Pl. sessilis Jordan sp., Decheni Gf. Gaskohle von Nyrschan (Böhmen); oberes Karbon von Commentry (Frankreich), Northumberland. Perm von Texas (Didymodus).

Diplodus Ag. Provisorisch beibehaltene Bezeichnung für isolierte Zähne. Ziemlich große Zähne mit reduzierter Mittelspitze. D. bohemicus Qu. Gaskohle, Böhmen etc. 
Anodontacanthus Davis. Nackenstachel ohne gezähnelte Ränder. Karbon, England.

Die Namen Dittodus, Ochlodus, Aganodus, Pternodus R. Owen, Thrinacodus St. John beziehen sich auf isolierte Zähne, Compsacanthus Newberry, Orthacanthus Ag., Lophacanthus Stock, Anodontacanthus Davis auf Stacheln, die zu Pleuracanthiden bzw. zu Pleuracanthus selbst gehören.

Chondrenchelys Traqu. $\left.{ }^{1}\right)$ Kein Dorsalstachel. Flossenträger unter der Dorsalis in nur einer Reihe. Paarige Flossen nicht bekannt (? fehlend; Scapula vorhanden). Unterkarbon (Calciferous sandstone), Schottland.

\section{Familie: Cladodontidae.}

Haut mit Placoidschüppchen, Innenskelett reich an Verkalkungen, Gliederung der Wirbelsäule aber nicht nachweisbar. Schwanzflosse heterocerk. Paarige Flossen mit langer, gegliederter Achse (Metapterygium) vor der mehrere kräftige Strahlen direkt dem Schultergürtel (bzw. dem Beckengürtel) inseriert sind. Ihre basalen Teile sind abgegliedert, aber nicht seitlich verschmolzen. Das erste große Segment der Achse läßt (in der Brustflosse) die Konkreszenz aus Strahlenteilen noch erkennen. Nur spärliche Strahlen gehen noch vom 2. und 3. Segment aus, alle anderen sind frei von Strahlen. Männchen mit Pterygopodien. Zähne in zahlreichen Reihen mit schlanker Hauptspitze, oft mit Nebenspitzen, längs gestreift oder gerippt, an der Basis abgestutzt. Fünf Kiemenspalten. Augen mit einem oder mehreren Kreisen dünner, unregelmäßig vierseitiger Plättchen.

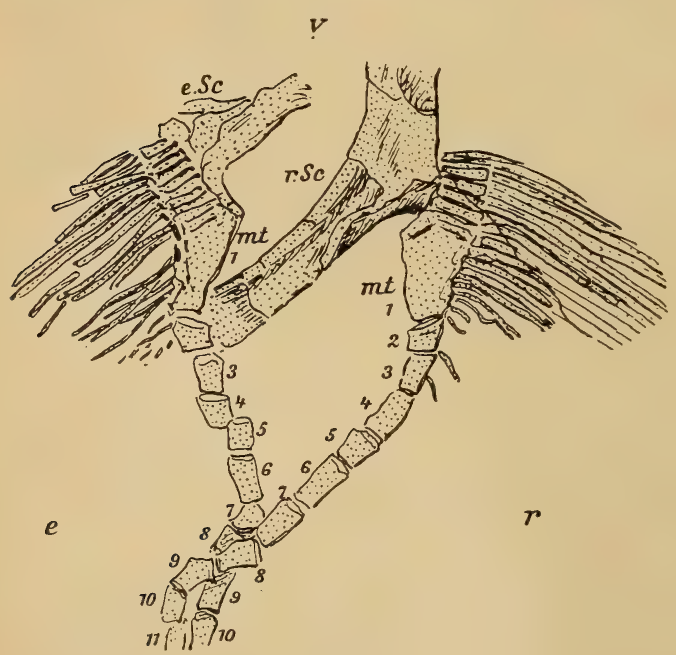

$$
h \text { Fig. } 59 \text {. }
$$

Cladodus Neilsoni Traquair. Unterkarbon. Brustflossen nach Traquair. e.Sc linke, r.Sc rechte Scapula, mt Metapterygium, 1-10 dessen knorpelige Segmente.

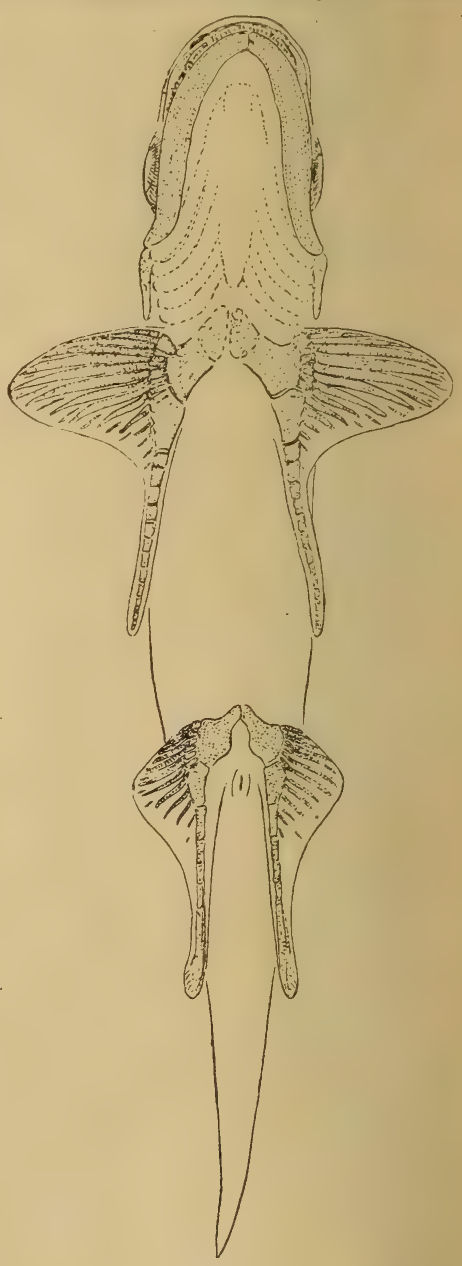

Fig. 60 .

Cladoselache Fyleri, Rekonstruktion von O. Jaekel.

1) Geol. Mag. 1888. p. 103. A. Sm. Woodw. Catal. I. S. 15. 
Devon bis Perm, wahrscheinlich Süß-und Brackwasserbewohner, aber auch in echt marinen Schichten. Sie schließen sich näher an die Pleuracanthiden an, als nach den verbreiteten Rekonstruktionsbildern angenommen werden konnte ${ }^{1}$.)

Cladodus Ag. (Cladoselache Dean). Spindelförmig, mit fast terminaler Mundspalte. Zwei Rückenflossen. Brustflossen groß, dreiseitig, nur die Radien außerhalb des Körpers, die lange, gegliederte Achse im Körper

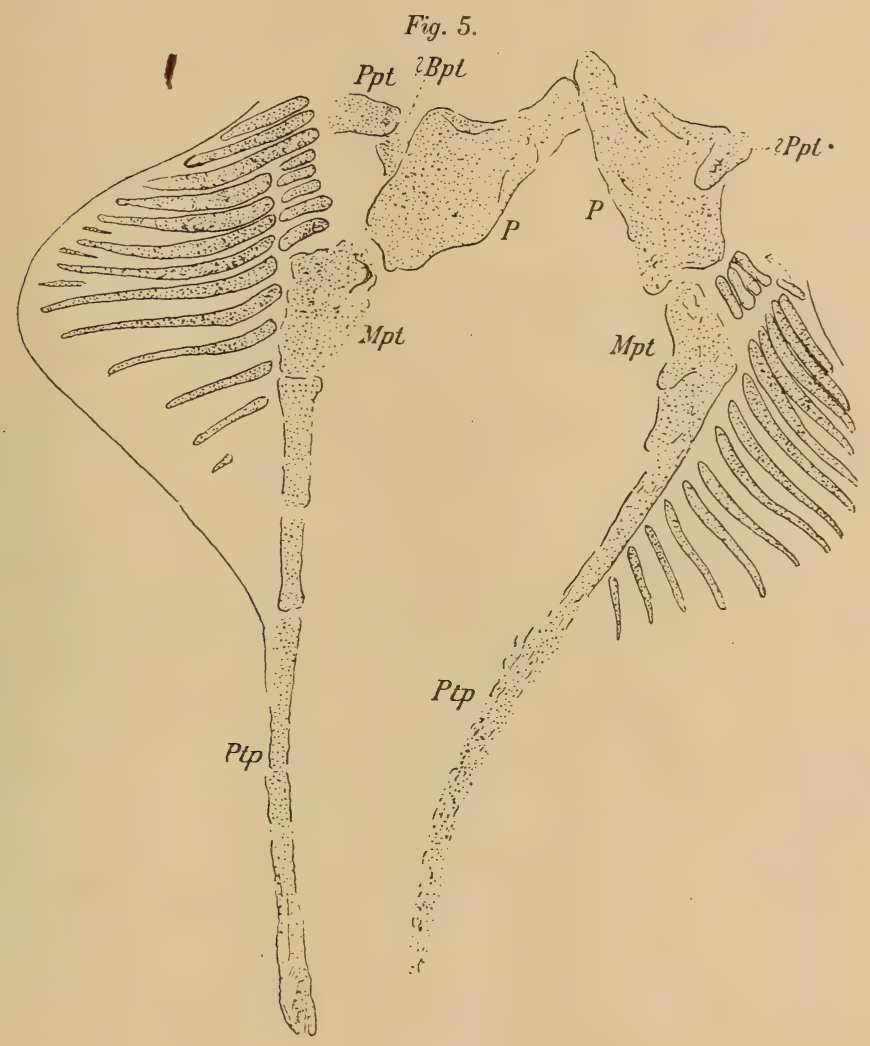

Fig. 61 .

Cladoselache Fyleri. Cleveland shales. Ohio. Beckenflossen nach Jaekel. Ppt Propterygium, Mpt Metapterygium, Ptp Pterygopodien, $P$ Becken.

gelegen. Die vorderen Strahlen sehr kräftig. Oberdevon (Rußland), Kohlenkalk und produktives Karbon; England, Irland, Belgien, Rußland, Nordamerika.

Die Gattungen Dicentrodus Traquair, Phoebodus, Lambdodus, Hybocladodus St. John \& Worthen, Dicrenodus Romanowsky (Carchariopsis Ag., Pristicladodus M. Coy) aus dem Kohlenkalk sind auf isolierte Zähne dieser Gruppe errichtet.

1) Braus $H$., Über neue Funde versteinerter Gliedmaßenknorpel und -Muskeln von Selachiern. (Phys. Med. Ges. Würzburg. 1901. XXXIV. 177.) - Dean, Bashford, Contributions to the Morphology of Cladoselache. Journ. of Morphol. 1894. vol. IX. - A new Cladodont from the Ohio Waverly. Trans. N. Y. Ac. Sc. 1894. XIII. - Jaekel, O., Úber die Beurteilung der paarigen Extremitäten. (Sitz.-Ber. Akad. Berlin. 1909. XXVI.) - Neuberry, St., Palaeoz. fishes of N. Amerika. U. S. Geol. Surv. Monogr. XVI. 1891. - Traquair, R. H., Geol. Mag. 1888. S. 83. - On Cladodus Neilsoni (Traqu.) from the Carboniferous limestone of East Kilbride. Trans. Geol. Soc. Glasgow. XI. 1897. 


\section{Ordnung. Acanthodi. Ag. $\left.{ }^{1}\right)$}

Körper spindelförmig, Chorda persistent; die Skelettknorpel des Kopfes auch innerlich stark verkalkt, zuweilen mit körneliger Oberfläche. A ugen mit einem einfachen Ring dünner dentinöser Sklerotikalplatten. Zähne fehlen. Brust. und Bauchflossen mit sehr schwachen, selten verkalkten äußeren Strahlen. Vor sämtlichen Flossen mit Ausnahme der heterocerken Schwanzflosse stehen kräftige Dentin. stacheln. $5 \mathrm{Kiemenbögen.} \mathrm{Körper} \mathrm{und} \mathrm{ein} \mathrm{Teil} \mathrm{der} \mathrm{Flossen}$ mit einem mosaikartigen Pflaster kleiner, dicker, quadratischer Dentinschuppen bedeckt; die deutliche Seitenlinie zwischen 2 Schuppenreihen auf der Mitte der Flanken. Schädeldach mit unregelmäßigen Hautplättchen. Beckenflosse ohne sexuale Klammerorgane (Pterygopodien).

Die Acanthodi wurden von Agassiz zu der Ganoiden gestellt, Huxley betrachtet sie als Mittelformen zwischen Ganoiden und Selachiern, Lütken und Fritsch reihten sie bei den Selachiern ein. Die Untersuchungen von Traquair, A. Smith Woodward, Reis und Jaekel haben die Richtigkeit dieser Stellung bestätigt, aber in manchen Einzelheiten sind wir leider noch immer nicht genügend unterrichtet.

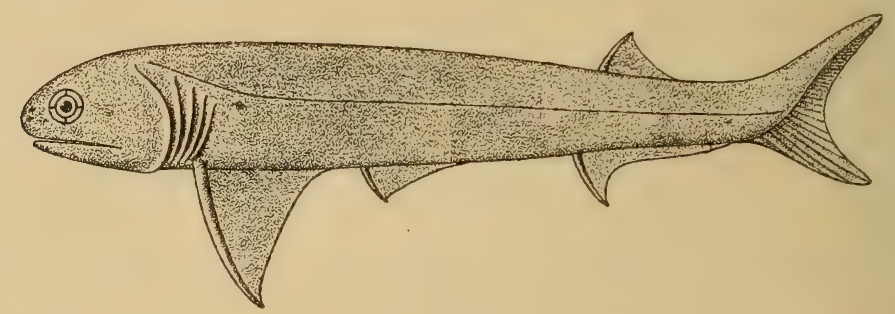

Fig. 62 .

Acanthodes Wardi, Oberkarbon von Staffordshire, ca. 1:3. Nach A. Sm. Woodward. Aus dem - Guide to the fossil Reptilia ete. Mit Genehmigung des Trustees des British Mus. of Nat. Hist.

Nach A. Smith Woodward kann man die Ordnung in 3 Familien (Acanthodidae, Ischnacanthidae, Diplacanthidae) zerlegen.

Die aus dem Obersilur und Devon als Onchus (Fig. 63) beschriebenen Stacheln stimmen so sehr 'mit Climatiusstacheln, daß man sie zum Teil auf Acanthodier zurückführen darf. Dasselbe gilt für andere paläozoische Gattungen, die auf fossile Flossenstacheln errichtet wurden, wie Haplacanthus, Byssacanthus, Homacanthus, Machairacanthus, Gyracanthus, Ptychacanthus.

1) Agassiz L., Poiss. fossiles. II. 1833-35. - Fritsch, A., Fauna der Gaskohle in Böhmen. Bd. II. 1889. - Huxley, Th., Geol. Survey of the United King. dom. Dec. X. 1861. - Kner, R., Sitz.-Ber. Akad. Wien. math.-phys. Klasse. LVII. 1868. - Powrie J., On the earliest known vestiges of vertebrate life. Edinburgh Trans. geol. Soc. 1869. I. 284-301. - Reis, O. M., Zur Kenntnis des Skeletts der Acanthodinen. Geognost. Jahreshefte. München. 1890. 1891. - Illustrationen z. Kenntnis des Skeletts von Acanthodes Bronni Ag. Abh. Senckenberg. Ges. Frankfurt a. M. 1895. - Utber Acanthodes Bronni Ag. (Morphol. Arbeiten. Herausg. v. Schwalbe. VI. Bd. 143-218. - Roemer, $F$., Uber Acanthodes gracilis. Zeitschr. d. deutsch-geol. Ges. 1857. S. 65. - Woodward, A. Sm., Catalogue of fossil fishes. II. S. $1-36$. 


\section{Familie: Acanthodidae.}

Nur eine weitnach hinten gerïckte Dorsalflosse. Brustflosse mit mächtigem Stachel. Acanthodes Ag. (Acanthoessus Ag., Holacanthodes Beyr., Traquairia Frtsch). Körper spindelförmig, Kopf kurz, Maul groß, terminal. Augenring mit 4 bis 5 dünnen, außen rauhen Platten. Das Palatoquadratum besteht aus drei Teilen; der Unterkiefer ist in eine Mandibula und einen prämandibularen Teil zerlegt, an die sich auf der Unterseite ein schmaler dermaler Knochen (Spleniale nach Jaekel, bei Reis als extramandibularer Stachel bezeichnet, Ceratohyale nach A. Sm. Woodward) anlegt. Seine Struktur ist dentinartig; eine Anzahl Kiemenstrahlen reihen sich ihm an. Die Hyoide (jederseits ein Hyoid und ein Prähyoid, durch ein Copula vorn verbunden) sind frei von Kiemenstrahlen, dagegen trägt das Hyomandibulare solche. Die Basis der Brustflosse besteht aus einigen (3) kurzen Knorpeln, die auch

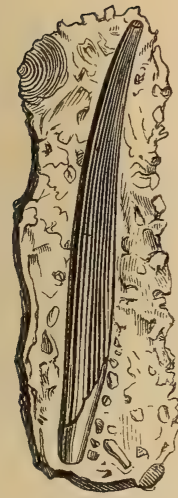

Fig. 63 .

Flossenstachel $\nabla$ on Onchus tenuistriatus Ag. Aus dem obersten Silur von Ludlow, England.

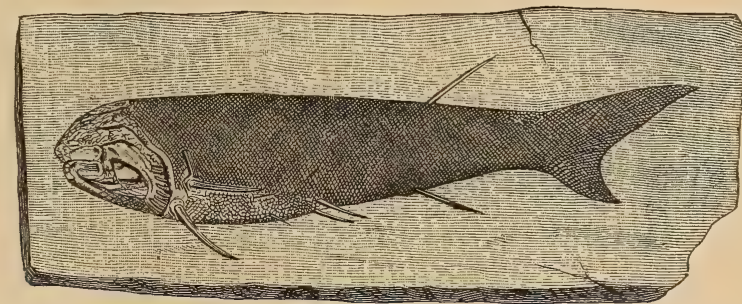

Fig. 64.

Acanthodes Mitchelli Egerton. Old red Sandstone. Farnell, Schottland. Nat. Gr. (Nach Egerton.)

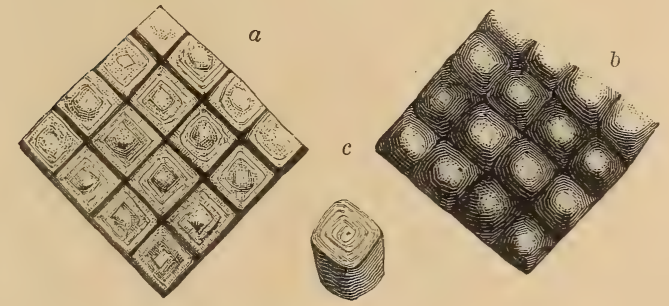

Fig. 65.

Schuppen von Acanthodes gracilis Beyr. $a$ von außen, $b$ von innen, $c$ eine isolierte Schuppe vergr.

verschmelzen können (Reis). Vom Schultergürtel fällt ein großes, rechtwinklig gegen den säbelförmigen Stachel gerichtetes Stück auf, das Reis wegen seiner äußerlich sehr dichten, dentinartigen Struktur als Claviculoid bezeichnet. Nach O. Jaekel ist es ein Hautknochen, dem Cleithrum vergleichbar, der die knorpelige Scapula einhüllt. Außer diesem nimmt er noch eine Suprascapula, ein Coracoid und ein Präcoracoid an. Rückenflosse gegenüber der Afterflosse. Bauchflossen bei den devonischen Arten fast so groß wie die Brustflossen, später mehr und mehr verkleinert und nach vorne gerückt. Häufig im Devon (Old red sandstone) von Schottland und Rußland, im Karbon von Schottland und Böhmen, im Rotliegenden des Saargebiets (Lebach), von Schlesien (Klein-Neundorf), Sachsen (Oschatz), Böhmen (Braunau). Typus: Ac. Bronni Ag. (gracilis). Rotliegendes.

Cheiracanthus Ag. Die Rückenflosse steht vor der Analflosse. Ch. Murchisoni Ag. Unteres Oldred.

Acanthodopsis Hancock u. Atthey. Mit 6 bis 8 kräftigen Zähnen im Ober- und Unterkiefer. A. Wardi Hanc. u. Att. Steinkohlenformation, Northumberland. 


\section{Familie: Ischnacanthidae.}

Zwei Rückenflossen. Die Brustflosse mit großem äußerem aber ohne medianen Stachel.

Ischnacanthus Powrie (Traquair) (Ictinocephalus Page). Mit wenigen großen konischen Zähnen, zwischen denen kleinere stehen. Stacheln längsgerippt. I. gracilis Egerton. Unteres Old red.

\section{Familie: Diplacanthidae.}

Zwei Rückenflossen. Die Brustflosse mit großem äußerem und kürzerem medianem Stachel. Zwischen Brust- und Bauchflosse überzählige Stachelpaare:

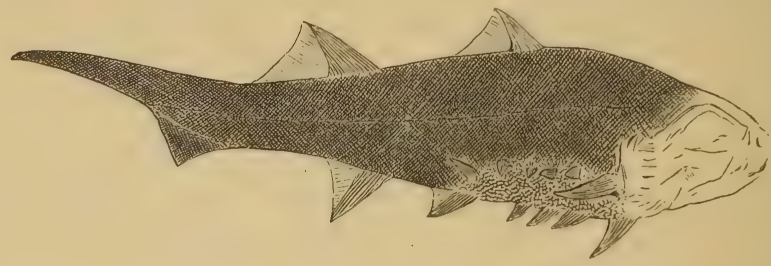

Fig. 66 .

Climatius scutiger Egerton. Old red Sandstone.

Foriarshire, Schottland. Nat. Gr. (Nach Powrie.)

Diplacanthus Ag. (Rhadinacanthus) Traqu. Bauchflossen kaum halb so lang wie die Brustflossen. Nur ein Paar überzähliger, kurzer Stacheln. D. striatus Ag. Unteres Oldred, England; Devon, Canada.

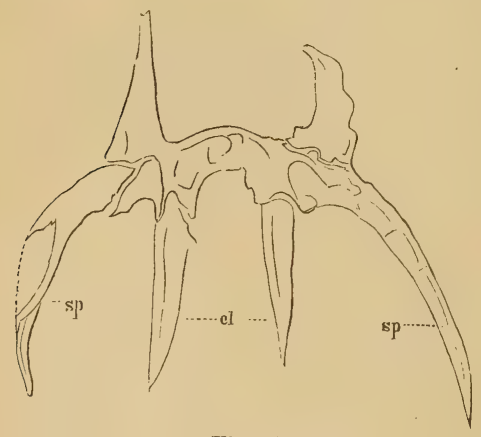

Fig. 67

Schultergürtel von Diplacanthus crassispinus Ag. Old red. Caithness, Schottland. Nat. Gr. (Nach Agassiz.)

Climatius Ag. (Brachyacanthus Egerton, Euthacanthus Egerton). Mehrere Paare kurzer, überzähliger Stacheln. Die Stacheln der Rückenflossen gleich lang, alle sehr kräftig, längsgerippt. $\mathrm{Cl}$. reticulatus $\mathrm{Ag}$. Unteres Oldred.

Parexus Ag. Mehrere überzählige Stachelpaare. Stachel der vorderenRückenflosse weit höher als die zweite; Stacheln längsgerippt, hinten gezähnelt. $P$. incurvus Ag. Unteres Oldred.

\section{Ordnung: Selachii.}

Brust-und Bauchflossen mit kurzen Basalknorpeln (nicht ar. chipterygial). Wirbelsäule meist deutlich gegliedert, die oberen Bogen mit Intercalarien wechselnd, kurz und gedrungen (exkl. Hybodontidae).

Die Selachier wurden von Hasse nach der Beschaffenheit ihrer Wirbel in vier Unterordnungen (Diplospondyli, Cyclospondyli, Asterospondyli, Tectispondyli) eingeteilt. Diese Gruppierung trägt den natürlichen Verwandtschaftsverhältnissen nicht immer genügend Rechnung und ist hier aufgegeben. Bei älteren fossilen Formen ist auch die Beschaffenheit der Wirbel schwer zu prüfen. Es ist aber immerhin für die Systematik und die Beurteilung der Verwandtschaften von Bedeutung, daß alle Rochen tectispondylische, die großen Familien der Lamniden, Carchariiden und Scylliiden astrospondylische Wirbel 
haben. Die Cestracioniden weichen von diesem Bau schon beträchtlich $a b$.

\section{Familie: Notidanidae.}

Wirbelsäule umrollkommen gegliedert, Chorda größtenteils persistent. Gelegentlich treten im Schuanz schwach astrospondylische Wirbel auf. Sech.s bis sieben ungedeckte Kiemenspalten. Zähne mit mehreven schief gestellten, parallelen Spitzen. Nur eine Rïckenflosse und Analfosse, keine Flossenstacheln. Seit dem Jura.

Notidanus Cuv., (Hexanchus, Heptanchus Müller und Henle). Maul auf der Unterseite. Bezahnung oben und unten verschieden. Oberkieferzähne schmäler als die des Unterkiefers, in der Nähe der Symphyse hakenförmig, Symphysenzahn einspitzig. Seitliche Zähne des Unterkiefers kamm-

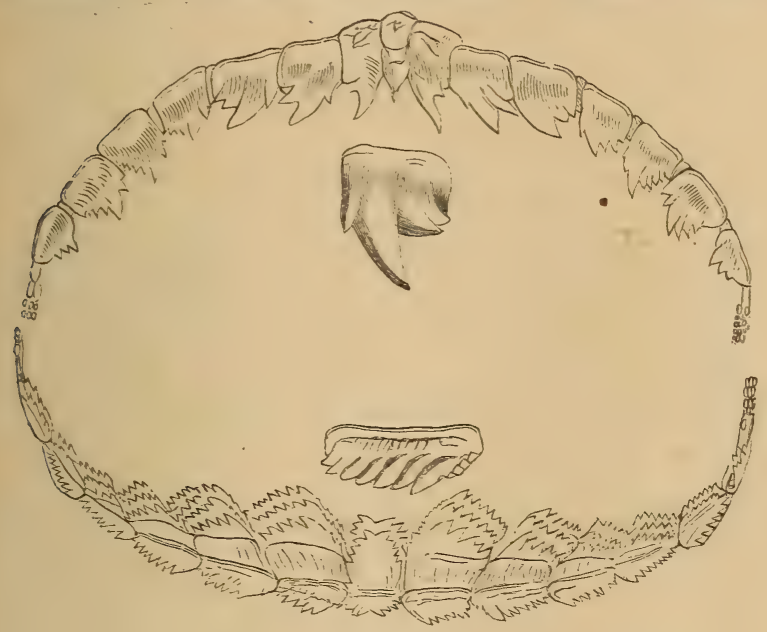

Fig. 68

Rachen vom indischen Grauhai Notidanus (Heptanchus) indicus, Rezent. förmig gezackt, mitmehreren von vorne nach hinten an Höhe abneh. menden Spitzen. In der Symphyse symmetrisch gebildete Zähne, mit mehreren Spitzen jederseits. Im lithographischen Schiefer von Solnhofen ein vollständiges Skelett von Notidamus Miinsteri Ag. Häufig im Tertiär.

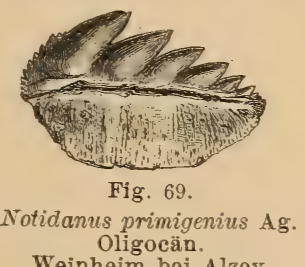

\section{Familie: Chlamydoselachidae.}

Wirbelsüule unrollkommen gegliedert, Chorda größtenteils persistent. Im Schuanz sind einige Wirbelkörper abgegliedert, mit schwach cyclospondylischer Anlage. Zühne von cladodontem. Typus. Sechs Kiemenspalten, von einem vorderen Hautlappen zum Teil gedeckt. Mund terminal. Eine Rückenflosse ohne Stachel.

Chlamydoselache Garm. Zähne mit breitem Sockel, an dessen Vorderrand sich drei schlanke, zurückgebogene Spitzen erheben, zwischen denen schwache Zwischenspitzchen stehen. Unterkiefer nur mit symphysialen Zähnen. Lebend Pliocän, Toscana.

\section{Familie: Spinacidae. Dornhaie.}

Körper spindelförmig bis dreikantig, eturas niedergedruickt. Schnauze stumpf. Die zuei Rückenflossen hëufig mit Stacheln. Kiemenspalten 5, Klein, seitlich in eine Höhe mit der Brustflosse gelegen. Wirbel cyclospondylisch (bzw. tectospondylisch). Brustflosse ohne Ausschnitt an der Basis.

Centrophorus M. u. H. Dorsalstacheln vorhanden. Obere Zähne aufrecht, dreieckig oder lanzettförmig, einspitzig; unten zusammengedrückt, mit seitwärts gerichteter Spitze. Obere Kreide, Libanon (Spinax primaerus Pictet). Tertiär. Rezent. 
A canthias Bonap. (Centrophoroides Davis.) Wie vorige, aber Zähne oben und unten gleich, mit seitwärts gewendeter Spitze. Obere Kreide, Libanon. Tertiär. Rezent. Rezent.

Centrina Cuv. (Oxynotus Rafin.) Sehr starke Dorsalstacheln. Neogen.

Spinax Cuv. (Acanthidium Lowe). Mit Dorsalstacheln. Pliocän. Rezent.

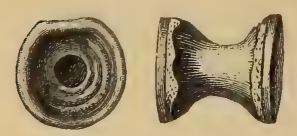

Fig. 70 .

Wirbel (zentraler Doppelkegel) von Centrophorus. Ob. Kreide. Maestricht. (Nach Hasse.)

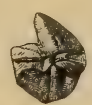

Fig. 71 .

Acanthias raclicans Probst. Miocän. Molasse. Baltringen. $2 / 1$. (Nach Probst.)

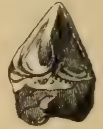

Fig. 72 .

Scymnus triangulus Probst. Miocän. Molasse, Baltringen. $3 / 1$. (Nach Probst.) Scymnus Cuv. (Fig. 72.) Ohne Dorsalstacheln.Ob.Zähne klein, zugespitzt; unt. groß, breit, dreieckig, komprimiert,aufrecht oder nur schwach seitwärts geneigt. Neogen, lebend.

Echinorhinus Blv. (Goniodus Ag.) Pliocän, lebend.

\section{Familie: Pristiophoridae. ${ }^{1}$ )}

Körper spindelförmig, die Brustflossen nicht bis zur Schnauze ausgedehnt. Rostrum stark verlängert, abgeplattet, jederseits mit starken Zähnen (Hautzühnen) besetzt. Die zwei Rückenflossen olne Stachel. Kiemenspalten seitlich. Wirbel cyclospondylisch. Kreide bis jetzt.

Sclerorhynchus A. Sm. Woodw. Obere Kreide, Libanon. (Nach A. Sm. Woodward vielleicht besser zu den Pristiden zu stellen.)

Pristiophorus M. u. H. Miocän, lebend.

\section{Familie: Scylliidae.}

Zwei Rückenflossen olne Stacheln, die vordere ïber oder hinter den Bauchflossen. Wirbel astrospondylisch, mit acht starken Radialstrahlen. Zähne klein, zahlreich, zugespitzt, meist mit Mittelspitze und einem Paar Nebenspitzen. Jura bis jetzt, aber fossil wenig verbreitet.

Palaeoscyllium Wagn. Erste Dorsalis über der Bauchflosse, zweite vor der Afterflosse. Brustflosse sehr breit. Zähne unbekannt, aber wohl sehr klein. Wirbel verkalkt, aber ohne Längsleisten. $P$. minus A. Sm. Woodw. Ob. weißer Jura, Solnhofen.

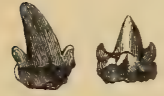

Fig. 73.

Scyllium distans Probst.Miocäne. Molasse. Baltringen. $2 / 1$. (Nach Probst.)

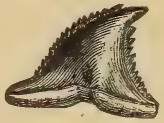

Fig. 74 Hemipristis serraAg. Miocän. Neudörfl, Ungarn.

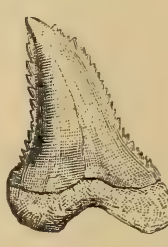

Scyllium Cuv. (Thyellina, Scylliodus Ag.) (Fig. 73.) Erste Dorsalis etwas hinter der Bauchflosse. Zähne klein, mit hoher Mittelspitze und zwei kleinen Nebenspitzen. Kreide, tertiär, lebend.

Pristiurus Bonap. Wie Scyllium, aber Schwanzflosse jederseits am Oberrand mit einer Reihe kleiner Stacheln. Zähne klein, dreispitzig. Pr. Hassei A. Sm. Woodw. Oberer weißer Jura, Solnhofen.

Mesiteia Kramberger. Schwanz außerordentlich verlängert, Schwanz. flosse ohne dermale Stacheln. Obere Kreide, Libanon. Eocän, Monte Bolca. - Chiloscyllium M. u. H., Ginglymostoma M. u. H. (Plicodus Winkl., Acrodobatis Leidy). Tertiär u. lebend.

Cantioscyllium A. Sm. Woodw. (Scylliodus Ag. z. T.). Obere Kreide.

1) O. Jaekel. Zeitschr. geol. Ges. 1890. S. 96. 


\section{Familie: Carchariidae.}

Zuei Rückenflossen ohne Stacheln, die vordere vor der Bauchflosse. Zühne hohl, dreieckig, zugespitzt, Seitenränder scharf oder gezähnelt. Wirbel astrospondylisch mit vier nach außen verbreiterten, verkalkten Radialkeilen. Kreide bis jetzt.

Hemipristis Ag. (Dirhizodon Klunzinger). (Fig. 1439.) Zähne dreieckig, mit grobgezackten Seitenrändern. Tertiär, lebend.

Galeocerdo M. u. H. Vorderrand der Zähne fein gezackt, Hinterrand ausgebuchtet und unten gezähnelt. Miocän bis jetzt.

\section{a Monte Bolca.}

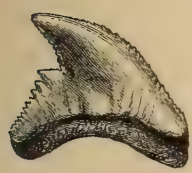

Galeus Ag. (Protogaleus Molin). Zähne klein, schief dreieckig, die Ränder nur über der Basis gezackt. Eocän bis jetzt.

Carcharias Cuv. Zähne meist schief dreieckig, ohne Nebenspitzen, oben und unten verschieden. Seitenränder bis zur Spitze (Prionodon M. u. H.), oder nur über der

$b$

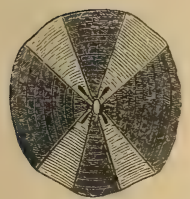

Fig. 75.

a Zahn von Galeocerdo aduncus Ag. Miocäne Molasse. Pfullendorf.

$b$ Wirbel von Galeocerdo. Miocäne

Molasse. Baltringen. (Nach Hasse.)

Basis gezackt (Hypoprion M. u. H.), oder scharfrandig (Scoliodon, Physodon M. u. H.), zuweilen auch aufrecht und scharfrandig (Aprionodon Günther). Tertiär, lebend. C. (Scoliodon) Cuvieri Ag. sp. Eocän, Monte Bolca.

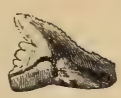

Fig. 76.

Galeus affinis Probst. Miocän. Baltringen,

Württemberg

(Nach Probst.)

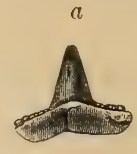

a Aprionodon frequens Dames. Eocän. Birket-el-Qurun. Agypten. (Nach Dames.)

b Hypoprion singularis Probst. c Scoliodon Kraussi Probst. d Prionodon similis Probst. $b-d$ aus der miocänen Molasse von Baltringen, Württemberg. (Nach Probst.)

Sphyrna Rafin. (Zygaena Cuv.). Tertiär, lebend.

Mustelus Cuv. Pliocän, lebend. Wirbel nach $\mathrm{H}$ asse im Danien von Ciply. Triaenodon, Triacis M. u. H. Rezent.

\section{Familie: Lamnidae.}

Zwei Rïckenflossen ohne Stachehn, die vordere vor der Beckenflosse. Zühne groß, zugespitzt, mit oder ohne Nebenzacken, mit Vasodentin fest ausgefiull. Wirbel

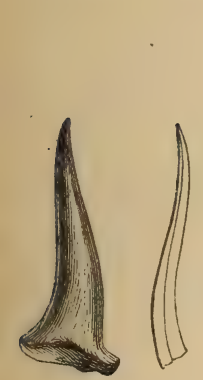

Fig. 78.

Orthacodus longidens Ag.

Weißer Jura $\gamma$. Böllert, Württemberg.

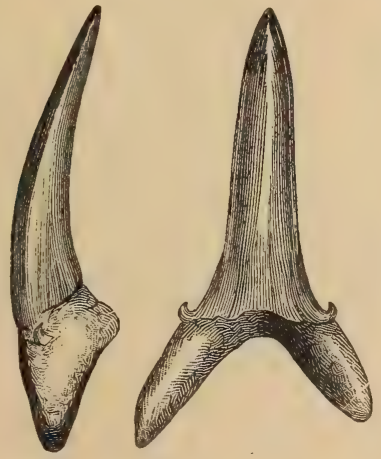

Fig. 79.

Lamna cuspidata Ag. Oligocän. Weinheim bei Alzey. astrospondylisch, mit nach außen gegabelten Radialstrahlen bzw. 4 Gruppen von Strahlen.

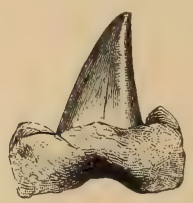

Fig. 80 .

Lamna (Otodus) appendiculata Ag. Pläner. Quedlinburg.

Lamna (Otodus) obliqua Ag. (Außenseite) Eocän. Sheppy. $4^{*}$ 
Orthacodus A. Sm. Woodw. (Sphenodus Ag.) Sehr schlanke, aufrechte Zähne ohne Nebenspitzen. Wurzel abgestutzt, einfach. Jura, untere Kreide. Odontaspis Ag. (Triglochis M. u. H., Rhinognathus Davis). Zähne mit schlanker, seitlich zugeschärfter, vorne abgeplatteter, hinten gewölbter Hauptspitze und 1-2 kleinen Nebenspitzen. Wurzel groß, zweilappig. Kreide bis jetzt. O. Hopei Ag., Monte Bolca. Eocän.
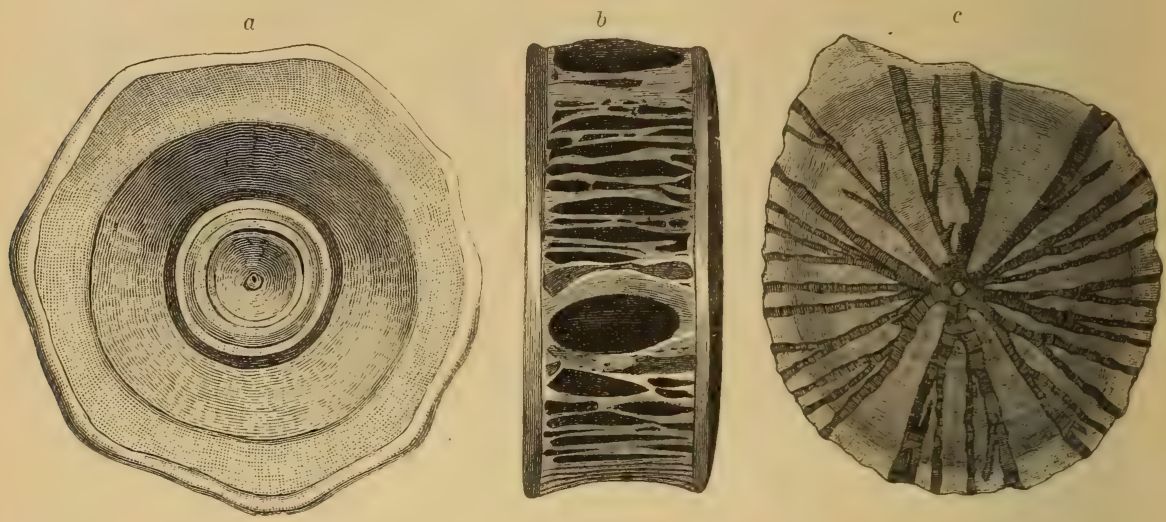

Fig. 82.

$a-b$ Lamna-Wirbel aus dem Oligocän von Flonheim, von vorne und von der Seite, $c$ vertikaler Medianschnitt aus dem Londonthon von Sheppey. Nat. Gr. (Nach Hasse.)

Scapanorhynchus A. Sm. Woodw. (Miksurina Jord.) Rostrum sehr verlängert, Kiefer mehr oder weniger vorstreckbar, unter dem Rostrum. Obere Kreide, Libanon. Lebend (japan. Meer).

Lamna Ag. (Otodus Ag.) Zweite Dorsalis und Analis sehr klein. Schwanz seitlich mit Kiel, Zähne wie bei Odontaspis, aber Mittelspitze meist etwas breiter und Nebenspitzen größer. Kreide, Tertiär, lebend, sehr verbreitet.

Oxyrh in a Ag. Zähne wie Lamna, aber ohne Nebenzacken. Kreide bis jetzt. O. Mantelli Ag. Kreide. Alopecias M. H. Tertiär, lebend.

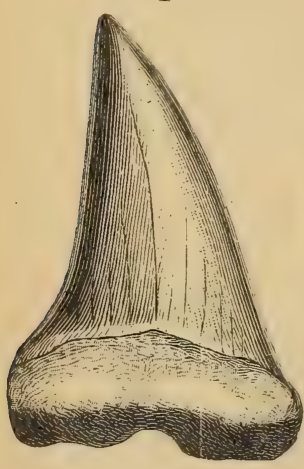

Fig. 83.

Oxyrhina plicatilis Ag. Miocän. Neudörfl, Ungarn.

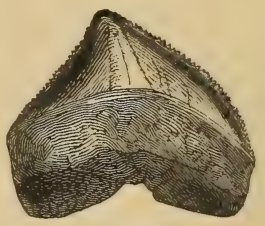

Fig. 84 .

Corax pristodontus Ag. Ob.Kroide. Oase Dachel. Libysche Wüste.

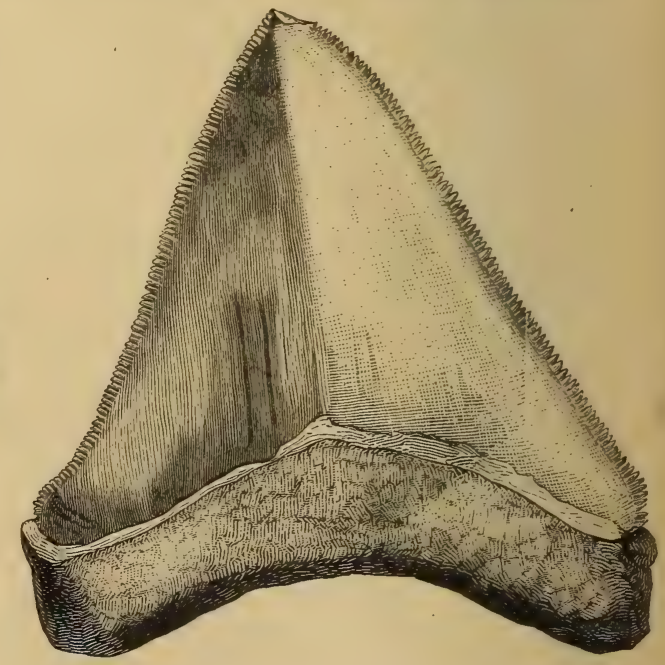

Fig. 85. Carcharodon megalodon Ag. Pliocän, Malta.

Corax Ag. Nur kurz dreieckige, an den scharfen Seitenrändern gezackte Zähne mit großer Wurzel bekannt. Mittlere und obere Kreide, häufig. 
Carcharodon M. H. Zweite Dorsalis und Analis sehr klein, Schwanz ohne seitlichen Kiel. Zähne sehr groß, dreieckig, vorne flach, hinten gewölbt, die Seitenränder gezähnelt. C. Rondeletii M. H. Lebend (auch Neogen). Andere Arten von der oberen Kreide an. C. megalodon Ag. Eocän bis Pliocän. Zähne bis $15 \mathrm{~cm}$ hoch.

Cetorhinus Blv. (Selache Cuv.) Zähne sehr klein, konisch, ohne Seitenzacken. Pliocän, lebend.

\section{Familie: Hybodontidae.}

Chordascheide ohne Verkalkung etwa vorhandener Knorpelbildungen. Neuralbögen lang, flattrig, im Schuanz reduziert. Thoracalregion mit langen Rippen, von der ersten Dorsalflosse an viel kürzere, den Rippen homologe Hämailspangen. Schwanzflosse ausgeprïgt heterocerk, mit starken, breiten Hämapophysen, reduzierten oberen Bögen. Analflosse niedrig, nahe der Schwanzflosse, mit Knorpelplatten. Zuei Dorsalflossen, jede mit starkem Stachel, der bis zur Spitze der Flosse reicht, mit ihr in Verbindung bleibt und von einer breiten $\mathbf{K}$ norpelplatte gestützt wird. Mehrere akzessorische Flossenstützen. Stachel mit Längsrippen und Marginaldornen. Brustflosse mit kleinem Propterygium und stark entwickeltem Mesopterygium. Beckenflosse mit dreiseitigem Basalstück. Hyomandibulare derb, vertikal verlängert, unten verschmälert und verdickt, in einer deutlichen Gelenkgrube dem Processus postorbitalis anliegend. In die unmittelbar davor liegende Grube faßt der aufsteigende Teil des Palatoquadratum, das aber auch vorn einen Fortsatz gegen den Processus präorbitalis entsendet. Lippenknorpel vorhanden. 5 Kiemenb.̈gen. Männchen mit. Pterygopodien und hakenförmigen Kopfstacheln (Sphenonchus). Diese Charakteristik der Familie gründet sich im wesentlichen auf die gut gekannte Gattung Hybodus Ag. Unterkarbon bis Kreide.

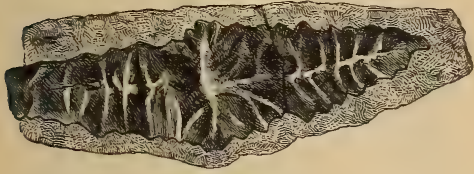

Fig. 86 .

Orodus ramosus Ag. Kohlenkalk. Armagh, Irland. (Nach Davis.)
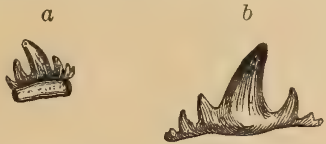

Fig. 87.

Zähne von a Hybodus plicatilis Ag. Muschelkalk. Laineck bei Bayreuth. b Hybodus reticulatus Ag. Unt. Lias. Lyme Regis, England. c Hybodus polyprion Ag. Dogger. Stonesfield, England.

Orodus Ag. (Fig. 86). Nur quer verlängerte, gekielte Zähne bekannt; der Kiel bildet eine stumpfe niedrige Mittelspitze und mehrere Nebenspitzen, von denen derbe Runzeln nach der Basis laufen. Wurzel sehr stark. O. cinctus Ag. (Typus). O. ramosus Ag. Kohlenkalk.

Ctenacanthus Ag. (Sphenacanthus Ag.) Zwei Dorsalflossen, jede mit starkem Stachel, dessen Längsrippen Knötchen tragen. Schnauze stumpf, Schwanz heterocerk. Bauchflossen der zweiten Dorsalis gegenüber. Neuralbögen lang, flattrig; im unteren Schwanzlappen lange Hämalia als Stützen. Zähne mit schlanker mittlerer Spitze und einigen Nebenspitzen. Placoidschüppchen mit strahligen Rippen.

Ct. costellatus Traquair. Unterkarbon, Schottland (ganzer Fisch).

Hybodus Ag. ${ }^{1}$ ) (Meristodon Ag., Orthybodus Jaek., Polyacrodus Jaek. pr. p.) Zähne quer verlängerty mit hervortretender Mittelspitze und mehreren Nebenspitzen (Fig. 87), der Schmelz mit vertikalen Fältchen. Zähne der Symphysengegend verhältnismäßig groß. Vasodentin bildet den Hauptbestandteil des Zahns und zieht sich hoch in die. Mittelspitze hinauf. Placoidschüppchen konisch, mit radialen Rippen. Kopfstachel des Männchens (Sphenonchus) hakenförmig, jederseits hinter den Augenhöhlen. Rücken-

1) Literatur vgl. E. Koken, Uber Hybodus. Pal. Abhandl. V. (N. F.) 1907. 
flossenstachel am ganzen Hinterrand mit Marginaldornen. Untere Trias bis Kreide, zahlreiche Arten, besonders in Muschelkalk, Keuper, oberen Karrooschichten, Lias, Jura, Wealden und Kreide. $H$. reticulatus Ag. Typus der Gattung. Unterer Lias. H. Hauffianus E. Fraas. Oberer Lias, Schwaben, in mehreren Skeletten bekannt. $H$. Fraasi Brown. Oberer weißer Jura, Solnhofen. $H$. basanus A. Sm. Woodw. Wealden.

Tristychius Ag. (Ptychacanthus Ag.) Stacheln distal mit drei Rippen, davon eine am Vorderrand; hinten zwei Reihen Marginalzähnchen. Karbon.

Acrodus Ag. (Thectodus Plieninger,Leiacanthus Ag:)Zähne der Symphysenregion mit Mittelund Nebenhöckern, sonst nur einfach gekielt. Schmelz fein ge-

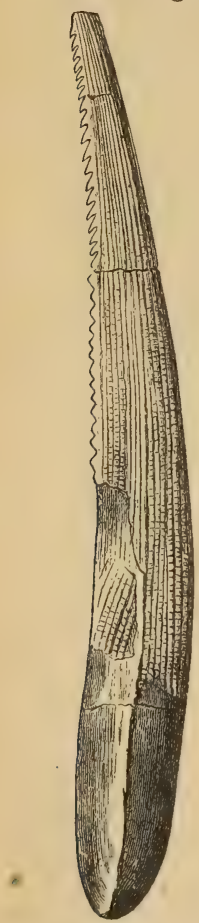

Fig. 88.

Ctenacanthus denticulatus M'Coy. Kohlenkalk. Monaduff, Irland. $1 / 2$ nat. Größe. fältelt; Zahnkörper wesentlich aus $\mathrm{Va}$ sodentin bestehend. Dorsalstacheln und Kopfstacheln wie bei Hybodus.

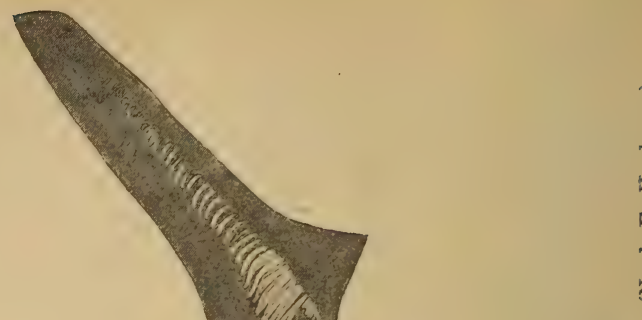




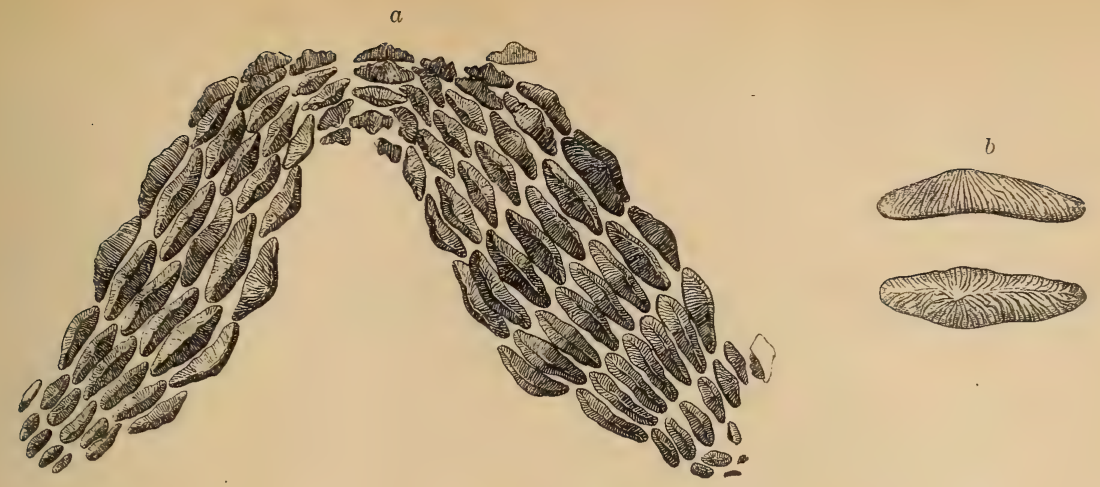

Fig. 91. Acrodus Anningiae Ag. Unt. Lias. Lyme Regis, England. $a$ Unterkiefer $1 / 3$ nat. Gr., $b$ ein einzelner Zahn nat. Gr. von der Seite und von oben.

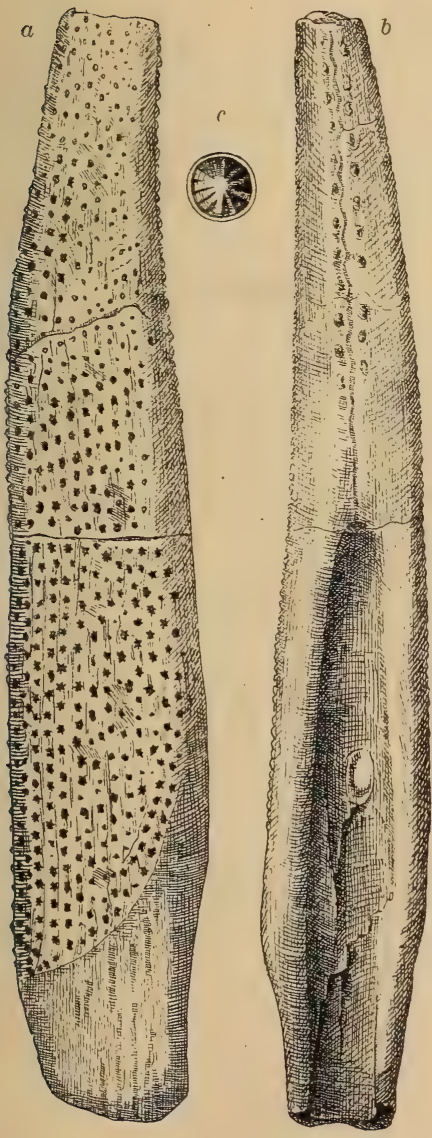

Fig. 92

Asteracanthus ornatissimus Ag. Portlandkalk. Solothurn. $a$ von der Seite, $b$ von hinten, $c$ ein Oberflächenkorn vergr.

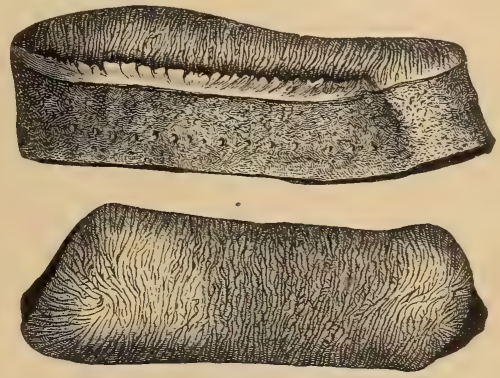

Fig. 93.

Strophodus reticulatus Ag. Coralrag. Tonnerre. Yonne.

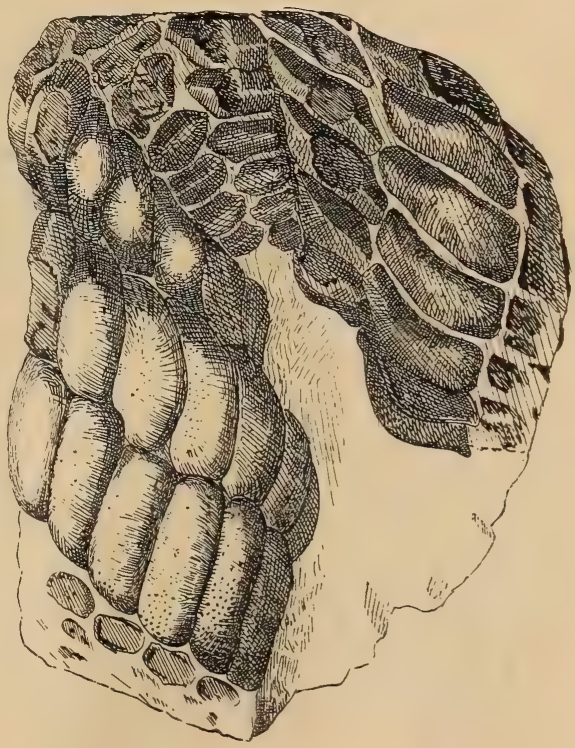

Fig. 94 .

Strophodus medius Owen. Unterkiefer. Großoolith. Caen-Calvados. $1 / 2$ nat. Gr. (Nach Owen.) 
Trias, Jura, Kreide Acr. lateralis Ag. (vgl. Jaekel). Muschelkalk etc A. Anningiae Ag. Unterer Lias (Fig. 94).

Polyacrodus Jaek. Nach Abtrennung der liassischen Formen (Hybodus) lassen sich Zähne, welche eine bedeutend stärkere Dentinbildung zeigen als Acrodus und Hybodus, mit diesem Gattungsnamen zusammenfassen. P. polycyphus Ag. Untere und mittlere Trias.

Asteracanthus Ag. (Strophodus Ag., Curtodus Sauvage). Zähne sehr verlängert vierseitig bis quadratisch, mit leicht gewölbter, fein netzförmig gerunzelter Krone und starker Basis. Symphysenzähne wenig, kleiner als die seitlichen Zähne, stark gewölbt, gekielt, aber ohne Nebenspitzen oder seitliche Höcker. Flossenstacheln mit relativ großen sternförmigen Höckern, von ungleicher Größe, am Hinterrand mit medianer Leiste und mit zwei seitlichen Zähnchenreihen. Männchen mit großen, hakenförmigen Kopfstacheln (Sphenonchus). Mittlerer und oberer Jura. Wealden. Ast. ornatissimus Ag. Brauner und weißer Jura.

Wodnika Mstr. Große, leicht gerundete Pflasterzähne in mehreren Reihen. Nur wenige Symphysialzähne. Rückenstachel mit breiten Längsleisten. W. Althausi Mstr. Kupferschiefer.

\section{Familie: Cestracionidae.}

Wirbelkörper verkalkt (meist deutlich astrospondylisch), Neuralbögen niedrig, gedrängt. Flossenstachel kürzer als die dorsalen Flossen, mit freien Spitzen, glatt

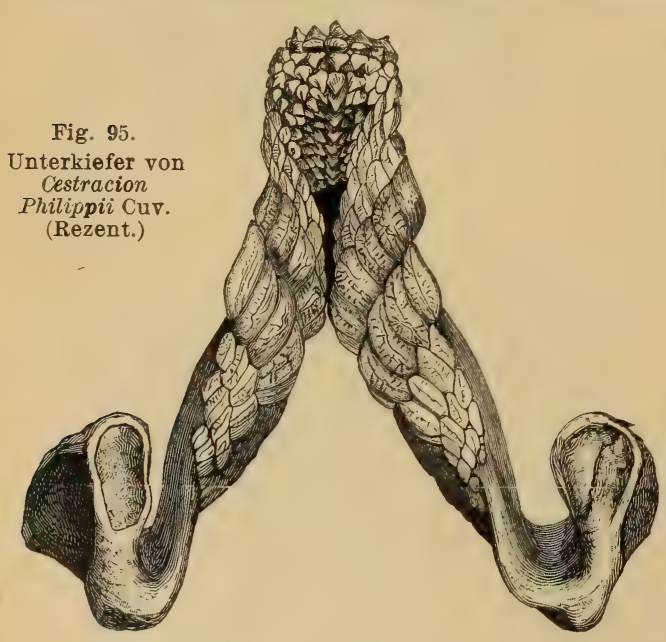
oder mit Höckern. Schwanzflosse weniger heterocerk als bei Hybodonten. Männchen ohne Kopfstacheln.

Cestracion Cuv. (Heterodontus Bl., Drepanephorus Egerton). Symphysenzähne zahlreich, klein, mit Nebenspitzen. Seitliche Zähne länger, schwach gekielt, fein gerunzelt. Flossenstachel glatt, ohne Zähnchen am Hinterrand. Kreide. Lebend, westl. Pazifik.

Paracestracion Koken. Flossenstachel auf den Seiten fein gekörnt. Zähne mit Mittelkante, auch in der Symphyse ohne Nebenspitzen. Oberer weißer Jura, Solnhofen, Nusplingen.

Palaeospinax Egerton. Vordere Zähne höher als die hinteren, mit mehreren, Symphysenzähne mit jederseits einem Nebenhöcker. Keine Kopfstacheln. Pterygopodien mit großen hakenförmigen oder gegabelten Stacheln. Flossenstachel glatt mit dickem Ganoin, über der Insertionsmarke zuweilen mit kleinen Höckerchen, kürzer als die Dorsalflosse, oben frei. Feines, dichtes Chagrin. P. priscus Egerton. Unterer Lias. P. Egertoni A. Sm. Woodw. Oberer Lias, Württemberg.

Synechodus A. Sm. Woodw. Ähnlich Palaeospinax; alle Zähne mit zahlreichen Nebenspitzen, fein gestreift. Wirbel astrospondylisch. Untere und obere Kreide. S. dubrisiensis Macki sp.

Bdellodus Quenst. Zähne vierseitig; leicht gebogen, flach, die vorderen aufgetrieben, aber nicht gekielt, die der vierten (hinteren) Querreihe sehr lang und groß. Bd. bollensis Qu. Lias E., Württemberg. 
Palaeobates H. v. Meyer. Zähne flach, gerundet, nicht gekielt; Krone fast ausschließlich aus Dentin gebildet; Wurzel mit Vasodentin, Placoinschmelz dünn. $P$. angustissimus Ag. sp. Muschelkalk.

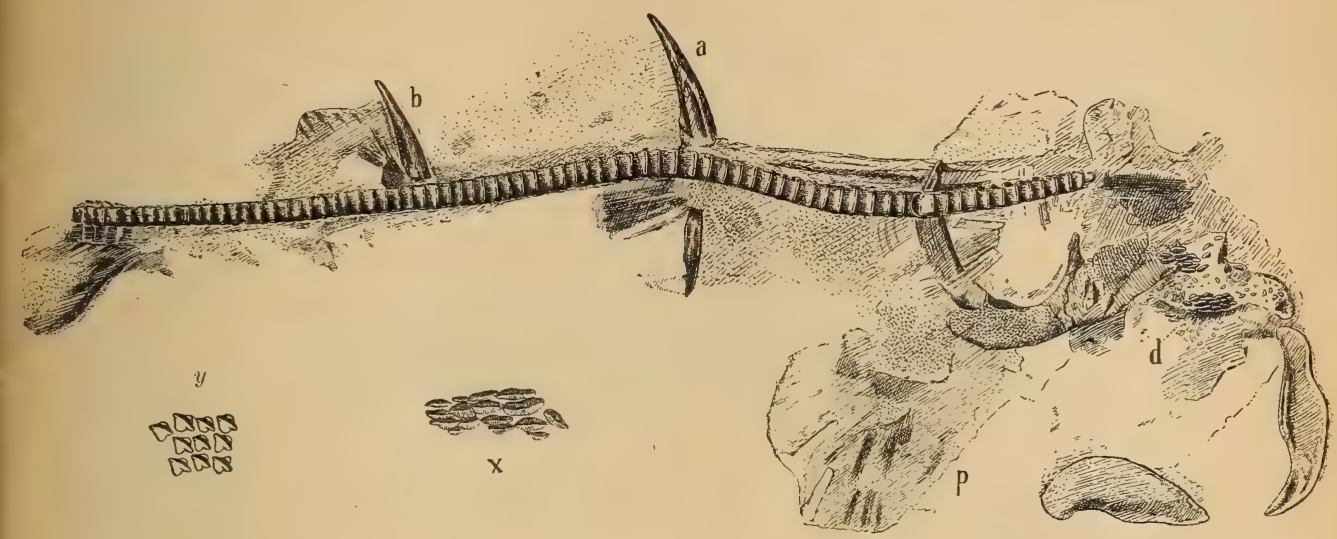

Fig. 96.

Paracestracion falcifer A. Wagner. sp. Lithographischer Schiefer. Solnhofen, Bayern. Ganzes Skelett 1/3 nat. Gr. $a$ vorderer, $b$ hinterer Flossenstachel, $p$ Brustflosse, $d$ Zähne, $y$ Schuppen, $x$ Zähne nat. Gr.

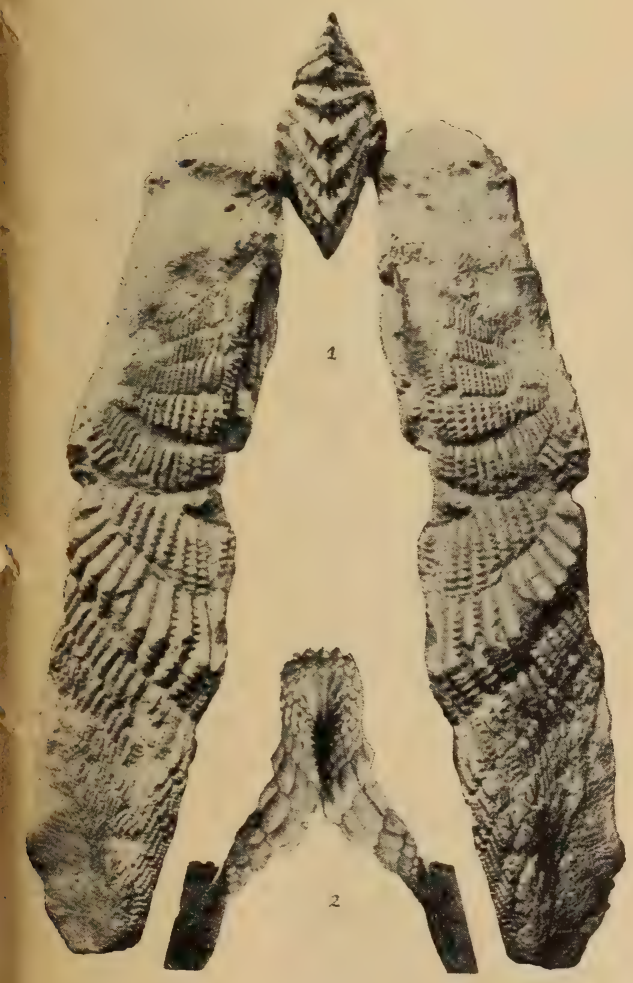

Fig. 97 .

1. Campodus variabilis Newb. u. Worth. Oberkarbon, Nebraska. Symphysialzähne zwischen die Äste des Unterkiefers eingefügt. $1: 2$.

Cestracion Francisci Girard. Zum Vergleich mit Campodus. (Nach Eastman.)
Campodus Kon. $\left.{ }^{1}\right)$ Zähne schmal, mit gleichmäßig gegen die Mitte ansteigenden Höckern, die durch tiefe Einschnitte getrennt sind. Diese Zähne stehen in zahlreichen Binden auf dem Kiefer. In der Symphysenregion eine spiral entwickelte Reihe winklig gebogener Zähne, mit höherer Mittelspitze. Missourian, Kansas.

1) St. John u. Worthen, Palaeont. Illinois. VI. p. 318. - De Koninck, Descr. Anim. foss. terr. carbon. Belg. 1844. 617. - Lohest, Recherches s. 1. terrains paléozoiques de Belgique. Ann. Soc. géol. Belg. XI. 1883. S. 314.

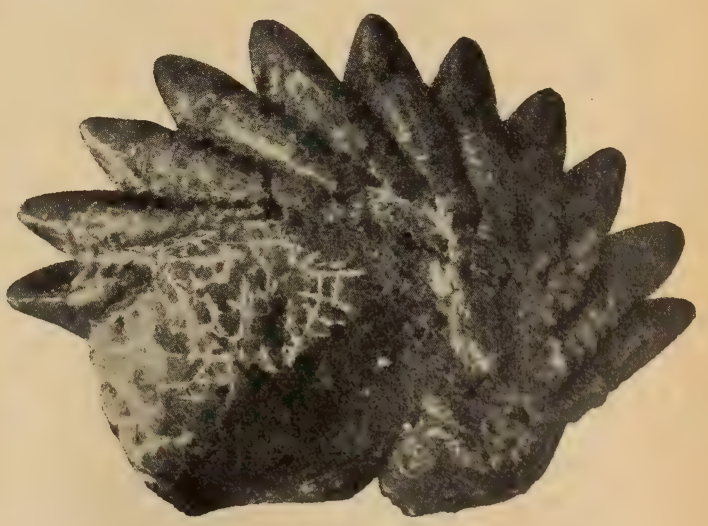

Fig. 98.

Campodus variabilis Newb. u. Worthen, Oberkarbon, Nebraska. $2: 5$. Symphysenbezahnung, wahrscheinlich des Unterkiefers. (Nach C. R. Eastman.) 


\section{Familie: Edestidae.}

Bekannt sind nur die zahn- oder stachelartigen Organe, die durch partielle oder totale Verschmelzung einzelner Segmente zustandekommen. Jedes Segment ist zahnartig, mit schmelzbedeckter Krone und einer langen Wurzel, aus Vasodentin aufgebaut. Die scharfen Seitenkanten der etwa an Carcharias erimnernden Zähne liegen aber in der Sagittalebene, sind also nach vorn und hinten, nicht seitlich. gerichtet.

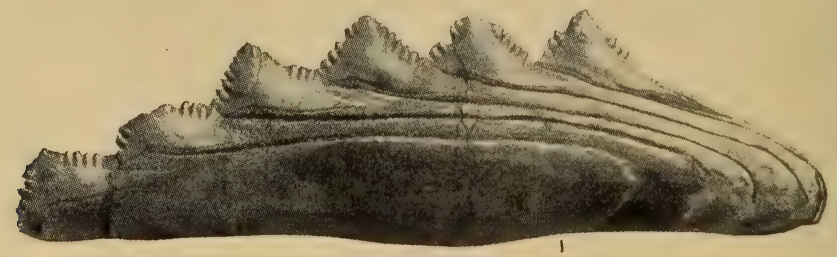

Fig. 99.

Edestus crenulatus Hay. Oberkarbon, Illinois. 2:5. (Nach Hay.)

Edestus Leidy. Die großen Stachel bestehen aus verwachsenen bzw. ineinander gefalzten Zähnen, deren Kronen sich vom Ober- oder Vorderrand des Organs frei erheben. Die Grenzen der einzelnen Zähne sind durch tiefe Furchen auf der Seite des Organs markiert.

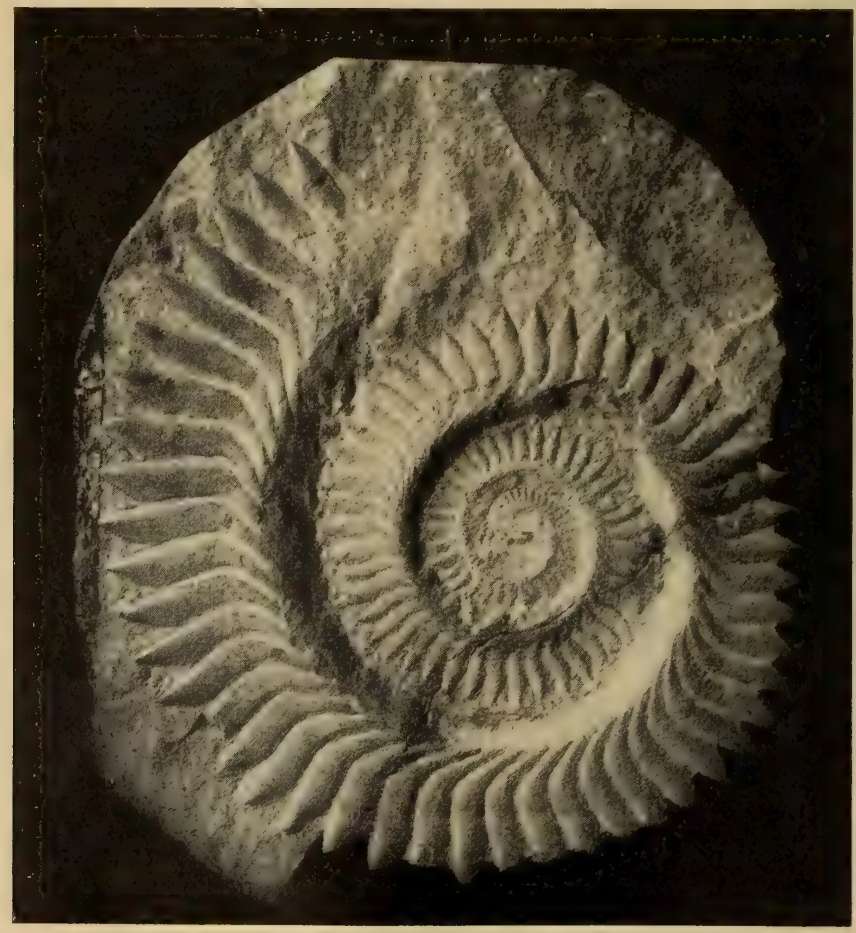

Fig. 100.

Helicoprion Bessonowi Karpinsky. Unteres Perm (Artinskische Stufe). Spiralorgan, 1: 2. (Nach Karpinsky.) 
Toxoprion Hay (Campyloprion Eastm.). Gekrümmte, aber nicht spiral gewundene Stachelorgane. T. Lecontei Dean. Obercarbon, Nordamerika.

Helicoprion Karpinsky. Das Organ bildet eine enggezogene Spirale, die aus einzelnen Segmenten zusammengewachsen ist. Die Zahnkronen scharf crenuliert. Der Schaft ist, wie andere Selachierknorpel, mit Kalkplättchen überzogen (nicht mit Placoidschüppchen, wie Karpinsky angibt). Nach Karpinsky am wahrscheinlichsten als verwachsene Symphysenzähne des Oberkiefers zu deuten, nach Eastman als solche des Unterkiefers. Nach $\mathrm{Hay}$ eine verschmolzene Folge von Stacheln, die sich vor oder an der Stelle einer Dorsalflosse entwickelten; die frei herausgedrängte Spirale mochte sich auf die eine Seite der Flosse geschoben haben.

Lissoprion Hay. Gekrümmt wie Helicoprion. Zähne am Rande glatt

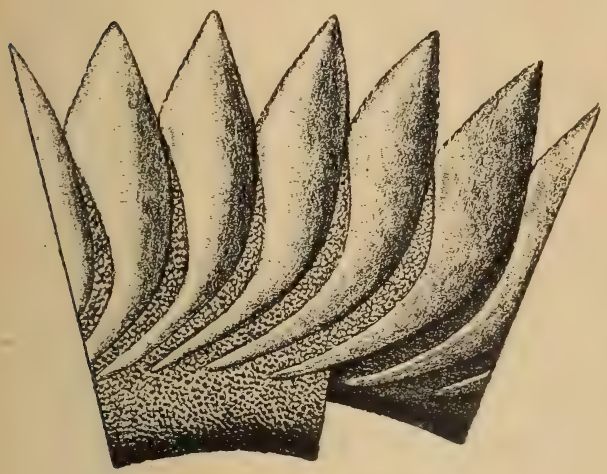

Fig. 101

Helicoprion Bessonowi Karpínsky. Restaurierter Teil des Spiralorgans. (Nach Karpinsky.) oder nur schwach crenuliert, die Wurzeln ohne Trennungsmarke verwachsen.

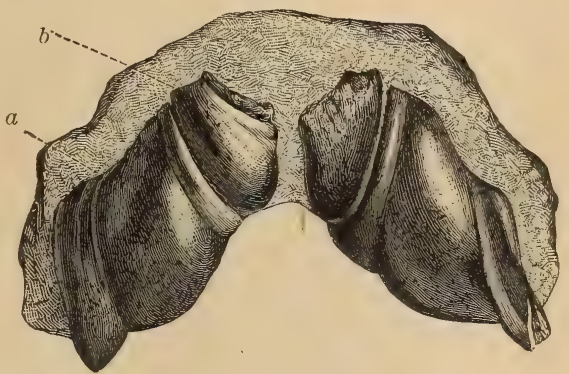

Fig. 102.

Cochliodus contortus Ag. Kohlenkalk. Armagh, Irland. $3 / 4$ nat. Gr. a Großer Hinterzahn, b Mittelzahn. (Die Vorderzähne fehlen.)

\section{Familie: Cochliodontidae.}

Paläozoische Fische mit wenigen gewölbten, an der Basis ausgehöhlten, mehr. oder weniger gebogenen Zähnen, die nicht gewechselt werden. Die Kronen sind fein punktiert und häufig mit stumpfen, schrägen Querfalten oder Furchen versehen. Jederseits (oben und unten) ein großer Hauptzahn, und vor diesem meist zwei oder mehr kleinere Vorderzähne.

Die Kenntnis dieser eigentümlichen, auf Karbon und Perm beschränkten Familie ist noch sehr ungenügend; meist liegen nur Zähne oder Flossenstacheln vor. A. Smith Woodward (und früher schon R. Owen) vergleicht die Cochtiodonten mit den Cestracioniden und faßt die gekrümmten Zahnplatten als Verschmelzungsprodukte von Einzelzähnen einer Querbinde auf. Jaekel gibt ihnen eine besondere Stellung als Trachyacanthidae (unter Bezugnahme auf den Befund bei Menaspis) und rechnet hieher unsymmetrische, wurzellose, rauh skulptierte Stacheln, die als Oracanthus, Pnigeacanthus, Cladacanthus, Platyacanthus, Gampsacanthus, Physonemus, Stichacanthus etc. beschrieben wurden.

Cochliodus Ag. Auf jedem Unterkieferast drei stark gebogene (eingerollte), gewölbte Zähne; der hintere sehr groß, mit breitem, vorn und hinten durch eine schiefe Querfurche begrenztem Mittelfeld; der zweite von rhomboidischer, der vordere von dreieckiger Gestalt. Wahrscheinlich mit kleinen Symphysenzähnen. C. contortus A. u. a. Kohlenkalk.

Streblodus Ag. Wie Cochliodus, aber Hauptzahn mit 2-3 breiten, schrägen Querfalten. Kohlenkalk.

Tomodus Davis. Unterkarbon. Diplacodus Davis. Oberkarbon.

Xystrodus Ag. Cyrtonodus Davis. Oberkarbon. 
Sandalodus Newb. u. W. (Trigonodus, Vaticinodus Newb. W., Orthopleurodus St. John u. W.) Obere Zähne dick, dreieckig, schwach eingerollt.

$B$

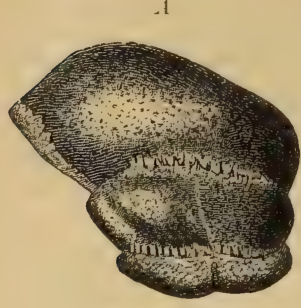

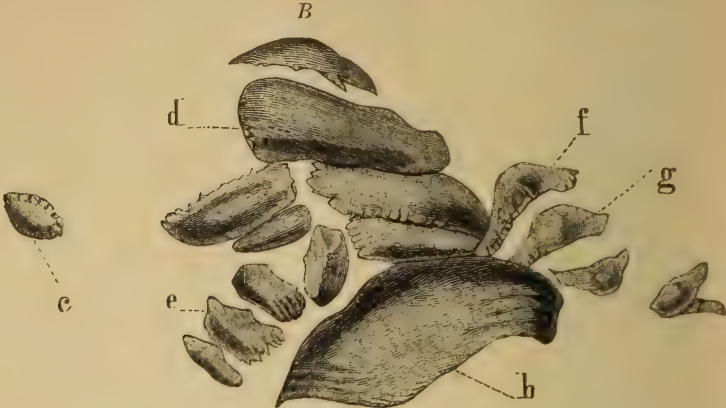

Fig. 103. Psephodus magnus Ag. A Drei zusammenhängende Zähne in nat. Gr. aus dem Kohlenkalk von Armagh, Irland. (Nach Davis.)

$B$ Psephodus magnus Ag. Zusammenhängende obere Zähne aus einem Schädelfragment von Kilbridge, Lankashire. b Großer Zahn etwas gebrochen, $c$ kleiner Zahn, identisch mit Helodus rudis M'Coy, d schmiale Zähne, identisch mit Helodus planus Ag., c Helodontenzähne, $f, g$ Zähne, identisch mit Lophodus didymus und laevissimus. (Nach Traquair.)

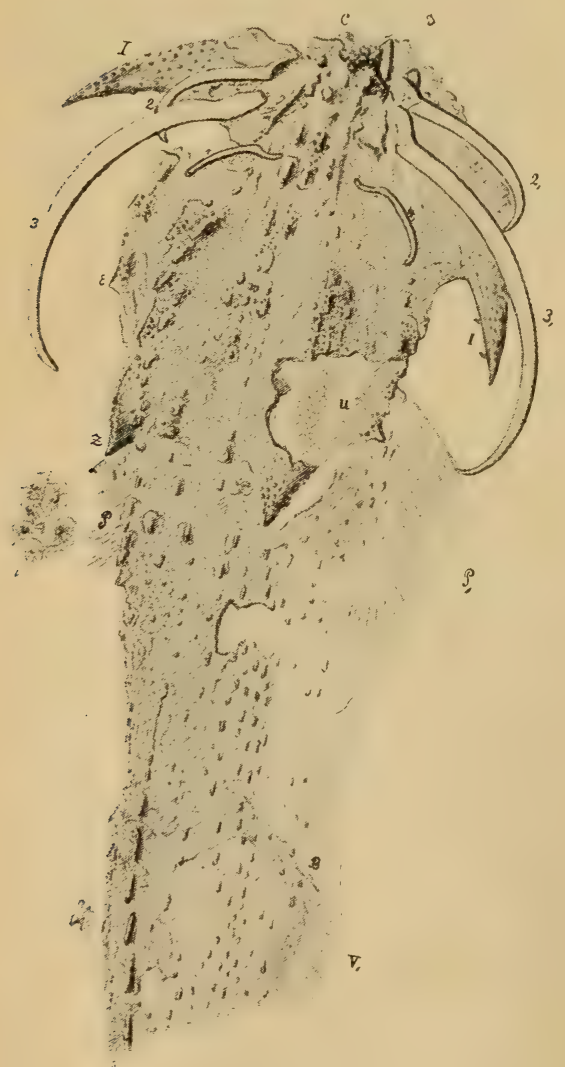

Fig. 104.

Menaspis armata Ewald. 2:3. Kupferschiefer. 2-4 und I Kopfstacheln, $E, Z$ zapfenartige Stachelschuppen, $P$ Brustflossenteile, $V$ Beckenflossenteile. (Nach Ja k k l.)
Im Unterkiefer 2 Zähne, davon der hintere subtriangulär oder keulenförmig, vorne zugespitzt, etwas eingerollt, mit 1-2 Diagonalwülsten; der vordere kurz, vorn abgestutzt, stark eingerollt.Kohlenkalk, Europa,Nordamerika. S.Morrisi Dav. Unterkarbon. Deltophychius Ag., Chitinodus St. John u. W., Poecilodus Ag., Deltodus Ag., Xystrodus Ag., Kohlenkalk.

Psephodus Ag. Große rhombische oder rhomboidische, schwach gebogene, konvexe Zähne mit gekerbten Rändern. Mit diesen großen Zähnen sind zuweilen eine größere Anzahl kleiner, quer verläiıgerter Zähne verbunden, die isolieri als Helodus, Lophodus, Aspidodus und Taeniodus beschrieben wurden. Kohlenkalk, Europa, Nordamerika. Ps. magnus Mc Coy sp.

Pleuroplax A. Sm. Woodw. (Pleurodus Hanc. Atthey). Kieferäste in spitzem Winkel vereinigt. Zahnplatten gekielt, mit Furchen und seitlichen Kerben, welche die Zahl der Komponenten andeuten. Dorsaler Flossenstachel komprimiert, breit, glatt oder t€in gestreift. Körper flach. Karbon, England.

Menaspis Ewald ${ }^{1}$ ) (Fig. 104)

1) Jaekel O., Uber Menaspis ar. mata. Sitz.-Ber. naturf. Freunde. Berlin 1891. - Reis, O. Utber die Kopfstacheln von M. armata. Geogn. Jahreshefte. München 1891. 
(Dichelodus Gieb., Chalcodus Zitt-). Kopf und Rücken mit Längsreihen von knochigen oder dornigen, teilweise gekielten Placoidschuppen und kleinen Chagrinkörnchen bedeckt. Zwei Längsreihen der größeren Schuppen enden nach hinten mit zwei scharf zugespitzten Zapfen. Am vorderen Teil des Kopfes jederseits ein dreieckiger, mit breiter hohler Basis versehener, gekörnelter Stachel, hinter ihm jederseits drei glatte, dünne, nach innen gebogene Stacheln, die mit einem vorspringenden Basalfortsatz auf der Kopfhaut befestigt sind. Nach Jaekel bestehen sie aus Vasodentin. Das mittlere Paar ist mehr als doppelt so lang als die beiden anderen. Gebiß cochliodont, an Deltoptychius erinnernd. M. armata Ewald. Kupferschiefer.

\section{Familie: Psammodontidae. De Koninck.}

Zühne in 1, 2 oder mehr Längsreihen, pflasterartig angeordnet, gro $\beta$, eben oder schwach gebogen, aus Vasodentin, mit punktierter oder fein runzliger Oberfläche. Umriß quadratisch oder oblong. Kohlenkalk Europa, Nordamerika. Copodus Davis (Mesogomphus, Rhymodus, Characodus, Pinacodus Ag.). Zähne vorn verschmälert, durch eine Quernaht in zwei ungleiche Teile zerlegt.

Psammodus Ag. (Homalodus, Astrabodus Davis) (Fig. 106.) Zähne groß, flach, viereckig, mit dicker platter Wurzel.

Lagarodus Jaekel. Zähne schmal rectangulär, scharf geknickt. Kohlenkalk. L. (Psammodus) angustus Tr.

Archaeobatis Newb. Kohlenkalk, Nordamerika.

\section{Familie :}

\section{Petalodontidae.}

Newberry und Worthen. ${ }^{1)}$

Zähne zusammengedrückt, quer verlän-

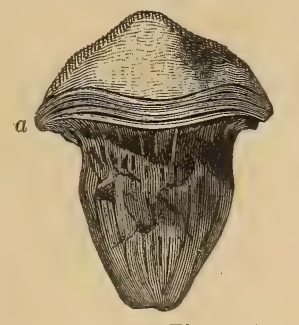

Fig. 105

Petalodus destruct or Newberry und Worthen. Steinkohlenformation. Springfield, Illinois. a Zahn von vorn, 1/2 nat. Gr., b Querschnitt.

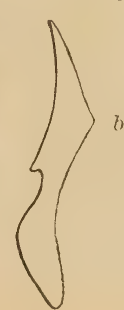

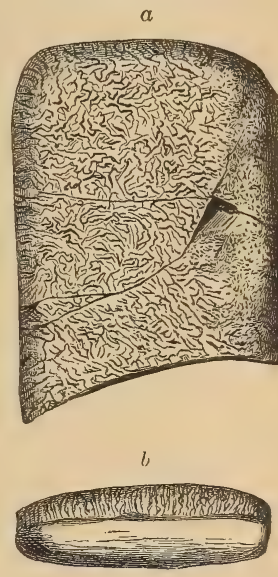

Fig. 106.

Psammodus rugosus Ag. Kohlenkalk. Armagh Irland. Nat. Gr.

gert, pflasterartig in Längs- und Querreihen geordnet. Krone aus Vasodentin, mit Schmelz bedecht, häufig durch eine Querschneide in eine vordere koncexe und eine hintere konkave Hälfte geteilt, und meist mehr oder weniger stark rïcküürts gebogen. Wurzel durch Schmelzfalten oder durch eine Kante von der Krone schaif abgesetzt, vertikal verlängert. Zähne persistent, beim Wachstum schuppenartig aufeinandergeschoben. Karbon. Perm.

Der Körper nur von Janassa (zum Teil) bekannt. Er ist rochenartig; die großen Brustflossen sind am Kopf angewachsen, von den Bauchflossen aber durch einen Zwischenraum getrennt. Der hintere Abschnitt mit zwei Dorsalflossen, der Schwanz schmal. Glatte, rundliche Chagrinkörperchen.

Petalodus Owen (Sicarius Leidy, Antliodus Newb., Chomatodus Ag., Lisgodus St. John u. W.) Zähne stark zusammengedrückt, quer verlängert; Krone blattförmig, mit Querschneide und scharfem Basalrand, vorn konvex, hinten konkav. Wurzel lang, dünn, stumpf abgestutzt. Kohlenkalk. Europa, Nordamerika.

Petalorhynchus Newb. u. W. Gebiß aus sechs Querreihen von je drei zugeschärften schneidenden Zähnen mit ungeteilter Wurzel bestehend. 
Nach Jaekel wäre Petalorhynchus auf obere Symphysenzähne von Petalodus gegründet, während Eastman an der Selbständigkeit der Gattung festhält.

Janassa Mstr. (Dictaea, Byzenos Mstr., Climaxodus Mc Coy, Peltodus Newb., Tancoodus St. John u. W.) Brustflossen groß, halbkreisförmig, etwa bis in die halbe Lünge des Kopfes reichend. Bauchflossen klein, halbkreisförmig, vorn mit einem abgegliederten Fortsatz (»Lauffinger« Jaekel). Wahrscheinlich zwei dorsale Flossen. Ein Paar Lippenknorpel dem Kieferbogen aufliegend. Gebiß gewölbt, vorn verschmälert, aus querverlängerten Zähnen mit punktierter ebener Krone zusammengesetzt, die in 5-7 Längsreihen und ca. 10 Querreihen angeordnet sind; die langen, unten verschmälerten Wurzeln sind in der Richtung von vorn nach hinten stark zusammen. gedrückt, etwas gebogen, auf der konvexen. Vorderseite quergerunzelt, auf der konkaven Hinterseite glatt. Die neu inFunktion tretenden Zähne legen sich über die älteren, so daß diese als Unterlage dienen (Fig. 107) und nicht abgestoßen werden. 'Die fast ebene Kaufläche wird lediglich von der Vorderseite der Krone gebildet, welche sich so stark zurückbiegt, daß sie nahezu horizontal liegt und einen Teil des dahinterstehenden Zahnes bedeckt. Chagrinkörner oval bis vierseitig, glatt. Karbon, Europa, Nordamerika. Perm (Kupferschiefer) von Hessen und Thüringen.

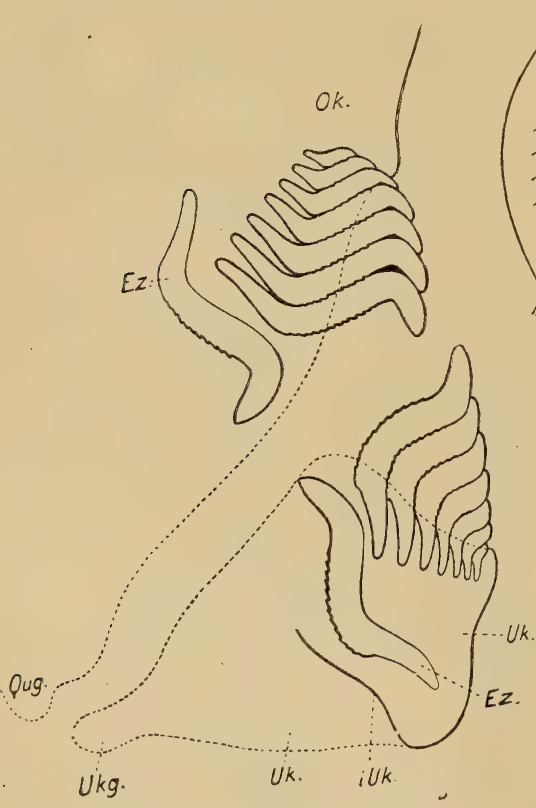

Fig. 107.

Querschnitt durch das Gebiß von Janassa bituminosa Schl. $O k$ Oberkiefer, $U k$ Unterkiefer, Ez Ersatzzähne der durchschnittenen Symphysenreihe, Ukg Unterkiefergelenk, Qug Quadratgelenk, $i U k$ Innenrand des Unterkiefers in der Symphysenebene. (Nach Jaeke1.)

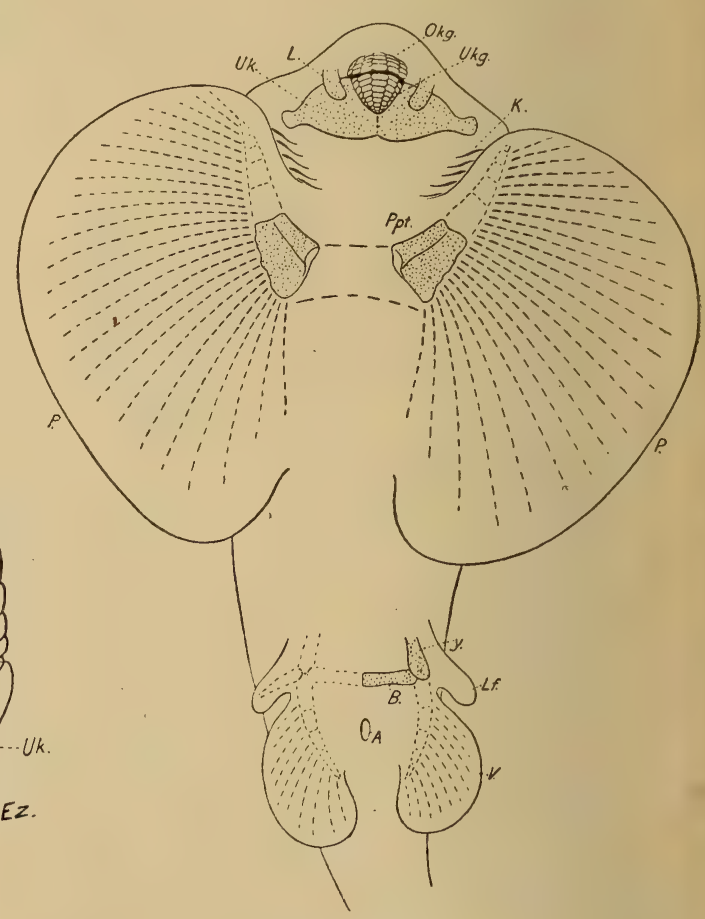

Fig. 108.

Janassa bituminosa Schloth. 1:2. - L Lippenknorpel, Uk Unterkiefer, $O \mathrm{~kg}$ Oberkiefergebiß, $U k g$ Unterkiefergebiß, $K$ Kiemenspalten, $P p t$ Propterygien, $P$ Brustflosse, $V$ Beckenflosse, Lf Lauffinger, A After, $B$ Basalknorpel d. Bauchflosse, $y$ Ilearproze $ß$ (?). (Rekonstruktion nach Jaekel.)

Fissodus Newb. u. W. Kohlenkalk, Nordamerika. Zähne wie Janassa, aber die Schneide durch 1-2 Ausbiegungen geteilt.

Polyrhizodus Mc Coy (Dactylodus Newb., Gyracanthus Ag.) Zähne dick, mit gewölbter, der Quere nach schneidender Krone und lappiger, viel- 
fach geteilter Wurzel. Mit diesen Zähnen sind in Rußland Flossenstachel gefunden, die sich durch ihre Krümmung nach vorn auszeichnen. (Gyracanthus Ag.) Vielleicht gehören Petrodus Mc Coy $=$ Ostinaspis Trautschold als Hautdornen zu derselben Gattung. Unteres und mittleres Karbon. Stichacanthus Davis umfaßt gleiche Stachel aus dem irischen Kohlenkalk, Xystracanthus Leidy (DrepanacanthusNewb. u. W.) ähnliche, ebenfalls nach vorn gekrümmte Stacheln aus amerikanischen Kohlenkalk.

Ctenoptychius Ag. (Ctenopetalus, Harpacodus, Petalodopsis Davis, Serratodus Kon., Peripristis St. John u. W.) Wird von Jaekel mit Petalodus vereinigt, während Eastman eine besondere Familie Peripristidae für berechtigt hält. Kleine, von vorn nach hinten stark zusammengedrückte Zähne, mit zugeschärfter gezackter Krone.

Callopristodus Traquair. Wie vorige, aber Wurzel geteilt. Nach Jaekel Schuppen. Karbon; Schottland.

Glossodus Mc Coy, Mesolophodus A. Sm. Woodw. Kohlenkalk.

Pristodus Davis. Symmetrische, ziemlich kleine 'Zähne mit niederer Wurzel. Krone halbkreisförmig, mit steil aufsteigender Schneide, nach hinten konkav abfallend, in eine Platte verbreitert. Wurzel durch eine Einschnürung abgetrennt. Kohlenkalk. Nach A. Smith Woodward Typus einer besonderen Familie, die vermutlich nur je einen Zahn in jedem Kiefer besaß. Nach Jaekel sind auch bei Pristodus zahlreiche Querreihen von Zähnen auf den Kiefern anzunehmen.

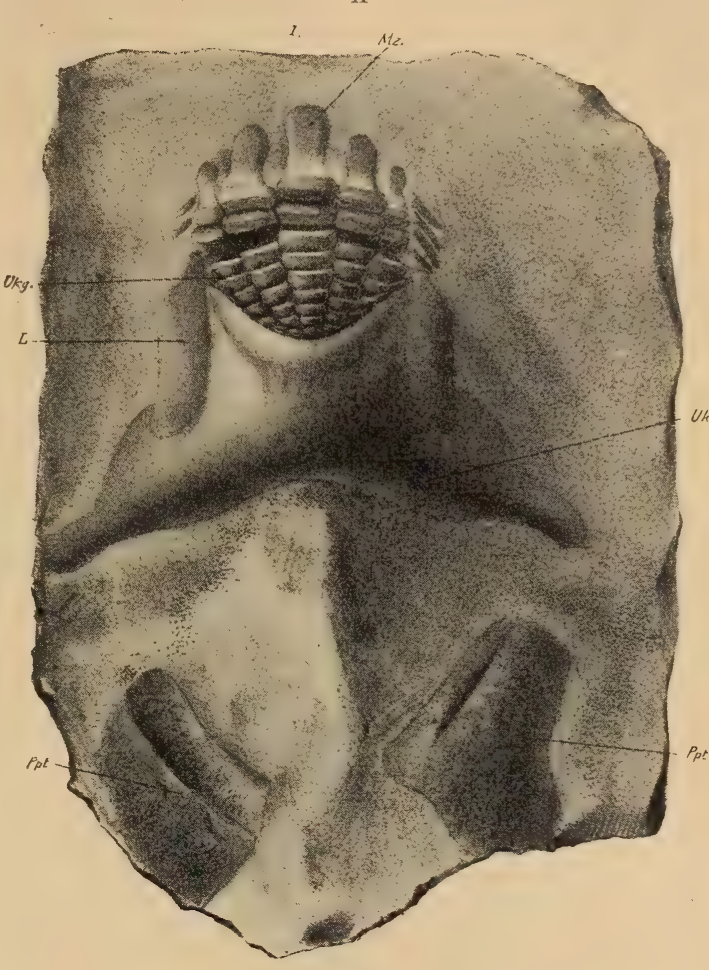

$B$

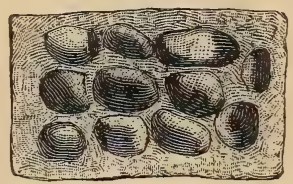

Fig. 109.

Janassa biluminosa Schloth. A Orig. Universitäts - Sammlung in Halle. Ukg Unterkiefergebiß, $M z$ mittlere Querreihe des Oberkiefergebisses, $U k$ Unterkiefer, $L$ Lippenknorpel, Ppt Propterygien der Brustflosse. $2 / 3$ nat. Gr. (Nach Jaekel.) $B$ Hautschuppen (vergr.)

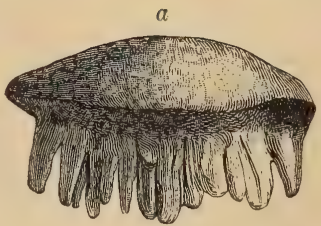

b
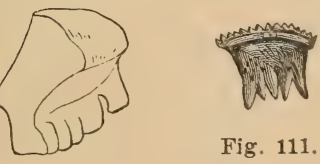

Fig. 111. Callopristodus pectinatus Ag. Kohlenkalk. Schottland.

Pulyrhizodus magnus M'Coy. Kohlenkalk. Armagh, Irland. 1/a nat. Gr. $a$ von vorn, $b$ Querschnitt. (Nach M'Coy.) 


\section{Familie: Squatinidae M. u. H. Meerengel.}

Körper breit, platt. Brustflossen groß, aber durch eine Spalte vom Kopf getrennt, so daß die Kiemenöffnungen noch auf den Seiten ausmünden liömen. Keine Afterflosse. Zwei Rückenflossen, ohne Dornen. Haut mit kleinen Placoid. schuppen bedeckt. Zähne spitz, kegelförmig, ohne Nebenzacken, mit breiter Wurzel, aus Pulpodentin bestehend. Tectispondylische Wirbel.

Squatina Aldrovandi (Rhina Klein, Thaumas Mstr., Phorcys Thioll., Scaldia Le Hon, Trigonodus Winkler z. T.). Jura bis jetzt. Vollständige Skelette von Squ. alifera Mstr. sp. (acanthoderma O. Fraas) und Squ. speciosa Meyer aus dem oberen weißen Jura ( $\zeta$-Platten, lithographischer Kalkstein)von Württemberg(Nusplingen) und Bayern, sowie von Cirin (Ain), vgl. aber Pseudorhina.) Ganze Skelette ferner in der oberen Kreide des Libanon ${ }^{1}$ ) und der Baumberge (Sendenhorst) in Westfalen.

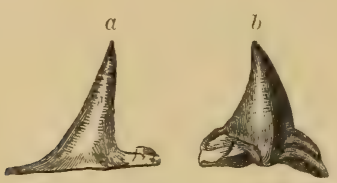

Fig. 112.

Zahn von a Squatina alifera Münst. sp. Lithographischer Schiefer. Solnhofen. $2 /$

$b$ Squatina Fraasi Probst. Miocäne Molasse. Baltringen. $2 / 1$.

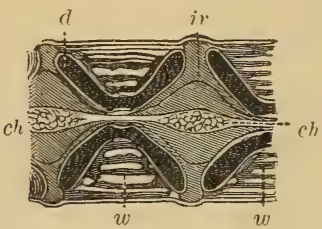

Fig. 113

Medianer Längsschnitt durch die Wirbelsäule von Squatina angelus Lin.

(Nach Hasse.) ch Chorda, $d$ verkalkter Doppelkegel, $w$ konzentrische Verkalkungsringe, $i v$ intervertebraler, mit Chordasubstanz erfüllter Zwischenraum.

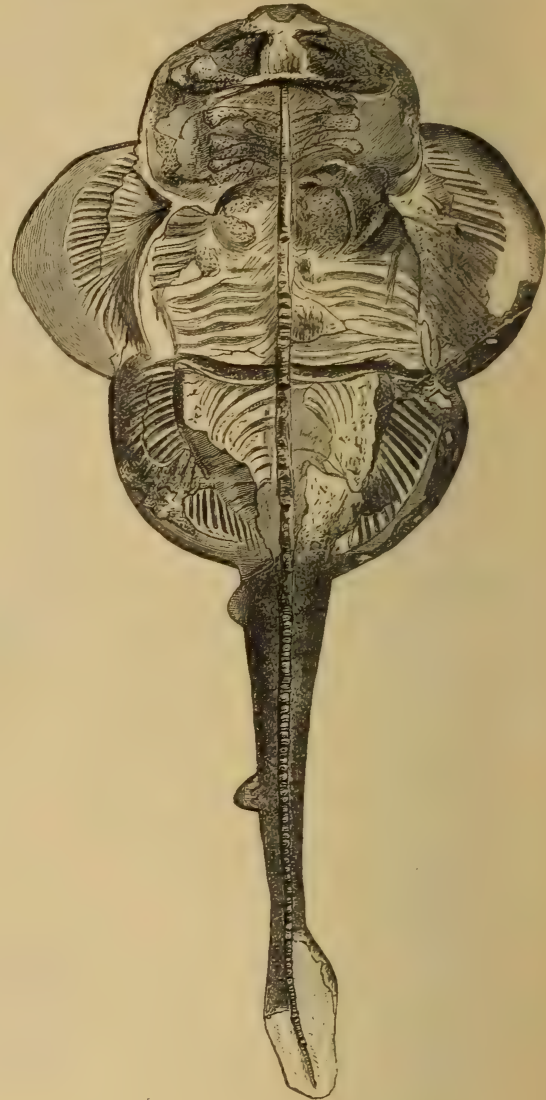

Fig. 114.

Squatina alifera Münst. sp. (= Squatina acanthoderma Fraas). Ob. Jura. Eichstätt, Mittelfránken. (Original im paläontolog. Museum in München.)

Pseudorhina Jaekel. Zähne mit höckerförmiger Krone. Keine Lippenknorpel. Schwanz länger als bei Squatina, sehr allmählich verdünnt, oben mit größerem, unten mit schwächerem Segel. Nur sehr kleine Dorsalflossen. ? 6 Kiemenbögen. Squ. alifera Mstr. (s. o.) Die Berechtigung dieser Gattung, in die wohl auch die anderen Squatinen des oberen Jura einzureihen wären, bedarf noch näherer Prüfung.

Familie: Pristidae Günther. Säg e fische.

hö口prè gleichmäßig gestreckt, wenig niedergedrückt. Brustflossen mäßig groß, mit dem Kopf verwachsen, aber nicht bis zu der abgeplatteten, schuertartigen Pristiden.

1) „Squatina crassidens gehört indessen . zu Sclerorhynchus und zu den 
Schnauze (Rostrum) verlängert, welche jederseits mit einer Reihe großer, meist in Alveolen steckender Zähne (Vasodentin = Placoidschuppen) besetzt ist. Zähne der Mundspalte klein, stumpf, aus Pulpodentin bestehend. Kiemenspalten auf der Unterseite. Tectispondylische Wirbel. Die Pristiden sind nach Jaekel von Rhinobatiden abgezweigt und haben sekundär eine haiartige Gestalt erlangt. Obere Kreide bis jetzt. lebend.

Pristis Latham. Tertiär,

Propristis Dames (Amblypristis Dames, Eopristis Stromer). Zähne stehen nur im vorderen Drittel der sehr großen (bis $2 \mathrm{~m}$ langen) Säge ${ }^{1}$ ); sie sind kurz, breit,dicht gedrängt,etwasschräg nach vorn gerichtet. $P r$. Schwein. furthi Dames. Eocän. Ägypten. Sclerorhynchus A. Sm. Woodw. Zähne der Säge nicht in Alveolen. Der mittlere Rostralknorpel geht bis zum Ende der Schnauze. Die Brustflossen reichen bis dicht an die Beckenflossen. Zähne der Mundspalte klein, spitzig. Scl. atavus A. Sm. W. Obere Kreide, Libanon.

Familie: Rhinorajidae Jaekel.

Die großen Brustflossen sind seitlich an das Rostrum angelehnt, treffen aber nicht vor der Schnauze zusammen. Kiemenspalten auf der Unterseite. Schwanz allmählich in den vorderen Körper übergehend, mit Seitenkielen. Zähne aus Pulpodentin, mit zweifliigeliger Wurzel. Tectispondylische Wirbel.

Jaekel faßt als $\mathrm{Rhi}$ norajiden die Rhinobatinae, Torpedininae, Rajinae zusammen. Ähnlich umgrenzt ist Gills Abteilung Pachyura, die aber auch die Pristiden noch umschließt. Ihnen gegenüber stehen die Centrobatidae Jaekels, mitden Trygoninae, Ptychodontinae, Myliobatinae und Ceratopterinae als Unterfamilien, den Masticura Gills entsprechend. Die fossilen Ptychodonten sind allerdings bei Gill nicht berücksichtigt, können aber auch keineswegs mit Sicherheit hier untergebracht

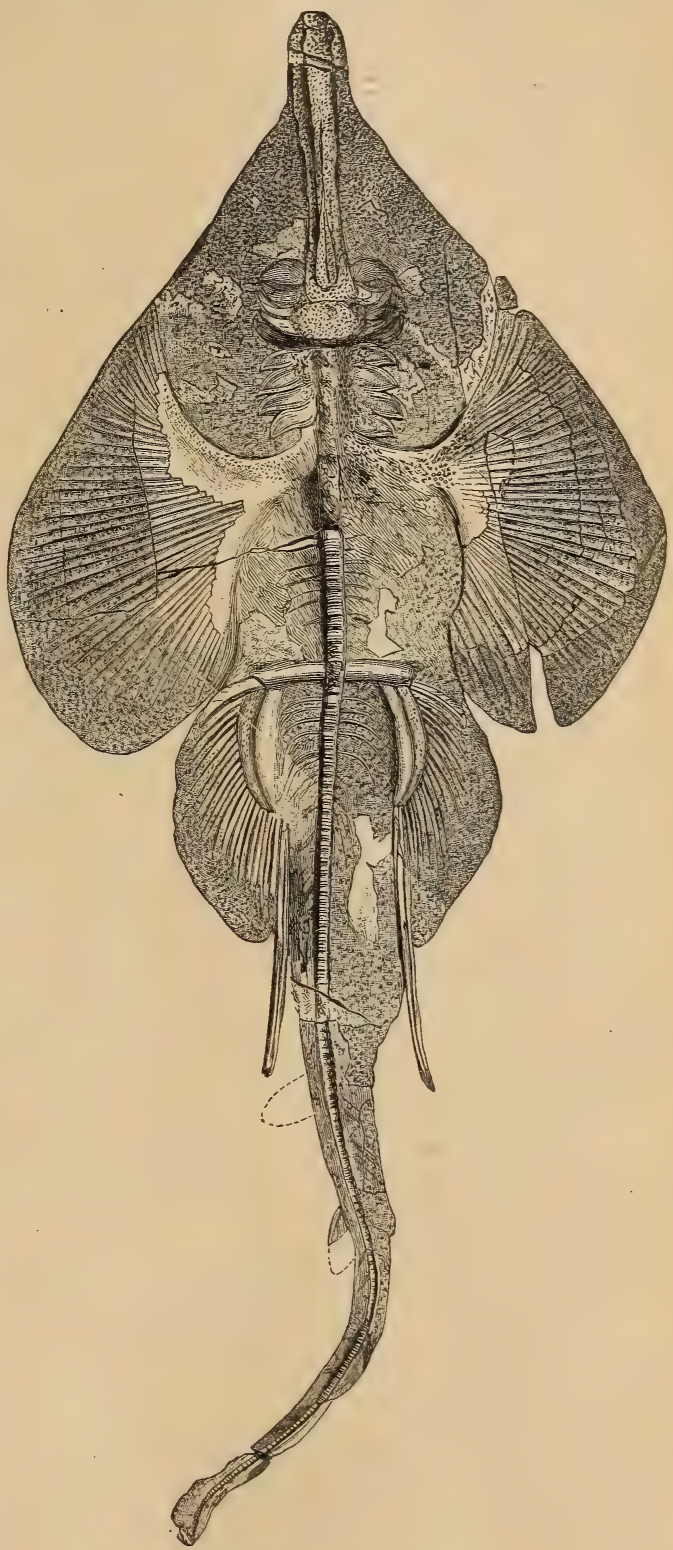

Fig. 115.

Rhinobatus mirabitis Wagn. Lithographischer Schiefer. Eichstätt, Bayern. (Nach einem 1,7 m langen Exemplar im Münchener paläontolog. Museum.) werden.

1) Bei jungen Exemplaren von Pristis cuspidatus Lath. ist der basale Teil der Säge ebenfalls unbezahnt. 
Unterfamilie: Rhinobatinae M. u. H.

Körper flach, aber lang gestreckt. Radien der großen Brustflossen nicht bis zu dem verlängerten Schnauzenende reichend. Schwanz hintere Hälfte des Körpers) kräftig, mit zwei Rückenflossen. Zähne klein, stumpf gekielt.

Rhinobatis Bloch (Euryarthra Ag., Spathobatis Thiollière). Rückenflossen ohne Stacheln. Die vordere weit hinter den Beckenflossen. Haut mit kleinen Chagrinkörnchen. Schwanzflossen ohne unteren Lappen. Oberer Jura bis jetzt. Rh. bugesiacus Thioll. (mirabilis Wagn.) Oberer weißer Jura, Cirin, Eichstätt.

Rh. Zignii Heckel. Eocän. Monte Bolca. Rh. maronita Pictet u.

Humb. Obere Kreide. Libanon.

Aste rodermus Ag. (Belemnobatis Thiollière). Rückenflossen mit kleinen Stacheln. Mit deutlich abgesetztem unteren Schwanzlappen. Chagrinschuppen ziemlich groß, sternförmig gestrahlt. Oberer weißer Jura, Cirin.

Trigonorhima M. u. H. Eocän (Monte Bolca) und lebend.

Rhynchobatus M. u. H. Tertiär, lebend. Vordere Rückenflosse gegenüber den Beckenflossen. Schwanzflosse mit unterem Lappen.

Unterfamilie: Rajinae Müller und Henle. Rochen.

Körper flach, breit scheibenförmig oder rhombisch. Brustflossen von der Schnauze bis zu den Bauchflossen reichend. Bauchflossen vorn mit kräftigem, gegliedertem Knorpelstrahl. Schwanz schmal, aber allmählich aus dem Vorderkörper entwickelt, ohne Stacheln. Schwanzflosse meist reduziert. Haut mit kleinen spitzen und vereinzelten größeren, stacheligen Placoidschuppen. Zähne klein, zweiwurzelig, mit rhombischer Krone aus Pulpodentin, zu einem Pflaster angeordnet. Bei einigen Arten haben die Münnchen spitze, die Weibchen stumpfe Zähne. Kreide bis jetzt.

Cyclobatis Egerton. Obere Kreide. Libanon.

Raja Cuv. (Actinobatis Ag.) $R$. expansa Davis. Obere Kreide, Libanon. Eocän, England. Pliocän. Lebend.

Platyrhina M. u. H. Eocän. Monte Bolca. Lebend.

Unterfamilie: Torpedininae Müller und Henle. Zitterrochen.

Körper flach, vorn gerundet, scheibenförmig. Brustflossen nicht bis zu dem breiten Vorderrande des Kopfes reichend. Schwanz breit, fleischig, mit Rückenflossen. Haut nackt. Eocän bis jetzt.

Torpedo Dum. (Narcobates Blainv.) Eocän, Monte Bolca.

Astrape M. u. H. Oligocän. Nur eine Rückenflosse.

Narcine Henle. Mit zwei Rückenflossen. Eocän, lebend. N. Molini Jaekel, Monte Bolca.

\section{Familie: Masticura. Gill (Centrobatidae Jaekel).}

Schwanz lang und schmal, scharf von der Körperscheibe abgesetzt. Tectispondylische Wirbel.

Unterfamilie. Trygoninae. Müller u. Henle. Stechrochen.

Körper flach, Brustflossen vor der Schnauze zusammenstoßend. Schwanz lang und schlank, die dorsalen Flossen oft peitschenförmig, 'sehr reduziert oder durch hintereinanderliegende, abgeplattete, randlich gezähnelte Stacheln (aus Vasodentin) ersetzt. Haut ohne Chagrin, aber mit großen, zuweilen gruppenweise vereinigten Hautplatten. Zähne klein, zu einem Pflaster vereinigt, mit zweiteiliger Wurzel. Tertiär bis jetzt.

Trygon Adanson (Trygonobatus Blv., Alexandrium Molin.) Skelette im Eocän des Monte Bolca: Tr. muricatus (Volta), Tr. Zignoi Molin. Isolierte 
Hautplatten wurden teils als Raja, teils als Accipenser, teils als Dynobatis und Acanthobatis beschrieben (Fig. 117).

Urolophus M. u. H. U. princeps Heckel, Eocän, Monte Postale. Xiphotrygon Cope (Heliobatis Marsh), Eocän, Wyoming. Oncobatis Leidy. Pliocän, Idaho. Rhombodus Dames. Kreide. Ptychotrygon Jaekel. Kreide. (Anacanthus Ehrenberg.)
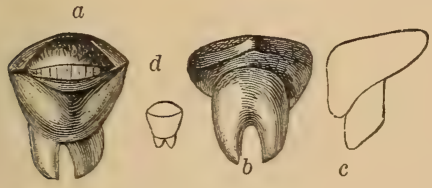

Fig. 116

Trygon rugosus Probst. Zahn a von vorn, $b$ von hinten und $c$ von der Seite. Vergr. d. nat. Gr. Miocäne Molasse.

Baltringen, Württemberg. (Nach Probst.)

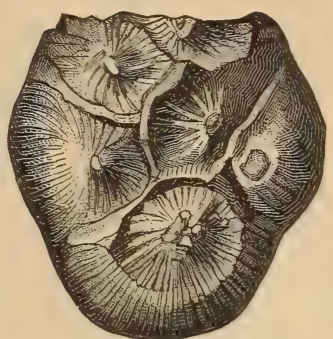

Fig. 117

Trygon (Acanthobatis) tuberculosus Probst sp. Miocäne Molasse. Baltringen. Hautschild in nat. $G r$.

Urogymnus M. u. H. Ohne Schwanzstacheln, aber mit scharfen, konischen Hautzähnen.

Cyclobatis Egerton. Schwanz sehr kurz. Beckengürtel mit auffallend großen Präpubis- und Ileal-Fortsätzen. C. oligodactylus Eg. Skelette aus der oberen Kreide, Libanon.

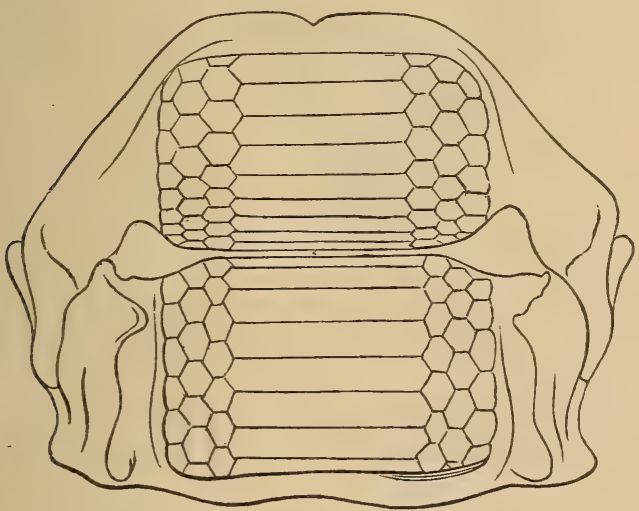

Fig. 118.

Gebiß von Mryliobatis aquila Cuv. Rezent. Mittelmeer. (Nach Agassiz.)

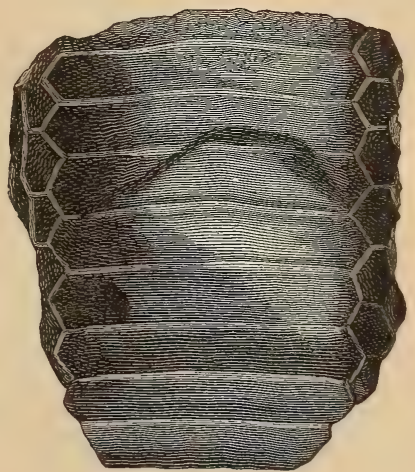

Fig. 119

Zahnpflaster von Myliobatis toliapicus Ag. Eocän. Braklesham Bay, England.

Unterfamilie : Myliobatinae. Müller u. Henle. Me eradler.

Vorderkörper glatt, Schwanz extrem verlängert, peitschenförmig, mit einem (oder mehr) abgeplatteten Stachel (spezialisierte Hautschuppe) hinter der Rückenflosse. Brustflossen zu beiden Seiten des Kopfes unterbrochen, aber am fleischigen Vorderende als unpaare oder paarige durch Flossenstrahlen gestützte Verlängerung wieder auftretend. Zähne ziemlich groß, zu einem Pflaster angeordnet. Haut nackt.

Die meisten lebenden Gattungen sind auch tertiär nachweisbar.

Myliobatis Cuv. (Pastinaca Gronov.)(Fig. 118, 119.) Die Zahnpflaster sind aus mehreren Reihen sechseckiger, flacher Zähne mosaikartig zusammengesetzt. An jungen Exemplaren haben alle Zähne gleiche Form und Größe, an ausgewachsenen zeichnet sich die Mittelreihe durch fast sechsfache Breite aus. Die Wurzeln auf der Unterseite und den steilen Seitenrändern mit 
parallelen Furchen. Flossenstachel flach, seitlich mit Zähnchen. (Fig. 120.) Sehr zahlreiche fossile Arten von Eocän an.

M. toliapicus Ag. Eocän. England. M. Pentoni A. Sm. Woodward. Eocän. Agypten.

Hypolophites Stromer. Statt der einen Reihe großer Mittelzähne bei Myliobatis mit 4 Querreihen größerer Zähne. Eocän. Togo.

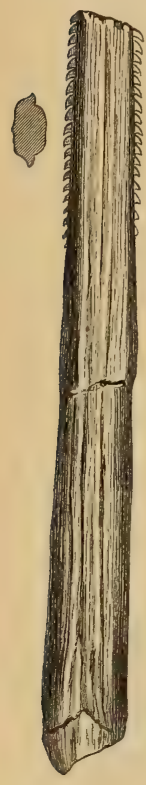

Fig. 120 . Stachel von $M y$ liobatis serratus H. $\nabla$. Meyer. Oligocän. Weinheim bei Alzey.

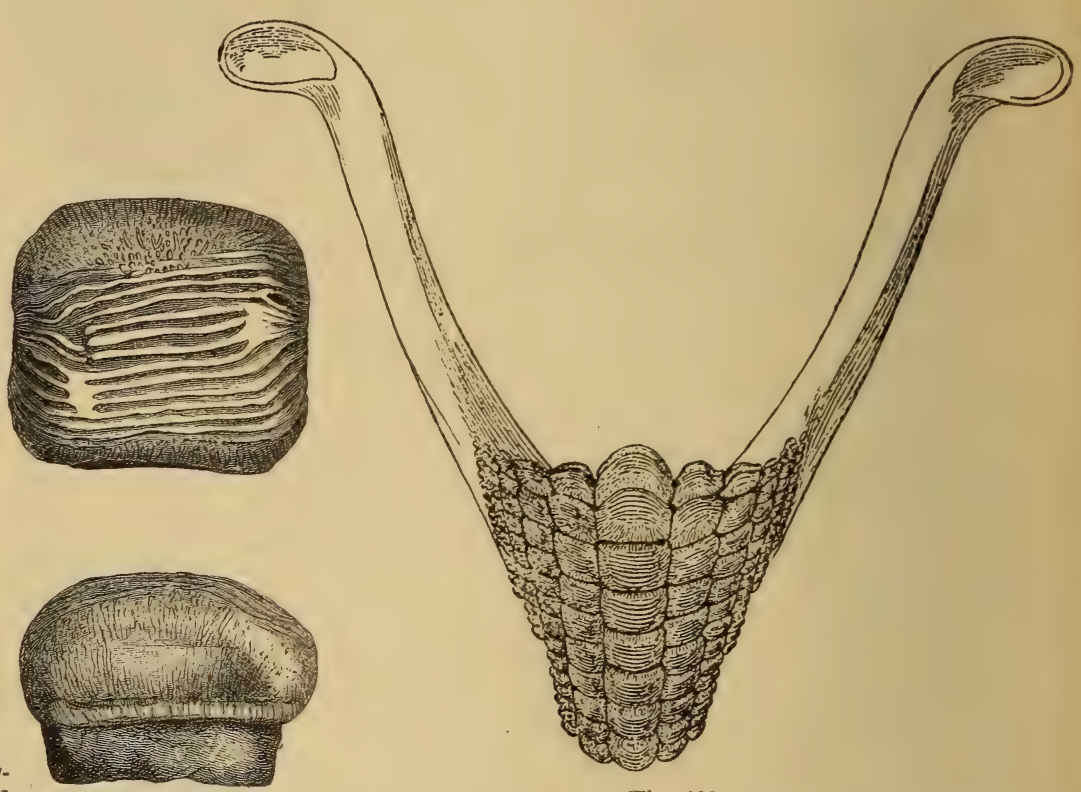

Fig. 121.

Fig. 122.

Ptychodus polygyrus Ag. Ptychodus decurrens, Lower Chalk, Sussex. Unterkiefer nach A. Sm. Grünsand. Regensburg. Wo odward. Aus "Guide to the fossil Reptilia etc. * mit Genehm. Nat. Gr. der Trustees des British Mus. Nat. Hist.

Rhinoptera Müller (Zygobates Ag., Mylorhina Gill). Zähne quer verlängert, hexagonal, in 5-7 Reihen, die nach außen an Breite abnehmen. Eocän bis lebend.

A ëtobatis Müller u. Henle. (Goniobatis le Hon) Zähne sehr breit, in einer einzigen Reihe. Tertiär, lebend. A. giganteus Schaffh. Mitteleocän, Bayern. A. irregularis Ag. Eocän, England.

Promyliobatis Jaek. P. Gazolae Zigno sp. Eocän, M. Bolca.

\section{Unterfamilie: Ptychodontinae.}

Zähne mit gewölbten, stark gerunzelten Kronen, in zahlreichen Reihen (13-14); im vermutlichen Unterkiefer sind die Zähne der mittleren Reihe die größten, im Oberkiefer schiebt sich eine symphysale Reihe kleiner Zähne zwischen zwei Reihen großer Zähne ein. Wirbel cyclospondylisch.

Ptychodus Ag. (Aulodus Dixon). Zähne quadratisch, mit gewölbter, gerunzelter Krone, die ungeteilte, sockelartige Krone durch eine Einschnürung scharf abgetrennt. Mittlere und obere Kreide.

Hemiptychodus Jaekel. Kreide. 


\section{Unterklasse. Holocephali.}

Chorda von zahtreichen verkalkten Knorpelringen umgeben. Die oberen Bögen mit Intercalarien wechselnd, den unteren Bögen an Zahl nicht genau entsprechend. Die Wirbelringe zahlreicher als die Bogenteile. Die vorderen Bogen verschmolzen zu einer die Chordascheide umschliejenden Hiilse. Palatoquadratum und Hyomandibuiare unbeweglich mit dem knorpligen Schädel verschmolzen (Autostylie). Nur eine äußere Kiemenspalte, welche durch eine Hautfalte teilweise bedeckt wird. Unterkiefer jederseits mit einem großen Zahn, dem oben je zwei Zähne (auf Vomer und Pterygopalatinum) gegenüberstehen. Haut nackt oder mit Chagrin (bei fossilen Gattungen). Starke Schleimkanäle (Haut-Sinnesorgane) verlaufen am Kopf und als Seitentinie am Rumpf, von zahlreichen verkalkten Ringen umgeben. Vor der Rückenflosse ein kräftiger, abgeplatteter Stachel, der mit einem knorpligen Träger gelenkig verbunden ist. Die Männchen mit Stirnstachel (bei Chimaera knorplig, vorn gerundet, mit Dornen besetzt), kleinen dornigen Stacheln vor den Bauchflossen und mit Pterygopodien, die durch dünne Kalkstäbe verstärkt sind; fossile Formen auch mit paarigen Stachelplatten am Kopf.

Durch die unvollkommen gegliederte Wirbelsäule mit̄ihrer großen Zahl von Knorpelringen, durch die Verschmelzung des Palatoquadratum und Hyomandibulare mit dem Schädel und durch die Form und Struktur der Zähne nehmen die Holocephaten eine sehr isolierte Stellung neben den Elasmobranchiern ein, mit denen sie doch durch manche wichtige Merkmale verbunden sind. Die Autostylie des Unterkiefers teilen sie mit den Dipnoern, die auch im Gebiß und in der Bildung des Labyrinths an sie erinnern.

Die Holocephalen werden im Devon zuerst genannt, indessen gehören die devenischen Ptyctodontiden nach neueren Beobachtungen zu den Arthrodiren.

Die von Jaekel beschriebene Gattung Rhamphodus, mit der Bezahnung der Ptyctodontiden, besitzt einen aus knöchernen Hautplatten zusammengefügten Schulterapparat ähnlich Coc-

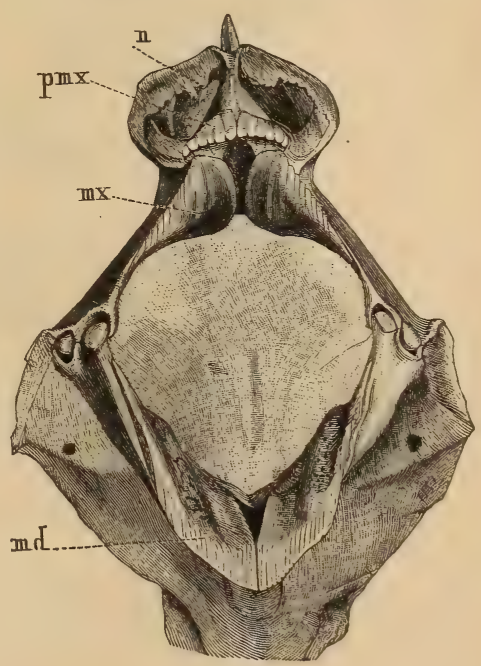

Fig. 123.

Gebiß einer jungen Chimaera monstrosa Lin. aus dem Mittelmeer. (Nat. Gr.) costeus. Darauf ist von Dollo die ganze Gruppe der Ptyctodonten zu den Arthrodiren gestellt (s. S. 83). Die ältesten sicheren Holocephalen gehören dann dem unteren Lias an.

\section{Familie. Squalorajidae. A. Smith Woodward.}

Körper niedergedrïckt, verlängert. Kopf in ein flaches Rostrum auslaufend. Gebißs unten aus 1 Paar, oben aus 2 Paar dünnen, quer gekrümmten Zähnen ohne Reibfläche (vgl. Chimaera) bestehend. Rückenflosse ohne Stachel. Münnchen mit langem, spießförmigen Frontalstachel. Dieser ist innen hohl, besteht aus verkalktem 
Faserknorpel und steht mit der Cutis, nicht mit dem knorpligen Innenskelett in Verbindung. Zahlreiche, verkalkte Wirbelringe, jeder aus konzentrischen Lamellen bestehend.

Squaloraja Riley (Spinacorhinus Ag.), im unteren Lias von England. Squ. polyspondyla Ag.

\section{Familie: Myriacanthidae. A. Sm. Woodw.}

Körper verlängert. Vordere Rückenflosse über der Brustflosse stehend, mit langem, geraden Stachel. Oben 2-3 Paar, unten 1 Paar Zahnplatten, außerdem 1 starker, unpaarer Symphysenzahn. Kopf mit einigen Hautplatten. Männchen mit großem Schnauzenstachel. Lias, Jura.

Myriacanthus Agassiz Metopacanthus Zitt. (Prognathodus Egerton, auf die Bezahnung bezogen). Der auf den Seiten mit Höckern bedeckte dorsale Flossenstachel trägt am Hinterrande jederseits scharfe Dornen, die distal in eine Reihe zusammenlaufen. Auch auf der Vorderseite stehen Dornen. Einige höckerige, seitlich in große Zähne auslaufende Hautplatten auf dem Kopfe. Die hinteren palatinalen Zähne größer als die vomerinen, vor der Symphyse des Unterkiefers ein meißelförmiger, unpaarer Zahn.

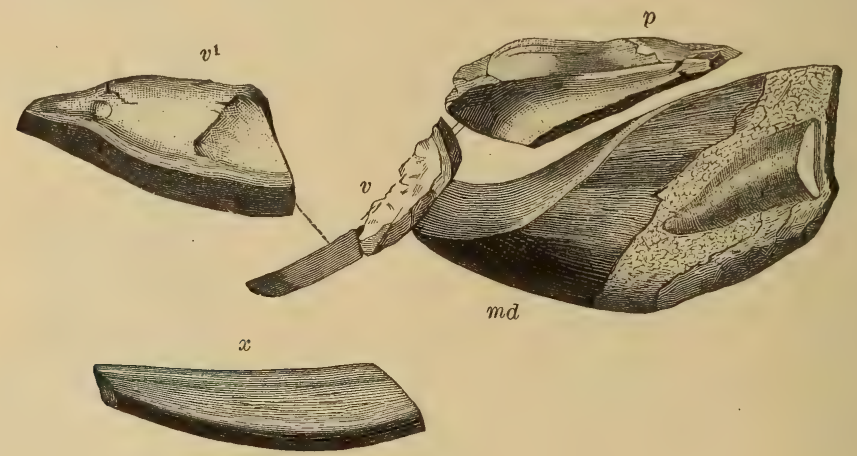

Fig. 124.

Chimaeropsis paradoxa Zitt. Lithographischer Schiefer. Eichstätt, Bayern. 1/2 nat. Gr. $m d$ Mandibularzahn, $p$ hinterer Oberzahn, $v$ vorderer Oberzahn von der Seite, $v^{1}$ derselbe von der Unterseite, $x$ schmaler vor dem Mandibularzahn liegender Zahn.

M. paradoxus Ag. Unt. Lias, England. M. bollensis E. Fraas (Stachel). Oberer Lias $₹$, Schwaben.

Acanthorhina E. Fraas. Rostrum in einen festen, verkalkten Stachel auslaufend. Männchen mit schmelzbedecktem, kleinen Stirnstachel. Oben 3 Paar flacher, gewellter Zahnplatten, im Unterkiefer nur 1 Paar. Flossenstachel sehr schlank, von einer großen Knorpelplatte getragen. A. Jaekeii E. Fraas. Ob. Lias $\varepsilon$, Holzmaden.

Chimaeropsis Zitt. Körper mit kleinen, konischen, radial gefurchten Placoidschuppen bedeckt. Unterkieferzähne schwach gebogen, mit großer Kaufläche; der Symphysenzahn außen (unten) konvex, innen (oben) flach oder konkav. Gaumenzähne $(p)$ und Vorderzähne $(v)$ dreieckig. Die ersteren hinten, die letzteren vorne zugespitzt. Dorsalstachel seitlich zusammengedrückt, mit sternförmigen Höckern and 2 Zähnchenreihen am Hinterrand. Ob. weißer Jura (lithogr. Schiefer), Bayern.

\section{Familie: Chimaeridae.}

Körper verlängert; Brustflossen sehr groß, mit einfachen Hornstrahlen. Vordere Rückenflosse mit kräftigem, auf knorpeliger Basis eingelenktem Stachel, 
hintere Rückenflosse niedrig, sehr lang. Oben jederseits ein kleiner Vorderzahn und ein großer Hinterzahn, unten je ein sehr großer, Innenseite und Oberrand des Kiefers bedeckender Mandibularzahn, welche in der Symphyse zusammenstoßen. Mehrere Tritoren oder Reibhïgel auf den Zähnen. Jura bis jetzt ${ }^{1}$ )

Jschyodus Egerton. (Leptacanthus Ag., Aulaxacanthus Sauvage, Chimaeracanthus Qu.). Unterkieferzähne rhomboidisch, dick, mit schmalem Symphysenrande, Oberrand zugeschärft. Aus einer dichten Dentindeckschicht erheben sich 4 rauhe, punktierte Tritoren. Gaumenzähne dreieckig, vorn zugespitzt, hinten nicht ausgeschnitten, mit 4 Tritoren ( 2 innen, 1 median, 1 außen. Vomerzähne vierseitig. Rückenstachel am Hinterrand mit zwei Reihen Zähnen. Kopfstachel des Männchens aus intensiv verkalktem Faserknorpel gebildet (O. M. Reis), am Ende mit Zähnchen besetzt, kurz und gebogen. I. aalensis Qu. Brauner Jura. I. Aalen. Brauner Jura, weißer Jura, Kreide von Mitteleuropa.

Ganodus Ag. Gaumenzähne hinten tief ausgeschnitten, mit zahlreichen, in zwei Reihen stehenden Tritoren. Mittlerer brauner Jura, Stones. field. Die als Ganodus bezeichneten Mandibularzähne scheinen besser zu Ischyodus zu passen.

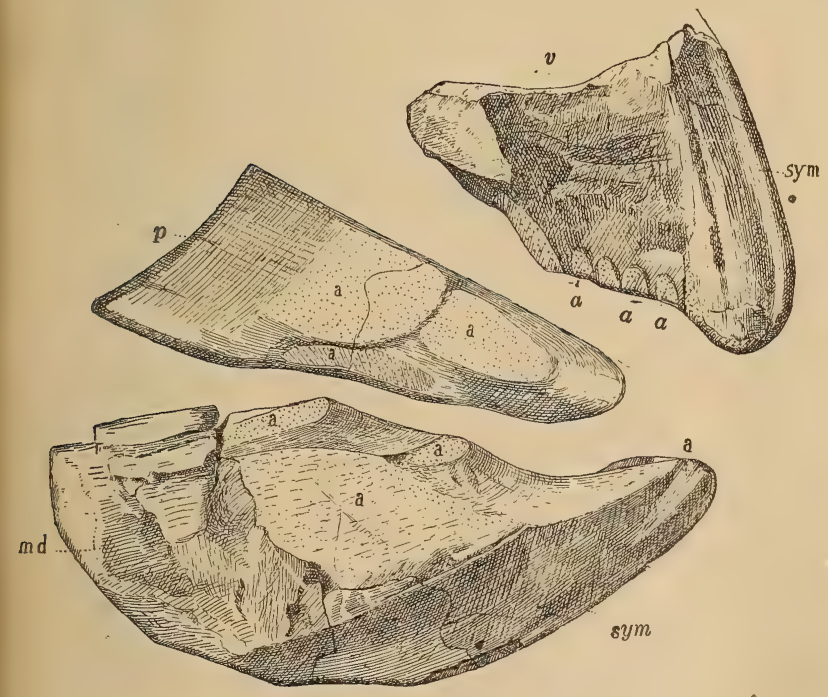

Fig. 125.

Edaphodon Sedgwickii Ag. sp. $v$ vorderer Oberzahn von der Innenseite aus dem Grünsand von Cambridge, $v$ vorderer, $p$ hinterer Oberzahn, md Unterkieferzahn (beide von innen). Ob. Kreide von Lewes. a Reibhügel und Kauflächen. sym Symphysenrand. Sämtliche Figuren in $1 / 8$ nat. Gr. (Nach Newton.)

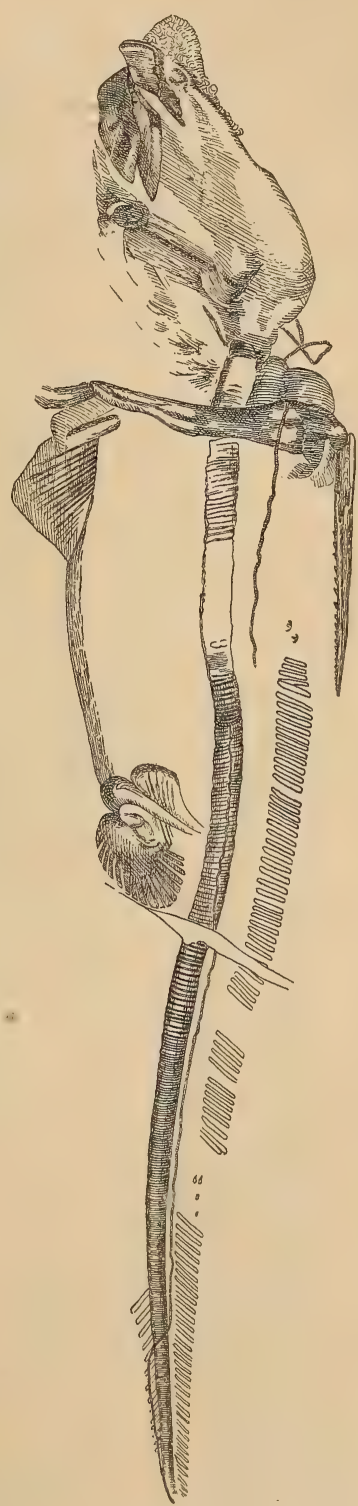

Fig. 126.

Ischyodus avita $\mathrm{H}$. $\nabla$. Meyer. Fast vollständiges Skelett $1 / 2$ nat. Gr.

Ob. Jura. Eichstätt, Bayern. (Nach H. v. Meyer.)

1) Newton E. T., The Chimaeroid fishes of the British cretaceous rocks. Mem. Geolog. Survey. Monogr. IV. 1878. Quart. Journ. geol. Soc. 1876. p. 326. 
Aletodus Jaekel. Mandibularzähne mit 3 länglichen Tritoren, von denen der äußere, schmale hart am Seitenrand liegt. Brauner Jura $\beta$ Württemberg. A. ferrugineus Qu. sp. Hierher gehören wohl auch die aus dem gleichen Lager bekannten Eikapseln.

Edaphodon Buckland (Passalodon Buckl., Eumylodus, Mylognathus Leidy, Dipristis Marsh, Leptomylus Cope). Mandibularzähne mit breitem Symphysenrand, Gaumenzähne mit 3 Tritoren (2 innen, 1 außen), hinten abgestutzt. Kreide, Eocän, Oligocän.

Pachymylus A. Sm. Woodw. Mandibularzähne massig, mit sehr breiter Symphysenfacette. Eine mittlere bucklige Reibfläche. Die hintere, äußere Reibfläche ist auf kleine Höckerchen reduziert, die übrigen Tritoren fehlen. Oxfordclay. Brachymylus A. Sm. Woodward. Oberer Jura, England.

Elasmodectes Newton (Elasmognathus Newton). Kimmeridgeclay. Kreide. Elasmodus Egerton. Eocän, England. Unteroligocän (Samland). Von den lebenden Gattungen Callorhynchus Gronow und Chimaera L. sind fossile Zähne aus dem jüngeren Tertiär von Neuseeland, Europa und Java bekannt.

\section{Ichthyodorylithen.}

Flossenstacheln finden sich häufig isoliert und lassen sich nur teilweise auf bekannte Genera beziehen. Sie werden dann mit besonderen Gattungsnamen geführt.

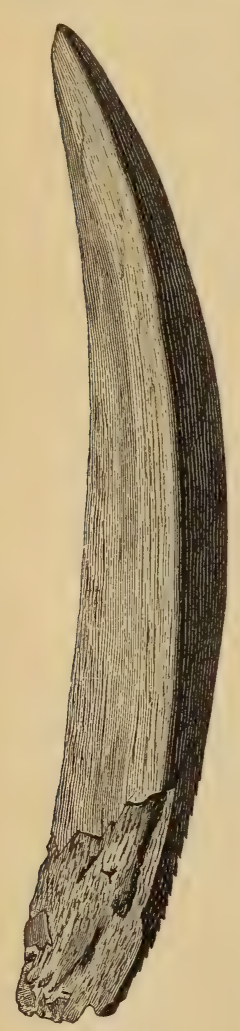

Fig. 127.

Machaeracanthus major Newberry. Devon. Sandusky, Ohio. $1 / 2$ nat. Gr. (Nach New berry.) Symmetrisch ausgebildete Stacheln gehören der Medianebene des Körpers, meist dem Rïcken oder dem Hinterende des Kopfes an. Unsymmetrisch gebildete treten nur als paarige Stacheln auf, entweder vor den paarigen Flossen (Acanthodier) oder auf den Seiten des Kopfes (Cochliodontidae, Hybodontidae). Bei den einseitigen Stacheln ist die Basis in der Regel abgestutzt, bei den symmetrischen Rückenstacheln dagegen meist verlängert und am proximalen Ende verschmälert.

Unter den nicht mit Sicherheit bei bestimmten Gat. tungen oder Familien unterzubringenden Stacheln mögen folgende erwähnt werden:

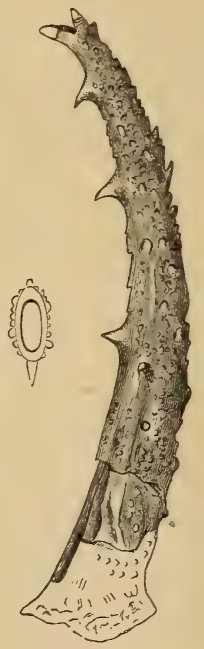

Fig. 128.

Gampsacanthus typus St. John und Worth. Kohlenkalk. St.Louis, Missouri. a) Schlanke, bilateral symmetrische Stacheln mit glatter und deutlich vom übrigen Teil unterschiedener $\mathrm{Ba}$ sis. Zum Teil wohl zu Acanthodiern und Cestracioniden gehörig:

Onchus Ag. (vgl. S. 47). Silur, Devon, Homacanthus Devon, Karbon, Acondylacanthus St. John. u. Worth., Compsacanthus Ag., Lispacanthus Davis, Karbon, Nemacanthus Ag., Trias, Jura, Pristacanthus Ag., brauner Jura.

b) Schlanke, symmetrische, hinten abgestutzte Stacheln; die innere Höhlung nur am unteren Ende offen: Gnathacanthus Davis, Karbon; Prista. canthus Ag., brauner Jura.

c) Paarige, asymmetrische Flossenstacheln. Machaeracanthus Newb. (Figur 127), Heteracanthus Newb., Haplacanthus Ag., Devon.

d) Asymmetrische Stacheln mit breiter, abgestutzter Basis und großer, innerer Höhlung, außen mit Körnern 
verziert. Wahrscheinlich seitliche Kopfstacheln (vgl. Cochliodontidae): Psammosteus Ag., Devon, Oracanthus Ag., Physonemus Mc Coy, Erismacanthus Mc Coy, Gampsacanthus (Fig. 128), Lecracanthus St. John u. W., Dipriacanthus. Me Coy.

\section{Unterklasse: Dipnoi.}

Wirbelsäule mit persistenter Chorda, Cranium überwiegend knorpelig, mit Hautplatten bedeckt. Palatoquadratum mit dem Schädel verwachsen (Autostylie des Unterkiefers). Gaumen (Pterygoide), Unterkiefer und Kiefer mit wenigen großen Zühnen mit erhabenen Kämmen. Paarige Flossen mit langer, gegliederter Achse (Archipterygium). Kiemenhautstrahlen fehlen. Schuppen cycloid, bei den älteren Formen mit dickem Schmelz. Bei den lebenden Formen: Arterienconus mit zahlreichen Klappen, Darm mit Spiralfalte, Augennerven nicht gekreuzt. Die Schwimmblase zu einem lungenartigen Organ umgebildet.

Das innere. Skelett ist überwiegend knorpelig, doch zeigen die Wirbelbögen, Rippen und Flossenträger Neigung zur Verknöcherung.

Durch die Umbildung der Schwimmblase in einen verlängerten, einfachen oder doppelten Sack mit zahlreichen, zelligen Räumen, der als Lunge dient und mittels eines kurzen Ganges mit der vorderen Wand des Schlundes in Verbindung steht, unterscheiden sich die lebenden Dipnoer so sehr von anderen Fischen, daß sie anfänglich als fischähnliche Amphibien oder Schuppenlurche betrachtet wurden. Auch Einrichtungen im Herzbau (so die Anordnung der einen Längsreihe von Klappen zu einer Spiralfalte, durch welche der Conus arteriosus in 2 Bahnen geteilt wird) und das Auftreten innerer Nasenlöcher sind singuläre Merkmale.

Die Entdeckung des »Barramundy " (Ceratodus Forsteri) in den Flüssen von Queensland bestätigte die schon von Huxley betonteVerwandtschaft mit den alten Crossopterygiern. Immerhin unterscheiden sie sich auch von diesen durch die autostyle Einlenkung des Unterkiefers und die Bezahnung. In beiden Eigenschaften nähern sie sich etwas den Holocephalen, interessanterweise auch in der Gestaltung des Gehörorgans. Auch die Coccosteiden (Arthrodira) werden bald mit ihnen, bald mit den Holocephalen in Verbindung gebracht. Wir teilen die Dipnoer in 4 Familien.

\section{Familie: Dipteridae.}

Schädeldach mit zahlreichen, kleinen, glänzenden Hautschildern, Rumpf mit runden, imbricierenden Schmelzschuppen Maxilla und Prämaxilla nicht differenziert, keine randlichen Zähne. Schwanzflosse heterocerk. Zwei weit nach hinten liegende Rückenflossen. Jugularplatten vorhanden.

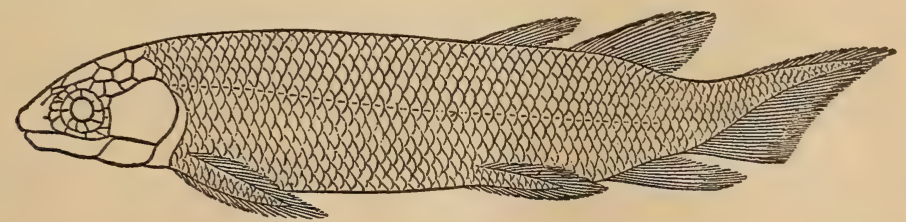

Fig. 129.

Dipterus Valenciennesi, ca. 1:5. Mittl. Oldred. (Nach R. Traquair.) Aus *Guide to the fossil Reptilia etc.* mit Genehmigung der Trustees des British Museum of Natural History. 
Dipterus Sedgw. u. Murch. (Catopterus Ag., Polyphractus Ag.) Die Schuppen auf dem freien Teil gekörnelt. Vordere Rückenflosse viel kleiner als die hintere, gegenüber der Beckenflosse, die hintere Rückenflosse der Analis gegenüber. Die Kopfplatten dick, glatt und porös. An das breite rhombische Parasphenoid ( $P S p h)$ legt sich jederseits ein Pterygopalatinum $(P)$, das vorne in eine dreieckige Platte verläuft, welche einem ebenfalls dreieckigen, mit gekerbten Radialkämmen versehenen Zahne als Basis dient.

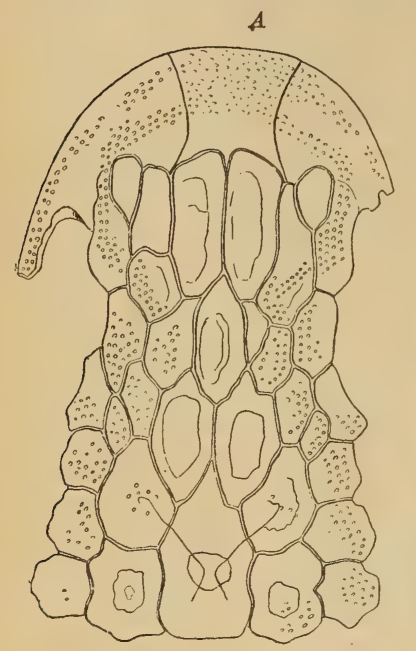
Die zwei Gaumenbeine stoßen in der Mitte gradlinig zusammen. Unterkiefer solid verknöchert, jederseits mit einem einzigen großen Zahn auf dem Operculare, dessen erhabene Kämme vom Innen-
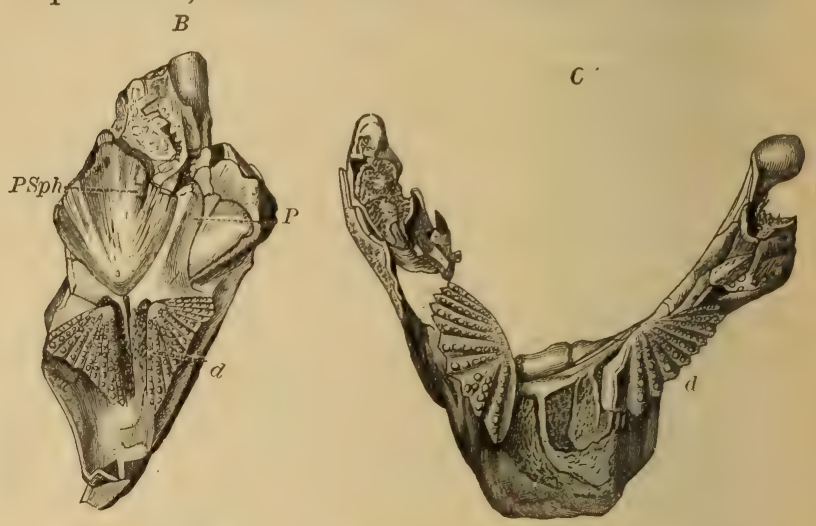

Fig. 130.

Dipterus platycephalus Ag. Old red Sandstone. Banniskirk. Schottland. A Schädeldach. $B$ Unterseite des Schädels ( $P S p h$ Parasphenoid, $P$ Pterygo-Palatinum, durch eine zufällige Bruchlinie hinten in zwei Stücke geteilt, $d$ Gaumenzahn). $C$ Unterkiefer ( $d$ Zahn). (Nach Pander.)

rand fächerförmig ausstrahlen. Vollständige, jedoch meist verdrückte Exemplare von Dipterus nicht selten im schottischen Oldred (besonders im un. teren Teile). Generisch unsicher sind die aus russischem Devon angegebenen Reste. Zähne werden zahlreich erwähnt aus dem Devon von Pennsylvanien. Einzelne im mitteldevonischen Lenneschiefer (CrinoidenkalkEinlagerung, also marin).

Palaedaphus Beneden (Heliodus Newberry). Nur die Zähne bekannt. Die bis $17 \mathrm{~cm}$ großen Unterkieferzähne haben 4 stumpfe Kämme. $P$. insignis Beneden. Ober-Devon, Belgien. Nordamerika (Chemung).

Conchodus Mc Coy, Cheirodus Pander von Mc Coy). Dünne, kleine, dreiseitige, glatte Zähne mit wenigen Radialkämmen. Devon, Rußland und Oldred.

Holodus Pander. Devon, Orel.

\section{Familie: Phaneropleuridae.}

Mundrand mit konischen Zähnen. Caudalis diphycerk. Jugularplatten vorhanden. Schädel mit zahlreichen Deckplatten.

Phaneropleuron Huxley (Fig. 133). Gaumenzähne dreieckig, mit geraden, gekerbten Radialfalten. Die lange Dorsalis gleichmäßig in die Caudalis übergehend. Analis schmal, dicht vor der Caudalis. Oberes Oldred, Schottland. Oberdevon, Kanada.

Scaumenacia Whiteavez. Oberdevon, Kanada. 
Uronemus Agassiz. Keine Analis. Eine sich isoliert erhebende, mit der Caudalis a.ber verbundene Dorsalis. Unterkarbon, Schottland.

Holodus Pander. Devon, Orel.

\section{Unbestimmte Stellung:}

Conchopoma Kner. Rotliegendes, Lebach. Ein großes, muschelförmiges Operculum. Zahnplatten mit zahlreichen, unregelmäßig stehenden rundlichen Zähnen.

\section{Familie: Ctenodontidae.}

Maxilla und Prämaxilla sind nicht differenziert, randliche Zähne auf den Kiefern nicht entwickelt. Jugularplatten fehlen. Caudalis diphycerk. Dïnne Cycloidschuppen.

Ctenodus Ag. Größer als Dipterus. Hinterhaupt mit einer Occipitalplatte. Zähne mit 12-14 gekerbten oder höckrigen Radialkämmen. Karbon. Perm von Europa, Nordamerika. Ct. cristatus Ag. Oberkarbon, England.

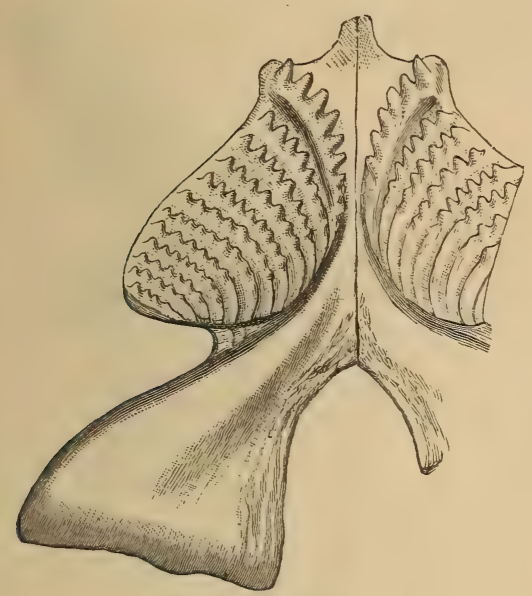

Fig. 131.

Ctenodus tuberculatus Atthey. Steinkohlenformation. Newsham, Northumberland. Pterygo-Palatinum mit Gaumenzähnen. $1 / 3$ nat. Gr. (Nach.At they u. Hancock.)

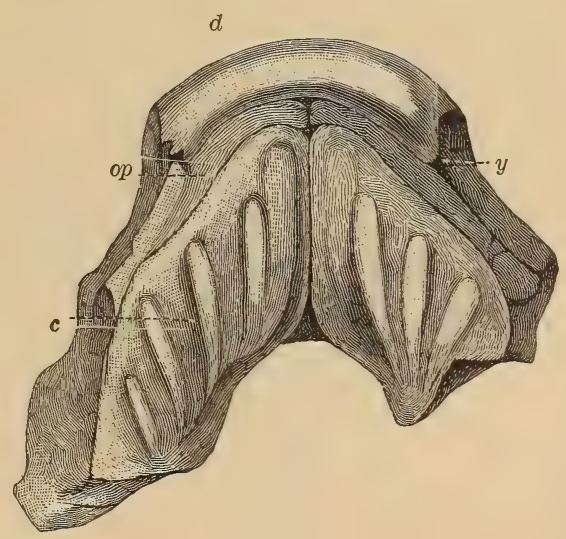

Fig. 132.

Palaedaphus insignis van Beneden und de Kon. Devon. Lüttich. Unterkiefer $1 / 4$. nat. Gr. (Nach Traquair.) $d$ Dentale, op Operculare, $c$ Zahn, $y$ seitliche Grube.

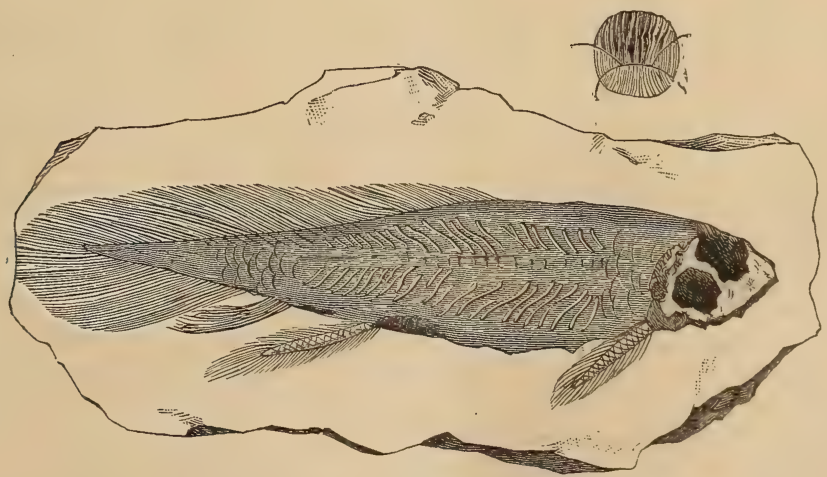

Fig. 133 ,

Phaneropleuron Andersoni Huxley. Old red Sandstone. Dura Den, Schottland. 1/3 nat. Gr. (Nach Nicholson.) 
Sagenodus Owen (Megapleuron Gaudry, Ptyonodus Egerton, Hemictenodus Jaekel p. p., Petalodopsis Barke.) Hinterhaupt mit zwei medianen Deckplatten. Zähne mit 3-10 einfachen oder gezähnten Falten. Verknöcherung stärker als bei Ceratodus, aber die Schuppen dünn, ohne Ganoin. Karbon, Perm, Europa, Nordamerika.

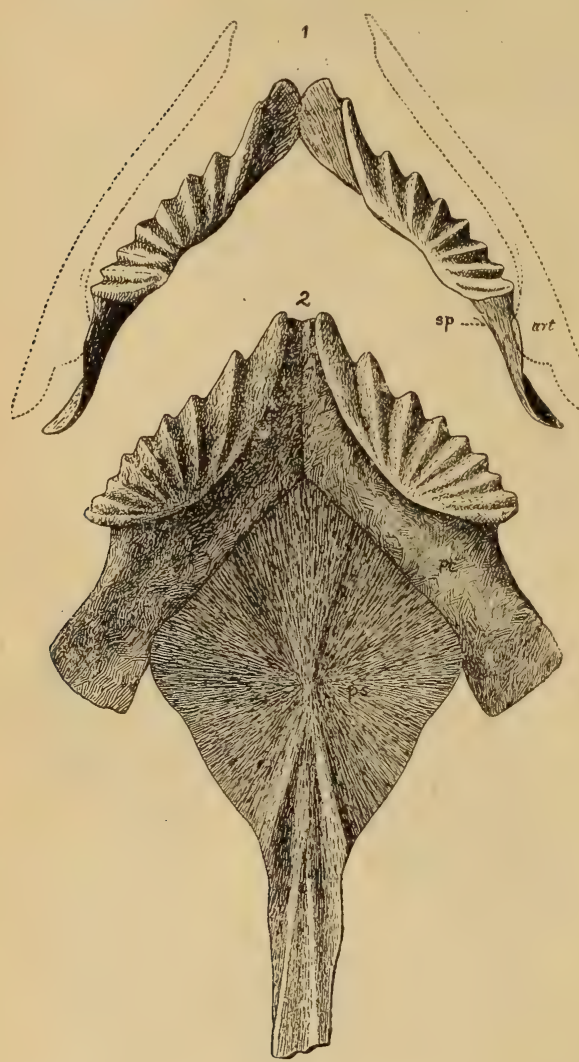

Fig. 134.

Sagenodus Copei Will. 1. Unterkiefer. sp Spleniale, art Articulare. 2. Oberkiefer. Pt Pterygopalatinum, ps Parasphenoid. (Nach Williston.)

\section{Familie: Ceratodontidae. $\left.{ }^{1}\right)$}

Schädeldach mit nur wenigen großen Hautknochen. Obere und un. tere Bögen regelmäßig entwickelt. Chordascheide zum Teil knorpelig, aber ohne Gliederung, Chorda persistent. Keine Intercalaria. Die untere Schicht der großen, dünnen, elastischen Schuppen, die wie bei Teleostiern in Taschen entstehen, ist fibrös, aber nicht gleich. mäßig sklerosiert, die nicht sklerosierten Partien entsprechen den Rinnen. der oberen Schicht. Die Faserlagen

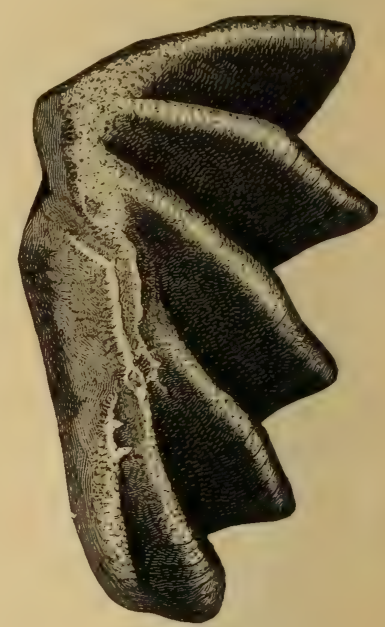

Fig. 135 .

Ceratodus runcinatus Plien. Obere Lettenkohle, Hoheneck bei Ludwigsburg. (Nat. Größe.)

1) Günther $A l b$, Description of Ceratodus, a genus of Ganoid fish recently discovered in rivers of Queensland, Australia. Philosophical Transactions vol. CLXI 1871/72. - Huxley, Th., On Ceratodus and the classification of fishes. Proceed. Zool. Soc. 1876 p. 24. - Miall, L. C, Monograph of the Sirenoid and Crossopterygian Ganoids. Palaeontogr. Soc. Part. I 1878. - Pander Ch. H., Uber die Ctenodipterinen des devonischen Systems. St. Petersburg $1858.4^{\circ}$ mit Altas in Querfolio. - Traquair, On the genera Dipterus, Palaedaphus, Holodus, Cheirodus Ann. IMag. nat.-hist. 18784 ser. vol. XVII u. 5 ser. vol. II p. 1. - Zittel, $K$. A., Uber Ceratodus. Sitzungsber. der Bayer. Akad. d. Wissensch. mathem.-phys. Cl. 1886. Teller Fr., Uber Ceratodus Sturi. Abhandl. geol. Reichsanstalt. Wien 1891. Bd. XV. Dollo. Sur la phylogénie des Dipneustes. (Bull. soc. belge de Géol. IX. 1895. 79-128). - E. Stromer, Uber das Gebiß der Lepidosireniden und die Verbreitung tertiärer und mesozoischer Lungenfische (Hertwig-Festschrift II. 1910). $S$. W. Williston, A new species of Sagenodus from the Kansas Coal measures (Kansas Univ. Quart. 1899, Nr. 4). 
der unteren Schicht in drei Richtungen gekreuzt, denen auch die Knochenzellen folgen. Obere Schicht ohne Knochenzellen. Maxilla und Prämaxilla nicht differenziert, keine randlichen Kieferzähne. Keine Iugularplatten. Die Zähne entstehen ontogenetisch durch Konkreszenz von konischen Einzelzähnen (Hilgendorff, Semon), welche durch ein maschiges Knochengewebe basal verbunden werden. Rückenflosse sehr lang, ïber die hintere Hälfte des Körpers ausgedehnt, ebenso wie die ebenfalls lange Analis in die diphycerke Schwanzflosse übergehend; Strahler sehr fein, zahlreicher als die Träger, welche mit den Dornfortsätzen korrespondieren und artikulieren.

Ceratodus wird gewöhnlich mit Lepidosiren (Sümpfe des Amazonasgebiets) und Protopterus (tropisches Afrika) zu einer Abteilung zusammengefaßt (Sirenoidea). Es muß betont werden, daß es sich um drei durchaus geschiedene Familien handelt, von denen genauer nur die der Ceratodontiden fossil bekannt ist. Diese hängt mit den Ctenodontiden genetisch unmittelbar zusammen und dürfte durch diese von den Dipteriden abstammen.

$A$
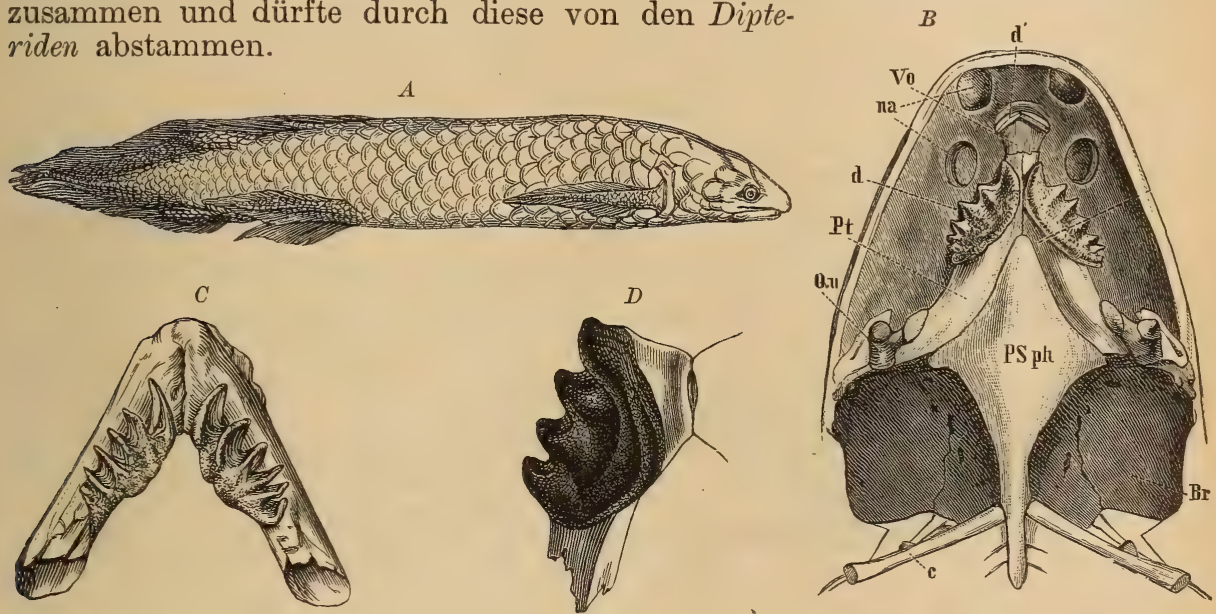

Fig. 136.

Ceratodus Forsteri Krefft (Barramundi) aus Queensland. A Seitenansicht des Fisches, verkleinert. $B$ Unterseite des Schädels. $C$ Unterkiefer (nach $\mathrm{G}$ ün ther).

Qu Quadratum, PSph Parasphenoid, Pt Pterygo-Palatinum, Vo Vomer, $d$ Zähne, na Nasenlöcher, $B r$ Kiemenhöhle, $c$ vorderste Rippe.

$D$ Ceratodus Kaupi Ag. Lettenkohlensandstein. Hoheneck bei Ludwigsburg. Unterkieferzahn auf knöcherner Basis. $1 / 3$ nat. Gr.

Ceratodus Ag. (Hemictenodus Jaekel p. p.) Das flache Schädeldach wird nur durch zwei große Medianplatten und 2 Paar Seitenplatten gebildet. An das lange, vorn rhombisch verbreiterte Parasphenoid legen sich seitlich die Pterygopalatina an, die vorn in einer Mediannaht gradlinig zusammentreffen. Sie tragen jederseits einen großen, mit Radialfalten versehenen Zahn, die knorpeligen Vomer je einen meißelförmigen Zahn. Auch der Unterkiefer trägt jederseits auf seinem, dem Spleniale (Operculare) entsprechenden inneren Teil einen Zahn mit hohen Radialkämmen. Verknöchert sind Operculum und Suboperculum, der Zungenbeinbogen, die Kiemenbögen, der Brustgürtel, die Rippen, obere und untere Bögen samt Dornfortsätzen und die Flossenträger, zum Teil in Form von knöchernen Hülsen. Das Quadratum bleibt knorpelig.

Der Name Ceratodus ist ursprünglich den fossilen Zähnen beigelegt, die sich aber nur unwesentlich (bedeutende Größe, geringere Zahl der Kämme) von der lebenden Gattung unterscheiden. Die Zähne der lebenden Form haben $6 \mathrm{Kämme}$, bei den fossilen besitzen die Oberkieferzähne meist 5 , die Unterkieferzähne 4 Kämme. An einem Schädel aus den Raibler- 
Schichten (unt. Keuper) von Lunz in Niederösterreich beobachtete Fr. Teller, daß die Seitenlinie in tief eingesenkten Kanälen der Knochen verläuft, daß die Verknöcherung massiger ist, und daß die paarigen Lateralia des Schädeldaches hintereinander liegen (C. Sturi Teller). Er möchte hiernach den fossilen Ceratodus von dem lebenden Epiceratodus abgrenzen.

Häufig in der Trias. Buntsandstein (C. arenaceus Qu.), Muschelkalk, Lettenkohle (Hohenecker Kalk), Keuper, Rhät.; in den oberen Karruschichten Südafrikas (C.capensis A. Sm. Woodw.), in der Kota-Maleri-Gruppe (unterer Keuper) Indiens. Seltener im braunen Jura (Stonesfield Slates), im oberen Jura von Colorado, in Fort Union-Schichten (oberen Kreide) von Montana.

\section{Unterklasse. Arthrodira.}

Kopf und Rumpf mit symmetrisch angeordneten Platten bedeckt, der Kopf mit dem Rumpfpanzer gelenkig verbunden und hinter dem Kopfschild eine größere Lücke des Panzers, die eine verschiedene Stellung des Kopfes erlaubt. Augenhöhlen seitlich. Große Zühne am Unterkiefer und an zwei Belagknochen des Pterygopalatinum (Gaumenbein und Vomer), Maxilla und Prämaxilla zahnlos. Die Zähne sind mit den knöchernen Unterlagen meist verschmolzen und treten als Zacken an diesen auf. Offene dermale Kanäle in den Panzerknochen. Chorda persistent, Bogenteile verknöchert und wohl entwickelt. Brustflosse fehlt, Beckenflosse reduziert, aber mit schlankem, spatelförmigem Basipterygium und einigen Flossenstrahlen.

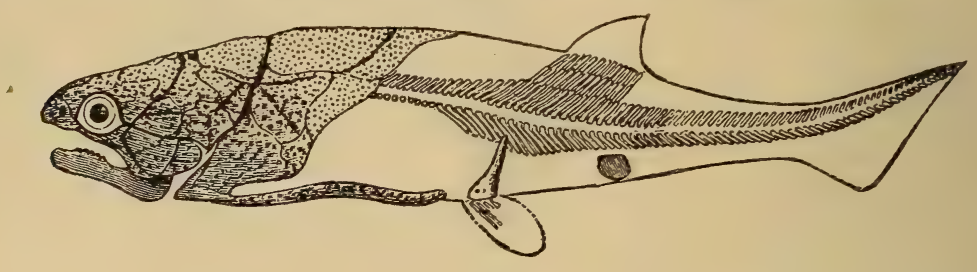

Fig. 137.

Coccosteus decipiens, nach A. Sm. Woodward. Mittl. Oldred, Schottland. Ca. 1:4. Aus "Guide to the fossil Reptilia etc." mit Genehmigung der Trustees des British Mus. of Nat. Hist.

Zum Schultergürtel rechnet A. Sm. W oodward die sich bei Coccosteus vor den ventralen Panzerplatten hinziehenden und in der Mitte zusammenstoßenden schmalen Interlateralplatten (Traquairs); Jaekel nennt sie Iugularia und interpretiert den ganzen Ventralpanzer (d. h. die paarigen vorderen und hinteren Ventralplatten und die beiden in der Mediane liegenden Platten) als Schultergürtel. Die vorderen Platten nennt er Claviculae oder Deckknochen der Procoracoide, die hinteren Postclaviculae (Deckknochen der Coracoide), die mittlere Zentralplatte Interclavicula, die davor auftretende (unpaare) Präclavicula.

Die bei einigen Formen nachgewiesenen »Ruderorgane» sind stab. förmige oder verlängert dreieckige Hautknochen, die an der Grenze von Jaekels Clavicula und Cleithrum sich anlegen.

In einer späteren Notiz wird der über der Clavicula auf der Seite folgende Knochen als Cleithrum, der zwischen diesem und der großen Nackenplatte sich einschiebende, Collare genannt. Letzteres soll durch die Bahn der Seitenlinie gekennzeichnet und damit auch als derselbe Teil festgelegt sein, der bei Teleostomen gelegentlich Supraclavicula genannt ist ${ }^{1}$ ).

1) J a ekel, Zeitschr. geol. Gesellsch. 1903. Sitz.-Ber. Ges. naturforsch. Freunde. 1906. 
Wenn diese Vergleichung richtig ist, so würde es sich empfehlen, die Bezeichnung Epioticum durch Squamosum zu ersetzen, da die sog. Epiotica der Stegocephalen ebenfalls als Homologa der Supraclavicula gelten.

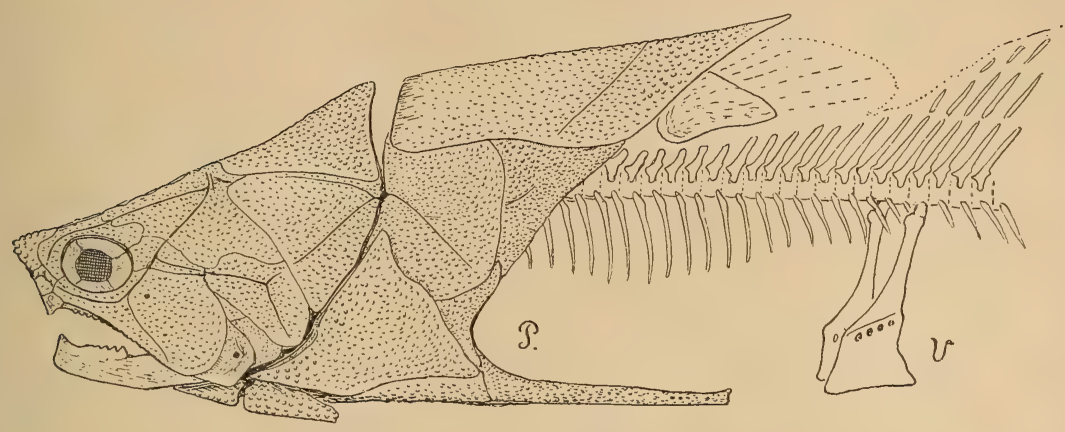

Fig. 138 .

Coccosteus decipiens Ag. Kopf und Rumpf rekonstruiert nach Jaekel. $P$ Lage der Brustflosse, $V$ Lage der Bauchflosse.

Die Stellung der Arthrodira im System ist eine recht selbständige, die weder durch die Einreihung bei den Dipnoern noch bei den Placodermen zum Ausdruck gebracht wird. Die Beziehungen zu den Accipenseroiden sind neuerdings wieder von Jaekel hervorgehoben. Daß das Gebiß der lebenden Störe mit den mächtigen Zahnplatten der Arthrodira im ganzen ähnliche Formverhältnisse zeigen soll, ist schwer verständlich, da bei den Stören die Bezahnung rückgebildet ist. Die Accipenseriden (und schon Chondrosteus) sind geradezu extrem hyostylisch, da der kleine Kieferbogen durch ein langes Symplecticum mit dem Hyomandibulare verbunden und von Primordialcranium abgerückt ist, während bei Dinichthys diese Verhältnisse an die Autostylie der Dipnoer erinnern (Verschmelzung der zahntragenden Platten mit dem Suborbitale oder Maxillare genannten Knochen). Der Vergleich der vorderen Panzerplatten des Rumpfes mit dem Schultergürtel der Accipenseriden läßt sich durchführen, jedoch ist zu beachten, daß bei Stören die Beteiligung des primären, knorpeligen Schultergürtels eine recht umfängliche ist und die Brustflosse gerade dem coracoidalen und scapularen Knorpel anhaftet, während bei Coccosteus eben die Panzerplatten lückenlos aneinanderschließen und echte dermale Bildungen sind. Der Pectoralstachel der Störe ist aus verschmolzenen Flossenstrahlen hervorgegangen und nicht homo. log dem »Ruderorgan« der Coccosteus etc., in dem Jaekel auch zugleich das Homologon des »Ruderorgans» der Aster-

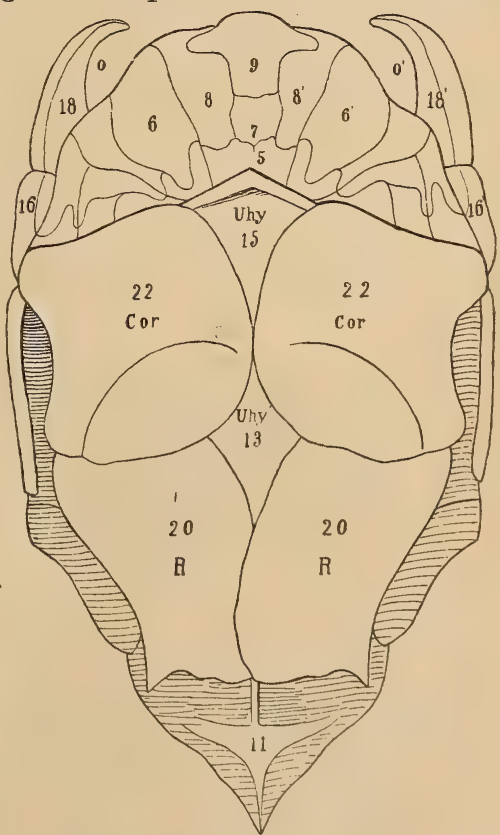

Fig. 139.

Coccosteus, restauriert von $\mathrm{Pander}$. Von der Unterseite; außer dem Ventralpanzer sieht man Teile des Kopfpanzers von der Unterseite. Cor (22) Claviculae, $\boldsymbol{R}(20)$ Postclaviculae, Thy

(13) Interclavicula, Uhy (15) Präclavicula. (Benennungen nach Jaekel.) 
olepiden und der "Cornua " (seitliche hintere Verlängerungen des Kopfschildes) der Cephalaspiden erblickt.

Sehr ähnlich wie bei den Placodermen ist die Anordnung der Platten im Ventralpanzer, aber die räumliche Anordnung großer Hautknochen in einer begrenzten Region des Körpers muß immer eine gewisse Ähnlichkeit zeigen, die durch Konvergenz zu auffallender Übereinstimmung gesteigert werden kann. Die Anlage des Kopfpanzers ist schon dadurch fundamental verschieden, daß den Kieferteilen bei Coccosteus etc. eine erhöhte Bedeutung zuerteilt ist. Das Ruderorgan ist ein einheitlicher Knochenstab, der mit dem kompliziert gebauten Anhang der Asterolepiden gar keine Ähnlichkeit hat; er ist eher mit den Präopercularstacheln gewisser Stachelflosser zu vergleichen, deren Abgliederung allerdings noch nicht beobachtet ist.

Auch das Auftreten einer Beckenflosse bei Coccosteus ist ein wichtiges, die Grenze gegen die Asterolepiden festigendes Merkmal. Diese bilden eine Abteilung innerhalb eines größeren Kreises, in dem Bildung paariger Flossen überhaupt unbekannt ist. Die kleine, wenn auch rudimentäre Beckenflosse bezeichnet die Coccosteiden als eine Abteilung, die normal paarige Extremitäten entwickelt und bei der es schon zu einer starken Rückbildung gekommen ist, der die Brustflossen ganz verfielen.

Die Ähnlichkeit mit den Dipnoern liegt besonders in der Bildung des Gebisses und in der vermutlichen Autostylie. Die Angabe von gelegentlichen Ossifikationen im Bereich des Primordialcraniums sind noch näher zu prüfen. Demgegenüber steht aber eine Anzahl wichtiger Unterschiede, vor allem die ganz abweichende Bepanzerung der Ventralseite des Rumpfes, während die Anordnung der Platten im Kopf eines devonischen Dipterus oder Phaneropleuron besonders in der mittleren Region sich wohl vergleichen läßt.

Die Ordnung der Arthrodira umfaßt die Familien der Coccosteidae und der Ptyctodontidae, welche sich vielleicht noch die ungenügend bekannten Asterosteidae und Mylostomatidae anreihen.

\section{Familie: Coccosteidae.}

Kopfschild zusammengesetzt aus großen Deckplatten. Die mittlere Region wird gebildet von der unpaaren Occipitalplatte, den großen paarigen Parietalien, einem kleinen Frontale (mit Epiphysengrube; in der englischen Literatur Ethmoid
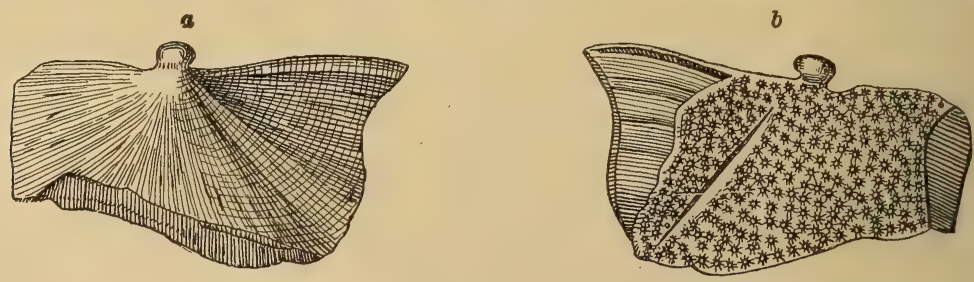

Fig. 140.

Coccosteus decipiens Ag. a Vordere Seitenplatte des Rückenschildes von innen, $b$ von außen.

genannt), einem größeren unpaaren Nasale bzw. Ethmoid, das sich unmittelbar anschließen kann oder durch die großen, paarigen Präfrontalien abgedrängt ist, wenn diese in der Mittellinie zum Kontakt kommen. Seitlich neben dem oberen Hinterhauptsbein liegen die sog. Epiotica, denen sich nach vorn ein Supratemporale, Postfrontale und Jugale (auch Suborbitale und Maxillare bezeichnet) anreihen.

1) Dollo L., Les Ptyctodontes sont des Arthrodères (Bull. Soc. belge de Géol. 1907). - Eastman Charles R., Observations on the dorsal shields in the Dinich. thyids (American Geologist. 1896. 222). - Hussakof L., The systematic relationship of certain American Arthrodires (Bull. Amer. Mus.-Nat.-Hist. XXVI. 263-272). - 
Nasenlöcher klein, weit vorne, zuweilen von selbständigen kleinen Knochen seitlich begrenzt, die als Septomaxillaria oder als Prämaxillen gedeutet werden können. Rumpf mit einer großen, hinten zugespitzten, dicken, innerlich mit Mediankiel versehenen Dorsalplatte, daneben zwei Paar Lateralplatten, wovon die vorderen mit Gelenkzapfen. Bauchpanzer aus jederseits zwei Seitenplatten und ein bis zwei unpaaren Medianplatten zusammengesetzt. Die Orbitae sind entweder knöchern

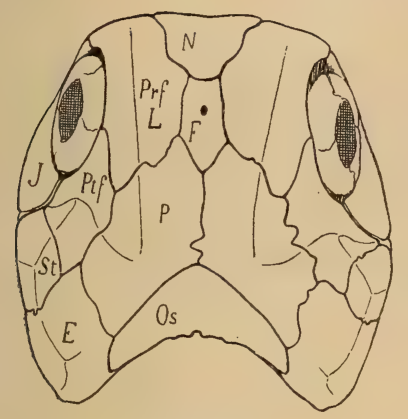

Fig. 141.

Pachyosteus bulla Jaekel. Kopf von oben. (Nach Jaekel.)

$N$ Nasale, $F$ Frontale, $P$ Parietale, os Supraoccipitale, $E$ Epioticum, St Supratemporale, $J$ Jugale, Ptf Postfrontale, $\operatorname{Prf} L$ Präfrontale und Lacrimale. Oberdevon, Wildungen.

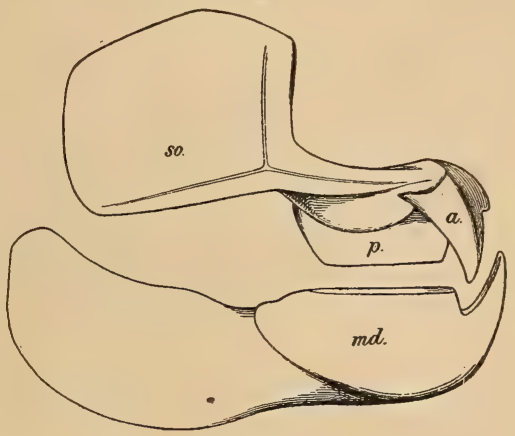

Fig. 142.

Dinichthys intermedius. Kiefer der rechten Seite von außen. so Suborbitalplatte mit Schleimkanal, md Unterkiefer, $a$ vordere, $a$ hintere Zahnplatte. Oberdevon, Ohio 2:9. Nach A. Sm. W o odw ard. Aus » Guide to the fossil Reptilia etc. * mit Genehmigung der Trustees des Brit. Mus. of Nat. Hist.

umgrenzt (Homosteus u. a.) oder in der vorderen Seitenwand des Kopfschildes „eingeschnitten" (Coccosteus u. a.), wenn das Suborbitale, das die untere Begrenzung abgibt, zurïckgebildet wird.

Coccosteus Ag. (Liognathus Newb.) Kopf und Rumpf breit, die Panzerplatten mit runden Höckerchen bedeckt. Kopfplatten übergreifend.

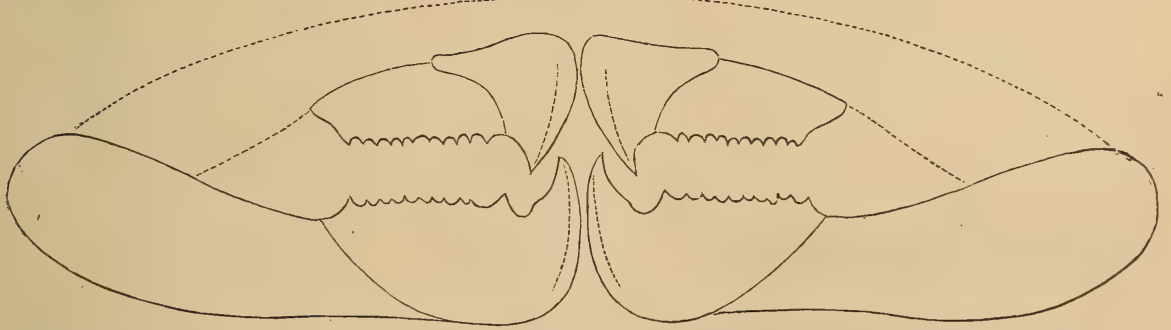

Fig. 143.

Dinichthys Hertzeri Newberry. Devon (Huron shales). Delaware. Ohio. Schematische Abbildung des Zwischenkiefers, Oberkiefers und Unterkiefers. 1/6 nat. Gr. (Nach Newberry.)

Orbita »eingeschnitten «, mit knöchernem Scleroticalring. Ventralschild mit einer rhombischen Medianplatte und einer keilförmigen, medianen Vorderplatte. Vor dem Bauchpanzer zwei schmale Platten, die A. Sm. Wood. ward zum Schultergürtel rechnet (s. o.). Dorsalflosse kurz. C. decipiens Ag. Die typische Art, aus dem unteren Oldred. Coccosteusarten sind sehr ver-

Jaekel, Neue Wirbeltierfunde aus dem Devon von Wildungen. Sitz.-Ber. Ges. naturf. Freunde. 1906. - v. Koenen, Zeitschr. d. deutsch. geol. Ges. 1880. Abhandl. Ges. d. Wiss. Göttingen. 1883. - Rohon, Beitrag zur Kenntnis der Gattung Ptyctodus. Verh. russ. mineral. Ges. Petersburg 1895. XXXII. S. 15.) - Traquair R. H., On the structure of Coccosteus decipiens. Ann. Mag. nat. hist. 1890.

- Woodward A. Sm., Catalogue etc. II. S. 277.

Zittel, Grundzüge der Paläontologie II. 
breitet im Oldred von Schottland und Irland und im Devon von Böhmen, der Eifel, von Nassau, Rußland.

Pachy osteus Jaekel. (Fig. 141.) Präfrontalia sehr groß, nicht imKontakt; die Orbitae vollkommen umgrenzt, seitlich gestellt. Oberdevon, Wildungen.

Brachydirus v. Koenen. Kopfschild seitlich und unten mit einem schlanken Stachel (sog. Ruderorgan). Oberdevon, Nassau.

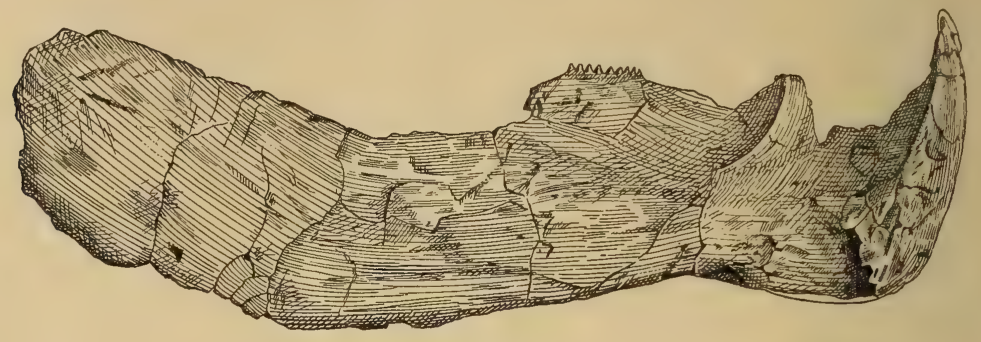

Fig. 144.

Dinichthys Hertzeri Newb. Unterkieferast. Devon. Delaware. Ohio. 1/3 nat. Gr. (Nach Newberry.)

Phlyctaenaspis Traquair, Nordamerika (Oberdevon, Delaware, Ohio). Chelyophorus Ag. Unterdevon, England, Nordamerika.

Dinichthys Newberry. Riesige Fische, deren Kopf bis $1 \mathrm{~m}$ lang wird. Die mittlere Hinterhauptsplatte dreiseitig mit hinten vorragendem medianem Fortsatz, die Squamosa oder Epiotica mit tiefen Gruben zur Aufnahme des Gelenkkopfes der vorderen Seitenschilder (Collare) des Rückenpanzers. Platten glatt oder fast glatt, die des Schädels im Alter verwachsen. Schwanzregion ohne Schuppen. Frontale sehr klein (Ethmoid) mit Durchbohrung. Orbitae außen nicht knöchern begrenzt. Ein Maxillare (Suborbitale) entwickelt, zahnlos; die oberen zahntragenden Platten werden dem Vomer und Palatinum zugeschrieben; sie verwachsen mit dem Maxillare (Suborbitale, Jugale) zu einem Komplex. Unterkieferäste in der Symphyse durch Naht vereinigt, vorn in einem scharfen, schnabelartigen Fortsatz auslaufend, mit einer

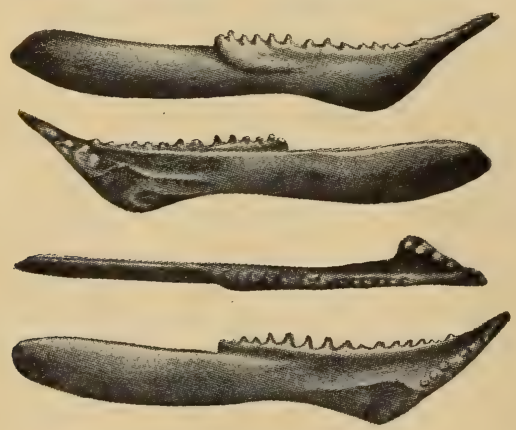

Fig. 145.

Diplognathus mirabilis Newberry. $1 / 6$ nat. Gr. Unterkieferäste in verschiedener Stellung. (Nach Newberry.)

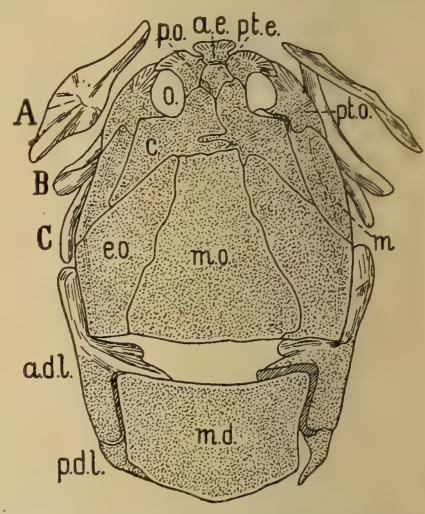

Fig. 146. Homosteus Milleri, Mittl. Oldred, Caithness. 1:9. $A, B, C$ unbestimmte Knochen, mo oberes Hinterhauptsbein, eo sog. Epiotica bez. Exoccipitalia, $c$ Parietalia, pt.e Frontale, Ethmoid oder Pineale, ae Nasale (Ethmoid), po Präfrontale (Präorbitale), pt.o Postfrontale (Postorbitale), $m$ Jugale (Marginale), md Nackenschild, Nuchale, mittleres Dorsale. a.d.l. vordere Seitenplatte, p.d.l hintere Seitenplatte, Schleimkanäle punktiert.

(Nach R. Traquair.) Entnommen aus "Guide to the fossil Reptilia etc. mit Genehmigung der Trustees des British Museum for Nat. Hist.

Reihe dem Knochen fest aufgewachsener Zähne. Mittlere Platte des Rückenschildes massig, mit Mediankiel auf der Innenseite, am Vorderrand mit 
mittlerem Fortsatz, aber zugespitzt. Die Platten des Ventralpanzers sind wie bei Coccosteus angeordnet, aber die medianen Platten sind zu einem einzigen langen Stück verschmolzen. Kurze, derbe Pectoralstachel. Oberdevon, Nordamerika (Cleveland shales, Ohio und anderes). Unsichere Reste im Mitteldevon der Eifel.

Titanichthys Newberry. Noch größer als Dinichthys. Unterkieferäste ohne Zahnzacken, vorn grubig. Oberdevon, Cleveland shales, Ohio.

Macropetalichthys

Norwood u. Owen. Platten des Kopfes im Alter verschmolzen. Die Parachordalia sollen ossifiziert sein. Dermale Kanäle sehr entwickelt, mit schlauchförmigen Einsenkungen in die Knochen. Devon. Nordamerika, Eifel.

Diplognathus Newberry. Die Unterkieferäste gehen nach kurzer Symphyse wieder gabelförmig auseinander und sind hier auf der Innenseite mit scharfen, gekrümmten Zähnen besetzt. Ähnliche Zähne besetzen den Rand des Unterkiefers bis zur Hälfte seiner Länge. Oberdevon, Ohio. (Fig. 145.)

Ho mo steus Asmuss. Große Fische mit flachem Schädel. Orbita von Knochen umschlossen. Die Hinterhauptplatte sehr lang, die mittlere Rückenplatte breiter als lang, hinten nicht zugespitzt. Devon, Livland. Unteres Oldred, Schottland. (Fig. 146.)

Heterosteus Asmuss. Isolierte Panzerteile von riesiger Größe aus dem De-

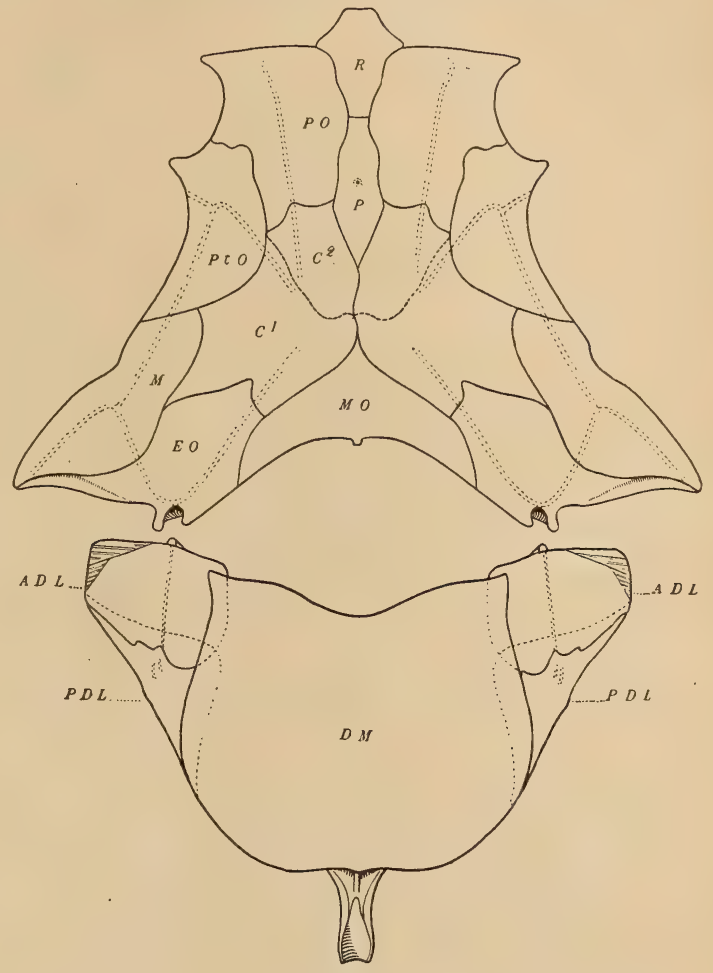

Fig. 147.

Dinichthys intermedius Newb. Clevelandshale, Ohio. 1:6. $D M$ Mittlere Dorsalplatte, $A D l$ vordere, $F D L$ hintere dorsale Seitenplatte, Mo Supraoccipitale, Eo Epioticum, $P$ Frontale (Pineale), $R$ Nasale (Rostrale), $C^{1}$ Parietalia, $C^{2}$ Postfrontalia, PO Präfrontalia, PtO Postorbitalia (Jugale Jaekel), II Supratemporale (Marginale.) (Nach Eastman.) von von Dorpat. Die Gelenkfortsätze des Collare mehr als zweimal so lang als der Rest des Knochens. Devon.

Aspidichthys Newberry, Glyptaspis Newberry. Anomalichthys v. Koenen.

Familie: Ptyctodontidae. A. Sm. Woodward.

Meist nur große, seitlich zusammengedrückte Zahnplatten bekannt, von denen je zwei, oben und unten, in der Symphyse schnabelartig zusammenstojen. Devon. Eifel, Rußland, Nordamerika.

Ptyctodus Newb. (Aulacosteus Eichw.) Symphysenfläche schmal. Die Reibinseln (Tritoren) sind aus schrägen Lamellen zusammengesetzt und sehr hart. Mitteldevon (Hamilton), Nordamerika, Rußland.

Rhynchodus Newb. Symphysenfläche schmal. Tritoren nicht differenziert. Mitteldevon; Nordamerika, Eifel. 
Palaeomylus A. Sm. Woodward. Symphysenfläche sehr breit. Eine unbestimmt umgrenzte Tritorenfläche, die nicht lamelliert, sondern punk. tiert ist. Mitteldevon, Nordamerika.

Rhamphodus Jaekel (Fig. 148). Belagknochen des Schultergürtels nach Jaekel aus Cleithrum, Clavicula, Collare und einem stachelartigen Spinale zusammengesetzt. Bezahnung ähnlich Rhynchodus. Oberdevon, Wildungen.

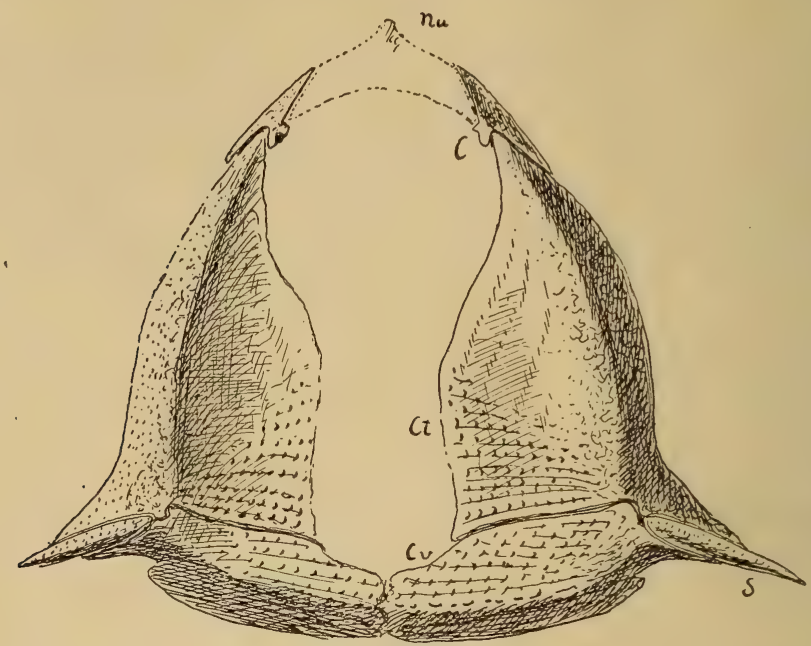

Fig. 148.

Rhamphodus tetrodon Jaekel. Schulterapparat von vorn. In $2 / 3$ nat. Gr. C Collare, Ct Cleithrum, $C v$ Clavicula, $S$ Spinale. (Nach Jaekel.)

In die Nähe der Coccosteiden werden noch provisorisch gestellt:

Asterosteidae. Platten des Kopfschildes verschmolzen. Die paarigen Nasenlöcher zwischen den Orbiten. Klein. Asterosteus stenocephalus Newberry. Oberdevon, Ohio.

Phyllolepidae. Dünne Hautplatten mit feinen, konzentrisch oder strahlig angeordneten Runzeln. Phyllolepis Ag. Oberes Oldred, Schottland. Devon, Belgien. Holonema Newberry. Oberdevon, Nordamerika.

Mylostom a Newberry. (Palaeozoic fishes of N.-Amerika. 1889.) Dicke Zahnplatten von bedeutender Größe, welche wahrscheinlich zu mehreren im Unterkiefer und im Gaumendach standen. Das knochenartige Gewebe wird gegen die Oberfläche dicht und emailartig; die Oberfläche ist punktiert. Oberdevon, Ohio.

\section{Unterklasse: Teleostomi.}

Mundspalte von Kieferdeckknochen umrandet. Kiefer nicht autostylisch sondern durch einen Kieferstiel mit dem Schädel verbunden. Operculum knöchern. Innen- und Aujienskelett mehr oder weniger verknöchert. Die Deckknochen des Schultergürtels mit denen des Hinterkopfes verbunden.

Diese Unterklasse umfaßt als Ordnungen die Crossopterygier, die Ganoiden und die Teleostier und somit weitaus die meisten aller bekannten Fische. Man faßt die beiden letztgenannten als Actinopery- 
gier zusammen, deren Flossen durch eine verkürzte Achse und kräftige Strahlen sich vor denen der Crossopterygier auszeichnen.

\section{Ordnung: Crossopterygii. ${ }^{1}$ )}

Paarige Flossen quastenförmig, mit beschuppter Achse. Zwei große Jugularplatten $z$ wischen den Unterkiefern, daneben bei paläozoischen Formen oft noch kleinere Seiten. platten und eine mediane Vorderplatte. Schwanz diphycerk oder hetero-diphycerk. Devon bis jetzt (Polypterus).

\section{Familie: Holoptychiidae Traquair.}

Körper mit runden, imbrizierenden Ganoidschuppen bedeckt. Chorda persistent. Brustflossen mit langer, beschuppter Achse, die in der Art eines Archipterygiums gegliedert ist. Schwanaflosse heterocerk, mit kleinem oberen Lappen. Die zwei

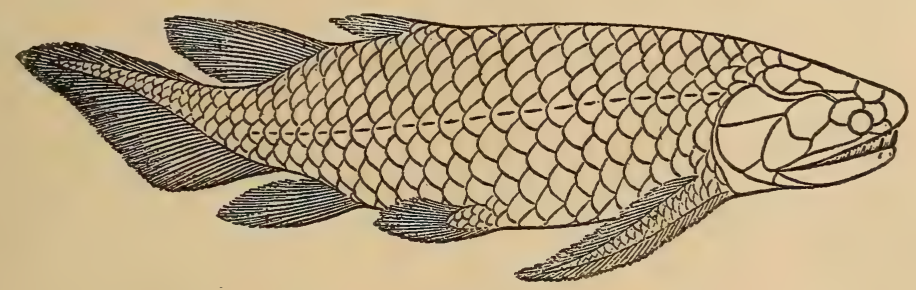

Fig. 149.

Holoptychius Flemingi. Oberes Oldred, Fifeshire. 1:8. Nach Traquair. Aus »Guide to the fossil Reptilia etc." mit Genehm. d. Trustees des Brit. Mus. Nat. Hist.

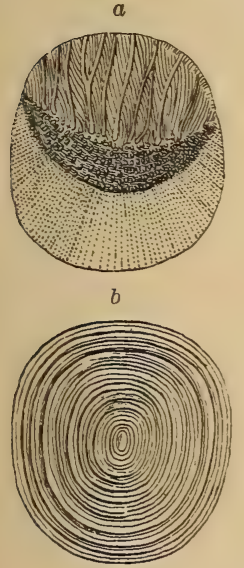

Fig. 150.

Schuppe von Holoptychius (Glyptolepis). Alter roter Sandstein. Wik, Rußland. (Nach Pander.) $a$ von außen. $b$ von innen.

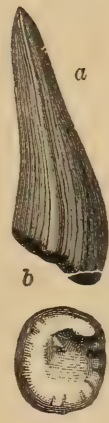

Dendrodus biporcatus Ag. Devon. Fluß Aa, Livland. a von der Seite, $b$ von unten. Nat. Gr. c Querschnitt, stark vergr. (Nach Pander.)

1) Huxley T. H., Illustrations of the structure of the Crossopterygian Ganoids. Mem. Geol. Survey. Dec. XII. 1866. - Reis O. M., Die Coelacanthinen mit besonderer Berücksicht. d. im weißen Jura Bayerns vorkommenden Gattungen. Palaeontographica. Bd. XXXV. 1888. Geognost. Jahreshefte. 1892. - Woodward A. Sm., Catalogue etc. II. $316 \mathrm{ff}$. 
Dorsalflossen und die Analflosse je durch einen einfachen, distal verbreiterten Träger (Axonost) gestützt, auf welchen 1 bis 2 Reihen kurzer Basalstücke (Basioste) folgen, welche die feinen äußeren Flossenstrahlen tragen bzw. sich zwischen sie schieben. Seitliche Jugularplatten. Infraclavicula. Kopf und Kiemenregion mit glänzenden Hautknochen bedeckt. Marginale Zähne klein, zahlreich, konisch, außerdem einzelne große, zweischneidige Fangzähne in einer inneren Reihe des Unterkiefers (auf mehreren isolierten Splenialknochen) und (ein Paar) im Oberkiefer. Dentin labyrinthisch gefaltet.

Holoptychius Ag., Glyptolepis, Platygnathus Ag. (Fig. 149, 150), Devon; besonders im Oldred sandstone von Schottland, Irland, den russischen Ostseeprovinzen, Kanada, aber auch in marinen Schichten von Nordamerika, Belgien, Böhmen, der Eifel usw. Einzelne Arten erreichen bedeutende Größe.

Isolierte Zähne sind als Dendrodus Owen (Fig. 151), Lamnodus Ag. und Apedodus Leidy beschrieben.

\section{Familie: Rhizodontidae.}

Von den Holoptychiden durch die kurze Achse der Brustflossen unterschieden. Dentin der Zähne nur im unteren Teil der Krone radial gefaltet. Devon, Karbon. Rhizodus Owen (Megalichthys Ag. pr. p.) (Fig. 152). Sehr große Fische

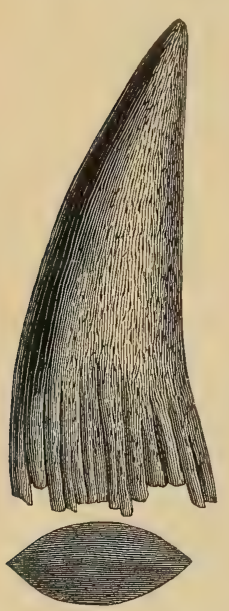

Fig. 152.

Zahn von Rhizodus Hibberti Ag. Steinkohlenformation.

Edinburgh. $1 / 2$ nat. Gr.

mit runzligen cycloiden Ganoidschuppen. Infraclavicula mit einem langen Fortsatz nach oben. Zähne glatt, zweischneidig. Steinkohlenformation. Schottland, England, Nordamerika. Strepsodus Young (Dendrop. tychius Young, Archirhthys Hancock). Große und mittelgroße Fische. Zähne schlank, etwas gebogen, seitlich nicht zugeschärft. Steinkohlenformation. England, Kanada.

Rhizodopsis Young (Dittodus, Ganolodus, Characodus, Gastrodus Owen, Orthognathus Barkas) (Fig. 153). Schup.

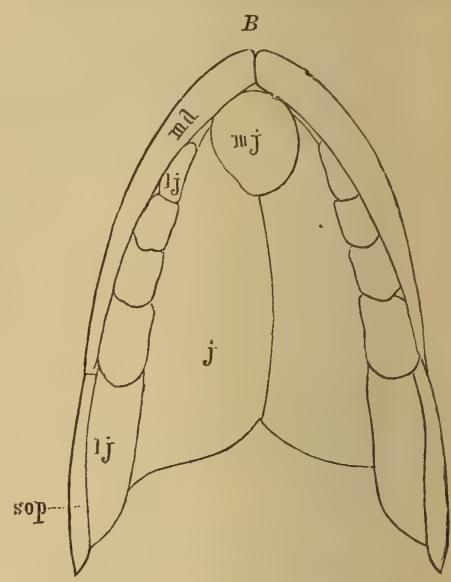

C

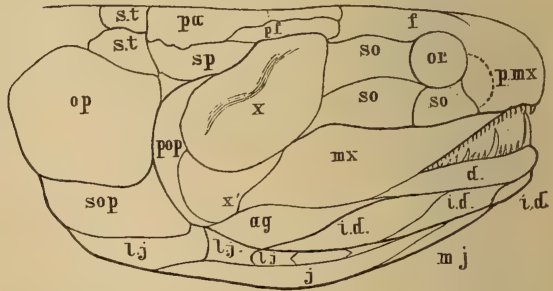

Fig. 153.

Rhizodopsis sauroides Williamson sp. Steinkohlenformation. Manchester. Kopf restauriert. $A$ von oben. $B$ von unten. $C$ von der Seite. (Nach Traquair.) $p a$ Parietale. $f$ Frontale. $p f$ Postfrontale. $s q$ Squamosum. st Supratemporalia. $p m x$ Prämaxilla. or Orbita. so Suborbitalia. $m x$ Maxilla. $x$ und $x^{\prime}$ Wangenknochen. pop Präoperculum. op Operculum. sop Suboperculum. $m d$ Unterkiefer. ag Angulare mandibulae. $d$ Dentale. $i d$ Infradentalia. $j$ Hauptkehlplatte. $l j$ seitliche Kehlplatten. $m j$ mittlere Kehlplatte. 
pen oval, mit dünnem Ganoidüberzug, auf der Innenseite mit einem Höcker in der Mitte. Zähne im Querschnitt rund, glatt. Wirbelsäule mit Hohlwirbeln. Steinkohlenformation. England, Schlesien, Neu-Schottland.

Gyroptychius McCoy, sehr nahe mit Rhizodopsis verwandt. Schuppen auf der Innenseite mit einer Leiste. Unteres Oldred.

Tristichopterus Egerton. Im Abdomen mit Hohlwirbeln. Hetero. cerk. Unteres Oldred.

Eusthenopteron Whiteaver. Im Abdomen mit Hohlwirbeln. Diphycerk oder wenig heterocerk; Schwanzflosse sehr groß, ausgeschnitten, in der Richtung der Körperachse mit verlängerten Strahlen. Oberdevon, Kanada.

Cricodus Ag. (Polyplocodus Pander), Devon, Rußland, Schottland, Belgien. Sauripterus Hall. Devon (Oldred und Catskill-Gruppe) von Europa und Nordamerika.

\section{Familie: Osteolepidae. ${ }^{1}$ )}

Schlank, mit rhombischen Ganoidschuppen. Ringwirbel in der Schwanzregion. Interopercula und seitliche Jugularplatten fehlen. Brustflossen mit kurzer Achse. Zähne nur an der Basis außen gefaltet, die innere Reihe mit einigen großen Fangzähnen. Devon.

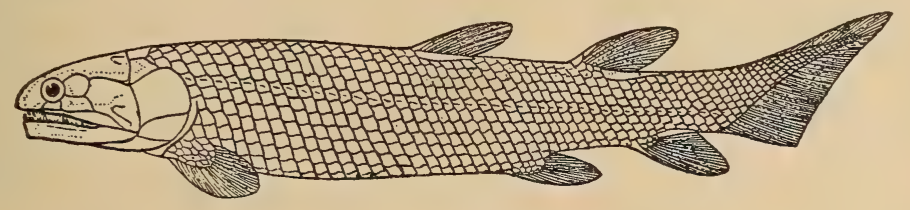

Fig. 154.

Osteolepis macrolepidotus. Mittl. Oldred, Schottland. 1:3. Nach Traquair. Aus "Guide to the fossil Reptilia etc." mit Genehmigung der Trustees d. British Mus. Nat. Hist.

Osteolepis Ag. (Tripterus, Triplopterus McCoy). Die vor den Parietalien liegenden Knochen des Schädeldaches verschmolzen. Frontallech vorhanden. Zähne im Querschnitt rund. Schuppen glatt oder punktiert. Schwanz ausgeprägt heterocerk. Erste Dorsalis vor den Bauchflossen. Oldred, Schottland.

Thursius Traquair. Wie Osteolepis, aber 1. Dorsalis gegenüber den Bauchflossen. Oldred, Schottland.

Diplopterus Ag. Devon.

Gly p to p o mus Ag. (Glyptolaemus Huxley). Knochen des Schädeldaches nicht verschmolzen und wie die Schuppen mit Runzeln und Körnern. Schwanz diphycerk. Oldred. Schottland.

Megalichthys Ag. (Centrodus McCoy, Rhomboptychius Young, Ectosteorhachis Cope, Parabatrachus Owen). Steinkohlenformation.

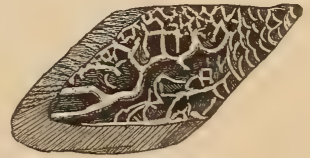

Fig. 155 . Schuppe von Glyptopomus
Kinnairdi Huxley. Vergr. (Nach Huxley.)

\section{Familie: Onychodontidae. ${ }^{2}$ )}

Schuppen cycloid. Unterkiefer mit einem Präsymphysialknochen, der mit großen Zähnen besetzt und sigmoidal gebogen oder spiral eingerollt ist.

1) Außer Agassiz, Poiss. foss. II. vgl. Pander, Saurodipt., Dendrodont. usw. des devonischen Systems. 1860. - Traquair $R$. H., Geol. Mag. 1888. Ann. Mag. Nat. Hist. 1890. - Woodward A. Sm., Catalogue II.

2) Newberry J. S., Bull. National Institute. 1857. Rep. Geol. Survey Ohio. Vol. I. pt. 2. 1873. Palaeozoic fishes of North America. Monogr. U. S. Geol. Surv. XVI. 1889. 
Onychodus Newberry. (Fig. 156, 157.) Unterdevon, Ohio. Unteres Oldred, England.

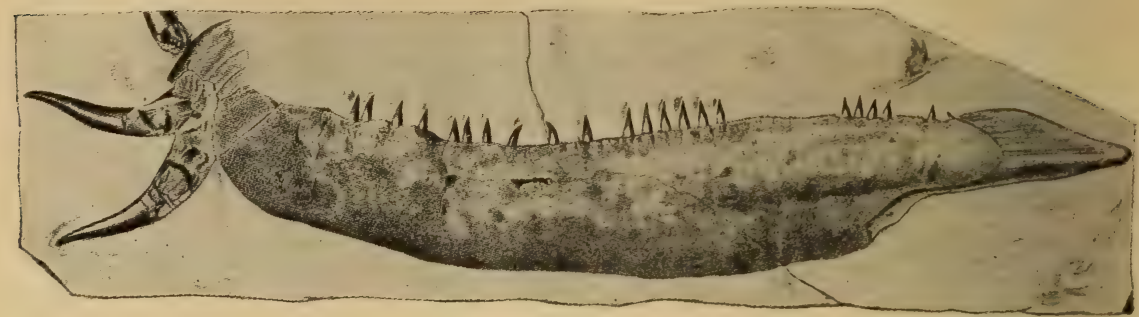

Fig. 156.

Onychodus sigmoides Newb. In $1 / 3$ nat. Gr. Mit den symphysealen Zähnen in situ. (Nach New berry.)

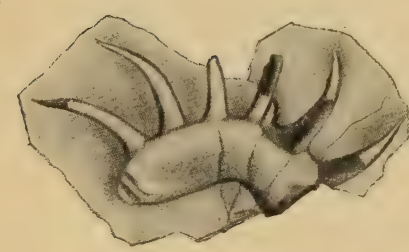

Fig. 157.

Onychodus Ortoni Newb. In $1 / 2$ nat. Gr. Die intermandibulare (symphyseale) Zahnreihe.

(Nach Newberry.)
Familie: Coelacanthidae Huxley.

Körper mit dünnen, cycloiden Ganoidschuppen bedeckt. Wirbelsäule nicht verknöchert. Bögen, Dornfortsätze und die Interspinalia der Schwanzflosse von Knochenscheiden umgeben. Chondrocranium zum Teil verknöchert. Paarige Flossen mit kurzer, stumpfer Achse. Die 2 Dorsalflossen und die Afterflosse durch eine einfache, proximal meist gegabelte Platte getragen, auf welche bei der vorderen Dorsalis unmittelbar die äußeren Strahlen folgen. Schwanzflosse diphycerk, durch zahlreiche, einfache Träger gestützt, und in einer weit vorspringenden, kleineren Pinselflosse endigend. Träger der Beckenflosse einfach, nicht in der Mediane verbunden. Nur ein Operculum und ein paar Jugularplatten. Mehrere Splenialia. Schwimmblase verknöchert. Perm bis Kreide.

Coelacanthus Ag. (Hoplopygus Ag., Conchiopsis Cope, Rhabdoderma Reis). Außenrand der Kiefer ohne Zähne, nur einige wenige der inneren Reihe vorhanden. Kopfknochen und Schuppen runzelig und körnelig; Flossenstrahlen nicht gezähnelt. Karbon, Perm. England, Deutschland

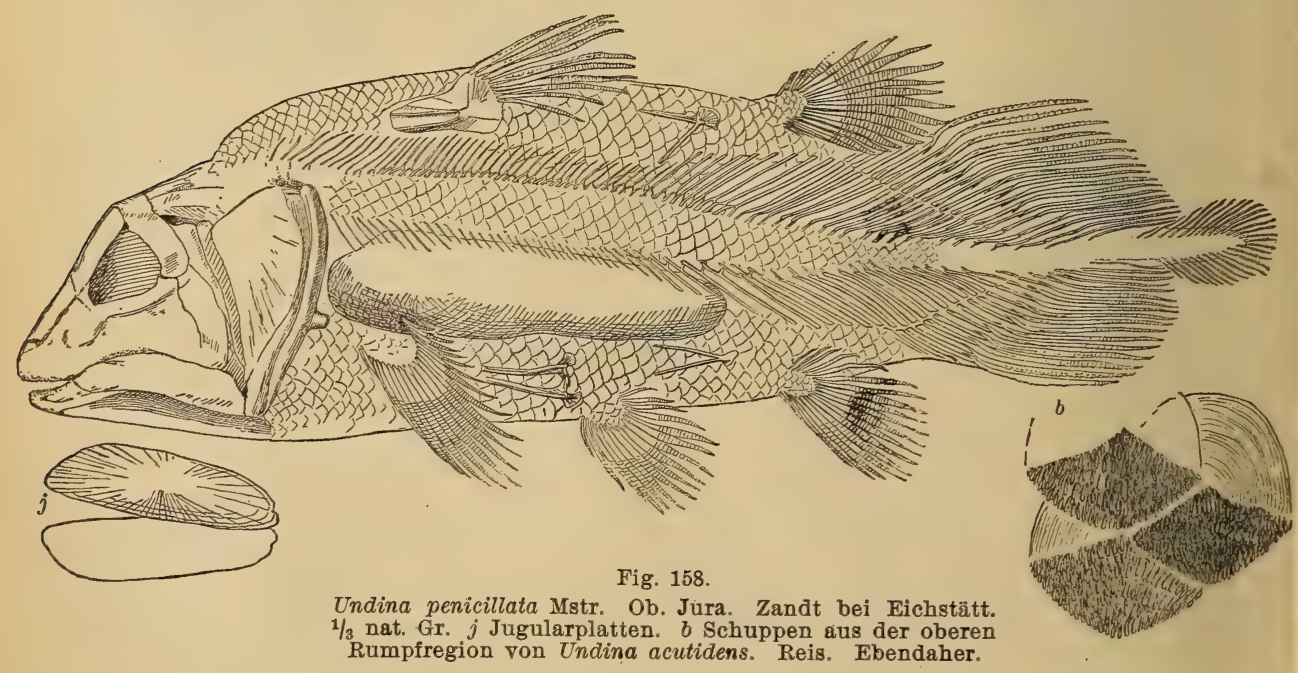


(Kupferschiefer), Nordamerika. Fraglich Trias, falls Coel. lunzensis Teller aus d. Raibler Sch. hierher gehört.

Graphiurus Kner, Obere Trias von Raibl. Heptanema Belloti, Oberer Muschelkalk, Perledo. Diplurus Newb. Trias, Nordamerika.

Undina Mstr. (Holophagus Egerton). Sämtliche Flossenstrahlen breit, gegen außen fein gegliedert, mit feinen Zähnchen am vorderen Strahl der ersten Dorsalis und der Schwanzflosse. Kopfknochen und Schuppen runzelig und körnelig. Lias und oberer Jura. U. gulo Ag. Lias von England. U. penicillata Mstr. Oberer weißer Jura, Süddeutschland. Libys Mstr., Coccoderma Quenst. Oberer weißer Jura.

Macropoma Ag. Maxilla, Vomer, Palatina mit konischen Zähnen. Flossenstrahlen kräftig, wenig gegliedert, distal nicht verbreitert. Strahlen der Dorsalis und Caudalis am Vorderrand gezähnelt. Pinselflosse nicht bekannt. Obere Kreide. England, Frankreich, Sachsen, Böhmen.

\section{Familie: Polypteridae Huxley.}

Dicke, rhombische Ganoidschuppen. Wirbelsäule und Innenskelett verknöchert. Zwei Jugularplatten. Brustflossen mit kurzer, stumpfer Achse; als Stïtze der zahlreichen, kurzen Basalstiicke dienen zwei divergierende Knochenspangen, die eine mittlere Platte einschließen (als Propterygium, Mesopterygium, Metapterygium bezeichnet). Rückenflosse sehr lang, bis zur Schwanzflosse reichend, mit zahlreichen Stacheln und ebensoviel Flossenträgern. Zähne mit einfacher Pulpa, Dentin nicht gefaltet. Tropisches Afrika, Flußfische. Polypterus, Calamoichthys. Fossil selten im jüngeren Tertiär.

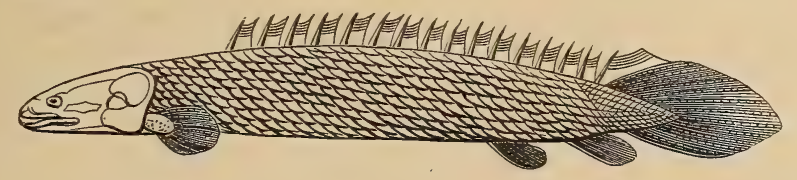

Fig. 159. Polypterus Bichir. Geoffroy. Oberer Nil.

Diese Familie steht den eigentlichen Crossopterygiern recht selb: ständig gegenüber, so daß man sie auch als besondere Unterordnung: oder Ordnung auffassen kann. A. Sm. Woodward bezeichnet sie als Cladistia, die hier besprochenen älteren Crossopterygier als Rhipidistia und Actinistia.

\section{Abteilung: Actinopterygii.}

Paarige Flossen mitverkürztem Achsenskelett und kräftigen Flossenstrahlen. Meist gelenken eine Anzahl basaler Radien (knorpelig oderverknöchert) direkt am Schultergürtel. Kiemenhautzwischen den Unterkieferästen mitknöchernen, plattigen Strahlen.

A. Smith Woodward teilt sie in 10 gleichartige Unterordnungen, von den Chondrostei, den Knorpelganoiden, bis zu den Acanthopterygii, den in gegenwärtigen Meeren herrschenden Stachelflossern. Die Grenze zwischen Ganoiden und Teleostiern ist, wie genügend bekannt, keine scharfe, da Ganoiden wie Plotidophorus, Caturus und ähnliche den Clupeiden durch die fossilen Leptolepiden sehr nahekommen. Im ganzen wird man aber die beiden großen Gruppen der Actinopterygier als Ordnungen beibehalten können. Die heute noch lebenden Ganoiden weichen von den Teleostiern in wichtigen 
inneren Eigenschaften $a b$; sie stellen die Ausläufer großer Stämme dar, die mit den lebenden Teleostiern nicht direkt genetische Beziehungen haben. Auch Amia steht für sich. Die Linie der Abstammmung führt von den jurassischen Leptolepis und Thrissops zu den jurassischen Nebenzweigen der Amia ähnlichen Ganoiden, zu den Pholidophoriden und Caturiden hinüber; in dieser Linie muß der Schnitt willkürlich geführt werden. In anderen Fällen wird man kaum praktisch in Verlegenheit kommen.

\section{Ordnung. Ganoidei. Schmelzschupper. ${ }^{1}$ )}

Rumpf und Schwanz mit Ganoidschuppen bedeckt, selten nackt oder mit Knochenplatten- Wirbelsüule 1nnorpelig oder in verschiedenem Grade verknöchert, Schwanzflosse diphycerk, heterocerk oder hemiheterocerk. Paarige Flossen wohl entwickelt. Flossenstrahlen gegliedert, häufig Fulcra vorhanden. Schädel mit Hautknochen bedeckt oder vollständig verknöchert. Kieferstiel durch Ligament am Schädel befestigt. Muskulöser Arterienstiel mit zahlreichen Klappen. Sehnerven nicht vollständig gekreuzt (Chiasma). Darm mit Spiralklappe. Schwimmblase mit Ausfiihrungsgang.

Bei Aufstellung der >Ordnung « der Ganoiden hatte L. Agassiz auschließlich das Hautskelett berücksichtigt und unter dieser Bezeichnung alle Fische mit Schuppen, die aus einer knöchernen Unterlage und einer Schmelzdecke zusammengesetzt sind, zusammengefaßt.

Eine auf anatomische Merkmale begründete Definition der Ganoiden suchte Joh. Müller zu schaffen. Nach Entfernung der als echte Knochenfische erkannten Plectognathen, Lophobranchier und Siluroiden und nach Versetzung des Lepidosiren zu den Dipnoern blieben als echte Ganoiden noch immer eine große Menge fossiler und rezenter Fische übrig, welche nach Joh. Müller eine eigene Unterklasse zwischen den Selachiern und den Knochenfischen bilden. Während die Beschaffenheit des muskulösen Arterienstieles, die unvollständige Kreuzung der Sehnerven, der mit Spiralklappe versehene Darm mit den ersteren übereinstimmen, weist die Anordnung der Kopfknochen, der Bau der Flossen und häufig auch die Verknöcherung des Skelettes auf die Knochenfische hin. Ja nachdem C. Voigt in Amia einen im anatomischen Bau echten Ganoiden mit dünnen, elastischen Cycloidschuppen und vollkommen verknöchertem Skelett erkannt hatte, schien die Grenze nach den Teleostei gänzlich verwischt. Lütken entfernte

1) Cope Edw., Trans. Amer. Philos. Soc. 1871, XIV S. 445-460 u. American Naturalist. XIX, XX, XXI, XXIII (1885-89). - Huxley Th., Preliminary essay upon the systematic arrangements of the fishes of the Devonian Epoch. Mem. geol. Survey U. Kingdom 1861. Dec. X. - Kner Rud., Betrachtungen über die Ganoiden als natürliche Ordnung. Sitzungsber. d. Wiener Akad. 1866. Bd. LIV. S. 519. Lütken Chr., Uber die Begrenzung und Einteilung der Ganoiden. Palaeontographica Bd. XXII (übersetzt aus Videnskabel. Meddelelser fra den naturhistoriske forening; Kjöbenhavn 1868). - Müller Joh., Über den Bau und die Grenzen der Ganoiden, Abhandl. d. Berl. Akad. d. Wissensch. 1834 (1836). - Traquair R. H., The Ganoid fishes of the British Carboniferous formations. Palaeontogr. Soc. 1877. - Vogt C., Quelques observations qui servent à la classification des Ganoides. Ann, des scienc. nat. Zoologie 3 sér. IV. p. 53-68. - Koken $E$., Über die natürl. Systematik der Fische. Zeitschr. deutsch. geol. Ges. 1891. S. 154 ff. 
die Placodermen, Acanthodier, Dipnoer und Chondrostei aus der Unterklasse der Ganoiden und betonte die nahe Verwandtschaft der letzteren mit den Knochenfischen (Physostomen). Noch entschiedener gingen Kner, Thiollière, Owen und neuerdings Cope und Sm. Woodward vor, indem sie die Ganoiden überhaupt als eine selbständige Gruppe unterdrücken und deren Angehörige, soweit sie nicht zu den Crossopterygiern gestellt werden, mit den Teleostei unter der gemeinsamen Bezeichnung Teleostomi vereinigen.

Das auffallendste, wenn auch nicht ausschließliche Merkmal der Ganoiden beruht in den Schuppen, welche aus einer dicken knöchernen Unterlage und einer äußeren Schmelzschicht bestehen. Eine gelenkartige Verbindung der Schuppen ist wenigstens für die Rhombenschupper unter den Ganoiden charakteristisch. Freilich gibt es auch Ganoidschuppen von rundlicher Form, welche sich genau wie die Cycloid- und Ctenoidschuppen dachziegelartig decken, und welche zuweilen nicht wesentlich dicker sind als die letzteren, allein auch diese Kreisschuppen (Caturus, Megalurus, Macrorhipis, Amia) zeigen unter der Schmelzdecke eine mit Knochenkörperchen ausgestattete Unterlage von zuweilen freilich nur minimaler Stärke. Durch starke Rückbildung der Schuppen, die sich nur im Schwanz erhalten,

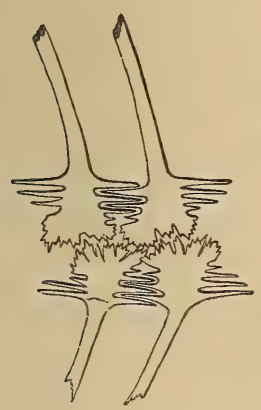

Fig. 160 .

Zwei Schwanzwirbel von Pycnodus platessus Ag. (Nach Heckel.) zeichnen sich die Spatulariden aus; bei den Stören ist der Rumpfmit großen Knochenplatten teilweise bedeckt.

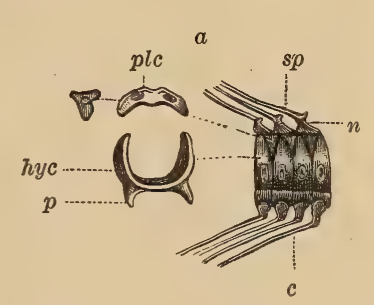

Fig. 161

$a$ Wirbel von Euthynotus. $b$ Wirbel von Caturus furcatus. $n$ obere Bogen, sp der gespaltene obere Dornfortsatz, hyc Hypozentrum. plc Pleurozentrum, $p$ Parapophyse, $c$ Rippe.

Von besonderem Interesse ist die Ausbildung des inneren Skeletts und namentlich der Wirbels äule bei den Ganoiden. Vollkommen knorpelig bleibt die Wirbelsäule nebst ihren Bögen und Anhängen bei einigen Chondrostei (Accipenser); aber schon bei Spatularia, bei fast allen Heterocerken und Pycnodonten und einem Teil der Lepidostei findet eine von außen nach innen vorschreitende teilweise oder vollständige Verknöcherung der Bogen, Dornfortsätze und gleichzeitig auch der unpaaren Flossenstützen statt, wobei jedoch häufig noch ein knorpeliger Kern von den hohlen Hülsen umgeben ist. Diesen >Nacktwirbeln« (Fig. 160) stehen die sog. 》Halbwirbel « und »Hohlwirbel《 gegenüber. Bei den ersteren (Fig. 161) tritt an der Basis der Chorda eine hufeisenförmige Knochenplatte (Hypocentrum, Intercentrum) auf, an welche sich in der Schwanzregion die unteren Bögen anlegen; die nach oben gerichteten Schenkel dieser Hypocentra sind meist verschmälert und zugespitzt. Das eigentliche 
Wirbelzentrum wird durch zwei seitliche, meist nach unten zugespitzte Knochenplatten (Pleurocentra) repräsentiert, welche häufig dorsal verwachsen und ebenfalls einen hufeisenförmigen Halbring bilden. Je nach ihrer Größe umschließen die Hypocentra und Pleurocentra die weiche ungegliederte Chorda mehr oder weniger vollständig, zuweilen bilden sie auch, indem sich ihre oberen und unteren Hörner nicht zuspitzen, sondern in gleicher Breite dorsal und ventral zusammenstoßen, zwei Halbringe, welche die Chorda vollständig umhüllen (Fig. 162). Bei manchen Gattungen (Eurycormus) besteht die vordere Rumpfregion aus Halbwirbeln, die Schwanzregion aus Hohlwirbeln, die aus zwei Hälften zusammengesetzt sind. Durch vollständige Verwachsung der beiden Halbringe entstehen einfache, hülsenartige Hohlwirbel (Fig. 163). Bei den Amiaden sind die Wirbelcentren in der Rumpfregion verknöchert, amphicöl, in der Schwanzregion aber noch in zwei Hälften geteilt, welche den Hypo- und Pleurocentren entsprechen (Fig. 162b).

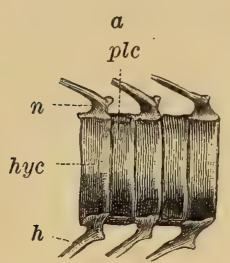

Fig. 162.
ycormus sp
va aus de
audalregion

a Schwanzwirbel von Eurycormus speciosus. $b$ Ein Stück der Wirbelsäule von Amia calva aus dem vorderen Abschnitt der

Fig. 162.
curycormus specios
Calva aus dem
Caudregion. b

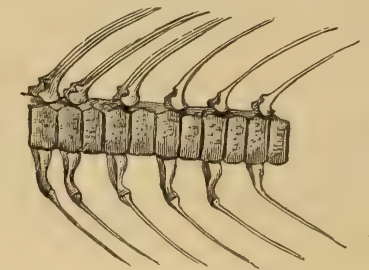

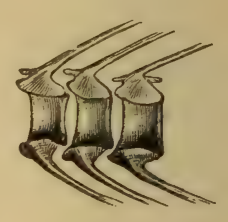

Fig. 163.

Aspidorhynchus.

Ein Stück der Wirbelsäule aus der Schwanzregion mit aufsitzenden Bögen und Dornfortsätzen.

Eine gänzliche Verknöcherung der Wirbelsäule, beobachtet man nur bei den jüngsten Vertretern der Ganoiden. Bei den Lepidosteiden sind die Wirbelcentren hinten ausgehöhlt, vorne konvex (opisthocöl).

Das hintere Ende der Wirbelsäule verlängert sich stets in die Schwanzflosse. Sehr häufig findet sich rein heterocerke, hemiheterocerke oder innerlich heterocerke, nur äußerlich homocerke Schwanzbildung (vgl. S. 14).

Bei vielen Ganoiden sind die unpaaren und zuweilen auch die paarigen Flossen am Vorderrand mit sog. Fulcra, schuppenförmigen, mit Schmelz bedeckten Stacheln oder Platten besetzt, welche in einer Reihe aufeinanderfolgen und sich teilweise bedecken. Sämtliche Flossenstrahlen bestehen aus zwei Hälften, sind quer gegliedert und distal gespalten.

Wie die Wirbelsäule, so bietet auch der Schädel sehr verschiedene Stadien der Verknöcherung dar. Bei den Knorpelganoiden beschränkt sich dieselbe auf eine Anzahl Belegknochen auf dem Schädeldach und der Schädelbasis. Pterygoid und Gaumenbeine sind noch verschmolzen, der Unterkiefer und ein Teil des Zungenbeinbogens verknöchert, der Opercularapparat schwach entwickelt. Bei den Heterocerci, Lepidostei und Pycnodonti steht die Verknöcherung jener der Teleostier ziemlich gleich und auch die Zahl und Anordnung der einzelnen Knochen stimmt im wesentlichen mit den letzteren überein. 
Im Bau des Brustgürtels und namentlich der vorderen Extremitäten zeigen die verschiedenen Ordnungen der Ganoiden große Abweichungen. Bei den Chondrostei und Heterocerci besteht die Clavicula noch aus drei gesonderten Belegknochen, während bei den Orthoganoidei, Amioidei und Pycnodonten der untere Abschnitt (Infraclavicula) vollständig mit der Clavicula verschmilzt. Die hinter der Clavicula folgenden, der Scapula, dem Coracoideum und Präcoracoideum entsprechenden kleinen Gebilde bleiben bei den Chondrostei knorpelig, sind dagegen bei den übrigen Ganoiden genau wie bei den Teleostiern verknöchert. Auch bezüglich der Lage und Zahl der Basalstücke in den Brustflossen stimmen die meisten Ganoiden mit den Knochenfischen überein.

Neben der Hautbedeckung und dem inneren Skelett gibt es noch einige anatomische Merkmale, wodurch sich die Ganoiden als eine selbständige Abteilung erweisen. So ist der muskulöse, etwas verlängerte Stiel der Hauptarterie (conus arteriosus) im Innern ähnlich wie bei den Selachiern mit mehreren Reihen von Klappen versehen, welche den Rücktritt des Blutes aus der Arterie in die vordere Herzkammer verhindern. Die Kiemen dagegen liegen stets, wie bei den Teleostiern, frei unter einem meist aus mehreren Knochenplatten bestehenden Deckel. Auch durch den Besitz einer Spiralklappe im Darme sowie in der Ausbildung des Urogenitalsystems nähern sich die Ganoiden mehr den Selachiern als den Teleostiern; dagegen besitzen alle eine Schwimmblase mit Luftgang und zahlreiche kleine Eier. Durch vollständige Kreuzung der Sehnerven unterscheiden sich die Knochenfische von den Ganoiden, bei denen die in Äste zerteilten Sehnerven ein sog. Chiasma bilden. Die aufgeführten Eigenschaften teilen die Ganoiden aber mit den Crossopterygiern, soweit man diese nach dem lebenden Polypterus beurteilen kann.

Die Ganoiden haben ihre Hauptverbreitung in paläozoischen, triasischen und jurassischen Ablagerungen und werden mit Beginn des Kreidesystems mehr und mehr durch die Knochenfische verdrängt. Die wenigen noch jetzt existierenden Ganoiden leben entweder ausschließlich oder doch zeitweilig in süßem Wasser, während die fossilen vorwiegend in rein marinen Ablagerungen vorkommen. Nur die tertiären Ganoiden stammen aus Süßwasserabbildungen.

Die Ganoiden sind hier eingeteilt in 7 Unterordnungen: 1. Chondrostei, 2. Belonorhynchidae, 3. Heterocerci, 4. Pycnodonti, 5. Orthoganoidei, 6. Lepidostei, 7. Amioidei. Es sind zum Teil die von Zittel angegebenen Abteilungen, jedoch sind die lebenden Lepidostei schärfer von den übrigen Ganoiden getrennt, die Zittels Lepidostei bilden, und damit ergab sich die Notwendigkeit, für die bedeutendste Abteilung der Ganoiden einen neuen Namen einzuführen. Sie sind als Orthoganoidei und damit auch gleichsam als Kern der ganzen Abteilung hingestellt. Sie decken sich fast mit der Abteilung Protospondyli bei A. Sm. Woodward. Die Belonorhynchiden sind eine kleine, aber sehr isolierte Gruppe, deren Aufführung bei den Chondrostei auf große Bedenken stößt; ihre morphologischen Eigentümlichkeiten rechtfertigen es, sie trotz des geringen Umfangs als Unterordnung gleichwertig neben die Chondrostei zu stellen. Die Aspidorhynchiden habe ich zu den Orthoganoiden gestellt und nicht zu den Lepidosteiden, mit denen 
zusammen sie bei A. Sm. Woodward die Gruppe der Aetheospondyli ausmachen. Es ist kaum mehr als eine habituelle Ähnlichkeit vorhanden (die allen Ganoiden gemeinschaftlichen Züge vorausgesetzt). Sie stehen unter den Orthoganoiden wohl etwas für sich, aber wir haben in dieser Gruppe kaum mehr die Möglichkeit, weitere Teilungen oder Zusammenhänge systematisch anschaulich $\mathrm{zu}$ machen. Zittels Amioidei sind ungefähr in ihrem alten Umfange beibehalten; den größten Teil derselben findet man bei Woodward unter den Protospondyli, wo die Amiidae, Eugnathidae und Pachycormidae als gleichwertige Familien erscheinen. Die. Pholidophoriden und Oligopleuriden (hier bei den Orthoganoiden geführt) eröffnen im System Woodwards die Abteilung der Isospondyli, zu der weiter auch die Clupeiden und sich anschließende Physostomen gerechnet sind. Für meine Anschauung ist leitend gewesen, daß auch die Clupeiden und ihre Verwandten, trotz mancher mit Ganoidfischen gemeinsamer Züge (es kommen sogar Reste einer Spiralklappe im Darm vor) sich doch von den lebenden Ganoiden weit unterscheiden, und daß dies auch für ihre direkten Vorfahren im Jura gilt. Hiernach habe ich die Grenze zwischen Ganoidei und Teleostei gezogen. Daß dabei genetische Linien geschnitten werden, ist zweifellos, wird aber in keiner Systematik sich vermeiden lassen, die nicht allein nach dem Prinzip nachweisbarer Deszendenz arbeitet. Unter den lebenden Ganoiden ist Amia diejenige Gattung, welche zu den Clupeiden die nächsten Beziehungen hat; unter den fossilen sind es meines Erachtens die Caturiden und Pachycormiden. So sind sie bei den Amioidei verblieben, zu denen sie auch Zittel gestellt hatte.

\section{Unterordnung: Chondrostei. ${ }^{1}$ )}

Inneres Skelett und Schädel knorpelig, Kopf mit knöchernen Hautschildern bedeckt. Rumpf nackt oder mit Reihen von knöchernen Platten. Echte Ganoidschuppen im oberen Teil des Schwanzes. Kiemendeckel reduziert, Kiemenhautstrahlen häufig fehlend. Zähne klein oder fehlend. Schwanzflosse echt heterocerk. Der obere Lappen mit Fulcren. Bauchflossen mit einer Reihe knorpeliger Basilarstïcke. Eine Rücken-, eine Afterflosse.

\section{Familie: Chondrosteidae. A. Sm. Woodm.}

Kopf mit verlängerter Schnauze, oberer Kiefer klein, zahnlos. Prämaxillen fehlen. Parietalia und Frontalia paarig; neben den Parietalien ein großes Squamosum. Kiemenhautstrahlen kräftig. Operculum klein, Suboperculum groß. Körper nackt, nur das in den oberen Lappen der Schwanzflosse verlängerte Ende mit derben Ganoidschuppen. Rückenflosse über der Bauchflosse.

Chondrosteus Egerton. Unterer Lias, England. Kopfdeckknochen teilweise mit Ganoin. Unterkiefer-Suspensorium sehr schief. Flossenstrahlen mit sehr dünnem Belag von Ganoin, sehr fein gegliedert (mit Ausnahme der vordersten in der Brustflosse). Hyomandibulare zum Teil ossifiziert, ebenso das Ceratohyale. Fulcra des oberen Schwanzlappens von besonderen Knorpelstücken gestützt. Keine Rippen. Obere Bögen- und Dornfortsätze

1) Browne M., On a fossil fish (Chondrosteus) from Barrow-on-Sear. (Trans. Leicester Literary a. Phil. Soc. 1889). - Woodward A. Sm., Catalogue etc. II, III. 
etwas verkalkt. Im unteren Schwanzlappen kräftige untere Bögen. Ch. accipenseroides Eg.

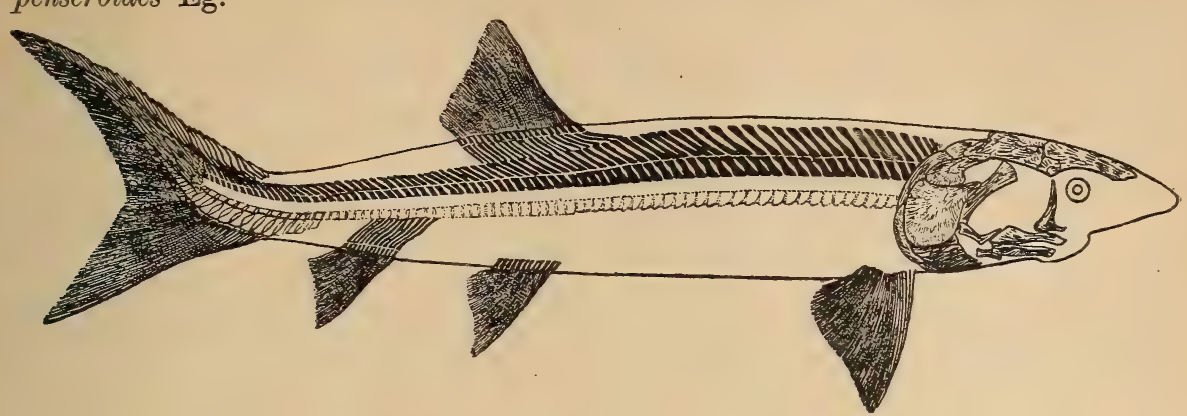

Fig. 164.

Chondrosteus accipenseroides, Unt. Lias, Lyme Regis. 1:12. Rekonstruktion nach A. Sm. Woodward. Aus "Guide to the fossil Reptilia etc." mit Genehmigung der Trustees d. Brit. Mus. Nat. Hist.

\section{Familie: Accipenseroidei. Störe.}

Große langgestreckte Fische mit verlängerter Schnauze; zahnlos. Parietalia und Frontalia unpaar, gekörnelt. Rumpf mit (5) Längsreihen von gekielten Schildern. Opercula unvollkommen entwickelt, die Kiemenöffnung nicht vollständig bedeckend; Kiemenhautstrahlen fehlen. Rïcken- und Afterflosse mit 2 Reihen an Flossenträgern (Axonoste, Baseoste). Riickenflosse ïber der Analis. Chordascheide fibrillär, ungegliedert; Bogenteile mit Intercalarien, knorpelig. Ossifikationen in den Dornfortsätzen, seltener in den Bogenstïcken.

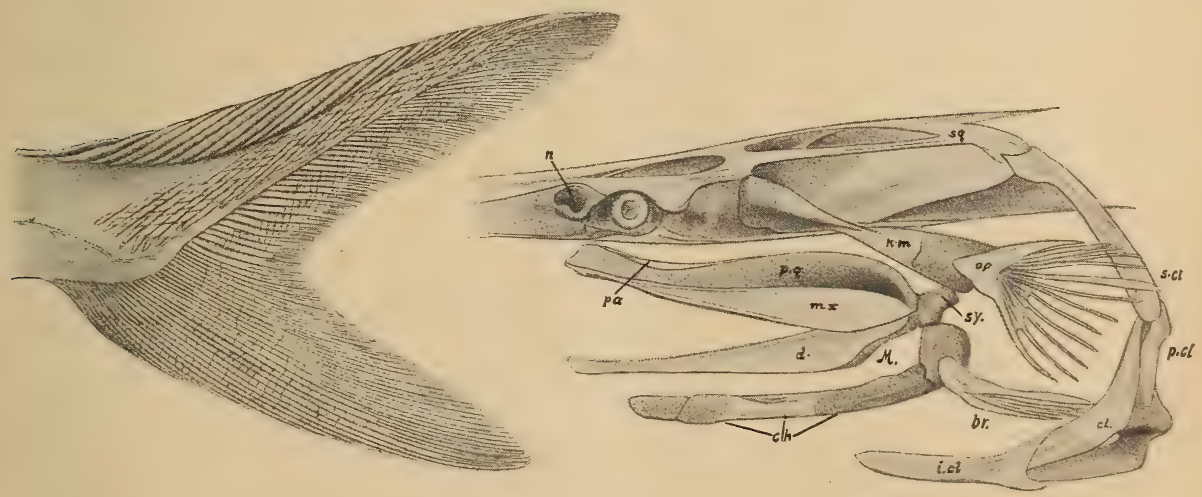

Fig. 165.

Schwanz von Polyodon (Spatularia) folium L. Zeigt die ganoide Beschuppung des Schwanzes. Polyodon (Spatularia) folium L. Knorpel sind dunkler im Ton. $n$ Nasentasche, dahinter das Auge. $s q$ Squamosum, h.m Hyomandibulare, op sy Symplecticum, p.q Palatoquadratknorpel, $m$ Meckelscher Knorpel, $p a$ Palatopterygoid, $m$ Maxilla, $d$ Dentale, c.h Ceratohyale, o.p Operculum, br Branchiostegalia (verwachsen), s.cl Supraclavicula, p.cl Postclavicula, cl Clavicula, i.cl Infraclavicula. (Nach Traquair.)

Von den zwei lebenden Gattungen Accipenser (Fig. 17, 20) und Scaphirhynchus leben die Störe in den Meeren der nördlichen Halbkugel, von wo sie in die Flüsse Europas, Asiens und Nordamerikas aufsteigen. Fossil nur in vereinzelten Resten vom Eocän an.

Accipenser toliapicus Ag. Eocän, Londonton.

Gyrosteus A. Sm. Woodw. Oberer Lias, Whitby. Sehr groß. Deckknochen ohne Ganoin. Hyomandibulare und Ceratohyale völlig verknöchert. Kleine, verknöcherte Rippen. G. mirabilis Ag. Ob. Lias, England. 

bekannt.

Pholidurus A. Sm. Woodw. Obere Kreide, England. Unvollständig

\section{Familie: Polyodontidae. Löffelstöre.}

Schnauze sehr lang, spatelförmig. Haut nackt, nur der obere Schwanzlappen beschuppt. Kiefer mit kleinen Zühnen. Parietalia und Frontalia unpaar. Kiemenhautstrahlen fehlen.

Von den zwei lebenden Gattungen findet sich Polyodon (Spatularia) (Fig. 165) im Mississippi, Psephurus in chinesischen Flüssen.

Crossopholis Cope. Eocän Wyoming. Schnauze kürzer als bei Polyodon, Operculum größer. Kleine, dünne, hinten gezackte Schuppen, in Schrägreihen, aber nicht in Kontakt. Cr. magnicaudatus Cope.

\section{Unterordnung. Belonorhynchidae.}

\section{Familie: Belonorhynchidae. A. Sm. Woodw.1)}

Schädel mit verlängerter, zugespitzter Schnauze, in die ein langes Ethmoid eintritt. Die Deckknochen des Kopfes sind im Alter mehr oder weniger verschmolzen. Opercula reduziert, keine Branchiostegalia. Unterkiefer hinten sehr hoch. Bezahnung ungleich, zwischen großen Hechelzähnen stehen mehrere kleine. Die Beschuppung beschränkt auf eine dorsale, eine ventrale und je eine laterale Längsreihe, welche die Seitenlinie begleitet. Dorsalis und Analis kurz, aber hoch, opponiert, weit hinten. Caudalis abgestutzt, symmetrisch durch die Wirbelsäule geteilt. Paarige Flossen sehr klein. Chordx persistent, Chordascheide ohne Ossifikationen.

Reis möchte die Belonorhynchiden, die er von den Chondrostei entfernt, zu den Crossopterygiern stellen. Er stützt sich besonders auf die diphycerke Bildung der Schwanzflosse, auf das coelacanthinenartige Ectopterygoid, das anscheinende Fehlen eines Symplecticum und die lappige Pectoralis. Letztere Angabe gründet sich auf die Abbildung des Saurichthys macrocephalus Deecke. Man kann aus ihr keine volle Sicherheit gewinnen, zu betonen ist aber, daß »lappige « Brustflossen solcher Art sich bei manchen Teleostiern, z. B. Periophthalmus, Bostrichthys finden.

Die Grenze zwischen Belonostomus und Belonorhynchus ist hier mit Woodward gezogen. Belonostomus umfaßt Fische des oberen Jura mit verknöcherter Wirbeisäule, praesymphysialen Knochen im Unterkiefer und innerlich heterocerker Schwanzflosse.

Saurichthys Ag.2) Schädel ganz von Deckknochen umgeben, mit langer zugespitzter Schnauze (Rostrum) und entsprechend langem Unterkiefer. Das Rostrum wird von den Prämaxillen, zwischen die sich noch die Nasalia und wohl vor diesen das Ethmoid. einschieben, gebildet, doch ist die Begrenzung der Knochen schwer zu verfolgen. Im eigentlichen Schädeldach erkennt man ein kleines Supraoccipitale, große paarige Parietalia, große, bucklige Frontalia, ein nach vorn lang zugespitztes Ethmoid und große Maxillaria. Auf der Unterseite zeichnet sich das große Paraphenoid aus, dem vorn ein ebenfalls langer Vomer angeschlossen ist. Der Unterkiefer besteht wesentlich aus dem einheitlichen langen Dentale, einem kleineren Spleniale und dem Angulare (mit dem das Articulare verschmolzen ist). Ein Coronoidfortsatz fehlt. Zähne auf schwach gefaltetem Sockel. Muschelkalk, Keuper, Rhät.

1) Reis O.M., Zur Osteologie und Systematik der Belonorhynchiden und Tetragonolepiden. Geogn. Jahresh. München 1892. - Woodward A. Sm., Catalogue etc. III.

2) Frech, Lethaea mesoz. Deutsche Trias. S. 11. - Hennig E., SaurichthysFunde von Rüdersdorf. (Centralbl. f. Mineral. 1909.) 
Belonorliynchus Bronn. In der Umgrenzung Woodwards = Saurorhynchus Mstr., Reis; Ichthyorhynchus Bellotti, Giffonus Costa, Stylorhynchus Martin). Typus: B. striolatus Bronn, Raibler Sch. Schädelknochen im Alter verschmolzen, daher im einzelnen nicht sicher bekannt. Der steile Hinterrand des Unterkiefers liegt in der Verlängerung des Hyomandibulare. Das

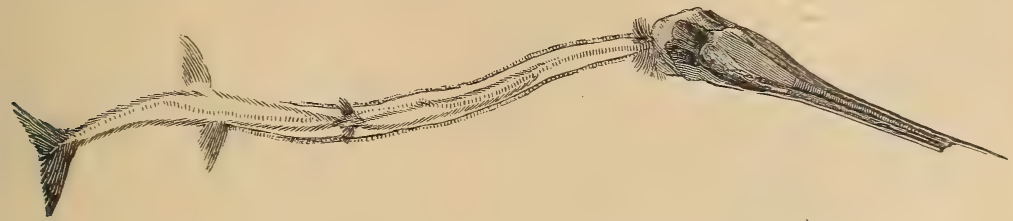

Fig. 166. Belonorhynchus striolatus Bronn. Karnische Sch. Raibl, Kärnthen. (Nat. Gr.)

ovale Operculum dicht dahinter. Das Supraoccipitale springt weit nach hinten vor. Die Orbitae im hinteren Drittel des Schädels, etwas vor ihnen jederseits ein Nasenloch. Im Unterkiefer ist das ArticuloAngulare ähnlich entwickelt wie bei Saurichthys. Kein präsymphysialer Knochen. Chorda persistent, Bögen wohl entwickelt. Paarige Flossen klein, mit kurzem Stil. Die Träger der unpaaren Flossen derb, weniger zahlreich als die Strahlen; keine Fulcra. Schuppen auf dem Rücken, dem Bauch und in der Seitenlinie in imbrizierenden Reihen. Die Abgrenzung gegen Saurichthys ist unsicher; Reis zieht sie zusammen, Henning reserviert den Namen Belono-

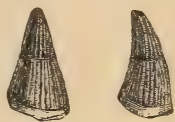

Fig. 167.

Zahn von Saurich thys acuminatus Ag. Rhätisches Bane-

bed. Württemberg. rhynchus für Liasformen. B. acutus Ag. Unterer und oberer Lias. England. Württemberg. Hawkesbury-Sch., Neu-Südwales. Oberer Muschelkalk von Perledo. Raibler Sch., Seefelder Sch.

\section{Unterordnung. Heterocerci. ${ }^{1}$ )}

Mit dicht gestellten rhombischen oder whomboidischen, selten cycloidischen Schuppen. Chorda persistent, Bögen, Dornfortsëtze, Flossenträger und Rippen verknöchert. Schwanzfosse heterocerk. Kiemendeckiel groß, Kiemenhautstrahlen zahlreich. Infraclavicula vorhanden. Unpaare, häufig auch paarige Flossen mit Fulcren besetzt. Flossenstrahlen der Dorsalis und Analis gegliedert, zahlreicher als ihre Träger. Devon bis Jura.

Die Heterocerci wurden von Traquair mit den Chondrostei zu einer Ordnung $A c$ cipenseroide $i$ vereinigt, und es ist auch wahrscheinlich, daß die Störe und Chondrosteiden von den Palaeonisciden oder ihnen nahestehenden Formen abstammen. Aber

1) Lambe L. L., Palaeoniscid fishes from the Albert Shales of New Brunswick (Contrib. Canadian Palaeont. III. Part V. 1910) - Traquair $\boldsymbol{R}$. H., The Ganoid fishes of the British carboniferous formations. Monogr. Palaeont. Soc. 1877. Vol. I. Ferner: Quart. Journ. Geol. Soc. 1877. Report on the fossil fishes collected in Eskdale. Trans. Roy. Soc. Edinburgh 1881. XXX. - Woodward A. Sm., Catalogue. II, III.

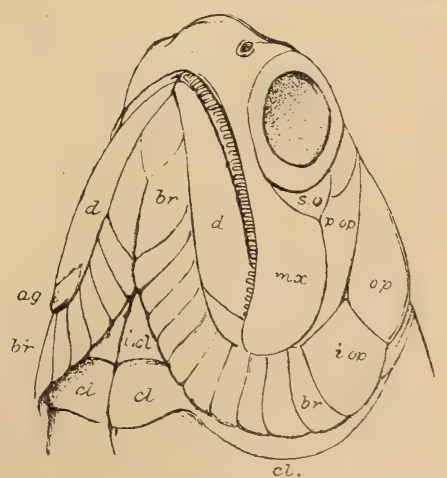

Fig. 168

Gonatodus punctatus Ag. sp. Interkarbon. Restaurierter Kopf schrïg von unten. 5:4. (Nach Traquair.) ag Angulare, $m x$ Maxillare, d Dentale, br Branchiostegalia, icl Infraclaviculare, cl Clavicula, op, Operculum, po Präoperculum, iop Interoperculum, so Suborbitale. 
auch mit den Lepidosteiden bestehen Ähnlichkeiten, besonders mit den Stylodonten, so daß die Abtrennungen immer etwas Gezwungenes haben. A. Sm. Woodward zieht den Rahmen seiner Unterordnung Chondrostei so,

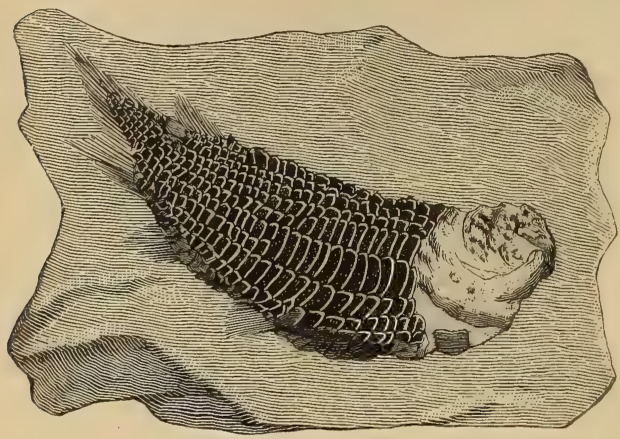

Fig. 169.

Eurylepis tuberculatus Newb. Karbon. Linton, Ohio. daß in ihr Palaeoniscidae, Platysomidae, Catopteridae, Chondrosteidae, Belonorhynchidae, Accipenseridae und Polyodontidae zu stehen kommen, während die Semionotiden neben den Macrosemiiden, Pycnodontiden, Eugnathiden, Amiiden und Pachycormiden unter den Protospondyli stehen. Im wesentlichen ist der Grad der Verknöcherung der Wirbelsäule hierfür maßgebend, der aber bei Formen verschied ener genetischer Verwandtschaft ein gle i cher sein kann; schwache Verknöcherung ist auch als Merkmal regressiverEntwickelung denkbar.

\section{Familie: Palaeoniscidae.}

Körper schlank, mit rhombischen Ganoidschuppen. Hautknochen des Kopfes mit Schmelz ïberzogen. Krëftige Fulcra. Zïhne klein, konisch und griffelartig. Devon bis oberer Jura.

Cheirolepis Ag. Schuppen winzig, rhombisch. Rückenflosse hinter der Afterflosse. Kiefersuspensorium schief. Flossenstrahlen dichotom. Kiefer mit einer äußeren Reihe winziger und einer inneren Reihe stärkerer Zähne. Mittel-Devon (mittleres Oldred); Schottland. Rußland. Oberes Devon; Canada.

Nematoptychius, Rhadinichthys Traqu., Cycloptychins Young. Karbon.

Palaeoniscus, Blainv. emend. Traquair. (Fig. 170). Flossen klein, die Strahlendichotom gespalten und gegliedert. Dorsalis vor der Analis, Caudalis tief ausgeschnitten. Unterkiefer-Suspensorium sehr schief. Zähne klein, ungleich. Schuppen rhombisch, mit unregelmäßigen schiefen Querfurchen, am Hinterrand gewöhnlich gezähnelt. Sehr häufig im Kupferschiefer von Thüringen und Hessen, sowie im oberen Perm von England, Frankreich, Rußland.

Pygopterus Ag. Analflosse sehr groß. Schuppen klein, glatt oder schwach verziert. Kupferschiefer.

Elonichthys Giebel (Rhabdolepis Troschel, Cosmoptychius Traqu.) (Fig. 171, 172). Kieferzähne in zwei Reihen, die inneren groß, kegelförmig. Schuppen groß, schräg skulptiert, der überschobene Vorderrand sehr schmal. Flossen groß, mit Fulcren. Kein Suboperculum. Karbon, Rotiegendes; Europa, Nordamerika.

Acrolepis Ag. Karbon, England. Kupferschiefer, Deutschland. Mit dicken, weit übereinander fassenden, schräg skulptierten Schuppen.

Canobius Traquair, Gonatodus Traqu. (Fig. 168). Karbon, Schottland.

Ambly pterus Ag. Unterkiefer-Suspensorium vertikal. Fulcren schwach. Schuppen glatt. Flossenstrahlen geteilt. Rotliegendes; Saargebiet, Böhmen, Frankreich etc. A. latus Ag., A. Duvernoyi Ag.

Eurylepis Newb. (Fig. 169). Unterkiefer-Suspensorium vertikal. Flossenstrahlen einfach, Caudalis schief abgestutzt. Schuppen verziert, am Hinterrande gezackt, in der vorderen Hälfte des Körpers auf den Seiten sehr hoch. Karbon; Ohio. 

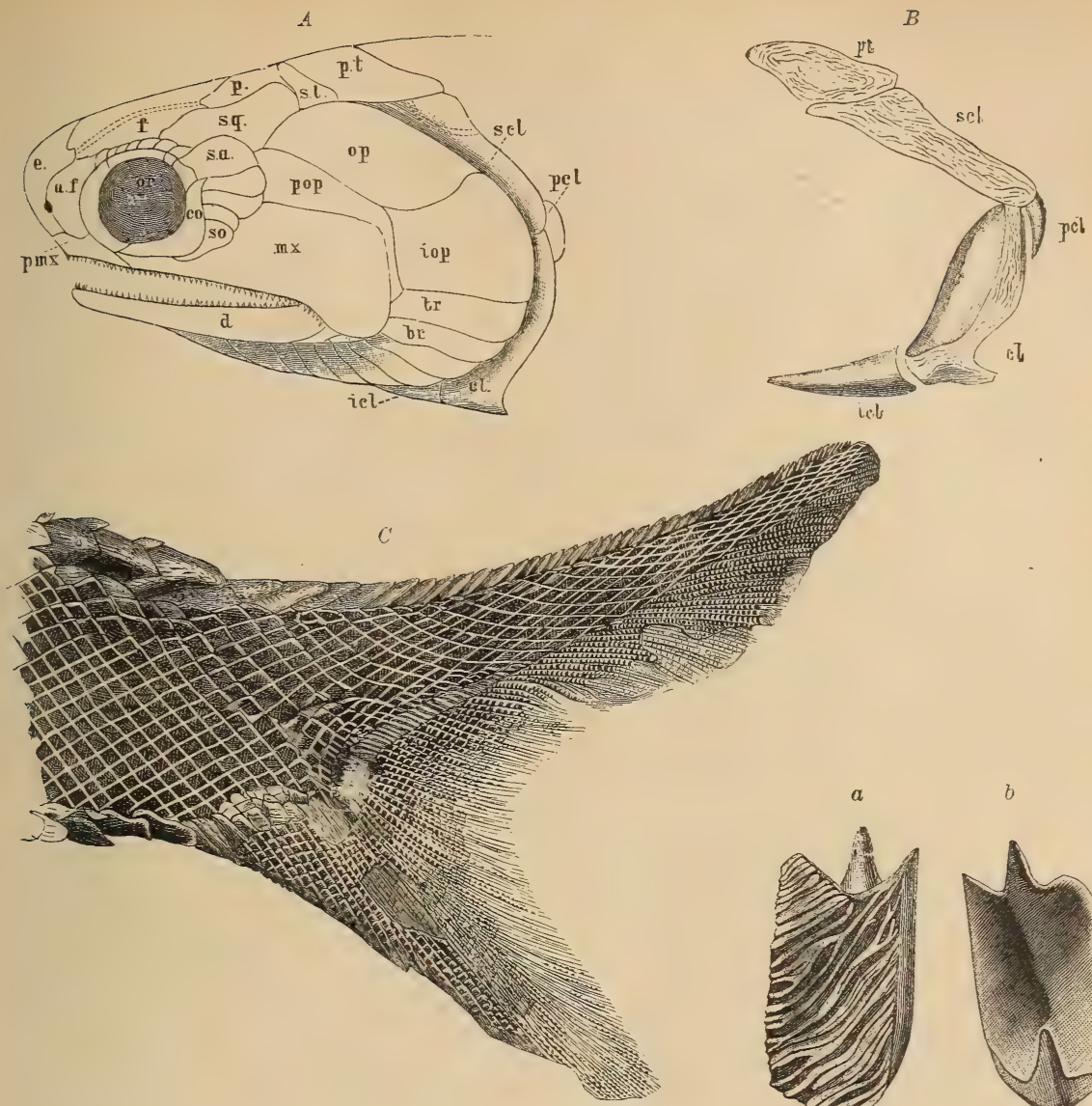

Fig. 170.

Palaconiscus Freiestebeni Blv. Aus dem Kupferschiefer von Riechelsdorf. $A$ Kopf restauriert. $B$ Schultergürtel restauriert (nach Traquair). pt Posttemporale, scl Supraclavicula, $p c t$ Postclavicula, $c l$ Clavicula, icl Infraclavicula. $C$ Schwanzfiosse (nat. Gr.)

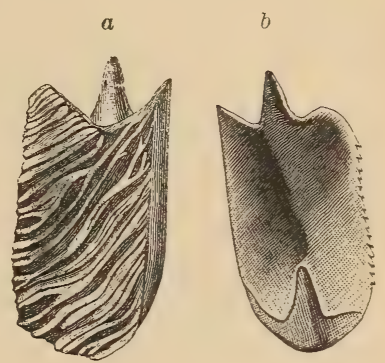

Fig. 171

Elonichthys (Cosmoptychius) striatus Schuppe.Ag.sp. (Nach Traquair.) $a$ von außen, $b$ von innen. $3 / 1$.

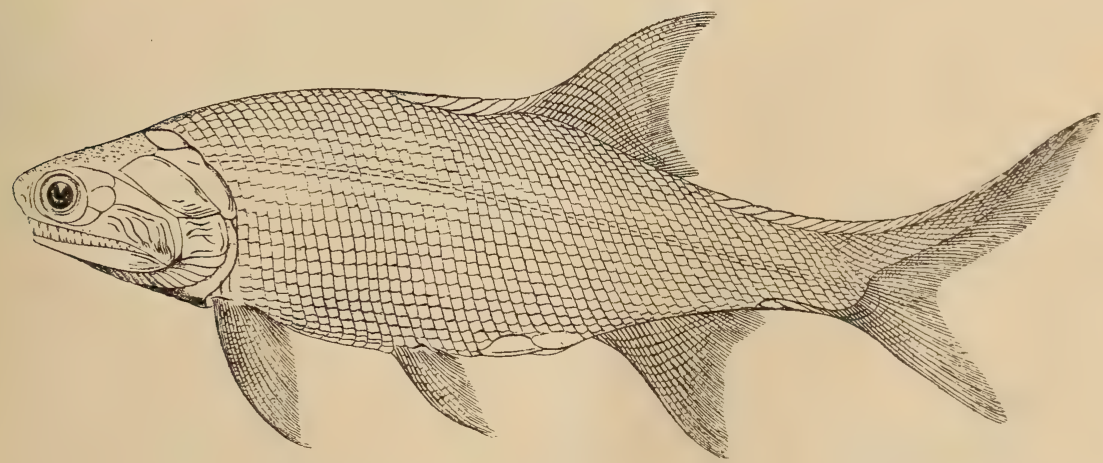

Fig. 172 .

Elonichthys Robisoni Hibbert sp. var. intermedia Traquair. Unterkarbon, Wardie. 2:3. (Nach Traquair.) 
Gyrolepis Ag. (Fig. 173.) Strahlen der Brustflosse ungegliedert, mit Ausnahme der distalen Enden. Operculum schmal und hoch. Schuppen dick, weit übereinander fassend, mit schiefen, welligen Runzeln. Analis sehr groß. Muschelkalk, Keuper.

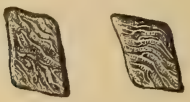

Fig. 173 .

Schuppen von (ryrolepis ornatus Gieb. Muschelkalk. Esperstiadt, Braunschweig.

(Vergn nach Dames.)

Myriolepis Egerton. Trias, Australien.

Atherstonia A. Sm. Woodw. Hydropesium Broom. Helichthys Broom. Obere Karru-Schichten Südafrika.

Cleithrolepis Ag. Körper sehr hoch oder rhombisch. Obere Karru-Schichten, Südafrika.

Oxygnathus Egerton (Thissonotus Ag., ('osmolepis Egert.) Flossen groß mit sehr kleinen Fulcren. Dorsalis vor der Analis. Strahlen der Pectoralis nur distal gegliedert. Schuppen klein, dick, schief skulptiert, wenig übergreifend. Unterer Lias, England.

Platysiagum Egerton. Unterer Lias, England. Centrolepis Egert. Unterer Lias, England.

Coccolepis Ag. Kleine Fische mit großen dünnen, cycloiden Schuppen, die sehr weit übereinander greifen und außen gekörnt sind. Flossen groß, Fulcra schwach oder fehlend. Dorsalis ror der Analis. Unterer Lias (England), oberer weißer Jura (Süddeutschland), Purbeck(England). Obere Hawkesbury-Schichten, Neu-Südwales.

\section{Familie: Platysomidae.}

Körper seitlich zusammengedrïclt, hoch, oval oder rhombisch. Schuppen höher als breit, rhomboidisch, anf der Imnenseite mit einem dem Vorderrand parallelen Kiel und einem Stachel am Oberrand. Rïcken- und Afterflossen sehr lang. Mundöffinung kilein, Untertiefer-Suspensorium fast vertital. Zähne niedriger als bei Palaeonisciden, stumpfkonisch.

Die Platysomiden sind den Palaeonisciden nahe verwandt, von denen sie sich wesentlich nur durch die Körperform und die Bezahnung unterscheiden. Karbon, Perm.

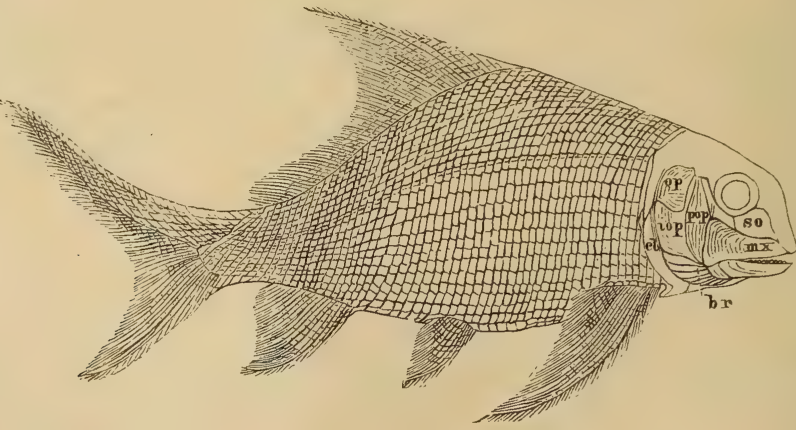

Fig. 174.

Eurynotus crenatus Ag. Steinkohlenformation. Edinburgh. Restauriert. (Nach Traquair.)

Eurynotus Ag. (Plectrolepis Ag.) Körper hoch, spindelförmig. Brustflossen groß, aber auch die Beckenflossen noch normal entwickelt. Dorsalis sehr hoch über der Beckenflosse beginnend, dann rasch niederer werdend, bis zur Schwanzflosse ausgedehnt. Stumpfkonische bis kuglige Zähne. Unterkarbon, Schottland, Irland, Belgien. E. crenatus Ag. 
Mesolep is Young (Pododus Ag.) Zähne derb, griffelförmig, einreihig auf dem Unterkiefer. Unterkarbon, Schottland.

Globulodus Mstr. Zähne niedriger; eine innere Reihe kleinerer Reibzähne. Kupferschiefer und Marlslate.

Wardichthys Traquair. Unterkarbon.

Cheirodus Mc. Coy (Amphicentrum Young, Hemicladodus Davis). Körper hoch, rhombisch. Brustflossen sehr klein, Bauch. flossen fehlend (? unbekannt). Rücken- und Afterflosse sehr lang, symmetrisch gestellt. Kieferränder zahnlos, innere Fläche von Maxilla und Pterygoid mit Häufchen kleiner Zähne. Orale Seite des Pterygoids und Spleniale mit gezackter Leiste. Karbon, England.

Cheirodopsis Traquair. Karbon, Schottland. Etwas länger, mit Beckenflossen.

Platysomus Ag. (Fig. 176, 177). Körper

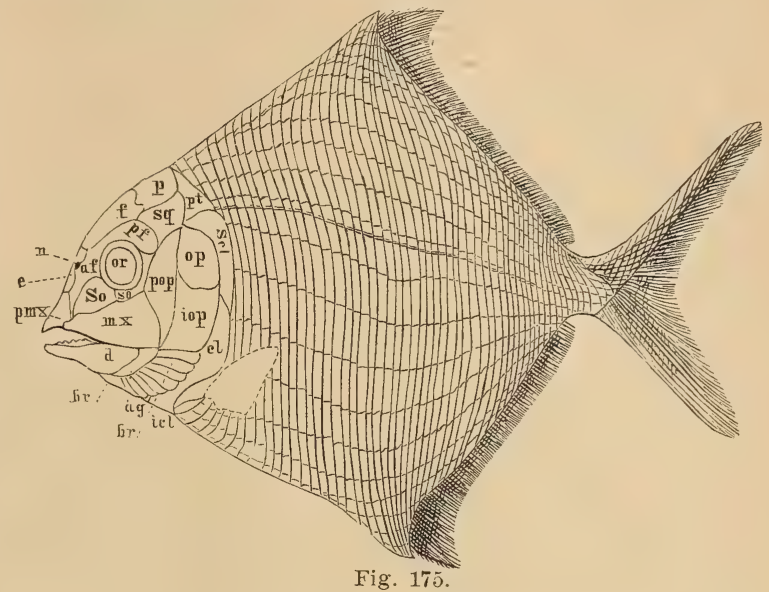

Cheirodus granulosus Young sp. Steinkohlenformation. NorthStaffordshire. Restauriert. (Nach Traquair.)

pmx Prämaxilla, $m x$ Maxilla. e Ethmoideum, $n$ Nasenöffnung, or Augenhöhle, So Suborbitalia, af Präfrontale, pf Postfrontale, $f$ Stirnbein, $p$ Scheitelbein, $s q$ Squamosum, $p t$ Posttemporale, op Operculum, $p o p$ Präoperculum, iop Interoperculum, d Dentale, ag Angulare, br Branchiostegalia, scl Supraclavicula, cl Clavicula, icl Infraclavieula.

hoch, rhombisch oder gerundet. Kieferränder mit kleinen griffelförmigen Zähnen, nach innen noch kleine Höckerzähne. Paarige Flossen klein. Kupferschiefer, Deutschland. Karbon und Perm, England.

Dorypterus 1 ) Germ. Beschuppung auf wenige Bauchschuppen beschränkt, die sich nach oben fadenförmig ausziehen. Obere und untere

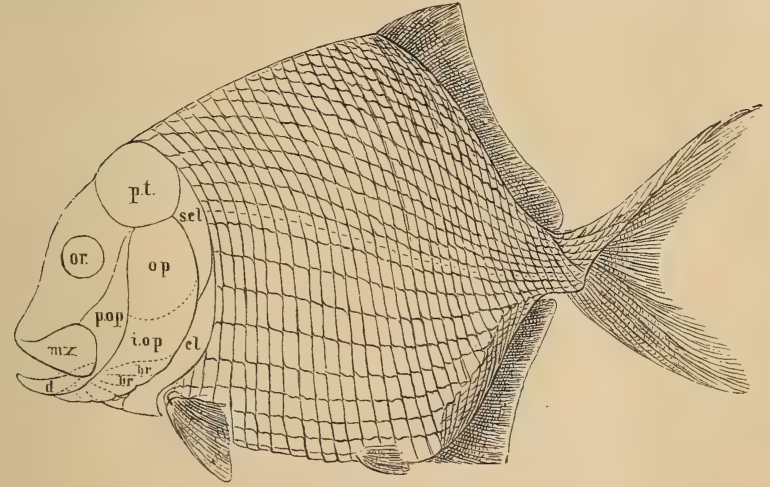

Fig. 176.

Platysomus striatus Ag. Magnesian limestone. England. Restauriert nach Traquair. (1/4 nat. Gr.)

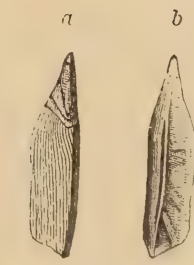

Fig. 177

Schuppe von Plat!ysomus parvulus Ag. $3 / 1$.

$a$ von außen, $b$ von innen.

Bögen kräftig, Chorda persistent. Flossenträger in zwei Reihen geordnet, von denen die baseostalen (proximalen) breite Platten sind. Analis fast so groß wie die Dorsalis, nur niedriger. Schwanz tief ausgeschnitten. Beckenflossen weit vorn, sehr klein. Kupferschiefer.

1) Reis, Geogn. Jahreshefte. 1892. 


\section{Familie: Catopteridae.}

Schwanzflosse mit großem unteren Lappen, daher äußerlich fast homocerk. Kopfknochen gut entwickelt, mit Ganoin, kine mittleve Reihe im Schädeldach. Zähne schlank, kegelförmig. Kiefer-Suspensorium schief; Kiemenhautstrahlen vorhanden. Dorsalis kurz, weit zurückliegend. Rhombische Schmelzschuppen.

Catopterus Redfield. Die Dorsalis beginnt erst hinter der Analis. Trias, Connecticut.

Dictyopyge Egerton. Die Dorsalis beginnt vor oder über der Analis. Trias, Virginia. Buntsandstein, Basel; Keuper, Franken. Obere Karroo, Südafrika. Hawkesbury-Schichten, Neu-Südwales.

\section{Unterordnung. Pycnodonti. $\left.{ }^{1}\right)$ Lütken,}

Körper seitlich zusammengepreßt, sehr hoch, oval. Schmelzschuppen rhomboidisch, höher als lang, zureilen auf den vorderen Teil des Körper's beschrïnlit. Vorderrand innen leistenartig verdicht. Dic Leisten tieffen anfeinander und ordnen sich zu rippenartigen Zügen. C'hordascheirle olue Verkiüchermngen, Bogenteile, Dornfortsätze und Rippen verknöchert. Schwanzflosse tief ausgerandet, äußerlich homocerk, innerlich schuach heterocerk. Banchflossen klein, unter. die Brustflossen gerïrlit. Rücken- und Afterflosse hinter der Mitte, hoch und spitz beginnend, als schmaler Saum bis zur Candalis verlängert. Keine Fulcra. Träger der unpaaren Flossen von gleicher Zahl wie die gegliederten Strahlen, die Bogenteile mit blattförmigen, imbrizierenden Fortsätzen. Operculum schmal und hoch (Supraclavicula autt.), das Präoperculum seh groß (Operculum autt.), Suboperculum und Interoperculum fehlen. Kiemenbögen oft mit dicht gedrängten Knochenfäden besetzt. Nur 2 Kiemenhautstrahlen (bei Mesturus und Gyrodus benbachtet.) Gularplatte fehlt. Oberhiefer dïnn, hinten ausgebreitet, zahnlos; Vomer mit 5 Reihen rundlicher orler ovaler Mallzähne. Zwischenkiefer mit meißelförmigen Schneidezühnen. Unterkiefer massiv mit einem hohen Kronfortsatz und mehreren Reihen von runden Mahlzähnen. Die kurzen, nach hinten spitzigen und in einer Rinne des Unterkiefers gelagerten Dentalia (? Prädentalia) bilden die Schnanze und tiagen vorn die meißelförmigen Schneidezähne. Clavicula vertikil gestellt, oben spitz, unten verbreitert. Infraclavicula fellt. Coracoid und Scapula unbekannt. Die Pycnodonten sind vielleicht Abkömmlinge der Platysomiden, von denen sie sich durch die Bezahnung, die Beschaffenheit der Kiefer und den unvollstïndigen Opercularapparat unterscheiden. Jura bis Eocän.

Gyrodus Ag. (Fig. 178-181.) Körper oval, gleichmäßig beschuppt. Schnauzesteil abfallend. Caudalis tief gegabelt. Gaumen mit 5 Reihen bohnen. förmiger Zähne, deren gewölbte Krone einen runzlichen Rand und eine vertiefte Mitte besitzen. Die Mittelreihe ist viel stärker als die Nebenreihen. Operculare mit 4 Reihen von Mahlzähnen, Dentale (Prädentale) mit 3 meißelförmigen Schneidezähnen. Häufig im Jura vom Bathonien an, besonders im Oxford, Kimmeridge, Portland und lithographischem Kalkschiefer. Ferner im Tithon (Sizilien), Wealden, Neocom und in der oberen Kreide. Einzelne Arten aus dem lithographischen Schiefer ( $G$. titanius Wagn.) erreichen eine Länge und Höhe von $1 \mathrm{~m}$.

Microdon Ag. (Fig. 182, 183, 185.) Schuppen in der hinteren Körper hälfte sehr dünn, oft fehlend. Schwanzflosse gegabelt. Gaumen mit 5 Reihen

1) Hennig, E., Gyrodus und die Organisation der Pyknodontiden. (Palaeontographica. LIII. Bd. 1906.) 
vierseitiger, flacher, glatter Zähne. Zwischen die großen Zähne der Mittel. reihe schieben sich alternierend die kleineren Zähne der beiden Seitenreihen ein. Operculare mit einer Reihe großer, vierseitiger, quer verlängerter, glatter Zähne, welche nach innen von einer, nach außen von zwei Reihen kleinerer Zähnchen begrenzt ist. Weißer Jura, vom Oxford bis zum Purbeck.

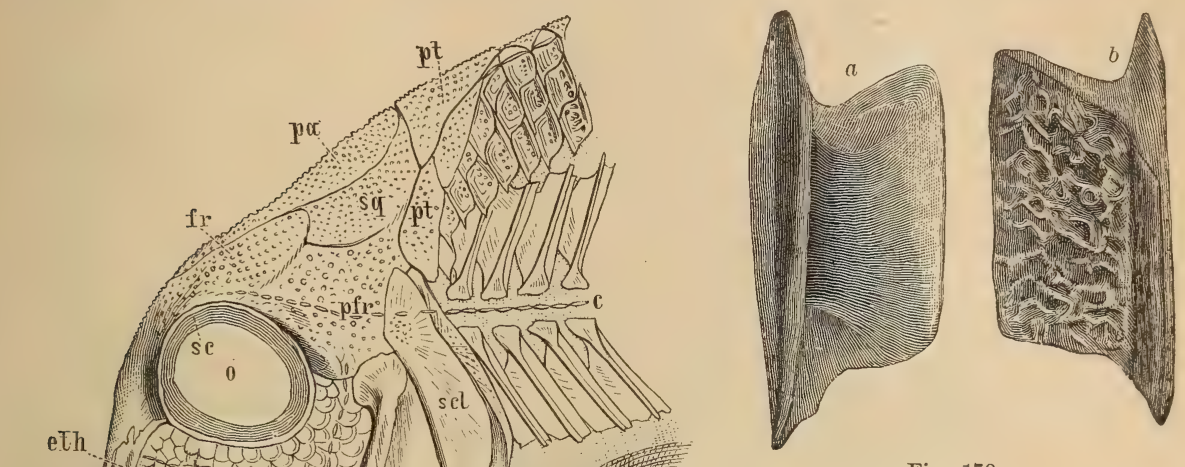

Fig. 179.

$a, b$ Gyrodus titanius-Wagn. Ob. Jura. Kelheim. Eine Schuppe $a$ von innen, $b$ ron außen. (Nat. Gr.)

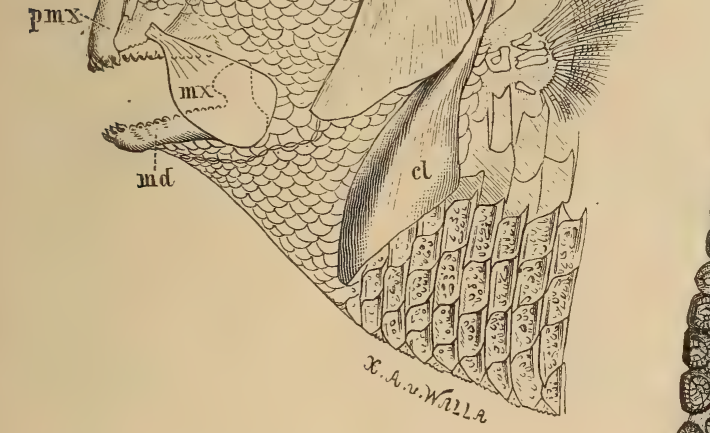

Fig. 178.

Kopf von Gyrodus macrophthalmus Ag. aus dem lithographischen Schiefer von Kelheim, 'Bayern. fr Stirnbein, eth Ethmoideum, $p f r$ Hinterstirnbein, $s q$ Squamosum, $p a$ Scheitelbein, $p t$ Posttemporalia', $m x$ Oberkiefer, $p m x \mathrm{Z}$ wischenkiefer, $O$ Augenhöhle, $s c$ Scleroticaring, $m d$. Unterkiefer, op Operculum, scl Supraclavicula, cl Clavicula, c Schleimkanäle.

Mesodon Wagner. (Fig. 184). Schwanzflosse gerundet. Zähne des Gaumens in 5 geschiedenen Reihen. Die große Zahnreihe des Unterkiefers von 3 bis 4 irregulären Reihen kleiner Zähnchen außen und 1 bis 2 Reihen innen begrenzt. Lias (M. liassicus Egert.) bis untere Kreide.

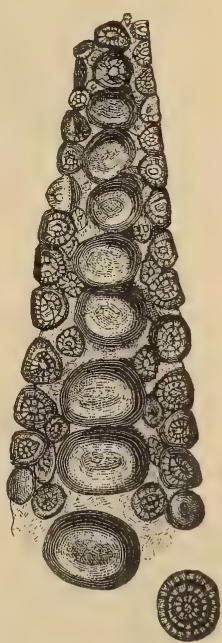

Fig. 180.

Gyrodus titanius Wagn. Ob. Jura Kelheim.

Gaumenplatte mit Zähnen.

(Nat. Gr.)

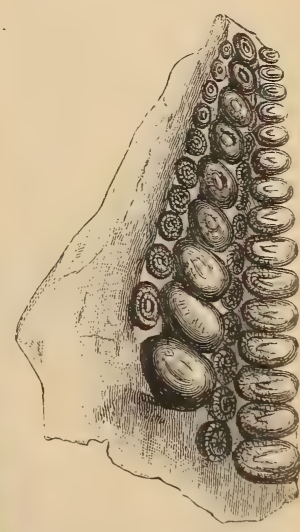

Fig. 181.

Gyrodus titanius Wagn. Rechter Unterkieferast (Spleniale)

mit vier Zahnreihen. Ob. Jura. Kelheim. (Nat. Gr.)

Arthrodon Sauvage. Mit tiefer Symphysialfacette; Zähne des Unterkiefers unregelmäßiger gestellt, sonst ähnlich Mesodon. Oberster weißer Jura, Purbeck, Cenoman.

Mesturus Wagn. Die über den ganzen Körper verteilten Schuppen sind innerhalb der Vertikalreihen durch zackige Nähte verbunden. Vomer mit 3 Reihen größerer Zähne, die durch unregelmäßig gestellte kleinere getrennt werden. Unterkiefer mit 2 Reihen größerer Zähne; kleinere Zähne 
zwischen und neben diesen Reihen. M. Leerlsi A. Sm. Woodw. Oxfordton. M. verrucosus Wagn. Ob. weißer Jura. Oxfordton. Solnhofener Schiefer.

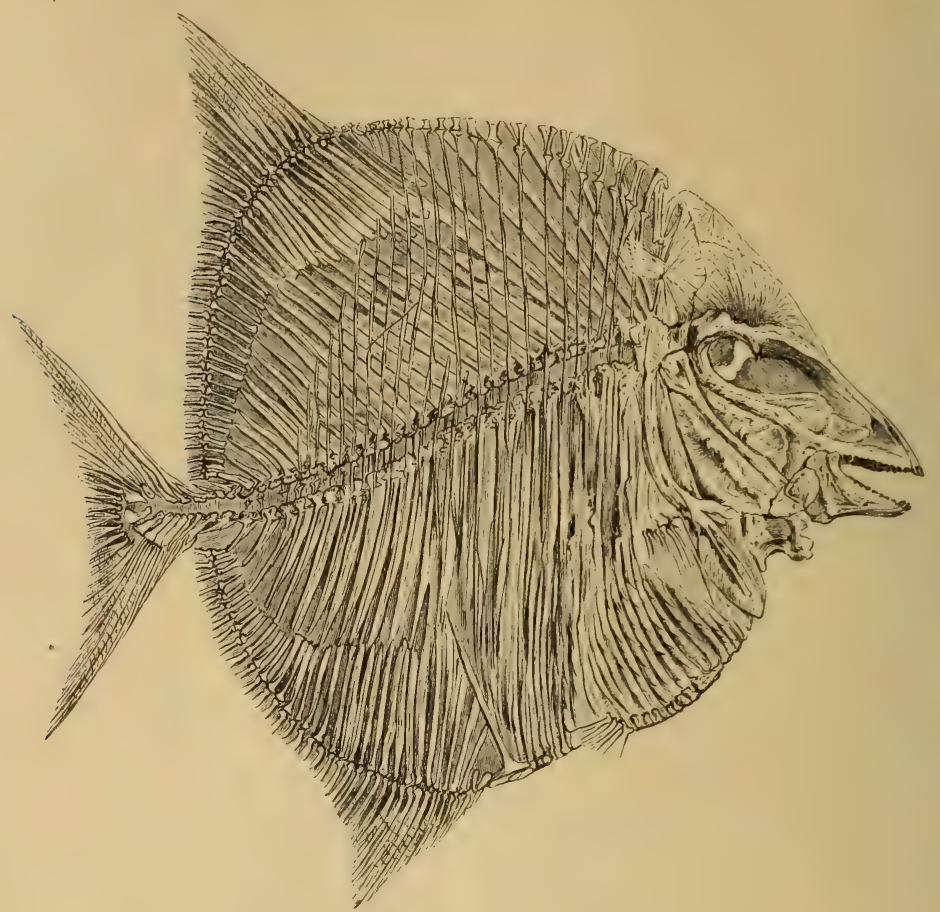

Fig. 182

Microdon Wagneri Thiollière. Ob. Jura. Cerin, Ain-Dep. 1/3 nat. Gr. (Nach Thiollière.)
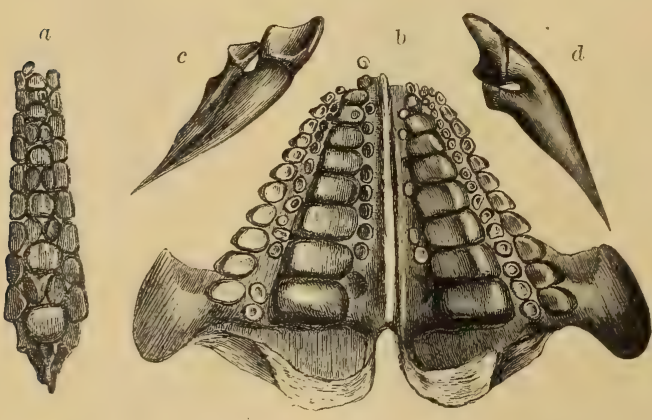

Fig. 183.

Gaumen und Unterkiefer von Microdon elegans Ag. Ob. Jura. Kelheim, Bayern. Nat. Gr. a Vomer-Palatinum, $b$ Hauptzahnplatten des Unterkiefers (splenialia), $c$ Vorderzähne des Unterkiefers von innen, $d$ dieselben von außen.

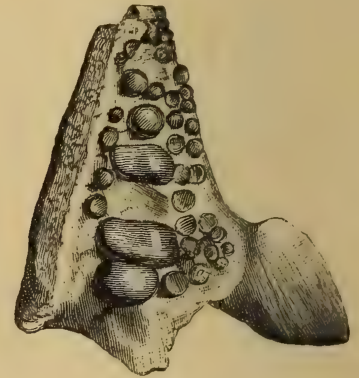

jig. 184 .

Unterkiefer von Mesodon macropterus Ag. Ob. Jura. Kelheim. Nat. Gr.

Stemmatodus Heckel. Kleiner Gaumen mit 5, Unterkiefer mit 3 Reihen rundlicher, fast gleicher Zähne. Untere Kreide, Castellamare und Neapel.

Coelodus Heckel. (Fig. 186.) Schwanzflosse seicht ausgerandet oder schwach konvex und jederseits der Mitte mit schwacher Ausbuchtung. 
Gaumen mit einer Mittelreihe großer, quer elliptischer Zähne und jederseits 2 Reihen kleiner Zähnchen. Unterkiefer mit 1 Reihe großer, quer ver-

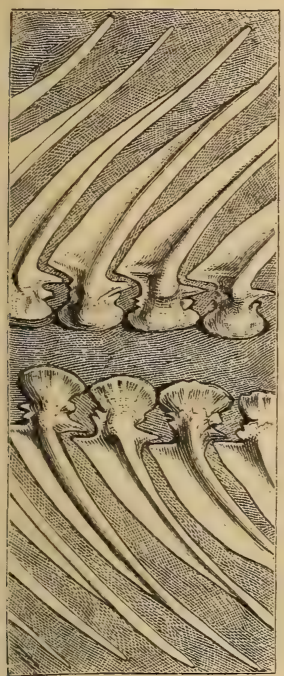

Fig. 185.

Ein Teil der Wirbelsäule von Iicrodon Itieri

Thioll. unt. der Rückenflosse. Cerin. Ain. Nat.

Gr: (N. Thiollière.)

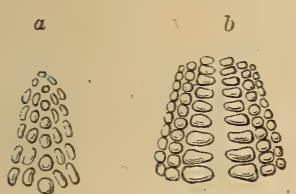

Fig. 187.

Pycrodus. a Gaumenzähne, $b$ Unterkieferzähne.

(Nach Heckel.) längerter Zähne und Nebenreihen. Wealden. Untere Kreide (Istrien, Dalmatien, Süditalien, England). Cenoman, Jura und Senon von England und Nordamerika.

Anomoeodus Forir. Ob. Kreide.

Coccodus Pictet, Xenopholis Davis. Occipitale mit langem Stachel. Ob. Kreide, Libanon.

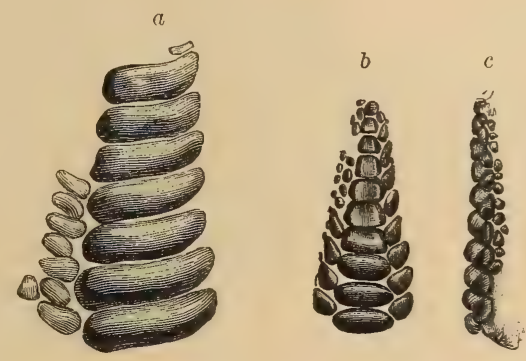

Fig. 186.

Coelodus Münsteri Ag. Grünsand. Kelheim. $a$ Unterkieferzähne, $b$ Vomerplatte, von unten, $c$ von der Seite.

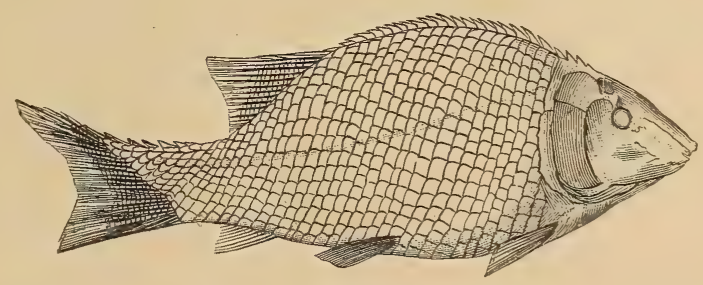

Fig. 188.

Semionotus Kapffi Fraas. Keuper (Stubensandstein). Stuttgart. $2 / 3$ nat. Gr. (Nach Fraas.)

Palaeobalistum Blv. Obere Kreide, Libanon. Eocän, Mte. Bolca.

Pycnodus Ag. (Periodus Ag.) (Fig. 187). Körper länglich, mäßig hoch. Rückenflosse viel länger als die Afterflosse. Schwanzflosse mit doppelter, seichter Ausbuchtung. Schuppen nur im vorderen Teil des Körpers, dünn. Gaumen mit 3 Zahnreihen, von denen die Außenreihen etwas größere, elliptische Zähne enthalten. Unterkiefer mit 3 Reihen Zähne, von denen die inneren größer und quer elliptisch sind. Die oberen und unteren Bögen umschließen mit ihren verbreiterten Basalteilen die Chorda. P. platessc Blv. sp. Obereocän, Mte. Bolca.

\section{Unterordnung. Orthoganoidei.}

Wit rhombischen oder rhomboidischen, in schiefen Reihen geordneten Schmelzschuppen. Unpaare, zuveilen auch paarige Flossen mit Fulcren. Schwanzflosse hemiheterocerk, Chordascheide mit angelegten Pleurocentren und Hypocentrum, mit Halb- und Hohlwirbeln, oder ganz verknöchert (amphicöl). 
Familie: Stylodontidae. Wagner.

Chorda persistent, die Chordascheide mit Halbwirleln oder Ringen. Rhombische Schmelzschuppen, mit Stachelfortsatz ineinandergreifend. Schwanz innerlich stets heterocerk, äuferlich durch Vergröfierung des unteren Lappens oft fast homocerk. Alle Flossen mit Fulcren. Randbezahnung der Kiëfer griffelförmig (Krone zuweilen gezackt), auf den inneren Knochen oft Mahlzühne (mit vertikalem Ersatz).

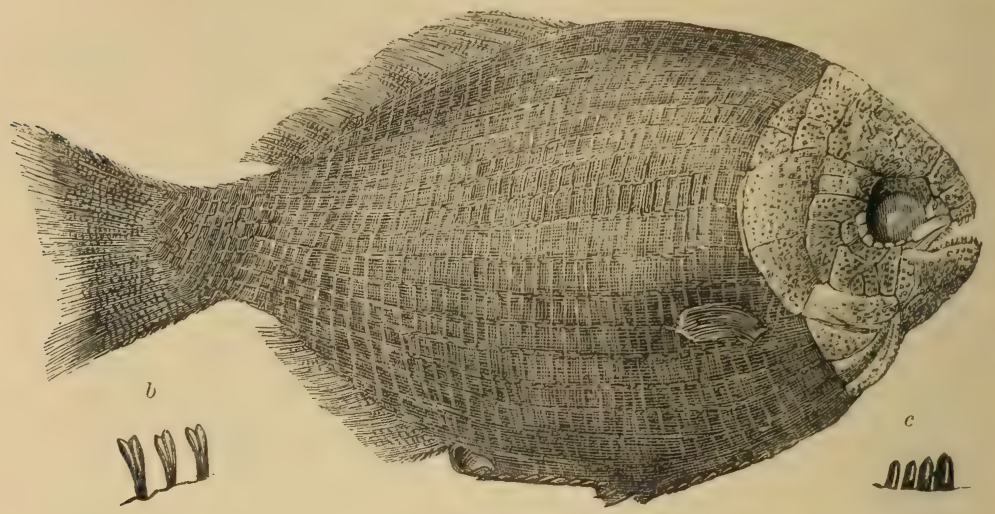

Fig. 189.

Dapedius pholidotus Ag. Boll, Württemberg. $1 / 2$ nat. Gr. (Nach Quenstedt.) b, c Zähne nat. Gr.

Semionotus Ag. (Ischypterns Egerton). Körper länglich, mäßig hoch. Schuppen rhombisch, der Rücken mit großen, gekielten Schuppen, Rückenflosse hoch, ziemlich lang, vor der Analis stehend; die übrigen Flossen klein.

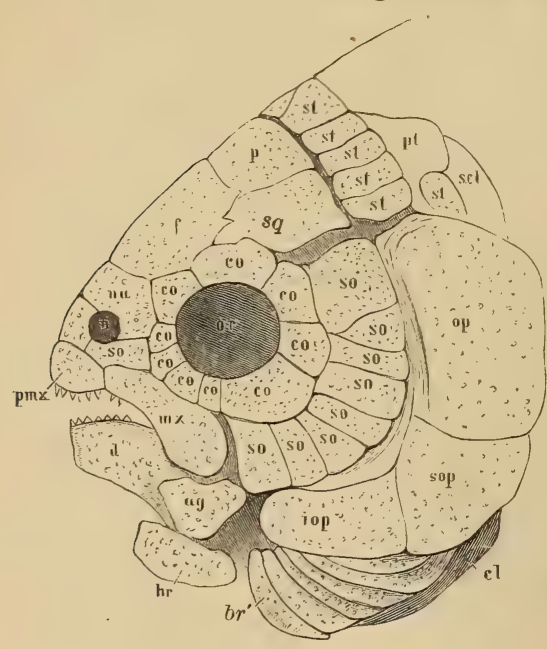

Fig. 190.

Kopf von Dapedius. (Nach Traqua i r.) $f$ Stirnbein, $p$ Scheitelbein, na Nasenbein. sq Schuppenbein, st vordere Nackenplatten (Supratemporalia), pt hintere Nackenplatte (Posttemporale), $p m x Z$ wischenkiefer, $m x$ Oberkiefer, co innerer Augenring (Circumorbitalia), so äußerer Augenring (Wangenplatten, Postorbitalia), op Operculum, sop Suboperculum, iop Interoperculum, $d$ Zahnbein, ag Eckbein, $b r$ mittlereKehlplatte, $b r^{\prime}$ Kiemenhautstrahlen, cl Clavicula, scl Supraclavicula. Alle Zähne griffelförmig. Häufig im Keuper von Franken (Semionotus-Sandstein) und Thüringen. Bunter Sandstein, Vogesen. Oberer Muschelkalk der Alpen (Perledo), Raibler Schichten, Seefelder Schichten. Obere Trias von Nordamerika. Obere Karru-Schichten von Südafrika. Hawkesbury-Schichten, Neu-Südwales. England.

A centrophorus Traquair. Perm,

Dapedius de la Bêche. ${ }^{1}$ ) (Amblyurus Ag., Aechmodus Egerton. Tetragonolepis Ag. non Bronn. Omalopleurus Costa). Hohe, seitlich zusammengedrückte Fische, rhombisch bis oval. Schuppen auf den Flanken höher als breit, dorsale und ventrale Kielschuppen unauffällig. Fulcra uniserial, d. h. gegen die Spitze zu fest verwachsen. Dorsalflosse lang, in der Mitte des Rückens beginnend, Analis etwas kürzer, der hinteren Hälfte der Rückenflosse gegenüber. Schwanzflosse kaum

1) M. Browne. Revision of a genus of fossil fishes. Dapedius. (Trans. Leicester Literary and Phil. Soc. 1890.) 
ausgeschnitten. Paarige Flossen sehr klein; die Brustflossen hoch auf der Seite inseriert. Opercula vollständig bogenförmig angeordnet, aber Präoperculum fast oder ganz bedeckt von den Suborbitalien (Postorbitalien). Augen mit geschlossenem Ring von kleinen Circumorbitalplatten. Alle Deckknochen des Kopfes mit Ganoin und höckerig verziert. Auch die Supratemporalia und Posttemporalia sind in größerer Zahl vorhanden. Chordacranium verknöchert. Blattförmige Branchiostegalia (ca. 6), zwischen ihnen eine Jugularplatte. Die Ossifikation der Wirbelsäule beschränkt sich auf die Bogenteile. Kieferknochen außen mit keulenförmigen, innen mit kleinen, fast bürstenförmigen Zähnen besetzt. Verbreitet im unteren und oberen Lias von Mitteleuropa. D. pholidotus Ag., caelatus Qu., Lias $\varepsilon$; doch auch in der alpinen 'Trias (St. Cassian, Seefeld) und in den Gondwana-Schichten Indiens (Kota-Maleri).

A phuelepis A. Sm. Woodw. Pristisomus A. Sm. Woodw. Obere Trias (obere Hawkesbury-Sch.), Neu-Südwales.

Serrolepis Qu. Lettenkohle, Württemberg. Crenilepis Dames. Muschelkalk.

Dollopterus Abel. (Dolichopterus Compter.) Mit außerordentlich großen Brustflossen. (Flugfisch.) Ob. Muschelkalk.

Cleithrolepis Egerton. Körper hoch, Umriß rhombisch, die dicken Schuppen höher als breit. Dorsale und ventrale Kielschuppen ausgeprägt. Ob. Trias, Stormberg beds, Südafrika. Hawkesbury-Schichten, Neu-Südwales.

Aetheolepis A. Sm. Woodw. Obere Trias (Hawkesbury-Sch.), NeuSüdwales.

Tetragonolepis Bronn (Pleurolepis Qu., Homoeolepis Wagn.). Kleine, ovale oder fast kreisrunde Fische mit kleinen Brust- und Bauchflossen. Brustflosse hoch auf der Seite. Rücken- und Afterflossen sehr lang, die Strahlen durch Träger gestützt, von denen je 2 zwischen 2 Dornfortsätzen eingeschaltet sind. Schuppen auf den Seiten sehr hoch, am Vorderrand verdickt und Hautrippen bildend. Chordascheide mit Pleurocentren und Hypocentren. Kopfknochen zum Teil mit Schmelzhöckern. Ob. Lias, Württem. berg, Franken, England. T. semirinctus Br. Kota-Maleri-Schichten, Indien.

Familie: Sphaerodontidae. Wagner.

Dicke, rhombische Schuppen. Oberkiefer, Gaumenbein, Vomer und Unter. kiefer mit mehreren Reihen halbkugeliger Zühne, Zwischenkiefer mit stumpf konischen oder meifielförmigen Schneidezähnen. Oberkiefer und Dentale noch mit schwächeren konischen Randzähnen. Keine Gularplatte. Chorda persistent.

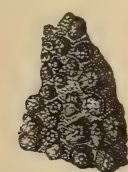

Fig. 191.

Zähne von Colobodus varius Gieb. Muschelkalk. Bayreuth.
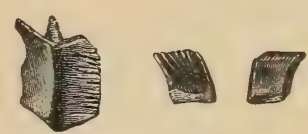

Fig. 192

Schuppen von Colobodus (Gyrolepis Alberti p. p. Ag.) Muschelkalk. Bayreuth. (Nat. Gr.)

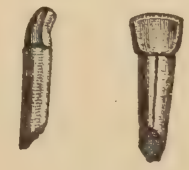

Fig. 193.

Sargodon tomicus Plien. Rhätisches Bonebed.

Württemberg.

Colobodus Ag. (Asterodon Mstr., Tholodus Meyer, Dactylolepis Kunisch, Eupleurodus Gürich, Nephrotus Meyer, Omphalodus Meyer.) Kopf etwas nieder. gedrückt, vorn gerundet. Zähne halbkugelig, in der Mitte der Krone zitzenartig erhöht. Schuppen mit parallelen Rippen, am Hinterrand gezïhnt. Dorsalis und Analis sehr hoch. Muschelkalk, Lettenkohle; Cassianer Schichten, Seefelder Schichten der alpinen Trias. 
Hemilopas Meyer, Cenchrodus Meyer. Auf einzelne Zähne aus dem Muschelkalk angewendet.

Sargodon Plien. (Fig. 193). Nur Schneidezähne bekannt. Rhät.

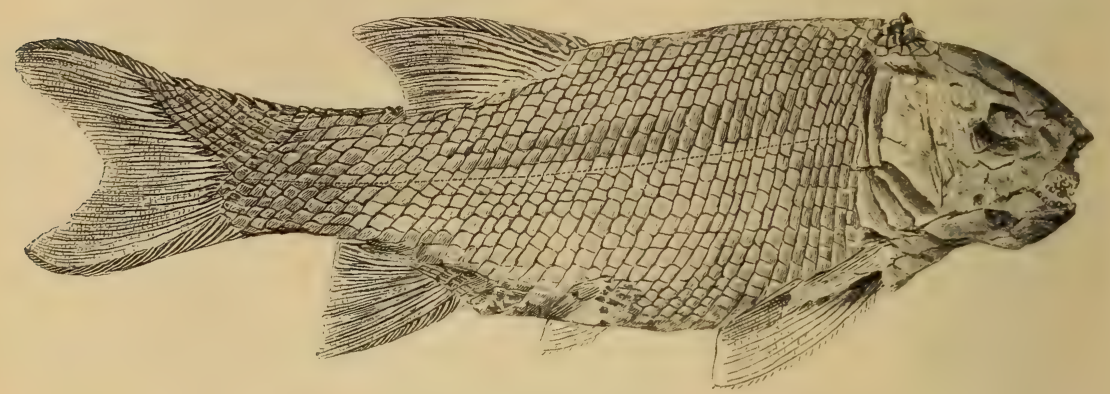

Fig. 194.

Lepidotus notopterus Ag. Lithographischer Schiefer. Solnhofen. 1/5 nat. Gr.

Lepidotus Ag. (Spllaerodus Ag. p. p., Plesiodus Wagner, Piolepidotus Michael. Ścrobodus Mstr., Lepidosanins Meyer). Körper lïnglich, gedrungen,
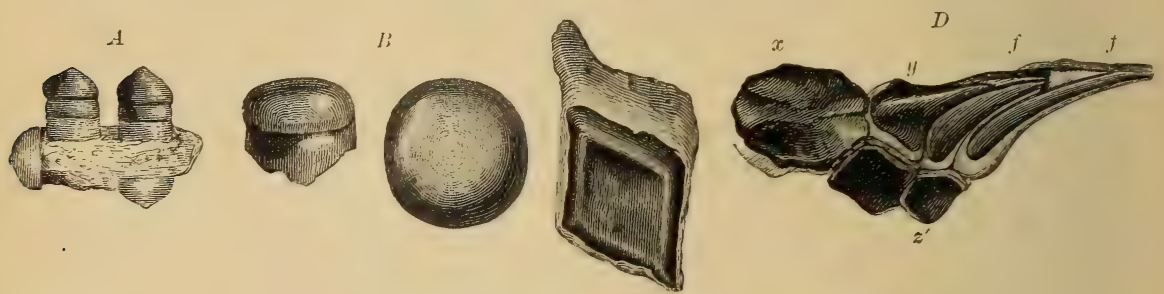

Fig. 195.

Lepidotus. A Kieferfragment mit Ersatzzähnen. $B$ ein Zahn von der Seite und von oben. C Schuppe (nat. Gr.). D Fulcrenbesatz der Rückenflosse. $x$ unpaare Rückenschuppe, $y$ erste Basalschuppe der Rückenflosse, $f f$ Fulcrenstücke, $z$ und $z^{\prime}$ Seitenschuppen.

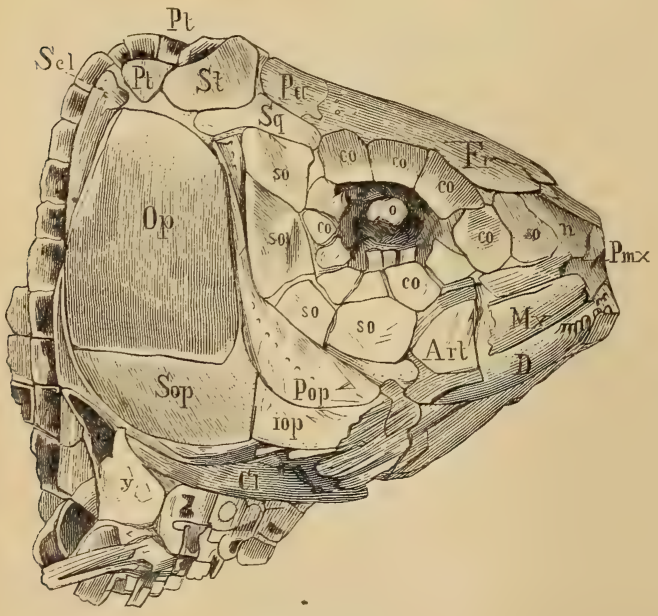

Fig. 196.

Kopf von Lepidotus Elvensis Blv. aus dem oberen Lias von Boll. 1/3 n. Gr. (Nach Quenstedt.) mit dicken, glatten oder nur schwach verzierten Schuppen. Die imbrizierten Schuppenränder sind nach vorn verlängert. Rückenflosse vor der Analis, beide groß. Brustflossen groß, tief inseriert. Beckenflossen sehr klein. Schwanzflosse ausgeschnitten. Kopfknochen alle mit Schmelz überzogen, glatt odergekörnelt. Häufig in Trias, Jura und unterer Kreide in Europa, Asien, Brasilien. IL. elvensis Blv. Ob. Lias ع. L. Leedsi A. Sm. Woodw., Oxfordton. L. maximus Ag. Ob. weißer Jura. Solnhofen. L. Mantelli Ag., Wealden. L. Mawsoni A. Sm. Woodw. Kreide. Bahia. 


\section{Familie: Macrosemiidae.}

Chorda persistent, Chordascheide mit Pleurocentren und Hypocentren oder entsprechenden Ringen. Bezahnung kräftig. auf Kiefern, Pterygopalatinum, Vomer, Dentale und Spleniale. Tenige Kiemenhautstrahlen. Schwanzflosse mit ziemlich gleichen Lappen, aber innerlich heterocerk. Dorsalis lang und hoch, alle Flossen mit gegliederten und geteilten Strahlen. Schuppen rhombisch.

Macrosemius Ag. (Disticholepis Thioll.) Rückenflosse vom Nacken bis zum Schwanz reichend. Nur die gerundete Caudalis mit Fulcren. Schwanz ventral mit großen Kielschuppen; die übrigen Schuppen dünn, dorsal und ventral reduziert. ? Brauner Jura, Stonesfield. Lithographischer Schiefer von Bayern, Cerin.

Histionotus Egerton. (Fig. 198). Erster Strahl der langen Rückenflosse verlängert, mit Fulcren besetzt. Caudalis tief gegabelt. Fulcra an allen Flossen, Beschuppung vollständig. Ob. weißer Jura, Bayern, Cerin. Purbeck.

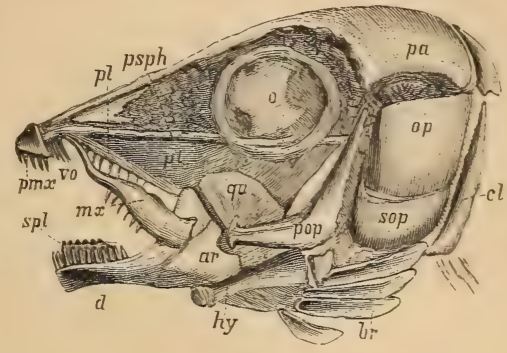

Fig. 197

Kopf von Macrosemius tatiusculus Wagn. Ob. Jura. Kelheim. (Nat. G).) pa Scheitelbein, $p s p h$ Parasphenoid, vo Vomer, $p m x$ Prämaxilla, $m x$ Oberkiefer, $p l$ Gaumenbein, $q u$ Quadratbein, op Operculum. sop Suboperculum, pop Präoperculum, a Dentale, spl Spleniale des Unterkiefers, hy Zungenbeinbogen, br Kiemenhautstrahlen, cl Clavicula.

Ophiopsis Ag. Sehr schlank, Dorsalis die Hälfte bis zwei Drittel der Rückenlänge einnehmend. Caudalis gegabelt, der obere Lappen teilweise beschuppt. Fulcra an allen unpaaren Flossen. Beschuppung rollständig, Schuppen mit Zahngelenk. Dünne Ringwirbel. Vom oberen Muschelkalk (Perledo) an bis zum Purbeck. Besonders ob. weißer Jura von Bayern, Cerin. O. temiservata Ag. sp.

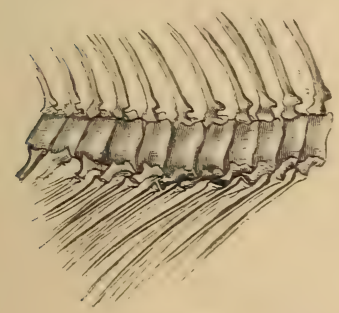

Fig. 198.

Wirbelsāule von Histionotus Oberndorferi Wagn. Ob. Jura. Kelheim. Bayern. (Nat. Gr.)

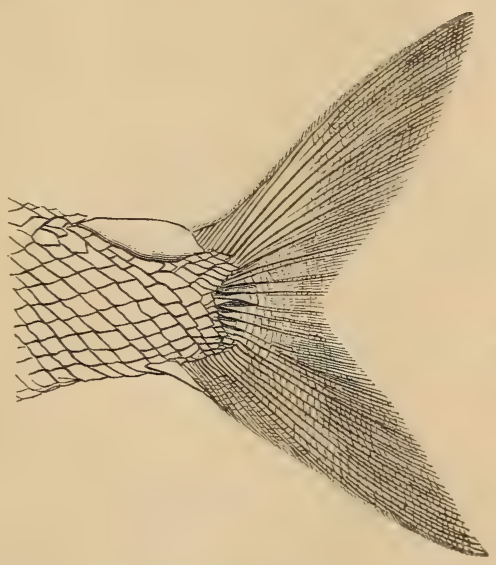

Fig. 199.

Photidophorus striolaris Ag. Ob. Jura. Eichstätt. Sehwanzflosse.

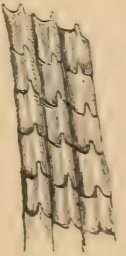

Fig. 200 Pholidophorus micronyx Ag. Schuppen von der Innenseite.

Eusemius Vetter. Flossenstrahlen nicht geteilt, sonst wie Oplliopsis. Ob. weißer Jura. Solnhofen.

Le gnonotus Egerton. Rhät.

Petalopteryx Pictet (Aphanepygus Bassani). Beschuppung kriiftig, aber unregelmäßig, die vertikalen Reihen nach oben und unten zuweilen dichotom. Analis angeblich fehlend. Obere Kreide, Libanon, Dalmatien.

Propterus Ag. (Rhynchoncodes Costa). Die grobe und hohe Dorsalis zweiteilig, der vordere Teil höher. Caudalis tief gegabelt. Paarige Flossen 
ohne Fulcra. Beschuppung vollständig regelmäßig. Verknöcherung der Chordascheide sehr zart, meist Ringwirbel. Ob. weißer Jura. Solnhofen.

Notagogus Ag. (Blenniomoeus Costa, Calignathus Costa). Vordere Strahlen der geteilten Dorsalis nicht verlängert, Caudalis nicht gegabelt. Ringwirbel kräftiger. Ob. weißer Jura, Solnhofen, Cerin. Untere Kreide, Neapel.

\section{Familie: Pholidophoridae.}

Schlanke Fische mit rhombischen Ganoidschuppen. Zühne klein, spitzig. Flossen mit kleinen Fulcren. Dorsalis und Analis klein. Mundspalte oben von Prämaxilla und Maxilla begrenzt. ('horla persistent; Pleurocentra und Hypo.

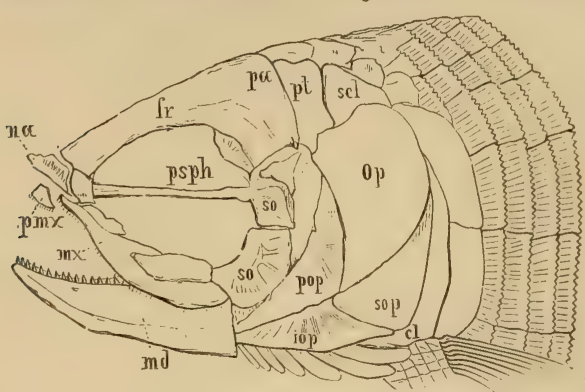

Fig. 201.

Kopf von Pholidophorus striolaris Ag. Ob. Jura. Eichstätt, Franken. centra zuweilen zu Ringwirbeln verschmolzen. (Fig. 199-202.)

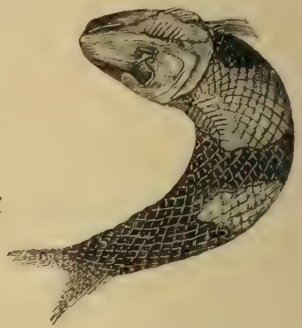

Fig. 202 .

Pholidophorus pusillus Ag. Norische Sch. Seefeld, Tirol. (Nat. Gr.)

Pholidophorus Ag. (Brachyichtlıys Winkler). Schuppen dünn, aber glänzend, auf den Flanken etwas höher als lang; mit Zahnverbindung. Rückenflosse etwas vor der Analis. Paarige Flossen klein. Schwanzflosse

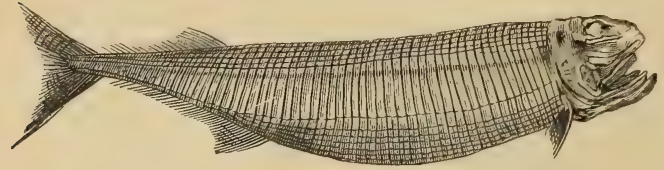

Fig. 203.

Thotidopleurus typus Bronn. Karnische Sch. Raibl, Kärnten. $2 / 3$ nat. Gr. (Nach Kner.) tief ausgeschnitten, äußerlich homocerk; vor ihr öfter eine große unpaare Dorsalschuppe. Raibler Sch. (Ph. Bronni Kner), Seefelder Sch. Unt. Lias, Lyme Regis (Ph. Bechei Ag.). $\mathrm{Ob}$. Lias $(\varepsilon)$ von Württemberg, Franken, Calvados ( $P h$. germanicus Quenst.). Ob. weißer Jura; Süddeutschld., Cerin. Purbeck.

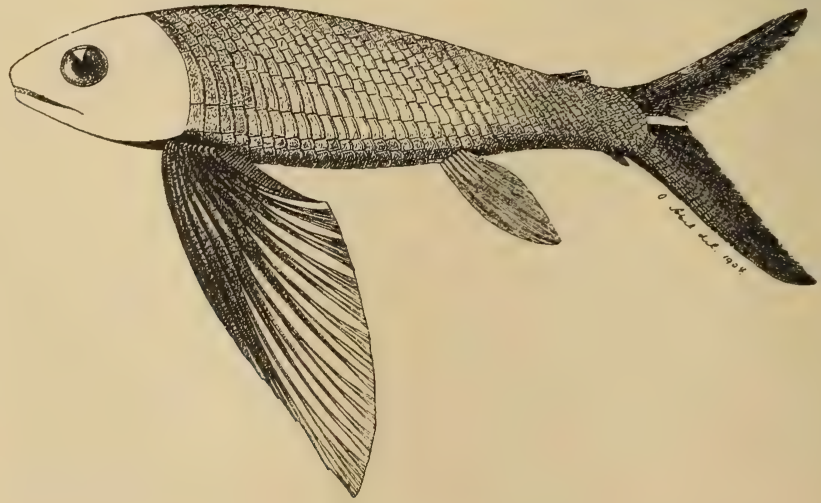

Fig. 204. Thoracopterus Niederristi Bronn. Raibler-Schichten. Rekonstr. von O. A be1. 
Thoracopterus Bronn (Pterygopterus Kner). (Fig. 204.) Mit sehr großen Brustflossen, die 2/3 der Körperlänge erreichen. Raibler Sch. Gigantopterus Abel. Raibler Sch. Beide Gattungen Flugfische.

Pholidopleurus Brown. (Fig. 203.) Klein, schlank. Schuppen dick, glatt, mit dünnem Ganoin, auf den Flanken sehr hoch und kurz, Seitenlinie deutlich. Dorsalis und Analis lang, weit nach hinten gerückt. Beckenflossen fehlen. Wirbel ringförmig. Raibler Sch.

Peltopleurus Kner. Dorsalis und Analis kurz. Mit Beckenflossen. Raibler Sch. Seefelder Sch.

Pleuropholis Egerton. Dorsalis und Analis lang, opponiert. Sehr hohe, kurze Schuppen auf den Flanken. Kleine Beckenflossen. Wirbel ringförmig. Ob. weißer Jura, Bayern, Cerin; Pl. Egertoni Wagn. Purbeck. seeland).

Archaeomene A. Sm. Woodw. Ob. Trias (Hawkesbury beds, Neu-

Ceramurus Egerton: Purbeck.

\section{Familie: Oligopleuridae.}

Wirbelsüule vollständig verknöchert, in den oberen Schwanzlappen verlängert. Dorsalis kurz. Schwanzflosse groß, ausgeschnitten, äußerlich homocerk. Fulcra vorhanden. Schuppen dünn, cycloid.

Oligopleurus Thiollière. Schuppen groß, dïnn, weit imbrizierend, cycloid. Caudalis mäßig ausgeschnitten. Ob. weißer Jura, Cerin. Wealden.

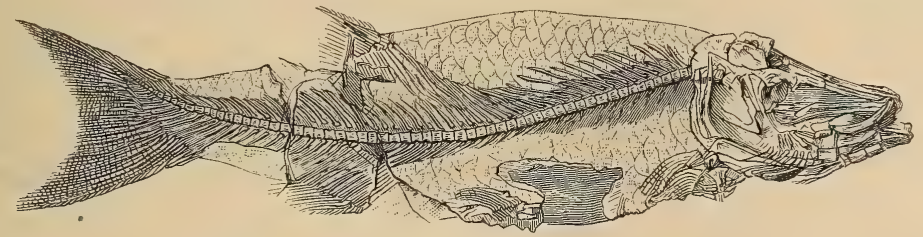

Fig. 205.

Oligopleurus esocinus Thiollière. Ob. Jura. Cerin, Ain. 1/4 nat. Gr. (Nach Thiolli ère.)

Oenoscopus Costa (Attakeopsis Thiollière, Macrorhipis Wagn.). Rückenflosse länger, zum Teil vor der Analis. Schwanzflosse tief ausgeschnitten. Ob. weißer Jura, Süddeutschland, Cerin. Untere Kreide, Italien (Pietraroja).

Spathiurus Davis (Amphilaphurus Davis). Rückenflosse über den größten Teil des Rückens ausgedehnt. Caudalis mäßig ausgeschnitten. Sp. dorsalis Davis. Ob. Kreide, Libanon.

Opsigonus Kramb. aus der unteren Kreide von Lesina ist ungenügend bekannt, vielleicht mit Spathiurus identisch.

\section{Familie: Aspidorhynchidae.}

Sehr schlanke, langgestreckte Fische, mit rhomboidischen Schmelzschuppen, deren Schmelzbelag bei einigen reduziert ist. Schnauze schnabelartig zugespitzt. Unterkiefer mit isoliertem Prädentale (Präsymphysale). Wirbel ringförmig oder. amphicöl. Zühne schlank, spitz. Flossen klein, mit breiten Strahlen, Fulcra reduziert oder fehlend. Schwanzflosse äußerlich homocerk. Zahlreiche Branchiostegalia.

Aspidorhynchus Ag. Schlanke, dünne, bis $1 \mathrm{~m}$ lange Fische, mit mäßig dicken, auf den Flanken hohen, glänzenden, aber nicht mit eigentlichem Schmelz bedeckten Schuppen. Das lange, den Unterkiefer bedeutend überragende Rostrum ist besonders von Prämaxillen, Vomer und Ethmoiden gebildet. Die Maxilla ist isoliert, schlank. Zähne am größten auf Prämaxilla, Palatinen und Präsymphysale. Zwischen den Suborbitalien und Präoperculum ein Schaltknochen. Wirbelkörper ringförmig, zart. Bauch. 
flosse hinter der halben Körperlänge, Afterflosse und Rückenflosse opponiert. Caudalis tief ausgeschnitten. Von braunem Jura an (Stonesfield slates). Besonders häufig im oberen weißen Jura von Solnhofen, Cerin. Purbeck.

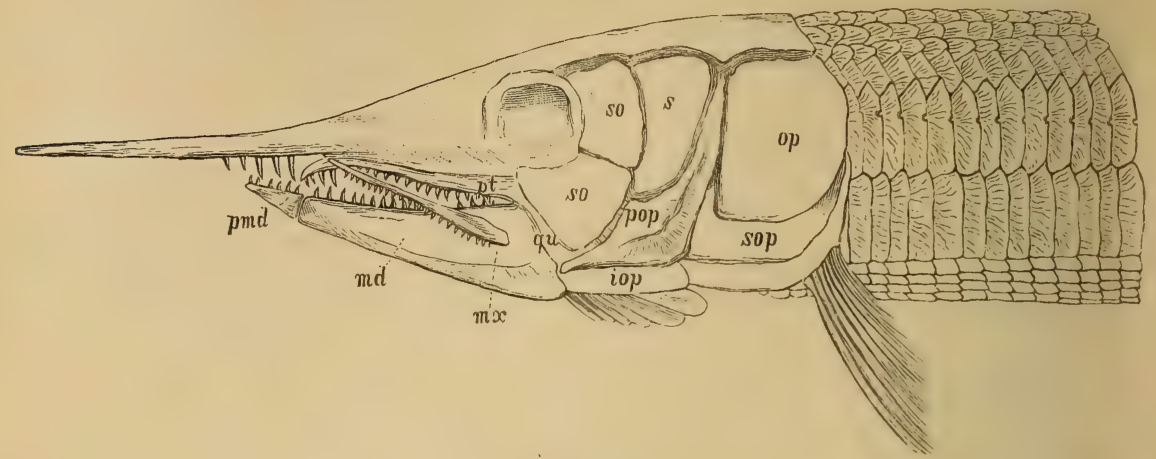

Fig. 206 .

Aspidorhynchus acutirostris Ag. ()b. Jura. Solnhofen, Bayern.

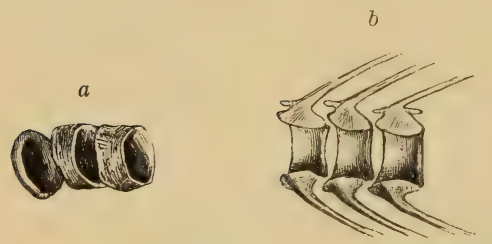

Fig. 207 .

Aspidorhynchus. a Hohlwirbel von vorn, $b$ ein Stück der Wirbelsäule aus der Schwanzregion mit aufsitzenden Bogen und Dornfortsätzen.
Belonostomus Ag. Unterkiefer fast ebensolang als die Schnauze. Schuppen mit Schmelz; die der Seiten. linie höher als die übrigen. Suborbitalia nicht durch eine $Z_{\text {wischenplatte }}$ vom Präoperculare getrennt. Wirbel amphicöl, aber durchbohrt. Oberer weißer Jura von Süddeutschland und Cerin; B. tenuirostris Ag. Untere Kreide (Italien) und obere Kreide (England, Brasilien, Queensland).

\section{Unterordnung. Lepidosteidae.}

Wirbel verknöchert, opisthocöl. Intercalaria zwischen den oberen Bögen. Kopf mit zahlireichen dicken, schmelzbedeckten Belaghnochen, insbesondere um die Orbita und zwischen Squamosum und Opercularen. Maxilla in melirere Teilstücke zerfallen. Unterkiefer mit großem Dentale, Spleniale, einem gesonderten
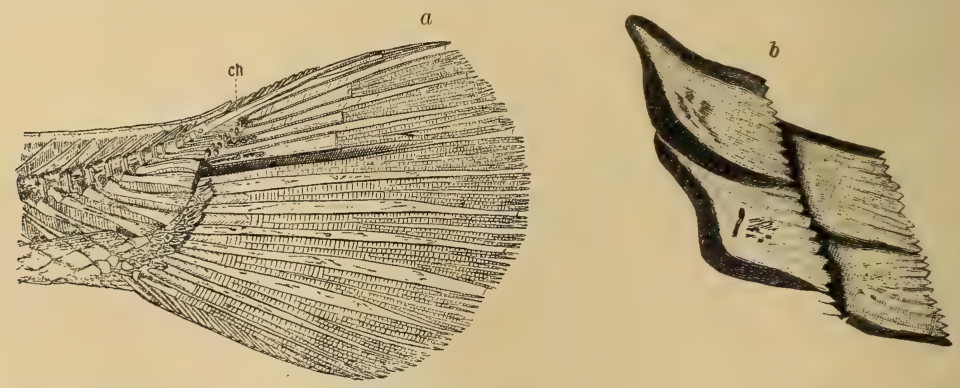

Fig. 208

Lepidosteus osseus Lin. a Schwanzflosse, $b$ Schuppen. Rezent. Nordamerika.

Angulare und Complementare (Coronoideum); kein Prädentale oder Präsymplysale. Derbe Schmelzschuppen, festgefügt. Auf den Kieferrändern eine Anzahl großer spitzer Zühne; dazwischen bedentend kleinere. Kleine Zähne auch auf dem Pterygo- 
palatinum und auf der Imenseite des Dentale (Spleniale). Wenige Branchiostegalia, keine Gularplatten. Alle Flossen mit biserialen Fulcren, klein, Schwanzflosse gerundet, innerlich heterocerk.

Die einzige Familie der Lepidosteiden (mit der lebenden Gattung Lepidosteus) steht sehr isoliert. Ihre Beziehung zu fossilen Ganoidfischen bedarf weiterer Klärung. Die Zusammenstellung mit den Semionoten, Lepidoten, Pholidophoren etc. (zu einer Ordnung) ist hier aufgegeben.

Lepidosteus Lacépède. Vom Eocän an. Clastes Cope, Eocän von Nordamerika (Wyoming), ist wohl nicht wesentlich verschieden.

\section{Unterordnung. Amioidei.}

Schuppen sehr düm, dachziegelartig übereinandergreifend, cycloid óder rhombisch. Schwanzflosse äußerlich homocerk oder gerundet, innerlich heterocerk. Wirbelsüule mit Nacktwirbeln, Halbwirbeln oder vollständig verknöchert. Kiemenhaut. strahlen blattförmig, eine mediane Ingularplatte vorhanden. Zähne zugespitzt, konisch. Lebend Amia, in Flüssen der südlichen Vereinigten Staaten und Zentralamerikas. Fossil vom Lias an.

Familie: Pachycormidae Döderlein.

(Microlepidoti und Cyclolepidoti Zittel.)

Ossifikationen der Chordascheide beschränkt; Nacktwirbel oder Halbwirbel. Schwanzflosse tief' ausgeschnitten, kriftig, nu innerlich heterocerk. Vor der Rückienflosse meist einige blinde Flossentrïger. Fulcra kilein oder fehlend. Fthmoid und Vomer zu einem Rostrum verlängert. Kiemenhautstrahlen sehr zahlreich $(30-40)$. Lias bis untere Kreide.
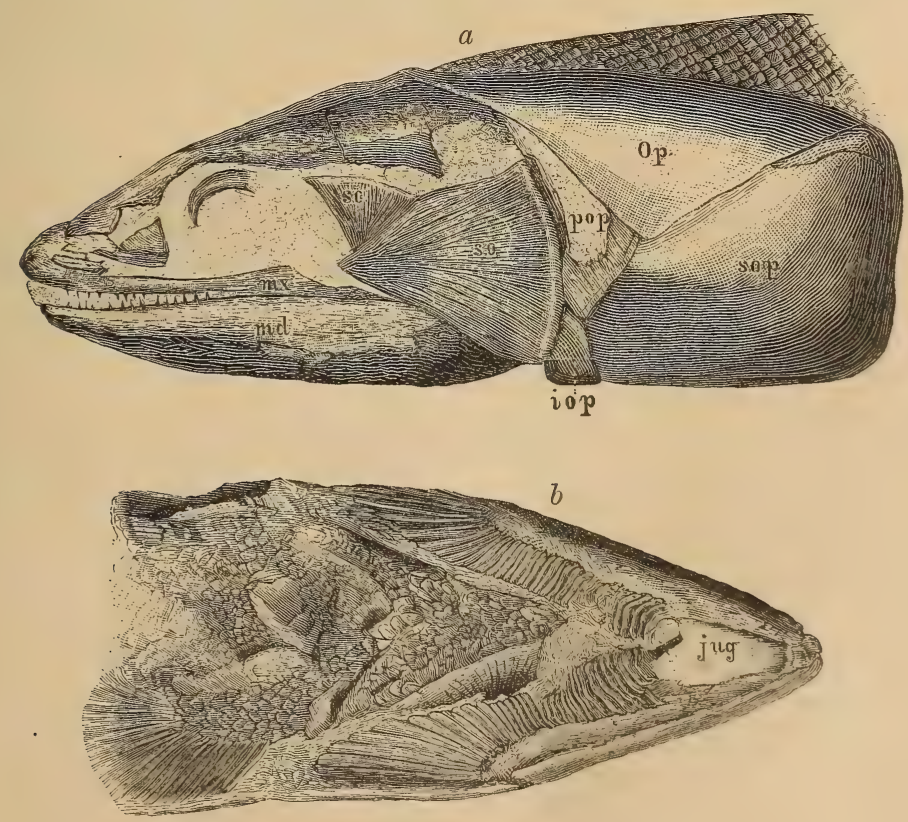

Fig. 209.

Pachycormus macropterus Ag. Ob. Lias. Ilminster. England. a von der Seite, $b$ von unten Zittel, Grundzüge der Paläontologie II. 
Pachycormus Ag. (Saurostomus Ag., Cephenoplosus Sauv.). Große Fische, vorn mit Nacktwirbeln, hinten mit Halbwirbeln. Schuppen klein, rhombisch. Beide Lappen der tief ausgeschnittenen Schwanzflosse mit stab. förmigen Fulcren. Bauchflossen sehr klein; Rückenflosse vor der Afterflosse beginnend. Flossenstrahlen sparsam gegliedert. Operculum, Suboperculum und Suborbitalia sehr groß. Lias und Jura. P. bollensis Qu. Ob. Lias.

Sauropsis Ag. (Diplolepis Vetter). Schuppen klein, die ventralen breiter als hoch. Chordascheide ohne Verknöcherungen. Fulcra fehlen. S. latus Ag. Oberer Lias. S. longimanus Ag. Oberer weißer Jura.

Prosauropsis Sauvage. Oberer Lias.

Euthynotus Wagn. (Heterothrissops, Psendothrissops Sauvage). Hypocentra und Pleurocentra als Halbwirbel entwickelt. Schuppen rhombisch, an den Ecken gerundet. Bauchflossen weit nach vorn gerückt. E. speciosus Wagn. Oberer Lias.

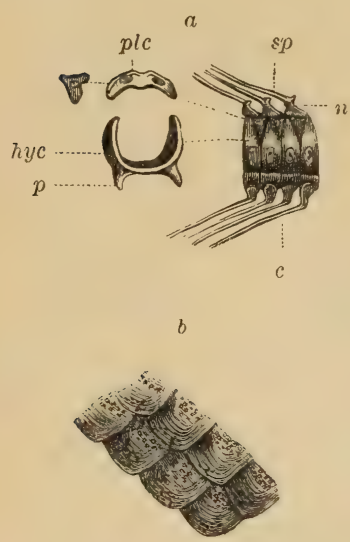

Fig. 210 .

$a$ Wirbel, $b$ Schuppen von Euthynotus micropodius Ag. sp. aus dem oberen Lias von Boll Württemberg.

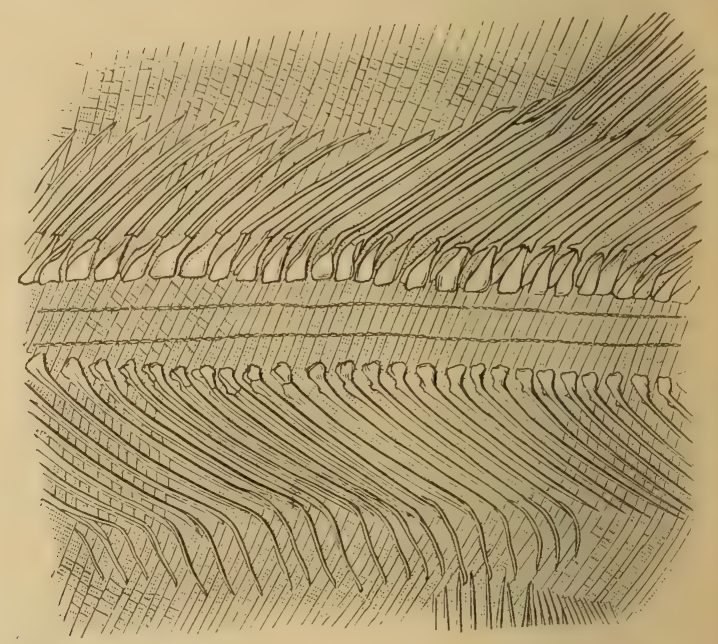

Fig. 211.

Hypsocormus insignis Wagn. Lithographischer Schiefer von Eichstätt. Stück der Wirbelsäule.

Hypsocormus Wagn. Große Fische mit winzig kleinen rhombischen Schuppen. Wirbelsäule nackt, nur Bogen und Dornfortsätze verknöchert. Schwanzflosse mächtig groß, tief ausgeschnitten, die vorderen Strahlen ungegliedert, durch stabförmige Fulcren getrennt. Weißer Jura. H. Leedsi A. Sm. Woodw. Oxfordton. H. insignis und macrodon Wagn. Oberer weißer Jura (lithogr. Schiefer) Bayerns.

Asthenocormus A. Sm. Woodw. (Agassizia Vetter.) Ossifikationen der Chordascheide fehlen oder sind rudimentär. Kleine Fulcra. Keine Beckenflosse. Sehr groß. A. titanius Wagn. sp. Oberer weißer Jura, Solnhofen.

\section{Familie: Caturidae.}

Verknöcherung der Wirbel unvollkommen. Flossenstrallen stark gegliedert, oben geteilt. Unpaare Flossen mit Fulcren. Schuppen der älteren Formen dick, rhombisch, spüter sehr dïnn, fast oder ganz cycloid. Zülne kräftig. Schwanzflosse groß, ausgerandet, mit zwei fast gleichen Lappen, innerlich heterocerk. Dorsalis kurz, hoch.

Caturus Ag. (Uraeus Ag.) Lachsartige Raubfische. Schuppen weit übereinandergreifend, abgerundet rhombisch, fast cycloid. Kleine Hypocentra und Pleurocentra oder gar keine Ossifikationen der Chordascheide. 
Kieferrand mit großen Zähnen, Zähne des Spleniale viel kleiner, in einer Reihe. Fulcra an allen Flossen, biserial. Unterer Lias (C. heterurus Ag.) oberer weißer Jura (C. furcatus Ag., Bayern, Württemberg, Cerin). C. insignis

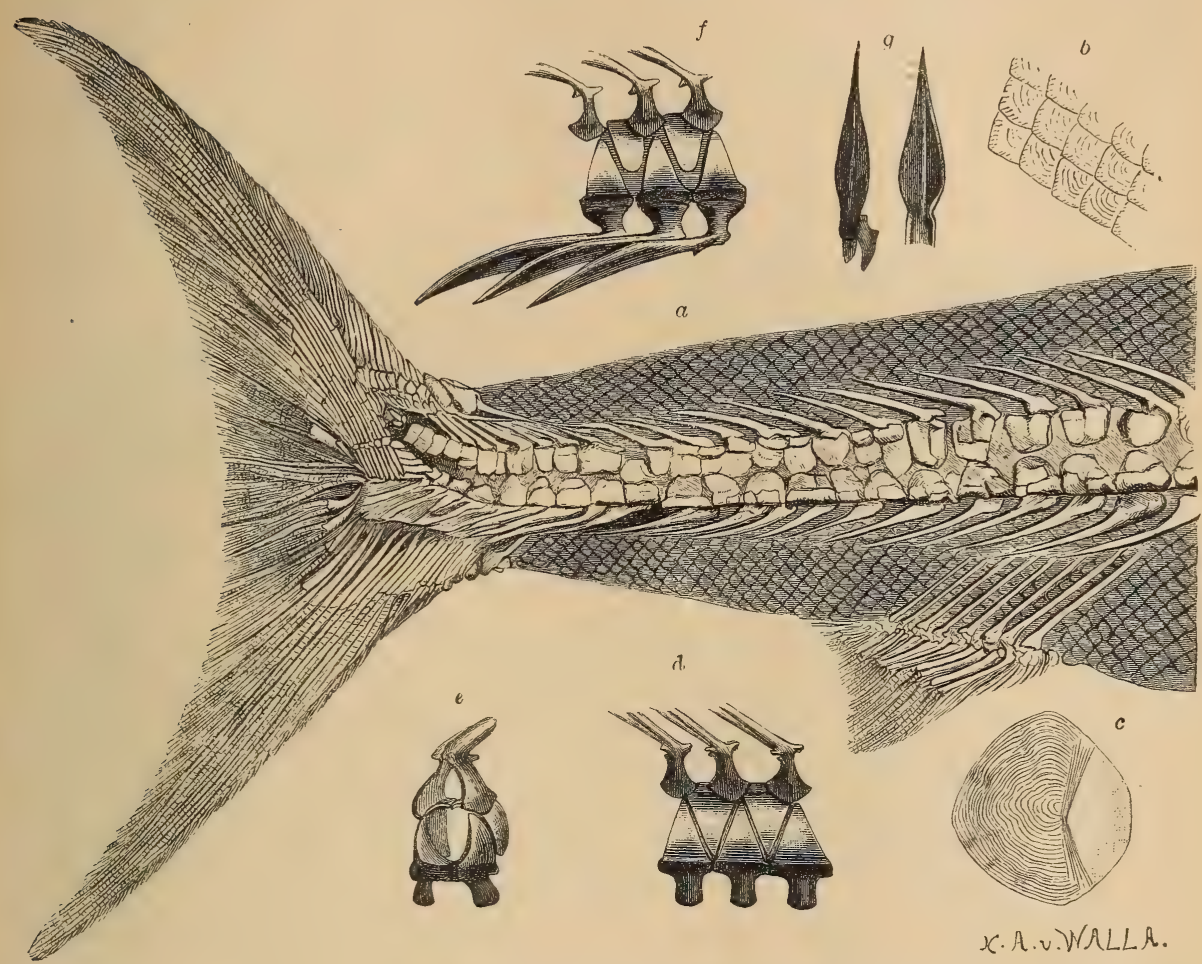

Fig. 212.

a Caturus maximus Ag. Schwanz. $b-g$ Caturus furcatus Ag. aus dem oberen Jura von Kelheim und Solnhofen, $\dot{b}$ Schuppen in nat. Gr., $c$ Schuppe vergr. $d$ Wirbel aus der Rumpfregion von der Seite. $e$ ein Rumpfwirbel von vorne. $f$ Schwanzwirbel. $g$ Dornfortsätze der Hämapophysen.

Kner (Euguatlus), obere Trias von Seefeld, ist generisch unsicher. Hierher auch Strobilodus Wagn., Conodus Ag., Eudactis Egert., Thlattodus Owen, Ditaxiodus Owen) von denen einige sich vielleicht als Untergattungen halten ließen).

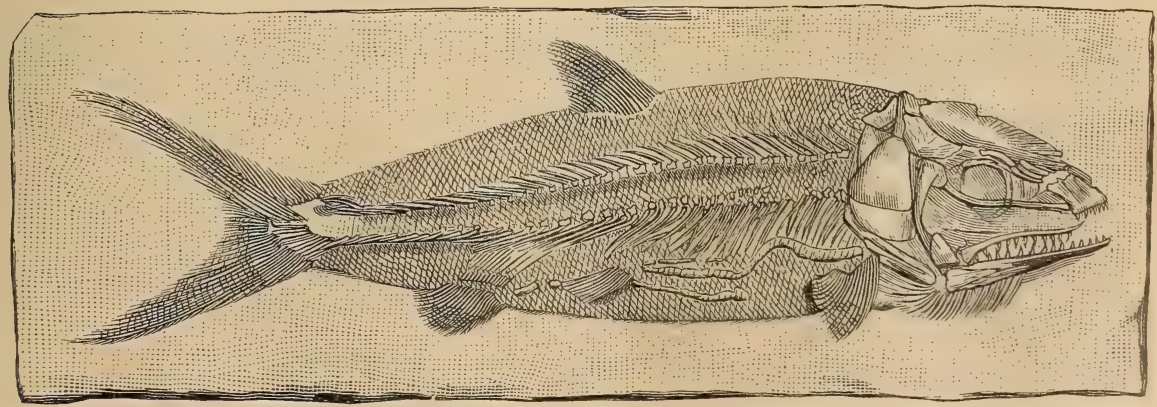

Fig. 213. Caturus elongatus Ag. Ob. Jura. Cerin. Ain. 1/2 nat. Gr. 
Callopterus Thiollière. Sehr ähnlich Caturus; die Dorsalis steht "über der Analis. Lithographischer Schiefer, Bayern, Cerin.

Osteorliachis Egerton. Hypocentra und Pleurocentra, aber keine Ringwirbel, Schuppen höckerig, dünn, aber mit Gelenkfortsätzen ineinandergreifend. Unterer Lias, England.

Emycomms Ag. Hypocentra und Pleurocentra, im Schwanz zu ringförmigen Halbwirbeln entwickelt. Zähne des Oberkiefers und Spleniale klein,

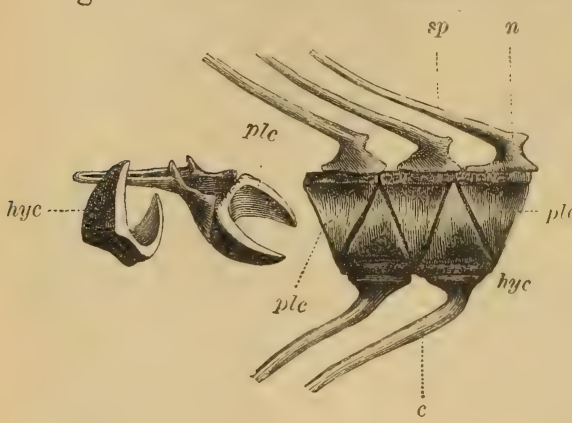

Fig. 214,

Wirbel von Callopterus Agassizi Thiollière Ob. Jura. Kelheim. (Etwas verkleinert.) des Dentale groß. Schuppen dünn, ohne Gelenkfortsätze. Oberer weißer Jura, Bayern, Württemberg, England.
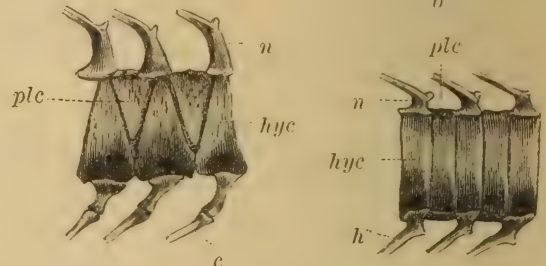

Fig. 215.

Eurycormus speciosus Wagn. a Rumpfwirbel, b Schwanzwirbel.

Eugnathus Ag. Schlanke Fische mit dicken, rhombischen Schmelzschuppen. Chordascheide meist ohne Ossificationen. Kieferränder mit großen Zähnen, auf der Innenseite sehr kleine Zähne in Häufchen. Die Kopfknochen stimmen im wesentlichen mit Caturus überein. Unterer Lias, England. (E. orthostomus Ag.) Oberer weißer Jura, Bayern, Württemberg.

Nahe verwandt ist Heterolepidotıs Egert. Oberer Muschelkalk, Perledo. Oberer alp. Keuper (Seefeld), Unterer Lias (England), oberer weißer Jura (Solnhofen). Deutliche, ossifizierte Halbwirbel.

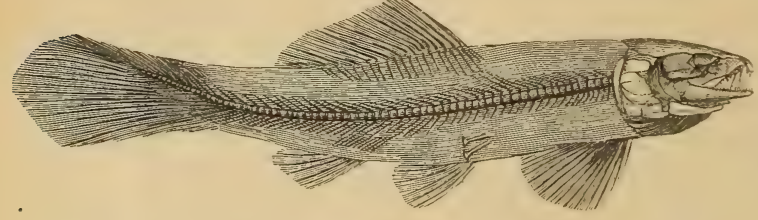

Fig. 216.

Megalurus elegantissimus Wagn. Ob. Jura. Solnhofen. ${ }^{2}$ is nat. (ir.

Allolepidotus Deecke. Plumpere Form. Keine oder nur schwache Ossificationen in der Chordascheide. Oberer Muschelkalk, Perledo. Oberer alp. Keuper, Seefeld.

Ptycholepis Ag. Sehr schlank. Deckknochen stark skulptiert, Schuppen dick, mit longitudinalen Falten.

l)

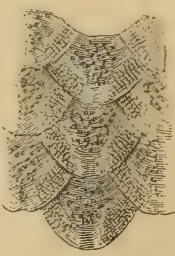

Fig. 217

Megalurus polyspondylus Mstr. Ob. Jura. Kelheim. a ein Stück der Wirbelsäule (nat. Gr.), b Schuppen vergr.

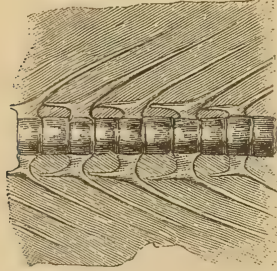
Randliche Zähne klein. Pt. bollensis Ag. Oberer Lias etc., Württemberg. Außerdem Arten im unteren Lias (Eng. land) und in der oberen Trias (Connecticut, U.S. A., Raibl in Kärnten).

Familie : Megaluridae Zitt. (Halecomorphi Cope, Amiidale A. Sm. Woodw.)

Schuppen düm, cycloid. Wirbelsüule verknöchert, hinten in den oberen Teil der abgerundeten Schwanzflosse verlängert. Die Caudalregion ans vertikal geteilten 
Halbuiveln bestehend (diplospondylisch), wovon rie hinteren Scheiben die oberen und unteren Bögen tragen. Fulcren meist ganz fehlend. Kiemenhautstrahlen breit, uenig zahlieich. Ingularplatte groß. Zähne konisch, krïtig. Jura bis jetzt.

1Legal»is Ag. Rückenflosse lang, über den Bauchflossen beginnend und bis zum hinteren Ende der Afterflosse reichend. Schwanzflosse hinten konvex, sehr kräftig; Wirbelsäule weit in den oberen Teil verlängert. Flossen ohme Fulcren. Caudalregion mit langgestreckten, aus zwei gleichen Hälften bestehenden Wirbeln. Oberer weißer Jura (lithogr. Schiefer) von Süddeutschland, Cerin; Purbeck.

A miopsis Kner. Obere Kreide, Istrien. Ungenügend bekannt.

Amia $a^{1}$ ) L. (Cyclurus, Notceus Ag.) Rückenflosse vor der ventralen beginnend, bis zur Schwanzflosse reichend. Fulcren fehlen. Lebend in Nordamerika; fossil in tertiären Süßwasserablagerungen Europas. A. (Notceus) longicauda Ag. (Montmartre), A. (Cyclurus) Valenciennesi Ag. (Armissan), A. Kehreri Andreae (Messel bei Darmstadt).

Pappichthys Cope. Eocän. Nordamerika, Rheims, aus isolierten Resten ungenügend bekannt, ebenso Protamia Leidy. und Hypamic Leidy (Eocän).

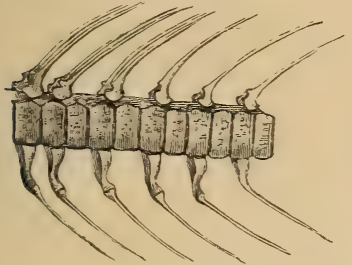

Fig. 218 .

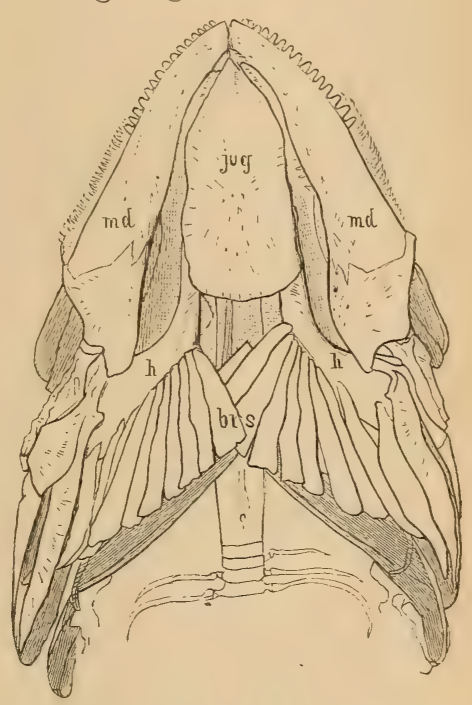

Fig. 219.

Kopf von Amia calva Bonap. von unten. Süd-Carolina. $h$ Hyoideum, brs Kiemenhautstrahlen, jug Jugularplatte, md Unterkiefer.

Ein Stück der Wirbelsäule von Amia calva.

Liodesmus Wagn. (Lophiurus Vetter). Chordascheide ohne Ossifikationen. Dorsalis kurz. Caudalis hinten konvex oder wenig ausgerandet. Keine Fulcra. Sehr kleine Schuppen. Oberer weißer Jura, Solnhofen. Durch die geringe Verknöcherung der Wirbelsäule steht die Gattung innerhalb der Familie isoliert.

\section{Unterklasse. Teleostei. $\left.{ }^{2}\right)$}

Hout mit diimen Cycloid- oder Ctenoidschuppen, seltener mit knöchernen Platten. Wirbelsäule verknöchert, Schwanzflosse homocerk. Fulcren fehlen. Kiemendeckel wohl entwickelt. Gräten mehr oder weniger reichlich. Arterienstiel mit mu. zuei Klappen. Sehnerven gekrenzt, ohne Chiasma. Darm ohne Spiralklappe.

Der Unterschied zwischen Teleostiern und Ganoiden beruht teils im Hautskelett, teils in anatomischen Merkmalen. Beide Cnterklassen sind auf

1) Leriche, $M$., Sur la présence du genre Amia dans les Hamstead Beds (Olig. inf.) de l'île de Wight (Bull. Soc. belge de Géol. XXII. 1908).

$\left.{ }^{2}\right)$ Jaekel, O., Zeitschr. d. deutsch. geol. Gesellsch. 1890. S. 86. - Reis M. O., Paläohistol. Beitr. z. Stammesgeschichte d. Teleostier. Neues Jahrb. 1895. I. Woodward A. Sm.; Catalogue etc. III.-IV. Teil. 
das engste miteinander verknüpft und die Grenzlinie zwischen Amioidea und physostomen Teleostiern häufig nahezu verwischt. Dies gilt insbesondere von den Schuppen, welche bei den ersteren bereits dünn und elastisch geworden sind und sich in nichts von denen einiger Physostomen unterscheiden, bei denen unter der äußeren glänzenden Schicht eine fibrillär gebaute mit Knochenzellen zur Entwicklung gelangt.

Bei den Teleostiern ist das innere Skelett sehr dicht und arm an Knochenzellen. Nach Kölliker entbehren fast alle Acanthopterygier (excl. Thynnus), Pharyngognathen, Anacanthinen, Plectognathen und Lophobranchier, auch mehrere Gruppen der Physostomen, der Knochenzellen im Innenskelett.

Die Bildung der Wirbelkörper beginnt mit einer Sklerosierung (Verkalkung) eines Ringes der Chordascheide; intervertebral kann sich die Chorda noch verdicken. Die Bogen werden knorplig angelegt und durch das Wachstum des knöchernen Wirbelkörpers z. T. in diesen eingeschlossen (Knorpelkreuz auf Querschnitten).

Die Schwanzflosse ist stets äußerlich homocerk, während innerlich meist eine starke Aufbiegung des Endes der Wirbelsäule beobachtet wird. Sie wird ausgeglichen durch die starke Entwicklung der ventralen Flossenträger (unteren Bögen). Im Bereich der letzten Wirbel und der unteren Bögen kommen Verwachsungen vor, bis zur Darstellung einer einheitlichen Platte.

Die Bauchflossen rücken bei den differenzierteren Formen zuweilen weit nach vorn. Die Strahlen der Rückenflosse sind bald gegliedert, bald ungegliedert.

Die Teleostier werden meist in die zwei Ordnungen der $\mathrm{Phys}$ ostomi und Physoclysti zerlegt, je nachdem die Schwimmblase mit dem Ösophagus durch einen Gang in Verbindung steht oder nicht. Physostom sind auch die lebenden Ganoiden. In die Schwimmblase kann aus den Kapillaren der umgebenden Gewebe Sauerstoff abgesondert werden, der bei manchen im Schwimmblasengang wieder zur Atmung verwendet wird (Aale); der Schwimmblasengang dient also nicht dazu, Luft aus der Atmosphäre aufzunehmen. Die Diffusion von Gasen in die Schwimmblase kommt auch bei Physoclysten vor und ohne daß eine Beziehung zur Atmung nachweisbar wäre; sie kann dann aber als statisches Organ wirksam sein.

Unter den Physoclysten sind hier die Unterordnungen der A nacan : thini, Acanthopterygii, der Lophobranchii und Plectognathi beibehalten.

\section{Ordnung. Physostomi.}

Schwimmblase mit Ausführungsgang. Bauchflossen stets abdominal; alle Flossenstrahlen gegliedert, nur die vorderste der Rücken- und Brustflossen zuweilen ungegliedert. Cycloidschuppen. Die Deckschicht der Schuppen enthält häufig eingeschlossene Knochenkörperchen. Die Basalplatte ist gewöhnlich zellenlos und durch Entwicklung von strah. ligen Kalkkörperchen verkalkt.

Die hier summierten Merkmale habeq zur Zusammenstellung einer Reihe von Formen geführt, die sicherlfch innerhalb des größeren Rahmens noch in Unterabteilungen zu zerlegen sind. Bei E. D. Cop e ${ }^{1}$ ) und A. Smith Woodw ard sind die Leptolepiden, Elopiden, Albuliden, Osteoglossiden, Notopteriden, Chirocentriden, Ctenothrissiden, Clupeiden, Salmoniden, Halosauriden, Notacanthiden, Dercetiden, Enchodontiden, Scopeliden, Gonorhynchiden, Chirotrichiden, Esociden und

1) Pr. Amer. Phil. Soc. XIV. 
Cyprinodontiden als Isopondyli geführt. Die Characiniden, Cypriniden und Siluriden bilden bei A. Sm. Wood ward die Unterordnung der Ostariophysi, die Muraenidae die der Apodes. Die amerikanischen Autoren gehen weiter in der Teilung und Bewertung der Gruppen. Es ist anzunehmen, daß innerhalb der alten Physostomi mehrere genetisch ganz verschiedene Gruppen stehen, von denen einige sich recht gut abgrenzen lassen, so die Clupeiden (mit Leptolepiden und Salmoniden), die Esociden, die Muraeniden, die Cypriniden und Siluriden (welche auf Grund wichtiger anatomischer Übereinstimmungen trotz verschiedenen Aussehens nicht weit getrennt werden dürfen).

\section{Familie: Leptolepidae.}

Wirbelkörper durchbohrt. Schwanzflosse ohne verschmolzene oder verbreiterte ventrale Flossenstïtzen. Keine Fulcra. Gräten vorhanden. Schuppen cycloid, imbrizierend, mit dünnem Schmelz. Parietalia in Berïhrıng. Oberrand der Mundspalte von Oberkiefer und Zwischenkiefer gebildet.

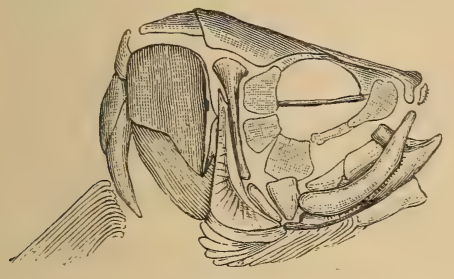

Fig. 220.

Kopf von Leptolepis Knorri Ag. Ob. Jura. Kelheim.

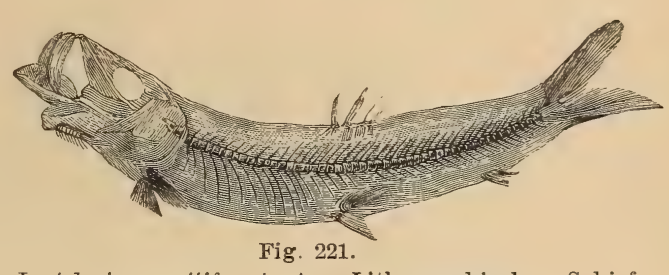

Leptolepis sprattiformis Ag. Lithographischer Schiefer. Eichstätt, Franken. (Nat. Gr.)

Leptolepis Ag. (Tharsis Gieb., Sarginites Costa, Megastoma Costa). Rückenflosse gegenüber der Bauchflosse. Afterflosse klein. Kopfknochen glatt; Zähne winzig. Dentale vorn mit steilem Fortsatz. Meist kleine, häringartige Fische. Lias bis untere Kreide. A. sprattiformis Ag. Oberer weißer Jura, Solnhofen etc.

Tharsis ist nach A. Sm. Wo odward als Subgenus von Leptolepis zu führen, mit $T h$. dubius Ag. Solnhofen.

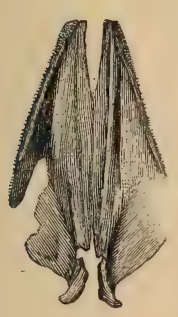

Fig. 222 .

Die beiden Unterkiefer von Thrissops formosus $\mathrm{Ag}$. Ob. Jura. Kelheim. (Nat. Gr.)
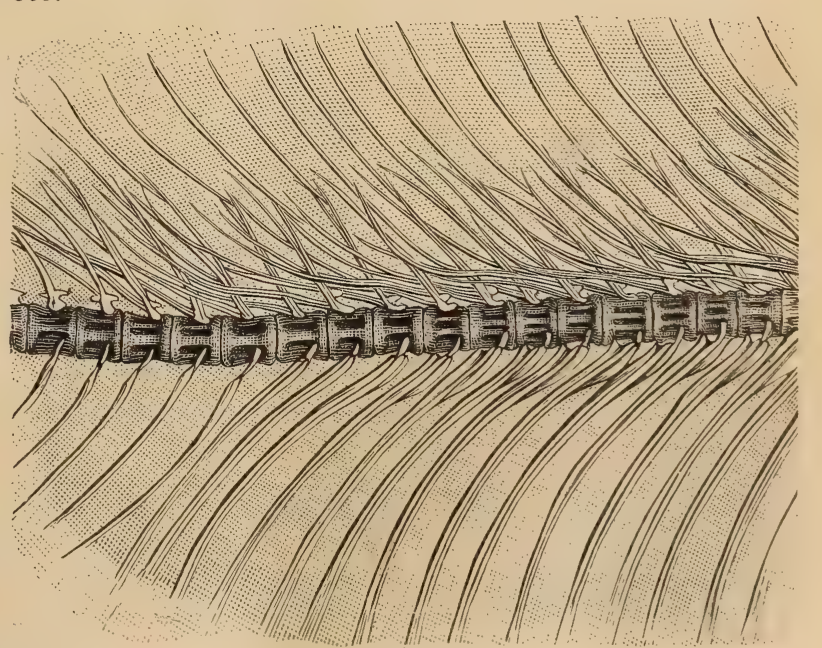

Fig. 223.

Ein Stück der Wirbelsäule von Thrissops formosus Ag. Ob. Jura. Kelheim. Bayern. 
Thrissops Ag. Ziemlich groß, Zähne kräftig. Dentale ohne Fortsatz. Rückenflosse gegenüber der großen Afterflosse. Oberer Jura, untere Kreide. T7. formosus Ag. (Fig. 222, 223.) Oberer weißer Jura, Solnhofen etc.

A ethalion Mstr. Wie Leptolepis, aber Dentale ohne Fortsatz. A. Knorii Ag. Oberer weißer Jura; Solnhofen etc.

Lycoptera J. Müll. Die Wirbelkörper breit durchbohrte Zylinder. Sonst ähnlich Thrissops. Jura von Transbaikalien und China.

Tharrias Jordan und Branner. Operculum sehr viel größer als Suboperculum. Mehr Wirbel als Leptolepis. Kreide von Brasilien.

\section{Familie: Clupeidae.}

Schlanke Fische mit rycloiden Schuppen. Wirbelhiöper nirht durchbolert, die abdominalen mit hurzen Qnerfortsätzen. Rürkenflosse lin\%, in der Mitte des Rürkens, Keine Fettflosse. Parietalia getrenut. Oberrand der Mundspalte com Oberkiefer und Zwischenkiefer gebildet. Zühne spitzig, lilein, seltener fehlend. Kiemendeckel vollständig.

Die 'lupeiden leben in Schwärmen in der Nähe der Küste, steigen aber zur Laichzeit auch in den Flüssen herauf. Von den Salmoniden durch

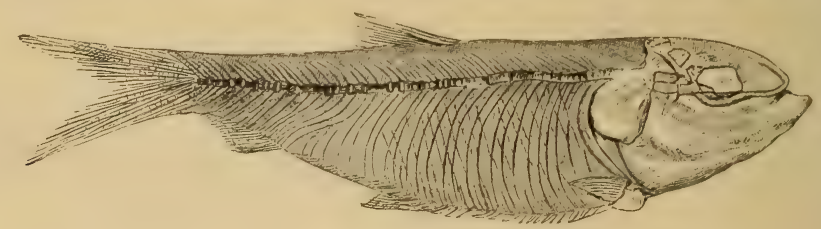

Fig. 224.

Clupea ventricosa H. v. Meyer. Unt. Miocän. Unterkirchberg bei Ulm.

den Mangel einer Fettflosse unterschieden. Sie leiten sich von Leptolepiden ab und treten von der unteren Kreide an auf.

Clupea Cuvier (inkl. Alosa Cuv.). Häring. (Fig. 224.) Auf der Ventralseite bilden gekielte Schuppen eine sägeartige Bauchkante. Auf Kiefer und Gaumen kleine, auf Vomer und Zungenbein stärkere Zähne. Neocom bis jetzt. Sehr häufig in der oberen Kreide des Libanon (c\%. Bottce Pictet), Eocän des Monte Bolca, Miocän von Schwaben (Kirchberger Schichten), Österreich, Kroatien, Toskana, Sizilien.

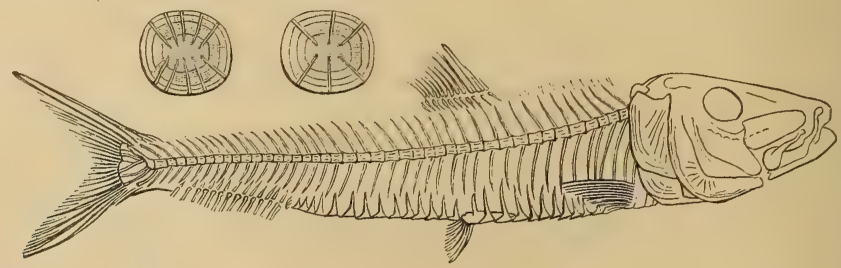

Fig. 225 .

Meletta sardinites Heckel. Unt. Oligocän. Radoboj, Kroatien.

(Nach $\mathrm{H}$ e c k e l.)

Chatoessus Cuv. Obermiocän, Österreich.

Scombroclupe a Kner. Hinter der Analflosse einige vereinzelte Flossenstrahlen. Untere Kreide, Comen. Obere Kreide, Libanon.

Diplomystus Cope. Außer dem Bauchkiel eine Reihe von Rücken. schildern vom Kopf bis zur Rückenflosse. Vollständige Skelette im Eocän von Wyoming. Obere Kreide des Libanon, Kreide von Brasilien, Oligocän von Wight. 
Weletta Val. (Fig. 225). Kleine Fischchen mit dicken Schuppen, deren jede mit 3-6 Paar radialen Rippen verziert ist. Zahnlos. Bauchschuppen kräftig. Tertiär, lebend. Sehr häufig in den unteroligocänen Melettaschiefern der Karpaten, in Rumänien, Kroatien: im Unteroligocän des Elsaß, im Flysch (Fischschiefer) von Glarus.

Engraulis Cuv. Oberkiefer länger als der Unterkiefer. Lebend und tertiär vom Eocän an.

Ohne die charakteristischen Bauchschuppen sind:

Pseudoberyx Pictet, obere Kreide. Histiothrissa A. Sm. Woodw., obere Kreide. Halecopsis A. Sm. Woodw., Eocän.

\section{Familie: Salmonidae. Lachse.}

Wie die Clupeiden, aber mit einer Fettflosse hinter der Rückenflosse. Da diese sich fossil nicht erhält, ist die Unterscheidung der fossilen Funde von den Clupeiden eine unsichere.

Salmo L. Obermiocän, Kroatien. Vom lebenden Mallotus villosus Cuv. finden sich Skelette häufig in Konkretionen an der Küste Grönlands und in Glacialablagerungen Canadas.

\section{Familie: Osteoglossidae.}

Große Süßwasserfische von Südamerika, Indien und Afrika. und Mexico.

Dapedoglossus Cope, Anaedopogon Cope. Tertiär von Wyorning

\section{Familie: Albulidae.}

Schlanke, häringsartige Fische. Bauch gerundet, ohne Kielschuppen. Oberkiefer vorspringend. Keine Gula'platten. Opercularia rollzählig. Bezahnung schwach oder fehlend. Wenige Branchiostegalia.

Albula Bloch u. Schneider. Parasphenoid, Entopterygoid und Zunge mit rundlichen Zähnen; kleine, borstenförmige Zähne auf Prämaxilla, Vomer, Palatinen und Dentale. Maxillen unbezahnt. Tertiär und lebend. A. Owemi Ag. sp. (Owen) (Pisodıs Owen, die Bezahnung des Paraphenoids). Eocän.

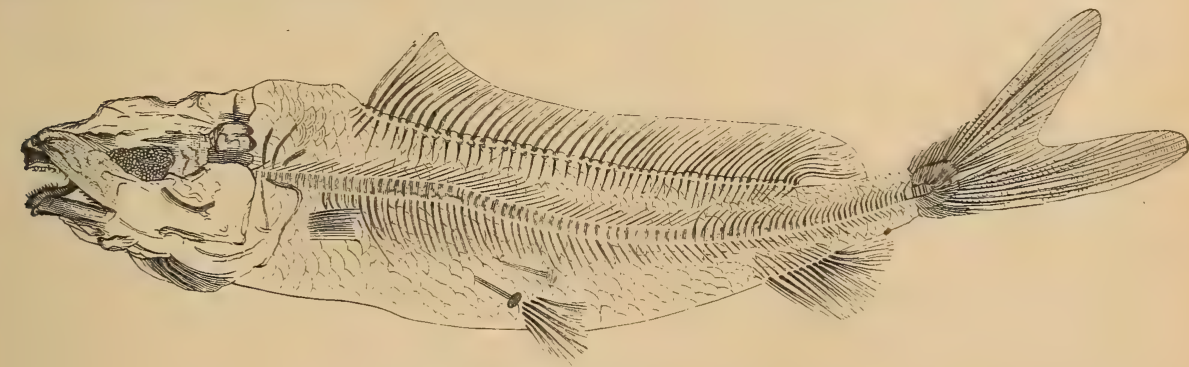

Fig. 226 .

Istieus mesospondylus v. d. Marck. Ob. Kreide. Sendenhorst. Westfalen. (Nach V. d. Marck.)

Istieus Ag. Dorsalflosse über den größten Teil des Rückens aus. gedehnt. Kleine Zähnchen am Kieferrand, größere im Munde. Gegen 100 Wirbel. I. grandis Ag. Obere Kreide.

Chanoides ${ }^{1}$ ) A. Sm. Woodw., Eocän. Chanos Lacepède, tertiär und lebend. Prochctuos Bass. Untere Kreide. Ancylostylus Kramb., obere Kreide.

1) Chanoides, Chanos, Prochanos u. A. bilden bei Boulenger eine besondere Unterfamilie der Clupeiden. Auch Day trennt die umbezahnten Chaninae als besondere Gruppe ab. 


\section{Familie: Chirocentridae.}

Sehr schlanke, komprimierte Fische, Dorsalflosse weit hinten, gegenuiber der Analflosse. Bauch kantig, aber olme sügezühnige Kielschuppen. Ol,erer Mundrand ron Maxilla und Prämaxilla gebildet. Großse Zühne anf den Kiefern, selir kleine auf Palatinen, Pterygoiden und Zunge. Parietalia durch Supraorcipitale getrenut. Squamosum verkümmert, Pterotica vorstehend. Opercularia rollzählig, nur wenige Branchiostegalia (8). Keine Gularplatten. Aldominalwirbel mit Querfortsätzen. Knochenzellen im Innenskelett.

Einzige lebende Gattung (thirocentrus Cuv., mit horizontal gestellten großen Zwischenkieferzähnen. Im Roten Meer, Indischen Ozean und malayischen Gewässern. (siehe d.).

A. Sm. Woodward stellt hierher auch die großen Ichthyodectidae

Platinx Ag., ('oelogaster Ag., Monopterus Volta. Eocän, Monte Bol('a.

Chiromystus Cope. Obere Kreide, Bahia.

Chirocentrites Heckel. Untere Kreide, Istrien.

Spathodactylus Pictet, Neocom.

Cladocyclus Ag. Obere Kreide; England, Brasilien.

Die ('tenothrissidae umfassen die beiden Gattungen ctenothrissa A. Sm. Woodw. (mit Ctenoidschuppen) und Aulolepis Ag. (mit Cycloidschuppen), beide aus der oberen Kreide. Durch die lockere Verbindung der Maxillen nähern sie sich den Clupeiden. Die Beckenflossen sind weit nach vorn gerückt.

\section{Familie: Cyprinodontidae. Zahnkarpfen.}

Kleine Fische mit Cycloidschuppen. Oberer Rand der Mundspalte nur vom bezahnten Zuischenkiefer gẹldet. Linterliefer und Schlundlinochen mit spitzen

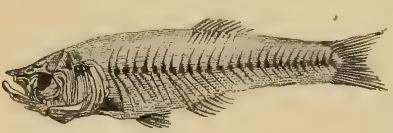

Fig. 22\%.

Lebias Meyeri Ag. Litorinellenthon. Frankfurt a. M. (Nat. Gr.) Zähmen. Keine Fettflossen und Bartfäden. Meist Süßwasserfische, einige anch in Brackwasser und an den Kiisten.

Prolebias Sauvage (Lebias Cuv. z. T.). Sehr häufig im Oligocän und Miocän.

\section{Familie: Esocidae.}

Körper gestrecht, mit groß3en Cycloidschuppen. Oberrond der Mundspalte von Zwischenkiefer und Oberkiefer gebildet. Maxilla zalmlos: Zwischenhiefer, Vomer, Gaumenbein, Unterkiefer mit starken Hechelzähmen. Rückenflosse weit zurück.

Esox L. vom Oberoligocän an nachweisbar.

\section{Familie: Seombresocidae.}

Körper mit Cycloidschuppen, anßerdem jederseits am Bauch eine Reihe gelielter Schuppen. Oberrand der Mundspalte von. Zwischenkiefer und Oberkiefer gebildet. Untere Schlundhnochen zu einem Stück veruchsen. Rückenflosse veit hinten, der Afterflosse, gegenüber. Bauchflossen abdominal. Flossenstrahlen ge. gliedert, weich.

Scombresox Cuv., Belone Cuv. Miocän, lebend.

\section{Familie: Cyprinidae. Weißfische, Karpfen.}

Schuppen cycloid. Oberrand der Mundspalte vom Zwischentiefer gebildet. Kiefer, Gaumen- und Zungenbein zahmlos. Untere Schlundhnochen mit 1 bis 3 Reihen 
griffelartiger, hohler Zähne besetzt. Meist nu. 3 Kiemenhautstrahlen. Bartfäden meist vorhanden. Gehörorgan ausgezeichnet durch Größe und Lage des Asteriscus, wie bei Siluriden.

Die Cypriniden bewohnen die süßen Gewässer der alten Welt und Nordamerikas. Fossil häufig im Tertiär, meist die noch existierenden Gattungen

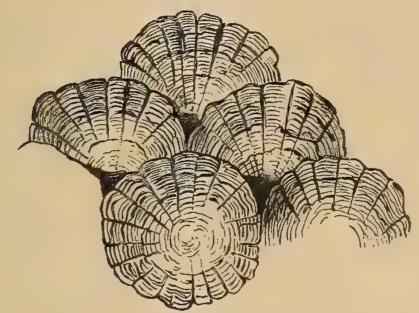

Fig. 228 .

Schuppen von Leuciscus Oeningensis Ag. Ob. Miocän. Oeningen, Baden. (Vergr. nach Winkler.)

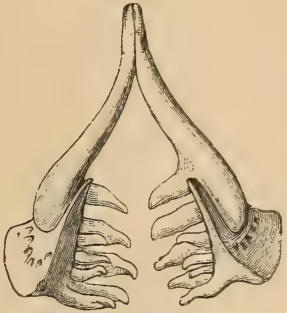

Fig. 229.

Schlundknochen und Schlundzähne von Aspius rapax Ag. Rezent. (Nach Heckel und Kner.)

wie Lenciscus (Fig. 228), Tinca, Gobio, Barbus Cuv., Rhodeus, Aspius (Fig. 229), Cyprinus, Thynnichthys Günth., Nemachilus Cuv., an die sich einige nahestehende erloschene Genera wie Amyzon, Diastichus, Oligobehıs Cope u. a. anschließen. Hierher auch Capitodus Mstr. z. T. und Soricidens Mstr. (Schlundzähne). Mittelmiocän, Österreich.

\section{Familie: Characinidae.}

Oberrand der Mundspalte teilweise auch vom Kiefer gebildet. Kiefer bezahnt. Untere Schlundknochen nicht sichelförmig. Keine Bartfäden; meist eine Fettflosse vorhanden.

Die Characiniden vertreten die Cypriniden im tropischen Amerika und Afrika. Fossil im Tertiär von S. Paulo, Brasilien (Tetragonopterus).

\section{Familie: Siluridae. Welse. (Nematognathi Cuvier).}

Nackt, schuppenlos oder mit Knochenschildern bepanzert. Kiefer stark bezahnt. Die Zwischenkiefer bilden meist allein den Oberrand der Mundspalte, die zahnlosen rudimentüren Maxillen tragen Bartfäden. Subopercula (zuweilen anch Opercula) fehlen. Brustflosse vorn meist mit starkem Knochenstachel (reruachsene Strahlen). Webersche Knöchelchen vorhanden. Das Labyrinth stimmt in der Lage und Größe des Asteriscus, der Bogengänge etc. mit den Cypriniden überein.

Die Panzerwelse besitzen Hautzähnchen (mit Dentin und Schmelz), welche selbständig oft $\mathrm{zu}$ mehreren auf einer knöchernen Unterlage stehen und beweglich durch Bindegewebe verbunden sind. Bei Hypostoma sind kleine, in schrägen Reihen angeordnete Schüppchen zwischen den vorderen Flossen beobachtet (Kner).

Fossile Reste dieser sehr formenreichen, über die gemäßigten und tropischen Breiten der ganzen Erde verbreiteten Familie von Süßwasserfischen (von denen einige auch die Meeresküsten aufsuchen und in Lagunen leben) sind selten. Sie sind im Eocän von England (Buctilcindium, Arins) von Ägypten (Fayumia Stromer, Socnopaea Stromer), von Nordamerika (Rlineastıls, Astephus), im Oligocän Deutschlands (Arius), im Miocän von Ungarn (Pimelodus), im oberen Miocän und Pliocän der Siwalik Hills (Indien) und von 
Padang (Sumatra) vertreten. Von Interesse ist das häufige Vorkommen der leicht kenntlichen Otolithen (Fig. 230) in echt marinen Ablagerungen Europas, von Paleocän an durch alle Stufen des Tertiärs.

Die Clariasarten besitzen ein akzessorisches Atmungsorgan für atmosphärische Luft und können lange Zeit auf dem Lande leben. Bei Saccobranchus ist das entsprechende Organ ein an die Kiemenhöhle angeschlos. sener Sack, der sich zwischen die Muskulatur schiebt (Day).

\section{Familie: Plethodidae. Hay.}

Auf dem Parasphenoid und horrespondierend auf dem. Glossolingale bzu. den Branchiostegalien entwirkeln sich nmparie Kanplatten, die gegeneinander veiben und mit kleinen Gruben bedecht sind. Sie bestehen aus dichtem Knochen. Schwanzflosse tief ausgeschnitten, die

Flossenstrahlen ungegliedert. Obere und untere Bögen nicht mit dem Wirbel verwachsen. Wirbel am Ende der Wirbelsäule verkiurzt und zusammengedrüngt, ein Hypurale vorhanden. Dorsalflosse lang.

Anogmius Cope. Obere Kreide, Kansas.

Syntegmodus Loomis, Thryptodus Loomis, Pseudothryptodus Loomis sind mit Anogmius nahe verwandt und wohl Synonyma.

Plethodus Cope. Prämaxillen und Ethmoide koossifiziert. Nur eine Kauplatte (die untere). Obere Kreide, Kansas.

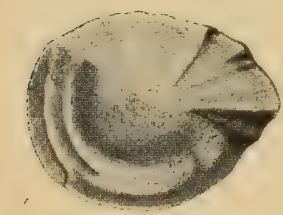

Fig. 230 .

Arius germanicus Koken. Otolith Unteroligocän. Lattdorf. $2: 1$
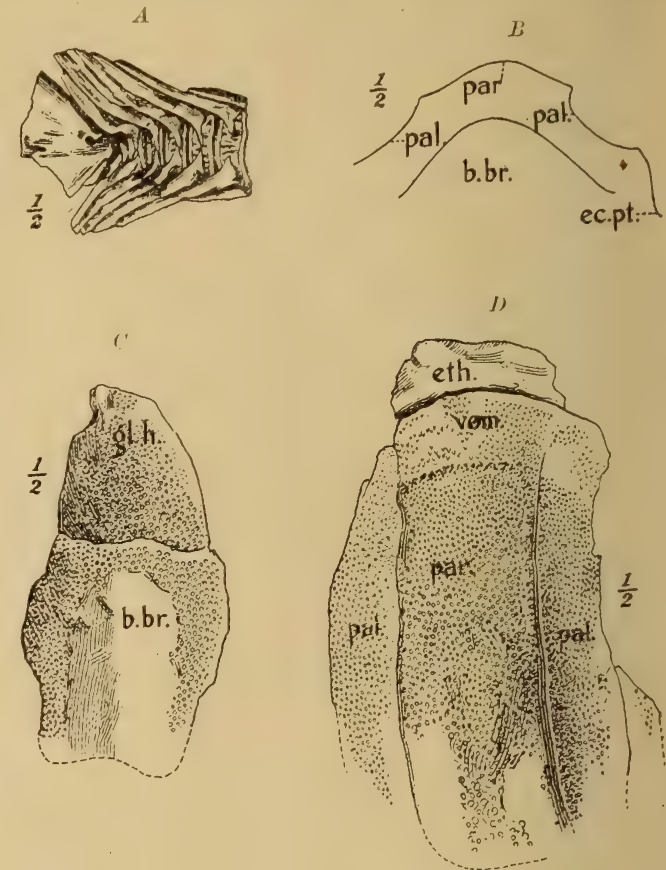

Fig. 231.

Anogmius aratus Cope. A Letzte sp. Schwanzwirbel. 1:2. $B$ Querschnitt durch die Mundhöhle. pal Palatinum, par Parietale, ec pt Ectopterygoid, b.br Basibranchiale. $C 1: 2$. Basibranchiale und Glossohyale. $D$ 1:2 Grumendach. eth Ethmoid, pal Palatinum, par Parasphenoid, vom Vomer. Nach O.P. Hay.

\section{Familie: Elopidae.}

Drei starke Suborbitalplatten, hinter und unter der Orbita; Squamosa mit den Parietalien durch Naht verbunden. Opercularapparat mit 20-30 Kiemenhautstrahlen und einer Gularplatte zwischen den Mandibeln. Rückenflosse hurz, fast in der Mitte; keine Fettflosse. Dünne, imbrizierende Cycloidschuppen.

Lebend Elops, Megalops, tropische Gewässer.

Hierher werden zahlreiche ausgestorbene Gattungen, besonders aus der Kreide, gerechnet. 
Elopopsis Heckel. ${ }^{1}$ ) Parietalia in Berührung. Zähne groß. Untere und obere Kreide.

Osmeroides Ag. z. T., (A. Sm. Woodw.) Parietalia in der Mittellinie verbunden. Etwa 20 Branchiostegalia. Zähne klein. Obere Kreide von Europa, Kleinasien (Libanon), Turkestan. O. lexwisiensis Mant., Turon und Senon.

Rhacolepis Ag. Parietalia durch das Supraoccipitale getrennt. Zähne klein. Schuppen hinten an den Ecken gezähnelt. Obere Kreide, Brasilien.

Pachyrhizodus Ag. Dixon. ${ }^{2}$ ) Parietalia getrennt. Zähne derb, mit dem Knochen verschmolzen, pleurodont. Obere Kreide, Europa, Nordamerika. Spaniodon Pictet. Parietalia getrennt. Unterkiefersymphyse mit zwei großen Zähnen. Obere Kreide. Libanon, Kansas.

Thrissopteroides v. d. Marck. Dorsalis nach hinten verschoben. Obere Kreide, Eocän.

Enneles Jordan u. Branner. Zähne noch weiter gestellt als bei Pachyrhizodus und etwas ungleich. Kreide, Brasilien. Calamopleurus A. Sn. Woodw., Notelops A. Sm. Woodw. Kreide, Brasilien.

\section{Familie: Dercetidae. (Hoplopleuridae Pictet z. T.)}

Schlanke Raubfische mit großen Zähnen. Oberrand der Mundplatte ganz von den Prämaxillen gebildet. Parietalia vereinigt, Squamosa gut entwickelt. Kieferränder bezahnt. Mehrere Reihen großer, gekielter Schuppen.

Dercetis Ag. Eine Reihe Hautschilder längs der Seitenlinie, ventral und dorsal je 2 Reihen. Kleine Schuppen fehlen. Dorsalis fast über den ganzen Rücken ausgedehnt. Obere Kreide, Europa.

Leptotrachelus v. d. Marck. Dorsalis kürzer. Analis weiter nach hinten. Obere Kreide, Europa, Libanon, Kansas.

Pelargorhynchus v. d. Marck. Mit kleinen Schuppen zwischen den Schildern; zwei Reihen großer Schilder auf den Seiten. Obere Kreide, Westfalen.

Stratodus Cope. Obere Kreide, Kansas. Triaenaspis Cope. Obere Kreide, Kansas.

Zittels Hoplopleuriden umfassen auch Saurorhamphus, eine mit Eurypholis Pictet idente und zu den Enchodontiden gehörende Gattung. Von den Stratodontiden gehört gerade Stratodus wahrscheinlich zu den Dercetiden (Hay rechnet ihn allerdings zu den Enchodontiden).

$\mathrm{Zu}$ den Tiefseefischen Halosauridae dürften Echidnocephalus v. d. Marck und Enchelurus v. d. Marck, obere Kreide Westfalens, Englands, vom Libanon gehören. $\mathrm{Zu}$ den ebenfalls abyssisch lebenden (physostomen) Notacanthide" rechnet A. Sm. Woodward die Gattung Pronotacanthus A. Sm. Woodw. Obere Kreide, Libanon.

\section{Familie: Enchodontidae.}

Schuppen cycloid, klein oder fehlend; einige Gattungen mit Längsreihen großer Knochenschilder. Zühne sehr kräftig, oben nicht nur auf den imneren Mundhnochen, auf sockelförmigen Erhöhungen oder pleurodont. Maxilla etwas an der Bildung des oberen. Mundrandes beteiligt. Parietalia getrennt, Squamosum ieduziert. P'terotica vorstehend. Flossenstrahlen gegliedert.

Ausgestorbene Raubfische, mit den abyssisch lebenden Odontostominten und Alepisauriden vielleicht verwandt. Kreide.

1). Wird auch zu den Enchodontiden gestellt.

2) Hay hält die ursprünglich von Cope aufgestellte Familie der Pachyrhizodontiden aufrecht, bis die hierher gerechneten Formen besser bekannt sind. Hierher auch Oricardinus 'Cope. 
Enchodus Ag. (Tetheodus Cope; Holcodon Kramb., Solenodon Kramb.). Unterkiefer auf der Innenseite mit großen aufgewachsenen Zähnen, marginal mit sehr kleinen Zähnen. Maxilla mit sehr kleinen Zähnen oder zahnlos.

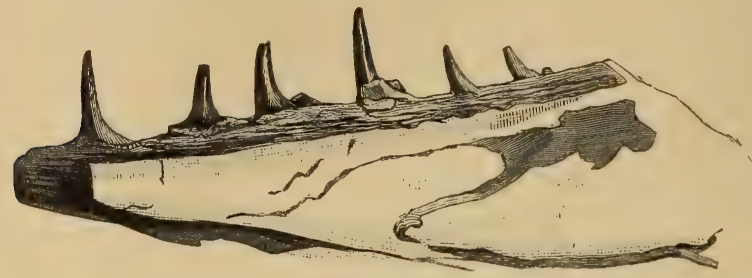

Fig. 232.

Unterkiefer von Enchodus halocyon Ag. ()b. Kreide. Lewes, England. (Nach A gassiz.)

Palatinum mit einem großen Fangzahn, Ectopterygoid mit einer Reihe hoher Zähne. Hautschilder zwischen Hinterhaupt und Dorsalis und längs der Seitenlinie.

Eurypholis Pictet (Saurorliamphus Heckel). Hechtartig, Schnauze verlängert,

Zwischenkiefer mit Fangzähnen. Die kleinen Bauchflossen weit vor der Rückenflosse. Rücken, Flanken, wahrscheinlich auch Bauch mit je einer Reihe großer Schuppen. Untere Kreide, Comen; obere Kreide, Libanon. Pomognathus Dixon, Phylactocephalus Davis. Mit kleinen Schuppen, ohne Schilder. Palatina mit einer Reihe Zähne. Untere und obere Kreide.

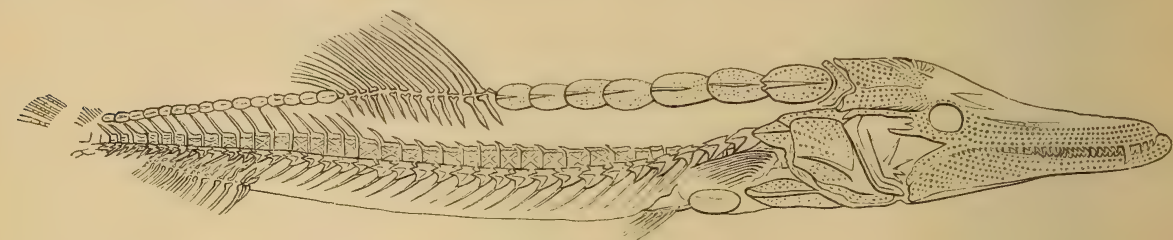

Fig. 233.

Saurorhamphus Freyeri Heckel. Neocom. Comen im Küstenland. (Restauriert, nach Heckel.)

Halec Ag. Palaeolycus v. d. Marck. Obere Kreide, Westfalen.

Cimolichthys Leidy (? Empo Cope). Ähnlich Enchodus; Palatina mit zwei Iängsreihen von Zähnen. Große Schilder auf dem Rücken bis zur Dorsalis; kleinere begleiten die Seitenlinie. Obere Kreide, England, Kansas.

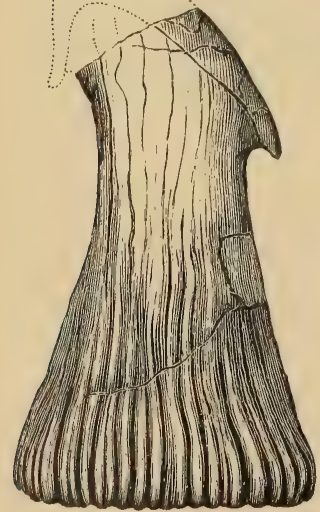

Fig. 234 .

Gigantichthys Pharao Dames. Ob. Kreide. Wüste unfern der Pyramiden von Gizeh. (Nach Dames.)
Prionolepis Egerton. Obere Kreide; England. Kansas.

Gigantichtys Dames (Fig. 234). ${ }^{1}$ ) Spitze der großen Zähne pfeilspitzenähnlich. Sockel mit starken Längsfurchen. Ob. Kreide, Gizeh.

\section{Familie: Tomognathidae. A. Sm. Woodw.}

Mundspalte sehr weit, Maxilla lose. Starke Bezahnung, Prämaxilla und Dentale mit langen Fangzähnen. Augenhöhlen sehr groß, weit vorn. Supraoccipitale sehr dick, die Parietalia trennend. Opercularia vollzählig; nur. wenige Branchiostegalia, keine Gularplatte.

Vielleicht verwandt mit den rezenten $S$ tomatiden der Tiefsee.

Tomognath us mordax Dixon sp. Obere Kreide, England.

1) Sitz.-Ber. Naturf. Freunde Berlin. 1887. 
Familie: Muraenidae. Aale (Apodes).

Körper sehr stark verlängert, olne Bauchflossen. Haut nackt oder mit rudimentären Cycloidschuppen. Rückenflosse lang, hüufig in die Schwanzflosse verlaufend. Brustgürtel nicht mit dem Schädel verbunden. Zwischenkiefer mit Vomer und Ethmoid verschmolzen; Oberrand der Mundspalte durch die bezahnten Oberkiefer begrenzt. Chorda mehr oder weniger persistent.

Meer- und Süßwasser-Fische; letztere wandern zur Fortpflanzungszeit in das Meer zurück und erlangen dort die Geschlechtsreife. Die junge Brut lebt anfänglich abyssisch im Meer und kehrt dann in die Flüsse zurück. Die ältesten Formen in der oberen Kreide des Libanon (Anguilla Sahel-Almae, hakelensis Davis; nach Storms ist die Gattungsbestimmung unsicher). Anguilla, Sphagebranchus Cuv., Ophisurus Lacép., Enchelops Ag. Eocän, Monte Bolca.

Eomyrus Storms. Wenig verschieden von Myrus. Eocän, Belgien.

Urenchelys A. Sm. Woodw., Rhynchorhinus A. Sm. Woodw., Praeanguilla Blecker, Eocän. Anguilla auch im Oligocän (Aix) und oberen Miocän (Oeningen).

\section{Familie: Gonorhynchidae.}

Lebend nur Gonorhynchus Greyi, im indischen und pazifischen Ocean Hierher werden gerechnet Charitosomus v. d. Marck. Obere Kreide, Westfalen, Libanon. Notogoneus Cope. Eocän, Oligocän. Europa. Nordamerika. N. longiceps v. Mayer. Oberoligocän, Mombach.

\section{Ordnung. Physoclysti.}

Schwimmblase ohne Ausführungsgang. Bauchflossen nach vorn gerückt.

\section{Unterordnung. Anacanthini. Weichflosser.}

Sämtliche Flossenstrahlen gegliedert, weich. Bauchflossen kehl- oder brustständig.

Familie Ladidae. Schellfische.

Langgestreckt, mit kleinen, glatten, cycloiden Schuppen. Rückenflosse fast den ganzen Rücken einnehmend oder in 2-3 Teile zerlegt. Afterflosse ebenfalls lang oder zerlegt. Bauchflossen an der Kehle. Kopf breit, Oberrand der Mundspalte fast ganz von dem kräftig bezahnten Zwischenkiefer gebildet.

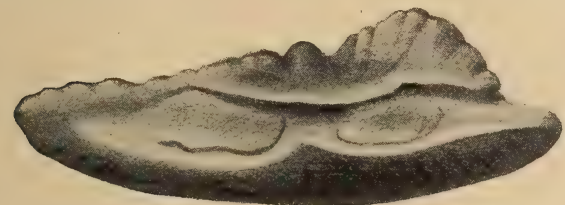

Fig. 235 .

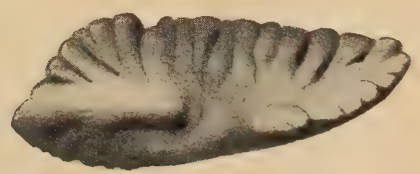

Merluccius emarginatus Koken. Oberoligocän. , Sternberger Gestein. 4:1.

Sehr verbreitet schon im älteren Tertiär, aber meist nur durch Otolithen bekannt. Paleocän von Kopenhagen, Eocän von Frankreich, England, Nordamerika. Oligocän, Deutschland. Miocän von Österreich, Kroatien, Bordeaux, Sizilien usw., in den Gattungen Gadus, Brosmius, Merluccius, Strinsia, Raniceps, Phycis (O. elegans Koken). Andere Reste seltener; Nematopteryx Troscheli v. Rath, Unteroligocän, Glarus.

Familie: Macruridae.

Tiefseeformen der Gadiden.

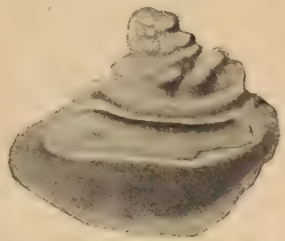

Fig. 286 .

Macrurus - Otolith. Pliocän Orciano von Pisa. 2:1. 
Otolithen zahlreich im norddeutschen Septarienton, im miocänen Regel von Baden, Monte Giozo, im Pliocän von Orciano und ähnlichen Sedimenten tiefen Wassers.

Familie: Ophidiidae. Schlangenfische.

Bauchflossen felılen oder sind rudimentäi. Unpaare Flossen meist zu einem zusanmenliängenden Saum vereinigt. Auch die Brustflossen fellen zuveilen.

Fierasfer in tertiären Tonen nicht selten (Otolithen). Opliidium L. Otolithen aus dem Miocän bekannt.

Familie: Pleuronectidae. Schollen.

Scheibenförmige, seitlich stark zusammengedrückte asymmetıische Fische, mit einer gefärbten Ober'seite und einer hellen Unterseite. Beide Augen wander'n auf' die Oberseite, wodurch die Lage der Kopfknochen, Zälıne und Flossen verschoben wird. Scliuppen ctenoid oder felilend. Rücken- und Afterflosse fast den ganzen Rumpf umsärmend. Baucliflossen jugular, vor den Brustflossen. Schwimmblase fehlt.

Die Pleuronectiden sind vermutlich weiter von den Giadiden zu trennen als gewöhnlich geschieht. Auch die inneren Organe weichen z. T. stark von den anderen Anacanthinen ab. An sandigen Küsten, auch in Flußmündungen.

Rhombus Blainv., Pleuronectes Cuv., Solea Cuv., Citharus Cuv. auch tertiär, vom Eocän an. Otolithen nicht selten.

\section{Unterordnung. Acanthopterygii.}

Flossenstratilen, namentlich der musaren Flossen und der Bectienflossen, teilweise ungegliedert, stachelig. Bauchflossen meist weit nach vorn gerïcht.

\section{Familie: Ichthyodectidae. Crook.}

Große ausgestorbene Raubfische mit kräftigem Gebiß. Zülıne der Kiefer in Alveolen; Vomer und Parasplienoid zalinlos. Mundrand oben aus der langen Maxilla und der kurzen dicken Prämaxilla gebildet. Unterkiefer massig, hoch, vorn steil abgestutzt. Brust- und Bauchflossen aus derben ungegiiederten, paarigen Knochenstralilen zusammengesetzt, die innen und außen ungleich ausgebildet sind und sich distal in parallele Stäbe zerteilen. Rückenflosse und die tief ausgeschnittene, mächtige Schwanzflosse mit ungegliederten, geraden, nur distal gespaltenen Strahlen. Parietalia vor dem Supraoccipitale median vereinigt. Innenskelett mit Knochenzellen.

A. Sm. Woodward stellt diese Formen mit dem lebenden Chiroceutrus in eine Familie, Chirocentridae.

Portheus Cope (Hypsodon Ag.) (Fig. 237.) Sehr große Fische, bis $2 \mathrm{~m}$. Zähne verschieden groß, vorn einige als Fangzähne ausgebildet, von ovalem Durchschnitt mit zylindrischer Spitze. Ethmoideum und Postfrontale gelenkig verbunden. Palatinum mit hammerartiger Verdickung. Augen mit Scleroticalring und drei großen Suborbitalien. Kiemendeckel wohl entwickelt, groß. P. molossis Cope. Obere Kreide, Kansas. P. Mantelli Newton. Obere Kreide, Europa.

Suuroceptialus Harlan (Saurodon Harlan, Daptinus Cope). Obere Kreide, Kansas, Eıgland. Zähne von gleicher Größe, vorn und hinten zugeschärft. Sauroceplicllus-Arten sind auch aus dem Mittelmiocän von Österreich angegeben. Einige Arten sind auf einzelne Zähne gegründet und ganz unsicher. 
Ichthyodectes Cope. Wie Portheus, aber kleiner. Zähne klein, alle von gleicher Länge. Obere Kreide, Kansas, England, Libanon.

Gillicus Hay. Maxilla sichelförmig. Bezahnung reduziert. Schädelknochen dünn. Obere Kreide, Kansas.

\section{Familie: Protosphyraenidae.}

Schädel mit langer, solider, zylindrisch-konischer Schnauze, welche von den verschmolzenen Ethmoiden und Vomer gebildet wird.und weit über die dreieckigen vorn zugespitzten Zivischenkiefer vorragt. Vomer mlt zwei langen, in Alveolen stehenden Fangzälinen. Oberkiefer und Unterkiefer schlank, mit einer inneren Reihe

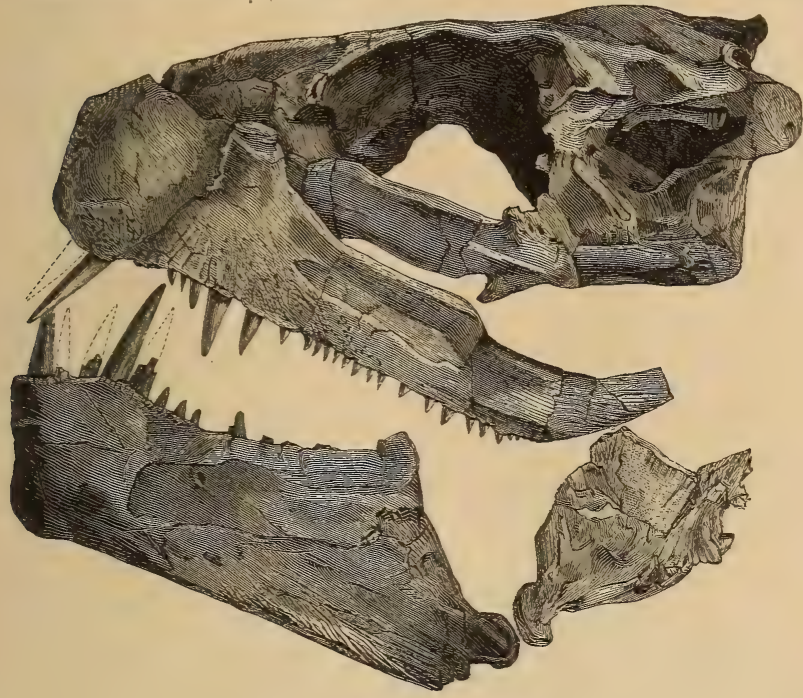
großer, in Alveolen stehender Zähne und zahlreichen äußeren aufgewachsenen Zähnchen. Dentale vorn verdickt mit zwei großen Fangzähnen. Suborbitalia vorhanden. Brustflossen sehr groß.

Fig. 237.

Schädel ron Portheus molossus Cope. Ob. Kreide. Fox Cañon, Kansas. $1 / 4$ nat. Gr. (Nach Cope.)
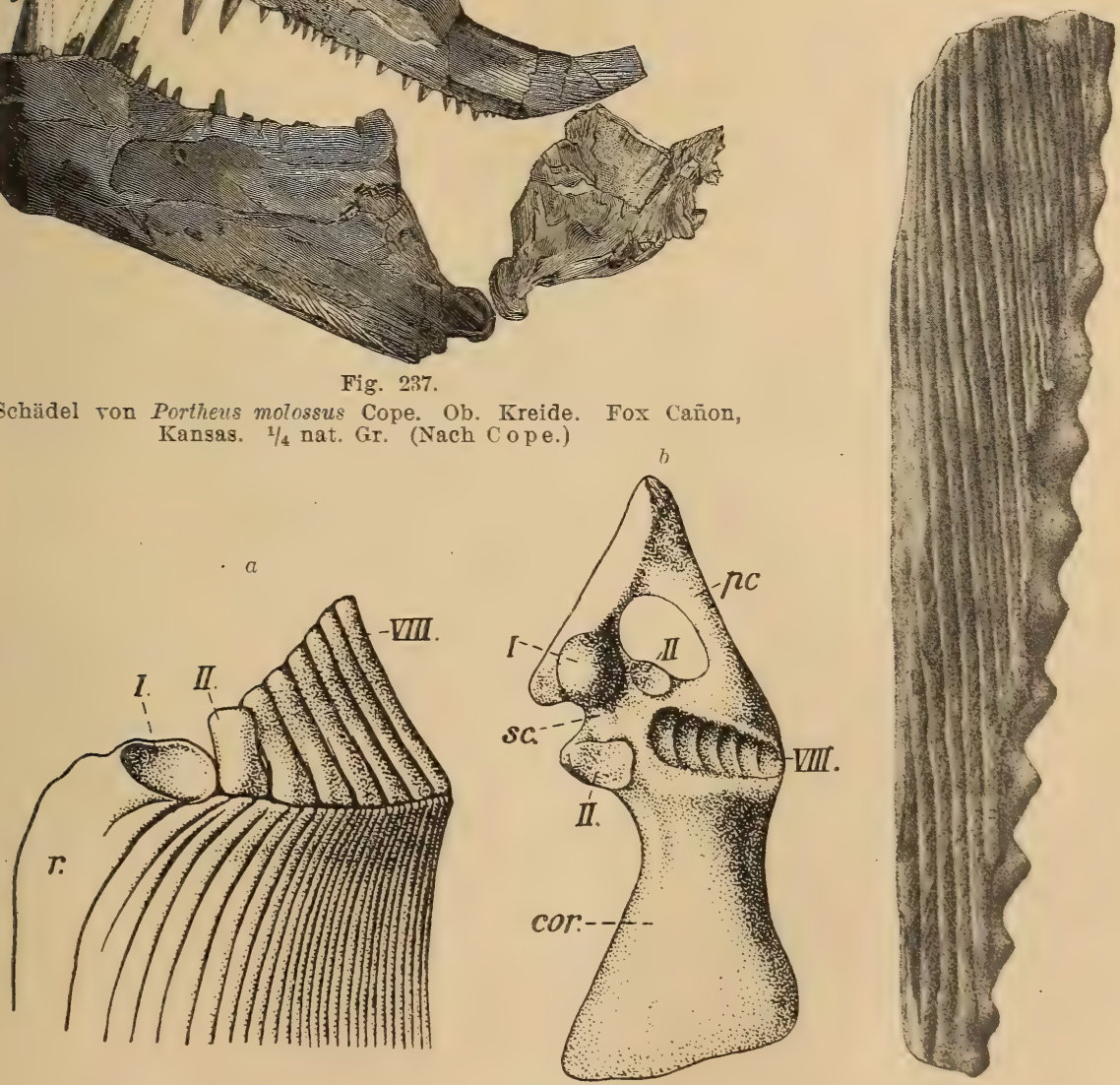

Fig. 238.

Protosphyraena. Nach A. Smith Woodward. a Brustfloße. $r$ Vorderer Flossenstrahl, I. II. TIII Baseoste. $b$ Brustgürtel von außen. cor Coracoid, sc Scapula, $p c$ Präcoracoid, I, II, VIII Gelenkfacetten für die Baseoste. c Teil der Brustflosse. 1:2. Obere Kreide. Surrey. 
A. Sm. Woodward stellt sie zu den Pachycormiden, jedoch ist der Bau der Flossen sehr abweichend; die Wirbelsäule ist nicht sicher bekannt.

Protosphyraena Leidy (Erisichthe Cope). Die Brustflossen von Agassiz als Pelecopterus beschrieben. Zähne in tiefen Gruben. Scapula und Cora-

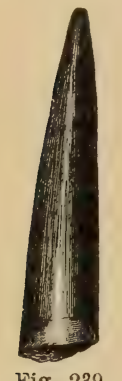

Fig. 239.

Zahn von Protosphyraena ferox Leidy. $O b$. Kreide. Maestricht. (Nat. Gr.) coid knöchern. Brustflosse sehr lang, aus über 40, distal meist zerteilten, proximal flach komprimierten Strahlen zusammengesetzt, die nicht miteinander verschmelzen. Vorderrand der Flosse mit zahnartigen Hervorragungen, von denen in der proximalen Hälfte je einer auf einen Strahl kommt, während distal (wo die Strahlen zerteilt sind) in einer Vorragung je zwei Strahlenäste endigen. Von diesen Randhöckern laufen leistenartige Wülste quer über die Flossenbreite.

Die Pectoralis gelenkt an Coracoid und Scapula mit acht Basalgliedern (Baseosten), von denen die beiden oberen sich übereinandergelagert haben. Die Angabe eines Prädentale (Felix) beruht auf irriger Beobachtung.

Pr. ferox Leidy. Obere Kreide von Kansas. Maastricht etc.

\section{Familie: Scopelidae.}

Fische mit sehr weiter Kiemenöffnung. Oberrand der Mundspalte ausschlie/slich vom Zwischenkiefer gebildet. Schuppen meist vorhanden, aber keine Schilder. Zälne meist schwach, nur auf den Prämaxillen zuveilen groß. Mit Fettlosse.

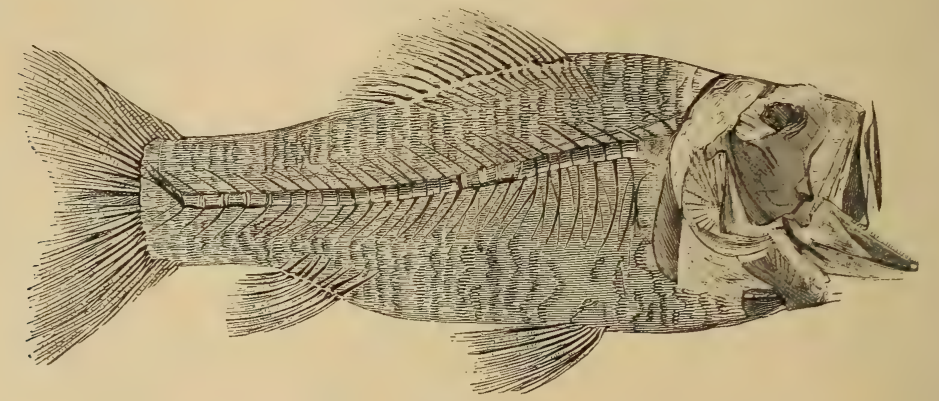

Fig. 240.

Sardinioides Monasterii $\nabla$. d. Marck. Ob. Kreide. Sendenhorst. Westfalen. 1/2 nat. Gr.

Fossile Vertreter dieser pelagischen und abyssischen Meerfische beginnen in der unteren Kreide von Istrien. (Hemisaurida Kner.)

Sardinius v. d. Mark. Schuppen ctenoid, Pectoralis mit gegen 18 Strahlen, Analis mit zirka 20 Strahlen; zirka 45 Wirbel. Obere Kreide, Westfalen.

Sardinioides v. d. Marck. Prämaxilla zart. Analis sehr klein, ganz hinter der Dorsalis. Maxilla hinten breit. Brustflossen klein. Schuppen ctenoid. S. Monasterii v. d. Marck. Obere Kreide, Westfalen.

Rhinellus Ag. (Ichthyotringa Cope). Kleine Fische. Prämaxillen und Unterkiefer zu einem derben, langen Rostrum verlängert. Große Zähne. Schuppen nicht gezackt. Rückenflosse hoch, Brustflosse sehr groß. Rh. furcatus Ag. Obere Kreide, Westfalen, Libanon, Kansas. 
Leptosomus. v. d. Marck. Pectoralis schmal, Analis kurz, gegen 30 Wirbel. Schuppen cycloid (Unterschied von Sardinius). Obere Kreide, Westfalen, Libanon, Kansas.

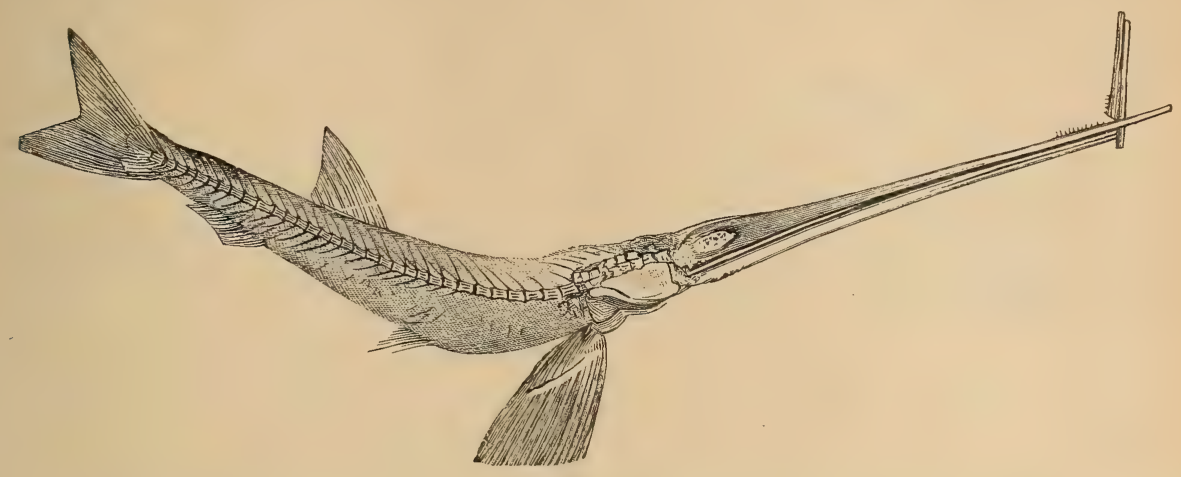

Fig. 241.

Rhinellus furcatus Ag. Ob. Kreide. Sendenhorst, Westfalen. (Nach v. d. Marck.)

Dactylopogon v. d. Marck, Osmeroides v. d. Marck, Microcoelia v. d. Marck, Acrognathus Ag., Nematonotus A. Sm. Woodw., Opisthopteryx Pict. Humb., Apateodus A. Sm. Woodw. Obere Kreide.

Holosteus. Eocän. Monte Bolca.

Scopeloides Wettst. Unteroligocän, Glarus. Sehr verbreitet im österreichischen Mittelmiocän (Otolithen).

\section{Familie: Beryeidae.}

Körper kurz, gedrungen, ziemlich hoch, mit Ctenoidschuppen, selten nackt; Seitenlinie deutlich. Orbitae groß, Mundspalte schief, Prämaxilla vorstreckbar. Kiefer, meist auch Gaumenbeine mit hechelförmigen Z̈̈̈hnen. Kopf mit großen Schleimhöhlen. Kiemendeckel mehr oder weniger gezackt oder gekerbt.

Die lebenden Beryciden sind Meerfische und meist Bewohner größerer Tiefe. Fossil von der Kreide an.

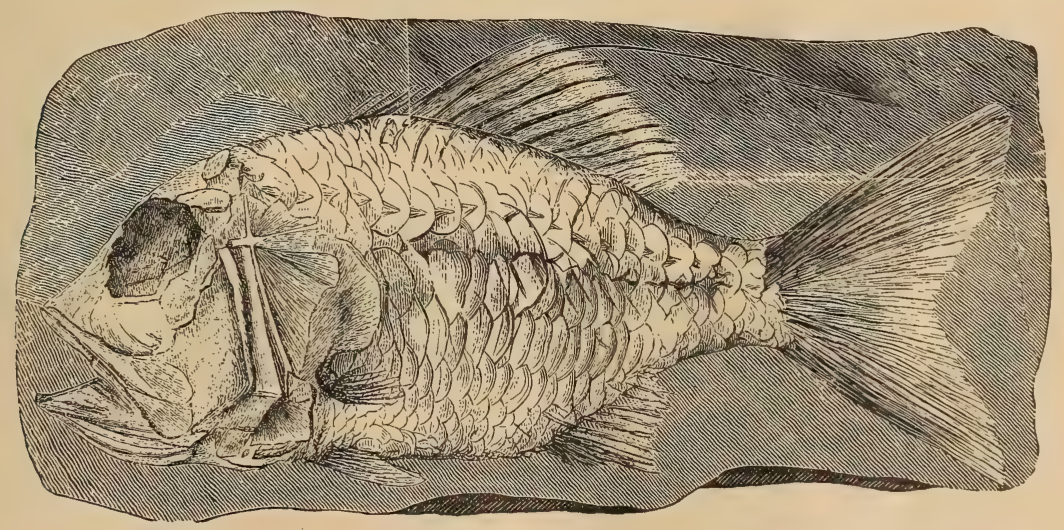

Fig. 242.

Beryx Zippei Reuss. Unt. Pläner. Wehlowita, Böhmen. $1 / 3$ nat. Gr. (Nach Frits ch.)

Beryx Cuvier (Hoplopteryx Ag.). (Fig. 242.) Kopf kurz; Rückenflosse hoch mit mehreren Stacheln, Bauchflossen mit sieben oder mehr weichen 
Strahlen, unter der Brustflosse. Afterflosse mit vier Stacheln. Häufig in der oberen Kreide. B. lewesiensis Mont.

Pycnosterinx Heckel, Acrogaster Ag., Hoplopteryx Ag., Dinopteryx A. Sm. Woodward, Homonotus Dixon, Splienocephalus Ag., Mucrolepis v. d. Marck. Obere Kreide.

Pristigenys Ag. Eocän. Monte Bolca.

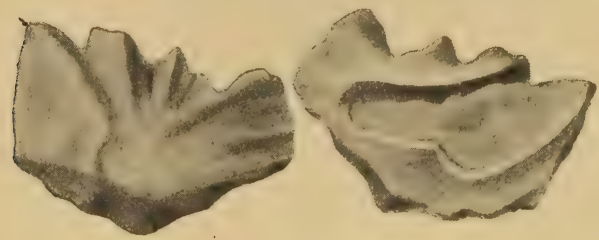

Fig. 243.

Hoplostethus Lawleyi Koken. Pliocän. Orciano b. Pisa. $4: 3$.

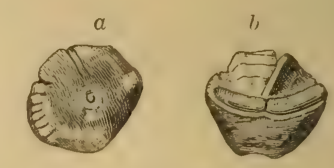

Fig. 244

Monocentris subrotundus Koken. Oligocăn. Lattdorf.

Nat. Gr.

$a$ von außen, $b$ von innen.

Hoplostethus. (Fig. 243.) Große Otolithen, vom Paleocïn an, besonders häufig im Oligocän und Pliocän (Orciano).

Die noch lebenden Gattungen Holocentrum Gron. und Myripristis Cuv., bei denen der stacheltragende Teil der Dorsalis sich von dem weicheren getrennt hat, im Eocän des Monte Bolca, Myripristis auch im Miocän von Malta.

Monocentris. Otolithen nicht selten im Oligocän und jüngeren Tertiär (Fig. 244).

\section{Familie: Aphreidoderidac.}

Ausgestorbene, den Beryciden ähnliche Süßwasserfische. Prämaxilla nicht vorstreckbar, Seitenlinie nicht erkennbar.

Amphiplaga Cope, Erismatopterus Cope, Trichophanes Cope. Eocän. Nordamerika. Hierher auch die Asineopidae, mit Asineops Cope. Eocän, Wyoming.

\section{Familie: Cyttidae.}

Schädel ohne Schleimhöhlen. Prämaxilla vorstreckbar, Seitenlinie nicht erkennbar. Fossil selten. Hierher vielleicht Cyttoides glaronensis Wettst., Unteroligocïn von Glarus. Zeus von Oberoligocän an (Steiermark). Pliocïn, Orciano.

\section{Familie: Sciaenidae. Adlerfische, Umberfische.}

Im Tertiär häufig, aber meist nur durch Otolithen bekannt. Eocän, Nordamerika, Frankreich. Oligocän, Deutschland. Miocän, Österreich etc.
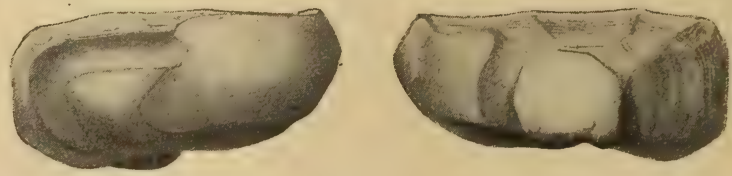

Fig. 245 .

Scicena holsatica Koken. Otolith. Miocän von Langenfelde. Etwa um $1 / 3$ vergrößert.

Familie: Percidae. Barsche.

Längliche Fische mit Ctenoidschuppen. Zwischenkiefer, Unterkiefer, Vomer und Gaumenbein mit Hechelz̈̈hnen. 6-7 Kiemenhautstrahlen. 1 oder 2 große, mit langen Stacheln versehene Rückenflossen. Bauchflossen brustständig, mit einem 
Stachel vorn und J Strahlen. Raubfische fast aller Meere und süßer Gewässer. (Fossil von der Kreide an.)

Prolates Priem. Ob. Kreide, Mont Aimé.

Serranus L. Eocän Belgiens, Cyclo. poma Ag., Enoplosus Ag. Eocän, Monte Bolca. Centropristis (Otolithen), Dentex, Eocän Belgiens; Otolithen häufig.

Krambergeria Simionescu. Oligocän, Rumänien. Properca Sauvage. Percichthys A. Sm. Woodw., Pelates, Dules, Gerres, Labrax, Lates Cuv., Acanus Ag., Mioplosus Cope, Perca Art., Smerdis Ag. (Fig. 246), in tertiären Ablagerungen bekannt.

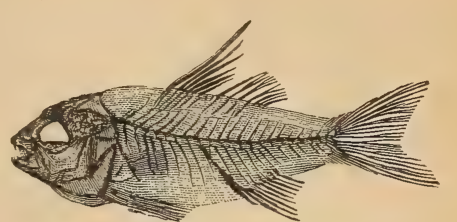

Fig. 246.

Smerdis minutus Ag. Oligocän. Aix, Provence.

\section{Familie: Pomacentridae. (Glyphidodontidae.)}

Köıper ziemlich kurz, komprimiert. Bezahnung der Kiefer schwach. Gaumenbein zalmlos. Rückenflosse lang, mit zalilreichen Stacheln, Afterflosse mit 2 bis 3 Stacheln. Bauchflossen bruststïndig mit einem Stachel und 5 weichen Strahlen. Untere Schlundknochen verwachsen. In tropischen Meeren, wenige Arten in gemäßigten Breiten. Im Skelett von den Chromiden nicht sicher zu scheiden.

Odonteus Ag. Eocän. Monte Bolca.

Priscacara Cope. Eocän (Green River Shales), Wyoming.

\section{Familie: Labridae. Lippfische.}

Lünglich, mit Cycloidschuppen und wulstigen, fleischigen Lippen. Rücken. flosse lang, mit gewölinlich so viel harten als weichen Strahlen. Bauchflossen an der Brust, mit einem Stachel und כ̃ gegliederten Strahlen. Kiefer krüftig bezahnt, Gaumenbein zahnlos. Untere Schlundknochen verwachsen, stark verdicht, mit derben Mahlzähnen besetzt. Auch die oberen Schlundknochen tragen ähnliche Zühne und stoßen in der Mittelebene zusammen. Vorwiegend in tropischen Meeren, besonders an Riffen.

Die Labriden (Scaroidei), Chromiden und Pomacentriden bilden einen Teil der Pharyngognathi, zu denen J. Müller auch die Scombresociden rechnet. Die Verschmelzung der unteren Schlundknochen, die auch bei einzelnen Arten der Percidengattung Gerres vorkommt, kann allein diese Zusammenstellung nicht rechtfertigen. Die Scombresociden gehören in die Nähe der Cyprinodontiden.

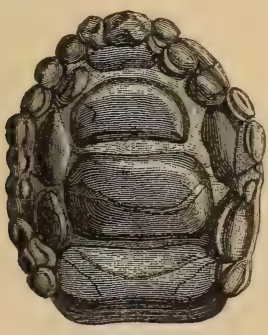

Fig. 247.

Phyllodus medius Ag. Londonthon. Sheppey. Nat. Gr. (Nach Cocchi.)

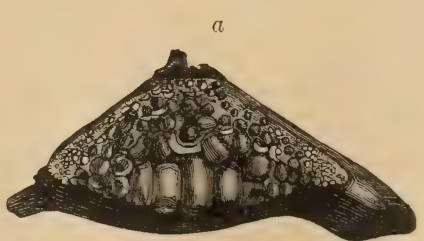

Fig. 248 .

Nummopalatus multidens Münst. sp. Miocän. Teudörfl a. d. March. a Untere Schlundknochen mit Zahnpflaster, $b$ ein oberer Schlundknochen.

Phyllodus Ag. Schlundknochen mit glatten, ebenen Pflasterzähnen. Kaufläche der oberen Platte leicht konkav, die der unteren konvex. Zïhne in Reihen, die der Mittelreihe sehr groß. Meist liegen mehrere Schichten 
Ersatzzähne unter den funktionierenden. Eocïn. Ph. toliapicus Ag. Londonton. Ph. cretaceus Reuß, obere Kreide, ist generisch nicht bestimmbar.

Labrodon Gervais (Nummopalatus Renault, Pharyngodopilus Cocchi). (Fig. 248.) Untere Schlundknochen dreieckig, mit einem Pflaster kleiner, rundlicher oder oblonger Mahlzähne bedeckt, von denen stets mehrere übereinander liegen (bei Labrus ist immer nur ein Ersatzzahn vorhanden). Oberer Schlundknochen kleiner, dreieckig, mit Mahlzähnen. Miocän, Pliocän. Is. multidens Mstr. sp.

Die lebenden Gattungen Labrus Ag. und Scarus Forsk. (die in mehrere Untergattungen aufgeteilt werden), Julis, (renilabrus auch im Tertiär. ()tolithen von Crenilabrus (Symphodus Raf.) im Miocän Üsterreichs. Labrus Valenciennesi Ag. Eocän, Monte Bolca.

Egertonia Cocchi, Eocän. Platylaemus Dixon, Eocän. Pseudospliaerodon Noetling, Unteroligocän, Samland. Taurinichtlıs Cocchi, Miocän. Crommyodus Cope, Protautoga Leidy, Miocän. Stylodus Sauvage, Miocän.

\section{Familie: Chromidae.}

Untere Schlundknochen vereinigt, mit erhaltener Naht. Süfiwasserfische von Afrika, Amerika, Indien.

Die Zugehörigkeit von Pycnosterinx Heckel und Omosoma Costa (obere Kreide, vgl. S. 138) zu dieser Familie ist sehr unsicher.

\section{Familie: Chaetodontidae.}

Körper hoch, zusammengedrückt. Mund klein, vorgestreckt, Kiefer mit Borstenzähnen. Vomer und Palatina unbezahnt. Weicher Teil der Dorsalflosse größser als der stacheltragende. Analis mit 3-4 scharfen Stacheln. Cycloide oder selir. feine ctenoide Schuppen, die sich auf einen Teil der unpaaren Flossen linaufziehen. Tropische Meere.

Von den lebenden Gattungen Epliippus Cuv., Scatopliagus Cuv., schon Arten im Eocän des Monte Bolca. Ferner Pygaeus Ag., Pomacantlius im Eocän des Monte Bolca.

Die nahestehenden Toxotiden, mit bezahnten Vomer und Palatinen, sind ebenfalls im Eocïn des Monte Bolca gefunden. Toxotes antiquus Ag.

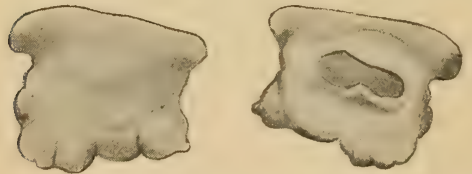

Fig. 249

Gobius francorurtanus Koken. Otolith. Untermiocän, Frankfurt a. M. 10:1.

Gobiidae sind weit verbreitet in limnischen und brackischen Schichten, besonders des jüngeren Tertiärs (von Oligocän an), aber meist nur durch ihre leicht kenntlichen Otolithen nachgewiesen.

Die nahestehenden Trachiniden sind im Eocän (Monte Bolca) durch Callipterix Ag. vertreten. Otolithen schon im Eocän (Paleocän von Kopenhagen, $T r$. seelandicus Koken).

Die Lophiiden sind fossil selten. Loplius brachysomus Ag. Eocän, Monte Bolca, die älteste Art von Lophius selbst; L. unicus Bassoli, ein Otolith aus dem Miocän. Histionotopterus Eastman (Histiocephalus Zigno), Eocän, Monte Bolca.

\section{Familie: Chirotrichidae.}

Ausgestorbene, pelagische, zum Teil fliegende Fische. Oberer Mundrand von der stabförmigen Prïmaxilla gebildet. Bezahnung schwach. Paarige Flossen sehr groß; Bauchflossen weit vorn. Keine Gularplatten. Wirbel in der Abdominalregion mit derben Querfortsätzen. Kreide. 
Chirothrix Pictet. Mit enormen, dicht hinter den kleineren Brustflossen stehenden Bauchflossen. Der 5. Brustflossenstrahl ist fadenförmig verlängert. Ob. Kreide. Libanon, Westfalen.

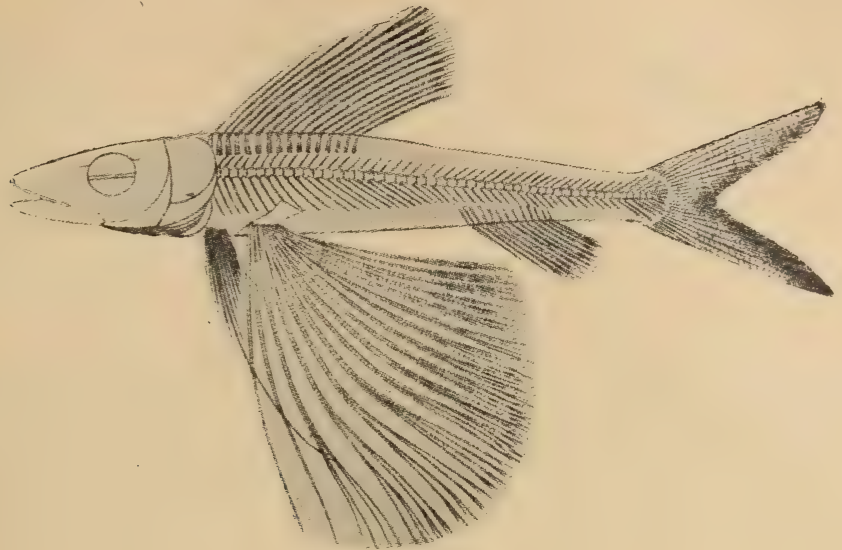

Fig. 250

Chirothrix libanicus Pict, et Humb. Obere Kreide, Libanon. Rekonstruktion von A. Sm. Woodward. Catalogue of the Fossil Fishes in the British Museum. IV. Mit Erlaubnis der Trustees des Brit. Museum.

Telepholis v.d. Marck. Ob. Kreide, Westfalen. Exocoetoides Davis. Ob. Kreide, Libanon.

Von den nahe verwandten Familien der Mugiliden, Sphyraeniden und Atheriniden kommen Vertreter schon in der oberen Kreide von Colorado und Neumexiko vor: Syllaemus, Apsopelix, Pelycorapis Cope. Im Eocän des Monte Bolca finden sich Sphyraena, Rhamphognathus, Mesogaster, Atherina, im oberen Eocän von Aix Mugil princeps Ag., im Obermiocän Kroatiens Sphyraena.

\section{Familie: Teuthiidae.}

Perciden mit nur einem Zahn auf dem Kieferrand. Fossil selten. Archaeoteuthis Wettst., Unteroligocän, Glarus.

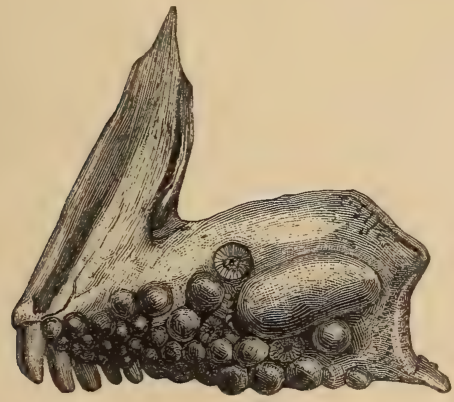

Fig. 251.

Oberkiefer von Chrysophrys aurata Lin. Rezent. Mittelmeer.
Familie: Sparidae. Meerbrassen.

Bunte, ziemlich hohe Fische mit feingezackten Ctenoidschuppen. Opercularia ohne Stacheln. Kiefer vorn mit schneidenden oder kegelförmigen Zü̈hnen, hinter

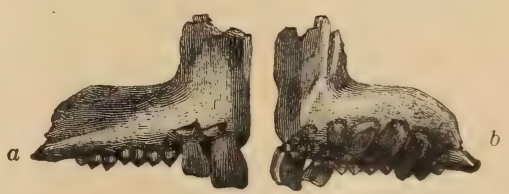

Fig. 252.

Oberkiefer eines rezenten Sargus aus dem Mittelmeer. $a$ von außen, $b$ von innen. (Nat. Gr.)

welchen meist melirere Reihen rundlicher oder ovaler Pflasterzäline folgen. Gaumenbeine uud Vomer zahnlos. Rückenflosse ungeteilt, der stachlige Teil dem weichen 
ziemlich gleich. Analis mit 3 Stacheln. Bauchflossen brustständig, mit einem. Stachel und 5 Strahlen. Verbreitet besonders in tropischen Meeren, an muschelreichen Küsten und Riffen. Sie leben hauptsächlich von Mollusken und Krebsen (conchivore Bezahnung).

Pagrus Cuv. und Pagellus Cuv. Lebend and tertiär. Pagellus besonders durch Otolithen nachgewiesen. Pagellus leptosteus Ag., ob. Kreide, Libanon, ist sehr zweifelhaft. P. microdon Ag. Eocïn, Monte Bolca.

Sparnodus Ag., Eocän, Monte Bolca; Chrysoplirys Cuv., Sargus Cuv. (Trigonodon Sismonda, Fig. 252), Box (Otolithen), tertiär und lebend.

Die nahestehenden Pristipomatiden sind schon aus dem Eocän des Monte Bolca bekannt (Pr. furcatum Ag.), die Apogonidae ebenfalls aus dem Eocän (Apogon macrolepis Storms, Eocën, Belgien). Otolithen von Apogon von Paleocän an.

\section{Familie: Palaeorhynehidae.}

Langgestreckte, seitlich zusammengedrückte Fische. Schnauze in einen langen Schnabel ausgezogen. Kiefer zahnlos oder mit winzig kleinen Zülinchen. Rückenflosse vom Nacken bis zum Schwanz, Afterflosse vom After bis zur gespaltenen Schwanzflosse reichend. Bauchflossen brustständig, mit meltreren Strahlen. Wirbel lang, Fortsütze und Rippen dünn.

Palaeohrynchus Blv.' (Hemirhynchus Ag.) (Fig. 254.)

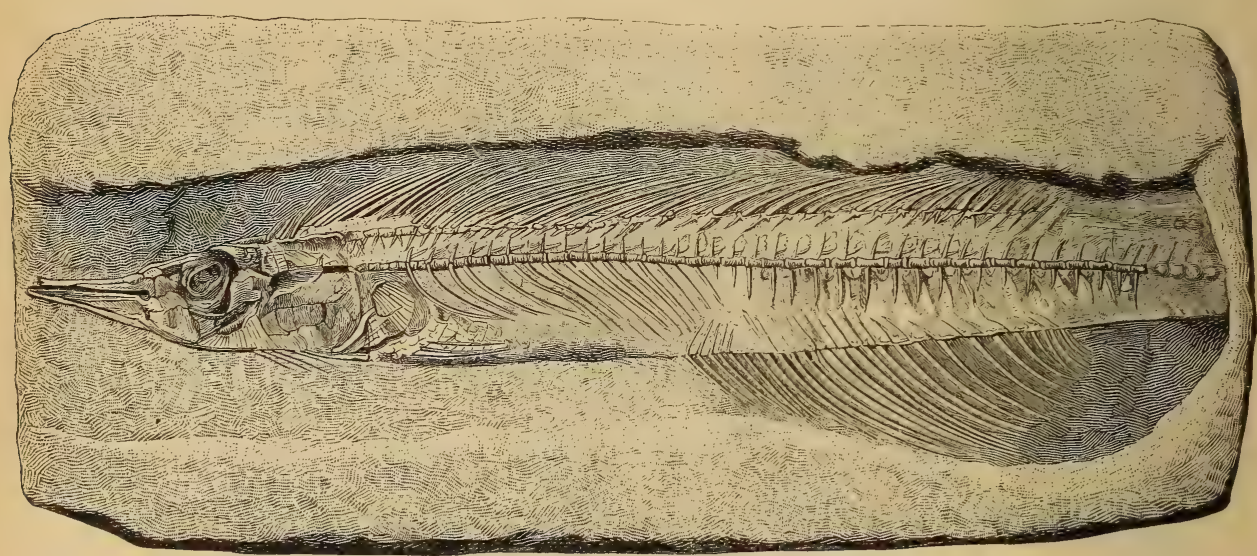

Fig. 253.

Palaeorhynchus Zitteli Kramb. sp. Ob. Eocän. Rajcza, Galizien. 1/3 nat. Gr.

P. Deshayesi Ag. Lutétien von Paris. Buchsweiler im Elsaß. P. Zitteli Kramb., Obereocän von Galizien. P. glarisianus Blv., Unteroligocän, Glarus.

Familie: Trichiuridae. Degenfische.

Fast bandförmige, zusammengedrürkte Raubfische mit weite Mundspalte. Kiefer und Gaumenbeine mit kräftigen, konischen Zähnen. Rïckenflosse und Afterflosse sehr lang, mit ungegliederten Strahlen. Bauchflossen brustständig, zuweilen verkïmmert, Schwanzflosse oft fehlend. In tropischen und subtropischen Meeren, in der Nähe der Küsten, aber auch abyssisch.

Lepidopus Gouan (Anenchelum Blv., Lepidopides Heckel), aus den unteroligocänen Schiefern von Glarus, den Melinitschiefern der Karpathen (L. carnathicus Kramb.) Obermiocän, Sizilien, Toskana. 

(Sizilien.)

Trichiurichthys Sauvage, Hemithyrsites Sauv., Miocän von Licata

\section{Familie: Carangidae. Bastard-Makrelen.}

Körper zusammengedrïckt, meist hoch, nackt oder mit nur kleinen Schuppen. Mundspalte klein, Banchflossen brustständig, zuneilen mdimentür oder fehlend. Stacheliger Teil der Rückenflosse kürzer als der weiche. Im Tanf der Seitentinie, meist größere Schuppen oder Schilder. Raubfische in tropischen und gemäßigten Breiten. Fossil von der Kreide an.

Platax Cuv. Körper sehr hoch und komprimiert, mit enormen Rücken- und Afterflossen. Keine Schilder in der Seitenlinie. Kleine Ctenoidschuppen. Zähne bürstenförmig, an der Spitze dreiteilig. Fraglich obere Kreide, Libanon. Eocän, Monte Bolca; Crag von Norfolk und lebend.

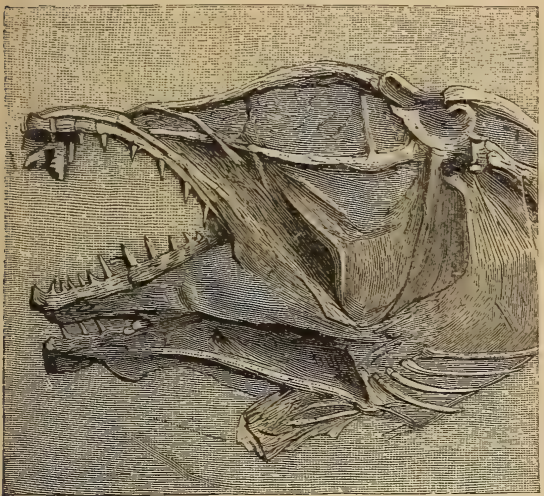

$b$

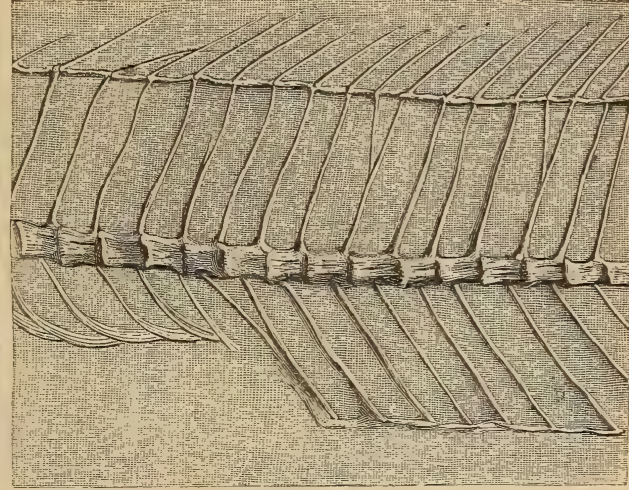

Fig. 254 .

Lepidopus (Anenchelum) Glarisianus Ag. Obereocäner Schiefer von Matt bei Glarus. $a$ Kopf, $b$ ein Stück des Rumpfes nat. Gr. (Nach Wet tistein.)

Semiophorus Ag. (Fig. 255). Stacheltragender Teil der Rückenflosse ausgedehnt und viel höher als der hintere Abschnitt. Eocän. S. velifer Ag., Eocän, Monte Bolca. Belgien.

Proantigonia Kramb. Oligocän, Rumänien. Obermiocän, Kroatien. Hierher auch Amplistinm Ag. ${ }^{1}$ ), Vomer Cuv., Caranx Cuv. (Eocün, Monte Bolca; Obermiocïn, Österreich), Carangopsis Ag., Lichic Cuv., Ductor Ag., Trachynotus Lacép., Seriola, Equula Cuv., A canthonemus Ag. (Fig. 256) u.a.

\section{Familie: Acronuridae (Acanthuridae). ${ }^{2}$ )}

Körper komprimiert, hoch, mit sehr kleinen Schuppen. Am Schwanz seitlich gencöhnlich 1-3 Hautschïder oder Stacheln. Afterflosse mit 2-3 Stacheh. Banchflossen brustständig. Kieferzähne in einer einzigen Reihe, oft gelappt, vorn hünfig als Schneidezïhne entwickelt. Tropische Meere, besonders in der Nïhe von Riffen.

Aulorhamphus Zigno (Calamostoma Steind. non Ag.), Eocän, Monte Bolca. Apostcisis Kramb., Oligocän, Miocän.

Die rezenten Gattungen Acruntlumus Lacép. und Nuseus Commerson vom Eocän an (Monte Bolca, Lutétien). Miocän, Wiener Becken.

1) Amphistiidae Easton.

2) Werden auch zu den Chaetodontiden gestellt. 


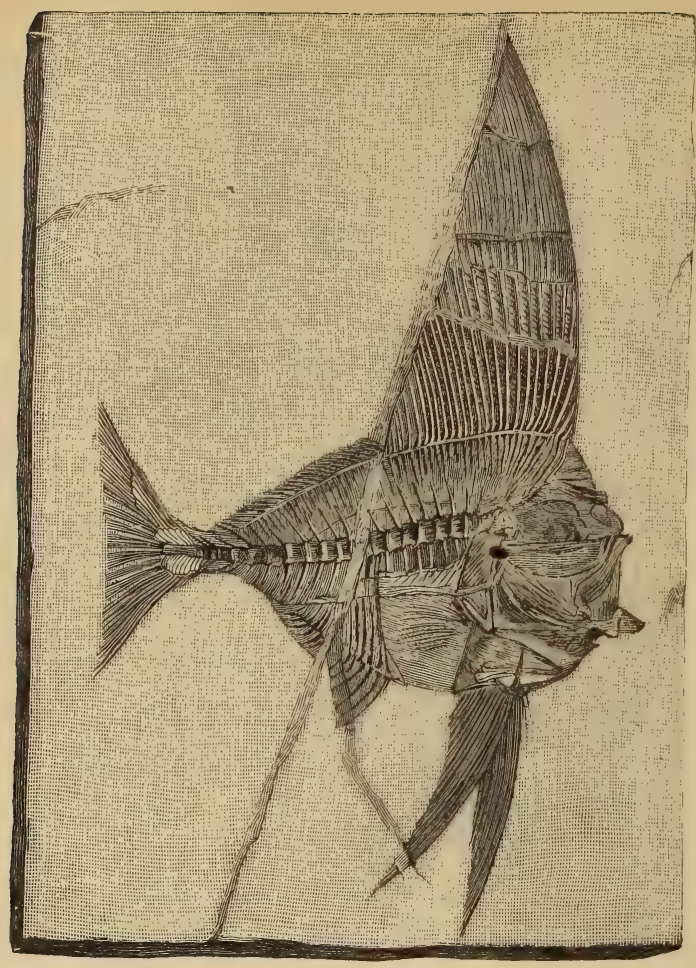

Fig. 255 .

Semiophorus velifer Ag. Eocän. Monte Bolca. 1/8 nat. Gr. (Nach Agassiz.)

\section{Familie: Stromateidae.}

Vor der langen Dorsalis und Analis einige verkürzte Stacheln. Körper hoch. In tropischen und gemäßigten Breiten.

O moso ma Costa. Obere Kreide Libanon. Platycormus v. d. Marck. Obere Kreide, Westfalen. Berycopsis Dixon, Obere Kreide, England.

\section{Familie: Coryphaenidae.}

Körper seitlich zusammengedriickt. Eine lange Dorsalis ohne Stacheln, auch die lange Analis ohne Stacheln. Kleine Cycloidschuppen. Pelagisch in tropischen und gemäßigten Breiten.

Goniognathus Ag. Eo. cän, Monte Bolca (auch als Scorpaenide aufgeführt). Mene Lacép. Körper oval, sehr kom. primiert, mit sehr entwickeltem, scharfkantigem Abdomen. Bauchflossen brustständig, vorn mit sehr langem Stachel. Vom Eocän an. M. rhombus, Monte Bolca.

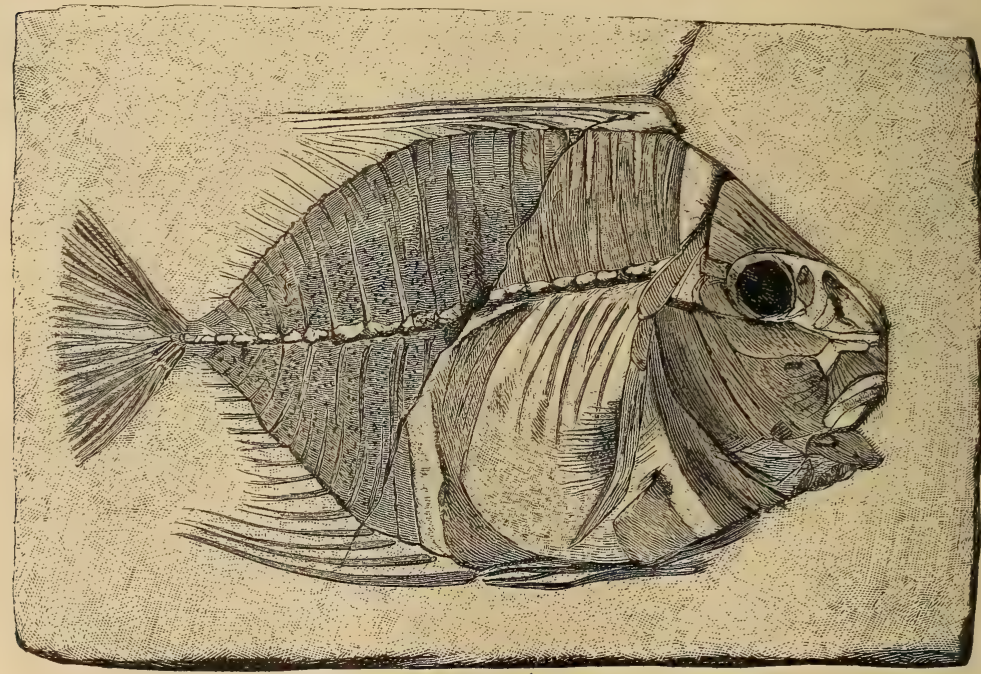

Fig. 256.

Acanthonemus filamentosus Ag. Eocän. Monte Bolca. $2 / 3$ nat. Gr. (Nach Agassiz.) 
Familie: Scombridae. Makrelen.

Körper gestreckt, nackt oder kleinschuppig. Zähne konisch.* Zwei Rückenflossen, deren hintere meist aus getrennten Biischeln bestelt. Bauchfossen brustständig. Vom Eocän an.

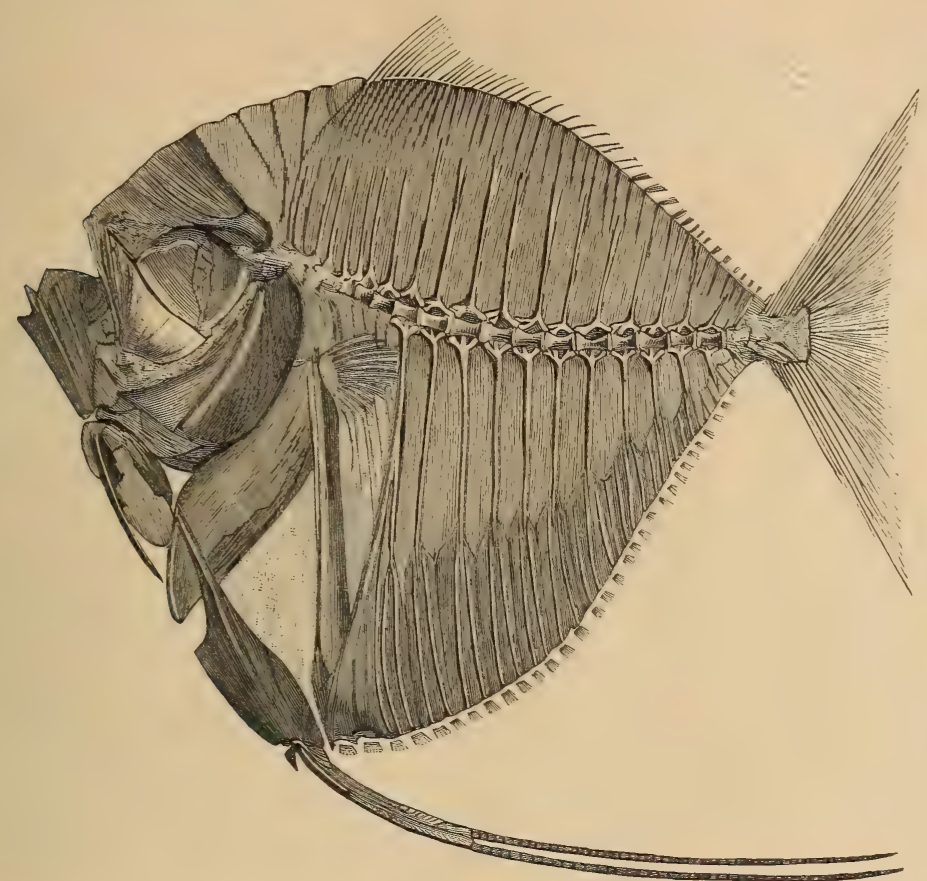

Fig. $25 \%$,

Yene (Gasteronemus) rhombeus Ag. Eocän. Monte Bolca. 1/2 nat. Gr.

Thynnus Cuv. (Orcymus Cuv.) Thunfisch. Meist große, zylindrische Fische. Vordere Dorsalis mit 12-14 nicht sonderlich langen Stacheln; auf die sehr genäherte zweite Dorsalis folgen 6-9 getrennte Flossenbüschelchen. Zähne klein. Mehrere Arten im Eocïn des Monte Bolca. Miocän, Pliocän (Crag).

Cybium Cuv. Eocän, Oligocän (Belgien), Miocän. Hierher auch Scomberodon.

Pelamycybium Toula, Kongerienschichten bei Wien. Miocän.

Sphyraenodus Ag. (= Dictyodus Owen). Oligocän (Mainzer Becken),

Scomber Art., Auxis Cuv. vom Miocän (Kroatien) an.

Eothynnus A. Sm. Woodw. (Coelocephalus Ag.) Untereocän.

A eropoma Owen, Eacynodon Owen, Xiphopterus Ag., Eocïn, Monte Bolca.

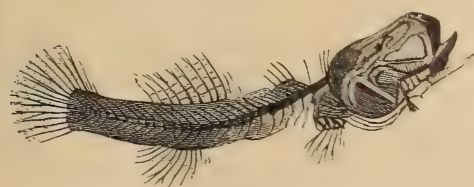

Fig. 25s

Lepidocottus brevis Ag. sp. Miocän. Oeningen Baden. Nat. Gr. (Nach Ag assiz.)

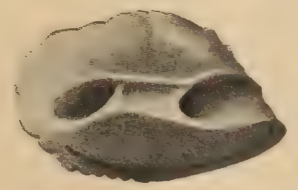

Fig. 250

Trigla elliptica Koken. Otolith. Mitteloligocän, Söllingen. $7: 1$. 
Palimphyes, Isurichthys A. Sm. Woodw. (Isurus Ag.), Echeneis Art. Unteroligocän, Glarus.

\section{Familie: Xiphiidae. Schwertfische.}

Langgestreckte Fische. Die Prïmaxillen sind zu einem Rostrum entuickelt. Zühne schucach oder fehlend. Dorsalis sehr lang, mit wenigen Stachehn. In tropischen und subtropischen Meeren.

Lebend Histiophorus Lac. (auch tertiür), Tetraptems Cuv., Xiphirus L. Xiphiorynchus Beneden, Brachyrhynchus Ben., Eocïn.

\section{Familie: Scorpaenidae.}

Pröoperculum oder mehrere Knochen des Konfes mit Stucheln. C'ircumn. orbitalia durch eine Knochenbrïclie mit dem Prïoperculum verbunden. Bristflosse mit breiter Basis. Beckienflosse bruststündin, mit 1 Stachel und hörhistens 5 Strahlen

Amp her istus König. Eocäin. Histiocephralus Zigno, Scorpaenoides Priem, Eocän. Scorpaenoptems Steindachn., (tenopoma Heckel, Miocä̈. Scorpaena von Miocïn an.

\section{Familie: Cottidae.}

Kopf flach, breit. Posttemporale frei. Supraclavicula normal.

E ocottus A. Sm. Woodw. Eocän, Monte Bolca. Lepidocottus Sauvage, Oligocän, Miocïn. (Fig. 258.) ('ottus L., Mitteloligocän, Belgien.

\section{Familie: Triglidae.}

Wangen von den großen Suborbitalien bedeckt. Posttemporale mit dem Schïdel verschmolzen, Sumaclacicula rïrlwärts verlängert nud mit dem Posttemporale im Kontakt.

Trigla L. (Fig. 259.) Otolithen vom Eocän an. Miocän. Trigloides Beneden; Miocän, Pliocän. Auch Podopteryx Sauvage, Miocïn, gehört wohl hierher.

\section{Familie: Aulostomidae.}

Langgestreckte Fische mit röhrenförmiger Schnonze und kleinem, endstündigem Irunde. Dorsalis weit nach hinten gerïcht. Stacheln wenig entuickelt. Zühne kilein. Schuppen fehlend oder kilein. Hinterhaupt gelenkig mit der Wirbelsäule verbunden. In tropischen und subtropischen Meeren.

Solenognathus Pictet u. Humb. Obere Kreide, Libanon.

Fistularia L., Aulostoma Lacép., Lrosphen Ag., Rhamphosus Ag. schon im Eocän, Monte Bolca.

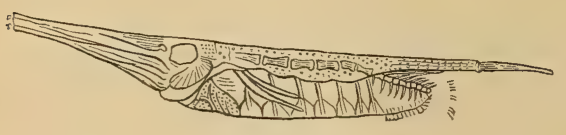

Fig. 260

Amphisyle Heinrichi Heckel. Ob. Eocän. Krakowiza. Karpathen. Nat. Gr. (Nach Heckel.)

\section{Familie: Centriscidae.}

Schnauze röhrenförmig, mit kleinem, endständigem Munde. Keine Zühne. Schuppen fehlend oder klein. Rücken mit einheitlichem Panzer oder einzelnen. Hauschildern. Zwei Rückenflossen, weit zurïckgeschoben, die vordere mit Stacheln. Bauchflossen reduziert.

Amphisyle (Klein) Cuv. Lang, seitlich zusammengedrückt. Rücken. panzer hinten mit langem Stachel. Ind. und pazif. Ozean. Obereocäne Menilitschiefer von Galizien (A. Heimrichi Heck.); Melettaschichten im OberElsaß und Wiener Becken.

\section{Familie: Blochiidae.}

Langgestreckte Fische mit seh. langer, schnabelartiger Schnauze, welche voin den gleichmäßig verlängerten, mit Bürstenzähnen besetzten Kiefern gebildet uird. 
Der ganze K̈̈̈per mit herzförmigen oder rhombischen, meist getielten, imbrizierenden Knochenschuppen bedecht. Rückenflosse im Nacken beginnend und fast bis zum Schuanz reichend, ans entfernt stehenden langen Stacheln zusammengesetzt; Afterflosse ähnlich, in der Mitte des Rumpfes begimnend. Bauchflossen hlein, unter den Brustflossen. Schwanzflosse groß.

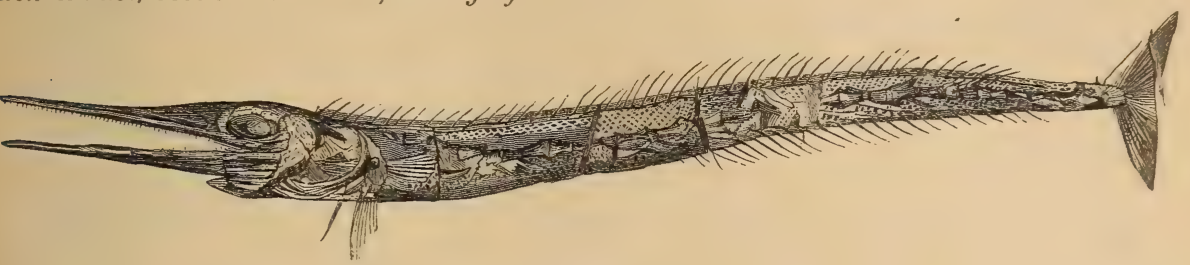

Fig. 261

Blochius longirostris Volta. Eocän. Monte Bolca bei Verona. 1/6 nat. Gr. (Nach Agassiz.)

Einzige Gattung Blochius Volta (Fig. 261), Eocïn, Monte Bolca.

Pterygocéphalus Ag. (Eocïn, Monte Bolca) gehört vielleicht zu den Blenniiden.

\section{Familie: Ophiocephalidae.}

Körper lang, vorn rundlich. Dorsalflosse lang, ohne Stacheln; Afterflosse elenso, aber liïrzer. Bauchflossen brustständig oder fehlend. Schucanzflosse gerundet. Alizessorische Hohlräume neben der Kiemenhöhle. Suprabranchialorgan angeblich fehlend. In Fliissen und Sïmpfen, oft am Lande. Afghanistan indische Inseln.

\section{Familie: Labyrinthici.}

Anal- und Dorsalflossen mit Stacheln Körper kïrzer als bei Ophiocephaliden. Lnteres Suprabranchialorgan der Luftatmung angepaßt. Fliisse, Sümple und Brackwasser, oft lange auf dem Lande. Asien, Siidafrika.

Anabas Cuv., Polyacanthus Cuv., Osphromenus Lacép., Trichogaster Bl. Selten tertiär.

\section{Unterordnung. Lophobranchii.}

Kiemen in Bïscheln an den Kiemenbogen, durch einen einzigen Deckel geschïtzt (Opercularia zu einer Platte verschmolzen). Schnanze röhrenförmig verlängert, Mund klein, terminal, Kiefer zahnlos. Haut mit diumen Knochenplatten. Brustflossen, häufig auch Schwanz- und Afterflossen vertiümmert. Die Fische schwimmen in aufrechter Haltung mittels der Rïckenflossen.

Die langgestreckten Solenostomiden haben in Solenorhynchus Heckel einen eocänen Vorläufer (M. Postale); Siphonostoma (lebend im Mittelmeer) im Obermiocän von Licata (Sizilien) und Gabbro (Toskana).

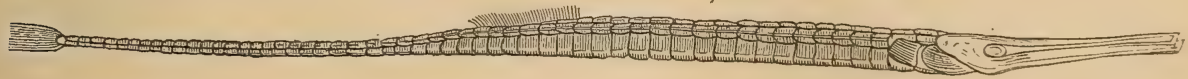

Fig. 262.

Siphonostoma Albyi Sauvage. Ob. Miocän. Licata, Sizilien. (Nach Saurage.)

Auch die Syngnathiden treten schon eocän auf. Syngnathus im Eocän, Monte Bolca, Oligocän, Rumänien, und Obermiocïn, Österreich. Pseudosyngnathus und Calamostoma, Eocän, Monte Bolca. Einige Arten der Syngnathiden (so von Dorcichthys) gehen in die Flüsse.

Die Hip pocampiden (Seepferdchen), die sich mit ihrem Wickelschwanz an treibende Sachen klammern, sehr selten im Tertiür. 


\section{Unterordnung. Plectognathi.}

Haut mit raulien Schuppen, knöchernen Stacheln oder Schildern, selten nackt. Skelett unvollständig verknöchert. Wirbel wenig zahlreich. Kiemen kammförmig. Kiemenspalte eng und klein. Oberkiefer und Zwischenkiefer unbeweglich miteinander verwachsen. Rückenflosse gegliedert, der Afterflosse gegenüber; Bauchflosse fehlend oder durch Stacheln ersetzt.

\section{Familie: Gymnodontidae.}

Körper kurz, bauchig; Kiefer schnabelartig, oben und unten mit schneidender, ungeteilter oder aus zwei Hälften zusammengesetzter Zahnplatte. Keine Rückenstacheln. Körper mit Knochenstacheln. Tertiär und lebend.

Portis ${ }^{1}$ ) unterdrückt alle für fossile Gymnodonten vorgeschlagenen Gattungen (Heptadiodon, Gymnodus, Progymnodus) und unterscheidet nur drei Sektionen innerhalb Diodon.

Diodon im Eocän, Oligocän, Miocän. Progymnodus Dames, Obereocän. Ägypten. Heptadiorlon, Eocän des Monte Postale. Tetrodon L. Eocän, Pliocän, Italien. Orthagoriscus L., Pliocän, Belgien.

\section{Familie: Selerodermidae.}

Kiefer mit einer kleinen Anzahl getrennter Zähne. Haut mit Schuppen oder rauh. Meist Rückenstachel vorhanden. Tertiär und lebend.

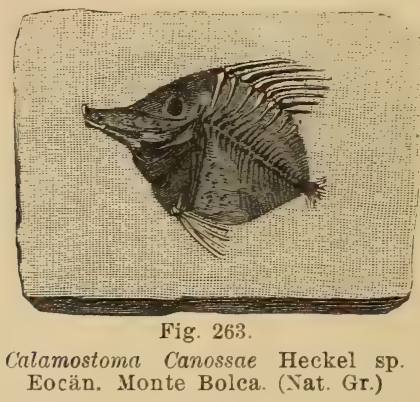

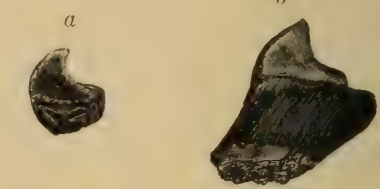

Fig. 264.

Schlundzähne von a $A n$ cistrodon libycus Zitt.

Ob. Kreide. Gasr Dachl. Libysche Wüste.

$b$ Ancistrodon armatus Gervais sp. Eo cän. Mokkatam bei Cairo. (Nach Dames.)

Ostracion L. und Protobalistum Massal. im Eocän, Monte Bolca. A canthoderma Ag., Acanthopleurus Ag., Unteroligocän, Glarus.

Die als Ancistrodon Roemer (Fig. 264) beschriebenen Zähne aus der oberen Kreide, dem Eocän und Oligocän sind nach Dames Schlundzähne von Sclerodermiden.

1) Di alcuni gimnodonti fossili italiani. Boll. comit. Italia. 1889 


\section{Klasse. Amphibia. Amphibien. Lurche. ${ }^{1}$ ) (Bearbeitet von F. Broili.)}

Wechselwarme, nackte, seltener mithornigen Schuppen oder Hautverknöcherungen ausgestattete Wasser-oder Landtiere mit Lungen und vor übergehender oder persistenter Kiemenatmung. Entwicklung ohne Amnion und Allontois, in der Regel mit Metamorphose. Herz mit einer Kammer und zwei Vorkammern. Hinterhaupt mit zwei Gelenkköpfen. Ein Sacralwirbel. Extremitäten zum Gehen, Springen oder Schwimmen geeignet, selten fehlend.

Nur die äußere Gestalt der Amphibien erinnert - einige Anuren ausgenommen - in der Regel mehr an Reptilien als an Fische. Der meist walzenförmige Körper endigt häufig in einem stark entwickelten Ruderschwanz, doch gibt es auch völlig schwanzlose Formen von gedrungenem Bau (Anura). Bei den schlangenartigen, in feuchtem Boden lebenden Blindwühlern und einzelnen fossilen Stegocephalen fehlen die Extremitäten ganz, in anderen Fällen sind dieselben verkümmert oder reduziert, in der Regel aber sind zwei Paar Extremitäten vorhanden, die bei den geschwänzten Formen als Nachschieber zur Fortbewegung des langgestreckten Rumpfes dienen, während sie bei den schwanzlosen Amphibien zum Laufen, Springen, ja selbst zum Klettern gebraucht werden.

Unter den lebenden Amphibien besitzen nur die Blindwühler (Coecilia) zwischen den Hautringen eingesprengte Schuppen, ferner entwickeln einige Anuren (z. B. Ceratophrys) in ihrer Rückenhaut Verknöcherungen, die in einem Falle (Brachycephalus ephippium) mit den Dornfortsätzen der Wirbel in Verbindung treten; unter den ausgestorbenen Formen zeichnen die Stegocephalen sich durch den Besitz eines in Form von knöchernen Schuppen und Stäbchen oder Knochenplatten ausgebildeten Hautskeletts aus, von denen letztere verschiedentlich auch hier sich mit den Dornfortsätzen vereinigen können.

Die Wirbelsäule besteht je nach der Länge des Körpers und namentlich des Schwanzes aus einer sehr verschieden großen Anzahl von Wirbeln und differenziert sich in Hals-, Rumpf-, Beckenund Schwanzregion.

Bei den meisten paläozoischen Stegocephalen verknöchert die Wirbelsäule unvollkommen, insofern die Chorda nur teilweise von den durchweg einen embryonalen Charakter tragenden Ossifikationen ver-

$\left.{ }^{1}\right)$ Bütschli O, Vorlesungen über vergl. Anatomie 1. Leipzig 1910. - ClausGrobben, Lehrbuch d. Zoologie, 7. Aufl. Marburg 1905. - Eastman-Zittel. TextBook of Palaeontology. vol. II. l'ertebrata. London u. New York 1902. - Gegenbaur C., Vergleichende Anatomie der Wirbeltiere. Leipzig 1898. - Gadow H., Amphibia and Reptilia (Cambridge Nat. Hist. VIUI). 1901. - Hertuig R., Lehrbuch d. Zoologie, 9. Aufl. Jena 1910. - Hoffmann C. K., Amphibien (Bronn's Klassen und Ordnungen etc. 1873 bis 1878). - Sedguick A., A students textbook of Zoology. Bd. 2. Amphioxus and Vertebrata. Cambridge 1905. - Steinmann G. und Döderlein L., Elemente der Paläontologie. Leipzig 1890. - Steinmann G., Einführung in die Paläontologie. 2. Aufl. Leipzig 1907. - Schimkewitsch $W$., Lehrbuch d. vergl. Anat. d. Wirbelt. Stuttgart 1909. - Wiedersheim $\boldsymbol{R}$., Vergleichende Anatomie der Wirbeltiere. 7. Aufl. Jena 1909. 
drängt wird. Bei den lebenden Amphibien wird aber, wenn auch die Chorda vielfach persistieren kann (Gymnophionen, Peremnibranchiaten u. a.) stets ein knöcherner Wirbelkörper (Wirbelzentrum) ausgebildet. Derselbe wird amphicöl (auf der vorderen und hinteren Verbindungsfläche ausgehöhlt), wenn der zwischen zwei aufeinander folgenden Wirbelkörpern entwickelte Intervertebralknorpel reduziert wird; ein o pis th o cöler (vordere Verbindungsfläche konvex, hintere konkav) oder procöler (vordere Verbindungsfläche konkav, hintere konvex) Wirbelkörper und damit gleichzeitig eine gelenkige Intervertebralverbindung zweier aufeinander folgender Wirbelkörper entsteht, wenn der sich ausdehnende Intervertebralknorpel die Chorda verdrängt.

Der Wirbelkörper ist mit dem das Rückenmark umschließenden oberen Bogen (Neurapophyse) entweder nur durch Nähte verbunden oder vollkommen zum eigentlichen Wirbel verschmolzen. Dieser meist früher und vollständiger als der Wirbelkörper verknöchernde, ursprünglich aus zwei getrennten Anlagen hervorgegangene obere Bogen verwächst dorsal in der Regel zu einem mehr oder weniger entwickelten Dornfortsatz (spina dorsalis, processus spinosus). Der gegenseitige Zusammenschluß der oberen Bogen wird durch meist schräg gestellte vordere und hintere Gelenkfortsätze (Prä- und Postzygapophysen) derart vermittelt, daß die hinteren Fortsätze eines Wirbels die vorderen des nächsten Wirbels überlagern (Fig. 269). Neben dieser Art der Gelenkung kommt es noch in seltenen Fällen (Diplocaulidae) zu der bei den Reptilien häufiger auftretenden Artikulation von Zygosphen und Zygantrum, wobei ein zwischen den Präzygapophysen entwickelter keilförmiger Fortsatz (Zygosphen) in eine entsprechend geformte, zwischen den Postzygaphysen des vorausgehenden Wirbels liegende Vertiefung (Zygantrum) gelenkig eingreift (Fig. 268b). In der Regel geht von den oberen Bögen auch ein Querfortsatz aus (processus transversus: Diapophyse), welcher zur Anheftung der Rippen dient, da aber die letzteren häufig zweiköpfig sind, so entsendet in diesem Falle auch der Wirbelkörper einen meist kürzeren Querfortsatz die Parapophyse. Untere Bogen (Haemapophysen, chevron-bones, untere Rippen) sind in der Regel nur an den Schwanzwirbeln vorhanden, wo sie von den Wirbelkörpern ausgehend den Caudalkanal umschließen. Bei den Batrachiern verschmelzen sämtliche Schwanzwirbel zu einem langen dolchförmigen Knochen (Coccyx). Der Halsabschnitt wird durch den ersten Wirbel, den A.tlas, repräsentiert, dessen mit zwei Gelenkfacetten versehene Vorderfläche (Fig. 274) mit den beiden verknöcherten oder verknorpelten Gelenkköpfen des Hinterhauptes einlenkt; häufig (Urodelen) ist sein Körper in einen vorderen, zwischen die Condylen hineinragenden Fortsatz ausgezogen. Am hinteren Ende des Rumpfes stützt ein einziger Sacralwirbel (nur bei einigen Anuren und Stegocephalen finden sich deren zwei) das Becken, das sich entweder direkt an eine ungewöhnlich starke Diapophyse oder an eine meist abweichend geformte Sacralrippe anheftet.

Im Gegensatz zu den bei den meisten der Stegocephalen stark gekrümmten, zur Umschließung der Leibeshöhle dienenden und vielfach differenzierten $\mathrm{Rippen}$ sind dieselben bei den rezenten Amphi- 
bien, wo sie mit Ausnahme des ersten Wirbels an der gesamten Rumpfregion und den ersten Schwanzwirbeln entwickelt sein können, klein und unbedeutend und verbinden sich nie mit dem Sternum.

Der Schädel (Fig. 265) verknöchert nur unvollständig, indem nur einzelne Teile des knorpeligen Primordialcraniums in Ossificationen - die sog. primären Knochen - umgewandelt werden, während andere Teile zeitlebens ihre knorpelige Beschaffenheit beibehalten. An der Hinterhauptsregion verknöchern die Ex occipitalia lateralia (Pleuroccipitalia) in der Regel (mit Ausnahme eines Teiles der Stegocephalen), sie werden vom Nervus vagus durchsetzt, umschließen das Foramen occipitale größtenteils und bilden die Condyli occipitales; ein Occipitale superius und ein Basioccipitale
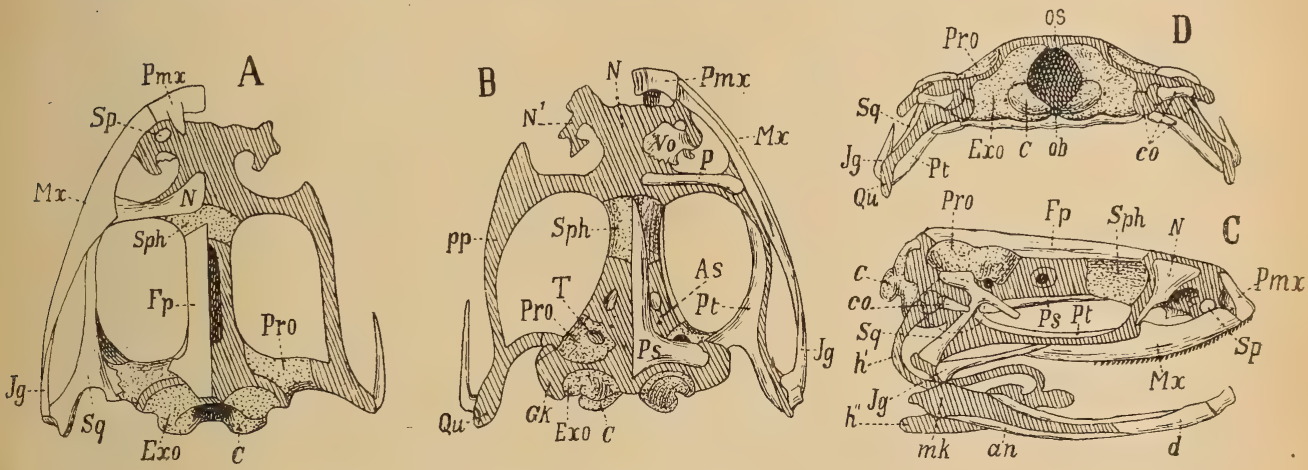

Fig. 265 .

Froschschädel $A$ von oben, $B$ von unten, $C$ von der Seite, $D$ von hinten.

In $A$ und $B$ sind von der rechten Hälfte des Schädels die Deckknochen entfernt, so daß das Primordialcranium mit seinen Ossifikationen vollständig sichtbar wird. Die primären Knochen sind punktiert, die Belegknochen weiß, der Knorpel schraffiert.

Knorpeliges Primordialcranium: $G K$ Gehörkapsel, $N N_{1}$ Nasenkapsel, $P P$ Palatinspange, As Alisphenoidknorpel, $Q u$ Quadratknorpel, $o b$, os Knorpel, aus dem sonst Basioccipitale $u$. Supraoccipitale hervorgehen. Primäre Knochen: Exo Exoccipitale lat. mit Condyl. occip. C., Pro Prooticum mit dem Trigeminusloch $T$., Sph Sphenethmoid, os en ceinture. Belegknochen: Pmx Prämaxillare, $M x$ Maxillare, $J g$ Jugale, $N$ Nasale, $S p$ Septomaxillare, Vo Vomer, $P$ Palatinum, $P t$ Pterygoid, $F p$ Frontoparietale, $P s$ Parasphenoid, $S q$ Squamosum. Unterkiefer: $m k$ Meckelscher Knorpel, $d$ Dentale, an Angulare. Zungenbeinbogen: Co Columella, $h^{\prime} h^{\prime \prime}$ Hyoid u. Copula. (Nach Gegenbaur, Bütschli, Parker, Wiedersheim und R. Hertwig.)

kommt bei den Amphibien nicht zur Entwicklung, da beide Regionen knorpelig bleiben (das sog. Supraoccipitale der Stegocephalen ist ein Belegknochen). Die Ohrgegend wird vorne von dem an seinem Vorderrand vom Nervus trigeminus durchbohrten und die Ohröffnung (Fenestra ovalis) begrenzenden Pro o ti c um (Petrosum) bedeckt, außerdem können noch ein Opisthoticum und ein Epioticum auftreten (das Epioticum der Stegocephalen ist ein Belegknochen). In der Augengegend der Urodelen kommt es zur Bildung eines paarigen Knochens des Sphenethmoids (Orbito-Sphenoid), welcher bei den Anuren in der Nasenregion sich durch mediane Verschmelzung zu einem ringförmigen Gürtelbein (os en ceinture) umgestalten kann. $\mathrm{Zu}$ diesen Verknöcherungen am Primordialcranium kommen noch als sekundäre Belegknochen, die Ossificationen des Hautskeletts: Am Schädeldach die paarigen $\mathrm{Nas}$ alia (Nasenbeine), Frontalia (Stirnbeine) und Parietalia (Scheitelbeine) - die bei den Anuren zu 
Frontoparietalia verschmelzen - ferner bei den meisten Urodelen und einigen Gymnophionen ein Praefrontale und in seltenen Fällen ein L a crimale, auf der Schädelunterseite entwickelt sich wie bei den Fischen ein großes ungeteiltes Parasphenoid. Ein kleiner Deckknochen der Nasenhöhle wird Septomaxillare bezeichnet. Bei den Stegocephalen kommen außerdem noch verschiedene andere Belegknochen zur Ausbildung, so außer den obengenannten ein P ostorbitale, Postfrontale und Supratemporale. Hierzu treten als Ergänzung die Verknöcherungen des Visceralskeletts: Am hinteren, unteren Abschnitt des Palatoquadratums, dem Quadratknorpel, entsteht mehr oder weniger ossificiert das Quadratum, während es oben durch einen Belegknochen vom Schädeldach her, das meist ausgedehnte Squamosum (Tympanicum) geschützt wird, nach vorne entwickeln sich auf der Palatinspange als Belegknochen Vomer, Palatin und Pterygoid und vor denselben Prämaxillare und Maxillare. Die Verbindung zwischen letzterem Element und dem Quadratum kann durch eine meist ansehnliche, von Jugale und ev. Quadratojugale gebildete Knochenspange hergestellt werden. Am Unterkieferknorpel, dem Mandibulare, können wie bei den Fischen 3-4 Belegknochen sich bilden: ein die Gelenkung mit dem Quadratum vermittelndes, selten verknöchertes Articulare, das zahntragende und die Reste des Meckelschen Knorpels umschließende Dentale, das Angulare und manchmal ein Operculare (Spleniale). Hyomandibulare und die Gehörknöchelchen: Columella auris und Operculum, die bei den Gymnophionen sich zu einem einheitlichen Knochen, dem Stapes, vereinigen können, werden von vielen Autoren in genetische Beziehung gebracht.

Das übrige Visceralskelett wird aus 2 starken knöchernen, durch 1-2 unpaare Copulae verbundene Hyoidea (Zungenbeinbögen) gebildet, auf welche bei den Kiemenatmern noch bis 4 teilweise verknöchert erhaltene Kiemenbögen folgen.

Die $\mathrm{Z} a \mathrm{~h} n \mathrm{e}$ sind spitzkonisch und stehen in der Regel auf Prämaxillare, Maxillare, Unterkiefer, Vomer und Palatinum. Ausnahmsweise können auch Parasphenoid und Pterygoid und manche andere, Zähnchen tragen. Vollkommen zahnlose Gattungen kommen nur bei den Fröschen vor. Der Zahnsockel befestigt sich bei den Amphibien entweder auf dem freien Kieferrand (acrodonte Bezahnung) oder seitlich an dem etwas erhöhten Außenrand des Kiefers (pleurodonte Bezahnung). Der Zahnwechsel erfolgt, wie bei den Ganoid- und Knochenfischen, nicht durch einen unter dem funktionierenden Zahn befindlichen Ersatzzahn, sondern der junge Zahn entwickelt sich neben dem vorhandenen und stellt sich, nachdem der Sockel und der Knochenfortsatz des letzteren resorbiert ist; allmählich an dessen Stelle. Die Amphibienzähne unterscheiden sich von den Fischzähnen hauptsächlich durch den Mangel an Vasodontin; ihre große Pulpa enthält zelliges Bindegewebe und ist an fossilen Zähnen entweder hohl oder durch fremde, infiltrierte Substanzen (am häufigsten Kalkspat) ausgefüllt. Die Stegocephalenzähne zeichnen sich vielfach durch eine starke, häufig labyrinthische Faltung der Dentinsubstanz aus, die an gewisse paläozoische Ganoiden erinnert. Nicht selten sind außerdem bei den Stegocephalen große Massen dicht 
gedrängter kleiner (Chagrin-) Zähnchen entweder in verschiedenen Gruppen oder ziemlich gleichmäßig auf der ganzen Schädelunterseite als Stachelpolster verteilt.

Extremitäten fehlen nur wenigen Amphibien. Am Brustschultergürtel ist der dorsale Abschnitt, die Scapula, wenigstens in seinem unteren Teil, wo er mit dem ventralen Abschnitt dem Coracoid und der Clavicula bzw. dem Procaroid zusammenstößt und mit dem ersteren die Gelenkpfanne für den Humerus bildet, ossificiert. Coracoid und Clavicula können mehr oder weniger verknöchert sein und ebenso erhält die weiterhin dorsal an die Scapula angegliederte knorpelige Suprascapula nicht selten einen Knochenbelag. Außerdem läßt sich bei einer Reihe von Stegocephalen in Verbindung mit der Clavicula ein Cleithrum nachweisen. Der ventrale Zusammenschluß des Brustschultergürtels bleibt bei den meisten Amphibien noch ein sehr lockerer, da die mit dem Coracoid bzw. mit der Clavicula in Verbindung treteriden Knorpel: Sternum und Episternum (Omosternum) nicht oder unvollständig verknöchern. Die vorderen Extremitäten selbst bestehen aus einem stämmigen langen $\mathrm{Humerus}$ (Oberarm), zwei Vorderarmknochen, Radius und Ulna, einem knorpeligen oder aus zwei Reihen kleiner Knöchelchen bestehenden Carpus (Handwurzel), 3-5 Metacarpalia (Mittelhandknochen), denen sich die aus 3-4 (? 5) Fingern (mit 1-3 Phalangen) zusammengesetzten Hände anschließen. Cf. Fig. 313, 319.

Am Beckengürtel heftet sich fast stets der dorsale Abschnitt, das in der Regel völlig verknöcherte Ilium, an die Rippe oder den Querfortsatz des einen Sacralwirbels an; das Ilium bildet ferner mit dem hinteren Ast des ventralen Abschnittes, dem gleichfalls ossificierten Is chi u m, bei den lebenden Amphibien die Gelenkpfanne (Acetabulum) für den Femur, an deren Umgrenzung sich auch der vordere Ast des ventralen Abschnittes: das bei den Stegocephalen meist verknöcherte $\mathrm{Pub}$ is beteiligen kann, welches bei den lebenden Amphibien gewöhnlich knorpelig bleibt. Der Femur (Oberschenkel) ist zumeist langgestreckt, der Vorderfuß besteht aus Tibia (Schienbein) und Fibula (Wadenbein), welche bei den Fröschen verschmelzen, ihre Gelenkenden bleiben wie diejenigen der entsprechenden Elemente der Vorderextremitäten häufig knorpelig. Der Tarsus (Fußwurzel) bleibt gleichfalls knorpelig oder ist mit einer Anzahl kleiner Knöchelchen versehen, der Hinterfuß dem Vorderfuß ähnlich, jedoch meist fünfzehig.

Die Amphibien werden in vier Ordnungen eingeteilt: Stegocephali, Coecilia, Urodela und Anura.

\section{Ordnung. Stegocephali. Panzerlurche. Schuppenlurche. $\left.{ }^{1}\right)$}

Salamander-oderkrokodilähnliche geschwänzte Amphibien, mit einem aus soliden Deckknochen bestehenden, nur von Augenund Nasenlöchern und dem Foramen parietale und in seltenen Fällen von einer Facialgrube durchbrochenen Schädeldach.

1) Literatur (vergleiche auch weiter unten):

Ammon v., Die permischen Amphibien der Rheinpfalz. München, Straub, 1889. - Broili, $F$., Permische Stegocephalen und Reptilien aus Texas. Palaeontographica, 51. Bd. 1904. ibid. Ausführliche Literatur bis 1904. Beobachtungen an Cochleo- 
Zähne spitzkonisch, meist mit großer Pulpa und einfacher oder radial gefalteter Dentinsubstanz. Wirbelkörper mit Chordaresten, teils hülsenförmig, teils aus getrennten Stücken bestehend, oder solid verknöchert und amphicöl. An der Kehle drei außen kulp. tierte, dermale, zum Brustgürtel gehörige Platten. Häufig knöcherne Schuppen oder Stäbchen vorhanden. Oberes Devon. ${ }^{1}$ ) Karbon-Trias.

saurus bohemicus. ibid. 52. 1905. Über Sclerocephalus aus der Gaskohle etc. Jahrb. d. k. k. geol. Reichsanstalt. 58. 1908. - Burmeister, H., Die Labyrinthodonten aus dem bunten Sandstein von Bernburg, zoologisch geschildert. Berlin 1849. Labyrinthodonten aus dem Saarbrücker Kohlengebirge. Berlin 1850. - Case, E. C., The Vertebrates of the Permian Bonebed of Vermilion Co. Ill. Journ. of Geology. Vol. VIII. 1900. - Cope, E.D., Synopsis of the extinct Batrachia and Reptilia of North America. Transact. Americ. Philos. Soc. XIV. 1869. Synopsis of the extinct Batrachia from the Coal Measures. Rep. of the Geol. Surv. of Ohio. Palaeontology II. 1875. Description of extinct Batrachia and Reptilia from the Permian formation of Texas. Proc. Americ. Philos. Soc. XVII. 1878. XIX. 1880. Pal. Bulletin. 32. XX. 1882. XXII. 1884. The Batrachia of the Permian Period of North America. Americ. Naturalist 1884. - Credner, H., Die Stegocephalen und Saurier aus dem Rotliegenden des Plauenschen Grundes bei Dresden. I-X, Zeitschr. d. d. geol. Gesellschaft. 33. - 45. Bd. 1881-1893. - Fraas, E., Die Labyrinthodonten der schwäbischen Trias. Palaeontographica. 35. 1889. - Fritsch, A. v., Fauna der Gaskohle und der Kalksteine der Permformation Böhmens. Prag, Bd. I. 1883. Bd. II. 1885. Bd. III. 1895. Bd. IV. 1901. - Fürbringer, M., Zur vergleichenden Anatomie des Brustschulterapparates und der Schultermuskeln. Jenaische Zeitschr. f. Naturwissenschaft. 34. 1901. - Gaudry, A., L'Actinodon. Paris 1887. Ferner: Les enchaînements du monde animal dans les temps géol. Foss. primaires. Paris 1883. - Hay, O. P., Bibliographie and Catalogue of the foss. Vertebr. of North America. Bull. U.S. geol. Surv. No. 79, 1902. Huene, F.v., Neubeschreibung des permischen Stegocephalen Dasyceps Bucklandi aus Kenilworth. Geol. u. Pal. Abhandl. XII. 1910. - Huxley, Th. D., Description of Vertebrate Remains from the Jarrow Colliery, Kilkenny. Trans. Roy. Irish. Soc. Dublin 1867. Vol. 24. - Jaekel, O., Uber die Klassen der Tetrapoden. Zool. Anzeiger, Bd. 34, 1909. Die Labyrinthodonten der Trias, in Frechs Lethaea. Trias. 1903. Uber Ceraterpeton, Diceratosaurus und Diplocaulus. Neues Jahrb. für Mineralogie etc. 1903. Bd. I. - Lydekker, R., Catalogue of the fossil Reptilia and Amphibia in the British Museum. 1888-90. ibid. weitere Literatur. - Maggi L., Plache osteodermiche interparietali degli Stegocephali etc. Rendiconti R. Ist. Lombardo d. Sc. e Lett. Ser. 2. Vol. XXXI. Milano 1898. - Meyer, H.v., und Plieninger, Th., Beiträge zur Paläontologie Württembergs. Stuttgart 1844. - Meyer, $H$. v., Uber d. Archegosaurus der Steinkohlenformation. Palaeontographica I. 1848. Weitere Arbeiten ibid. VI. VII. XV. - Miall, L. C., Report on the Structure and classification of the Labyrinthodonts. Rept. of the 42. 43. meet. Brit. Assoc. f. th advanc. of Science. Bradford 1873. Belfast 1874. - Moodie, R. L., The Lateral Line System in extinct Amphibia. Journ. of Morphol. Vol. XIX. 1908. A. contribut. to a Mongoraph of the extinct Amphibia of North America etc. Journ. of Geol. Vol. XVII. 1909. Carboniferous air-breathing Vertebrates of the U. S. National Museum. Proc. U. S. Nat. Museum. No. 1696. 1909. - Thevenin, A., Amphibiens et Reptile du terrain houiller de France Ann. de Paleontologie T. I. 1906. Les 'plus anciens Quadrupèdes de France. ibid. T. V. 1910 (ibid. Literatur.) - Versluys, J., Die Salamander und die ursprünglichsten vierbeinigen Landwirbeltiere. Naturwissensch. Wochenschrift. N. F. VIII. Bd. 3. 1909. - Williston, S. W., The skull and extremities of Diplocaulus. Kans. Acad. of Science. Geol. Pap. (Separat.) 1910. New or little-known Permian Vertebrates. Trematops, Journ. of Geol. Vol. XVII. 1909. The Faunal relations of the early Vertebrates. ibid. Dissorophus Cope. ibid. Vol. XVIII. 1910. - Wintrebert, $P$., Sur le Déterm. d. 1. Métamorphose chez les batraciens. Comp. rend. des séanc. d. 1. Soc. d. Biologie. Bd. 58 u. 59. 1910. Masson, Paris. - Wiman, C., Ein paar Labyrinthodontenreste aus der Trias Spitzbergens. Bull. Geol.-Instit. Ups. Vol. IX. 1910. - Woodward, A. S., On two new Labyrinthodont skulls of the genera Capitosaurus and Aphaneramma. Proc. Zool. Soc. London 1904. Vol. II.

1) Fußspuren, die mit ziemlicher Sicherheit auf Stegocephalen zurückzuführen sind, finden sich nach Marsh bereits im obersten Devon (Chemung Stufe) von W. Pennsylvanien. 
Im Gegensatz zu den lebenden Amphibien besitzen die Stegocephalen in der Regel ein wohlausgebildetes, aus verknöcherten Schuppen oder Stäbchen bestehendes Hautskelett (Fig. 266) das namentlich auf der Bauchseite zur Entwicklung kommt, zuweilen die Unterseite der Extremitäten bedeckt und vereinzelt auch auf der Dorsalseite des Körpers beobachtet wird. Die Bauchschuppen zeichnen sich gegenüber den meist dünneren Rückenschuppen zuweilen durch ansehnliche Stärke aus und bilden einen sehr dichten, schützenden Panzer, welcher aus schrägen, nach vorne konvergierenden und in der Mitte des Bauches winklig zusammenstoßenden Reihen gebildet wird. In der Hals- und Kehlregion, sowie unter dem Schwanz und den Extremitäten zeigen die Schuppen eine abweichende Anordnung. Die Form dieser aus Knochensubstanz bestehenden Bildungen ist oval, rhombisch, oblong, spindel-, haferkorn- oder sogar dünnstabförmig. Außer diesen kleineren Hautverknöcherungen können dorsal solide, kräftige, skulptierte Knochenplatten auftreten, die sich mit den distal verbreiterten Dornfortsätzen der Wirbel verbinden und so zur Bildung eines teilweise vollständig geschlossenen Rückenpanzers beitragen (z. B. Aspidosaurus, Dissorophus, Cacops).

Als Kammplatten (clasping organs) werden kammförmige, gekrümmte Knochenstäbchen bezeichnet, die wahrscheinlich nur bei fußlosen Stegocephalen (Ophiderpeton, Molgophis) in der Kloakengegend als Hilfsorgan bei der Paarung dienten.

Die Wirbelsäule ${ }^{1}$ der Stegocephalen bewahrt meist

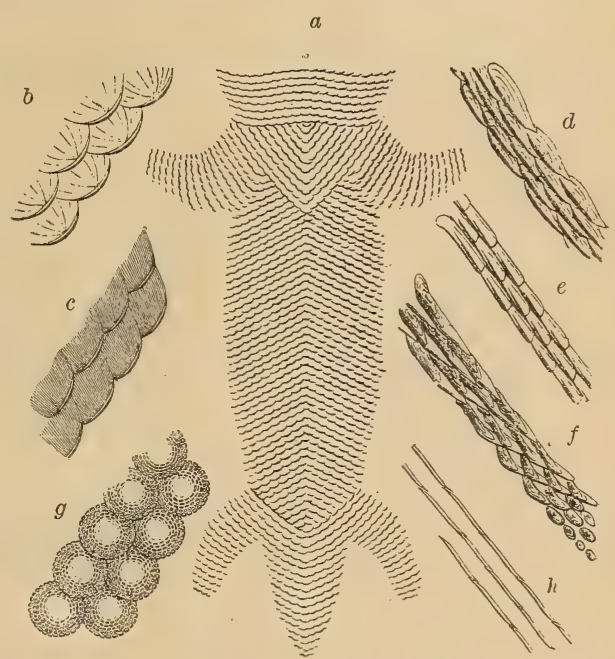

Fig. 266.

a Bauchpanzer von Branchiosaurus, $b$ Schuppen von Branchiosaurus c von Hylonomus, $d$ von Pelosaurus, $e$ von Archegosaurus, $f$ von Sclerocephalus, $g$ von Discosaurus, $h$ von Petrobates. (Naeh Credner.) einen embryonalen Charakter und erinnert in vielem an diejenige der Ganoidfische, nur bei den höchststehenden Formen kommt es zur Bildung amphicöler, manchmal noch von der Chorda durchbohrter Wirbel, bei allen übrigen

1) Bezüglich der Literatur über den Wirbelbau der Stegocephalen und die Homologien derselben zu den Wirbeln der Ammoniten siehe: Baur G., Archegosaurus. Americ. Naturalist. XXXI. 1897. The Stegocephali: a phylogenetic study. Anat. Anzeiger XI. 1896. - Branson E. B., Structure and Relationships of Americ. Iabyrinthodontidae Journ. of Geol. Vol. XIII. 1905. - Broili F., Ein Beitrag zur Kenntnis von Eryops megacephalus. Paläontographica 44. Bd. 1899. Uber die rhachitomen Wirbel der Stegocephalen. Zeitschrift d. d. geol. Gesellsch. Bd. 60. 1908. (Monatsberichte 8/10). - Cope, On the intercentrum of the Terrestrial Vertebrata Trans. Am. Philos. Soc. Bd. XVI. - Credner H., Die Urvierfüßler (Eotetrapoda) des sächsischen Rotliegenden. Allgemein-verständl. naturwissenschaftl. Abhandl. Heft 15. Berlin, Dümmlers Verlag 1891. - Gadow H., Evolution of the vertebral Column of Amphibia and Amniota. Philos. Transact. of the Royal soc. 
bleiben stets mehr oder weniger umfangreiche Chordareste neben unverkalkten knorpeligen Teilen am unvollkommen verknöcherten Wirbelkörper bestehen.

Der unvollkommenste Wirbelbau kommt den Phyllospondyli (Blattwirblern) zu. Ein phyllospondyler Wirbel (Fig. 267) besteht aus einer von vier zarten Knochenblättern gebildeten und sowohl Rücken-

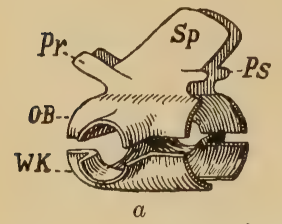

Fig. 267.

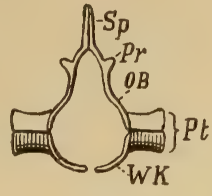

b

Phyllospondyler Rumpfwirbel von Branchiosaurus. $a$ von der Seite, $b$ von vorne. (In $a$ sind die 4 Teile voneinander getrennt). $W K$ Wirbelkörper, $O B \mathrm{Ob}$. Bogen, $P r$ Präzygapophyse, $P s$ Postzygapophyse, Sp Processus spinosus, $P t$ Processus transversus. Stark vergr.

(Nach Credner und Thevenin.) mark wie Chorda umschließenden Röhre. Die zwei oberen dieser Knochenblätter, welche, im Besitze vorderer und hinterer Gelenkfortsätze, dorsal zu einem median noch nicht verschmolzenen Dornfortsatz verlängert sind und mit ihren Seitenschenkeln die Oberfläche des meist sehr kräftigen knorpeligen Querfortsatzes bedecken, bilden den oberen Bogen; die zwei unteren Knochenblätter, welche die ventrale Hälfte der Chorda rinnenförmig umfassen, in der ventralen Mittellinie aneinander grenzen und sich seitlich auf die Unterseite der Querfortsätze erstrecken, sind als die Verknöcherungen des Wirbelkörpers selbst anzusehen.

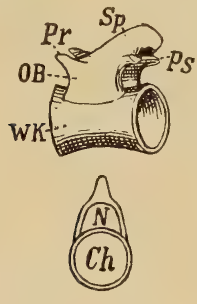

$a$
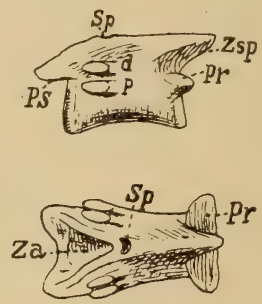

b

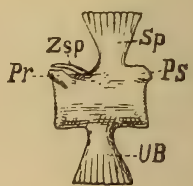

c

Fig. 268.

Lepospondyle Rumpfwirbel $a$ von Hylonomus (von der Seite und im Vertikalschnitt) (nach Credner); $b$ von Diplocaulus von der Seite und von vorne. (Nach Broili). c Schwanzwirbel von Urocordylus (nach Schwarz.) $d$ Diapophyse, $\boldsymbol{P}$ Parapophyse, Zsp Zygosphen, Za Zygantrum, UB unterer (Bogen) Dornfortsatz, $C h$ Chorda, $N$ Neuralrohr. Sonstige Bezeichnungen wie früher. $a$ u. $c$ stark vergrößert, $b$ ca. $1 / 2$ nat. Gr.

Bei den Hülsenwirblern Lepospondyli (Fig. 268) umgibt der Wirbelkörper als kontinuierliche knöcherne Hülse die meist stets peristierende Chorda, die intervertebral sich erweitert, intravertebral hin-

London. Vol. 187, 1897. - Gaudry, Les enchaînements du monde animal. I. Fossiles primaires. Paris 1883. - Götte A., Utber den Wirbelbau bei den Reptilien und einigen and. Wirbelt. Zeitschr. f. wissenschaftl. Zool. Vol. 62. 1897. - Jaekel O., Die Organisation von Archegosaurus. Zeitschr. d. d. geol. Gesellsch. Vol. 48. 1896. Uber die Bildung der ersten Halswirbel $\mathrm{u}$. die Wirbelbildung im allgemeinen. Tbid. Bd. 56. 1904. - Osborn H. $\boldsymbol{F}$., Intercentra and Hypapophysis in the cervical region of Mosasaurs, lizards and Sphenodon. Americ. (Nat. 34; Nr. 397. 1900). - Schwarz A., Uber die Morphogenie der Wirbelsäule der Tetrapoden. Sitzungsbericht d. Gesellsch. naturforsch. Freunde. Berlin 1908. Nr. 10. Über die Wirbelsäule u. d. Rippen holospondyler Stegocephalen (Lepospondyli Zitt.), Beitr. z. Pal. u. Geol. Österreich-Ungarns u. d. Orients. Bd. XXI. 1908. Ibid. weitere Literatur. - Williston S. W., Cacops, Desmospondylus, new genera of Permian Vertebrates. Bull. Geol. Soc. of Americ. Vol. 21. 1910. - Rhachitomus Vertebrae. Journ. Geol. Vol. XVIII. 1910. 
gegen etwas eingeschnürt zeigt, wodurch der gewöhnlich langgestreckte Wirbelkörper eine sanduhrähnliche - tief amphicöle - Gestalt erhält.

Die gelenkige Verbindung wird außer den meist wohl entwickelten paarigen Prä- und Postzygapophysen des dem Wirbelkörper nur lose aufsitzenden oder mehr oder weniger mit ihm verschmolzenen oberen Bogens zuweilen durch Zygosphen und Zygantrum (s. o.) sowie durch unpaare, über den Prä- bzw. Postzygapophysen am Processus spinosus entwickelte Gelenkfortsätze vermittelt. (Nach H. Schwarz sollen auch vereinzelt am Wirbelkörper selbst untere Gelenkfortsätze zur Ausbildung gelangen. Dolichosoma.) Querfortsätze können sowohl am oberen Bogen wie am Wirbelkörper angelegt sein, außerdem kommt es an den Schwanzwirbeln einiger Formen, z. B. Urocordylus, zur Bildung besonders spezialisierter Haemapophysen sog. unterer Dornfortsätze.

Einen anderen Bau besitzen die aus mehreren getrennten Stücken zusammengesetzten Kranzwirbel (Schnittwirbel), die Temnospondyli. Auch hier beginnt wie in den übrigen Fällen die Ossifikation mit dem oberen Bogen und zwar bleiben die beiden seitlichen Schenkel desselben anfänglich getrennt (Discosaurus) und wachsen erst später unter Bildung eines meist kräftigen, distal zuweilen verdickten Dornfortsatzes zusammen. Die Gelenkfortsätze zeigen sich gut ausgebildet. Der Wirbelkörper

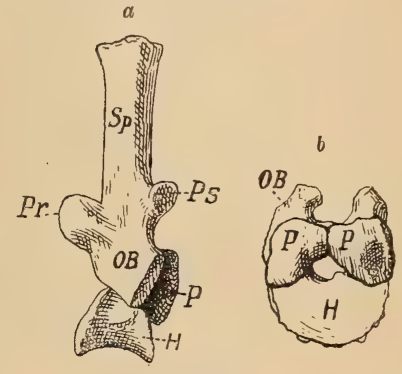

Fig. 269.

Rhachitomer Rumpf Wirbel von Eryops. $a$ von der Seite. (Teilweise ergänzt). $H$ Hypocentrum, $P$ Pleurocentrum. (Sonstige Bezeichnungen wie früher.) $b$ von hinten. (Der dorsale Abschnitt des ob. Bogens mitDornfortsatz etc. nich terhalten) Ca. $1 / 2$ nat. Gr.

(Nach Broili.) selbst weist entweder $\mathrm{rh}$ a chito me oder e m b ol o m e r e Beschaffenheit auf. Im ersteren Falle besteht er (Fig. 269-71 aus einem vorderen

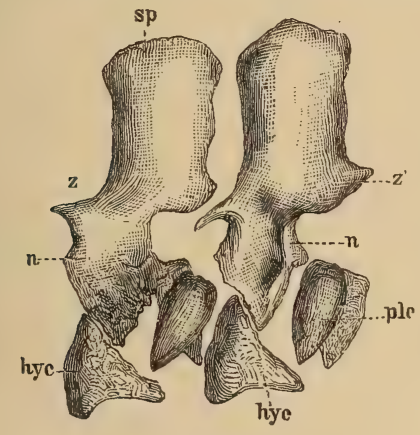

Fig. 270.

Rhachitome Rumpfwirbel von Archegosaurus.

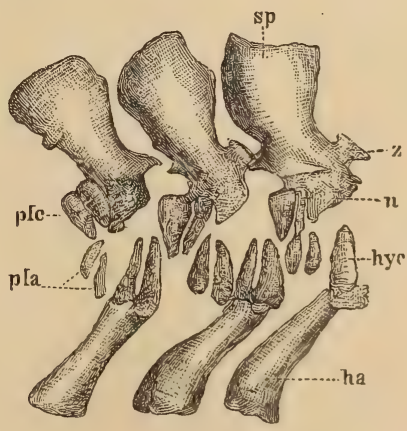

Fig. 271.

Rhachitome Schwanzwirbel von Archegosaurus.

$s p$ Dornfortsatz, $\boldsymbol{z} z^{\prime}$ Zygapophysen, $n$ oberer Bogen, hyc Hypocentrum, plc Plourocentrum, pla unteres Stück desselben in der Schwanzregion, ha Hämapophysen.

ventralen Knochenstück, dem Hypocentrum (Intercentrum) und zwei hinteren, lateralen Ossifikationszentren: Pleurocentra. Ersteres hat bei nach oben zugespitzten Seiten im allgemeinen halbmondförmigen Umriß, ist dorsal median für die persistierende Chorda rinnen- 
förmig vertieft und repräsentiert den ventralen Halbring des Wirbel. körpers; die Pleurocentra sind von keilförmiger Gestalt, können aber in der Schwanzregion (Archegosaurus) jederseits in ein oberes und unteres Stück zerfallen (das untere Paar soll bei Sphenosaurus ${ }^{1}$ ) zu einem Hypocentrum pleurale verschmelzen), bei relativ höher entwickelten Formen (Eryops) vereinigen sich dieselben über der Chorda zum dorsalen Halbring des Wirbelkörpers. Unter Bögen (Hämapophysen) zeigen sich bei Archegosaurus mit den Hypocentra der Schwanzregion im Zusammenhang $(h a)$. Die Rippen des rhachitomen Typus legen sich sowohl an die Diapophysen des oberen Bogens als auch, bei zweiköpígen Rippen, an eine schwach konkave Vertiefung - parapophyse Facette - am oberen Hinterrand des Hypocentrums an. Der sehr seltene embolomere (Cricotus, Diplovertebron, Nummulo. saurus) Typus des Wirbelkörpers besteht darin, daß je zwei Knochenringe einem Körpersegment entsprechen (Fig. 273). Der vordere

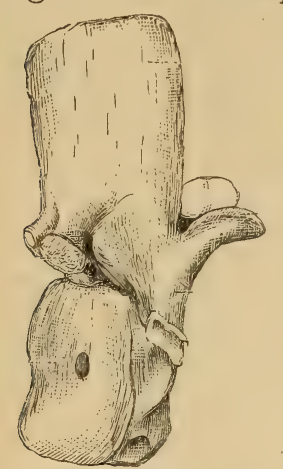

Fig. 272. Rückenwirbel von I oxomma Allmani Huxley. Schräg v. hinten. $1 / 2$ nat. Gr. stützt den oberen Bogen, trägt die Hämapophysen in der Schwanzregion und ist Träger der Rippen. Dieser Typus scheint gewissermaßen eine Modifikation des rhachitomen Wirbels darzustellen, insofern der vordere Ring durch dor-

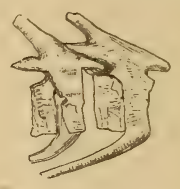

Fig. 273

Embolumere Wirbel von Diplovertebron punctatum Fritsch. Aus der Gaskoble von Nürschan. Nat. Größe. (Nach Fritsch.) sales Zusammenwachsen des Hypocentrums, der hintere Ring durch dorsale sowie ventrale Verschmelzung der Pleurocentra entstanden sein dürfte, im Gegensatz zu dieser Anschauung betrachtet Götte die rachitomen Wirbel als Übergangsstadium von embologeren zu Vollwirbeln.

Ein noch weiter vorgeschrittenes Stadium in der Verknöcherung der Wirbelsäule zeigen die Stereospondyli (Vollwirbler). Der Wirbelkörper bildet hier eine solid verknöcherte, kurze, schwach amphicöle Scheibe, welche zuweilen im Zentrum durchbohrt ist (Fig. 272) (Loxomma) oder unter dem Medullarkanal einen ursprünglich von der Chorda erfüllten Ausschnitt erkenmen läßt (Mastodonsaurus). Merkwürdigerweise begegnet uns ersteres auf die relativ höchste Entwicklungsstufe der Stegocephalen hinweisende Stadium unter den ältesten carbonischen Formen.

Soweit der erste Halswirbel, der Atlas (Fig. 274) der Stegocephalen erhalten ist, besitzt er bei den Lepospondylen (Diplocaulus) und Stereospondylen (Mastodonsaurus) auf seiner Vorderseite zwei konkave Gelenkfacetten für den doppelten Condylus. Bei Diplocaulus ist der obere Bogen nach vorn in ein kurzes Rohr verlängert, durch welches das Rückenmark in das Foramen magnum eintritt. Bei den Temnospondyli (Eryops, Dissorophus) finden sich zwei große Articulationsflächen am stark verbreiterten Hypozentrum und die beiden Hälften des oberen Bogens sind median nicht miteinander verschmolzen und legen sich eng an die Seiten des Dornfortsatzes des

1) Sphenosaurus ist vielleicht ein Reptil. 
zweiten Wirbels an. Rippen fehlen dem Atlas stets, hingegen sind die Postzygapophysen immer zur Ausbildung gelangt. Hinter dem Atlas folgen bis zum Becken die in der Regel nur wenig voneinander verschiedenen Rumpfwirbel, die gewöhnlich ein- oder zweiköpfige Rippen tragen. Zum Becken gehört ein einziger Sacralwirbel mit starkem Querfortsatz und kräftiger Sacralrippe. Ausnahmsweise können auch zwei Wirbel vorkommen (Cacops, die Microsaurier: Hylonomus und Petrobates).
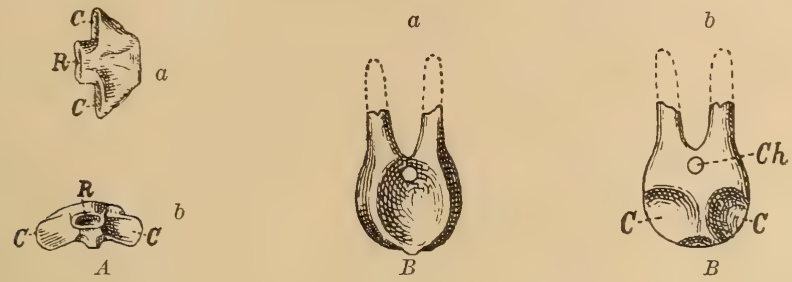

Fig. 274 .

Atlas $A$ von Diplocaulus (nach Broili) $a$ von unten, $b$ vion vorne.

Altas $B$ von Dissorophus (nach Williston.) $a$ von hinten, $b$ von vorne

c Gelenkfacetten für die Condyli, $R$ rohrförmige Verlängerung des oberen Bogens für das Rückenmark, Ch Chorda. Ca. $1 / 2$ nat. Größe.

Der Schädel (Fig. 275) besitzt die für die Amphibien charakteristische flache, breit dreiseitige Gestalt, ist jedoch oben durch ein solides Knochendach geschützt, dessen Zusammensetzung sich verschiedentlich von der Schädeldecke der übrigen Amphibien unterscheidet. Die, infolge eines Überzuges einer Modifikation von Osteodentin, oft schmelzartig glänzende Oberfläche der Kopfknochen ist entweder radial gestreift oder von rauher, grubiger, an Honigwaben erinnernder Beschaffenheit und zeigt ähnlich gewissen Ganoiden (Amia und Polypterus) häufig ein Furchensystem von Schleimkanälen (Fig. 306), die in der mittleren Region des Schädeldaches zwischen Augen- und Nasenöffnungen eine sog. Ly ra bilden können. Neuerdings glaubt Moodie ${ }^{1}$, die diesen Sinnesorganen ähnlichen, bei Fischen und Urodelen (Necturus) entwickelten 》Seitenlinien "im

1) Moodie R. L., The lateral line system in extinct. Amphibia. Journ. of Morphology Vol. XIX. Nr. 2. 1908 u. A Contribution to a Monograph of the extinct Amphibia of North America. New forms from the Carboniferous. Journ. of Geol. 17. 1909. The clasping organs of extinct and recent Amphibia. Biological Bullet. 14. 1908.

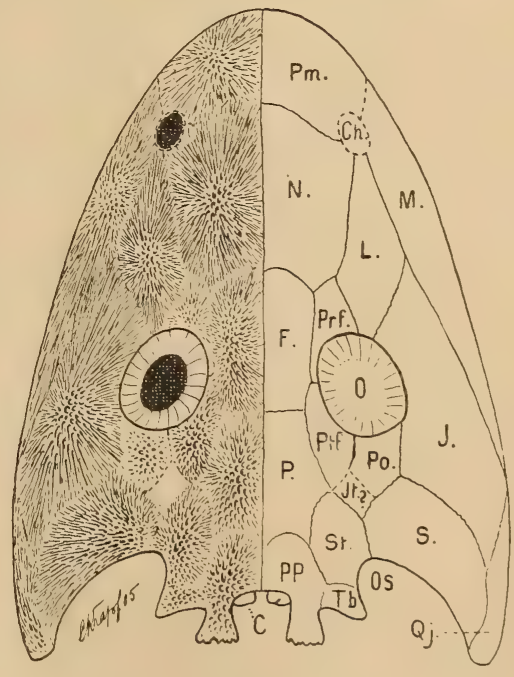

Fig. 275.

Cochleosaurus bohemicus Fritsch. Schädeldach verkleinert. (Nach Broili.) Bei unsicheren Stellen sind die Nähte und Begrenzungslinien punktiert eingezeichnet.

$O$ Augen mit Scleroticaring, Os Ohrenschlitze, Ch Nasenlöcher, PP Postparietale mit den löffelförmigen Fortsätzen, $T b$ Tábulare, $P$ Parie tale, $F$ Frontale, $N$ Nasale, $P m$ Prämaxillare, $M x$ Maxillare, $L$ Lacrimale, Prf Präfrontale, Ptf Postfrontale, Po Postorbitale, $J$ Jugale, It Intertemporale, St Supratemporale $S$ Squamosum, $Q j$ Quadratojugale, $C$ Condyli occipitales. 
Abdruck der fleischigen Teile eines Branchiosauriers (Micrerpeton) entdeckt zu haben.

Außer den meist ziemlich großen Augenöffnungen und den in der Nähe des vorderen Schnauzenrandes befindlichen Nasenlöchern befindet sich eine unpaare, rundliche Öffnung innerhalb der Parietalia. Dieses auch bei lebenden Reptilien noch zur Ausbildung gelangte Foramen parietale (Fig. 306, 7) stellt die Epiphysenöffnung dar, in welche unter der Haut ein unpaares dorsales Sinnesorgan (? Auge) eingelagert ist. Die Augenhöhlen sind häufig mit einem von den Augäpfeln ausgeschiedenen, aus einem Kranze vierseitiger Knochentäfelchen bestehenden Scler oticaring versehen. In seltenen Fällen zeigt sich auch, wie bei vielen Urodelen, zwischen Praemaxillaria und Nasalia (resp. Frontalia) eine sog. "F'acialgrube (= Cavum internasale) cf. Fig. 289 (Dasyceps, Trematops, Acanthosoma, Microbrachis), in welcher sich bei den Urodelen eine schleimabsondernde Drüse findet. Eine Eigentümlichkeit verschiedener triadischer Stegocephalen sind ferner die Foramina intermaxillaria, Durchbrüche in den Prämaxillaria, die bestimmt sind, bei geschlossenem Rachen die Fangzähne des Unterkiefers aufzunehmen. (Bezügl. der Ohrenschlitze s. w. unten!)

Ausnahmsweise kommt es auch zur Bildung einer (sonst nur bei gewissen Sauropsiden entwickelten) Präorbitalöffnung, die bei Trematops mit den Nasenlöchern und bei Loxomma anscheinend mit den Augendurchbrüchen verschmilzt.

Die in der Regel wenig dicken, plattigen Schilder des Schädeldaches sind, wie bei den Ganoiden und vielen Teleostiern V erknöcherungen der Haut; nur selten sind die Suturen bei stärkerer Ossifikation und bei älteren Individuen verwischt, bei der überwiegenden Mehrzahl aber kann man die einzelnen Knochenelemente auseinanderhalten. Demnach finden sich median paarweise: über dem Hinterhaupt die Postparietalia $\left.{ }^{1}\right)(=$ Supraoccipitalia $=$ Dermosupraoccipitalia), über dem Gehirn die breiten, das Foramen parietale umschließenden P a rietalia, zwischen den Augen die langgestreckten Frontalia, denen sich nach vorne die Nasalia anschließen, die gewöhnlich mit den, den Schnauzenrand bildenden Prämaxillaria die Nasenöffnungen begrenzen. An die Supraoccipitia legt sich jederseits das Tabulare (=Epioticum) an. An der Umrahmung der Augen nimmt das Frontale nur selten Anteil, gewöhnlich wird dasselbe innen und oben von Prä- und Postfrontale, außen und unten von Jugale und Postorbitale und zuweilen durch das zwischen Jugale und Präfrontale sich zurückschiebende Lacrimale eingefaßt. Die hintere untere Ecke des Schädels wird von dem nach vorne in das zahntragende Maxillare übergehenden Quadratojugale eingenommen, auf dessen Unterseite sich zuweilen ein kleines aber deutlich umgrenztes verknöchertes Quadratum zeigt, welches die Gelenkung für den Unterkiefer vermittelt. Der Zwischenraum

1) Da die bisher in der Regel verwendeten Benennungen für die dermalen Elemente des Stegocephalenschädels: Supraoccipitale u. Epioticum im Vergleiche mit den ebenso bezeichneten primären Ossifikationen der Amnioten vielfach zu Mißdeutungen führten, wurde hier für das $S$ upraoccipitale die von Broom gebrauchte und bereits in die Literatur übernommene Bezeichnung Postparietale und für das Epioticum das Copesche Tabulare zur Verwendung gebracht. 
zwischen dem Quadratojugale, dem Tabulare und Parietale, sowie den die Umrahmung des Auges bildenden Elementen wird von 2-3 Belegknochen ausgefüllt, von denen der untere als Squamosum (Supratemporale aut, Prosquamosum Owen, Paraquadratum), der obere als Supratemporale und das vor dem letzteren sich ev. einschaltende Element als Intertemporale (Intersquamosum) bezeichnet wird. Squamosum, Supratemporale und Tabulare (Epioticum) begrenzen sehr häufig einen buchtartigen Einschnitt am Hinterrand des Schädels, den Ohrenschlitz; ausnahmsweise kann derselbe auch völlig von den genannten Elementen zu einer ,falschen“ Schläfenöffnung eingefaßt (Cyclotosaurus, Cacops, Trematops) oder völlig überwuchert werden (Diplocaulus) (Fig. 277, 278, 293, 300).

Das Hinterhaupt(Fig. 276) bleibt bei vielen Stegocephalen noch knorpelig, bei einer großen Anzahl verknöchern aber die Exoccipitalia

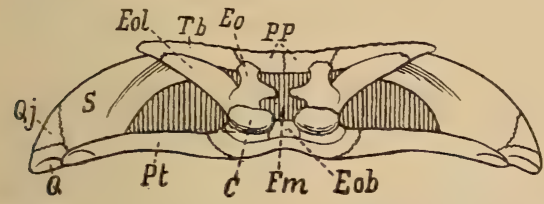

Fig. 276. Hinterhaupt von Mastodonsaurus giganteus Jäger. (nach E. Fraas u. A. S. Woodward). Fm Foramen magnum, PP Postparietale, Tb Tabulare. $S$ Squamosum, Q Quadratojugale, $Q$ Quadratum, Pt Pterygoid, EO Exoccipitale laterale, $\boldsymbol{C}$ Condyli occipitales, Eol Seitlicher Flügel, Eob Basale Verschmelzung des Exoccipitale laterale. Stark verkl.

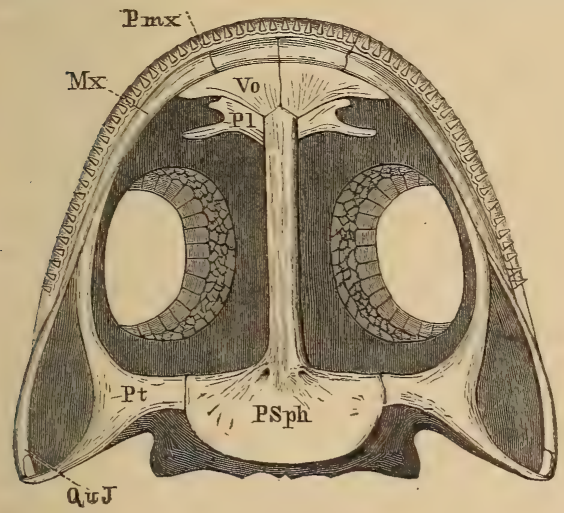

Fig. 277.

Branchiosaurus. Unterseite des Schädels. Restauriert. 2/1. (Nach Credner.) Pmx Zwischenkiefer (Prämaxillare), $M[x$ Oberkiefer (Maxillare), $Q u J$ Quadratjochbein, Pt Flügelbein (Pterygoideum), PSph Parasphenoid, Pl Gaumenbein (Palatinum), Vo Pflugscharbein (Vomer). lateralia, und ihr basaler Teil bildet die zwei Condyli occipitales. $\left.{ }^{1}\right)$ Die Unterseite des Schädels (Fig. 277, 78) zeichnet sich

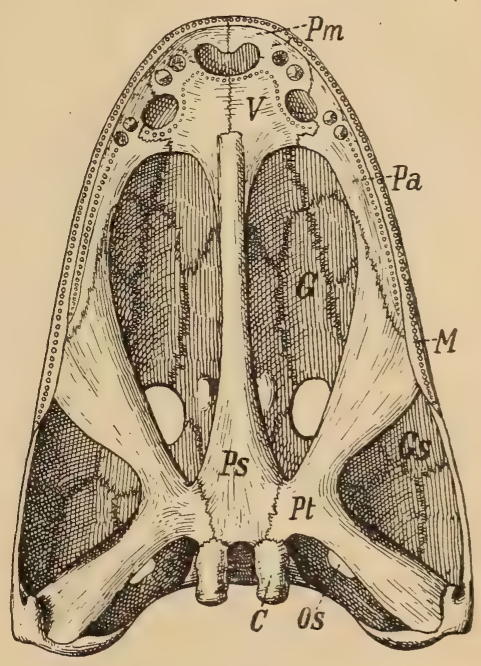

Fig. 278 .

Cyclotosaurus robustus H. v. Meyer. Schädelunterseite. $C$ Condylus occipitalis, $P t$ Pterygoid, $P$ s Parasphenoid, $V$ Vomer, $P a$ Palatinum M Maxillare, $P m$ Prämaxillare, $G$ Gaumengruben, GS Gaumenschläfengruben, $O S$ hinten geschlossene Ohrenschlitze (falsche Schläfen. öffnung). Schilfsandstein des untern Keuper Stuttgart. (Stark verkleinert. Nach E. Fra as).

durch ungemein große Gaumengruben aus. In der Mitte werden sie durch den vorderen, spanförmigen 'Teil des meist ansehnlichen Parasphenoids getrennt, dessen hinterer, an die Pterygoidea angrenzender Teil gewöhnlich sich verbreitert zeigt. Der vordere Teil

1) Nach den Beobachtungen Willistons bei Cacops und Trematops soll hier ein verknöchertes Basisphenoid vorkommen. 
des Parasphenoids (Processus cultriformis) fügt sich in den unmittelbar davor gelegenen, paarig angelegten, zuweilen aber zu einer einheitlichen Platte verschmolzenen Vomer ein; letzterer wird vorn und seitlich von den Prämaxillaria und Maxillaria begrenzt. Vom hinteren Teil des Parasphenoids geht jederseits ein sich teilendes Pterygoid aus, der eine Ast desselben erstreckt sich nach rückwärts und aufwärts zum Quadratojugale, wobei ihm gleichzeitig die Aufgabe zufällt, den Schädel nach rückwärts abzuschließen. Der vordere Ast, welcher zugleich mit dem hinteren jene, die hintere Ecke des Schädels einnehmende, große Gaumenschläfengrube von innen begrenzt, bildet eine Brücke zum Maxillare bzw. auch zum Palatinum. In einigen Fällen ist auch ein zwischen Pterygoid, Palatinum und Maxillare sich einschaltendes Os transversum nachgewiesen worden. Das Palatinum, das in der Regel sich vom Vomer an ziemlich weit nach rückwärts an das Maxillare anlegt, umschließt gewöhnlich mit diesen beiden Elementen die innere Nasenöffnung, die Choane.

Der Unterki efer (Fig. 279, 308) besitzt fast bei allen Stegocephalen einige wenige Gattungen wie Diplocaulus, Diceratosaurus ausgenommen, die Länge des ganzen Kopfes. Von den drei Hauptstücken, aus welchen jede Hälfte besteht, bildet das Dentale den bezahnten Oberrand und den Vorderrand des Kiefers, das Angulare den Unterrand; die Verbindung mit dem Schädel wird durch das hinter dem Dentale und über dem Angulare liegende Articulare vermittelt, das nicht selten mit einer doppelten Gelenkpfanne ausgestattet ist. Außer diesen können noch weitere Belegknochen, ein Operculare (Spleniale) Complementare, Infradentale, Supraangulare entwickelt sein. Die zahlreichen spitzen Zähne des Unterkiefers stehen in einer Reihe und nehmen von vorn nach hinten an Stärke ab; nur in der Symphysenregion, wo die beiden Äste in vielen Fällen offenbar nur durch Ligament verbunden waren, stehen zuweilen jederseits ein oder zwei groß3e Fangzähne, denen dann auf den Praemaxillaria ebensolche entsprechen. Ähnliche Fangzähne, häufig in paarweiser Entwicklung; begegnen uns auch auf dem Vomer und auf den Palatium in der Nähe der Choanen. Außerdem können sämtliche Knochen der Schädelunterseite mit kleinen (Chagrin) Zähnchen dicht besetzt sein.

Die $\mathrm{Z} a ̈ h n e^{1}$ ) der kleineren paläozoischen Stegocephalen stellen glatte, schlanke Kegel mit großer Pulpa dar (Fig. 279) und sind entweder direkt oder durch eine Zementbasis mit den zahntragenden Knochen verwachsen. Sehr häufig sind die untere Hälfte oder zwei Drittel der Außenseite der Länge nach gefurcht oder gestreift, und in diesem Falle zeigt die Dentinsubstanz bis zur gleichen Höhe eine von der Pulpa ausgehende radiale Faltung (Fig. 280). Von den radialen Pulpaausstülpungen, welche diese Falten bilden, strahlen dichtgedrängte Dentinröhrchen nach den Seiten und nach der Peripherie aus. Die Ausbuchtungen der Pulpa können sich bei den komplizierter gebauten Zähnen noch verzweigen und die sekundären Äste wieder laterale Ausstülpungen aussenden; gleichzeitig dringen alsdann zwischen die

1) Credner Herm., Zur Histologie der Faltenzähne paläozoischer Stegocephalen. Abhandl. k. sächs. Ges. Wissensch. math.-phys. Kl. 1893. Bd. XX. 
radialen Dentinbündel von außen dünne Streifen von Zementsubstanz, welche die Oberfläche des Zahnes bedeckt, in das Innere ein und machen dabei wellige oder mäandrische Biegungen. Dadurch entsteht jene überaus charakteristische Labyrinthstruktur, welche vorzugsweise bei den geologisch jüngeren und größeren Vertretern der Stegocephalen vorkommt (Fig. 281). Da die Ausstülpungen der Pulpa nur so weit reichen, als äußerlich die Furchung oder Streifung vorhanden ist, so wird die Struktur der Zähne nach oben immer einfacher, und die eigentliche, mit Schmelz bedeckte Krone zeigt nur noch eine enge einfache Pulpa, von welcher radiale Dentinröhrchen nach außen ausstrahlen.

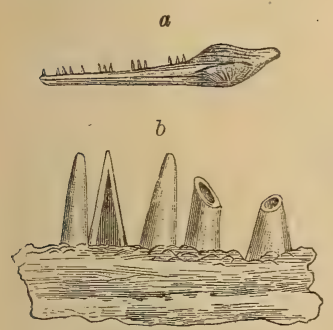

Fig. 279.

Unterkiefer von Branchiosaurus mit einfachen glatten Kegelzähnen. $a$ nat. Gr., $b$ vergr. (Nach Credner.)

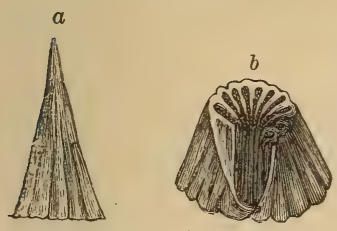

Fig. 280 .

Zahn von Archegosaurus. Vergr. $a$. von außen, $b$ untere Hälfte aufgebrochen, um die Faltung der Dentinsubstanz zu zeigen.

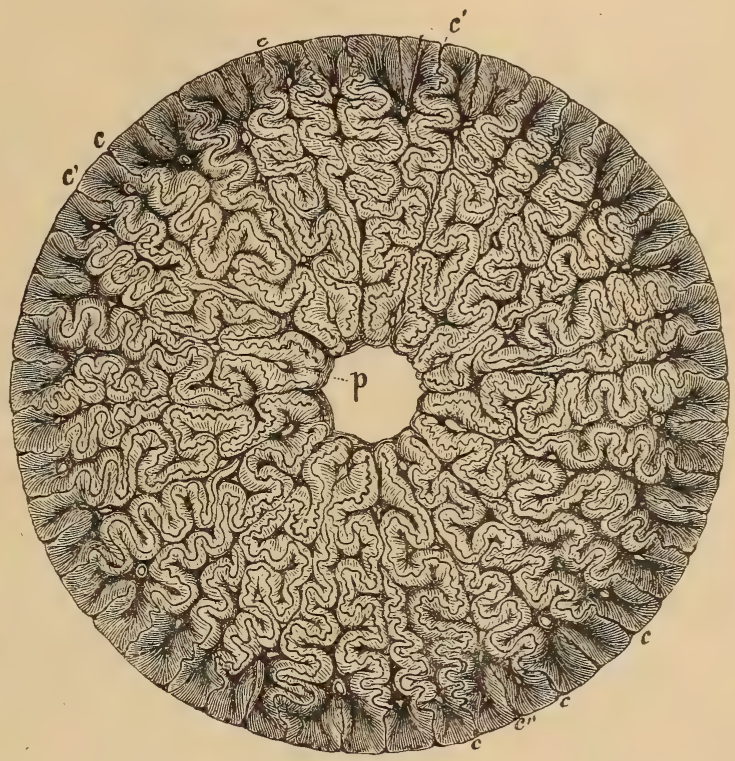

Fig. 281.

Querschnitt durch einen Zahn von Mastodonsaurus Jaegeri. $3 / 1$. (Nach R. Owen.) P Pulpa, $c$ Zement.

Neben acrodonter und pleurodonter Bezahnung (s. b. Amphibien) finden sich auch Formen, bei denen die Zähne in seichten Alveolen (oder in Alveolarrinnen) stehen ${ }^{1}$ ), auf deren Boden sie festgewachsen sind (protothecodont).

Der Bru stgürtel (Fig. 282, 83) besitzt bei den Stegocephalen einen höchst charakteristischen, von dem der übrigen Amphibien erheblich abweichenden Bau. Die auffallendsten, größten und meist auch best erhaltenen Knochen liegen auf der Bauchseite und bilden unter der Kehle einen aus drei Platten zusammengesetzten, meist noch in der Haut gelegenen, äußerlich sichtbaren und in der Regel wie die Schädelknochen mit starken Skulpturen bedeckten Kehlbrustpanzer. Die Mittelplatte, das Episternum (Interclavicula, Entosternum) unterscheidet sich bei den verschiedenen Gattungen sehr erheblich nach Größe und Form; am häufigsten ist sie von rhombischer, zuweilen

1) C. Röse, Das Zahnsystem der Wirbeltiere. Frgebnisse d. Anat. u. Entwicklungsgesch. v. Merkel u. Bonnet. II. Abt. 1894. 
auch von quer ovaler Gestalt oder verlängert sich hinten in einen stielförmigen Fortsatz.

Die beiden seitlichen, meist dreiseitigen Platten, die Claviculae, lagern sich entweder nur den Seiten des Episternums an, oder sie legen sich teilweise auf dasselbe oder aber sie vereinigen sich gegenseitig vor seinem Vorderrand. Nach hinten und oben ist die Clavicula stielartig verlängert und tritt hier mit einem dünnen, spangen- oder

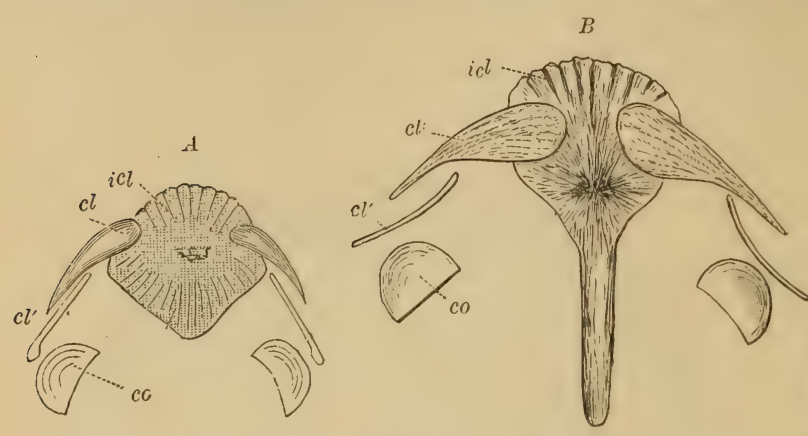

Fig. 282.

A Schultergürtel von Branchiosaurus. B Schultergürtel von Melanerpeton. (Vergr. nach $\mathrm{C} \mathrm{r} \in \mathrm{d} \mathrm{n} \boldsymbol{\mathrm { r }}$.)

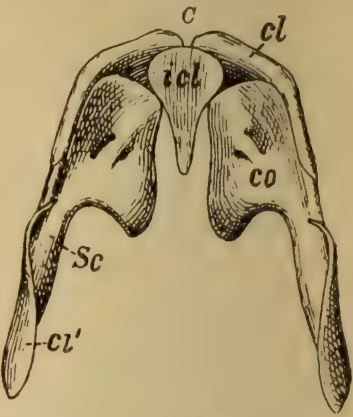

Fig. 283. $C$ Schultergürtel von Cacops aspidephorus (nach Williston). Dorsalansicht. icl Episternum, cl Clavicula, Co Coracoid, Sc Scapula, $c l^{\prime}$ Cleithrum. $1 / 8$ n. Gr.

löffelförmigen Knochen, dem $\mathrm{Cl}$ eithrum, in Verbindung. Scapula und Coracoid verknöchern vielfach nicht oder nur als unvollständige Knochenkerne; so wird ein scheibenförmiger, an einem Ende bogenförmiger, abgerundeter, am anderen Ende abgestutzter oder auch ausgeschnittener Knochenkern gewöhnlich als Coracoid(Omoplate) gedeutet, in andern Fällen sind aber beide Elemente verknöchert und z. B. bei Eryops, Trematops, Cacops zu einem einheitlichen Knochen verschmolzen, der außer einem Foramen supracoracoideum und einem

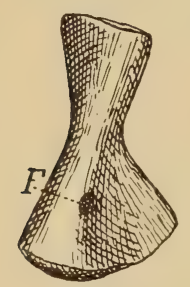

Fig. 284 .

Humerus v. Diplocaulus. (Dorsalansicht) mit Foramen entepicondyloideum $F$. n. Williston. $1 / 2$ nat. Gr. fensterartigen Durchbruch (Fenestra coraco-scapularis), auch eine von beiden gebildete Gelenkhöhle für den Humerus (Fossa glenoidalis) aufzuweisen hat.

Extremitäten fehlen nur in seltenen Fällen (Aistopodidae), die Knochen der Vorderextremitäten stimmen vielfach (Phyllospondyli, Lepospondyli) in Form, Zahl und Anordnung mit denen der jetzt lebenden Urodelen überein. Der Humerus (Fig. 284) besitzt nur ausnahmsweise Gelenkköpfe und bleibt in der Regel knorpelig. Bei den Temnospondyli dürfte bei der Mehrzahl der bekannten Formen der proximale Teil des Humerus um den distalen um $90^{\circ}$ gedreht sein. Ein Foramen entepicondyloideum findet sich selten (Diplocaulus, Cochleosaurus). Radius und Ulna, die beiden Vorderarmknochen, sind stets getrennt und ohne Gelenkflächen. Der Carpus bleibt vielfach knorpelig, in anderen Fällen (z. B. Eryops) sind zwei Reihen von Knöchelchen nachgewiesen. Die Metacarpalia und die Phalangen der 4 oder 5 Finger sind längliche Knöchelchen. 
Der Beckengürtel (Fig. 285) ist kräftig entwickelt, jedoch selten günstig erhalten. An die eine Sacralrippe heftet sich jederseits ein stämmiges, median gewöhnlich etwas verengtes Ilium (Hüftbein) an, der hintere Ast des ventralen Abschnittes das Ischium (Sitzbein) vereinigt sich zuweilen mit dem vorderen, häufig durch ein Foramen obturatorium charakterisierten Element, dem P u b is (Schambein) zu einer einzigen Platte (Eryops), die dann mit der entsprechenden Platte der Gegenseite in der Symphyse sich vereinigt. Häufig bleibt das Pubis, namentlich bei kleinen Formen überhaupt knorpelig, zuweilen bleiben auch die beiden Ossifikationen getrennt (Mastodonsaurus).

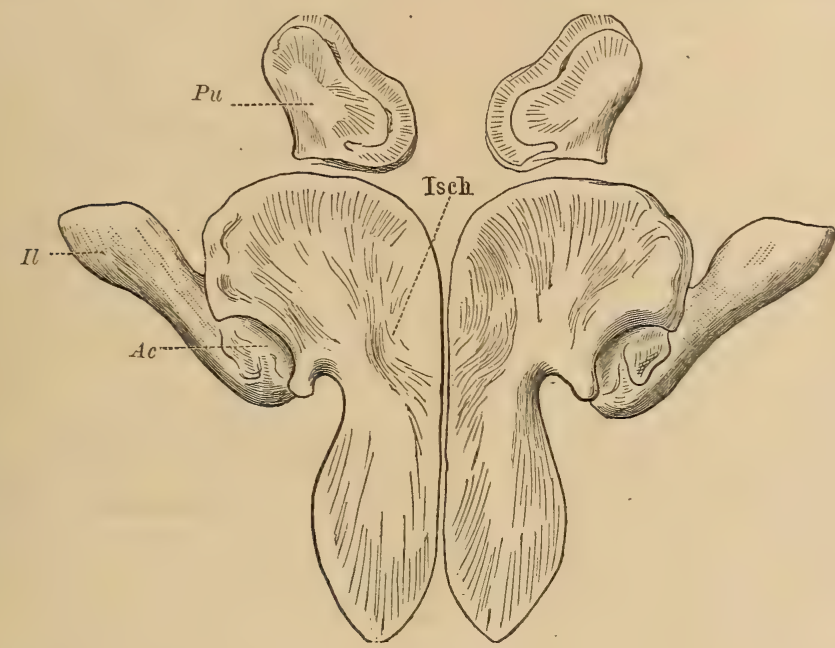

Fig. 285 .

Becken von Mastodonsaurus giganteus Jaeg. (Nach Eb. Fra a s.) Il (Ilium) Darmbein. Isch (Ischium) Sitzbein. $P u$ Schambein (Pubis). Ac Pfanne (Acetabulum) für das Femur.

Die Hinterfüße übertreffen die Vorderfüße fast immer etwas an Länge. Der Femur (Oberschenkel) ist ein im Verhältnis zum Humerus kräftiger, schlanker Knochen ohne verknöcherten Gelenkkopf, aber nicht selten unterhalb der proximalen Gelenkfläche mit einer kräftigen Vorragung (Trochanter minor) ausgestattet, distal sind hingegen die Condylen häufig wohl ausgebildet. Tibia und Fibula sind getrennt und gleichen den homologen Vorderarmknochen. Der Tarsus ist knorpelig oder mit zwei (drei bei Trematops) Reihen von Knöchelchen versehen. Die Metatarsalia und Phalangen sind wenig verschieden von denen des Vorderfußes; von den fünf Zehen ist bald die zweite, bald die dritte am längsten.

Die Stegocephalen bilden eine im oberen Devon schon durch Fußspuren nachgewiesene, im Karbon bereits verbreitete und in der oberen Trias aussterbende Ordnung, welche die größten Vertreter der Amphibien enthält. Sie durchlaufen wahrscheinlich alle ein Larvenstadium mit Kiemenatmung, deren Reste uns in den häufig erhaltenen Ki emenbogenzähnchen jugendlicher Individuen vorliegen. Sämtliche genauer bekannte Gattungen sind mehr oder weniger geschwänzt, die meisten vierbeinig, einige wenige fußlos. Aus ihrem Vorkommen in den petrographisch verschiedenartigsten Sedimenten der genannten 
Zeitdauer ergibt sich, daß diese teils kleinen, salamandergleichen, teils mittelgroßen, plumpen und schwerfälligen, häufig an Krokodile erinnernden Lurche in süßen, brackischen, selbst in Küsten-Gewässern (Trias, von Spitzbergen), in sumpfigen Deltaniederungen (Texas) und auf dem Festland gelebt haben. Die kleineren Formen scheinen sich vielfach in hohlen Baumstämmen eingenistet zu haben, da ihre Reste in Neuschottland vorzugsweise in Sigillarien- und Lepidodendronstämmen vorkommen. Die größeren Stegocephalen waren meistens Raubtiere, die sich von kleineren Amphibien oder Reptilien, Fischen und Crustaceen nährten.

Sie unterscheiden sich von den übrigen Amphibien, unter welchen die Gymnophionen mit ihrem solid verknöcherten Schädel und ihren verschiedentlich auftretenden Hautverknöcherungen eine gewisse Ähnlichkeit nicht verkennen lassen, durch die konstant größere Zahl der das geschlossene Schädeldach bildenden Belegknochen, ferner durch den Besitz des Foramen parietale, durch den charakteristischen Bau des Brustgürtels und die enorme Entwicklung eines Hautpanzers sowie vielfach noch durch die labyrinthische Struktur der Zähne.

Das von Deckknochen gebildete Schädeldach mit seinen Schleimkanälen, die von M o o di e nachgewiesene Seitenlinien, die Entwicklung der Wirbel, die Faltung der Zähne, der Besitz eines an zahlreichen Koprolithen konstatierten Spiraldarmes ${ }^{1}$ ) sind Merkmale, die an die Fische, in ihrer Gesamtheit aber an Dipnoer, besonders die Ganoiden (Amia, Polypterus, Dendrodus, Caturus, Eurycormus) erinnern, ein wirklich vermittelndes. Glied hat sich indessen noch nicht nachweisen lassen. Weit inniger gestalten sich aber die verwandtschaftlichen $\mathrm{Be}$ ziehungen der temnospondylen Stegocephalen zu den Cotylosauriern unter den Reptilien, die, abgesehen vom Gesamthabitus, in der Anordnung der, die gleichfalls geschlossene Schädeldecke bildenden, Belegknochen (Seymouria), im Bau des Schultergürtels und Beckengürtels sich von höher entwickelten Stegocephalen kaum unterscheiden, so daß diese beiden Gruppen wohl im innigen genetischen Zusammenhange stehen dürften:

\section{Unterordnung. Phyllospondyli (Credner). Blattwirbler.}

Wirbel tonnenförmig von zwei ventralen und zwei dorsalen zarten Knochenblättern gebildet, die Rückenmark und die nicht eingeschnürte Chorda umschließen. Prä- und Postzygapophysen und Processus spinosus an den zwei dorsalen Blättern entwickelt. Zähne einfach mit großer Pulpa. Karbon und Perm.

\section{Familie. Branchiosauridae. Fritsch.}

Salamanderähnliche, kurzgeschwänzte Lurche, mit breitem, stumpfem Schädel. Hinterhaupt nicht verknöchert. Carpus und Tarsus knorpelig. Rippen kurz, dick, gerade. Keine verknöcherten Schambeine vorhanden. Bauchschuppen dünn, schmal und zugespitzt, in Reihen angeordnet.

Branchiosaurus Fritsch (= Protriton Gaudry2), Syn. Pleuronura Gaudry) Fig. 266, 67, 77, 82, 86, 87. Körper 15-120 mm lang, kurz ge-

1) Neumayer L., Die Koprolithen des Perms von Texas. Palaeontographica. 51. Bd. 1904.

2) Nach Lydekker u. Thevenin gebührt sProtriton« die Priorität. Aus Zweckmäßigkeitsgründen ist hier noch der alte allgemein gebrauchte Name vorangesetzt. 
schwänzt. Schädel fast ebenso breit als lang, vorn stumpf abgerundet, hinten gerade abgestutzt. Neben den Tabularia ein seichter Ohrausschnitt. Kopfknochen dünn, radial gestreift und mit Grübchen bedeckt. Augenhöhlen sehr groß, rundlich-oval, mit einem aus ca. 30 Plättchen zusammengesetzten Scleroticaring und einem aus kleinen Plättchen bestehenden Augenlidpflaster. Schädelbasis (Fig. 277) hauptsächlich vom langgestielten Parasphenoid gebildet, an dessen hintere große schildförmige Platte sich jederseits ein in zwei Arme sich gabelndes Pterygoid anschließt. Vomer paarig, quer dreieckig. Palatin unsicher bekannt. Praemaxillare und Maxillare, Dentale (Fig. 279)

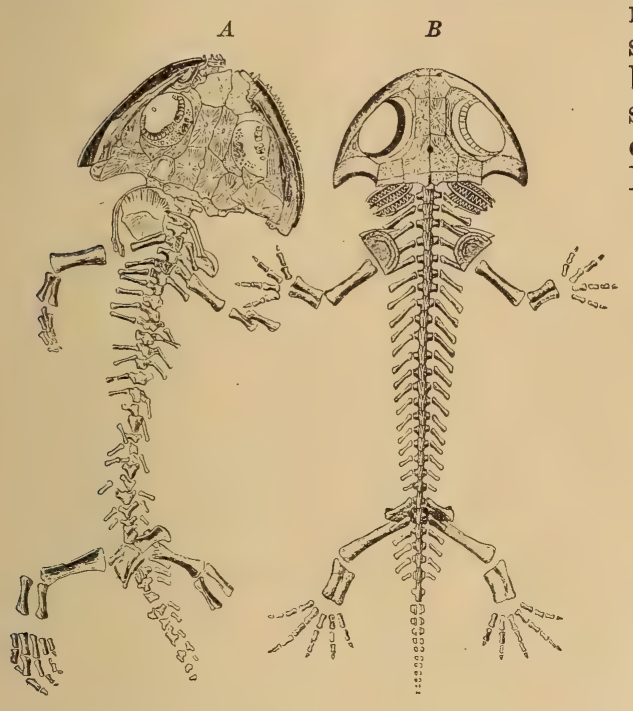

Fig. 286

Branchiosaurus (Protriton) amblystomus Credner. Rotliegendes. Niederhäßlich bei Dresden. A Skelett eines ausgewachsenen Individuums (nat. Gr.). $B$ Restauration einer Larve mit Kiemenbogen. (Nach Credner.) mit je einer Reihe dichtsteheder, schlanker, spitzkonischer Zähne besetzt. Episternum abgerundet vierseitig, gekrümmt. Ilia kräftig; Ischia dünn, dreiseitig; Hände mit vier, Füße mit fünf Zehen.

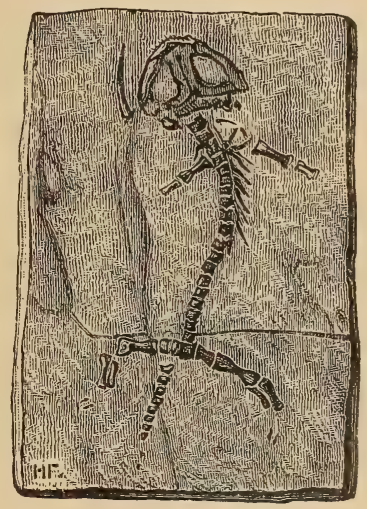

Fig. 287.

Branchiosaurus (Protriton) petrole Gaudry. Rotliegendes. Autun Nat. Gr. (Nach Gaudry.)

Zahl der präsacralen Wirbel (je nach dem Altersstadium) 20-26, 15 Schwanzwirbel. Rumpf, Schwanz und Extremitäten ventral mit Reihen dachziegelartig sich deckender Schuppen von quer ovaler Gestalt bedeckt (Fig. 266a). Dieselben sind in fünf Systemen angeordnet: die auf der Kehle bilden horizontale Querreihen, die auf der Brust schiefe, nach hinten konvergierende und in der Mitte zusammenstoßende Reihen; die Bauchschuppen dagegen bestehen aus parallelen, schräg nach vorn gerichteten und in der Mitte winklig sich vereinigenden Fluren; Schwanz und Extremitäten werden von schwach gebogenen Querreihen bedeckt. Die Larven von Branchiosaurus besaßen knorpelige, mit verkalkten und infolgedessen fossil häufig erhaltenen Zähnchen besetzte Kiemenbögen.

Neben Archegosaurus ist Branchiosaurus die häufigste und bestbekannte paläozoische Amphibiengattung. Sie findet sich häufig im grauen, dünnplattigen Kalkstein des mittleren Rotliegenden von Niederhäßlich im Plauen. schen Grund unfern Dresden. Die Knochen der kleinen Skelette heben sich durch ihre weiße Farbe scharf von dem grauen Gesteine ab. Credner konnte seinen sorgfältigen Untersuchungen über die Anatomie und Entwicklung dieser Art mehr als 1000 Exemplare zugrunde legen.

Branchiosaurus ist außerdem noch aus gleichalterigen Schichten von Oberhof und Friedrichsroda, dem Oberkarbon (Gaskohle) von Nürschan in Böhmen, aus dem unteren Rotliegenden von Braunau (Böhmen), aus den 
Lebacherschichten der Rheinpfalz und dem ? obersten Karbon (Stephanien) und dem unteren Perm von Autun (Frankreich) bekannt geworden.

Micrerpeton Moodie. Branchiosaurus sehr nahestehend. 17 Schwanzwirbel. (Zähne und Scleroticaring nicht beobachtet.) In der Schwanzregion durch Moodie Seitenlinien nachgewiesen. Oberkarbon. (Allegheny Series) Illinois.

Pelosaurus Credner (Fig. 266d). 18-20 cm lang. Kopf sehr groß, vor der Augenhöhle ein Lacrimale vorhanden. Im Rotliegenden von Niederhäßlich bei Dresden. Im unteren Perm von Autun. P. laticeps Credn.

Melanerpeton Fritsch. 25-130 mm lang. Schädeldach ähnlich Branchiosaurus, jedoch der hintere Teil desselben stark hinter die flügelartig ausgeschweiften Squamosa zurückspringend. Episternum hinten in einen stielförmigen Fortsatz auslaufend (vgl. Fig. 282 B). Ein eigentlicher Bauchpanzer nicht bekannt, dagegen zuweilen winzige chagrinartige Kalkpünktchen in großer Menge vorhanden. Jugendliche Exemplare mit Kiemenbögen. Im Rotliegenden von Braunau (Böhmen), Niederhäßlich (Sachsen) und Lhotka in Mähren.

Dawsonia Fritsch. Sämtliche obere Mundknochen mit Zähnen besetzt. Ob. Karbon. Böhmen.

\section{Unterordnung. Lepospondyli (Zitt). Hülsenwirbler} (= Microsauria Dawson).

Wirbelkörper aus einheitlichen, sanduhrühnlichen Knochenhülsen bestehend, welche Reste der Chorda umschließen. Ob. Bogen mit denselben fest veruachsen, durch Naht verbunden oder nur lose aufsitzend. Zühne einfach, mit großer Pulpa. Karbon. Perm.

\section{Familie. Microsauridae Dawson.}

Salamander-oder eidechsenïhnliche Stegocephalen mit wohlausgebildeten, zum Gehen oder Schwimmen brauchbaren Vorder- und Hinterextremitïten. Carpus und Tarsus verknöchert oder knorpelig. Rippen dünn, gebogen, häufig zweiköpfig. Schambeine meist verknöchert. Bauch (selten auch Rücken) mit rundlichen bis schmal spindelförmigen Schuppen bedeckt.

Die Systematik der Microsauridae, bei denen verschiedentlich ein verknöchertes Hinterhaupt und Schleimkanäle beobachtet werden, ist eine

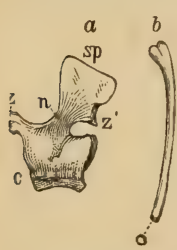

Fig. 288 .

$a$ Wirbel und $b$ Rippe von Hylonomus Lyelli Dawson. Karbon. Joggins, Neuschottland c Wirbelkörper, $n$ Ob. Bogen, $z$ Prä-, $z^{\prime}$ Postzygapophyse, $s p$ unbefriedigende. Manche Formen von noch wenig differenziertem Gesamthabitus (Hylonomus, Petrobates) werden von verschiedenen Autoren zu den Reptilien gestellt1).

Einen relativ kurzen Schwanz besitzen folgende Vertreter (Hylonomidae, Microbrachidae Fr., Limnerpetontidae Fr.):

Hylonomus Dawson (Hyloplesion Fritsch) (Fig. 268, 288). Schädelknochen glatt oder leicht skulptiert. Augenhöhlen klein, nach vorne gerückt. Tarsus, Carpus und Pubis ver. knöchert. 22-23 präsacrale Wirbel. Ob. Bogen dem Wirbelkörper nur lose aufsitzend. Rippen zweiköpfig. Schwanz halb so lang als der Rumpf. Rücken und Bauchseite nach Fritsch mit dachziegelartig sich deckenden ovalen Schuppen gepanzert. Ob. Karbon Neuschottland. Nürschan, Kounova. Mittl. Rotliegend. von Niederhäßlich.

1) Baur G. (Anat. Anz. XIV, 1897, S. 148) schließt auf die Reptiliennatur von Hylonomus und Petrobates aus den Abbildungen bei Credner, daß bei diesen zwei Sacralwirbel vorhanden wären. Abgesehen davon, daß dies den tatsächlichen Beobachtungen Credners widerspricht, wäre der Besitz von zwei Sacralwirbeln nicht ausschlaggebend, da solche sowohl bei lebenden Anuren als bei temnospondylen Stegocephalen beobachtet werden. 
Petrobates, Credner (Fig. 266h). Schädel schlanker wie der von Hylonomus, ca. 19 präsacrale Wirbel. Ob. Bogen mit dem Wirbelkörper verwachsen. Schwanz fast so lang wie der Rumpf. "Bauchrippen« aus spitz. spindelförmigen Elementen zusammengesetzt. Mittl. Rotl. von Sachsen.

Seeleya Fritsch. Klein, eidechsenförmig, großköpfig, kurzschwänzig. Schädelunterseite stark bezahnt. Rippen zweiköpfig. Ganzer Körper beschuppt. Ob. Karb. Nürschan, Böhmen. Orthocosta, Ricnodon Fr. Ob. Karbon. Nürschan. Gephyrostegus Jaekel. Schädeldach an Stelle der Schläfendurchbrüche verdünnt. Ob. Karbon. Nürschan. Odonterpeton Moodie. Ob. Karb. Linton, Ohio.

Limnerpeton Fr. Schädel groß, breit, mit großen, in der vorderen Schädelhälfte gelegenen Augen. 24 präsacrale Wirbel. Schwanz mäßig lang. Rippen einköpfig. Pubis verknöchert. Nur ventral zwischen Vorder- und Hinterextremitäten beschuppt. Ob. Karb. Nürschan.

Dendrerpeton Dawson. Oberkarbon Neuschottland und Böhmen.

Amphibamus Cope. Im Gesamthabitus ähnlich Limnerpeton, nur kürzerer Schwanz. Pubis unverknöchert. Ob. Karb. Illinois. Pelion Wyman. Ob. Karb. Nordamerika. Die Gattungen: Hylerpeton Owen, Brachy. dectes Cope, Amblyodon, Eoserpeton, Erpetosaurus Moodie, aus dem Oberkarbon von Neuschottland und Nordamerika sind ungenügend und unvollständig bekannt.

Acanthostoma Credner (Fig. 289). Schädel spitz parabolisch, grubig skulptiert. Facialgrube vorhanden. Augen mäßig groß, rund, in der hinteren Schädelhälfte. Elemente der Schädelunterseite mit einzelnen größeren Zähnen und Chagrinbezahnung dicht besetzt. Os transversum entwickelt. Rotliegendes. Niederhäßlich bei Dresden.

Microbrachis Fr. Schädel länglich dreieckig. Skulptiert. Facialgrube vorhanden. Augen mäßiggroß, ca.36Rumpfwirbel. Vorderextremitäten bedeutend kleiner. als die Hinterextremitäten. Ob. Bogen dem Wirbelkörper nur lose aufsitzend. Unt. Bogen zwischen den Schwanzwirbeln. Ob. Karb. Nür-

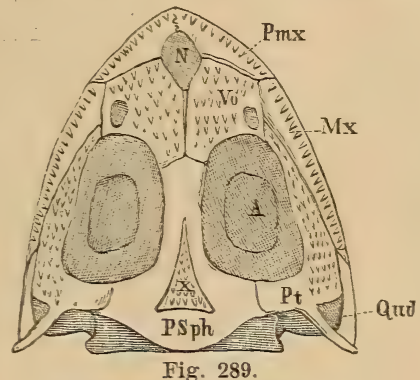

Unterseite des Schädels von Acanthostoma vorax. Restauriert in nat. Gr. (Nach Credner.) A Augenhöhle, $N$ Cavum internasale (Facialgrube) Pmx Prämaxilla, $M x$ Oberkiefer, QuJ Quadrato-Jugale, $P S p h$ Parasphenoid, Pt Pterygoid. VoVomero-palatiaa mit d. Choanen.

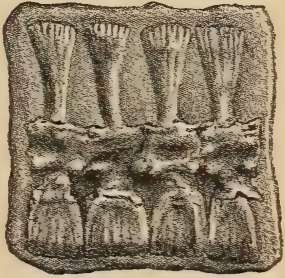

Fig. 290.

Urocordylus Wandesfordii Huxley. Steinkohlenformation. Kilkenny, Irland. Schwanzwirbel. Nat. Gr. (Nach Huxley.) schan.

Mit einem sehr langen, seitlich komprimierten Ruderschwanz sind in der Regel folgende Formen ausgestattet (Nectridae Miall, Ptyonidae Cope):

Urocordylus Huxley und Wrigth (Fig. 268, 290). Schädel dreieckig, hinten fast gerade abgestutzt. Kleine Augen in der vorderen Schädelhälfte. Schwanz fast doppelt so lang als der Körper, präsacrale Wirbel 20-27. $\mathrm{Ob}$ Bogen mit dem Wirbelkörper fest verwachsen. An den hinteren Rückenwirbeln am Processus spinosus, unpaarer vorderer und hinterer Gelenkfortsatz. Schwanzwirbel mit oberen und unteren fächerförmig ausgebreiteten Dornfortsätzen, von denen die oberen durch Zygosphen und Zygantrum gelenken. Vordere Extremitäten kleiner als die Hinterfüße. Bauchseite mit knöchernen, spindelförmigen Stäbchen bedeckt. Ob. Karb. Kilkenny Irland, Nürschan Böhmen. Ähnlich: Oestocephalus, Ptyonius Cope. Ob. Karb. von Linton (Ohio) und Nürschan Böhmen. 
Scincosaurus Fritsch (Fig. 292). Schädel breit, dreiseitig gerundet. Augen klein, weit vorne liegend. Ob. Bogen mit dem Wirbelkörper verwachsen. Ob. und unt. Bogen der Schwanzwirbel als seitlich gekerbte Platten ausgebildet. Carpus und Tarsus verknöchert. Bauchseite zwischen Schultergürtel und Becken von vierseitigen kräftigen Knorpelschuppen bedeckt. Ob. Karbon Nürschan.

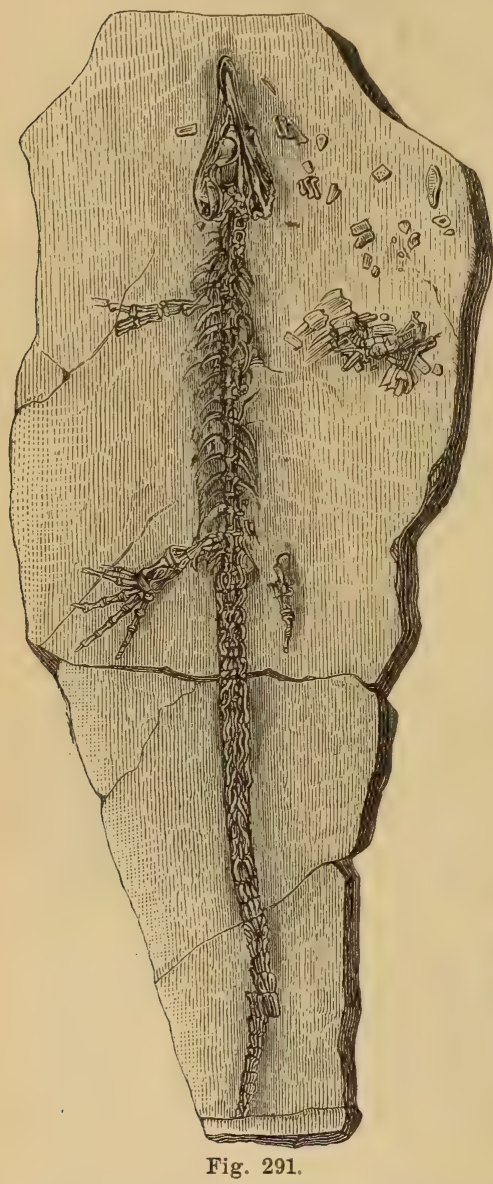

Lepterpeton Dobbsii Huxley. Steinkohlenformation. Kilkenny, Irland. $3 / 4$ nat. Gr. (Nach Huxley.)

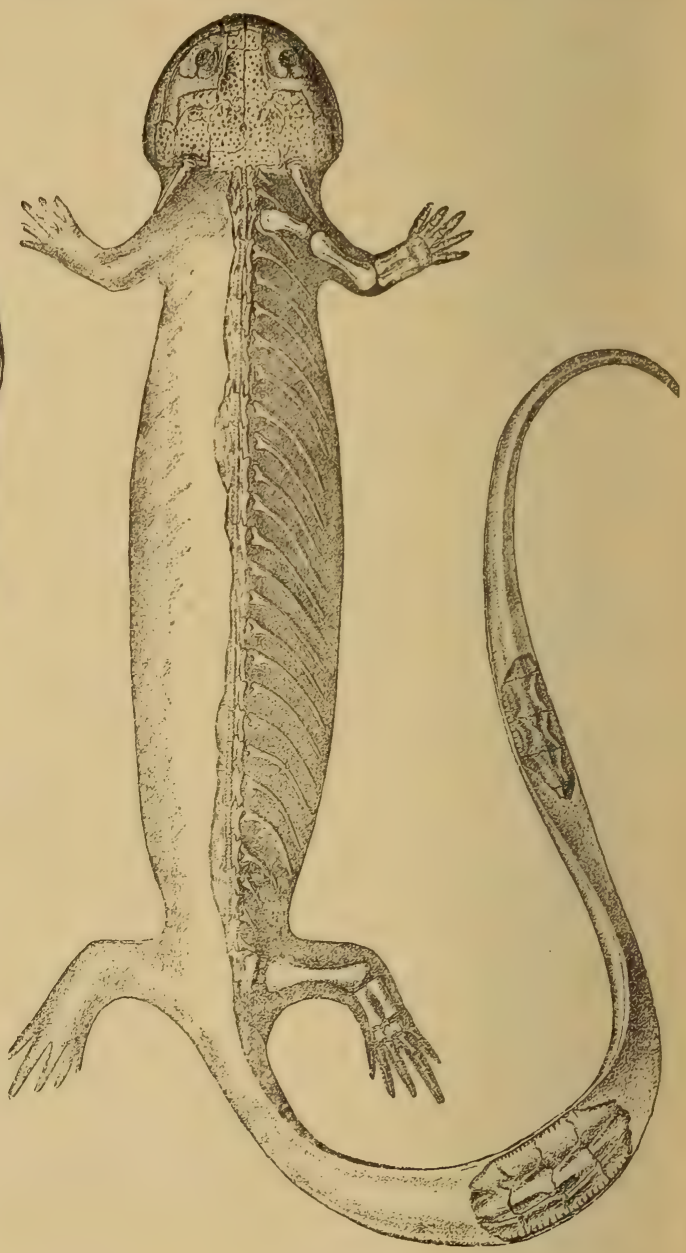

Fig, 292

Scincosaurus crassus. Fritsch. Oberkarbon. Gaskohle. Nürschan. Nat. Gr. Restauriert. (Nach Fritsch.) Die stachelartigen Fortsätze am Schädelhinterrand sind wahrscheinlich unrichtig.

Keraterpeton Huxley. Schädel dreiseitig, vorne abgestutzt, rückwärts in zwei »supraoccipitale« (postparietale) stachelartige Fortsätze verlängert. Augen groß. Präsacralwirbel 15-20. Bis zu 75 Schwanzwirbel, mit oberen und unteren Dornfortsätzen. Carpus und Tarsus unverknöchert. Füße gleich groß. Oberkarbon von Schottland und England.

Diceratosaurus Jaekel. Die hinteren seitlichen Belegknochen des grubigen Schädeldaches (Squamosum, Tabulare, Supratemporale und Intertemporale) zu einem großen, rückwärts stark verlängerten Knochen verschmolzen (Perisquamosum). Schädelunterseite mit Os transversum und ver- 
knöcherten Exoccipitalia lateralia. 12 präsacrale Wirbel. Bis zu 100 Schwanzwirbel. Rückenwirbel mit Zygosphen und Zygantrum. Dornfortsätze, distal verbreitert, in Verbindung mit grubigen Hautplatten. Ob. Karb. Linton, Ohio.

Lepterpeton Huxley (Fig. 291). Schädel länglich, dreieckig, Schnauze verschmälert. Augen in der Mitte der Schädellänge. Carpus und Tarsus nicht verknöchert. Hinterfüße etwas stärker als die vorderen, fünfzehig. Bauchschuppen länglich rhomboidisch. Ob. Karb. Kilkenny Irland.

Tuditanus, Sauropleura, Ctenerpeton, Pleuroptyx Cope, Stegops Moodie etc. aus dem Karbon von Nordamerika, sind unvollständig bekannt.

\section{Familie. Diplocaulidae. Cope.}

Körper langgestreckt, Froschlarvenähnlich, mit unverhältnismäßig kleinen Vorder- und Hinterextremitäten. Rippen kräftig, zweiköpfig, Hinterhaupt verknöchert.

Diploca ulus Cope(Fig.268, 274,293). Schädel halbmondförmig, sehrflach, grubig skulptiert. Nähte und Foramen parietale bei jugendlichen Individuen wahrnehmbar. Augen sehr weit nach vorne gerückt. Belegknochen rückwärts der Frontalia und Postfrontalia abnorm vergrößert, die Ohrenschlitze überwuchernd und seitlich flügelartig verbreitert. Frontalia miteinander verschmolzen. Quadratum in der vorderen Schädelhälfte. Maxillarzahnreihe

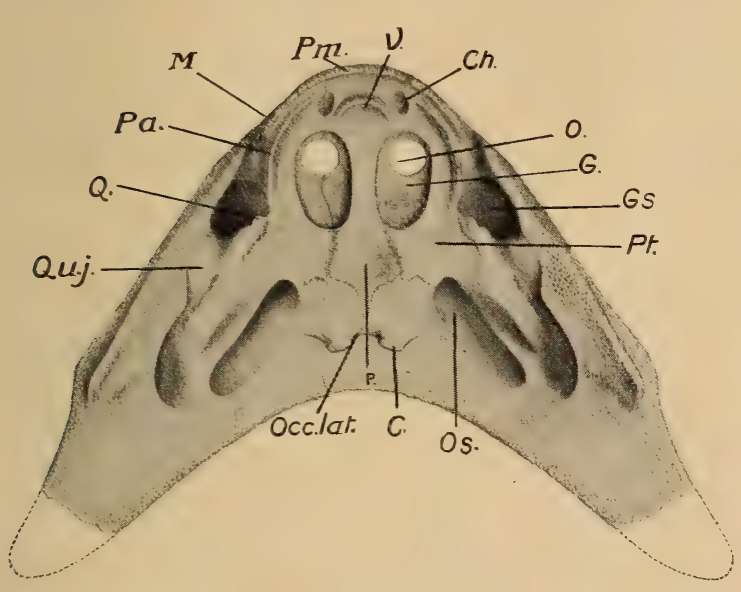

Fig. 293.

Diplocaulus magnicornis. Cope. Schädelunterseite. (Nach Broili.)

$O$ Augenöffnungen, Ch Choanen, $V$ Vomerregion, $P a$ Palatinregion, $M$ Maxillarregion, $P m$ Prämaxillare, $Q u j$ Quadratojugale, $P$ Parasphenoid, $P t$ Pterygoid, Occ. lat Occipitalia lateralia, $G$ Gaumengruben, $G s$ Gaumenschläfengruben, $O s$ Ohrenschlitzgruben (geschlossen.) Perm. Seymour, Baylor Co. Texas. ca. $1 / 5$ nat. Gr.

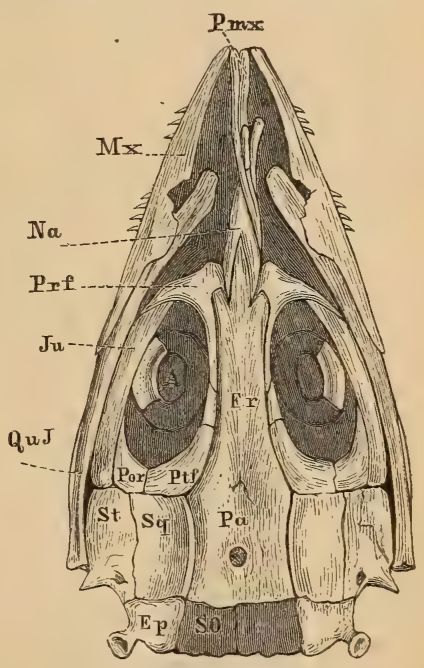

Fig. 294 .

Kopf von Dolichosoma longissimum Fritsch. Ob. Karbon. Nürschan, Böhmen. Restauriert in dreifacher Vergr. $S q$ Supratemporale, St Squamosum, So Postparietale, Ep Tabulare Sonstige Bezeichnungen wie früher.

ca. $1 / 2-1 / 3$ der ganzen Schädellänge einnehmend. Auf dem Palatin- bzw. Vomer zweite Zahnreihe. Zähne klein, gleich groß. Wirbelkörper tief amphicöl, fest mit oberem Bogen verschmolzen. Zygosphen-Zygantrum. Dornfortsätze nicht verknöchert. Vorderextremitäten kleiner als die Hinterextremi. täten. Humerus mit Foramen entepicondyloideum. Diplocaulus war wahrscheinlich nur ein Wasserbewohner. Perm. Nordamerika.

Crossotelos Case. Perm. Oklahama.

\section{Familie. Aistopodidae. Miall.}

Körper sehr lang, schlangenartig, ohne Extremitäten und Brustgïrtel. Rippen dünn, grätenartig. 
Dolichosoma Huxley (Fig. 291). Schädel schmal, dreieckig, mit zugespitzter Schnauze; die Kopfknochen glatt. Scheitel-, Stirn- und Nasenbeine bei $D$. longissimum miteinander verschmolzen. Zwischenkiefer sehr klein. Wirbel sanduhrförmig. Oberer Bogen breit mit niederem Dornfortsatz. Rippen einköpfig, zart. Bauchpanzer scheint zu fehlen. Steinkohlenformation von Kilkenny, Irland und Gaskohle von Nürschan, Böhmen.

Phlegethontia, Cope. Zygosphen zwischen den Postzygapophysen. Rippen und Schuppen kaum entwickelt. Oberer Karbon. Nordamerika.

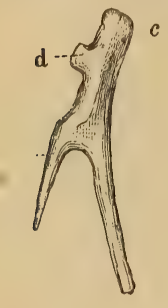

Fig. 295 .

Ophiderpeton granulosum Fritsch. Rippe in sechsfacher Vergr. Ob. Kar. bon. Gaskohle. Nürschan. c Capitulum, $d$ Tuberculum.

(NachFritsch)

Ophiderpeton Huxley (Fig. 295). Schädel unvollständig bekannt, kürzer und stumpfer als bei Dolichosoma. Oberer Bogen fest mit dem Wirbelkörper verwachsen. Dornfortsatz nieder. Unterer Querfortsatz als breite Platte in der vorderen Hälfte des Wirbels entwickelt. Rippe zweiköpfig aus einem ventralen Abschnitt (Capitulum und langen Fortsatz) und einem dorsalen Teil (Tuberculum und kurzen Fortsatz) bestehend. Bauchschuppen haferkornförmig, schmal, lang, vorn und hinten zugespitzt; Rückenschuppen ähnlich Chagrinkörnern. O. Brownriggi Huxley aus Kilkenny in Irland wird 40-60 cm lang. Fünf kleinere Arten in der Gaskohle von Nürschan, Böhmen.

Tyrsidium Cope. Ähnlich den vorigen. Oberes Karbon. Nord-Amerika.

Molgophis Cope. Unterer Querfortsatz als kräftige Leiste ausgebildet, ohne Schuppen. Oberes Karbon. Nordamerika.

3. Unterordnung. Temnospondyli (Zitt). Kranz-oder Schnittwirbler.

Wirbelkörper aus mehreren getrennten Knochenstïcken bestehend, meist rhachitom, selten embolomer. Chorda persistierend. Hinterhaupt knorpelig oder verknöchert. Carpus und Tarsus verknöchert. Zahnsubstanz radial gefaltet. Karbon. Perm und untere Trias.

\section{A. Rhachitomi.}

Archegosaurus H. v. Meyer (Fig. 266, 270, 271, 296, 297). Körper bis $1,5 \mathrm{~m}$ lang, mit ziemlich langem, seitlich komprimierten Schwanz. Schädel in der Jugend stumpf, dreieckig, wenig länger als breit, im Alter stark verlängert, mit schmaler, vorn abgerundeter Schnauze. Die Kopfknochen mit von Ossificationszentren ausstrahlenden Leisten und unregelmäßigen Gruben verziert. Augenhöhlen in der hinteren Hälfte, an jungen Individuen in der Mitte der Schädellänge; Scleroticaring aus 20-23 Plättchen bestehend. Nasenlöcher länglich. Hinterhaupt nur bei alten Individuen verknöchert, sonst knorpelig. Auf Palatin und Vomer einzelne größere Zähne vorhanden. Os transversum entwickelt. Kieferzähne bis zur halben Höhe mit tiefen Furchen, mit einfachen, radialen Einstülpungen der Zahnsubstanz (Fig. 280). Jugendliche Individuen besitzen Kiemenbögen mit Zähnchen. Ca. 25 Rumpfwirbel. In der Schwanzregion heften sich starke untere Bögen an die Hypocentra an und die Pleurocentra bestehen jederseits aus zwei Stücken. (Fig. 270, 271 plc, pla).

Die rhomboidische mittlere Kehlbrustplatte (Episternum) ist halb so lang als der Schädel, und wie die dreieckigen seitlichen Claviculae radiär skulptiert. Rippen sehr verschieden geformt. Pubis anscheinend nicht verknöchert. Vorderfüße vierzehig, viel schwächer als die fünfzehigen Hinterfüße. Bauchpanzer aus schmalen und langen gekielten, an einem Ende zu- 
gespitzten Schuppen gebildet, welche dachziegelartig übereinander liegen. (Fig. 266e.)

Sehr häufig in den Sphärosideritknollen des Rotliegenden von Lebach bei Saarbrücken. Rotliegendes von Sachsen.

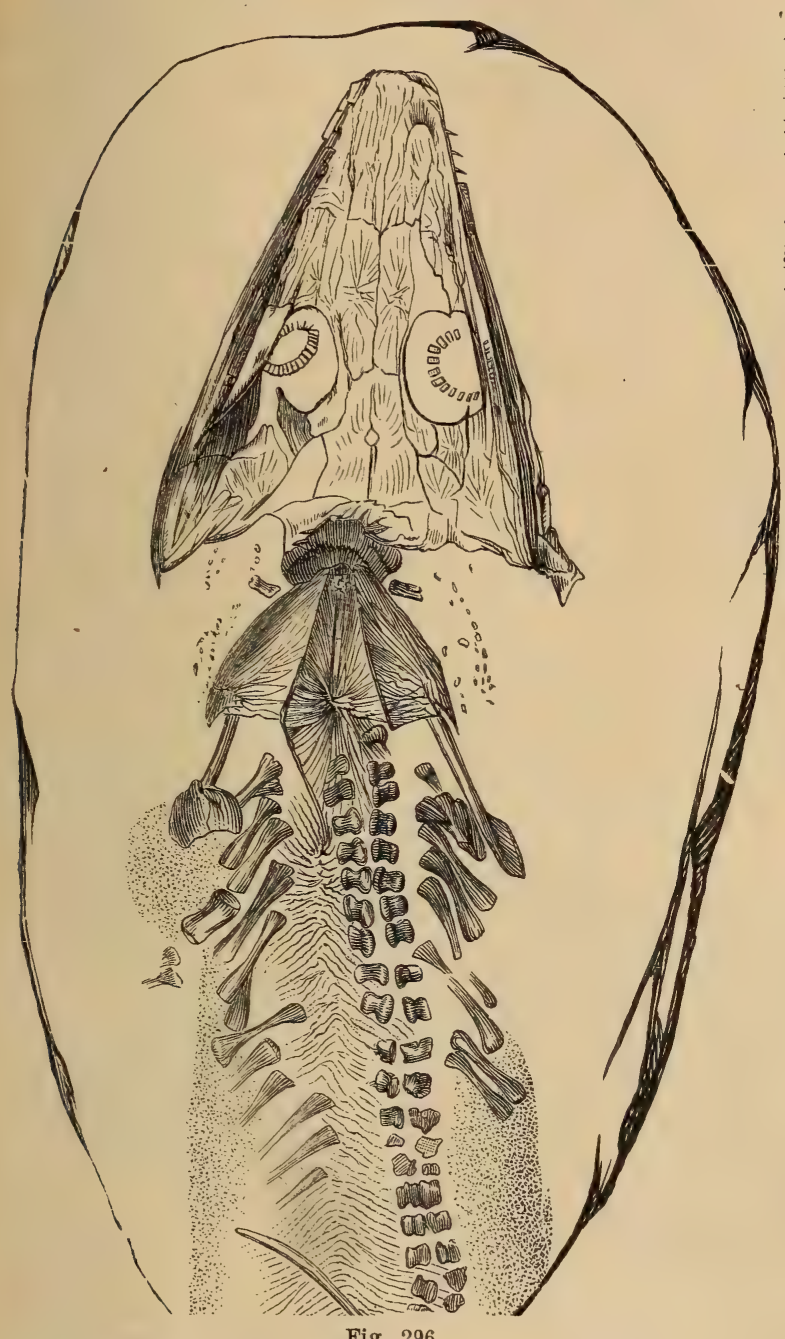

Archegosaurus Decheni H. v. Meyer. Aus dem Rotliegenden von Lebach bei Saarbrücken. Junges Exemplar mit Kiemenbögen in nat. Gr. (Nach H. v. Meyer.)

Als Archegosaurus ornatus wird von A. S. Woodward ein Schädelrest eines Stegocephalen aus dem Permokarbon von Kashmir beschrieben.

Sparagmites Fritsch, Discosaurus Credner (Figur $266 \mathrm{~g}$ ). Rotliegendes von Niederhäßlich und Böhmen.

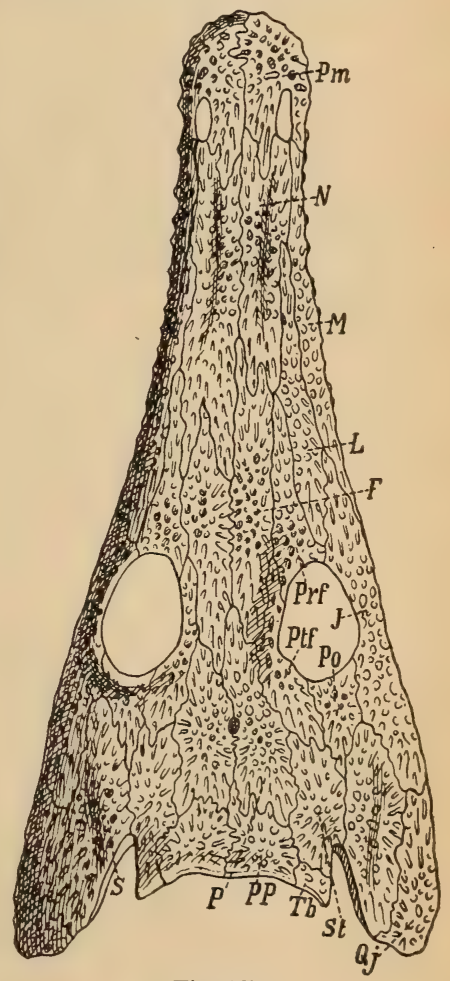

Fig. 297

Archegosaurus Decheni $\mathrm{H}$. v. Meyer. Schädel eines ausgewachsenen Exemplars. Rotliegendes, Lebach bei Saarbrücken ca. 1/, nat. Gr. nach Jaeckel. Bezeichnungen wie früher.

Cochleosaurus Fritsch (Fig. 275) (? Gaudrya Fritsch). Postparietalia (Supraoccipitalia) löffelförmig verlängert. Condyli occipitales bei erwachsenen Individuen verknöchert. Palatin mit einigen größeren Zähnen und wie die meisten übrigen Knochen der Schädelunterseite dicht mit Chagrinzähnchen besetzt. Humerus mit Foramen entepiconyloideum. Bauchpanzer aus spinçelförmigen Knochenstäbchen. Oberes Karbon. Nürschan Böhmen.

Chelydosaurus Fritsch. Tabulare (Epioticum) nach hinten spitz ausgezogen. Unteres Rotliegendes. Braunau. Böhmen. 
Nyrania Fritsch. Oberes Karbon. Nürschan. Böhmen. Böhmen.

? Sphenosaurus von Meyer. Möglicherweise ein Cotylosaurier. Perm.

Actinodon Gaudry (Euchirosaurus Gaudry) (Fig. 289.). Vomer und Palatin mit je einem großen Zahn und zahlreichen Körnchenzähnen. Augen groß. Becken ähnlich dem von Eryops. Unteres Perm. Autun. Frankreich.

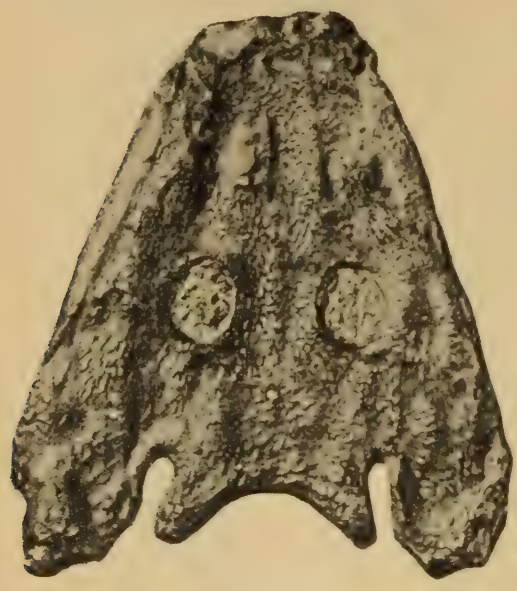

Fig. 298.

Actinodon Frossardi Gaudry. Schädel von oben. Ca. $1 / 3$ nat. Gr. (nach Thevenin.) Perm von Autun. Frankreich.
Dasyceps Lloyd em. v. Huene. Mit großer Facialgrube. Perm. Kenilworth b. Warwik).

Sclerocephalus Goldf. (Onchiodon Gein., Weissia Branco, Osteophorus H. v. M.) Für den auffallend breiten, stark skulptierten Schädel sind die kleinen, runden, im hinteren Drittel gelegenen Augen bezeichnend. Nasenlöcher weit vorn. Palatina mit kräftigen Fangzähnen. Bauchschuppen haferkornförmig. Die Gattung kann bedeutende Größe bis zu einem Meter, erreichen. Oberes Karbon. Nürschan. Rotliegendes der Pfalz und Niederhäßlich, Sachsen.

Melosaurus, Chalcosaurus, $\mathrm{H}$. v. Meyer, Zygosaurus Eichw., Platy ops Trautsch. Perm, Rußland.

? Pholidogaster Huxley. Unteres Karbon. Edinburg. Schottland.

Ery ops Cope. (Rhachitomus, Epicor. dylus, Parioxys) Cope (Fig. 269, 299). Größter bis jetzt in Nordamerika nachgewiesener
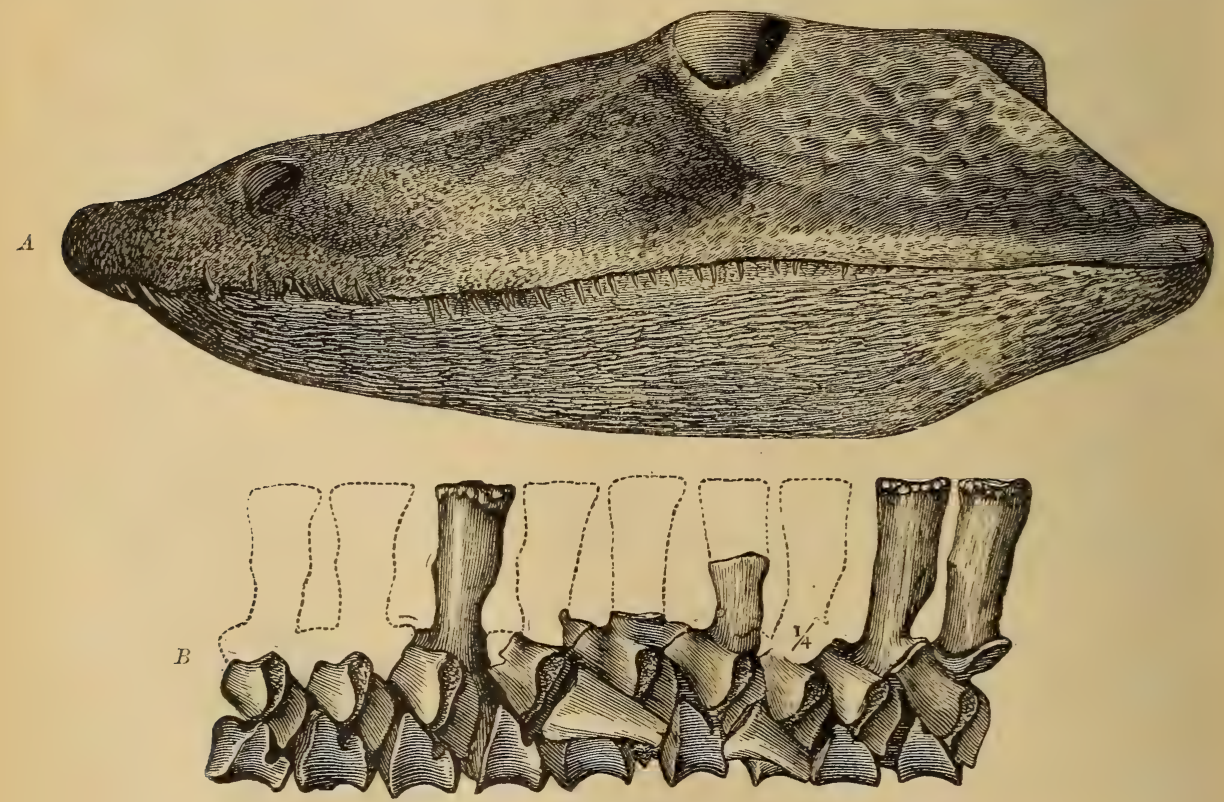

Fig. 299.

Eryops megacephalus Cope. Perm. Texas. A Schädel von der Seite. 1/5 nat. Gr. $B$ Stück der Wirbelsäule. $1 / 4$ nat. Gr. (Nach Cope.) 
Stegocephale. Schädel bis über $60 \mathrm{~cm}$ lang und hinten $30-46 \mathrm{~cm}$ breit. Nähte und Foramen parietale im Alter verwischt. Skulptur höckerig, grubig. Augen relativ klein, in der hinteren Schädelhälfte. Nasenlöcher groß. Zähne verhältnismäßig klein, auf Palatin und Vomer einige größere Zahnpaare. Quadratum und Condyli verknöchert. Parasphenoid dolchförmig. 25-26 präsacrale Wirbel. Schwanz kurz. Rippen stark differenziert. Sacralrippe blattförmig. Becken in der Symphyse verschmolzen, alle 3 Elemente verknöchert. Vorderfuß mit 5, Hinterextremität mit ? 4 Zehen. Perm, Nordamerika.

Trimerorhachis, Zatrachis, Acheloma,? Anisodexis Cope. Car. diocephalus Broili. (Gymnarthrus Case.) Tersomius Case. Perm. Texas und Neu-Mexico.

Cacops Williston. Fig. 283. Schädel rauh skulptiert. Nasenlöcher und Augen ziemlich groß, weit voreinander getrennt. Foramen parietale groß. Die großen Ohrenschlitze von rückwärts geschlossen, so daß eine "falsche《

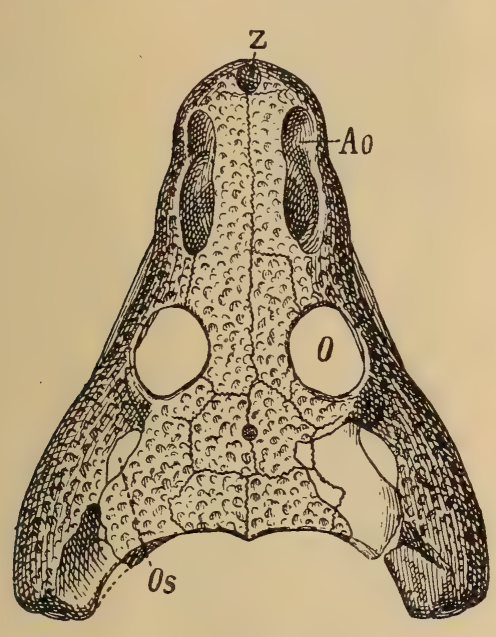

Fig. 300.

Trematops Milleri. Williston. Schädeloberseite. Perm von Texas (nach Williston).

$Z$ Facialdurchbruch, $A O$ Präorbitalöffnung und Nasenloch, $O$ Augen, $O S$ hintere geschlossene Ohrenschlitze (falsches Schläfenloch). (Nach Williston.) $3 / 10$ nat. Gr.

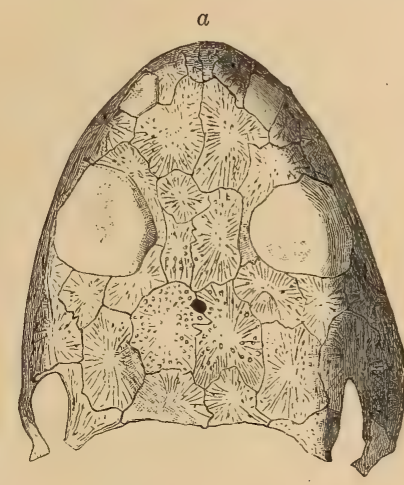

$b$

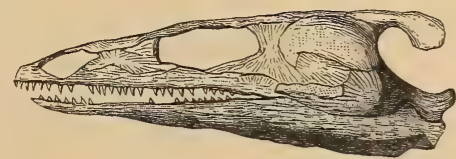

Fig. 301

Micropholis (Petrophryne) granulata Owen. Trias. Tafelberg, Südafrika. Schädel $a$ von oben, $b$ von der Seite. In nat. Gr. (Nach Owen.)

Schläfenöffnung entsteht. Quadratum und Condyli verknöchert. Parasphenoid in der Mitte spachtelförmig verbreitert. Vor und hinter der Choane ein größerer Zahn. 21 präsacrale Wirbel, zwei Sacralwirbel. Die distal verbreiterten -Dornfortsätze bilden mit dazwischen sich einschiebenden Hautverknöcherungen einen Rückenpanzer. Die vorderen Rippen zweiköpfig. Am Schultergürtel Cleithrum auffallend groß. Vollständige Skelette beschreibt Williston aus dem Perm von Texas.

Dissorophus Cope. Fig. 274B. Besitzt einen ähnlich gebildeten, aber viel mächtiger entwickelten, halb-tonnenförmigen Rückenpanzer. Perm. Texas. Otocoelus Cope. Nahe verwandt, wenn nicht identisch mit Dissorophus. Perm. Texas.

A spidosaurus Broili. Rückenpanzer dem First eines Daches ähnlich. Die Hautverknöcherungen grenzen aneinander. Perm. Texas.

Trematops Williston (Fig. 300). Schädel mit großem Facialdurchbruch, langgestreckte Präorbitallücken, deren vorderer Teil von den Nasen. löchern eingenommen wird. Ohrenschlitze wie bei Cacops von rückwärts 
geschlossen. Zwei Condyli occipitales. Basisphenoid vorhanden. Parasphenoid reduziert oder fehlend. Palatinum mit zwei Paar größeren Zähnen. Zirka 23 präsacrale rhachitome Wirbel. Nur ein Sacralwirbel. Rippen kurz. Perm. Texas.

Micropholis Huxley (Petrophryne Owen) (Fig. 301). Nur der flache, niedrige Schädel erhalten; Augenhöhlen groß, vor der Mitte, Nasen. löcher weit vorne. $\mathrm{Z}$ wischen den Unterkiefern kleine polygonale Knochenschuppen (Gularplatten). Trias. Süd-Afrika. Afrika.

Batrachosuchus Broom. Trias Süd-

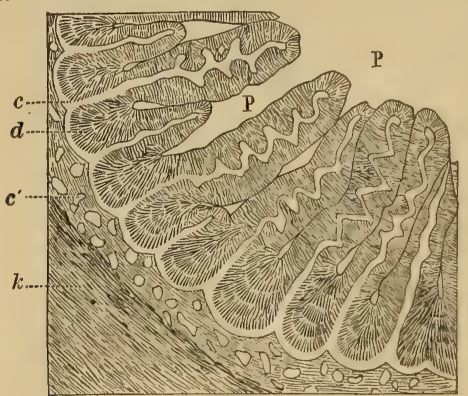

Fig. 302.

Querschnitt eines Zahnes von Loxomma Allmanni Huxley in der Nähe der Basis. Steinkohlenformation. Northumberland. Vergr. (Nach Embleton u. Atthey.) $k$ Knochensubstanz des Kiefers, $c^{\prime}$ Zahnsockel aus Zement, $d$ Dentin $u$. Zementeinstülpung en, $P$ Pulpa.

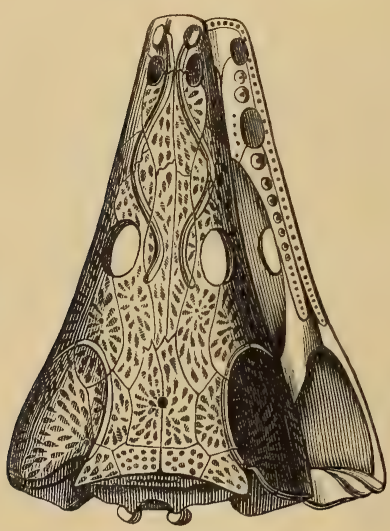

Fig. 303.

Schädel von Trematosaurus Brauni Burmeister, mit deutlicher Lyra aus dem Buntsandstein von Bernburg. 1/4 nat. Gr. (Nach Burme ister.)

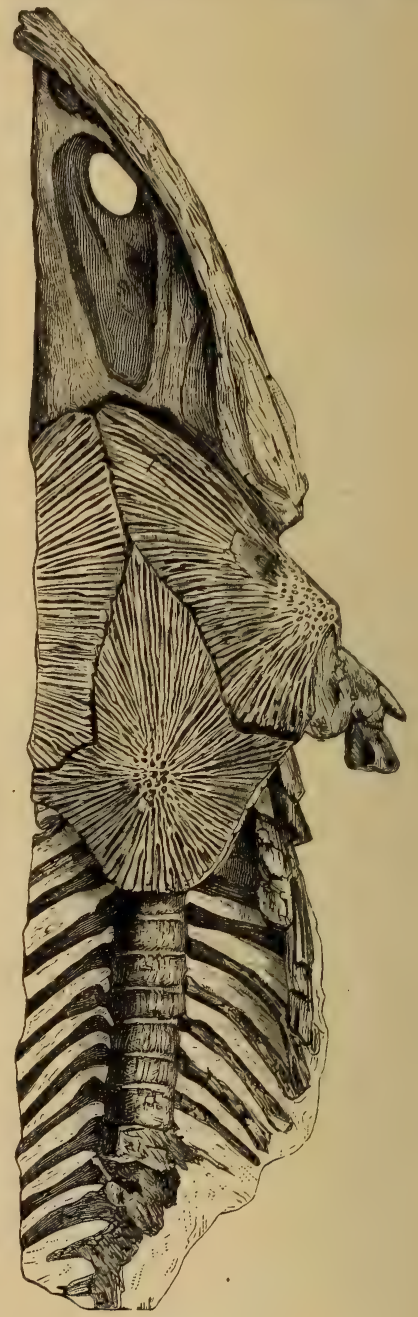

Fig. 304.

Metopias diagnosticus. H. $\mathbf{\text { v. Meyer. }}$ Skelettfragment von der Unterseite. Keupersandstein von Hahnweiler bei Stuttgart. $1 / 8$ n. Gr. (Nach Eb. Fraas.)

Brachyops Owen, Gondwanosaurus Lydekker. Perm. ? Trias (Gondwana.Schichten). Ostindien.

Bothriceps Huxley. Schädel dreieckig; Kopfknochen rauh skulptiert. Nasenlöcher weit vorn. Parietalia sehr groß. Zähne spitzkonisch, außen gefurcht. Trias. Australien und Südafrika. 


\section{B. Embolomeri.}

Cricotus Cope. Körper langgestreckt, mit kurzen stämmigen Extremitäten. Schädel verlängert, dreieckig. Schnauze verschmälert. Augenhöhlen groß, länglich oval, etwa in der halben Länge des Schädels gelegen. Kopfknochen schwach skulptiert, Schleimkanäle vorhanden. Zähne spitz, von ungleicher Größe. Wirbel embolomer, aus zwei getrennten, in der Mitte durchbohrten Scheiben bestehend, wovon nur die vordere obere Bögen und Rippen trägt. Bauchschuppen rhomboidisch Perm. Texas und Illinois. Diplovertebron Fritsch (Fig. 273). Nur Fragmente vom Schädel und der Wirbelsäule bekannt. Ob. Karbon. Nürschan. Böhmen.

Nummulosaurus Fr. Wirbel anscheinend wie bei Diplovertebron. Ob. Karb. Tremosna Böhmen.

\section{Unterordnung. Stereospondyli. (Zitt.) Vollwirbler. (= Labyrinthodontidae Owen, Euglypta Miall.)}

Wirbelkörper aus einer vorn und hinten etwas ausgehöhlten amphicölen, im Zentrum zuweilen durchbohrten Knochenscheibe bestehend. Hinterhaupt verknöchert. Dentinsubstanz der Zähne labyrinthisch gefaltet. Schleimkanäle häufig zwischen den Augenhöhlen und den Nasenlöchern eine Lyra bildend. Unteres Karbon bis obere Trias.

Die Stereospondyli sind in der Regel durch gewaltige Fangzähne auf Vomer und Palatinum ausgezeichnet und ihr Schädel ist stark skulptiert. Ein Scleroticaring und Bauchpanzer ist bis jetzt bei den triadischen Formen noch nicht beobachtet worden.

Anthracosaurus Huxley. Schädel breit, dreieckig, bis $1 / 2 \mathrm{~m}$ groß, grubig skulptiert. Augenhöhlen gerundet. Wirbelkörper amphicöle, leicht von der Chorda durchbohrte Scheibe. Bauchschuppen an einem Ende zugespitzt. Ob. Karbon. England. Schottland.

L ox om ma Husley (Fig. 272, 302). Schädel mit sehr gut entwickelten Schleimkanälen. Augenhöhle nach vorne in eine Präorbitalöffnung übergehend, wodurch seitlich am Schädel ein langgestreckter Durchbruch entsteht. Die ältesten Reste finden sich bereits im Eisenstein von Gilmerton (Unteres Karbon), Edinburg, Schottland. Oberes Karbon England.

Eosaurus Marsh. Nur große amphicöle Wirbelkörper bekannt, die auf ein sehr großes Tier schließen lassen. Oberes Karbon. Neuschottland.

? Baphetes Owen. Unvollkommenes Schädelfragment. Oberes Karbon. Neuschottland. ? Macrerpeton Moodie. Oberes Karbon Linton, Ohio.

Erpetosuchus Moodie. Unt. Perm. Kansas.

Anaschism a Branson. Der über $1 / 2 \mathrm{~m}$ große Schädel fast dreieckig, skulptiert. Ohrenschlitze klein. Augen in der vorderen Schädelhälfte, klein. Die großen Nasenlöcher mit den Prämaxillardurchbrüchen der großen Vomerzähne zusammenfallend. Os transversum entwickelt. Wirbelkörper platycöl Trias (Lander region) Wyoming. Zu dieser Gattung dürfte auch Metoposaurus Fraasi Lucas aus der Trias von Arizona gehören.

Dictyocephalus Leidy. Ähnlich Trematosaurus. Trias. Chatham Co. North Carolina. Eupelor, Pariostegus Cope. Trias. Nordamerika. Aphaneramma A. S. Woodward. Schädel sehr langgestreckt mit schlanker Schnauze. Schleimkanäle. Wirbelkörper amphicöl. Mit dieser Form zusammen findet sich der nahestehende

Lonchorhynchus Wiman, in Ablagerungen marinen Charakters in der Trias (Muschelkalk Spitzbergens).

Tremat́osaurus Braun (Fig. 303). Schädel länglich dreieckig mit vorn abgerundeter Schnauze. Augenhöhlen in der Mitte des Schädels. Lyra sehr deutlich. Auf dem Palatin eine zweite Zahnreihe, außerdem über den 
Choanen und dem Vomer einige größere Zähne. Unterkiefer mit großen Fangzähnen, denen am Schädel zwei getrennte Prämaxillardurchbrüche entsprechen. Episternum lang, gestielt. Buntsandstein. Bernburg. ? Trias (Burghersdorp beds, Südafrika).

Metopias H.v. M. (= Metoposaurus Lydekker)1) (Fig. 304). Schädel breit, mit stumpfer Schnauze. Augen groß, in der vorderen Schädelhälfte, weit voneinander getrennt. Episternum hinten gerundet. Bezahnung verhältnismäßig schwach. Keuper. Württemberg.

Capitosaurus H. v. M. (Fig. 307, 308). Kopf vorne breit, gerundet. Augen klein, in der hinteren Schädelhälfte. Nasalia ungemein groß. Kleiner Ohrenschlitz. Buntsandstein. Bernburg. Muschelkalk. Schlesien; Keuper. Franken; ? Trias. Südafrika.

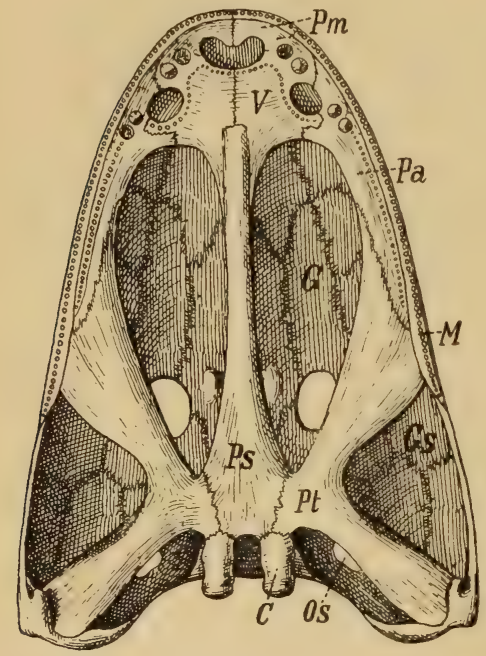

Fig. 305.

Cyclotosaurus robustus H. v. Meyer. Schilfsandstein d. unt. Keuper. Bezeichnungen wie früher. (Nach E. Fraas.)

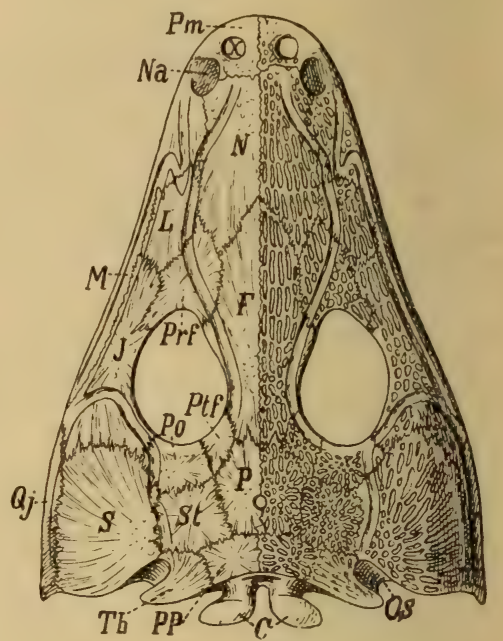

Fig. 306.

Mastodonsaurus giganteus Jaeger. Mit deutlicher Lyra. Lettenkohle Gaildorf b. Stuttgart. Alle übrigen Bezeichnungen wie frïher. Ca. $1 / 16$ nat. Gr. (Nach E. Fraas.)

Cyclotosaurus E. Fraas (Fig. 305). Schädel ähnlich Capitosaurus, aber bedeutend größer und Ohrenschlitz von hinten zu einer *falschen " Schläfenöffnung geschlossen. Keuper. Württemberg. Hierher dürfte wegen der geschlossenen Ohrenschlitze auch Capitos. stantonensis A. Woodward aus der mittleren Trias Spitzbergens zu stellen sein. ? Trias. (Burghersdorp beds) Südafrika.

Ma sto do n saurus Jaeger em. E. Fraas (Fig. 276, 281, 285, 306). Schädel bis $1 \mathrm{~m}$ lang. Frontalia, nehmen wie bei Capitosaurus und Cyclotosaurus an der Begrenzung der Augen teil. Augenhöhlen sehr groß, mit ihrem Vorderrand bis in die Mitte der Schädellänge reichend. Vor den Nasenlöchern zwei Prämaxillardurchbrüche. Palatin mit zweiter Zahnreihe. Die Fangzähne des Vomer und $\mathrm{Pa}$. auf der Innenseite von einer Reihe kleiner Zähnchen begrenzt. Episternum rhombisch und wie die dreieckigen Claviculae stark skulptiert. Ischium groß. Pubis klein, nicht miteinander verschmolzen. Wirbelkörper dorsal für die Chorda ausgebuchtet. Buntsandstein, Muschelkalk und Keuper von Württemberg. Alaunschiefer Gaildorf und Franken. ? Buntsandstein Elsaß. ? Keuper England. ? Indien.

1) Metopias ist nach Lydekker bereits 1842 für eine Coleoptere verwendet. 
Labyrinthodon Owen. Keuper. Schwaben. England.

Plagiosternum E. Fraas. Muschelkalk und Lettenkohle- Schwaben.

Rhytidosteus Owen. Trias. Oranje Republik.

Rhynesuchus Broom. Perm. Südafrika.

Aus der Trias von Ostindien werden neben anderen unvollkommenen Resten, die vielfach mit einer der zuletzt genannten Genera identifiziert werden, Pachygonia, Gonioglyptus Huxley beschrieben.

Auch aus permokarbonischen (? triadischen) Ablagerungen von Australien werden verschiedentlich Reste von Labyrinthodonten angeführt.

Fußspuren (Fährten) von Stegocephalen finden sich bereits im obersten Devon Thinopus antiquus Marsh (Chemung-Stufe) von W. Pennsylvanien ${ }^{1}$, nicht selten in der Steinkohlenformation von NeuSchottland 2), Pensylvannien und Kansas, im Rotliegenden von Thüringen, Böhmen und Sachsen ${ }^{3}$ ), im Karoo-Sandstein von Südafrika und namentlich im Buntsandstein von Thüringen (Fig. 309) und Franken (Chirotherium), sowie im

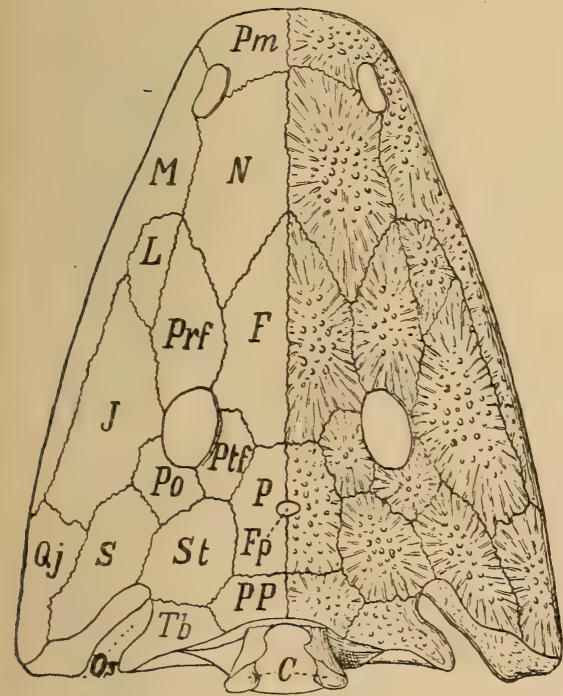

Fig. 307.

Capitosaurus nasutus H. v. Meyer. Wie oben. Verkl. Buntsandstein Bernburg. Bezeichnungen wie früher.

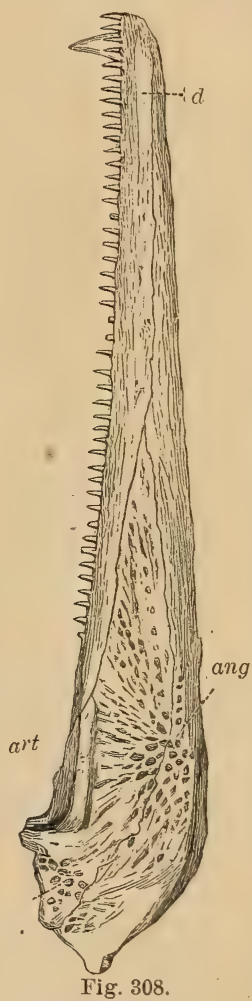

Unterkiefer von Capitosaurus nasutus H. v. Meyer. Verkl. Von Bernburg.

art Articulare, ang An gulare, $d$ Dentale.

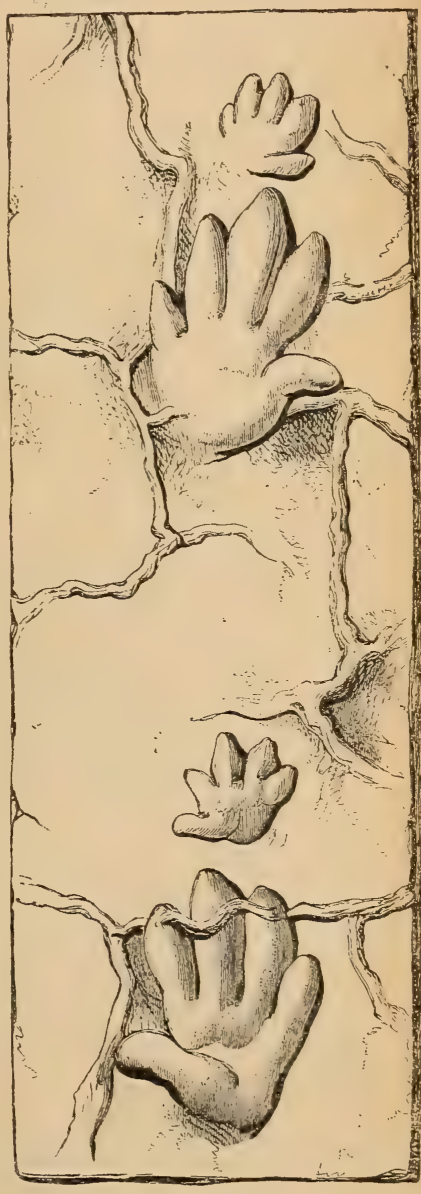

Fig. 309.

Fährten von Chirotherium Barthi

Kaup. Buntsandstein von Heßbers bei Hildburghausen. 1/6 nat. Gr. (Nach R. O wen.)

Keupersandstein von Thüringen und England. Die vertieften Fährten befinden sich stets auf Schichtablösungsflächen; die darüber liegende Sand.

1) Marsh, Americ. Journ. Science 1896. Vol. 2. S. 374.

2) Matthew G.F., An attempt to classify Palaeozoic Batrachian footprints Proc. and Transact. Roy. Soc. Canad. 2. Ser. Vol. IX. 1903. New Species and a new genus of Batrachian footprints of the Carb. Syst. in Canada. Ibid. Vol. X. 1904.

3) Pabst $W$., Beiträge zur Kenntnis der Tierfährten in dem Rotliegenden Deutschlands. Zeitschr. d. deutsch. geol. Gesellsch: 52. u. 57. Bd. (ibid. Meitere Literatur). Siehe auch Zittel, Handbuch III. 
stein- oder Schieferschicht enthält auf der Unterseite den erhabenen Reliefabdruck der Fährten und meist auch ein Netzwerk unregelmäßig sich kreuzender, leistenförmiger Wülste, die offenbar den Ausfüllungen von Spalten entsprechen, welche sich beim Austrocknen des ursprünglich feuchten Bodens gebildet hatten. Die Tiere, von denen diese in Reihen auf einander folgenden Fährten hinterlassen wurden, besaßen meist fünfzehige, seltener vierzehige Extremitäten, wovon die vorderen meist kleiner als die hinteren sind.

\section{Ordnung. Coeciliae (Gymnophiona). Blindwühler.1)}

Körper wurmförmig, mit in ringförmigen Hautfalten eingelagerten, kleinen Schuppen. Schädel solid verknöchert. Wirbel amphicöl mit Chordaresten. Kiefer, Palatinum und Vomer mit kleinen gekrümmten Zähnchen, Extremitäten sowie deren Gürtel fehlen.

Die infolge der unterirdisch grabenden Lebensweise mit kleinen unter der Haut gelegenen Augen ausgestatteten Blindwühler bilden eine kleine, auf die Tropen der Alten und Neuen Welt beschränkte Ordnung, von welcher sichere fossile Vertreter bis jetzt nicht bekannt sind. Der wie bei den Stegocephalen solid verknöcherte Schädel unterscheidet sich von diesen durch den Mangel eines Foramen par. sowie auch die geringe Anzahl der sich entwickelnden Belegknochen, von denen ihnen neben anderen stets die Postparietalia (Supraoccipitalia) und Supratemporalia fehlen.

\section{Ordnung. Urodela. Schwanzlurche. ${ }^{2}$ )}

Nackthäutige, langgestreckte, geschwänzte Lurche mit oder ohne äußere Kiemen und meist mit vier kurzen Extremitäten. Wirbelkörper gewöhnlich solid verknöchert. Foramen parietale fehlt.

Die Urodelen unterscheiden sich von den Stegocephalen hauptsächlich durch nackte Haut, durch verknöcherte (nur selten von der Chorda durchbohrte), gestreckte, amphicöle oder opisthocöle Wirbel mit schwach entwickelten Quer- und Dornfortsätzen, durch den Mangel eines Foramen parietale und durch den abweichenden Bau des Brustgürtels, sowie durch die wesentlich geringe Zahl der das Schädeldach bildenden Belegknochen.

Der flache, breite, vorne abgerundete Schädel besteht auch im ausgewachsenen Zustande noch teilweise aus Knorpel, ist aber durch Deckknochen geschützt, oder aus Knorpelknochen zusammengesetzt. Am Schädel finden sich außer den Exoccipitalia lateralia, dem Prooticum und dem Sphenethmoid stets Parietalia, Frontalia und in

1) Wiedersheim, Die Anatomie der Gymnophionen. Jena 1879.

2) Dollo L., Note s. 1. Batracien (Hyaelobatrachus) de Bernissart. Bull. d. Mus. R. d'hist. nat. de Belg. 1884. III. - Laube G., Andriasreste aus d. böhmischen Kreideformation. Abhandl. d. deutsch. naturwiss. Ver. f. Böhmen ,Lotos«. Prag 1897. Amphibienreste aus dem Diatomaceenschiefer von Sullowitz im böhm. Mittelgebirge. Ibid. 1898. - Meyer H. v., Zur Fauna der Vorwelt. Fossile Säugetiere, Vögel u. Reptilien aus dem Molassemergel von Oeningen 1845. S. 18-40. - Palaeontographica Bd. II p. 70, VII p. 46-73 und X p. 292. - Stefano G. de, Sui batraci urodeli delle fosforiti del Quercy. Boll. d. S. Geol. Ital- Vol. XII. 1903. - Wiedersheim Rob., Salamandrina perspicillata. Versuch einer vergleichend. Anatomie d. Salamandrinen. Würzburg 1875. $8^{\circ}$. - Das Kopfskelett der Urodelen. Leipzig 1877. 
1. Unterordnung. Ichthyoidea. Fischlurche, Kiemenlurche.

Wirbel amphicöl, mit Chordaresten. Drei Paar persistierende äufsere Kiemen 2-3 Kiemenspalten (Perennibranchiaten) oder ein Kiemenloch-(Derotremen) vorhanden. Augen klein, ohne deutliche Lider. Wasserbewolner.

$\mathrm{Zu}$ dieser Gruppe gehört wahrscheinlich Hyaelobatrachus Dollo aus dem Wälderton von Bernissart in Belgien, wovon nur ein einziges Exemplar bekannt ist; ferner der schon von J. J. Scheuchzer als Homo diluvii tristis testis beschriebene Riesensalamander (Andrias Scheuchzeri) von Oeningen in Baden (Fig. 311). Derselbe erreicht eine Länge von mehr als $1 \mathrm{~m}$ und unterscheidet sich von dem in Japan lebenden Cryptobranchus v. d. Hoeven (Megalobatrachus Tschudi) nur durch unerhebliche Differenzen im Skelettbau. Eine zweite kleinere Form (Andrias Tschudii Meyer) findet sich in der Braunkohle von Rott bei Bonn, auch aus oberoligocänen Kohlenschichten von Böhmen wird durch Laube eine Art beschrieben.

\section{Unterordnung. Salamandrina. Molche.}

Wirbel amphicöl, selten (Desmognathinae) opisthocöl, vollständig verkinöchert. Kiemen, oder Kiemenlöcher fehlen. Augenlider vorhanden.

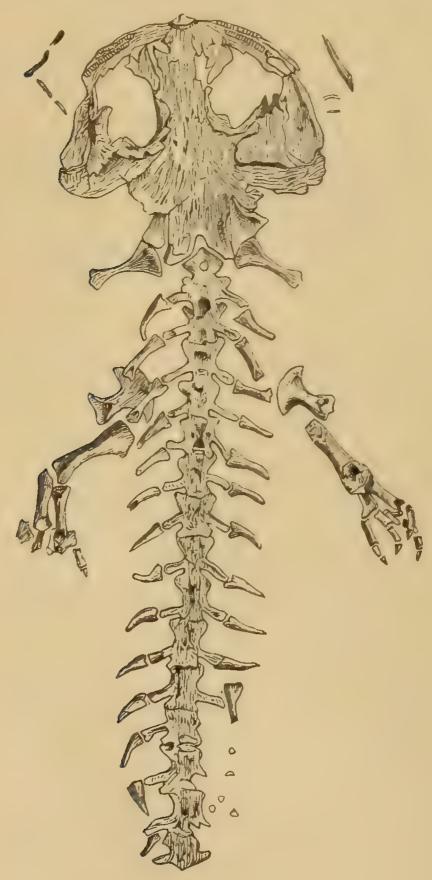

Fig. 311 .

Andrias Scheuchzeri Tschudi. Miocän. Oeningen, Baden.

Das Scheuchzersche Originalexemplar nach der Bearbeitung durch Cuvier. $1 / 6$ nat. Gr.

Verschiedene, den jetzt lebenden Salamandern nahestehende fossile Gattungen (Polysemia, Heliarchon, Archaeotriton H. v. Meyer, Chelotriton Pomel, Heteroclitotriton de Stef.,
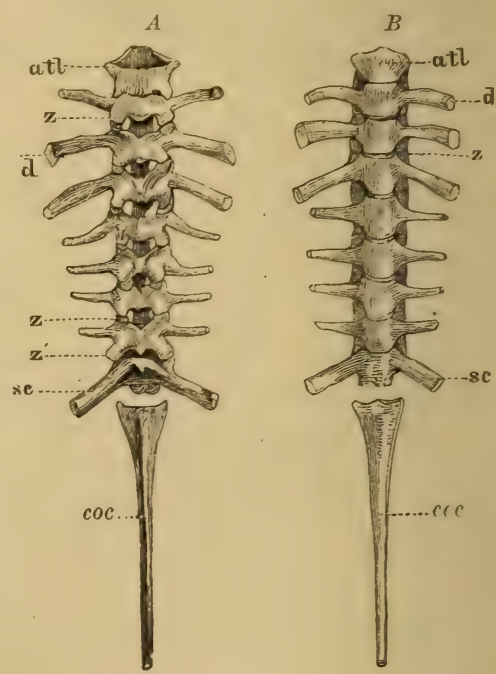

Fig. 312.

Wirbelsäule von Rana esculenta. A von oben, $B$ von unten. (Nat. Gr.) atl Atlas, $d$ Querfortsätze (Diapophysen), $z$ vordere, $z^{\prime}$ hintere Gelenkfortsätze (Zygapophysen), sc Sacralwirbel, coc Coccyx.

Megalotriton Zitt.) sind aus dem Tertiär (Quercy, Sansan; Rott und Erpel bei Bonn, Böhmen etc.) bekannt, jedoch überall selten. 


\section{Ordnung. Anura. Froschlurche. ${ }^{1}$ )}

Nackthäutige, schwanzlose Lurche von gedrungenem Körperbaù. Wirbel meist procöl. Schwanzwirbel zu einem dolchförmigen Knochen (Coccyx) verwachsen. Foramen parietale fehlt. Entwicklung durch Metamorphose.

Der gedrungene Körperbau der Anuren wird durch die geringe Anzahl der meist procölen (selten opisthocölen: Aglossa, Discoglossidae, einige Pelobatidae) Wirbel veranlaßt, insofern bereits der 6. (Hymenocheirus) meistens aber der 9. Wirbel als einziger Sacralwirbel mit dem Jlium sich verbindet. In seltenen Fällen (Pelobates, Pipa, Hymenochirus) sind als alleinige Ausnahme unter den lebenden Amphibien zwei Sacralwirbel entwickelt. Hinter dem Sacralwirbel folgt ein langer, dolchförmiger Knochen (Coccyx), welcher aus der Verschmelzung mehrerer Schwanzwirbel hervorgehen dürfte (Fig. 312). Kurze Rippen kommen nur bei den Discoglossiden vor, dagegen sind die Querfortsätze (Diapophysen) gewöhnlich als kräftige dornartige Gebilde entwickelt.

Für den Schädel (Fig. 265) sind die zu einem Knochenpaar (Frontoparietalia) vereinigten Parietalia und Frontalia bezeichnend, ebenso wie das ringförmige, teilweise von den Nasalia bedeckte Gürtelbein (Os en ceinture), das durch mediane Verschmelzung der Sphenethmoidea hervorgegangen ist. Exoccipitalia lateralia und Prooticum sind verknöchert ebenso das T-förmige Parasphenoid, ferner Pterygoid, Palatin (kann fehlen), Squamosum und Jugale, welches den Quadratknorpel mit dem Maxillare verbindet. Kleine, bürstenförmige Zähnchen finden sich auf diesem wie auf den Prämaxillare und Vomer (sehr selten auf Parasphenoid und Palatin).

Der Brustgürtel (Fig. 313) besteht aus einer großen, meist mit einer unvollkommen oder gar nicht ossifizierten Suprascapula, beweglich verbundenen Scapula, mit welcher Clavicula und Coracoid auf die gleiche Weise in Zusammenhang treten. Das große, gewöhnlich knorpelige Brustbein enthält zwei verknöcherte Stücke,

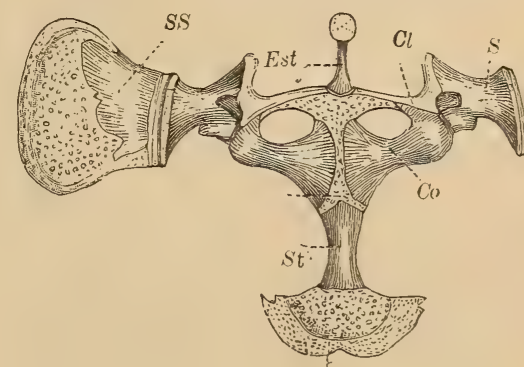

Fig. 313 .

Brustschultergürtel von Rana temporaria. Est Episternum, St Sternum, S Scapula, SS Suprascapula, $C l$ Clavicula, Co Coracoid.

ein vorderes Episternum und ein hinteres Sternum, welches in einer knorpeligen, halbkreisförmigen Platte endigt. In der vorderen 4 finge-

1) Dall W. H., An historical and systematic review of the frog shells and tritons. (Smiths. Mix. Coll.) Vol. 47. 1904. - Meyer H. v., Zur Fauna der Vorwelt. Fossile Wirbeltiere von Oeningen. 1845. - N. Jahrb. f. Mineralogie 1843. S. $395,580.1845$ S. 798.1846 S. 351.1847 S. 192.1851 S. 78.1852 S. $57,465$. 1853 S. 162.1858 S. 202.1863 S. 187 und Palaeontographica Bd. II u. VII. Vidal L. M., Sur la présence de l'étage kiméridgien au Montsech (etc.) et découverte d'un Batracien dans ses assises (Mém. de l. R. Acad. de Ciencas y Artes de Barcelona 4. Nr. 18. 1902). - Wolterstorff W., Uber fossile Frösche, insbesondere Palaeobatrachus. Jahresber. des naturw. Vereins in Magdeburg für 1885 und 1886 (mit vollständigem Literaturnachweis) I. II. 1886. 1887. 
rigen Extremität (der 5. Finger bleibt rudimentär) verwachsen Ulna und Radius, die kleinen Carpalia liegen in zwei Reihen.

Im Beckengürtel bilden 'das stark verlängerte Ilium mit dem kleinen Ischium die Gelenkpfanne für den Femur. Das unbedeutende Pubis verknöchert nur in Ausnahmefällen. Tibia und Fibula verwachsen, von den Tarsalia sind die zwei der proximalen Reihe (Astragalus und Calcaneus) stark verlängert und können gleichfalls miteinander verwachsen; di€ Füße fünfzehig.

Fossile Frösche sind selten. Die ältesten sicher bestimmbaren Reste finden sich im ob. Jura (Kimmeridgien) von Montsech (Provinz Lerida, Spanien), wo ein Abdruck eines vollständigen Individuums entdeckt wurde Palaeobatrachus Gaudryi Vidal), im Eocän von

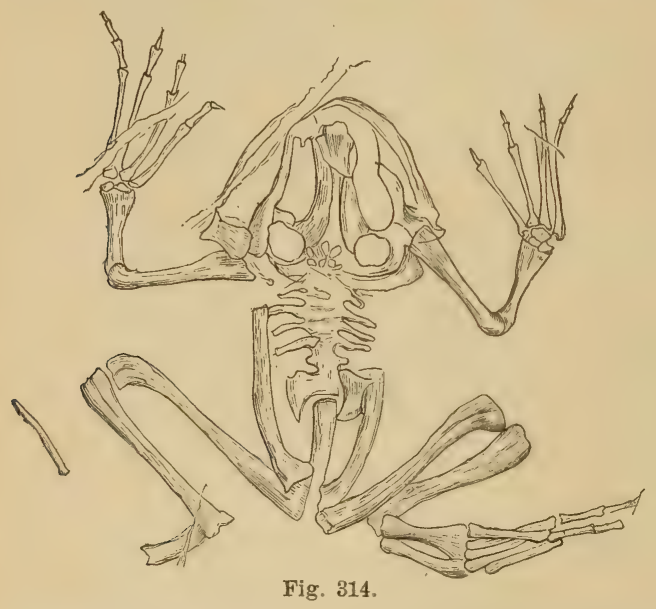

Palaeobatrachus grandipes Giebel. Braunkohle. Orsberg. im Siebengebirge. $2 / 3$ nat. Gr. (Nach Wolterstorff).
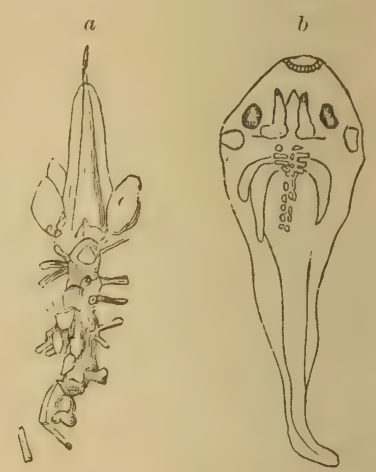

Fig. 315

Larven von Palaeobatrachus Fritschii Wolterst. Miocäne Braunkohle von Kaltennordheim, Rhön. Nat. Gr. (Nach Wolterstorfi u. Meyer.)

Ostindien (Oxyglossus pusillus Owen sp.) und Wyoming; sie werden zahlreicher im oberen Eocän, Oligocän und unteren Miocän von Südfrankreick, Oberitalien und Mitteleuropa, wo namentlich die Gattungen Rana und Palaeobatrachus durch zahlreiche Arten vertreten sind. In den Phosphoriten von Quercy findet man Mumien von Rana plicata Filhol., auch aus dem jüng. Tertiär Böhmens werden verschiedene Reste angeführt. In der Braunkohle des Siebengebirgs (Rott) und der Rhön (Sieblos) sind auch Larven von Palaeobatrachus (Fig. 314, 315) häufig. Von dem ersten Fundort wird auch Discoglossus genannt. Vollständige Skelette von großen Kröten (Latonia Seyfriedi v. Meyer und Pelophilus Agassizi Tschudi) sind aus dem miocänen Süßwassermergel von Oeningen bekannt; auch die gleichalterigen Ablagerungen von Günzburg, Sansan und Sinigaglia enthalten Reste von Anuren. Die diluvialen Frösche rühren wie die daselbst vorkommenden Urodelen von noch jetzt lebenden Gattungen her. 
Zeitliche Verbreitung der Amphibien.

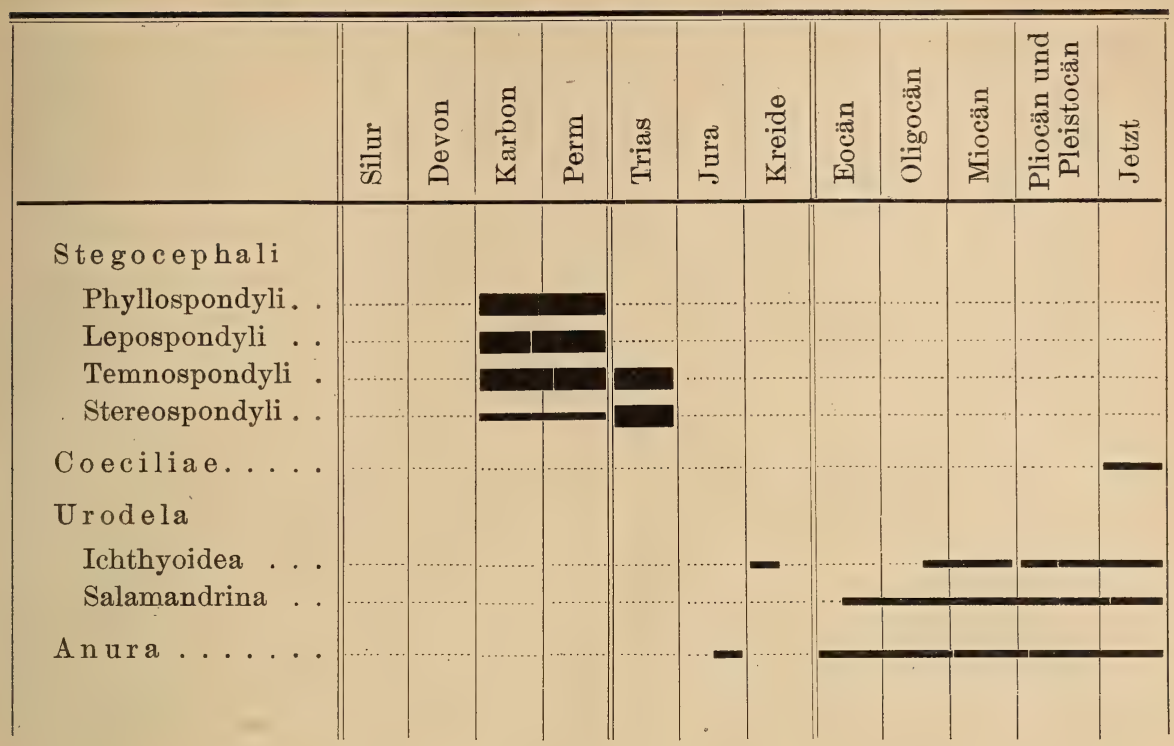

3. Klasse. Reptilia. Reptilien. Kriechtiere. ${ }^{1}$ ) (Bearbeitet von F. Broili.)

Wechselwarme, beschuppte, mitknöchernen Platten gepanzerte oder nackte Land-oder Wassertiere mit ausschließlicher Lungenatmung. Herz mit doppelter Vor$\mathrm{kammer}$ und meist unvollkommen zweigeteilter Kammer. Skelett vollständig verknöchert. Entwicklung der Embryonen ohne Metamorphose mit Amnion und Allantois. Hinterhaupt mit einem Gelenkkopf. Im allgemeinen herrscht ein langgestreckter, walzenförmiger Leib vor.

In der äußeren Erscheinung (Fig. 316) stehen die Reptilien in bezug auf den langgestreckten walzenförmigen Leib den Amphibien am nächsten, zeichnen sich aber zum Teil durch viel bedeutendere Dimensionen und verschiedentlich auch durch weit größere Mannigfaltigkeit aus, insoferne manche von ihnen einen äußerst gedrungenen Bau (Schildkröten), andere eine an die Vögel erinnernde Gestaltungsform (Flugsaurier) besitzen. Außerordentlich verschieden gestaltet sind nament-

1) Baur G., On the phylogenetic arrangement of the Sauropsida. Journal of Morphology. Vol. I. 1887. Boston. - Brïhl, Reptilienkopf. Wien 1886. - Cope $E d w$., Synopsis of the extinct. Batrachia, Reptilia and Aves of North America. Transactions Amer. Philos. Soc. 1869. vol. XIV. - Gadow H., Amphibia and Reptiles. Cambridge Nat. Hist. Vol. VIII. 1901. - Hay O. P., Bibliographie and Catalogue of the fossil Vertebrata of North America. U. S. Geol. Surv. Bull. 179. 1902. Hoffmann C. K., Die Reptilien in Bronn's Klassen und Ordnungen des Tierreichs. Bd. VI 3. Abt. 1879-1889. - Lydekker $R$., Catalogue of the fossil Reptilia and Amphibia in the British Museum. Part. I-IV. London 1888-1890. - Meyer H. v., Zur Fauna der Vorwelt. 1.-4. Abt. Frankfurt a. M. 1847-59. Folio. - Owen Rich., Report on British fossil Reptilia. I. Rep. of the IX. meet. Brit. Assoc. for the advancement of Science for 1839 p. $43-126$. II. Tbid. for. 1841 p. 60-204. Siehe auch bei Amphibia. 
lich die Extremitäten. Bei den Pterosauriern fungieren die Vorderfüße als Schwingen und besitzen eine fein gefältelte Flughaut, bei gewissen Dinosauriern erlangen die Extremitätenknochen eine Länge und Stärke,

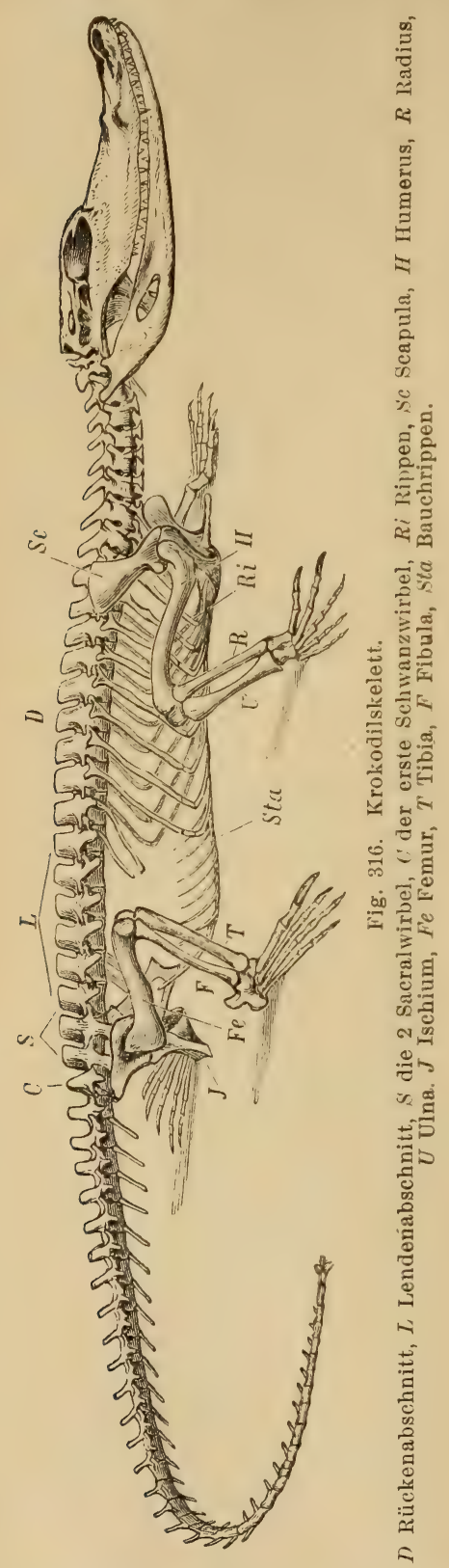
wie sie sonst nur bei den größten Landsäugetieren vorkommen, bei den Meersauriern nehmen sie paddelartige Gestalt an, bei den meisten Eidechsen, Theromoren, Krokodilen u. a. sind es Gehfüße, und bei den Schlangen und manchen Eidechsen fehlen sie vollständig.

Die Haut der Reptilien ist von derberer Beschaffenheit als bei den Amphibien und häufig durch Verknöche. rung der Cutis und Verhornung der Epidermis zu einem förmlichen Hautskelett umgestaltet. In der Regel haben die Verhornungen und Verknöcherungen die Form von Schuppen (squamae), Schildern (scuta) oder Platten; erstere legen sich dachziegelförmig übereinander, die Schilder und Platten stoßen mit ihren Rändern häufig einfach aneinander und bilden zuweilen einen förmlichen Panzer.

Die Wirbelsäule ist stets verknöchert, doch können teilweise noch Chordareste persistieren. Wo überhaupt Extremitäten vorhanden sind, unterscheidet man Hals-, Rumpf-, Beckenund Schwanz-Region; ja in vielen Fällen läßt sich an der Rumpfregion noch ein Brust- und ein Lenden-Abschnitt unterscheiden. Die vorderen und hinteren Endflächen der Wirbelcentra sind entweder ausgehöhlt oder in verschiedener Weise gewölbt, so daß amphicöle, platycöle (vorn und hinten schwach vertiefte), p r ocöle und opisthocöle Wirbel vorkommen. Mit den oberen Bögen sind die Wirbelkörper entweder nur durch knorpelige Epiphysen und Sutur verbunden oder vollständig verwachsen. Die Dornfortsätze sind stets solid yerknöchert, zuweilen ungemein verlängert, zuweilen vergabelt oder horizontal ausgebreitet und mit Hautplatten verschmolzen (Schildkröten). Die etwas schiefen oder fast horizontalen, noch oben gerichteten Gelenkflächen der vorderen Präzygapophysen werden von den hinteren Postzygapophysen des vorhergehenden Wirbels bedeckt. Zuweilen sind die Wirbel auch noch durch einen medianen Fortsatz an der Vorderseite oder 
Hinterseite der oberen Bögen (Zygosphen, Hyposphen), welcher in eine Grube an der Hinterseite oder Vorderseite des vorhergehenden Wirbelbogens (Zygantrum, Hypantrum) paßt, miteinander verbunden. Die rippentragenden $\mathrm{Querfortsätze}$ (Processus transversus) gehen entweder vom Wirbelkörper selbst oder vom oberen Bogen an seiner Grenze gegen den letzteren aus. Der auf den Atlas folgende Wirbel. wird bei den Reptilien zum Epistropheus. Ihre von den übrigen Wirbeln abweichende Gestalt erhalten diese beiden dadurch, daß der knorpelige Wirbelkörper des Atlas mit demjenigen des Epistropheus frühzeitig verwächst und zum Zahnfortsatz - Processus odontoides - desselben wird, der seinerseits in die selbständig gebliebenen und durch ventralen Zusammenschluß ringförmig verknöcherten Bogenhälften des Atlas eingreift. Auf diese Weise wird eine größere Beweglichkeit des Kopfes erreicht. Wie bei den Amphibien können auch hier an den Schwanzwirblern Untere Bogen (Chevron bones) zur Entwicklung gelangen. Am Sacralabschnitt nehmenbei den lebenden Reptilien nie mehr als zwei Wirbel teil, bei den fossilen schwankt die Zahl der Sacralwirbel zwischen 2 und 10. Sind mehr als drei vorhanden, so verschmelzen sie häufig zu einem beweglichen Heiligenbein. Durch den Mangel eines differenzierten Sacralabschnittes zeichnen sich die Schlangen, verschiedene Lacertilier, Pythonomorpha und Ichthyosauria aus. Nicht selten schalten sich vom Epistropheus an bis in die Schwanzregion hinein, ventral, zwischen alle Wirbelkörper kleinere keilförmige Knochenscheiben, die Intercentra, ein.
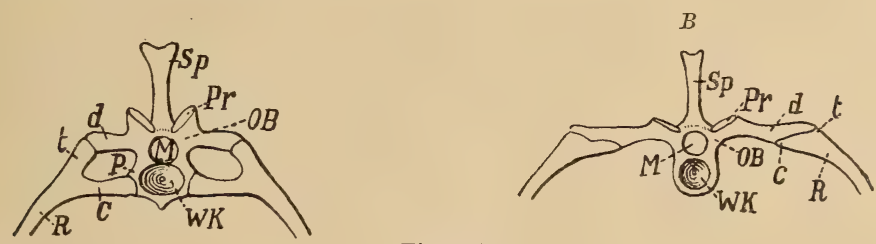

Fig. 317.

$A$ Vorderer, $B$ hinterer, procöler Brustwirbel von Alligator lucius. (Nach Gegen baur.)

$W K$ Wirbelkörper, $O B$ Ob. Bogen, $s p$ (Dornfortsatz), Processus spinosus, Pr Vorderer Gelenkfortsatz (Präzygapophyse), $d \mathrm{Ob}$. Querfortsatz (Processus transversus) = Diapophyse, $p$ Unterer Querfortsatz $=$ Parapophyse, $t$ Tuberculum, $c$ Capitulum der Rippe $R, M$ Rückenmarkskanal.

Mit Ausnahme der letzten Schwanzwirbel können vom Epistropheus ab sämtliche Reptilienwirbel Rippen tragen. (Fig. 317.) Die Halsrippen sind in der Regel kurz, am distalen Ende meist vorn und hinten verbreitert und beilförmig gestaltet. Ist ein Brustbein vorhanden, woran sich die in der Regel nur knorpeligen distalen Abschnitte (= Sternocostatia) der Rippen (Sternalrippen) im Gegensatz zu den Amphibien anheften, so sind Hals und Rumpf scharf geschieden; fehlen jedoch Sternalrippen, so bleibt die Grenze zwischen Hals- und Rückenabschnitt etwas unsicher. Hinter den Sternalrippen folgen eine Anzahl freier, nicht am Brustbein befestigter Rippen, und gehen dem Sacralabschnitt rippenlose Wirbel (Lumbar, Lendenwirbel) voraus, so wird'der Rumpf in eine Rücken- und Lendenregion zerlegt. Die Rippen sind entweder ein oder zweiköpfig, im letzteren Fall unterscheidet man an den proximalen Gelenkköpfen ein unteres Capitulum und ein oberes Tuberculum, von denen das erstere durch die 
Parapophyse, das letztere durch die Diapophyse des Wirbels (unterer und oberer Querfortsatz) getragen wird. Vereinzelt (Rhynchocephalen) findet sich auch an der oberen hinteren Hälfte der Rippe ein nach hinten und aufwärts gerichteter Fortsatz (Processus uncinatus). Bei den Schildkröten verwachsen die Rippen gewöhnlich mit breiten Knochenplatten des Hautskelettes.

In seltenen Fällen ist bei einigen paläozoischen Reptilien (Va. ranosaurus) ein ventrales Hautskelett in Gestalt verknöcherter Stäbchen beobachtet worden; bei anderen Formen (Sauropterygier, Crocodilier, Rhynchocephalen etc.) kommen auf der Bauchseite dünne, rippenartige Gebilde vor, welche in der Regel aus einem Mittelstück und zwei oder mehr Seitenteilen bestehen. Diese sog. B a u chrippen sind Ossifikationen des Bindegewebes und entsprechen jenen Knochenstäbchen und den Bauchschuppen, die wir bei den Stegocephalen bereits kennen gelernt haben.

Der S chädel (Fig. 318) stimmt in den allgemeinen Verhältnissen seines Baues mehr mit den Vögeln als mit den Amphibien überein und namentlich die Verknöcherung des Primordialcraniums ist in der Regel viel vollständiger als bei letzteren. In der Hinterhauptsregion verknöchern außer den Exoccipitalia lateralia (Pleuroccipitalia), noch das Basioccipitale und das Supraoccipitale, die sich entweder alle oder teilweise an der Umrahmung des Foramen magnum beteiligen können. Ein unpaarer, häufig dreigeteilter Condylus occipitalis, der entweder vom Basioccipitale allein oder im Verein mit den Exoccipitalia lateralia gebildet wird, lenkt sich in die ringförmige Vertiefung des Atlas ein. An das Hinterhaupt schließen sich seitlich die Knochen der Gehörkapsel an und zwar ist das an seinem Vorderrand von dem 3. Ast des Trigeniums durchbohrte Prooticum(Petrosum), das neben der Fenestra ovalis noch eine weitere Durchbrechung, die Fenestra rotunda, begrenzt, stets ein gesonderter Knochen, während Epioticum und Opisthoticum (Paroccipitale) häufig mit den Exoccipitalia lateralia verschmelzen. Wie bei den Amphibien findet sich auch hier ein besonderer Gehörknochen in die Fenestra ovalis eingefügt: Columella auris (Stapes). An der Schädelbasis folgt auf das Basioccipitale des Basisphenoid, das nach vorne in einen zugespitzten Fortsatz (R o stru m, Präsphenoid aut.) - das rudimentäre Paras phenoid ausläuft. Ein selbständig ossifiziertes Parasphenoid findet sich bei den Reptilien als Seltenheit (Schildkröten: Dermochelys).

Die übrigen bei den Reptilien in seltenen Fällen entwickelten Sphenoidalia werden als ? Alisphenoid und Orbitosphenoid (Crocodilia) gedeutet, an ihre Stelle tritt zuweilen (z. B. Hatteria) das häufig entwickelte, umfangreiche knorpelige, manchmal teilweise verknöcherte Interorbitalseptum. Das Schädeldach wird vorzugsweise von Belegknochen gebildet; diese sind die paarigen, manchmal verschmolzenen Parietalia und Frontalia, ferner Präfrontalia (= Lacrimalia) und Postfrontalia, Postorbitalia und Nasalia und nicht selten auch Lacrimalia (Adlacrimalia, Gaupp) ${ }^{1}$ ), manchmal auch Septomaxillaria. Wie bei den Amphibien bleibt bei den Reptilien vom Visceralskelett der hintere Abschnitt des Palato-Quadratum, das

1) Gaupp E., Das Lacrimale des Menschen u. d. Säuger u. seine morphologische Bedeutung. Anat. Anzeiger. Bd. 36. 1910. 
hier stets verknöcherte $\mathrm{Quadratum}$ bestehen, das bei nahezu sämtlichen Eidechsen, Schlangen und Pythonomorphen mehr oder weniger beweglich durch Bänder (Streptostylica), bei den übrigen Reptilien hingegen mehr oder weniger fest (Monimostylica) meist durch das Squamosum (Paraquadratum) mit dem übrigen Schädel verbunden ist. Z wischen das letztere und das Parietale kann sich ein weiterer Belegknochen, das Supratemporale einschieben. Die
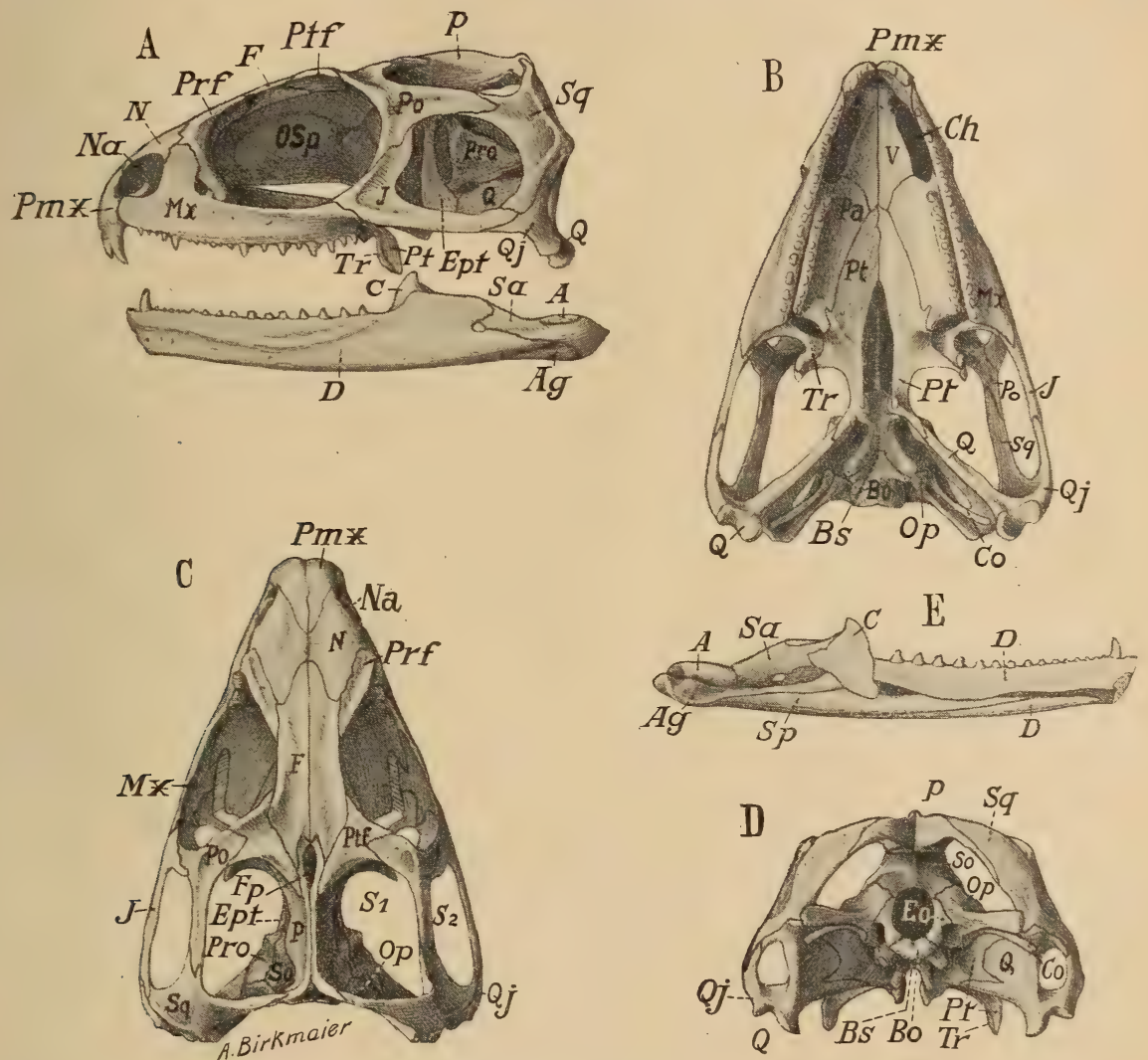

Fig. 318. Sphenodon (Hatteria) punctatum Gray von Neu-Seeland. ${ }^{1}$ )

$A$ Schädel mit Unterkiefer v. d. Seite. $B$ Schädel v. unten. $C$ Desgl. v. oben. $D$ Desgl. v. hinten $E$ Unterkiefer von innen.

$\mathrm{Na}$ Außere Nasenlöcher, OSp Augenöffnung mit Interorbitalseptum, $F p$ Foramen parietale, $S_{1} S_{\varepsilon}$ obere und untere Schläfenöffnung, $P m x$ Prämaxillare, $M x$ Maxillare, $N$ Nasale, Prf Präfrontale, $F$ Frontale, Ptf Postfrontale, Po Postorbitale, P Parietale, So Supraoccipitale, Sq Squamosum, Eo Exoccipitale laterale, Op Opisthoticum, Pro Prooticum, Ept Epipterygoid, Co Columella auris, Bo Basioccipitale, Bs Basisphenoid mit dem dolchförmigen Rostrum, Pt Pterygoid, Pa Palatin, $V$ Vomer, Ch innere Nasenlöcher (Choanen), Tr Transversum, $J$ Jugale, Qj Quadratojugale, Qu Quadratum, $A$ Articulare, $A g$ Angulare, $S p$ Spleniale (Operculare), $S a$ Supraangulare, $C$ Complementare mit Coronoidfortsatz, $D$ Dentale. $4 / 5$ nat. Gr.

Verbindung des Quadratum mit den Belegknochen der Maxillarreihe: Maxillare und Prämaxillare, wird durch das Quadratojugale und Jugale hergestellt, innerhalb der Maxillarreihe begegnen

1) Der Figur liegt das Original $F$. Siebenrocks in Wien zugrunde (Sitzungs-Ber. Akad. Wissensch. Wien, Vol. 102, 1893, der mir dasselbe in liebenswürdigster Weise zur Verfügung stellte. Herrn Dr. H. Fuchs (Straßburg) verdanke ich wertvollen Aufschluß bezüglich des Quadratojugale. Beiden Herren sei auch hier bestens gedankt. 
uns wiederum die Elemente der Palatinreihe: Pterygoid, Palatinum und Vomer. Bezeichnend für die meisten Reptilien ist das aus einem Fortsatz des Quadratknorpels hervorgegangene Epiptery goid (Columella aut.), das in senkrechter Richtung sich als schlanker, säulenförmiger Knochen gewöhnlich vom Parietale zum Pterygoid erstreckt. Ebenso charakteristisch für die Mehrzahl der Reptilien ist ein, Pterygoid mit dem Maxillare verbindendes, bereits bei einigen Stegocephalen entwickeltes Os transversum.

Nur bei einer Gruppe den Cotylos a uriern kommt es konstant durch Auftreten weiterer Belegknochen im dorsalen Abschnitt des Schädels noch zu einem vollkommen geschlossenen Schädel. dach wie bei den Stegocephalen; sehr häufig finden sich bei den Reptilien hinter den Augen und von diesen durch Postfrontale, Postorbitale und einem Fortsatz des Jugale getrennt große Durchbrüche, die obere und untere (seitliche) Schläfengrube, die durch eine von Squamosum und Postfrontale bzw. Postorbitale gebildete Knochenspange (ob. Schläfenbogen) geschieden werden. Der untere Abschluß der auf diese Weise gebildeten unteren Schläfenlücke erfolgt durch die, Maxillare und Quadratum verbindende, Brücke (unt. Schläfenbogen) von Jugale und Quadratojugale. Die rückwärtige Begrenzung der Schläfengruben wird durch das Quadratojugale, Squamosum und eventuell noch durch das Supratemporale erreicht. Beide Schläfengruben finden sich z. B. bei den Rhynchocephalen und Crocodiliern wohl entwickelt, durch den Verlust bzw. die Reduktion des unteren bzw. des oberen Bogens begegnet uns dann nur eine Schläfengrube, Verhältnisse wie wir sie im ersten Falle z. B. bei vielen Lacertiliern, im zweiten Falle z. B. bei den Vögeln antreffen. ${ }^{1}$ ) Eine Reduktion beider Bögen findet bei den Schlangen und einigen Lacertiliern und Schildkröten statt.

An weiteren Schädeldurchbrüchen zeigt sich zwischen der Nasenöffnung und dem Augenloch bei Dinosauriern und Pterosauriern, Parasuchiern etc., eine sehr große Präorbitallücke, welche zuweilen mit der Nasenöffnung verschmilzt. Für die meisten Reptilien ist die Epiphysenöffnung, das große Foramen parietale, bezeichnend, in welche unter der Haut ein dorsales unpaares Sinnesorgan (? Auge) eingelagert ist. Auch die Hypophyse tritt in einem weiten Kanal (can. cranio-pharyngeus, pituitary canal) z. B. auf der Ventralseite des Basisphenoids bei der Gattung Ichthyosaurus, Opthalmosaurus und einigen Sauropoden aus.

Wie bei den Amphibien ist der Unterkiefer aus Dentale, dem Angulare und Articulare, sowie in der Regel aus einem Operculare (Spleniale) zusammengesetzt, zu denen meist noch ein Supraangulare und innen das häufig in einen Coronoidfortsatz ausgezogenes Complementare kommen.

Ein vor dem Dentale entwickeltes Prädentale bei gewissen Dinosauriern kann im Oberkiefer mit einem vor den Prämaxillaren befindlichen Rostrale korrespondieren. Auch bei den Reptilien finden sich häufig noch Reste des Meckelschen Knorpels.

1) Osborn H. F., The Reptilian Subclasses Diapsida and Synapsida etc. Mem. Americ. Mus. Nat. Hist. Vol. I. 1903. - Fuchs H., Betrachtungen über die Schläfengegend am Schädel der Quadrupeda. Anat. Anzeiger 35. Bd. 1909. 
Die je nach der Nahrung verschieden ausgebildeten $\mathrm{Z}$ ähn $\mathrm{e}^{1}$ ) fehlen nur bei Schildkröten und vereinzelten Vertretern anderer Ordnungen. In der Regel stehen sie in größerer Anzahl auf den Kiefern, können aber auch auf Palatinum, Pterygoid, Vomer und anderen Elementen der Schädelunterseite vorkommen. Im wesentlichen bestehen die Zähne aus dichtem Dentin und einem Überzug von Sch melz. Zement, d. h. dichteres Knochengewebe, nimmt nur in untergeordnetem $\mathrm{Maß}$ an ihrer Zusammensetzung teil; Vasodentin fehlt gänzlich. Vereinzelt lässt sich ähnlich wie bei den Stegocephalen eine Faltung des Dentins feststellen wie bei den Champsosauridae und Ichthyosauridae. Die Form ist in der Regel spitzkonisch oder hakenförmig, doch gibt es auch niedrige, halbkugelige oder pflasterförmige, seitlich zugeschärfte, blatt- oder schaufelförmige, zuweilen sogar mehrspitzige Zähne. Außer den schon von den Amphibien her bekannten acrodonten, pleurodonten und protothecodonten (z. B. Cotylosaurier, Pelycosaurier) Zähnen finden sich bei den Reptilien auch in Alveolen eingelassene - thecodonte Zähne, im letzteren Falle sind eine oder selten auch zwei Wurzeln ausgebildet.

Abgesehen von den Schlangen und einigen Eidechsen besitzen alle Reptilien zwei paar Extremitäten ${ }^{2}$ ); (Fig. 316) die vorderen lenken sich in den Brust- oder Schultergürtel ein, welcher stets aus zwei Knochenpaaren (Coracoideum, Scapula) besteht, von denen das Coracoid häufig eine größere Ausdehnung hat und entweder allein oder mit dem nach oben und hinten gerichteten Schulterblatt (Scapula) die Gelenkpfanne für den Humerus bildet. Hiezu treten meist noch Clavicula und Episternum (Interclavicula). Während Coracoid und Scapula niemals fehlen, gehören Clavicula und Episternum zu den unbeständigeren Elementen. Ein nach vorne gerichteter, häufig knorpelig gebliebener Fortsatz, das Coracoid, wird als Procoracoid (Praecoracoid) bezeichnet. Das Schlüsselbein (Clavicula) liegt dem vorderen Scapularrand an und verbindet ventral den Schultergürtel mit dem vorderen unpaaren Schlußstück Episternum, das rhombische, kreuzförmige oder T-Gestalt besitzt. Vereinzelt ist außer der Clavicula das bei den Stegocephalen noch mehr verbreitete Cleith r um nachweisbar (z. B. Pareiasaurus). Hinter dem Episternum und diesem sowie dem Coracoid als Träger dienend, folgt häufig ein flaches, rhomboidisches oder schildförmiges Brustbein, das Sternum (s. str.) (Prosternum), das von den vorderen Rumpfrippen getragen wird; nach hinten ist das Sternum meist in rippenartige Fortsätze ausgezogen oder stabförmig verlängert - Xiphis ternum (Metasternum). Ist das Sternum nicht entwickelt, so stoßen dann die Coracoidea in der ventralen Symphyse zusammen (z. B. Sauropterygier) oder sind durch Ligamente verbunden. Nicht selten bleibt das Sternum knorpelig; außerdem können am Schultergürtel noch weitere mehr oder weniger ausgedehnte Knorpelteile auftreten wie Suprascapula und Epicoracoid.

1) R. Burckhardt, Das Gebiß der Sauropsiden. Morphologische Arbeiten. B. V. 1895 .

2) Fürbringer $M$., Zur verg]eichenden Anatomie des Brustschulterapparates u. d. Schultermuskeln. Ibid. Literatur. Jenaische Zeitschr. f. Naturwissenschaft. 34. 1900. Jena. 
Während Scapula, Coracoid und Procoracoid (primärer Schultergürtel) und Sternum (primäres Brustbein) knorpelig präformiert sind, sind Clavicula, Cleithrum (sekundärer Schultergürtel) sowie Episternum (sekundäres Brustbein) Deckknochen und dermaler Abkunft.

Die vorderen Extremitäten (Fig. 319) bestehen aus einem mehr oder weniger stämmigen Oberarm ( $\mathrm{H} \mathrm{um}$ erus) und zwei Vorderarmknochen ( $\mathrm{R}$ a dius und Ulna), welche in der Regel den entsprechenden Knochen bei Amphibien ähnlich sind. Der Humerus zeigt sich sowohl in seinem proximalen wie in seinem distalen Teile stark verrbeitert

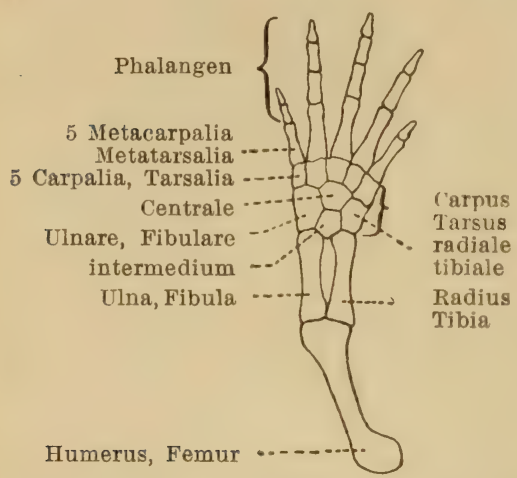

Fig. 319.

Schema der Gliederung von Hand oder Fuß. (Nach Gegenbaur.) und gewöhnlich ist der letztere um den ersteren in einem Winkel von $90^{\circ}$ gedreht. Häufig findet sich auf seiner medialen (ulnaren) Seite ein Foramen entepicondyloideum, dem auf der lateralen (radialen) Seite ein Foramen ectepicondyloideum entsprechen kann. Nicht selten ist die Ulna etwas länger als der Radius und zuweilen mit einem proximalen olecranonartigen Vorsprung: versehen. Der Carpus enthält stets zwei Reihen von Knöchelchen, wovon die proximale Reihe meist 3 Elemente (ulnare, intermedium, radiale) zu denen noch am ulnaren Carpusrand ein Pisiforme (? Rudiment eines 6. Fingers) kommen kann, die distale aus 3-6 Knöchelchen besteht, dazwischen treten noch 1 bis 2 Centralia; Metacarpus und Zehen sind je nach der Lebensweise außerordentlich verschieden. Die Zahl der Zehen schwankt zwischen 2 und 5 , überschreitet bei manchen Ichthyosauriern sogar die Fünfzahl. Am dritten und vierten Finger ist die Zahl der Phalangen meist am größten.

Auch das Becken und die Hinterfüße bieten große Verschiedenheiten. Mit Ausnahme der Ichthyosauria, Pythonomorpha und der Schlangen besitzen alle Reptilien einen Sacralabschnitt, welcher aus 2-6 oder mehr Wirbeln besteht. Das Becken ist bei der Mehrzahl der Schlangen und einigen fußlosen Lacertilien, zumeist bis auf geringe Rudimente reduziert. Bei den übrigen Reptilien sind überall drei Knochenpaare (Ilium, Pubis, Ischium) vorhanden, welche meist alle (ausgenommen die Crocodilia nur mit Ilium und Ischium) an der Bildung der in ihrem Grund (Crocodilia, Dinosauria) manchmal durchbohrten Gelenkpfanne (Acetabulum femoris) teilnehmen. Das Darm- oder Hüftbein (Ilium) ist dorsal häufig mehr oder weniger stark nach vorne und hinten verlängert; der Canalis obturatorius tritt durch das Foramen obturatum entweder im Pubis selbst aus, z. B. Cotylosaurier, Rhynchocephalen, Lacertilia oder unterhalb der Gelenkpfanne zwischen Pubis und Ischium (z. B. Anomodontia); häufig (Crocodilia, Schildkröten, Dinosauriern) fällt seine Mündung auch mit dem Pubis und Ischium trennenden Foramen pubo-ischiadicum zusammen; Pubis und Ischium sind in der Symphysenebene direkt oder durch Knorpel mit den entsprechenden Knochen der Gegenseite verbunden. Bei den Dinosauriern erhält das Becken durch das sehr 
stark nach hinten und unten gerichtete, langgestreckte Ischium und einem diesem parallel ebenso verlängerten Fortsatz des Pubis (Postpubis) sowie durch das dorsal nach vorne verlängerte Ilium ein vogelartiges Gepräge. Die Hinterextremitäten ähneln in der Regel den vorderen und bestehen aus einem verlängerten Femur (Oberschenkel), welcher proximal mit einem oder zwei vorragenden Trochantern versehen ist, zwei Vorderfußknochen (Tibia und Fibula), einem aus einer oder zwei Knöchelchenreihen bestehenden Tarsus, den Metatarsalien und Phalangen. Die proximale Reihe des Tarsus erfährt vielfach durch Verschmelzung der einzelnen Bestandteile eine Umgestaltung, so können bei verschiedenen Schildkröten und Lacertilien sich sämtliche Elemente zu einem Knochen vereinigen, bei den Crocodiliern geht aus der Concrescenz von Tibiale, Intermedium und Centrale der Astragalus hervor, während das mit einem Fersenhöcker ausgestattete Fibulare als Calcaneus bezeichnet wird. Auch im Hinterfuß bieten die verschiedenen Ordnungen der Reptilien große Verschiedenheiten, welche im speziellen Teil näher erörtert werden sollen.

Als ausschließliche Lungenatmer sind die Reptilien vorzüglich auf terrestrische oder amphibische L e b e $\mathrm{n} \mathrm{s}$ w e i s e angewiesen. Die wenigen Schildkröten, Eidechsen und Krokodile, welche im Meere oder an der Meeresküste leben, kommen wenigstens zeitweilig ans Land und legen ihre Eier im Sande ab, nur einige wenige gebären lebende Junge wie die Ichthyosaurier, unter den Eidechsen die Blindschleiche und unter den Schlangen die Kreuzotter. Unter den fossilen Reptilien waren die Ichthyosauria, Sauropterygia und Pythonomorpha Meeresbewohner, deren paddelartige Extremitäten am Ufer keine oder nur eine höchst unbeholfene Fortbewegung gestatteten. Die Mehrzahl der fossilen Reptilien gehörte zu den Landbewohnern; ja die Pterosaurier konnten sich sogar mittels wohl ausgebildeter Flugorgane in die Luft erheben.

Es sind über 4000 lebende Reptílien beschrieben, welche meist wärmere und heiße Klimate bevorzugen, denen eine zwar numerisch viel geringere Menge fossiler Formen gegenübersteht, die aber in der Organisation weit größere Mannigfaltigkeit aufweisen als die recenten, so daß ein volles Verständnis des Bauplanes der Reptilien nur durch Berücksichtigung der erloschenen Formen zu gewinnen ist. Die ersten Reptilien erscheinen im Oberkarbon; ihre Blütezeit fällt in das mesozoische Zeitalter und namentlich in die Trias- und Jurazeit.

Systematik. Die Reptilien wurden zuerst von Blainville (1816) und Merrem (1820) den Amphibien als gleichwertige Klasse gegenübergestellt. Eine befriedigende Systematik konnte jedoch erst begründet werden, nachdem durch $\mathrm{R}$. O wen, H. v. Meyer, Hux ley, Marsh, Cope u. a. auch die fossilen Formen genauer untersucht worden waren. Nach dem Besitz von ein oder zwei Schläfenbogen teilt H. F. Osborn die Reptilien in zwei Unterklassen, die Synapsida und Diapsida. Eine völlige Übereinstimmung in der Abgrenzung der verschiedenen Ordnungen ist allerdings bis jetzt noch nicht erzielt, doch wird von den meisten neueren Autoren die Einteilung in 10 Ordnungen: Theromora, Rhynchocephalia, Lepido. sauria, Ichthyosauria, Sauropterygia, Testudinata, Parasuchia, Crocodilia, Dinosauria und Pterosauria angenommen. 


\section{Ordnung. Theromora Cope. (Theromorpha Cope.)}

Schädeldach geschlossen oder mit einem Paar (? selten zwei Paar) großer Schläfenöffnungen. Foramen parietale zumeist beobachtet. Quadratum fest mit dem Schädel ver. bunden. Zähne protothecodont oder acrodont. Foramen entepicondyloideum in der Regel nachgewiesen. Scapula, Coracoid und das groBe Procoracoid, ferner Ilium, Ischium und Pubis entweder vollständig miteinander verschmolzen oder durch Naht unbeweglich gegenseitigverbunden. Wirbel tief amphicöl. Gewöhnlich zwei oder vier, selten drei Sacralwirbel. Vorder- und Hinterextremität fünfzehig, meist mit Krallen. Ob. Karbon. Perm. Trias.

Die Theromora, die in der Hauptsache land- oder küsten. bewohnende Formen umfassen, zerfallen in mehrere Unterordnungen, die Cotylosauria, Pelycosauria, Theriodontia und Anomodontia. Unter diesen weisen die Pelycosaurier, trotz mancher Ähnlichkeit in der Zusammensetzung des Schädels mit den Phynchocephalen, auf Grund vieler gemeinsamer Merkmale im Bau des Schulterund Beckengürtels und der Extremitäten auf eine nahe Verwandtschaft $\mathrm{zu}$ den primitiven Cotylosauriern hin. Die Theriodontier und namentlich die Anomodontia erscheinen gegenüber den Pelycosauriern und Cotylosauriern als mehr differenzierte und spezialisierte Gruppen, die indessen unter sich auch eine große Reihe gemeinsamer Punkte aufzuweisen haben; immerhin scheint eine Verwandtschaft zwischen Theriodontiern und Pelycosauriern zu bestehen, die sich besonders in der Art der Bezahnung geltend macht. Es erscheint deshalb gerechtfertigt, Theriodontier und Anomodontier bei den Theromora zu belassen.

\section{Unterordnung. Cotylosauria. Cope. $\left.{ }^{1}\right)$}

Schädeldach vollkommen von soliden, meist skulptierten Deckknochen geschlossen. Foramen parietale groß. Nasenlöcher getrennt. Zähne entweder konisch oder quer verlängert mit Höckern, in einer oder mehr Reihen auf den Kiefern. Chagrinbezahnung häufig. Wirbel tief amphicöl. In der Regel zuei Sacralwirbel. Rippen ein- und zweiköpfig. Scapula, Coracoid und Procoracoid sowie Ilium, Ischium und Pubis bei ausgewachsenen Individuen gewöhnlich verschmolzen. Becken in der Symphyse zusammenstoßend. Pubis mit Foramen obturatorium. Humerus meist mit Foramen entepicondyloideum. Vorder- und Hinterextremität fünfzelig. ? Ob. Karbon. Perm. Trias.

Die Cotylosaurier bilden eine auf das Perm und die Trias von Nordamerika, Europa und Südafrika beschränkte Gruppe primitiver, altertümlicher Reptilien, die mit den ihnen sehr nahe verwandten Stegocephalen noch

1) Boulenger G. A., On the Characters and affinities of the Triassic Reptile Telerpeton elginense. Proc. Zool. Soc. Lond. 1904. - Broili F., Permische Stegocephalen u. Reptilien von Texas. Palaeontographica. Bd. 51. 1904. ibid. weitere Literatur. Stammreptilien. Anatomischer Anzeiger 25. Bd. 1904. Ein montiertes Skelett von Labidosaurus etc. Zeitschr. der deutsch. g. Gesellsch. 60. Bd. 1908. - Broom $R$., On an almost perfect skeleton of Pareiasaurus serridens. Annals South. Afric. Mus. Vol. IV. 1903. On the classification of the Theriodonts and their allies. Rpt. South Afric. Asoc. f. the adv. of Sci. 1903. On the Pareiasaurian genus Propappus. Ann. South Afric. Mus. Vol. IV. 1908. On the origin of the mammal like Reptiles. Proc. Zool. Soc. London 1907. II. ibid. weitere Literatur. - 
eine Reihe gemeinsamer Merkmale teilen, die sich im Bau des vollkommen geschlossenen Schädeldaches und der Extremitätengürtel sowie des verschiedentlichen Auftretens von Ohrenschlitzen (Conodectes, Seymouria), eines Cleithrums (Pareiasaurus, Propappus, Stephanospondylus, Diadectes), von Hautpanzerung (Pareiasaurus, Sclerosaurus) und von Bauchrippen (Pariotichus, Procolophon) dokumentieren. Ihre Bezahnung ist häufig wie bei manchen Stegocephalen eine protothecodonte, $d$. $h$. ein Übergang von acrodonter-pleurodonter $z u$ thecodonter Bezahnung, insofern es zur Bildung von Alveolen kommt, an deren Boden aber der Zahnsockel ebenso wie an dem umwallenden Kieferknochen festgewachsen ist. Es sind kleine bis mittelgroße, vereinzelt (Pareiasaurus) auch sehr große Formen und zumeist plumpe, niedrig gestellte Tiere mit offenbar trägen, schwerfälligen Bewegungen. In der Hauptsache scheinen sie Strandbewohner gewesen zu sein. Ihr Gebiß weist teilweise wenigstens auf Pflanzennahrung hin (Diadectes), die überhängenden Prämaxillarzähne anderer (Labidosaurus und Pariotichus) lassen auf die Fähigkeit schließen, kleinere Tiere (wie Lysorophus) aus ihrem Bau zu graben, die meist in Krallen endigenden Phalangen dürften außer als Waffe auch für letzteren Zweck gedient haben. Die mangelhafte und dürftige Erhaltung einiger Gattungen gestattet in systematischer Beziehung noch kein abschließendes Urteil. Auf Grund der Bezahnung lassen sich folgende Gruppen auseinanderhalten:

\section{Kieferzähne in einer Reihe, transversal nicht verbreitert:}

Pareiasauridae Seeley.

Seymouria Broili (Fig. 320). Die mäßig großen Augen seitlich in der hinteren Hälfte des gerundet dreiseitigen, skulptierten, noch alle Belegknochen der Stegocephalen aufweisenden und mit Ohrenschlitzen ausgestatteten, ca. $12 \mathrm{~cm}$ langen Schädeldaches. Kehlbrustapparat wie bei den Stegocephalen aus einer mittleren rhomboidalen, nach hinten verlängerten Platte und zwei seitlichen Elementen zusammengesetzt. Basioccipitale mit

Case E. C., A redescription of Pariotichus incisivus. Zool. Bull. Vol. II. Nr. 5, Boston 1899. The osteology of the Diadectidae and their relations to the Chelydosauria. Journ. of Geol. Vol. XIII. 1905. Restoration of Diadectes ibid. 1907. New or little known Reptiles and Amphibians from the Permian of Texas. Bull. Americ. Mus. nat. Hist. Vol. 28. 1910. - Cope E. D., Americ. Naturalist 1880. S. 304. The Reptilian order Cotylosauria Proc. Americ. Philos. Soc.' Vol. 35. 1895. Sec. Contribution to the history of the Cotylosauria ibid. Vol. 36. 1896. - Fürbringer M., Zur vergl. Anatomie d. Brustschulterapparates u. d. Schultermuskeln. Jenaische Zeitschr. f. Naturw. 34. 1900. - Huene F. v., Ubersicht über die Reptilien der Trias. Geol. u. Pal. Abhandl. N. F. VI. 1902. - Uber die Procolophoniden etc. Zentralblatt für Mineralogie 1911. Nr. 3. - Lydekker $R$., Catalogue of the fossil Reptilia and Amphibia in the British Museum (I-IV). 1888 bis 1890. - Newton $E$. T., On some Reptiles from the Elgin sandstone. Philos. Trans. Roy. Soc. Lond. 1893 u. 94. - Osborn H. $F$., The Reptilian subclasses Diapsida and Synapsida and the early history of the Diaptosauria. Mem. Americ. Mus. Nat. Hist. Vol. I. 8. 1903. - Owen R., Descriptive and illustrated Catalogue of the fossil Reptiles of South Africa in the Collections of the British Museum. - Seeley, On Pareiasaurus bombidens und the significance of its affinities to Amphibians, Reptiles and Mammals Philos. Trans. Roy. Soc. Vol. 179. 1888. Further observations on Pareiasaurus ibid Vol. 183. 1892. The armour of the extinct Reptiles of the genus Pareiasaurus Proc. Zool. Soc. Lond. 1908. On an Anomodont Reptile, Aristodesmus, Rütimeyeri etc. Quart. Journ. Geol. Soc. Vol. 56. 1900. On the primitive Reptile Procolophon. Proc. Zool. Soc. Lond. 1905. - Stappenbeck $R$., Uber Stephanospondylus u. g. u. Phanerosaurus H. d. M. Zeitschr. d. d. geol. Ges. 1905. - Thevenin M., Les plus anciens Quadrupèdes de France. Ann. d. Paléontol. T. V. 1910. - Williston S. W., The Cotylosauria. Journ. of Geology Vol. XVI. 1909. New or little known Permian Vertebrates. Pariotichus. Biol. Bull. Vol. XVII. 1909. The skull of Labidosaurus. Americ. Journ. of Anat. Vol. 10. 1910. 
Condylus. Basisphenoid mit kräftigen seitlichen Fortsätzen. Rostrum kurz, dolchförmig. 24 präsacrale Wirbel. ${ }^{1}$ ) Perm. Texas.

Desmospondylus Williston. Perm. Texas.

Labidosaurus Cope. (Fig. 321-23). Skelett, ca. $70 \mathrm{~cm}$ lang, montiert in München. Schädel skulptiert, herzförmig, mit schnabelartig über die Unterkiefer übergreifenden Prämaxillen, von denen jedes drei rechenartig hervortretende Zähne besitzt. Maxillaria mit je 17 ziemlich gleichartigen pleurodonten Zähnen. Transversum vorhanden. Außer den Postparietalia noch ein unpaares Supraoccipitale. Unterkiefer mit 16 Zähnen.

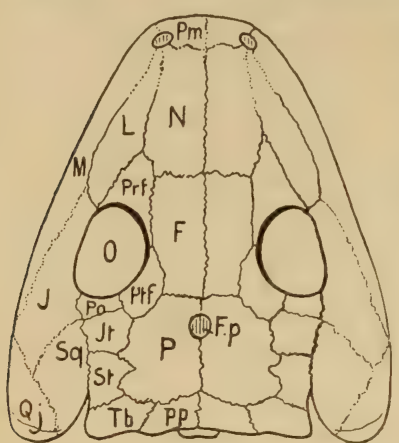

Fig. 320 .

Seymouria Baylorensis Broili. (Ca. 1/s n. Gr.) Perm. Texas. (Die punktierten Linien geben an beschädigten Stellen den vermutlichen Verlauf der Suturen an.) $P m$ Prämaxillare, $N$ Nasale, $F$ Frontale, $P$ Parietale, $F p$ Foramen parietale, Po Postparietale, Prf Präfrontale, Ptf Postfrontale, Po Postorbitale, $I$ Lacrimale, $J$ Jugale, $M$ Maxillare, It Intertemporale, St Supratemporale, Sq Squamosum, Qj Quadratojugale, $P P$ Postparietale, $T b$ Tabulare. Ca. 24 Präsacralwirbel. 2 Sacralwirbel. Ca. 25 Schwanzwirbel. Intercentra vorhanden. Rippen einköpfig. Episternum T-förmig, mit den beiden seitlichen Platten verschmolzen. Humerus mit Foramen entepicondyloideum. Femur gedrungen, mit kräftigem Trochanter. Extremitäten fünfzehig. Perm. Texas.
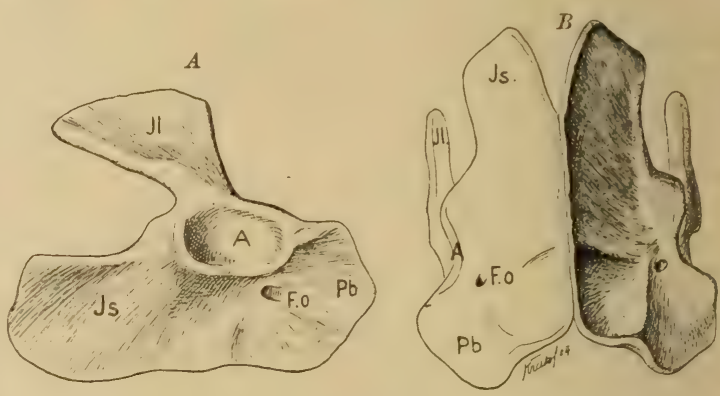

Fig. 321.

Labidosaurus hamatus Cope. Perm. Texas. Becken a rechte Hälíte, $b$ von unten.

$I l$ nium, Is Ischium, $P b$ Pubis, A Acetabulum femoris, Fo Foramen obturatorium. Ca. $1 / 8$ nat. Gr. (Nach Broili.)

? Conodectes Cope. Perm. Texas.

Sclerosaurus H. v. Meyer (Aristodesmus Seeley). Schädeldach $8 \mathrm{~cm}$ lang, mit Kopfstacheln, ähnlich Elginia. Die kegelförmigen Zähne in einer Reihe

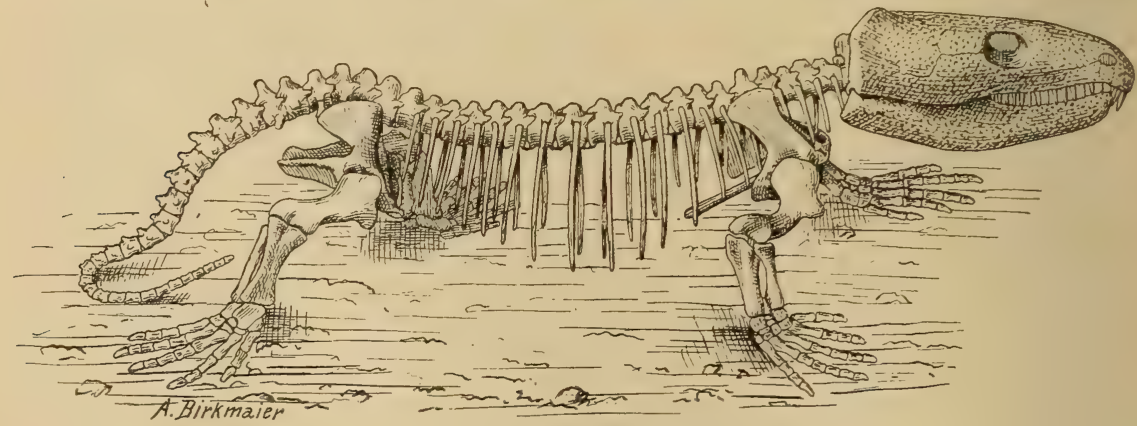

Fig. 322 .

Labidosaurus hamatus Cope. (Ca. 1/5 nat. Gr.). Perm. Seymour. Baylor Co. Texas. Montiertes Skelett in der Münchner Sammlung.

auf den Kiefern. Ca. 22-24 präsacrale Wirbel. Wahrscheinlich 2-3 Sacralwirbel. Rumpf geschwänzt. Intercentra vorhanden. Episternum T-förmig.

1) Nach freundlicher Mitteilung von Herrn Prof. Williston. 
Auf dem Rücken vom Sacrum bis zum Beginn des Halses 6 Längsreihen von Hautpanzerplatten. Oberer Hauptbuntsandstein von Riehen bei Basel.

Pareiasaurus Owen (Fig. 324, 25). Skelett (Britisches Museum, Capstadt, Petersburg) bis $3 \mathrm{~m}$ lang. Schädel niedergedrückt, breit und kurz, mit seitlichen, mäßig großen Augen, rauh oder mit kräftigen Höckern verziert, von denen einer, zapfenartig verlängert, für die mittlere Hälfte der Unterseite jedes Unterkieferastes charakteristisch ist. Bis 20 präsacrale Wirbel,

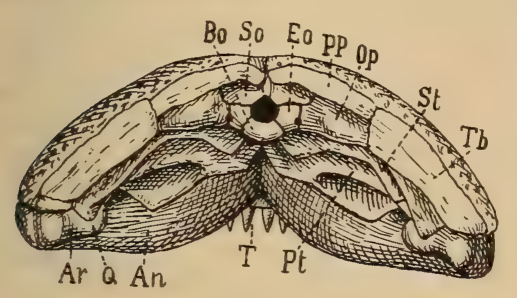

Fig. 323.

Labidosaurus hamatus Cope. Perm, Texas. Schädel von hinten, man sieht die überhängenden Zähne $T$ der Prämaxillaria. N. Willi s to $n$. $P P$ Postparietale, $T b$ Tabulare, So Supraoccipitale, Bo Rasioccipitale, Eo Exoccipitale laterale, Op Opisthoticum, St Stapes, Pt Pterygoid, Qu Quadratum, Ar Articulare, $A n$ Angulare. $1 / 2$ nat. Gr.
2 (4) Beckenwirbel, ca. 30 Schwanzwirbel. Intercentra zwischen den Rumpfwirbeln. Schwanzwirbel mit Chevrons. Rippen, mit Ausnahme der 5-8 vorderen zwei-

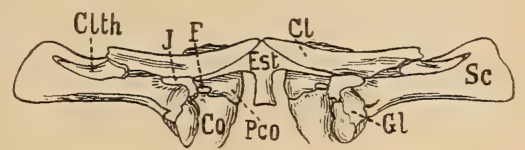

Fig. 324 .

Pareiasaurus Baini Seeley (sehr verkleinert). Ob. Perm. Südafrika. Restauration des Brustschulterapparates nach Seeley u. Fürbringer. Cl Clavicula, Clth Cleithrum, Est Episternum, Gl Fossa glenoidalis pro humero, F Foramen supracoracoideum, $J$ Incisura (Fenestra?) coracoscapularis, Co Coracoid, Pco Procoracoid, Sc Scapula.

köpfigen, einköpfig. Dem Vorderrand der Scapula ein stabförmiges Cleithrum aufliegend. Episternum T-förmig. Der stämmige Humerus mit Foramen entepicondyloideum. Die 5 Phalangen der Vorder- und Hinterextremität krallenartig zugeschärft. 1-3 Reihen plattiger Hautverknöcherungen auf dem Rücken. Untere Beaufort beds. Perm von Südafrika. Idente oder nahestehende Form von N. Rußland. Suchona. ? Obere Dyas oder Untere Trias.

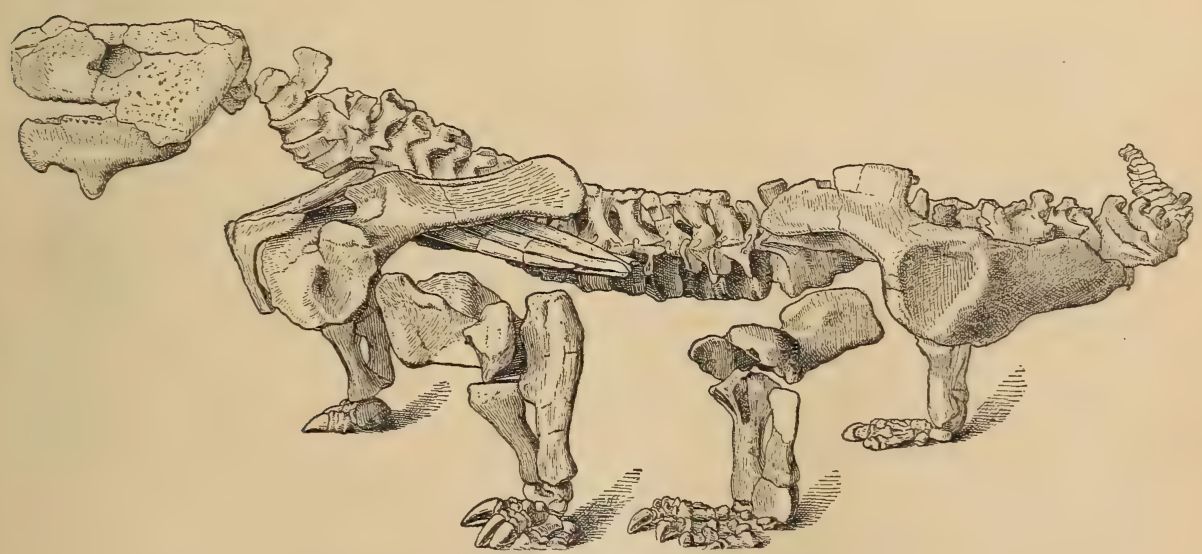

Fig. 325 .

Skelett von Pareiasaurus Baini Seely. Ob. Perm. Tambor Fontein, Kapkolonie.

$1 / 20$ nat. Gr. (Nach Seeley.)

Placerias Lucas. Obere Trias. Arizona.

Brachibrachium Williston. Trias. Wyoming.

Propappus Seeley. Ähnlich Pareiasaurus, aber Rücken dicht mit Knochenplatten gepanzert. Perm. Südafrika.

Anthod on Owen. Perm. Südafrika. 
Elginia Newton. Schädel dreieckig, vorne verschmälert, hinten breit, mit fast terminalen Nasenlöchern. Außer der rauhen Skulptur zeigt das Schädeldach, besonders an seinem Hinterrande verschiedene, hornartig verlängerte, konische Knochenzapfen. Zähne mit etwas eingeschnürtem Hals, die Krone kammförmig eingeschnitten. Unt. ob. Trias. Elgin. Schottland.

\section{Kieferzähne in mehr als einer Reihe, transversal nicht verbreitert:}

\section{Pariotichidae Cope.}

Pariotichus Cope (Ectocynodon Cope). Kleine Tiere mit bis $6 \mathrm{~cm}$ langem, unregelmäßig skulptiertem, dreiseitigem Schädel. Augen groß, ungefähr in der Mitte, Prämaxillare mit einer Reihe größerer Zähne und 2-3 Reihen kleiner protothecodonter auf Sockeln stehender Zähnchen auf den Kiefern. Episternum T-förmig. 24 präsacrale Wirbel mit Rippen. Intercentra vorhanden. Zwei Sacralwirbel. Schwanzwirbel mit Chevrons. Vorder- und Hinterextremität fünfzehig mit Krallen. Nach Williston mit Bauchrippen. Perm. Texas.

Captorhinus, Pantylis, Hypnopous Cope. Perm. Texas.

Stephanospondylus Stappenbeck. Schädel gerundet dreiseitig, skulptiert, mit großem Scheitelloch. Zähne acrodont. Prämaxillarzähne einfach kegelfömig. Maxillare mit ? 2 Reihen kegelförmiger, unterhalb der Krone eingeschnürter, quer zur Kieferachse gestellter Zähne. Wirbelkörper mit oberem Bogen fest verwachsen. Die zwei Beckenwirbel miteinander verschmolzen. Intercentra nicht beobachtet. Episternum rhomboidal und wie die plattenförmigen Claviculae rauh skulptiert. Cleithrum sehr groß. Die Elemente des Schulter- und Beckengürtels nicht miteinander verschmolzen. Rippen ein- und zweiköpfig. Humerus mit Foramen entepicondyloideum. Phalangen mit Klauen. Mittleres Rotliegendes von Sachsen.

Phanerosaurus H. v. Meyer. Schädel unbekannt. Wirbelkörper von oberem Bogen durch. Naht getrennt, Sacralwirbel nicht miteinander verschmolzen. Mittleres Rotliegendes von Sachsen.

\section{Seitliche Kieferzähne mit den Kronen quer zur Kieferachse verbreitert, Diadectidae Cope.}

Diadectes Cope (Nothodon Marsh). Schädel zirka $20 \mathrm{~cm}$ lang, oberflächlich tief gefurcht. Augen klein, seitlich; Foramen parietale auffallend groß. Schläfengegend breit. Prämaxillare mit flach meißelförmigen Zähnen, auf dem Maxillare zirka 11 quer zur Kieferachse gestellte protothecodonte Zähne, mit zwei ungleich hohen Spitzen. Rostrum sehr reduziert. Episternum T-förmig. Cleithrum mit dem Vorderrand der Scapula verschmolzen. 22-24 präsacrale Wirbel, 2 Sacralwirbel. Schwanzwirbel mit Chevrons. Die präsacralen Wirbel mit Hyposphen-Hypantrum-Articulation. Intercentra vorhanden. Die 3.-5. Rippe distal verbreitert, die 6.-8. Rippe von schmalen, dünnen knöchernen Hautplatten überlagert. Extremitäten auffallend gedrungen und kurz. Oberes Karbon. Perm. Nordamerika.

Empedias, Chilonix Cope. Perm. Texas.

Diasparactus Case. Perm. Neu-Mexico.

Bolosaurus Cope. Eine kleine Form. Schädel zum größten Teil ohne Skulptur. Kieferzähne quer gestellt mit einer Spitze auf der Außenseite am Oberkiefer, auf der Innenseite am Unterkiefer. Rostrum sehr lang. Perm. Texas.

Desmatodon Case. Perm. Pittsburg, Pa.

Telerpeton Mantell. Skelett ca. $24 \mathrm{~cm}$ lang, Schädel dreiseitig, platt. Schläfengegend schmal. Augen auffallend verlängert (nach Huene: Augenund Schläfenöffnung). Maxillarzähne verbreitert, quer zur Kieferachse ge- 
stellt, zweihöckerig, acrodont auf Sockeln. Zirka 23 Präsacralwirbel. 2 Sacralwirbel. Schwanz lang. Intercentra fehlen. Bauchrippen beobachtet. Untere obere Trias von Elgin. Schottland.

Procolophon Owen. Schädel und Bezahnung ähnlich wie bei Teler peton. Einige Arten, bei einer Pr. laticeps Seeley, hinter den Augen ein sehr kleines als ? Schläfenöffnung gedeutetes Loch. Episternum T-förmig. Bauchrippen vorhanden. Trias. Südafrika.

Koiloskiosaurus v. Huene. Zähne anscheinend quer gestellt. Bauchrippen vorhanden. Oberer Buntsandstein. Koburg.

Incertae sedis: Sauravus Thevenin. Schädel platt, zirka 25 präsacrale Wirbel, mindestens 2 Sacralwirbel. Über 25 Schwanzwirbel. Bauch. rippen vorhanden. Intercentra nicht beobachtet. Episternum T-förmig. Oberstes Karbon (Stephanien). Unterstes Perm. Autun. Frankreich.

Isodectes Cope. ${ }^{1}$ ) Schädel unbekannt. Zwei Sacralwirbel. Oberes Karbon. Linton. Ohio.

\section{Unterordnung. Pelycosauria. Cope. ${ }^{2}$ )}

Schädeldach mit einem (selten zwei) Paar seitlicher Schläfenöffnungen. Foramen parietale vorhanden. Nasenlöcher getrennt. Zähne protothecodont, häufig die vordere und hintere Kante gezähnelt. Prämaxillar- und vordere Maxillarzähne in der Regel größer. Außerdem Körnchenzähne besonders auf Palatinum und Pterygoid. Wirbel amphicöl, Intercentra gewöhnlich vorhanden. Rippen ein- und zweiköpfig. Dornfortsïtze bei den mehr spezialisierten Formen sehr hoch. Episternum gewöhnlich T-förmig. Coracoid und Procoracoid erst im Alter mit der Scapula verschmolzen. Cleithrum vorhanden. Pubis, Ilium und Ischium miteinander verschmolzen, Becken in der Symphyse zusammenstoßend. Pubis mit Foramen obturatorium. Humerus mit Foramen entepicondyloideum. Vorder-und Hinterextremität fünfzehig. Oberstes Karbon. Perm. Trias.

Die vor allem in Nordamerika, seltener in Mitteleuropa sich findenden Pelycosaurier sind teils schlanke, langgeschwänzte, in ihrem Habitus an getrisse Lacertilier (Varanus) erinnernde, wahrscheinlich ziemlich behende Tiere, teils sehr spezialisierte, infolge ihrer enorm verlängerten Dornfortsätze äußerst bizarre und plumpe Geschöpfe. Wie die Cotylosaurier dürften sie in der Hauptsache Strandbewohner gewesen sein; ihre teilweise furchtbare Bezahnung (Dimetrodon) läßt auf eine Raubtiernatur schließen, während das Gebiß anderer Formen (Edaphosaurus) eher auf Mollusken- oder Crustaceennahrung hinzuweisen scheint.

1) Williston, Journ. of Geol. Vol. XVI. 1908. Moodie. Proc. U. S. Nat. Mus. Vol. 37. 1909.

2) Siehe auch Cotylosaurier! Ferner:

Case E. C., Revision of the Pelycosauria of North America. Carnegie Inst. of Washington. Publication Nr. 55. 1907. Dort ausführliche Literatur bis 1907. Cope E. D., Proc. Philos. Acad. Philadelphia 1870 XI. 1877 XVI. 1878 XVII. 1880 XIX. 1886 XXIII. 1887 XXIV. etc. Trans. Americ. Philos. Soc. Philad. 1888 XVI. 1892 XVII. Americ. Naturalist. 1878. 80. 81. 82. 84. 85. 86 etc. Literatur siehe bei Case! - Huene F. v., Neue u. verkannte Pelycosaurier-Reste aus Europa. Zentralblatt f. Mineral etc. 1908. Nr. 14. Pelycosaurier im deutschen Muschelkalk. Neues Jahrb. f. Mineral.etc. Beilageband 20. 1905. - Jaekel O., Naososaurus Credneri im Rotliegenden v. Sachsen. Zeitschr. (Monatsb.) d. deutsch. geol. Gesellsch. Bd. 62. 1910. Nr. 8/10. - Matthew W. D., A four horned Pelycosaurian from the Permian of Texas. Bull. Americ. Mus. Nat. Hist. Vol. XXIII. 1908. - Osborn H.F., A mounted skeleton of Naosaurus etc. Bull. Americ. Mus. Nat. Hist. Vol. XXIII. 1907. Seeley H. G., Farther evidences of the skeleton in Deuterosaurus and Rhophalodon etc. Philos. Trans. Roy. Soc. 1894 B. 


\section{Familie. Poliosauridae. Case.}

Schïdel niedrig, langgestreckt und zugespitzt. Lücke zuischen Prämaxillar. und Maxillarzülnen nicht oder kaum entwickelt. Dornfortsïtze nieder. 2 Sacralwirbel. Langgeschwänzt. Perm. ? Trias.

Poliosaurus Case. Schädel unvollständig erhalten. Oberer Bogen nicht mit dem Wirbelkörper verschmolzen. Intercentra anscheinend fehlend. Hautverknöcherungen vorhanden. Zirka $70 \mathrm{~cm}$ langes Tier.

Varanosaurus Broili. Schädel langgestreckt, leicht skulptiert, mit spitzer, überhängender Schnauze, zirka $15 \mathrm{~cm}$ lang. Zirka 54 meist gleichartige, kleine ungezähnelte Zähne auf Prämaxillare und Maxillare. Zwei größere vorne am Maxillare. Körnchenzähne auf dem Pterygoid. Eine große seitliche Schläfenöffnung beobachtet. Oberer Bogen mit dem Wirbelkörper verschmolzen. Intercentra vorhanden. Rippen einköpfig (Capitulum? rudimentär). 26 präsacrale Wirbel. Schwanz sehr lang. Schwanzwirbel mit Chevron bones und Intercentra. Endphalangen mit Klauen. Skelett $60 \mathrm{~cm}$ bis $1 \mathrm{~m}$ lang. Perm. Texas.

Poecilospondylus Case. Perm. Texas.

Theropleura Cope (Diopeus Cope, Ophiacodon Marsh). ${ }^{1}$ ) Schädel unvollständig erhalten. 5 Zähne auf dem Prämaxillare, zirka 30 aủ dem Maxillare, von denen der 5. und event. 6. stärker sind. 30 gleichartige, durch Intercentra getrennte Präsacralwirbel. Intercentra und Chevrons nicht an den Schwanzwirbel beobachtet. Skelett 2-5 $\mathrm{m}$ lang. Perm. Texas.

Stereorhachis Gaudry. Zirka 1,50 m lang, mit mäßig hohen Dornfortsätzen, Hautverknöcherungen und wohl entwickelten Gelenkflächen an den Extremitäten. Intercentra sind nicht beobachtet. Unteres Perm von Autun, Frankreich.

Elcabrosaurus Case. Perm. Neu-Mexiko.

Incertae sedis: Archaeobelus Cope. Perm Illinois. Pleuristion Cope. Perm Oklahoma.

Dolichobrachium Williston. Trias. Wyoming.

Anomosaurus v. Huene. Auf eine großere Anzahl pelycosaurierähnliche Wirbel hin begründet, aber mit Hyposphen. Deutscher Muschelkalk.

Oxyodon v. Huene. Perm. Kenilworth. England.

\section{Familie. Clepsydropidae. Cope.}

Schädel seitlich homprimiert mit erhöhter Gesichtsregion, Einschnitt zwischen Prämaxillare und Maxillare vorhanden. Dornfortsätze sehr hoch. 3 Sacralwirbel. Gelenkfächen der Extremitätenknochen gut ausgebildet. Oberstes Karbon. Perm. Trias.

Clepsydrops Cope. Schädel unvollständig erhalten. Der Einschnitt zwischen Prämaxillare und Maxillare mit kleineren Zähnen ausgefüllt. 1-2 sehr große Zähne auf dem Maxillare (insgesamt 21 Zähne). Prämaxillare mit 4 Zähnen. Alle Zähne mit schneidenden nicht gezähnelten Kanten. Oberer Bogen in der Jugend frei, im Alter verwachsen, Intercentra vor. handen. Hautverknöcherungen nicht beobachtet. Perm. Texas. Illinois.

Dimetrodon Cope (Embolophorus p. p. Cope). (Fig. 326,327.) Der bis $45 \mathrm{~cm}$ lange hoch gebaute Schädel mit verhältnismäßig weit zuürckliegenden mäßig großjen Augen und einem Paar seitlicher ebensolcher Schläfenlöcher. Ein zweites Paar oberer kleinerer Schläfendurchbrüche kann außerdem zur Ausbildung gelangen, aber auch völlig fehlen. Prämaxillare mit einigen Fangzähnen. Hinter dem meist zahnfreien Einschnitt folgt das Maxillare mit ein bis zwei gewaltigen Fangzähnen, denen zirka 20 kleinere folgen. Oberer Bogen

1) Prof. Williston in Chicago hatte die große Liebenswürdigkeit, mich über die Identität der Marsh'schen Typen mit denen von Cope aufzuklären. 
Texas. Pennsylvanien. Oberstes Karbon (Grenzschicht) von Kounova (Böhmen), Rotliegendes von Sachsen.

Edaphosaurus Cope. Schädel nieder, mit kleinen Augen. Eine große seitliche Schläfenöffnung sicher nachweisbar. Prämaxillarzähne flach, meißelförmig. Von den 14 Maxillarzähnen die 5 vorderen dünne, dreiseitige, hinten und vorne zugeschärfte Platten, die hinteren konisch. Palatin und Pterygoid zum großen Teil mit plumpen kegelförmigen Zähnen besetzt. Möglicherweise der Schädel von Naosaurus. Perm. Texas.

Tetraceratops W. Matthew. Zahnfreie Lücke zwischen Maxillare und Prämaxillare sehr groß. Schädel mit 2 Paar »hornartigen« Knochenzapfen, die an den Prämaxillaria bzw. den Präfrontalia aufsitzen. Perm. Texas.

Incertae sedis: Bathygnathus Leidy. Kieferreste aus dem Perm von Prince Edward Island, Kanada. Dürfte wahrscheinlich in die Nähe von Dimetrodon zu stellen sein.

Tomicosaurus Case, Metamosaurus Cope. Casea Williston. Perm Texas. Embolophorus p. p. Cope. Trispondylus Williston. Perm Texas. Sphenacodon Marsh. Perm Neu-Mexiko.? Geosaurus cynodus Gervais aus dem Perm von Moisset (Departement Jura).

\section{Anhang.}

Im System vorläufig noch unsicher ist die auf unvollständige Reste hin begründete Familie der Deuterosauridae Seeley aus dem Perm von Rußland. Deuterosaurus Eichwald und Rhophalodon Fischer zeigen ähnliche große gezähnelte Fangzähne auf Prämaxillare und Maxillare wie Dimetrodon und anscheinend nur eine Schläfenöffnung. Bei Rhophalodon findet sich im Auge ein Scleroticaring. Wirbel amphicöl. 2 Sacralwirbel. Schultergürtel und Beckenreste pelycosaurierähnlich. Die Gattungen Brithopus, Orthopus, Syodon Kutorga und Dinosaurus und Eurosaurus Fischer sind auf vereinzelte Fragmente errichtet und gehören höchst wahrscheinlich zu Deuterosaurus und Rhophalodon. Ebenso zweifelhaft ist die Stellung von Cliorhizodus Twelvetrees.

\section{Unterordnung. Theriodontia. Owen. ${ }^{1}$ )}

Schädel unskulptiert, in der Regel mit einem Paar großer oberer Schläfen. öffnungen. Prämaxillar- und Maxillarzähne ähnlich wie bei den Mammalia differenziert in Schneidezähne, Eckzähne und Molaren. Zähne auf dem Gaumen unbedeutend und selten. Die Elemente des Schulter- und des Beckengürtels durch Naht unbeweglich verbunden. 2-4 Sacralwirbel. Hinterhauptscondylus häufig zweigeteilt. Unterkiefer mit großem Processus coronoideus. Scapula meist mit ansehnlichen Fortsatz (Acromion). Wirbel amphicöl. Perm. Trias. (Karooformation.)

1) Broom $R$, On the classification of the Theriodonts and their allies. Rpt. South. Afric, Assoc. Advanc, Science 1903. On an almost perfect skull of a new primitive Theriodont. (Lycosuchus Vanderrieti). Transact. South. Afric. Philos. Soc. 1903. On the remains of Lystrosaurus etc. Rec. Alb. Mus. Vol. I. 1903. On two new Therocephalian Reptiles. ibid. 1904. On the structure and affinities of the Endothiodont Reptiles ibid. 1904 (Vol. XVI). On some new primitive Theriodonts in the South Afric. Mus. Vol. IV. 2. 1903. On the Inter-relationships of the known Therocephalian genera. ibid. 8. 1908. Fossil Reptiles of the Karoo Formation in: An introduction to the Geology of Cape Colony by Rogers and du Toit. London 1909. - On the origin of the Mammal-like Reptiles. Proc. Zool. Soc. London 1907. II. ibid. weitere Literatur über diese Frage! - Broili $F$., Ein Dicynodontierrest aus der Karooformation. Neues Jahrbuch für Mineralogie etc. 1908. - Fürbringer M., Vergl. Anatomie des Brustschulterapparates etc. Jen. Zeitschr. für Naturwissensch. 34. Bd. 1900. - Jaekel O., Uber den Schädelbau der Dicynodonten. Sitzungsb. d. Ges. Naturforsch. Freunde. Berlin 1904. - Lydekker R., Ca- 
Die Theriodontia sind durchschnittlich mittelgroße Reptilien, von denen indessen einzelne (Cynognathus) die Größe eines Tigers erreichen können. Ihr teilweise furchtbares, raubtierartiges und ähnlich den Säugern in Schneidezähne, Eckzähne und Molaren differenziertes Gebiß, der Bau des Schädels mit seinem unbeweglichen, unbedeutenden Quadratum und seinem Doppelcondylus bei den höher stehenden Formen (Cynodontia), die Beschaffenheit des Schultergürtels und Beckens hat vielfach zu Vergleichen mit Säugetieren, besonders mit Marsupialiern Veranlassung gegeben, indessen erscheinen die uns bekannten Reste der Theriodontia bereits viel zu hoch differenziert, als da $\beta$ sie in direkten genetischen Zusammenhang mit denselben gebracht werden könnten. Viele der unten genannten Gattungen werden als Ver-
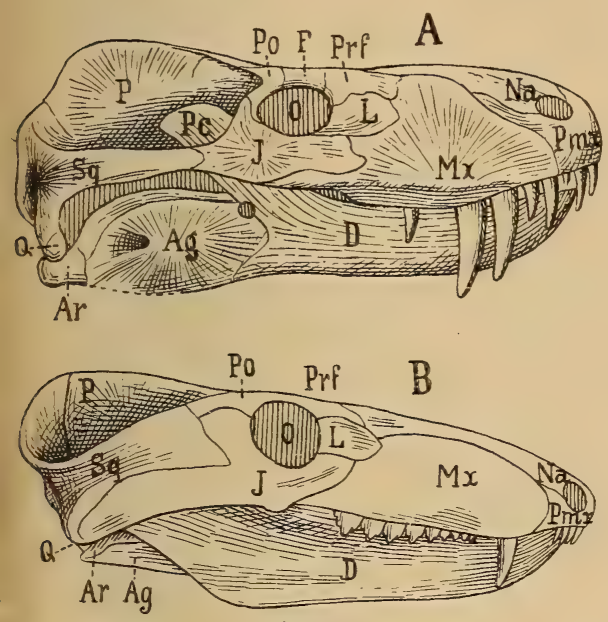

Fig. 329.

A Lycosuchus Vanderrieti Broom. Schädel (primitive Theriodontier) von der Seite. Perm Südafrika.

$B$ Cynognathus platyceps Seeley. Schädel (spezialisierter Theriodontier). Trias Südafrika.

0 Auge, $P m$ Prämaxillare, Mx Maxillare, Na Nasale, Prf Präfrontale, $L$ Lacrimale, $J$ Jugale, Po Postorbitale, $S q$ Squamosum, $P$ Parietale, $Q u$ Quadratum, $F$ Frontale. $A g$ Angulare, $A r$ Articulare, $D$ Dentale bei Lycosuchus mit großer Proc. coronoideus.

(Nach B room.) Ca. 1/4 nat. Gr.

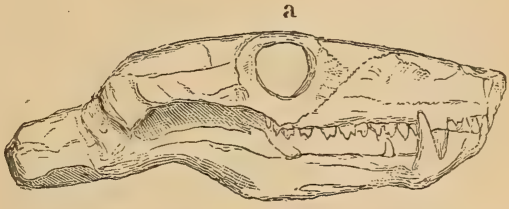

b
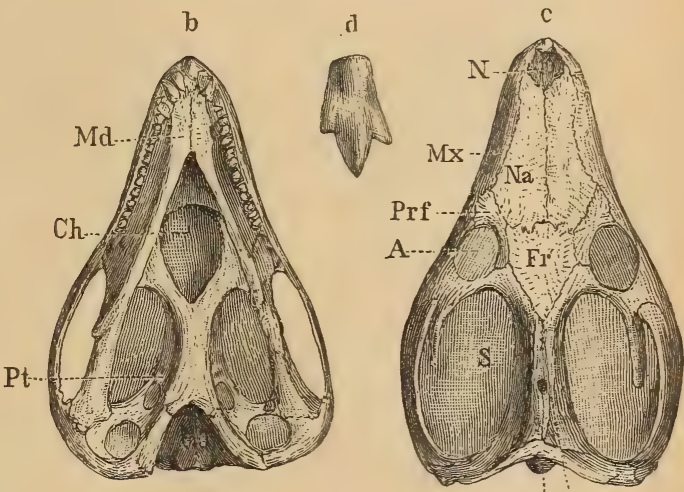

Bo $\mathrm{Pa}$

Fig. 330

Galesaurus planiceps Owen. Karooformation (Trias) Theba-Mou, Basutoland.

Schädel, $a$ von der Seite, $b$ von unten, $c$ von oben Etwas restauriert, $1 / 2$ nat. Gr. $d$ Backenzahn vergr. (Nach R. O w en.)

treter selbständiger Familien wie der Scylacosauridae, Aelurosauridae, Galesauridae, Gomphognathidae etc. angesehen.

Als primitive Theriodontier = Therocephalia Broom) werden haupt. sächlich aus dem Perm (Untere Beaufort beds) von Südafrika eine Reihe, vielfach auf mangelhafte Reste hin begründete Gattungen beschrieben, die

talogue of the foss. Rept. a. Amph. Brit. Mus. P. 4. 1890. - Newton E. T., Some new Reptiles from the Elgin Sandstone. Philos. Transact. R. Soc. Lond. 1893. Vol. 184. - Osborn H. F., The origin of the Mammalia. Americ. Naturalist 32. 1898. Owen R., On Dicynodon. Trans. geol. Soc. 1845. VII. On Dicynodont Reptiles Philos. Trans. 1862. Vol. CLII u. Quart. Journ. geol. Soc. 1860. Vol. XVI, Vol. XXXVI, Vol. XXXVII. Descriptive and illustrated Catalogue of the fossil Reptiles of South Africa in the Collections of the British Mus. London 1876. - Seeley H. G., Researches on the Structure, organization a. classific. of the foss. Reptilia III u. V. Philos. Trans. Roy. Soc. Lond. Vol. 179. 1888. VI. ibid. Vol. 180. 1889. IX. ibid. Vol. 186. 1895. Ferner eine Reihe von Aufsätzen im Quarterl. Journ. Geol. Soc. u. Annals and Magaz. of Nat. Hist. - Woodward A. S., Outlines of Vertebrate Paleontology etc. Cambrigde 1898. 
im Gegensatz zu den jüngeren Gattungen in der Regel 1-3 Eckzähne, einfache konische "Molaren«, ein großes Quadratum, ebensolches Foramen parietale sowie einen? einfachen Hinterhauptscondylus besitzen ferner eine Scapula ohne Acromion: Cynodraco, Cynochampsa, Tigrisuchus, Cynosuchus, Aelurosaurus Owen, Pristerognathus Seeley, Ictidosuchus, Lycosuchus (Fig. 329 A), Scylacosaurus, Ictidosaurus, Scymnosaurus, Alopecodon, Hyaenosuchus, Pardosuchus, Trochosuchus, Arnognathus Broom. Die noch permischen Formen Lycosaurus Owen von Südafrika und Inostranzewia Amal. von Nordrußland sowie Bauria Broom aus der unt. Trias Südafrikas scheinen die vermittelnden Bindeglieder zu den mehr spezialisierten jüngeren Formen $=$ Cynodontia Owen aus der Trias (ob. Beaufort, Burghersdorp beds) darzustellen.

Die wichtigsten Vertreter der letzteren sind:

Galesaurus Owen (= Nythosaurus Owen. Fig. 330). Der kleine Schädel mit vereinigten terminalen Nasenlöchern. 4 Paar Schneidezähne oben, 3 Paar unten, ein Paar Eckzähne auf jedem Kiefer, denen die seitlich verschmälerten meist teilweise dreispitzigen Molaren folgen. Trias. Südafrika.

Cynognathus Seeley. Fig. 329B. Bis 6 Fuß großes Raubtier. Schädel bis $40 \mathrm{~cm}$ lang, verhältnismäßig schmal und hoch mit terminalen getrennten Nasenlöchern. Eine kleine seitliche Schläfenöffnung vorhanden oder fehlend. Hinterhauptscondylus zweigeteilt. Unterkieferäste in der Symphyse miteinander verschmolzen. Coronoidfortsatz hoch. Prämaxillaria mit 4 Paar gezähnelten Schneidezähnen. Unterkiefer mit ? 3 Paar. Auf den oberen sehr kräftigen, teilweise gezähnelten Eckzahn, folgen auf dem Maxilare 9 seitlich verschmälerte konische, teilweise dreispitzige Molaren. 29 amphicöle präsacrale Wirbel, die vorderen mit Intercentren. Rippen zweiköpfig. 4 (2) Sacralwirbel. Zwischen Pubis und Ischium ein großes Foramen obturatorium. In der Symphyse ziemlich ansehnliches Foramen pubo-ischiadicum. Trias. Südafrika.

? Dicranozygoma Seeley ? Trias. Südafrika.

Gomphognathus Seeley. Ähnlich Cynognathus, aber Schädel nieder und breit und Molarzähne verbreitert. Vermutlich herbivor. Hinterhauptscondylus doppelt. Trias. Südafrika.

Microgomphodon Seeley. 2 Sacralwirbel. Triarchodon. Diademodon. ? Theriodesmus Seeley. Sesamodon, Melinodon Broom. Trias. Südafrika.

? Galechirus Broom. Schädel unvollständig bekannt. Scapula, Coracoid und Procoracoid sowie Beckenelemente miteinander verschmolzen. Perm. Südafrika. Nach Broom Repräsentant der Dromasauria Broom.

Die Gruppe der Dinocephalia Seeley mit Tapinocephalus Owen (Phocasaurus Seeley) und Delphinognathus, Titanosuchus, ? Gorgonops Owen Ecca. saurus, Pelosuchus Broom aus dem Perm Südafrikas und ? Eubrachiosaurus Williston Trias. Wyoming, die im Gegensatz $\mathrm{zu}$ den übrigen Theriodontiern mit einem Quadratojugale versehen ist scheint von der Therocephalia zu den Anomodontiern überzuleiten.

\section{Unterordnung. Anomodontia. Owen. (Dicynodontia.)}

Schädel unskulptiert mit einer weiten, oberen Schläfenöffnung. Foramen parietale vorhanden. Squamosum und Quadratum sehr groß. Prämaxillaria verschmolzen, zahnlos und weit ausgedehnt. Ein unvollständiger sekundärer Gaumen von den Maxillaria und Palatina gebildet. Condylus occipitalis einfach, dreigeteilt. Scapula mit Acromion. Scapula, Coracoid und Procoracoid sowie die Elemente des Beckens durch Naht unbeveglich verbunden. 4 oder? mehr Sacralwirbel. Extremitäten fünfzehig mit Klauen. Wirbel amphicöl. Perm. Trias.

Die Anomodontia sind herbivore, kleine bis mittelgroße, die Größe eines kleinen Flußpferdes erreichende, Reptilien, dem sie auch in bezug auf ihre schwerfällige Gestalt und wahrscheinlich ebenso in den Lebensgewohnheiten 
am meisten geähnelt haben dürften. An dem meist plumpen Kopf fehlt die Bezahnung auf den verschmolzenen, ursprünglich wohl mit Hornscheiden besetzten Prämaxillaria ebenso auch auf den Maxillaria entweder "gänzlich, oder sie ist an den letzteren auf kleine zahlreiche Molarzähnchen oder auf zwei mächtige Hauzähne reduziert, welche in einer langen, durch eine Anschwellung des Kiefers auch äußerlich sichtbaren Alveole ruhen. Der Schädel ist häufig sehr solid verknöchert und die Suturen infolgedessen verwischt, die Nasenlöcher liegen wie die Augen, in welch letzteren gelegentlich ein Scleroticaring beobachtet wird, seitlich. Charakteristisch für die Anomodontier ist das Squamosum, welches, meist mit dem Quadratum verschmolzen, ungewöhnlich vergrößert ist und nicht nur den größten Teil der Begrenzung des Schläfenlochs bildet, sondern auch abwärts in einen stielför. migen Fortsatz ausgezogen ist, dessen untere Seite von der Gelenkfläche des Quadratum eingenommen wird.

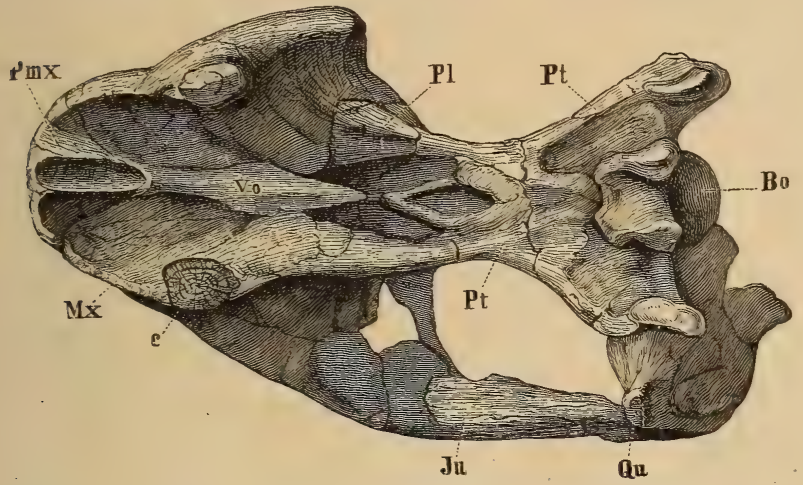

Fig. 331. Dicynodon pardiceps Owen. Perm (Karooformation). Fort Beaufort, Kapkolonie. Von unten. 1/4 nat. Gr. (Nach R. O wen.) $P m x$ Prämaxillare, $M x$ Maxillare, $P l$ Palatin, Vo Vomer, $P t$ Pterygoid, Bo Basioccipitale, Qu Quadratum, c Zahn.

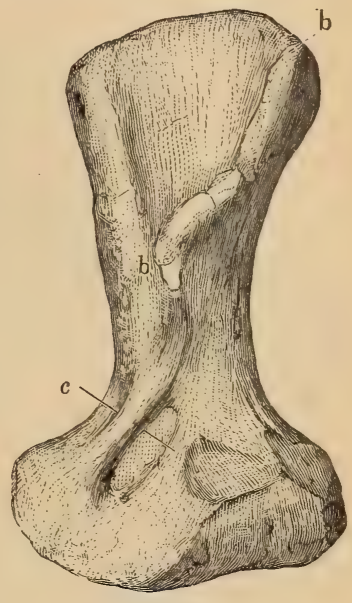

Fig. 332.

Oberarm von Dicynodon par diceps Owen. 1/4 nat. Gr. Von vorn gesehen. $b$ crista deltopectoralis, $c$ foramen entepicondyloideum. (Nach O we n.)

Die Hinterhauptsregion bildet eine gerade, ebene Fläche, die gewöhnlich zwei kleine Durchbrüche (Gehöröffnungen) zeigt. Die zwei zahnlosen, offenbar auch mit Hornscheiden besetzt gewesenen Unterkiefer, sind in der Symphyse verschmolzen und weisen seitlich noch eine große Öffnung für den

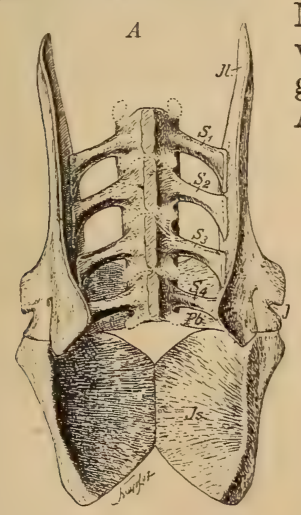

Meckelschen Knorpel auf. Die nur von wenigen Formen bekannte Beckengegend läßt 4 Sacralwirbel erkennen. Am Ilium findet sich eine vom Ace.

Fig. 333.

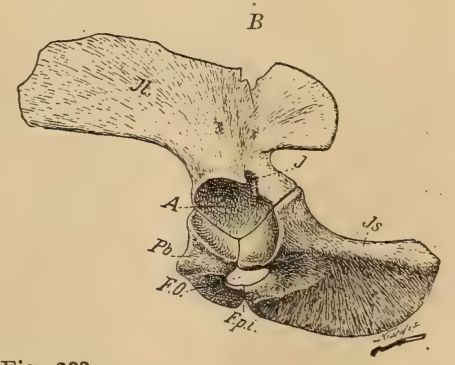
Die 4 Sacralwirbel und Becken eines Dicynodontiers? Dicynodon Seeleyi.
Broili. ? Perm Südafrika. A von oben und $B$ von der Seite.

$I l$ nium, Is Ischium, $P b$ Pubis, $J$ Incisur am nlum, $A$ Acetabulum femoris, FO Foramen obturatorium, Fpi Foramen pubo-ischiadicum, $S_{1}$ bis $S_{4}$ die 4 Sacralwirbel. Ca. $1 / 3$ nat. Gr.

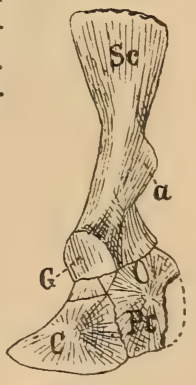

Fig. 334 .

Schultergürtel (rechte Seite) eines Dicynodontiers. Perm Südafrika. Sc Scapula mit Acromion $a, C$ Coracoid, $P c$ Procoracoid, $G$ Gelenkfläche für den Humerus.

(Nach Ly dekker.)

Ca. 1/4 nat. Gr. 
tabulum ausgehende Incisur, zwischen Ischium und Pubis das Foramen obturatorium und in der Symphyse ein Foramen pubo-ischiadicum.

Dicynodon Owen (Keirognathus Seeley. Fig. 331-334). Scheitel und Stirnregion allmählich mit mehr oder weniger starker Krümmung in Nasenund Prämaxillarregion übergehend. Augen und Schläfenlöcher gewöhnlich groß. Jedes Maxillare mit einem kräftigen Hauzahn. Schultergürtel mit Cleithrum. Zahlreiche Formen im Perm und in der Trias von Südafrika von der Größe einer Ratte bis zu der eines kleinen Flußpferds (Schädellänge bis $0,5 \mathrm{~m})$.
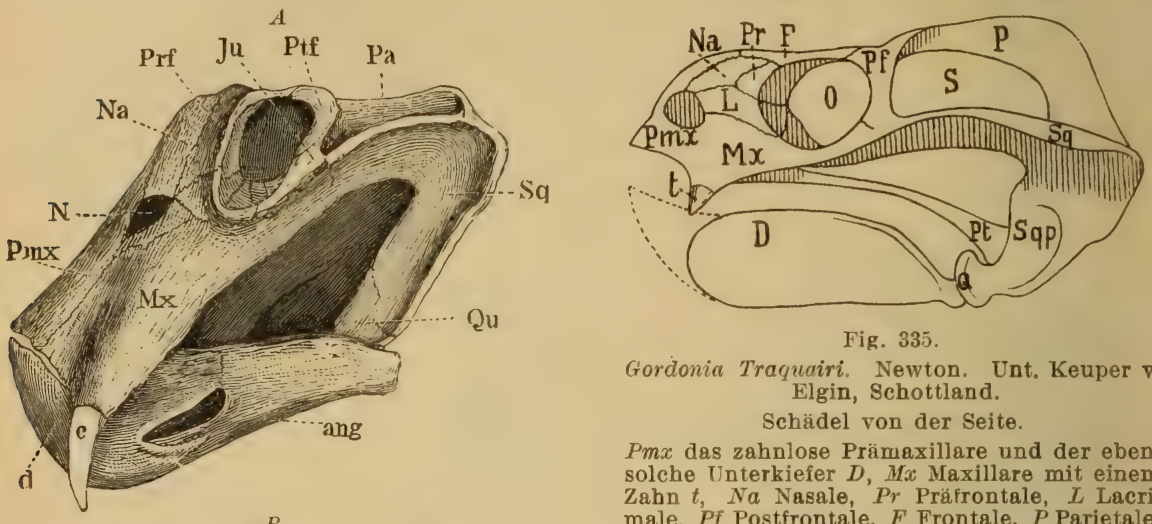

Fig. 335 .

Gordonia Traquairi. Newton. Unt. Keuper $\nabla$. Elgin, Schottland.

Schädel von der Seite.

Pmx das zahnlose Prämaxillare und der eben. solche Unterkiefer $D, M x$ Maxillare mit einem Zahn $t, \quad N a$ Nasale, $\operatorname{Pr}$ Präfrontale, $L$ Lacrimale, $P f$ Postfrontale, $F$ Frontale, $P$ Parietale, $S q$ Squamosum, Sqp Stielförmige Verlängerung derselben, $Q u$ Quadratum, Pt Pterygoid,

0 Augen-, S Schläfenloch. Nach Newton und A. S. Woodward. Ca. $1 / 3$ nat. Gr.

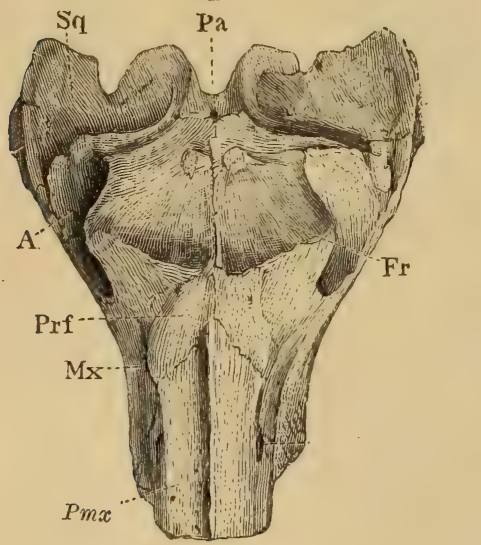

Fig. 336 .

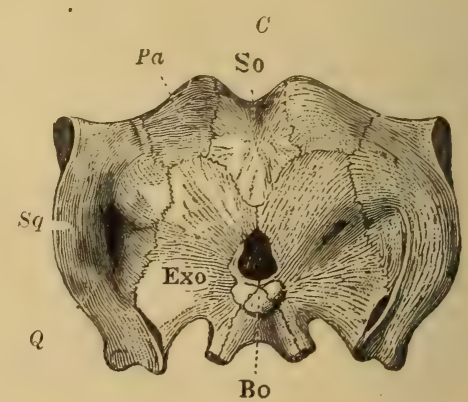

Schädel von Lystrosaurus declivis Owen. $A$ von der Seite, $B$ von oben, $C$ von hinten. 1/s nat. Gr. Trias (Karooformation). Rhenosterberge, Kapkolonie. (Nach R, Owen.)

Bo Basioccipitale mit dem dreigeteilten Condylus, Exo Exoccipitale, So Supraoccipitale, Sq Squa mosum, Qu Quadratum, Pa Parietale, Fr Frontale, Ptf Postfrontale, Prf Präfrontale, Ju Jugale, La Lacrimale, Na Nasale, $M x$ Oberkiefer, Pmx Zwischenkiefer, A A genhöhle, $N$ Nasenloch, ang Angulare, $d$ Dentale, $c$ Eckzahn des Oberkiefers.

Oudenodon Owen. (Platypodosaurus. Owen.) Sehr ähnlich Dicynodon, aber zahnlos oder nur Rudimente von Zähnen. Vielleicht die Weibchen von Dicynodon. Perm. Trias. Südafrika.

Lystrosaurus Cope. (Fig. 336.) (Ptychognathus Owen, Ptychosiagum Lydekker.) Prämaxillar - Nasalgegend gegen die Frontal-Parietalregion und diese gegen das Hinterhaupt stark winklig abgesetzt. Augen sehr groß mit Scleroticaring, Nasenlöcher weit zurückliegend. Auf jedem Maxillare ein Hauzahn. Cleithrum nicht beobachtet. Extremitäten stämmig. Gelenkenden anscheinend nicht verknöchert. Perm. Südafrika, Indien. 
Gordonia Newton. Fig. 335 . Schädel bis $18 \mathrm{~cm}$ lang, ähnlich Dicynodon, nur schwächere Kopfknochen und die 2 Zähne bedeutend kleiner. Unt. ob. Trias. Elgin. Schottland. ? Perm. Nordrußland. Geikia Newton. von ebendaher, völlig zahnlos.

Kistecephalus Owen. Perm. Südafrika.

Diesen Formen, welche auch als Dicynodontidae und Lystrosauridae auseinander gehalten werden, reihen sich noch die $E n d o$ thiontidae an, Gattungen, die auf den Maxillaria und auf den rückwärtigen Teilen des Unterkiefers eine oder mehrere Reihen von kleinen Zähnchen und außerdem ein gerundetes Episternium besitzen.

Endothiodon Owen. Kopf verhältnismäßig groß. Cleithrum vorhanden. 4 Sacralwirbel. Perm. Südafrika. Von dort stammen auch Esoterodon Owen, Cryptocynodon Seeley, Prodicynodon Broom. Opisthoctenodon Broom Pristerodon Huxley. Chelyposaurus Broom.

\section{Ordnung. Rhynchocephalia. ${ }^{1}$ )}

Körper meist eidechsenähnlich. Wirbel in der Regel amphicöl, zuweilen mit Chordaresten. Intercentra gewöhnlich gut entwickelt. Fast stets nur zwei Sacralwirbel. Rumpfrippen einköpfig. Bauchrippen entwickelt. Quadratum unbeweglich. Oberer und unterer Schläfenbogen vorhanden. Unterkieferäste in der Symphyse durch Ligament verbunden. Zähne acrodont. Brustgürtel mit knorpeligem Sternum. Extremitäten fünfzehig, manchmal dem Wasserleben angepaßt. Haut mit hornigen Schuppen. Perm bis jetzt.

Gleichzeitig mit den Theromora im Perm treten die Rhynchocephalen auf, von denen gegenwärtig nur noch eine Gattung Sphenodon (Hatteria) in Neu-Seeland lebt. Die Rhynchocephalen zeigen sich

1) Barnum Brown, The Osteology of Champsosaurus. Mem. Americ. Mus. Nat. Hist. Vol. IX. P. I. 1905. - Baur G., Palaeohatteria and the Proganosauria. Amer. Journ. Sc. 1889. XXXVII. p. 310. - Boulenger G. A., On Reptilian Remains from the Trias of Elgin. Philos. Transact. Roy. Soc. London, Ser. B, Vol. 196. 1903. - Burckhardt R., On Hyperodapedon Gordoni. Geol. Magaz. Dec. IV. 7. 1900. - Credner $H$., Utber Palaeohatteria und Kadaliosaurus. Zeitschr. d. deutsch. geol. Gesellsch. 1888 Bd. XL und 1889 Bd. XLI. - Dames W., Beitrag zur Kenntuis der Gattung Pleurosaurus. Sitzungsb. d. k. pr. Akad. d. Wissenschaft. 1895. II. - Dollo L., Bull. Mus. Roy. d'hist. nat. Belg. III, Bull. Soc. Belge de Géol. Pal. et Hydrol. $1891 \mathrm{~V}$ und Revue des questions scientif. 1885. - Etzold, Úber Proterosaurus. Neues Jahrbuch 1898. II. S. 449. - Günther Alb., On the Anatomy of Hatteria. Philos. Trans. 1867. vol. 157. - Huene F. v., Über einen echten Rhynchocephalen aus der Trias v. Elgin etc. Neues Jahrb. für Mineral. etc. 1910. II. ibid. weitere Literatur. - Die Dinosaurier d. europ. Triasformation etc. Kapitel IX. Geol. u. Pal. Abhandl. Suppl. I. Jena 1907-08. - Huxley Th., Quart. journ. geol. Soc. London $1859 \mathrm{XV}, 1869 \mathrm{XXV}$ und 1887 XLIII. - Lemoine V., Etude sur les charact. gener. du Simaedosaurus. Reims 1884 und 1885. - Lortet L., Les Reptiles foss. du Bassin du Rhone. Arch. Musée d'hist. nat. Lyon 1892. vol. V. - Merriam J. C., The Thalattosauria etc. Memoirs Calif. Acad. Science. Vol. V. N. I. 1905; ferner: Bull. Dep. Geol. University of Calif. Publicat. Vol. 5 Nr. 13. Berkeley 1908. - Meyer H. v., Zur Fauna der Vorwelt. Saurier aus dem Kupferschiefer 1857 und Reptilien aus dem lithographischen Schiefer 1860. - Osborn H. F., The Reptilian subclasses Diapsida and Synapsida and the early bistory of the Diaptosauria. Mem. Americ. Mus. Nat. Hist. Vol. I. P. VIII. 1903. - Seeley H. G., On Protorosaurus. Phil. Trans. 1887. vol. 178. - Stefano, G. de, Nuovi rettili degli strati a fosfato della Tunisia, Boll. d. Soc. Geol. It. Vol. XXII, 1903. - Wagner A., Saurier aus dem lithograph. Schiefer. Abhandl. bayer. Akad. II. Cl. 1852. Bd. VI. 1853 Bd. VII. 1861 Bd. IX. - Woodward A. S., On Rhynchosaurus articeps. Rep. British Assoc. Advanc. Science York 1906. 
in der Hauptsache als Küstenbewohner, von denen die meisten wie Sphenodon befähigt gewesen sein dürften, stundenlang, ohne zu atmen, unter Wasser zu bleiben; einzelne von ihnen besitzen die Bauart vortrefflicher Schwimmer wie Pleurosaurus; einige wie die Thalattosauridae erscheinen endlich als marine, vollständig dem Wasserleben angepaßte Tiere. Ihr Körper ist in der Regel eidechsenähnlich, langgeschwänzt und wie bei dem lebenden Sphenodon finden sich bei einzelnen fossilen Formen Schuppen. Die Wirbel mit ihren Fortsätzen
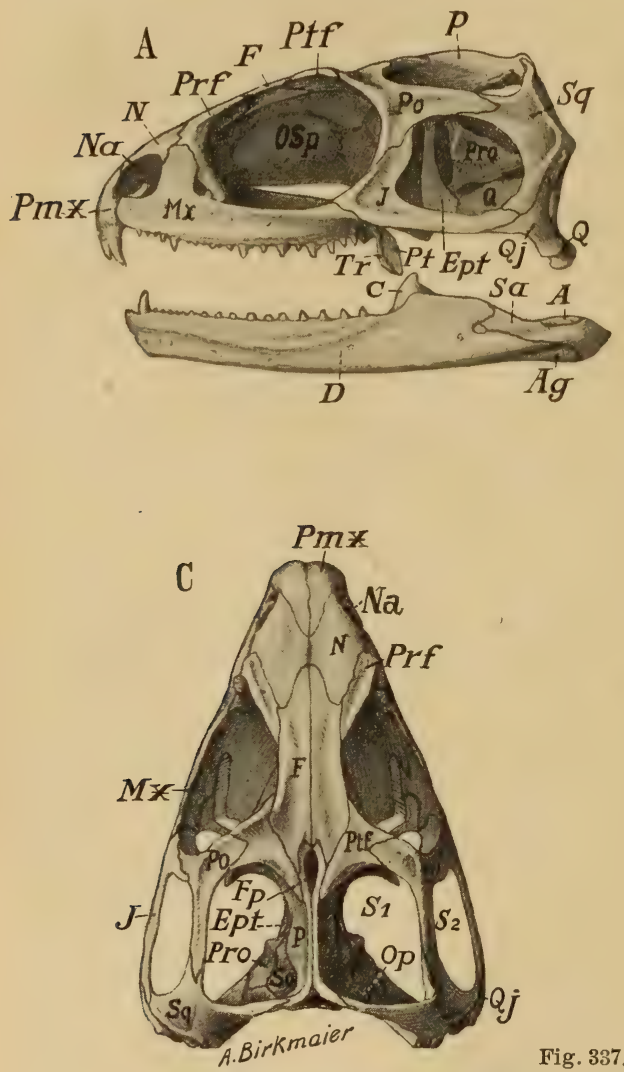

Fig. 337.
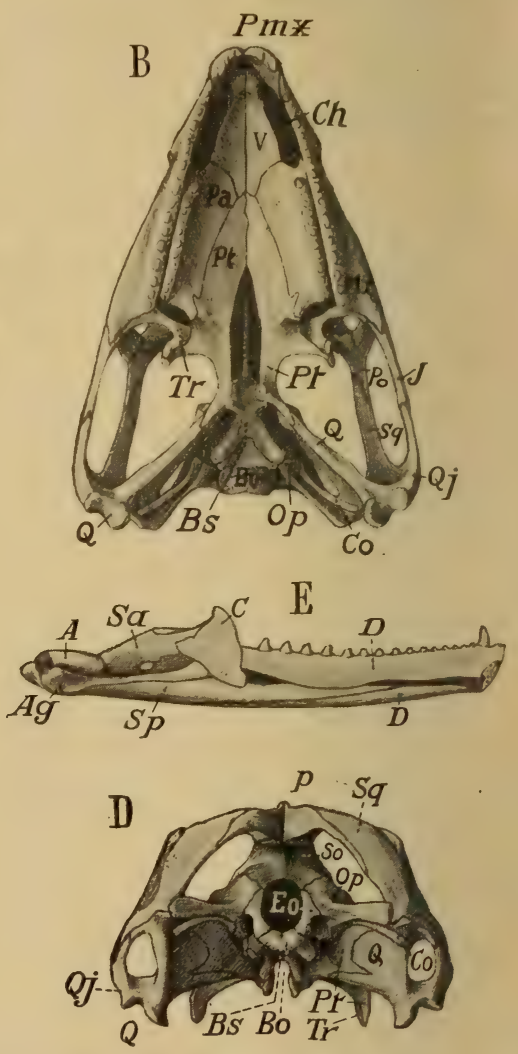

Sphenodon (Hatteria) punctatum Gray. Neuseeland rezent. Erklärung s. o.

zeigen sich wohl ausgebildet, die Rippen der Halsregion sind zumeist zweiköpfig, die der Rumpfregion einköpfig. Intercentra können außer am Halse auch zwischen sämtlichen übrigen Wirbeln auftreten. Auf der Ventralseite liegen zwischen dem Brustgürtel und dem Becken zahlreiche, aus mehreren Stücken zusammengesetzte, gegen die Mitte zu konvergierende Bauchrippen. Der Schädel ist ausgezeichnet (Fig. 337) durch große, seitliche Augen, ein kleines selten fehlendes Foramen parietale, getrennte oder vereinigte Nasenlöcher und zwei große Schläfengruben, die durch eine bei Sphenodon von Postorbitale und Squamosum gebildete Knochenspange getrennt sind. Das Quadratum ist unbeweglich mit dem Schädel verbunden, die Pterygoidea bilden mit den beiden Palatina und Vomera zumeist einen festgeschlossenen 
harten Gaumen. Außer auf den Kiefern können auf Vomer, Palatin und Pterygoid acrodonte oder in ganz seichten Gruben stehende Zähne auftreten. Zahnlose Formen sind selten (Sauranodon).

Der Schultergürtel enthält noch ziemlich viel Knorpel. Die Scapula ist verknöchert, die Suprascapula bleibt knorpelig, das gleiche gilt auch für den medialen Teil des Coracoids; die schlanke, gebogene Clavicula verbindet die Scapula mit dem T-förmigen oder langgestielten rhombischen Episternum, das über dem großen knorpeligen Sternum liegt. Der Humerus kann neben dem Foramen entepicondyloideum auch ein Foramen ectepicondyloideum aufweisen, die Gelenkenden sind, wie auch die von Radius und Ulna, meist unvollständig ossifiziert, Carpus und Tarsus verknöchern.

Die drei Beckenelemente beteiligen sich an der Gelenkpfanne für den Femur. Das Ilium ist ziemlich schlank, das scheibenförmige Pubis und Ischium werden durch ein Foramen getrennt.

An die lebende Gattung Sphenodon schließen sich einige mesozoische Formen an, auch in paläozoischen Sedimenten kommen verwandte Formen vor; verschiedene unvollständig bekannte wie Protorosaurus bleiben freilich vorläufig im System unsicher und andere, wie die triadischen Thalattosauriden, erinnern vielfach an die Pythonomorphen.

\section{Familie. Protorosauridae.}

Wirbel amphicöl, Prämaxillare, Maxillare, Dentale und Palatinum mit kräftigen spitzkonischen protothecodonten oder acrodonten Zähnen. Vomer mit Chagrinzähnchen. Meist Bauchrippen beobachtet. Rippen einköpfig. Episternum quer rhombische Knochenplatte mit langem Stil. Humerus mit Foramen entepicondyloideum. Perm.

Palae ohatteria Credner (Fig. 338). Körper 40-45 cm lang, rhynchocephalenartig, jedoch von primitiverem und mehr generalisiertem Gepräge. Wirbelcentra amphicöle Knochenhülsen mit persistierender Chorda, oberer Bogen durch Naht getrennt. Intercentra vorhanden, die der Schwanzregion zu Chevrons modifiziert. Zwei (? 3-4) Sacralwirbel, ca. 25-27 präsacrale Wirbel. Extremitäten fünfzehig, mit Krallen. Bauchrippen stabförmig. Mittleres Rotliegendes von Niederhäßlich bei Dresden.

Haptodus Gaudry. Sehr nahe verwandt, wenn nicht identisch mit Palaeohatteria. Unterstes Perm. Autun. Frankreich.

Callibrachion Boule et Glang. Ähnlich Palaeohatteria. Fundort wie vorige.

Kadaliosaurus Credner, mit außerordentlich starkem Abdominalskelett. Extremitäten sehr lang und schlank. Gelenkenden verknöchert. Lacertilierähnlich. Mittleres Rotliegendes von Niederhäßlich bei Dresden.

? D a the os a u rus Schröder. Schlecht erhaltenes, $90 \mathrm{~cm}$ langgeschwänztes Skelett. Im System unsicher. Unterstes Rotliegendes von Neurode, Schlesien.

Protorosaurus. H. v. Meyer. Im System unsicher. Körper bis $11 / 2 \mathrm{~m}$ lang. Wirbelcentra vollständig verknöchert und mit dem oberen Bogen verschmolzen. Intercentra zwischen den präsacralen Wirbeln, Zahl der letzteren ca. 24. Sacralwirbel ? 3. Rippen einköpfig, die der langen (8) Halswirbel spießförmig. Kiefer mit starken protothecodonten spitzkonischen Zähnen. Vomer mit kleinen Zähnchen besetzt. Schädel sehr unvollkommen erhalten mit ? Präorbitaldurchbrüchen. Vorderfüße kürzer 
als die Hinterfüße. Bauchrippen vorhanden. Oberes [Perm. Deutschland und England.

Aphelosaurus. Gervais. Ähnlich Protorosaurus. Unterstes Perm. Autun. Frankreich.
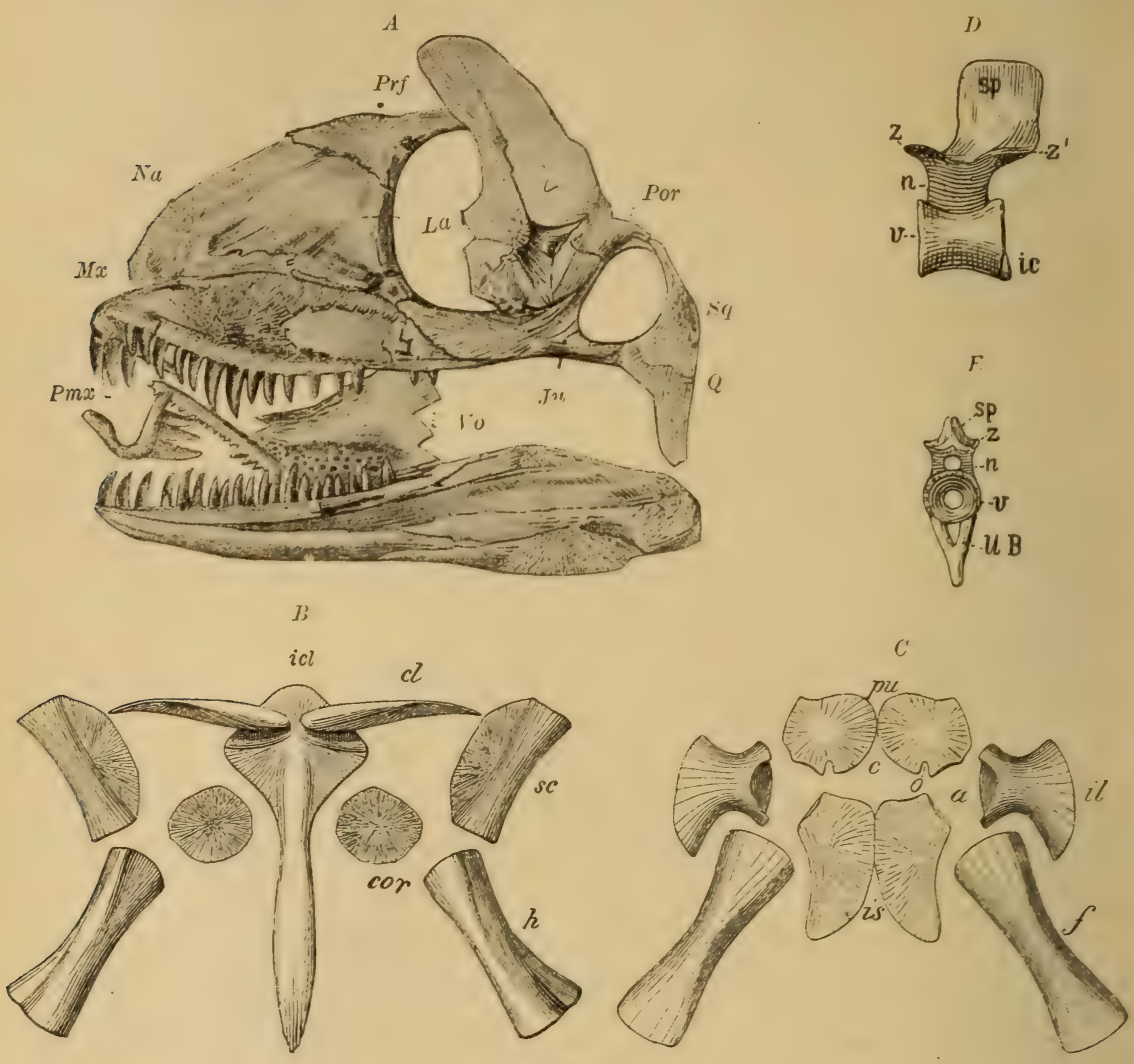

Fig. 338 .

Palaeohatteria longicaudata Credner. Rotliegendes. Niederhäßlich bei Dresden.

$A$ Schädel (nat. Gr.). Einzelne Elemente sind dislociert. Na Nasenbein, Prf Präfrontale, La Lacrimale, Por Postorbitale, Sq Squamosum, Ju Jugale, Q Quadratum, Mx Maxillare, Pmx Prämaxilla, Vo Vomer). $B$ Schultergürtel (icl Episternum (Interclavicula), cl Clavicula, cor Coracoideum, sc Scapula). ( $C^{\prime}$ Beckengürtel (il Ilium, $p u$ Pubis, is Ischium, $f$ Femur, $c$ Foramen puboischiadicum). $o$ Incisura obturatoria. $D$ Rückenwirbel von der Seite, $v$ Wirbelkörper, $n$ Oberer Bogen, $h$ Humerus, z Präzygapophyse, $z^{\prime}$ Postzygapophyse, $s p$ Processus spinosus, $i c$ Intercentrum). $E$ Schwanzwirbel von, vorn. $U B$ Unterer Bogen (Cherron), Ubrige Bezeichnungen wie bei $D$. (Nach Credner.)

\section{Familie. Champsosauridae. (Choristodera Cope.)}

Wirbel amphicöl. Intercentra nur in der Halsregion entwickelt. Schädel sehr verlängert, gavialähnlich. Äußere Nasenlöcher vereinigt, terminal. Zähne auf Ober- und Unterkiefer, spitzkonisch, acrodont. Dentin gefaltet. Außerdem kleine Zähnchen auf Vomer, Palatin, Pterygoid und Transversum. Halsrippen zweiköpfig, Rückenrippen einköpfig. Bauchrippen kräftig. Episternum T-förmig. Zwischen Pubis und Ischium kein Foramen. Foramen obturatorium im Pubis. Unterkieferäste in der Symphyse verschmolzen. Foramen parietale fehlt. Obere Kreide. Eocän.

Champsosaurus Cope. Skelett bis $1 \frac{1}{2} \mathrm{~m}$ lang. 26 präsacrale Wirbel, zwei Sacral- und ein Sacrocaudalwirbel. Äußere Nasenlöcher von 
Prämaxillaria und Nasalia begrenzt. Maxillare von der unteren Begrenzung des Auges ausgeschlossen. 40 Zähne auf jeder Unterkieferhälfte. Obere Kreide und unteres Eocän von Nordamerika.

Simoedosaurus Gervais. Skelett bis $2^{1 / 2} \mathrm{~m}$ lang. Zwei Sacralwirbel. Maxillare die untere Begrenzung des Auges bildend. Äußere Nasenlöcher von Prämaxillaria, Maxillaria und Nasalia begrenzt. 60 Zähne auf jeder Unterkieferhälfte. Obere Kreide und Unteres Eocän von Nordfrankreich und Belgien.

Hierher dürften auch die unvollständig bekannten Dryosauridae de Stefano (Dryosaurus) (Unt. Eocän. ? Kreide von Tunis) gehören.

\section{Familie. Rhynchosauridae.}

Wirbel amphicöl. Intercentra nicht beobachtet. Prämaxillare zahnlos, schnabelartig abwärts gekrümmt. Maxillare und Palatin mit je einer oder mehreren Reihen kleiner, pyramidaler Zähnchen besetzt. Kein Foramen parietale. Außere Nasenlöcher vereinigt. Bauchrippen kräftig. Bauchschuppen polygonal. Trias.

Rhynchosaurus Owen. Schädel mäßig breit mit großen Augen. Schnabel rückwärts gekrümmt $z$ wischen kurzen Fortsätzen des Unterkiefers. Zähne auf Palatinum und Maxillare in einer Reihe. ? 23 präsacrale Wirbel. Keuper. England.

Hyperodaped on Huxley. (Fig. 339.) Skelett bis $2 \mathrm{~m}$ lang. Schädel sehr breit mit kleinen Augen. Schnabel zwischen divergierenden zugespitzten Fortsätzen des Unterkiefers. Zähne auf Palatinum und Maxillare in zwei

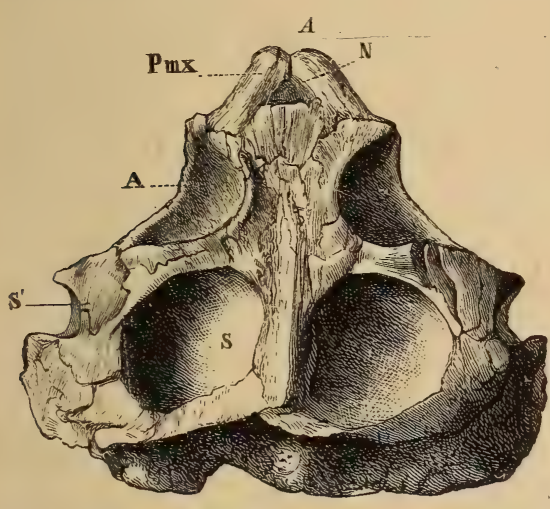
und mehr Reihen. Ca. 22-23 präsacrale Wirbel, die der Halsgegend anscheinend opisthocöl. Unt. ob. Trias v. Schottland. Maleri Sandstein (? Trias) v. Indien.

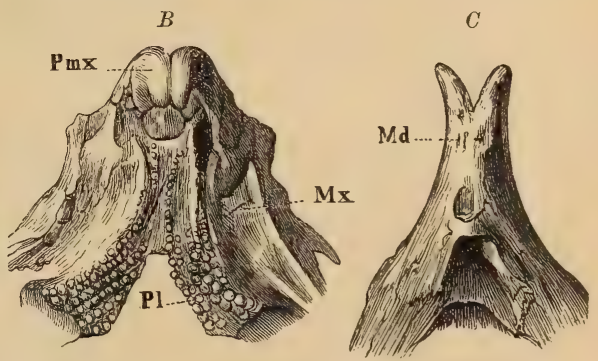

Fig. 339.

Hyperodapedon Gordoni. Huxley. Unt. Keuper. Elgin, Schottland. A Schädel von oben. $B$ Gaumen. $C$ vorderes Ende des Unterkiefers von unten. 1/4 nat. Gr. (Nach H uxley.) (Pmx Zwischenkiefer, $M x$ joberkiefer, $P l$ Gaumenbein, $A$ Augenhöhle, S oberes, $S^{\prime}$ seitliches Schläfenloch, Md Unterkiefer.)

Stenometop on Boulenger. Schädel bis $18 \mathrm{~cm}$ lang, mäßig breit mit kleinen Augen. Schnabel nach vorwärts gerichtet, nicht umfaßt von den nach aufwärts gerichteten Fortsätzen des Unterkiefers. Zähne auf Palatinum und Maxillare in zwei und mehr Reihen. Unt. ob. Trias. Elgin.

Howesia Broom. Schädel fragmentär ohne Schnauze und Nasen. gegend. Mehrere Reihen von Zähnen auf der Schädelunterseite. Foramen parietale rudimentär. Episternum T-förmig. Trias. Südafrika.

\section{Familie. Sauranodontidae.}

Wirbel procöl. Zähne fehlen. Ober- und Unterkiefer schnabelartig gekrïmmt, mit scharfen Rändern. Schädeldach mit kleinen oberen und seitlichen Schläfengruben. Postorbitale groß. Foramen parietale fehlt. Nasenlöcher getrennt. Zweite 
Sacralrippe distal gespalten. Bauchrippen krïftig. Schuppen gestrecht vierseitig. Vorderfüße kürzer als die Hinterfüße; beide fünfzehig. Oberster Jura.

Einzige Gattung der langgeschwänzte Sauranodon Jourdan (Sapheosaurus H. v. Meyer) mit 22 präsacralen Wirbeln. Die prachtvollen Skelette von S. incisicus Jourdan aus dem obersten Jura von Cerin (Dpt. Ain) erreichen eine Länge von über $60 \mathrm{~cm}$.

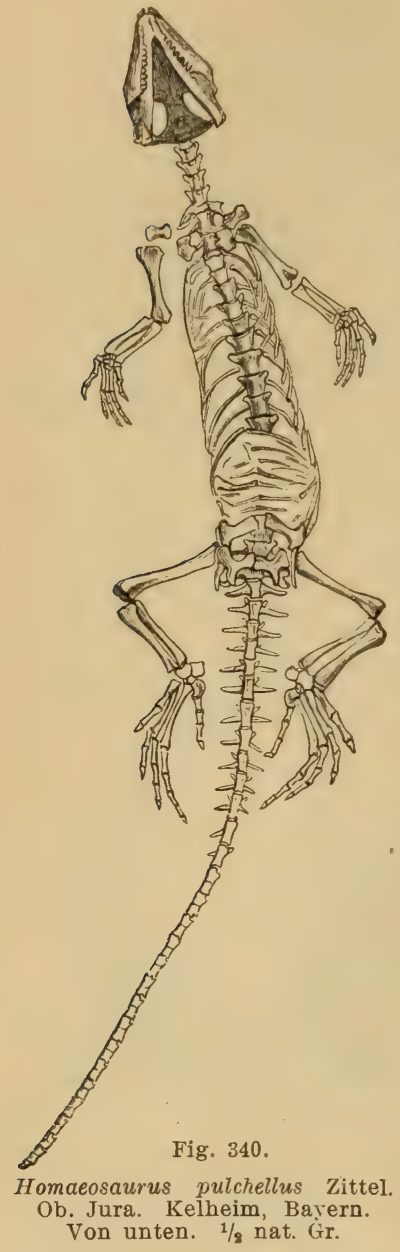

\section{Familie. Sphenodontidae.}

Wirbel amphicöl, mit Chordaresten. Intercentra vorhanden. Das überhängende Prämaxillare mit einem schneidenden Zahn oder? zahnlos. Maxillare, Palatinum und Unterkiefer mit einer Reihe abgeplatteter, dreieckiger, acrodonter Zähne. Nasenlöcher getrennt. Vomer in der Regel zahnlos. Foramen parietale vorhanden. Epister. num Tförmig. Baüchrippen kräftig. Bauchschuppen quer vierseitig. Halsrippen zweiköpfig, Rumpfrippen einköpfig. Trias. Oberster Jura. Rezent.

Eifelosaurus Jaekel. Buntsandstein. Eifel. ? Polysphenodon Jaekel. Keuper. Hannover.

Palacrodon Broom. Trias. Südafrika.

Brachyrhinodonv. Huene. Kurzschnauzig. Augen groß. Ca. 25 Präsacralwirbel. Untere obere Trias. Elgin. Schottland.

Homaeosaurus H. v. M. (Fig. 340). Sehr ähnlich dem lebenden Sphenodon, aber kleiner (15-20 cm lang) und Intercentra nur in der Hals. und Schwanzregion. Ca. 23 Präsacralwirbel. Rippen ohne Processus uncinatus, die zweite Sacralrippe gegabelt. Bauchrippen kräftig. Scleroticaring. Oberster Jura (Tithon) von Mitteleuropa.

Ardeosaurus H. v. Meyer. Oberster Jura. Solnhofen.

Opisthias Gilmore. Nur Kiefer bekannt. Oberer Jura. Wyoming.

Sphenodon Gray (Hatteria Gray.). (Fig. 337.) 25 präsacrale Wirbel. Intercentra auch in der Rumpfregion. Vomer in der Jugend bezahnt. Lebend. Neuseeland.

Pleurosaurus H. v. Meyer (Anguisaurus Mstr., Saurophidium Jourdan). Körper schlangenartig, bis $11 / 2 \mathrm{~m}$ lang. Schwanz $2 / 3$ der Körperlänge einnehmend. Schnauze zugespitzt. Bauchrippen kräftig. Über 45 Prä-sacralwirbel. Vorderfüße kürzer als die Hinterfüße. Oberster Jura von Bayern und Cerin (Ain).

Acrosaurus H. v. M. Mit Scleroticaring. Oberster Jura. Solnhofen. Wird mit Pleurosaurus auf Grund eines ? einfachen Schläfenbogens auch als Familie der Acrosauridae abgetrennt.

\section{Familie. Thalattosauridae (= Thalattosauria Merriam).}

Wirbel amphicöl. Schädel verlängert. Außere Nasenlöcher getrennt, ueit zurïck vor den großen, mit Scleroticaring versehenen Augen liegend. Zwei Paar Schläfenöffnungen und Foramen parietale vorhanden. Quadratum unbeweglich. Vordere Kieferzühne leicht gekrïmmt und konisch, hintere Kieferzühne abgeplattet. Vomer und Pterygoid dicht bezahnt. Rückenrippen einköpfig. Bauchrippen vorhanden. Trias. 
Hierher gehören die in der mittleren und oberen marinen Trias des westlichen Nordamerika sich findenden bis $2 \mathrm{~m}$ großen Gattungen Thalattosaurus und Nectosaurus Merriam mit mehr (Nectosaurus) oder weniger gestreckten (Thalattosaurus), flossenartigen Extremitäten. Die Thalattosauridae, die namentlich in der Art der Bezahnung an Pythonomorphen erinnern, dürften nach Merriam vielleicht aus dem Formenkreis der Protorosauridae hervorgegangen sein und sich frühzeitig dem Aufenthalt im Wasser angepaßt haben.

Zeitliche Verbreitung der Rhynchocephalia.

\begin{tabular}{|c|c|c|c|c|c|c|c|}
\hline & مี & 蛋 & $\stackrel{5}{\Xi}$ & 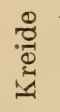 & 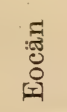 & $\begin{array}{l}\tilde{I} \\
80 \\
8 \\
0 \\
0\end{array}$ & 密 \\
\hline 1. Protorosauridae & & & & & & & \\
\hline $\begin{array}{l}\text { 2. Champsosauridae. } \\
\text { 3. Rhynchosauridae . }\end{array}$ & & - & & - & & & \\
\hline 4. Sauranodontidae . & & & - & & & & \\
\hline 5. Sphenodontidae & & - & - & & & & $\ldots$ \\
\hline 6. Thalattosauridae & & & & & & & \\
\hline
\end{tabular}

3. Ordnung. Lepidosauria (Squamata). Schuppensaurier.

Wirbel procöl, sehr selten amphicöl. Sacrum mit 2 Wirbeln oder fehlend. Rippen einköpfig. Bauchrippen fehlen. Quadratbein fast stets beweglich, nur proximal am Schädel befestigt. Gaumen von größeren oder kleineren Öffnungen durchbrochen. Nasenlöcher getrennt. Haut mit hornigen, seltener ossifizierten Schuppen bedeckt. Trias-jetzt.

$\mathrm{Zu}$ den Lepidosauria gehören die Lacertilia und Ophidia Sie stehen den Rhynchocephalen in ihrem äußeren und ihrem anatomischen Bau verwandtschaftlich sehr nahe und lassen sich höchst wahrscheinlich auf eine gemeinsame Wurzel zurückführen.

\section{Unterordnung. Lacertilia (Saurii). Eidechsen. ${ }^{1}$ )}

Körper beschuppt, langgeschwänzt zuweilen schlangenartig. Schädel meist mit stabförmigem Epipterygoid und in der Regel mit beweglichem Quadratum. Unterer Schläfenbogen stets, oberer Schläfenbogen zuweilen fehlend. Ali- und Orbitosphenoid nicht verknöchert. Unterkieferäste in der Symphyse gewöhnlich durch Sutur verbunden. Zähne zumeist acrodont oder pleurodont. Am Brustgürtel ein Sternum fast stets vorhanden. Gliedmaßen fünfzehig, zuweilen rudimentär oder fehlend. Trias bis jetzt.

1) Broom $\boldsymbol{R}$., On the skull of a true Lizard from the Triassic beds of South Africa. Rec. Alb. Mus. Vol. I, Nr. 1 1903. - Boulenger. Crataceous Lizards and Rhynchocephalians. Ann. Magaz. Nat. Hist. 1893. - Cope Edw., Rep. of the U. S. geol. Survey of the Territories vol. III. The Vertebrata of the tertiary formations of the West 1883. p. 101 und 777-781. - Fürbringer M., Zur vergl. Anatomie des Brustschulterapparates etc. Jen. Zeitschr. f. Naturwissensch. 34. Bd. 1900. - Gorganovic-Kramberger C., Aigialosaurus, eine neue Eidechse etc. Societas historic. nat. levatica. VII. Zagrab. 1892. - Kornhuber A., Carsosaurus Marchesetti. Abhandl. 
Die meisten Eidechsen besitzen ein aus hornigen, seltener aus verknöcherten Schuppen, Platten, Schildern oder Stacheln bestehendes Hautskelett, das sowohl den Kopf als auch den ganzen Körper bedecken kann. Die Wirbelsäule besteht aus zahlreichen procölen Wirbeln (nur die Geckonen und Uroplatiden besitzen amphicöle), deren obere Bögen fest mit dem Wirbelkörper verschmolzen sind. Die Halsregion enthält bei den lebenden Formen höchstens neun Wirbel, davon besteht der Atlas aus zwei dorsal getrennten oder vereinigten Bogenstücken und einem ventralen Mittelstück. Der Processus odontoideus ist fest mit dem Epistropheus verbunden. Am Sacrum beteiligen sich in der Regel zwei Wirbel. Außer den Zygapophen kann auch die Gelenkung mit Zygosphen-Zygantrum eintreten (z. B. Iguano-

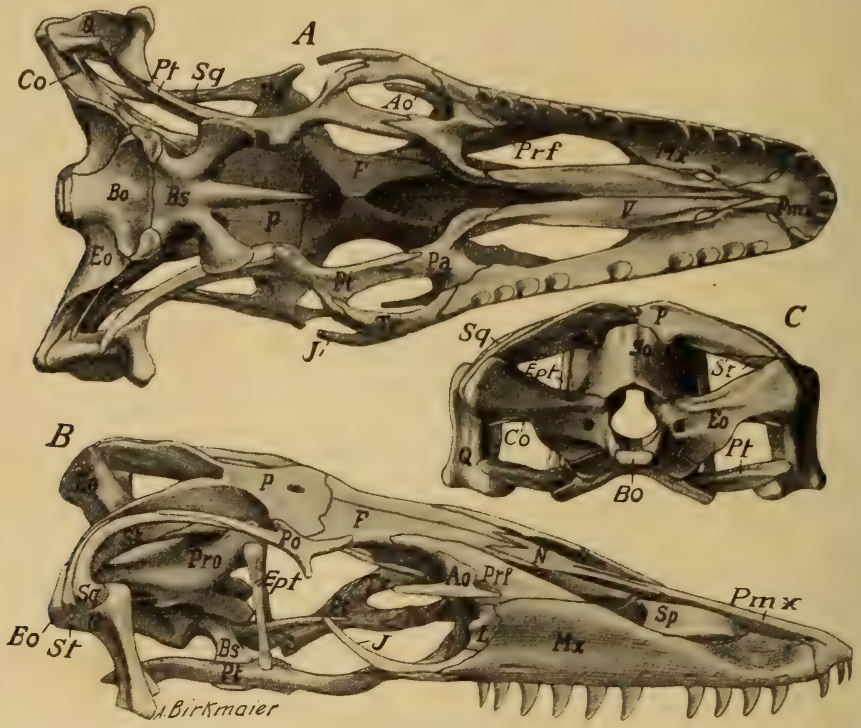

Fig. 341.

Schädel von Varanus monitor $\left.{ }^{1}\right) A$ von unten, $B$ schräg von der Seite, $C$ von hinten $P m x$ Prämaxillare, $M x$ Maxillare, $S p$ Septomaxillare (Concha), $N$ Nasale, Prf Präfrontale, $L$ Lacrimale, $A 0$ Supraorbitale, $F$ Frontale, $P$ Parietale mit Foramen par., So Supraoccipitale, Eo Exoccipitale laterale, St Supratemporale, Sq Squamosum, Po Postfrontale (Postorbitale), Co Columella (Stapes), Q Quadratum, Pro Prooticum Bo Basioccipitale, Bs Basisphenoid, Pt Pterygoid, Ept Epipterygoid, Tr Transversum, $\mathrm{Pa}$ Palatinum, $V$ Vomer. $3 / 5$ nat. Gr.

donten). Die Schwanzwirbel tragen statt der Rippen kräftige Querfortsätze und sind mit Haemapophysen (Sparrenknochen, chevron bones) versehen. Die Querfortsätze der Hals- und Rumpfregion sind schwach entwickelt, die Rippen selbst sind einköpfig und können an allen Wirbeln mit Ausnahme des Atlas und des letzten und vorletzten präsacralen Wirbels

d. k. k. geol. Reichsanstalt Wien. Bd. XVII. Heft 3. 1893. Opetiosaurus Buschichi etc. ibid. Bd. XVII. Heft 5. 1901. - Meyer H. v., Lacerten aus der Braunkohle des Siebengebirges. Palaeontographica. VII. S. 74-78. - Nopcsa F. v., Utber die varanusartigen Lacerten Istriens. Beiträge z. Geol. u. Paläontol. Österreich-Ungarns etc. Bd. XV. 1903. Zur Kenntnis der fossilen Eidechsen. Ibid. Bd. XXI. 1908. Dort a u g ührliche Literatur! - Stefano de G., I Sauri del Quercy etc. Atti Soc. Ital. Science Nat. Vol. 42. 1904. - Versluys J., Die mittl. u. äußere Ohrsphäre der Lacertilia u. Rhynchoceph. Jena. Fischer 1898.

1) Das Exemplar, dem die Zeichnuug in der Hauptsache zugrunde liegt, erhielt ich durch die freundliche Vermittlung von Herrn Prof. Goldschmidt aus dem hiesigen Zoologischen Institut. 
auftreten. Die vorderen Rumpfrippen befestigen sich mit einigen wenigen Ausnahmen (z. B. Amphisbaenidae und andere fußlose Formen) mit ihrem in der Regel nur knorpeligen ventralen Abschnitt am Sternum.

Der Schädel, Fig. 341, 342, unterscheidet sich von dem der Rhynchocephalen vor allem durch das bewegliche, freistehende Quadratum - ausgenommen die Chamaeleontidae - und durch den Mangel eines unteren Schläfenbogens. Das sehr schlanke vom Pterygoid zum Parietale bzw. dem Prooticum aufsteigende Epipteryg o id fehlt nur den Amphisbaenidae, Chamaeleontidae und Anniella. Die äußeren Nasenlöcher sind getrennt und meist in die Nähe der Augen gerückt. Das gewöhnlich unpaare Parietale besitzt fast stets ein Foramen parietale. Das Opisthoticum ist mit dem Exoccipitale laterale verschmolzen, der distale Fortsatz bildet mit dem Squamosum und Supratemporale die Stütze für das Quadratum. Das Supratemporale schiebt sich zwischen Parietale und dem mit dem Postfrontale $(+$ Postorbitale $=$ Postorbitofrontale $)$ den oberen Schläfenbogen bildende Squamosum ein. Zwischen Präfrontale und Lacrimale kann sich ein Supraorbitale einfügen. Der unpaare (selten doppelte: bei Amphibaena) Hinterhauptsscondylus wird von Basioccipitale und den beiden Exoccipitalia lateralia gebildet. In der Nasenhöhle findet sich jederseits ein meist an-

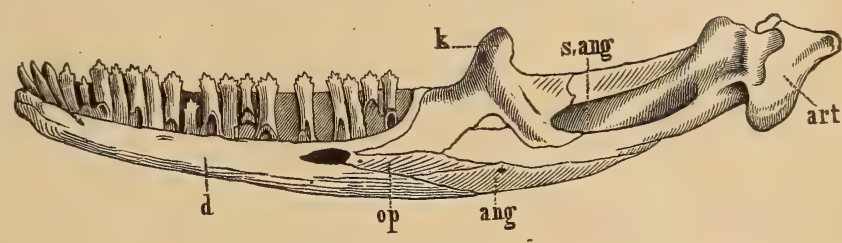

Fig. 342.

Unterkiefer von Iguana mit pleurodonten Zähnen. (Nach Cuvier.) d Dentale, op Operculare (Spleniale), ang Angulare, art Articulare, s.ang Supraangulare, $k$ Coronoidfortsatz. sehnliches Septoma-

xillare (Concha). Die Unterkieferäste sind durch Sutur verbunden. Alle Eidechsen besitzen auf den Kiefern Zähne, seltener auf dem Palatinum, Pterygoid und Vomer; dieselben sind entweder spitz- oder stumpfkonisch, blattförmig, pfeilspitzenförmig mit gezackten oder zugeschärften vorderen und hinteren Rändern, zuweilen auch halbkugelig. Sie verwachsen meist im Alter an ihrer Basis vollständig mit dem anliegenden Knochen und sind entweder pleurodont oder acrodont. Die neuen Zähne entwickeln sich neben der Basis der alten auf der Innenseite.

In der Regel sind die vier fünfzehigen Gliedmaßen entwickelt, zuweilen aber kann ein oder beide Paare reduziert werảen oder gänzlich verschwinden (z. B. Anguis, Ophisaurus). Der Brustgürtel ist immer vorhanden, ein Sternum fehlt nur einigen Amphisbaenidae, die Clavicula und das T- oder †förmige Episternum fehlt nur den Chamaeleontidae und einigen fußlosen Formen. Die Scapula besteht aus zwei Stücken, einem ventralen mit dem Coracoid verschmolzenen, verknöcherten Abschnitt und einem dorsalen, meist knorpeligen, seltener verkalkten Teil.

Die Knochen der Vorderextremität ähneln gewöhnlich den entsprechenden Elementen der Rhynchocephalen, doch findet sich im Humerus kein Foramen entepicondyloideum. Bei den fünfzehigen Formen zeigt der Carpus in der proximalen Reihe 3 , in der distalen 5 kleine Knöchelchen auf. Der Daumen hat bei den lebenden Formen meist 2, der zweite 3, der dritte 4, der vierte 5 und der fünfte 3 Phalangen. Die letzten Zehenglieder tragen Krallen.

Der Beckengürtel kann bei den fußlosen Formen stark reduziert werden, verschwindet indessen nie vollständig. Häufig ist ein knorpeliges oder verkalktes Epipubis vorhanden.

Das Ilium gelenkt fast stets beweglich mit den knorpeligen Enden der Sacralrippen. Pubis und Ischium stoßen in der medianen Symphyse zusammen. Der Femur übertrifft den Humerus meist an Länge, Tibia und 
Fibula bleiben getrennt. Im Tarsus besteht die proximale Reihe aus zwei größeren Knöchelchen (dem tibialen Astragalus und dem fibularen Calcaneus); in der distalen Reihe findet sich häufig nur ein großes mit dem Calcaneus articulierendes Cuboideum IV und ein Tarsale III, die übrigen Tarsalia sind meist mit den Metatarsalia verschmolzen. Zahl der Phalangen an den fünf Zehen gewöhnlich 2, 3, 4, 5, 4 .

Die Eidechsen halten sich gegenwärtig hauptsächlich in den warmen und gemäßigten Zonen auf; man kennt über 1800 rezente Arten. Nach den Einteilungsprinzipien von M. F ürbringer und S. W. Willis t on läßt sich die Unterordnung der Lacertilier folgendermaßen gliedern in: 1. Superfamilie Platynota (Familien: Varanidae, Dolichosauridae, Aigialosauridae). 2. Superfamilie Mosasauria (Familie Mosasauridae). 3. Superfamilie Lacertilia vera (Kionocrania). 4. Su perfamilie Amphisbaenia. 5. Superfamilie Chamaeleontia (Rhiptoglossa). Im Vergleich zu der großen Menge der lebenden Eidechsen gegenüber treten die fossilen Vertreter der Lacertilia vera, Amphisbaenia und Rhiptoglossa relativ zurück:

Eine auf einen nicht vollständig erhaltenen Schädel hin begründete Gattung Paliguana Broom, aus der südafrikanischen Trias, wird von Broom zu den Iguaniden gestellt. Im obersten Jura (Tithon) von Cerin (Ain) findet sich Euposaurus Jourdan, welche zu den A nguinid en gerechnet wird, während die systematische Stellung von Macellodus Owen aus dem Purbeck unsicher scheint. Auch in der Kreide sind Lacertilier recht spärlich und meist infolge

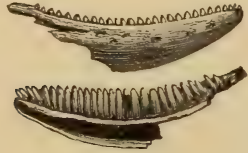

Fig. 343 .

Iguana europaea Filhol. Phosphorit. Quercy. Dentale des Unterkiefers von außen und innen. (Nat. Gr.)

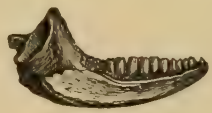

Fig. 344.

Plestiodon Cadurcensis Filhol. Phosphorit. Quercy. Unterkiefer von innen. (Nat. Gr.)

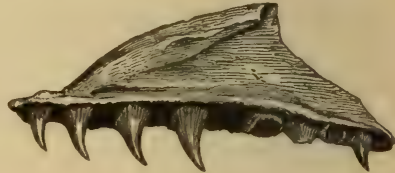

Fig. 345.

Palaeovaranus Cayluxi Filhol Phosphorit. Isabenque. Quercy. Oberkieferfragment. (Nat. Gr.)

ihrer höchst ungenügenden Erhaltung im System schwankend.: Chamops Marsh aus der ob. (Laramie) Kreide Nordamerikas dürfte vielleicht zu den Teiidae zu stellen sein. Im Eocän werden die Reste etwas häufiger, aus dem Untereocän von Wyoming werden an Helodermatidae (Thinosaurus), von Anguinidae (Glyptosaurus, Saniva, Xestops), von Iguanidae (Iguanavus und Chamaeleontidae (Chamaeleo) genannt; in den obereocänen - bis miocänen Phosphoriten von Quercy und den obereocänen Mergeln von Apt in Frankreich finden sich Vertreter der Agamidae (Agama), Iguanidae (Iguana) (Fig. 343), Anguinidae (Diploglossus, Propseudopus) Helotermatidae (Placosaurus), Lacertidae (Lacerta), Scincoidae (Plestiodon) (Fig. 344) etc. Aus dem Oligocän von Nordamerika (Dakota) werden auch einige Amphisbaenidae (Rhineura, Aciprion, Diacium, Platyrachis etc., Cope, Hyporhina G. Baur, genannt.

Von Interesse ist, daß die jetzt auf die westliche Hemisphäre beschränkte Iguana auch im Tertiär von Europa auftritt. Die aus dem Miocän der Auvergne, der Braunkohle von Rott, den Süßwassermergeln von Steinheim, Haslach, Günzburg, Sansan und Colorado bekannten Reste gehören teils $\mathrm{zu}$ noch jetzt existierenden Gattungen oder gestatten keine genauere Feststellung ihrer systematischen Beziehungen. Das gleiche gilt für die aus pliocänen und pleistocänen Fundorten bekannten Formen.

Weit wichtiger sind die fossilen Vertreter der Platynota und Mosasauria:

\section{Superfamilie: Platynota.}

Terrestre, aber meist wasserliebende oder dem Wasserleben mehr oder weniger angepaßte procöle Lacertilia mit 7-13 Halswirbeln. Clavicula und Episternum wohl entwickelt. Neocom bis jetzt. 
Von der 1. Familie der Varanidae finden sich die ältesten Vertreter (Palaeovaranus) (Fig. 345) in den obereocänen Phosphoriten von Quercy in Frankreich, ferner verdient eine Riesenform aus dem Pleistocän von Queensland, die eine Größe von $10 \mathrm{~m}$ erreicht haben soll, Varanus (M e ga lania) priscus Owen, Beachtung.

\section{Familie. Dolichosauridae. Kramb. em. Nopcsa.}

Wasserbewohnende Reptilien mit kleinem Varanusähnlichem Kopf, langem, aus 13 Wirbeln bestehendem Hals, 26-27 Rumpf-, zwei Sacralwirbeln unả einem aus über 60 Wirbeln zusammengesetztem mit kräftigen Hämapophysen versehenem Ruderschwanz. Rippen kurz, gleich lang. Keine Ventralrippen. Extremitäten reduziert. Ruderfiiße. Vorderfuß etwa halb so lang als der hintere. Zähne pleurodont. Untere bis Obere Kreide.

Die hierher zu stellenden Formen sind kleine, dem Wasserleben angepaßte Lacertilia mit walzenförmig verlängertem, schlangenähnlichem Leib. Die Genera Actaeosaurus H. v. Meyer, Adriosaurus Seeley, Pontosaurus G. Kramberger finden sich im Neocom von Dalmatien, Dolichosaurus Owen, ? Coniosaurus Owen in der oberen Kreide Englands.

\section{Familie. Aigialosauridae. Kramb. em. Nopcsa.}

Reptilien mit großem pythonomorphenartigem Schädel, kurzem, aus sieben Wirbeln bestehenden Hals, 21 Rückenwirbeln, zwei Sacralwirbeln und zahlreichen Schwanzwirbeln, Rippen lang und gebogen. Sechs Ventralrippen treten mit dem Sternum in Verbindung. Vorder- und Hinterfuß annähernd gleich groß und nur wenig reduziert. Neocom.

Die Aigialosauridae sind Küstenbewohner mit verhältnismäßig gedrungenem kurzen Rumpf; sie zeigen im Bau der Extremitäten bereits Anpassungserscheinungen an aquatische Lebensweise auf und erreichen eine Größe von $1-2^{1} / 2 \mathrm{~m}$. Ihr Schädel ähnelt ganz auffallend dem der Mosasauridae und unterscheidet sich eigentlich nur von diesem durch das Fehlen der Zähne auf dem Pterygoid. Sie nehmen eine Zwischenstellung ein zwischen den Varaniden und Mosasauridae, aus ihnen haben sich offenbar die letzteren entwickelt. Hierher gehören die Gattungen Aigialosaurus G. Kramberger, Carsosaurus, Opetiosaurus Kornhuber und ? Mesoleptos Cornaglia aus dem Neocom von Dalmatien.

\section{Superfamilie Mosasauria. $\left.{ }^{1}\right)$}

\section{Familie Mosasauridae Gervais. (Pythonomorpha.)}

Große, langgestreckte, beschuppte Meersaurier mit paddelförmigen Extremitäten. Wirbel procöl. 7 Halswirbel. Halsuirbel mit Hypapophysen. Ein Sacralwirbel. Schädel eidechsenartig. Nur der obere Schläfenbogen vorhanden. Nasalia zumeist mit den Prämaxillaria zu einem einzigen Knochen (Naso-Prämaxillare) verschmolzen. Quadratum groß, beweglich, durchbohrt. Ein Foramen parietale im

1) Baur G., Morphology of the skull of Mosasauridae. Journ. of Morphology. 1892. vol. XII. - Cope Edw., The Reptilian orders Pythonomorpha and Streptosauria. Proceed. Boston Soc. nat. hist. 1869. XII. 250. - Rep. U. S. geol. Surv. of Territ. 1875. vol. II. The Vertebrata of the cretaceous formations of the West p. 113-178 und p. 264. - Dollo L., Bull. Mus. Roy. d'hist. nat. de Belgique 1882 t. I. u. 1885 t. IV. Bull. Soc. Belge de Géol., Paléont. et Hydrologie 1889 III. 1890 IX. 1892 VI. 1893 VII. Les Mosasauriens d. 1. Belgique. Bull. d. 1. Soc. Belge de Géologie etc. T. XVIII. 1904. Un Nouvel opercule tympanique de Plioplatecarpus Mosasanrien plongeur. Ibid. T. XIX. 1905. Les ancêtres des Mosasauriens. Scient. Giard. Vol. 38. Brüssel 1903. L'origine des Mosasauriens. Bull. d. 1. Soc. belg. de Géol. 1904. Mém. - Gaudry A., Les Pythonomorphes de France. Mém. Soc. 
unpaaren Parietale. Augen mit Scleroticaring. Unterkieferäste in der Symphyse durch Ligament verbunden, außerdem jeder Ast ungefähr in der Mitte durch gegenseitige Gelenkung der einzelnen Elemente beweglich gemacht. Zähne groß,

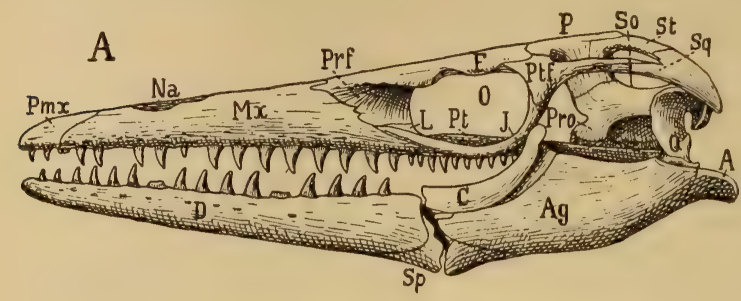
konisch auf den Kiefern und den Pterygoidea, in Gruben stehend und mit den angrenzenden $K$ no. chen verwachsen. Brustund Beckengürtel entwickelt. Extremitätenknochen kurz, mit 5 aus schlanken, öfters überzähligen Phalangen zusammengesetzten, krallen.

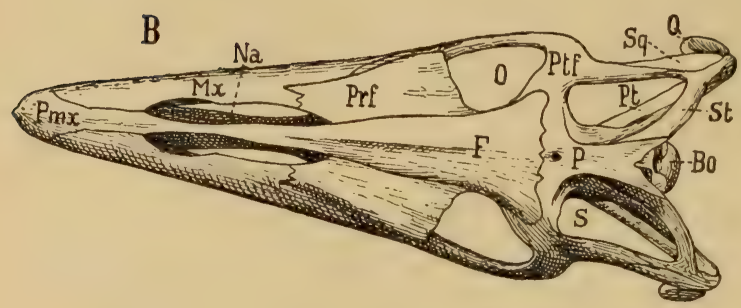
losen Fingern. Obere Kreide. Marin.

Die Mosasauridae sind eine völlig dem Leben im Meer angepaßte Gruppe langge. streckter, meist großer, ähnlich Varanus beschuppterReptilien, die nach den Untersuchun-

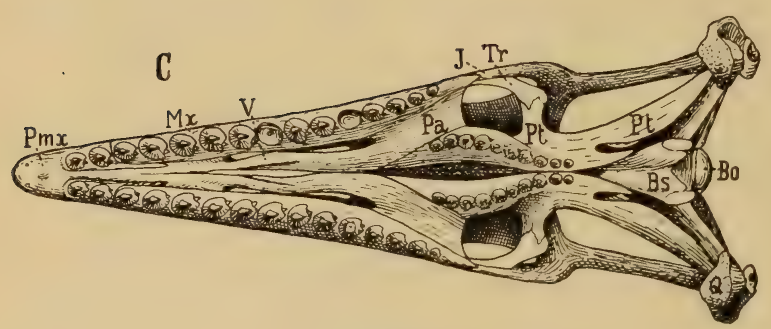

Fig. 346.

A Clidastes velox. Marsh, ca. 1/5 nat. Gr., Schädel von der Seite, $B$ Tylosaurus proriger Cope, ca. 1/7 nat. Gr., von oben, $C$ von unten. Ob. Kreide von Kansas. (N. Willis ton.) Na Nasenöffnung, $O$ Augenöffnung, S Schläfenloch, $P m x$ Prämaxillare, $M x$ Maxillare, F Frontale, Prf Präfrontale, Ptf Postorbitale (Postorbitofrontale), $P$ Parietale mit Foramen, So Supraoccipitale, $L$ Lacrimale, $J$ Jugale, St Supratemporale, $S q$ Squamosum, $Q$ Quadratum, Pro Prooticum, Bo Basioccipitale, Bs Basisphenoid, Pt Pterygoid (das Epipterygoid ist nicht erhalten!), $\operatorname{Tr}$ Transversum, $P a$ Palatin $V$ Vomer, $D$ Dentale, $A g$ Angulare, $S p$ Spleniale, $C$ Complementare, $A$ Articulare.

gen durch L. Dollo zumeist Oberflächenschwimmer (Mosasaurus), seltenerTauchtiere (Plioplatecarpus) gewesen sein mögen.

Wie bei den Ich. thyosauriern erscheint auch hier der lange Schwanz in der Hauptsache als der eigentliche Locomotionsapparat. Den Feststellungen von L. Dollo, Kramberger, Nopcsa, Williston u. a. zufolge stammen die Mosasauridae von den Aigialosauridae, die . ihrerseits $\mathrm{zu}$ landbewohnenden Lacertiliern überführen. Thre Reste, deren kräftige Bezahnung auf gefährliche Raubtiere schließen läßt, finden sich in der marinen Oberkreide von Neuseeland, Nord- und Südamerika und Europa.

géol. de France. No. 10. 1892. - Goldfuß, Nova acta Acad. Leop. nat. cur. Bd. XXI. - Huene F. v., Ein ganzes Tylosaurus Skelett. Geol. Pal. Abhandl. N. F. Bd. VIII. (XII) 6. 1910. - Leidy Jos., Cretaceous Reptiles of the U. S. Smithson. Contrib. 1864. - Rep. U. S. geol. Survey of Territ. I. Extinct vertebrata fauna of the Western Territories. Washington 1873. - Marsh O., Amer. Journ. Sc. and arts 1871 Bd. 101. 1872 Bd. 103 u. 1880 Bd. 119. - Merriam F. C., Die Pythonomorphen der Kansas-Kreide. Palaeontographica 1894. XLI. - Nopcsa F. v., Origin of the Mosasaurs. Geol. Magaz. N. S. Dec. 4. Vol. X. 1903. - Osborn H. F., A complete Mosasaur skeleton. etc. Mem. Americ. Mus. Nat. Hist. Vol. I. P.4. 1899. - Owen Rich. 
Die ersten Mosasauridae wurden in der obersten Kreide von Maestricht gefunden (1780) und anfänglich für Cetaceen oder Krokodile gehalten. Erst Cuvier erkannte die große Übereinstimmung des Schädels mit der Eidechsengattung Varanus.

Der Schädel (Fig. 346 u. 347) weicht nicht erheblich von dem der Eidechsen, namentlich von Varanus ab. Parietale und Frontale sind ebenso wie das Prämaxillare unpaar. Selbständige Nasalia sind in der Regel nicht entwickelt. Die oberen Schläfenlöcher werden außen von den meist mit dem Postfrontale vereinigten Postorbitale (Postorbitofrontale) und dem Squamosum und Supratemporale - welches Element zwischen Parietale und Squamosum eingeschaltet liegt - innen vom Parietale begrenzt. Das Jugale vereinigt sich mit einem absteigenden Ast des Postorbitale und umrahmt mit Lacrimale und dem ansehnlichen Präfrontale die großen, in der Regel seitlichen, von einem Scleroticaring eingefaßten Augen. Das Prooticum ist wohl entwickelt, während das Opisthoticum mit dem Exoccipitale verschmilzt. Das Quadratbein hat ansehnliche Größe, ist beweglich mit dem Squamosum und Supratemporale verbunden und für den Gehörgang (meatus auditorius) entweder gefenstert oder eingebuchtet. Das Quadratum (Fig. 348 u. 349) variiert erheblich bei den ver schiedenen Gattungen und liefert gut systema. tische Merkmale. Neben der verknöcherten Co. lumella (Stapes) kann auch noch eine teilweise oder vollständige ossificierte Extracolumella und ein calcifiziertes Trommelfell (operculum tympanicum) (Plioplatecarpus) auftreten. Das Transversum ist' in der Regel klein, das Epipterygoid schlank. Die beiden Äste des Unterkiefers sind vorne nur durch Ligament verbunden, außerdem ist jeder Unterkieferast ungefähr in der Mitte durch eine quere, gegenseitige gelenkige Verbindung

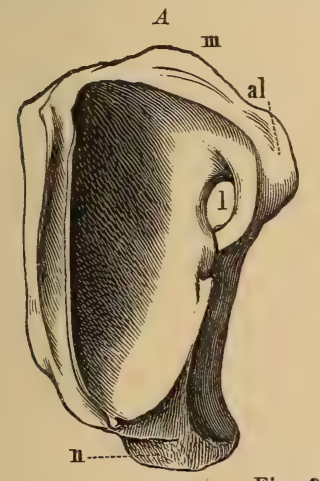

Fig. 348.

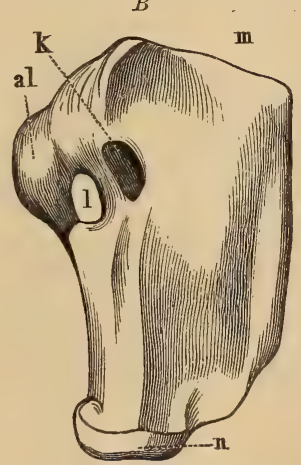

Quadratbein von Mosasaurus Camperi H. v. Meyer. $A$ von innen, $B$ von außen. 1/4 nat Gr. (Nach R. Owen) $m$ Oberrand, $n$ Unterrand, $l$ Meatus auditorius, $k$ Stap

Obius, $k$ Stapedialgrube, al flügelartiger Fortsatz des
Oberrandes.

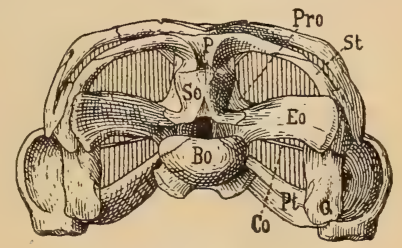

Fig. 347.

Platecarpus coryphaeus Cope. Ob. Kreide. Kansas. Von hinten (nach Williston). $1 / 6$ nat. Gr. Eo Exoccipitale laterale. Pro Prooticum Co Columella (Stapes), So Supraoccipitale; übrige Bezeichnungen übrige Bezei
wie früher.

Quart. Journ. geol. Soc. 1877. Bd. 33 p. 682 und 1878 Bd. 34 p. 748. - Pompeckj J. F., Uber einen Fund von Mosasaurierresten im Ob. Senon v. Haldem. 3. Jahresbericht d. niedersächs. geol. Ver. Hannover 1910. - Thevenin A., Mosasauriens d. 1. craie grise etc. Bull. Soc. géol. de France. 3. Ser. 24. 1896. - Williston S. W., Kansas Mosasaurs. Univ. Geol. Surv. Kansas. Vol. 4. P. I. Topeka 1898. The Relationships and habits of the Mosasaurs. Journ. Geol. Vol. XII. Nr. 1. 1904, ferner in ZittelEastman Textbook of Palaeontology II. 1902. - Williston and Case, Kansas Mosasauridae. pt. I. u. II. Kansas University Quaterly 1892. 1893. 1895. 
von Dentale und Supraangulare, und Operculare und Angulare beweglich gemacht, wodurch dem Rachen das Verschlingen größerer Bissen erleichtert wird. Ansehnlich große, spitzkonische Zähne stehen in einer

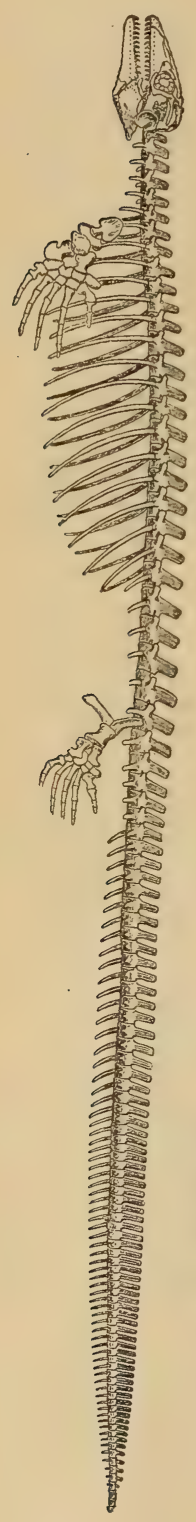

Fig. 350.

Restauriertes Skelett $\nabla$ on Platecarpus. Ca. $1 / 35$ nat. Gr (Nach Merriam.) Reihe auf den Kiefern und den Pterygoidea. Thre glänzende, mit Schmelz bedeckte Krone ist meist vorn und hinten zugeschärft oder durch mehrere Kanten facettiert. Alle Zähne stehen in seichten Alveolen und sind mit den angrenzenden Knochen fest verwachsen. Die Ersatzzähne entwickeln sich auf der Innenseite der funktionierenden Zähne, um diese allmählich durch Druck zu verdrängen.

In der Wirbelsäule (Fig. 350 u. 351) zählt man bis zu 130 und mehr Wirbel, welche sich als Hals-, Rücken- und Schwanzwirbel unterscheiden lassen. Die oberen Bögen sind fest mit den procölen Wirbelkörpern verschmolzen, die Dornfortsätze mäßig hoch, zuweilen aber in der hinteren Schwanzregion relativ ziemlich verlängert. Die Querfortsätze der präsacralen Wirbel sind kurz und dick, sie tragen einköpfige Rippen, die der Schwanzwirbel erscheinen verlängert, ohne Rippen zu tragen. Die Zygapophysen sind in der Hals- und vorderen Rückengegend gut entwickelt, um nach rückwärts schwächer zu werden und in der Schwanzregion zuweilen völlig $\mathrm{zu}$ verschwinden. Zuweilen kommt zu denselben noch die bei den Schlangen und verschiedenen Eidechsen bekannte Verbindung der Wirbel durch Zygosphen und Zygantrum hinzu. Der Atlas besteht aus einem keilförmigen ventralen Mittelstück (Intercentrum, Hypapophyse), zwei seitlichen Bogenstücken und dem als Zentrum gedeuteten Zahnfortsatz (Processus odontoideus) des Epistropheus. Zwischen diesem und dem Atlas befindet sich ein zweites Intercentrum. Der Epistropheus und die folgenden fünf $\mathrm{Halsw}$ irbel besitzen ungewöhnlich große und verlängerte, mit dem Wirbel-

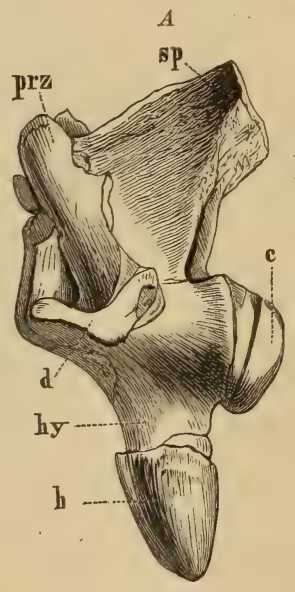

Fig. 351

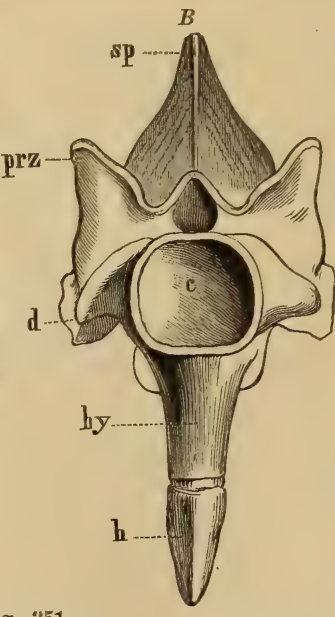

Clidastes stenops Cope. Halswirbel $A$ von der Seite, $B$ von vorn, c Zentrum, $s p$ Dornfoitsatz, $d$ Querfortsatz, prz Präzygapophyse, hy Hypapophyse, $h$ zapfenartiges Endstück der Hypapophyse. 1/2 nat. Gr. (Nach Cope.) körper verschmolzeneHypapophysen welche, ventral abgestutzt, mit einem freien, zapfenartigen Fortsatz (Epiphyse) gelenken, welcher das Intercentrum repräsentieren dürfte. Am letzten Halswirbel vermissen wir diesen Fortsatz. Mit Ausnahme der er. sten auf den einen Sacralwirbel folgenden Wirbel (Pygal. wirbel) besitzen alle Schwanzwirbel Y. förmige Hämapo. physen (chevron bones), welche mit den zugehörigen Wirbelkörpern gelenken.

Im Brustgürtel (Fig. 352) zeichnet sich das C orac oid durch ansehnliche Größe aus; das verdickte Gelenkende zeigt zwei Facetten auf, während der 
gegenüberliegende flachere Innenrand bogenförmig und häufig mit einem tiefen Einschnitt versehen ist. Außerdem findet sich noch ein kleines Foramen supracoracoideum. Hinten grenzen die Coracoidea an das Sternum an welches wahrscheinlich nicht verknöcherte, sondern ebenso wie die mit ihm in Verbindung tretenden Sternalrippen aus verkalktem Knorpel bestand. Die Scapula ist jener der Rhynchocephalen ähnlich. Zuweilen findet sich ein spanförmiges Episternum. Claviculae sind bis jetzt noch nicht nachgewiesen. Der $\mathrm{Humerus}$ ist sehr kurz, gedrungen und

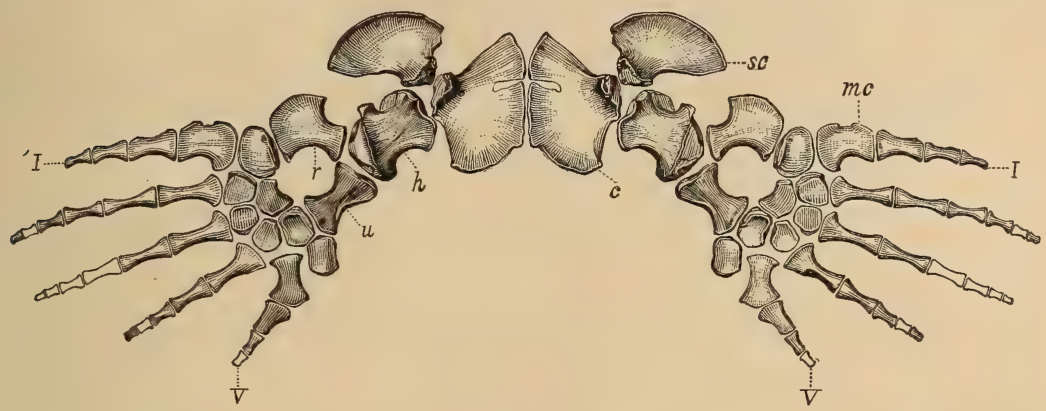

Fig. 352 .

Brustgürtel von Clidastes velox Marsh. Von oben gesehen. 1/5 nat. Gr. (Nach Marsh.) c Coracoideum, sc Scapula, $h$ Humerus, $r$ Radius, $u$ Ulna, $m c$ Metacarpus, $I$ erster, $V$ fünfter Finger.

an beiden Enden verbreitert und distal mit zwei Facetten für die gleichfalls sehr kurzen, getrennten Vorderarmknochen versehen. Die Carpalia schwanken in der Zahl zwischen 7 (in zwei Reihen) bei Clidastes etc. und 1-2 rudimentären Knöchelchen bei Tylosaurus. Die fünf Metacarpalia tragen die aus einer wechselnden Anzahl von Gliedern zusammengesetzten Finger.

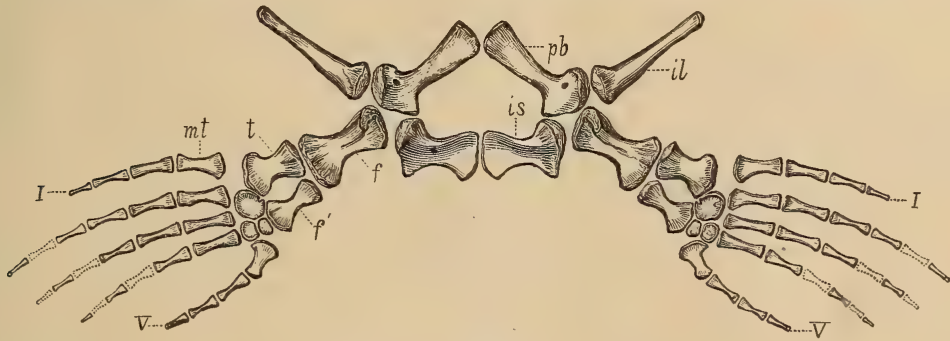

Fig. 3503.

Platecarpus simus Marsh sp. Ob. Kreide. Smoky Hill, Kansas. Beckengürtel und Hinterextremitäten. il neum, $p b$ Pubis, is Ischium, $f$ Femur, $t$ Tibia, $f^{\prime}$ Fibula, $m t$ Metatarsus, $I$ erste, $V$ fünfte Zehe. $1 / 12$ nat. Gr. (Nach Marsh.)

Der Beckengürtel (Fig. 353) ist schwächer als der Brustgürtel. Das Ilium ist ein stabförmiger Knochen, sein Oberrand war entweder frei oder durch lockeres Ligament leicht mit dem einen Sacralwirbel verbunden, Ischium und Pubis erinnern an Eidechsen. Femur, Tibia und Fibula ähneln den homologen Knochen der Vorderextremität, bleiben aber schmäler und schlanker. Am Tarsus sind 1-3 Knöchelchen beobachtet. Die 4 oder 5 Zehen sind auf gleiche Weise wie die Finger zusammengesetzt. Im allgemeinen übertreffen die Vorderextremitäten die hinteren an Iänge.

Mosasaurus Conyb. (Leiodon Owen) (Fig. 348, 354, 356). Schädel 1,2 m, Körper über $12 \mathrm{~m}$ lang. Rumpf langgestreckt. Wirbel ohne ZygosphenZygantrum. Über 130 Wirbel, davon 46 präsacral ( 7 Hals-, 39 Rückenwirbel). Nasalia nicht mit den Prämaxillaria verschmolzen. Die mächtigen Zähne 
(auf dem Oberkiefer 14, auf dem Pterygoid 8) vorne und hinten kantig begrenzt. Quadratum klein, oben mit kurzem Fortsatz. Hinterextremität mit 4 Zehen. Höchstzahl der Phalangen 6. Tarsus und Carpus vollständig verknöchert. Chevrons der Schwanzwirbel mit den Wirbeln verwachsen. ? Cenoman. Neuseeland. Ober-Turon. Senon von Maestricht (Holland), Belgien, Norddeutschland, Frankreich, Norditalien ${ }^{1}$ ) und Nordamerika.

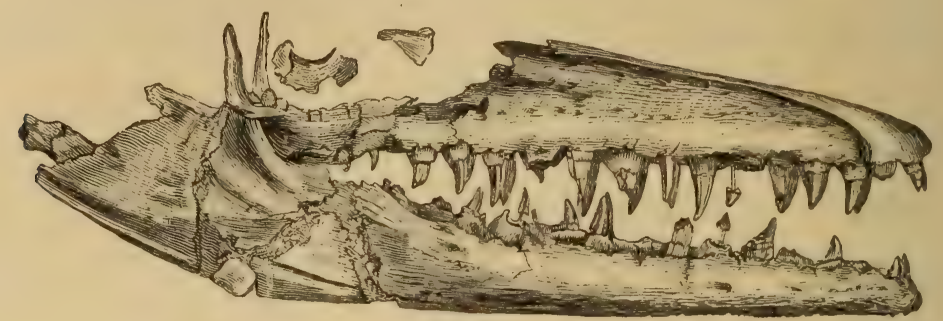

Fig. 354 .

Mosasaurus Camperi H. . Meyer. Oberste Kreide. Petersberg bei Maestricht. Schädel im Brüsseler Museum, von der Seite. Ca. $1 / 12$ nat. Gr. (Nach Dollo.)

Clidastes Cope (Edestosaurus Marsh) (Figur $346 \mathrm{~A}, 349,351,352)$. Schädel $40-70 \mathrm{~cm}$ lang, schmal, niedrig. Zähne, facettiert auf der Außen-, glatt auf der Innenseite, oder auf beiden Seiten glatt. Dentale mit ca. 17 Zähnen. Maxillare mit 15, Pterygoid mit 12-15. Präsacralwirbel ca. 43. Wirbel mit Zygosphen-Zygantrum. Dornfortsätze in der hinteren Schwanzregion verlängert. Chevrons und Extremitäten wie bei Mosasaurus. Oberes Turon. Unteres Senon. Nordamerika.
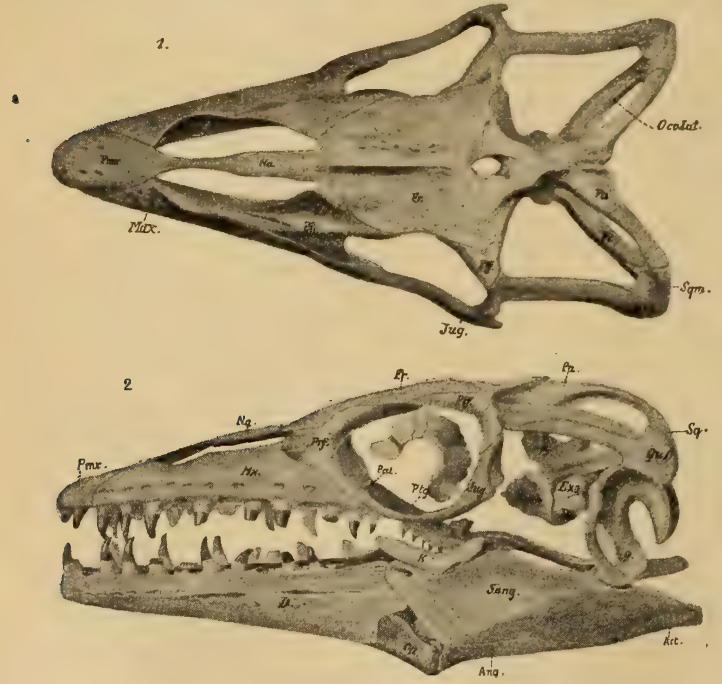

Fig. 355.

Platecarpus coryphaeus Cope. Obere Kreide. Logan County Kansas. Schädel von oben und von der Seite. 1/7 nat. Gr. (Nach Merriam.) Qj Squamosum, Sq Supratemporale, op Spleniale, Sang. Supraangulare, $K$ Komplementare, $A n$ Angulare, $D$ Dentale.

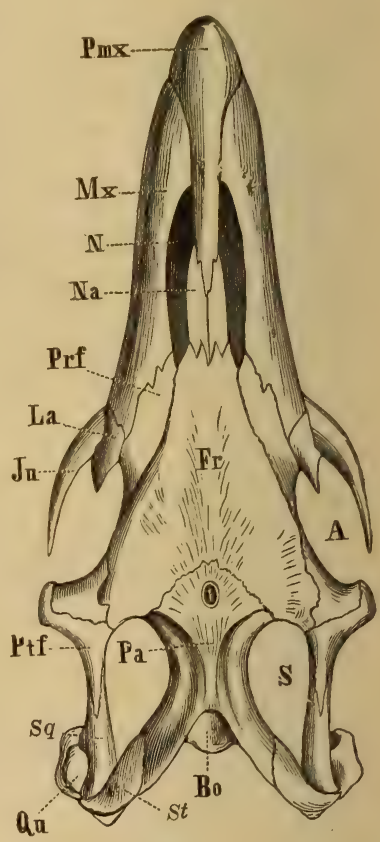

Fig. 356.

Schädel von Mosasaurus (Liodon) restauriert (nach Owen), von oben. A Augenhöhle, S Schläfenloch, $N$ Nasenloch, $P a$ Scheitelbein, Fr Stirnbein, Prf Präfrontale, Ptf Postfrontale, La Lacrimale, Ju Jochbein, Mx Oberkiefer, Pmx Zwischenkiefer, $\mathrm{Na}$ Nasenbein, St Supratemporale, $Q u$ Quadratbein, $S q$ Squamosum, Bo Basioccipitale.

1) Der von $R$. Nicolis (R. Ist. Venet. Sci. 59. 2. 1900) aus der Scaglia (Senon) beschriebene Mosasaurier ist in seiner generischen Zugehörigkeit unsicher. 
Platecarpus Cope (Lestosaurus Marsh) (Fig. 347, 350, 353, 355). Körperlänge ca. $5 \mathrm{~m}$, von welcher auf den Schädel $1 / 8$ fällt. Scheitelloch groß, am Vorderrand des Parietale, Augen seitlich. Quadratum groß, oben mit langem Fortsatz. Öffnung für den Meatus auditorius groß, nicht vollständig umschlossen. Zähne schlank und leicht rückwärts gekrümmt, auf der Außenseite facettiert, auf der Innenseite gestreift. Rumpf gedrungen. Höchstens 30-32 präsacrale Wirbel (nach Williston 7 Halswirbel, 23 Rückenwirbel). Zygosphen rudimentär. Coracoid medial mit Ausschnitt. Episternum vorhanden. 4 Carpalia und 3 Tarsalia. Hinterextremität fünfzehig. Chevrons groß, locker gelenkend. Häufig im oberen Turon und Untersenon von Kansas, Wyoming, Colorado, North Dakota, Texas und Frankreich.

Holosaurus Marsh. Ähnlich dem vorigen Genus, vielleicht ident nur Coracoidea medial ohne Ausschnitt. Obere Kreide. Kansas.

Sironectes Cope. Obere Kreide. Kansas.

Plioplatecarpus Dollo (Oterognathus, Phosphorosaurus Dollo). Ähnlich Platecarpus. Bezahnung reduziert, Augen nach oben gerichtet. Extracolu. mella verknöehert. Trommelfell calcifiziert. Foramen parietale sehr groß. Basioccipitale mit medianem Kanal. 38 präsacrale Wirbel. Senon. Maestricht und Belgien.

? Iserosaurus, Hunosaurus Fritsch. Turon. Böhmen.

Prognathosaurus Dollo. Schädel ca. 0,6 m lang. Pterygoidea fast ebenso groß wie die Maxillaria und mit sehr kräftigen Zähnen. Quadratum mit großem oberen Fortsatz, der sich mit einem von unten aufsteigenden Fortsatz vereinigt. Chevrons frei. Senon. Belgien.

Brachysaurus Williston. Ähnlich Prognathosaurus, aber die Chevrons mit den zugehörigen Wirbelcentra verschmolzen. Obere Kreide. S. Dakota.

Baptosaurus Marsh. Obere Kreide. Nordamerika. seeland.

Taniwh a saurus Hektor. Verwandt mit Platecarpus. Cenoman. Neu-

Tylosaurus Marsh (Liodon Cope, Macrosaurus Owen, Rhinosaurus Marsh). Fig. 346 B. Schädel $70 \mathrm{~cm}$ bis $1,20 \mathrm{~m}$. Skelett bis $8^{1} / 2 \mathrm{~m}$ lang. Zwischenkiefer schnabelartig verlängert; Quadratum dick, mit kurzem oberen Fortsatz. Maxillare mit ca. 13 Zähnen. Rumpf gedrungen. 7 Halswirbel, 22-23 Rückenwirbel. Kein Zygosphen. Über 70 Schwanzwirbel. Chevrons leicht gelenkend. Coracoid ohne Einschnitt. Ein oder zwei Carpalia und Tarsalia vorhanden. Hinterextremität fünfzehig. Zahlreiche Phalangen. Oberes Turon. Unteres Senon. Nordamerika.

Hainosaurus Dollo. Schädel bis über $1,50 \mathrm{~m}$ lang. Prämaxillare schnabelartig verlängert. Zähne verschiedenartig. Weniger Phalangen als bei Tylosaurus. Paddeln relativ größer. Femur länger als der Humerus. Oberes Turon. Oberes Senon. Belgien.

\section{Anhang. Paterosauridae. ${ }^{1}$ )}

Schädel solid verknöchert, langgestreckt, schmal, Lacertilier ähnlich mit unbeweglichem, nach vorne gerichtetem Quadratum. Foramen parietale fehlt. Hinterhaupt mit dreiteiliger, von Basioccipitale und Exoccipitale lateralia gebildeter Gelenkung. Interorbitalseptum verknöchert. Seitliche Schläfenlücke und Orbitalöffnung nicht voneinander durch eine knöcherne Spange getrennt. Erstere unten

1) Broili $F$., Systematische u. biologische Bemerkungen zu der permischen Gattung Lysorophus. Anat. Anz. Bd. XXXIII. 11 u. 12. 1908. - Case E. C., Notes on the skull of Lysorophus tricarinatus Cope. Bull. americ. Mus. Nat. Hist. Vol. XXIV. Art. 26. 1908. - Williston S. W., Lysorophus a Permian Urodele. Biol. Bull. Vol. XV. Nr. 5. 1908. New Permian Reptiles. Rhachitomous vertebrae. Journ. Geol. Okt./November 1910. 
nicht knöchern begrenzt. Basioccipitale und Basisphenoid ähnlich wie bei Amphisbaena als breite Platten entwickelt. Unterkiefer sehr kurz, nicht zuei Drittel der Schädellänge betragend. Zähne gleichmäßig groß, spitz. Auf dem Vomer eine zweite Zahnreihe. Zwischen den Unterkiefern Hautverknöcherungen (Jugular-

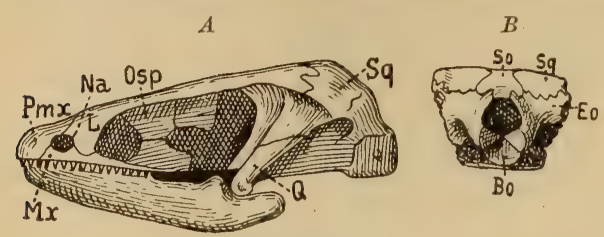

Fig. 357.

Lysorophus tricarinatus Cope. Perm. Texas. A von der Seite, n. Case. $B$ von hinten, n. Broili. So Supraoccipitale, Exo Exoccipitale laterale, $S q$ Squamosum, Q Quadratum, $L$ Lacrimale, $N$ Nasenöffnung, $O s p$ Interorbitalseptum (sonstige Bezeichnungen wie früher), Bo Basioccipitale. platten). Ein Paar verknöcherter Ce. ratobranchialia und drei Paar eben. solcher Epibranchialia. Körper lang. gestreckt. Wirbel amphicöl mit persistierender Chorda, oberer Bogen nicht mit Wirbelkörpern verwachsen und dorsal noch durch eine Sutur getrennt. Intercentra fehlen. Rippen lang, ein. köpfig. Perm. Texas. Illinois.

Die einzige hierhergehörige, mit den genannten Merkmalen aus gestattete Form ist Lysorophus Cope, Fig. 357, aus dem nordameri-

kanischen Perm. Mit der einspringenden Gelenkung des Hinterhauptes stand wahrscheinlich noch Knorpel in Verbindung. Extremitäten sehr klein. Bei seinem wurmförmigen Körper dürfte Lysorophus ähnlich Amphisbaena ein unterirdisches, grabendes Leben geführt haben. Die systematische Stellung ist noch umstritten. S. Williston und Case stellen die Form zu den Urodelen.

\section{Unterordnung. Ophidia. Schlangen. $\left.{ }^{1}\right)$}

Körper mit Hornschuppen, stark verlängert, ohne Brustgürtel, fußlos. Parietale ohne Foramen. Wirbel procöl mit Zygosphen und Zygantrum; die vorderen mit starken ungegliederten Hypapophysen. Temporalbögen und Epiptery. goid fehlen. Quatratbein ebenso wie Pterygoid, Maxillare und Palatinum beweglich und lose mit dem Schädel verbunden; Zwischenkiefer sehr klein; Unterkieferäste in.der Symphyse durch Ligament verbunden. ? Kreide. Eocän bis jetzt.

Das Skelett besteht nur aus Schädel und Wirbelsäule mit ihren An: hängen. Brustgürtel und Vorderextremität fehlen stets, vom Beckengürtel und der Hinterextremität finden sich nur Rudimente (z. B. Boiden, Opoterodonten). Die Zahl der Wirbel ist eine sehr beträchtliche (zuweilen mehr als 400); sie sind procöl, hinten mit halbkugeligen Gelenkflächen versehen, und sowohl durch diese, als auch durch Zygapophysen, sowie durch Zygosphen und 7ygantrum sehr fest miteinander verbunden, die oberen Bögen stets vollständig mit dem Centrum verschmolzen. Die vordersten (bis ca. 30) besitzen ungegliederte Hypapophysen auf der Unterseite (Fig. 358); die Querfortsätze sind kurz, knotig. Die langen, gebogenen, häufig hohlen Rippen, welche schon am dritten Wirbel beginnen, sind in der Schwanzregion durch verlängerte Querfortsätze ersetzt. Sie sind einköpfig und äußerst beweglich. Untere Bögen (Hämapophysen oder Chevrons bones) fehlen den Schlangen, dagegen vertreten deren Stelle kräftige absteigende Fortsätze der Diapophysen (Fig. 359).

Der Schädel (Fig. 360) unterscheidet sich von dem der Lacertilier durch die solide Verknöcherung der Schädelkapsel — was durch die Ver-

1) Filhol H., Ann. des Sc. geol. 1887 VIII p. 270-273. - Owen Rich., Fossil Reptilia of the London clay; part. II Palaeont. Soc. 1850. - Janensch W., Uber Archaeophis etc. Beitr. zur Pal. u. Geol. Österr.-Ungarns etc., Bd. XIX. 1906. Pterosphenus Schweinfurthi etc. Archiv f. Biontologie. I. 1906. Berlin. Friedländer. - Rochebrune A. F. de, Revision des Ophidiens fossiles, Nouv. Archives du Musée d'hist. nat. de Paris. 1880. 2. ser. vol. III. 
schmelzung des Prooticums mit dem unpaaren Parietale und dadurch, daß die stark abgebogenen Seitenränder des letzteren und der paarigen Frontalia sich bis zum Basisphenoid erstrecken, erreicht wird, - ferner durch den Mangel der Schläfenbögen und des Epipterygoids sowie die geringe Entwicklung des Prämaxillare. Das große Quadratum und meist auch das Squamosum sind in der Regel beweglich mit dem Schädel verbunden, ferner zeigt das meist bezahnte Pterygoid wie Maxillare und Palatin, die durch ein langgestrecktes Transversum in Verbindung stehen, ebenso wie die in der Symphyse durch Ligament verknüpften Unterkieferäste große Verschiebbarkeit. Die Schädelknochen sind derb, fast elfenbeinartig und durch glatte Nähte verbunden, die Exoccipitalia mit den Opisthotica verwachsen.

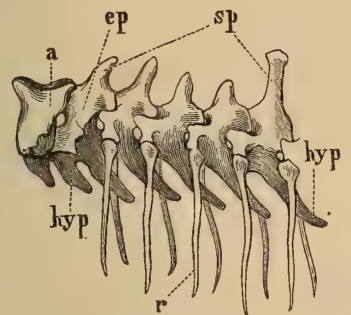

Fig. 358 .

Die 6 vorderstenWirbel von Python bivittatus Nat. Gr. (Nach d'A1ton.) a Atlas, ep Epistropheus, hyp Hypapophysen, $r$ Rippen, $s p$ Dornfortsätze.

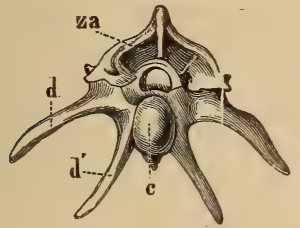

Fig. 359 .

Ein Schwanzwirbel von Python bivittatus von hinten. c Gelenkkopf des Zentrum za Zygantrum, d Querfortsatz mit absteigendem Ast $\left(d^{\prime}\right)$.

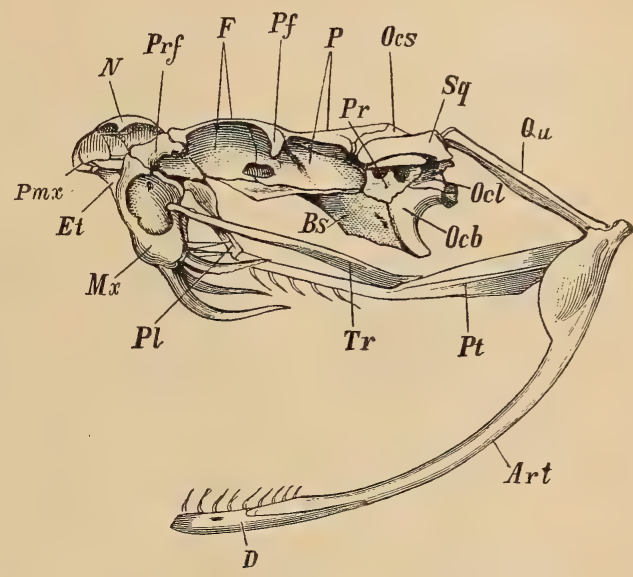

Fig. 360 .

Schädel der Klapperschlange (Crotalus horridus.) (Nach Claus.) Ocb Basioccipitale, Ocl Exoccipitale laterale, Osc Supraoccipitale, Pr Prooticum, Bs Basisphenoid, Sq Squamosum, $P$ Parietale, $F$ Frontale, Pf Postfrontale, Prf Präfrontale, Et Ethmoideum, $N$ Nasale, Qu Quadratum, $P t$ Pterygoideum, $P l$ Palatinum, $M x$ Maxillare, Pmx Prämaxillare, Tr Transverum, $D$ Dentale, Art Articulare des Unterkiefers.

Die spitzkonischen, nach hinten gekrümmten, acrodonten Z Z̈ h n e können auf Oberkiefer, Zwischenkiefer, Palatina und Pterygoid und dem Dentale des Unterkiefers stehen. Sie fehlen zuweilen (Uropeltis etc.) auf den Palatina, sehr häufig auf den rudimentären Zwischenkiefern, selten sind sie nur auf dem Oberkiefer bzw. Unterkiefer beschränkt. (Opoterodonten.) Bei den Giftschlangen sind einzelne der vorderen Maxillarzähne mit einem inneren Kanal versehen, welcher an der Zahnspitze mit einer schlitzförmigen Öffnung endigt oder sie sind mit einer Längsfurche ausgestattet.

Die Bewegung der Schlangen erfolgt hauptsächlich durch seitliche Krümmung der Wirbelsäule, sowie durch die mit den Wirbeln gelenkig verbundenen Rippen, die vor- und zurückgeschoben werden können und so die Bewegung des Körpers unterstützen.

Die Schlangen sind vorzugsweise in den wärmeren Zonen verbreitet und größtenteils Landbewohner. Man unterscheidet etwa 400 lebende Gattungen mit nahezu 1800 Arten. Im Vergleich damit haben die spärlichen fossilen Vertreter - die aus der Kreide beschriebenen Reste sind alle mehr oder weniger problematisch, vielleicht mit Ausnahme der Gattung Symoliophis Sauvage aus dem Cenoman von der Charente und von Portugal welche aus tertiären oder diluvialen Ablagerungen stammen, nur geringe 
Bedeutung; auch lassen die überlieferten Reste meist nur unbedeutende Abweichungen von recenten Formen erkennen. Da von der Mehrzahl der fossilen Arten nur Wirbel bekannt sind, so bleibt die zoologische Bestimmung in manchen Fällen ziemlich zweifelhaft.

Ganze Skelette wurden bis jetzt nur im Eocän des Monte Bolca bei Verona, im miocänen Süßwasserkalk von Oeningen und Euböa und in der Braunkohle von Rott im Siebengebirge aufgefunden. Die überwiegende Mehrzahl der fossilen Reste gehört zu den giftlosen Schlangen.

Im älteren Tertiär von England und Cuise la Mothe, ferner in Belgien finden sich Wirbel von großen Pythoniden (Palaeophis Owen), im Eocän von New Yersey eine vikarierende Gattung (?=Palaeophis, Titanophis Marsh), im Mitteleocän des Fayum in Ägypten neben anderen unvollständigen Schlangenresten und im Eocän von Alabama die Palaeophis nahe stehende Gattung Pterosphenus Lucas. Aus der obersten Kreide (? Tertiär) Patagoniens beschreibt A. S. Woodward eine Ilysia nahestehende Gattung: Dinilysia. Die eocänen Ablagerungen von Neu-Mexiko liefern Helagris Cope, die von Wyoming Boavus, Lithophis und Limnophis Marsh. Im Eocän des
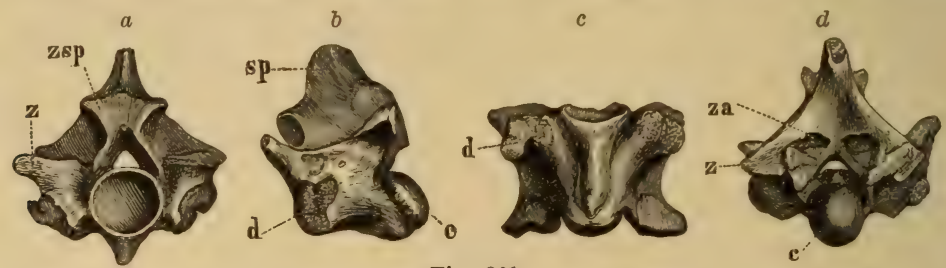

Fig. 361 .

Palaeopython Cadurcensis Filhol sp. Ob. Eocän (Phosphorit). Escamps. Quercy. Wirbel in nat. Gr. $a$ von vorn, $b$ von der Seite, $c$ von unten, $d$ von hinten. ( $c$ Gelenkkopf des Zentrum, $8 p$ Dornfortsatz, $d$ Querfortsatz (Diapophyse), $z$ Zygapophyse, zsp Zygosphen, za Zygantrum.)

Monte Bolca tritt eine hochspezialisierte Wasserschlange Archaeophis Mass. em. Janensch auf. Die Phosphorite von Quercy und die eocänen Ablagerungen in der Schweiz, im Pariser Becken und in England enthalten Palaeo. python (Fig. 361) Paleryx Owen und Scytalophis Rochbr.

Unter den miocänen Schlangen zeichnet sich das stattliche Skelettfragment von Heteropython Euboeicus Roem. von Kumi auf Euböa durch treffliche Erhaltung aus; verschiedene Gattungen, namentlich Colubriden (Elaphis) und Eryciden sind aus dem miocänen Süsswasserkalk von Oeningen, Steinheim, Mosbach-Biebrich (Provipera Kink., älteste Giftschlange), Günzburg, Haeder, Sansan, der Touraine u. a. O., sowie aus der intermiocänen Braunkohle von Rott und dem Süßwasserkalk von Weisenau bei Mainz und Ulm beschrieben. Im Miocän von Colorado und Oregon kommen mehrere Erycidae und eine Crotalide vor. Die pleistocänen Schlangenreste gehören zu noch jetzt lebenden Gattungen.

\section{Ordnung. Ichthyosauria. Fischsaurier. ${ }^{1}$ )}

Marine, langgeschwänzte, nackthäutige Reptilien mit fischartigem Körper ohne ausgebildeten Hals. Extremitäten paddelförmig, zuweilen mit mehr als 5 Phalangenreihen, von Schwimm. haut umgeben. Der schmale, hohe Schädel mit stark verlänger.

1) Andrews C. W., Notes on the osteology of ophthalmosaurus icenicus etc. Geol. Magaz. Dec. 5. 4. Bd. 1907. A descriptive Catalogue of the Marine Reptiles of the Oxford clay etc. Part. I. London printed b. o. the Trustees British Mus. 1910. - Bauer F., Die Ichthyosaurier d. ob. weiß. Jura. Palaeontographica 44. Bd. 1898. Ichthyosaurus bambergensis. XVII. Ber. d. naturf. Gesellsch. in Bamberg. 1900. Osteologische Notizen über Ichthyosaurier. Anat. Anz. XVIII. Bd. 1905. Baur G., Amer. Naturalist 1887. XXI. S. 837. Über den Ursprung der Extremitäten 
ter, zugespitzter Schnauze; die seitlichen meist großen Augen mit Scleroticaring. Die kleinen Nasenlöcher getrennt vor den Augen liegend. Ein Paar großer oberer Schläfenöffnungen. Außer dem hier $z w i s c h e n$ Parietalia und Frontalia austretenden ansehnlichen Foramen parietale, im Basisphenoid (bei Ichthyosaurus, Ophthalmosaurus) ein Hypophysenloch. Quadratbein fest mit dem Schädel verbunden. Zähne spitzkonisch, gewöhnlich in gemeinsamen Alveolarrinnen auf dem sehr langen Prämaxil. lare, Maxillare und Dentale eingefügt, zuweilen in der Zahl reduziert. Wirbel zahlreich, sehr kurz, tief amphicöl. Bauchrippen vorhanden. Sternum nicht verknöchert. Schultergürtel aus dem T-förmigen Episternum, den Coracoidea, Scapulae und Claviculae zusammengesetzt. Nackthäutig. Marin. Trias bis Kreide.

Die nackthäutigen marinen Ichthyosaurier entfernen sich durch ihren zugespitzten, delphinähnlichen Kopf, durch ,ihren fischartigen Körper mit seinen kurzen amphicölen Wirbeln, durch ihre paddelförmigen aus Reihen polygonaler Knochenplättchen zusammengesetzten Extremitäten am weitesten von allen jetzt lebenden Reptilien; sie verhalten sich in bezug auf Körperformen, Extremitätenbildung und Lebensweise zu den typischen Reptilien wie die Cetaceen zu den übrigen Säugetieren und nehmen wie jene eine ganz isolierte Stellung ein.

der Ichthyopterygier. Bericht 20. Versamml. d. oberrh. geol. Vereins 1887. Palatingegend d. Ichthyosaurier. Anat. Anzeiger X. Bd. 14. 1894. - Boulenger G. A., Proc. geol. Soc. London. 1904. I. S. 424. - Branca W., Sind alle im Innern von Ichthyosaurier liegenden Jungen ausnahmslos Embryonen? Abhandl. d. k. pr. Akad. d. Wiss. 1907. Ferner Sitzb. k. pr. Akad. d. W. 1908. XVIII. - Broili $F$., Ein neuer Ichthyosaurus aus der nordd. Kreide. Palaeontographica 54. Bd. 1907.' Neue Ichthyosaurier aus der Kreide Norddeutschlands und das Hypophysenloch etc. Ibid. 55. Bd. 1909. Ichthyosaurierreste aus der Kreide. Neues Jahrb. Beilageband XXI. 1908. - Dames W., Uber die Ichthyoperygier der Triasformation. Sitzungsb. d. k. pr. Ak. d. W. Berlin 46. 1895 . Dollo L., Laudition chez les Ichthyosauriens. Bull. Soc. Belge de Géologie XXI. 1907, Brüssel. - Fraas Eberh., Die Ichthyosaurier der süddeutschen Trias- und Jura-Ablagerungen. Tübingen 1891. - Die Hautbedeckung von Ichthyosaurus. Jahresh. für vaterl. Naturk. Württembergs. 1894. - Gilmore $K$. W., Osteology of Baptanodon. Mem. Carnegie Mus. Pittsburg Pa. Vol. II. N. 2 u. 9. 1905. - Hawkins Thom., Memoirs of Ichthyosauri and Plesiosauri. London 1834. gr. folio. - Jaekel O., Eine neue Darstellung von Ichthyosaurus. Zeitschr. d. deutsch. geol. Gesellsch. Bd. 56. 1904. - Koken E., Die Reptilien d. norddeutschen unteren Kreide. Zeitschr. d. d. geol. Gesellsch. 1883. Lydekker $P$., Note on the classification of the Ichthyoperygia. Geol. Magaz. 1888. Dec. III. Vol. V. - Maggi L., Omologie craniale fra Ittiosauri etc. Il canale craniofaringeo negli Ittiosauri etc Rendiconti R. Istituto Lombardo Sc. e Lettere. Ser. 2. 31. Bd. Milano 1898. - Merriam J.C., Triassic. Ichthyosauria with spec. reference to the Americ. forms. Mem. Univ. calif. Vol. I. N. 1. 1908. Tbid. weit. Literatur. Owen Rich., Monograph on the fossil Reptilia of the liassic formations $1881 \mathrm{p}$. III. Paläont. Soc. p. 83-130 und Monograph on the fossil Reptilia of the cretaceous formations. Ibid. 1851. p. I p. 68-79. - Osburn R. C., Adaptive modifications of the limb skeleton in aquatic Reptiles and Mammals. Ann. N. J. Acad. Science. Vol. XVI. 1905. - Repossi E., Il Mixosauro degli strati triasici di Besano in Lombardia. Att. soc. Ital. Sc. Nat. Vol. 41. 1902. - Sauvage, Recherches sur les vertébrés du kimméridgien supérieur de Fumel. Mém. d. l. Soc. geol. d. France. 9. Fasc. 4. Mém. 25. 1902. - Stromer E., Neue Forsch. über fossile lungenatmende Meeresbewohner. Fortschritte der naturwissenschafll. Forsch. 2. Bd. Berlin, Urban \& Schwarzenberg. 1910. - Theodori C., Beschreibung des kolossalen Ichthyosaurus trigonodon in der Lokal-Petrefaktensammlung zu Banz. München 1854. - Wiman C., Ichthyosaurier aus der Trias Spitzbergens. Bull. Geol. Inst. Upsala. Vol. X. 1910. - Woodward A.S., Outlines of Vertebrate Palaeontology Cambridge 1898. Yakowlew N., Neue Funde von Trias-Saurien auf Spitzbergen. Verhandl. d. k. r. mineral. Gesellsch. Bd. 40. 1902 u. Bd. 41. 1904. 
Die gestreckten Vorderarmknochen der älteren triadischen Formen (Mixosaurus etc.), die relativ noch nicht in so hohem Grade dem Wasserleben angepaßt erscheinen wie die entsprechenden stark verkürzten plattenähnlichen Elemente der geologisch jüngeren Ichthyosaurier, sprechen für eine Abstammung von landbewohnenden Vorfahren.

Daß die Ichthyosaurier durch Lungen atmeten, geht aus der Abwesenheit von Kiemenbögen und aus der Form der Zungenbeine hervor. Auch über Fortpflanzung und Ernährung geben günstige Funde sicheren Aufschluß. Die in den Leibern von Ichthyosauriern verschiedentlich aufgefundenen Jungen lassen darauf schließen, daß sie vivipare Tiere waren, oder daß die Jungen bei oder kurz nach der Geburt die Eihüllen zerrissen. Nach den Darlegungen Brancas scheinen andere Jungen von den Muttertieren gefressen worden zu sein, außerdem finden sich im Mageninhalt der äußerst gefräßigen Tiere Reste von Sepien, Belemniten sowie zahlreiche Gräten und Fischschuppen.

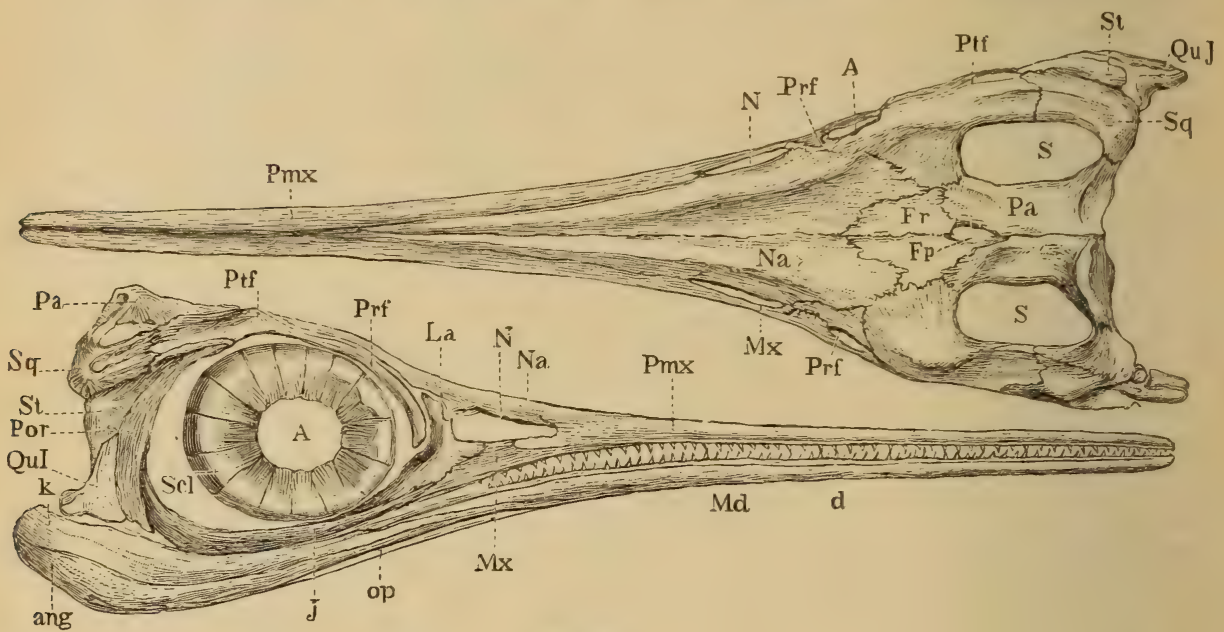

Fig. 362 .

Schädel von Ichtyosaurus longifrons Owen. (Nach E. Deslongchamps.) Ob. Liss. Curcy, Calvados. $1 / 2$ nat. Gr. A Auge, Scl Scleroticaring, $S$ Schläfenloch, N Nasenloch, Pa Parietale, $S q$ Squamosum, Fr Frontale, Ptf Postfrontale, Prf Präfrontale, La Lacrimale, J Jugale, Por Postorbitale, Qj Quadratjugale, St Supratemporale, $N a$ Nasale, Pmx Prämaxillare, $Y x$ Maxillare, $M d$ Unterkiefer ( $d$ Dentale, op Operculare, ang angulare, $k$ supraangulare).

Der mit einer langen delphinartigen Schnauze ausgestattete Schädel (Fig. 362) zeichnet sich durch große bis riesige, seitliche, mit einem (je nach den Gattungen) aus $14-20$ Knochenplatten bestehenden Scleroticaring versehene Augenhöhlen aus. Das Scheitelloch tritt zwischen der paarigen, ansehnlichen Parietalia und den kleinen Frontalia aus. Neben den Parietalia befindet sich jederseits ein elliptisches Schläfenloch, das außen und unten von Postfrontale und Squamosum begrenzt ist. Die weit zurückliegenden, getrennten äußeren Nasenlöcher sind durch eine mehr oder weniger schmale, von Präfrontale und Lacrimale gebildete Knochenbrücke von den Orbiten getrennt. Das Lacrimale bildet auch mit dem schlanken spangenförmigen $\mathrm{Jugale}$ die untere, das schmale, etwas 
gebogene Postorbitale mit dem stattlichen Postfrontale die hintere und obere Begrenzung der Augen. Zwischen dem sich an das Jugale anschließendenund die äußere hintere Schädeldecke bildenden Quadratojugale und dem mit sehr kräftigen Gelenkteil ausgestatteten hakenförmigen $\mathrm{Quadratum}$ liegt ein ansehnliches Fenster. Hinter dem Postorbitale befindet sich eingeschaltet zwischen diesem, dem Squamosum, Postfrontale und Quadratojugale ein unregelmäßig drei- oder vierseitiges Element, das gewöhnlich Supratemporale bezeichnet wird. Die vor den Augen sich verlängernde Schnauze besteht aus den Nasalia und den langgestreckten, durch eine gerade Naht miteinander verbundenen Prämaxillaria. Das Maxillare ist ein kleines, länglich dreieckiges, zwischen Prämaxillare, Lacrimale und Jugale eingeschaltetes Knochenstück.

Am Hinterhaupt wird die Begrenzung des Foramen magnum durch das kleine, aber sehr kräftige, den runden Gelenkkopf bildende Basioccipitale, die beiden seitlichen Exoccipitalia lateralia und ein unpaares bogenförmiges Supraoccipitalia gebildet. Seitlich vom Basioccipitale bzw: teilweise noch vom Exoccipitale liegt die keulenförmige Columella (Stapes) und das Opisthoticum, von denen erstere sich in eine rinnenförmige Vertiefung auf der Oberseite des Pterygoids einlegt und mit ihrem distalen Teil in eine runde Grube im Quadratum eingreift, während das letztere die Verbindung mit dem Squamosum anstrebt. Vor dem Opisthoticum liegt jederseits ein kleines Prooticum. Auf der Schädelunterseite (Fig. 363) folgt auf das Basioccipitale ein gedrungenes vierseitiges $\mathrm{Basi}$ sphenoid das eine einfache oder durch eine crista geteilte Hypophysenöffnung auf-

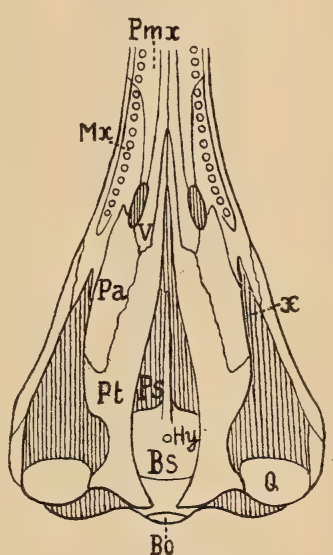

Fig. 363.

Unterseite von Ichthyosaurus longifrons Owen (schemat.) Bs Basisphenoid, Ps Rostrum, Hy Hypophysenöffnung, $P a$ Palatinum, $V$ Vomer, $M x$ Maxillare, Pmx Prämaxillare. Vor $V$ die Choane (innere Nasenöffnung), $x$ ? Ansatzstelle des nicht erhaltenen Transversum. 1/5 nat. Gr. (Nach A. S. Woodward.) zeigt, und das ein langes dolchförmiges, die großen Gaumenöffnungen teilendes Rostrum aussendet. Das Pterygoid ist langgestreckt und schmal. Auf seinem hinteren Ende steht dorsal das senkrechte Epipterygoid. An der Begrenzung der inneren Nasenlöcher nehmen die ansehnlichen Palatina, Maxillaria, Prämaxillaria und Vomera teil. Ein Transversum ist wahrscheinlich entwickelt. In der Hinterregion des Schädels unter den Flügelbeinen bemerkt man zuweilen zwei rippenartige starke $\mathrm{Z}$ ungenbeinhörner, auch ein plattiges $\mathrm{Hyoid}$ ist beobachtet worden. Die beiden schlanken Äste des Unterkiefers vereinigen sich vorne in einer sehr langen Symphyse und besitzen keinen eigentlichen Coronoidfortsatz.

Zähne (Fig. 364 u. 365) von spitzkonischer Form mit rundlicher, oder vorne und hinten zugeschärfter Krone und gewöhnlich dicker Wurzel finden sich - einige meist geologisch jüngere Formen ausgenommen - in der Regel in sehr großer Zahl auf den Kiefern. Sie sind gewöhnlich in eine gemeinsame tiefe Rinne, seltener in geson- 
derte Alveolen (Mixosaurus), eingelassen und wurden darin im ersten Falle lediglich vom Zahnfleisch gehalten. Die aus demselben hervortretende Krone ist sehr fest auf Dentin aufgebaut und mit einem

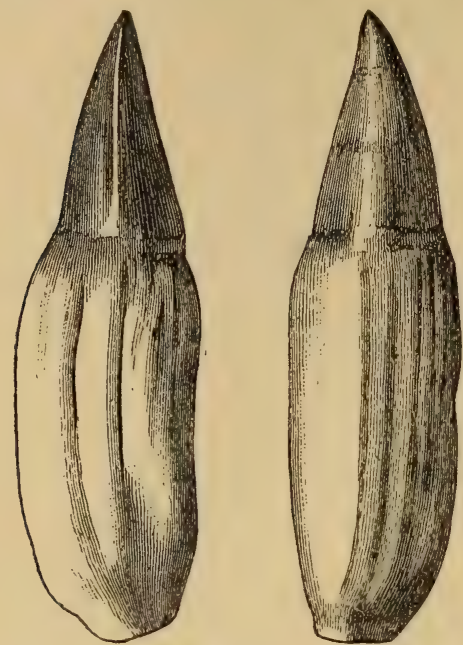

Fig. 364.

Ichthyosaurus platyodon Conyb. Unt. Lias. Lyme, Regis, England. Zahn von der Seite und von vorne. Nat. Gr. (Nach Lydekker.)

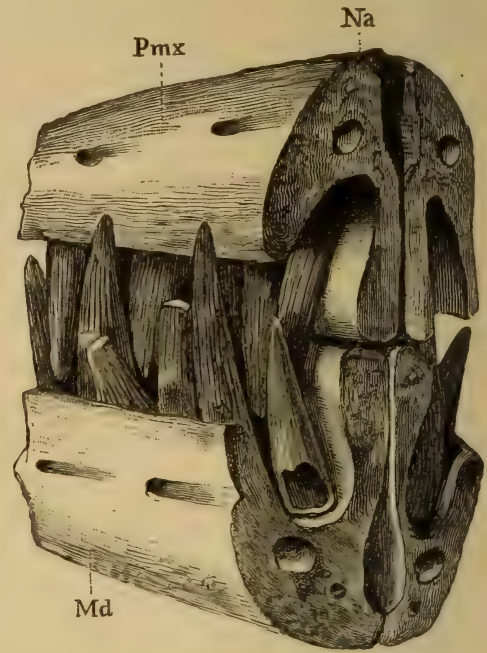

Fig. 365.

Schnauzenfragment von $I$. Quenstedti Zitt. aus dem oberen Jura (Bohnerz) von Melchingen (nach Qu'enstedt). Na Nasenbein, Pmx Zwischenkiefer, $M d$ Unterkiefer.

zarten glänzenden Überzug von Schmelz versehen; der untere Teil, die Wurzel, zeigt eine rauhe, gefurchte Oberfläche und ist aus einer von starken Gefäßen durchzogenen und mit Knochenkörperchen erfüllten knochenähnlichen Zementmasse zusammengesetzt, die einen mehr oder weniger gefalteten Dentinring umgibt.

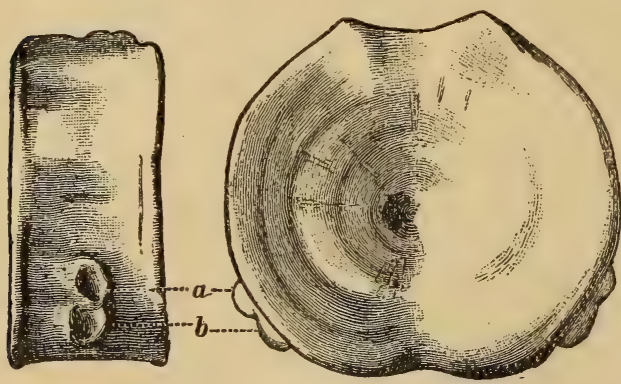

Fig. 366. Ichthyosaurus trigonus Owen. Zentrum eines hinteren Rumpfwirbels. $a, b$ tuberkularer und capitularer Gelenkhöker für die Rippe. Kimmeridge clay. WoottonBasset, England. $1 / 3$ nat. Gr. (Nach Ly dekker.)

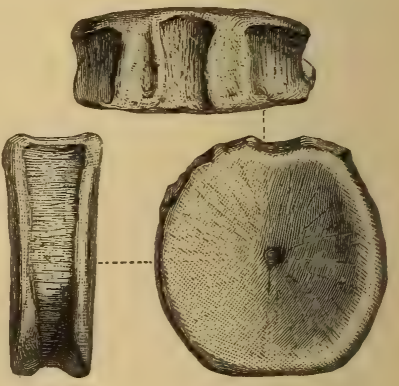

Fig. 367.

Schwanzwirbel von Ichthyosaurus aus dem oberen Lias von Banz, Franken. Nat. Gr.

Die Wirbelsäule (Fig. 366 u. 367) zerfällt, da ein größerer Halsabschnitt nicht entwickelt ist, in einen präcaudalen und caudalen Abschnitt. Die Zahl sämtlicher Wirbel ist stets eine sehr große und kann bei a usgewachsenen Formen 200 erreichen. (Bei verschiedenaltrigen Individuen derselben Art kann ein Unterschied bis über 
30 Wirbeln bestehen.) Die Vermehrung der Wirbel erfolgt ausschließlich im caudalen Teile; ca. $2 / 3$ aller Wirbel entfallen auf den Schwanz, $1 / 3$ auf den Rumpf. Die Wirbelkörper (Zentra) sind ungemein kurz und tief amphicöle, fischwirbelähnliche Scheiben. Die der ersten Wirbel besitzen zumeist einen fünfseitigen, alle übrigen in der Regel nahezu einen kreisrunden, seltener einen sechseckigen Umriß. Die oberen Bogen waren nur durch Knorpel am Wirbelkörper befestigt und lösen sich beim Fossilisationsprozeß leicht ab; auf der Dorsalseite der infolgedessen häufig isolierten Wirbelkörper lassen sich daher neben der schwach vertieften Rinne für das Rückenmark unregelmäßig dreieckige oder länglich vertiefte rauhe Insertionsstellen für die oberen Bogen erkennen. Letztere vereinigen sich $\mathrm{zu}$ einem starken, seitlich zusammengedrückten Dornfortsatz. Die Prä- und Postzygapophysen sind schwach ausgebildet. Die zwei vordersten Wirbel bilden als Atlas und Epistropheus den Halsabschnitt. Ihre Wirbelkörper sind - abgesehen von den triadischen Formen - bei ausgewachsenen Individuen miteinander fest verwachsen,

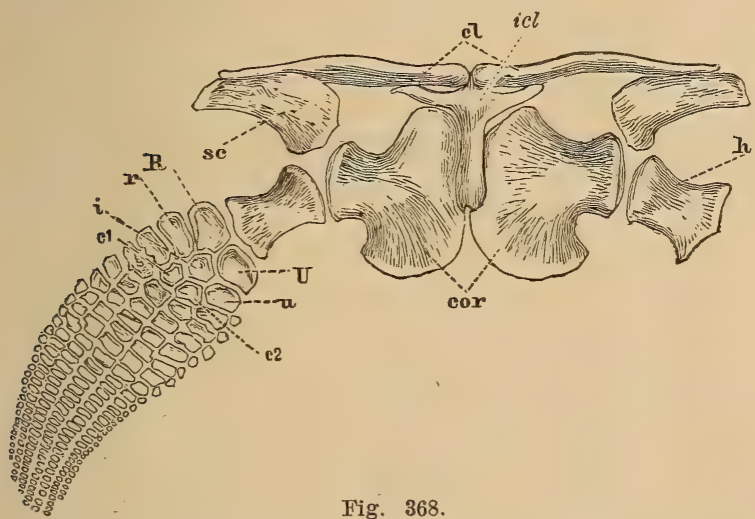

Brustgürtel und Vorderextremität des latipinnaten Ichthyosaurus communis. Conyb Unt. Lias England. icl Episternum, $\mathrm{cl}$ Schlüsselbein (clavicula), cor Coracoideum, sc Scapula, $h$ humerus, $R$ Radius, $U$ Ulna, $r$ radiale, $i$ intermedium, $u$ ulnare des Carpus. $c_{1} c_{2}$ die beiden Centralia.

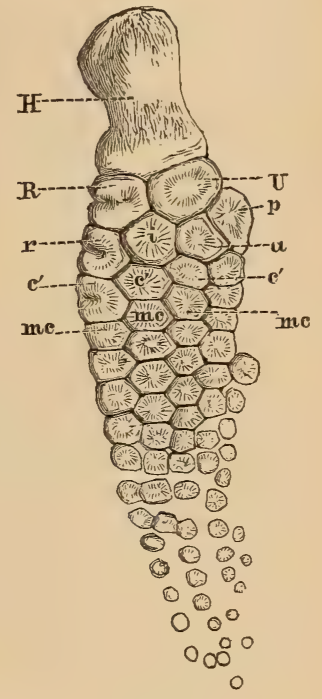

Fig. 369 .

Vorderfuß d. longipinnaten Ichthyosaurus triscissus QuenstOb. Lias von Boll, Württemberg. $H$ Oberarm (Humerus). $R$ Radius, $U$ Ulna, $r$ Radiale, $\boldsymbol{u}$ Ulnare, $\boldsymbol{i}$ Intermedium des Carpus, $c^{\prime}$ Platten der distalen Carpusreihe. Das mittlere $c^{\prime}$ unter $i=$ das eine Centrale. $p$ Pisiforme, me Metacarpalia.

jedes von ihnen läßt ventral vorn und hinten (bei sehr guter Erhaltung) ein kleines Intercentrum erkennen. Untere Bögen sind in der Schwanzregion bei den triasischen Gattungen, wo sie sich vereinigen, besonders wohl entwickelt, können aber auch bei den meisten jüngeren Formen auftreten, wo sie getrennt bleiben. Vom Atlas an besitzen die Wirbelkörper von Ichthyosaurus, Baptanodon, Ophthalmosaurus statt der Querfortsätze zwei getrennte Höcker zur Anheftung der zweiköpfigen, namentlich in der vorderen Rumpfregion besonders langer und stark gebogener, häufig mit einer tiefen Längsfurche versehenen Rippen. Gegen hinten rücken die beiden Höcker, unter gegenseitiger Annäherung immer tiefer an den Seiten des Wirbelkörpers herab, bis sie schließlich von der Beckengegend ab 
zu einer einzigen Protuberanz verschmelzen. Die Schwanzrippen selbst sind einköpfig, kurz und gerade und begleiten einen großen Teil des Schwanzes als kurze seitliche Fortsätze. Bei Cymbospondylus, Delphinosaurus, Shastasaurus tragen nur einige vordere Rückenwirbel zweiköpfige Rippen, alle hinteren sind einköpfig.

Der letzte Abschnitt des Schwanzes ist nach abwärts gebogen (Cymbospondylus, Mixosaurus) oder vollständig nach unten abgeknickt (Ichthyosaurus) und verläuft in den unteren Lappen einer gewaltigen vertikalen Schwanzflosse, welche in der Hauptsache den eigentlichen Locomotionsapparat des Tieres darstellte. Dieselbe ist an Exemplaren aus dem Lias von Holzmaden und dem lithographischen Schiefer im deutlichen Abdruck erhalten. Die Paddeln dürften im Gegensatz zu Plesiosaurus zumeist nur als Balancemittel gedient haben. Zwischen den Extremitätengürteln liegen zahlreiche dünne grätenartig gebogene Bauchrippen.

Für die Fähigkeit der Ichthyosauren, im Wasser sich energisch $\mathrm{zu}$ bewegen, spricht auch die Zusammensetzung des ungemein kräftigen Brustgürtels. (Fig. 368.) Ein knöchernes Sternum ist nicht erhalten, dagegen findet sich stets ein dreiseitiges, in der Regel aber T-förmiges

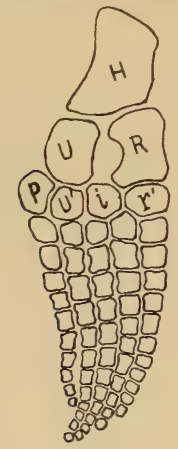

Fig. 370 .

RechteVorderextremität von $M i$ xosaurus cornalianusBassani. Ob. alp. Trias. Besano. Lombardei. $H$ Humerus, $U$ Ulna, $R$ Radius, $U^{\prime}$ Ulnare, $R^{\prime}$ Radiale, i Intermedium, $P$ Pisiforme. N. Repossi.
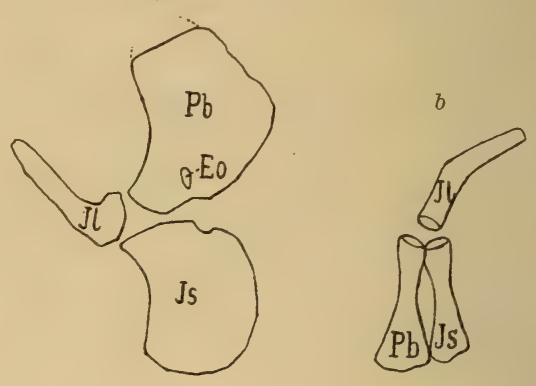

Fig. 371.

$a$ Rechte Beckenhälfte von Cymbospondylus petrinus Leidy. Ventral - Ansicht. Mittl. Trias. Nevada. $P b$ Pubis mit Foramen obturat Eo; $J s$ Ischium, $H$ Ilium, ca. $1 / 7$ nat. Gr. (nach Merriam). b Linke Beckenhälfte von Ichthyosaurus communis Conybeare. Unt. Lias. England. V. d. Seite, $2 / 9$ nat. Gr.

(Nach A. S. W o o d ward.)

Episternum, welches den schlanken, leicht gebogenen Claviculae anliegt oder zwischen sie eingeschaltet ist. Die Coracoidea sind große breite, hinten abgerundet endende Knochenplatten, deren Innenränder sich gegenseitig berühren, ihr Vorderrand zeigt gewöhnlich einen mehr oder weniger tiefen Ausschnitt, am Außenrand ragt ein kurzer, stark verdickter, breiter Fortsatz mit zwei Gelenkflächen vor, wovon die vordere zur Aufnahme der länglichen, in der Mitte etwas eingeschnürten, proximal verdickten und verbreiterten Scapula, die hintere für den kurzen stämmigen Humerus bestimmt ist, Der proximal verdickte Humerus (Fig. 369, 370) gelenkt zum größten Teil mit dem Coracoid zum kleineren mit der Scapula, distal ist er abgeplattet und mit zwei, seltener mit drei Facetten versehen, von denen die vordere den Radius, die hintere die Ulna und im letzteren Falle die mittlere, das Intermedium, aufnimmt. 
Radius und Ulna, die bei triasischen Gattungen noch relativ gestreckte median eingeschnürte Elemente darstellen, sind bei den späteren Formen polygonale oder rundliche Knochenplatten (Fig. 370, 369). Die zwei folgenden Querreihen kleiner, meist polygonaler oder rundlicher Platten werden dem Carpus (in der proximalen Reihe häufig ein ulnares, seltener auch ein radiales Sesambein - Pisiforme), die dritte dem Metacarpus zugeschrieben, an welchem 3-5 Längsreihen ebensolcher Knöchelchen beginnen, welche gegen das Ende der Paddel immer kleiner werden. Durch dichotome Spaltung einzelner Strahlen kann die Zahl der Finger auf 8-10 erhöht werden. Die Menge der eine solche Paddel zusammensetzenden Täfelchen ist sehr wechselnd, kann aber mehr als 100 betragen. Häufig bemerkt man am Radius und den folgenden Platten des Vorderrandes einen tiefen Einschnitt. Je nachdem in der distalen Reihe des Carpus mit dem Intermedium ein oder zwei Centralia gelenken unterscheidet man Longipinnati oder Latipinnati Ichthyosaurier.

Am Beckengürtel (Fig. 371) sind bei den triasischen Formen (Mixosaurus, Cymbospondylus) Pubis und Ischium breite, ansehnliche Platten, von denen ersteres meist das Foramen obturatorium

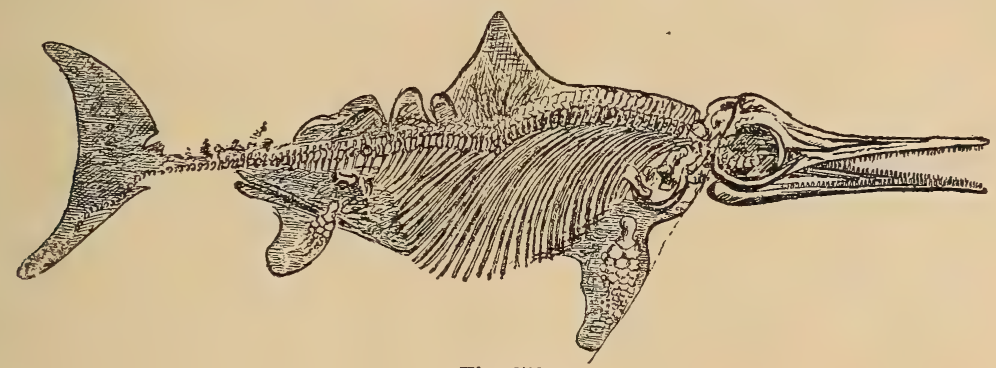

Fig. 372.

Skelett von Ichthyosaurus quadriscissus Quenst; zeigt den Umriß der (etwas beschädigten) Rücken- und Schwanzflosse. Ob. Lias. Holzmaden, Württemberg. (Nach Eb. Fraas.)

aufzeigt, bei den jüngeren Gattungen (Ichthyosaurus) hingegen sind diese beiden Elemente beträchtlich reduziert, und bei einigen Arten, z. B. Ophthalmosaurus, verschmelzen sie völlig miteinander. Das Ilium ist ein mehr oder weniger schlanker Knochen, der, da weder Sacralwirbel noch Sacralrippen existieren, frei im Fleisch steckt. Die Hinterpaddel ist ähnlich wie die vordere gebaut, nur bei den späteren Formen kleiner und schwächer (ausgenommen $J$. longirostris).

Die Ichthyosaurier waren nackthäutige Reptilien" mit hoher, fleischiger Rückenflosse und bedeutend größerer Schwanzflosse (Fig. 372). Die polyongalen Knochenplatten der paarigen Paddeln lagen in sehr muskulöser Haut, welche, distal sich zuspitzend, ziemlich weit über das Skelett vorragte. Der Paddelvorderrand war mit Hornschuppen bekleidet.

Die mehr oder weniger gesellig lebenden Ichthyosaurier finden sich im marinen Mesozoicum, sie treten zuerst im unteren Muschelkalk auf, finden sich im Lias (England, Süddeutschland) in erstaunlicher Fülle und Formenreichtum, wo einzelne Arten eine Länge von über $10 \mathrm{~m}$ erreichen, werden auffallend selten in Dogger, um dann 
gegen Schluß des oberen Jura und im Neocom-Gault erneuten Aufschwung zu nehmen. Die aus späteren cretaceischen oder dem Tertiär beschriebenen Reste sind teils, abgesehen von einem Schnauzenfragment aus der Scaglia (oberer Kreide)der Emilia (Italien), mangelhaft, teils unvollständig beschrieben, teils (Miocän von Malta), höchst problematisch.

Mixosaurus Baur (Fig. 370). Verhältnismäßig kleine (bis ca. $1 \mathrm{~m}$ ) Tiere mit leicht abgebogenem, nicht geknicktem Schwanzende. Schwanzwirbel mit Y-ähnlichen Chevrons. Episternum dreiseitig. Radius und Ulna, Tibia und Fibula verhältnismäßig gestreckt. Vorderextremität beträchtlich größer als die Hinterextremität. Pubis und Ischium plattenförmig. Schädel im Verhältnis zum Körper groß. Augen groß. Zähne mehr oder weniger dichtstehend in Alveolen. Rippen ? einköpfig (bei J. Nordenskiöldi die vorderen Wirbel zweiköpfig). Obere alpine Trias (? Wengener). Südalpen. Mittlere Trias, Spitzbergen. Hierher dürften auch die wenigen Reste aus dem unteren Muschelkalk Süddeutschlands (M. atavus Quenst.) gehören.

Phalarodon Merriam. Zähne in Alveolen. Vordere konisch, hintere zusammengepreßt. Verwandt mit M. atavus. Mittl. Trias. Nevada.

Cymbospondylus Leidy (Fig. 371a), em. Merriam. Große Formen. Schädel über $1 \mathrm{~m}$ lang, Schwanzende nur leicht abgebogen. Vorderextremität kaum größer als die Hinterextremität. Humerus, Radius und Ulna gestreckt. Pubis und Ischium plattenförmig. Die vorderen Rückenrippen zweiköpfig, die hinteren einköpfig. Augen relativ klein. Zähne zahlreich, teilweise in Alveolen. Mittlere Trias. Nevada.

Toretocnemus Merriam. Rückenrippen zweiköpfig. Hinterextremität nahezu so groß wie die Vorderextremität. Radius und Ulna, Tibia und Fibula gestreckt. Obere Trias. Californien.

Merriamia Boulenger. Rückenrippen einköpfig. Coracoid ohne Einschnitt. Hinterextremität kleiner als die vordere. Obere Trias. Californien.

Delphinosaurus Merriam. Obere Trias. Nordamerika.

Shastasaurus Merriam. Nur die vorderen Rückenrippen zweiköpfig. Humerus, Radius und Ulna relativ stark verkürzt. Hinterextremität sehr klein. Obere Trias. Californien.

Pessosaurus Wiman. Mittlere Trias. Spitzbergen.

? Pessopteryx Wiman. Zähne pflasterartig. Wurzel mit Schmelzfalten. Mittlere Trias. Spitzbergen.

Ichthyosaurus König (Fig. 362, 363-369, 372, 371 b). Rumpfrippen zweiköpfig, Schwanzrippen einköpfig. Schwanzende geknickt. Episternum T-förmig. Pubis und Ischium stark reduziert. Radius und Ulna, Tibia und Fibula gewöhnlich sehr klein, in gegenseitigem Kontakt. Augen sehr groß. Zähne zahlreich in einer gemeinsamen tiefen Rinne eingelassen. Obere Trias bis Kreide. Das Hauptlager für Ichthyosaurier ist der Lias, und zwar finden sich die schönsten Skelette im unteren Lias von England (Lyme Regis), im oberen Lias von Yorkshire (England), Calvados und ganz besonders im oberen Lias von Württemberg (Boll, Holzmaden) und Franken (Banz, Altdorf); ferner wird Ichthyosaurus aus oberen weißen Jura von Bayern, Frankreich, England, Südamerika angeführt. Die weiteste Verbreitung erreicht Ichthyosaurus in der Kreide (Neocom, Gault), wo er nicht nur aus Europa, sondern auch aus Indien, von Ceram, von Australien, Neuseeland, Patagonien genannt wird.

Baptanodon Marsh. Zähne in der Zahl reduziert, aber sich auf die ganze Kieferlänge erstreckend. Claviculae miteinander verschmolzen. Humerus distal mit drei Gelenkfacetten, welche mit drei unregelmäßig polygonalen Elementen gelenken. Alle übrigen Knöchelchen der Paddel mehr oder weniger gerundet und durch Knorpel zusammengehalten. Oberer Jura. Nordamerika. 
Opthalmosaurus Seeley. Augen sehr groß. Zähne klein, leicht befestigt und nur auf die vorderen Teile der Kiefer beschränkt. Claviculae durch Sutur miteinander verbunden. Episternum T-förmig. Vorderextremität ähnlich Baptanodon. Hinterextremität klein, Femur mit zwei distalen Gelenkflächen. Das mit dem Ischium verschmolzene Pubis mit Foramen obturat. Oberer Jura bis untere Kreide. England.

\section{Ordnung. Sauropterygia. Owen. $\left.{ }^{1}\right)$}

Der eidechsenähnliche Körper (ausgenommen die Placodontier) mit langem Hals und kurzem Schwanz. Extremitäten fünfuehig, mehr oderweniger paddelartig. Schädel klein mit Foramen parietale und einem Paar großer oberer Schläfenöffnungen. Außere Nasenlöchergetrennt. Quadratum unbeweg lich mit dem Schädel verbunden. Gaumendach mehr oder weniger geschlossen, Pterygoidea sehrgroß, in der Mittesich vereinigend. Zähne zugespitzt, in Alveolen. Wirbel mäßig amphicöl-

1) Andrews C. W., On the Development of the shoulder-girdle of a Plesiosaur (Cryptoclidus) etc. Ann. Magaz. Nat-Hist. Ser. 6. Vol. XV. 1895, ferner ibid. Uber Muraenosaurus. Vol. XVI. On the structure of the skull in Peloneustes Vol. XVI, ferner Geol. Magaz. Dec. 4. Vol. 3. 1896. On the struct. of a skull of a Pliosaur. Quart. Journ. Geol. Soc. Lond. 53. 1897. On the struct. of the Plesiosaurian skull ibid. 52. 1896. On some new Plesiosauria etc. Ann. Magaz. Ser. 8 Vol. 31909. A descriptive Catalogue of the marine Reptiles of the Oxford Clay. 1. c. British Museum 1910. - Boulenger G. A., On a Nothosaurian Reptile etc. Transact. Zool. Soc. London Vol. XIV. 1896-98. - Dames W., Die Plesiosaurier der süddeutschen Liasformation. Abhandl. d. k. pr. Akad. d. Wissensch. Berlin 1895. - Deeke W., Úber Lariosaurus und einige andere Saurier der lombardischen Trias. Zeitschr. d. deutsch. geolog. Ges. 1886 Bd. XXXVIII S. 170. - Saurierreste aus den QuiriquinaSchichten. Neues Jahrb. Beilageband. X. 1896. - Fraas E., Die schwäbischen Trias-Saurier etc. Stuttgart 1896. Schweizerbart. Plesiosaurier aus dem ob. Lias v. Holzmaden. Palaeontographica 57. Bd. 1910. - Frech. (Philippi. Volz). Lethaea geognostica. Mesozoicum. Stuttgart 1903-08. S. 15 etc. Dort Literatur über Nothosauridae. - Fürbringer M., Zur vergl. Anatomie des Brustschulterapparates etc. Jenaische Zeitschr. f. Naturwissensch. 34. 1900. Jena. - Hawkins Th., Memoirs on Ichthyosauri and Plesiosauri. London 1834. - Hulke T. W., Proceed. Roy. Soc. 1892. vol. 51. - Jaccard F., Sur le Peloneustes philarchus etc. Bull. Soc. Vaud. Sc. Nat. Vol. 43. 1907. - Jaekel O., Uber den Schädelbau der Nothosauriden. Sitzungsber. d. Gesellsch. naturforsch. Freunde. Berlin 1905-06. - Knight W. C., Some new Jurassic Vertebrates from Wyoming. Americ. Journ. Science. Vol. 5. 1898. - Koken $E$., Beiträge zur Kenntnis der Gattung Nothosaurus. Zeitschr. d. deutsch. geol. Gesellsch. 45. Bd. 1893. Die Dinosaurier, Sauropterygier und Crocodiliden des norddeutschen Wealden. Pal. Abhandl. Bd. III. 1887 u. Bd. VII. 1896 (Fischer, Jena). Lydekker R., Catalogue fossil Rept. ete. l. c. P. II. - Meyer H. v., Zur Fauna der Vorwelt. Die Saurier des Muschelkalks. Frankfurt 1847-55. - Owen Rich., Monograph of the Reptilia of the liassic formations. Sauropterygia. Palaeontographical Society und Fossil Reptilia of the Cretacoous formations. Pal. Soc. p. 58-68 und Supplement Nr. IV. - Riabinin A., 2 Plesios. aus der Jura- u. Kreide-Abl. Rußlands. Mém. Com. Geol. N. Ser. 41-50. 1908-09. - Seeley H. G., Ann. Mag. nat. hist. 3 ser. XV. p. 49 und 232. - Quarterly-Journal geol. Soc. London Vol. XXX, XXXII. XXXIII. u. XXXVIII und (Shouldergirdle) Proceed. Royal. Soc. 1892 vol. 54 und 1893 vol. 54. - Sollas W. (and Whidborne) On a new species of Plesiosaurus etc. Quart-Journ. geol. Soc. London 37. 1881. - Volz W., Proneusticosaurus, eine neue Sauropterygiergattung etc. Palaeontographica 49. Bd. 1902. - Watson D., A prelim. Note on two new genera of upper Liassic Plesiosaurs. Mem. Proc. Manchester Lit. Philos. Soc. Vol. 54. P. I u. III 1909-10. - Williston S. W., North American Plesiosaurs. P. I. Field Columb. Mus. Publ. 73. Geol. Ser. Vol. II. Nr. 1, Chicago 1903. N. A. Plesiosaurs. Elasmosaurus etc. Americ. Journ. Science. Vol. XXI. 1906. N. A. Plesiosaurus: Trinacromerum. Journ. of Geology Vol. XVI. 1908. - Woodward A. S., Vertebrate Palaeontology etc. Cambridge 1898. 
platycöl. Halsrippen nur mit den Wirbelkörpern, nie mit den oberen Bogen gelenkend. Rückenrippen einköpfig. Bauchrippen zwischen den mächtigen Extremitätengürteln sehr kräftig entwickelt. Sacrum mitzweibis sechs Wirbeln. Brustgürtel uhne knöchernes Sternum. Nackthäutig. Trias. - Obere Kreide.

Die geologische Verbreitung der Sauropterygier erstreckt sich über Trias, Jura und Kreide. Aus dem Vorkommen ihrer Überreste in marinen Schichten unà aus der ganzen Organisation läßt sich schließen, daß sie zumeist auf den Aufenthalt im Meere angewiesen waren. Die Sauropterygier s. str. zerfallen in 1. Nothosauridae und 2. Plesiosauridae, zu denen die in ihrem Skelett noch unvollständig bekannten Placodontidae kommen dürften. Die Nothosauridae gehören ausschließlich der Trias an; einige von ihnen scheinen, wie der zierliche Neusticosaurus, in der Hauptsache Landbewohner gewesen zu sein, andere, deren Extremitäten, wie z. B. bei Lariosaurus, nicht nur zum Schwimmen dienlich waren, sondern auch die Möglichkeit der Fortbewegung auf dem Lande gestatteten, dürften Bewohner des Strandes oder der Küste darstellen, während sich manche (Nothosaurus) schon bereits mehr dem Wasserleben angepaßt zeigen. Das letztere ist in weit höherem Maße bei den Plesiosauridae der Fall, ihre Extremitäten sind als kräftige Ruderpaddeln ausgebildet und dürften kaum mehr zu einer Bewegung auf dem Lande gedient haben. Die Reste der Sauropterygier sind von der oberen Trias an bis zur oberen Kreide aus allen Weltteilen bekannt geworden. Die mehr langlebigen Plesiosaurier und die nur auf die Trias beschränkten Nothosaurier sind einander nahe verwandt, in mancher Beziehung, wie z. B. im Bau der Schädelunterseite, sind aber die letzteren vollkommener organisiert als die Plesiosaurier. Aller Wahrscheinlichkeit nach lassen sich beide Familien auf eine gemeinsame Stammform zurückführen.

Die hier als Anhang angeführten Mesosauridae sind infolge ihres ungenügend bekannten Schädels im System noch unsicher, der Bau der Wirbel und der Extremitätengürtel zeigt indessen mit gewissen Nothosauridae (Proneusticosaurus) viele gemeinsame Merkmale.

\section{Familie. Nothosauridae.}

Extremitäten noch mit den Merkmalen von Gehfüßen mit verlängertem Radius und Ulna, Tibia und Fibula; fünfzehig. Brustgürtel mit großen Claviculae. Coracoidea mäßig groß, nicht mit den Scapulae bzw. dem Episternum verbunden. Trias.

Nothosaurus Münster (Opeosaurus H. v. M.) (Fig. 373, 374, 375, $376,377)$. Schädel langgestreckt, vorne etwas verschmälert (bei N. mirabilis bis $35 \mathrm{~cm}$, bei anderen Formen $65 \mathrm{~cm}$ bis $1 \mathrm{~m}$ lang), niedrig gebaut, mit einem Paar großer (oberer) Schläfenlöcher, die durch das schmale, unpaare vom Scheitelloch durchbohrte Parietale getrennt werden. Von den Schläfenlöchern durch Postorbitale und Postfrontale getrennt liegen etwas vor der Mitte die relativ kleinen, ovalen, durch das gleichfalls unpaare Frontale geschiedenen Augen (ohne Scleroticaring) und nicht weit vor denselben die Nasenlöcher. Die Nasalia sind paarig entwickelt, die beiden Prämaxillaria bilden die etwas verlängerte Schnauze. Dem Maxillare fällt mit dem kleinen Präfrontale die vordere Begrenzung der Augen und mit 
dem sich nach oben und rückwärts sich anschließenden Jugale auch die untere Begrenzung zu; nach rückwärts ist es in einen Fortsatz, den ? Rest des unteren Schläfenbogens, ausgezogen. Die den Schläfenbogen nach unten abschließende Knochenspange wird vom Postorbitale und einem Fortsatz des Squamosum gebildet, welch letzteres auch die äußere hintere Ecke des Schädels bildet und nach abwärts in das die Gelenkung mit dem Unterkiefer vermittelnde Quadratum übergeht. Auf der Unterseite erreichen Pterygoidea und Palatina eine stattliche Größe und bilden mit den kleinen Transversa und den beiden Vomera, die auch verschmelzen können, ein geschlossenes Gaumendach, das weit vorne von den getrennten Choanen

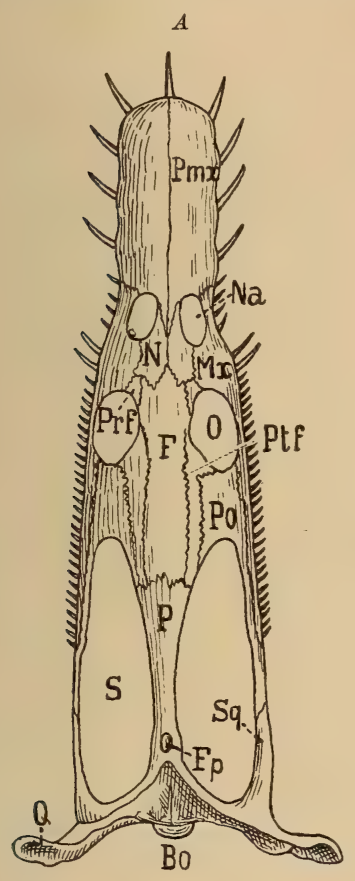

Fig. 373

Nothosaurus mirabilis Münster. ob. Muschelkalk. Bayreuth. (Nach Qu enstedtu. H. v. Meyer ergänzt). $A$ von oben. $B$ von der Seite. $P m x$ Prämaxillare, $M x$ Maxillare, $N$ Nasale, $F$ Frontale, $P$ Parietale, $\operatorname{Prf}$ Präfrontale, Ptf Postfrontale, Po Postorbitale, Sq Squamosum, Bo Basioccipitale, $P O$ P terygoid, TrTransversum, $P a$ Palatinum, $V$ Vomer, $N a$ Nasenlöcher, OlAugen, S Schläfenlöcher, Ch Choanen, $F p$ Foramen pariefale.

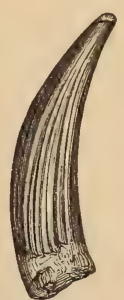

Fig. 374

Zahn von Nothosaurus mirabilis

H. $\nabla$. Meyer. Muschelkalk. Bayreuth. (Nat. Gr.)
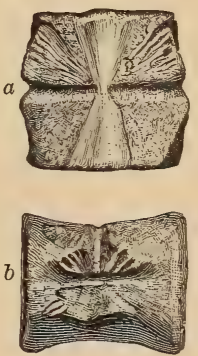

Fig. 375 .

Körper eines Halswirbels von Nothosaurus. (nat. Gr.)

$b$ von der Seite,

$a$ von oben.

Muschelkalk. Bayreuth.

durchbrochen wird. Die Kiefer sind mit konischen, etwas gekrümmten und gerieften, thecodonten Zähnen versehen, wovon sich die am vorderen. Teile der Schnauze befindlichen und einige des Maxillare durch ansehnliche Größe auszeichnen.

Die platycölen, eingeschnürten Zentra der Wirbel sind mit den Bögen, die relativ hohe Dornfortsätze tragen, durch Naht verbunden, sie trennen sich leicht von denselben, wobei auf der Dorsalseite der Zentra eine kreuzförmige Zeichnung entsteht (Fig. 375). Der lange Hals enthält ca. 22 Wirbel, die mit Ausnahme des Atlas und Epistropheus kurze, hakenförmige, zweiköpfige, nur mit dem Wirbelkörper gelenkende Rippen tragen, an den (20-? 30) Rückenwirbeln gehen die einköpfigen Rippen von kräftigen Diapophysen der oberen Bogen aus; an den Schwanzwirbeln, die außerdem ventral zwei Höcker zur Gelenkung mit den unteren Bogen besitzen, rücken 
die einfachen Querfortsätze wieder auf das Zentrum. Die Zahl der Beckenwirbel ist unsicher (? 2-3).

Die kräftigen Bauchrippen bestehen aus einem winklig gebogenen Mittelstück, dessen Schenkel nach hinten spitz auslaufen, und je einem zwischen letztere sich einschaltenden Seitenstück. Im Brustgürtel schließen die inneren Enden (Fig. 377) der starken Claviculae das kleine ovale Episternum ein und heften sich mittels Naht an den stämmigen ventralen Ab-

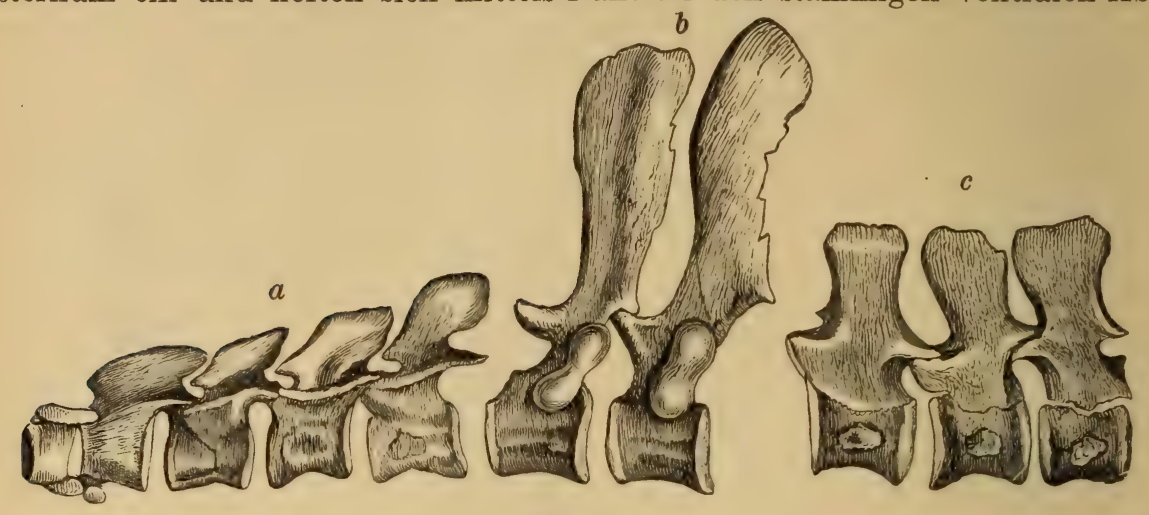

Fig. 376 .

Nothosaurus mirabilis Mst. Muschelkalk. Bayreuth. a die vier vordersten Halswirbel, $b$ zwei Rückenwirbel, $c$ drei Schwanzwirbel. 1/3 nat. Gr. (Nach H. v. Meyer.)

schnitt der Scapula, von deren verdicktem Gelenkende ein aufwärts und rückwärts gerichteter Dorsalfortsatz ausgeht. Die großen abgeplatteten Coracoidea senden am Vorderrand einen breiten abgestutzten Fortsatz aus. Zwischen den Coracoidea und dem Episternum befindet sich ein großer

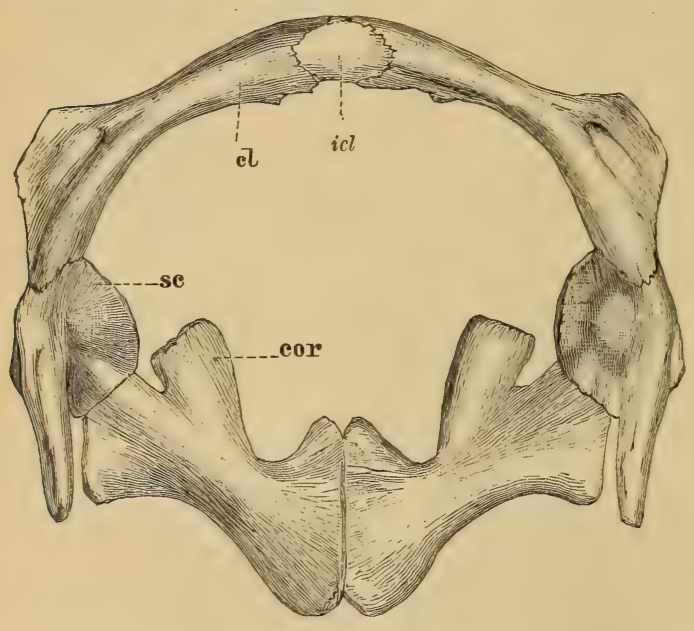

Fig. 377.

Brustgürtel von Nothosaurus mirabilis Mstr. Dorsalansicht Muschelkalk. Bayreuth. 1/4 nat. Gr. cl Episternum, cl Schlüsselbein (Clavicula), sc Schulterblatt (Scapula), cor Fortsatz des Coracoides. leerer Raum, welcher zu Lebzeiten des Tieres vielleicht von einem knorpeligen Procoracoid ausgefüllt war. Der gekrümmte, ziemlich lange Humerus ist von dem Foramen entepicondyloideum durchbohrt. Die beiden Vorderarmknochen sind ziemlich lang und schlank, die 4-5 Metacarpalia längliche, in der Mitte eingeschnürte Knochen. Zahl der Carpalia und Phalangen nicht genauer bekannt. Die ebenso wie der Schultergürtel sehr kräftigen, aber gegenseitig weniger fest verbundenen Elemente des Beckengürtels finden sich meist nicht mehr im Zusammenhang sondern isoliert, sie sind proximal ziemlich dicke, distal mehr oder weniger verbreiterte Elemente; das Pubis besitzt neben der proximalen Gelenkfläche am Vorderrand einen Ausschnitt oder ein Foramen. Der Femur ist länger und schlanker als der Humerus, fast gerade, an beiden Enden mäßig verdiekt, mit gewölbten Endflächen. Von sonstigen Hinterfußknochen ist wenig bekannt. 
Die Gattung Nothosaurus ist auf die Trias beschränkt, die ältesten seltenen Reste finden sich im Buntsandstein von Sulzbad in den Vogesen, sie wird etwas häufiger im unteren Muschelkalk (subg. Eurysaurus Frech) und erreicht im oberen Muschelkalk und der Lettenkohle ihre Hauptverbreitung. In der Hauptsache zeigt sie sich in der germanischen Trias. Die in gleichalterigen Ablagerungen der Alpen gefundenen Reste sind für eine exakte Identifizierung zu unvollständig. $N$. mirabilis Mstr. war mindestens $3 \mathrm{~m}$ lang.

Cymatosaurus v. Fritsch. Unterer Muschelkalk. Schlesien. Thüringen.

Lamprosaurus. Conchiosaurus H. v. M. Muschelkalk.

Pistosaurus H. v. Meyer. Nur der Schädel mit der spitz zulaufenden, von den Prämaxillaria gebildeten Schnauze bekannt. Nasenlöcher klein,
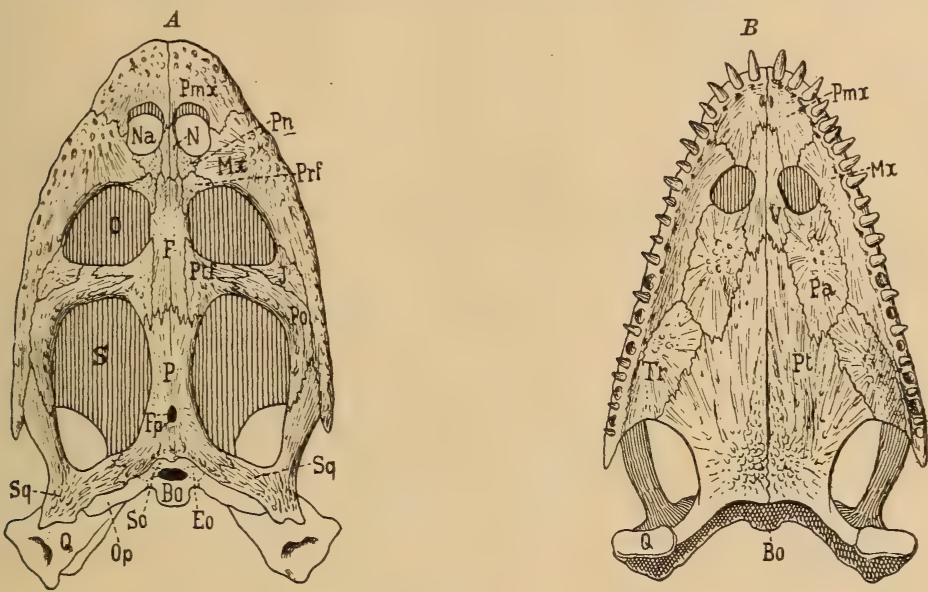

Fig. 378 .

Simosaurus Gaillardoti H. v. M. Ob. Muschelkalk. Crailsheim. A Schädel von oben. $B$ von unten. $N a$ Nasenöffnungen, $O$ Augen, $S$ Schläfenlöcher, $N$ Nasale, $P n$ Postnasale, $P m x$ Prämaxillare, $M x$ Maxillare, $F$ Frontale, $P$ Parietale mit Foram. par., Fp. Prf. Prae $=P t f$ Postfrontale, $J$ Jugale, Po Postorbitale, $S q$ Squamosum, Q Quadratum, Bo Basioccipitale, Eo Exoccipitale laterale, So Supraoccipitale, $O p$ Opisthoticum, $V$ Vomer, $P a$ Palatin, $P t$ Pterygoid, $T r$ Transversum. 1/6 nat. Gr. (Nach Jaekel.)

von Maxillare und Prämaxillare eingeschlossen. Nasalia klein, nach hinten geschoben. Gaumendach mit einem unpaaren Foramen zwischen den Prämaxillaria und Vomera. Oberer Muschelkalk. Bayreuth.

Simosaurus H. v. Meyer. (Fig. 378.) Schädel breit, niedrig, mit gerundeter Schnauze; Zähne kräftig, stumpfkonisch gerieft. Transversa sehr groß. Oberer Muschelkalk und Lettenkohle.

Partanosaurus, Microleptosaurus Skuphos. Alpine Trias (Partnachschichten) Vorarlberg.

Anarosaurus Dames. Schläfenlöcher sehr klein. Ca. 24 Halswirbel, ca. 26 Rückenwirbel. Mindestens 3 Sacralwirbel. Muschelkalk. Provinz Sachsen.

Lariosaurus Cur. (Macromerosaurus Curioni) (Fig. 379). Kleine, 20 bis $90 \mathrm{~cm}$ lange, eidechsenähnliche Saurier mit langem (ca. 20-21 Wirbel) Hals, gedrungenem Rumpf (ca. 24-26 Wirbel) und kräftigen fünfzehigen Gehfüßen. 5 Sacralwirbel, ca. 40 Schwanzwirbel. Halsrippen kurz, beilförmig, zweiköpfig. Rumpfrippen einköpfig, stark gebogen. Die Dornfortsätze niedrig. Bauchrippen aus drei Elementen zusammengesetzt. Carpus in der proximalen Reihe mit zwei, in der distalen mit fünf kleinen Knöchelchen. Fünf längliche Metacarpalia. Phalangen kurz, eidechsenähnlich. Hinterextremität schlank, länger als die Vorderextremität. In der proximalen Reihe des Tarsus zwei querverlängerte, scheibenförmige Knochen besonders 
groß. Macromerosaurus stellt offenbar die Jugendformen von Lariosaurus dar. Die Unterseite eines solchen Exemplars zeigt das Gaumendach noch nicht in dem Maße geschlossen wie bei Nothosaurus und läßt die inneren Augenöffnungen noch unbedeckt. Lariosaurus dürfte deshalb und auf Grund der noch sehr eidechsenähnlichen Extremitäten einen ursprünglichen Vertreter der Nothosauriden darstellen. Alpine Trias (?Wengener). Lombardei.

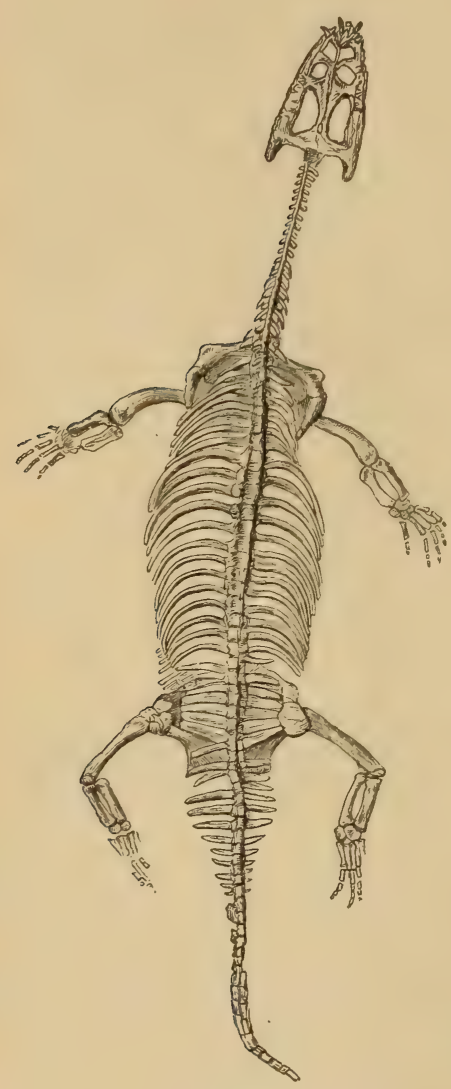

Fig. 379.

Lariosaurus Balsami Curioni. ? Wengener Schichten. Perledo am Comersee. 1/8 nat. Gr.

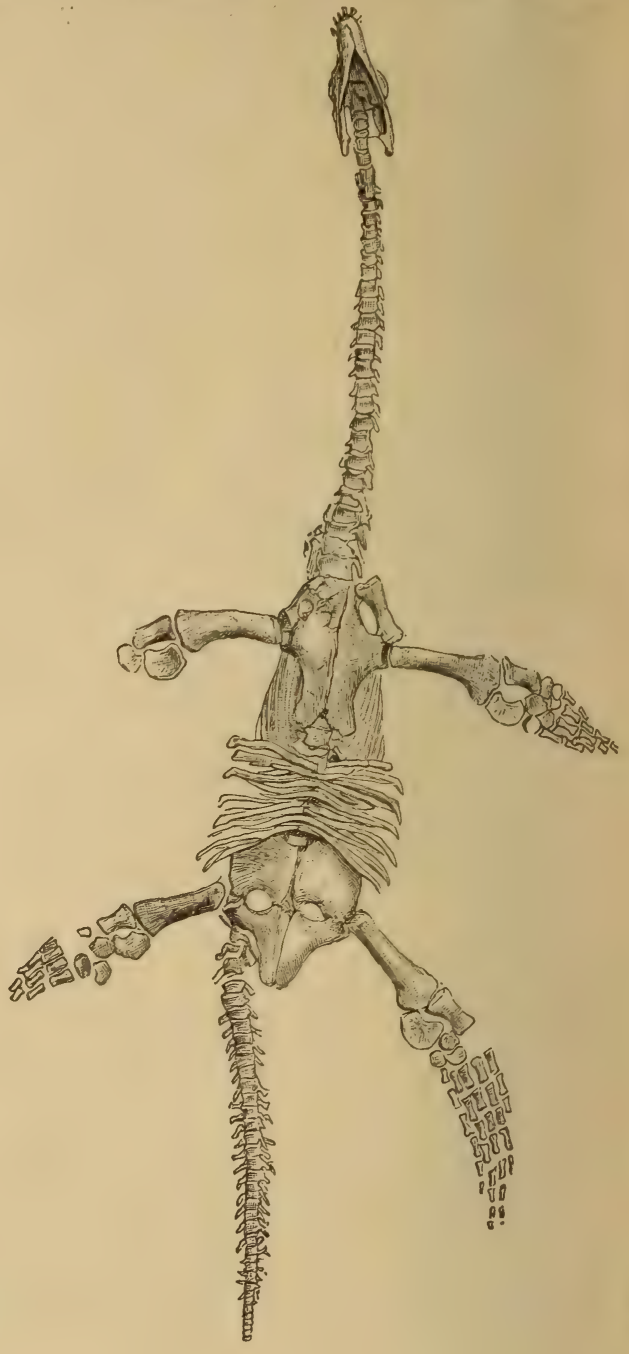

Fig. 380.

Plesiosaurus Hawkinsi Owen. Nahezu vollständiges Skelett (von 5 Fuß 8 Zoll Länge) aus dem unteren Lias von Lyme Regis. Dorset. (Nach Hawkins.)

Proneusticosaurus Volz. Die platycölen Wirbel tönnchenförmig, mit gedrungenem oberen Bogen, niederem Dornfortsatz und kurzer Diapophyse. Wahrscheinlich sechs Sacralwirbel. Bauchrippen aus einem Mittelstück und zwei Paar Seitenstücken bestehend. Extremitäten fünfzehig, dem Wasserleben angepaßt. Unterer Muschelkalk. Schlesien.

Dactylosaurus Gürich, Doliovertebra v. Huene. Unterer Muschelkalk.

Neusticosaurus Seeley (Pachypleura Curioni). Eidechsenartig, klein, $16-35 \mathrm{~cm}$ groß, mit kurzem, 16 Wirbel zählendem Hals, 23 prä- 
sacralen und 3 Sacralwirbeln. Lettenkohle. Schwaben. Alpine Trias (? Wengener Schichten). Lombardei.

\section{Familie. Plesiosauridae.}

Extremitäten paddelartig. Vorderarm und Vorderfußknochen stark verkürzt und die fünf Finger durch überzählige Plättchen vermehrt. Claviculae und Episternum auf Kosten der Scapulae reduziert, die eine gegenseitige Verbindung bzw. eine Vereinigung mit den vorderen Fortsätzen der großen plattenförmigen, in der Symphyse zusammenstoßenden Coracoidea erstreben, welch letztere außerdem auch noch mit den Claviculae und Episternum sich vereinigen können. Trias bis Kreide.

Plesiosaurus Conybeare (Fig. 380 u. 381). Schädel klein mit kurzer Schnauze. Augen rundlich, ungefähr in der Mitte der Schädellänge. Die großen Schläfenlöcher unregelmäßig vierseitig. Äußere Nasenlöcher klein, dicht vor den Augen. Parietalia gering entwickelt, kammartig aneinander gefügt mit kleinem Foramen parietale. Squamosum sehr groß, unten von dem kleinen aber kräftigen Quadratum begrenzt, nach vorne mit dem Postorbitale die untere Begrenzung des Schläfenbogens bildend. Gaumen nicht vollständig geschlossen (im Gegensatz zu Nothosaurus) sondern einzelne

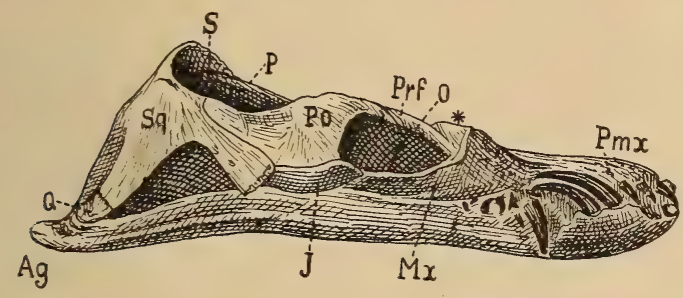

Fig. 381.

Plesiosaurus macrocephalus, Buckland. Unt. Lias $\nabla$. Lyme Regis. Schädel von der Seite. Nach Andrews u. A. S. Woodward. $S$ Schläfenloch, $O$ Augenöffnung, * Lage der äußeren Nasenlöcher, $\$ q$ Squamosum, $Q$ Quadratum, $P$ Parietale, Po Postorbitale, $J$ Jugale, Prf Präfrontale, M $x$ Maxillare, Pmx Prämaxillare, Ag Angulare. $1 / 6$ nat. Gr.

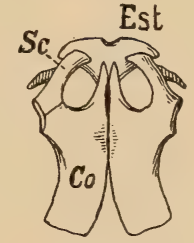

Fig. 382 .

Brustgürtel von Plesiosaurus Hawkinsi Owen. Unt. Lias von Dorsetshire. Von der Ventralseite nach L y dekker u. Für bringer. Verkl. Est. Mittelstücke (Episternum Claviculae) Sc Scapula, Co Coracoid. Stark verkleinert.

Lücken freilassend. Unterkiefer in der kurzen Symphyse fest verschmolzen. Zähne zugespitzt, konisch, schlank, fein gestreift bis tief gefurcht, in tiefen Alveolen; oben und unten in einer Reihe, vorne meist einige größere.

$\mathrm{Hals}$ auffallend lang, zuweilen die Länge der ganzen übrigen Wirbelsäule erreichend, je nach den Arten aus ca. 30-40 Wirbeln zusammen. gesetzt. Wirbelkörper kurz, flach platycöl, seitlich eingeschnürt. Die oberen Bogen verhalten sich zu ihnen wie bei Nothosaurus. Zentrum des Atlas mit stumpfer dicker, Epistropheus mit etwas größerer Rippe, die übrigen Centra der Halswirbel mit zuerst beilförmigen, später gestreckten, zweiköpfigen Rippen. Bei den vorderen Rückenwirbeln (Brustwirbel) die Querfortsätze auf den Zentren allmählich zum oberen Bogen rückend. Hintere Rückenwirbel mit einköpfigen, vom oberen Bogen ausgehenden Rippen. Die zwei Sacralwirbel mit kürzeren Querfortsätzen und distal verbreiterten Rippen. Der relativ kurze gedrungene Schwanz kann bis über 40 Wirbel erreichen, die mit Ausnahme der hinteren, kurze, vom Zentrum ausgehende einköpfige Rippen und ventral nicht verschmelzende Hämapophysen tragen. Bauchrippen sehr kräftig aus einem Mittelstück und jederseits aus ? 1, 2-5 Seitenstücken bestehend.

Am Brustgürtel (Fig. 382) zeichnen sich die Coracoidea durch ansehnliche Größe aus; sie sind länger als breit, tafelförmig und stoßen in der Mittellinie geradlinig zusammen. Nach vorne sind sie in einen Fortsatz 
ausgezogen, der mit dem Mittelstück bezw. dem vorderen Schenkel der Scapula in Verbindung tritt. Ein eigentliches Brustbein fehlt, dagegen bildet ein einheitliches oder aus drei Elementen (ein mittleres und zwei seitliche) bestehendes Mittelstück, das dem Episternum und dem Claviculae entspricht, den vorderen Abschluß des Brustgürtels. Die anfänglich schwache, von oben und hinten, nach unten und vorne verlaufende Scapula teilt sich in einen hinteren mit dem Coracoid sich fest verbindenden Schenkel und bildet die Gelenkung für den Humerus, während ihr vorderer, medial gerichteter Schenkel (? Procoracoid) mit dem Mittelstück oder (bei Thaumatosaurus) mit dem vorderen Fortsatz des Coracoids sich vereinigt.

Humerus stämmig, distal verbreitert und abgeplattet mit zwei winklig zusammenstoßenden Facetten für die kurze plattige Ulna und dem ebensolchen Radius. Die 7-10 Carpalia in zwei Reihen, sie tragen fünf schlanke, in der Mitte verdünnte Metacarpalia, die sich von den darauf folgenden, in ihrer Zahl sehr unkonstanten Phalangen wenig unterscheiden. Der dritte und vierte Finger ist stets der längste. Die Hinterfüße gleichen in jeder Hinsicht den Vorderfüßen. Wahrscheinlich waren die Extremitäten mit einer knorpeligen Schwimmhaut umgeben. Am Becken das plattenförmige Pubis und das in der Mitte eingeschnürte Ischium ein Foramen obturatorium umschließend und in der Symphyse vollständig oder größtenteils verwachsen. Ilium meist von der Bildung des Acetabulum femoris ausgeschlossen.

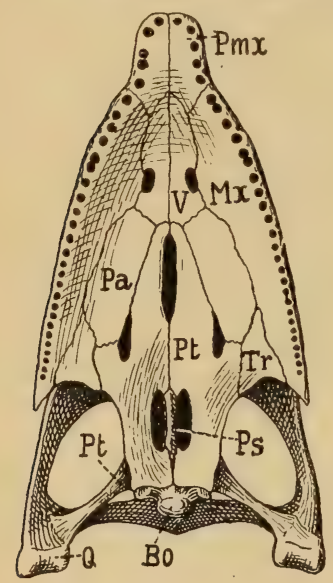

Fig. 383.

Thaumatosaurus victor E. Fraas. Ob. Lias v. Holzmaden. Schädel von unten. Bo Basioccipitale, $P s$ Rostrum, Q Quadratum, Pt Pterygoid, $T r$ Transversum, $P a$ Palatinum, $V$ Vomer, $M x$ Maxillare, $P$ mx Prämaxillare, Ch Choanen. $1 / 6$ nat. Gr. Nach E. Fraas.

Die Gattung Plesiosaurus läßt sich bis in das Rhät, vielleicht schon in den Muschelkalk zurückverfolgen und findet ihre Hauptverbreitung im Lias. Im unteren Lias von Lyme Regis in England kommen prachtvoll erhaltene Skelette von $P$. dolichodeirus Conyb. ( $3 \mathrm{~m}$ lang) und $P$. Congbeari Sollas (5 m lang), vor. Auch im oberen Lias von Yorkshire, von Banz in Franken und Holzmaden in Württemberg finden sich Reste. Von letzterer Lokalität befindet sich im Berliner $\mathrm{Mu}$ seum für Naturkunde und im Naturalienkabinett in Stuttgart je ein ganzes Skelett von P. Guilelmi imperatoris Dames. Auch aus der unteren Kreide werden von verschiedenen Punkten Europas Plesiosaurus genannt. Es handelt sich hier fast durchwegs um isolierte Wirbel, die teilweise $\mathrm{zu}$ anderen Gattungen der Familie gehören, teilweise aber auch wie $P$. Degenhardti Koken (Wealden) sich mit Plesiosaurus identifizieren lassen.

Thaumatosaurus H. v. Meyer em. Lydekker (Rhomaleosaurus Seeley) (Fig. 383). Sehr nahe verwandt mit Plesiosaurus, aber Schädel relativ sehr groß, Unterkiefersymphyse kurz, Hals verhältnis. mäßig kurz (25-27 Wirbel). Unterer Lias bis Oberer Jura. Europa, Indien.

Eretmosaurus Seeley. Hinterer und vorderer Schenkel der Scapula mit dem Coracoid fest verwachsen. Unterer Lias. England.

Colymbosaurus Seeley. Oberer Jura von Frankreich und England.

Muraenosaurus Seeley. Schädel klein, kurz und breit. Der dritte, vierte und fünfte Maxillarzahn größer. Untersymphyse kurz. Ca. 44 Halswirbel. Episternum wohl entwickelt. Claviculae reduziert. Vorderextremität etwas größer als die hintere. Unterer oberer Jura. England.

Cryptocleidus Seeley. Ähnlich Plesiosaurus aber durchaus nur mit einköpfigen Rippen. Ca. 32 Halswirbel und ca. 25 Rückenwirbel. ? 3-4 Sacral- 
wirbel. Bauchrippen aus einem mittleren und je drei seitlichen Stücken zusammengesetzt. Am Brustgürtel das Mittelstück aus zwei kleinen dreiseitigen (Claviculae) und zuweilen einem rudimentären Episternum bestehend, an ausgewachsenen Individuen der in der Jugend noch getrennte vordere Schenkel der Scapula den vorderen Fortsatz des Coracoids erreichend. Oxford. (Unterer oberer Jura.) England.

Tricleidus Andrews. Schädel kurz, breit. Zähne lang, schlank, scharf zugespitzt, 5 am Prämaxillare, 15 am Maxillare, am Maxillare größere, 26 Präsacralwirbel mit konkaven. Zentren. Am Schultergürtel Mittelstück aus großem Episternum und ebensolchen Claviculae bestehend. Humerus außer mit Radius und Ulna noch mit einem Pisiforme und einem kleinen akzessorischen Knochen gelenkend. Unterer oberer Jura. England.

Picrocleidus Andrews. Über 39 Halswirbel mit einköpfigen Rippen. Schultergürtel mit kleinem Episternum und dünnen blattartigen Claviculae. Humerus nur mit Radius und Ulna gelenkend. Unterer oberer Jura. England.

Microcleidus Watson. Schädel klein, Hals sehr lang aus 40 Wirbeln mit zweiköpfigen Rippen. 32 Rückenwirbel mit sehr hohen Dornfortsätzen. Brustgürtel ähnlich Cryptocleidus, ohne Episternum mit zwei kleinen Claviculae. Drei Sacralwirbel. Radius und Ulna lang. Oberer Lias. England.

\section{Stenaro-}

saurus Watson. Oberer Lias. England.

Cimolia. saurus, Oligosi. mus, Piratosaurus, Brimosaurus Leidy, Piptomerus, Orophosaurus, Embaphias, Taphrosaurus, Uronautes Cope, Manisaurus Hector, sind meist nur auf ungenügende Reste hin aufgestellt und finden sich

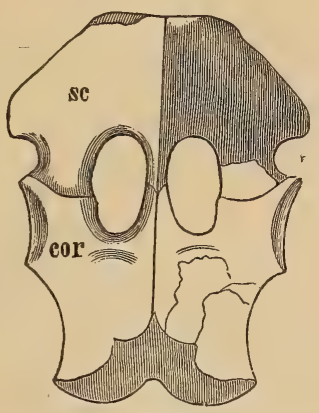

Fig. 389.

Brustgürtel von Elasmosaurus platyurus Cope. Kreide von Kansas. cor Coracoid, sc Scapula. Die schattierten Teile sind nicht erhalten. Stark verkleinert. (Nach Cope.)

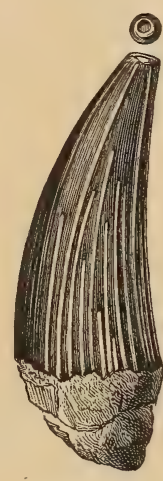

Fig. 385.

Zahn von Polyptychodon interruptus Owen. Grünsand. Kelheim. Nat. Gr.

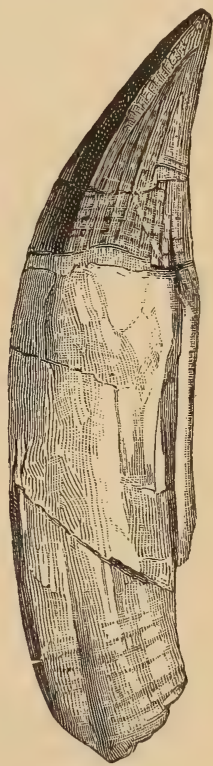

Fig. 386 .

Zahn von Pliosaurus grandis Owen. $1 / 4$ nat. Gr. Ob. Jura. Kimmeridge.Dorset. (Nach R. Owen.) selten in der unteren, meist in der mittleren und oberen Kreide von Europa, Nord- und Südamerika, Australien und Neuseeland.

Pliosaurus Owen (1schyrodon H. v. M., Peloneustes Lydd., Liopleurodon Sauvage, Spondylosaurus Fischer) (Fig. 386). Saurier von riesenhaften Dimensionen mit verhältnismäßig großem niedrigem Kopf (bis 1,3 m lang), kurzem Hals und sehr langer Symphyse der Unterkiefer. Auf den Kiefern jederseits eine Reihe (bis 35) von mächtigen, in der oberen Hälfte häufig dreikantigen, bis $25 \mathrm{~cm}$ langen, in Alveolen stehenden Zähnen. Die ca. 20 kurzen, scheibenförmigen Wirbelkörper dès Halses mit zwei Gelenkfacetten. Extremitätengürtel ähnlich Plesiosaurus. Lias bis Oberster Jura. England, Frankreich, Schweiz, Bayern (Kelheim), Rußland, Indien.

Simolestes Andrews. Schädel breit, kurzschnauzig, Zähne ungekielt, ca. 26 auf jeder Seite; 5 oder 6 vordere auf der ausgedehnten Symphyse 
vergrößert. Hals aus 20 Wirbeln mit zweiköpfigen Rippen. Unterer oberer Jura. England.

Megalneusaurus Knight. Vorderextremität über $2 \mathrm{~m}$ lang, Radius und Ulna sowie die erste Reihe des Carpus polygonale miteinander gelenkende Platten. Oberer Jura Wyoming.

Elasmosaurus Cope (Fig. 384). Ein Skelett im Museum von Philadelphia mißt über $13 \mathrm{~m}$ Länge. Unterkiefersymphyse kurz. Die oberen Bögen der Wirbel sind mit dem Zentrum verschmolzen, die 60-76 Halswirbel länger als hoch mit kurzen, einköpfigen Rippen. Die Chevrons gelenken mit den Schwanzwirbeln. Schultergürtel ähnlich Cryptocleidus. Obere Kreide. Nordamerika.

Trinacromerum Cragin (Dolichorhynchus Williston). Kopf groß, langschnauzig. Augen mit Scleroticaring. Symphyse der Unterkiefer sehr lang. Zähne klein, zahlreich. Vomer sehr groß. Innere Nasenlöcher klein, von Vomer und Palatin eingeschlossen. Der 19 bis ca. 23 Wirbel zählende Hals nur wenig länger als der Kopf mit einköpfigen Rippen, ca. 30 Rückenwirbel. 3 Sacralwirbel. Episternum und Clavicula selbständig, nicht miteinander verschmolzen, die Clavicula mit dem vorderen Fortsatz des Coracoids gelenkend. Obere Kreide von Kansas.

Polycotylus Cope. Nahe verwandt, wenn nicht identisch mit Trinacromerum. Kreide. Nordamerika.

Brachauchenius Willist. Über $1 \mathrm{~m}$ großer relativ breiter Schädel mit kurzer Unterkiefersymphyse. Pterygoid mit kräftiger Kante. Hals sehr kurz (13 Wirbel) mit einköpfigen Rippen. Kreide. Nordamerika.

Polyptychodon Owen (Fig. 385). Unvollständig bekannt. Zähne mit zahlreichen Schmelzleisten, wovon nur die stärksten die Spitze erreichen. Mittlere und Obere Kreide. Europa. ? Mexico.

\section{Familie. Placodontidae. ${ }^{\text {) }}$}

Schädel mehr oder weniger niedrig, mit Foramen parietale. Ein Paar von Schläfenlöchern groß, nach oben gerichtet. Augen- und die getrennten Nasenöffnungen seitlich. Prämaxillare und Symphyse des Unterkiefers mit prothecodonten, zylindrisch-konischen Schneidezähnen oder zahnlos. Palatinum mit großen, pflasterartigen Zähnen. Maxillare mit einer Reihe acrodonter rundlicher Backenzähne, Unterkiefer rückwärts mit großen Pflasterzähnen und ansehnlichem Processus coronoideus. Wirbel flach amphicöl. Gelenkenden der mäßig gestreckten Extremitäten nicht verknöchert. Trias. Mitteleuropa.

Da das Skelett der sehr spezialisierten Placodontier noch recht unvollständig bekannt ist, läßt sich ihre Stellung im System nicht völlig sicher präzisieren. Der Bau der Schädelunterseite sowie die platycölen Wirbel scheinen indessen für ihre Verwandtschaft $\mathrm{zu}$ den Sauropterygiern zu sprechen.

Die Placodonten zeichnen sich in erster Linie durch ihre auffallende Bezahnung aus. Die acrodonten Zähne auf Gaumen und Unterkiefer erreichen zuweilen ansehnliche Größe, ihre Krone ist schwach gewölbt oder fast eben, glatt oder mit feinen Runzeln bedeckt, lebhaft glänzend und meist von tiefschwarzer oder dunkelbrauner Farbe. Unter denselben ent-

1) Gürich, Über einige Saurier des oberschles. Muschelkalks. Zeitschr. d. d. geol. Gesellsch. 36. 1884. - Huene F. v., Utbersicht über d. Rept. d. Trias. Geol. u. Pal. Abhandl. N. F. VI. 1902. - Jaekel O., Placochelys placodonta aus der Obertrias des Bakony. Result. d. wiss. Erforsch. des Balatonsees I. Bd. 1. Teil. Pal. Anhang. 1907. Budapest. - Meyer H. $v$, Palaeontographica 1862. X. 1863. XI. Münster G., Graf v., Uber einige ausgezeichnete fossile Fischzähne etc. 1830. Beiträge zur Petrefaktenkunde 1843. Heft 4. - Owen R., Description of the skull and teeth of Placodus laticeps etc. Philos. Transact. Roy. Soc. 1858. 
wickeln sich die Ersatzzähne. Beachtenswert ist die Vereinigung der Pterygoidea, Palatina und des unpaaren Vomer zu einer fast die ganze Schädelunterseite einnehmenden Gaumenplatte. Die weit nach vorne gerückten Choanen werden durch einen Fortsatz des Vomer getrennt.

Die ersten Reste von Placodontiern wurden von $H$. v. Meyer und Agassiz für Fische gehalten und erst R. Owen erkannte sie als Reptilien.

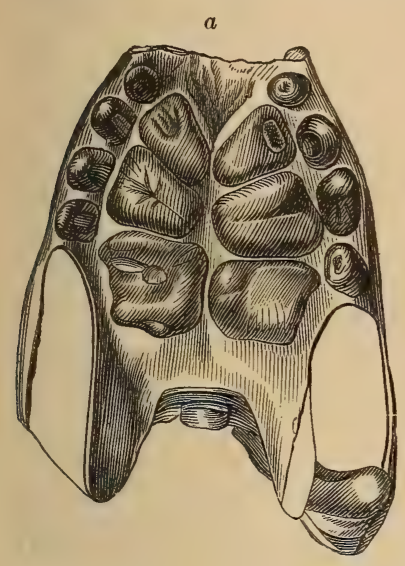

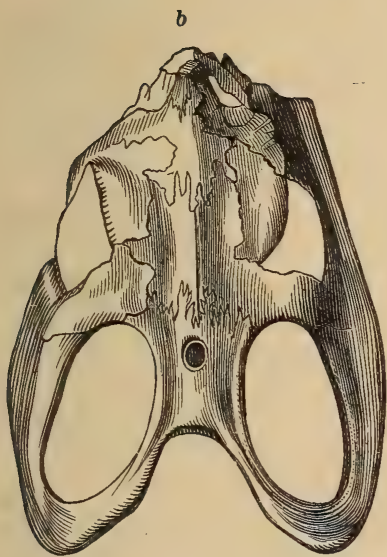

Fig. 387.

Placodus gigas Ag. Muschelkalk. Bayreuth.

$a$ Schädel von der Unterseite, $b$ von oben, $c$ Unterkiefer von oben, $d$ von der Seite. $1 / 3$ nat. Gr.
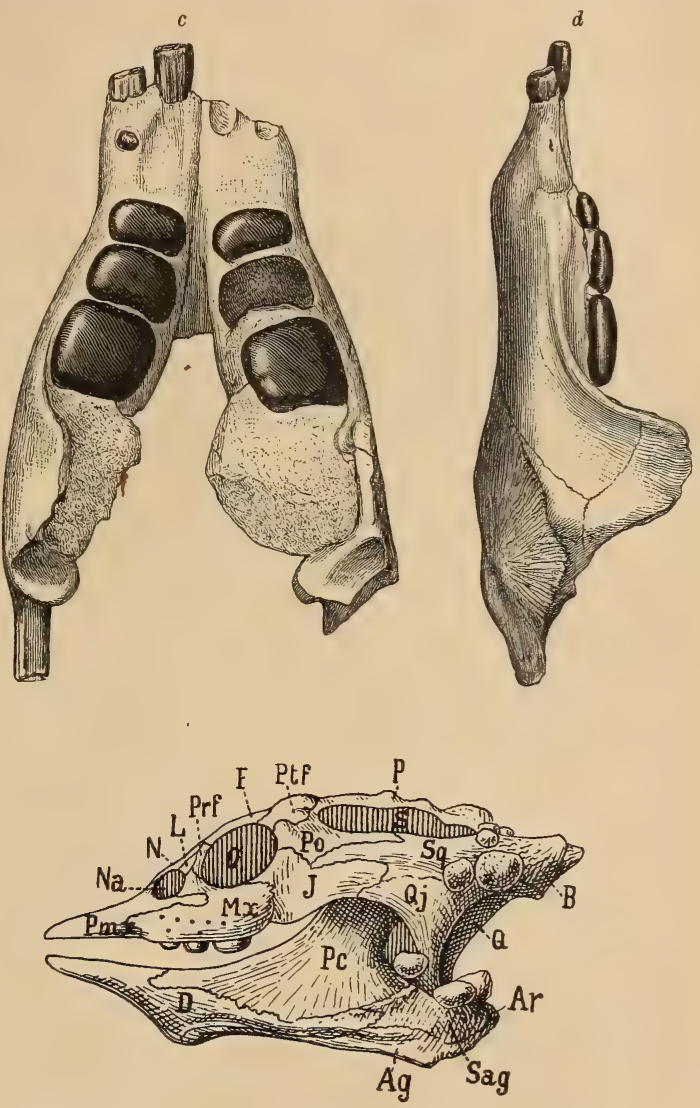

Fig. 388.

Placochelys placodonta Jaekel. Unt. Keup. Veszprém. Ungarn Schädel von der Seite. $P m x$ Prämaxillare, M $x$ Maxillare, $L$ Lacrimale, Prf Präfrontale, $N$ Nasale, $F$ Frontale, Ptf Postirontale, $P o$ Postorbitale, $J$ Jugale, $P$ Parietale, $S q$ Squamosum, $Q j$ Quadratojugale, QQuadratum, $N a$ Nasen-, $O$ Augen-, $S$ Schläfenloch,

$D$ Dentale, $P c$ Processus coronoideus, $A g$ Angulare, Sag Supraangulare, Art Articulare, $B$ Knochenbuckeln. $1 / 3$ nat. Gr.

Sie waren wahrscheinlich auf seichte Uferlinien beschränkte Meeresbewohner und ihrem Gebiß nach in der Hauptsache Muschelfresser, zu deren Abstoßen von ihrem Standort bei Placodus und Cyamodus das Schneidegebiß, bei Placochelys ein mit Hornschutz versehener Schnabel gedient haben mag.

Placodus Ag. (Fig. 387). Schädel länger als breit, oben schwach gewölbt, Schnauze etwas verlängert. Zwischenkiefer und Symphyse des Unterkiefers mit zylindrisch-konischen Schneidezähnen. Palatinum und Unterkiefer jederseits mit drei großen, vierseitigen Pflasterzähnen, Oberkiefer mit kleineren, bohnenförmigen Zähnen besetzt. Isolierte Zähne häufig im 
Muschelkalk von Deutschland und Frankreich, selten im Keuper. Vereinzelte Zähne in der alp. Trias. (Kössener.) Ganze Schädel bei Bayreuth.

Cyamodus H. v. Meyer. Schädel dreieckig. Schnauze stark verschmälert. Schläfenlöcher bis dreimal so groß als die im vorderen Drittel der Schädellänge gelegenen Augenhöhlen. Nasenlöcher klein, nahe am Schnauzenende. Auf dem Palatinum jederseits 2-3 schwarze Pflasterzähne von elliptischer oder rundlicher Form, wovon der hintere mindestens doppelt so groß als der vordere ist. Sonstige Bezahnung ähnlich Placodus. Muschelkalk. Deutschland.

Placochelys Jaekel (Fig. 388). Schädelumriß spitzig herzförmig, der Hinterrand des Squamosum mit konischen Knochenbuckeln besetzt. Prämaxillaria und Symphyse der Unterkiefer zahnlos, ursprünglich wohl

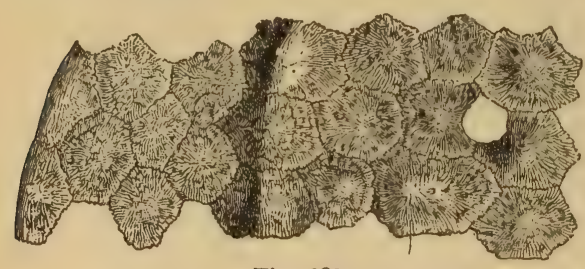

Fig. 389 .

Psephoderma Alpinum H. v. Meyer.

$1 / 4$ nat. Gr. Dachsteinkalk. Ob. Trias. Ruhpolding, Oberbayern. mit einem Hornschnabel versehen. Palatinum mit zwei, Maxillare mit drei, Unterkiefer mit zwei Pflasterzähnen. Von den flach amphicölen Wirbeln fallen 7-10 auf die Hals-, ca. 12 auf die Rumpf- und Becken- und ca. 10 bis 15 auf die Schwanzregion. Ein aus knöchernen Buckeln von wechselnder Größe zusammengesetzter geschlossener, von kräftigen Rippen gestützter Rückenpanzer und ein entsprechender kräftiger Bauchpanzer ist vorhanden. Extremitäten langgestreckt, ohne Epiphysen. Unterer Keuper. Veszprém, Ungarn.

? Psephoderma H. v. M. (Fig. 389). Nur der aus ziemlich gleichmäßigen Platten gebildete Panzer bekannt. Rhät. Bayer. Alpen. Lombardei. England.

\section{Anhang. Mesosauridae. ${ }^{1}$ ) (Proganosauria Osborn.)}

Wirbel plump, amphicöl. Schädel verlängert. Äußere Nasenlöcher getrennt, weit zurückliegend. Kieferzähne un. gemeinzart, lang, bürstenförmig, dichtgedrängt in Alveolen. Kleine Zähnchen am Vomer. Zwei Sacralwirbel. Humeras mit Foramen entepicondyloideum. Bauchrippen vorhanden. Brust- und Beckengürtel plattenförmig. Rippen einköpfig, beweglich, sehrdick, an allen Präsacralwirbeln mit Ausnahme des Atlas. Carpus und Tarsus verknöchert. Fünfzehig. Perm.

Die Mesosauridae sind kleine (60-70 cm lange), Süßwasser bewohnende Reptilien. Von den beiden hierher gehörigen Gattungen findet sich der mit verknöcherten Schuppen ausgestattete Mesosaurus Gervais (Ditrochosaurus Gürich) mit 11 Halswirbeln und 18 Rückenwirbeln im Perm von Südamerika und Südafrika.

Stereosternum Cope mit 12 Halswirbeln und 22 Rückenwirbeln im Perm von Südamerika.

Infolge der ungenauen Kenntnis der rückwärtigen Schädelpartie (? nur ein oder zwei Schläfenlöcher) ist die Stellung der Mesosouridae im System

1) Broom $R$., Observations on Mesosaurus. Transact. S. Afric. Philos. Soc. vol. XV. 1903. - Mc. Gregor J. H., On Mesosaurus Brasiliensis etc. Commissão de Estudos das Minas de Carvão de Pedro do Brazil. 1908. Rio de Janeiro. Gürich G., Ditrochosaurus capensis etc. Zeitschr. d. d. geol. Gesellsch. 1889. - Osborn H. F., The Reptilian Subclasses Diapsida et Synapsida etc. Mem. Americ. Mus. Nat. Hist. I. P. VIII. 1903. - Seeley H. G., The Mesosauria of South Africa. Quart Journ. Geol. Soc. 1892. 
unsicher. Trotz mancher Ähnlichkeit mit den Rhynchocephalen scheinen sie besonders auf Grund der Ähnlichkeit im Bau der Extremitätengürtel eher auf eine Verwandtschaft zu gewissen Sauropterygiern (Proneusticosaurus Voltz) hinzuweisen.

\section{Ordnung. Testudinata. Schildkröten. ${ }^{1}$ )}

Rumpf gedrungen und kurz, in eine knöcherne Kapsel (Theca) eingeschlossen, welche aus einem gewölbten Rückenund einem flachen Bauchschild besteht. Kiefer zahnlos, von Hornscheiden umgeben. Quadratum unbeweglich. Nasenlöcher vereinigt am vorderen Ende der Schnauze gelegen. Nur ein Paar von Schläfenöffnungen vorhanden. Extremitäten fünfzehig, entweder Schwimmfüße oder Gehfüße. Trias bis jetzt.

1) Andrews Ch. W., A descriptive Catalogue of the Tertiary Vertebrata of the Fajûm, Egypt. London. Print. by th. ord. of the British Museum. 1906. Arthaber G. v., Uber Trionyx rostratus etc. Beiträge zur Geologie ÖsterreichUngarns etc. Bd. XI. 1898. - Capellini G., Il Chelonio Veronese etc. (Protosphargis Veronense) etc. R. Accad. dei Lincei. Mem. d. Cl. di Sci. fis. mat. e nat. Vol. 18. 1884. - Case.E. C., On the osteology and relationships of Protostega. Journ. of Morph. Vol. XIV. 1897. - Coker $R$. E., Diversity of the skutes of Chelonia. Journ. of morphology. Philad. Vol. 21. 1910. - Dames W., Die Chelonier der norddeutschen Tertiärformation. Paläont. Abhandl, von Lames und Kayser. 1894 Bd. VI. - Dollo L., Bull. Musée Roy. d'hist. nat. de Belgique 1884 vol. III p. 63 IV. p. 69 , 129. V. p. 59. - Première note sur les Chéloniens oligocènes et néogènes $d$. 1 . Belgique Bull. Mus. R. nat. Belg. 1888. Sur l'origine de la Tortue Luth. (Dermochelys coriacea). Bull. Soc. R. Sc. méd. et nat. Brux. 1901. Eochelone brabantica etc. et l'Evolution des Chéloniens marins. Bull. Acad. R. Belg. 1903. Nouv. Note sur les Reptiles de l'Eocène inférieure etc. Bull. Soc. belg. Géol., Paléont. et Hydr. 1907. - Fraas E., Proganochelys Quenstedtii Baur. Jahreshefte d. V. f. vaterl. Naturkunde in Württ. 1899. Thalassemys marina E. Fraas aus dem ob. weißen Jura von Schnaitheim nebst Bemerkungen über die Stammesgesch. d. Schildkröten. ibid. 1903. - Fucini A., Le Chelone Sismondai etc. Palaeontographica ital. 15. 1909 - Gray J. E., Notes on the families and genera of Tortoises and on characters afforded by the Study of their skulls. Proc. zool. Soc. London 1869. XII p. 165. - Hay O. P., On the group of turtles known as the Amphichelydia etc. Bull. Americ. Mus. Nat. Hist. XXI 1905. - The fossil Turtles of North America. Carneg. Instit. of Washington. Publication 75. Washington 1908. Mit 113 Tafeln und 704 Textfiguren. Dort ausführliche Literaturnachweise! Ferner Proc. U. S. National Museum. Vol. 35. 1908 u. Vol. 38. 1910. - Hoffmann C. K., in Bronn's Klassen u. Ordnungen des Tierreichs. Bd. VI. Chelonii 1879. - Jaekel O., Placochelys placodonta l. c. s. o.! - Lörenthey $E$, Zwei neue Schildkrötenarten aus dem Eocän von Kolozsvár. Földteni Közling. Bd. XXXIII. 1903. - Lydekker R., Sivalik and Narbada Chelonia. Palaeont. Indica. Ser. X vol. III 1886. - Maack G. A., Die bis jetzt bekannten fossilen Schildkröten etc. Palaeontographica Bd. XVIII. 1869. - Meyer H. v., Zur Fauna der Vorwelt. I. u. IV. Frankfurt 1845 u. 1860. Folio. - Owen R. and Bell, Palaeontogr. Soc. 1851 u. 1853. - Palmer W., A new species of Leatherback Turtle etc. (Miocän Maryland.) Proc. U. S. Nat. Mus. Vol. 36. 1909. Pictet et Humbert, Monographie des Cheloniens de la Molasse Suisse. Mater. pour la Paléont. Suisse. Genève 1856. 4 . - Portis Aless., Palaeontograph. 1878 Bd. XXV. Mem. Soc. paléont. Suisse 1882. vol. IX. - Reinach A. v., Schildkrötenreste im Mainzer Tertiärbecken etc. Abhandl. Senkenberg. Naturforsch. Gesellsch. Frankfurt. Vol. 28. 1900. Schildkrötenreste aus dem ägyptischen Tertiär. ibid. Bd. 29. 1903. - Rïtimeyer L., Verhandl. naturforsch. Gesellsch. Basel 1872. Bd. III S. 255. - Die fossilen Schildkröten von Solothurn und der übrigen Juraformation. I. Abt. Denkschrift d. schweiz. naturf. Gesellsch. 1867. Bd. XXII. II. Abt. ebenda 1873 Bd. XXY. - Sacco F., Trionici di Mt. Bolca. Atti d. R. Acc. d. Science di Torino. 29. 1894. Trionici di Monteviale. ibid. 30. 1895. I Cheloni Astiani del Piemonte. Memorie d. R. Ac. d. Soc. di Torino 39. 1889. - Siebenrock F., Synopsis der rezenten Schildkröten mit Berücksichtigung der in historischer Zeit ausgestorbenen Arten. Zool. Jahrbücher. Fischer, Jena. Suppl. 10. Heft 3. 1909. - Stache G., Sontiochelys etc. 
Die Schildkröten bilden durch ihre eigentümliche Organisation eine nach allen Seiten hin abgeschlossene Ordnung, deren Ursprung vorläufig noch völlig im dunkeln liegt. Die Morphologie ihres Schädels erinnert an Rhynchocephalen und Lacertilier, aber auch die Sauropterygier zeigen im Bau des Gaumens und Schultergürtels mit den Testudinaten gemeinsame Merkmale auf. Die Schildkröten treten schon in der Trias vollkommen fertig mit allen typischen Merkmalen auf und erleiden von da an bis in die Jetztzeit keinerlei durchgreifende Veränderung; erst verhältnismäßig spät, in der Kreide, erfolgt die vollkommene Anpassung einer Gruppe: der Cheloniidae an das Meerleben.

Das auffallendste Merkmal der Schildkröten ist die Umkapselung des kurzen und gedrungenen Rumpfes durch einen festen knöchernen Panzer (Theca), welcher teils aus Verbreiterungen der Dornfortsätze und Rippen, teils aus Hautknochen zusammengesetzt ist, die mit jenen in mehr oder weniger innige Verbindung treten. Diese knöcherne Kapsel, in welche oft Kopf, Füße und Schwanz zurückgezogen werden können, ist von einer lederartigen $\mathrm{Haut}$ oder verhornten Epidermis (Schildpatt) überzogen, welch letztere durch vertiefte Nähte in eine Anzahl Schilder (Scuta) zerlegt wird. (Siehe Fig. 398.) Auf dem Rückenpanzer zählt man 5 mittlere Vertebral-Scuta und je 4 (zuweilen 5) seitliche Lateral- oder Costal-Scuta, zu denen noch 24 oder mehr kleiner Randschilder (Marginalscuta) kommen. Auch der Bauchschild (Plastron) ist in der Regel mit 6 (oder 5) Paar Hautschildern bedeckt, wovon die vordersten als GularScuta, die andere als Humeral-Pectoral-Abdominal, Femoral und Anal (Caudal)-Scuta bezeichnet werden. Diese Epidermisverhornungen die in der Hauptsache nur den Trionychiidae und Dermochelidae fehlen und denen in systematischer Hinsicht eine erhebliche Bedeutung zukommt, entsprechen in ihrer Größe und Form keineswegs den darunter liegenden knöchernen Platten, auf deren Oberfläche ihre Grenzen vertiefte Nähte hinterlassen. Letztere sind bei fossilen Formen allein erhalten, da die eigentlichen Hornschilder durch den Fossilisationsprozeß meist vollständig zerstört werden. Bei den Dermochelyidae (Lederschildkröten) findet sich in der Lederhaut ein Pflaster polygonaler schuppenartiger Knochenplatten, das sich panzerartig (Carapace athèque) über den spärlichen Verknöcherungen des Rücken- und Bauchschildes zusammenfügt.

Der knöcherne R ücken panzer (Rückenschild, Carapace) (Fig. 390A) verdankt seine Entstehung teils horizontalen Ausbreitungen der Dornfortsätze und Rippen, teils den damit in Verbindung treten-

Verhandl. d. k. k. geol. Reichsanstalt 1905. - Stefano G. de, Ptychogaster mioc. della Francia etc. Palaeontographica italica. 9. 1903. Studio sul Emys Curieri de Stef. dell' Eocene sup. parig. Boll. della Soc. Zool. Ital. XI. Ser. 3 (1, 2, 3) 1902. Cheloniani fossili cenozoici. Boll. S. g. ital. XXI. 1901. Nuovi rettili degli strati a fosfata ibid. XXII. 1903. - Wagner A., Abhandl. der k. bayer. Akad. math.phys. Kl. 1853 Bd. VII S. 291 und 1861 Bd. IX. I. Abt. S. 68-94. - Wieland G. R., Osteology of Protostega. Mem. Carn. Mus. Vol. 2. 1906. Revision of the Protostegidae. Americ. Journ. Science. Vol. XXVII. 1909. ibid. Literatur! (Siehe auch ibid. Vol. XIV. XVII. XVIII. XX). - Woodward A. S., On some extinct Reptiles from Patagonia, of the Genera, Miolania, Dinylisia a. Genyodectes. Proc. Zool. Soc. London 1901. 1. 
den, darüber gelagerten Hautverknöcherungen. Die Zahl und Anordnung der den Rückenpanzer bildenden Knochenplatten ist daher wesentlich bedingt durch die darin enthaltenen Wirbel und Rippen. Die acht rippenlosen $\mathrm{Halswirbel}$, die amphicöl, procöl und opisthocöl sein können, verschieben sich sehr leicht aneinander, während die zehn Rückenwirbel meist unbeweglich verbunden sind. Die oberen Bogen des verlängerten zweiten bis neunten Rückenwirbels breiten sich zu acht (selten mehr) medianen Knochenplatten, Neural(Vertebral)-Platten, aus, von denen einzelne zuweilen nicht zur Entwicklung gelangen, bei australischen Pleurodiren fehlen dieselben gänzlich. Auch die Rippen (zweite bis neunte) wandeln sich in breite

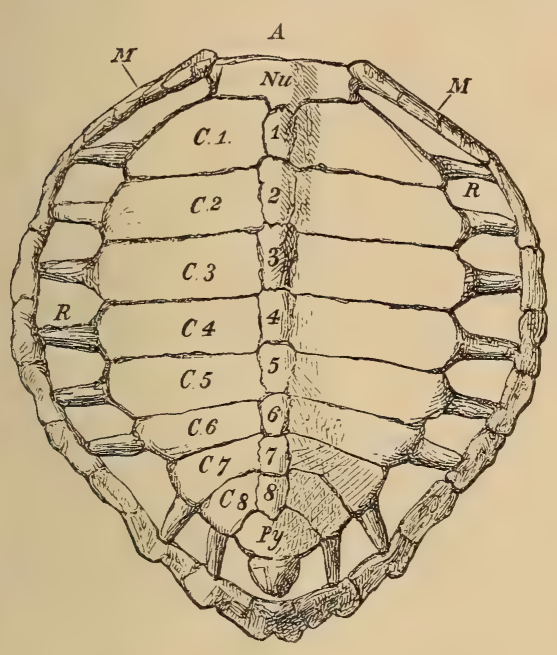

Fig. 390.

Chelonia midas Latr. Atlantischer Ozean.

A Rückenschild von außen,

$B$ Querschnitt des Panzers,

$C$ Bauchschild von unten.

$N u$ Nuchal- oder Nackenplatte, $N$ und 1-8 Neuralplatten, $P y$ Pygalplatte, $C^{1}-C^{8}$ Costalplatten, $M$ Randplatten, $K$ Rippen, $W$ Wirbel, $P$ Plastron, $e$ Entoplastron, Ep Epiplastron, Hyp Hyoplastron, Hpp Hypoplastron, $X_{p}$ Xiphiplastron.
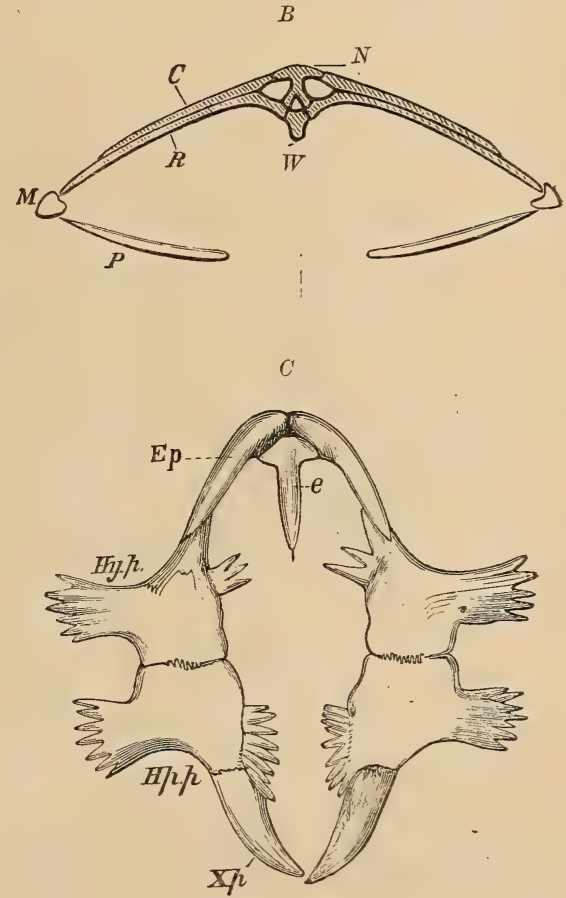

Knochenplatten (Costalplatten) um, welche untereinander und mit den Neuralplatten in Verbindung treten. Die Rippen selbst bleiben auf der Innenseite der Costalplatten häufig mehr oder weniger deutlich sichtbar und ragen, wenn das Rückenschild keinen vollkommen geschlossenen Panzer bildet, mit ihren distalen Enden über die Costalplatten hinaus. Vor der vordersten Neuralplatte wird der erste Rückenwirbel und manchmal auch der letzte Halswirbel von einer quer verbreiterten Hautknochenplatte bedeckt ( $\mathrm{Nuchal-} \mathrm{oder} \mathrm{Nackenplatte),}$ die entweder frei ist oder in Verbindung mit den Dornfortsätzen der beiden Wirbel treten kann. In gleicher Weise sind die letzten Wirbel in der Regel von einer bis drei Suprapygal- (Supraneural, Supracaudalia, Pygalia)-Platten bedeckt, auf welche noch eine Pygalplatte folgt. Zur Vervollständigung des aus Neural- und Costalplatten zusammengesetzten »Diskus« (Scheibe) dienen gewöhnlich 11 
(seltener 12) Paar nebst einer unpaaren hinteren Platte: Randplatten Marginalia (Peripheralia). Bei den Trionychia fehlen in der Regel die Randplatten.

Während den Neural- und Costalplatten Wirbel und Rippen, somit Teile der Wirbelsäule zugrunde liegen, sind die Nuchal-, Marginal- und Pygal-Platten reine Hautverknöcherungen. Auch das Bauchschild (Plastron) ist vollständig eine dermale Bildung. In der Regel besteht dasselbe aus neun Stücken, einem medianen unpaaren am Vorderrand gelegenen Entoplastron (Episternum, Interclavicula) und vier Paar seitlichen, die als Epiplastron (Claviculare), Hyoplastron, Hypoplastron und Xiphiplastron bezeichnet werden.
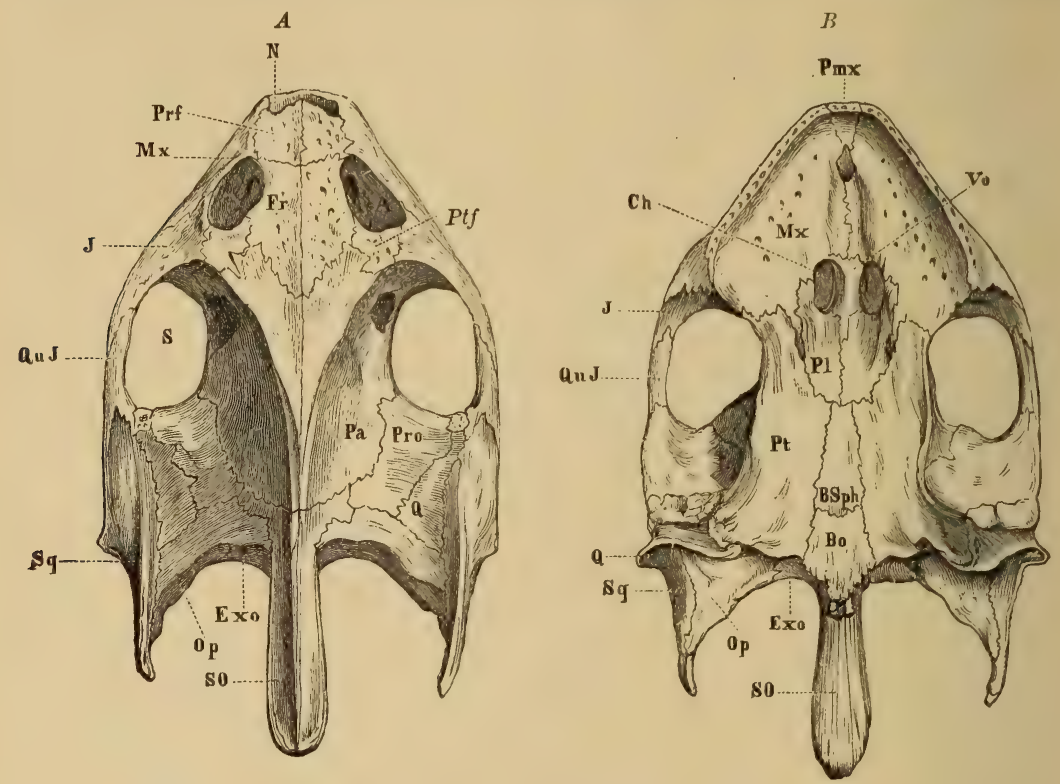

Fig. 391.

Schädel von Trionyx Gangeticus Cuv. A von oben. $B$ von unten. $N$ Nasenlöcher, $S$ Schläfenloch, Bo Basioccipitale, Exo Exoccipitale, SO Supraoccipitale, Op Opisthoticum, Pro Prooticum, $S q$ Squamosum, $P a$ Parietale, Fr Frontale, Ptf Postfrontale, Prf Präfrontale, $Q$ Quadratum, QuJ QuadratoJugale, $J$ Jugale, $M x$ Maxilla, $P m x$ Prämaxilla, $C h$ innere Nasenlöcher, $\nabla o$ Vomer, Pl Palatinum, Pt Pterygoideum, BSph Basi-Sphenoid. (Nach H of fmann.)

Bei den Chelonidae sind Hyoplastron und Hypoplastron durch eine große Lücke (F ontanelle) getrennt (Fig. 390B), bei anderen (z. B. Chersidae) (Fig. 398) vereinigen sich die Stücke gegenseitig und bilden so eine geschlossene Platte, zwischen diesen Extremen können alle Übergangsstufen vorkommen.

Zuweilen fehlt das Entoplastron (z. B. Cinosternidae, Dermochelyidae) oder es schaltet sich zwischen Hyoplastron und Hypoplastron ein (bis 2) Mesoplastron ein. Die Verbindung zwischen Rücken- und Bauchschild ist entweder nur eine verhältnismäßig lockere, teils durch Ligamente, teils durch seitliche Fortsätze von Hyo- und Hypoplastron oder diese beiden sind mit den umgeknickten Marginalia fest durch Sutur verbunden. Es entsteht im letzteren Falle dann eine Brücke (Sternalbrücke). Verlängern sich die vorderen und inneren Flügel 
der Sternalbrücke nach innen und heften sie sich an die Innenseite von Costalplatten an, so entstehen sogenannte Sternalkammern.

Am Sacrum nehmen in der Regel zwei (selten drei oder mehr) Wirbel teil, deren Rippen durch Sutur mit dem Wirbelkörper und dem oberen Bogen verbunden und distal - namentlich die ersten verbreitert sind. Der biegsame kurze Schwanz besteht aus procölen (selten opisthocölen) sehr beweglichen Wirbeln mit nur sehr niederen oder völlig fehlenden Dornfortsätzen, deren kurze Rippen in der Regel mit den Wirbelkörpern und den ob. Bögen sich zu querfortsatzartigen Gebilden verschmelzen.

Die Knochen des Schädels, dem ein Foramen parietale fehlt (Fig. 391), bilden ein häufig verlängertes, breites gewölbtes Dach, welches sich in einen starken, supraoccipitalen Hinterhauptskamm fortsetzt. Die seitlichen Augenhöhlen $(A)$ liegen vor der Mitte, die weiten, vereinigten, vertikalen Nasenöffnungen $(N)$ vorn am Schnauzenende. Das paarig entwickelte ansehnliche Parietale sendet mit Ausnahme der Dermochelyidae einen von manchen Autoren in Beziehung zum Epipterygoid gebrachten breiten Fortsatz zum Pterygoid (an Stelle des fehlenden? Alisphenoids), die Seitenwandungen der Schädelkapsel werden von dem meist ansehnlichen Prooticum und Opisthoticum eingenommen. Das Epioticum verschmilzt mit dem Supraoccipitale. Die paarigen Frontalia und Präfrontalia, welche die Augenhöhlen innen und vorne begrenzen, sind kräftig entwickelt, Nasalia kommen nur bei den meisten Chelyidae vor und Lacrimalia und Postorbitalia fehlen stets. Der Vorderrand der Schnauze wird von den kleinen und gewöhnlich getrennten Prämaxillaria gebildet. Das Squamosum begrenzt Prooticum und Opisthoticum und ruht auf dem Quadratum, das durch einen nach oben verlängerten Fortsatz sich fest in die Gehörgegend eingefügt und durch eine Naht vom Quadratojugale getrennt ist. Dieses letztere begrenzt als Jochbogen mit dem Jugale und den Fortsätzen des Squamosum und Postfrontale von unten die Schläfenöffnung, die aber durch seitliche plattige Ausbreitungen dieser Elemente und des Parietale, namentlich bei den Seeschildkröten, mehr oder weniger vollständig geschlossen werden kann. Ausnahmsweise kann der Jochbogen durch Reduktion des Quadratojugale auch vollständig fehlen (z. B. Terrapene, Cistudo). Ein hinterer Abschluß der Schläfenöffnung wird manchmal durch einen Parieto-Squamosalbog en erzielt.

An der Umgrenzung des Foramen magnum nehmen Supraoccipitale, Exoccipitalia und manchmal auch das Basioccipitale teil, das mit den letzteren den in der Regel dreiteiligen Condylus bildet. Bei Dermochelys bleibt derselbe knorpelig.

Der knöcherne Gaumen wird von den ausgedehnten Maxillaria und den in der Regel ziemlich verbreiterten Palatina sowie dem unpaaren Vomer gebildet, der die einander sehr genäherten Choanen von innen begrenzt. Auch die Pterygoidea sind als breite Knochenplatten entwickelt. Der Stapes (Columellae auris) ist verknöchert. Am Unterkiefer unterscheidet man 6 Knochen (Dentale, Angulare, Complementare, Operculare, Supraangulare, Articulare), welche sich jedoch an ausgewachsene Individuen so fest aneinander schließen, daß der Kiefer wie aus einem Stück zusammengesetzt erscheint. Zähne 
fehlen vollständig, dagegen sind Ober- und Unterkiefer wie bei den Vögeln an ihren Rändern mit scharf schneidenden Hornplatten überkleidet.

Schulter- und Beckengürtel (Fig. 392) befinden sich auffallenderweise innerhalb des Panzers, da dieselben jedoch im Fötus vor und hinter sowie außerhalb der Rippen liegen, so erhalten sie ihre abnorme Lage erst bei fortschreitender Entwicklung. Der Schultergürtel ist ein dreischenkeliger Skelettkomplex. Der dorsale,

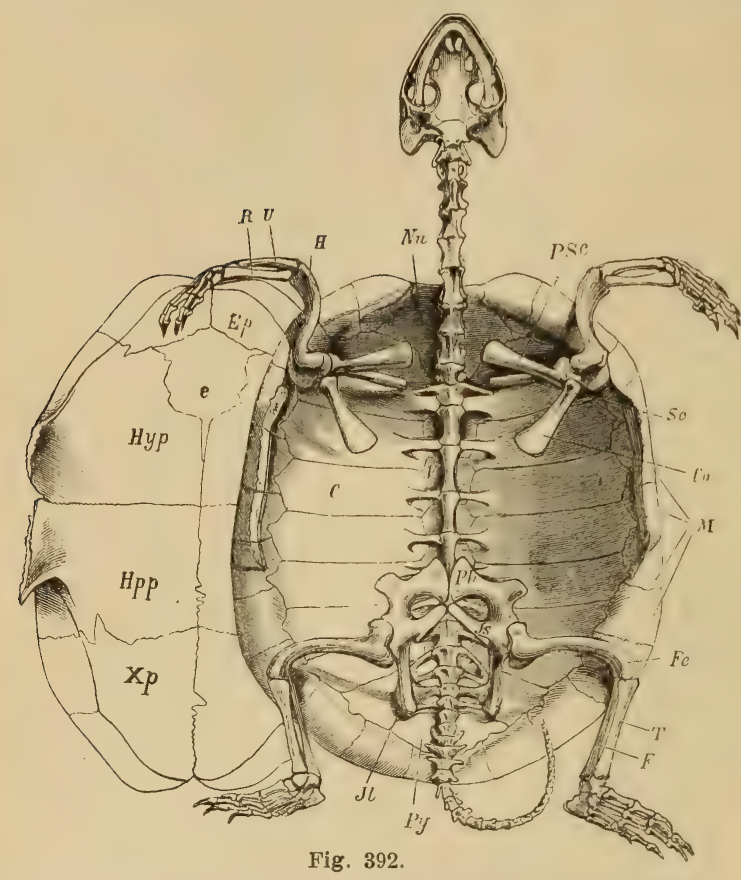

Emys orbicularis Linné. Skelett von unten gesehen, nach Entfernung des Bauchschildes. Nu Nuchalplatte, $C$ Costalplatte, $M$ Marginalplatten, Py Pygalplatte, $e$ Entoplastron, Ep Epiplastron, Hyp Hypoplastron, Hpp Hypoplastron, $\bar{X} p$ Xiphiplastron, Co Coracoid, PSc Procoracoid, Sc Scapula, $H$ Humerus, $\boldsymbol{R}$ Radius, $U$ Ulna, $I l$ nlium, $P b$ Pubis, Is Ischium, Fe Femur, $T$ Tibia, $F$ Fibula. stabförmige Schenkel, die Scapula, wird durch Band oder Knorpel am Rückenschild in der Nähe des vordersten Wirbels befestigt, der vordere ventrale Schenkel das Procoracoid verbindet sich ebenso mit dem Entoplastron (Episternum), während der hintere ventrale Schenkel, das Coracoid, sich unter distaler Verbreiterung nach innen erstreckt. Der häufig stark gekrümmte Humerus zeichnetsich durch seinen dicken, kugeligen Gelenkkopf aus, im Vorderarm bleibt die Ulna bei den Chelonidae gegenüber dem Radius an Länge zurück. Der Carpus enthält in der Regel in der proximalen Reihe4, in der distalen 5 Knöchelchen - doch kommen häufig Verschmelzungen vor. Die 5 Metacarpalia zeigen bei den verschiedenen Familien große Differenzen und auch die Fingerglieder weichen an Länge und Zahl stark voneinander ab.

An dem lacertilierähnlichen Beckengürtel heften sich die Ilia gewöhnlich an den Sacralrippen an, häufig sind sie auch mit den letzten Costalplatten knorpelig durch Naht verbunden. Bei den Pleurodiren sind auch Pubes und Ischia an dem Plastron unbeweglich befestigt. Der Femur ist ein gekrümmter, zylindrischer Knochen, Tibia und Fibula erreichen nahezu gleiche Länge. Im Tarsus treten in der Regel Konkreszenzen ein, so entsteht durch Verschmelzung des Tibiale und Intermedium ein Astragalus und aus dem Fibulare ein Calcaneus - bei den Emydae können beide Knochen oft $\mathrm{zu}$ einem einzigen Element verwachsen, die distale Reihe des Tarsus enthielt 4 (Chelonidae) oder 5 Knöchelchen. Die 5 Metatarsalia und Zehen gleichen dem Vorderfuß. 
Die Schildkröten leben teils auf dem Festland, teils im süßen Wasser, teils im Meer. Gegenwärtig kennt man ca. 270 Arten, die größtenteils auf warme und tropische Zonen beschränkt sind. Sie pflanzen sich durch Eier fort, welche in der Erde oder bei den wasserbewohnenden Formen am Ufer im Sande eingescharrt werden. Ihre Nahrung besteht vorherrschend aus Pflanzen, viele von ihnen nähren sich aber auch von Fischen, Mollusken und Crustaceen.

\section{Unterordnung. Pleurodira. Lurchschildkröten.}

Rücken- und Bauchschild vollständig verknöchert, Becken mit dem Rückenschild und gewöhnlich auch mit dem Plastron unbeweglich verbunden. Mesoplastra vorhanden oder fehlend. Hals und Kopf seitlich bewegbar. Halswirbel mit starken Querfortsïtzen. Hornschilder vorhanden. Schwimmfüße mit 4-5 Krallen. Trias bis jetzt.

Sämtliche lebende Pleurodiren sind Süßwasserbewohner und finden sich in Afrika, Madagaskar, Südamerika, Australien und Neu-Guinea.

\section{Familie. Amphichelydidae.}

Mesoplastra vorhanden. Becken häufig noch nicht mit dem Plastron verwachsen. Intergulare Scuta wahrscheinlich immer entwickelt. Epiplastra in Kontakt mit dem Hypoplastra. Trias bis ? Miocän.

Die hier vereinigten fossilen Vertreter aus Trias, Jura und Kreide in Europa und Nordamerika, die sich vielleicht in Proganochelynae, Pleurosterninae und $\mathrm{B}$ a enina e gliedern lassen, vereinigen noch Merkmale der Cryptodira und Pleurodira; Lydekker, dem sich G. Baur und Hay $^{1}$ ) anschlossen, nannte sie darum Amphichelydia und betrachtete sie als eine den übrigen gleichwertige Unterordnung der Schildkröten.

? Chelyzoon v. Huene. Wirbelkörper $3 \mathrm{~cm}$ hoch und $9 \mathrm{~cm}$ lang, opisthocöl. Muschelkalk. Bayern und Schwaben.

Proganochelys Baur em. E. Fraas. (Psammochelys Quenstedt. ? Chelytherium H. v. Meyer.) Sehr große (65 cm lange) Form. Plastron mit dem Rückenschild unter Bildung von Sternalkammern verwachsen. 5 Vertebralscuta außerordentlich groß und breit auf Kosten der Lateralscuta, im vorderen und hinteren Winkel zahlreiche, mit Höckern versehene Supramarginalscuta. Rückenwirbel weit vom Rückenschild abstehend und mit ihm durch die dünnen Dornfortsätze verbunden. Becken mit dem Rückenschild und Bauchschild verwachsen. Keuper (Stubensandstein) Schwaben.

Proterochersys E. Fraas. ${ }^{2}$ ) Halb so groß wie Proganochelys, hochgewölbt, mit mächtig entwickeltem, fest an Ober- und Unterschale verwachsenem Becken. Keuper (Stubensandstein) Schwaben.

Pleurosternum Owen. Rückenschild sehr flach, hinten gerundet, Neuralia mäßig verlängert; Nuchalscutum fehlt, Rückenschild mit Plastron durch eine große Brücke fest verbunden. Mesoplastron sehr breit. Oberer Jura und Wealden von England und Norddeutschland. ? Miocän. Lausanne, Sehweiz.

Helochelys v. Meyer. Cenoman. Kelheim.

1) Hay teilt dieselben in Proganochelydae, Pleurosternidae und Baenidae.

2) Nach einer freundlichen Mitteilung von Herrn Prof. E. Fraas. 
Platychelys A. Wagner (Helemys Rütimeyer). (Fig. 393.) Rückenschild schwach gewölbt, mit drei Längsreihen, starker kegelförmiger Höcker, von denen radiale Rippen ausstrahlen. Diese Höcker entsprechen den darüber liegenden Vertebral- und Costalscuta. Neuralplatten breit, ungleich groß. Plastron kreuzförmig, durch kurze Brücke mit dem Rückenschild

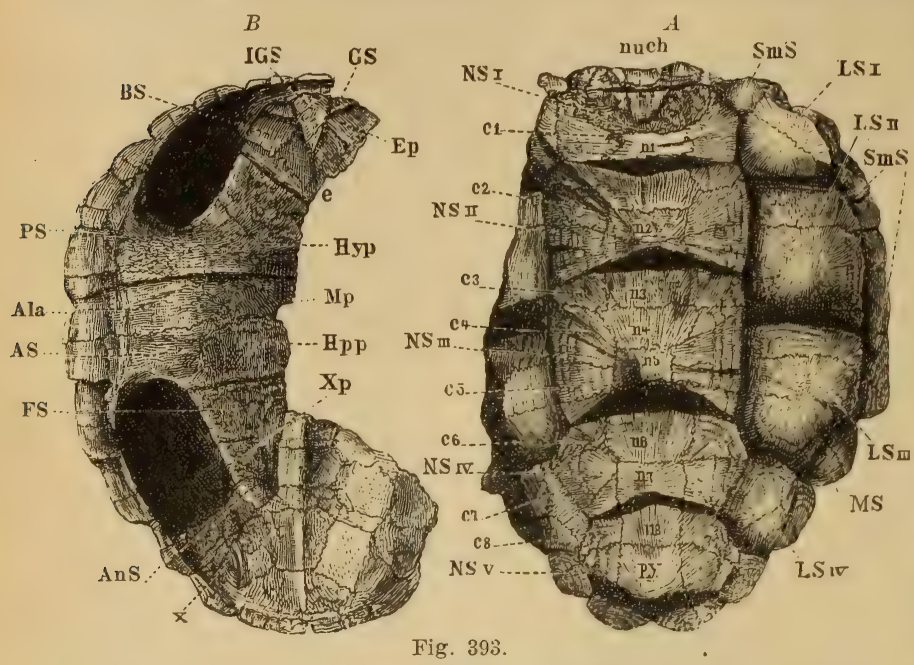

Platychelys Oberndorferi Wagn. Ob. Jura. Kelheim, Bayern. 1/4 nat. Gr. $A$ Rückenschild, $B$ Bauchschild. $n$ 1-8 Neuralplatten, $c 1-8$ Costalplatten, $p y$ Pygalplatte, NS Vertebral- oder Neuralscuta, LS Lateralscuta, SmS Supramarginalscuta, MS Marginalscuta, e Entoplastron, Ep Epiplastron, Hyp Hyoplastron, Mp Mesoplastron, Hyp Hypoplastron, $X p$ Xiphiplastron, $I G S$ Intergularscutum, $G S$ Gularscutum, $B S$ Brachialcsutum, $x$ Anheftstelle des Darmbeins, PS Pectoralscutum, AS Abdominalscutum, FS Femoralscutum, $A n S$ Analscutum. verbunden. Becken nicht mit dem Plastron verwachsen. Oberst.Jura.Bayern, Frankreich, Engl. Glyptops Marsh (Compsemys Leidy). Rückenschild flach, mit dem Plastron durch Sutur fest verbunden. Becken nicht mit dem Bauchschild verwachsen. Halswirbel amphicöl. Oberer Jura bis Obere Kreide. Vereinigte Staaten von Nordamerika.

Probaëna Hay. Nahe verwandt mit Platychelys. Untere Kreide (Como beds). Nordamerika.

Baёna Leidy. Rückenschild flach,

fest mit dem Plastron durch Sutur verbunden. Mesoplastron ansehnlich, mit ausgebreiteten äußeren Enden. Obere Kreide. Eocän. Nordamerika. Eubaëna Hay. Chisternon Leidy. Boremys,? Neurancylus Lambe. ? Thescelus, Charithemys Hay. ? Polythorax Cope.? Naomichelys Hay. Obere Kreide: Nordamerika.

\section{Familie. Pelomedusidae.}

Plastron aus 11 Elementen zusammengesetzt. Mesoplastron vorhanden, ein knöcherner Schläfenbogen, aber kein Parieto-Squamosalbogen vorhanden. Nasalia fehlen. Präfrontalia miteinander verbunden. ? Gault. Obere Kreide bis jetzt.

Die lebenden Gattungen Sternothaerus Bell, Pelomedusa Wagl, Po. docnemis Wagl. fiinden sich in Afrika, Madagaskar und Südamerika, die beiden ersten fossil im Mittelpliocän von Ägypten, letztere schon im Mitteleocän, Podocnemis (Fig. 396) wird bereits aus dem Eocän von England, dem Mittel-Obereocän und Untermiocän von Ägypten und ? Indien genannt. Stereogenys Andrews. Mittel-Obereocän Ägypten. Die systematische Stellung von Rhinochelys Seeley (Fig. 395) aus dem Gault von England ist unsicher.

Die Gattungen Bothremys Leidy, Taphrosphys Cope, Amblypeza, Naiadochelys Hay aus der oberen Kreide Nordamerikas werden auch auf Grund eines wohl entwickelten Vomers als eigene Familie: Bothremydidae betrachtet.

\section{Familie. Chelyidae.}

Plastron aus 9 Elementen zusammengeselzt. Keine Mesoplastra. Schläfenbogen in der Regel fehlend, dafür ein Parieto-Squamosalbogen vorhanden. Palatina 
durch den Vomer getremnt. Nasalia vorhanden. Präfrontalia von einander getremnt. Eocän bis jetzt. Lebend (10 Gattungen) in Südamerika, Australien, NeuGuinea.

Chelodina Fitz. Pleistocän und rezent. Hydraspis Bell. Südamerika rezent und Eocän Indien. Emydura Bonap. Australien. ? Pleistocän.

\section{Familie. Miolanidae.}

Panzer unvollständig bekannt. Becken mit den Costalia verwachsen. Schädel mit vollkommen überü̈lbten Schläfenöffnungen und mit hornühnlichem Knochenzapfen skulptiert. Schwanz in einer aus Verschmelzung ähnlicher Hautossifikationen hervorgegangenen knöchernen Scheide eingeschlossen. ? Kreide. Pleistocän.

Die einzige riesige Gattung Mio la ni a Owen. (Schädel am hinteren Ende bis $0,58 \mathrm{~m}$ breit) wurde zuerst aus dem Pleistocän von Queensland (Australien) beschrieben. Neuerdings sind sehr vollkommene Reste aus der ? obersten Kreide (? Tertiär) von Patagonien bekannt geworden.

\section{Familie. Plesiochelyidae.}

Mesoplastra fehlen. Nur Pubis mit dem Plastron verwachsen. Schläfenregion überwölbt. Oberer Jura bis Untere Kreide.

Plesiochelys Rütim (Fig. 394). Rückenschild bis $1 / 2 \mathrm{~m}$ lang, massiv, kreis-herzförmig. 8 Neuralia, lang

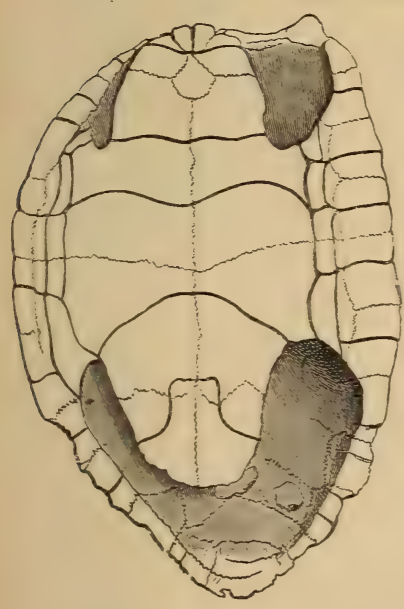

Fig. 394

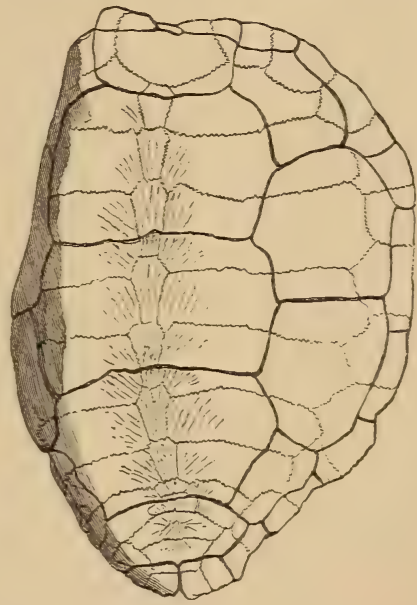

Plesiochelys Solodurensis Rütimeyer. Ob. Jura (Kimmeridge.) Solothurn, Schweiz. 1/8 nat. Gr. (Nach Rütimeyer.)

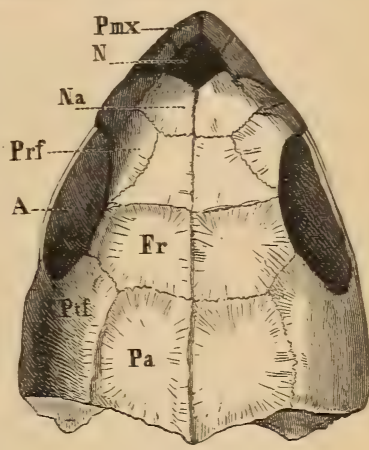

Fig. 395.

Rhinochelys Cantabrigiensis Lyd. Schädel in nat. Gr. aus dem Grünsand von Cam. bridge. (Nach Lydekker.) A Augenhöhle, $N$ Nasenloch, Pa Parietale, Fr Frontale, Prf Prä-, Ptf Postfrontale, Na Nasale, $P m x$ Zwischenkiefer.

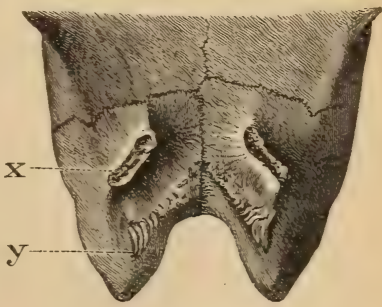

Fig. 396

Podocnemis expansaWagl, Rezent. Brasilien. Hinteres Ende des Bauchschildes von innen; $m$. den Anheftstellen für Scham-u. Sitzbein $(x, y)$. (Nach Rütime yer.)

schmal, 3 Suprapygalplatten. 11 Paar Marginalia mit einer unpaaren, in die Quere gestreckten Nuchalplatte. Sternalbrücke sehr groß. Entoplastron und Epiplastra sehr klein. Hyoplastra groß. Plastron mit oder ohne bleibende Fontanelle. Oberer Jura. Untere Kreide. Deutschland, Frankreich, Schweiz. Idiochelys H. v. Meyer. (Chelonemys Jourdan.) Höchstens 7 Neuralia und ein Suprapygale vorhanden. Oberster Jura. Bayern und Cerin. (Ain.) Hydropelta H. v. Meyer. Oberer Jura. Von eben dort. ? Chelonides Maak. Oberer Jura. Norddeutschland. Hyaelochelys Lyd. Oberer Jura und Wealden. Europa. 
Karst.

? Sontiochelys G. Stache. Neuralia fehlen vollständig. Cenoman.

\section{Unterordnung. Cryptodira.}

Rücken- und Bauchschild mehr oder weniger vollständig verknöchert, gegen. seitig nur leicht verbunden. Epiplastra im Kontakt mit den Hyoplastia. Marginalia vorhanden. Kopf und Hals in vertikaler Richtung in die Schale zurückziehbar. Halswirbel ohne oder nur mit kurzen Querfortsätzen. Becken nicht mit dem Plastron verwachsen. Klump- oder Schuimmfüjse mit 4-5 Krallen. Hornschilder. Ob. Jura-jetzt.

\section{Familie. Thalassemydidae.}

Panzer mehr oder weniger unvollständig verknöchert. Plastion gewöhnlich mit großer Mittelfontanelle. Häufig Fontanellen zwischen Marginalia und Costalia. Plastron mit der Rückenschale durch seitliche Fortsätze verbunden. Schläfengegend mehr oder weniger ïberdacht. Hals kurz. 5 Krallen. Jura bis Kreide. Eocän.

Diese ausgestorbene Familie enthält Schildkröten aus marinen Ablagerungen, welche während der Jura-Eocänzeit die Meerküsten bewohnten

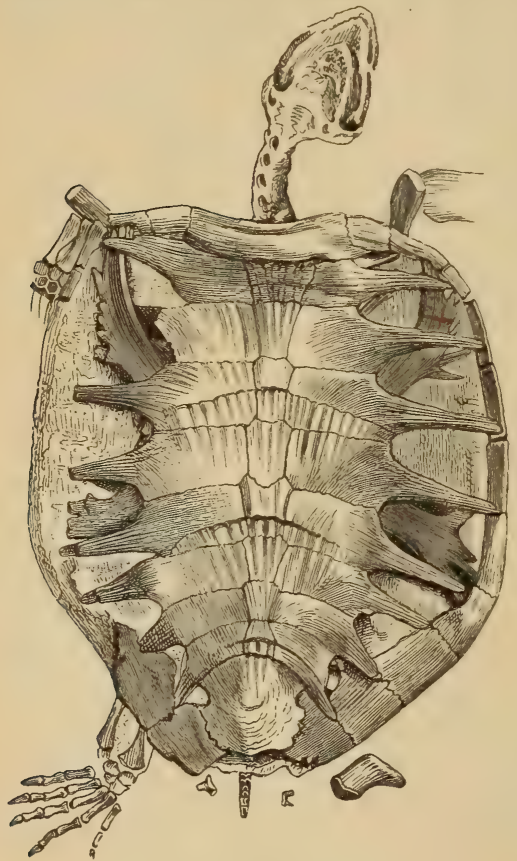

Fig. 397

Eurysternum Wagleri H. v. Meyer. Ob. Jura. Zandt bei Eichstädt. $1 / 3$ nat. Gr. und in ihrer ganzen Erscheinung eine Verbindung von Merkmalen der heutigen Cheloniidae (Meerschildkröten) und Emydidae (Sumpfschildkröten) zur Schau tragen. Die meist unvollständige Verknöcherung des Rückenschildes, sowie die bleibenden Fontanellen im Bauchschild drücken den Thalassemyden äußerlich den Stempel der Meerschildkröten auf; allein die Form der Plastronstücke, die stark verlängerten und etwas aufwärts gebogenen Flügel der Hyo- und Hypoplastra erinnern weit mehr an die Sumpfschildkröten als an die Cheloniidae. Ebenso ähnelt die Beschaffenheit der Extremitäten denen der Emydidae. Die fünf mäßig verlängerten, gelenkig verbundenen Zehenglieder endigten mit Krallen und waren ursprünglich wahrscheinlich durch eine Schwimmhaut vereinigt, konnten somit zum Gehen und Schwimmen gebraucht werden.

Eurysternum Wagler (Aplax, Acichelys, Achelonia, Palaeomedusa v. Meyer) (Fig. 397). Das Rückenschild verknöchert erst in hohem Alter vollständig, das Plastron bewahrt stets größere Fontanellen. Schläfengegend vollständig überdacht. Extremitäten mit 5 kurzen Zehen. Im Lithographischen Schiefer von Solnhofen (Bayern) und Cerin (Dep. Ain). Thalassemys Rütimeyer (Enaliochelys Seeley). Ähnlich Eurysternum, aber hintere Neuralia mit dachähnlichem Rücken. ? Verwandt mit Glyptops. Ob. Jura. Purbeck. Schweiz. Schwaben. England.

Chitracephalus Dollo. Schädel stark verlängert, niedrig. Gesichtsteil kurz. Schläfengegend nicht überdacht. Wealden. Belgien. Tropidemys Rütimeyer, Pelobatochelys Seeley. Ob. Jura und Wealden. Europa. In ihrer Stellung unsicher sind folgende Formen, die manche Autoren auch mit den Cheloniidae vereinigen. 
Osteopygis Cope. Rückenpanzer nahezu geschlossen. 8 Paar Costalia, 11 Paar Marginalia. Plastron relativ klein. Ob. Kreide. Nordamerika. Nahe verwandt, wahrscheinlich identisch ist Propleura Cope. Das gleiche gilt für Catapleura Cope. Ob. Kreide. Nordamerika.

Lytoloma Cope, (? Euclastes Cope, ? Glossochelys Seeley). Unvollständig bekannt. Ob. Kreide. Eocän. Europa, Nordamerika, Afrika (Tunis).

Erquelinnesia Dollo (Pachyrhynchus Dollo). Ob. Kreide. Eocän. Nordamerika. Europa.

Rhetechelys Hay. Ob. Kreide Nordamerika.

\section{Familie. Chelydridae.}

Am Rïckenschild Nuchale mit rippenartigen Fortsätzen. Sämtliche Neuralia vorhanden. 25 Marginalia. Plastron aus 9 Elementen bestehend, klein, kreuzförmig, mit dem Riickenschild locker (durch Gomphose) verbunden. Schläfenregion unvollständig überdeckt. Schwanz lang mit meist opisthocölen Wirbeln. Fiißße mit fïnf mäßig langen, durch Schwimmhaut verbundenen Zehen, vorne fünf, hinten vier Krallen. Ob. Jura bis jetzt.

Tretosternum Owen (Peltochelys Dollo). Rückenschild mit grubiger Oberfläche, sein Vorderrand tief ausgeschnitten. Purbeck u. Wealden. England und Belgien.

Gafsachelys de Stefano. Unt. Eocän. (? Kreide). Tunis.

?Acherontemys Hay. Miocän. Nordamerika.

Macroclemys Gray (Machochelys Gray). Fossil im Pleistocän von Nordamerika. Lebend in Flüssen und Sümpfen von Nordamerika.

Chelydra Schweig. Lebend in Nord- und Zentralamerika. Fossil im Miocän von Europa, Pleistocän von Nordamerika.

Devisia D. Ogilby. Rezent. Neu-Guinea.

\section{Familie. Testudinidae.}

Nuchalplatte ohne rippenähnliche Fortsätze. Panzer vollständig geschlossen, Plastron mit dem Rïckenschild in der Regel durch Sutur verbunden. Schläfengegend nicht überwölbt.

Unterfamilie. Emydinae. (Sumpfschildkröten.)

Rückenschild schwach gewölbt, Plastron in der Regel durch Sutur, selten durch Ligamente mit dem Rückenschild verbunden, aus 9 Elementen zusammengesetzt, Mesoplastron fehlt. Sternalkammern wohl entwickelt. Quadratum hinten offen. Zehen kurz, kräftig, die mittleren gewöhnlich mit drei Phalangen (Terrapene mit zwei), durch Schwimmhaut verbunden. 4 bis 5 Krallen. Eocän bis Jetzt.

Im Bau der knöchernen Schale stehen die Emydinae den Testudininae (Landschildkröten) sehr nahe, mit denen sie von verschiedenen Autoren auch direkt vereinigt werden, unterscheiden sich von diesen aber hauptsächlich durch flachere Wölbung des Rückenschildes, tieferes Eingreifen der Sternalflügel nach innen und die dadurch bewirkte Ausbildung von Sternalkammern, sowie durch den Bau ihrer Extremitäten, denen überdies Hautverknöcherungen fehlen. Sie lassen sich als zwei deutlich getrennte Gruppen bis in das Eocän zurück verfolgen.

Die Emydinae (20 Genera) leben gegenwärtig in Flüssen und Sümpfen in allen wärmeren Teilen der Erde mit Ausnahme des Australischen Gebiets, fossile Formen sind mit Sicherheit erst aus dem Tertiär bekannt. Die ältesten Reste in Europa stammen aus dem Eocän von England, ihre genorische Stellung zu Chrysemys Gray erscheint fraglich. Die Gattung Emys Dum. (Cistudo) wird in Europa bis in das Obereocän zurück genannt. Die unter dem Namen Emys (Fig. 392) aus dem Oligocän und Miocän Europas 
beschriebenen zahlreichen Schildkröten scheinen fast alle eher auf Clemmys Wagl. und Okadia Gray hinzuweisen. Ptychogaster Pomel zeigt sich im Oligocän und Miocän in ziemlich weiter Verbreitung. In den Vereinigten Staaten ist im Eocän Ectomatemys Hay und Clemmys Wagl. häufig, im Oligocän findet sich Graptemys Agass. und im jüngeren Tertiär verteilen sich die Funde auf Trachemys Agass. Terrapene Merrem, Chrysemys Gray, Clemmys Wagl. u. a.

Unterfamilie. Testudininae. Landschildkröten. (Chersidae.)

Rückenschild hoch gewölbt. Plastron durch Sutur mit dem Rückenschild verbunden, aus 9 Elementen zusammengesetzt. Sternalkammern kaum entuickelt. Quadratum hinten geschlossen. Kurze Klumpfüße mit Hautverknöcherungen, die Mittelzehen nur mit zwei Phalangen. Vorne gewöhnlich mit fün, hinten mit vier geraden, dicken Nägeln. Ohne Schwimmhäute. Eocän bis Jetzt.

Die Verteilung der lebenden Testudineae (5 Genera) ist dieselbe wie der Emydinae. Im australischen Gebiet fehlen sie gleichfalls.
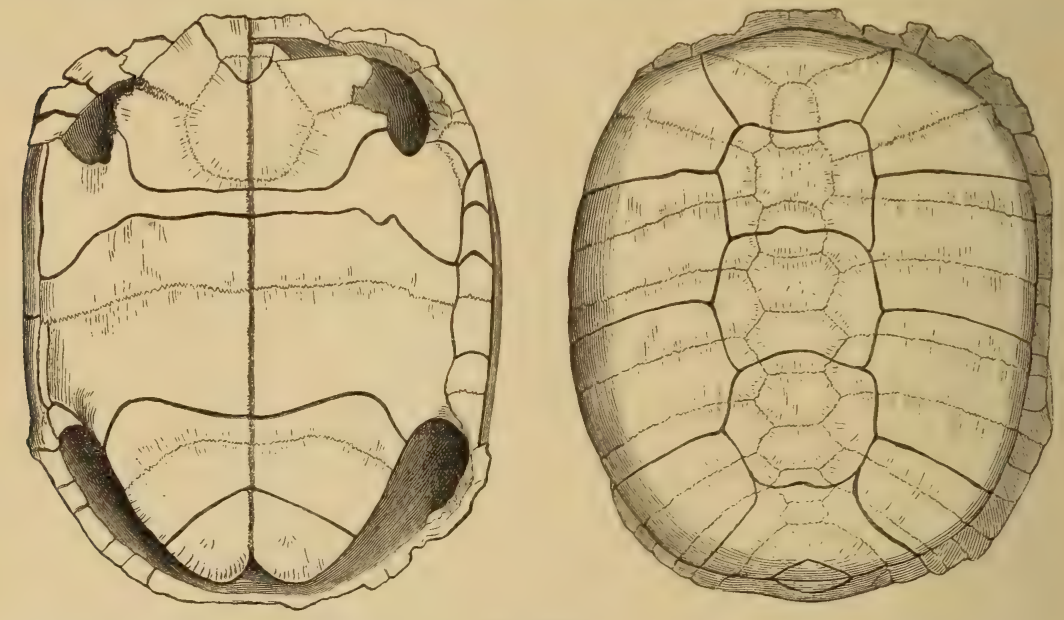

Fig. 398.

Stylemys Nebrascensis Leidy. Miocän. Mauvaises terres des White River, Dakota. 1/3 nat. Gr. (Nach Leidy.)

Die älteste und relativ häufig bekannte Landschildkröte ist Hadria nus Cope aus dem Eocän der Vereinigten Staaten, seltener erscheint Achitem ys Hay, im Oligocän und älteren Miocän findet sich neben Stylemys Leidy (Fig. 398) bereits Testudo Linné sehr verbreitet, welch letztere sich von da ab im Tertiär Nordamerikas allein findet. In dem Obereocän des Fajum in Ägypten zeigt sich neben kleineren Arten, die sehr ansehnliche Testudo Ammoni Andrews. Die oligocänen Reste dieser Gattung in Europa sind nicht völlig sicher, dagegen wird sie ziemlich häufig aus dem Miocän und Pliocän genannt. Eine Riesenform T. Perpiniana Gaudry aus dem Pliocän von Serrat (Ostpyrenäen) hat einen Rückenpanzer von $1,20 \mathrm{~m}$ und T. Atlas Falc. und Cantley aus dem ob. Miocän von Sivalik (Indien) sogar von 2 m Länge. Auch aus dem Pliocän von Malta sind Reste von gewaltigen Landschildkröten bekannt.

\section{Unterordnung. Cheloniidea.}

Rücken und Brustschild unvollkommen verknöchert. Hals unvollständig in die Schale zurückziehbar. Sehr kurze Querfortsätze an den Halswirbeln vorhanden. 
Becken mit dem Plastron nicht fest verbunden. Ruderfïße. Epidermis verhornt. oder Haut lederartig und mit einem Pflaster polygonaler dünner Knochenplatten (Carapace athèque $=$ mosä̈que superficielle Dollo). Obere Kreide bis jetzt.

\section{Familie.}

\section{Dermochelyidae.}

(Lederschildkröten.)

(Athecae Cope.)

Wirbel und Rippen frei. Dom Rückenschild nur die Nuchalplatte entwickelt. Plastron von 8 Knochen gebildet. Entoplastron fehlt. Der ganze Rumpf von einer lederartigen Haut überzogen, in welche ein dichtes Mosaik. pflaster polygonaler, in Reihen angeordneter Knochenplättchen eingelagert ist. Parietalia ohne absteigende Fortsätze. Ruderfiiße ohne Krallen. Eocän bis Jetzt.

Die einzige lebende Lederschildkröte Der mochelys Blainv. (Sphargis), deren Kopf nicht zurückziehbar ist, gehört zu den größten und weitverbreitetsten, aber auch seltensten Gattungen; sie findet sich im Atlantischen, Indischen und Stillen Ozean, gelegentlich auch im Mittelmeer. Kopf mit kleinen Schildern bedeckt. Der Hinterhauptscondylus soll unverknöchert bleiben, ein selb. ständig ossificiertes Parasphenoid ist vorhanden. Das dünne Mosaikplastron der Rückenseite mit 7 Reihen, das der Bauchseite mit 5 Reihen größerer als Kiele hervortretenden Plättchen. Die Elemente des Plastrons, Epiplastron, Hyoplastron, Hypoplastron und Xiphiplastron sind dünn und schlank und umschließen eine weite Fontanelle. Cope und Dollo stellen Dermochelys und Verwandte als Athecae allen übrigen Schildkröten den Thecophora gegenüber; jedenfalls stellen sie die meist spezialisierte Gruppe unter den Cheloniidea dar.
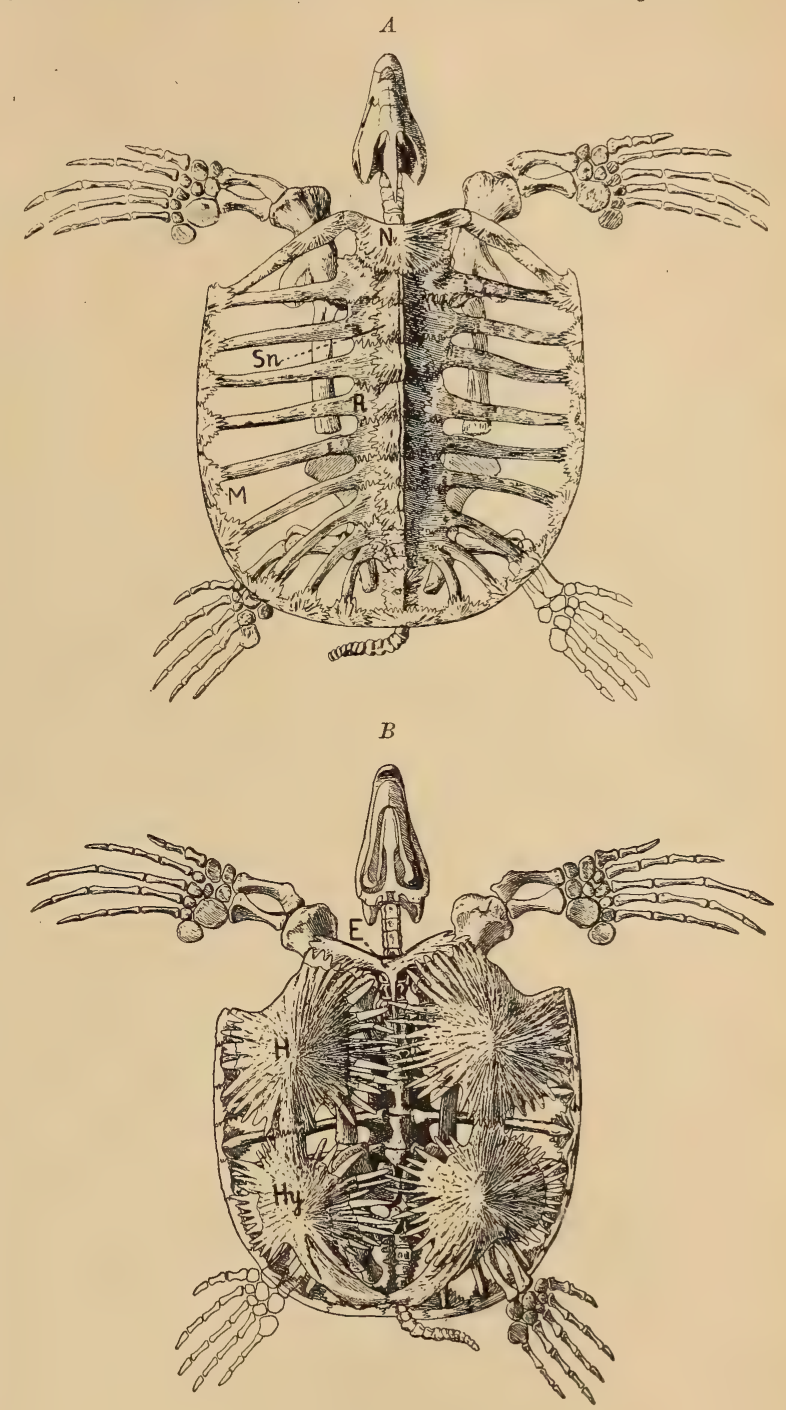

Fig. 399.

Archelon ischyros Wieland. Ob. Kreide. Dakota. $A$ von oben. $B$ von unten. $N$ Nuchalplatte, hinter derselben 11 Sn Supraneuralplatten und eine Pygalplatte, $R$ Rippen, $M$ Marginalia, $E$ Entoplastron, $H$ Hyoplastron, $H y$ Hypoplastron. 1/48 nat. Gr. (Nach Wieland.) 
Psephophorus v. Meyer. Schädel dicker, kürzer und relativ größer als bei Dermochelys. Rücken- und Bauchpflaster aus einem dichten Mosaik von kleinen, stets ungekielten Knochenplatten bestehend. Mitteleocän, Oligocän, Miocän, Pliocän. Europa. Miocän. Maryland. Obereocän. ?Ägypten.

\section{Familie. Protostegidae.}

Rückenschild stark reduziert, Rippen mit ihrer größeren Hälfte über den Discus hervorragend. Marginalia vorhanden. Plastron kräfiig, nur wenig reduziert. Entoplastron Tförmig. Epiplastra sehr klein; Hyoplastron und Hypoplastron sehr groß, fingerförmig gelappt. Xiphiplastron kurz. Eine Lederhaut mit eingelagerten Knochen wahrscheinlich vorhanden. Schläfenregion überdacht. Parietalia mit absteigenden Fortsätzen. Ruderfüße mit drei oder melır Krallen. Ob. Kreide. Oligocän.

Protostega Cope. Prämaxillare zu einem kurzen Schnabel ausgezogen. Unterkieferäste sehr frühzeitig miteinander verschmolzen. Neuralia normal, ohne Gruben. Ob. Kreide. Nordamerika.

Archelon Wieland. (Fig. 399.) Prämaxillare zu einem großen und stark gekrümmten Schnabel ausgezogen. Unterkieferäste erst in hohem Alter miteinander verschmolzen. Nuchale sehr groß und sehr dünn. Die Neuralia sehr dünn und reduziert, das vorderste anscheinend fehlend, über den Neuralia und den proximal plattenartig verbreiterten (9 Paar) Rippen, eine Reihe (11) dünner, median gekielter Supraneuralplatten, die offenbar wie bei Dermochelys in der inneren Lederhaut eingebettet waren. Entoplastron Tförmig. Ob. Kreide. S. Dakota. Nordamerika.

Protosphargis Cap. Ca. $3 \mathrm{~m}$ große Schildkröte, nicht vollständig erhalten. Plastron ähnlich dem von Protostega, aber Entoplastron nicht beobachtet. Marginalia vorhanden. Ob. Kreide. (Scaglia). Valpolicella bei Verona.

Pseudosphargis Dames. Schädelfragment groß, ca. $38 \mathrm{~cm}$ breit, $15 \mathrm{~cm}$ hoch. Sehr ähnlich Dermochelys aber mit absteigenden Fortsätzen der Parietalia. Ob. Oligocän. Norddeutschland. Möglicherweise eine Dermochelide.

\section{Familie. Cheloniidae. Meerschildkröten.}

Rückenschale gewöhnlich herzförmig, flach, in der Regel noch mit Fontanellen zwischen Marginalia und Costalia, Plastron mit 9 Knochen, gewöhnlich mit mittlever und seitlicher Fontanelle, nur durch Ligamente mit der Rückenschale in Verbindung. Schläfenregion vollstündig überdacht. Pavietalia mit absteigenden Fortsätzen. Der ganze Panzer von dichten Hornschildern bedeckt. Ruderfüße mit 1-2 Krallen. Obere Kreide bis jetzt.

Die lebenden Meerschildkröten Chelonia Latr. (Fig. 390), (Chelone Brgt., Eretmochelys) und Caretta Rafinesque (Thalassochelys Fitz.) (Fig. 400), von denen letztere in erwachsenem Zustand eine vollständig verknöcherte Rückenschale besitzt (5 Costalia), sind auf tropische und gemäßigte Meere beschränkt. Chelonia fossil : ? Eocän von Nordamerika (p. p. Puppigerus Cope). ? Mitteleocän von Europa und Ägypten. Mitteloligocän von Belgien. Unvollständige Reste, ebenso wie von Caretta im Miocän und Pliocän von Europa. Allopleuron Baur. (Fig. 401.) Durch das langgestreckte, schmale Rückenschild und das vorne ausgeschnittene, große Nuchale ausgezeichnet. Obere Kreide von Belgien. Nahestehende, wenn nicht idente Reste sind aus gleichaltrigen Sedimenten von England bekannt.

Argillochelys Lyd. Ähnlich Caretta, aber nur mit Costalia. Eocän. England, Belgien.

Eosphargis Lyd. ${ }^{1}$ ) Rückenpanzer sehr stark reduziert nur von Nuchale, Neuralia Costalia, Pygalia und Marginalia zusammengesetzt. Unteres Eocän. England, Belgien.

1) Nach einer freundl. schriftl. Mitteilung von Herrn Prof. Dr. Dollo, stellt derselbe Eosphargis auf Grund neuer Funde zu den Cheloniidae. 
Eochelone Dollo. Schädel dick, niedrig. Choanen sehr weit vorne. Rückenpanzer gestreckter wie bei Chelonia, ungekielt. Mitteleocän. Belgien. Chelyopsis, Bened. Aus dem Oligocän von Belgien und Norddeutschland, Peritresius Cope aus der oberen Kreide, Lembonax Cope aus dem Eocän, Scyllomus Cope aus dem Miocän, Procolpochelys Hay aus dem Miocän der Vereinigten Staaten sind alle auf mehr oder weniger dürftige Reste begründet und mit Ausnahme der letzteren im System unsicher.

Nahe verwandt mit den Cheloniidae sind die auch von manchen Autoren als selbständige Familie betrachteten Toxochelydae, deren Rückenpanzer mit dem Plastron leicht gelenkt, deren Vorderfuß zum mindesten 2 Krallen besitzt und noch nicht vollständig als Ruderfuß entwickelt ist.

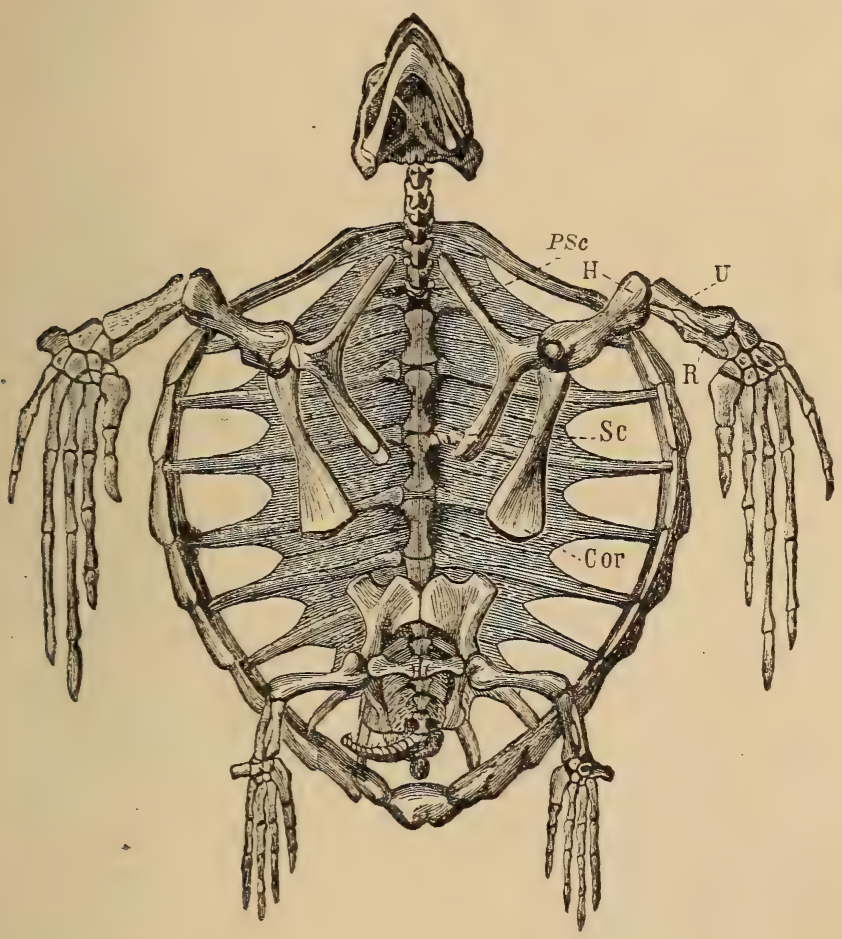

Fig. 400 .

Skelett von Caretta L. sp., aus dem Mittelmeer. Von unten gesehen. Das Plastron ist entfernt. Cor Coracoid, PSc Procoracoid. Sc Scapula, $H$ Humerus, $R$ Radius, $U$ Ulna.

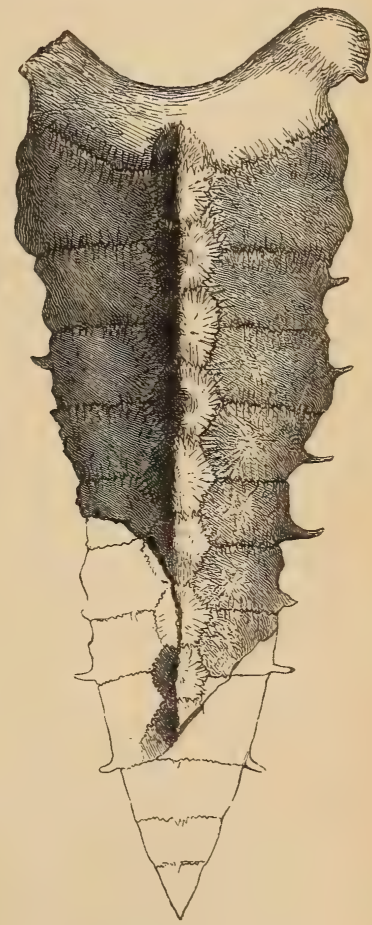

Fig. 401.

Rückenschild von Allopleuron Hofmanni Gray. $\mathrm{Ob}$ Kreide. Petersberg bei Haestricht, Holland. $1 / 8$ nat. Gr.

Hierher gehört Toxochelys Cope und Porthochelys Williston aus der oberen Kreide von Nordamerika, von denen letztere wohl entwickelte Nasalia besitzt, die der ersteren fehlen. ? Cynocercus Cope. Obere Kreide. Kansas.

Auch die Desmatochelydae mit Desmatochelys Williston, die mit großen Nasalia ausgestattet sind, aus der Kreide von Kansas dürften hier mit? Neptunochelys Wieland und? Atlantochelys Agass. anzureihen sein.

\section{Familie. Dermatemydidae.}

Rückenschale und das große Plastron wollständig verknöchert und zumeist durch feste Naht miteinander verbunden. Nuchale mit oder ohne rippenähnliche 
Fortsätze. Neuralia in der Zahl gewöhnlich reduziert. 11-12 Paare von Marginalia. Schläfengegend nicht überwölbt. Schwanz kurz, aus procölen Wirbeln. Obere Kreide bis jetzt.

$\mathrm{Zu}$ dieser gegenwärtig in Zentralamerika verbreiteten Familie ( $D$ erma . temys Gray) wird eine ganze Anzahl fossiler Formen gestellt, so: $B$ asilemys Hay, Compsemys Leidy, Adocus, Agomphus, Zygoramma, Homorophus Cope aus der oberen Kreide. Alamosemys, Hoplochelys, Kallistina Hay, Notomorpha, Baptemys, Anosteira Leidy aus dem Eocän. Xenolchelys Hay aus dem Oligocän, sämtliche aus den Vereinigten Staaten Anosteira auch aus dem Oligocän von England. Trachyaspis H. v. Meyer aus dem Oberen Mitteleocän. Miocän von Europa und Afrika.

Von der Familie der Cinosternidae (Claudius Cope, Mexiko, Stauro. typus Wagl. Zentralamerika, Cinosternum Spix (Aromochelys) Nord- und SüdSüdamerika) sowie von der Familie der Platysternidae (Platysternum Gray, Südchina, Birma, Siam, Philippinen) sind fossile Vertreter bis jetzt nicht mit Sicherheit nachgewiesen.

\section{Unterordnung. Trionychia. Flußschildkröten.}

Rücken und Bauchschild unvollständig verknöchert, mit rauher, wurmförmiger Oberfläche, nur von Haut bedeckt, ohne Hornschilder. Marginalia vorhanden (21) mit dem Discus durch Naht verbunden (Carettochelydae), oder nur eine unvollständige Reihe im Lederrand des Discus ohne festen Zusammenhang mit demselben oder fellend. Entoplastron platten- (Carettochelys) oder stabförmig. Epiplastron von Hyplastra nur durch eine Naht (Carettochelys) oder durch das Entoplastron getrennt. Plastron in der Regel mit großer Fontanelle. Becken mit dem Plastron nicht fest verbunden. Hals in vertikaler Ebene in die Schale zurückziehbar, Halswirbel ohne oder nur mit kurzen Querfortsätzen. Zehen gelenkig verbunden und mit Schwimmhaut umgeben, vorn und hinten mit 2 (Carettochelydae) oder 3 Krallen (Trionychidae). Obere Kreide bis jetzt.

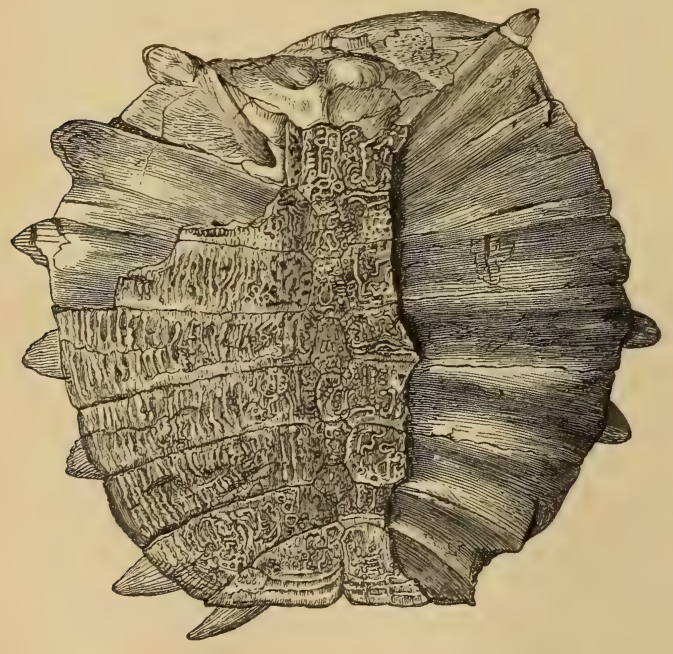

Fig. 402.

Rückenpanzer von Trionyx Styriacus Peters. Miocäne Braunkohlenschichten von Eibiswald, Steiermark. 1/4 nat. Gr. (Nach Peters.) Die rauhen Hautknochen des Rückenpanzers haben sich auf der rechten Hälfte ron den Rippen abgelöst.
Unter den Schildkröten lassen die Trionychia den allgemeinen Organisationsplan dieser Reptilien noch deutlich erkennen. Der Panzer ist schwach ausgebdilet, das Plastron zeigt in der Regel große Fontanellen und ist mit der Rückenschale durch Haut verbunden (ausgenommen Carettochelys, wo eine feste Verbindung des soliden Plastron erfolgt). Das Rückenschild besteht gewöhnlich aus einer unvollständigen Decke von Verknöcherungen, aus welcher die Rippenenden meist frei herausragen.

$\mathrm{Zu}$ der durch die einzige auf Neu-Guinea vorkommenden Gattung Carettochelys Ramsay repräsentierten und durch die obengenannten Merkmale von der Trionychiidae 
verschiedenen Familie der Carettochelyidae dürfte aller Wahrscheinlichkeit nach Pseudotrionyx Dollo aus dem Mitteleocän von Belgien und England gehören.

Die zahlreichen, noch jetzt lebenden Trionychiidae (ca. 26 Arten) halten sich in den größeren Flüssen der gemäßigten und heißen Zone in Asien, Afrika und Nordamerika auf, sie fehlen in Australien und Südamerika. Die fossilen Reste dürften zum größten Teil zu der noch lebenden Genus Gattung Trionyx Geoffr. (Fig. 402) gehören und sind als Amyda Oken, Aspideretes, Conchochelys, Helopanoplia, Axestemys (Axestus), Temnotrionyx Hay, Platypeltis Fitzinger, Castresia de Stefano etc. beschrieben worden. Die ältesten Reste finden sich spärlich in der oberen Kreide von Nordamerika, zahlreiche Arten dagegen werden aus allen Ab. teilungen des Tertiärs von Europa, Afrika, Ostindien, Nordamerika genannt.

\section{Ordnung. Parasuchia. ${ }^{1}$ )}

Körper eidechsenartig und in der Regel mehr oder weniger mit Knochenplatten gepanzert. Frontalia und Parietalia paarig. Zähne thecodont. Äußere Nasenlöcher getrennt. Zwischen Nasen- und Augenöffnungen ein großer präorbitaler Durchbruch. Zwei Paar Schläfenlöcher. Foramen parietale fehlt fast stets. Quadratbein unbeweglich. Kein harter Gaumen. Schultergürtel mit wohl entwickelter Clavicula. Augen ohne Scleroticaring. Gelenkpfanne des Beckens von Ilium, Ischium und Pubis gebildet. Wirbel platycöl bis amphicöl. Rippen zweiköpfig. Schwanzwirbel mit Chevron bones. Extremitäten fünfzehig. Femur meist S-förmig gekrümmt. Episternum dolchförmig. Außer dem Postfrontale ein Postorbitale vorhanden. Unterkiefer noch mit ansehnlichen Resten des Meckelschen Knorpel ebenso wie die Crocodilier. Trias.

Die auf die Trias beschränkte, kurz- und langschnauzige Formen umfassende Gruppe der Parasuchia gleicht zwar durch ihren äußeren Habitus, die Panzerung des Rumpfes und die Bezahnung sehr den Crocodilia, allein ihr Skelettbau weicht doch so erheblich von diesen $\mathrm{ab}$, daß eine direkte Vereinigung mit diesen nur eine gezwungene wäre.

1) Brïhl C., Das Skelett der Crocodiliden, Wien 1862. - Fraas E., Die schwäbischen Trias-Saurier. Stuttgart 1896 etc. 1. c. Aetosaurus crassicanda n. sp. Jahreshefte d. Ver. f. vat. Naturkunde in Württemberg 1907. - Fraas O., Aëtosaurus ferratus. Württemb. naturw. Jahreshefte 1867. XXIII. - Mc. Gregor, The Phytosauria, with especial reference to Mystriosuchus and Rhytidodon. Mem. Americ. Mus. Nat. Hist. Vol. IX. Part. II. 1906. ibid. ausführl. Literatur! Huene F. v., Die Dinosaurier der europ. Triasformation etc. Geol. Pal. Abhandl Suppl. I. 1907-08. Kapitel 9, ferner Zentralblatt für Mineral., Geol. u. Pal. 1909 Nr. 19. Über Erythrosuchus, Vertreter der neuen Reptilordnung Pelycosimia , und Beiträge zur Kenntnis und Beurteilung der Parasuchier. Geol. und Pal. Abhandl. N. F. Bd. 10 (14). 1911. - Huene und Lull R. S., The Triassic Reptile Hallopus. Americ. Journ. Science. Vol. 25. 1908. - Huxley Th., Quart. journ. geol. Soc. London 1859 vol. XV p. 440-460 und 1875 XXXI p. 423. - Jaekiel O., Über einen neuen Belodonten aus d. Buntsandstein ron Bernburg. Sitzungsberichte Gesellsch. naturforsch. Freunde. Berlin. Nr.5. 1910. - Meyer H. v., Uber Belodon. Palaeontographica Bd. VII, X und XIV. - Newton E. T., Reptiles from the Elgin Sandstone. Philos. Trans. 1894. vol. 185. Williston J. W., Notice on some new Reptiles from the upper Trias of Wyoming. Journ. of Geol. XII. 1904. - Wodward A. S., On a new Dinosaurian Reptile (Scleromochlus) etc. Quart. Journ. Geol. Soc. Lond. 63. 1907. On some fossil Rept. Bones from the State of Rio Grande do Sul. Brazil. Geol. Magaz. 5. 1908 Dec. 5. 
Die allgemeine Morphologie des Schädels erinnert ebenso wie der Schultergürtel sehr an die Rhynchocephalen, besonders an Protorosaurus; mit den Ichthyosauriern teilen die langschnauzigen Formen neben anderen gemeinsamen Merkmalen die von den Prämaxillarien gebildete lange Schnauze, die rückwärtige Stellung der durch die Nasalia getrennten äußeren Nasenlöcher sowie die Lage der durch die Vomeres geschiedenen Choanen. Größere Verwandtschaft scheint zu den Dinosauriern, speziell nach v. Huene zu den Theropoden (Thecodontosauridae, Plateosauridae) zu bestehen, was durch die gemeinsame charakteristische Präorbitalöffnung und namentlich durch die große Ähnlichkeit der Beckenelemente Pubis und Ischium, sowie den Bau der Extremitäten dokumentiert wird.

Die Parasuchier sind in der Hauptsache wasserliebende Reptilien, welche die Flüsse, Seen und Sümpfe der Triaszeit bevölkerten. Die Bewegung im Wasser dürfte manchen von ihnen durch Schwimmhäute zwischen den Zehen sowie durch den langen als Ruder wirkenden Schwanz erleichtert worden sein. Die lange Schnauze verschiedener Vertreter dürfte außer zum Ergreifen der Nahrung auch zum Wühlen im Schlamm gedient haben. Sie finden sich in der Trias von Deutschland, England, Schottland, den Vereinigten Staaten von Nordamerika, in Indien und Südafrika.

\section{Familie Phytosauridae. Me. Gregor.}

Ansehnliche große Parasuchier mit sehr langer, beinahe vollständig von den Prämaxillaria gebildeler Schnauze. Äußere Nasenlöcher von den Nasalia begrenzt, weit zurück in der Nähe der nach oben gerichteten Augen gelegen, innere Nasenlöcher direlit darunter. Schädeldach rauh skulptiert. Seitliches Schläfenloch groß, die rïckwärtige knöcherne Begrenzung des kleinen, oberen Schläfenloches (hinterer Schläfenbogen) in der Regel nach abwärts verlagert. Epipterygoid und Septomaxillare vorhanden. Wirbel platycöl. Zwei Sacralwirbel. Bauchrippen vorhanden. Hals, Rücken und Schwanz und manchmal auch der Bauch mit knöchernen Platten bedeckt. Trias.

Mesorhinus Jaekel. Schädel $1 / 2 \mathrm{~m}$ lang. Obere Schläfenlöcher hinten vollständig knöchern von den Parietalia umgrenzt. Ein kleines Foramen parietale erhalten. Zähne ziemlich groß, spatelförmig komprimiert. Choanen hinter den Nasenlöchern in einer von den inneren Flügeln der Palatina und Pterygoidea gebildeten Rinne mündend. Mittlerer Buntsandstein. Bernburg.

Staganolepis Huxley. Rückenpanzer aus 2 Reihen schmaler stark skulpierter Mittelplatten und je einer Seitenreihe. Bauchpanzer aus 6 bis 8 Reihen vierseitiger Platten gebildet. Pubis Theropoden ähnlich. Unt. Obere Trias, Elgin. Schottland.

Phytosaurus Jäger (Belodon H. v. M.) (Fig. 403, 404). Der bis über $1 \mathrm{~m}$ große Schädel nach vorne in eine lange, allmählich sich verschmälernde, aber hohe Schnauze auslaufend; vordere Zähne mit rundlichem Querschnitt, hintere Zähne hinten und vorne zugeschärft, glatt. Rückenpanzer mit zwei Reihen großer Platten, seitlich mit.je einer Reihe kleinerer Randplatten. Vordere Teil der Bauchseite gepanzert. Keuper Württemberg (Naturalienkabinett Stuttgart). Franken. Braunschweig. Trias. Vereinigte Staaten von Nordamerika. Mystriosuchus E. Fraas. An dem bis $80 \mathrm{~cm}$ langen Schädel ist $\operatorname{die}^{2} / 3$ der Länge einnehmende,schlanke, vorne löffelartig verbreiterte Schnauze von dem eigentlichen sehr hohen, schmalen Cranium scharf abgesetzt. Die zahlreichen Zähne, von denen 23-24 auf das Prämaxillare treffen, 
schwach gerieft meist mit rundem Querschnitt. Rückenpanzer aus vier Reihen gleichartiger Platten zusammengesetzt. Ventral ein aus ca. 35 kleinen Knochenplättchen zusammengesetztes Halsschild. Stubensandstein (mittl. Keuper) Württemberg.

Rhytidodon (Rutiodon) Emmons (Fig. 405). Nahe verwandt, wenn nicht identisch mit Mystriosuchus. Ca. 26 präsacrale Wirbel. Trias. Vereinigte Staaten v. Nordamerika.
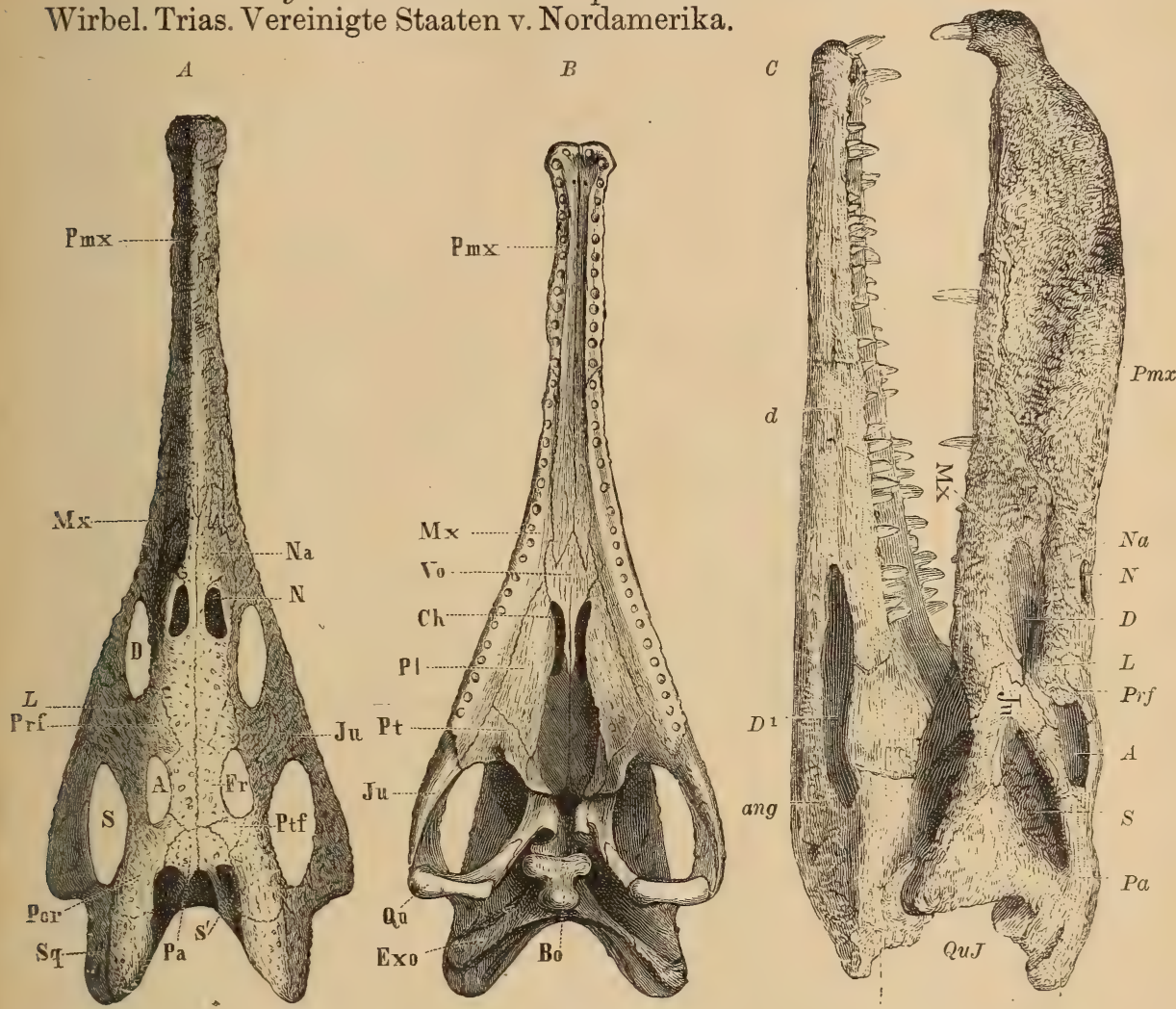

Fig. 403.

Phytosaurus (Belodon) Kapffi H. v. Meyer. A Schädel von oben, $B$ von unten, $C$ Schädel und Unterkiefer aus dem oberen Keuper (Stubensandstein) von Stuttgart (ca. 1/7 nat. Gr.). A Augenhöhle, $N$ Nasenloch, $S S^{\prime}$ Schläfenöffnungen, $D$ Präorbitalöffnung, $P m x$ Zwischenkiefer, Mx Maxillare, Fr Frontale, Prf Präfrontale, L Lacrimale, Pa Parietale, Ptf Postfrontale, Por Postorbitale, Sq Squamosum, Quj Quadratojugale, Q Quadratum, Ju Jugale, Vo Vomer, $P l$ Palatin, $P t$ Transversum, das Pterygoid schließt sich nach innen an und ist beschattet. Bo Basioccipitale, davor das Basisphenoid, Ch Innere Nasenlöcher (Choanen) d Dentale, ang Angulare, art Articulare, $D^{\prime}$ Meckelscher Knorpel.

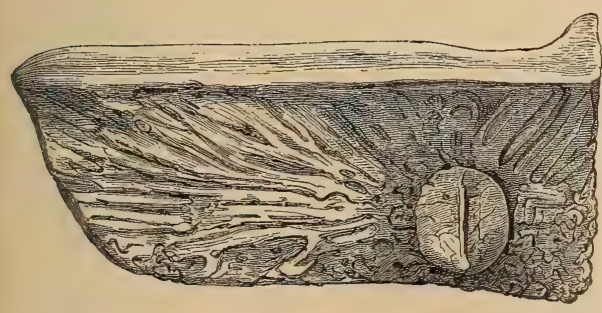

Fig. 404 .

Phytosaurus (Belodon) Kapfi H. V. Meyer. a Rückenplatte. 1/3 nat. Gr. (Nach H. v. Me yer.)

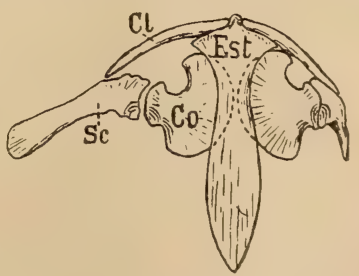

Fig. 405 .

Schultergürtel von Rhytidodon (? Phytosaur?s) carolinensis Emmons. Trias. Nord-Carolina (nach Mc. Gregor). Ventralansicht. Linke Scapula in normaler Stellung. Die rechte verschoben, um die Verhältnisse klarer zu zeigen. Est Episternum, Co Coracoid, Sc Scapula, Cl Clavicula. 
Palaeorhinus Williston. Schädel $73 \mathrm{~cm}$ lang. Nasenlöcher relativ weit voran. Obere Trias. Wyoming.

Parasuchus Huxley ? Trias. (Maleri Sandstein). Indien.

? Episcoposaurus Cope. Trias. Texas. Neu-Mexiko.

? Clepsysaurus Lea. Trias. Nordamerika.

Rileya v. Huene. Unt. ob. Trias. England.

? Erythrosuchus Broom. em. Huene. Schädel Parasuchier ähnlich mit 2 Schläfenöffnungen und kleiner Präorbitalöffnung aber Prämaxillaria kurz und Nasenlöcher an der Schnauzenspitze. Femur pelycosaurierähnlich. Trias. Südafrika. Neuerdings betrachtet von Huene diese Form mit Scaphonyx. A. S. Woodward aus der Trias von Rio Grande do Sul (Brasilien) als Vertreter einer eigenen Ordnung der Pelycosimia.

\section{Familie Aetosauridae. (Pseudosuchia Zittel.)}

Meist kleine zierliche Parasuchier mit kurzer Schnauze. Außere Nasenlöcher seitlich, weit vorne zwischen den kurzen Prämaxillaria und den großen Nasalia gelegen.. Innere Nasenlöcher weit vorne gelegen oder nach rückwärts verschoben. Schädeldach meist glatt. Seitliche und obere Schläfenlöcher gro $\beta$ und normal ausgebildet (ausgenommen Aetosaurus). Augen sehr groß, seitlich. Wirbel amphicöl bis platycöl. 2-4 Sacralwirbel. Vorderfüße kürzer als die hinteren. Rücken in der Regel mit zwei Reihen quer oblonger Knochenplatten bedeclit. Trias.

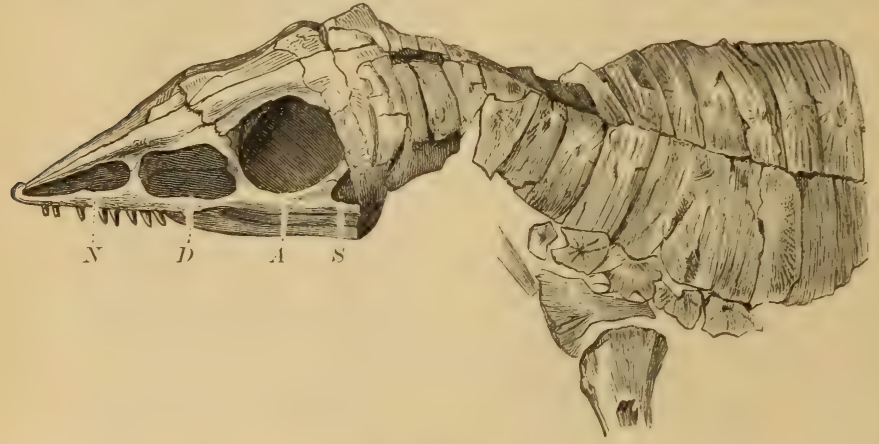

Fig. 406.

Aëtosaurus ferratus. Fraas. Stubensandstein (Mittl. Keuper). Heslach bei Stuttgart. Kopf und vorderer Teil des Rumpfes. 1/2 nat. Gr. (Nach O. Fraas.) $A$ Augenhöhle, $S$ seitliches Schläfenloch, $D$ präorbitale Offnung, $N$ Nasenloch.

Aetosia $u$. rus O. Fraas. (Figur 406.) Körper langgeschwänzt. (A. ferratus bis $0,86 \dot{\mathrm{m}}, A$. crassicauda ca. $1,50 \mathrm{~m}$ lang); der Rücken mit zwei Längsreihen von großen quer vierseitigen, strahlig verzierten Platten, Seiten und Bauch mit kleineren, fast quadratischen Platten gepanzert. Schädel dreieckig, zugespitzt. Zähne nur in der vorderen Kieferpartie. Zwischen den großen Augenöffnungen und den seitlichen fast am Schnauzenende gelegenen ansehnlichen Nasenlöchern eine weite Präorbitallücke. Anscheinend nur ein Paar kleine seitliche Schläfenöffnungen. Nasalia sehr groß. Prämaxillaria winzig. 28 präsacrale Wirbel, 2 Sacralwirbel. Zähne zugespitzt. Im Stubensandstein von Heßlach bei Stuttgart auf einer Platte 24 vollständige Individuen von verschiedener Größe. Naturalienkabinet Stuttgart.

Dyoplax O. Fraas. U. Keuper. Württemberg. Typothorax Cope. Trias. Neu-Mexiko. Stegomus Marsh. Obertrias. Connecticut.

Erpetosuchus Newton. Schädel vorne verschmälert und abgerundet, Augen oval nach oben und vorne gerichtet. Obere Schläfenlöcher rundlich, seitliche dreieckig. Präorbitalöffnung stark verlängert, niedrig. Innere Nasenlöcher getrennt, weit vorn gelegen. Zähne konisch, schlank und rückwärts gekrümmt, nur auf der vorderen Kieferhälfte. Wirbel amphicöl. Am Hals und Rücken zwei Reihen quer vierseitiger, rauh skulptierter Platten beobachtet. Unt. Obere Trias. Elgin. 
Proterosuchus Broom. Trias. Südafrika.

Ornithosuchus Newton. Schädel vorn zugespitzt, sehr ähnlich Aetosaurus (11 cm lang). Präorbitalöffnung sehr groß. Obere Schläfenlöcher klein, rundlich, seitliche hoch, $>$-förmig. Innere Nasenöffnungen weit zurück gelegen. Zähne leicht gekrümmt, zugeschärft und fein gekerbt. Wirbelcentra amphicöl. Von den 3 Sacralwirbeln die 2 hinteren anscheinend miteinander verschmolzen. Pubis lang und schmal. Panzerplatten rundlich, Unt. Obere Trias. Elgin.

Scleromochlus A. S. Woodward. Ca. $20 \mathrm{~cm}$ lang, große langgeschwänzte Form mit schlanken hohlen Extremitäten, von denen die hintere fast doppelt so groß als die vordere ist. Schädel verlängert, dreieckig. Präorbitalöffnung groß. Zähne nicht beobachtet. 21 Präsacralwirbel, 4 Sacralwirbel. Becken mit dem schlanken gedrehten Pubis Theropoden-ähnlich. Rückenpanzer fehlt, Bauchpanzer von dicht liegenden Bauchrippen gebildet. Unt. Obere Trias. Elgin.

? Hallopus Marsh. 3 Sacralwirbel. Obere Trias. Wyoming.

\section{Ordnung. Crocodilia. ${ }^{1}$ )}

\section{(Mesosuchia und Eusuchia Huxley. Crocodilia vera Koken.)}

Körper eidechsenartig, langgeschwänzt, meist von an. sehnlicher oder mittlerer Größe. Äußere Nasenlöcher am vorderen Endeder Schnauze vereinigt. Innere Nasenlöcher (Choanen) vereinigt, weit nach hinten gerückt. Maxillaria, Palatina und zuweilen auch Pterygoidea in der Mittellinie zusammenstoßend und ein geschlossenes Gaumendach (harter Gaumen) bildend. Das unpare Parietale ohne Foramen. Zwei Paar Schläfenöffnungen. Quadratbein unbeweglich. Zähne

1) Abel O., Zentralbl.f. Mineral. etc. Bd. VIII. 1907. - d'Alton u. Burmeister, Der fossile Gavial von Boll. Halle 1854. - Ammon L. v., Über jurassische Krokodile aus Bayern. Geognost. Jahresh. 1905. 18. Jg. - Andrews C. W., A descriptive Catalogue of the Tertiary Vertebrata of the Fajûm etc. London. British Museum 1906. - On some new Steneosaurs etc. Annals a. magaz. Nat. hist. Vol. 3. Serie 8. 1909. - Arthaber v., Beiträge zur Kenntnis etc. des Genus Metriorhynchus. Beitr. zur Paläontol. u. Geol. Österreich-Ungarns etc. Bd.19. 1906; ferner Zentralbl. f. Mineral., etc. Bd. VIII. 1907. Auer E., Uber einige Krokodile der Juraformation. Palaeontographica 55. Bd. 1908 bis 1909. ibid. Literatur! Ferner Zentralblatt für Mineral., Geol. u. Pal. Bd. VIII. 1907. - Bronn H. G. und Kaup J., Über die gavialartigen Reptilien der Liasformation. Stuttgart 1841. Folio. - Deslongchamps-Eudes J. A., Mém. sur les Teléosauriens de l'époque jurassique du departement du Calvados. Mém. Soc. Lin. Norm. 1863. vol. XIII. - Deslongchamps-Eudes, Eugène, Notes paléontologiques 1863-1869. - Dollo L., Première note sur les crocodiliens de Bernissart. Bull. Mus. R. Not. Belg. T. 2. 1883. - Fraas E., Die Meerkrokodilier (Thalattosuchia) d. ob. Jura etc. Palaeontographica 49. Bd. 1902. - Gilmore A., Leidyosuchus etc. Proc. U. St. Nat. Mus Vol. 38. 1910. - Hooley $R$. W., On the skull and greater Portion of the skeleton of Goniopholis etc. Quart-Journ. Geol. Soc. London 53. 1907. - Hulke $J . W$., Skeletal anatomy of the Mesosuchia based on fossil Remains from Peterborough. Proceed. zool. Soc. London 1888 part. IV p. 417. - Huxley Th., Notes on the specific and generic Characters of recent Crocodilia. Proceed. Linn. Soc. (Zoology) 1860. vol. IV pt. I. - Koken E., Die Dinosaurier, Crocodiliden und Sauropterygier des norddeutschen Wealden. Paläont. Abh. von Dames und Kayser 1887. III. Die Reptilien d. norddeutschen unt. Kreide. Z. d. deutsch. geol. Ges. 35. 1883, ferner ibid. 40. 1888. - Lambe L., On a new Crocod. Genus etc. Trans. Roy. S. Canada. 3. Ser. Vol. I. Sect. 4. Oktober 1908. - Leeds E., On Metriorhynchus etc. Quart. Journ. Geol. Soc. Vol. 54. 1908. - Lortet L., Les Rep. foss d. Bassin du Rhône. Arch. Mus. d'hist. nat. de Lyon. Vol. II. 1892. - Lydekker R., Siwalik Crocodilia etc. Palaeont. Indica. 1886. Ser. X Bd. III. S. 209-235. - Nopcsa F. v., Über Neustosaurus etc. Centralblatt für Mineralogie etc. 1903. - Oven $R$., On the Associat. of dwarf Crocodilier with the dim. Mammals etc. Quart. Journ. geol. 
thecodont. Augen meist ohne Scleroticaring. Wirbel platycöl oder procöl. Zwei Sacralwirbel. Bauchrippen vorhanden. Brustgürtel mit knorpeligem Sternum, aber ohne Clavicula. Pubis vonder Gelenkpfanne fürden Femurausgeschlossen. Vorderfüße mit fünf, Hinterfüße mit vier Zehen und einem rudimentären Stummel, zum Gehen und durch Schwimmhäute zwischen den Zehen auch zum Schwimmen geeignet. Ganzer Körper mit hornigen Schuppen bedeckt, unter welchen sich meist auf Rücken und Bauch Reihen von Hautknochen be. finden. Lias - jetzt.
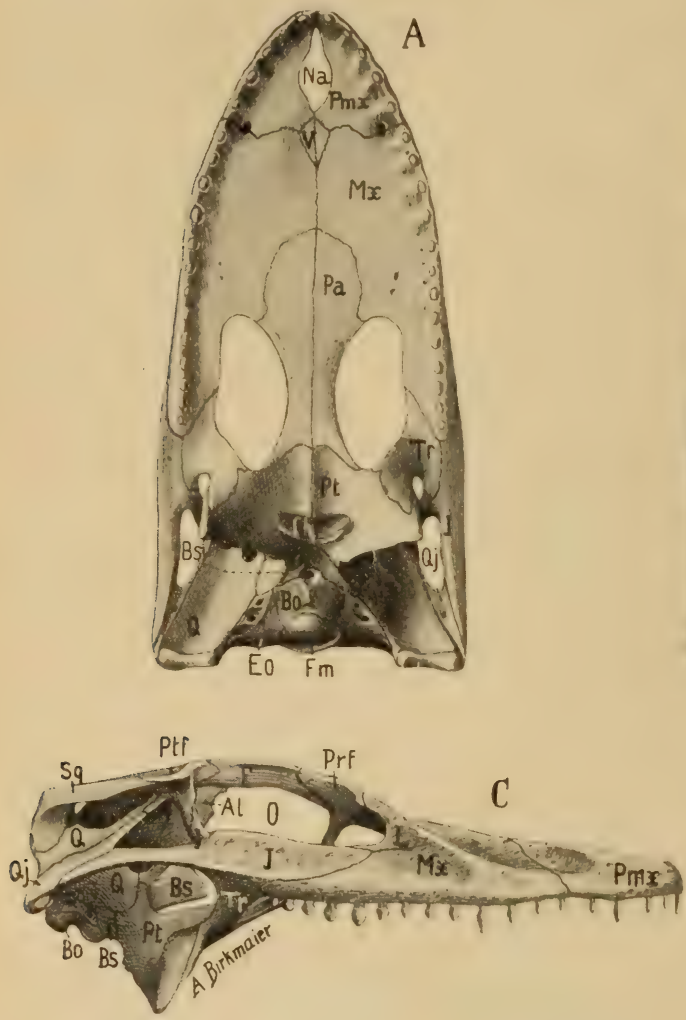
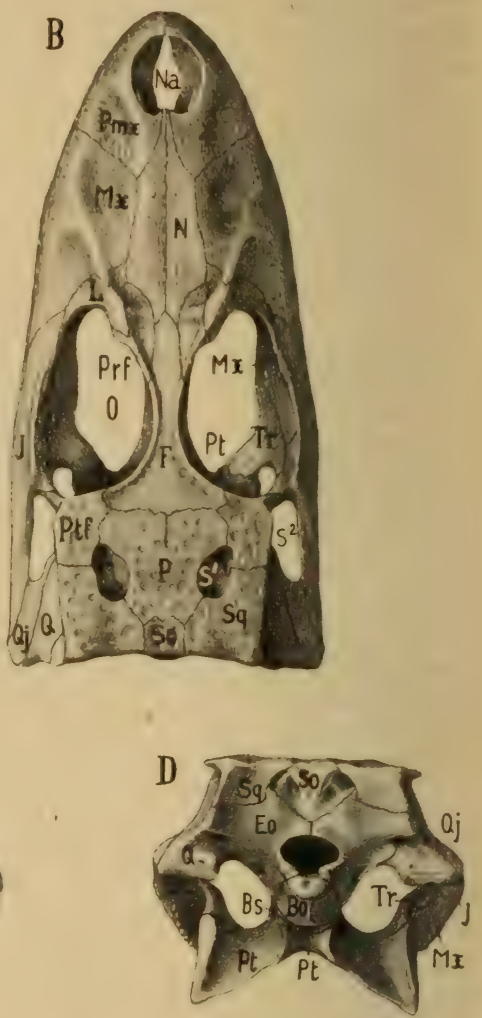

Fig. 407 .

Schädel von Caiman niger. Spix rezent. Brasilien. $A$ von unten, $B$ von oben, $C$ von der Seite, $D$ von hinten. Na Nasenlöcher, $O$ Augen, $S^{1}, S^{2}$ Obere und seitliche Schläfenlöcher, Ch Choanen, $P m x$ Prämaxillare, $M x$ Maxillare, $N$ Nasale, $F$ Frontale, Prf Präfrontale, Ptf Postfrontule, L Lacrimale, $P$ Parietale, SO Supraoccipitale, Sq Squamosum, Bo Basioccipitale, Bs Basisphenoid, Eo Exoccipitale laterale, $A l$ ? Alisphenoid (Orbitosphenoid), $Q j$ Quadratojugale, Q Quadratum, Pt Pterygoid, Tr Transversum, Pa Palatin, $\nabla$ Vomer, Fm Foramen magnum. $3 / 5$ nat. Gr.

Die wasserliebenden Krokodile oder Panzerechsen nehmen durch ihre innere Organisation unter den lebenden Reptilien die höchste Rangstufe ein. Sie ähneln durch ihre äußere Erscheinung am meisten den Parasuchiern und Lacertiliern, unterscheiden sich aber von beiden durch fundamentale Unterschiede im anatomischen Bau.

Soc. Vol. XXXV. 1879. Monograph on the fossil Reptilia of the Wealden- and Purbeck-Formations. Pal. Soc. 1853-1864. - Monograph on the fossil Reptilia of the London clay. Ibid. 1849-58. - Sacco F., I Cocodrilli del Monte Bolca. Mem. 
Der Schädel (Fig. 407) ist oberflächlich, meist rauh skulptiert. Die rundlichen Augen sind bei den älteren Formen ringsum geschlossen und nach oben oder nach der Seite gerichtet, bei den jüngeren und den rezenten Krokodilen durch eine Ausbuchtung äußerlich mit den seitlichen Schläfenlöchern verbunden. Nasenlöcher vereinigt, am Schnauzenende gelegen; beide Schläfenlöcher wohl entwickelt. Die Größe der seitlichen Schläfenlöcher steht gewöhnlich im umgekehrten Verhältnis zu jener der oberen. Das meist kleine Parietale und gewöhnlich auch das Frontale ist bei ausgewachsenen Individuen unpaar. Die obere Schläfenöffnung wird hinten und außen vom Squamosum, vorne vom Postfrontale begrenzt, das seinerseits zugleich als hintere Begrenzung des Auges mit seinem absteigenden Fortsatz nebst dem Jugale und Transversum die vordere bzw. untere Umrahmung des hinten und oben vom Quadratojugale umfaßten seitlichen Schläfenloches übernimmt. Am Vorderrande der Orbita beteiligen sich Präfrontalia und Lacrimalia von verschiedener Größe. Die langen, dreieckigen Nasalia erreichen mit ihrer Spitze bei den kurzschnauzigen und einem Teil der langschnauzigen Krokodile (z. B. Tomistoma) die Prämaxillaria, bei den ersteren sogar die Nasenlöcher, in welchen sie alsdann eine mediane knöcherne Scheidewand bilden können. Bei den übrigen langschnauzigen Krokodilen sind die Nasalia durch einen ansehnlichen Zwischenraum von den Prämaxillaria geschieden und vorne vollständig von den sehr langgestreckten Maxillaria umschlossen, die kurzen paarigen Prämaxillaria umgeben hier ringsum die nach oben gerichteten Nasenlöcher. Auf Grund dieser Merkmale hat man unter den Krokodilen Brevirostres und Longirostres unterschieden. Dieselben sind aber, wie aus den rezenten Formen hervorgeht, durch Übergänge miteinander verbunden, daß eine so scharfe Trennung nicht mehr gerechtfertigt erscheint.

Die Unterseite des Schädels wird zum größten Teil von dem harten Gaumen, einer die Nasenhöhle von der Mundhöhle abtrennenden knöchernen Scheidewand, bedeckt, welcher durch horizontale Ausbreitungen der Prämaxillaria, Maxillaria, ferner der Palatina und zuweilen der Pterygoidea gebildet wird und unter den Augen zwei Gaumenlöcher enthält. Durch das Zusammenstoßen der Maxillarund Palatinlamellen wird der meist vom Gaumendach ausgeschlossene paarige Vomer nur selten sichtbar (z. B. Tomistoma, Caiman niger). Infolge dieses geschlossenen Gaumendaches münden die vorne von den Vomeres umgebenen inneren Nasengänge bei den älteren Formen hinter den Palatina aus = Mesosuchia $\mathrm{Huxley} \mathrm{(Fig.} \mathrm{408);} \mathrm{bei} \mathrm{einigen}$ cretaceischen, den tertiären und rezenten Crocodiliern hingegen, bei

R. Acc. Science Torino. Ser. 2. T. 45. 1894. - Sauvage H. E., Contrib. à l'étude des poiss. e. d. Reptiles du Jur. et du Cret. Vertébrés foss. du Portugal. Mém. des trav. géol. du Portugal. Lisbonne 97. 98. - Vaillant Leon, Etudes zool. sur les Crocodiliens foss. tertiaires de St. Gérand le Puy, Annales des sciences géolog. 1872. vol. III. - Voeltzkow A., Biologie u. Entwickl. d. äußeren Körperformen von Croc. madagascariensis. Abhandl. d Senkenbg. naturf. Gesellsch. II. Bd. 1899. ibid. Literatur!

- Williston S. W., Americ. Amphic. Crocodiles. Journ. Geol. Vol. XIV. 1906. Woodward A.S., On the Literature and nomenclature of British fossil Crocodilia. Geol. Mag. 1885. 3 Dec. II. p. 496. - On two Mesoz. Crocod. etc. Annales Mus. La Plata. Paleont. Argentina IV. 1896. 
welchen die Pterygoidea durch horizontale Verbreiterungen an der Ausbildung des harten Gaumens teilnehmen, liegen die inneren Nasenlöcher $($ Choanen $=C h$ ) innerhalb der Pterygoidea in ganz geringer Entfernung vom Hinterhaupt (Eusuchia Huxley Fig. 409). Die bei den Crocodiliern verknöcherten Spenoidalia - bisher allgemein als Alisphenoide bezeichnet - sollen nach E. Gaupp die Orbitosphenoide repräsentieren. Das Transversum ist stets wohl ausgebildet. Beim lebenden ausgewachsenen Gavial kommen neben den Palatina große halbkugelige Knochenblasen vor, die mit den über dem Gaumendach verlaufenden inneren Nasengängen kommunizieren und offenbar als Luftbehälter dienen (Fig. 409).

Der Unterkiefer besteht jederseits aus den bekannten 6 Stücken. Das Articulare ist pneumatisch. Die im hinteren Drittel befindliche Öffnung für den Meckelschen Knorpel ist sehr groß. An der suturösen Symphyse der beiden Äste kann bei den langschnauzigen Formen auch das Operculare teilnehmen.

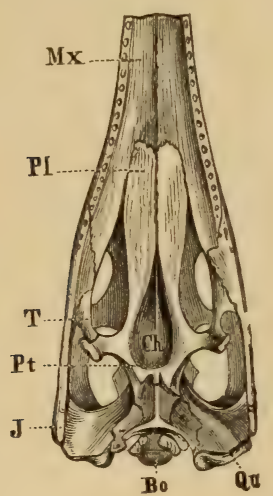

Fig. 408.

Pelagosaurus temporalis Blv. Ob. Lias Celvados. Unterseite des Schädels mit mesosuchen Choanen $(C h)$.

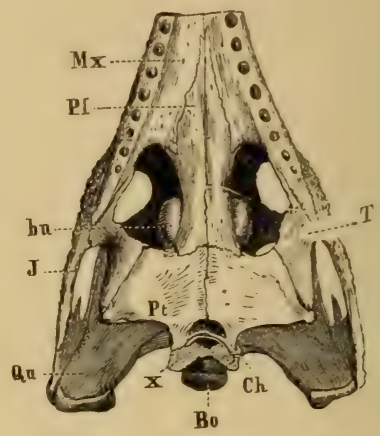

Fig. 409 .

Unterseite des hinteren Schädelteiles vom Gavial mit eusuchen Choanen. $M x$ Oberkiefer, $P l \mathrm{Pala}-$ tinum, Pt Pterygoid, $J$ Jugale, $T$ Transversum, Q Quadratum, Bo Basioccipitale, Ch Choanen, $x$ Offnung des intertympanischen Kanals, bu knöcherne Luftblasen.

Die zahlreichen in tiefen Alveolen stehenden kegelförmigen, häufig vorne und hinten zugeschärften, glatten oder gestreiften Z Zähne sind auf die Kiefer beschränkt; die Zahl der in einer Reihe stehenden, häufig in Größe und Form verschiedenen Zähne, bleibt bei ein und derselben Art, zuweilen sogar bei einer ganzen Gattung, konstant.

Die Wirbelsäule besteht aus 24-25 präsacralen, 2 Sacralund 35 oder mehr Schwanzwirbeln. Bei den lebenden Crocodiliern sind alle Wirbel mit Ausnahme von Atlas und Epistropheus, des 2. Sacralwirbels und des vordersten Schwanzwirbels procöl, bei den mesozoischen in der Regel platycöl, die oberen Bögen meist durch eine bleibende Sutur an dem Wirbelkörper befestigt und die Dornfortsätze kräftig entwickelt. Zum $\mathrm{Hals}$ werden die vorderen $7-9 \mathrm{Wir}$ bel gerechnet. Der A tlas (Fig. 410) besteht aus 4 Stücken: aus einem ventralen unpaaren, jederseits mit einer spießförmigen, einköpfigen Rippe versehenen Mittelstück, das bald für das Zentrum (Hypocentrum), bald für ein Intercentrum, bald für eine Hypapophyse angesehen wird, ferner aus zwei seitlichen, symmetrischen Bogenstücken 
und einem unpaaren dorsalen Dachstück, welches meist als das Rudiment eines besonderen Wirbels (Proatlas), von manchen Autoren auch als Hautknochen, angesehen wird. Der Atlas ist mit dem großen Processus odontoideus des Epistropheus durch Sutur verbunden. Die 5-7 folgenden kürzeren Halswirbel besitzen wohlausgebildete Gelenk- und Dornfortsätze, auf der Ventralseite häufig eine Hypapophyse, außerdem am oberen Bogen jederseits einen Querfortsatz und in der vorderen Hälfte des Wirbelkörpers, ziemlich tief unten, einen zweiten Gelenkhöcker. Die kurzen zweiköpfigen Halsrippen sind distal beilförmig ausgebreitet. An den zwei vordersten Rückenwirbeln sind Diapophysen und Parapophysen nur noch wenig voneinander entfernt, und vom dritten Rückenwirbel an rückt der Capitularfortsatz auf den oberen Bogen, verbindet sich mit der stark verlängerten Diapophyse und bildet an der Basis derselben eine Art von Staffel, welche das Capitularende der langen zweiköpfigen, mit dem Brustbein verbundenen

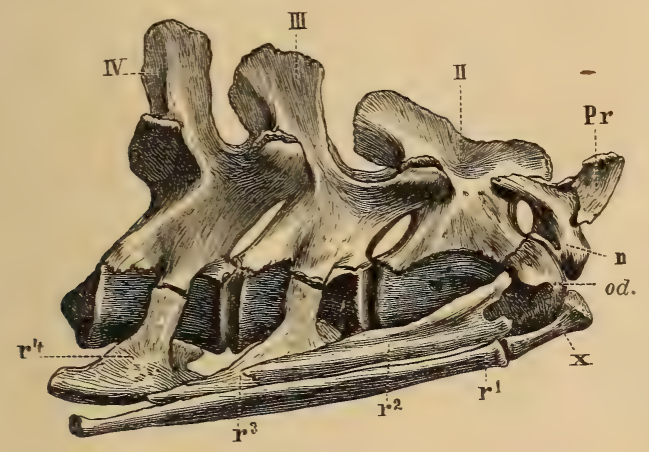

Fig. 410.

Die vier vordersten Halswirbel von Crocodilus vulgaris. $\operatorname{Pr}$ Proatlas (Dachstück), $n$ Seitenstück des Atlas, $x$ Basalstück des Atlas, $p$. od. eigentliches Zentrum des Atlas (processus odontoideus), II. III. IV. zweiter bis vierter Halswirbel, $r^{1}-r^{4}$ Rippen.

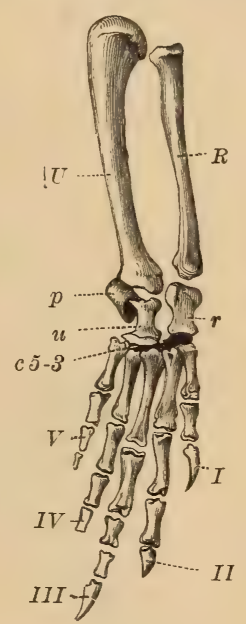

Fig. 411.

Vorderfuß vom Krokodil. $R$ Radius, $U$ Ulna, $r$ Radiale, $u$ Ulnare, $p$ Pisiforme, $c^{4}-{ }^{3}$ Carpalia der distalen Reihe, $I-V$ erster bis fünfter Finger.

Rippen aufnimmt, während sich das Tuberculum an das verlängerte Ende der Diapophyse anfügt (Fig. 317). In den folgenden Rückenwirbeln rückt die Staffel immer weiter nach außen, bis sie schließlich die Gelenkfläche des Tuberculum erreicht und mit dieser verschmilzt, so daß die Rippen des hintersten Rückenwirbels einköpfig werden. Die $(4-6)$ Lendenwirbel haben lange, von den oberen Bögen entspringende Querfortsätze aber keine Rippen. Die kurzen, kräftigen Sacralrippen sind in der Regel distal verbreitert und proximal durch Naht mit den oberen Bögen und den Wirbelkörpern verbunden. Der letzte Sacralwirbel ist opisthocöl, der erste Schwanzwirbel bikonvex. Die Wirbel der vorderen Schwanzhälfte tragen ziemlich lange, horizontal abstehende Fortsätze, welche wie die Sacralrippe durch Naht an der Vereinigung vom oberen Bogen und Zentrum befestigt sind. Hämapophysen, sog. Chevron bones, heften sich mit Ausnahme der vordersten und der hintersten Schwanzwirbel an den ventralen Hinterrändern der Wirbelkörper an. 
Mit dem knorpeligen, großen, rhombischen Sternum des Brustgürtels treten 6-9 Brustrippen in Verbindung; dem Sternum aufgelagert ist das stabförmige Episternum. Eine Clavicula fehlt dem Brustgürtel. Die Scapula ist ziemlich lang, distal und proximal verbreitert, das Coracoid ebenfalls verlängert, der Scapula ähnlich und von einem Foramen (supracoracoideum) durchbohrt. Der schlanke, etwas gekrümmte $\mathrm{Hum}$ erus besitzt wohlausgebildete Gelenke und einen ansehnlichen Processus lateralis. Die Ulna ist - abgesehen von den Metriorhynchidae - meist etwas länger als der Radius. Die proximale Reihe des Carpus (Fig. 411) besteht in der Regel aus einem Radiale und Ulnare, sowie einem kleinen an die Hinterseite der Ulna befestigten Pisiforme, das durch Bänder mit dem V. Metacarpus verbunden ist. Die distale Reihe ist nur sehr unvollständig verknöchert. Die drei radialen Zehen sind etwas stärker als die ulnaren.

Hinter dem Brustbein liegen in der Bauchwand in der Regel 7 Querreihen von Bauchrippen.

Das Becken (Fig. 412) besteht aus 3 Knochen, wovon sich jedoch nur zwei (Ilium und Ischium) an der Bildung der in ihrem

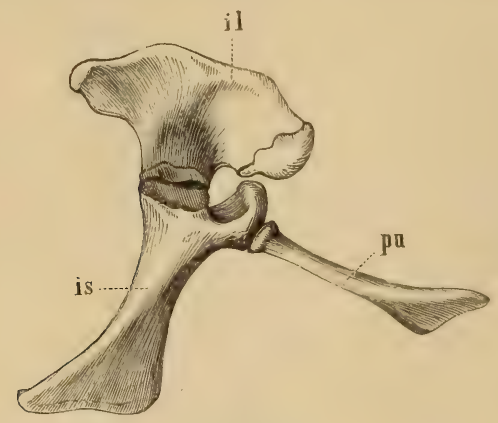

Fig. 412.

Rechte Beckenhälfte vom Krokodil. il nium, Is Ischium, pu Pubis.

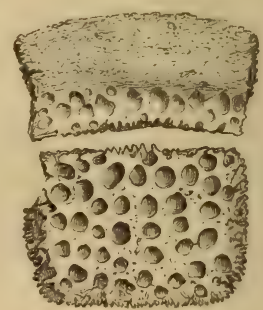

Fig. 413.

Eine aus zwei Stücken zusammengesetzte Bauchplatte von Diplocynodon von außen.

Grund von einem Foramen durchbohrten Gelenkpfanne beteiligen, während das nach vorne und innen gerichtete, distal mehr oder weniger spatelförmig verbreiterte $\mathrm{Pub}$ is davon ausgeschlossen ist. An diese Verbreiterung schließt sich ein knorpeliges Epipubis an, das sich mit dem der Gegenseite durch Band vereinigt. Mit dem kräftigen, am Oberrand bogig gerundeten und nach vorne und hinten verlängertem Ilium treten die 2 distal verbreiterten Sacralrippen in Verbindung; die ventral beilartig verbreiterten Ischia stoßen in der Symphyse zusammen. Der Femur ist länger und schlanker als der Oberarm ohne vorspringenden inneren Trochanter. Tibia und Fibula sind schlanke, fast gleich lange und gleich starke Knochen. In der proximalen Reihe des Tarsus liegen 2 größere Knöchelchen, ein Calcaneus oder Fibulare (nach hinten in einen ansehnlichen Fortsatz für die Sehne des Hauptstreckmuskels ausgezogen) und ein Astragalus (Tritibiale). Die distalen Tarsalia sind meist auf $2 \mathrm{Knöchelchen} \mathrm{beschränkt,} \mathrm{ebenso} \mathrm{ist} \mathrm{der}$ 5. Finger bis auf das 5. Metatarsale reduziert. Die drei inneren Zehen der Vorder- und Hinterfüße sind mit spitzen Krallen bewehrt. 
Sämtliche rezente und fast alle Crocodilia besitzen auf dem Rücken, zuweilen auch auf dem Bauch, ein aus knöchernen Platten bestehendes (auf dem Rücken) rauh skulptiertes $\mathrm{Haut}$ skelett (Fig. 413), über welches noch stets Hornschilder gelagert liegen. Die lebenden Formen leben in der Hauptsache im süßen, einige auch im brackischen Wasser.

\section{Familie. Teleosauridae.}

Wirbel platycöl, Schnauze sehr lang, schmal. Zähne zahlreich, schlank. Nasalia durch einen weiten Zwischenraum von den kleinen Prämaxillaria getrennt. Choanen am hinteren Ende der Palatina ausmündend. Augen ringsum geschlossen, erheblich kleiner als die sehr großen, oberen unregelmäßig vierseitigen

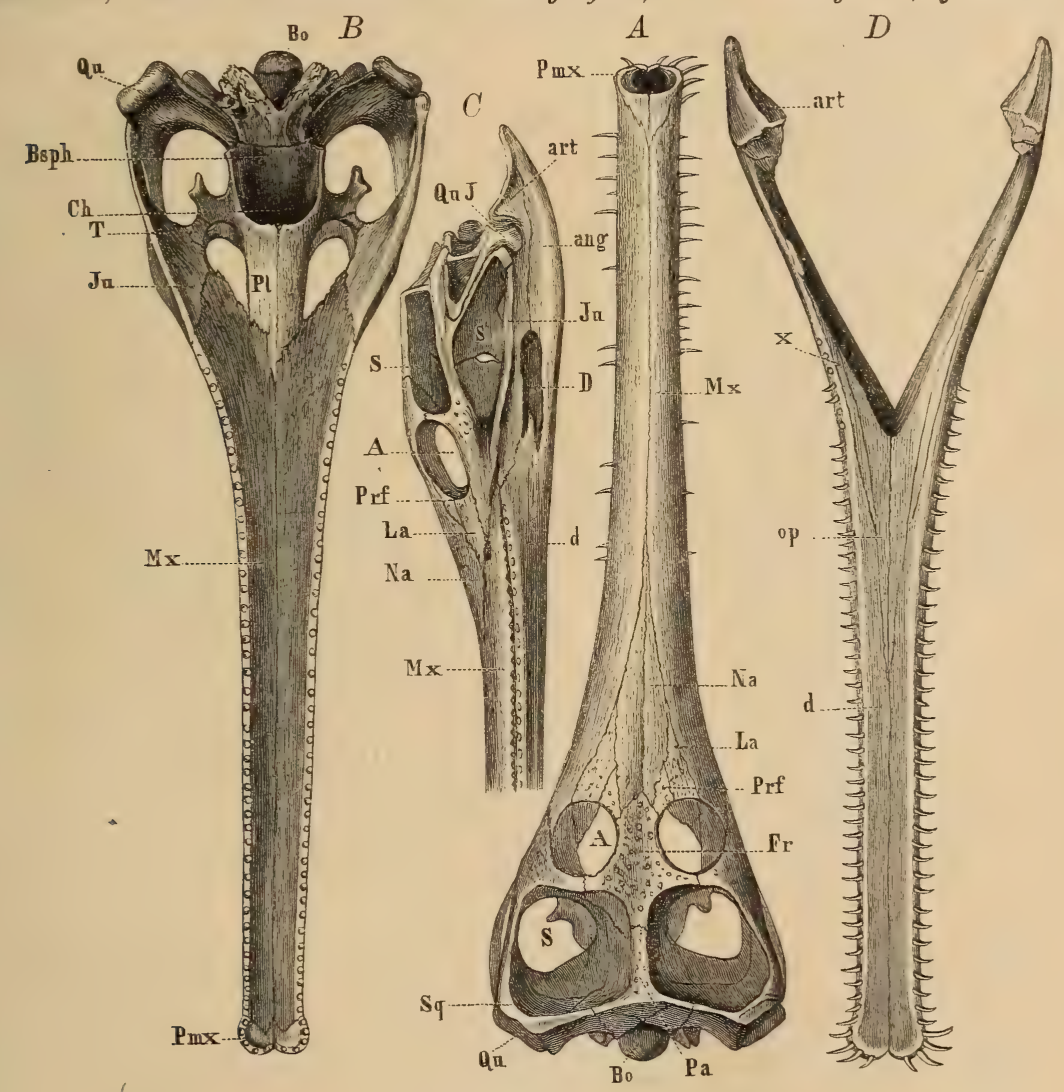

Fig. 414.

Teleosaurus Cadomensis Cuv, sp. Großoolith. Caen, Calvados. Schädel $A$ von oben, $B$ von unten, $C$ von der Seite. $D$ Unterkiefer (nach Eug. Deslong champs.) Bo Basioccipitale, Qu Quadratum, QuJ Quadrato-Jugale, Ju Jugale, Bsph Basisphenoid, Pl Palatinum, $M x$ Oberkiefer, $P m x \mathrm{Zwischen-}$ kiefer, Na Nasale, $F r$ Frontale, Prf Präfrontale, La Lacrimale, $P a$ Parietale, Sq Squamosum. $A$ Augenhöhle, Ch innere Nasenlöcher (Choanen), $S$ oberes, $S^{\prime}$ seitliches Schläfenloch, $D$ Durchbruch (Heckelscher Knorpe1), art Articulare, op Operculare, $d$ Dentale, $x$ Complementare des Unterlkefers.

Schläfenlöcher. Zuweilen eine kleine Präorbitalöffnung vorhanden. Präfrontale klein, Lacrimale groß. Vorderfüße kaum halb so lang als die Hinterfüße. Rücken mit zwei Reihen von größeren, Bauch mit mehreren Reihen von kleineren Knochenschildern bedeckt. Marin. Jura. ? Ob. Kreide.

Die Teleosauridae stehen in ihrer ganzen Erscheinung und Größe dem lebenden Gavial nahe, unterscheiden sich aber durch kleineren Kopf, 
kürzere und zierlichere Vorderfüße, starken Bauchpanzer, platycöle Wirbel, die Lage der Choanen, die sehr großen oberen Schläfenöffnungen und den Mangel von Hypapophysen an den Halswirbeln. Die fünfzehigen noch als Schreitfüße entwickelten Extremitäten dürften den in der Hauptsache wohl im Wasser sich aufhaltenden Tieren eine wenn auch schwerfällige, watschelnde Bewegung im Schlamm und im Seichtwasser gestattet haben.

Stenosaurus Geoffroy (Mystriosaurus Kaup, Leptocranius Bronn, Sericodon H. v. M.). Schädel sehr flach, Schnauze stark verlängert, vorne löffelförmig verbreitert. Bei manchen Formen kleine Präorbitalöffnung vorhanden. Augen und die sehr großen, lang gestreckten oberen Nasenlöcher nach oben gerichtet. Die zahlreichen Zähne zweikantig. Am hinteren Ende

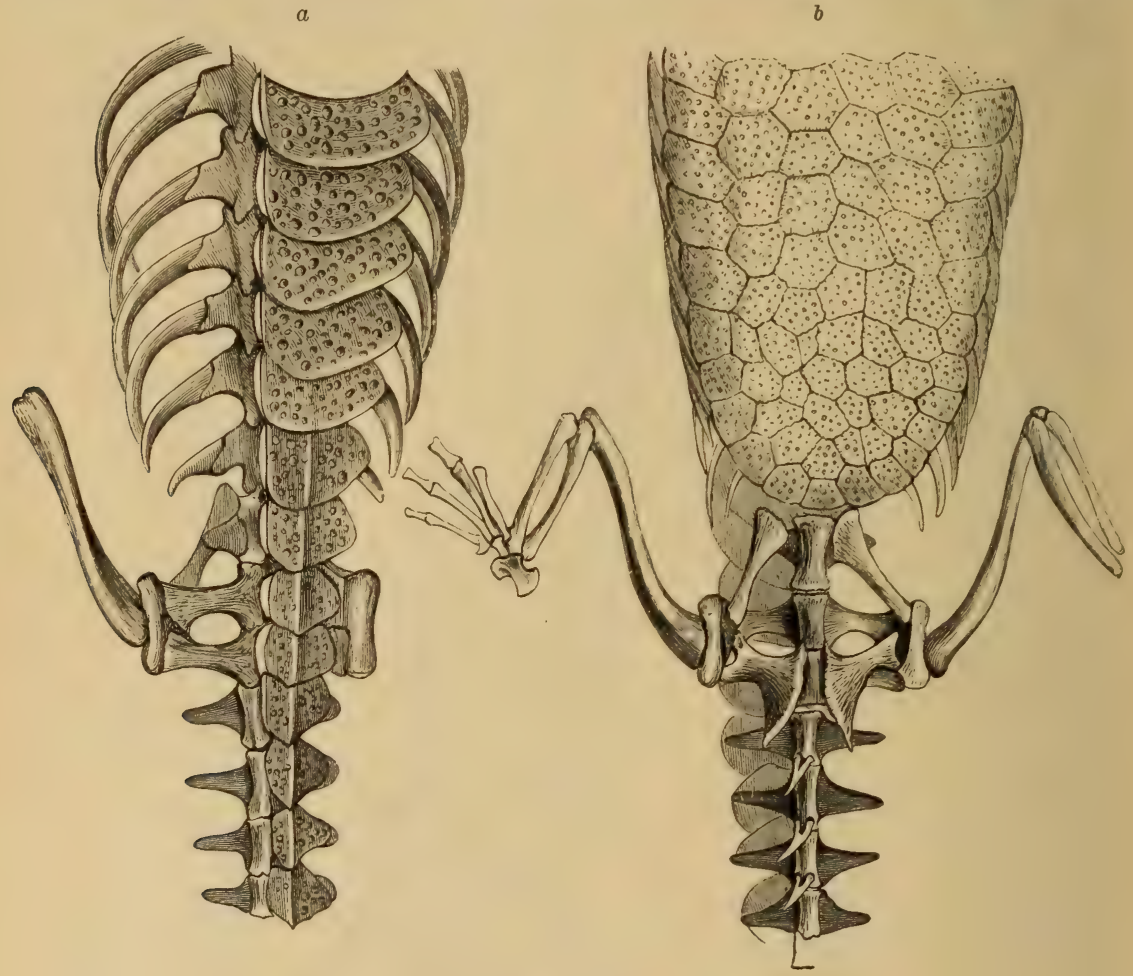

Fig. 415 .

Teleosaurus Cadomensis Cuv. sp. Ein Stück der Rücken-, Lenden- und Schwanzregion mit a Rücken- und b Bauchpanzer. Restauriert. (Nach E. Deslongehamps.)

der Palatina die rundliche große Choanenöffnung. Nicht selten die verknöcherten Ringe der Luftröhre erhalten. Oberer Lias bis Malm. Europa. Madagaskar. Besonders schöne Reste finden sich im oberen Lias von Württemberg (Boll, Holzmaden), Franken (Banz) und den Oxford von England und Frankreich. St. bollensis Jäger aus dem oberen Lias wird $4 \mathrm{~m}$ und St. Chapmanni ca. $6 \mathrm{~m}$ lang.

Pelagosaurus Bronn (Fig. 408) aus dem oberen Lias der Normandie England und Württemberg bleibt erheblich kleiner als Stenosaurus und hat bei einem höheren Schädeldach die Augen statt nach oben nach den Seiten gerichtet, ferner breitere obere Schläfenlöcher. Die Choanen enden vorn in einer Spitze, die sich zwischen die Palatina einschiebt.

Teleosaurus Geoffroy (Fig. 414 u. 415). Schädel vor den Augen schroff zur langen, dünnen Schnauze verschmälert. Zähne abwechseld höher 
und tiefer stehend, zahlreicher und schlanker als bei Stenosaurus. Dogger bis Malm.

Teleidosaurus Deslonch. Suchodus Lydd. Aeolodon v. Meyer. Crocodileimus Jourd. Gnathosaurus Münster. Oberer Jura.

? Teleorhinus Osborn. Obere Kreide. Nordamerika.

\section{Familie. Metriorhynchidae. (Thalattosuchia E. Fraas.)}

Wirbel platycöl, Schnauze mäßig lang, hinten breit. Nasalia groß, bei manchen Formen die Prämaxillaria erreichend. Choanen am hinteren Ende der Palatina. Präfrontalia sehr groß, dachartig über die Augen vorspringend. Lacrimalia klein. Augen vorn und hinten ausgebuchtet, mit Scleroticaring, kleiner als die oberen Schläfenlöcher. Haut ohne Knochenplatten. Marin. Ob. Dogger-Neocom.

Die Metriorhynchiden sind im hohen Grade dem Wasserleben angepaßte nackthäutige Crocodilier, ihre Vorderextremität zeigt die Um. wandlung eines Schreitfußes zu einem Schwimmfuß - einer Paddel in geradezu klassischer Weise, eine Erscheinung, die sich teilweise auch an der Hinterextremität (Tarsus von Geosaurus) geltend macht; ihre hintere, nach abwärts geknickte Schwanzpartie stand offenbar wie bei Ichthyosaurus mit einer vertikalen Schwanzflosse in Verbindung. Wie die Teleosauridae sind sie auf landbewohnende - bisher unbekannte - Vorfahren zurückzuführen.

Metriorhynchus. H. v. Meyer. Schnauze gedrungen, allmählich sich verschmälernd, mehr oder weniger lang. Bei manchen Formen erreichen die Nasalia die äußere Nasenöffnung. Zähne gewöhnlich zahlreich, gekielt mit 2 scharfen Kanten. Zahlreiche Arten im oberen Dogger und im Oxford von Nordfrankreich und England. Jura von Patagonien.

Dacosaurus Quenstedt. (Plesiosuchus $\mathrm{O}$ wen, Plerodon H. v. M.) Schädel bis $1 \mathrm{~m}$ lang, $1 / 2 \mathrm{~m}$ breit. Schnauze mäßig lang, gedrungen, vorn gerundet. Zähne kräftig, leicht gekrümmt mit seitlicher Schneide. Nasengrube ausschließlich von den Prämaxillaria umschlossen. Ein fast vollständiges fast $6 \mathrm{~m}$ langes Skelett von D. maximus aus Staufen bei Giengen a. d. Br. im Stuttgarter Museum. Oberer Jura, Schwaben, Franken, Frankreich, England.

Geosaurus Cuvier (Cricosaurus Wagner,

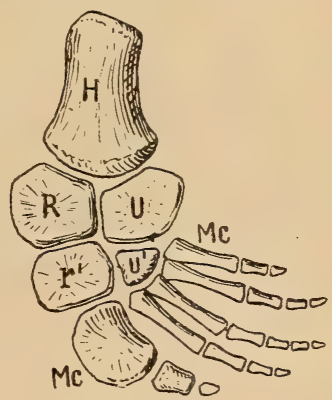

Fig. 416.

Vorderextremität von Geosaurus suevicus E. Fraas zeigt die Umbildung des Gehfußes zur Paddel. 1/3 nat. Gr. $H$ Humerus, $R$ Radius, $U$ Ulna, $r^{\prime}$ Radiale, $U^{\prime}$ Ulnare, IC Metacarpalia. Nach E. Fraas.

Rhacheosaurus H. v. Meyer). (Fig. 416). Schädel fast glatt mit spitzer Schnauze und tiefliegenden kleinen Augen. Die Tarsalia in polygonale Scheiben umgewandelt. Oberer Jura. Franken und Schwaben.

Neustosaurus Raspail. Unteres Neocom. Vaucluse. ? Enaliosuchus Koken. Neocom. Norddeutschland.

\section{Familie. Macrorhynchidae.}

Wirbel platycöl. Schnauze stark verlängert, schmal, hinten scharf vom cranialen Teil absetzend. Zähne rundlich, längs gefurcht und gerippt. Nasalia schmal und lang, die nach hinten verlängerten, spitzen Fortsätze der Prämaxillaria erreichend. Choanen am hinteren Ende der Palatina, jedoch seitlich von den beträchtlich vergrößerten Pterygoiden begrenzt. Augen nach der Seite gerichtet, oval, hinten ausgebuchtet und äußerlich mit den seitlichen Schläfenöffinungen verbunden, wenig kleiner als die oberen Schläfenlöcher. Rücken- und Bauchpanzer vorhanden. Oberer Jura bis untere Kreide. 
Die Macrorhynchiden, die sich nur fossil in brackischen und Süßwasserablagerungen des Purbeck, Wealden und der unteren Kreide finden, zeigen nahe verwandtschaftliche Beziehungen zu den Gavialidae.

und England.

Pholidosaurus H. v. M. (Macrorhynchus Dunker). Wealden von:Hannover England.

Petrosuchus Owen. Purbeck. England. Hylaeochampsa Owen. "Wealden

\section{Familie, Atoposauridae.}

Körper klein, eidechsenartig. Schnauze kurz. Wirbel amphicöl. Augen beträchtlich größer als die oberen Schlïfenlöcher. Nasenlöcher durch die verlängerten Nasalia geteilt. Rücken mit zwei Längsreihen, unmittelbar hinter dem Kopf beginnender Platten von quer oblonger Form bedeckt. Bauchpanzer nicht beobachtet. Fossil in marinen Seichtwasserbildungen des oberen Jura.

Alligatorium Jourd. $40 \mathrm{~cm}$ lang. Hinterextremität kräftiger und länger als die vordere. Oberer Jura. Frankreich (Cerin) und Painten (Oberpfalz).

Alligatorellus Jourd. (Fig. 417.) Skelett $22 \mathrm{~cm}$ lang. Schädel dreieckig. Augen fast dreimal so groß als die oberen Schläfenlöcher. Schwanz sehr lang. Oberer Jura. Frankreich, Cerin (Ain).

Atoposaurus H. v. Meyer. Klein, eidechsenartig. Oberer Jura. Frankreich. Cerin (Ain) und Painten (Oberpfalz).

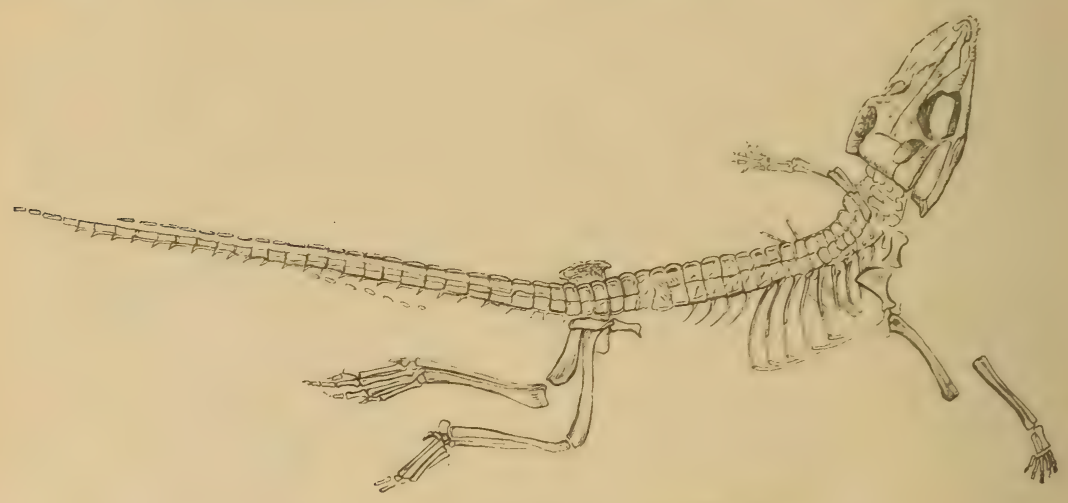

Fig. 417.

Alligatorellus Beaumonti Jourdan. Ob. Jura. Cerin, Ain. 1/2 nat. Gr.

\section{Familie. Goniopholidae.}

Körper mittelgroß. Wirbel platycöl. Schnauze breit, mäßig verlängert. Choanen weit zurückliegend, von den Palatina und Pterygoiden begrenzt. Rücken mit zwei oder mehr Reihen, vorne und hinten gelenkig verbundener Platten. Jura. Kreide. Eocän. Zumeist im Purbeck und Wealden.

Machimosaurus H. v. Meyer (Fig. 419). Zähne stumpf konisch, längs gerieft: Dogger. Malm.

Goniopholis Owen (Diplosaurus Marsh, Amphicotylus Cope). (Fig. 418). Skelett bis $2 \mathrm{~m}$ lang. Schnauze mäßig verlängert. Nasalia nicht vollständig die äußere Nasenöffnung erreichend. Augen kleiner als die Schläfengruben. Zähne (23 auf jedem Kiefer) dick, mit zwei Kanten und mit Längsfurchen. Bauchpanzer aus 7-10 Längsreihen allseitig durch Sutur verbundene Platten zusammengesetzt. Oberer Jura. Nordamerika. Purbeck und Wealden von Europa. Kreide von Brasilien und Nordamerika.

Nannosuchus, Theriosuchus. Owen. Purbeck. England.

Hyposaurus Owen, Coelosuchus Williston. Kreide. Nordamerika. 
Bernissartia Dollo. Bis $1 \mathrm{~m}$ lang. Augen größer als obere Schläfenlöcher. Nasalia die äußere Schläfenöffnung nicht erreichend. 20 Zähne auf jedem Kiefer. Vorderextremität beträchtlich kürzer als die hintere. Rückenpanzer mit mehr als 2 Reihen von Knochenplatten. Wealden. Belgien.

Notosuchus A. S. Woodward. Schädel ca. $18 \mathrm{~cm}$ lang. Kurzschnauzig. Nasalia die äußere Nasenöffnung erreichend. Eine kleine Präorbitalöffnung vorhanden. Obere Schläfenöffnung, kleiner als die großen Augen. Prämaxillare mit 4, Maxillare mit 7 Zähnen. Vorderfuß nicht viel kleiner als der hintere. Panzer nicht beobachtet.

Obere Kreide. ? Eocän. Nord-Patagonien. ebendort.

Cynodontosuchus A. S. Woodward. Von

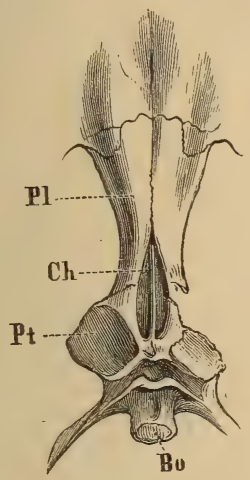

Fig. 418.

Goniopholis simus Owen. Aus dem mittleren Purbeckkalk von Swanage. Dorset. Hinterer Teil des Gaumendachs. $P l$ Palatin, Pt Pterygoid, Bo Basioccipitale, Ch Choanenöffnung. (Nach Hulke.)

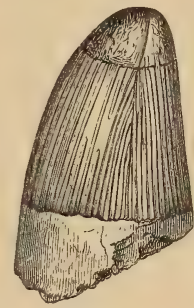

Fig. 419.

Zahn von Machimosaurus Hugi H. v. Meyer. Kimmeridge. Lindnerberg bei

Hannover. Nat. Gr.

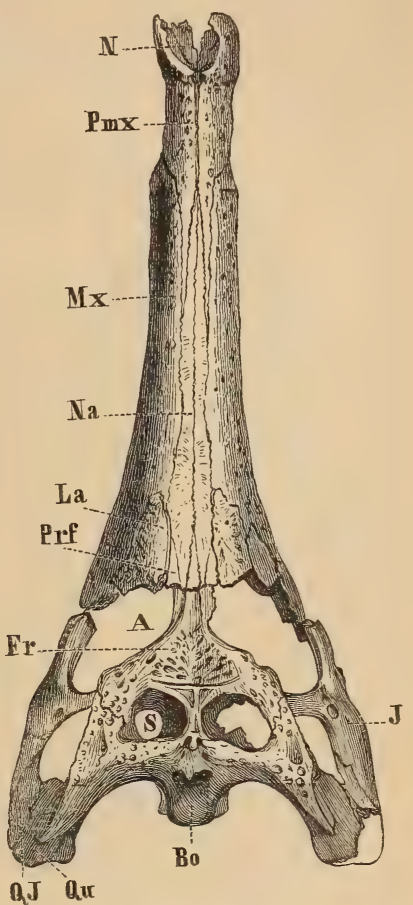

Fig. 420 .

Tomistoma (Gavialosuchus) Eggen burgensis Toula und Kail. Miocän. Eggenburg bei Horn. Niederösterreich. Schädel von oben. $1 / 10$ nat. Gr. (Nach Toula.)

\section{Familie. Gavialidae.}

Wirbel procöl. Schnauze schmal, stark verlängert. Zähne zahlreich, gleichartig zugeschärft, glatt oder fein gestreift. Nasalia weit getrennt von der äußeren Nasenöffnung. Choanen weit nach hinten gerïckt und vollständig von den Pterygoidea umgeben. Kanäle der Eustachischen Röhre ringsum geschlossen. Augen unregelmäßig oval, fast ebenso groß oder größer als die oberen Schläfenlöcher, äußerlich mit den seitlichen Schläfenlöchern verbunden. Bauchpanzer fehlt.

Fossil in marinen Uferbildungen der oberen Kreide und im Tertiär. Lebend im Süßwasser.

Thoracosaurus Leidy. Zwischenkiefer spatelförmig erweitert, an die Nasalia angrenzend. Obere Schläfenlöcher quer vierseitig. Lacrimale sehr groß, davor eine ? Präorbitalöffnung. Obere Kreide von New-Jersey, Holland, Frankreich. Schonen.

Holops Cope. Obere Kreide bis Eocän. New-Jersey.

Eosuchus Dollo. Eocän. Belgien.

Tomistoma Müller (Rhynchosuchus Huxley, Gavialosuchus Toula und Kail). (Fig. 420.) Schnauze allmählich in den cranialen Teil übergehend. Nasalia an die Prämaxillaria angrenzend. Lacrimale nicht sehr groß. Parietale klein. Vomeres an der Bildung des Gaumendaches beteiligt. Lebend 
in Borneo, Sumatra und Malaischen Halbinsel. Fossil im Tertiär des Mittelmeergebietes und Ungarn.

Gavialis Oppel (Rhamphostoma Wagl). Schnauze scharf vom cranialen Teil abgesetzt. Nasalia durch einen weiten Zwischenraum von den Prämaxillaria getrennt. Lebend im südlichen Ostindien und in Birma, fossil im Pliocän der Sivalikschichten (Ostindien) mit dem riesigen (15 m lang) Rhamphosuchus crassidens Falc und Cantley zusammen.

Leptorhamphus, Oxydontosaurus Amegh. Tertiär. Argentinien.

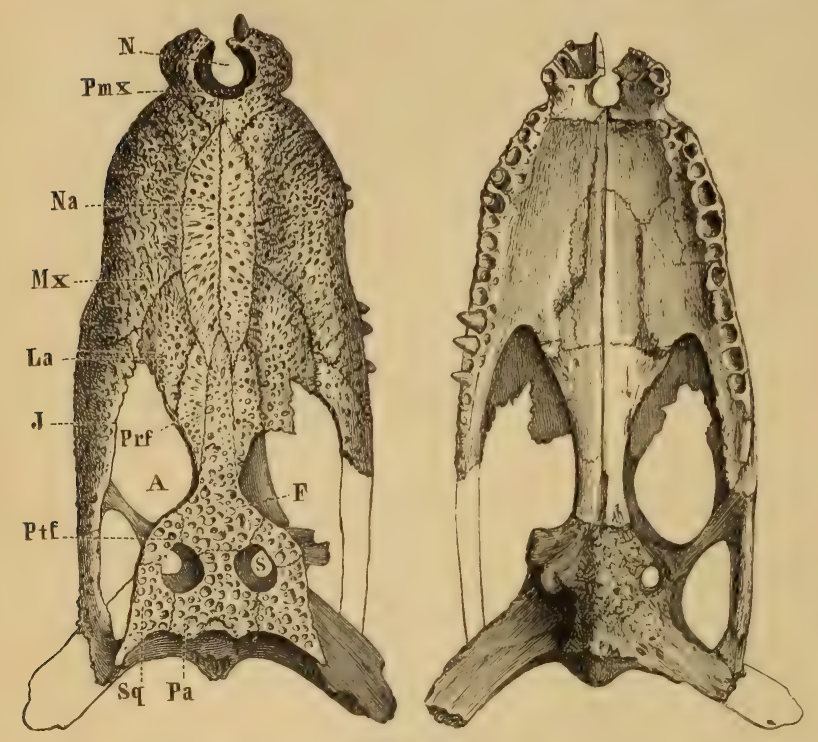

Fig. 421 .

Diplocynodon Gervaisi Aymard. Oligocän. Ronzon bei le Puy Schädel von oben und unten. $1 / 2$ nat. (ir. Sq Squamosum, Pa Parietale, $F$ Frontale, Ptf Postfrontale, Präfrontale, J Jugale, La Lacrimale, Na Nasale, $M x$ Oberkiefer, $P m x$ Zwischenkiefer, $A$ Augenhöble, $S$ oberes Schläfenloch, $N$ Nasenloch.

\section{Familie. \\ Crocodilidae.}

Wirbel procöl. Schnauze in der Regel breit und mäßig verlän. gert. Augenhöhlengrößer als die zuweilen rudimentären oberen Schläfenlöcher, mit den seitlichen Schläfenlöchern äußerlich verbunden.

Nasalia in der Regel die äußere Nasenöffnung erreichend, bisweilen eine knöcherne Nasenscheidewand bildend. Der 4. Unterkieferzahn gewöhnlich in eine Grube des Oberkiefers eingefügt. Zähne stark differenziert. Die weitzurïckliegenden Choanen vollständig von den Pterygoiden umschlossen. Rückenpanzer aus mehr als zwèi Reihen gelenkig verbundenen oder frei in der Haut liegenden Knochenplatten bestehend. Bauchpanzer vorhanden oder fehlend. Obere Kreide bis jetzt.

Diplocynodon Pomel (Fig. 421). Zähne ungleich groß, der erste Unterkieferzahn oben in eine Grube eingefügt, der 3. und 4. in einer Nische des Oberkiefers. Rücken- und Bauchpanzer stark entwickelt. Obereocän bis Miocän von Europa (besonders England, Frankreich, Deutschland). Eocän Neu Mexico.

Bottosaurus Agass. Obere Kreide. Nordamerika.

Alligator Cuv. Zähne sehr ungleichmäßig, jederseits 17-20 Zähne oben und 18-20 unten. Mit knöcherner Nasenscheidewand. Rückenpanzerplatten nicht gegenseitig gelenkig. Nordamerika. China (Jangtse).

Caiman Spix (Jaccare Gray). Fig. 407. 18-20 Zähne oben und 17-22 unten. Keine knöcherne Nasenscheidewand. Obere Schläfenöffnung klein oder fehlend. Rücken- und Bauchplatten gelenkig. Zentral- und Südamerika.

Osteolaemus Cope. Auf jeder Seite 16-17 Zähne oben und 14-15 unten. Nasalia eine knöcherne Nasenscheidewand bildend. Afrika.

Leidyosuchus Lambe. Eine Mittelform zwischen Crocodilus und Alligator. Obere Kreide. Nordamerika.

Deinosuchus Holland. 35-40 Fuß lang. Obere Kreide. Nordamerikà. 
Crocodilus Laur. Fig. 410, 411. 17-19 Zähne oben, 17-15 Zähne unten auf jeder Seite. Kurz- bis sehr langschnauzig. Ohne knöcherne Nasenscheidewand. Bauchpanzer fehlt. Trop. Asien. Trop. Afrika. Trop. Amerika. Nordaustralien. Neuguinea. Polynesien. Die ältesten Reste kommen aus der oberen Kreide von Europa (Provence, Gosau, ? Italien). Zahlreiche Arten aus dem Tertiär von Europa, Nordafrika, Nordamerika und Ostindien.

\section{Zeitliche Verbreitung und Stammesgeschichte der Crocodilia.}

Sichere Anhaltspunkte für die Entstehung der Crocodilier fehlen bis jetzt noch völlig. Aller Wahrscheinlichkeit nach haben sie von bis jetzt noch unbekannten landbewohnenden Formen ihren Ursprung genommen. Die ältesten Crocodilier (Teleosauridae) mit platycölen Wirbeln und mesosuchen Choanen treten unvermittelt im oberen $\mathrm{I}_{\mathrm{i}}$ a s von Europa auf und lassen sich bis zum oberen Jura (? Ob. Kreide) verfolgen. Etwas später im Dogger stellen sich die den Teleosauridae nahe verwandten, aber bereits weit mehr dem Wasserleben angepaßten Metriorhynchidae ein, von denen einzelne Gattungen riesige Größe erlangen und von denen sich die jüngsten Vertreter im Neocom finden. Die Angehörigen dieser beiden Familien kommen in $\mathrm{m}$ a r in e $\mathrm{n}$ Ablagerungen vor und haben anscheinend keine lebenden Nachkommen hinterlassen.

Am Schluß des Jura und zu Beginn der Kreide in den brackischlimmischen Ablagerungen des Purbeck und den Süßwassersedimenten des Wealden zeigen sich die platycölen Macrorhynchidae entwickelt, deren Choanen bereits seitlich von den Pterygoidea begrenzt werden; von ihnen leiten procöle, eusuche Formen wie Thoracosaurus und Holops aus der oberen Kreide und dem Eocän zu Tomistoma und Gavialis über. Ob die Crocodilidae (Alligatoridae) $\mathrm{zu}$ diesen letzteren in nähere Beziehungen zu bringen sind oder ob sie sich auf die mehr kurzschnauzigen Goniopholidae oder auf beide Gruppen zurückführen lassen, läßt sich noch nicht entscheiden. Gegenüber der gegenwärtigen Verbreitung der einzelnen Gattungen (s. oben) ist zu beobachten, daß Crocodilus und der mit Alligator sehr nahe verwandte Diplocynodon sich zumeist im älteren und mittleren Tertiär besonders von Europa und Nordamerika finden, während von Tomistoma bis jetzt nur Reste aus dem Tertiär des Mittelmeergebietes und Ungarns sich nachweisen ließen.

\section{Ordnung Dinosauria. Owen. ${ }^{1}$ )}

Körper langhalsig und langgeschwänzt, meist von an sehnlicher, zuweilen sogar von gigantischer Größe. Schädel ohne Foramen parietale. Obere und untere Schläfenöff. nungen knöchern umgrenzt. Zähne thecodont. Sternum häufig teilweise verknöchert. Clavicula und Episternum unbekannt. Scapula sehr groß, zuweilen mit dem kleinen

1) Abel O., Die Rekonstruktion d. Diplodocus. Abh. d. k. k. Zool.-bot. Gesellsch. Wien. Bd. 5. 1910. Dort weitere Literatur! - Ameghino, Notes on the Geology and Palaeontology of Argentina. Geol. Magaz. 1897. Ferner An. Soc. Cient. Argent. Vol. 47. 1900. - Barnum Brown, The Ankylosauridae etc. Bull. Americ. Mus. Nat. Hist. Vol. XXIV. 1908. - Baur G., Remarks on the Reptiles generally called Dinosauria. Amer. Naturalist 1891 S. 434. - Beecher, Chas. The Reconstruction of a Cret. Dinos. Claosaurus etc. Transact. Conn. Ac. Vol. XI. 1902. - 
scheibenförmigen Coracoid verschmolzen. Procoracoid fehlt. Wirbel opisthocöl, amphicöl oder platycöl, cavernöshohl oder massiv. 3-10 Sacralwirbel. Rippen zweiköpfig. Ilium großnach vorne und hinten verlängert. Ischium lang, schlank, gewöhnlich in der Symphyse verbunden. Pubis nach vorne und abwärts gerichtet, zuweilen mit einem dünnen, nach hinten gewendeten, dem Ischium parallelen Postpubis. Pubis, Ilium und Ischium an der Bildung des Acetabulum beteiligt. Vorderbeine kürzer als die Hinterbeine. Haut nackt oder mit Hautverknöcherungen. Trias bis Oberste Kreide (? Eocän).

$\mathrm{Zu}$ den Dinosauriern gehören nur ausgestorbene Reptilien, von äußerst mannigfaltiger, bald an Parasuchier, bald an Rhynchocephalen und an Lacertilier, bald an Vögel erinnernder Gestalt. Sie beginnen zur Zeit des Niederganges der Stegocephalen und Theromoren in der Trias und dominieren von diesem Zeitpunkt an als hauptsächliche Landbewohner während des ganzen Mesozoicums um gegen Schluß der Kreide (? Beginn des Tertiärs) allmählich den Mammalia zu weichen.

Sie nährten sich teils von Pflanzen, teils von Fleisch und hielten sich wahrscheinlich mit Vorliebe in sumpfigen Niederungen auf. Ihre Extremitäten waren entweder plantigrad (Sohlengänger) oder digitigrad (Zehenspitzengänger) oder in Verbindung beider Merkmale semiplantigrad. Ein großer Teil von ihnen benutzte alle 4 Extremitäten zum Gehen (Quadrupedal), während andere ihre Fortbewegung ausschließlich auf den Hinterextremitäten bewerkstelligten (Bipedal).

Cope Edw., Palaeontological Bulletin Mr. 22. 23. 24. 25. 26. 27. 28. in Proceed. Amer. Phil. Soc. Philadelphia 1876-77. - Deslongchamps Eudes, Poikilopleuron. Mem. Soc. Linn. de Normandie 1838. vol. VI. 36. - Dollo L., 1.-5. note sur les Dinosauriens de Bernissart. Bull. Musée roy. d'hist. nat. de Belgique. 1882-84. T. I. II. III. - Les Allures des Iguanodons etc. Bull. scient. d. 1. France et d. l. Belg. T. 40. 1905. - Fraas E., Ostafrikanische Dinosaurier. Palaeontographica 55. 1908. - Gilmore Cbas., Morosaurus agilis etc. Proc. U. St. Nat. Mus. Vol. 32. Washington 1907. - Osteology of the jur. Rept. Camptosaurus. Proc. U. S. Nat. Mus. Vol. 36. Was. hington 190y. - Hatcher J. B., Diplodocus, its osteology etc. Mem. Carn. Mus. Vol. I 1901. Osteology of Haplocanthosaurus etc. ibid. Vol. II 1903. - Hatcher J. B., Marsh O. C., Lull R. S., The Ceratopsia. Monographs U. S. Geol. Surv. Vol. 49. 1907. Ibid. Literatur! - Hay O. P., On the manner of Locomotion of Dinosaurs etc. Proc. Wash. Acad. Sc. Vol. XII. 1910. - On the skull and the brain of Triceratops etc. Proc. U. S. Nat. Mus. Vol. XXXII. 1909. On certain genera and species of carniv. Dinos. etc. ibid. Vol. 35. 1908. - Holland U. J., ()steology of Diplodocus Mem. Carn. Mus. Vol. II. 1906. - Huene F. v., Über die Dinosaurier der außereurop. Trias. Geol. u. Pal. Abhandl. 12 (8) 1906. - Die Dinosaurier der europ. Triasform. etc. ibid. Suppl. Band I. 1907-08. Dort ausführliche Literatur! - Zur Beurteilung der Sauropoden. Monatsbericht d. d. geol. Gesellsch. Bd.60.1908. - Skizze $\mathrm{zu}$ einer Systematik u. Stammesgeschichte der Dinosaurier. Zentralblatt f. Mineralogie etc. 1909. - Ein primitiver Dinosaurier aus der mittleren Trias v. Elgin. Geol. u. Pal. Abhandl. N F. Bd. VIII (XII) 1910. - Hulke J. W., On Polacanthus. Philos. Transactions I881 u. 1887. - On Hypsilophodon Foxii. Quart. Journ. geol. Soc. 1873 XXIX p. 522 und 1874 XXX p. 18 und Philos. Trans. 1882. Bd. 173. On Iguanodon. Quart. journ. geol. Soc. 1871 XXVII p. 199, 1874 XXX p. 24, 1878 XXXIV p. 744, 1885 XLI p. 473, 1886 XLII p. 435. - Hulke J. W., Presidential adresses to the geological Society. Quart. journ. 1883 and 1884 vol. XXXIX and XL. - Huxley Th., On the animals intermed. between Birds and Reptiles. Proceed. Roy. Soc. 1868 p. 278 and Ann. Mag. nat. hist. 1868. 4. ser. vol. II. und Quarterly journ. geol. Soc. London 1869 XXVI p. 3, 12 und 32. - On Hypsilophodon. Quart. journ. geol. Soc. 1870 XXVI p. 3. - Koken E., Die Dinosaurier, Crocod. etc. des norddeutschen Wealden. Pal. Abhandl. 3. Bd. 1887. 7. 1896. - Lambe L. M., (Osborn). On Vertebrata of the Mid-Cretaceous of the Northwest Terr. Geol. Surv. Canad. Contr. Can. Palaeont. 3. 1902; ferner Transact. R. Soc. Canad. Vol. 10 sec. 
Ein verknöchertes $\mathrm{Hautskelett}$ besitzen verschiedene Prädentaten und einige Theropoden, bei den übrigen Dinosauriern war die Haut wahrscheinlich nackt oder verhornt. Das Hautskelett selbst besteht entweder aus isolierten, meist in Reihen angeordneten Knochenplatten und Stacheln oder aus einem geschlossenen, aus festen Platten zusammengesetzten Panzer, der größere Partien des Körpers vollkommen umhüllte (z. B. Polacanthus).

Die Wirbel sind entweder opisthocöl, platycöl oder seltener amphicöl; die Zahl der Halswirbel schwankt zwischen 7 und 15, die der Rückenwirbel zwischen 10 und 19, die der mehr oder weniger miteinander verschmolzenen Sacralwirbel zwischen 3 und 10, und am Schwanz sind bis 70 Wirbel beobachtet worden. Die oberen Bogen sind meist durch Sutur mit dem Wirbelkörper verbunden. Die Dornfortsätze der Halswirbel (und zuweilen auch der vorderen Rückenwirbel) sind häufig sehr niedrig und manchmal gegabelt und nehmen erst weiter nach hinten an Größe zu. Mit Ausnahme der beiden vordersten tragen die übrigen Halswirbel zweiköpfige Rippen, deren Tuberculum an die Diapophyse des oberen Bogens, deren Capitulum an die Parapophyse des Wirbelkörpers sich einfügt. An den Rückenwirbeln rücken die Parapophysen von den Centren auf die Bogen hinauf. Die Schwanzwirbel tragen in der Regel kräftige, manchmal sehr verschiedenartig gestaltete Hämapophysen (Chevrons). Verschiedentlich sind Bauchrippen beobachtet worden.

Bei den Sauropoden und Theropoden kann die gelenkige Verbindung außer durch die Post- und Präzygapophysen auch durch einen

4.1904. - Lull R., Two new Ceratopsia ibid. Vol. 20. 1905. - The cranial musculatur etc. in the Ceratops. Dinos. ibid. 25. 1908. - The armor of Stegosaurus. Amer. Journ. Sci. 29. 1910. - Dinosaurian Distribution. Americ. Journ. Sci. Vol. 29. 1910. Lydekker $R$., The Dinosaurs of Patagonia. Annales del Museo d. 1. Plata. 1890 bis 1891. - Mantell G. Alg., Philos. Trans. 1825. 1841. 1848. 1849. - Marsh O., The Dinosaurs of North America. 16. Ann. Rpt. U. S. Geol. Surw. Washington 1896. Zahlreiche Abhandl. in American journ. of Sciences and Arts. 1878-1894. 3. ser. vol. XVI-XLVIII. - Matthew W. D., The Pose of Sauropod. Dinosaurs. Amer. Naturalist 1910. - Nopcsa F. v., Dinosaurierreste aus Siebenbürgen. Denkschrift math.-naturwissensch. Klasse d. k. Akad. d. Wissensch. Wien. Bd. 68. 1899. Bd. 72. 1902. Bd. 74:1904. Synopsis u. Abstammung der Dinosaurier. Földtani Közlöny. 31. Bd. 1901. British Dinosaurs Geol. Magaz. Dec. 5. Vol. II. Mai-Juni-Juli 1905. Vol. VIII. 1911. - Nenes über Compsognathus. Neues Jahrbuch für Mineralogie etc. Beilageband XVJ. 1903. - Osborn H. F., A Skeleton of Diplodocus Mem. Americ. Mus. Nat. Hist. Vol. I. P. 5, 1899. Ornitholestes Hermanni etc. Bull. Americ. Mus. Nat. Hist. Vol. 19. 1903. The skull of Creosaurus ibid. - Tyrannosaurus etc. ibid. Vol. 22. 1906. - Owen Rich., A Monograph of the fossil Reptilia of the mesozoic formations. Palaeont. Soc. 1874-89. - A Monograph of the Reptilia of the Wealden and Purbeck formations. T. I-V. - Palaeont. Soc 1853-61. and Supplements I bis IX. 1858-79. - Philipps J., Megalosaurus. Geology of Oxford. 1871 p. 196-219. - Plieninger Th., Zanclodon. Württemb. naturw. Jahreshefte VIII. - Riggs E., Structure and Relationships of opisthoc. Dinos. P. I. u. Pt. II. Field Columb. Mus. Publ. 82. 1903. ibid. 94. Chicago 1904. - Seeley H. G., Quart. journ. Geol. Soc. 1881 XXXVII p. 620 und Bunzel E., Abhandlg. geol. Reichs-Anstalt. Wien 1871. Bd. V. - On the classification of the Dinosauria. Proceed. Roy. Soc. 1878. - Thevenin A., Paléontologie de Madagascar. Dinosaurs. Annales de Paléontologie II. 1907.

- Tomier G, Utber alte und neue Diplodocus-Arbeiten. Monatsberichte d. d. geol. Gesellsch. Bd. 62. 1910. - Versluys J., Streptostylie bei d. Dinosauriern etc. Zool. Jahrb. Abt. f. Anatomie etc. 30. Bd. 1910. Waren die sauropoden Dinosaurier Pflanzenfresser? ibid. Abt. f. Systematik etc. 29. Bd. 1910. - Wagner And., Compsognathus. Abh. k. Bayer. Ak. II. Kl. 1861 IX. - Woodward A. S., On a skull of Megalosaurus. Quart. Journ. Geol. Soc. Vol. 66. 1910. 
keilförmigen, unterhalb der Postzyg:apophysen befindlichen Fortsatz das Hyposphen, erfolgen, der in eine, unter den Präzygapophysen ausgebildete Grube, Hypantrum, eingreift.

Der Schädel bildet bei den Theropoda und einem Teil der Prädentata einen rechten Winkel mit dem Hals, während bei den Sauropoden und den übrigen Prädentata (Ceratopsidae, Stegosauridae) seine Längsachse mehr oder weniger in die Verlängerung der Wirbelsäule fällt. Die großen Augen richten sich nach den Seiten, die Nasenöffnungen sind in der Regel getrennt und seitlich. Zwischen Orbita und Nasenlöchern befindet sich häufig, wie bei den Parasuchiern, Pterosauriern und Vögeln eine oder mehrere Prëorbitaöffnungen. Die oberen und seitlichen Schläfenlöcher sind knöchern umgrenzt und von verschiedener Größe und Form. Das an das Squamosum und das Quadratojugale angrenzende Quadratum ragt häufig stielförmig vor und scheint nach Nopesa und Versluys bei einigen Formen wie das Pterygoid (ähnlich wie bei den Vögeln) teilweise verschiebbar gewesen zu sein.

Die paarigen Prämaxillaria sind ziemlich groß und entweder bezahnt oder zahnlos. Die beiden Äste des Unterkiefers sind in der Symphyse nur knorpelig verbunden, zuweilen entwickelt sich vor dem Dentale ein zahnloser, scharfrandiger, halbmondförmiger Knochen, das Prädentale, welches wahrscheinlich mit Hornscheiden besetzt war. Ihm kann im Oberkiefer vor den Prämaxillaren ein Rostrale entsprechen. Nur die Kiefer tragen Zähne, die entweder in tiefe Gruben oder in nach innen offene Alveolarrinnen des Kieferrandes eingefügt sind.

Eine bemerkenswerte Eigentümlichkeit der Dinosaurier bildet die geringe Größe der Gehirnhöhle. Marsh hat Ausgüsse derselben von verschiedenen Gattungen beschrieben und gezeigt, daß die relative Größe des Dinosauriergehirns hinter dem aller landbewohnenden Wirbeltiere zurückbleibt. Im Gegensatz zu dieser schwachen Entwicklung des Gehirns tritt zuweilen eine beträchtliche Anschwellung des Rückenmarks, namentlich in der Sacralregion ein, so ist z. B. der Sacralkanal von Morosaurus zwei- bis dreimal, derjenige von Stegosaurus aber mindestens zehnmal so weit als die Schädelhöhle. Diese merkwürdige Anschwellung des Rückenınarks bei den Stegosauridae steht offenbar im Zusammenhang mit der massiven Ausbildung der hinteren Extremitäten (cfr. Fig. 443.)

Das Sternum ist bei den meisten Dinosauriern nur unvollkommen in Gestalt einer oder zweier Platten verknöchert, Clavicula und Episternum sind bis jetzt noch nicht beobachtet. Der Schultergürtel besteht aus einer mächtig entwickelten und gewöhnlich stark verlängerten Scapula und einem nicht selten mit ihr verschmolzenen, mehr oder weniger gerundeten Coracoid, das in der Nähe des Gelenkes von einer Gefäßöffnung durchbohrt ist. Die langen Knochen der Extremitäten sind bald massiv, bald hohl. Die Vorderextremitäten bleiben an Größe meist beträchtlich hinter den Hinterextremitäten zurück. Der Humerus ist gewöhnlich kürzer als die Scapula, Radius und Ulna sind kräftig und vollständig getrennt. Der Carpus ist oft unvollständig verknöchert und die Zahl der Metacarpalia häufig auf drei reduziert. Die Endphalangen sincl entweder stark gekrümmt, krallenförmig oder breit hufähnlich. 
Sind die Vorderextremitäten der Dinosaurier im wesentlichen nach dem Typus der Reptilien gebaut, so zeigen Becken und Hinterbeine wenigstens bei den Ornithopodiden gewisse äußere Ähnlichkeit mit Vögeln. Das Ilium ist melır oder weniger in der Richtung von vorne nach hinten verlängert und relativ niedrig, ein nach vorne und unten gerichteter Gelenkfortsatz dient zur Aufnahme des Pubis, an einem entsprechenden hinteren Fortsatz befestigt sich das Ischium. Das Acetabulum, an dessen Begrenzung sämtliche drei Knochen teilnehmen, ist teilweise durchbohrt. Die Ischia sind lange, schräg nach hinten, unten und innen gerichtete Knochen, welche zumeist in der Symphyse zusammenstoßen. Das ventral sich vereinigende Pubis der Sauropoden und Theropoden ist einander sehr ähnlich. Bei den meisten Prädentata (Fig. 422) teilt sich das Pubis in einen kürzeren und breiteren nach vorne gerichteten und einen schlanken nach hinten gewendeten, dem Ischium parallelen Ast. Die vorderen Äste ragen frei vor und vereinigen sich nicht in einer Symphyse. Sie entsprechen dem Pubis der übrigen Dinosaurier, während der hintere Fortsatz, den Marsh Postpubis nannte, in Lage und Form an das Schambein der Vögel erinnert. Nach den embryologischen Untersuchungen von Bunge und Mehnert entspricht jedoch das Präpubis

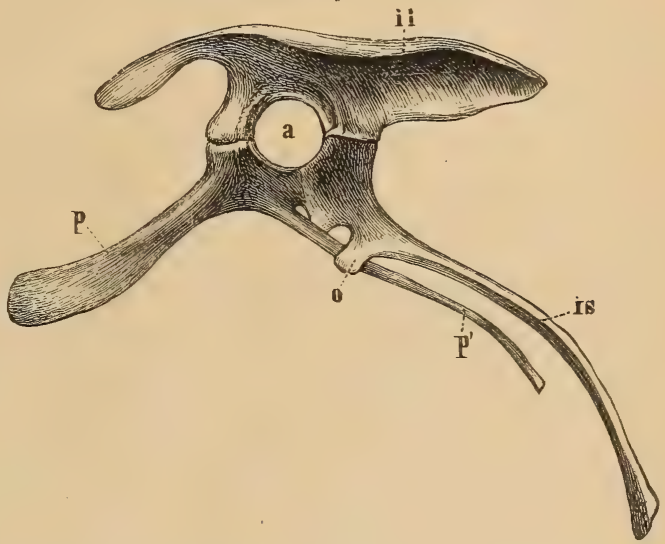

Fig. 422.

Becken von Iguanodon. Von links. 1/20. il Ilium, $p$ Pubis, $p^{\prime}$ Postpubis, is Ischium, o processus obturatorius, a Pfanne. der Prädentata keineswegs dem Processus pectinalis der Vögel, es macht vielmehr das anfänglich nach vorrre oder vertikal nach unten gerichtete Schambein der Vögel im Verlauf der Entwicklung eine Drehung nach hinten und ist somit dem eigentlichen Pubis der Reptilien homolog. Das Postpubis (Pubis) der Prädentata erscheint darum als eine besondere Differenzierung, welche in der Gewohnheit dieser Tiere, sich auf die Hinterbeine und den Schwanz zu stützen, ihre physiologische Erklärung findet. Der Femur übertrifft den Humerus gewöhnlich an Länge. Im Tarsus sind zwei Reihen von Knöchelchen vorhanden. Die proximale Reihe besteht aus einem niedrigen, oben konkaven, unten konvexen Astragalus (Tibiale) und einem kleineren Calcaneus (Fibulare). Bei den Stegosauridae verwächst der Astragalus mit der Tibia und bei den meisten Theropoden sendet er einen Fortsatz nach oben, der sich in eine seichte Vertiefung am distalen Ende der Tibia einlegt - eine Erscheinung, die mit gewissen Pterosauriern und Embryonen von Ratiten übereinstimmt. Die distale Reihe enthält, wenn sie überhaupt verknöchert ist, 2-3 flache, häufig zu einem einzigen Stück verschmolzene Knochen. Der Hinterfuß ist entweder fünfoder dreizehig, doch pflegen gewöhnlich die Metatarsalia I und V, 
auch wenn sie keine funktionierenden Zehen tragen, wenigstens angedeutet $\mathrm{zu}$ sein.

Dinosaurierreste finden sich von der Trias bis in die oberste Kreide (? Eocän); ihre Reste sind aus allen Weltteilen bekannt geworden, besonders häufig aus Nordamerika und Europa. Die ersten Überreste wurden im Anfang dieses Jahrhunderts im Groß-Oolith und der Wälderstufe von England entdeckt und durch Buckland und Mantell beschrieben. R. Owen errichtete für dieselben die Ordnung der Dinosaurier. Eine richtige Vorstellung von der Eigentümlichkeit dieser Reptilien erlangte man jedoch erst, als in Nordamerika und Europa eine Fülle, zum Teil vorzüglich erhaltener Skelette entdeckt wurde. Die Einteilung der Dinosaurier in drei Unterordnungen: Theropoda, Sauropoda, Prädentata (Orthopoden) stützt sich auf die Untersuchungen von O. C. Marsh. Manche Autoren stellen auch die Vertreter der Theropoden und Orthopoden als Saurischia den Prädentaten als Ornith ischia gegenüber.

\section{Unterordnung. Theropoda. Marsh.}

Schädel klein, ungefähr einen rechten Winkel mit dem Hals bildend. Kieferrand in der Regel mit Zälnen besetzt. Zähne thecodont. seitlich zusammen gedrückt, zugespitzt. Unterkiefer ohne Processus coronoideus mit seitlicher Öffnuny (Meckelscher Knorpel). Wirbel massiv oder hohl. Die Halswirbel in der Regel opisthocöl, die übrigen platycöl oder amphicöl. Extremitätenknochen meist röhrenartig. Vorderbeine beträchtlich kürzer als die hinteren. Hinterfüfie digitigrad. Zehen meist ungleich lang, mit spitzen gekrümmten Klauen. Sternum nicht verknöchert. Pubis schlank, nach vorne gerichtet, in der Symphyse - ähnlich wie die Ischia gewöhnlich verschmolzen und verbreitert. Femur mit innerem Trochanter. Fleisch. fresser. Trias bis oberste Kreide (? Eocän).

Die Theropoden sind fleischfressende Landbewohner mit spitzen, etwas rückwärts gekrümmten Zähnen, deren Dimensionen in weiten Grenzen, zwischen der Größe einer Katze (Compsognathus) und eines Elefanten schwanken (Megalosaurus). Ihre äußere Erscheinung erhält durch die hohen, geknickten Hinterbeine und die kurzen Vorderextremitäten ein absonderliches Gepräge. Thre Bewegung war entweder, wie bei den Kängurus, eine sprungweise, hüpfende, oder sie konnten, wie die Vögel, auf den Hinterbeinen einherschreiten und die Vorderfüße zum Greifen benutzen. Bei einigen älteren Formen (Thecodontosaurus antiquus) scheint nach v. Huene auch noch eine vierfüßige Gangart möglich gewesen zu sein. Der enorm lange, überaus kräftige Schwanz diente den Tieren als Stütze des Körpers, wenn sie in hockender Stellung ruhten, wobei die in der Symphyse verbundenen Schambeine und Sitzbeine wohl den Boden berührten. Das Skelett der meisten Theropoden war überaus leicht gebaut, bei den meisten sind nicht nur die Extremitätenknochen hohl, sondern häufig sind auch die Wirbel mit Hohlräumen versehen.

Schädel sind nur von wenigen Gattungen (Anchisaurus, Thecodontosaurus, Ceratosaurus etc.) bekannt. Die Nähte der dünnen Kopfknochen sind meist undeutlich. Bei manchen Gattungen sind zwei (Ornitholestes), vielleicht sogar drei (Tyrannosaurus) Präorbitalöffnungen entwickelt. Die meist opisthocölen Halswirbel sind in der Regel länger als die platycölen oder amphicölen Rückenwirbel, ihre Gelenkfortsätze für die langen geraden zweiköpfigen Rippen befinden sich am Wirbelkörper und am oberen Bogen. 
Die zweiköpfigen langen Rumpfrippen hingegen artikulieren nur mit dem oberen Bogen; den hinteren Schwanzwirbeln fehlen Rippen, dagegen sind die Hämapophysen stark entwickelt. Die Verbindung der hinteren Rückenwirbel wird häufig durch Hyposphen-Hypantrumgelenkung verstärkt.

Verschiedentlich sind Bauchrippen beobachtet worden. Am Brustgürtel bildet die Scapula meist eine schmale lange Platte und ist stärker und länger als der Humerus. Das Coracoid ist mehr oder weniger halbmond- oder halbkreisförmig, der Carpus in der Regel unvollständig verknöchert, die Zehen von mäßiger Länge und mit Krallen bewehrt. Im Beckengürtel zeichnet sich das Ilium durch seine niedrige langgestreckte Form aus, der präacetabulare Fortsatz ist kürzer und höher als der hintere Flügel. Charakteristisch ist eine mehr oder weniger horizontale, nach hinten gerichtete Verlängerung des distalen Endes der Schambeine. Die Hinterextremitäten zeichnen sich durch ansehnliche Länge aus. Die proximale Tarsusreihe besteht aus Astragalus und Calcaneus. Der Astragalus sendet sehr häufig einen Fortsatz nach oben, der sich unbeweglich an das distale Ende der Tibia anlegt.

Die Theropoden zerfallen in sechs Familien Plateosauridae, Anchisauridae, Megalosauridae, Labrosauridae, Coeluridae, Compsognathidae und lassen sich von der Trias bis zur obersten Kreide (? Eocän) verfolgen.

\section{Familie. Plateosauridae.}

Mittelgroße bis große Theropoden. Knochen hohl. Wirbel amphicöl,? 13 Halswirbel, 15 Riickenwirbel, 3 Sacralwirbel. Alle Rippen zweiköpfig. Bauchrippen vorhanden. Pubis breit, verlängert, distal coossifiziert. Ischium schaufelförmig, distal stielförmig verlängert, der Sförmige Femur länger als die Tibia. Astragalus ohne aufsteigenden Fortsatz. Vorderfuß mit rudimentärer 5. Zehe. Hinterfuß mit verkïrzter 1. und 5. Zehe. Trias. Jura.

Plateosaurus H. v. Meyer. (p. p. Zanclodon.) Zähne vorn und hinten zugeschärft und gekerbt. Außer der oben angegebenen Zahl noch ca. 42-45 Schwanzwirbel, die lange Hämapophysen tragen. Oberer Keuper. Rhät. Deutschland. Frankreich.

Gresslyosaurus Rütim. Keuper-Rhät. Mitteleuropa.

Pachysaurus v. Huene. Oberer Keuper. Deutschland.

Poikilopleuron Deslong. Callovien. Frankreich.

Teratosaurus H. v. M. Mittlerer Keuper. Deutschland. Euskelo. saurus. Huxley. Rhät. Kap-Kolonie.

Zanclodon Th. Plieninger (Z. laevis!) Zähne messerförmig, etwas rückwärts gekrümmt, glatt ohne Kerbung. Lettenkohle Deutschland.

Sellosaurus v. Huene. Mittlerer Keuper. Deutschland. v. Huene betrachtet Zanclodon und Sellosaurus als Repräsentanten selbständiger Familien.

\section{Familie Anchisauridae (Thecodontosauridae).}

Kleine, schlank gebaute Theropoden. Wirbel platycöl oder amphicöl. Knochen hohl. Ilium hinter dem Acetabulum verbreitert. Pubis stabförmig, distal nicht verwachsen. Extremitäten kräftig. Zehen teilweise rudimentär. Astragalus oline aufsteigenden Fortsatz. Trias.

Anchisaurus Marsh. (Fig. 423.) Schädel vogelähnlich, mit sehr großen Augen- und Präorbitalöffnungen. Nasenlöcher relativ klein. Obere Schläfenlöcher gerundet dreiseitig, seitliche sehr hoch. Quadratum nach vorne gerichtet. Die Kiefer oben und unten bis zur Schnauzenspitze mit Zähnen mit schneidenden Kanten. 9 langgestreckte Halswirbel, 14 Rüicken- 
wirbel, ? 3 Sacralwirbel. Vorderfuß ungefähr $2 / 3$ der Größe der Hinterextremität, vorne die 4 . und 5, hinten die 5. Zehe reduziert. Länge des Skeletts wenig mehr als $1 \mathrm{~m}$. Rhät. Östliches Nordamerika.

Thecodontosaurus Riley und Stuchb. (Megadactylus Hitc.) Muschelkalk-Rhät. Deutschland, England, östl. Nordamerika, Ostindien, Südafrika, Australien. Massospondylus Owen. Obere Trias Kap-Kolonie. Ammo-

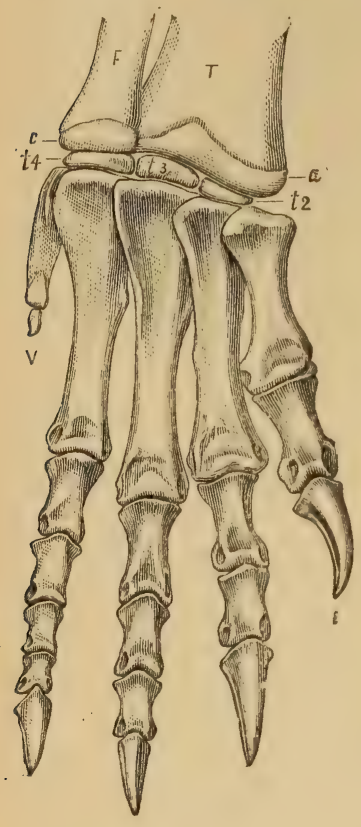

Fig. 428.

Anchisaurus major Marsh. Rechter Hinterfuß von vorne. Ob. Trias. Manchester. Conn. $1 / 4$ nat. Gr. (Nach Marsh.) $F$ Fibula, $T$ Tibia, a Astragalus, $c$ Calcaneus $t 2-4$ Tarsalia der distalen Reihe, $I$ erste, $V$ fünfte Zehe.

$a$

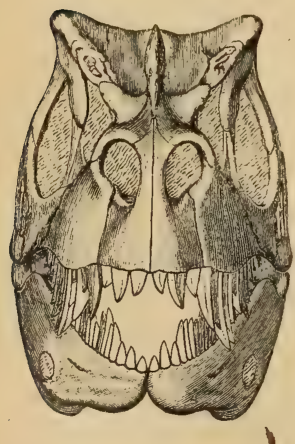

1 saurus Marsh. Rhät. Trias. Östliches Nordamerika. Alle meist nur in dürftigen Resten bekannt.

\section{Familie. Labrosauridae.}

Unterkiefer vorne zahnlos. Hals- und Rückenwirbel opisthocöl, hohl oder cavernös, Pubis kräftig mit-Interpubis. Femur länger als die Tibia. Astragalus mit aufsteigendem Fortsatz. Unterste Kreide.

Labrosaurus Marsh, mit den Merkmalen der Familie. Unterste Kreide. (Como beds.) Westliches Nordamerika. ? Antrodemus Leidy. Kreide. Westl. Nordamerika.

\section{Familie. Coeluridae.}

Kleine bis mittelgroße Theropoden. Halswirbel opisthocöl. Rückenuirbel platycöl. Neuralkanal stark erweitert. Wirbel und übrige Skelettknochen hohl. Halsrippen mit den Wirbelkörpern verschmolzen. Femur kürzer als die Tibia. Metatarsalia sehr lang und dünn. Trias bis oberste Kreide (? Eocän).

Coelurus Marsh (Aristosuchus Seeley). Unvollständig bekannt. Sämtliche Wirbelkörper nebst ihren Bögen und Fortsätzen sind hohl. Die oberen Bogen durch Sutur mit dem Zentrum verbunden. 5 Sacralwirbel. Untere Kreide Nordamerika. Wealden. England.

Coelophysis Cope. Obere Trias. Westliches Nordamerika. Calamospondylus Lyd. Wealden. England. Thecospondylus Seeley. Wealden. England.

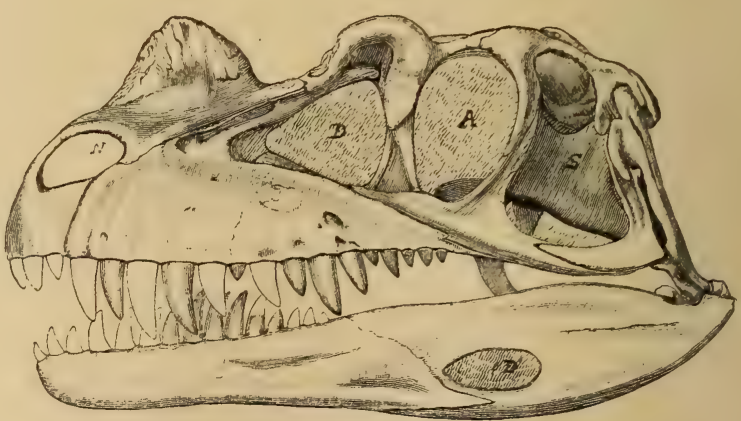

Fig. 424.

Ceratosaurus nasicornis Marsh. Unt. Kreide. Colorado. Schädel $a$ von vorne, $b$ von der Seite. $1 / 9$ nat. $G r$. $N$ Nasenlech, $D$ präorbitale Offnung, $A$ Augenhöhle, $S$ seitliches Schläfenloch. (Nach $\mathrm{M}$ arsh.) 
Tanystrophaeus. H. v. Meyer. Nur Schwanzwirbel mit kammartigem Dornfortsatz bekannt. Muschelkalk. Keuper Deutschland. ? Saltopus. v. Huene. Untere obere Trias. Elgin-Schottland.

Tyrannosaurus Osborn (Dynamosaurus Osborn.) Skelett über $5 \mathrm{~m}$ hoch. Schädel jederseits mit 2 (? 3) Präorbitalöffnungen. Ca. 23 Präsacralwirbel, 5 Sacralwirbel. Pubis distal fußförmig verbreitert. Bauchrippen aus einem mittleren und 2 seitlichen Stücken bestehend. Obere Kreide. Westliches Nordamerika.

Albertosaurus Osborn. Obere Kreide. Kanada.

Ceratosaurus Marsh. (Fig. 424 u. 425.) Skelett 4-5 m lang. Schädel auf dem hohen Nasenbein mit hoher rauher Crista. Präfrontalia dachartig über Augen, die kleiner als in seitlichen Schläfenöffnungen sind, vorspringend. Die Wirbel des langen Schwanzes mit starken Dornfortsätzen und Hämapophysen. 5 Sacralwirbel, Beckenelemente in der Pfanne fest

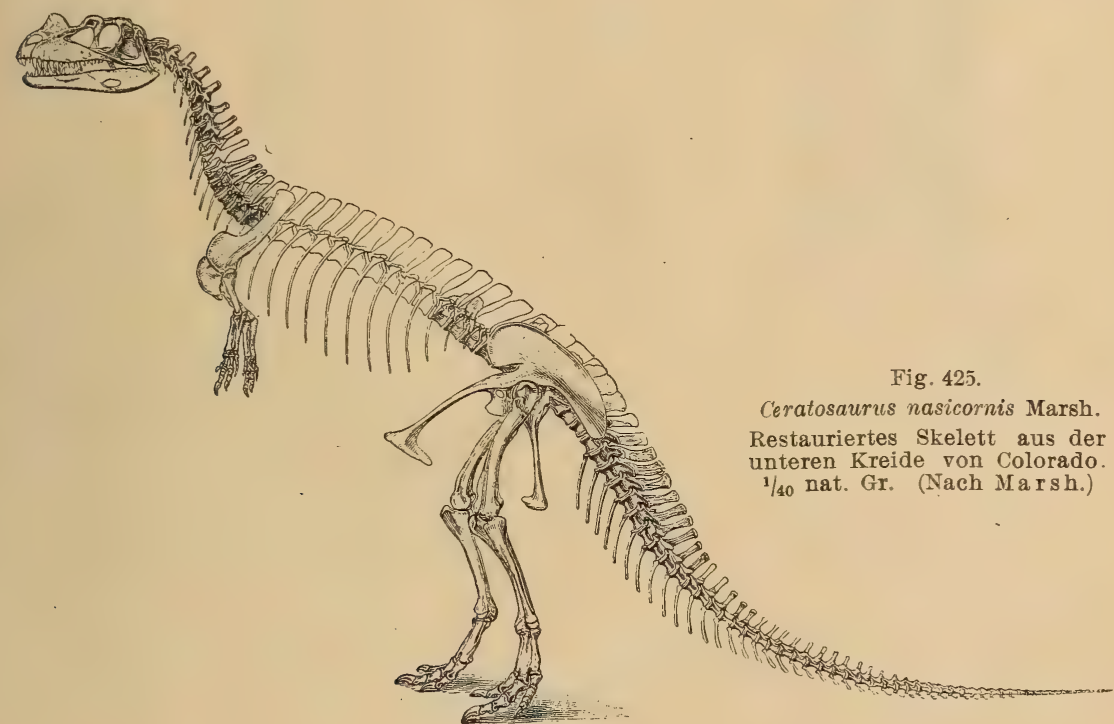

verschmolzen. Vorderbeine sehr kurz mit 4 funktionierenden Fingern. Der Femur ist stark gekrümmt. Nur drei Zehen vorhanden. Die 3 Metatarsalia sind untereinander und mit den distalen Tarsalia verschmolzen (Pathologisch ?) Hautverknöcherungen über dem Hals beobachtet. Unterste Kreide (Como beds.). Westl. Nordamerika.

Deinodon, Aublysodon Leidy, Oberste Kreide. Nordamerika.

? Nuthetes Owen. Purbeck. England.

Loncosaurus Ameghino, Genyodectes A. S. Woodward. Oberste Kreide (? Eocän). ${ }^{1}$ ) Patagonien.

\section{Familie. Megalosauridae.}

Meist große Theropoden. Halswirbel opisthocöl, Rückenwirbel amphicöl. Unterkiefer vorne zahnlos. ? 4-5 Sacralwirbel. Bauchrippen vorhanden. Ilium nach vorne verbreitert. Pubis schlank, distal coossificiert. Femur länger als die Tibia. Astragalus mit aufsteigendem Fortsatz. Vorderextremität mit 4-5, Hinterextremität mit 3-4 Zehen. Lias bis oberste Kreide (? Eocän).

$\left.{ }^{1}\right)$ Das Alter der betreffenden Schichten in Patagonien ist noch nicht sicher. 
Megalosaurus Buckland (Streptospondylus Cuvier). (Fig. 426.) Schädel mit großer Präorbitalöffnung. Zähne vorn und hinten zugeschärft und gekerbt. Extremitätenknochen hohl. Femur $1 \mathrm{~m}$, Scapula $0,8 \mathrm{~m}$ lang. Meist isolierte, $\mathrm{zu}$ dieser Gattung gestellte Reste wurden aus dem unteren Lias bis oberste Kreide (? Eocän) von Mittel- und Südeuropa, In. dien, Madagaskar, Australien und Südamerika beschrieben.

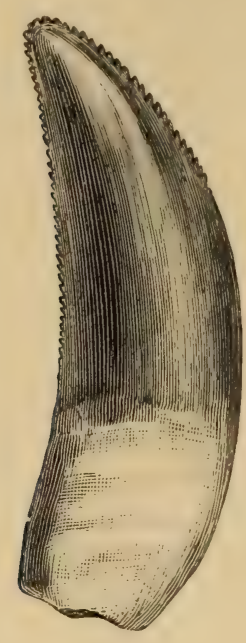

Fig. 426 .

Megalosaurus Buclilandi Meyer. Großoolith. Stones-field. Zahn nat. Gr.

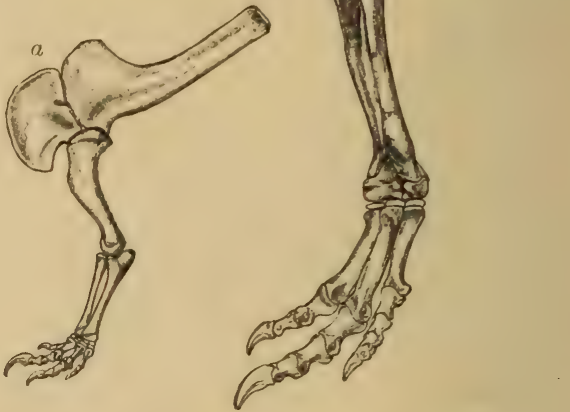

Fig. 427

Allosaurus agilis Marsh. Lnterste Kreide. Colorado. $a$ Vorderfuß, $b$ Hinterfuß, restauriert. 1/20 nat. $\mathrm{Gr}$. (Nach irars.)

Allosaurus Marsh. (Fig. 427.) Schädel jederseits mit 2 Präorbitalöffnungen. Untere Kreide. (Como beds. ${ }^{1}$ ) Westliches Nordamerika. Antrodemus. Leidy.

Creosaurus Marsh. Von eben dort.

Coelosaurus Leidy. Obere Kreide. Nordamerika.

Dryptosaurus Marsh. Schädel und Femur je 0,60 m lang. Präfrontalia kammförmig angeschwollen. Augen ungemein groß, durch eine dünne Knochenbrücke von der Präorbitalöffnung getrennt. Zähne und Skelett ähnlich Megalosaurus. Obere Kreide. Nordamerika.

L aelaps Cope. Von ebenda. Sehr ähnlich Dryptosaurus.

\section{Familie. Compsognathidae.}

Wirbel und Extremitätenknochen hohl. Halswirbel leicht opisthocöl; die übrigen Wirbel platycöl. Hals lang, biegsam mit spießförmigen Halsrippen. Pubis kräftig, länger als das schlanke Ischium. Femur kürzer als die Tibia. Astragalus mit langem, aufsteigendem Fortsatz, dem distalen Ende der Tibia dicht anliegend. Metatarsalia lang. Hand und Fuß mit drei mit Krallen bewaffneten funktionierenden Zehen, die übrigen rudimentär. Trias. Jura bis obere Kreide.

Compsognathus Wagner. (Fig. 428, 429.) Ein im Münchener Museum befindliches Skelett gehört dem kleinsten bis jetzt bekannten

1) Grenzschichten von Jura und Kreide, die meist zur unteren Kreide gerechnet werden. 
Dinosaurier Europas an; dasselbe rührte von einem vollständig ausgewachsenen Individuum her, das in seiner Leibeshöhle Reste enthält, die nach Marsh ein Embryo darstellen, nach v. Nopcsa aber auf einen Lacertilier hindeuten. Der vogelähnliche Schädel ist $75 \mathrm{~mm}$ lang und bildet gegen den ungewöhnlich langen Hals einen rechten Winkel. Die Länge der 22 präsacralen Wirbel beträgt $0,20 \mathrm{~m}$ und fast ebenso lang sind die überlieferten 15 Schwanzwirbel. Vorderbeine nur halb so lang als die Hinterbeine. Distale Tarsalia drei kleine Knöchelchen. Oberster Jura von Kelheim in Bayern. Eine verwandte Form im Keuper (Stubensandstein) von Pfaffenhofen (Stromberg) Württemberg.

Ornitho mim us Marsh. Untere Kreide (Como beds). Westl. Nordamerika. Ornitholestes Osborn. $2,22 \mathrm{~m}$ lang. Schädel jederseits mit 2 Präorbitalöffnungen. 4 verschmolzene Sacralwirbel. Finger stark verlängert,

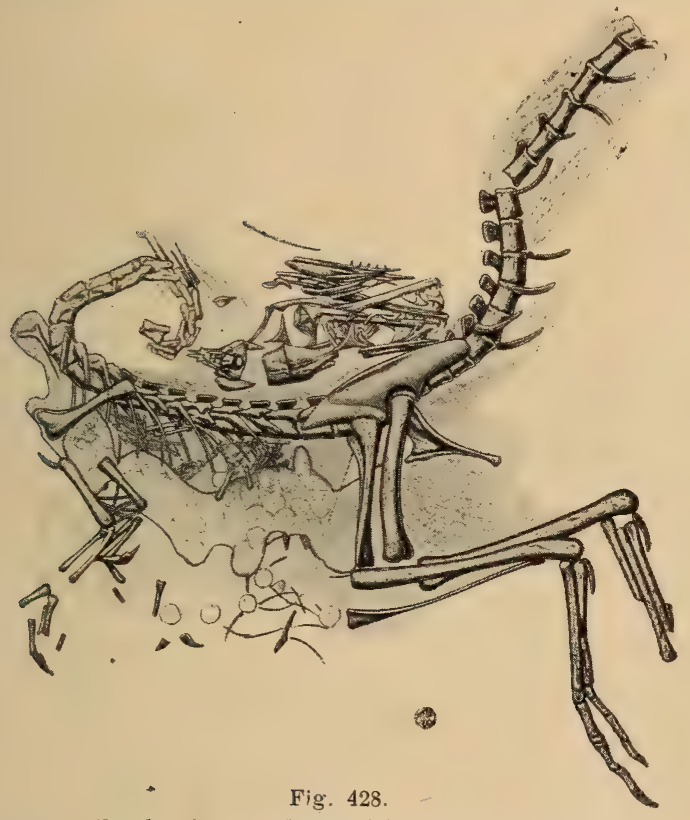

Compsognathus longipes A. Wagn. Lithogr. Schiefer von Kelheim (Bayern). 1/4 nat. Gr. (Nach v. Nopesa). 4. Finger reduziert, 5. fehlend. Obere Kreide. Nord. amerika.

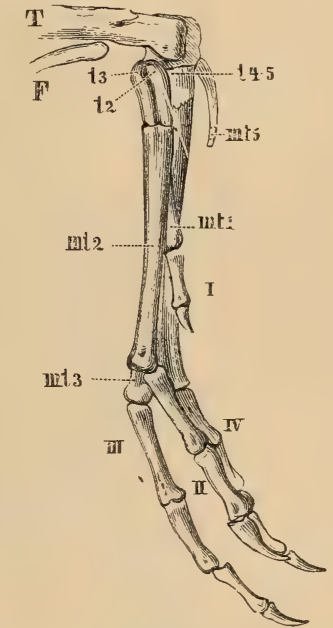

Fig. 429

Linker Hinterfuß von Compsognathus lonyipes Wagn. Nat. Gr. $T$ Tibia, $F$ Fibula, $t 2-5$ Tarsalia der zweiten Reihe, $m t$ Metatarsalia. (Nach B a ur.)

Halticosaurus v. Huene. Keuper-Deutschland, Incertae sedis: Craterosaurus Seeley. Untere Kreide. England. Diplotomodon Leidy. Obere Kreide. Nordamerika. Hypsirrhophus. Oberer Jura und Kreide. Nordamerika.

\section{Unterordnung. Sauropoda. Marsh.}

Schädel klein. Kiefer ganz oder teilweise bezahnt. Zähne lang, dünn, spateloder stiftförmig. Vor den großen Augen eine (selten zwei) mehr oder weniger große Präorbitalöffnung. Hals und die meisten - selten auch alle - Rückenwirbel opisthocöl. Die hinteren Rückenwirbel und die Schwanzwirbel gewöhnlich platycöl oder amphicöl (selten procöl). Die präsacralen, zuweilen auch die Sacralund ersten Caudal-Wirbel mit seitlichen Hohlräumen oder cavernös. Neuralkanal in der Sacralregion sehr erweitert. Extremitätenknochen fast ganz massiv. Vorderextremitäten wenig kïrzer oder ebensogroß. als die Hinterextremitäten. Alle 
4 Fiujse plantigrad (semiplantigrad), 5zehig, mit teilweise reduzierten Phalangen. Jura bis oberste Kreide (? Eocän).

Die Sauropoden sind plumpe, schwerfällige Dinosaurier, die nahezu sämtliche mehr oder weniger gigantische Dimensionen (bis $20 \mathrm{~m}$ Länge) erreichen. Als Bewohner von mit langsam fließenden Gewässern und mit seichten versumpfenden Seen bedeckten Gegenden (z. B. Wealden) dürften sie fast alle mehr oder weniger wasserliebende Reptilien gewesen sein, die sich in der Hauptsache von Pflanzen und zum Teile wahrscheinlich auch von Fischen nährten.

Ganze Schädel sind von Diplodocus, Morosaurus und Brontosaurus bekannt, jedoch nur von den ersten beiden genauer beschrieben. Die paarigen Prämaxillaria und mindestens der vordere Teil der Maxillaria sind mit einfachen spatel- oder stiftförmigen Zähnen besetzt. Vor den

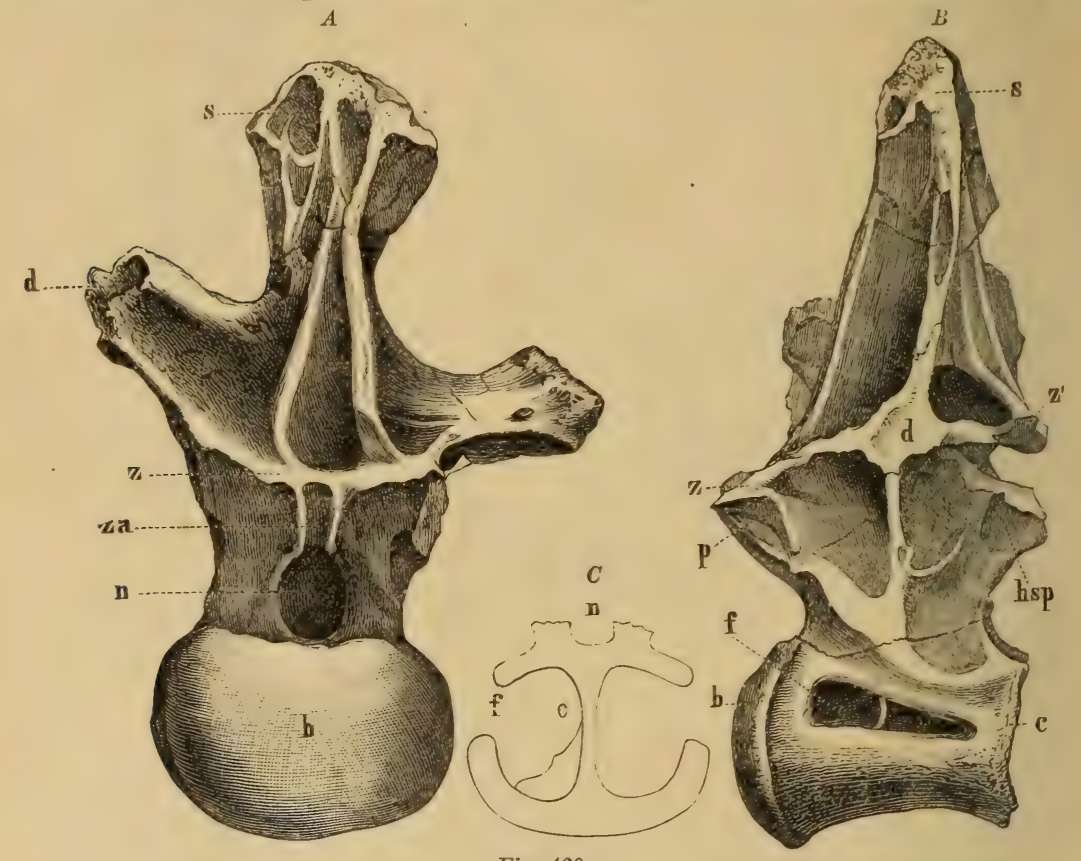

Fig. 430 .

Pelorosaurus aus dem Wealden von Wight. Ein Rückenwirbel $A$ von vorne, $B$ von der Seite, $C$ vertikaler Durchschnitt des Zentrums. 1/s nat. (ir. (Nach Hulke.) b vordere, $c$ hintere Gelenkfläche des Zentrums, $f$ seitliche Offnung zu dem inneren Hohlraum, $o$ Medianpfeiler, $n$ Rückenmarkskanal, $z$ vordere, $z^{\prime}$ hintere Zygapophysen, $z a$ Hypantrum, hsp Hyposphen, $d$ Diapophyse, $p$ Capitulargelenk der Rippe, $s$ Dornfortsätze.

großen seitlichen Augen befinden sich eine oder zwei präorbitale Öffnungen von verschiedener Form und Größe. Die großen Nasenlöcher liegen entweder getrennt seitlich (Morosaurus) oder vereinigt weit zurück auf das Schädeldach hinaufgerückt (Diplodocus). Die Halswirbel und die meisten Rückenwirbel (selten alle) sind opisthocöl und die zweiköpfigen Rippen teilweise mit ihren Wirbelkörpern bezw. oberen Bogen verschmolzen. Häufig zeigen sich die Dornfortsätze der Halswirbel und vorderen Rückenwirbel niedrig gebaut und gegabelt, die Gelenkung der einzelnen Wirbel kann außer den Zygapophysen auch durch Hyposphen-Hypantrum erfolgen. Die Wirbelkörper der Rumpfwirbel (Fig. 430) zuweilen auch noch anderer Regionen enthalten große Hohlräume, welche zu Lebzeiten des Tieres wahrscheinlich mit Luft erfüllt waren. Diese Hohlräume bilden in der Regel zwei große seitliche, durch eine mediane Längsscheidewand getrennte Kammern, die 
nach außen in einer rundlichen oder länglichen unter der Basis des oberen Bogens befindlichen Öffnung münden. Auch die oberen Bögen und Dornfortsätze der präcaudalen und zuweilen auch noch der vorderen Schwanzwirbel können cavernöse Beschaffenheit aufzeigen. Die 4-5 Sacralwirbel können, teilweise nicht nur mit ihren Wirbelkörpern und Gelenkfortsätzen sondern auch mit ihren Dornfortsätzen gegenseitig verschmelzen. Die meist soliden Schwanzwirbel sind entweder amphicöl, sẻltener procöl, unten gewöhnlich mit langen, sehr variierenden Hämapophysen (Chevrons) ausgestattet. Rückenmarkkanal in der Sacralgegend erweitert, zwei- bis dreimal so groß als die Gehirnhöhle.

Die Extremitätenknochen sind fast ganz solide gebaut. Das Sternum ist durch eine unpaare oder zwei Ossifikationen vertreten. Das Becken ist Theropoden ähnlich, aber das Ilium ohne hintere Spitze. Der gerade, mit dickem Gelenkkopf versehene Oberschenkel übertrifft den Unterschenkel beträchtlich an Länge. Der Astragalus besitzt keinen aufsteigenden Fortsatz. Die Phalangen sind kurz, und die Klauen waren wahrscheinlich mit Hornscheiden umgeben oder hufähnlich.

Die Sauropoden finden sich in mittel- und oberjurassischen Ablagerungen und in der Kreide von Europa, Nordamerika, Afrika, Madagaskar,

dien. Die jüngsten Reste stammen aus der obersten Kreide (? Eocän) Patagonien.

\section{Familie. Cetiosauridae.}

Halswirbel opisthocöl, vordere Rückenwirbel schwach opisthocöl, hintere Rückenwirbel amphicöl. Dornfortsätze nicht gegabelt. Alle Präsacralwirbel mit seitlichen Höhlungen. Sacral- und Schwanzwirbel solid. Eine unpaare Sternalplatte. Pubis plattenförmig. Foramen obturatorium groß. Scapula distal und proximal verbreitert. Vorderextremitäten nahezu ebensogroß oder gleichgroß wie die Hinterextremitäten. Jura bis Kreide.

Cetiosaurus Owen (Cardiodon Owen). Skelett zirka $12 \mathrm{~m}$ lang und $3 \mathrm{~m}$ hoch. Humerus und Femur fast gleichgroß, letzterer $1,7 \mathrm{~m}$ lang. Scapula $1,85 \mathrm{~m}$ lang. Ischium schwächer als Pubis und distal verschmälert. Dogger bis unterer Malm, England.

Brachiosaurus Riggs. Humerus und Femur über $2 \mathrm{~m}$ lang, Centra der Rückenwirbel nicht verlängert. Hypantrum-Gelenkung sehr kräftig entwickelt, 5 Sacralwirbel, von denen 1-4 mit den Gelenkfortsätzen 2 und 3 auch mit den Dornfortsätzen verschmolzen sind. Untere Kreide (Como beds). Westliches Nordamerika.

Haplacanthosaurus Hatcher. Centra. der 14 Rückenwirbel verlängert. Oberer Bogen der hinteren Rückenwirbel sehr in die Höhe gezogen. Querfortsätze der Rückenwirbel nach oben und außen gerichtet. 5 Sacral wirbel. Untere Kreide (Como beds). Westliches Nordamerika.

Distrophaeus Cope. Mittlerer Jura. Westliches Nordamerika.

\section{Familie. Atlantosauridae.}

Halswirbel und vordere Rückenwirbel opisthocöl. Hintere Rückenwirbel amphicöl. Präsacral-, Sacral- und vordere Schwanzwirbel cavernös. Halswirbel und vordere Rückenwirbel mit gegabelten Dornfortsätzen. Halsrippen mit seh. langem Capitulum und Tuberculum. Paarige verknöcherte Sternalplatten. Scapula distal nicht verbreitert. Untere Kreide.

A pa to s a urus Marsh. (Brontosaurus, Titanosaurus Marsh). (Fig. 431, 434. .) Skelett zirka $18 \mathrm{~m}$ lang. Schädel auffallend klein, Hirnhöhle winzig. Hals lang (13 Wirbel), Rumpf gedrungen (10 Wirbel). 5 Sacralwirbel (von denen 
die :3 mittleren frühzeitig und vollständig, die 2 äußeren erst in hohem Alter mit diesen und nur teilweise verschmelzen). Die Halsrippen, von denen die vorderen mit den Wirbelkörpern verschmolzen sind, beilförmig. Sämtliche Wirbel mit Ausnahme der hinteren Caudalwirbel mit großen Hohlräumen. Das Ischium viel schlanker als das proximal und distal verbreiterte Pubis. Untere Kreide (Como beds). Westliches Nordamerika.
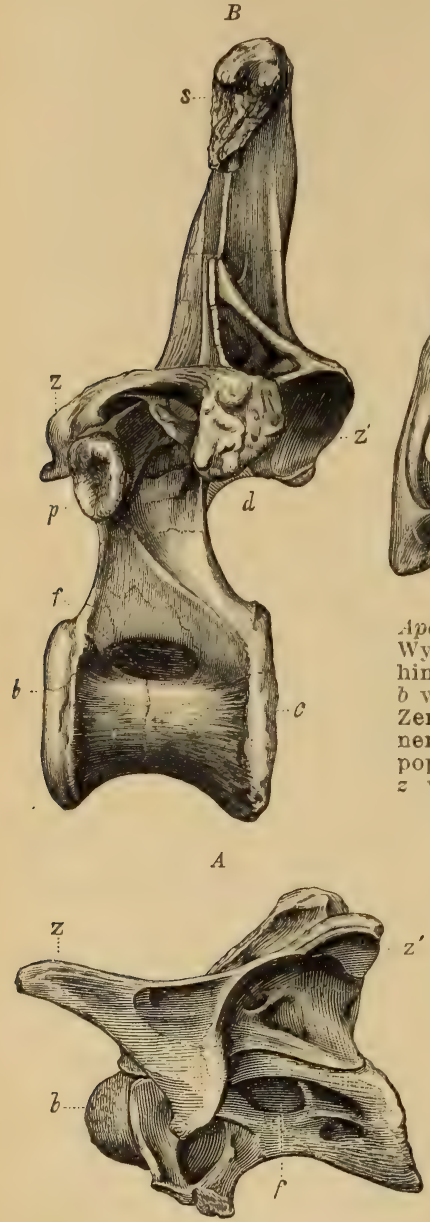

B

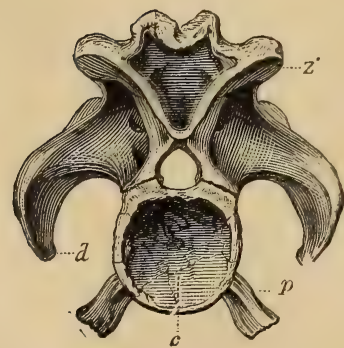

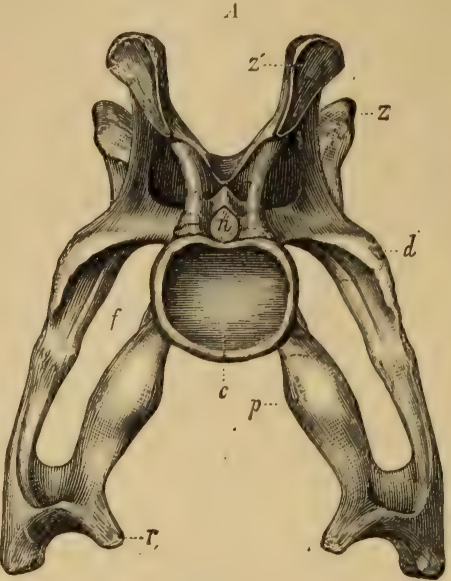

Fig. 431.

Apatosaurus excelsus Marsh. Ob. Jura. Wyoming. A sechster Halswirbel von hinten, $B$ Rückenwirbel von der Seite. $b$ vordere, $c$ hintere Gelenkfläche des Zentrums, $f$ seitliche Offnung des inneren Hohlraums, $n$ Neuralkanal, $d$ Diapophyse, $p$ Parapophyse, $s$ Dornfortsatz, $z$ vordere, $z^{\prime}$ hintere Zygapophyse, $r$ Rippe. (Nach $\mathrm{Y}$ alrsh.)

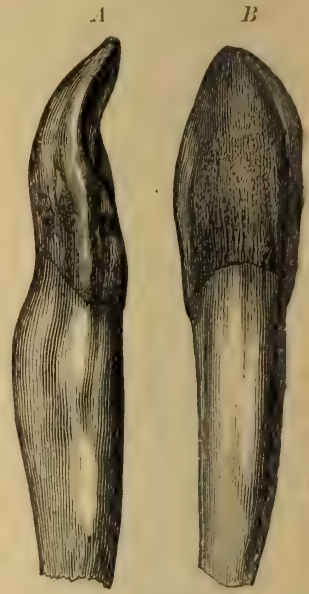

Fig. 432.

Morosaurus grandis Marsh. Ob. Jura. Wyoming.

$A, B$ Zahn von der Seite und von vorn.

$1 / 2$ nat. Gr.

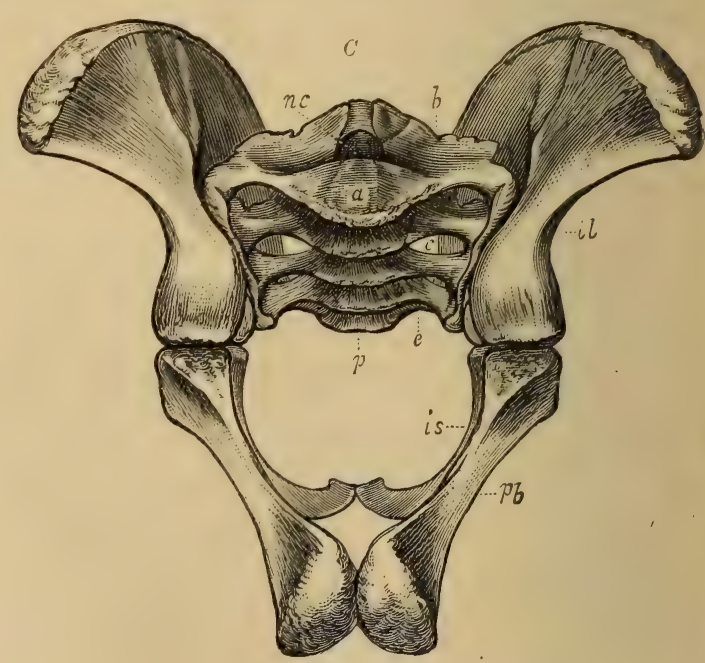

Fig. 433 .

Yorosaurus grandis Marsh. $A, B$ vierter Halswirbel von der Seite und von hinten. 1/8 nat. Gr. $b$ vordere, $c$ hintere Gelenkfläche, $z$ vordere, $z^{\prime}$ hintere Zygapophyse, $d$ Diapophyse, $p$ Parapophyse, $f$ seitliche Offnung, nc Neuralkanal.

$C$ Becken von vorne. $1 / 16$ nat. Gr. $a$ erster, $p$ letzter Sacralwirbel, $b, c, d, e$ Querfortsätze, $i l$ Ilium, $P b$ Pubis, is Ischium. (Nach Marsh.) 
Atlantosaurus Marsh. Von ebendort.

Barosaurus Marsh. Von ebendort.

\section{Familie. Morosauridae.}

Die (10) Hals- und (15) Rückenwirbel opisthocöl mit gegabelten Dornfortsätzen. Hals- und Rïckenwirbel cavernös. Die 4-5 Beckenwirbel beinahe solid. Schwanzwirbel solid. Scapula proximal stark, distal wenig verbreitert. Vorderextremitäten wesentlich kürzer als die Hinterextremitïten. Kreide (? Eocän).

Morosaurus Marsh. (Fig. 432 u. 433). Schädel mit großer Nasenöffnung und kleinem dreieckigen Präorbitaldurchbruch. Chevrons mitden Wirbelkörpern der Schwanzwirbel gelenkend. 4 Sacralwirbel. Pubis distal um $90^{\circ}$ gedreht, so daß die Symphyse durch die Seitenflächen anstatt durch die Endflächen gebildetwird. Untere Kreide (Como beds). Westliches Nordamerika und Wealden, England.

Camarosaurus Cope, $P l$ eu. rocoelus Marsh. Untere Kreide (Como beds). Westliches Nordamerika, letzterer auch Westeuropa.

Gigantosaurus E. Fraas, non Seeley. Zirka 14-15 m lang. 4 Sacralwirbel. Vordere Schwanzwirbel procöl. Obere Kreide. Deutsch-Ostafrika.

Titanosaurus Lydekker. (non Marsh.) Wealden von Westeuropa, mittlere Kreide Indien, obere Kreide Madagaskar. Oberste Kreide ? Eocän Patagonien.

Pelorosaurus Mantell. Bo. thriospondylus, Chondrosteosaurus, Chondrosteus Owen, Gigantosaurus Seeley non Fraas, Eucamarotus Ischyrosaurus Hulke, Neosodon Moussaye, Oplosaurus Gervais. Ornithopsis Seeley. (Figur 430.) Rückenmarkskanal der Rumpfwirbel sehr weit. 4 Sacralwirbel. Zahlreiche Wirbelund Skelettknochen von beträchtlicher Größe finden sich im obersten Jura und im Wealden v. England, außer dem im Jura und Wealden von Westeuropa und Madagaskar.

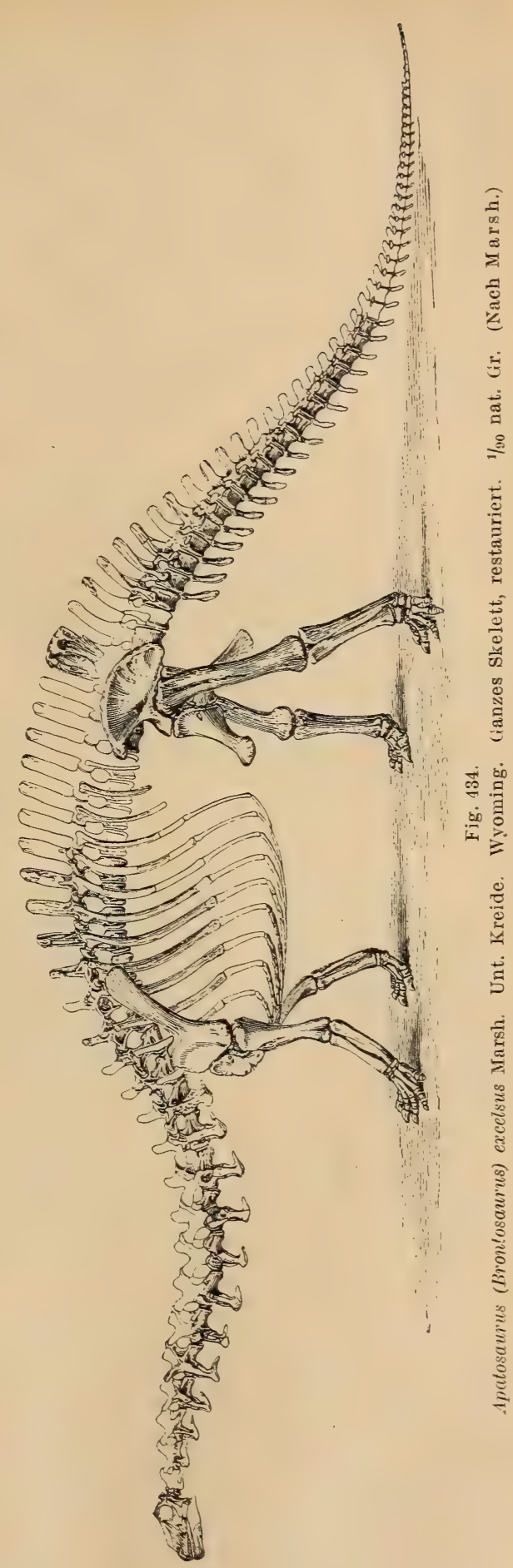




\section{Familie. Diplodocidae.}

Zähne zylindrisch, schlank, auf den vorderen Teil der Kiefer beschränkt. Nasenlöcher weit zurïck und oben zwischen der hinteren Präorbitalöffnung und den Augen gelegen. Die 15 Halswirbel und die 10 Rückenwirbel opisthocöl, Halswirbel und vordere Rückenuirbel mit gegabelten Dornfortsätzen. Präcaudal- und vordere Caudalwirbel cavernös. 2 paarige verknöcherte Sternalplatten. Pubis und Ischium distal verdiclit. Scapula distal und besonders proximal stark verbreitert. Untere Kreide.

Diplodocus Marsh. (Fig. 435.) Mit den Merkmalen der Familie, erreichte eine Länge bis $20 \mathrm{~m}$. Der $0,60 \mathrm{~cm}$ lange Schädel jederseits mit 2 Präorbitalöffnungen und weit zurückliegenden, nach oben auf das Schädeldach geschobenen, vereinigten und durch einen Fortsatz der Nasalia teilweise geteilten (zwischen den großen hinteren Präorbitalöffnungen und den wei-

A

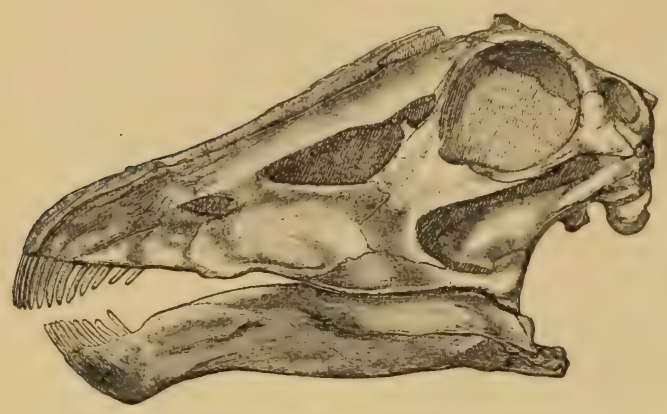

$B$

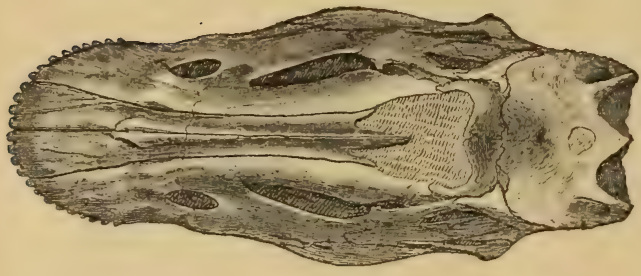

Fig. 435.

Schädel von Diplodocus longus Marsh. T'nt. Kreide. Cañon City, Colorado. ca. $1 / 8$ nat Gr. (Nach Marsh.) $A$ von der Seite. $B$ von oben. Vor den rundlichen großen Augen die beiden Präorbitalöffnungen. Die vereinigten Nasenlöcher (Fig. B) auf dem schädeldach zwischen Augen und hinterer Präorbitalöffnung. ten Augenhöhlen gelegenen Nasenlöchern. 5 Sacralwirbel. Über 70 Schwanzwirbel, von denen die vorderen mehr oder weniger procöl sind, mit sehr verschiedenartigen Chevrons. Untere Kreide (Como beds.) Westliches Nordamerika.

Sauropoden incertae sedis: Aepyosaurus Gervais. Untere Kreide. Frankreich. Algaosaurus Broom. Kreide. Südafrika. Argyrosaurus Ly. dekker. Oberste Kreide.? Eocän Patagonien.? Astrodon Leidy. Untere 'Kreide. Nordamerika. Caulodon Cope. Untere Kreide. Westliches Nordamerika. Di nodocus Owen. Kreide. Eng. land. Elosaurus Pet. und Gilm. Kreide Nordamerika. Epanterias Cope.Untere Kreide. Westliches Nordamerika. $H y$ pselosaurus Mathér. Obere Kreide. Südfrankreich. Micro coelus Lyd. Oberste Kreide. ?Eocän Patagonien. Morinosaurus Sauv. Malm Frankreich. Sympliyrosaurus Cope. Untere Kreide. Westliches Nordamerika.

\section{Unterordnung. Praedentata Marsh. (Orthopoda Cope.)}

Prämaxillaria meist zahnlos. Unterkiefer mit einem zahnlosen Symphysen.) iein (Praedentale.) Zühne in einer oder mehreren funktionierenden Reihen angeordnet. Zähne blattförmig, zusammengedrückt, am Vorder- und Hinterrand gezackt, bei längerem Gebrauch abgekaut. Äußsere Nasenlöcher sehr grof, weit vorn, seitlich. Wirbelcentra gewöhnlich solid, opisthocöl, amphicöl-platycöl. Pubis mit einem dem Ischium parallelen Postpubis von verschiedener Länge. Extre. mitätenknochen hohl oder massiv. Füße digitigrad oder plantigrad. Astragalus 
ohne aufsteigenden Fortsatz. Hautskelett sehr stark entwickelt oder fehlend. Obere Trias bis obere Kreide.

$\mathrm{Zu}$ den Praedentata gehören meist sehr große bipedale oder quadrupedale, herbivore Landtiere, die sich vor allem durch den Mangel an Zähnen am Vorderende der Schnauze und in der Symphyse des Unterkiefers, sowie den Besitz eines meist sehr langen Postpubis auszeichnen. Sie zerfallen in die Familie Ornithopodidae, Stegosauridae und Ceratopsidae.

\section{Familie. Ornithopodidae.}

Schädel klein, ungefähr einen rechten Winkel mit dem Hals bildend. Prämaxillaria in der Regel zahnlos. Zähne blattförmig, am Vorder- und Hinterrand zugeschärft und gezackt, zuweilen mit Mittelkiel. Wirbel solid, Halswirbel in der Regel und zuweilen auch vordere Rückenwirbel opisthocöl. Präorbitalöffnung häufig sehr klein. Nasenlöcher getrennt, grofs, weit vorne gelegen. Vorderbeine viel kürzer als die Hinterbeine. Hinterbein digitigrad, allein zum Gehen verwendet, mit Krallen oder mit Hufförmigen Endphalangen. Pubis mit langem, schlankem Postpubis. Hautskelett fehlt in der Regel. Obere Trias bis Kreide.

Die Ornithopodidae sind herbivore Dinosaurier, die sich in mehr oder weniger aufrechter Haltung ausschließlich auf ihren ungemein mächtigen Hinterbeinen fortbewegen.

with Unterfamilie. Hypsilophontidae.

Prämaxillaria zahnn. Zähne auf den Maxillaria in einer Reihe. Vordere Wirbel platycöl oder opishocöl. Sacralwirbel verschmolzen. Femur kürzer als Tibia. Hand mit 5 Fingern, Fuß mit 4 Zehen. Oberste Trias. Untere Kreide. Nanłosaurus Marsh. Ältester unvollständig bekannter kleiner Ortho. podide. Oberste Trias. Westliches Nordamerika.

Laosaurus Marsh. 8-10 Fuß hoch. Untere Kreide. (Como beds.) Westliches Nordamerika. Dryosaurus Marsh. Von eben dort.

Hypsilophodon Hulke. Nach v. Nopcsa mit Hautverknöcherungen. Verknöcherte Sehnen in der Dorso-caudal-Region. Wealden. England.

\section{Unterfamilie. Camptosauridae.}

Prämaxillaria zahnlos. Vordere Wirbel opisthocöl. Sacralwirbel nicht verschmolzen. Ilium mit langem, präacetabularem Fortsatz. Postpubis schlank, ebenso lang wie das Ischium. Femur länger als die Tibia. Hand mit 5 Fingern, Fuß mit 4 (3 funktionierenden) Zehen. Jura. Kreide.

Camptosaurus Marsh. (Camptonotus Marsh, Cumnoria Seeley.) Bis $10 \mathrm{~m}$ lang. Mit den Merkmalen der Unterfamilie. Zähne auf dem Maxillare groß, unregelmäßig. Pubis wohl entwickelt, mit breitem, vorderen Blatt. Femur gekrümmt. 4 (? 5 Sacralwirbel.) Untere Kreide. (Como beds.) Westliches Nordamerika. ? Oberer Jura, England, Frankreich. Wealden in England.

Mochlodon Seeley. Obere Kreide. Österreich-Ungarn.

Cryptosaurus (Cynodraco.) Seeley. Unterer Malm. England.

? Craspedodon Dollo. Obere Kreide. Belgien.

\section{Unterfamilie. Iguanodontidae.}

Prämaxillaria zahnlos, vordere Wirbel opisthocöl. Sacralwirbel mit einander verschmolzen. Postpubis sehr schlank, nicht so lang wie das Ischium. Sternum verknöchert. Femur länger wie Tibia. Hand mit 5 Fingern, Daumen stachelartig; Fuß mit 4 Zehen (von denen nur 3 funktionieren.) Untere Kreide. 
Iguanodon Mantell (Fig. 436-438). Schädel verhältnismäßig klein mit verlängerter, seitlich zusammengedrückter Schnauze. Auge höher als lang, kleiner als die hohen, schlitzartigen oder unregelmäßig dreieckigen,

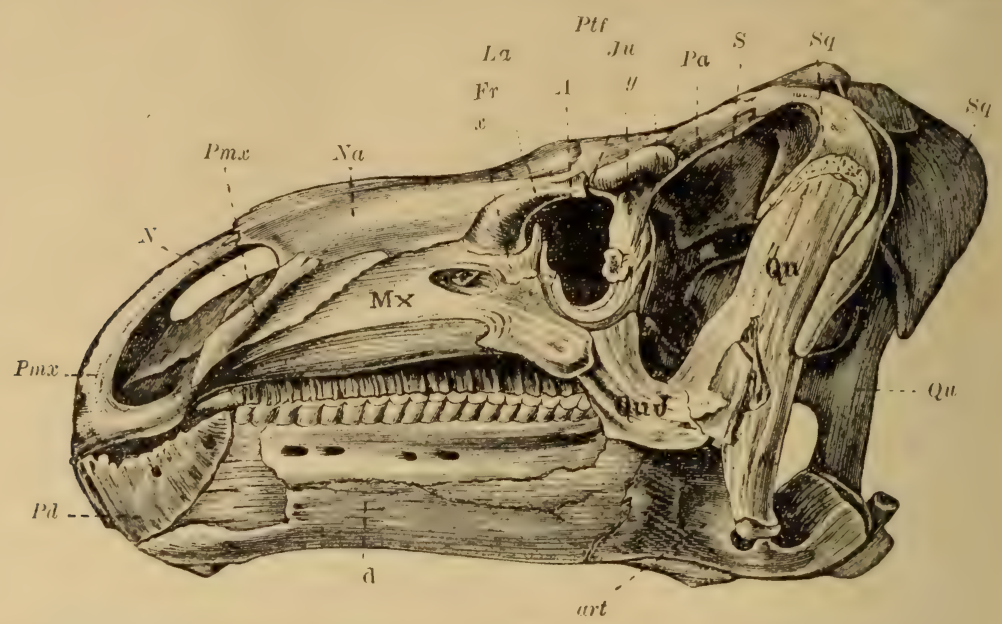

Fig. 436. Iguanodon Bernissartensis Boulenger. Wealden. Bernissart, Belgien. Schädel $1 / 8$ nat. Gr. (Nach Dollo.)

A Augenhöhle. N Nasenloch, s seitliche Schläfenöffnung, $P m x$ Primaxillare, $M x$ Maxillare, Na Nasale, La Lacrimale, Fr Frontale, Plf Postfrontale, $x, y$ Supraorbitalia, Ju Jugale, Pa Parietale, Sq Squamosum, Qu Quadratum, QuJ Quadrato-Jugale, $P d$ Prädentale, $d$ Dentale, art Articulare.

seitlichen Schläfenlöcher und die ovalen, am Schnauzenende gelegenen seitlichen Nasenöffnungen. Obere Schläfenlöcher klein, durch einen schmalen Parietalkamm getrennt. Vor den Augen seitlich der kleine ovale Präorbital-

Fig. 437.

Iguanodon Bernissartensis Boulenger. Wealden. Bernissart, Belgien. $1 / 60$ nat. Gr. (nach dem im Brüsseler Museum aufgestellten Skelett). sc Scapula, co Coracoid, I erster, V fünfter Finger, $p$ Pubis, $p p$ Postpubis, is Ischium, I-IV Zehen. Neben den Dornfortsätzen verknöcherte Sehnen. (Nach Dollo.)

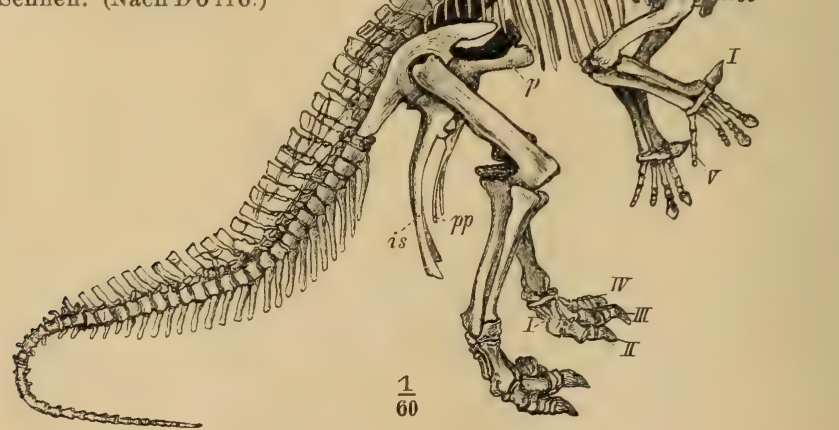

durchbruch. Frontale unpaar, sehr breit. Quadratum zu einem ungewöhnlich langen Gelenkfortsatz für den Unterkiefer ausgezogen, derselbe wird durch ein ansehnliches Quadratojugale mit dem halbmondförmigen, den Unterrand der Augenhöhle bildenden Jugale verbunden. Den Oberrand der 
Augenhöhle bilden 2 kleine Supraorbitalia. Lacrimale klein. Nasalia sehr lang. Prämaxillaria sehr lang, mit scharfen Rändern. Unterkiefer mit hohem Processus coronoideus, das Dentale vorne schräg abgestutzt und die Symphyse durch ein zahnloses scharfrandiges Prädentale gebildet. Auf Maxillare und Dentale in einer Reihe die zahlreichen, spatelförmigen Zähne, vorne und hinten gekerbt, nur außen in Alveolarrinnen eingefügt, nach innen freistehend. 10 Halswirbel, 18 Rückenwirbel, 4-6 Sacralwirbel, 40 bis 50 Schwanzwirbel. Die Halswirbel und vorderen Rückenwirbel opisthocöl. Hintere Rückenwirbel platycöl. Fast alle präsacralen Wirbel tragen Rippen.

Neben den hohen Dornfortsätzen der Rumpf- und Schwanzwirbel liegen häufig verknöcherte Sehnen (cf. Fig. 437). Scapula lang und schlank, Coracoid klein gerundet, Sternum von 2 verknöcherten gestielten Platten gebildet. Ilium vor und hinter der Pfanne stark verlängert.

Iguanodon Mantelli Owen aus dem untern Grünsand von England und den Wealden von Bernissart (Belgien) erreicht eine Länge von 5-6 m; J. Bernissartensis Bouleng. aus den Wealden von Bernissart und Eng. land eine solche von $18 \mathrm{~m}$. Fragmentäre Reste finden sich bereits im Purbeck von England. (? Mittlerer Jura von Portugal.)
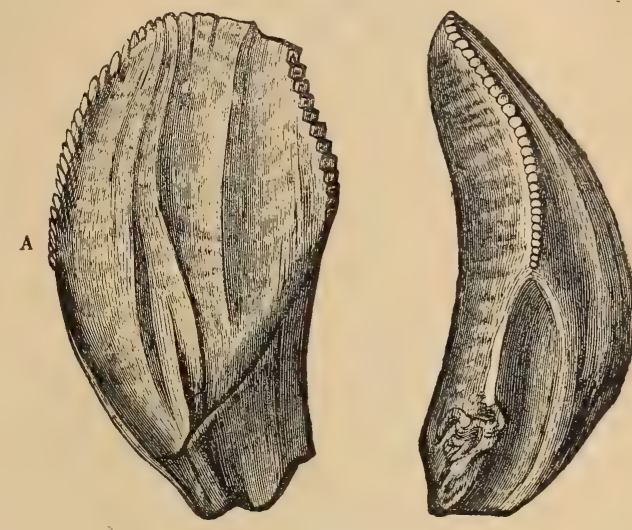

Fig. 438 .

Unterkieferzahn von Iguánodon Mantelli Owen aus dem Wealden der Insel Wight. $A$ von innen. $B$ von hinten. Nat. Gr. Ziemlich häufig sind drei-zehige Fährten im Wealdensandstein von England und Deutschland, welche sich auf Iguanodon zurückführen lassen. Im Wealden von Bernissart wurden 1873 nicht weniger als 23 meist vollständige Skelette ausgegraben, die jetzt im Museum von Brüssel aufgestellt sind. Die herbivoren Tiere schritten in aufrechter, leicht nach vorne gebeugter Haltung und benutzten lediglich die Hinterbeine zum Gehen und Laufen, in der Ruhe stützen sie sich auf den mächtigen Schwanz.

\section{Unterfamilie. Trachodontidae.}

Prämaxillaria zahnlos. Zähne in mehreren Reihen. Vordere Wirbel opisthocöl. Femur länger wie Tibia. Hand mit 4 Fingern. Fuß mit drei funktionierenden Zehen. Obere Kreide.

Trachodon Leidy (Hadrosaurus, Thespesius Leidy, Diclonius Cope). (Fig. 439-441.) Schädel verlängert, niedrig mit verbreiterter schnabelartiger Schnauze, großen Nasen- und Präorbitalöffnungen, vierseitigen Augenhöhlen und länglichen oberen und hohen seitlichen Schläfenöffnungen. Parietale sehr schmal. Unterkiefer mit Prädentale. Zähne dicht stehend, in einer nach innen offenen Alveolarinne eingelassen, die Ersatzzähne in mehreren Reihen übereinanderstehend. An der Kaufläche nehmen stets mehrere Reihen verschieden alter Zähne teil. Rückenwirbel opisthocöl. Schwanzwirbel platycöl. Skelett ähnlich Iguanodon. Extremitätenknochen hohl. Obere Kreide. Nordamerika.

Claosaurus Marsh. Bis $9 \mathrm{~m}$ groß. Schädel ähnlich Trachodon, jedoch Schnauze vorne wenig verbreitert. Von den zahlreichen Zähnen anscheinend nur eine Reihe in Gebrauch. 30 (? 33) präsacrale Rippen tragende Wirbel. 9 miteinander verschmolzene Sacralwirbel und über 60 mit 
langen Chevrons ausgestattete Schwanzwirbel. Die präsacralen und vorderen Schwanzwirbel opisthocöl. Sternum von 2 Knochen gebildet. Vorder. extremitäten ungewöhnlich kurz, an der Hand ist der erste Finger rudimentär und fehlt der 5. Fuß mit 3 mächtigen hufförmigen Zehen. Extremitätenknochen massiv. Obere Kreide. Nordamerika.

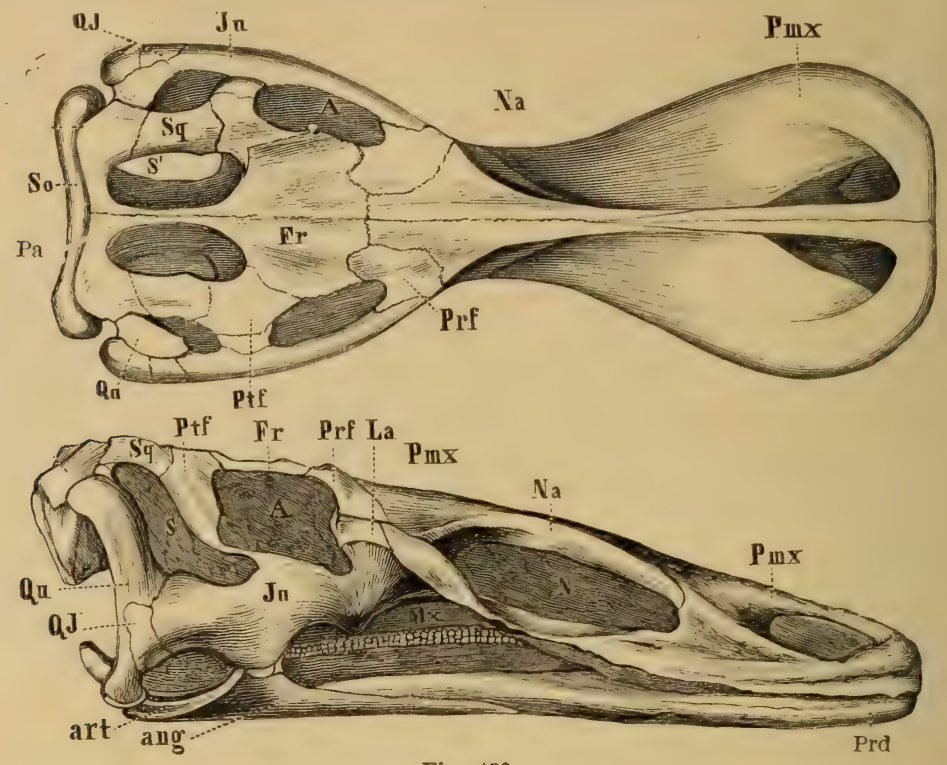

Fig. 439.

Trachodon mirabilis Leidy. (ob. Kreide (Laramie-Stufe). Dakota. Schädel von der Seite und von oben. 1/12 nat. Gr. (Yach Cope.) Pmx Prümaxillare, Ir: Maxillare, Na Nasale, F Frontale, $P$ Parietale, So Supraoccipitale, I'rf Präfrontale, I. a Lacrimale, Itf Postfrontale .J Jugale, Qj Quadratojugale, $Q^{*}$ Quadratum, $N^{\prime}$ Prïorbitaliffnung, A Auge, S'Seitliche, $S^{\prime}$ Obere Schläfenöffnung, art Arti-
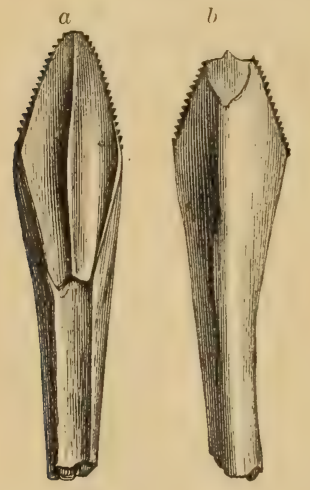

Fig. 440 .

Trachodon Foulkei Leidy. Ob. Kreide. New-Yersey. Unterkieferzahn in nat. Gr. $a$ von innen, $b$ von außen (etwas abgekaut), $c$ von der Seite. (Nach Leidy.) $c$

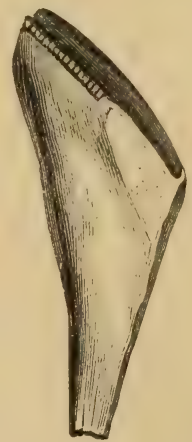

der Seite. (Nach culare, ang Angulare, Prd Prädentale.

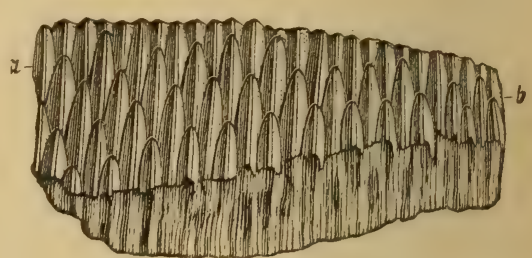

P.

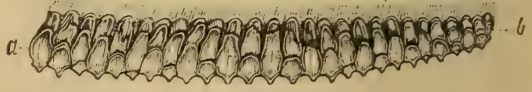

Fig. 441

Trachodion breviceps Marsh. Ob. Kreide. Montana. A rechtes Dentale des Unterkiefers von innen. $B$ von oben, $1 / 4$ nat. Gr. (Nach Marsh.)

Telmatosaurus v. Nopcsa (Limnosaurus v. Nopesa). Obere Kreide. Österreich-Ungarn. Hieher dürften vielleicht manche aus der oberen Kreide als Titanosaurus beschriebenen Reste zu stellen sein. Orthomerus Seeley. Obere Kreide. Belgien. Cionodon Cope. Obere Kreide. Nordamerika.

Sphenospondylus Seeley. Wealden. England. Alle mit Telmatosaurus nahe verwandt, vielleicht teilweise identisch. 
lich; seitliche länglich. Nasalia sehr lang, fast die Hälfte des Schädeldaches bildend. Unterkiefer hoch, mit zahnlosem Prädentale. Zähne zahlreich, spatelförmig, leicht befestigt, in einer einzigen funktionierenden Reihe. Wirbel amphicöl-platycöl. Halswirbel mit kurzen Rippen, Rückenwirbel mit sehr erhöhten oberen Bogen nebst langen Rippen und ansehnlichen Dornfortsätzen. 4 miteinander verschmolzene Sacralwirbel, deren Rückenmarkskanal an Volumen jenes der Gehirnhöhle um das Zehnfache übertrifft. Vordere Schwanzwirbel die größten der ganzen Reihe mit langen Cherrons. Vorderfüße mit 5 Fingern, Hinterfüße mit drei funktionierenden Zehen. Astragalus mit der Tibia verschmolzen. Auf Hals, Rücken und dem größten Teil des Schwanzes standen 2 Reihen großer vertikaler, ursprünglich mit Horn überzogener Knochenplatten, auf welche am Hinterende des Schwanzes 4 Paar lange Stacheln folgten. Ein Pflaster von kleineren Verknöcherungen bedeckte die Kehle. Skelette bis $9 \mathrm{~m}$ lang. Untere Kreide (Como beds). Westliches Nordamerika. Oxford von England.

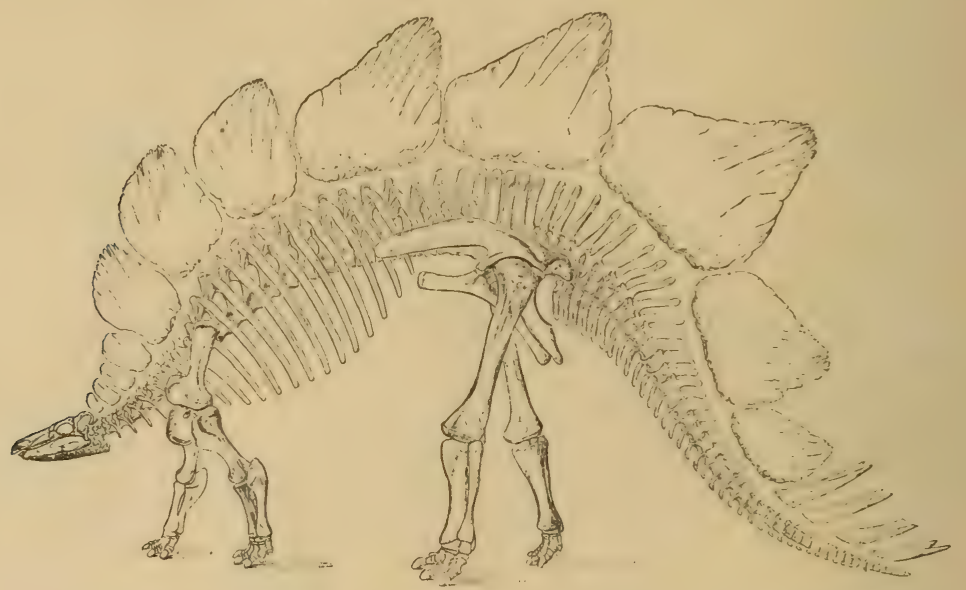

Fig. 444.

Skelett von Stegosaurus ungulatus Marsh. Untere Kreide. Kolorado. 1/60 nat. Gr. (Nach Marsh.)

Diracodon Marsh. Vielleicht ein jugendliches Individuum von Stegosaurus. Untere Kreide. (Como beds.) Westliches Nordamerika.

Omosaurus Owen (Dacentrurus Lukas) aus dem Dogger und Malm Englands ist mit Stegosaurus sehr nahe verwandt. 5 Sacralwirbel.

Polacanthus Hulke. Lenden und Sacralgegend von einem geschlossenen, aus skulptierten Knochenplatten bestehenden, Glyptodonten ähnlichen Panzer umhüllt. Hals, Rücken und Schwanz mit 2 Längsreihen knöcherner Stacheln. Wealden. England.

Stegopelta Williston. Obere Kreide. Nordamerika. Sehr ähnlich Polacanthus.

Palaeoscincus Leidy, Stereocephalus Lambe (Ankylosaurus Brown). Obere Kreide. Nordamerika. amerika.

Hierosaurus Wieland. Nodosaurus Marsh. Obere Kreide. Nord-

Echinodon Owen. Purbeck England, Stenopelix H.v. Meyer. Wealden Deutschland. Priconodon Marsh. Untere Kreide. Westliches Nordamerika. Hoplitosaurus Lucas. Untere Kreide. Nordamerika. Hyaeolosaurus Owen. Untere Kreide. England, Frankreich, ? Deutschland. Testisaurus Hulke. Wealden, Acanthopholis (Macrurosaurus) Seeley. Mittlere Kreide. Crataeomus Seeley (Damubiosaurus Bunzel). Struthiosaurus Bunzel. Obere 
Kreide. Oligosaurus, Hoplosaurus Seeley. Obere Kreide. Österreich, Frankreich, England.

? Sarcolestes Lyd. Malm England. ?Regnosaurus Mantell. Wealden England. Anoplosaurus, Eucerosaurus, Syngonosaurus, Priodontognathus Seeley. Obere Kreide. England. ? Apatodon, Brachyrophus, Macelognathus Marsh. Untere Kreide (Como beds). Westliches Nordamerika.

\section{Familie. Ceratopsidae.}

Schädel sehr groß, mit langen zugespitzten hornähnlichen Knochenzapfen und schirmförmigem, nach hinten vorspringendem Parietale und Squamosum. Keine Präorbitalöffnungen. Prämaxillaria zahnlos, miteinander verschmolzen, vor ihnen ein zugespitztes Schnauzenbein (Rostrale), welches dem zahnlosen Prädentale des

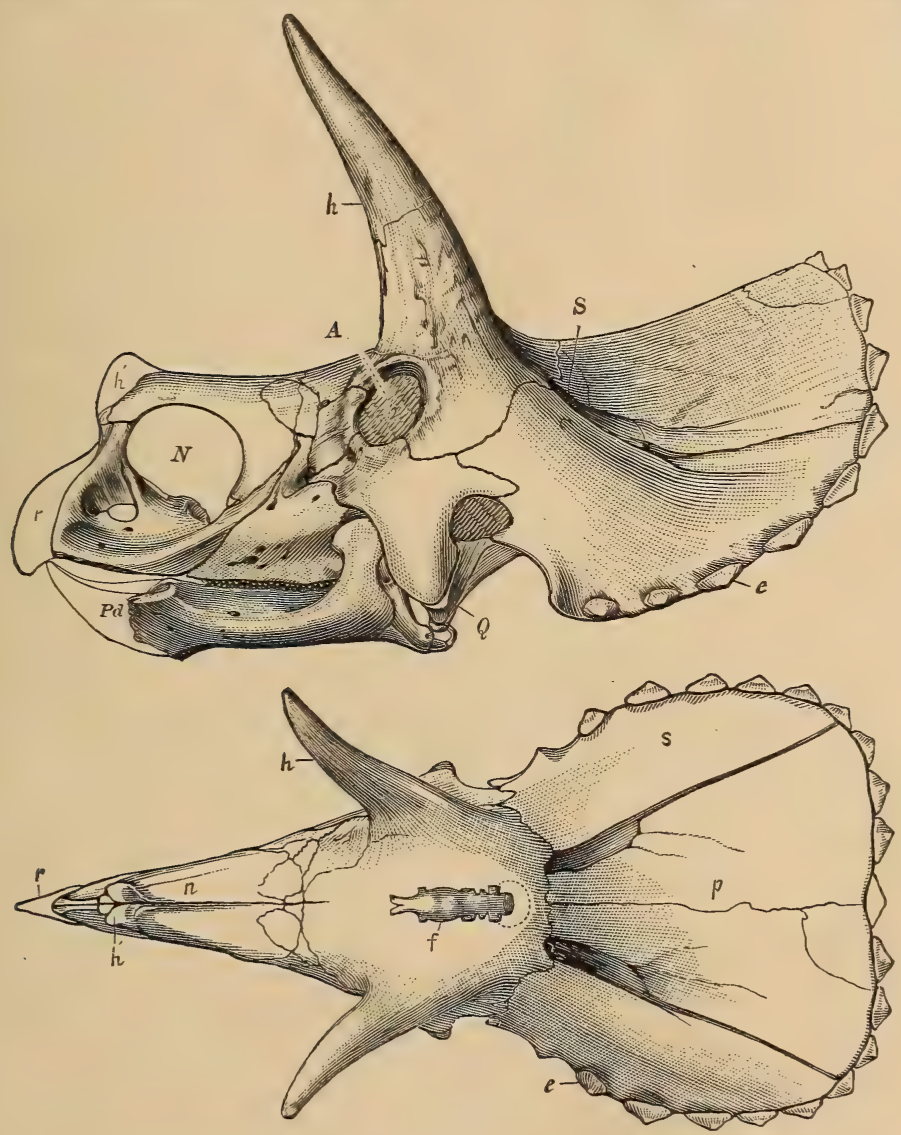

Fig. 445 .

Triceratops flabellatus Marsh. Oberste Kreide. Montana. 1/2n nat. Gr. (Nach Marsh.) Schädel von der Seite und von oben. $N$ Nasenloch, $A$ Augenhöhle, $S$ oberes Schläfenloch, $p$ Parietale, $s$ Squamosum, $e$ Randknochen der Parietale und Squamosa, $h$ Stirnzapfen, $h$ Nasenzapfen, $f$ Gehirn, $v$ Rostrale, $Q$ Quadratbein, $P d$ Prädentale.

Unterkiefers entspricht. Zähne anfangs mit einer, später mit 2 Wurzeln 4 (3) Halswirbel miteinander verschmolzen. Wirbel platycöl und wie die Extremitäten solid. Postpubis sehr reduziert. Neuralkanal in der Beckengegend nicht erweitert. Vorder. beine den Hinterbeinen an Größe wenig nachstehend. Femur länger wie Tibia. Ulna mit Trochanter. Alle Zehen mit hufförmigen Endphalangen. Hautskelett äußerst unvollständig. Obere Kreide. Nordamerika (Vereinigte Staaten und Canada). 
Das auffallendste Merkmal dieser meist gigantische Proportionen erreichenden pflanzenfressenden, quadrupedalen Dinosaurier besteht in den massiven, kräftigen, supraorbitalen Hörnern auf den Frontalia, die an die knöchernen Stirnzapfen der Bovidae erinnern. Sie zeigen auf der rauhen, porösen Oberfläche deutliche Gefäßeindrücke und waren wahrscheinlich von Hornscheiden umgeben; auch die Nasalia können einen kurzen, medianen Knochenzapfen tragen. Gewissermaßen als Gegengewicht zu diesen gewal-

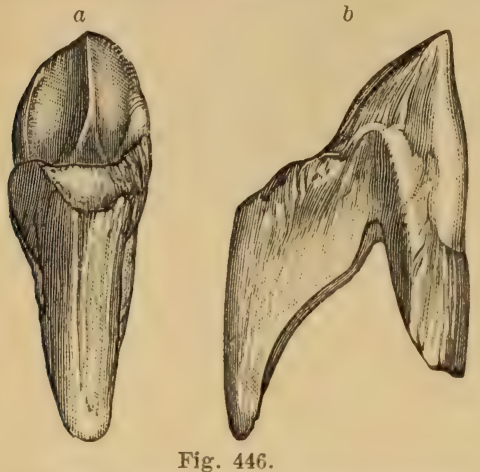

Iriceratops serratus Marsh. Oberkieferzahn a. von aufen, b ron der Seite. Nat. Gr. (Nach Marsh.) tigen Protuberanzen in der mittleren und vorderen Schädelpartie wirken die nach hinten dachartig über die vordere Halsregion ausgezogenen, an den Rändern mit einem Kranz kleiner Hautknochen besetzten Parietalia und Squamosa. Ebenso bezeichnend ist das unpaare, an Schildkrötenschnäbel erinnernde Rostrale.

Triceratops Marsh (Sterrholophus Marsh). (Fig. 445-447.) Skelett ca. $8 \mathrm{~m}$ lang, Schädel bis $2 \mathrm{~m}$ lang, vorn zugespitzt, hinten breit. Die supraorbitalen Hörner nach vorwärts und aufwärts gerichtet. Nasal-Horn mäßig groß und beinahe gerade nach vorwärts gestellt. Squamosum kurz und breit. Oberes Schläfen. loch von elliptischem Umriß zwischen $\mathrm{Pa}$ rietale und Squamosum, seitliches Schläfenloch klein, rückwärts unterhalb der Augen gelegen. Ein (bis zwei) postfrontales Foramen (Gefäßöffnung) vorhanden oder fehlend. Zähne spatelförmig mit seitlichem Kiel und im Alter mit 2 Wurzeln. Unterkiefer mit großem Processus coronoideus. Von den 8 (7) Halswirbeln sind die ersten 4 miteinander verschmolzen, um den gewal-

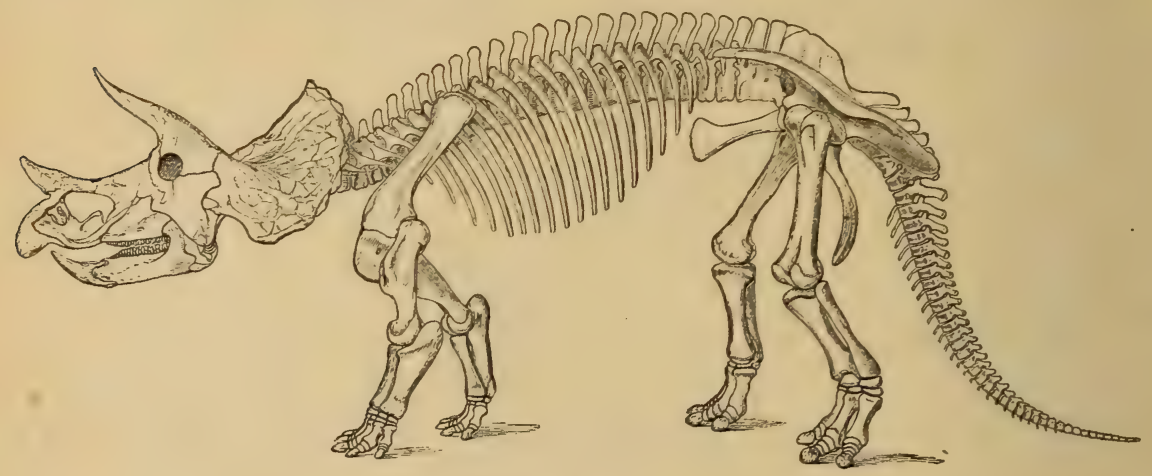

Fig. 447.

Triceratops prorsus Marsh. Ob. Kreide. Montana. Skelett restauriert, 1/70 nat. Gr. (Nach O. C. Marsh.)

tigen Kopf besser tragen zu können. 14 Rückenwirbel. Sacrum aus 10 verschmolzenen Wirbeln zusammengesetzt. Verknöcherte Sehnen sind nachgewiesen. Halsrippen zweikőpfig gerade, Rückenrippen zweiköpfig stark gekrümmt. Schwanzrippen einköpfig. Obere Kreide. Nordamerika.

Monoclonius Cope. Nasalhorn mächtig, groß und nach rückwärts gekrümmt. Obere Kreide. Nordamerika.

Diceratops Lull. Ohne Horn auf der Nase. Ob. Kreide. Nordamerika.

Centrosaurus Lambe. Agathaumas Cope. Ob. Kreide. Nordamerika.

Ceratops Marsh. Torosaurus Marsh. 
Zeitliche Verbreitung der Dinosaurier.

\begin{tabular}{|c|c|c|c|c|c|c|c|c|c|c|}
\hline & & & & : & $\stackrel{\frac{\infty}{2}}{\frac{\pi}{a}}$ & $\begin{array}{l}\dot{8} \\
80 \\
80 \\
8 \\
0\end{array}$ & $\stackrel{\Xi}{\Xi}$ & 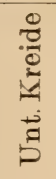 & $\begin{array}{l}0 \\
0 \\
0 \\
0 \\
0 \\
0 \\
0\end{array}$ & 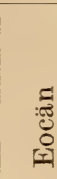 \\
\hline $\begin{array}{l}\text { 1. Theropoda } \\
\text { 1. Plateosauridae. }\end{array}$ & 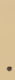 & . & & & & & & & & \\
\hline 2. Anchisauridae. & & & & & & & & & & \\
\hline 3. Labrosauridae . & & & & & & & & & & \\
\hline 4. Coeluridae . . & & 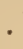 & & & & $\therefore$ & & & & $\frac{?}{3}$ \\
\hline 5. Megalosauridae. & & & & & & & & & & $?$ \\
\hline 6. Compsognathidae & & & & & & & & & & \\
\hline $\begin{array}{l}\text { 2. Sa uropoda } \\
\text { 1. Cetiosauridae. }\end{array}$ & & & & & & & & & & \\
\hline 2. Atlantosauridae & & & & & & & & & & \\
\hline 3. Morosauridae . & & & & & & & & & & $?$ \\
\hline 4. Diplodocidae & & & & & & & & & & \\
\hline $\begin{array}{l}\text { 3. Prädentata } \\
\text { 1. Ornithopodidae. }\end{array}$ & & & & & & & & & & \\
\hline 2. Stegosauridae . & & & & & & & & & & \\
\hline 3. Ceratopsidae . & & & . & & & & & & & \\
\hline
\end{tabular}

Die Dinosaurier beginnen in der Trias und erlangen in dem oberen Jura und der unteren Kreide den Höhepunkt ihrer Entwicklung um in der obersten Kreide (? Eocän Patagonien) auszusterben. Für die ehemalige Existenz zahlreicher triasischer Dinosaurier sprechen auch die in erstaunlicher Menge vorkommenden Fußspuren in den roten oder dunkel gefärbten Triassandsteinen in Massachusetts, Connecticut, Pennsylvania, Virginia, North-Carolina. Man hat namentlich im Connecticuttal etwa 100 verschiedenartige Fährten entdeckt, deren Größe zwischen $2,5 \mathrm{~cm}$ und $60 \mathrm{~cm}$ schwankt. Die meisten von ihnen sind dreizehig, einige aber auch 4- und 5-zehig. Da die ersteren von Tieren herrührten, die wahrscheinlich auf zwei Beinen einhergingen, so wurden sie vielfach (u. a. Hitchcok) für Spuren von Vögeln gehalten (Ornithichnites). Im auffallenden Gegensatz zu den häufigen Spuren stehen in den betreffenden Ablagerungen die seltenen Funde eigentlicher Skelettreste.

Über die Verwandtschaft, Entstehung und Entwicklung der Dinosaurier gewähren die bis jetzt bekannten Tatsachen noch keine bestimmte Auskunft. Ähnliche Merkmale, wie eine Präorbitalöffnung, treffen wir bereits bei den Stegocephalen (Trematops), der Bau des Schultergürtels erinnert teilweise ebenso wie die größere Zahl der Sacralwirbel an gewisse Theromora. Eine größere Zahl gemeinsamer Charaktere zeigen die Parasuchier (die ihrerseits Protorosaurus unter den Rhynchocephalen nahezustehen scheinen). Diese Eigenschaften sind besonders am Schädel der Parasuchier ausgeprägt, die, außer in der Präorbitalöffnung, in der Lage und Größe der Augen- und Nasen- 
löcher, in der knöchernen Umgrenzung der beiden Schläfenlöcher und in der Anordnung der Schädelknochen zum Ausdruck kommen, auch im Bau des Beckens zeigt sich zwischen ihnen und den Theropoden Ähnlichkeit.

Innerhalb der Dinosaurier selbst erscheinen die Sauropoden gegenüber den Theropoden als eine mehr spezialisierte Gruppe. Die Übertragung der Körperlast auf die hinteren Extremitäten, der aufrechte Gang verlieh vielen Dinosauriern ein vogelartiges Aussehen und diese äußere Ähnlichkeit findet auch in sehr bestimmter Weise im Knochenbau des Beckens und der Hinterbeine ihre Bestätigung, auf welche Merkmale bereits früher hingewiesen wurde. Obwohl nun diese Merkmale in der Hauptsache auf einer Convergenz mit den Vögeln begründet sein dürfte, so scheint es nicht ausgeschlossen, daß hierbei gemeinsam ererbte Anlagen eine Rolle spielen. Dafür spricht auch die teilweise Beweglichkeit des Schädels (durch Verschiebung der Pterygoidea und der unteren Enden der Quadratbeine) bei einigen Dino. sauriern, welche Eigentümlichkeit gleichfalls den Vögeln zukommt. Vögel und Dinosaurier haben daher mit einiger Wahrscheinlichkeit gemeinsame Ahnen, dürften aber dann bereits sehr frühzeitig selbständige, in verschiedener Richtung spezialisierte Seitenäste ein und desselben Hauptstammes geworden sein.

\section{Ordnung Pterosauria (Patagiosauria, Flugsaurier. ${ }^{1}$ )}

Reptilien von vogelähnlichem Aussehen, mit kurzem oder langem Schwanz. Wirbel- und Extremitätenknochen hohl, pneumatisch. Hals kräftig, ziemlich lang, mit dem Schädel nahezu einen rechten Winkel bildend. Präsacralwirbel procöl. Schwanzwirbel amphicöl. Sacrum aus 4-10 gewöhnlich mehr oder weniger verschmolzenen Wirbeln bestehend. Hals und vordere Rumpfrippen zweiköpfig. Bauchrippen vorhanden. Schädel mit zugespitztem Schnabel, Suturen in der Regel undeutlich oder obliteriert. Zähne thecodont, auf die Kieferränder beschränkt oder fehlend. Quadratum lang, unbeweglich am Schädel befestigt. Foramen parietale fehlt. Augen groß, seitlich, meist mit Scleroticaring. Obere und seitliche Șchläfenöffnungen vorhanden. Präorbitalöffnug groß, zuweilen mit der Nasenöffnung vereinigt. Stẹnum groß, schildförmig, vorne gekielt. Scapula und Coracoid schlank, Clavicula fehlt. Vorderfüße durch starke Verlängerung des 5. Fingers, woran sich eine Flughaut (Patagium) anheftet, als Flugorgan entwickelt. ? Pubis vom Acetabulum ausgeschlossen. Tarsus mit zwei Reihen von Knöchelchen. Die 5. Zehe selten ohne Phalangen. Haut nackt. Obere Trias bis obere Kreide.

1) Ammon L. v., Uber ein Flughautexemplar von Rhamphorhynchus. Geognost. Jahreshefte. 21. Bd. 1908. Branca W., Fossile Flugtiere u. Erwerb des Flugvermögens. Abhandl. d. k. pr. Akad. d. Wiss. 1908. - Döderlein L., Uber die Erwerbung des Flugvermögens bei Wirbeltieren. Zool. Jahrb. 14. Bd. 1900. - Eaton G. F., Osteology of Pteranodon. Mem. Connecticut Acad. Arts and Sci. Vol. II. New Haven 1910. Fraas O., Palaeontographica 1878. XXV S. 163. - Fürbringer M., Vergl. Anat. des Brustschulterapparats 1. c. - Goldfuß, Reptilien aus dem lithographischen Schiefer. Nova Acta Acad. Leop. 1831. XV p. 63. - Marsh O. C., Amer. Journ. Sc. 1871 I p. 472.1872 III p. 241. 1876 XI p. 507. 1876 XII p. 479. 1878 XVI p. 233. 1881 XXI p. 342. 1882 XXIII p. 251. 1884 XXVII p. 423. - Meyer Herm. v., Reptilien aus dem lithographischen Schiefer. Fauna der Vorwelt 1859 S. 7 -90. - Palaeonto. 
Die Flugsaurier sind ausgestorbene Reptilien, welche in ihrer äußeren Erscheinung und in ihrer Lebensweise die größte Ähnlichkeit mit Vögeln besaßen. Sie finden sich eingeschwemmt in marinen und brackisch-limnischen Schichten vom Rhät an bis an das Ende der Kreide. Sie dürften sich von Insekten, einige von ihnen, als Strandbewohner, auch außerdem von Fischen genährt haben und es erscheint nicht ausgeschlossen, daß sie ihre Krallenfinger zum Aufhängen bei der Ruhe gebrauchten. Ihre Vorderextremitäten waren zu einem Flugorgan umgestaltet, jedoch nicht mit Federn, sondern mit einer häutigen im anatomischen Bau wesentlich vom Vogelflügel verschiedenen Membran (Patagium) versehen. Die Flugfähigkeit der Pterosaurier war, wie jene der Fledermäuse, ohne $\mathrm{Z}$ weifel beschränkter als die der Vögel; immerhin zeichnet sich aber das Skelett, wie jenes der Vögel, durch pneumatische Beschaffenheit aus. Die Größe der Flugsaurier ist eine schwankende, manche von ihnen waren kaum größer als ein Sperling, während andere eine Spannweite der Schwingen von fast $7 \mathrm{~m}$ erreichten. Der rechtwinklig zum langen, kräftigen Hals stehende Kopf, die schnabelartig verlängerten und bei einigen Formen zahnlosen Kiefer erhöhten noch das vogelähnliche Aussehen dieser merkwürdigen Geschöpfe.

Die Wirbelsäule gliedert sich in einen Halsabschnitt mit 8 (bei Pteranodon 9), in einen Rumpfabschnitt von 10 bis zirka 15, in einen Sacrum von 4-10 und einen Schwanz von 10-40 Wirbeln. Auch können bis 2 Lendenwirbel (Rückenwirbel ohne Rippen) auftreten. Atlas und Epistropheus sind verschmolzen, ebenso können bei einigen Gattungen (z. B. Nyctosaurus, Pteranodon) die vorderen Rückenwirbel durch gegenseitige Anchylose sich zu einem sogenannten Notarium vereinigen. Die Dornfortsätze dieser so verschmolzenen Wirbel sind bei Pteranodon (ebenso wie die der 10 Sacralwirbel) miteinander durch eine dünne, überlagernde Verknöcherung, die Supraneuralplatte, verbunden. Die präsacralen Wirbel sind pro-

graphica Bd. I. VII. X. - Newton E. T., Philos. Trans. 1888. vol. CLXXIX S. 503. - Nopcsa F. v., Ideas on the Origin of Flight. Proc. Zool. Soc. London 1907. Owen Rich., Reptilia of the Liassic Formations. Palaeontogr. Soc. pt. II. 1863. - Plieninger $F$., Campylognathus Zitteli. Palaeontographica 1894 Bd. XLI. - Beiträge zur Kenntnis der Flugsaurier. Palaeontographica 48. Bd. 1901. - Die Pterosaurier der Juraformation Schwabens. Ibid. 53. 1907. Dort ausführliche Literatur! Ferner Zentralblatt für Mineralogie etc. 1906. (Nr. 10 u. 13) - Quenstedt F. A., Über Pterodactylus Suevicus. Tübingen 1855. $4^{\circ}$. - Seeley H. G., The Ornithosauria: an elementary study of the bones of Pterodactyles. Cambridge 1870. Dragons of the air. London 1901. - Stromer $\boldsymbol{E}$. v., Bemerkungen zur Rekon struktion eines Flugsaurier-Skelettes. Monatsb. d. deutsch. geol. Gesellsch. Bd. 62. 1910. - Wagner Andr., Abhandl. k. Bayer. Akad. math.-phys. Cl. 1837 II S. 163. $1851 / 52$ VI S. 129 u. 690. 1858 VIII S. 439. - Wanderer $K$, Rhamphorhynchus Gemmingi H. v. M., Palaeontographica 55. Bd. 1908. - Williston S. W., Kansas Pterodactyls I u. II. Kansas Univ. Quarterl. Vol. I u. Vol. II 1892 u. 93. - On the skull of Ornithostoma ibid. Vol. 4. 1896. Restoration of Ornithostoma ibid. Vol. 6. 1897. On the skeleton of Nyctodactylus with restoration. Americ. Journ. of Anat. Vol. 1. 1902. On the skull of Nyctodactylus etc. Journ. of Geol. Vol. 10. 1902. On the Osteology of Nyctosaurus etc. Field Columb. Mus. Public. 78. Geol. Ser. Vol. 2. Nr. 3. Chicago 1902. The Fingers of Pterodactyls. Geol. Magaz. Dez. 5. Vol. 1. 1904. Ferner in Zittel-Eastman 1. c. 1902 (Abschnitt über Pterosaurier!). Woodward A. S., On two skulls of the Ornithosaurian genus Rhamphorhynchus. Ann. and Magaz. Nat. Hist. Ser. 7. Vol. IX. 1902. - Zittel K. A., Über Flugsaurier aus dem lithographischen Schiefer Bayerns. Palaeontographica 1882 XXIX S. 49. 
cöl, die Schwanzwirbel amphicöl. Die oberen Bögen sind in der Regel fest mit den Wirbelkörpern verschmolzen und die Seiten der letzteren zeigen stets mehr oder weniger tiefe Gruben und Öffnungen, welche in das grobzellige, pneumatische Innere führen. Am Hals fehlen Rippen entweder ganz oder sie sind beträchtlich kürzer als die dünnen, verlängerten Rumpfrippen, die vorne zwei, hinten einen Gelenkkopf besitzen. Die vorderen Sacralwirbel haben starke Querfortsätze. Der Schwanz ist entweder kurz (Pterodactyloidea) oder er ist sehr lang (Ramphorhynchoidea) und besteht dann aus 30 bis 40 Wirbeln, die in einer förmlichen Scheide verknöcherter Sehnen stecken. Die dünnen Bauchrippen bestehen aus einem mittleren und 1-2 seitlichen Stücken.

Der Schädel (Fig. 448) erinnert in seiner ganzen Form, in der Anordnung und in der inuigen, häufig. ganz nahtlosen Verbindung der Kopfknochen an Vögel, und diese Ânnlichkeit wird bei den oberjurassischen Pterodactylen durch das Schwinden der Knochenbrücken zwischen Nasen-, Präorbital-Augenöffnungen noch erhöht. Die letzteren sind sehr groß, nach der Seite gerichtet und enthalten ge-

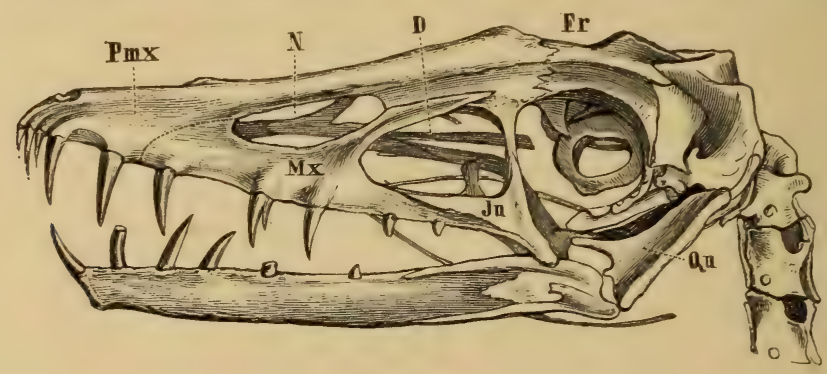

Fig. 448.

Schädel von Scaphognathus crassirostris Goldf. sp. Ob. Jura. Eichstätt. N Nasenloch, $D$ präorbitale Öffnung, $P m x \mathrm{Z}$ wischenkiefer, $Y x$ Oberkiefer, Fr Stirnbein, $Q u$ Quadratbein, Ju Jochbein.

wöhnlich einen aus zahlreichen dünnen Plättchen bestehenden knöchernen Scleroticaring. Vor der Augenhöhle befindet sich wie bei Dinosauriern, Parasuchiern und Vögeln eine Präorbitalöffnung, welche entweder durch eine Knochenbrücke von dem auf jeder Seite entwickelten großen, langgestreckten Nasenloch geschieden oder mit demselben vereinigt ist. Die oberen kleinen Schläfenlöcher sind ringsum knöchern umgrenzt. Die seitlichen Schläfenlöcher bilden schmale, schräger nach vorne und unten verlaufende, hinten vom Quadratum begrenzte Schlitze, die hinter der Augenöffnung liegen. Das Schädeldach wird von den großen Frontalia und den kleinen Parietalia gebildet, denen ein Foramen fehlt. Die in der Regel miteinander verschmolzenen Frontalia bedecken nicht nur das Gehirn, sondern erstrecken sich bis zur Mitte oder bis zum vorderen Ende der Augen und bilden die seitliche und einen Teil der hinteren Umwandung der letzteren. Ein dreigabeliges Postfrontale trennt die Augenhöhle von der seitlichen Schläfenöffnung, der nach hinten gerichtete Ast begrenzt zugleich das obere Schläfenloch von außen und vereinigt sich mit dem Squamosum. In der vorderen Ecke der Augenhöhlen liegt ein kleines Präfrontale (? Lacrimale + Präfrontale), das 
sich mit einem von unten entgegenkommenden schmalen Fortsatz des langen, schlanken Jugale vereinigt und mit diesem die vordere $\mathrm{Be}$ grenzung der Augenhöhle bildet.

Das Quadratum ist ein ziemlich langer, schmaler, stielförmiger Knochen, das oben durch Sutur mit dem Squamosum sich verbindet, während es unten mit dem Pterygoid in Zusammenhang tritt. Die Suturen der Nasalia sind schwer zu finden; die anscheinend stets verschmolzenen Prämaxillaria bilden das zugespitzte, selten abgerundete Ende der vogelartigen Schnauze. Die Grenzen zwischen Maxillare und Prämaxillare sind meist verwischt. Die Kiefer sind mit einer Reihe thecodonter, spitzkonischer, schlanker, in unregelmäßigen Abständen stehender Zähne besetzt, oder völlig zahnlos (z. B. Pteranodon); in diesem Falle dürften sie, wie bei den Vögeln, mit Hornscheiden besetzt gewesen sein. Die Ohrkapsel und das Hinterhaupt sind vollständig verknöchert. Die Gehirnhöhle besitzt eine geringe Größe und der Ausguß des Gehirns zeigt auffallende Ähnlichkeit mit dem Vogel-

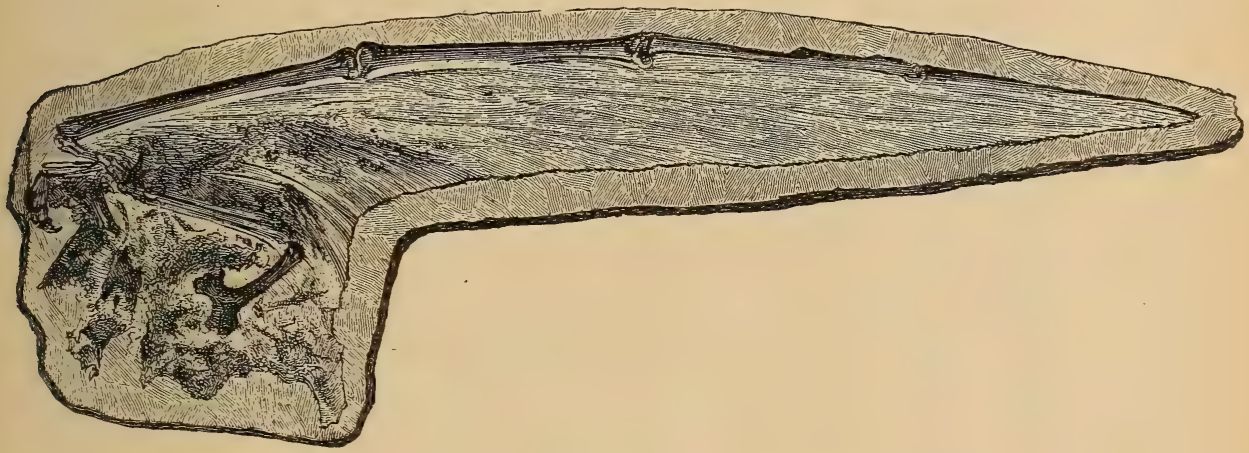

Fig. 449 .

Flugfinger von Rhamphorhynchus Gemmingi mit wohlerhaltener Flughaut. Ob. Jura. Eichstätt. (Das Original im paläontolog. Museum in München.)

hirn. Die beiden Unterkieferäste, die weit vorne unter den Angen mit dem Quadratum gelenken, sind in der Symphyse fast stets verschmolzen, besitzen keinen Coronoidfortsatz. Die Suturen der einzelnen Elemente zeigen sich in der Regel verwischt.

Für den Brustschulterapparat ist das ansehnliche, schildförmige, median vorn gekielte und in einen Fortsatz (Cristospina) auslaufende Sternum bezeichnend, das an die verkalkten oder verknöcherten Sternocostalia der Rippen befestigt ist. Der Schultergürtel besteht lediglich aus einer langen, schlanken und manchmal etwas gekrümm. ten Scapula und einem ebenfalls verlängerten Coracoid, das mit dem Sternum gelenkt. Procoracoid und Clavicula fehlen. Das proximale Ende des mäßig langen Humerus ist stark ausgebreitet, der Processus lateralis und medialis sind wohl ausgebildet. Radius und Ulna erreichen zuweilen die doppelte Länge des Humerus.

Die Zahl der den zweireihigen Carpus bildenden Knöchelchen schwankt beträchtlich. Der Metacarpus enthält 4 gleich lange Kno. chen, der äußere derselben übertrifft aber die 3 anderen um das 3- oder 4 fache an Stärke und trägt den aus 4 ungewöhnlich langen 
Phalangen zusammengesetzten ulnaren Flugfinger. Die übrigen Metacarpalia liegen dicht nebeneinander und sind zuweilen zu ganz dünnen, fadenförmigen Knochenstäbchen reduziert, die von außen nach innen gezählt $4,3,2$ krallentragende Phalangen tragen. Die letzteren ragen hervor, die Flughaut heftet sich lediglich an den innersten Finger an. Ein faden- und rippenförmiger dünner Knochen lenkt sich auf der Radialseite dem Carpus ein, wendet sich nach rückwärts und folgt dem Radius. Dieser "Spannknochen“, der verschiedentlich auch als verknöcherte Sehne angesehen wurde, wird bald als rudimentärer Daumenknochen (Metacarpale des 1. Fingers), bald als Sesambein betrach-

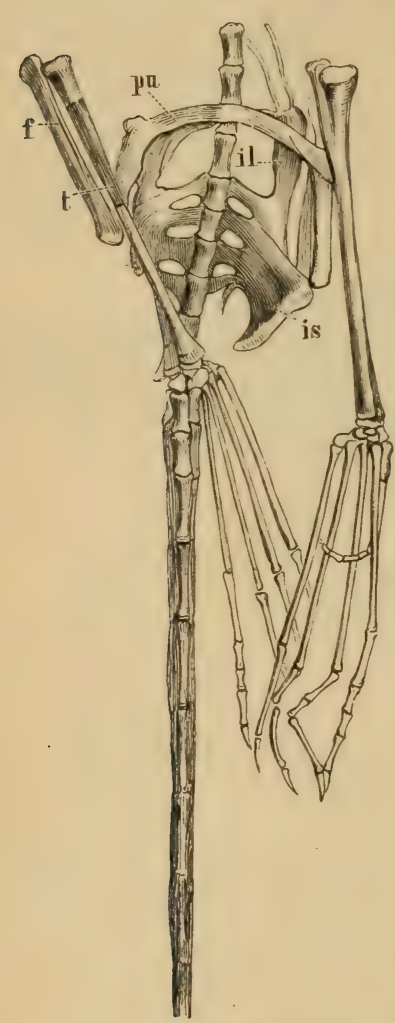

Fig. 450

Becken, Schwanz und Hinterbeine von Rhamphorhynchus Gemmingi $\mathrm{H}$. v. Meyer. Ob. Jura. Eichstät, Franken. Nat. Gr. il Ileum, $p u$ Schambein, is Sitzbein, $f$ Femur, $t$ Tibia. tet und infolgedessen der Flugfinger als 5. oder 4. Finger gezählt. Die Flughaut (Patagium) (Fig. 449) hat nur geringe Breite und bildet eine zugespitzte, schmale, schwalben- oder mövenähnliche Schwinge, welche sich an den Rumpf anheftet. Die Flugmembran besitzt eine Anzahl größerer Längsfalten und außerdem feine, in ziemlich engen Abständen stehende, fast geradlinige Streifen, die anfänglich den Fingergliedern parallel laufen, innen aber sich in einem spitzen Winkel dem Außenrande nähern. Bei Rhamphorhynchus ist an verschiedenen Exemplaren am distalen Ende des Schwanzes eine blattähnliche Schwanzsegelmembran erhalten.

Das Becken (Fig. 450, 451) der Flugsaurier enthält ein niedriges, vor und hinter dem undurchbohrten Acetabulum stark verlängertes Ilium, das am meisten Ähnlichkeit mit dem Ilium der orthopoden Dinosaurier besitzt.

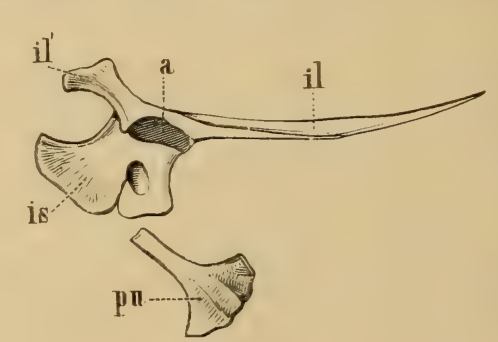

Fig. 451.

Becken von Pterodactylus antiquus Soemm. sp. a Acetabulum, $i l$, $i l^{\prime}$ Ileum, is Ischium, $p u$ Pubis. Sein nach vorn gerichteter Fortsatz ist entweder zuweilen verbreitert (Rhamphorhynchus) oder schlank und verschmälert(Pterodactylus). Das Ischium verschmilzt häufig vollständig mit dem Ilium und

schließt das ? Pubis von dem Acetabulum aus, das letztere selbst heftet sich an das etwas verdickte vordere Ende des Ischium an und scheint ziemlich lose daran befestigt gewesen $\mathrm{zu}$ sein, da man es in der Regel etwas abgerückt und dislociert findet.

Manche Autoren deuten diesen Knochen als Präpubis und betrachten das gewöhnlich nur als Ischium angesprochene Element, als das verschmolzene Ischiopubis, zumal unterhalb des Acetabulums nicht selten ein deutliches - bei den übrigen Reptilien im 
Pubis allein (Foramen obturatorium) oder an der Grenze von Pubis und Ischium Foramen puboischiadicum nie aber im Ischium selbst entwickeltes - Foramen auftritt. (Fig. 451, ebenso Pteranodon!)

Bei Pterodactylus sind die in der Fig. $451^{*}$ als Pubis bezeichneten Knochen gestielte, distal scheibenförmig ausgebreitete Elemente, die wahrscheinlich in der Symphyse knorpelig verbunden waren; bei Rhamphorhynchus, Nyctodactylus sind sie schmal, bandförmig und bestehen jederseits aus einem gerade nach vorne gerichteten Ast, welcher distal eine knieförmige Knickung macht, sich nach innen wendet, um mit dem korrespondierenden inneren Ast des anderen Astes in der Mitte der Bauchseite zusammenzuwachsen. Bei Pteranodon, dessen Pubis (Präpubis) distal eine ähnliche Verbreiterung zeigt wie Pterodactylus, verschmelzen die Ischia (Ischiopubes) in der Symphyse, auch bei Nyctodactylus bilden diese letzten eine Sym. physe, möglicherweise waren sie aber auch hier und bei Rhamphorhynchus durch einen medianen Knorpelstreifen verbunden.

Der Femur ist schlanker und häufig etwas länger als der Oberarm; die gerade und kräftige Tibia übertrifft den Femur, wie bei den Vögeln, beträchtlich an Länge. Die Fibula ist ein dünner, grätenartiger Knochen, welcher mit seinem zugespitzten distalen Ende höchstens kaum über die halbe Länge der Tibia hinausreicht, manchmal verschmilzt sie mit derselben, in anderen Fällen scheint sie völlig zu fehlen (amerikanische Kreideformen). Der Tarsus besteht aus zwei Reihen von Knöchelchen, von denen die proximale mit der Tibia verschmelzen kann.

Der Hinterfuß ist ganz reptilienartig gebaut. Die vier inneren Metatarsalia sind meist schlank und dünn und haben nahezu die gleiche Länge und Stärke, der Metatarsus der kleinen Zehe dagegen ist kurz, stummelartig und trägt zuweilen manchmal nur eine einzige, zuweilen aber auch bis 3 Phalangen (Ornithocheiridae gar keine). An den übrigen Zehen ist die Zahl der Phalangen von innen nach außen 2, 4, 5. Die Endphalangen sind krallenförmig, spitz und waren offenbar mit Horn umgeben.

Auf Grund der Untersuchungen Seeleys, F. Plieningers und Willistons lassen sich die Pterosaurier in zwei Unterordnungen, Rhamphorhynchoidea (Pterodermata) und Pterodactyloidea (Ornithocheiroidea) gliedern.

\section{Unterordnung. Rhamphorhynchoidea. F. Plieninger.}

\section{(= Pterodermata Seeley.)}

Schwanz lang. Metarcapale des Flugfingers kürzer als der halbe Vorderarm. Präorbital- und Nasenöffnung voneinander getrennt. Kiefer bezahnt. Jura.

Diese Unterordnung umfaßt, so weit bis jetzt bekannt, ausschließlich jurassische, mehr generalisierte Pterosaurier, deren langer, steifer Schwanz mit einer Scheide verknöcherter Sehnen umgeben war. Die Zähne nehmen nach hinten an Stärke und Größe ab, und die Schnauzenspitze ist zuweilen zahnlos. Scapula und Coracoid zeigen sich häufig proximal verschmolzen, ebenso ist die proximale Reihe der Tarsus mit der Tibia verschmolzen. 


\section{Familie. Rhamphorhynchidae.}

Mit den Charakteren der Unterordnung.

Dimorphodon Owen. Schädel relativ ungewöhnlich groß aber sehr leicht gebaut. Präorbital- und Nasenöffnungen viel größer als die kleinen gerundet dreiseitigen Augenlöcher. Kiefer bis zum Schnauzenende bezahnt. Die vorderen Zähne kräftig, leicht gekrümmt und in unregelmäßigen Abständen stehend, die hinteren klein, dicht aufeinanderfolgend. Wahrscheinlich
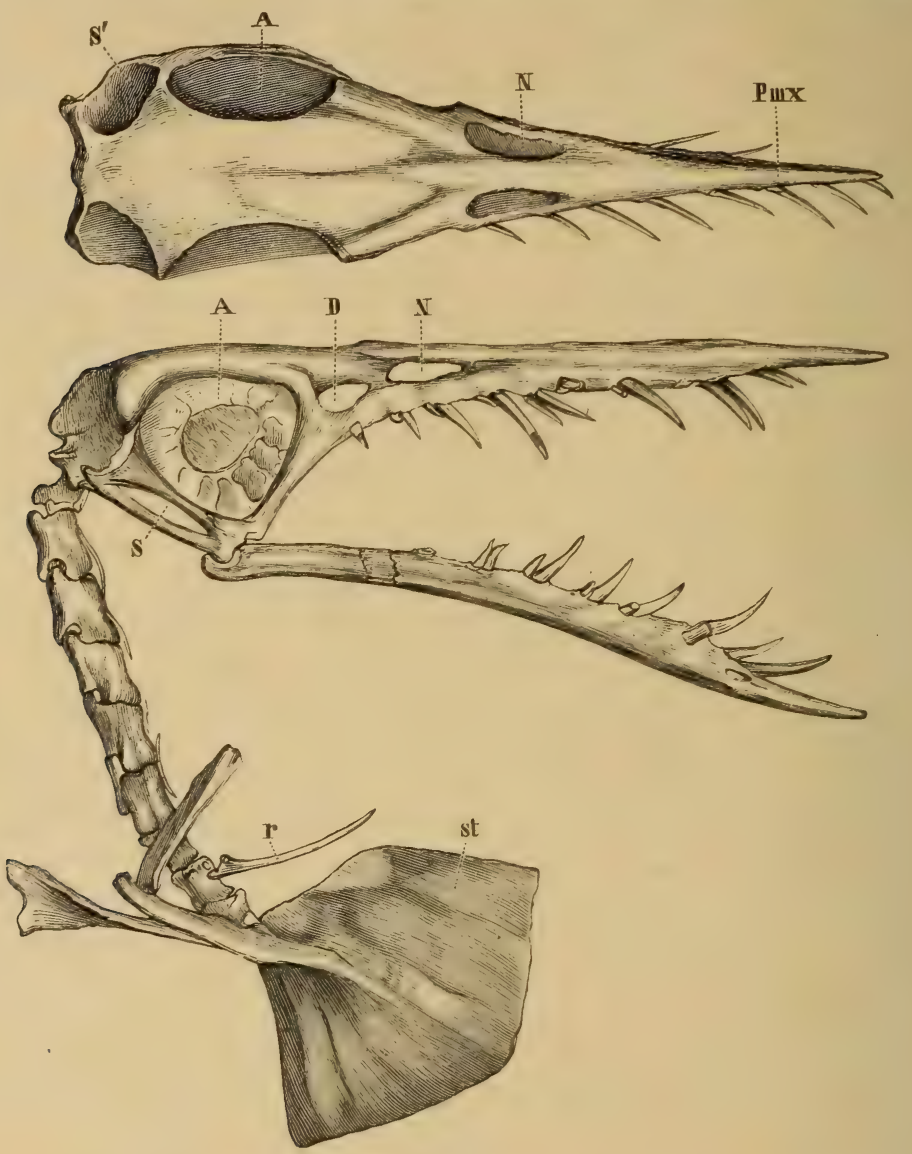

Fig. 452.

Rhamphorhynchus Gemmingi H. v. Meyer. Ob. Jura. Eichstätt, Franken. A Augenhöhle, $N$ Nasenloch, $D$ präorbitale Durchbruchsöffnung, $s$ seitliches, $8^{\prime}$ oberes Schläfenloch, P'mx Zwischenkiefer. st Brustbein, $r$ Rippe.

4 Sacralwirbel, Schwanzwirbel ca. 30, an einigen Chevrons beobachtet. Der Schädel der einzigen bekannten Art wird bis $20 \mathrm{~cm}$ groß. Unt. Lias. Dorsetshire, England.

Dorygnathus Opp. Ob. Lias. Württemberg und Franken und Rhamphocephalus Seeley aus dem Dogger von Stonesfield sind noch ungenügend bekannt.

Campylognathus F. Plieninger. Ein fast vollständiges Skelett aus dem ob. Lias von Holzmaden. Der ca. $13 \mathrm{~cm}$ lange Schädel bis zur Schnauzenspitze bezahnt. Auge größer als Nasen- und Präorbitalöffnung. Letztere größer als die dreieckige Präorbitalöffnung. Unterkiefer mit seinem vor- 
deren Drittel nach abwärts geschwungen, an der Spitze zahnlos, die beiden Hälften in der Symphyse nicht verwachsen. Scapula und Coracoid verwachsen. Erste Flugfingerphalange mehr als doppelt so lang als der Vorderarm. 4 Sacralwirbel. Fibula sowie proximale Tarsusreihe mit Tibia verwachsen. C. Zitteli.

Scaphognathus Wagner. (Fig. 448). Ähnlich der vorigen, aber Unterkiefer vorne bezahnt und nicht abwärts gebogen. Nasenöffnung und Auge kleiner als die ovale Präorbitalöffnung. Ob. Lias. Yorkshire, England und ob. Jura (Solnhofen) Bayern.

Rhamphorhynchus v. Meyer (Fig. 449, 450, 452). Schädel manchmal bis $20 \mathrm{~cm}$ lang. Schnauze verlängert, zugespitzt, das vorderste Ende des Prämaxillare und Unterkiefers zahnlos. Zähne lang, unregelmäßig groß, nach vorne gerichtet. Nasen- und Präorbitalöffnung klein. Augenhöhle sehr groß mit Scleroticaring. Scapula und Coracoid gewöhnlich verschmolzen. Pubis (Präpubis) schmal, bandförmig, in der Symphyse verwachsen. Ob. Jura von Bayern und Württemberg.

\section{Unterordnung. Pterodactyloidea. F. Plieninger.}

(Ornithocheiroidea Seeley).

Schwanz kurz. Metacarpale des Flugfingers mindestens ebenso lang als der Vorderarm. Präorbital und Nasenöffnung ganz oder teilweise miteinander ver-

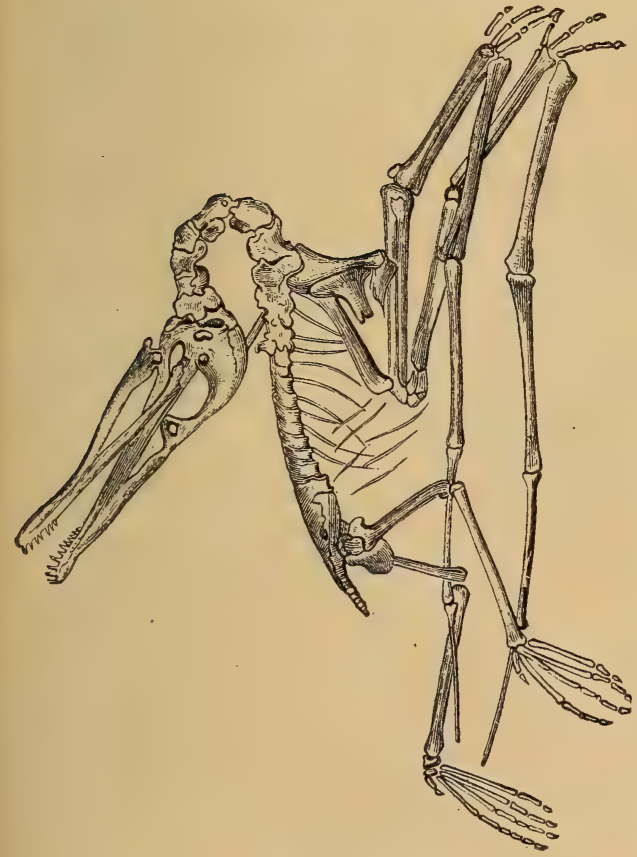

Fig. 453.

Pterodactylus elegans Wagn. Lithographischer Schiefer. Eichstätt, Bayern. Nat. Gr. einigt. Zähne manchmal fehlend. Oberer Jura bis Kreide.

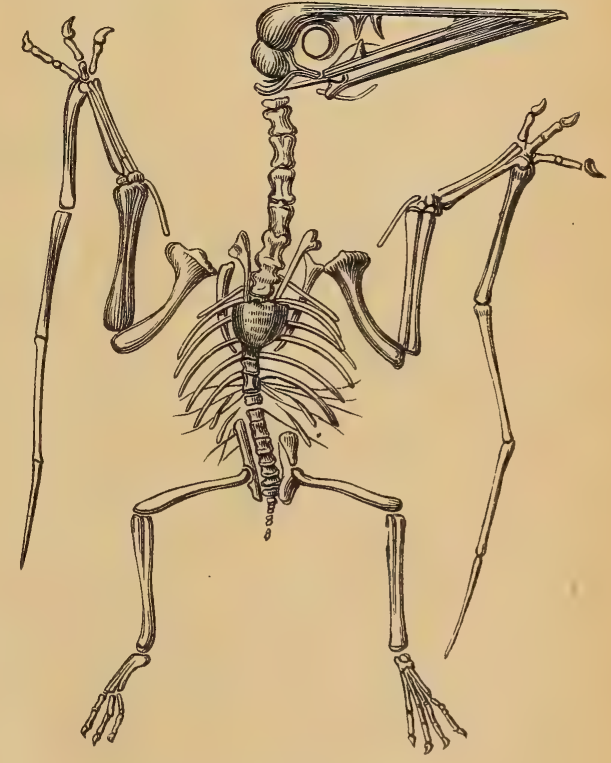

Fig. 454.

Pterodactylus spectabilis Meyer. Lithograph. Schiefer. Eichstätt, Mittelfranken. $3 / 4$ n. Gr. (Nach H. v. Meyer.)

Die Angehörigen dieser Unterordnung, von denen einzelne die Größe eines Sperlings besitzen, während bei anderen die Spannweite der Schwingen beinahe $7 \mathrm{~m}$ beträgt, finden sich vom oberen Jura bis zur oberen Kreide. Die generische Bestimmung der aus der obersten Trias (Rhät) beschriebenen 
Reste zu Pterodactylus ist unsicher. Ungenau bekannt ist Tribelesodon Bassani aus den Raibler-Schichten der Südalpen.

\section{Familie. Pterodactylidae.}

Schädel mit zugespitzter Schnauze und kleinen seitlichen Schlïfenöffinungen. Die große Augenhöhle nicht völlig gegen die, unvollständig von der Nasenöffnung getrennte Präorbitalliicke abgeschlossen. Vordere Rückenwirbel nicht zu einem sog. Notarium verschmolzen. Kiefer bis zur Spitze bezahnt. Fibula vorhanden. ? Rhät. Lias. Ob. Jura.

Pterodactylus Cuvier (Ornithocephalus, Sömmering, Diopecephalus, Cycnorhamphus, Seeley, Ptenodracon Lyd.) (Fig. 451, 453-454). 4-5 Sacralwirbel. Pubis (Praepubis) in der Symphyse wahrscheinlich nur durch Knorpel verbunden. Pterodactylus, dessen Arten in der Größe zwischen einem Sperling und einem Adler schwanken, finden sich in zahlreichen Spezies und in prachtvoll erhaltenen ganzen Skeletten im lithographischen Schiefer des ob. Jura von (Solnhofen, Eichstätt, Kelheim) Württemberg (Nusplingen) und Cerin (Dep. Ain). Vereinzelte Knochen aus dem Kimmeridgeton von England dürften ebenfalls hieher gehören, dagegen ist die Bestimmung von Flugfingergliedern aus dem Rhät und Lias unsicher.

\section{Familie. Ornithocheiridae.}

Schädel langgestreckt, schlank. Augenhöhle von der mit der Präorbitalöffnung vereinigten Nasenöffnung vollständig getrennt. Vordere Rückenwirbel zu einem Notarium verschmolzen. Kiefer bezahnt oder zahnlos. Die proximale Tarsusreihe mit der Tibia verschmolzen. Fibula nicht gesondert entwickelt. Ob. Jura bis ob. Kreide.

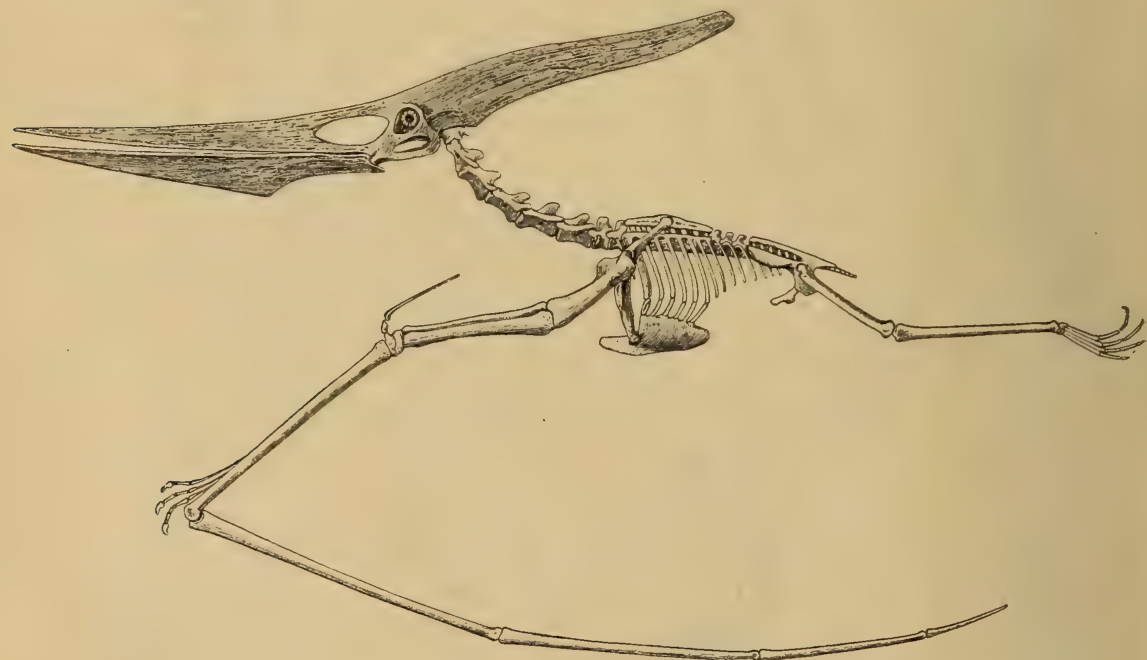

Fig. 455.

Pteranodon Marsh. Auf Grund verschiedener Individuen restauriertes Skelett. Der Deutlichkeit der Darstellung halber sind die rechten Extremitäten weggelassen und die linken Schwingen mehr gebogen, als es in Wirklichkeit der Fall wäre. (Stark verkleinert nach Eaton.)

1. Unterfamilie. Ornithocheirinae.

Distales Ende der Scapula verdickt, mit der Supraneuralplatte gelenkend. Schädel mit Supraoccipitalcrista. 
Pteranodon Marsh (Fig.455). Schädel stark verlängert mit schlanken, zugespitzten, zahnlosen Kiefern und zu einem langen, hohen, dabei sehr dünnen, möglicherweise beweglichen Supraoccipitalkamm (an dem vielleicht noch Temporalmuskeln inserierten) ausgezogen. Auge mit Scleroticaring. Sternum flach mit schmalem Kiel. 9 Halswirbel. 11 Rückenwirbel, von denen die Wirbelkörper der 8 vorderen fest zu dem sog. Notarium verschmolzen, und deren Dornfortsätze durch eine dünne knöcherne Supraneuralplatte gegenseitig verbunden sind. Letztere zeigt zwischen dem 3. und 4. Wirbel eine Gelenkfläche für die Scapula. Die 10 Sacralwirbel gleichfalls fest miteinander verschmolzen und dorsal durch eine ebensolche bandähnliche Knochenplatte verbunden. Pubis (Präpubis) distal verbreitert, ebenso wie Ischia (Ischiopubes) in der Symphyse verschmolzen. Schwanz sehr kurz. Carpus zweireihig mit 3 Knochen. Hinterextremität relativ klein. Femur kurz und gekrümmt. Distale Reihe des Tarsus mit 2 Knochen. 4 Phalangen mit Klauen, der 5. Finger durch ein kleines klauenähnliches Metatarsale repräsentiert. Spannweite der Schwingen bis $7 \mathrm{~m}$. Ob. Kreide. Kansas.

Ornithostoma Seeley. Grünsand von Cambridge unvollständig bekannt. Vielleicht ident mit Pteranodon.

Ornithocheirus Seeley. Ähnlich Pteranodon, aber bezahnt. Wealden bis oben Kreide. England.

\section{Unterfamilie. Nyctosaurinae.}

Distales Ende der Scapula verbreitert, nicht mit der Supraneuralplatte gelenkend. Schädel ohne Supraoccipitalcrista.

Nyctosaurus (= Nyctodactylus) Marsh (Figur 456). Kopf schlank, Kiefer zahnlos. 8 Halswirbel, 10. Rückenwirbel, von denen die vorderen 3 zum Notarium verschmolzen sind. 6 Sacralwirbel, ca. 10-14 Schwanzwirbel. Vordere Rippen stämmig zweiköpfig, hintere Rippen auffallend schlank, gerade und einköpfig. (Standen möglicherweise wie bei Draco mit der Flughaut in Verbindung.) 3 Paar förmige Bauchrippen. Humerus kurz. 3 Carpalia. Spannweite der Schwingen 2 m. Ob. Kreide. Kansas.

Incertae sedis: Ornithodesmus, Doratorhynchus Seeley, Palaeornis Mantell. Purbeck. Kreide England. Dermodactylus Marsh. Unt. Kreide (Como beds) Wyoming. Apatomerus Williston. Unt. Kreide. Kansas.

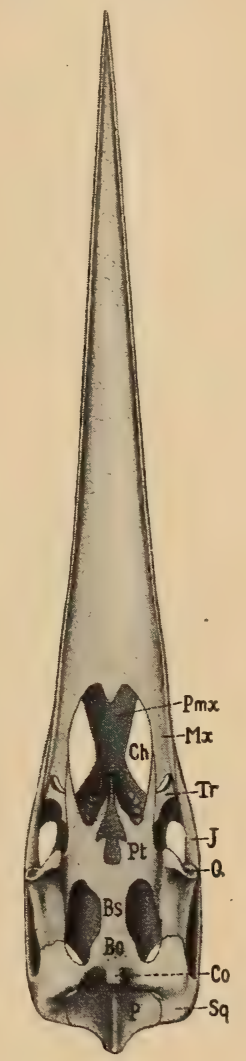

Fig. 456 .

Nyctosaurus (Nyctodactylus) gracilis Marsh. Schädel von unten. Pmx Prämaxillare, $N x$ Maxillare, Ch Choane, Tr Transversum, Pt Pterygoid, J Jugale, Q Quadratum, Bs Basisphenoid, Bo Basioccipitale mit Condylus $(\mathrm{Co})$, $S q$ Squamosum, $P$ Parietale $1 / 3$ nat. Gr. (Nach Williston.)

\section{Zeitliche Verteilung und Stammesgeschichte der Pterosaurier.}

Abgesehen von dem problematischen Tribelesodon aus den Raiblerschichten sowie von einigen nicht genauer bestimmbaren Resten aus dem Bonebed der rhätischen Stufe sind die Flugsaurier auf Jura und Kreide beschränkt. Ihre Hauptverbreitung fällt in den oberen Jura. Über ihre Stammesgeschichte läßt sich wenig sagen. Sie treten mit langschwänzigen Formen im Lias mit allen typischen Merkmalen 
- ähnlich wie die Schildkröten in der Trias - ausgerüstet auf, im oberen Jura zeigen sich neben den langgeschwänzten Flugsauriern bereits eine große Anzahl kurzgeschwänzter Vertreter, die dann in der Kreidezeit, wo sie die höchste Entwicklung erreichen, allein do. minieren, um am Schluß dieser Formation, ohne irgendwelche modifizierte Nachkommen zu hinterlassen, auszusterben. Die Veränderung ihres Flugorgans innerhalb dieses Zeitraums bezieht sich in der Hauptsache nur auf die Länge des Metacarpale des Flugfingers, das bei den Langschwänzen kurz und gedrungen, bei den jüngeren Kurzschwänzen langgestreckt sich entwickelt zeigt. Außerdem ist bei den Kreideformen neben der völligen Zahnlosigkeit einiger Formen eine gewisse Starrheit des Rumpfabschnittes durch gegenseitige Verschmelzung der vorderen Rückenwirbel und der Sacralwirbel, die vielleicht mit der mächtigeren Entwicklung der Schwingen in Beziehung zu bringen ist, beachtenswert. Die Flugsaurier stellen somit einen nicht weiter entwicklungsfähigen Seitenast des Reptilienstamms dar, welcher zwar große Ähnlichkeit mit den Vögeln aufzuweisen hat, jedoch von diesen ebenso scharf geschieden ist, wie von den übrigen Ordnungen der Reptilien.

\section{Klasse. Aves. Vögel. ${ }^{1}$ ) Bearbeitet von M. Schlosser.}

Warmblütige, eierlegende, befiederte Wirbeltiere mit a usschließlicher Lungenatmung. Herz mit vollkommen getrennten Kammern. Hinterhauptsgelenkkopf einfach. Quadratum frei. Vorderextremitäten zu Flügeln umgebildet. Proximale Tarsusreihe mit der Tibia verschmolzen - Tibiotarsus. - Distale Tarsusreihe mit den verwachsenen Metatarsalien $z u$ einem einzigen Knochen verbunden - Tarsometatarsus. - Hinterextremität stets ohne fünfte Zehe.

Die Vögel bilden trotz ihres Formenreichtums doch in bezug auf die Gesamtorganisation die einheitlichste Klasse der Wirbeltiere. Als Abkömmlinge von Reptilien haben sie mit diesen so viele Merkmale gemein, daß $\mathrm{H} \mathrm{uxley}$ beide Klassen in eine einzige - Sauropsidae vereinigte, was aber wegen der wesentlichen Unterschiede, Befiederung, Umwandlung der Vorderextremität in Flügel, Verwachsung der Tarsalia mit Tibia resp. Metatarsus, Warmblütigkeit, nicht zweckmäßig erscheint.

1) Beddard F. E., The structure and classification of Birds. London 1898. - Fürbringer M., Untersuchungen zur Morphologie u. Systematik der Vögel. Amsterdam 1888. - Gaillard $\mathrm{Cl}$., Les oiseaux des phosphorites du Quercy. Ann. de l'Université de Lyon. 1908. - Huxley T. $H$., On the classification of Birds. Proc. Zool. Soc. London 1867. p. 415-472. - Lucas Fr. A., Aves. Zittel, Text Book of Palaeontology. London. 1902. - Lydekker R., Catalogue of the fossil Birds in the British Museum 1891. - Marsh O. C., Odonthornites. A monograph of the extinct toothed Birds of North America. Washington 1880. - Menzbier M. v., Vergleichende Osteologie der Pinguine in Anwendung zur Haupteinteilung der Vögel. Bull. Soc. imp. des Nat. Moscou. 1887. - Milne Edwards A., Recherches anatomiques et paléontologiques pour servir á l'historie des oiseaux fossiles de France. Paris 1867 bis 1872. - Neuton A., Dictionary of Birds. London 1893-96. - Pycraft W. P., Contributions to the osteology of Birds. Proc. Zool. Soc. London 1898-1900. Selenka $E$. und Gadow $H$., Aves, Bronns Klassen und Ordnungen des Tierreichs $1869-91$. 
Das Hautskelett der Vögel besteht aus Federn, aus den Hornscheiden des Schnabels und der Krallen und aus Spornen und Hornplatten am Fuß. Die Federn bedecken den Rumpf, meist auch Kopf, Hals und die Flügel, jedoch sind sie am Rumpf nicht gleichmäßig verteilt, sondern auf gewisse Stellen beschränkt - Federfluren, Pterilae zwischen welchen nackte Stellen - Federraine, Apteria - liegen. Bei der Fossilisation werden die Federn zerstört, sie bleiben nur ausnahmsweise als Abdrücke erhalten im lithographischen Schiefer, im Green River Süßwasserkalk und in Quelltuffen.

Das Skelett der Vögel zeichnet sich durch pneumatische Ausbildung und große Leichtigkeit, verbunden mit erheblicher Festigkeit aus. Die Wandungen der Röhrenknochen sind dünn, aber von sehr dichter und fester Struktur; in der Jugend enthalten sie ein mit Blutgefäßen durchzogenes Mark, das jedoch außer bei einigen Wasservögeln bald verschwindet und mit Luft gefüllten Hohlräumen Platz macht. Bei den Pinguinen sind die Knochen mit spongiöser knöcherner Substanz ausgefüllt. Die bedeutendsten Hohlräume finden sich am Schädel, am Oberarmknochen, in den Halswirbeln und am Oberschenkelknochen.
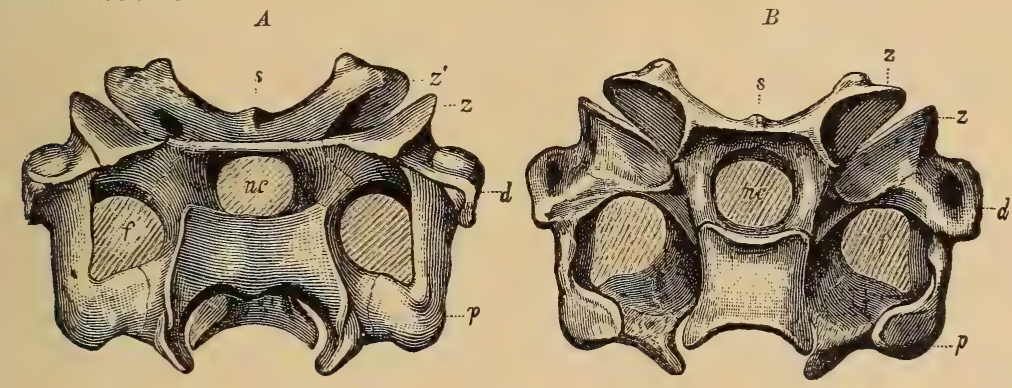

Fig. 457.

Hesperornis regalis Marsh. Dreizehnter Halswirbel $A$ von vorne, $B$ von hinten. $d$ Diapophyse, $p$ Parapophyse, $z$ vordere, $z^{\prime}$ hintere Zygapophyse, $s$ rudimentärer Dornfortsatz, nc Neuralkanal, $f$ Arterienkanal zwischen Rippe und Wirbelkörper. (Nach Marsh.)

Die Wirbelsäule besteht aus der Hals-, Rücken-, Sacral- und Schwanzregion, von denen die Sacralregion, das Sacrum oder Synsacrum viel mehr verschmolzene Wirbel enthält als bei den übrigen Vertebraten. Die freibleibenden Wirbel haben sattelförmige Gelenke, welche zu großer Beweglichkeit befähigen. Nur bei mesozoischen Vögeln Archaeopteryx und Hesperornis, beim Embryo und in der Caudalregion sind die Wirbel amphicöl. Opisthocöle Wirbel besitzen die Pinguine und Kormorane; der Atlas aller Vögel ist procöl.

Die Halsregion (Fig. 457) enthält 13-25 Wirbel, meist 14-15, deren Körper gestreckt erscheint. Die Zahl der Dorsalwirbel (Fig. 458) schwankt zwischen 6 und 10, von denen der erste sich dadurch bemerkbar macht, daß er durch eine dorsale und eine sternale Rippe mit dem Brustbein verbunden wird. Die hintersten Dorsalwirbel sind mit dem Sacrum vereinigt, aber durch den Besitz von Rippen noch als Rückenwirbel gekennzeichnet. Die Zahl der freien Rückenwirbel ist im Minimum 3, im Maximum 7-8. Sie haben kurze Körper. Bei Wasservögeln - Pinguin-Alken - bleiben alle präsacralen Wirbel 
frei, sonst verwachsen 2-4 Rückenwirbel mit einander und auf sie folgt dann noch vor dem Synsacrum ein freier Wirbel. Das Synsacrum besteht beim erwachsenen Vogel aus einigen Rücken-, aus den Lenden- und den Sacralwirbeln nebst einer Anzahl von Schwanzwirbeln. Die Dornfortsätze der verschmolzenen Wirbel bilden wie auch bei jenen der Dorsalregion einen zusammenhängenden vertikalen Kamm. Die echten Sacralwirbel sind jene zwei, welche hinter der die Nieren enthaltenden Grube liegen und Querfortsätze und Sacralrippen zwischen dem Wirbelkörper und dem Ilium besitzen. Die Mehrzahl der Wirbel des Synsacrums ist mit den Ilia durch Diapophysen oder durch Querfortsätze des Neuralbogens verbunden.

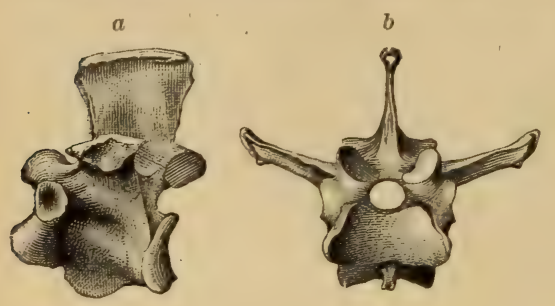

Fig. 458

Hesperornis regalis Marsh. Rückenwirbel. Obere Kreide Kansas. $A$ von der Seite, $B$ von rorne. $1 / 2$ nat. Gr. (Nach Marsh.) Auf die echten Sacralwirbel folgt eine Anzahl verschmolzener 》Urosacralwirbel «, auf diese folgen in der Regel 6 freie Caudalwirbel und zuletzt das aus $4-6$ verwachsenen Wirbeln bestehende pflugscharähnliche Pygostyl; Archaeopteryx hingegen besaß wenigstens 20 freie und lange Schwanzwirbel.

Mit Ausnahme des Atlas tragen alle präsacralen Wirbel Rippen, auch die zwei oder drei vordersten Sacralwirbel können mit Rippen versehen sein. Abgesehen von den beiden hintersten, verschmelzen die Rippen der Halsregion mit ihren Wirbeln; beim Embryo, beim jungen Strauß und bei Archaeopterys sind sie frei. In den meisten Fällen besitzt der letzte Halswirbel und jeder Rückenwirbel außer dem letzten einen Processus uncinatus, eine schmale Knochenplatte, welche nach rückwärts und aufwärts verläuft und sich auf die folgende Rippe legt, wodurch der Brustkorb an Festigkeit gewinnt. Nur selten bleiben diese Fortsätze von der Rippe getrennt - Moa und einige Wasservögel -, auch fehlen sie nur ganz ausnahmsweise. An die Rumpfrippen schliel3en sich Sternalrippen an, von denen sich 2-5 Paare am Sternum anheften.

Das wohl nie fehlende Brustbein ist breit und nach außen konvex. Es deckt bald nur den vorderen Teil des Brustkorbs, oder es reicht bei den Wasservögeln bis unter das Becken. In der Mitte der Unterseite trägt es einen Kiel - Crista, Carina - der besonders bei guten Fliegern sehr kräftig wird und zur Anheftung der Brustmuskeln dient. Wenn aber die Vorderextremität verkümmert ist, kann dieser Kiel vollständig fehlen - »Ratitae«. An der Vorderseite des Sternums heften sich die Coracoide an und unmittelbar dahinter folgt jederseits ein Costalfortsatz, an welchem Abdominaloder Sternalrippen endigen.

Der Schädel (Fig. 459) ist charakterisiert durch die frühzeitige Verschmelzung aller Knochen, besonders der Cranialregion, wo sogar alle Suturen verschwinden. Die Gehirnkapsel übertrifft an Geräumigkeit jene der Reptilien mit allenfallsiger Ausnahme der Pterosaurier. Die Anordnung der Kopfknochen ist jener der Reptilien, namentlich der Pterosaurier, ähnlich, jedoch fehlt stets ein oberer Temporalbogen, während dafür stets ein unterer vorhanden ist. Die großen 
Augenhöhlen liegen fast immer seitlich und sind unten nur unvollständig begrenzt und mit einem aus vielen Knochenplatten bestehenden Scleroticalring versehen. Wegen des Fehlens des oberen Schläfenbogens gibt es auch keine oberen und unteren Temporallöcher. Der untere Schläfenbogen besteht aus dem Jugale und dem Quadratojugale, welches mittels des Quadratums mit dem Maxillare beweglich verbunden ist. Wie bei den Dinosauriern, Pterosauriern und Krokodiliern ist eine Antorbitalöffnung vorhanden, vor welcher nahe der Basis des Schnabels die äußeren Nasenlöcher liegen, während die inneren sich zwischen den Gaumen- und Pflugscharbeinen befinden.

$A$

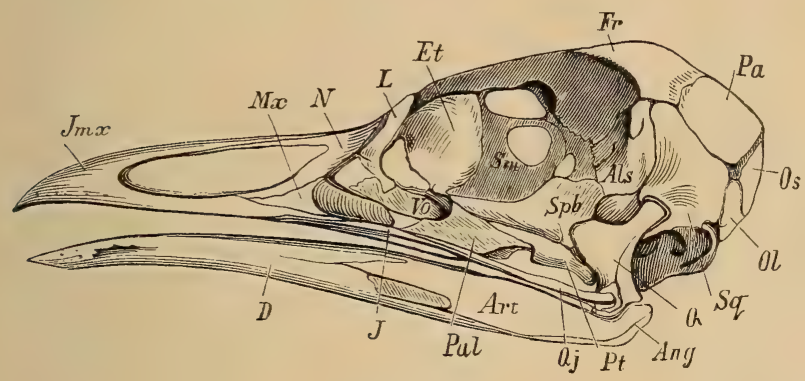

Fig. 459

Schädel von Otis tarda Lin. $A$ von der Seite, $B$ von unten. $O b$ Basioccipitale, $C$ Condylus, ol Occipitalia lateralia. Os Occipitale superius, $B t$ Basitemporale, $S p b$ Basisphenoid, Als Alisphenoid, Sm Septum interorbitale, Et Ethmoideum, Pa Parietale, $F r$ Frontale, $M x$ Maxillare, Im $x$ Intermaxillare (Prämaxilla), $N$ Nasale, $L$ Lacrimale, $J$ Jugale, $Q j$ Quadratojugale, Q Quadratum, Pt Pterygoideum, Pal Palatinum, Vo Vomer, $D$ Dentale, Art Articulare, Ang Angulare (nach Claus.)

Der einfache, hauptsächlich aus dem Basioccipitale bestehende Gelenkkopf richtet seine gewölbte Oberfläche nach unten, so daß der Kopf mit dem Hals fast einen rechten Winkel bildet. Die paarigen Scheitelbeine stehen an Ausdehnung den Stirnbeinen nach, welche den größten Teil des Cranialdaches und den Oberrand der Augenhöhlen einnehmen. Postorbitalia und Postfrontalia fehlen. Die seitlich an die Scheitelbeine grenzenden Schläfenbeine verschmelzen vollständig mit der Gehörkapsel, welche ihrerseits aus der Verwachsung der Perioticumelemente hervorgegangen ist. Am Squamosum und am Perioticum lenkt sich das freibleibende Quadratum ein, dessen Unterseite eine quere Gelenkfläche für den Unterkiefer besitzt. Häufig findet sich am Vorderrand der Augenhöhle ein Lacrimale. Das knöcherne oder häutige Interorbitalseptum hat stets bedeutende Ausdehnung. Der Schnabel besteht hauptsächlich aus den verschmolzenen Zwischenkiefern, mit denen seitlich die Oberkiefer verwachsen sind. Die Gaumenregion zeigt zweierlei Typen. Bei dem einen ist der Vomer breit und vereinigt sich vorne mit den Maxillopalatina, während er hinten die Hinterenden der Palatina und die Vorderenden der Pterygoide aufnimmt, welche daher das Sphenoidalrostrum nicht berühren - Drom a e ognathen-Typus, Strauße, Apteryx, Crypturi.-Bei dem anderen 
Typus umfaßt der Vomer hinten zwischen den Palatina das Sphenoidalrostrum und die Palatina berühren die Pterygoide und das Sphenoid - Euornithischer Typus. Bei dem ersteren Typus hat das Quadratum auch nur ein deutliches proximales Gelenk, beim letzteren aber zwei.

Die Unterkieferäste verschmelzen bei allen lebenden Vögeln frühzeitig in der Symphyse und sind nur bei einigen mesozoischen - Ichthyornis - wie bei den Reptilien durch Sutur und Ligament verbunden. Die Zahl der ursprünglichen bei den modernen Vögeln stets verwachsenen Elemente des Unterkiefers ist sechs. An der Seite befindet sich häufig zwischen dem Dentale und dem Spleniale eine Lücke.

$\mathrm{Z}$ ähne besaßen nur die mesozoischen Vögel. Diese Zähne waren konisch und in Alveolen eingefügt, bei den lebenden Vögeln bildet der Mangel an Zähnen ein wesentliches Merkmal, doch kommen bei Embryonen von Papageien und Straußen noch Zahnpapillen vor. Die Funktion der Zähne wird durch die scharfen Ränder der Hornscheiden übernommen, welche die Kiefer bedecken.

Der Brustgürtel ist mit dem Thorax viel solider verbunden als bei allen übrigen Wirbeltieren, da die Flugorgane fester Stützpunkte am Rumpf bedürfen. Die lange säbelförmige Scapula legt sich über die Brustrippen und bildet mit dem fast säulenförmigen Coracoid die Gelenkgrube für das Caput des Humerus. Die Schlüsselbeine heften sich an die Coracoide und vereinigen sich vor dem Brustbein zu dem $V$-förmigen Gabelknochen - Furcula. Ihr Anschluß an die Coracoidea und unten an den Kiel des Sternums bietet den Flügelmuskeln beim Fliegen eine Stütze, jedoch sind sie selbst bei manchen guten Fliegern, Tauben, Kolibri, auffallend dünn. Bei den Dromaeognathcie (Ratiten) und einigen Euornithes (Carinaten) Papageien - bleiben die Schlüsselbeine getrennt oder verkümmern

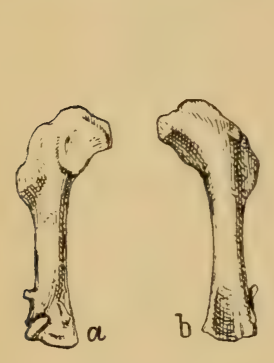

Fig. 460 .

Aigialornis gallicus Lydekker. Phosphorite ron Quercy. Humerus, nat. Gr. $a$ von innen, $b$ von außen.
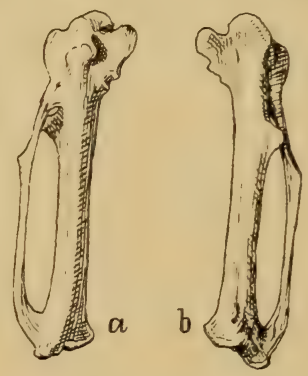

Fig. 461.

Lagopus albus Gmelin. Metacarpus $a$ von innen, $b$ von außen. Pleistocån. Velburg. mehr oder weniger vollständig.

Der Humerus (Figur 460) ist am Oberende verbreitert und seitlich mit einem Deltopectoralkamm zur Anheftung des Brustmuskels versehen, der Gelenkkopf in die Quere verlängert und darunter, an derInnenseite, befindet sich oft ein Luftloch. Das Unterende besitzt einen vorspringenden schrägen Condylus zur Gelenkung des Radius, aber niemals ein Condylarforamen. Der Humerus der Nichtflieger kann vollkommen verkümmern. Ulna und Radius sind meist länger als der Humerus und die erstere ist kräftiger als der Radius. Sie trägt an der Außenseite häufig eine Reihe kleiner Höckerchen zur Anheftung der Schwungfedern. Der Carpus besteht im ausgewachsenen Zustande nur aus zwei Knöchelchen, Radiale und Ulnare. Beim Embryo sind 
aber außerdem zwei distale Knorpelstücke vorhanden, welche dann mit den Metacarpalien verwachsen. Von den drei Metacarpalien (Fig. 461) ist das erste kurz und mit einem, selten mit zwei kurzen Phalangen versehen, und trägt mit ihnen den sog. Nebenflügel - Alula. Auf das zweite Metacarpale folgen zwei und auf das dritte eine Phalange. Metacarpale II und III sind länger als I und miteinander oben und unten verwachsen. Der erste und zweite Finger hat manchmal eine Kralle, bei Archaeopteryx ist auch der dritte bekrallt.

Das Becken (Fig. 462) besteht aus drei fest miteinander und mit dem Synsacrum verwachsenen Elementen - bei Archaeopteryx bleiben sie noch frei und bei den Pinguinen erfolgt nur unvollständige Verschmelzung. Das langgestreckte Ilium ist mit dem Sacrum innig

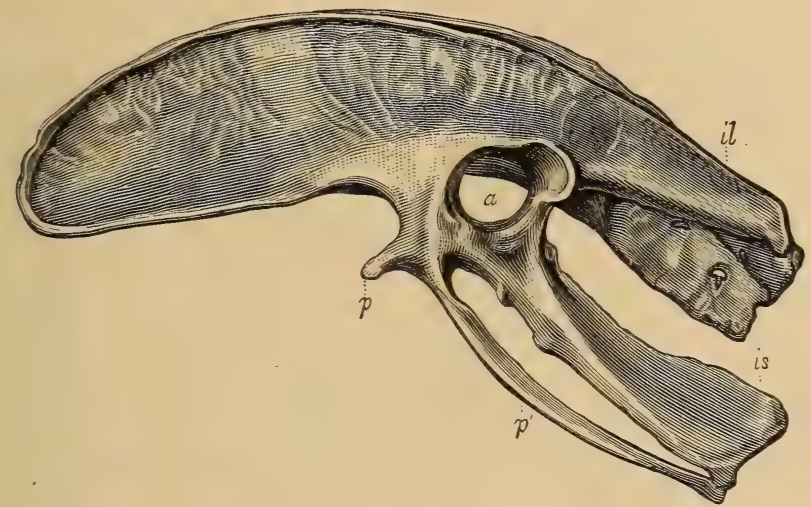

Fig. 462.

Becken von Apteryx australis Owen. $3 / 4$ nat. Gr. (nach Marsh). il nium, is Ischium, $p$ processus pectinealis, $p^{\prime}$ Pubis, a Gelenkpfanne.

verbunden und häufig nach vorwärts stärker ausgedehnt als nach rückwärts. Pubis und Ischium schauen nach rückwärts. Die dünnen schmalen Pubis bleiben manchmal getrennt von den Ilia, auch verschmelzen sie außer beim Str a u niemals miteinander zu einer festen Symphyse. Da die Rückwärtsdrehung der Pubis nach den embryologischen Befunden eine sekundäre Modifikation darstellt, kann von einer Homologie der Pubis mit dem Postpubis der ornithopoden Dinosaurier keine Rede sein und der Processus pectinealis erweist sich als ein den Vögeln allein zukommendes Merkmal.

Das Femur ist kurz und dick, sein Hals und Kopf stehen rechtwinklig zur Längsachse. Die äußere distale Gelenkrolle ist stets kräftiger als die innere, in der dazwischenliegenden Furche befindet sich meist eine Patella. Das Kniegelenk wird vollständig von Fleisch und Federn verdeckt. Die Tibia zeichnet sich durch ansehnliche Länge aus, ihr verbreitertes proximales Gelenk besitzt eine Procnemialcrista, das distale Gelenk besteht aus einer in der Mitte vertieften Rolle, welche senkrecht zur Längsachse steht. Bei jungen Vögeln erscheint das distale Gelenkende durch eine Naht vom übrigen Knochen getrennt. Es besteht aus dem Astragalus und dem Calcaneum, welche dann zusammen mit der Tibia den Tibiotarsus bilden. Die Fibula verschmilzt außer bei den Moas, wo sie stark 
verkürzt ist, mehr oder weniger vollständig mit der Tibia. Am läng. sten ist sie bei den Pinguinen und den Eulen.

Wie der Tibiotarsus, so entsteht auch das Laufbein, der Tarsometatarsus (Fig. 463 u. 464) durch Verschmelzung von Tarsalien mit dem anstoßenden Knochen, dem Metatarsus, mit dessen Oberende die distalen Tarsalia verwachsen. Das fünfte Metatarsale verkümmert vollständig, die drei mittleren sind beim Embryo noch getrennt, verwachsen aber bald seitlich miteinander bis auf die rollenartigen distalen Gelenkenden. Metatarsale III ist etwas länger als II und IV, Metatarsale I fehlt häufig ganz und wenn vorhanden, ist es stark verkürzt und auf die Hinterseite des Laufes verschoben und in der Regel an dessem Oberende festgewachsen. Metatarsale II trägt in der Regel drei, III vier und IV fünf Zehen. Die fünfte meist nach hinten gerichtete Zehe wird nur durch zwei Phalangen angedeutet.

Unter allen Knochen sind Humerus und Tarsometatarsus weitaus die charakteristischsten und daher am leichtesten generisch bestimmbar oder doch am ehesten geeignet zur Ermittlung der näheren Verwandtschaft.

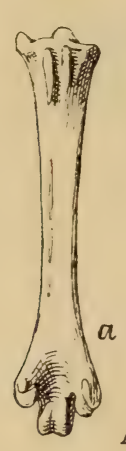

A
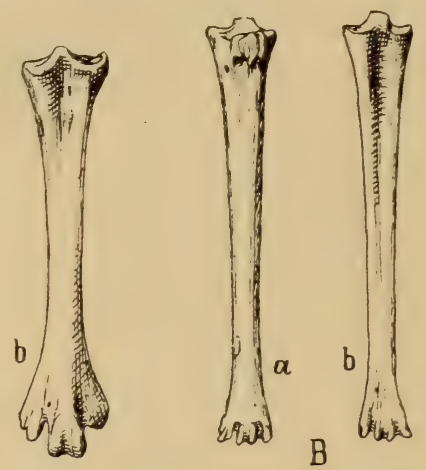

Fig. 463.

A Lagopus albus Gmelin. Tarsometatarsus, nat. Gr., $a$ von hinten, $b$ von vorne $B$ Corvide Tarsometatarsus, nat. Gr. $a$ von hinten, $b$ von vorne. Pleístocän. Velburg.

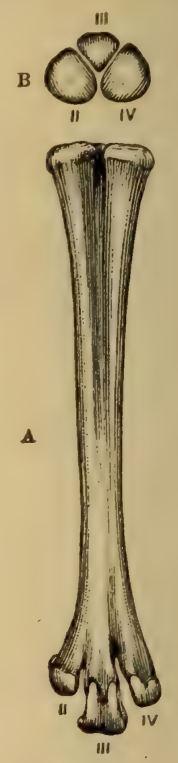

Fig. 464

Lauf (Tarsometatarsus) von einem jungen Truthahn (Meleagris gallipavo Lin.). $A$ von vorne, $B$ proximales Gelenkende.

(Nach Marsh.)

Fossile Vogeleier sind im allgemeinen noch seltener als Vogelknochen. Sie gehören teils den ausgestorbenen Riesenvögeln Aepyornis von Madagaskar, Moa von Neuseeland, - teils, wie jene aus der Kreide und dem Míocän, Wasservögeln und Laufvögeln an. Von den als Vogelfährten gedeuteten Fußspuren dürften nur jene aus dem lithographischen Schiefer von Solnhofen wirklich von Vögeln - Archaeopteryx - herrühren, während die von Hitchcock beschriebenen dreizehigen Fährten aus der Trias des Connecticut-Tales aller Wahrscheinlichkeit nach von Dinosauriern stammen.

Im Vergleich zu der großen Anzahl lebender Vögel, deren über 10000 Arten beschrieben sind, spielen die 400-500 fossilen und subfossilen Formen eine sehr untergeordnete Rolle, allein es befinden 
sich namentlich unter den ältesten Vögeln aus Jura und Kreide einige Typen, welche in systematischer und morphologischer Hinsicht besonderes Interesse verdienen. Hingegen schließen sich die Vögel des Tertiär zum größten Teil schon enge an lebende Formen an und selbst viele lebende Gattungen lassen sich weit im Tertiär zurückverfolgen.

Das spärliche Vorkommen fossiler Vögel erklärt sich sehr leicht aus ihrer Lebensweise und aus der hervorragenden Fähigkeit, drohenden Gefahren auszuweichen. Namentlich die häufigste Todesursache der Landtiere, das Ertrinken, kommt für erwachsene oder schon flügge junge Vögel nur ganz ausnahmsweise in Betracht. Immerhin kommen doch Überreste ein und derselben oder von nur wenigen Arten manchmal in sehr großer Menge vor, so z. B. in miocänen Quelltuffen und zwar sind es in diesem Falle Wasservögel, die offenbar durch Kohlensäureausströmungen zugrunde gingen, sowie in jungpleistocänen Höhlenablagerungen, wo die meist vom Schneehuhn stammenden Knochen als Überreste von Eulengewöllen überliefert sind. In den Phosphoriten von Quercy gehört ein großer Teil der Vogelknochen dem mit Cypselus verwandten Aigialornis an, der in den Klüften des Kalkplateaus offenbar nach Schwalbenart in Scharen genistet und daher auch an seiner Wohnstelle verhältnismäßig zahlreiche Überreste hinterlassen hat. Dagegen dürfte die Anhäufung der Knochen der australischen und neuseeländischen Riesenvögel vielleicht dem Menschen zuzuschreiben sein, während die Aepyornis von Madagaskar wenigstens zum Teil wohl in den Torfmooren versunken sind.

Im Tertiär sind Vogelreste am häufigsten in den Phosphoriten von Quercy, in den Süßwassertuffen des Departements Allier und vom Ries, ferner am Fossil Lake in Oregon und in den MiocaenSchichten von Santacruz in Patagonien.

Die Systematik der fossilen Vögel bietet noch größere Schwierigkeiten als jene der lebenden, da uns in der Regel bloß einzelne Knochen zu Gebote stehen und diese ihren Merkmalen nach nicht allzuselten in ganz verschiedene Gruppen passen können. Nichtsdestoweniger sind es aber doch nur verhältnismäßig wenige Reste, deren systematische Stellung noch nicht genauer ermittelt werden konnte.

Die lebenden Vögel werden von den meisten Autoren in die zwei großen Gruppen der Ratitae und der Carinatae gegliedert, nach der Beschaffenheit des Brustbeins, das bei den letzteren mit einem Kiel versehen ist, doch gibt es hiervon Ausnahmen, wie überhaupt nach den Ausführungen Pycrafts ${ }^{1}$ ) diese beiden Gruppen künstlich sind. Nach dem Vorgang von Lucas ${ }^{2}$ ) werden auch hier diese Namen durch Dromaeognathae und Eurnithes ersetzt.

1) Morphology and Phylogeny of the Palaeognathae (Ratitae and Crypturi) and Neognathae (Carinata) Trans. Zool. Soc. London. Vol. XV 1900 p. 149.

2) Zittel, Textbook of Palaeontology. Vol. II 1902. 


\section{Subklasse. Saururae. Haeckel. $\left.{ }^{1}\right)$}

Schwanzfedern paarweise an jeder Seite der zahlreichen langen Schwanzrippen. Wirbel amphicöl. Sternum rudimentär. Bauchrippen vorhanden. Dorsalrippen ohne Processus uncinatus. Halsrippen frei. Pelvis. knochen sowie Metacarpalia frei. Finger mit Krallen.

\section{Ordnung. Archaeornithes.}

Schädel echtvogelartig, mit einer Reihe in konischen Alveolen steckender Zähne auf $Z$ wischen- und Unterkieferrand. Schwanz eidechsenartig, länger als der präsacrale Abschnitt der Wirbelsäule. Flügel mit Schwung- und Deckfedern.

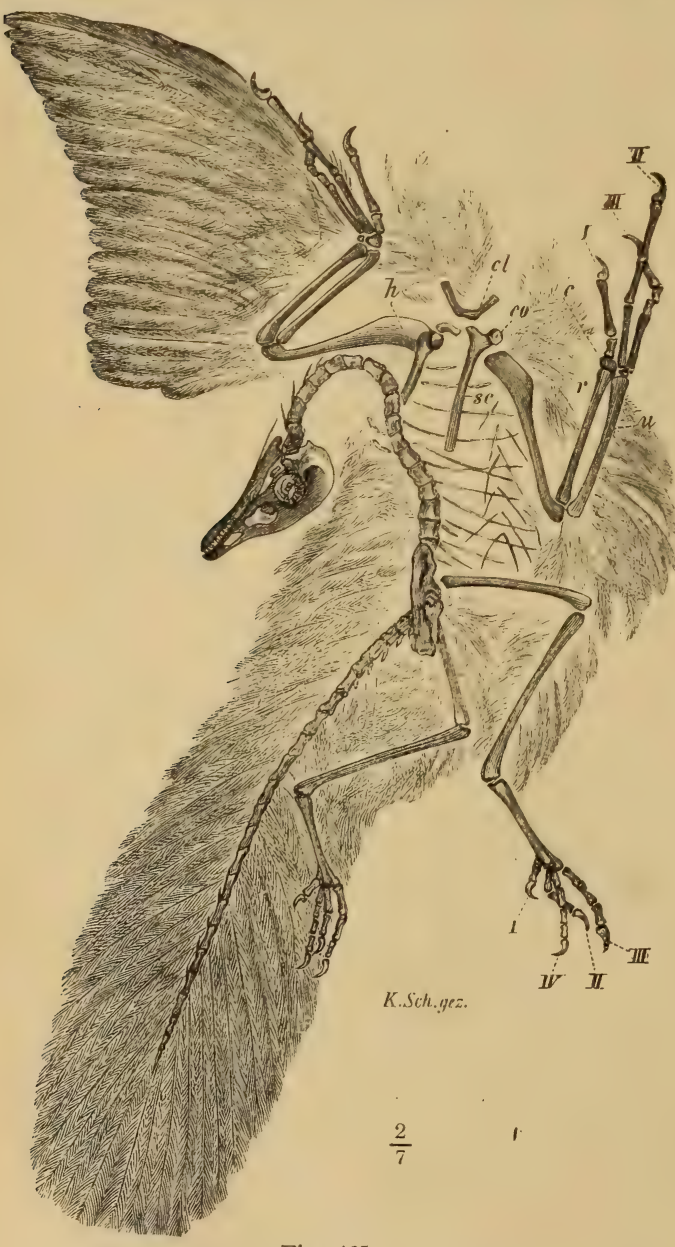

Fig. 465 .

Archaeopteryx Siemensi Dames:' Berliner Skelett aus dem lithographischen Schiefer von Eichstätt. $2 /$ nat. Gr.

cl Clavicula, co Coracoid, $h$ Humerus, $r$ Radius, $u$ Ulna, $c$ Carpus. (Aus Steinmann-Döderlein.)
Oberer Jura von Eich. stätt in Bayern.

Archaeopteryx von Meyer (Griphosaurus Wagner) Fig. 465. Die beiden jetzt in London und Berlin befindlichenExemplare ergänzen sich so gut, daß die gesamte Osteologie mit Ausnahme des Brustbeins und die Art der Befie. derung dieses primitiven Vogels ziemlich genau bekannt ist. Im Gegensatz zur großen Mehrzahl der jüngeren Vögel scheint der Urvogel keine pneumatischen Knochen besessen zu haben. Die Wirbelsäule besteht aus etwa 50 Wirbeln, von denen $10 \mathrm{bis}$ 11 zur Hals-, 11 oder 12 zur Rücken-, 2 zur Lendenregion, 5 bis 6 zum Sacrum und 20 bis 21 zum Schwanz gehören. Hals und Rückenwirbel sind amphicöl, die Quer- und Dornfortsätze schwach entwickelt. Die Halswirbel tragen kurze freie, die Rumpfwirbel lange dünne Rippen ohne Processus uncinatus. $\mathrm{Zu}$ diesen reptilien-

1) Owen Rich., On the Arc h a e o p teryx. Phil. Trans. London 1863, p. 33-47. - Dames W., Utber Archaeopteryx. Paläont. Abhandl. von Dames und Kayser 1884. II. Bd. V. Sitzungsber. d. $k$ preuß. Akad. d. Wiss., Berlin 1897, Bd. 38, p. 818. Pycraft W. P., The Wing of A rcha e o t eryx. Nat. Science. Vol. VIII, 1896, p. 261. 
ähnlichen Rippen kommen noch 12-13 Paare feiner Bauchrippen, die jedoch nicht durch ein abdominales Sternum verbunden waren.

Der an dem Berliner Exemplar (Fig. 465) erhaltene Kopf erinnert in seiner Form, in der Größe des Craniums, in dem Mangel von Schläfenlöchern, in der Beschaffenheit der Orbita, der großen präorbitalen Öffnung, und der schlitzartigen weit -vorne stehenden Nasenlöcher durchaus an die echten Vögel, mit denen er auch die Verschmelzung der.Suturen gemein hat. Das Auge ist wie bei den Pterosauriern von einem aus vielen Knochenplättchen bestehenden Scleroticalring umgeben. Scheitel- und Stirnbeine sind groß, Post- und Präfrontalia nicht gesondert, das Tränenbein ziemlich ausgedehnt, das Quadratum frei, Zwischenkiefer mäßig lang und wie die Oberkiefer mit in Alveolen steckenden Zähnchen versehen. Die Zahl der Zähne ist oben 13, am Unterkiefer sind noch drei erhalten.

Im Brustgürtel stimmt die lange schlanke Scapula mit Vögeln und Pterosauriern überein und zeigt, wie bei den Carinaten, ein gut entwickeltes Acromion. Coracoid und Furcula sind durchaus vogelartig. Das Brustbein ist leider nicht vollständig erhalten. Radius und Ulna sind gerade und etwas kürzer als der Humerus. Vom Carpus ist nur das Radiale bekannt. Von den drei Metacarpalien bleiben $I I$ und $I I I$ voneinander getrennt. Mc. II ist das längst und mit drei langen Phalangen versehen, Mc. I, das kürzeste, trägt zwei und Mc. III vier Phalangen. Die Endphalangen sind als Krallen ausgebildet.

Das Becken besteht aus drei anscheinend miteinander verwachsenen Knochen und besitzt ein durchbrochenes Acetabulum. Die im Wesentlichen vogelartige Hinterextremität hat eine nur schwache Cnemialcrista der Tibia und vier bekrallte Zehen mit der Phalangenzahl 2.3. 4. 5 (von Mt. $I-I V$ ).

Die Befiederung besteht am Flügel aus 7 Primär- und 10 Sekundärschwungfedern nebst Deckfedern. Die Steuerfedern des Schwanzes sind paarweise an je einem Wirbel angeordnet und schräg nach hinten gerichtet. Am Hals und neben der Tibia bemerkt man Konturfedern.

Archaeopteryx schwankt in der Größe zwischen einer Taube A. Siemensi Dames - und eines Huhns - A. lithographica v. Meyer -. Er konnte sich jedenfalls frei in der Luft bewegen trotz der noch etwas mangelhaften Flugorgane und mittels seiner Krallen an Bäumen und Felsen emporklettern. Dreizehige Fährten aus dem lithographischen Schiefer von Solnhofen zwischen denen eine Furche den langen nachschleppenden Schwanz andeutet, hat $\mathrm{Oppel}$ auf Archaeopteryx bezogen.

\section{Subklasse. Ornithurae. Lucas.}

Schwanzfedern fächerförmigum dieverkürzten, meist teilweise zu einem Pygostyl verschmolzenen Schwanzwirbel gruppiert. Sternum ohl entwickelt. Brustrippen mit Processus uncinatus, Halsrippen mit den Wirbeln, und Beckenknochen miteinander proximal verwachsen. Metacarpalia fest miteinander vereinigt.

\section{1. Überordnung, Odontolcae. Marsh.}

Kiefer mitkonischen, in einer Rinne eingepflanzten Zähnen, Unterkiefer nicht zu einer festen Symphyse verwachsen, nur durch Ligament miteinander verbunden. Ohne Baśipterygoidfortsatz, Quadratum einköpfig. Beckenknochen hinten frei. Wirbelgelenke sattelförmig. 


\section{Ordnung. Hesperornithes. Marsh.}

Flügelrudimentär nur aus dem verkümmerten Humerus bestehend, Hinterbeine sehr kräftig, als Schwimmfüße ausgebildet. Zähne auf den Unterkiefer und Oberkiefer beschränkt, Zwischenkiefer zahnlos.

Hesperornis Marsh (Fig. 466). Von diesem Vogel ist das Skelett ziemlich vollständig bekannt. Am Brustbein fehlt die Carina. Das Coracoid ist kurz und breit und mit der Clavicula gelenkig verbunden. Erwähnung verdient die riesige Entwicklung der Patella. Obere Kreide von Kansas.

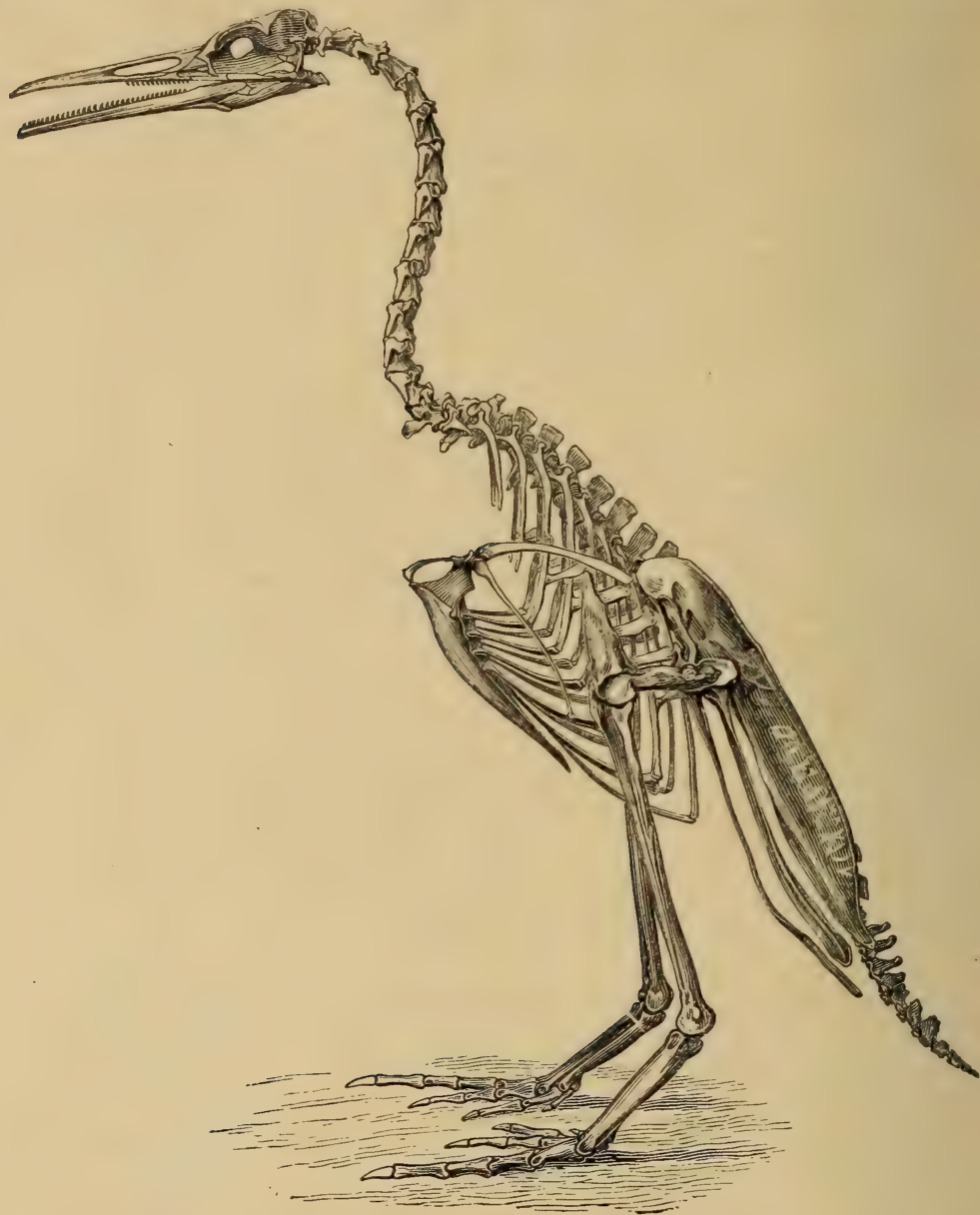

Fig. 466 .

Hesperornis regalis Marsh. Obere Kreide von Kansas. Restauriertes Skelett. 1/8 nat. Gr. (Nach Marsh.)

Baptornis Marsh, obere Kreide von Kansas und Enaliornis Seeley aus dem Grünsand von Cambridge, beide nur auf einzelne Knochen begründet.

2. Überordnung. Odontormae. Marsh.

Zähne in Alveolen des Ober-und Unterkiefers. Unterkiefer nicht in einerSymphyse verwachsen. Quadratum ein- 
köpfig. Sternum mit hoher Carina. Pelvisknochen hinten voneinander getrennt.

Ichthyornis Marsh (Fig. 467 u. 468). Von der. Größe einer Taube, war ein guter Flieger, was aus der Länge des Humerus und der Höhe der

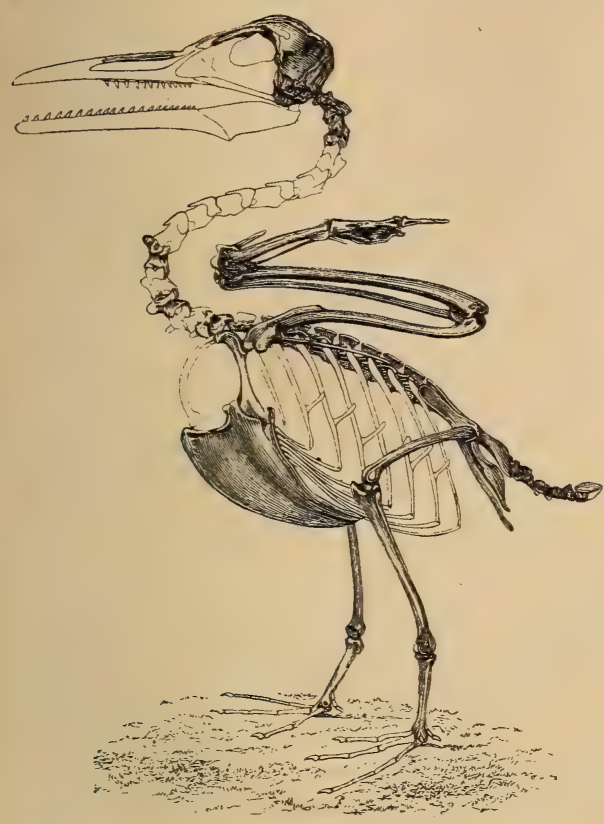

Fig. 467.

Ichthyornis victor Marsh. Obere Kreide von Kansas. Restauriertes Skelett. $1 / 2$ nat. Gr. (Nach Marsh.)
Brustbeincarina hervorgeht. Hat wohl auch stammesgeschichtliche Bedeutung. H. victor, dispar Marsh. Obere Kreide von Kansas.

Hargeria Loomis und Apatornis Marsh. Ebenda.

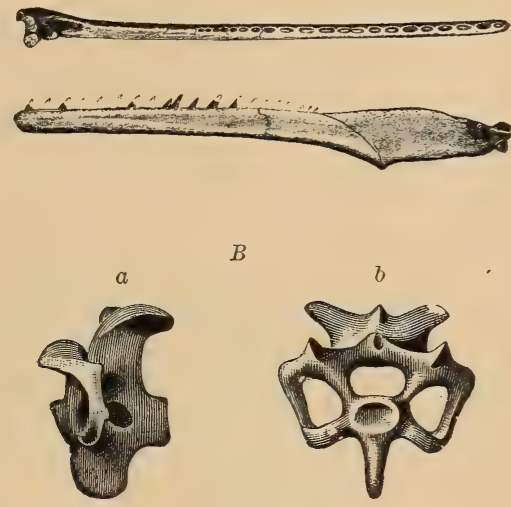

Fig. 468 .

Iehthyornis dispar Marsh. Obere Kreide von Kansas. $A$ Unterkiefer. $3 / 4$ nat. Gr. $B$ Halswirbel $a$ von der Seite, $b$ von vorne. $2 / 1$ nat. Größe. (Nach Marsh.)

\section{3. Überordnung. Dromaeognathae. Pycraft.}

Vomer breit und vorne mit den Maxillopalatina verwachsen. Vorderende der Pterygoide das Sphenoidrostrum nicht berührend, Quadratum einköpfig. Unterkiefer eine feste Symphyse bildend. Ischia schlank und frei, nur mit dem distalen Ende am Ilium angewachsen. Oberende des Tarsus ohne Sehnenkanäle. Schwanzwirbel frei, nicht zu einem Pygostyl verwachsen.

Die Dromaeognathae umfassen wenige, aber zumeist sehr große Vogeltypen, welche vielleicht den Überrest der alten Vogelfauna darstellen und untereinander größere Verschiedenheit aufweisen als alle übrigen Vögel. Die Strauße haben keinen Kiel auf dem Sternum. Der Schultergürtel zeigt verschiedene Grade der Rückbildung, von der Abwesenheit der Schlüsselbeine bis zum vollständigen Fehlen der Flügel. Die Pelvisregion variiert in der Ausbildung des Ischium und des Pubis.

\section{Ordnung. Struthiones.}

Große Vögel ohne Flugvermögen. Basypterygoidfortsatz am Körper des Parasphenoid entspringend. Nasenlöcher holorhinal. Sternum ungekielt, Scapula und Coracoid kurz und miteinander verwachsen. Flügel rudimentär. 
Diese Ordnung umfaßt die echten Strauße, die Rheas, die Kasuare und Emus, die Moas oder Dinornithiden und die madagassischen Aepyornithiden.

\section{Familie. Struthionidae. Strauße.}

Beide Pubes zu einer Symphyse verwachsen, Anwesenheit von nur zwei Zehen, der dritten und vierten. Körperlast auf die diitte Zehe verlagert infolge der Anpassung an das Laufen.

In der Gegenwart auf Afrika beschränkt. Fossile Strauße im Pliocän der Siwalik und auf Samos. Fossile Eier aus Südrußland und Nordchina als Struthiolithus beschrieben. Eremopezus Andrews im Oligocän von Ägypten hat auch Anklänge an Emu, Kasuar und Aepyornis.

\section{Familie. Rheidae.}

Ischia einwärts gedreht und unter den Ilia zusammenstofiend. Vordere Schwanzwirbel zum Teil resorbiert. Fufs dreizehig.

Fossile Rhea-Reste kennt man aus dem Pleistocän von Südamerika, ebendaselbst noch lebend.

\section{Familie. Dromaeidae.}

Flügel stark reduziert. Fuß dreizehig.

Dromaeus, Emu, lebend in Australien, Casuarius, Kasuar auf Neuseeland, daselbst auch fossil. Genyornis mit massivem, fast $1 / 3$ Meter langem Schädel im Pleistocän von Australien, Hypselornis im Pliocän von Indien.

\section{Familie. Aepyornithidae. ${ }^{1}$ )}

Nur fossil bekannt, aus Pleistocaen oder sogar Alluvium von Nord-Madagascar. Diese Riesenvögel haben einen relativ kleinen Schädel, ein sehr kurzes breites Sternum mit deutlichen Coracoidgelenken und meist einen vierzehigen Fuß. Die Eier sind fast dreimal so groß als Straußeneier. A epyornis. Die Tibia der größten Art hat eine Länge von $80 \mathrm{~cm}$. Müllerornis. Diese Vögel waren sicher noch Zeitgenossen des Menschen.

\section{Familie. Dinornithidae. $\left.{ }^{2}\right)$ Moas.}

Flügel und Brustgürtel stark reduziert oder ganz fehlend. Schnabel kurz, Hinterextremität sehr massiv. Femur ohne Luftgänge. Fus dreizehig, zuweilen mit Hallux.

Die Überreste dieser meist riesigen Vögel verteilen sich auf minde. stens vier Gattungen und etwa 20 Arten, welche jedenfalls zum Teil noch mit dem Menschen zusammengelebt haben, zum Teil aber angeblich in das Pliocaen hinabgehen. Die Knochen finden sich zuweilen noch als Skelette vereinigt in Sümpfen, auch in alten Lagerplätzen der Maori kommen sie zusammen mit Eischalen in größerer Menge vor. Federn ähnlich wie beim Kasuar.

1) Bianconi G. G., Recherches sur l'A e pyornis maximus. Mem. Acad. di Scienze Bologna 1861, XII, 1863 IV, 1865 I, 1874 IV. - Milne Edwards A. et Grandidier A., Ann. Sc. nat. (5 Ser.) 1870 XII, p. 167. - Andrews C. W., Geolog. Magaz. Vol. IV, 1897, p. 241.

2) Hamilton A., Bibliography of D in or $\mathrm{n}$ ith i d a e. Trans. New Zeal. Inst. XXVI, 1893, p. 229. - Hutton F. W., New Zeal. Journ. Sc. 1891, p. 6. - Parker T. J., On the Cranial Osteology of Dinornithidae. Trans. Zool. Soc. London 1895, p. 188. - Andrews C. W., Skeleton of M e gal a pt ery x. Novitat. Zoologicae. Vol. II, 1897, p. 188. 
Dinornis Owen. Schnabel breit und spitz zulaufend. Tarsometatarsus und Tibiotarsus lang und schlank. D. maximus Owen hatte aufrechtstehend eine Höhe von 3,5 Metern.

Palapteryx Owen (Eurapteryx Haast). Fig. 469. Kleiner, aber plumper als der vorige. Schnabel abgerundet. Hallux stets vorhanden. Höhe kaum 2 Meter.

Anomalapteryx. Reich. Kleine, relativ schlanke Vögel mit spitzigem Schnabel, Tarsometatarsus kürzer als Femur. Mit Hallux.

Megalapteryx, Mesopteryx Haast sind nicht vollständig bekannt.
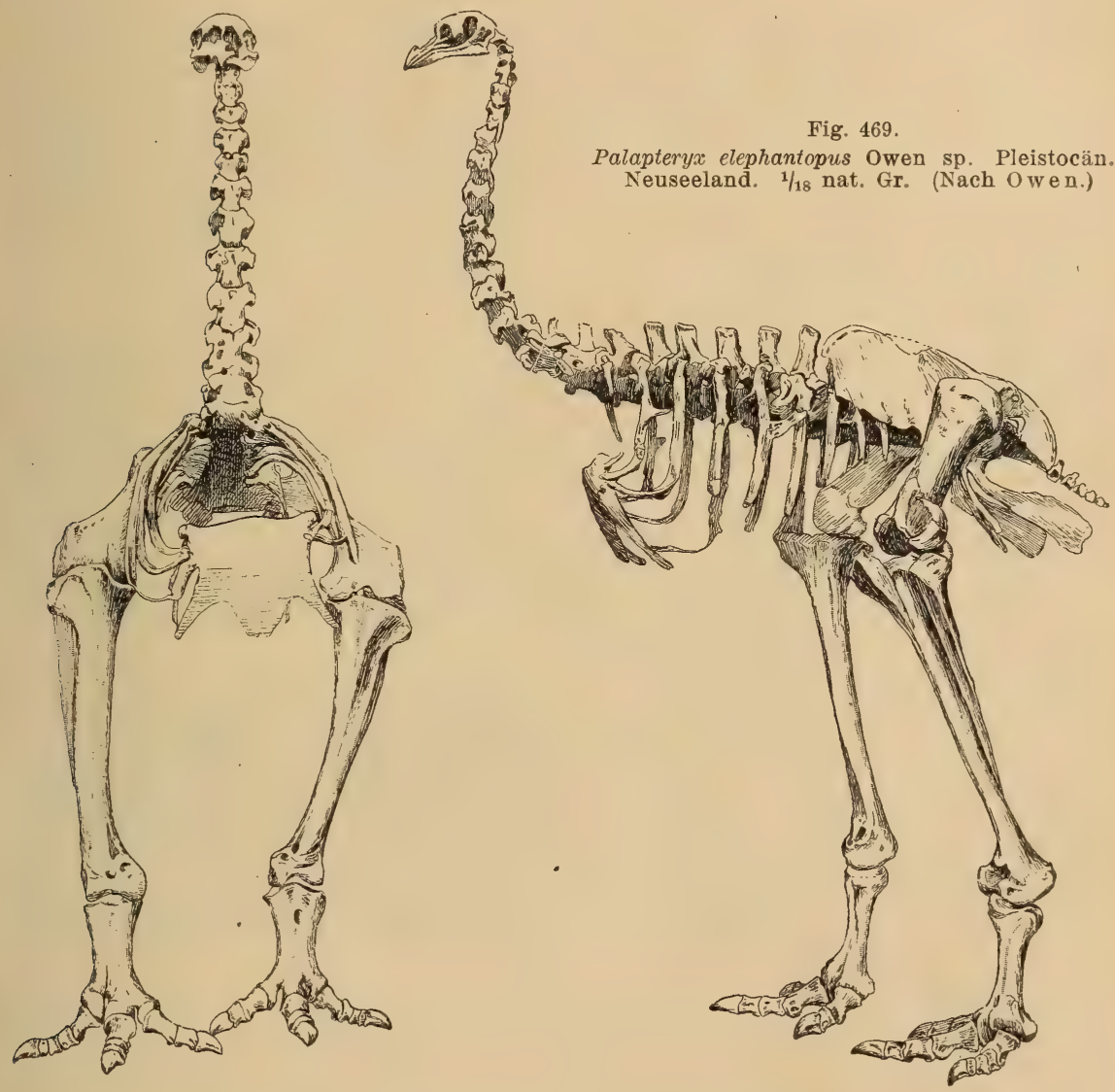

\section{Ordnung. Apteryges.}

Kleine Vögel mit langem schlanken Schnabel, an dessen Spitze die Nasenlöcher stehen. Sternum breit, Flügel ganz rudimentär, Fuß vierzehig, erste Zeheklein, über den anderen stehend.

Apteryx lebend und fossil in Neu-Seeland.

\section{Ordnung. Crypturi.}

Die Crypturi oder Tinami haben ein langes, gekieltes Sternum, auch in der Gaumenbildung nähern sie sich den Euornithes und zwar den Gallinaceiden, in der übrigen Organisation und in ihrem äußeren Habitus 
dagegen den Straußen. Sie haben nur ein beschränktes Flugvermögen und bewohnen Südamerika und Mexiko. Tinamus fossil in brasilianischen Höhlen.

\section{4. Überordnung. Euornithes.}

Vomer hinten zwischen den Palatina das Sphenoidalrostrum umschließend. Pterygoidea und Sphenoid mit den Palatina artikulierend. Sternum gekielt, außer bei Nichtfliegern. Ilium und Ischium hinten miteinander verschmolzen. Tarsometatarsus mit ein oder mehr Kanälen für Sehnen.

\section{Ordnung. Impennes. Pinguine.}

Die Pinguine zeigen hochgradige Spezialisierung zum Schwimmen, denn die kurzen Flügel sind zu Rudern umgewandelt. Die Schädelknochen bleiben zum Teil lange Zeit frei. Die Scapula ist hinten verbreitert, die Rücken. wirbel sind opisthocöl, der breite kurze Tarsometatarsus zeigt mehr oder weniger unvollständige Verwachsung der Metatarsalien. Die Pinguine bewohnen die antarktische Region, gehen aber an der Westküste von Südamerika bis zum Äquator.

Palaeeudyptes, ein riesiger Pinguin im angeblichen Eucän von NeuSeeland. Auch Anthropornis aus dem Eocän der Seymour-Insel hat riesige Dimensionen. Die übrigen dort vorkommenden Gattungen, Pachypteryx, Eospheniscus, Delphinornis und Orthopteryx sollen nach Wim a n primitiver organisiert sein. Zahlreiche Gattungen und Arten haben auch Ameghino, Mercerat und Moreno aus dem Miocän von Patagonien beschrieben - Palaeospheniscus (Fig. 470), Perispheniscus, Paraptenodytes etc., von denen manche nach Ameghino mit Wimanschen Gattungen identisch sind. Cladornis
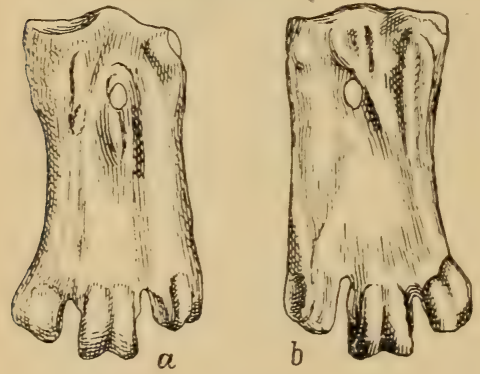

Fig. 470 .

Palaeospheniscus planus Ameghino. Miocän. Patagonien. Metatarsus $a$ von vorne, $b$ ron hinten. (Nach Ameghino.) und Cruschedula stammen aus den Pyrotherienschichten von Patagonien.

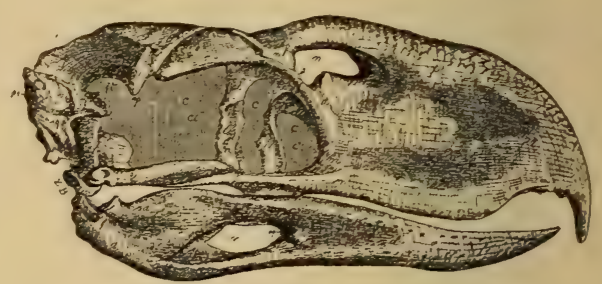

Fig. 471.

Phororhacus inflatus Ameghino. Yiocän. Santacriz. Patagonien. Schädel und Unterkiefer von der Seite. $1 / 6$ nat. Gr. (nach A meghino.)

2. Ordnung. Cecomorphae. Schwimmvögel.

Schwimmvögel mit abgestutztem Kiefergelenk.

Sturmvögel - Puffinus im Miocän von Dep. Allier und 'Maryland. Albatroß - Diomeda im Red Crag. Taucher-Colymboides im europäischen Eocän und Miocän. Colymbus und Podiceps im Pliocän von Italien, MövenLarus im Miocän von Dep. Allier und Mancalla, mit den Alken verwandt, im Obermiocän von Kalifornien.

\section{Ordnung. Grallae. Su mpfvögel.}

Kraniche - Grus in Europa im Eocän, Miocän und Pliocän. Charadivius im Eocän von Colorado, Aletornis im Eocän von Wyoming. - Schnepfen Totanus, Numenius im ganzen europäischen Tertiär, Tringa im Miocän ron 
Dep. Allier. An die Rallen, von denen Rallus und Fulica in Europa schon im Eocän auftreten, schließen sich am besten an Orthocnemus und Elaphrocnemus aus den Phosphoriten von Quercy und Gypsornis aus dem Pariser Gips, während Dolichopterus von Ronzon, Osteornis aus den Glarner Schiefern und Hydrornis aus Dep. Allier in die Nähe von Numenius gestellt werden. Die ältesten Grallae sind Palaeotringa und Telmatornis Marsh aus der Kreide von New-Jersey.

Die patagonischen Riesenvögel Phororhacus (Fig. 471) und Pelecyornis aus den Pyrotheriumschichten und dem Santacruzeno sind grallenartige Vögel, verwandt mit Cariama, die zugleich auch Merkmale der Reiher an sich haben. Sie zeichnen sich durch den hohen komprimierten, scharf zugespitzten Schnabel, durch die Kleinheit des Sternum und des Schultergürtels und der Flügel und die unverhältnismäßig großen Halswirbel aus. Der Schädel ist über 1/2 Meter lang. Der mit ihnen vergesellschaftete Brontornis hat einen kurzen dicken Tarsometatarsus, Diatryma aus dem Eocän von Neu-Mexiko ist wahrscheinlich mit Phororhacus verwandt.

Otis, Trappe, ist aus dem Miocän von Frankreich beschrieben.

\section{Ordnung. Chenomorphae. Entenvögel.}

Dieser im ganzen wohlumgrenzten Ordnung schließen sich die südamerikanischen Gattungen Palamedea und Chauna an, welche äußerlich den Hühnervögeln gleichen und ebenso die Flamingo-Amphimorphae Huxley - welche Anklänge an die Reiher zeigen und vielleicht den Überrest jener Gruppe darstellen, aus der sowohl die Enten als auch die Reiher hervorgegangen sind.

Flamingo ähnliche Formen sind Scaniornis aus der Kreide von Schweden, Agnopterus aus dem Eocän von Paris und England, Elornis aus dem Oligocän von Ronzon, Palaelödus aus dem Miocän von Dep. Allier, Phoenicopterus ebendaselbst und im Pliocän von Oregon. Gastornis aus dem Eocän von Frankreich, zeichnet sich außer durch seine Größe auch dadurch aus, daß seine Schädelknochen nicht verwachsen. Entenvögel beginnen vielleicht schon in der oberen Kreide von Nordamerika, Laornis Marsh. Anas häufig im europäischen Miocän, selten im Eocän und Pliocän. Chenornis im Obermiocän, Fuligula und Spatula im Pliocän von Europa. Cygnus im Miocän von Böhmen und Belgien und Mergus im Pliocän der Siwalik, beide auch im Pleistocän. Aus Südaustralien kennt man fossile Reste von Archaeocygnus, Chenopsis, Biziura und Drias. Aus dem Pleistocän von NeuSeeland stammt der große ungeflügelte Cnemiornis. Aus dem Miocän von Patagonien werden zu den Anatiden gestellt Eoneornis und Eutelornis.

\section{Ordnung. Herodii. Reiher.}

Fossil sind bekannt Proherodius aus 'dem Eocän von England, Propelargus und Pelargopsis aus den Phosphoriten von Quercy, Amphipelargus aus dem Pliocän von Samos, Ardea aus den Phosphoriten und aus dem europäischen Miocän; Ibidopsis aus dem Eocän von England, Ibidopodia und Ibis aus dem Miocän von Dep. Allier, Leptopilus im Pliocän der Siwalik, Xenorhynchus aus Pliocän (?) von Südaustralien, daselbst auch Ibis. Protibis aus den miocänen Santacruzschichten von Patagonien.

\section{Ordnung. Steganopodes.}

Kormorane - Phalacrocorax sind fossil bekannt aus dem europäischen Miocän und Pliocän und aus dem Pliocän der Siwalikhügel. $\mathrm{Zu}$ den Steganopoden gehören auch Actiornis aus dem Eocän von England sowie Argillornis, Eupterornis und der mit zahnartigen Vorsprüngen des Kiefers ver- 
sehene Odontopteryx aus dem Untereocän von England und aus dem Tertiär von Brasilien und Graculavus aus der Kreide von Nordamerika. Prophaeton im London Clay. Sula kommt im Oligocän von Ronzon und im Miocän von Dep. Allier und von Nord Carolina vor. Pelecanus fossil im europäischen Miocän, im Pliocän der Siwalikhügel und im Pliocän (?) von Südaustralien, hier auch Plotus. Cyphornis im Eocän von Vancouver.

\section{Ordnung. Opisthocomi.}

Nur die einzige Gattung Opisthocomus, Hoactzin von Südamerika.

\section{Ordnung. Gallinae. Hühnervögel.}

Echte Hühner sind Palaeortyx im europäischen Obereocän und Miocän, Palaeocryptonyx im Eocän und Pliocän, Paraortyx in den Phosphoriten von Quercy. Taoperdix und Palaeoperdix im Miocän. Phasianus im Miocän und Pliocän, Gallus und Tetrao im Pliocän. In Nordamerika Meleagris schon im Oligocän. Überreste von Schneehuhn - Lagopus - finden sich sehr häufig in jungpleistocänen Ablagerungen der europäischen Höhlen zusammen mit Lemming und Pfeifhase. Wyoming.

Anissolornis im Miocän von Patagonien, Gallinuloides im Eocän von

\section{Ordnung. Columbae, Tauben.}

Columbra im Miocän des Dep. Allier und in brasilianischen Höhlen, Goura im Pleistocän von Queensland und Lencosarica im Pliocän von Südaustralien. Pterocles in den Phosphoriten von Quercy und im Dep. Allier. Didus ineptus von der Insel Mauritius und Pezophaps von Rodriguez sind vom Menschen ausgerottet worden.

\section{Ordnung. Accipitres. Tagraubvögel.}

Aquila ist fossil im europäischen Miocän und in den Phosphoriten von Quercy und im Pliocän von Nebraska. Palaeocircus im Obereocän und Haliaetus, Milvus und Palaeohierax im Miocaen von Frankreich, Falco im Pliocän von Italien, Teracus im Oligocän von Ronzon. Aus dem Londonclay kennt man Lithornis, aus den Phosphoriten von Quercy Amphiserpentarius und Tapinopus, beide sowie Serpentarius aus dem Miocän des Dep. Allier, Verwandte des in Afrika lebenden Schlangengeiers, während Plesiocathartes aus den Phosphoriten mit den Sarcorhamphen des tropischen Amerika verwandt ist. Aus dem Miocän von Afrika wird Gypogeranus erwähnt, aus dem Pliocän von Mexiko Palaeoborus, aus den Santacruzschichten von Patagonien Thegornis, aus dem Pliocän von Südaustralien Taphaetus und Aeturaetus und aus dem Pleistocän von Neuseeland der riesige Harpagornis.

\section{Ordnung. Psittaci. Papageien.}

Im Gegensatz zu den übrigen Vögeln entspringen hier am Lacrimale, Postfrontale und Squamosum Fortsätze, welche öfters eine suborbitale Spange bilden. Psittacus fossil im Miocän des Dep. Allier.

\section{Ordnung. Picariae.}

Diese Ordnung umfaßt die Spechte - Pici - Eisvögel - Alcedines -, die Colii - Trogon -, die Racken - Coraciae -, Nashornvögel - Buceros -, Mauerschwalben - Macrochires -, Ziegenmelker - Caprimulgi -, Kuckucke Cuculi - und die Musophagi. Von diesen kommen fossil vor: Spechte - Picus 
im Miocän vom Dep. Allier, Colii - Trogon ebendaselbst und Archaeotrogon in den Phosphoriten von Quercy, Coraciae - Geranopterus ebendaselbst, Mauerschwalben - Aigialornis und Cypselavus in den Phosphoriten und Cypselus und Callocalia im Miocän vom Dep. Allier - Filholornis aus den Phosphoriten und Necrornis aus dem Miocän von Frankreich sind Verwandte der Musophagi, Halcyornis aus dem Eocän von England ist angeblich ein Eisvogel. Aus dem Eocän von Wyoming stammt Uintornis, ein Specht, aus dem Eocän von Frankreich Cryptornis, verwandt mit den Nashornvögeln, und aus dem Miocän des Dep. Allier Limnatornis, ein Wiedehopf.

An die Ziegenmelker schließen sich in ihrer Organisation die Eulen an, von welchen Bubo aus dem Eocän von Wyoming, aus den Phosphoriten von Quercy, aus dem Miocän des Dep. Allier und aus dem Forestbed bekannt ist, während Asio, Necrobyas und Strigogyps auf die Phosphorite von Quercy beschränkt sind und Strix im Miocän durch zwei Arten vertreten ist.

\section{Ordnung. Passeres. Singvögel.}

Diese Ordnung umfaßt beinahe die Hälfte aller lebenden Vogelarten, welchen freilich nur sehr wenig echt fossile Arten gegenüberstehen. Die Skelettunterschiede sind so gering, daß man hiernach nur zwei Gruppen gut begründen kann. Die ältesten Singvögel sind Cimolopteryx aus der oberen Kreide (Laramiebed), Palaeospiza aus dem Eocän von Wyoming und Laurillardia und Palaeogithalus aus dem Pariser Gips. Aus dem Miocän vom Dep. Allier wird erwähnt Motacilla und Lanius, aus dem Obermiocän und Pliocän von Frankreich Corvus und aus dem Pliocän von Italien Sitta und Alauda. Überreste von Singvögeln kennt man auch aus den brasilianischen Höhlen, darunter von Hirundo, Schwalbe. Nicht selten sind Knochen von Turdiden - Drosseln - und Corviden - Raben - darunter auch Alpendohle, Pyrhocorax, in Mitteleuropa in postglazialen Ablagerungen zusammen mit vielen Resten von Schneehuhn, Lemming und Pfeifhase. Turdus auch schon im Pliocän von Roussillon.

Die Stammesgeschichte der Vögel wird sich schwerlich jemals in voll. kommen befriedigender Weise klarstellen lassen. Wir wissen nur, daß sie aus Diapsiden-Reptilien hervorgegangen sind und zwar aus solchen, aus welchen auch die Dinosaurier entstanden sind. Aber zwischen Archaeopteryx, welcher noch viele Reptilienmerkmale aufweist und den Vögeln aus der oberen Kreide, welche ihrerseits schon zum Teil bedeutende Spezialisierung zeigen, - Hesperornithidae - und sicher sehr bald erloschen sind, besteht eine gewaltige Lücke, die auch kaum so bald ausgefüllt werden dürfte. Immerhin sind wir berechtigt, einem Teil der bis jetzt bekannten Kreidevögel, den Ichthyornithiden, eine gewisse phylogenetische Bedeutung zuzuschreiben. Mit dem Beginn des Tertiärs erscheint bereits ein großer Teil der noch jetzt lebenden Ordnungen und schon vom Obereocän an treffen wir eine Anzahl moderner Gattungen. Im Miocän endlich hat nahezu jede Ordnung der heutigen Vogelwelt Vertreter aufzuweisen, von denen weitaus die meisten sogar modernen Gattungen angehören, während fast alle rezenten Säugetiergattungen erst im Plicän beginnen.

\section{Klasse. Mammalia. Säugetiere. ${ }^{1}$ ) (Bearbeitet von M. Schlosser.)}

Warmblütige, meist behaarte, seltener nackte oder mitknöchernen Platten oder hornigen Schuppen bedeckte Land- und Wassertiere mit auschließlicher Lungen-

1) Ameghino Fl., Contribucion al conocimiento de los Mamiferos de la Republica Argentina. Buenos Aires 1889. - Enumeration synoptique des éspèces de Mammifères fossiles des formations éocènes de Patagonie. Buenos Aires 1894. 
atmung. Herz mitdoppelter Kammer und doppelter Vorkammer. Hinterhaupt mit zwei Gelenkköpfen. Coracoid (fast immer) verkümmert und mit der Scapulaverschmol. zen. Jeder Unterkieferast aus einem Stück bestehend und mit dem Schläfenbein artikulierend. Gliedmaßen als Gehfüße, seltener als Hände oder Flossen ausgebildet.

Die Säugetiere nehmen unter den Vertebraten die höchste Rangstufe ein. Ihre Funktionen sind spezialisierter, ihr Nervensystem, ihre Sinnesorgane entwickelter, ihr Gebiß und ihre Bewegungsorgane verschiedenartiger differenziert als in irgend einer anderen Tierklasse. Auch an Größe und Mannichfaltigkeit der äußeren Erscheinung können sich nur die Reptilien und Fische mit den Säugetieren messen. Mit einziger Ausnahme der Monotremen gebären die

Première contribution à la connaissance de la faune des couches à Pyrotherium. Boletin del Inst. geogr. Argentino T. XV 1895. - Mammifères crétacés de l'Argentine. Ibidem. T. XVIII 1897. - Ongulés nouveaux des terrains crétacés de Patagonie. Boletin. Acad. nac. de Cordoba 1901. - Mammifères nouveaux des terrains crétacés. Ibidem 1902. - Paleontologia Argentina. Public. de la Univers. de la Plata 1904. - Andrews C. W., Descriptive Catalogue of the Tertiary Vertebrata of the Fayum. Egypte. London. 1906. - Blainville H., Ducrotay de, Ostéographie ou description iconographique des Mammifères. 4 Bände. Text u. Atlas mit 323 Taf. Paris 1839-64. - Cope E. D., Tertiary Vertebrata of the West. Rep. U. S. Geol. Survey of Territories. Book I 1884. - Synopsis of the Fauna of the Puerco Series. Trans. Amer. Phil. Soc. 1889. Vol. XVI. - Cuvier G., Recher. ches sur les ossements fossiles. $1 \mathrm{Ed}$. Paris 1812. 4 Ed. 1834-1836. - Depéret Ch., Archives Museum hist. nat. Lyon. IV. 1886, V. 1892. - Les animaux pliocènes de Roussillon. Mém. soc. géol. de France 1890. - Les vértébrés olig. de Pyrimont (Savoie). Mém. soc. paléont. suisse XXIX 1902. - Falconer H. and Cautley P. T., Fauna antiqua sivalensis London 1846-49. - Filhol H., Ann. sc. géol. 1872 III. 1874. V. 1876. VII. 1877. VIII. 1879. X. 1883. XIV. 1885. XVII. 1891. XXI. - Flower W. H., Introduction to the Osteology of the Mammalia. 3th ed. London 1885. - Gaudry Alb., Animaux fossiles et Géologie de l'Attique. Paris 1862-67. - Animaux fossiles du Mont Lébéron (Vaucluse) Paris 1873. - Enchaînements du Monde animal dans les temps géol. Mammifères tertiaires. Paris 1878. - Fossiles de Patagonie. Annal. de Paléontol. T. 1. 1906. T. 11. 1996. - Gerrais P., Zoologie et Paléontol. franc. Paris 1859. - Giebel G. und Leche W., Die Säugetiere, in Bronn's Klassen u. Ordnungen des Tierreichs Bd. VI. 5. Abt. 1874-1906. - Gregory W. K., The orders of Mammals. Bull. Amer. Mus. Nat. Hist. 1910. - Hofmann A., Die Fauna von Göriach, Abh. k. k. geol. Reichsanst. Wien 1893. - Leidy Jos., The extinct Mammalian Fauna of Dakota and Nebraska. Journ. Acad. Nat. Sc. Philad. VII. 1869. - Lemoine V., Mammifères fossiles de Reims. Bull. soc. géol. France 1883-85. 89. - Lydekker R., Catalogue of the fossil Mammalia in the British Museum. Part I-V London 1885-87. - Indian Tertiary and Praetertiary Vertebrata. Palaeontol. Indica. Mom. geol. Surv. East. India ser. X. vol. I-IV. 1875-86. - Palaeontologia Argentina. Ann. Museo de la Plata II. 1894. - Matthew W. D., Zahlreiche Abhandl. in Bull. Amer. Mus. Nat. Hist. New York 1897-1909. - Fossil Mammals of Northeastern Colorado. Mem. Amer. Mus. 1901. - Osborn H. F., Zahlreiche Abhandl. in Bull. Amer. Mus. New York 1892-1910. - Osborn and Scott. Trans. Amer. Phil. Soc. XVI. 1889. - Roger O., Verzeichnis der fossilen Säugetiere. Ber. nat. Ver. Augsburg. 1896. - Rütimeyer L., Eocäne Säugetiere aus dem Schweizer Jura. Denkschr. der schweiz. Ges. für die gesammte Naturwiss. XIX. 1862. - Abh. schweiz. paläont. Ges. XVIII. 1891. - Schlosser M., Die Säugetiere aus den süddeutsch. Bohnerzen. Paläont. Abh. Koken 1902. - Die fossilen Säugetiere Chinas. Abh. k. bayr. Akad. d. Wiss. II. Cl. XXII. 1903. - Scott W. B. and Sinclair W. B., Mammalia of the Santa Cruz beds. Rep. Princeton Universitys Expeditions to Patagonia 1903-09. - Weber M., Die Säugetiere. Jena 1904. - Wortman J. L., Zahlreiche Abhandlungen in Bull. Amer. Mus. Nat. Hist. New York 1892-99 und Journ. of Sc. and Arts. 1901-02. 
Säugetiere lebendige Junge; die Embryonen sind von einem Amnion umgeben, mit Allantois versehen und besitzen keine äußeren Kiemen. Die Jungen werden nach der Geburt mehr oder weniger lang durch in Milchdrüsen (Mammae) der Mutter abgesonderte Milch ernährt. Das Herz ist in zwei Kammern und zwei Vorkammern abgeteilt, das Blut warm.

Die Wirbelsäule der Säugetiere besteht aus Hals-, Rücken-, Lenden-, Sacral- und Schwanzwirbeln; ein besonderer Sacralabschnitt fehlt nur den Cetaceen und Sirenen. Die Verbindung der Wirbel wird nicht durch Gelenke bewerkstelligt, wie bei Vögeln und Rep. tilien, sondern durch zwischengelagerte elastische Knorpelscheiben; es sind darum auch die vorderen und hinteren Flächen der Wirbelzentren eben; nur die Halswirbel vieler Huftiere zeigen opisthocöle Gelenkverbindung. Die oberen Dornfortsätze haben in der Rückenund Lendenregion ihre stärkste Entwicklung, verkümmern dagegen häufig in der Hals- und Schwanzregion. Die Bögen verwachsen frühzeitig mit dem Zentrum; dagegen bilden sich am vorderen und hinteren Ende des Wirbelkörpers durch selbständige Verknöcherung besondere dünne Knochenscheiben (Epiphysen)aus, welche später mit dem Zentrum verschmelzen.

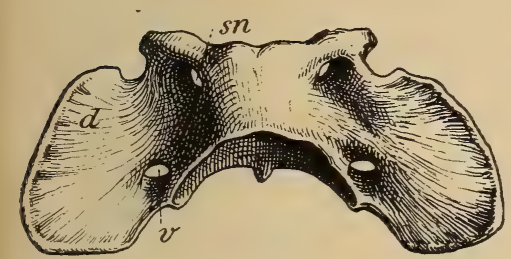

Fig. 472.

Erster Halswirbel (Atlas) vom Hund (von oben) $d$ verbreiterter Querfortsatz, $v$ Arterienkanal, sn Nervenkanal.

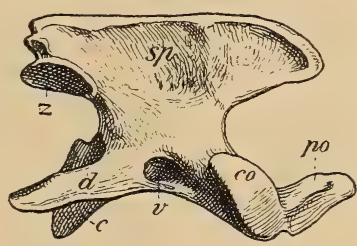

Fig. 473 .

Zweiter Halswirbel vom Hund (von d. Seite): $s p$ Spina dorsalis, $c$ Zentrum, $d$ Diapophyse, $z$ Postzygapophyse, $v$ Arterienkanal, sn Nervenkanal, po processus odontoideus, co Gelenkfasette für den Atlas.

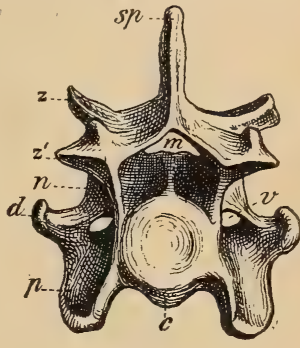

Fig. 474.

Sechster Halswirbel vom Hund (von hin ten) $c$ Zentrum, $s p$ Spina dorsalis, $n$ oberer Bogen, $d$ Diapophyse, $p$ Parapophyse mit der nach unten verlängerten Lamina, $v$ Arterienkanal, $m$ Rückenmark-(Medullar-) Kanal, $z$ vordere, $z^{\prime}$ hintere Zygapophyse.

Der Hals besteht fast regelmäßig aus 7 Wirbeln. Die Länge des Halses wird also nicht, wie bei den Reptilien und Vögeln durch die Zahl, sondern durch die Streckung der einzelnen Wirbel bedingt. Durch Verbindung der nach abwärts gebogenen Enden der vom oberen Bogen ausgehenden Diap ophysen (d) mit den vom Zentrum entspringenden Parapophysen $(p)$ entsteht jederseits vom Zentrum ein Loch $(v)$, durch welches die Halsarterie verläuft. Der erste Halswirbel oder Atlas (Fig. 472) zeichnet sich durch den Mangel des Zentrums und Dornfortsatzes, sowie durch starke Verbreiterung seiner Querfortsätze aus, an deren Basis sich vorne die beiden concaven Gelenkflächen für die Gelenkköpfe des Hinterhaupts und hinten die Gelenkfasetten für den zweiten Halswirbel oder E pistropheus (Axis) befinden. Dieser (Fig. 473) hat am vorderen Ende seines Zentrums einen starken, bald konischen, bald halbzylindrischen oder löffelförmigen Fortsatz, Processus odontoideus po), der entwicklungsgeschichtlich als Zentrum des Atlas zu betrachten ist. 
Die Brust- oder Rückenwirbel (Fig. 475 A) zeichnen sich in der Regel durch starke Dornfortsätze, kurze, am distalen Ende mit Gelenkfasetten für das sog. Tuberculum der Rippen versehene Diapophysen und biplane Zentren aus. Die Gelenkflächen der vorderen Zygapophysen sind nach oben, jene der Postzygapophysen nach unten gerichtet. Als ersten Brustwirbel betrachtet man denjenigen, dessen Rippen mit dem Brustbein in Verbindung treten. In der

4

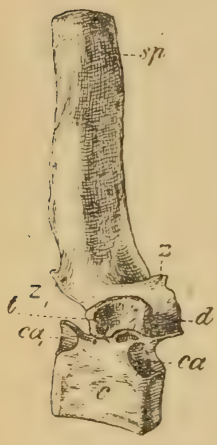
Regel sind 13 (seltener 10-20) Dorsalwirbel vorhanden. An die Lendenwirbel (Fig. $475 B$ ) heften sich keine Rippen an; dagegen sind ihre Querfortsätze sehr stark entwickelt, die kräftigen Dornfortsätze meist

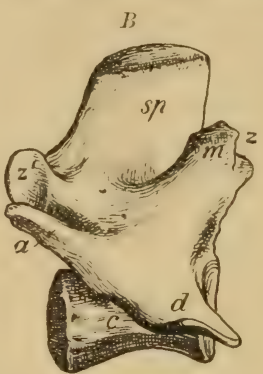

Fig. 475 .

A zweiter Rückenwirbel vom Hund (von der Seite.)

$B$ zweiter Lendenwirbel vom Hund (von der Seite.)

c Zentrum, sp Dornfortsatz, d Diapophyse, z vordere, $z^{\prime}$ hintere Zygapophrse, $m$ Metapophyse, a Anapophyse, $t$ Fasette für das Tuberculum, ca Fasetten für das Capitulum. schräg nach vorne gerichtet, und die Zentren erheblich länger als jene der Brustwirbel.

Das Kreuzbein oder Sacrum dient zur Anheftung des Hüftbeines und fehlt als differenzierter Teil der Wirbelsäule nur bei den Walen und Sirenen, deren hintere Extremitäten durch Verkümmerung verloren gegangen sind. An der Bildung des Sacrums nehmen meist $3-4$, zuweilen auch 2 , oder 8-9 Wirbel teil. Ihre Zentren und oberen Bögen und öfters auch ihre Dornfortsätze sind mehr oder weniger rollständig miteinander verschmolzen, so daß dasSacrum einen unbeweglichen, von vorne nach hinten an Breite abnehmenden Abschnitt der Wirbelsäule darstellt.

Die Schwanzwirbel bieten nach Zahl und Form die größte Mannigfaltigkeit. Die vorderen besitzen in der Regel wohl ausgebildete obere Bögen, Dornfortsätze, Diapophysen, Zygapophysen und zuweilen $\bigvee$ förmige Hämapophysen (Chevron-bones). Weiter hinten tritt eine allmähliche Modifikation der Wirbel ein. Die Zentren verlängern sich, die oberen Bögen und sämtliche Fortsätze verkümmern oder verschwinden gänzlich, und das allein übrigbleibende Zentrum nimmt zylindrische oder mehrkantige Form an.

Rip pen verbinden sich nur mit den Brustwirbeln; die vorderen (wahren Rippen) heften sich durch besondere knorpelige oder unvollkommen verknöcherte Sternocostalstücke an das Brustbein an, die hinteren 》falschen " Rippen endigen frei in den Muskeln des Brustkorbes. Das Tuberculum lenkt sich in eine schwach vertiefte Fasette der Diapophyse ein, während das Capitulum am vorderen Teil des Wirbelkörpers oder an der Basis des oberen Bogens befestigt ist. Sehr häufig liegt die vertiefte Fasette für das Capitulum zwischen zwei Wirbeln, so daß ihre vordere Hälfte noch auf das hintere Ende des Zentrums des vorhergehenden Wirbels übergreift.

Das Brustbein (Sternum) besteht nicht aus einer einfachen Knochenscheibe wie bei Vögeln und Reptilien, sondern aus einer Reihe von abgeplatteten Knochenstücken, die in der ventralen Mittellinie in einer Längsreihe hintereinander liegen. 
Der Schädel (Fig. 476, 477) der Säugetiere unterscheidet sich ron dem der Fische, Amphibien, Reptilien und Vögel durch geringere Zahl der ihn zusammensetzenden Knochen, durch die unbewegliche Terbindung des Oberkiefers mit der Schädelkapsel, dureh die Unterdrückung des Kieferstieles und direkte Einlenkung des Unterkiefers am Schläfenbein. Der Mangel eines gesonderten Quadratbeines und die Anwesenheit von zwei Hinterhauptsgelenkköpfen sind weitere Merkmale der Säugetiere. Die Form des Schädels wird wesentlich von der Größe des Gehirns, von der Entwicklung der Kiefer, von dem Vorhandensein vorspringender Kämme, Knochenprotuberanzen, Stirnzapfen etc. bedingt und bietet bei den verschiedenen Ordnungen und Familien außerordentlich große Abweichungen.
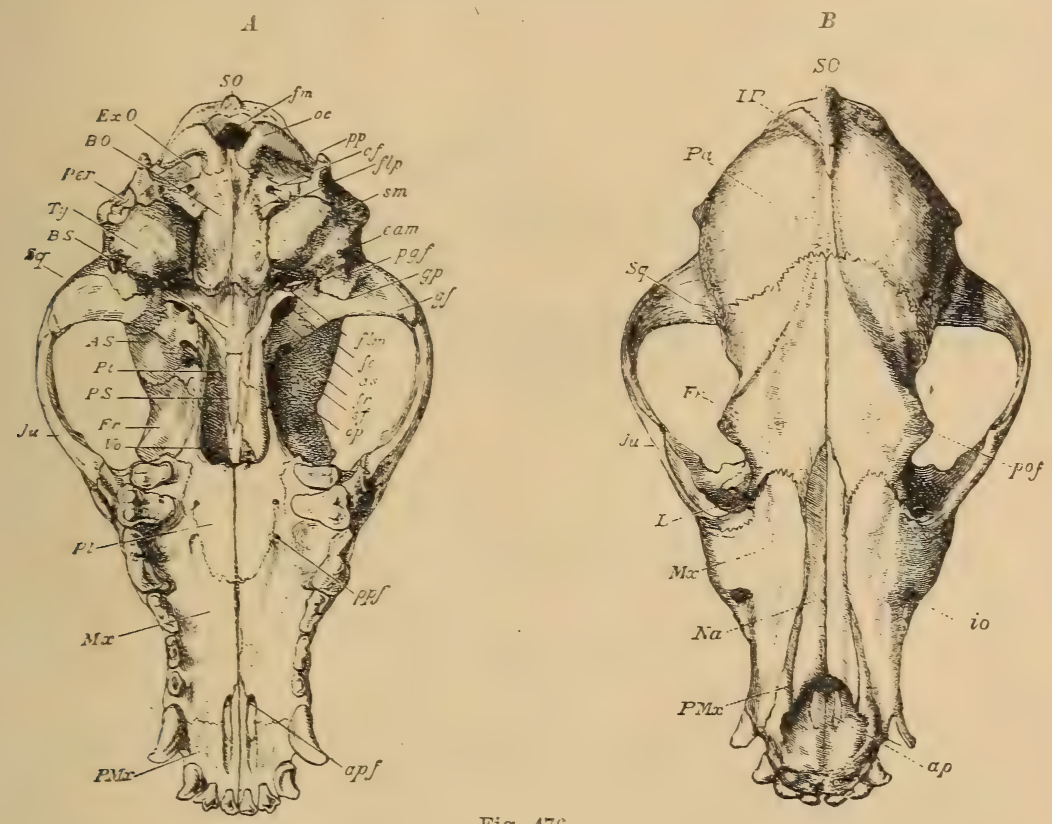

Fig. 476 .

Schädel vom Hund (Canis familiaris). A von unten, $B$ von oben. (Nach Flower.) SO oberes Hinterhauptsbein. $P a$ Scheitelbein, IP Interparietale, Sq Schläfenbein, $F r$ Stirnbein, $L$ Tränenbein, Ju Jochbein, $Y_{x}$ Oberkiefer, $P m x \mathrm{Z}$ wischenkiefer, $N a$ Nasenbein, BO Basioccipitale, Exo Exoccipitale, Per Perioticum, Ty Tympanicum, BS Basisphenoid, PS Präsphenoid, AS Alisphenoid, Pt Pterygoid, To Vomer, $P l$ Palatinum, pof Processus postorbitalis, io Foramen infraorbitale, oc Condylus occipitalis, $p p$ Processus paroccipitalis, gp Processus postglenoidalis, gf Gelenkgrube für den Unterkiefer, im Foramen magnum (Hinterhauptsloch), cf Foramen condyloideum, fip Foramen lacerum posterius, ecm meatus auditorius externus (äußerer Gehörgang), pgf Foramen postglenoidale, flm Foramen lacerum medium, fo Foramen ovale, as hintere Offnung des Alisphenoid-Kanals, fr Foramen rotundum und vordere Offnung des Alisphenoid-Kanals, si Keilbeinspalte oder Foramen lacerum anterius, op Foramen opticum, $p p f$ hintere Gaumenlöcher, $a p$ und apf vordere Gaumenlöcher.

Man unterscheidet am Kopf die eigentlichen Schädelknochen, welche die Hirnhöhle, und die Gesichtsknochen, welche die Nasenhöhle und Mundhöhle umschließen. Von den Schädelknochen, welche das Hinterhauptsloch (Foramen magnum $f m$ ) umgeben, sind die seitlichen Hinterhauptsbeine oder Exoccipitalia (Occipitalia lateralia Exo) mit gewölbten Gelenkköpfen (Condyli occipitales oc) versehen und oben durch das unpaare große Hinterhauptsbein (Supraoccipitale $S O$ ) verbunden. Am vorderen Teil der Exoccipitalia springt 
ein von den Condylen durch eine tiefe Depression getrennter Fortsat\% (Processus paroccipitalis p. p., Processus paramastoideus, Pr. jugularis) vor, der zur Anheftung von Muskeln dient und bei den Huftieren besonders stark entwickelt ist. Auf der Unterseite schiebt sich das untere Hinterhauptsbein oder Basioccipitale $(B O)$ zwischen die Exoccipitalia, erstreckt sich aber mehr nach vorne und bildet einen ansehnlichen Teil der Schädelbasis. Es ist von dem kleinen runden Foramen condyloideum $(c f)$, welches den Zungennerv durchläßt, durchbohrt. Auf das Basioccipitale folgt nach vorne in der Schädelbasis das hintere Keilbein oder Basisphenoid $(B S)$, auf dieses das vordere Keilbein oder Praesphenoid (PS) und vorne das kleine Pflugscharbein (Vomer Vo). Das Basisphenoid ist oben in der Mitte etwas ausgehöhlt, steigt aber am vorderen und hinteren Ende wieder etwas an und bildet den sog. Türkensattel (Sella turcica) zur Aufnahme der

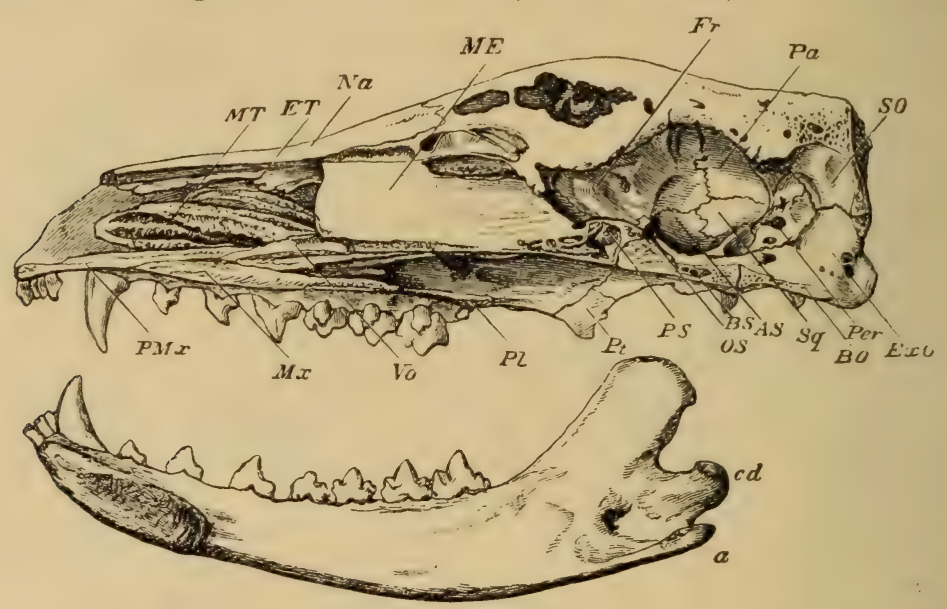

Fig. 477

Schädel vom Beutelwolf (Thylacinus cynocephalus) in sagittaler Richtung durchgeschnitten, nebst Unterkiefer. 1/2 nat. Gr. (Nach Flower.) SO Supraoccipitale, ExO Exoccipitale, BO Basioccipitale, Per Perioticum, BS Basisphenoid, PS Präsphenoid, AS Alisphenoid, OS Orbitosphenoid, Sq Squamosum, $P a$ Parietale, Fr Frontale, ME Mesethmoideum, Na Nasale, ET Ethmoturbinale, MT Maxilloturbinale, $P m x$ Prämaxilla, $I x$ Maxilla, Io Vomer, $P l$ Palatinum, $P t$ Pterygoideum, $c d$ UnterkieferCondylus, $a$ angulus.

Hypophyse (pituary body) des Gehirns. Die beiden Keilbeine ver schmelzen häufig frühzeitig zu einem sog. Wespenbein. Von dem Basisphenoid entspringt jederseits eine flügelartige, nach oben und außen gerichtete Knochenplatte, das Alisphenoid ( $A S$ ala major) und vom Praesphenoid ein entsprechender Knochen, das Orbitosphenoid ( $O S$ ala minor). Das Alisphenoid ist meist von drei Öffnungen durchbohrt, von denen das hintere (Foramen ovale fo) einem Nerven Austritt gewährt, während das mittlere (Canalis alisphenoideus as) die äußere Schlagader (Carotis) und das vordere (Foramen rotundum $f r$ ) den zweiten Ast des Trigeminus-Nervs durchläßt. $\mathrm{Z}$ wischen dem Orbito- und Alisphenoid befindet sich das Foramen lacerum anterius.(sf) als Durchgang für Nerven. Auch das Orbitosphenoid besitzt eine Öffnung (Foramen opticum $o p$ ) für den Sehnerv.

Die seitlichen Flügel der Keilbeine bilden die untere Seitenwand der Hirnhöhle und grenzen oben an die großen Scheitelbeine 
(Parietalia $P a$ ) und Stirnbeine (Frontalia Fr), welche das Schädeldach und den oberen Teil der Seitenwand des Schädels bilden. Zwischen die Scheitelbeine und die Hinterhauptsschuppe schaltet sich manchmal das kleine Interparietale $(I P)$ ein, das zuweilen getrennt bleibt, zuweilen mit den Scheitelbeinen (Huftiere), noch häufiger mit der Hinterhauptsschuppe (Carnivoren) verschmilzt. Die mehr oder weniger steil abfallende Hinterhauptsfläche (Occiput) wird in vielen Fällen durch einen vorspringenden Kamm (crista occipitalis) begrenzt, welcher zur Anheftung der Nackenmuskeln dient.

Die Scheitelbeine sind in der Mitte des Schädeldachs durch die zackige Pfeilnaht (Sagittal-Naht) verbunden; sie verschmelzen meist vollständig miteinander und bilden zuweilen über der Pfeilnaht einen vorspringenden Kamm..(crista sagittalis), welcher sich nach vorne meist in zwei divergierende Äste teilt. Sie sind mit der Hinterhauptsschuppe durch die Lambdanaht, mit den Stirnbeinen durch die quer zur Längsachse des Schädels verlaufende Kronennaht verbunden. Die Stirnbeine verwachsen zuweilen miteinander und tragen bei vielen Huftieren knöcherne Fortsätze (Stirnzapfen, Geweihe). In der Regel springt das Stirnbein hinter den Augenhöhlen vor und nimmt durch den Processus postorbitalis ( $p \circ f)$ an der hinteren Umgrenzung der Augenhöhlen teil. Bei vielen Huftieren, namentlich bei den gehörnten Wiederkäuern ist nicht nur das ganze Stirnbein, sondern häufig auch das Scheitelbein, ein Teil des Oberkiefers und namentlich auch das Praesphenoid mit Luftzellen erfüllt, und bei den Proboscidiern zeichnen sich fast alle Schädel- und Gesichtsknochen durch ungewöhnlich starke Entwicklung dieser Luftzellen aus. Zwischen dem Stirnbein, dem vorderen Keilbein (Praesphenoid) und Vomer schließt eine vertikale, mehr oder weniger ausgedehnte Knochenplatte, das Siebbein (Mesethmoideum ME), die Hirnhöhle nach vorne ab. Dasselbe besteht aus einer dem Vomer aufruhenden medianen, in der Längsrichtung ausgedehnten Lamelle (lamina perpendicularis oder crista galli) und zwei seitlichen querstehenden meist siebförmig durchlöcherten Platten (laminae cribrosae), durch welche die Riechnerven aus dem Gehirn in die Nasenhöhle eindringen. Die Lamina perpendicularis geht nach vorne in die fast immer knorpelig bleibende Nasenscheidewand über.

Zwischen dem Alisphenoid und Supraoccipitale liegt oben vom Scheitelbein und zuweilen auch vom hinteren Teil des Stirnbeins begrenzt das Schläfenbein (Schuppenbein, Squamosum $S q$ ), das mit seinem oberen flachen, schuppenartigen Teil (Schuppe) die seitliche Begrenzung der Hirnhöhle vervollständigen hilft, an seiner Basis aber einen sehr starken, dem Quadratojugale der Reptilien entsprechenden Fortsatz (Processus zygomaticus) nach außen sendet, welcher sich bald nach vorne biegt und auf seiner Unterseite eine konkave Gelenkfläche (Fossa glenoidalis $g f$ ) zur Aufnahme des Unterkiefercondylus besitzt. Der Hinterrand dieser Gelenkfläche ragt häufig als Fortsatz (Processus postglenoidalis $g p$ ) vor. Der Raum zwischen dem Schläfenbein und dem Exoccipitale wird von den Knochen der Gehörkapsel ausgefüllt. Aus einer gemeinsamen Knorpelmasse, in welcher die Ossifikation von drei Zentren beginnt, die dem Prooticum, Opisthoticum und Epioticum entsprechen, entsteht ein sehr fester Knochen, das 
Felsenbein oder Perioticum (Per), welches das Gehör-Labyrinth und das innere Ohr umschließt und öfters einen nach unten gerichteten Fortsatz (Processus mastoideus) besitzt. Das Pa ucken bein oder Tympanicum besteht in frühester Jugend aus einem einfachen knöchernen Ring und behält bei den Marsupialiern und manchen Insectivoren diese Beschaffenheit auch zeitlebens bei. In der Regel verlängert sich aber bei weiterer Entwicklung der äußere Rand des Ringes in horizontaler Richtung nach außen und bildet den zur Ohrmuschel führenden äußeren Gehörgang (meatus auditorius externus eam); die Unterseite wird durch eine Knochenplatte bedeckt, welche sich zuweilen zu einer blasig aufgetriebenen, hohlen oder mit zelligem Knochengewebe erfüllten Anschwellung (Bulla tympanica Ty) umgestaltet. Am vorderen Ende des Tympanicum ragt zuweilen ein griffelförmiger zugespitzter Fortsatz (Processus styloideus) nach unten vor. In dem Zwischenraum zwischen Perioticum und Tympanicum und zwar zwischen dem vom Trommelfell geschlossenen äußeren Gehörgang und der Fenestra ovalis liegen die drei Gehörknöchelchen Ambos (Incus), Hammer (Malleus) und Steigbügel (Stapes). Am vorderen und inneren Ende des Paukenbeins liegt clie Mündung der Eustachischen Röhre, welche Luft in die Gaumenhöhle führt, und hinten dringt die innere Kopfblutader durch das Foramen lacerum posterius ( $f(p)$ ein und tritt am vorderen Ende des Tympanicums durch das Foramen lacerum medium $(\mathrm{fm})$ wieder aus.

Die Physiognomie des Schädels wird sehr wesentlich durch die Entwicklung der Gesichtsknochen und namentlich des Ober-. kiefers (Maxilla $M x$ ) bedingt. Der untere Außenrand des Oberkiefers ist meist mit Zähnen besetzt, nach innen sendet er eine horizontale Platte, welche an der Zusammensetzung des harten Gaumens teilnimmt. Am Hinterrand ragt ein zuerst nach außen gerichteter Fortsatz (Processus zygomaticus) vor, welcher sich dann nach hinten verlängert und durch das Jochbein (Jugale, Malare ju) mit dem Processus zygomaticus des Schläfenbeins in Verbindung tritt. Die beiden genannten Fortsätze und das Jochbein setzen den Jochbogen zusammen, welcher die untere Begrenzung der Augenhöhlen und der Schläfengruben bildet. Am vorderen Rand der Augenhöhle zwischen Stirnbein, Oberkiefer und Ethmoideum liegt das vom Tränenkanal durchbohrte Tränenbein (Lacrimale La). Die paarig entwickelten $\mathrm{Z}_{\mathrm{w}}$ ischenkiefer (Praemaxillae $P m x$ ) bilden den vorderen und meist auch einen Teil des Seitenrandes der Schnauze. In der Regel enthalten sie an ihrem Alveolarrand Schneidezähne. Die N asenbeine (Nasalia $\mathrm{Na}$ ) fügen sich in einen einspringenden Winkel an Vorderrand der Stirnbeine ein und werden seitlich vom Oberkiefer und meist auch noch vom Zwischenkiefer begrenzt. Die Nasenhöhle selbst enthält mit Ausnahme der Wale und Sirenen eigentümliche, sehr dünne, stark eingerollte und durchlöcherte Knochenlamellen, die bei Tieren mit scharfem Geruch stark labyrinthisch entwickelt sind und eine Schleimhaut tragen, in welcher sich die Verzweigungen der Riechnerven ausbreiten. Diese Riechmuscheln (conchae interiores) gehören zum Siebbein und sind lediglich als Fortsätze desselben zu betrachten; sie erscheinen in mehrere Gruppen angeordnet und werden hinten von der Lamina perpendicularis des Mesethmoids in zwei 
Hälften zerlegt. Die Lamellen, welche den hinteren und oberen Raum der Nasenhöhle jederseits ausfüllen, werden Ethmoturbinalia $(E T)$ genannt, während die dem harten Gaumen aufliegenden und den vorderen und unteren Teil der Nasenhöhle einnehmenden Blätter als Maxilloturbinalia $(M T)$ bezeichnet werden.

Die Unterseite des Schädels wird im hinteren cranialen Teil vom Basioccipitale und den Keilbeinen gebildet. Vom Basisphenoid und Alisphenoid springt eine kurze vertikale Knochenplatte, das Flügel bein (Pterygoid $P t$ ); nach unten vor und begrenzt jederseits den hinteren Nasengang, dessen Basis durch die Haut des weichen Gaumens gebildet wird. Vorne schließt sich das Flügelbein an den vom Praesphenoid und Orbitosphenoid absteigenden Teil des Gaumenbeins (Palatinum Pl) an, - welcher sich nach vorne und oben verdickt und eine horizontal ausgebreitete Platte bildet und mit der horizontalen Platte des Oberkiefers und dem Zwischenkiefer den harten Gaumen, die Basis der Nasenhöhle bildet. Der Hinterrand des Gaumenbeins ist seitlich meist etwas ausgeschnitten, springt in der Mitte häufig in eine Spina nasalis posterior vor und zeigt den Ausgang der hinteren Nasenlöcher (Choanen) in die Mundhöhle an. Der harte Gaumen wird von mehreren kleinen Öffnungen zum Austritt von Blutgefäßen und Nerven durchbohrt.

Der Unterkiefer besteht aus zwei symmetrischen, nach hinten divergierenden Ästen, welche vorne in der Mitte mit einer rauhen Fläche (Symphyse) zusammenstoßen und entweder durch Bindegewebe aneinander befestigt sind oder im Alter fest miteinander verwachsen. Der Oberrand oder Alveolarrand ist meist gerade und mit Zähnen besetzt, der Unterrand etwas verdickt und konvex, in der Symphysenregion ansteigend; das hintere Ende des Unterrandes bildet den Winkel (Angulus $a$ ), der öfters in einen vorspringenden Fortsatz ausgezogen oder nach innen gekrümmt ist. Der obere Rand steigt hinter dem letzten Backenzahn in der Regel zu einem hohen, seitlich zusammengedrückten Kronfortsatz (Processus coronoideus) an, welcher dem Temporalmuskel zur Anheftung dient. An der mehr oder weniger tief ausgehöhlten oder mit erhabenen Leisten versehenen Außenfläche des Kronfortsatzes befestigt sich der starke Massetermuskel. Der Hinterrand des aufsteigenden Astes endigt oben über dem Winkel in einem verdickten und gewölbten Gelenkk op f (Con. dylus $c d$ ), welcher sich in die Gelenkgrube des Schläfenbeins einfügt und bald quer verlängert, bald rundlich, bald schräg von oben nach unten gerichtet ist. Der Unterkiefer wird der Länge nach von einem ziemlich weiten Kanal durchzogen (Alveolarkanal), in welchem ein Blutgefäß und der Unterkiefernerv verlaufen, die zahlreiche Seitenäste in die Zähne aussenden. Auf der Innenseite jedes Astes verläuft zuweilen eine seichte Furche (Sulcus mylohyoideus), die bei gewissen Beuteltieren besonders deutlich entwickelt ist.

Die Hirnhöhle besitzt bei den Säugetieren meist eine viel größere Ausdehnung als bei den übrigen Wirbeltierklassen. Im allgemeinen zeigt sich bei den verschiedenen Ordnungen 'eine beträchtliche Abstufung in Größe und Ausbildung des Gehirns, so daß dasselbe von $\mathrm{O} w$ en als Basis der Systematik verwendet wurde. Sehr bemerkenswert ist die von Marsh zuerst beobachtete-Tatsache, daß der 
Gehirnumfang bei den Säugetieren der Eocänzeit durchwegs geringer ist als jener bei verwandten Formen aus dem jüngeren Tertiär oder aus der Jetztzeit. Ja bei den riesigen eocänen Amblypoden ist die Hirnhöhle so winzig, daß man deren Ausguß durch den Medullarkanal der Wirbelsäule ziehen kann.

Entwicklung und Umgestaltung des Schädels. Wie bei den Reptilien und Vögeln ist die Schädelbasis knorpelig präformiert, während sich die Knochen der Schädeldecke in einer häutig fibrösen Grundlage entwickeln. Die verschiedenen Knochen sind anfänglich alle getrennt und entstehen von besonderen Ossifikationszentren, nach und nach stoßen sie aneinander, werden durch Nähte verbunden oder verschmelzen vollständig. Je nach der Art, wie sich diese Knochen im Verlauf der Entwicklung gestalten, hängt die Ausbildung und äußere Erscheinung des Kopfes ab und auf Grund ontogenetischer oder phylogenetischer Erfahrung lassen sich bestimmte Zustände als ursprünglich, andere als mehr oder weniger weitgehende Umgestaltungen bezeichnen.

$$
\text { Primitiver Zustand. }
$$

Schädelknochen durch Nähte vereinigt.

Hirnkapsel klein, schmal.

Schädel niedrig, Profil fast gerade.

Schnauze vor der Hirnhöhle verlängert.

Nasenbeine lang; Nasenlöcher nach vorn gerichtet.

Oberkiefer niedrig.

Jochbogen geschlossen.

Augenhöhle hinten offen, in die Schläfengrube übergehend.

Stirnbein und Praesphenoid dicht oder mit schwach entwickeiten Luftzellen.

Knochen der Schädeldecke glatt.

Tympanicum ringförmig, unten offen, frei.

Gelenkgrube für den Unterkiefer seicht, hinten mit Processus postglenoidalis.

Unterkieferäste in der Symphyse durch Ligament verbunden.
Fortgeschrittener spezialisierter $\mathrm{Zustand}$.

Schädelknochen verschmolzen.

Hirnkapsel groß, breit, gewölbt.

Stirnregion gewölbt oder steil ansteigend.

Gesichtsteilkurz, steil abfallend oder Vorderpartie der Kiefer gestreckt.

Nasenbeine kurz oder verkümmert; Nasenlöcher weit zurückreichend oder nach oben gerichtet.

Oberkiefer hoch.

Jochbogen unterbrochen oder rudimentär.

Augenhöhle hinten geschlossen.

Stirnbein, zuweilen auch benachbarte Kopfknochen und Schädelbasis mit Luftzellen erfüllt.

Scheitel-, Stirn- und Hinterhauptsbeine mit vorragenden Kämmen, Protuberanzen, Stirnzapfen oder Geweihen.

Tympanicum unten geschlossen oder aufgeblasen, mit äußerem Gehörgang; mit dem Perioticum verwachsen.

Gelenkgrube eine stark vertiefte Quer- oder Längsrinne bildend; Processus postglenoidalis fehlt.

Unterkieferäste in der Symphyse verschmolzen.

Der Schultergürtel hat im Vergleich mit den niedrigen Vertebratenklassen eine bedeutende Reduktion erlitten und besteht häufig nur aus dem Schulterblatt, zu dem bei denjenigen Formen, welche ihre Vorderextremitäten mehr zum Greifen als zur Fortbewegung benutzen, noch ein Schlüsselbein (Clavicula) kommt. Ein selbständig entwickeltes Coracoid nebst einem Präcoracoid findet sich nur bei Monotremen, bei allen übrigen ist dasselbe mit der Scapula verschmolzen und stark reduziert. 
Das Schulterblatt (Scapula) (Fig. 478) ist eine ziemlich große, aus Knorpeln hervorgehende Knochenplatte von oval-dreieckiger Form, welche auf der Außenseite durch eine vorspringende Leiste (Spina oder Crista scapulae) in einen vorderen und hinteren Abschnitt geteilt wird. Das untere Ende dieser Leiste ragt in der Regel als ein etwas verlängerter und gekrümmter Fortsatz (Acromion) vor. Der verschmälerte Unterrand ist zu einer vertieften Gelenkfläche (Fossa glenoidalis g) zur Aufnahme des Oberarms verbreitert und endigt vorne in einem kurzen Caracoidfortsatz $(c)$, der aus einem besonderen Ossifikationszentrum hervorgeht, in frühester Jugend auch noch durch Sutur mit der Scapula vereinigt ist, später aber vollständig damit verschmilzt.

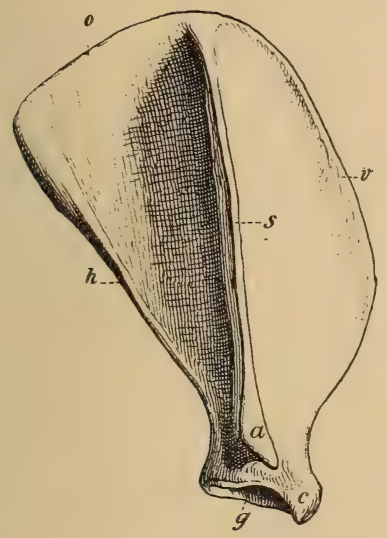

Fig. 478.

Rechtes Schulterblatt vom Hund. s Kamm (spina scapulae), a Acromion, c Coracoidfortsatz, $g$ Gelenkfläche, $v$ vorderer (Coracoid) Rand, $h$ hinterer (Glenoidal-) Rand, o oberer Rand.

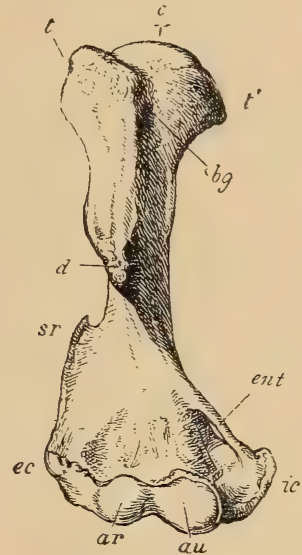

Fig. 479

Rechter Oberarmknochen (Humerus) des Wombat (Phascolomys wombatus) von vorne. $1 / 2$ nat. Gr. (Nach Flower.) $c$ oberer Gelenkkopi (caput), $t$ tuberculum majus, $t^{\prime}$ tuberculum minus, $b g$ fossa bicipitalis, $d$ Deltoidrauhigkeit, $s r$ crista supinatoria, ent Foramen entepicondyloideum, ec äußerer, $i c$ innerer Gelenkknorren, ar radiale, au ulnare Gelenkrolle.

Das Schlüsselbein (Clavicula) ist ein paariger, dünner, zylindrischer, etwas gebogener Knochen, welcher sich am Acromion des Schulterblattes und am vordersten Ende des Brustbeins mittels Ligaments befestigt. Es fehlt den Cetaceen, Sirenen, Ungulaten und den meisten Carnivoren, wo es übrigens häufig noch als Rudiment in den Muskeln liegt.

Der kräftige, gerade oder etwas gebogene Oberarm (Humerus) (Fig. 479) hat am oberen (proximalen) Ende einen ziemlich dicken, gerundeten Gelenkkopf $(c)$ und zwei vorstehende, zur Anheftung von Muskeln bestimmte Höcker (tuberculum majus und tub. minus), welche durch die Fossa bicipitalis $(b g)$ getrennt werden. Von dem außen gelegenen großen Höcker zieht sich in der Regel ein etwas vorstehender, breiter rauher Kamm zur Anheftung des Deltoidmuskels eine Strecke weit am Schaft des Humerus herab (crista deltoidea $d$ ). Das untere oder distale Ende ist quer verbreitert und mit einer breiten, halbzylindrischen Gelenkrolle (Trochlea) versehen, die meist durch eine mediane Vertiefung oder durch eine erhabene Leiste (crista intertrochlearis) in eine radiale (ar) und eine ulnare (au) Gelenk- 
fläche geteilt wird. Neben der Gelenkrolle ragt außen ein knorriger Vorsprung, der äußere Gelenkkopf (Ectocondylus ec) und auf der inneren Seite der interne Condylus (ic) vor. Über dem letzteren ist der Humerus bei den primitiveren Formen der Säugetiere von einem Foramen entepicondyloideum (ent) zum Durchtritt eines Nervs und Blutgefäßes durchbohrt. Über der Gelenkrolle befindet sich auf der Hinterseite eine mehr oder weniger tiefe Grube zur Aufnahme des Ellenbogenfortsatzes der Ulna (Fossa olecrani), die zuweilen den Humerus durchbohrt. In der Jugend sind die beiden Gelenkextremitäten durch Epiphysen vom eigentlichen Schaft (Diaphyse) getrennt.

Der Vorderarm (Fig. 480) besteht aus zwei Knochen, der Speiche (Radius) und der Elle (Ulna, Cubitus), wovon der Radius mit der äußeren und vorderen, die Ulna mit der inneren und hinteren Gelenkrolle des Humerus artikuliert. Bei denjenigen Säugetieren, welche die Vorderextremität mehr zum Greifen als zum Gehen

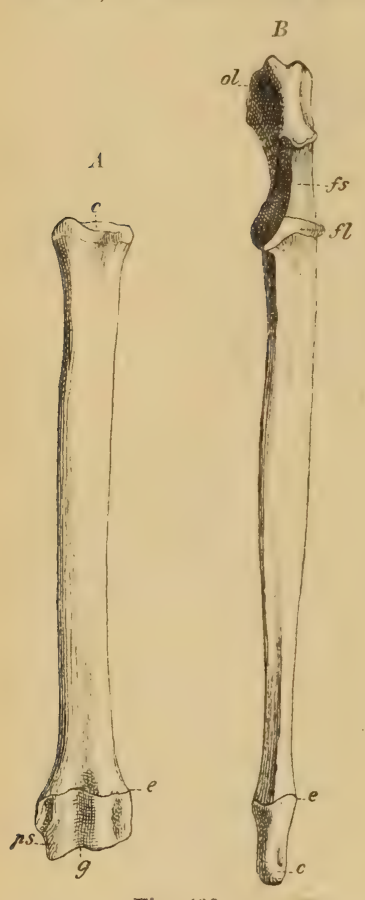

Fig. 480 .

A Linker Radius vom Hund von vorne. $c$ obere, $g$ untere Gelenkfläche, $p s$ processus styloideus, $e$ Epiphyse.

$B$ Linke Ulna vom Hund von vorne. ol Olecranon, fs Fossa sigmoidea, $f$ Fossa lunaris,

c Capitulum, e Epiphyse. benützen, sind beide Knochen wohl ausgebildet, jedoch in der Art übereinander gekreuzt, daß am distalen Ende die Ulna außen, der Radius innen liegt, bei den übrigen steht die Ulna hinter dem Radius. Bei den vorgeschritteneren Huftieren verkümmert der untere Abschnitt der Ulna und verwächst vollständig mit dem Radius.
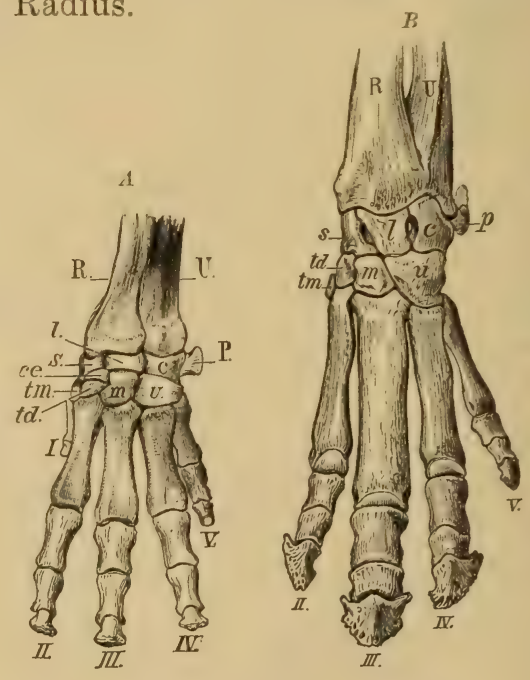

Fig. 481 .

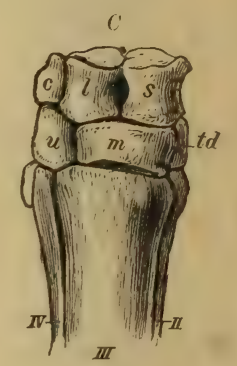

III

A linker Vorderfuß von Procavia (Dendrohyrax) arborea. $B$ Tapirus americanus. $C$ rechter Vorderfu $B$ vom Pferd. $R$ Radius, $U$ Ulna, $s$ Scaphoideum, $l$ lunare, $c$ Cuneiforme, $p$ Pisiforme, $c e$ Centrale, $t m$ Trapezium, $t d$ Trapezoid, $m$ Magnum, $u$ Unciforme, $I-V$ erster bis fünfter Finger.

Das obere Ende des Radius hat eine seichte, quer ovale Gelenkgrube, deren konvexer Innenrand sich dicht an die Ulna anlegt. Der Schaft ist etwas abgeplattet, das untere Ende quer verbreitert und die ausgehöhlte Gelenkfläche innen durch einen kurzen zugeschärften Vorsprung (Processus styloideus ps) begrenzt. Am oberen 
Ende der Ulna ragt ein starker, vierseitiger, distal abgestutzter und verdickter Knorren (Ellenbogenfortsatz, Olecranon ol) mehr oder weniger weit vor, dessen Vorderseite durch eine halbmondförmige Gelenkfläche (Fossa lunaris), an welche sich der Radius anlegt, senkrecht abfällt. Das untere distale Ende der Ulna ist in den meisten Fällen schmäler als der Radius, hat eine konvexe Gelenkfläche und meist auch einen Processus styloideus auf der Außenseite.

Der Carpus oder die Handwurzel (Fig. 481) besteht bei allen Säugetieren aus zwei Reihen kleiner platter Knöchelchen. Bei den primitiveren Formen schaltet sich, wie bei den Reptilien, ein kleines Os centrale zwischen die beiden Reihen ein. Von den drei Knöchelchen der ersten oder proximalen Reihe entspricht das innere (Scaphoideum) dem Radiale, das äußere (Cuneiforme) dem Ulnare, das mittlere (Lunare) dem Intermedium der Reptilien; ein viertes äußeres und etwas nach hinten gerichtetes Knöchelchen (das Erbsenbein oder Os pisiforme) wird nicht zu den eigentlichen Carpalknöchelchen gezählt, sondern bald als Rudiment eines sechsten Fingers, bald als ein großes Sesambein betrachtet. Die Knöchelchen der distalen Reihe werden entweder Carpalia I bis V, oder Trapezium, Trapezoid, Magnum und Unciforme (Fig. 481) genannt. Im primitiven Carpus (Fig. $481 \mathrm{~A}$ ) bleiben sämtliche Knochen getrennt und sind eher etwas alternierend als serial angeordnet. Wird von der Hand nicht nur Beweglichkeit, sondern auch Stärke und Tragfähigkeit verlangt, so erleidet der Carpus sehr verschiedenartige, dem jeweiligen Bedürfnis entsprechende Umbildungen. Die obere Reihe gewinnt zuweilen dadurch eine größere Festigkeit, daß Scaphoideum und Lunare miteinander verschmelzen und ebenso findet in der zweiten Reihe eine Verschmelzung von zwei oder mehr benachbarten Knöchelchen statt. In anderer Weise erfolgt eine Verfestigung des Carpus dadurch, daß sich die Carpalia der zweiten Reihe derart von außen nach innen verschieben, daß eine alternierende und verschränkte Anordnung zustande kommt. Denselben Erfolg hat auch eine ungewöhnliche Breitenausdehnung eines Knöchelchens, z. B. des Magnum (Fig. 481 C). Die seitliche Verschiebung oder ungleiche Ausdehnung der distalen Carpalia führt häufig zur gänzlichen Verdrängung des Trapezium.

Auf den Carpus folgen die Metacarpalia oder Mittelfußknochen, und zwar artikulieren am Unciforme stets die zwei äußeren Metacarpalia (IV und V), während die übrigen Mittelhandknochen je einem Carpale als Stütze dienen. Ursprünglich lagen die proximalen, häufig schwach ausgehöhlten Gelenkenden der Metacarpalia in gleicher Ebene; meistens greifen dieselben aber ziemlich weit in den Carpus herein und verstärken dadurch das Knochengefüge. Der distale gewölbte Gelenkkopf der Metacarpalia wird häufig durch einen vorspringenden, zugeschärften Kamm (Leitkiel) in zwei Hälften geteilt.

Von den fünf Fingern heißt der erste oder innere Daumen (Pollex). Mit Ausnahme der Cetaceen hat kein Säugetier mehr als drei Phalangen an jedem Finger, doch verkümmern am Daumen und kleinen Finger in der Regel ein oder zwei Glieder und bei den Edentaten tritt zuweilen eine Verschmelzung von zwei Phalangen ein. Bei den Fledermäusen verlängern sich sowohl die Metacarpalia 
als die Phalangen in ungewöhnlicher Weise zur Befestigung der Flughaut.

Die Endphalangen haben sehr verschiedene Form und werden ringsum oder vorne von hornigen Hufen, Krallen oder Nägeln umschlossen. An den Gelenkverbindungen von Metacarpus und den ersten Phalangen liegen auf der Hinterseite der Hand sehr häufig paarig entwickelte, kleine, halbmondförmige Sesambeine, die im Bindegewebe entstehen.

Das Becken (pelvis Fig. 482) wird jederseits aus drei in der seitlich gelegenen Gelenkpfanne für den Oberschenkel zusammenstoßenden, meist sehr frühzeitig zu einem sog. Os innominatum verschmolzenen Knochen, dem Hüftbein oder Darmbein (Ilium $I l$ ), dem Schambein (Pubis $\mathrm{Pb}$ ) und dem Sitzbein (Ischium Is) gebildet. In der Mitte der Bauchseite stoßen die

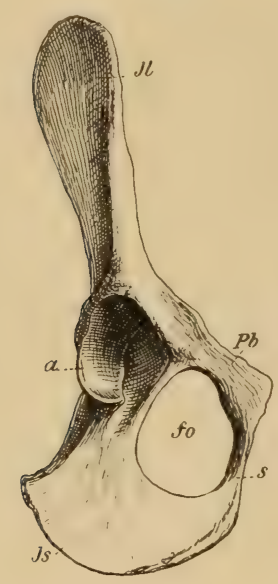

Fig. 482 .

Rechte Beckenhälfte vom Hund von vorn gesehen. $I l$ Ilium, $\mathrm{Pb}$ Pubis, Is Ischium, a Pfanne, fo Foramen obturatorium, s Symphyse.

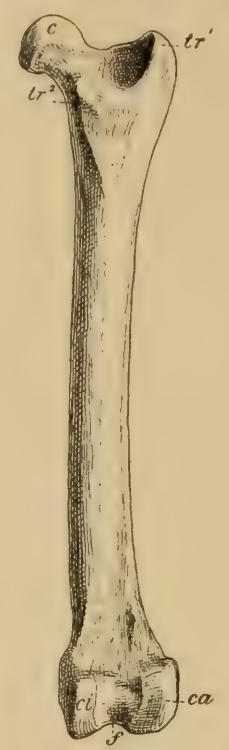

Fig. 483.

Rechtes Femur vom Hund von hinten. c Condylus, $\operatorname{tr}^{1}$ großer, $t r^{2}$ kleiner,

ci innerer Gelenkkopf, (Entocondylus),

ca äußerer Gelenkkopf, fFossaintercondyloidea.
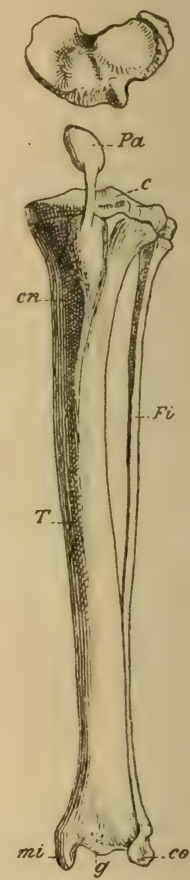

Fig. 484.

Linke Tibia $(T)$ und Fibula ( $F i$ nebst Patella $(P a)$ vom Hund von vorne. $c$ oberes Gelenkende, $g$ unteres Gelenkende der Tibia, en Procnemialkamm, $m i$ malleus internus, co unteres Gelenkende der Fibula.

beiden Beckenhälften in einer Symphyse zusammen und umschließen jederseits eine große, mit Muskeln und Bindegewebe erfüllte Öffnung (Foramen obturatorium $f o$ ).

Der Oberschenkelknochen (Femur Fig. 483) ist meist lang zylindrisch. Am oberen Ende ragt ein halbkugeliger, durch eine Einschnürung (Hals) vom eigentlichen Schaft getrennter Gelenkkopf nach innen und vorne vor. Dem Kopf gegenüber befindet sich auf der hinteren und äußeren Seite ein kräftiger Muskelansatz, der große Trochanter (Trochanter major $t r^{1}$ ), begrenzt von einer mehr oder weniger vertieften Grube (Fossa digitalis). Ein kleiner, konischer Höcker, der kleine Trochanter (Trochanter minor $t r^{2}$ ) liegt unmittel- 
bar unter dem Kopf auf der vorderen Innenseite. Ein dritter Trochanter (Trochanter tertius $t r^{3}$ ) ragt am Hinterrand in einiger Entfernung unter dem großen Trochanter vor, ist jedoch nur bei Huftieren, Nagern, Insectivoren und Edentaten deutlich entwickelt. Das distale Ende des Femur wird durch die stark verdickte, vorne schmale und jederseits von einem vorragenden Kamm begrenzte Gelenkrolle gebildet. Dieselbe wird außen und innen durch je einen großen knorrigen gerundeten Gelenkkopf (Ectocondylus und Entocondylus) begrenzt, zwischen denen auf der Hinterseite eine ziemlich tiefe und breite Grube (Fossa intercondyloidea $f$ ) liegt.
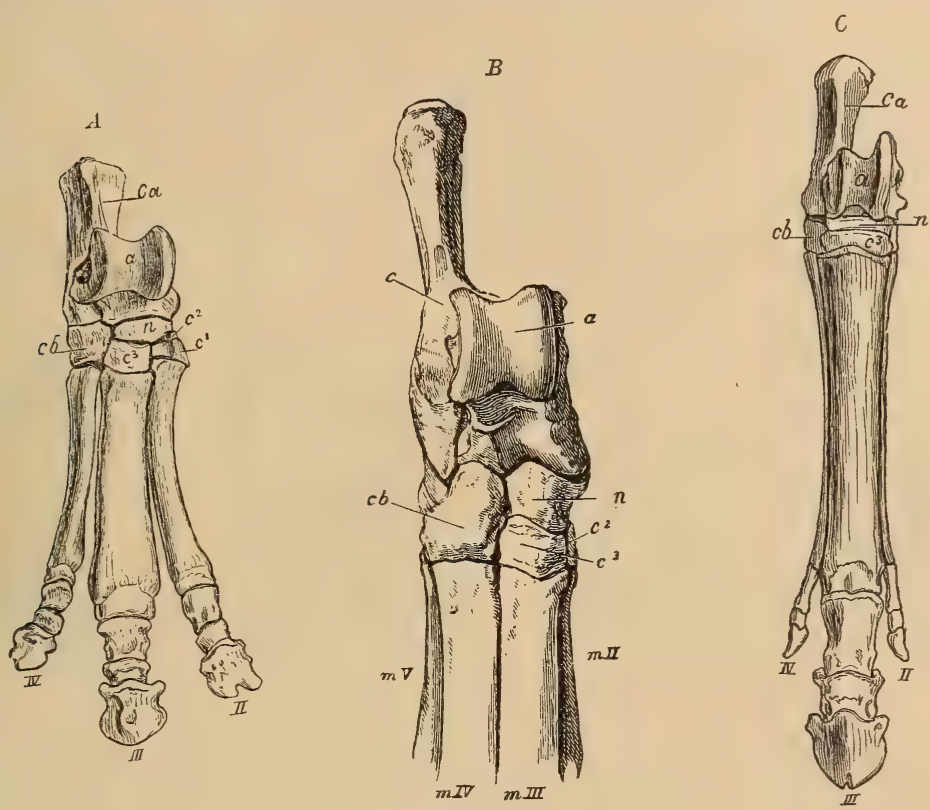

Fig. 485.

Rechter Hinterfuß $A$ von Palaeotherium, $B$ vom Schwein, $C$ von Hipparion. ca und c Calcaneum, $a$ Astragalus, $n$ Naviculare, $c b$ Cuboideum, $c^{3}, c^{2}, c^{1}$ Cuneiforme tertium, secundum, primum, $m$ Metatarsalia, $I I-V \mathrm{zweite}$ bis fünfte Zehe.

Das verdickte obere Ende der Tibia (Fig. 484) bildet eine dreieckige, wenig vertiefte Gelenkfläche $(c)$, die durch eine mediane Erhöhung in zwei Hälften zerlegt wird; die Hinterseite des Schaftes ist abgeplattet und jederseits kantig begrenzt; die Vorderseite bildet unter dem oberen Gelenkende einen mehr oder weniger zugeschärften Kamm (Procnemialcrista cn), und das distale Ende eine quer verbreiterte Gelenkfläche $(g)$, die häufig durch eine gerundete Mittelerhebung halbiert wird; auf der Innenseite wird dieselbe durch einen Vorsprung (Malleolus internus mi) begrenzt. Das Wadenbein (Fibula Fi) ist stets ein dünner Knochen, dessen unteres Ende (co) häufig als ein dem Malleolus internus entsprechender Fortsatz vorragt und sich auf die vordere Außenfläche des Astragalus oder auf das Calcaneum stützt. Bei den vorgeschritteneren Huftieren verkümmert die Fibula entweder vollständig oder bis auf ein kleines distales, seltener proximales Rudiment. 
Zwischen Femur und Tibia liegt auf der Vorderseite die kleine, durch Bänder mit der Tibia verbundene Kniescheibe (Patella $\mathrm{Pa}$ ).

Die Fußwurzel oder der Tarsus (Fig. 485) besteht wie die Handwurzel aus zwei Knöchelchenreihen, zwischen welche sich jedoch stets ein wohl entwickeltes Zwischenknöchelchen (Naviculare oder Centrale) einschiebt. Die proximale Reihe besteht lediglich aus Sprungbein (Astragalus) und Fersenbein (Calcaneum). Der Astragalus (Fig. 486) liegt auf der inneren, das Calcaneum auf der äußeren Seite; ersterer bildet mit dem distalen Ende der Tibia das Sprunggelenk; seine nach vorne und oben gerichtete tibiale Gelenkfläche ist bei den plumpsten Huftieren (Amblypoda, Proloscidea) fast eben, in der Regel jedoch als ein vorspringender halbzylindrischer Gelenkkopf ausgebildet, der sich durch eine mehr oder weniger tiefe mediane Aushöhlung in eine Gelenkrolle (Trochlea) umwandeln kann. Der distale Teil des Astragalus verlängert sich häufig zu einem Hals und wird entweder durch eine flache oder
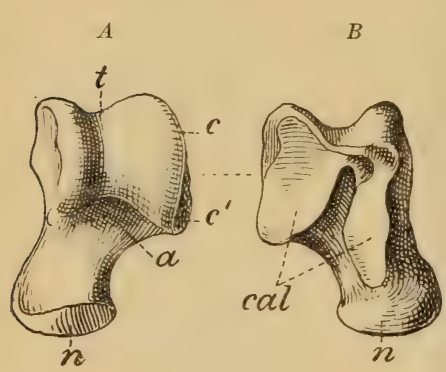

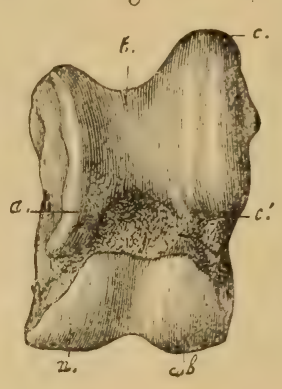

Fig. 486.
J)

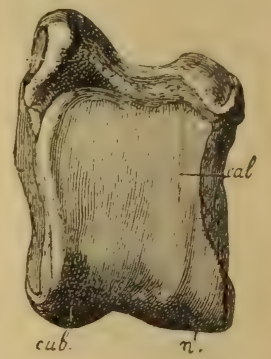

Linker Astragalus vom Hund. $A$ von vorne und oben, $B$ von hinten und unten.

C. D. Linker Astragalus eines großen Wiederkäuers (Helladotherium). C von vorne und oben, $D$ von hinten und unten. $1 / 3$ nat. Gr. (Nach Gaudry.) $t$ tibiale Gelenkrolle (Trochlea), $c$, $c^{\prime}$ der mit dem Calcaneum zusammenstoßende Seitenrand, $a$ Grube zur Aufnahme des Unterrandes der Tibia, $n$ Fasette für das Naviculare, cub Fasette für Cuboideum, cal Fasetten für Calcaneum.

schwach gewölbte Gelenkfläche für das Naviculare abgestutzt oder besitzt am distalen Ende eine breite, gewölbte, nach hinten verlängerte Gelenkrolle, die sich auf Naviculare, Cuboideum und Calcaneum stützt (Fig. $487 \mathrm{~B}$ ). 'Auf der Hinterseite hat der Astragalus ein Dis zwei Fasetten für das Calcaneum und eine für das Cuboideum. Bei altertümlichen Formen befindet sich oberhalb der proximalen Fasette ein Foramen.

Das Calcan eum (Fersenbein, Fig. 487) ist ein länglicher, kantiger Knochen, dessen hinterer Teil zu einem abgestutzten Stiel (Tuber calcis ic) ausgezogen ist, der bei den Sohlengängern auf dem Poden aufruht und die Ferse bildet, bei den Zehengängern und Huftieren aber schräg nach oben und hinten gerichtet ist. Am distalen Ende stößt das Calcaneum mit dem Cuboideum (cub) zusammen, während es mit der vorderen und oberen ausgehöhlten Seite den Astragalus stützt. Ein nach innen vorspringender Fortsatz (sustentaculum) enthält die innere oder sustentaculare Fasette (as) für den Astragalus, während am entgegengesetzten äußeren Teil sich die häufig 
durch einen Querkamm geteilte ektale oder peroneale Fasette $\left(p^{\prime}\right)$ befindet. Zuweilen ist noch eine Gelenkfläche $(p)$ für die Fibula vorhanden.

Das Cuboideum (Würfelbein) ist ein würfelförmiger oder unregelmäßig vierseitiger Knochen, dessen Höhe die Breite meist übertrifft. Das Naviculare breitet sich über die drei nebeneinander liegenden $\mathrm{Cuneiformia}$ aus.

Die Metatarsalia $(M t)$ stimmen im wesentlichen mit den Metacarpalia überein, doch sind ihre proximalen Gelenkflächen fast immer abgeplattet, dicht an die distalen Fasetten der Tarsalia angepreßt und meist in einer Ebene gelegen. Am Cuboideum artikulieren die zwei äußeren Metatarsalia (Mt IV und $V$ ), alle übrigen Tarsalia werden nur durch je einen

Mittelfußknochen gestützt. Durch Verstärkung und Ausdehnung von Mt III und Mt IV treten am Hinterfuß dieselben Reduktionen ein wie am Vor. derfuß, und zwar fällt derselben zuerst die große oder erste Zehe (Hallux), darauf die fünfte, dann die zweite und im äußersten Falle (beim Pferd) auch die vierte Zehe zum Opfer. Bei den Wiederkäuern verschmelzen $M t I I I$ und $I V$ wie am Vorderfuß zu einem Canon.

Die Phalangen und Sesambeine der Hinterextre-

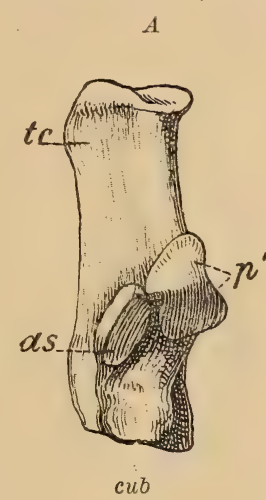

Fig. 487.

Linkes Calcaneum $A$ vom Hund, $B$ von Macrauchenia. tc tuber calcis, su Sustenta culum, as sustentaculare Fasette für den Astragalus, $p^{\prime}$ ectale Fasette für den Astragalus, cub distale Fasette für das Cuboideum, $p$ Fasette für die Fibula.

mitäten unterscheiden sich in Zahl, Form und Größe in der Regel nicht wesentlich von denen der Vorderfüße; die Endglieder sind auch hier von Krallen, Hufen oder Nägeln umgeben.

Im allgemeinen steht die Ausbildung der. Extremitäten im engsten Zusammenhang mit den Verrichtungen derselben, also auch mit der Lebensweise des Tieres. Da nun die Extremitäten in vielen Fällen ausschließlich zum Gehen, in anderen zum Gehen und Greifen, zum Klettern und Graben, zum Fliegen oder Schwimmen dienen, so entspricht jeder dieser Funktionen eine besondere Einrichtung, die unter Umständen in ähnlicher Weise bei Tieren von sehr verschiedener Organisation wiederkehrt. Es setzt diese Tatsache eine gewisse Plastizität des ganzen Organismus und damit auch des Knochengerüstes voraus, welche sich häufig sehr deutlich in den verschiedenaltrigen Vertretern einer bestimmten Gruppe in Gestalt phylogenetischer Durchgangsstadien kund gibt. Das Studium der Veränderungen im Säugetierskelett während der phyletischen Entwicklung, die sog. »Kinetogenese", ist in neuester Zeit vorzüglich durch Cope und Osborn gefördert und im Sinne der Lamarckschen Anschauungen ausgebaut worden. ${ }^{1}$ )

1) Cope E. D., The Origin of the foot structures of the Ungulata. Journ. Acad. nat. hist. Philad. 1874. - On the effect of impact and strains on the feet of Mammalia. Amer. Naturalist 1881 p. 542. - The mechanical causes of the development 
Neben dem eigentlichen Knochengerüst hat bei den Säugetieren das $\mathrm{Gebi}^{1}$ ) das größte praktische Interesse, indem die Zähne nicht nur eine außerordentlich mannigfaltige Differenzierung aufweisen, sondern auch in engster Beziehung zur Ernährung und zum ganzen Skelettbau stehen. Sie wurden darum von jeher mit Vorliebe für die Systematik verwertet und spielen insbesondere in der Paläontologie wegen ihrer Widerstandsfähigkeit gegen die zerstörenden Einflüsse der Fossilisation eine wichtige Rolle.

Die meisten Säugetierzähne bestehen aus Schmelz, Dentin und Zement und enthalten eine mit zelligem Gewebe erfüllte und mit Blutgefäßen und Nerven versehene Pulpa (Fig. 488). Vasodentin kommt nur bei den Edentaten vor. Das Zement (Crusta petrosa) bedeckt in der Regel als dünner Überzug die Wurzel; nicht selten
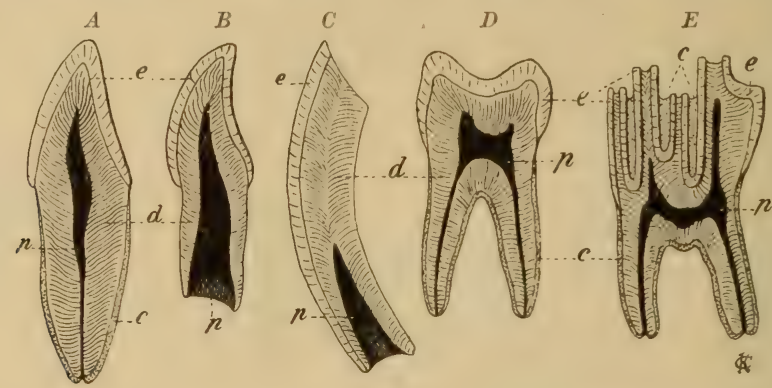

Fig. 488.

Vertikale Durchschnitte verschiedener Zähne. $e$ Schmelz, $d$ Dentin, $c$ Zement, $p$ Pulpa. $A$ einwurzeliger Schneidezahn, ausgewachsen, die Pulpa in einen feinen Kanal ausgezogen. $B$ junger, in der Entwicklung begriffener Schneidezahn mit weit offener Pulpa. $C$ schneidezahn eines Nagers nur an der Vorderseite mit Schmelz bedeckt, mit persistenter Pulpa. $D$ zweiwurzeliger Backzahn des Menschen mit niedriger, breiter Krone. E Backzahn eines Ochsen mit hoher Krone und tiefen Schmelzfalten, deren Zwischenräume mit Zement ausgefüllt sind. Der Schmelz ist an der Oberfläche abgekaut und dadurch die Dentinsubstanz an der Usurfläche bloßgelegt.

aber auch als eine mehr oder weniger dicke weiße Kruste die Krone, oder es füllt Vertiefungen und Zwischenräume derselben aus. Die Pulpa bildet an jungen Zähnen in Krone und Wurzel einen großen Hohlraum: bei mehrwurzeligen Zähnen verzweigt sie sich und sendet in jede Wurzel eine Verlängerung. An jungen in der Entwicklung

of the hard parts of the Mammalia. Journ. of Morph. 1889. - Primary factors of organic evolution 1896. - Osborn H. F., The evolution of the Ungulate foot. Trans. Amer. Phil. Soc. 1889. - Schlosser M., Úber die Modifikationen des Extremitätenskelettes bei den einzelnen Säugetierstämmen. Biolog. Zentralblatt 1890. - Scott W. B., On some of the factores of the evolution of Mammalia. Journ. Morph. 1891, p. 739.

1) Ameghino $\mathrm{Fl}$., Sur l'évolution des dents des mammifères. Bol. Acad. Nacion. Cienc. Cordoba. 1896. - Recherches de morphologie phylogénétique sur les molaires supérieures des Ongulés. Anal. Mus. Nac. Buenos Aires 1904. - Cope E. D., The mechanical causes of the development of the hard parts of the Mammalia. Journ. Morph. 1889. - Flower W. H., Remarks of the homologies and notation of the teeth of the Mammalia. Journ. Anat. Physiol. 1869 p. 262. - Kowalewsky W., Anthracotherium. Palaeont. 1874. XXII. - Leche W., Zur Entwicklungsgeschichte des Zahnsystems der Säugetiere. Bibliotheca Zoologica. Heft 17, 1895. - Osborn H. F., Evolution of Mammalian molar teeth to and from the triangular type. New York 1907. - Owen R., Odontography. London 1840-1845. - Schlosser M., Biolog. Zentralbl. 1890 , p. 81 , p. 238. - Scott W. B., The evolution of the premolar teeth, in the Mammalia. Proc. Acad. nat. sc. Philad. 1892, p. 405. - Wortman J.L., The comparative anatomy of the teeth of the vertebrata. Washington 1886. 
begriffenen Zähnen ist die Pulpa an der Basis des Zahnes weit geöffnet und nach vorne verengt. Diese Beschaffenheit erhält sich dauernd bei allen wurzellosen, mit sog. persistenter Pulpa versehenen Zähnen. Zähne mit niedriger Krone, wohl entwickelten Wurzeln und an der Basis verengter Pulpa werden brachyodont, solche von hoher zylindrischer oder prismatischer Gestalt mit weit offener Pulpa, ohne oder mit nur im hohen Alter vorhandenen schwachen Wurzeln hypselodont oder hypsodont genant.

Die Ausbildung der Säugetierzähne wird wesentlich durch ihre physiologische Funktion beeinflußt. Dienen sie lediglich zum Ergreifen und Festhalten der Nahrung, so entspricht der einfache Kegelzahn am besten dieser Aufgabe; werden sie als Waffe oder als Instrumente zur Beseitigung von Hindernissen verwendet, so verlängern sie sich, ragen aus der Mundhöhle vor und wandeln sich in Stoßzähne um. Ist die Nahrungszufuhr reichlich, und bedarf es zur Zerkleinerung derselben einer vollkommeneren Einrichtung, so tritt Arbeitsteilung und Spezialisierung des Gebisses ein. Gewissen Zähnen fällt die Funktion zu, die Nahrung zu ergreifen und festzuhalten, anderen dieselbe zu zerreißen oder zu zerschneiden oder zu zermalmen, und da diese Arbeiten meist in verschiedenen Teilen der Mundhöhle ausgeführt werden, so erleiden die vorderen Zähne andere Differenzierungen als die hinteren.

Ein gänzlicher Mangel an Zähnen tritt nur dann ein, wenn, wie bei den Walen, Ameisenfressern und Schnabeltieren eine Zerkleinerung der Nahrung überhaupt nicht erforderlich ist; eine gleichförmige Ausbildung aller Zähne (I s od ontie) kommt nur bei Meersäugetieren vor, deren Zähne, wie die der meisten niederen Vertebraten, lediglich zum Festhalten der Nahrung dienen. Weitaus die meisten Säugetiere besitzen ein 》anisodontes « differenziertes Gebiß, dessen Zähne sich in den beiden Kieferhälften symmetrisch wiederholen. Die im Zwischenkiefer und in der Symphyse des Unterkiefers eingepflanzten, stets einwurzeligen oder mit persistenter Pulpa versehenen Zähne heißen Schneidezähne (dentes incisivi $J$ ). Auf die Schneidezähne folgt jederseits im Oberkiefer unmittelbar hinter der Zwischen- und Oberkiefernaht ein meist konischer, ein- selten zweiwurzeliger $\mathrm{Eckzahn}$ (dens caninus oder laniarius C), dem im Unterkiefer ein ähnlich geformter Zahn entspricht, welcher bei geschlossenem Kiefer unmittelbar vor dem oberen Eckzahn eingreift. Hinter dem Eckzahn beginnen die Backenzähne (dentes, molares), wovon die vorderen, meist etwas einfacher gebauten als Lückenzähne oder Praemolares (Molares spurii $P$ ), die hinteren als echte Molaren (Molares veri $M$ ) bezeichnet werden. Sind in einem Gebiß sämtliche Sorten von Zähnen vorhanden, so gilt dasselbe für vollständig; es ist unvollständig, wenn entweder Schneidezähne, Eckzähne oder Backenzähne fehlen.

Bei den Zahnwalen, Sirenen und den meisten Edentaten bleiben die einmal vorhandenen, meist sehr einfachen Zähne zeitlebens in Gebrauch. Diesen wenigen monophyodonten Formen steht die große Mehrzahl der übrigen diphyodonten Säuger gegenüber, bei denen ein Zahnwechsel stattfindet. Die Ersatzzähne bilden sich jedoch nicht wie bei Fischen, Amphibien und Reptilien das ganze Leben hindurch, sondern nür ein einzigesmal; sie verdrängen die zuerst vor- 
handenen sog. Milchzähne und treten als definitives oder Ersatzgebiß (Dauergebiß) an deren Stelle. Im Milchgebiß werden ebenfalls Schneidezähne, Eckzähne und Backenzähne unterschieden, wovon die beiden ersteren fast immer mit ihren Ersatzzähnen in Zahl und Form übereinstimmen, während die Milchbackenzähne in geringerer Anzahl vorhanden sind und in ihrer Ausbildung häufig mehr den hinteren echten Molaren als ihren Ersatzzähnen entsprechen. Den echten (d. h. hinteren) Molaren des definitiven Gebisses gehen niemals Milchzähne voraus, dagegen werden die Milchbackenzähne durch Praemolaren verdrängt. Nicht immer folgen sämtlichen Zähnen des Milchgebisses Ersatzzähne. Bei Huftieren treten z. B. öfters nur drei Praemolaren an Stelle von vier Milchbackenzähnen, ja bei den Beuteltieren wird meist nur ein einziger (der letzte) Milchbackenzahn ersetzt, die vorderen bleiben dauernd in Funktion und vertreten die Antemolaren der übrigen Säugetiere. Der Zahnersatz ist offenbar im Verschwinden begriffen, denn selbst bei den Säugetieren mit vollständigem Milchgebiß erfolgt der Zahnwechsel in einem früheren Altersstadium als bei ihren Ahnen im älteren Tertiär.

Die Zahl der Zähne ist bei monophyodonten Säugern höchst variabel. Bei den Diphyodonten sind nicht nur die beiden Kieferhälften symmetrisch bezahnt, sondern es herrscht auch eine bestimmte Regel in der Zahl und Verteilung der verschiedenen Zähne. Beinahe in sämtlichen Ordnungen und Familien der Säugetiere besitzen die geologisch jüngeren Formen weniger Zähne als die älteren Vertreter derselben Entwicklungsreihe. Eine Vermehrung der normalen Zahnzahl im Verlauf der phyletischen Entwicklung kommt dagegen bei diphyodonten Säugern niemals vor. Die Reduktion beginnt fast immer mit den am Ende einer bestimmten Kategorie stehenden Zähnen, z. B. mit dem ersten $J$, dem vordersten $P$ oder dem letzten $M$ und schreitet von da nach vorne oder hinten weiter. ${ }^{1}$ )

Form und Größe der verschiedenen Zähne hängt ab von ihrer Stellung, von ihrer Funktion und ihrer Ernährung. Als primitives Gebiß der Säugetiere darf man wohl eine aus konischen, einwurzeligen Zähnen bestehende, durch gleichmäßige Lücken getrennte Zahnreihe annehmen. Die geringste Abweichung vom ursprünglichen Kegelzahn zeigen die Eckzähne. Sie sind in den meisten Fällen konisch, einspitzig, öfters etwas rückwärts gekrümmt, einwurzelig (nur

1) Zur Abkürzung der sog. Zahnformeln wird in der Regel nur die Bezahnung einer Kieferhälfte aufgenommen. Die Bezeichnung für das Tapirgebiß lautet demnach folgendermaßen:

A. Definitives Gebiß: $J \frac{3}{3}, C \frac{1}{1}, P \frac{4}{4} M \frac{3}{3}=44$ oder abgekürzt: $\frac{3 \cdot 1 \cdot 4,3}{3 \cdot 1 \cdot 4,3}=44$

B. Milchgebiß : $D J: \frac{3}{3}, D C \frac{1}{1}, D M \frac{3}{3}=28$ oder abgekürzt: $D=\frac{3 \cdot 1 \cdot 3 \cdot}{3 \cdot 1 \cdot 3 \cdot}=28$.

Sind Reduktionen eingetreten, so ergeben sich dieselben sofort aus der Zahnformel. Es hat z. B. die Ziege im definitiven Gebiß folgende Zahnformel:

$$
\frac{0.0 .3,3 .}{3.1 .3,3 .}=32 \text {. }
$$


bei einigen fossilen Beuteltieren und Insectivoren zweiwurzelig) und dienen hauptsächlich zum Ergreifen und Zerreißen der Nahrung, sie sind darum auch bei Fleischfressern am stärksten entwickelt.

Den Schneidezähnen liegt in der Regel die Funktion ob, die Nahrung zu ergreifen und zu zerschneiden. Im ersteren Fall behalten sie konische Form und gleichen den Eckzähnen, im zweiten plattet sich die Zahnkrone in der Richtung von vorne nach hinten $a b$, erhält einen schneidenden Rand und wird meißel- oder schaufelförmig. Sie sind stets einwurzelig. Fallen den Schneidezähnen besondere Verrichtungen zu, so modifiziert sich demgemäß ihre Form. So werden die zum Nagen benützten Incisiven groß, gekrümmt, an der Krone zugeschärft, meist sehr lang und sind häufig nur auf der Vorderseite mit Schmelz bedeckt. Die starken, konischen oberen Schneidezähne der Sirenen werden zum Herausreißen von Wasserpflanzen benützt; die gewaltigen, mit persistenter Pulpa versehenen, entweder schmelzlosen oder nur mit einem Schmelzband bedeckten Stoßzähne der Proboscidier und des Narwal dienen als Waffe oder zur Beseitigung von Hindernissen etc. Mit der Größenzunahme und besonderen Differenzierung einzelner Schneidezähne verbindet sich in der Regel die Verminderung ihrer Zahl; gänzlichen Mangel an Schneidezähnen findet man bei den meisten Edentaten; bei den Ruminantiern gehen die oberen, bei den meisten Proboscidiern die unteren $J$ durch Schwund verloren.

Bei weitem die mannigfaltigsten Verrichtungen kommen den Backenzähnen zu, und demgemäß weisen dieselben auch die größten Differenzierungen auf. Im allgemeinen haben sie die Tendenz, ihre Krone zu vergrößern, mit Spitzen, Höckern oder Leisten auszustatten und dadurch zum Zerkleinern der Nahrung geeigneter zu machen. Bei Fleisch- und Insektenfressern dienen die Backenzähne lediglich zum Zerschneiden der Beute und zum Zermalmen von Knochen. Zähne mit schmalen, verlängerten, zugeschärften und mehrspitzigen Kronen werden für die erste Verrichtung, breitere, mit spitzen Höckern versehene Kronen für die zweite am geeignetsten sein. Bei allen Insekten- und Fleischfressern haben demgemäß die besonders tätigen Backenzähne schneidende, mehrspitzige (sekodonte) Kronen und arbeiten wie die Blätter einer Schere, indem die unteren Zähne von den oberen umschlossen werden und letztere über die ersteren vorragen. Tiere, welche sich von gemischter Kost ernähren, haben bunodontes Gebiß, sie suchen die niedrigbleibende Krone der Backenzähne zu vergrößern und mit konischen Höckern auszustatten. Die Bewegung des Unterkiefers ist wie bei den Insekten- und Fleischfressern vertikal (orthal) und der Condylus quer gestellt.

Die verschiedenartigste Ausbildung erlangen die Backenzähne der reinen Pflanzenfresser. Auch hier zeigt sich das Bestreben, die Zahnkrone in die Breite und Länge zu vergrößern, mit Höckern auszustatten und zum Zerreiben der Nahrung geeignet zu machen. Die konischen Höcker des ursprünglich bunodonten Zahnes nehmen $\bigvee$ förmige Gestalt an, indem sich zwei konvergierende Grenzkanten bilden. Durch kräftige Entwicklung der Schenkel dieser $\bigvee$ förmigen Hügel und durch Zusammenstoßen ihrer Enden oder aber durch direkte Verbindung von zwei Höckern durch gerade oder gebogene Quer- 
kämme entstehen komplizierte, mit Jochen versehene, lophodonte Kronen. Einen wesentlichen Einfluß auf die Formierung und Richtung dieser Leisten und Joche übt die Bewegung des Unterkiefers; wird derselbe beim Kauen wie bei den meisten herbivoren Huftieren von außen nach innen (ektal) oder von innen nach außen (ental) bewegt, so sind die Vförmigen Höcker hintereinander nach der Längs. achse des Zahnes angeordnet, und die Seitenleisten der Höcker, sowie die Querjoche stehen schief zu derselben. Sehr häufig runden sich die Spitzen der $V$-Höcker ab und bilden alsdann halbmondförmige (selenodonte) Joche. Schiebt sich der Unterkiefer beim Kauen wie bei den meisten Nagern von vorne nach hinten (proale Mastikation), wobei der Condylus in einer Längsrinne der Schläfenbeinbasis bewegt wird, so stellen sich die Joche quer zur Längsachse.
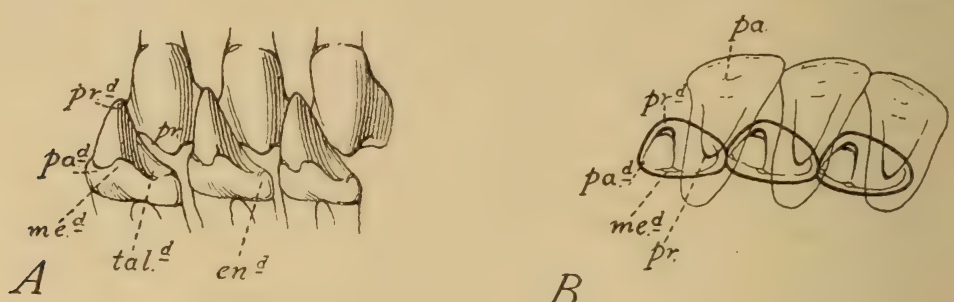

Fig. 489 .

Hypothetische Entwicklung des trituberkulären Zahnes. A Obere und untere Molaren von innen. $B$ obere und untere aufeinander gezeichnet. $p r$ Protocon, pa Paracon, 1 rd Protoconid, pad Paraconid, med Metaconid, end Entoconid, tald. Talonid. (Nach Gregory.)
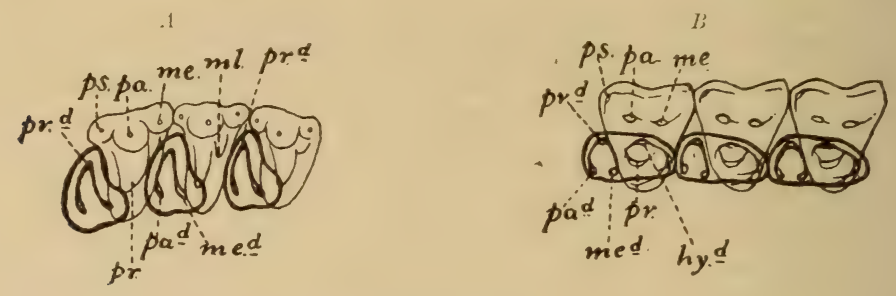

Fig. 490 .

A Dryolestes, Oberer Jura. Untere $M$ noch trituberkulär, ohne Hypoconid, obere $M$ trituberkulär mit Parastyl. $B$ Triisodon. Unterstes Eocän. Untere ir tuberkulärsektorial. Beide Zahnreihen aufeinandergezeichnet; $p r, p a, p r d, p a d$, med, end wie in Fig. 489. me Metacon, ps Parastyl, $m l$ Metaconulus, hyd Hypoconid. (Nach Gregory.)

Dieselbe Anordnung der Joche zeigt sich auch bei den Proboscidiern, deren Unterkiefer sich von hinten nach vorne (palinal) bewegt. Durch Fältelung der Schmelzjoche, durch Bildung von spornförmigen Fortsätzen, durch Einschaltung von Neben- und Zwischenhöckern, durch Entwicklung von Basalwülsten und schließlich durch Ansatz von Höckern und Jochen am hinteren Ende des Zahnes kann sowohl die bunodonte als auch die lophodonte Zahnkrone eine kompliziertere Ausbildung erlangen. Im allgemeinen sind die oberen Backenzähne, da sie über die des Unterkiefers vorragen, fast immer breiter als die unteren; die letzteren hingegen dehnen sich in der Längsrichtung aus.

E. Cope und H. F. Osborn haben versucht, die mannigfachen Modifikationen der Backzähne ron dem einfachen kegelförmigen Reptilienzahn abzuleiten. Aus diesem vhaplodonten. Zahn wird durch Hinzutreten von Nebenspitzen und 
durch beginnende Teilung der Wurzel der sprotodontes Zahn. Wenn seine Yebenspitzen fast ebenso groß geworden sind wie die ursprüngliche Hauptspitze, so entsteht entweder der vtrik on od onte, Zahn, dessen Spitzen sämtlich in einer geraden Linie angeordnet sind, oder der strituberkuläres Zahn, dessen Neben. spitzen seitlich von der Hauptspitze stehen und mit ihr alternieren. Beide Zahntrpen besitzen je zwei Wurzeln, jedoch erfolgt mit fortschreitender Komplikation des oberen trituberkulären Zahnes eine Zweiteilung seiner Außenwurzel.

Der trikonodonte Zahn ist auf ganz wenige Säugetiere beschränkt und hat auch keineswegs die Bedeutung für die weitere Entwicklung der Molaren, welche ihm früher beigelegt wurde, denn dieser liegt unzweifelhaft der trituberkuläre Zahntypus zugrunde, dessen erste Anfänge bereits bei gewissen $C y$ nodontia, den reptilienartigen Vorläufern der Säugetiere wahrnehm. bar sind.

Der strituberkuläre.

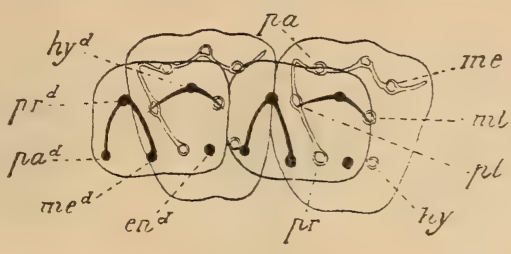

Fig. 491.

Entricklung der Huftiermolaren. Obere und untere $I I$ aufeinandergezeichnet. $p r, p a, m e, m i$, prd, pad, med, end, hyd wie in Fig. 490. hy Hypocon, $p l$ Protoconulus.

(Nach Osborn.) Zahn - >Trigon c im Oberkiefer, s Trigonid im Unterkiefer - genügte zwar, so lange die Tiere geringe Körpergröße besaßen und sich hauptsächlich von Insekten nährten. Die allmähliche Zunahme der Körperdimensionen und die hiermit verbundene Anpassung an Fleischnahrung oder gemischte Kost erforderte jedoch eine weitere Verstärkung der Backenzähne, welche dadurch betrerkstelligt wurde, daß an den unteren Molaren ein zwei- oder dreispitziges "Talonid « als Antagonist der Hauptspitze des entsprechenden oberen

$A$

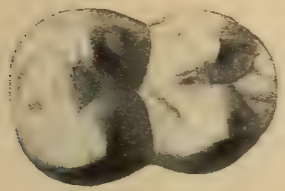

$B$

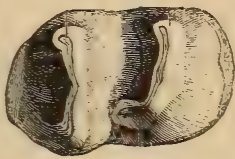

Fig. 492
$C$

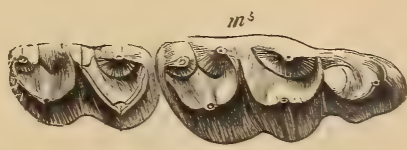

A Elotherium, unterer $M$ bunodont, $B$ Hyrachyus, unterer $M$ lophodont, $C$ Anoplotherium, Außenhügel halbmondförmig. Innenhügel konisch. $M_{3}$ mit drittem Halbmond.

Molaren entstand und an den oberen Molaren die beiden Außenspitzon sich vergrößerten und außerdem zwei kleine Zwischenspitzen sich bildeten, von welchen die hintere bei gemischter Kost öfter in einen zweiten Innenhöcker umgewandelt nurde; dieser zweite Innenhöcker erweist sich aber auch nicht selten als eine aus dem Basalband hervorgegangene Neubildung. Die einzelnen Bestandteile des fünfresp. sechshöckerigen Zahnes führen folgende Namen:

\section{A. Obere trituberculäre Molaren.}

\begin{tabular}{|c|c|c|c|c|c|}
\hline & e 0 & oder & Hö́cke & 18 & - pr. \\
\hline & & » & 》 & conus & - hy. \\
\hline e & Außenspitze & 2 & 》 & - Paraconus & - pa. \\
\hline e & 3 & $\gg$ & 》 & - Metaconus & \\
\hline re & Zwischen & & 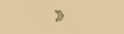 & - Protoconulus & \\
\hline re & , & D & 》 & - Metaconulus & $-n$ \\
\hline
\end{tabular}

B. Untere tuberculärsektoriale Molaren.

Vordere Außenspitze oder Höcker - Protoconid - prd.

hintere , , - Hypoconid - hyd.

vordere unpaare Spitze 》 \. - Paraconid - pad.

hintere,, - Mesoconid - msd.

vordere Innenspitze $>>$ - Metaconid - med.

hintere , , , - Entoconid - end. 
Die weitere Differenzierung äußert sich an den oberen Molaren in dem Auftreten von $A$ u $B$ en p feilern - Parastyl, Mesostyl, Metastyl - bei omnivorer oder herbivorer Lebensweise in Vergrößerung des Hypoconus und in Verschmelzung des vorderen Zwischenhöckers mit dem Protoconus (Fig. $493 \mathrm{~A}$ ) quadrituberkulärer Zahn, oder es verbinden sich die Zwischenhöcker mit dem benachbarten Innenhöcker zu je einem Querjoch (Fig. 493 C) lophodonter Zahn. An den unteren Molaren verschwindet das Paraconid und alle Innen- und Außenhöcker werden

$A$

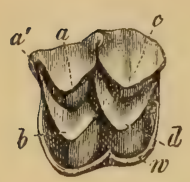

B

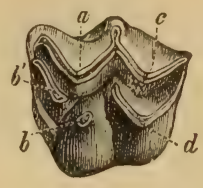

Fig. 493.

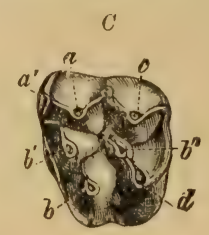

Vier-, fünf- und sechshöckerige obere Molaren von unten. $A$ Prodremotherium, $B$ Anoplotherium, $C$ Lophiotherium. gleich groß, wobei auch hier die Höcker sich paarweise zu Jochen verbinden können (Fig. 492 B). Am letzten unteren Molaren entsteht nicht selten ein dritter Lobus (Figur $492 \mathrm{C}$. Durch Hinzutreten von Querjochen kommen poly lophodon te Zähne (Figur 495) zustande. In ähnlicher Weise könnte man sich auch die multituberku lären Zähne (Fig. 494) entstanden denken, allein sie treten bereits gleichzeitig mit dem Trituberkulär- und Trikonodontentypus auf, was sich mit der Ableitung von einem dieser beiden Typen nicht gut vereinbaren läßt. Bei den Fleischfressern hingegen verkümmern nach und nach die oberen sowie die beiden letzten unteren Molaren, desgleichen auch das Metaconid und Talonid des ersten unteren Molaren. Dafür wird jedoch Paraconid und Protoconid sowie der letzte obere Prämolar verstärkt und beide Zähne wirken zusammen als eine Schere.

Die Praemola ren erlangen in der Regel nicht den hohen Grad der Differenzierung wie die Molaren. Sie sind meist einfacher, und selbst wenn sie ihnen gleich werden, ist doch die Reihenfolge der neu auftretenden Höcker eine andere als bei den Molaren, weshalb auch die einzelnen Höcker nicht mit denen der Molaren homologiiert werden können. Scott ${ }^{1}$ ) nennt sie:

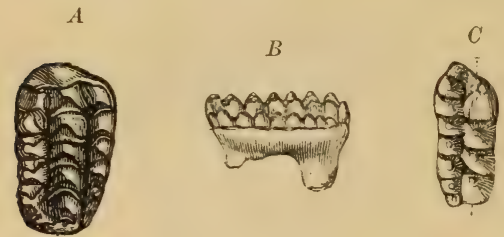

Fig. 494.

Multituberkuläre Backzähne von Allotherien. $A, B$ Oberkieferzahn von Cimolomys. $C$ Unterkieferzahn von Cimolomys. $8 / 1$ nat. Gr. (Nach Marsh.)

Untere P.

1 Außenhöcker Protoconid. Vorderhöcker Paraconid.

1 Innenhöcker Deuteroconid.

2 Außenhöcker Metaconid.

2 Innenhöcker Tetartoconid.

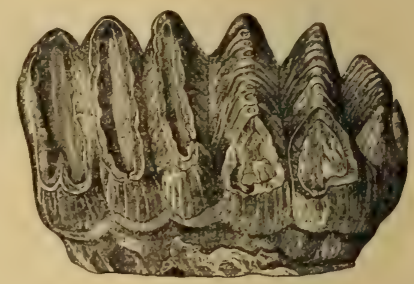

Fig. 495 .

Polylophodonter oberer $M$ von Stegodon. Ca. $1 / 2$ natürl. Größe.

Obere P.

1 Außenhöcker. Protoconus.

1 Innenhöcker Deuteroconus.

2 Außenhöcker Tritoconus.

2 Innenhöcker Tetartoconus.

Die Systematik der Säugetiere ist durch die Entdeckung zahlreicher fossiler Formen wesentlich beeinflußt worden, denn einerseits werden nicht selten durch sie scheinbar nicht verwandte lebende Gattungen und selbst Familien und Ordnungen miteinander verbunden und die vermeintlichen scharfen Grenzlinien zwischen ihnen mehr oder weniger verwischt, anderseits kamen aber auch fossile Formen zum Vorschein, für welche nicht bloß besondere Familien, sondern

1) The Evolution of the Premolar Teeth. Proc. Acad. Nat. Sc. Philad. 1892. 
sogar in einem Falle eine besondere Ordnung errichtet werden mußte, weil sie den übrigen Säugetieren durchaus fremdartig gegenüberstehen. In weitaus den meisten Fällen läßt sich die Stammesgeschichte der einzelnen Gattungen, Familien und Ordnungen mit viel größerer Sicherheit ermitteln als bei den übrigen Wirbeltieren, in keiner anderen Abteilung des Tierreiches finden wir ein so massenhaftes und geeignetes Material zur Aufstellung genetischer Formenreihen.

Was die Abstammung der Säugetiere von anderen Vertebraten betrifft, so kommen Vögel und Fische als deren Ahnen nicht in Betracht. Auch die Amphibien, von welchen sie $\mathrm{Huxley}$ ableiten wollte, stehen den Säugetieren viel ferner als die Reptilien. Unter diesen zeigen die Theromorpha so viele Beziehungen zu den Säugetieren, daß schon $\mathrm{Owen}$ und $\mathrm{Cope}$ sie als deren Vorläufer bezeichneten, und durch die neuesten Untersuchungen $\mathrm{Osb}$ or n s wird es zur völligen Gewißheit, daß die Säugetiere von synapsiden Reptilien, und zwar von Cotylosauriern und Theriodontiern abstammen, welche ihrerseits aus Stegocephalen hervorgegangen sind.

Die Säugetiere werden in der Regel nach ihrer Embryonalentwicklung in zwei Unterklassen, Eplacentalia und Placentalia eingeteilt. Die ersteren enthalten die Ordnungen der Monotremata und Marsupialia, die letzteren die Ordnungen der Insectivora, - inkl. Tillodontia - Chiroptera, Carnivora, Cetacea, Rodentia, Edentata, Ungulata, Notoungulata, Subungulata - inkl. Sirenia - und Primates.

\section{A. Unterklasse. Eplacentalia.}

Embryonalentwicklung ohne Placenta.

\section{Ordnung. Monotremata. $\left.{ }^{1}\right)$ Kloakentiere.}

(Ornithodelphia Blv.)

Brustgürtel mit selbständigem Coracoid, Praecoracoid und Interclavicula. Becken mit Beutelknochen. Schulter. blatt ohne Crista. Kiefer gestreckt, zahnlos oder mit Zahnrudimenten. Fortpflanzung durch Eier. Milchdrüsen ohne Zitzen, auf getrennten Drüsenfeldern mündend. Harnröhren und Genitalgänge in die Kloake mündend, welche in das untere Ende des Mastdarms führt. Körpertemperatur nicht überall gleich.

So interessant diese Ordnung ist hinsicht. lich ihrer vielen Anklänge an Reptilien einerseits und ihrer hochgradigen Spezialisierung anderseits, so hat sie doch für die Paläontologie nur geringe Bedeutung, denn die wenigen bekannten sicheren Überreste stammen aus dem

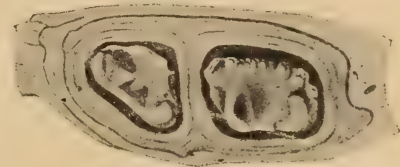

Fig. 496 .

Ornithorhynchus jung. Molaren des linken Unterkiefers. $5 / 2$ nat. Gr. (Nach Osborn.)

Pleistocän von Australien und gehören den beiden noch lebenden Gattungen Ornithorhynchus (Fig. 496) - in der Jugend mit $\frac{2}{2} M$ - und Echidna an. Es ist aber nicht ausgeschlossen, daß manche der im folgenden erwähnten mesozoischen Säugetiere Monotremen waren, wenigstens die Protodonta.

1) Gregory W.K., The Orders of Mammals. Bull. Am. Mus. Nat. Hist. 1909, p. 144-162. - Van Bemmelen J. F., Der Schädelbau der Monotremen. Semon. Zoolog. Forschungsreisen in Australien. 1901. 


\section{Ordnung. Marsupialia. ${ }^{1}$ )}

\section{(Didelphia Blv., Metatheria Huxley.)}

Verschiedenartig bezahnteheterodonte Pflanzen-oder Fleischfresser mit sehr unvollständigem Zahnwechsel. Schultergürtel ohne Coracoid, Becken mit Beutelknochen. Zitzen der Milch. drüsen meist von einer Hautfalte umschlossen, welche einen Beutel bildet, worin die ohne plazentale Entwicklung in unreifem Zustande geborenen Jungen längere Zeit getragen werden.

Die Beuteltiere bilden einen ziemlich großen Formenkreis, in welchem Fleisch- und Insektenfresser sowie huftier- und nagerähnliche Typen vertreten sind, und diese mannigfachen Differenzierungen äußern sich nicht

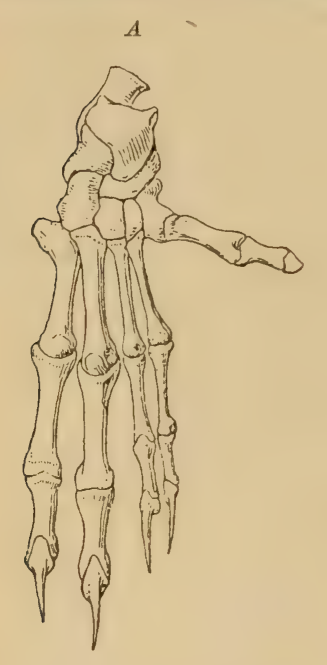

Fig. 497 .

A Trichosurus, Hinterfuß mit fünf fast gleichgroßen Zehen.

B Macropus, I-III Zehe reduziert (nach Dollo). bloß im Gebiß sondern auch im Skelett. Das Gehirn ist klein, die glatten Hemisphären des Großhirns bedecken weder die Sehhügel und Riechlappen noch das Kleinhirn. Die Nasenbeine sind groß, die Jochbogen vollständig, die Augenhöhlen hinten offen. An der Bildung der Gehörkapsel beteiligt sich das Alisphenoid, seltener das Mastoid und das halbringförmige Tympanicum. Der harte Gaumen ist stets von größeren oder kleineren Öffnungen durchbohrt. Die hintere Ecke des Unterkiefers ist nach innen eingebogen.

Das Gebiß erinnert teils an das von Herbivoren oder von Nagern, teils an das von Insectivoren oder von Fleischfressern. Bei den ersteren ist die Zahl der $J$ und $P$ sowie $\operatorname{der} C$ reduziert, dafür ist jedoch in jedem Kiefer ein $J$ sehr stark ausgebildet, die letzteren haben ein vollständiges Gebiß, in welchem meist bis zu $\frac{5}{4} J$ vorhanden und die $C$ kräftig entwickelt sind und zuweilen je zwei Wurzeln besitzen. Die $P$ haben in der Regel einen sehr einfachen Bau und geringe Größe, nur der hinterste ist meist groß und oft stark spezialisiert. Die meist in der Vierzahl vorhandenen $M$ sind entweder sekodont, bunodont oder lophodont. Der Zahnwechsel beschränkt sich auf den letzten $P$, aber die Embryonen der lebenden Beuteltiere besitzen viel mehr Anlagen von Zähnen als im definitiven Gebiß vorkommen.

1) Ameghino F. C., Los Diprotodontes del order de los Plagiaulacoideos. Anal. Museo Nacion. Buenos Aires. T. IX, 1903. - Cope E. D., The tertiary Marsupialia. Amer. Naturalist, 1884. - Goodrich E. S., Mammalia from the Stonesfield slate. Quart. Journ. microscopical Science. Vol. 35. - Gregory W. $K$., The Orders of Mammals. Bull. Am. Mus. Nat. Hist. 1909. p. 162-231. - Marsh O. C., Amer. Journ. Sc. and Arts 1880 XX, 1881 XXI, 1889 XXXVIII, 1892 XLIII. Osborn H. $F$., Proceed. Ac. nat. Scienc. Philad. 1887-1888. Journ. Ac. nat. hist. Philad. 1888. Vol. IX. - Evolution of the Mammalian Molar Teeth. New York 1907. - Owen R., Monograph of foss. Mammalia of the British Mesozoic Formations. Palaeont. Soc. 1871. - Rech. on the foss. remains of the extinct Mammals of Australia with a notice of the extinct Marsupials of England. London 1877. Sinclair W. J., Marsupialia of the Santa Cruz Beds. Rep. Princetons Univ. Expedit. to Patagonia. Vol. IV. Part. III. 1906. - Thomas Oldfield, On the Homologies and Succession of the teeth in the Dasyuridae. Philos. Trans. 1887. Vol. $178 \mathrm{~b}$. 
Charakteristisch für die Beuteltiere ist die Anwesenheit von je einem stabförmigen Knochen am Vorderrand des Schambeins. Diese Beutelknochen finden sich bei beiden Geschlechtern, sind aber bei den Thylacyniden durch Faserknorpel ersetzt. Die Länge der Hinterbeine übertrifft häufig die der Vorderbeine. Der Hinterfuß (Fig. 497) hat fünf oder vier Zehen, von denen die vierte stets am längsten ist, während die zweite und dritte bei Herbivoren sehr dünn werden können und stets von einer gemeinsamen Haut umgeben sind. Jedoch bestehen zwischen dieser spezialisierten und der ursprünglich fünfzehigen Extremität vielfache Übergänge. Der Hallux steht öfters den übrigen Zehen rechtwinklig gegenüber oder verkümmert ganz. Dollo leitet alle Marsupialier von fünfzehigen arborikolen Formen ab.

Mit Ausnahme der in Amerika verbreiteten Didelphidae und der südamerikanischen Caenolestidae sind die Beuteltiere gegenwärtig auf Australien und die benachbarten Inseln beschränkt. Die pleistocänen Formen hatten dieselben Wohnsitze wie die lebenden. Dagegen besaß im Tertiär und in der Jurazeit nicht bloß Nordamerika - hier auch in der Kreide - sondern auch Europa eine Anzahl fossiler Marsupialier, und aus dem Tertiär von Südamerika kennt man eine ziemliche Menge verschiedenartiger Typen. Man unterscheidet am zweckmäßigsten drei Unterordnungen, die Allotheria, die Diprotodontia und die Polyprotodontia, obschon die Caenolestidae zwischen den beiden letzteren den Übergang bilden.

\section{Unterordnung. Allotheria. Marsh. Multituberculata Cope. $\left.{ }^{1}\right)$}

Kleine ausgestorbene herbivore oder omnivore Säuger mit vielhöckrigen $M$, deren Höcker in zwei oder drei Längsreihen angeordnet sind. $P$ entweder den $M$ ähnlich, aber einfacher oder seitlich zusammengedrückt. In jedem Kiefer ein J kräftig, nagezahnartig entwickelt. Ohne C. Unterkiefer meist mit einwärts gebogenem Eckfortsatz. Coracoid vielleicht selbständig ausgebildet.

Die Allotheria finden sich in der Trias von Europa und Südafrika, im Jura von Europa und Nordamerika, in der Kreide von Nordamerika und im untersten Tertiär von Europa und Nordamerika. Auch gehören hierher möglicherweise einige Formen aus dem Eocän von Südamerika.

Von den meisten Gattungen liegen nur vereinzelte Zähne, Unterkiefer, selten Oberkiefer und Schädelteile vor. Nur von Ptilodus kennt man den Schädel und einige Knochen. Die systematische Stellung ist daher bei manchen sehr unsicher, der größere Teil gehört jedoch zu den Masupialiern, wennschon die Zähne meist eher an die rudimentären Backenzähne von Ornithorhynchus erinnnern. Der Astragalus von Polymastodon gleicht nach Co pe dem von Känguru.

\section{Familie. Tritylodontidae Cope.}

Schnauze abgestutzt, Zuischenkiefer mit je einem starken $C$ ähnlichen $J$ und dahinter ein kleiner stiftförmiger $J . P$ den $M$ ähnlich, aber einfacher, $M$ mit drei Höckerreihen. Trias von Südafrika und Europa.

1) Ameghino Fl., Anales Mus. Nac. Buenos Aires. T. IX, 1904. - Cope E. D., Amer. Naturalist 1881. 86. - Gidley J. W., Proceed. Unit. St. Nat. Mus. XXXVI. 1909, p. 611. - Lemoine $V$., Bull. soc. géol. Fr. 1883. 3 sér. - Marsh O. C., Amer. Journ. Sc. $1878-81$ 1889, 1892. - Osborn H. F., Journ. Acad. Nat. Sc. Philad. 1888. Proc. Acad. Nat. Sc. Phil. 1891. Amer. Naturalist July 1891. Bull. Amer. Mus. Nat. Hist. 1893. 
Tritylodon Owen (Fig. 498.) Trias Karrooformation Südafrika. Gehört nach Seeley zu den Reptilien (Theriodontia).

Triglyphus Fraas. Nur winzige viereckige Zähnchen mit zwei oder drei Höckerreihen bekannt. Im rhätischen Bonebed von Hohenheim bei Stuttgart.

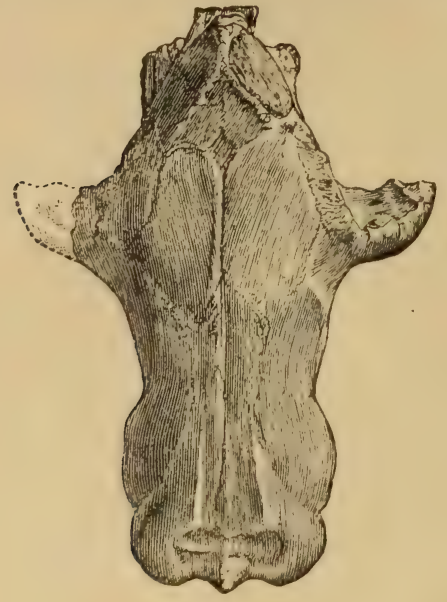

Fig. 498.

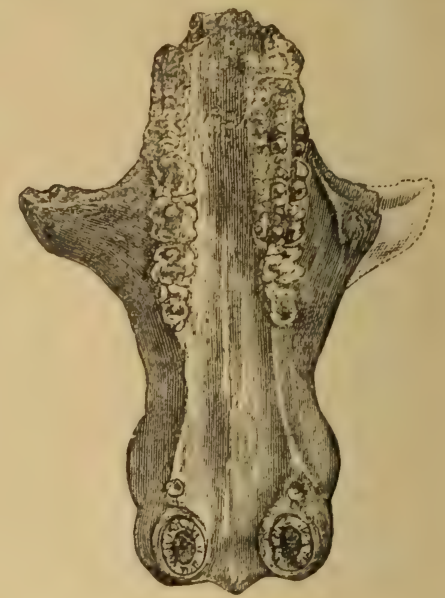

Tritylödon longacvus Owen. Trias von Basutoland. Schädel von oben und von unten. $2 / 1$ nat. Größe. (Nach Owen.)

\section{Familie. Plagiaulacidae Gill.}

Zwischenkiefer mit ein bis drei $J$, Unterkiefer mit einem $J ; J_{1}$ in beiden Kiefern nagezahnähnlich. Obere $P$ drei-bis fünflöckerig, der letzte manchmal mit mehr Höckern. Untere P seitlich zusammengsdrïckt, schneidend und mit vielen Einkerbungen versehen. Untere $M$ mit nur zuei, obere mit drei, selten mit nur zwei Höckerreihen. Unterkiefer viel kürzer als die Schnauze. Gelenk bis auf den Eckfortsatz ausgedehnt.

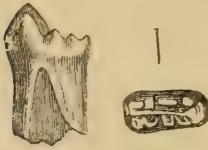

Fig. 499

Microlestes antiquus Plieninger. Backzahn aus dem Bonebed von Echterdingen, Württem-

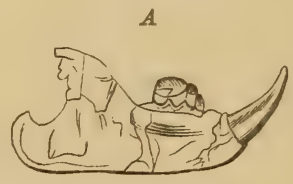

Fig. 500 .

Plagiaulax Becclesi Falc. Purbeck-Schichten von Swanage, Dorsetshire. A Unterkiefer $(1 / 1)$. B Plagiaulax minor Owen, ebendaher. $a$ Molar vergrößert, $b$ Unterkiefer vergrößert, $c$ derselbe in nat. Gr. (Nach Falconer.)

Microlestes Plieninger (Hypsiprymnopsis Dawkins). (Fig. 499.) Nur kleine, länglich vierseitige, in der Mitte vertiefte und außen und innen mit Höckern versehene Zähnchen aus dem rhätischen Bonebed von Württemberg und Sommerset bekannt.

Pla giaulax Falconer (Bolodon Owen). (Fig. 500, 501.) 1.1.4. 3. Unterkiefer mit hohem Kronfortsatz und niedrigem, über den Eckfortsatz sich erstreckenden Condylus. Vorderster oberer $J$ vertikal nach unten, unterer $J$ schräg nach oben und vorne gerichtet. Obere $P$ aus zweireihig angeordneten Höckern bestehend, letzter $P M$-artig, untere $P$ von vorne nach hinten größer 
werdend, schneidend, blattartig, mit gerieften Seitenfiächen. Obere und untere $M$ mit je zwei Reihen von Höckern. Purbeck von England.

Allodon Marsh. Oberkiefer ähnlich Plagiaulax, jedoch mit $3 \mathrm{~J}$. Oberer Jura. Wyoming. Allacod on Marsh (Fig. 502.) Obere Kreide. Nordamerika.

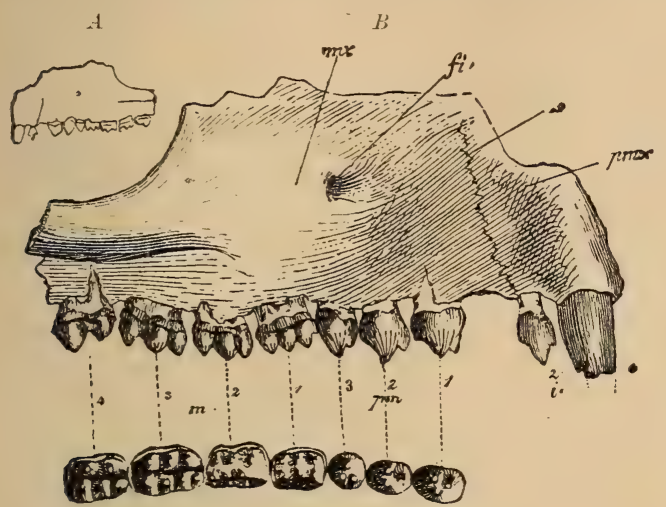

Fig. 501

Bolodon crassidens Owen. Purbeck-Schichtenvon Dorsetshire. $A$ Oberkieferfragment in nat. Gr. $B$ dasselbe in vierfacher Vergrößerung. (Nach Osborn.) $m x$ Oberkiefer, $p m x$ Zwischenkiefer, $s$ Naht zwischen Ober- 1nd Zwischenkiefer, $f i$ Foramen infraorbitale, $p m$ Lückenzähne, $m$ Backzähne.

Ctenacodon Marsh. (Figur 503.) Untere $P$ am Oberrand schwach gestreift. Obere $M$ mit nur zwei großen Außen. höckern. Ober. Jura.W yoming.

Neoplagiaula $x$ Lemoine (Liotomus Cope). Unterkiefer nur mit einem großen, gerieften $P$ und zwei $M$. Untereocän von Reims und Neu. mexiko.

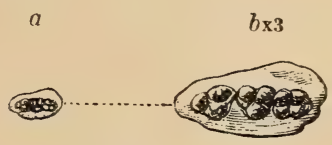

Fig. 502.

Allacodon pumilus Marsh. Ob. Kreide. Wyoming. Die drei Prämolaren des Oberkiefers $a$ in nat. Gr. $b$ in dreifacher Größe. (Nach Marsh.)

Ptilodus Cope (Chirox Cope). (Fig. 504.) $\frac{11.4 .2 .}{1.0 .2 .2 .} \quad$ Schädel niedrig und flach mit langer breiter Schnauze, Gaumen mit großen Lücken, Kiefergelenk nahe dem stark verbreiterten Hinterhaupt. Oberer $C$ ähnlich aber kleiner als $J, P^{1}$ mit $3, P^{2}$ mit $4, P^{3}$ mit 6 Höckern, $P^{4}$ langgestreckt mit zahlreichen Höckern. $M^{1}$ schmäler als $P^{4}$. $P_{3}$ reduziert, $P_{4}$ kräftig, an beiden Seiten gerieft. $\boldsymbol{M}_{1}$ mit mehr Höckern als $\boldsymbol{M}_{2}$. Humerus massiv, mit engem Entepicondylarforamen. Auch Becken, Ober- und Unterschenkel bekannt. Untereocän von Montana und Neumexiko.

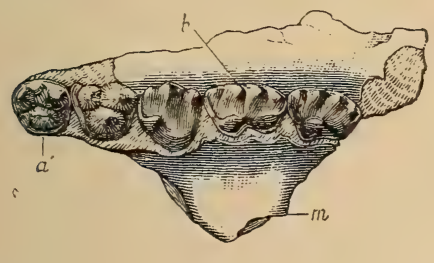

Fig. 503.

Clenacodon potens Marsh. Ob. Jura. Wyoming. Rechter Oberkiefer von unten 4/1. (Nach Marsh) $a^{\prime}$ erster, $b$-vierter Prämolar, $m$ Jochbogen.

$a$

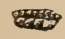

6

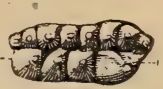

Fig. 505

Cimolomys (Cimolodon) nitidus Marsh. Obere Kreide. Wyoming. (Nach Marsh.) $a$ vorletzter unterer Backzahn.

Zittel, Grundzüge der Paläontologie II.
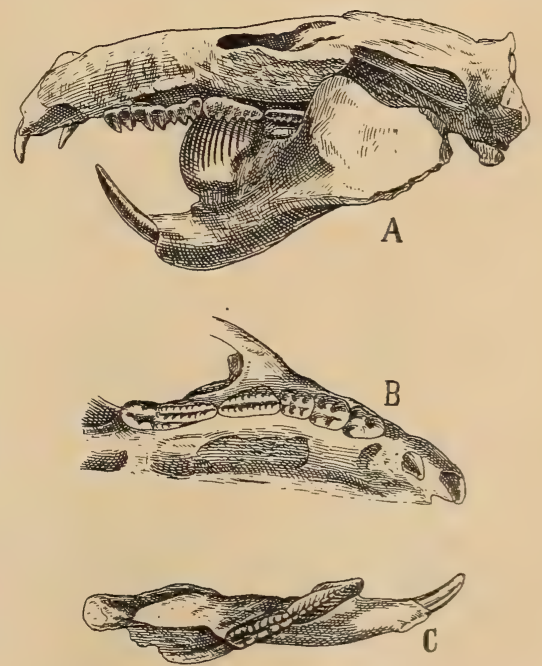

Fig. 504

Ptilodus gracilis Gidley. Unterstes Eocän. Fort Unionbed Montana: $A$ Schädel und Unterkiefer. $B$ Oberkiefer (Unterkiefer). $2 / 3$ nat. Gr. (N. Gidle y.) 
Cimolomys Marsh (Cimolodon, Nanomys, Marsh, Ptilodus, Halodon Osborn). (Fig. 505.) Obere $M$ mit drei Höckerreihen. Obere Kreide. Laramiebed von Wyoming und Montana und mittlere Kreide von Nordwest-Canada.

M eniscö̈ssus Cope (Dipriodon, Tripriodon, Selenacodon, Oracodon Marsh). (Fig. 506.) Fast nur isolierte Zähne bekannt. Obere $M$ mit drei Höckerreihen. Obere Kreide. Laramiebed von Nordamerika.

\section{Familie. Polymastodontidae Cope.}

Beide Kiefer jederseits mit einem sturken, nagezahnartigen $J$ und zwei grojsen $M$, vor denen sich ein kleiner einfacher $P$ befindet, der von $J$ durch eine lange Zahnlücke getrennt ist. Hinter dem großen oberen $J$ noch ein kleiner $J$ vorhanden. Die unteren $M$ mit zwei, die oberen mit drei Längsreihen von stumpfen Höckern. Unterkieferecke umgebogen. Kiefergelenk fast in der Hinterhauptsfläche gelegen. Im untersten Tertiär, Puerco von Neu-Mexiko.
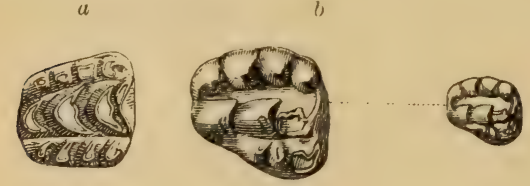

Fig. 506.

A Meniscoëssus conquistus Cope. Oberer Molar aus der obersten Kreide (Laramie-Stufe) von Dakota. 2/1. (Das Cope'sche Original nach Osborn.) $B$ Tripriodon coelatus Marsh. Ob. Kreide. Wyoming. Wahrscheinlich letzter oberer Molar in natürlicher und in doppelter Gr. (Nach Marsh.)

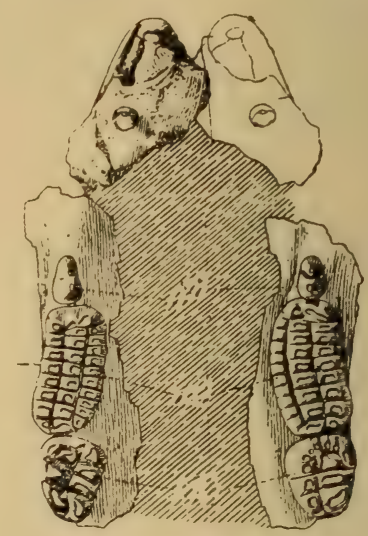

Fig. 507. Polymastodon attennatus Cope. Unterstes Eocän. Neu-Mexiko. Gaumen mit beiden Zahnreihen. Nat. Gr. (Nach Osborn.)

Polymastodon Cope (Taeniolabis, Catopsalis Cope). (Fig. 507.) $\frac{\text { 2.0.1.2. }}{1.0 .1 .2 .} \quad$ Von den Dimensionen eines Bibers.

\section{Familie. Polydolopidae. Ameghino.}

Untere $J$ fast horizontal. $P^{3}$ und $P^{4}$ und unterer $P_{4}$ höher als die $M$ und meist als gezähnelte Schneide entwickelt. Obere $M$ mit zwei oder drei, untere stets mit zwei Höckerreihen und von vorne nach hinten hleiner werdend. Meist drei, selten fünf Höcker in einer Reihe. $\frac{1.0 .2 .3 .}{1.0 .2 .3 .}$

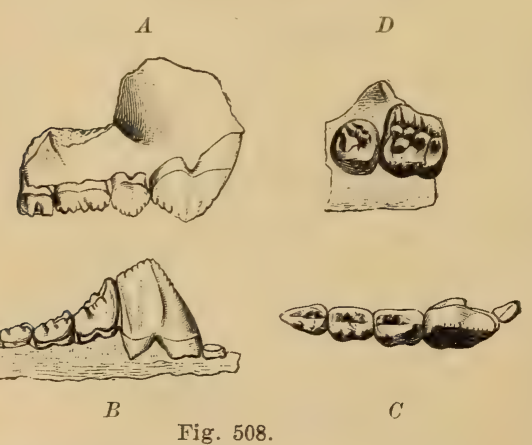

Polyclolops Thomasi Ameghino. Eocän. Notostylops-Schichten. Patagonien. A Ob. Zahnreihe, $B$ unt. Zahnreihe von außen, $C$ von oben. D Pliodolops primulus Ameghino. Ebenda. Obere $I I .2 / 1$ nat. Gr. (nach A meghino.)
Im älteren Tertiär von Patagonien (Notostylops-Schichten). Sie sind wahrscheinlich die Nachkommen von Plagiaulaciden. Thre Verwandtschaft mit den Caenolestiden ist schon wegen ihrer. beträchtlichen Größe unwahrscheinlich, wenn auch zwischen Polydolops und $A b$ derites einige Ähnlichkeit vorhanden ist.

Von den zahlreichen Gattungen, welche Am e g hin o meist nur auf einzelne Zähne begründet hat, zeichnen sich Orthodolops und Amphidolops durch undeutlich, Polydolops (Fig. 508), Pseudolops und Pliodolops durch scharf von einander geschiedene Höcker aus. An den oberen $M$ von Pliodolops (Fig. $508 D$ ) stehen sie in mehreren Reihen. 
Propolymastodon (Promysops?) Ameghino $\frac{1.0 .2 .3}{1.0 .1 .3}$. unterscheidet sich von den übrigen Gattungen durch den Besitz von nur einem, überdies ganz einfachen, ungekerbten $P$.

Eommanodon Ameghino. Miocän Colpodon-Schichten. Systematische Stellung unsicher.

\section{Unterordnung. Diprotodontia. Owen.}

Meist Pflanzenfresser mit je vier vierhöckerigen oder zweijochigen $M . P$ den $M$ ähnlich oder blattartig und schneidend. C fehlend oder sehr schwach entwickelt. Oben 4-1 J, davon der vorderste vergrößert, unten nur ein einziger aber sehr kräftiger nagezahnartiger $J$.

Die Diprotodontia sind wahrscheinlich Nachkommen von Polyprotodontia, welche sich einer gemischten oder ausschließlich vegetabilischen Kost angepaßt haben. Mit Ausnahme der südamerikanischen Gattung Caenolestes sind sie jetzt auf Australien beschränkt, wo sie auch im Pleistocän vorkommen. Aus dem Tertiär von Patagonien kennt man eine Anzahl erloschener Gattungen und Arten.

\section{Familie. Caenolestidae. Trouessart.}

\section{(Paucituberculata Ameghino.)}

Kleine, höchstens mittelgroße Beutler mit 3-4 kleinen vertikalen oberen $J$ und einem gropisen horizontal gestellten unteren $J$. Dahinter drei bis vier einfache stiftförmige Lïckenzühne, von denen einer im Oberkiefer zuweilen als kräftiger $C$ entwickelt ist. Obere $P^{2}$ und $P^{3}$ klein, $P^{4}$ größser und schneidend wie die beiden unteren $P . \quad M$ vierhöckerig, von vorne nach hinten kleiner werdend. Unterer $M_{1}$ häufig vergrößert, fünfhöckerig und zusammen mit dem oberen $P^{4}$ als Schere funktionierend, die ïbrigen $M$ vierhöckerig lophodont. Obere $M$ mit schwachem zweiten Innenhöcker. Fuß nicht syndaktyl. Lebend und fossil in Siidamerika.

\section{Unterfamilie. Caenolestinae.}

4. 1. 3. 4. Kein $P$ oder $M$ schneidend ausgebildet. Untere $M$ tuberkulärsektorial. $P$ und $M$ denen von Beutelratten ziemlich ähnlich.

A

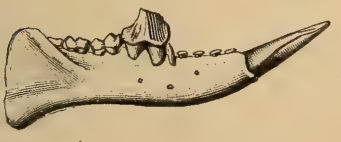

Fig. 509.
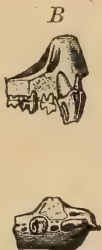

Abderites meridionalis Ameghino. Miocän. Santa Cruz. Patagonien. A Unterkiefer, $B$ Oberkiefer. Nat. Gr. (Nach A m e ghino.)
Caenolestes Thomas. Lebend in Ecuador.

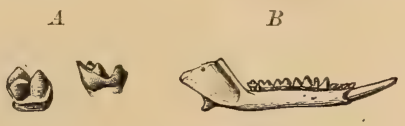

Fig. 510 .

A Garzonia typica Ameghino. Miocän. Santa Cruz. Oberer $\boldsymbol{M}$ von unten und hinten. $3 / 2$ nat. Gr. B Stilotherium dissimile Amegh. Ebenda. Unterkiefer, nat. Gr. (nach A meghino.)

Garzonia (Fig. 510) und Halmarhiphus Ameghino aus dem Miocäen von Santacruz, die erstere Gattung mit trituberkulären oberen $M$.

Stilotherium (Fig. 510 B) und Cladoclinus Ameghino (Pitheculites Clenialites) Amegh. Miocän von Patagonien.

Zygolestes Ameghino Pliocän. Parana-Stufe von Argentinien. 


\section{Unterfamilie. Palaeothentinae.}

1. 1. 3.4. Oberer $P^{4}$ und unterer $M_{1} z u$ einer. Schere ungestaltet. Im Unter. kiefer hinter $J_{1}$ drei bis vier kleine Lückenzühne. Schädel, namentlich Hinterhaupt stark verbreitert. Jochbogen weit vorspringend.

Palaeothentes Moreno (Fig. 511) (Epanorthus. Metepanorthus, Parepan. orthus Ameghino). Miocän von Patagonien. Alle $M$ fast gleich groß. $P$ kräftig. Callomenus, Decastis, Acdestis Ameghino. Ebenda. $M$ von sehr ungleicher Größe. Dipilus, Metriodromus, Halmaselus, Pichipilus, Essoprion Amegh. ganz unvollständig bekannt. Palaepanorthus Amegh., Untermiocän Pyrotheriumschichten.

\section{Unterfamilie. Abderitinae.}

$\frac{? ? ? !}{1.4 .1 .4 .} P^{4}$ vergrößert, unterer $M_{1}$ schneidend ausgebildet und an beiden Seiten mit Riefen versehen, die übrigen $M$ bunolophodont, vierhöckerig.

Der untere $M_{1}$ hat große Ähnlichkeit mit dem $P_{4}$ der Allotheria, aber er besitzt ein Talonid, das aber bei den Arten aus den Colpodonschichten noch schwach ist. Miocän von Patagonien.

Abderites Ameghino. (Fig. 509.) Zwischen dem $J_{1}$ und dem kleinen, seitlich stehenden $P_{4}$ vier Lückenzähne. Miocän-Santacruz.

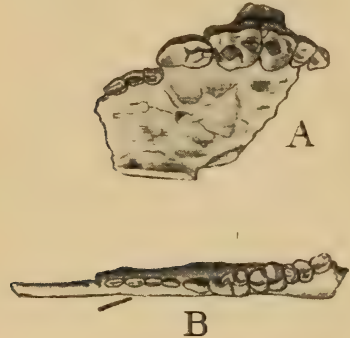

Fig. 511

A Palaeothentes intermedius Ameghino. Obere Backenzähne. B P. minutus Am. Untere Backenzähne. Obermiocän. Santa Cruz. $3 / 2$ nat. Gr. (n. Sinclair.)

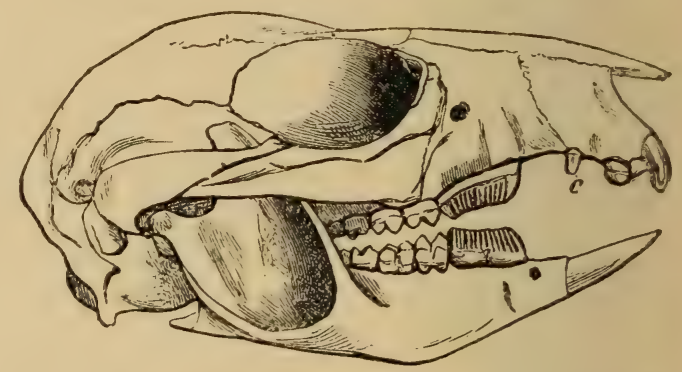

Fig. 512

Bettongia Grayi Gould. Schädel. Lebend. Australien.

Parabderites Ameghino. Zwischen $J_{1}$ und dem relativ großen $P_{4}$ fünf Lückenzähne. Miocän Colpodonschichten und Pyrotheriumschichten.

\section{Familie. Phalangeridae.}

Mannigfach spezialisierte Beuteltiere, teils omnivor, teils herbivor, teils zum Springen, teils zum Klettern und sogar zuweilen zum Fliegen befähigt. Gebiß niemals vollständig. $\frac{3.1 .3-1.4 .}{1.0 .3-1.4 .}$ Oberer $J^{1}$ größer als die übrigen, untere $J$ horizontal, nagezahnähnlich. Oberer $C$ stets klein, $P_{4}$ in beiden Kiefern in der Regel schneidend, öfters gerieft, oder sämtliche P M-artig. M vierhöckerig, Höcker gleich groß und paarweise zu Jochen verbunden. Vorderbeine meist kürzer als die Hinterbeine, an welchen die vierte Zehe stets am kräftigsten ist. Zweite und dritte Zehe reduziert und von einer gemeinsamen Haut umgeben. Schwanz meist lang und kräftig und teils als Greiforgan, teils zum Abschnellen dienend.

Lebend in Australien, Neuseeland, zum Teil auch in Neuguinea. Fossil im Pleistocän von Australien. 
1. Unterfamilie. Hypsiprymninae. Känguruh-Ratten.

Langgeschwänzte Beutler, höchstens von Kaninchengröße. $\frac{3.1 .1 .4}{1.0 .1-2.4} P_{4}$ in beiden Kiefern schneidend und an beiden Seiten gerieft. Extremitäten gleich lang. Hinterfuß meist füinfiehig.

A epy prymus und Bettongia (Fig. 512), letztere ohne Hallux, lebend in Australien, fossil im Pleistocän von Neu-Süd-Wales. Hypsiprymnodon mit zwei $P$.

Wynyardia Baldwin. Tertiär (Turritella Sandstein von Tablecap) vereinigt im Schädel- und Extremitätenbau Merkmale der Diprotodontia und Polyprotodontia. Systematische Stellung wegen des Fehlens der Zähne durchaus unsicher.

\section{Unterfamilie. Thylacoleoninae.} Owen.

31.3.1. Grosse ausgestorbene Beutler mit kräftigem ersten Incisiven. paar und langen schneidend entwickelten $P_{4}$. Die Lückenzähne und $M$ stark reduziert.

Thy lacoleo Owen. (Fig. 513.) Schädel dem des Löwen an Größe gleich kommend, hinten breit, Schnauze stark verkürzt und verschmälert. Jochbogen sehr kräftig, weit ausladend. Skelett unvollständig bekannt. Endphalangen der Füße große stark gekrümmte Krallen. Im Pleistocän von Australien, namentlich in Knochenhöhlen.

3. Unterfamilie. Phalangerinae. Kletter- und Flugbeutler.

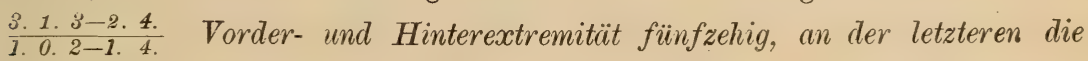
zweite und dritte Zehe dïnn und miteinander verbunden. vertreten.

Einige der in Australien lebenden Gattungen sind auch im Pleistocän

4. Unterfamilie. Macropodinae. Kängurus.

$\frac{\text { 3. } 0-1.2-1.4 .}{1.0 .2-1.4 .}$ Obere J meißelartig, untere nagezahnïhnlich, horizontal. $P$ und $M$ mit hohen Querjochen. Hinterbeine stark verlängert, fünfte, zweite und dritte Zehe reduziert, und die beiden letzteren in einer gemeinsamen Haut steckend. Hallux rudimentär.

Neben den in Australien lebenden Gattungen Macropus Shaw (Halmaturus Illiger) finden sich im dortigen Pleistocän eine Anzahl fossiler Formen (Sthenurus, Palorchestes etc.) von zum Teil riesiger Größe.

\section{Familie. Phascolomyidae. Wombate.}

Nagerähnliche plumpe Pflanzenfresser mit dickem Kopf, kurzem Hals, kurzen Beinen und stummelartigem Schwanz. $\frac{3-1.0 .1 .4}{1.0 .1 .4 .} J$ oben und unten verlängert, Backenzähne brachyodont oder prismatisch. Extremitäten plump, fünfzehig, vordere und hintere fast gleich lang. Lebend und im Pleistocän von Australien.

Phascolarctus Blainv. $\frac{3}{1} J$. Backenzähne brachyodont mit je vier, teils $\bigvee$-förmigen, teils mehr konischen Höckern. 
Phascolomys Geoffroy. $\frac{1}{1} J$. Backenzähne zylindrisch, aus zwei Querjochen bestehend, von denen jedes aus zwei $\bigvee$-förmigen Höckern zusammengesetzt ist.

Phascolonus Owen, fossil im Pleistocän, unterscheidet sich nur durch seine viel beträchtlichere Größe.

Nothotherium und Diprotodon Owen. $\frac{2}{7} J$. (Fig. 514.) Von der letzteren Gattung, welche fast Rhinozerosgröße besaß, kennt man eine Anzahl Skelette vom Kallabonnasee. Am Hinterfuß sind alle Knochen der ersten Zehe zu einem einzigen Stück verschmolzen. Hand und Fuß bestehen praktisch fast nur aus den vergrößerten Carpalien und Tarsalien und dem fünften Metapodium. $P$ und $M$ aus je zwei durch ein breites Tal getrennten Querjochen gebildet. Beide Gattungen nur fossil.

\section{Unterordnung. Polyprotodontia. Owen.}

Fleisch-oder Insektenfresser von meist geringer oder mittlerer Größe. Gebiß vollstündig. Im Oberkiefer 4-5, selten 3, im Unterkiefer 3-4 kleine J. C spitz und hoch, zuweilen zweiwurzelig, $P$ einspitzig, seltener mit Nebenspitzen, meist zweiwurzelig, M bei fossilen Formen öfters in grïßerer Anzahl, bei den rezenten in Vierzahl vorhanden, trikonodont oder trituberkulär.

$\mathrm{Zu}$ den polyprodonten Beuteltieren gehören die australischen Myrmecobiidae, Peramelidae, Dasyuridae, die amerikanischen Didelphyidae und eine große Anzahl fossiler Formen, unter denen sich die pleistocänen und tertiären enge an lebende anschließen, während die mesozoischen eigentüm-

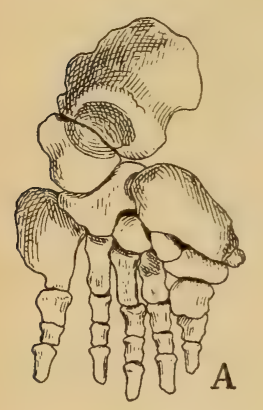

Fig. 514

Diprotodon australis Owen. Pleistocän. Kallabonna-See Australien. $A$ rechter Vorderfuß, $B$ rechter Hinterfuß, stark verkleinert. (Nach Stirling und Zietz.) liche primitive Merkmale aufweisen, die ihre Einteilung in das zoologische System erschweren. O w e n betrachtete die letzteren als Vorläufer der Polyprotodontia, betonte jedoch bereits ihre Beziehungen $\mathrm{zu}$ den placentalen Insektivoren.

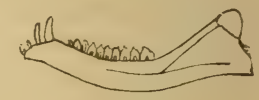

Fig. 515.

Dromatherium sylvestre Emmons. Ob. Trias. Chatham, Nordcarolina. Unterkiefer nat. Gr.

\section{Familie. Dromatheriidae Osborn.}

(Protodonta Osborn? Promammalia Haeckel).

$P$ griffelförmig, einspitzig. $M$ mit großer Hauptspitze und schwacher Vorderund Hinterspitze, die Wurzel unvollkommen geteilt. Unterkiefer hauptsächlich aus dem Dentale bestehend, höchstens mit schwachem Eckfortsatz.

Diesen winzigen und nur durch spärliche Überreste vertretenen Formen wird jetzt eine hervorragende phylogenetische Bedeutung beigelegt, weil sie die Cynodontia mit den Säugetieren verbinden sollen.

Dromatherim Emmons (Fig. 515) mit 3. 1.4.6 im Unterkiefer. Untere $J$ aufrecht, vordere $P$ vorwärts geneigt, Unterkiefer ohne Eckfortsatz und Microconodon Osborn mit niedrigeren $M$ und schwachem Eckfortsatz, vielleicht mit getrenntem Angulare am Unterkiefer. Obere Trias von NordCarolina. 
Tribolodon Seeley. $M$ mit kräftigen Nebenspitzen, aber undeutlicher Wurzelteilung, ohne Eckfortsatz und Karoomys Broom aus der Trias von Südafrika, der letztere ganz ungenügend bekannt.

\section{Familie. Triconodontidae. Osborn.}

Kleine Beutler mit $4 P$ und 3-6 M. Wurzeln der Backenzähne vollständig geteilt. $P$ ähnlich den $M$ aber einfacher. $M$ mit je drei in einer Reihe stehender Spitzen und starkem Basalband. C zuweilen zweiwurzelig. Winkel des Unterkiefers einwïrts getriimmt. Condylus nicht scharf vom Eckfortsatz geschieden. Kronfortsatz breit. Zahnuechsel auf den letzten $P$ beschränkt. Jura von England und Nordamerika.

Triconodon Oren (Tricanthodon Owen). (Fig. 516.) $\frac{\text { ?. 1. 4. 3-4. }}{3.3 .4 .3-4 .}$ Oberer $C$ zweiwurzelig. $P$ mit kleiner Vorder- und Hinterspitze, IV mit drei fast gleich starken Spitzen. Purbeck-Schichten von England.

Priacodon Marsh. Oberer Jura von Wyoming.
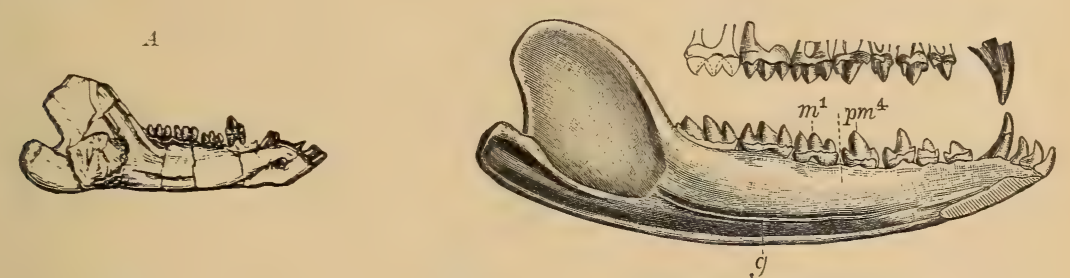

Fig. 516.

Triconodon mordax Owen. Purbeck-Schichten von Durdlestone Bay, Dorset. A Unterkiefer (nat. Gr.) nach Owen. $B$ Oberkieferzähne und Unterkiefer $2 / 1$ restauriert. (Nach Osborn.)

Amphilestes Owen. 4.1.4.5. $P$ und $M$ wenig verschieden. Mittelspitze höher als die vordere und hintere. Großoolith. Stonesfield. England.

Phascolotherium Owen. $\overline{4.1 .2 .5}$. Hinter dem $C$ eine Lücke. Mittelspitze der $P$ und $M$ höher als die Nebenspitzen. Großoolith von England.

Menacodon Marsh. ?. 1.3. 4 . Nebenspitzen kleiner als Hauptspitze und etwas einwärts gerückt. Oberer Jura. Wyoming.

Tinodon Marsh. Ebendaher. Owen.

Spalacotherium Owen. $\overline{3.1 .4 .6 .}$ Purbeck. England. Sp. tricuspidens

\section{Familie. Myrmecobiidae.}

Die in Australien lebende Gattung Myrmecobius steht den mesozoischen Pantotheria in der Zahnzahl und in der Kieferform sehr nahe.

\section{Familie. Peramelidae.}

Extremitäten stark spezialisiert. Hand öfters zum Graben eingerichtet. Fuß mit reduzierten Seitenzehen. Im Pleistocän von Australien durch spärliche Reste vertreten.

\section{Familie. Notoryctidae.}

Extremitäten ähnlich wie beim Maulwurf zum Graben spezialisiert. Notoryctes Stirling. Lebend in Australien. 
6. Familie. Pantotheriidae. (Trituberculata Osborn, Puntotheria Marsh.)

Kleine Insektivoren, ohne umgebogenen Unterkiefereckfortsatz, mit primitiven tuberkulärsektorialen unteren $M$ und trituberkulären oberen $M$. Untere $J$ meist. vorwärts geneigt, $P_{3}$ und $P_{4}$ größer als $M$. Meist 11 Zühne - $4 P, 7 M-$ hinter dem meist zweiwurzeligen $C$. Jura und Kreide von England und Nordamerika.

Diese kleinen, auf das jüngere Mesozojcum beschränkten Formen werden jetzt von $\mathrm{O}$ sborn zu den Placentalia gestellt. Es läßt sich zwar nicht läugnen, daß manche von ihnen gewiß den Ausgangspunkt für Insectivora und allenfalls auch für Credontia darstellen, allein sie schließen sich doch auch einerseits an die Triconodonta und anderseits an Myrmecobius an, von welchen der letztere trotz der kaum bemerkbaren Umbiegung des Eckfortsatzes zu den Marsupialia gehört und dürften daher schon wegen der zahlreichen $M$ doch besser ebenfalls zu diesen gestellt werden. An den unteren $M$ ist das aus Protoconid, Paraconid und Metaconid bestehende Trigonid wohl entwickelt, das Talonid hingegen noch sehr klein und meist nur durch einen Zacken repräsentiert. Auch werden die $M \mathrm{zu}$ weilen durch Reduktion einspitzig. $\mathrm{Zu}$ den drei Höckern der oberen $M$ kommen manchmal noch Nebenhöcker.

\section{Unterfamilie. Amphitheriinae. Owen.}

Untere $J$ fast senkrecht, untere $M$ tuberkulärsektorial mit kräftigem Talonid, zweiwurzelig. Kronfortsatz breit, Eckfortsatz gerundet, abwärts gerichtet. Gelenk tiefstehend. Hinter C 9-12 Zähne.

Amphitherium Owen (Thylacotherium Val.). (Fig. 517.) Dogger von England. 4.1.5.6. Ein schon im Jahre 1818 gefundener Kiefer wurde von Cuvier einem Beuteltier, von Blainville hingegen einem Reptil zugeschrieben.

\section{Amphitylus Owen. Ebenda.}

Peramus, Leptocladus Owen. Oberer Jura. Purbeck von England.

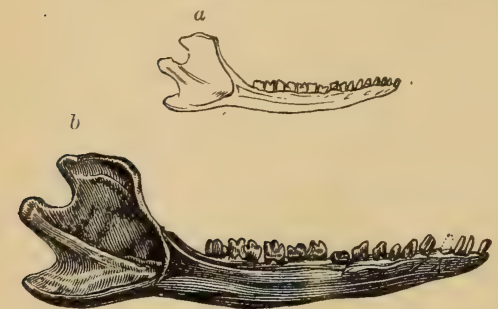

Fig. 517

Amphitherium Prevosti Blv. Dogger. Stonesfield bei Oxford. Linker Unterkiefer von außen; $a$ in nat. Gr., b vergr. (Nach Owen.)

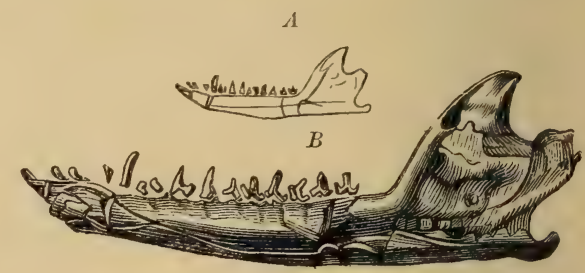

Fig. 518 .

Amblotherium soricinum Owen. Ob. Jura. Purbeck. England. Rechter Unterkieferast. $A$ in nat. Gr. $B$ vergr. (Nach R. Owen.)

2. Unterfamilie. Amblotheriinae Osborn. (Stylacodontidae Marsh.)

$M$ allmählich einspitzig und einwurzelig werdend. $C$ einwurzelig, Coronoidfortsatz schlank, Unterkiefereckfortsatz nicht scharf abgesetzt. J vorwärts geneigt, $P_{3}$ und $P_{4}$ größer als $M$. Hinter C 11-12 Zähne.

Amblotherium Owen. (Fig. 518.) Oberer Jura. Purbeck England. 4. 1. 4. 7. Hierher vielleicht die oberen $M$ von Peralestes Owen, die außer Protocon, Metacon und Paracon auch Parastyl und Metastyl besitzen. England.

Peraspalax Owen und Achyrodon Owen. Oberer Jura. Purbeck

Phascolestes (Dryolestes.) Marsh. Oberer Jura. Wyoming. 
Laodon und Asthenodon Marsh. Ebenda.

Stylodon Owen. (Stylacodon? Marsh.) Obere M Kurtodon Owen. (Fig. 519.) Oberer Jura. Purbeck von England.

\section{Unterfamilie. Paurodontinae Marsh.}

M zweiwurzelig, undeutlich tuberkulärsektorial, mit winzigen Nebenzacken. Unterkiefer kurz und massiv. Hinter Chöchstens 7 Zähne. Jura von Wyoming. Paurodon Marsh. Wohl 3.1.4.3. wie die meisten Placentalier.

\section{Unterfamilie. Diplocynodontinae Marsh.}

Obere $M$ mit großem Protocon, untere $M$ mit breitem, beckenförmigem Talonid. Jura von Wyoming.

Diplocynod on Marsh. (Dicrocynodon Marsh.) 3. 1.4.8. (Fig. 520). Mittelspitze der $M$ und $P$ hoch. Kronfortsatz breit. Eckfortsatz klein. Kiefergelenk höher als die Zahnreihe.

Marsh.

Enneodon, Docodon

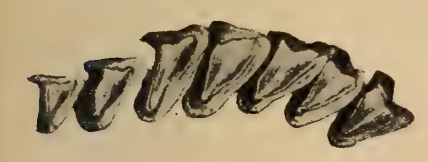

Fig. 519 .

Kurtodon Osborn. Obere Backenzähne. Oberer Jura von England, vergrößert. (Nach Osborn.)

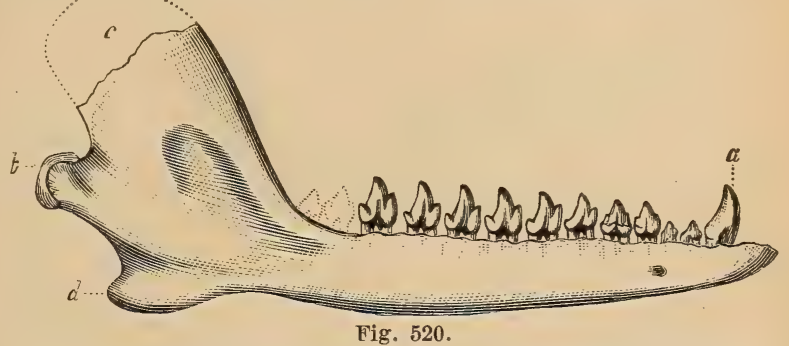

Dicrocynodon victor Marsh sp. Ob. Jura. Wyoming. Recht. Unterkiefer von außen. 2/1. (Nach Marsh.) $a$ Eckzahn, $b$ Condylus, $c$ Kronfortsatz, $d$ Winkel.

\section{Familie. Dasyuridae. Ra u b b eutler.}

Carnivore Beutler von mittlerer Größe. $\frac{3-4.1 .3 .4}{3.1 .3 .4 .} J$ und $C$ normal entwickelt. Obere $M$ trituberkulär mit zwei üußeren Spitzen, einer großen Innenspitze, Protocon, und einem schneidenden Metastyl. $M^{4}$ meist stark reduziert. Untere $M$ mit schneidendem Vorderzacken - Paraconid - und Hauptzacken - Protoconid - und kleinem grubigen oder sekodonten Talonid, aber ohne Metaconid. $P$ in beiden Kiefern ein-
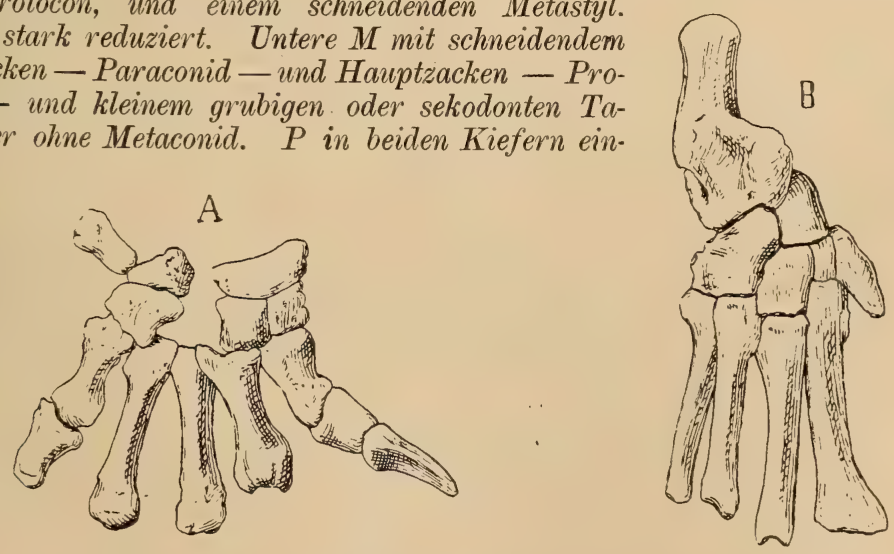

Fig. 521.

Cladosictis lustratus Ameghino. Obermiocän. Santa Cruz. Patagonien. $A$ Hand, $B$ Fuß, nat. Gr. (nach Sinclair.)

spitzig, zweiwurzelig, von vorne nach hinten gleichmäßig größser werdend, selten $P_{4}$ vergrößeert. Vorderfuß mit fünf bekrallten Zehen; Hinterfuß mit 5 oder 4 Zehen, Hallux häufig reduziert, zuweilen fehlend. Unterkiefereckfortsatz einwärts gebogen. 
Bei den noch in Australien lebenden und daselbst auch im Pleistocän vorkommenden Gattungen Dasyurus Geoffr. Sarcophilus Cuv. und Thylacinus Temm. wird nur der hinterste der drei $P$ gewechselt. Auch hat der Gaumen eine Lücke.

Bei den folgenden, auf das patagonische Tertiär beschränkten Gattungen - den Sparassodonta Ameghinos - fehlt die Gaumenlücke und der Zahnwechsel soll sich auch auf den $C$, sowie auf zwei $P$ erstrecken. Der Schädel ist groß, Hals und Schwanz lang, Beine kurz.

Cladosictis Ameghino (Fig. 521). $\frac{4}{3} J . M^{1-3}$ mit kräftigem Protocon $M^{4}$ stark reduziert. Untere $M$ mit mäßig starkem Talonid. $P$ gleichmäßig an Größe zunehmend. Schädel mit Alisphenoidbulla. Hallux reduziert. Humerus mit Foramen entepicondyloideum. Krallen spitz, komprimiert. Miocän. Santa Cruz.

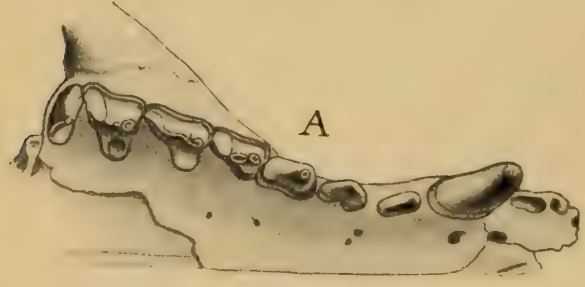

B

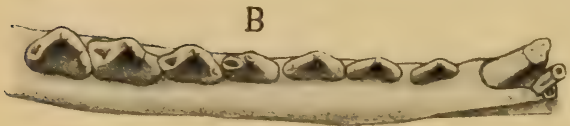

Fig. 522

Amphiproviverra manzaniana Ameghino. Obermiocăn. Santa Cruz. A obere, $B$ untere Zabnreihe. Nat. Gr. (nach Sinclair.)

Hathlyacynus Mercerat. Ebenda. Procladosictis, Pseu. docladotictis Ameghino. Eocän. Notostylopsschichten.

Amphiproviverra (Protoproviverra) Ameghino. (Fig. 522.) $\frac{4}{3} J$. Obere $M$ mit drei kräftigen Spitzen und kurzem Metastyl. $M^{4}$ wenig reduziert. Untere $P$ und $M$ schlank, die $M$ mit großem beckenförmigem Talonid. Hallux groß, opponierbar. Humerus ohne Foramen. Krallen spitz. Miocän. Santa Cruz.

Perathereutes, Sipalocyon, Agustylus, Acyon, Ictioborus Ameghino. Miocän. Santa Cruz.

Prothylacinus Ameghino. $\frac{4}{3} J$. $M^{1}$ und $M^{2}$ mit deutlichem, $M^{3}$ ohne Protocon, $M^{4}$ mit kleinem Protocon und Metacon, $P^{4}$ wenig größer als $P^{3}$. Untere $M$ mit schwachem Talonid. Schädel lang, ohne Alisphenoidbulla. Unterkiefer mit fester Symphyse. Hallux stark reduziert. Krallen spitz, zusammengedrückt. Miocän. Santa Cruz.

Napodonictis Ameghino. Ebenda. Pseudothylacinus Ameghino. Miocän. Colpodonschichten.

Borhyaena Ameghino. $\frac{3}{3} \mathrm{~J}$. Zähne plump, dicht aneinanderschließend. $M^{4}$ knopfartig. Talonid nur an $M_{1}$ und $M_{2}$ gut entwickelt. Schädel kurz, mit weit abstehenden Jochbogen. Ohne Alisphenoidbulla. Humerus ohne Entepicondylarforamen. Endphalangen stumpf, rundlich, an der Spitze gespalten. Miocän. Santa Cruz.

Acrocyon, Conodonictis Ameghino. Ebenda. Pseudoborhyaena. Miocän. Colpodonschichten. Proborhyaena, Pharsaphorus. Ameghino. Pyrotheriumschichten.

\section{Familie. Didelphyidae. Beutelratten.}

Meist kleine karnivore Beutler. $\frac{5.1 .3 .4 .}{4.1 .3 .4 .}$ J klein, dicht gedrängt. C stark entwickelt. Dem letzten, meist sehr hohen $P$ geht ein lange funktionierender Milchzahn voraus. Obere $M$ trituberkulär dreieckig, Protocon, Paracon und Metacon $\checkmark$ förmig, am Außenrand in der Regel einige kleine Basalhöcker vorhanden. Un- 
tere $M$ tuberhulärsehtorial mit kräftigem Metaconid und mehrhöckerigem, wohlausgebildetem Talonid. Extremitäten fünfzehig, Hallux opponierbar. Humerus mit Entepicondylarforamen.

Die beiden lebenden Gattungen Didelphys und Chironectes sind in Amerika verbreitet von Patagonien bis Canada. Fossile Vertreter sind im älteren Tertiär von Europa und Nordamerika nicht selten, in Südamerika im Tertiär und Pleistocän. Die ältesten Formen kennt man aus der Kreide. Laramiebed von Nordamerika. Von den Gattungen Didelphops, Cimolestes, Pediomys, Telacodon und Batodon Marsh aus der oberen Kreide von Wyoming sind nur isolierte Zähne und Kieferfragmente bekannt.

Didelphys Lin. (Peratherium Aymard. Oxygomphius Meyer, Amphiperatherium Filhol, Herpetotherium, Embassis Cope. (Fig. 523.) 5.1.3.4. Außer den drei $\vee$ förmigen Haupthöckern auch Nebenhöcker am Außenrand der oberen $M$ vorhanden. Untere $M$ schlank. In Europa vom Obereocän bis Untermiocän, in Nordamerika im Eocän, Oligocän und Pleistocän.

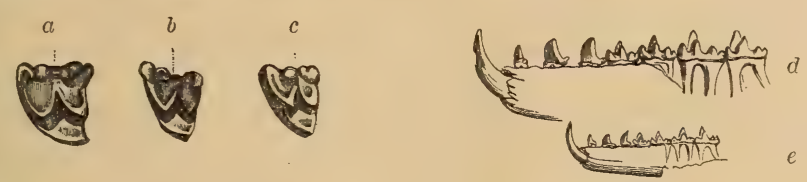

Fig. 523.

Didelphys (Oxyomphius) frequens H. v. Meyer. Miocän. Eckingen bei Ulm. $a, b, c$ drei Oberkieferzähne vergr. 3/1. $e$ Unterkiefer in natürl. Gr. und $d$ vergr. (Nach Schlosser.)

Microbiotherium Ameghino. $J$ kräftig. Obere $M$ aus drei konischen Höckern und einfachem Basalband bestehend, untere massiv mit großem Talonid. Obermiocän. Santa Cruz. Daselbst die problematischen Gattungen Hadrorhynchus, Stylognathus, Eodidelphys. Im Eocän, Notostylopsschichten von Patagonien Ideodidelphys Ameghino. Proteodidelphys Ameghino aus angeblichen Kreideschichten Patagoniens.

\section{Familie. Caroloameghinidae Ameghino.}

$\frac{5.1 .3 .4 .}{4.1 .34} C$ klein, $P$ einfach langgestreckt. Obere $M$ trituberkulär mit Zuischenhöcken. Untere $M$ mit niedrigem Trigonid und großem Talonid und Nebenhöcker vor und hinter dem hohen Metaconid. Unterkiefer schlank und niedrig.
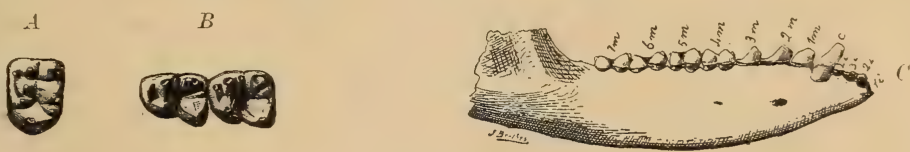

Fig. 524 .

Caroloameghinia nater Ameghino. Eocän. Notostylopsschichten. Patagonien. A oberer Molar. $B$ unteren Molaren. $3 / 1$ nat. Gr. $C$ Unterkiefer, nat. Gr. (nach A meghino.)

Die Form der $M$ erinnert teils an Primaten, teils an Nager.

Caroloameghinia Ameghino. (Fig. 524.) Eocän. Notostylopsschichten von Patagonien. 


\section{Zeitliche und räumliche Verbreitung der Marsupialier.}

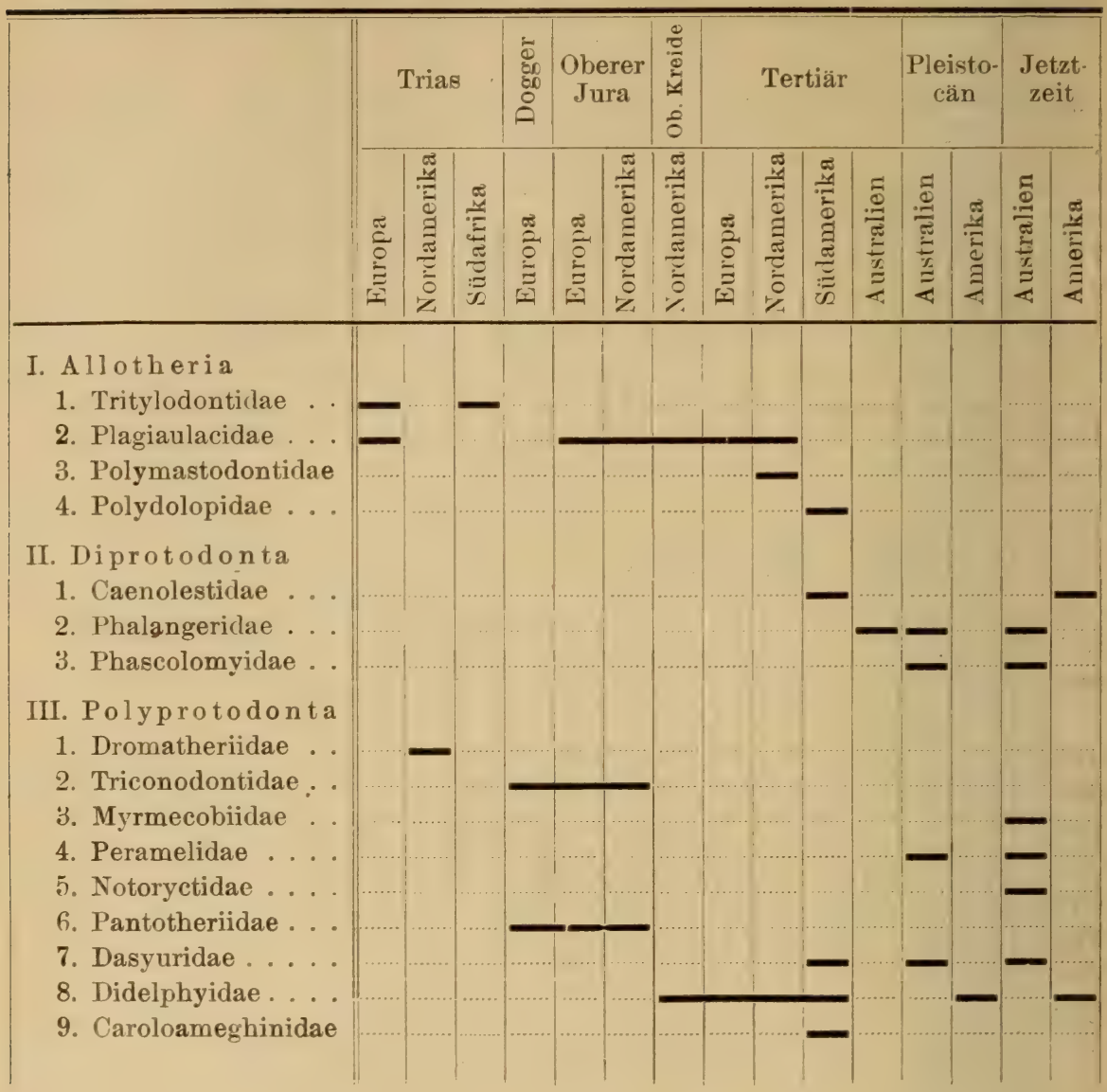

B. Unterklasse. Placentalia.

1. Ordnung. Insectivora. Insektenfresser. ${ }^{1}$ )

Meist kleine, in der Regel fünfzehige, bekrallte Sohlengänger. $J$ manchmal teilweise vergrößert, nicht selten teilweise reduziert. $C$ wenig von den $J$ und $P$ verschieden, 'manchmal auch groß und zweiwurzelig oder auch verkümmert, $P$ zugespitzt, letztere öfters sekodont, $M$ lophodont oder bunodont, die unteren mit meist fünf scharfen Höckern, die oberen tri-

1) Dobson G. E., Monograph of the Insectivora, systematical and anatomical. London 1882-90. - Gaillard Cl., Mammifères miocènes. Arch. Mus. Hist. nat. Lyon. T. VII. 1899. - Gregory W. $K$., The orders of Mammals. Bull. Amer. Mus. Nat. Hist. 1910. - Leche W., Zur Entwicklungsgeschichte des Zahnsystems der Säugetiere. Bibliotheca zoologica. Bd. XV. 1902. Bd. XX. 1907. - Matthew C. W., The Carnivora and Insectivora of the Bridger Basin. Middle Eocene. Mem. Amer. Mus. Tat. Hist. New York 1909. - Osborn H.F., American Eocene Primates and the Mixodectidae. Bull. Amer. Mus. Nat. Hist. New York 1902. - Schlosser M., Beitr. z. Paläontol. Österr.-Ung. Bd. VI 1887. 
oder quadrituberkulär, Milchgebiß meist frühzeitig ausfallend, selten funktionierend. Gehirn klein, mit glatten Hemisphären. Schlüsselbeine fast immer vorhanden.

Die typischen Insectivoren sind kleine, häufig unterirdisch lebende, grabende, nächtliche, seltener kletternde oder schwimmende Landtiere, welche sich von Insekten und Würmern nähren. Sie bilden unter den Placentaliern die primitivste Ordnung und haben enge Beziehungen zu den polyprotodonten Beuteltieren, wenigstens zu den Pantotheriidae. Jetzt werden ihnen auch eine Anzahl gänzlich erloschener Formen angereiht, die zum Teil ansehnliche Körpergröße besitzen und früher teils $\mathrm{zu}$ den Primaten gestellt, teils für eine besondere Ordnung angesehen wurden:

Gegenwärtig bewohnen die Insectivoren nur die Alte Welt und Nordamerika, sie fehlen dagegen in Südamerika und Australien. Die fossilen Formen haben im wesentlichen die nämliche Verbreitung, nur eine Gattung ist bloß auf Südamerika beschränkt. Sie beginnen mit ziemlich vielen, großenteils erloschenen Formen im Eocän und Oligocän von Nordamerika, spielen aber hier im späteren Tertiär nur eine untergeordnete Rolle, während sie in Europa vom Oligocän bis in das Obermiocän trotz ihrer Kleinheit keineswegs zu den Seltenheiten gehören.

Der Schädel zeichnet sich durch gestreckte, niedrige Form, durch das breite Hinterhaupt, durch die meist starke Entwicklung der Gesichtsknochen, die hinten meist offenen Augenhöhlen, die unvollständige Verknöcherung der Gehörkapsel, durch das ringförmige Tympanicum und durch die Kleinheit der Gehirnhöhle aus. Die Großhirnhemisphären sind glatt, der Jochbogen ist zuweilen ver. kümmert. Die Lendenregion besitzt öfters Intercentren. Der Humerus hat in der Regel ein Entepicondylarforamen. Ulna und Radius bleiben getrennt, dagegen sind Tibia und Fibula häufig distal verwachsen. Das Femur trägt manchmal einen dritten Trochanter. Die plantigrade Hand ist fast immer fünf-, sehr selten vierfingerig. Der Hallux kann verschwinden. Bei den grabenden Formen sind die Knochen der Vorderextremität stark spezialisiert.

Das Gebiß enthält alle Arten von Zähnen, doch sind die $C$ und die vorderen $P$ oft sehr wenig voneinander verschieden. Die normale Zahnzahl $\frac{\text { 3.1. 4.3 }}{3.1 .4 .3}$ erleidet manchmal eine Reduktion. Die $J$ sind zuweilen stark verlängert, fast nagezahnartig und mit Nebenzacken versehen und der $C$ hat nicht selten zwei Wurzeln. Die Zahl der $M$ übersteigt niemals die Zahl 3 . Der letzte $P$ wird manchmal $M$-artig. Die $M$ sind secondont, die oberen meist trituberkulär, selten quadrituberkulär, ihre Höcker frei oder durch Joche verbunden. Die unteren bestehen aus einem dreizackigen Trigonid und einem niedrigen, oft sehr kleinen zweispitzigen Talonid. Der Zahnwechsel erfolgt häufig schon im Embryonalzustand, bei einigen Gattungen erhält sich hingegen das Milchgebiß sehr lange. Die Insectivoren zerfallen in zwei Unterordnungen: die Menotyphla, deren Symphyse von den beiden Pubes und Ischia gebildet wird und die Lipotyphla, bei welchen eine Symphyse entweder fehlt oder sich nur auf die beiden Pubes erstreckt. Die Menotyphla umfassen die in Ostasien lebenden 
Tupajidae und die afrikanischen Macroscelididae. Sichere fossile Formen sind hiervon nicht bekannt.

Die Lipotyphla werden eingeteilt in Zalambdodonta und Dilambdodonta, welchen jetzt noch mehrere ausgestorbene Familien angereiht werden, die teils Anklänge an Primaten, teils an Creodontier, teils an Nager aufweisen.

\section{Unterordnung. Zalambdodonta. Gill.}

Obere M infolge der Reduktion der Außenhöcker undeutlich trituberkulär, untere mit kräftigem Trigonid und stark reduziertem Talonid.

\section{Familie. Chrysochloridae.}

Diese jetzt in Südafrika lebende und nach Art der Maulwürfe spezialisierte, aber mit hypselodonten $P$ und $I$ versehene Familie soll in Nordamerika im Oligocän (White Riverbed) einen Vertreter besitzen in Xenotherium Douglass.

\section{Familie. Necrolestidae. Scott. ${ }^{1}$ )}

Necrolestes Ameghino. 4.1.3.3. $J$ klein, $C$ normal entwickelt, $P_{2}$ in beiden Kiefern zweiwurzelig, der untere mit Vorder- und Hinterspitze, die übrigen wie die $M$ hypselodont und trituberkulär. Im Schädel-, Zahnbau und Spezialisierung der Extremitäten sehr ähnlich den südafrikanischen Chrysochloridce, aber langschnauziger. Obermiocän von Santa Cruz. Patagonien.

\section{Familie. Centetidae.}

Diese Familie ist heutzutage auf Madagaskar beschränkt, mit Ausnahme der auf Kuba lebenden Gattung Solenodon und mit den westafrikanischen

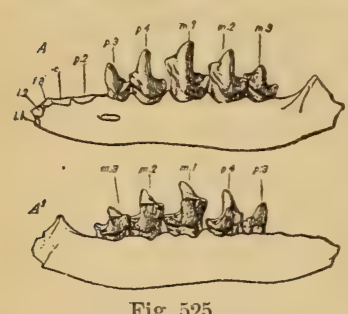

Fig. 525.

Micropternodus borealis Matthew. Oligocän. Unterstes White Riverbed Montana. Unterkiefer von außen und innen. $2 / 1$ nat. Gr. (nach Matthew.) Potamogalidae nahe verwandt. Fossil in Nordamerika. Oligocän (White Riverbed) von Montana.

Micropternodus Matthew. (Figur 525.) 3.1.3.3. $M$ wie bei Centetes aus hohem Trigonid und kleinem Talonid bestehend.

Apternodus Matthew. 2.1.3.3. Talonid sehr stark reduziert. $P^{4}$ in beiden Kiefern $M$-artig. Schädel dem von Ericulus ähnlich, aber durch die starke Entwicklung des Mastoids ausgezeichnet.

\section{Unterordnung. Dilambdodonta. Gill.}

Obere .II echt trituberkulär, oft mit Hypocon versehen. Untere II tuberkulär sektorial, mit kräftigem Talonid.

\section{Familie. Leptictidae. Cope.}

$\frac{2.1 .4 .3 .}{2-3.1 .4 .3 .}$ Obere $M$ sehr breit, dreieckig, trituberkulär, meist mit schwachem Hypocon. Außenhöcker konisch. $J$ spitz, wenig verschieden von den C. $P_{4}$ in beiden Kiefern M-artig. Schädel meist mit zuei Scheitelkämmen, schlanken Jochbogen und spitzer, mäßig langer Schnauze. Humerus mit Entepicondylarforamen.

1) Report of the Princeton Univers. Exped. to Patagonia. 1905. Vol. V. Part. II. 
Palaeictops Cope. Untereocän (Wasatchbed) von Nordamerika, Phenacops Matthew, Diacodon Cope.

Leptictis, Ictops Leidy. (Fig. 526.) Schädel mit doppeltem Scheitelkamm. Oligocän. White Riverbed von Nordamerika.
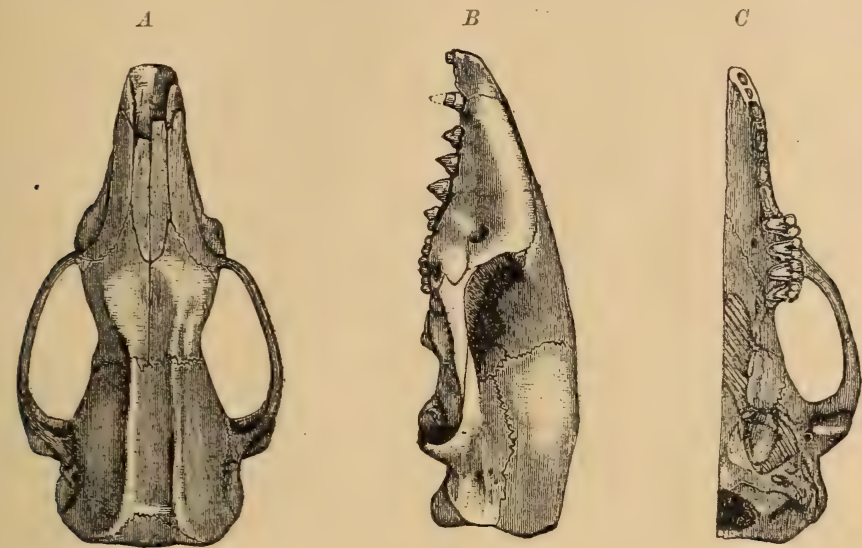

Fig. 526.

Leptictis Haydeni Leidy. Unt. Miocän. Dakota. Schädel von oben, von der Seite und unten. Nat. Gr. (Nach Leidy.)

\section{Familie. Talpidae. Maulwürfe.}

$\frac{3-2.1 .4-3.3 .}{3-1.1 .4-3.3 .}$ Obere II trituberkulür, Außenhöcker $\vee$ förmig. Schnauze stark verlängert, Jochbogen dünn. Bullae osseae gewölbt. Vorderextremität als breites, schaufelartiges Grabwerkzeng entwickelt. Tibia und Fibula distal verschmolzen. Becken stark verlängert. Schwanz kurz.

Die Talpiden sind kleine, unterirdisch lebende Wühler mit verkümmerten Augen und langer Schnauze. Beim Maulwurf reicht das Manubrium bis unter den zweiten Halswirbel und nimmt vorne das kurze fast quadratische Schlüsselbein auf, welches mit dem distalen Énde des kurzen, stark verbreiterten Humerus artikuliert und durch Bänder mit der schmalen langgestreckten Scapula verbunden ist. Der $\mathrm{Hu}$ merus besitzt einen weit vorspringenden Deltoidkamm und neben jedem Condylus einen spornartigen Fortsatz. In den oligocänen Phosphoriten von

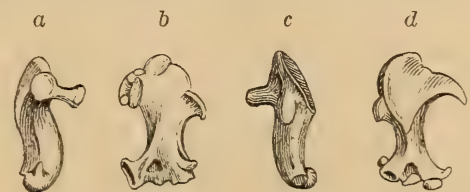

Fig. 527.

Talpa Meyeri Schlosser. Unt. Miocän. Weisenau bei Mainz. Humerus $a$ von innen, $b$ von hinten, $c$ von außen, $d$ von vorne, $e$ von unten. Nat. Gr. (Nach Schlosser.)

Quercy Amphidozotherium Filhol, im europäischen Miocän die Gattungen Scaptonyx M. Edwards, Proscapanus Gaillard und Talpa Linn (Fig. 527), die letztere auch im Pliocän und Pleistocän. Eine Art auch im Miocän von Montana.

Proscalops Matthew. (Fig. 528.) $J$ vergrößert. $P$ mit Ausnahme von $P^{4}$ klein. Zähne niedriger als bei Scalops. Schädel hinten stark verbreitert. Untermiocän. Colorado.

Domnina Cope. Oligocän. White Riverbed von Nordamerika.

Nyctitherium (Talpavus, Nyctilestes) Marsh. Obere $M$ mit kräftigem Hypocon. Mittleres Eocän. Bridgerbed von Nordamerika. 
Entomacodon (Centracodon) Marsh. Myolestes und Entomolestes Matthew. Ebendaselbst.

Echinogale Pomel im Untermiocän von Frankreich. Sysîtematische Stellung unsicher.

Myogale Cuvier. Lebend und im Pleistocän von Europa.

\section{Familie. Soricidae. Spitzmäuse.}

Die Spitzmäuse zeichnen sich durch kräftige, im Oberkiefer vierzackige $M$ und durch die Vergrößerung des vordersten $J$ aus. Der obere $J$ ist hakenförmig, der untere steht horizontal und besitzt einen zugeschärften oder gezackten Oberrand. Die zwischen diesen $J$ und den $M$ befindlichen Zähne $\frac{4-6}{2}$ sind mit Ausnahme des $P^{4}$ wenig, die Extremitätenknochen dagegen stark differenziert. Überreste von Soriciden finden sich in Europa vom Oligocän an, Phosphorite von Quercy, im Untermiocän von Ulm und Mainz, im Obermiocän von La Grive St. Alban und im Pleistocän. Sie gehören den Gattungen Sorex Lin. (Fig. 529.) Crocidura und Crossopus Wagler an.

Protosorex Scott. Im Oligocän (White Riverbed) von Nordamerika mit zahlreichen $P$.

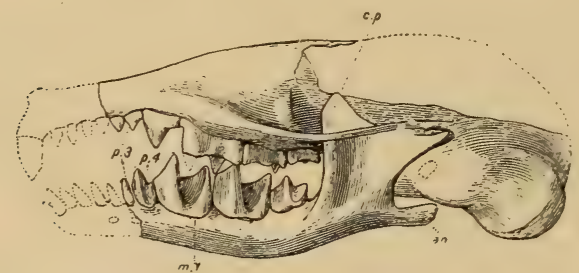

Fig. 528

Proscalops miocaenus Matthew. Miocän. Colorado. Schädel und Unterkiefer. $2 / 1$ nat. Gr. (nach Matthew.)

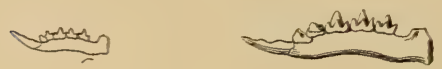

Fig. 529.

Sorex pusillus Meyer. Miocän. La Grive St. Alban. Isère. Unterkiefer von innen in nat. Gr. und vergr. (Nach Depéret.)

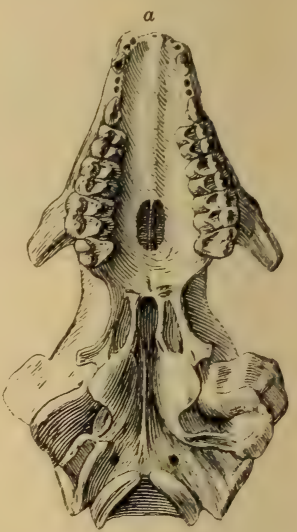

b)

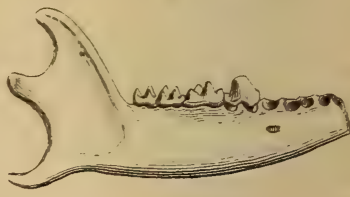

$c$

atcos?

Fig. 530 .

Necrogymnurus Cayluxi Filhol. Phosphorit. Quercy. $a$ Schädel von unten, $b$ Unterkiefer mit drei Molaren und $P_{4}$ von der Seite, $c$ derselbe von oben. Nat. Gr. (Nach Filhol.)

\section{Familie. Dimylidae.}

$\frac{2}{2} M$, davon $M_{1}$ in beiden Kiefern sehr gro $\beta$. J, C, P mit Ausnahme von $P_{4}$ sehr einfach. Humerus ähnlich dem von Talpa. Nur aus dem europäischen Miocän bekannt.

Dimylus und Cordylodon Meyer. Letzterer mit knopfförmigen $P$. Im Untermiocän.

Plesiodimylus Gaillard und Metacordylodon Schlosser im Ober. miocän. 


\section{Familie. Erinaceidae. Ig el.}

Obere $M$ meist vierhöckerig, viereckig. $P^{4} M$-ähnlich, die ïbrigen $P$ einfacher. Gymnurinae. $\frac{3 \text { 1.4.3. }}{3.1 .4 .3 .}$ C kräftig.

Necrogymnurus (Cayluxotherium) Filhol. (Fig. 530.) Eocän. Phosphorite von Quercy. cän Ronzon.

Tetracus Aymard. Oligo-

Galerix Pomel. (Parasorex v. Meyer.) (Fig. 531.) Im Obermiocän von Europa. als $\frac{4}{4} P$.

Erinaceina e mit weniger

Erinaceus. Linn. $\frac{3.1 .3 .3 .}{2.1 .2 .3}$ Vorderster $J$ vergrößert, die übrigen, sowie $C$ und $M^{3}$ reduziert. Obermiocän bis Gegenwart.

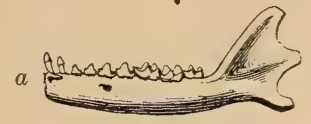

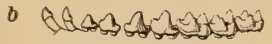

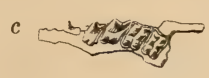

d

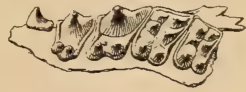

Fig. 531.

Galerix exilis Blv. sp. (Parasorex socialis H. v. Meyer.) Miocän. Steinheim, Württemberg. a Unterkiefer nat. Gr., $b$ Unterkieferzähne vergr., c Oberkiefer von GriveSt. Alban nat. Gr., $d$ vergr. (Nach Depéret.)

Palaeoerinaceus Filhol. Untermiocän.

Proterix Matthew. 3.1.3.3. Oligocän. White River. Süd-Dakota.

\section{Familie. Adapisoricidae Lemoine.}

Kleine ausgestorbene, unvollständig bekannte Insectivoren mit $2 J, 1 C, 4 P$, $3 M$ im Unterkiefer. Obere $M$ trituberkulär. Untere $J$ klein, nagezahnartig. C klein. $P$ zweiwurzelig mit Hauptspitze und Talonid. M mit hohem dreizackigem Trigonid und starkem, grubigem Talonid. Systematische Stellung durchaus unsicher. Adapisorex und Adapisoriculus Lemoine im untersten Eocän von Cernays und Ay bei Reims.

\section{Familie. Hyopsodontidae Schlosser.}

3.1.4.3. Schädel niedrig, Schnanze mäßig lang, mit breiter Stirn und breitem Hinterhaupt. Obere $M$ viereckig, sechshöckrig, untere vierhöckierig, Trigonid kaum höher als Talonid. Alle vorderen Zühne einspitzig, fast aneinander schließsend und allmählig in einander iibergehend, obere $P_{2}$ bis $P_{4}$ mit Innenhöcker, unterer $P_{4}$ sehr kompliziert.
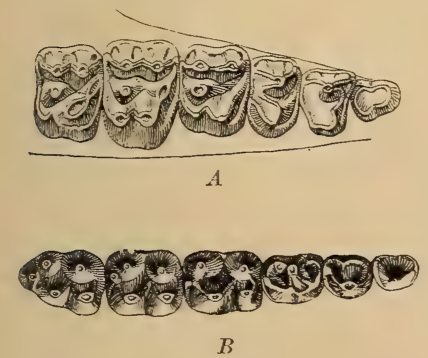

Fig. 532 .

Hyopsodus paulus Leidy. Eocän (Bridgerbed.) Wyoming. A obere Backzähne von unten vergr. $2 / 1$ nat. Gr. $B$ untere Backzähne von oben, $2 / 1$ nat. Gr.

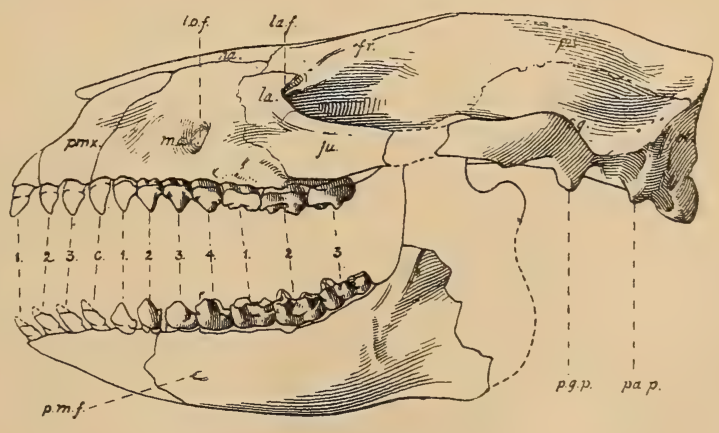

Fig. 533 .

Hyopsodus decipiens Matthew. Mitteleocän. Bridgerbed. Wyoming. Schädel und Unterkiefer nat. Gr. (nach Matthew.)

Diese gänzlich erloschene Familie wurde bisher vor kurzem wegen der Ähnlichkeit ihrer Zähne zu den Primaten gestellt. Der Schädel zeigt jedoch Anklänge an den von Erinaceus, und die Metapodien haben keine knopf- 
förmige, sondern eine gekielte distale Gelenkfläche. Auch fehlt die Opponierbarkeit der ersten Zehe und des Daumens. Wir haben es vermutlich mit dem Überrest einer Insectivorengruppe zu tun, welche dem Ausgangspunkt der Primaten sehr nahe steht. Sie schließt sich anderseits auch wieder an die kleineren Mioclaeniden an.

Hyopsodus Leidy (Lemuravus Marsh). (Fig. 532, 533.) J, C und die vordersten $P$ spitz, kegelförmig, $P^{3}$ und $P^{4}$ mit großen, dicken Außen- und $\bigvee$ förmigem Innenhöcker. Obere $M$ mit zwei kantigen Außen-, zwei $\bigvee$ förmigen Innenhöckern und zwei kräftigen Zwischenhöckern. Unterer $P_{4}$ mit großer Innenspitze und zweihügeligem Talonid. Untere $M$ mit vier stumpfen, undeutlich alternierenden Höckern und kleinem Hinterhöcker. An dem breiten Schädel steht die Augenhöhle seitlich; das Tympanicum bildet keine knöcherne Bulla. Humerus mit Entepicondylar- und Supratrochlearformen. Extremitätenknochen denen von Erinaceus ähnlich. Astragalus mit flacher Trochlea. Endphalangen klein, rundlich, nicht gespalten. Zahlreiche Arten im Eocän von Nordamerika. Wasatchbed. H. lemoinianus; miticulus Cope, Wind Riverbed. H. Wortmani Osborn, Bridgerbed. H. paulus, minusculus Leidy. Uintabed uintensis Osborn.

\section{Familie. Mixodectidae Cope (Proglires Osborn).}

3-1.1.3.3. Obere M nicht viel breiter als lang, mit konischen Ausen- und kleinen Zwischenhöckern, $\bigvee$ förmigem Protocon und schwachein Hypocon. Unterer und oberer $J_{1}$ vergrößsert und vorwïrts geneigt. $J_{1}$ und $J_{3}$ meist fehlend klein, ebenso $P_{1}$ oder $P_{2}$ oder fehlend, oder $P_{3}$ wie $P_{4}$ schneidend, mit hoher Spitze. $P^{4}$ anfangs zweihöckerig, später kompliziert. Untere $M$ mit fünf undeutlich alternierenden Höckern, die beiden inneren konisch, Protoconid und Hypoconid $\bigvee$ förmig. Paraconid mur als Kante entwickelt. Trigonid nicht viel höher als Talonid, das namentlich an $M_{3}$ sehr großs wird.

Die Backenzähne haben große Ähnlichkeit mit jenen der Anaptomorphiden, weshalb die Mixodectiden früher zu den Primaten gestellt wurden. Wegen der Vergrößerung des $J_{2}$ und der Reduktion der übrigen $J$ und der vorderen $P$ hielt sie Osborn für die Vorläufer der Nager und nannte sie Proglires. Wegen der Ähnlichkeit der $M$ mit denen der Hypsodontidae dürfte es sich empfehlen, sie ebenfalls provisorisch $\mathrm{zu}$ den Insectivoren zu stellen, obschon eine gewisse Verwandtschaft mit Primaten - Chiromysnicht ausgeschlossen $\mathrm{zu}$ sein scheint.

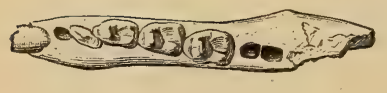

$B$

Fig. 534

A Microsyops gracilis Leidy, Oberkiefer. $B$ M. elegans, Unterkiefer. Mitteleocän. Bridgerbed

Wyoming (nach Wortman.)

Olbodotes Osborn. Mit 3 unteren $J$. Untereocän. Torrejonbed. Neu-Mexiko. O. Copei Osborn. Ein ähnlicher $M$ auch aus dem Fort Union. bed von Montana bekannt.

Mixodectes Cope. $J_{2}$ stark vergrößert. $P_{3}$ öfters noch vorhanden. Trigonid höher als Talonid. Ebenda. M. pungens Cope.

Microsyops Leidy. (Fig. 534.) (Limnotherium, Bathrodon, Mesacodon Marsh, Palaeacodon Leidy.) Talonid fast ebenso hoch wie Trigonid. Wind Riverbed. M. scottianus Cope. Bridgerbed. M. gracilis Leidy, speciosus Marsh.

Indrodon Cope. 2.1.3.3. Nur Oberkiefer bekannt. $P$ einfach. Untereocän. Torrejonbed.

bed. Cynodontomys

Smilodectes Wortman. $P_{4}$ kurz. Mitteleocän. Bridgerbed. S. gracilis Marsh sp. 
Metolbodotes Schlosser. Mit $3 J$. Höcker der $M$ innig miteinander verbunden. $M_{1}>M_{2}$ und $M_{2}>M_{3}$. Oligocän Fajum. Ägypten $M$. Stromeri. Schl.

\section{Familie. Plesiadapidae Lemoine.}

2.1.2.3. Unterkiefer hoch mit breitem Kronfortsatz und Diastema hinter den vergrößjerten $J$. Oberer $J^{2}$ zweispitzig, $J^{3}$ und $C$ klein. Obere $P$ und $M$ trituberkulär. Untere $M$ tuberkulärsektorial mit mäßig hohem Trigonid und großem niedrigem Talonid. Untereocän von Europa.

Die Form des Unterkiefers und die Beschaffenheit des Gebisses spricht dafür, daß wir es möglicherweise mit einem Vorläufer der Nager zu tun haben.

Plesiadapis Lemoine. Untereocän von Reims und Belgien, vielleicht auch im Bohnerz von Egerkingen.

Protoadapis Lemoine. 2.1.3.3-Ohne Diastema. Eocän von Reims. Systematische Stellung ganz unsicher.

\section{Familie. Pantolestidae Matthew.}

3.1.4.3. C normal. Obere $J$ isoliert, $P$ einfach schneidend. Obere $M$ trituberkulär, untere tuberkulärsektorial mit dreispitzigem Trigonid und Talonid. Schnauze kurz und breit, Cranium lang und verbreitert mit hoher Supraoccipitalcrista und schwachem Scheitelkamm, ohne knöcherne Bulla.

Die Pantolestiden wurden zuerst für Artiodactylen gehalten. Matthew stellt sie jetzt $\mathrm{zu}$ den Insectivoren wegen der Anwesenheit eines Mental. foramens unter $M_{1}$ und der Kürze und Breite der Schnauze. Abgesehen von diesen Verhältnissen könnte man sie auch bei den Creodonten unterbringen. Der stark gekrümmte Humerus besitzt eine kräftige Deltoidcrista, und ein Entepicondylarforamen, das Femur ist mit einem dritten Trochanter versehen und Tibia und Fibula sind distal miteinander verwachsen. Der Astragalus hat eine breite, ausgefurchte Trochlea und einen kurzen Hals, die Krallen sind abgeflacht und breit. Der Schwanz hat beträchtliche Länge. Die Extremitäten zeigen Anpassung an das Leben im Wasser.

Pantolestes Cope. (Passalacodon, Anisacodon Marsh.) Paraconid klein. Mitteleocän. Bridgerbed.

Pala eosinopa Matthew. Paraconid kräftig. Untereocän. Wasatchbed.

Pentacodon Cope. Untereocän. Torrejonbed. Neu-Mexiko.

? Ptolemaia Osborn. Paraconid schwach. J und vordere $P$ reduziert. Oligocän von Ägypten.

\section{Familie. Tillodontidae. (Tillodontia Marsh.) ${ }^{1}$ )}

Ausgestorbene, fiunfzehige, bekrallte Sohlengänger mit vergrößertem, nagezahnähnlichen $J_{2}$ und brachyodonten $M$. Obere $M$ trituberkulär, mit Nebenhöckern, untere mit hohem, halbmondförmigem Trigonid und etwas niedrigerem halbmondförmigem Talonid. Scaphoid getrennt vom Lunatum.

Der Schädel ist im ganzen raubtierähnlich. Die Breite der Schnauze und des Hinterhauptes, das Fehlen einer postorbitalen Einschnürung und die Beschaffenheit der Ohrregion - flache Bulla - sowie die Form des Unterkiefergelenkes gestatten die Angliederung dieser Familie an die Insectivoren, womit sich auch die Differenzierung der $J$ und $C$ gut in Einklang bringen läßt. Von den $J$ geht das erste Paar verloren, das zweite wird vergrößert, die $C$ verwandeln sich in kleine Lückenzähne, wofür die hinteren $P M$-ähnlich werden.

1) Cope E. D., Vertebrata of the Tertiary Format. of the West 1877. - Tertiary Vertebrata 1884 . - Gregory $W . K$., Bull. Amer. Mus. Nat. Hist. New York 1910 p. 292. - Marsh O. C., Amer. Journ. Sc. 1875. IX. 1876 XI. 
Von Tillotherium ist das Skelett ziemlich vollständig, von Esthonyx aber nur teilweise bekannt. Nur im Eocän von Nordamerika und von England.

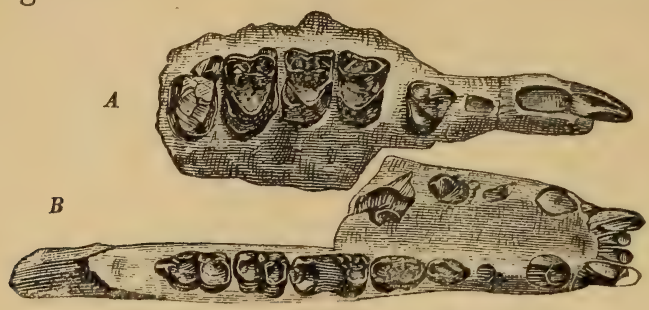

Fig. 53 כ.

Esthonyx Burmeisteri ('ope. Untereocän (Wasatch Beds) von Big Horn. Wyoming. A Zahnreihe des Oberkiefers, $B$ des Unterkiefers, von der Kaufläche gesehen, $2 / 3$ nat. Gr. (nach Cope.)

moine. Untereocän von Reims. Durchaus problematisch. $C$ ziemlich groß. Neu-Mexiko. England.

1. Unterfamilie. Esthonychinae.

2. 1. 3. 3. J ringsum von Schmelz bederkt, mit Wurzeln.

Esthonyx Cope. (Figur 535.) Im unteren Eocän. Wasatchbed von Wyoming und

Platychoeropus Charlesworth im Londonton von

Plesiesthonyx Lem.

\section{Unterfamilie. Tillotheriinae.}

2. 1.3. 3. Oberer und unterer $J_{2}$ stark entwickelt, nur an der Vorderseite mit Schmelz bedeckt und mit persistierender Pulpa. Zwischen den $J$, den kleinen $C$ und den vordersten $P$ kurze Lïcken.

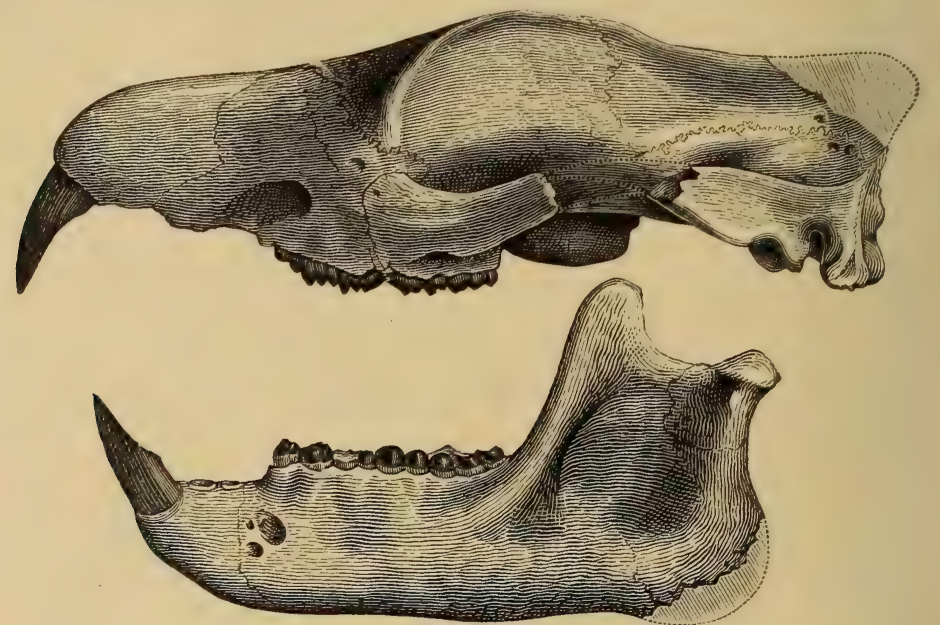

Fig. 536 .

Tillotherium fodiens Marsh. Eocän. Bridger. Wyoming. Schädel und Unterkiefer. 1/4 nat. Gr. (Nach Marsh.)

Tillotherium Marsh. (Fig. 536.) Schädel von Bärengröße mit kleiner Gehirnhöhle und verschmälerter Schnauze. Orbita hinten nicht von den Schläfengruben abgetrennt. Stirnbeine groß mit Luftzellen. Wirbel raubtierartig. Humerus mit Entepicondylarforamen. Femur mit drittem Trochanter. Fibula dünn, Astragalus niedrig. Mitteleocän. Bridgerbed. Wyoming.

Trogosus (Anchippodus) Leidy. Ebendaseibst. 


\section{Ordnung. Chiroptera. Fledermäuse. ${ }^{1}$ )}

Kleine Insekten-, selten Früchtefresser mit stark verlängerten und durch Flughaut verbundenen Vorderextremitäten. Gebiß vollständig, $J$ reduziert, $C$ groß, meist mit kräftigem Basalband, $P$ zugespitzt. $M$ sekodont, oder bunolophodont, obere trituberkulär mit $\bigvee$ förmigen Höckern, untere tuberkulärsektorial. Milchgebiß rudimentär. Hirn klein und glatt. Zwei brust. ständige Zitzen.

Die Fledermäuse bilden einen spezialisierten Seitenzweig von primitiven Insectivoren. Sie unterscheiden sich von den echten Insectivoren nicht bloß durch die eigentümliche Ausbildung der Vorderextremität, sondern auch durch die meist verkürzte Schnauze, den in der Regel sehr kräftigen Scheitelkamm, durch die starke postorbitale Einschnürung und die solid verknöcherte Gehörblase.

Die Vorderextremität ist zu einem Flugorgan umgebildet. Das lange Schlüsselbein verbindet das Brustbein mit dem Acromion des Schulterblattes. Der. Humerus ist schlank und im Verhältnis zur Größe des Caput und des Deltoidkammes sehr lang. Die Länge des Vorderarms übersteigt die des Oberarms mindestens um ein Drittel,

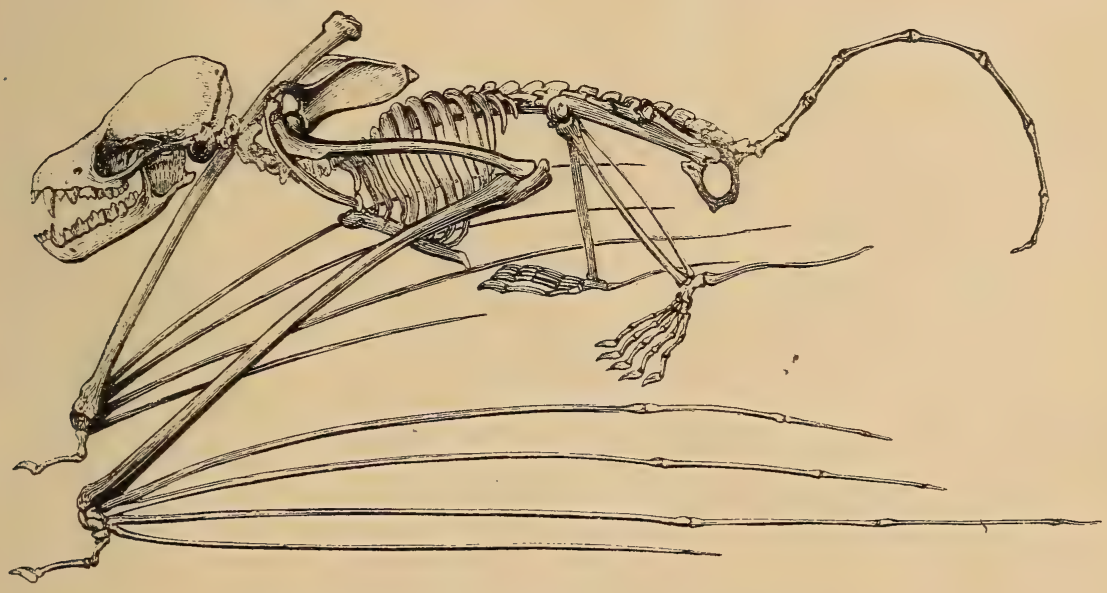

Fig. 537 .

Vespertilio murinus Lin. Skelett. (Nach Blainville.)

oft aber um das Doppelte. Die Ulna ist stark reduziert. Die proximalen Carpalia verschmelzen miteinander. Die Phalangen sind mit Ausnahme des kurzen, opponierbaren Daumens zu dünnen, langen, nadelähnlichen Gebilden umgestaltet und durch Flughaut verbunden, welche sich auch am Rumpf und am Schwanz sowie an einem langen knöchernen Sporn, der vom Calcaneum ausgeht, anheftet. Im Gegensatz zur Vorderextremität ist die Hinterextremität und das Becken

1) Gaillard C., Mammifères miocènes de la Grive St. Alban. Arch. Mus. Hist. Nat. Lyon. T. VII. 1899. - Schlosser M., Die Affen Lemuren. Chiropteren des europäischen Tertiärs. Beitr. Pal. Öst.-Ung. 1887. VI. - Weithofer A., Sitzungsbericht. Wien. Akad. math.-phys. Abt. Bd.96. 1887. - Winge H., Jordfundne og nulevende Flagernaus (Chịroptera) fra Lagoa Santa. E. Museo Lundii. Køjbenhavn 1892. 
schwach entwickelt. Der Fuß hat fünf gleichlange, mit Krallen versehene Zehen.

Die Fledermäuse zerfallen in die zwei Gruppen der Megachirop. tera, welche nur große frugivore Formen enthalten und in die kleinen, insektenfressenden Microchiroptera.

$\mathrm{Zu}$ den Megachiroptera gehört wahrscheinlich die Gattung $A$ r. chaeopteropus Meschinelli aus dem Oligocän von Monteviale.

Überreste von Microchiropteren fanden sich in größerer Menge nur in den Phosphoriten von Quercy sowie im Pleistocän in europäischen Höhlen und in Höhlen Brasiliens, aber diese pleistocänen Reste gehören fast ausschließlich rezenten Arten an. Im Eocän - Paris und Aix - sowie im Miocän sind Fledermausreste sehr selten mit Ausnahme von der Lokalität La Grive St. Alban.

Die Chiropteren aus den Phosphoriten verteilen sich auf die Gattungen Pseudorhinolophus (Fig. 538) und Vespertiliavus Schlosser, Taphozous Geoffr., Alastor und Necromantis Weithofer, von welchen sich die letzte Gattung an lebende südamerikanische Formen anschließt, was auch wohl für Provampyrus Schlosser aus dem Oligocän von Ägypten gilt. Im Miocän finden sich neben der ausgestorbenen Gattung Palaeonycteris schon die lebenden Gattungen Vespertilio, Vesperugo, Rhinolophus und $\mathrm{Cy}_{y}$ nonycteris.
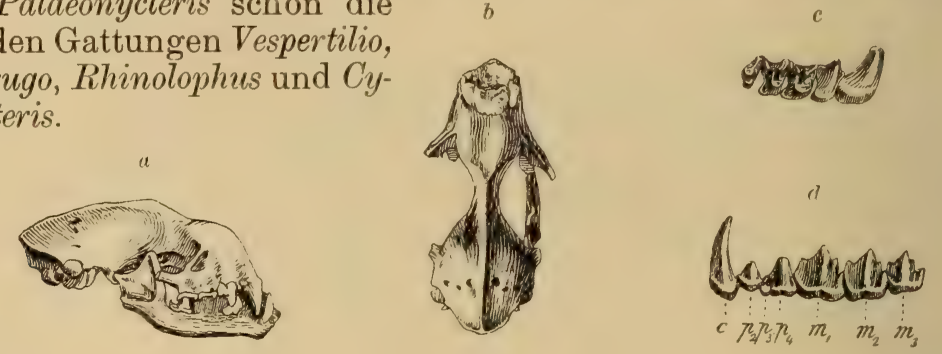

Fig. 538 .

Pseudorhinolophus sp. Phosphorit. Quercy. $a$ Schädel mit Unterkiefer von der Seite 1/1, $b$ derselbe von oben $1 / 1, c$ obere Zahnreihe von unten, vergr., $d$ unten Zahnreihe von außen, vergr.

(Nach Schlosser.)

\section{Ordnung. Carnivora. Fleischfresser.}

$\mathrm{Zu}$ den Fleischfressern gehören ausgestorbene und noch jetzt lebende, in der Größe sehr verschiedene Land- und Wasserbewohner mit vollständigem Gebiß und sehr kräftig entwickelten Caninen. Die vorderen Backenzähne sind meist schneidend, zum Zerkleinern von Fleischnahrung geeignet, die hinteren $M$ in der Regel höckerig und die oberen stark verbreitert. Das Gehirn zeichnet sich bei allen lebenden Formen durch ansehnliche Größe und starke Furchung der großen Hemisphären aus, bei den ältesten fossilen Formen - Creodontia - ist es wesentlich kleiner und auch weniger gefurcht. Die Extremitäten sind bekrallte digitigrade oder plantigrade Gehfüße mit 4-5 Zehen, zuweilen - Pinnipedia - aber auch flossenartig.

Die Fleischfresser zerfallen in drei Unterordnungen - Creodontia, Fissipedia und Pinnipedia. 


\section{Unterordnung. Creodontia. ${ }^{1}$ Urfleischfresser.}

Ausgestorbene digitigrade oder semiplantigrade Fleischfiesser mit kleinem schuachgefurchtem Gehirn, vollständigem Gebiß und Zahnwechsel. Meist $\frac{\text { 3. 1.4. 3. }}{3.1 .4 .3 .}$ M schneidend oder höckerig, meist gleichartig ausgebildet. Bulla tympanica nur ausnahmsweise verknöchert. Carpus in der Regel mit Centrale, Scaphoid und Lunatum nur selten verwachsen. Astiagalus flach gewölbt, nur wenig ausgefurcht. Endphalangen meist stumpf und an der Spitze gespalten, selten seitlich komprimiert.

Die von Cope von den Carnivoren abgetrennten Creodontia zeigen sowohl Anklänge an die Marsupialia als auch an die Carnivora fissipedia, mit welchen sie durch die Familie der Miacidae verbunden sind, bei welcher auch bereits $P^{4}$ und $M_{1}$ als Reißzähne entwickelt sind.

Der Schädel ist raubtierartig, aber meist sehr groß im Verhältnis zum Rumpf, die Schnauze oft verlängert. Das Cranium hat geringe Kapazität und gestreckte Form. Vom Gesichtsschädel ist es durch die starke postorbitale Einschnürung scharf abgesetzt. Die Bulla tympanica verknöchert nur ausnahmsweise. Das Gehirn ist klein und nur mit schwachen, wenig zahlreichen Windungen versehen. Der Gaumen hat keine Lücken, sondern nur zuweilen kleine Löcher, und der Unterkieferrand ist nur ausnahmsweise hinten schwach umgebogen. Das Gebiß besteht normal aus $\frac{\text { 3.1. . } 3.3 .1 .3 .}{3.1 .3 .}$ jedoch kann die Zahl der $J$ auf 2 , die der $P$ auf 3 und der $M$ auf 2 sinken, welche Reduktionen indes niemals gleichzeitig eintreten. Die geringe Zahl der $J$ unterscheidet die Creodontia von den Marsupialia, die stets normale Entwicklung aller $J$ und die Einwurzeligkeit des $C$ von den Insectivoren. Die $P$ sind komprimiert, einfach und höchstens mit Basalhöckern versehen, nur der hinterste kann namentlich im Oberkiefer annähernd $M$ ähnliche Zusammensetzung erreichen. Die Krone der oberen $M$ besteht in der Regel aus zwei äußeren und einem inneren Höcker, Protocon, von denen der letztere öfters $\vee$-förmig ist. Er kann aber auch zuweilen ebenso wie der Metacon starke Reduktion erfahren, wofür aber dann der Parastyl und namentlich der Metastyl sehr kräftig werden. Die $M$ des Unterkiefers sind normal tuberkulärsektorial, mit grubigem Talonid. Jedoch wird das Metaconid sehr häufig reduziert, und der Talonid verwandelt sich in eine Schneide, die auch sehr klein werden kann. Im Gegensatz zu den echten Carnivoren ist bei den echten Creodontia $M_{1}$ in der Regel kleiner als die folgenden $M$. Von den Milchzähnen gleicht der letzte dem vordersten $M$, der vorletzte dem hintersten $P$.

Im Vergleich zur Größe des Schädels haben die Extremitäten ge. ringere Länge als bei den lebenden Raubtieren und sind auch in der Regel etwas plumper und gedrungener. Der Humerus besitzt fast immer ein Entepicondylarforamen und meist eine ungeteilte Gelenkrolle, die bei vorgeschritteneren Formen bis an die Fossa Olecrani reicht. Ulna und Radius

$\left.{ }^{1}\right)$ Cope E. D., The Creodontia. American Naturalist. 1884. p. 255 u. 478. Filhol H., Ann. Sc. géol. 1872 III. 1876 VII. 1877 VIII. Ann. phys. et nat. Toulouse 1882. - Martin R., Revision der Creodonten Europas. Revue suisse de Zoologie Genève. 1906. - Matthew W. D., Additional observations on the Creodonta Bull. Amer. Mus. New York 1901. - The Osteology of Sinopa. Proc. U. S. Tat. Mus. Vol. XXX. 1906. - The Carnivora and Insectivora of the Bridger Basin. Mem. Amer. Mus. Tew York 1909. - Osborn and Wortman, Bull. Amer. Mus. New York 1892. 1900. - Schlosser M., Die Affen - Creodonten des europ. Tertiärs. Beitr. z. Paläont. Österr.-Ung. 1887. VI. - Scott W. B., Journal. Acad. Nat. Scienc. Philad. 1887, 1895. - Proceed. Acad. Nat. Sc. Philad. 1892 p. 291. - Wortman. Bull. Amer. Mus. Nat. Hist. New York 1894. 1899 und Eocene Mammalia in the Marsh Collection. I. Carnivora. Amer. Journ. of Science 1901. 1902. 
verwachsen niemals, das Olecranon kann beträchtliche Höhe erlangen. Zuweilen findet sich am Humerus ein Supratrochlearforamen. Die Carpalia bleiben immer getrennt - nur bei den zeitlich jüngsteri Gattungen kommt es manchmal zur Verschmelzung von Scaphoid und Lunatum. In der Regel ist ein freies Centrale vorhanden. Das Ilium ist schmäler als bei den echten Carnivoren und dem der Marsupialier und Insectivoren ähnlicher. Am Femur ragt meist ein dritter Trochanter vor. Die Anordnung und Form der Tarsalja stimmt im wesentlichen mit jener der lebenden Carnivoren überein, doch haben Astragalus und Calcaneum häufig gedrungenere Gestalt und liegen weniger fest aufeinander. Der Astragalus hat nicht selten ein Foramen und seine tibiale Gelenkfläche ist häufig nur schwach gewölbt und nur wenig oder gar nicht ausgefurcht.

Matthew teilt die Creodontia in die drei Gruppen der Acreodi, der Pseudocreodi und der Eucreodi ein, von welchen die letzten den Ausgangspunkt der echten Carnivoren darstellen.

\section{Tribus. Acreodi.}

Ohne scherenartige Ausbildung von Backenzähnen. $M$ primitiv, obere trituberkulär, untere tuberkulärsektorial oder mit stumpfen Zacken.

\section{Familie. Oxyelaenidae. Scott.}

$M$ primitiv, die oberen trituberculür, dreieckig oder oblong, die unteren tuberculärsectorial mit scharfkantigen Spitzen, aus hohem Trigonid und niedrigem

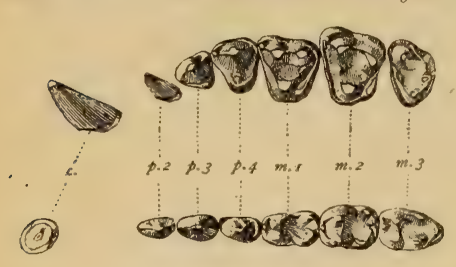

Fig. 539 .

Tricentes subtrigonus Cope. Unterstes Eocän. Torrejonbed Neu-Mexiko. obere und untere Zahnreihe, nat. Gr. (nach Matthew.)

Talonid bestehend. $P$ einfach, nur $P^{4}$, selten auch $P^{3}$ mit Innenhöcker.

Die unvollständig bekannten, meist nur durch Backenzähne vertretenen Genera gehören dem älteren Eocän von Neu-Mexiko und Montana an.

Oxyclaenus, Loxolophus, Carci. nodon Cope, Protochriacus Scott. Puercobed. Chriacus, Tricentes (Fig. 539), Del. tatherium Cope. Torrejonbed von NeuMexiko und im Fort Unionbed von Montana.

2. Familie. Mesonychidae. Cope.

$\frac{3-2}{;} M$. Obere $M$ trituberkulïr, untere durch Reduktion des Metaconids ti.ikonodont, mit stumpfen Zacken. $P^{4}$ meist $M$ ähnlich. Hand und Fuß paraxonisch, häufig digitigrad, 5 selten 4 zehig. Humerus mit Supratrochlearforamen. Fibula am Calcaneum articulierend. Krallen flach- und hufartig. Zygapophysen der Lendenwirbel zylindrisch oder eingerollt.

Die Mesonychidae erreichen zum Teil die Größe von Bären und ihre Extremitäten erfahren eine ähnliche Spezialisierung wie bei den Hunden, welche sie zu raschem, ausdauerndem Laufen befähigt, festgefügter Carpus und Tarsus, tiefausgefurchte Astragalusrolle, Verlust der ersten Zehe, parallele Stellung der Metapodién verbunden mit Digitigradie. - Die oberen $M$ zeichnen sich durch die Dreizahl der Höcker und das Fehlen eines Metastyls und die unteren durch Reduktion des Metaconid und einfache Form des Talonid aus, wodurch sie sekundär den Triconodontentypus erlangen. Obere und untere $M$ bilden niemals eine Schere. Im älteren Eocän von Nordamerika, Frankreich und Belgien. 
1. Unterfamilie. Triisodontinae. Matthew.

Untere $M$ mit Metaconid und beckenförmigem. Talonid. Aujsenhöcker der oberen $M$ frei.

Triisodon Cope. Puercobed. Sarcothraustes, Goniacodon, Microclaenodon Cope. Torrejonbed.

2. Unterfamilie. Mesonychinae. Matthew.

Untere $M$ mit schneidendem Talonid. Außenhöcker der oberen $M$ verwachsen. Dissacus Cope. Unt. M mit kleinem Metaconid. Untereocän. Torrejonbed.
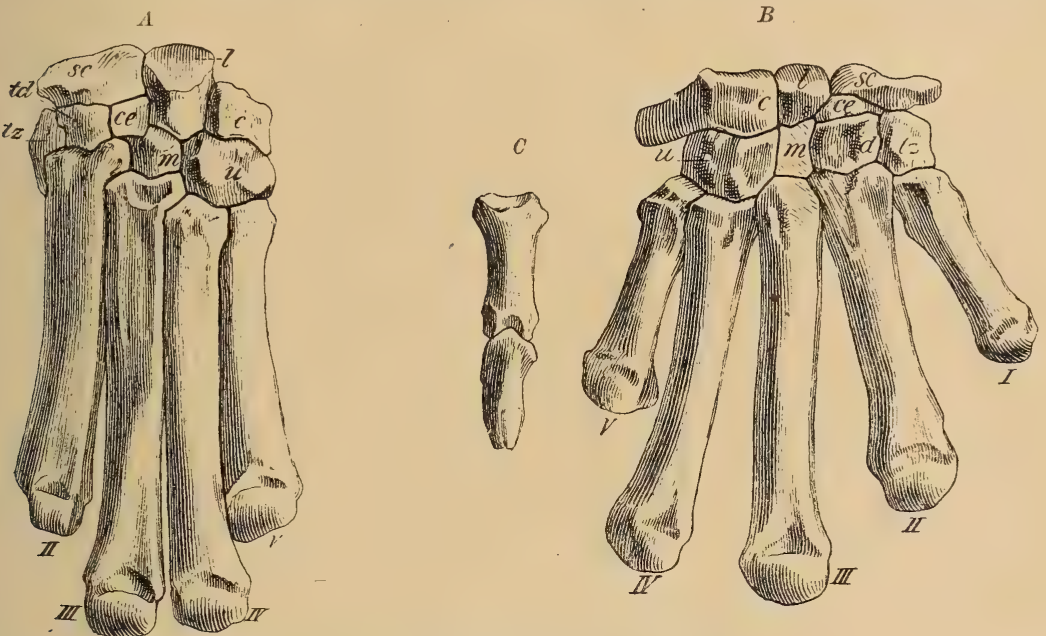

Fig. 540. Vorderfuß $A$ von Mesonyx, $B$ von Hyaenodon. ca. $2 / 3$ nat. Gr. (Nach Scott.) $s c$ Seaphoideum, $l$ Lunare, $c$ Cuneiforme, $c e$ Centrale, $t z$ Trapezium, $t d$ Trapezoid, $m$ Magnum, $u$ Unciforme, $I-V$ erster bis fünfter Metacarpus. $C$ die zwei letzten Phalangen von Hyaenodon.

Hyaenodictis Lemoine. Untereocän. Cernays bei Reims und Erquelinnes Belgien.

Hapalodectes Matthew. Zähne komprimiert. Eocän. Wasatch- und WindRiverbed.

Pachyaena Cope. Erreicht die Größe eines Bären. Eocän von Nordamerika, Wasatchbed und Mitteleocän. (Grobkalk von Paris.)

Harpagolestes Wortman.Schädel kurz und breit. Ohne $M^{3}$. Eocän. Bridgerbed. $H$. immanis Wortman. Von Bärengröße. Uinta. H. (Mesonyx) uintensis Scott.

Synoplotherium Cope (Dromocyon Marsh). Schädel und Beine mäßig

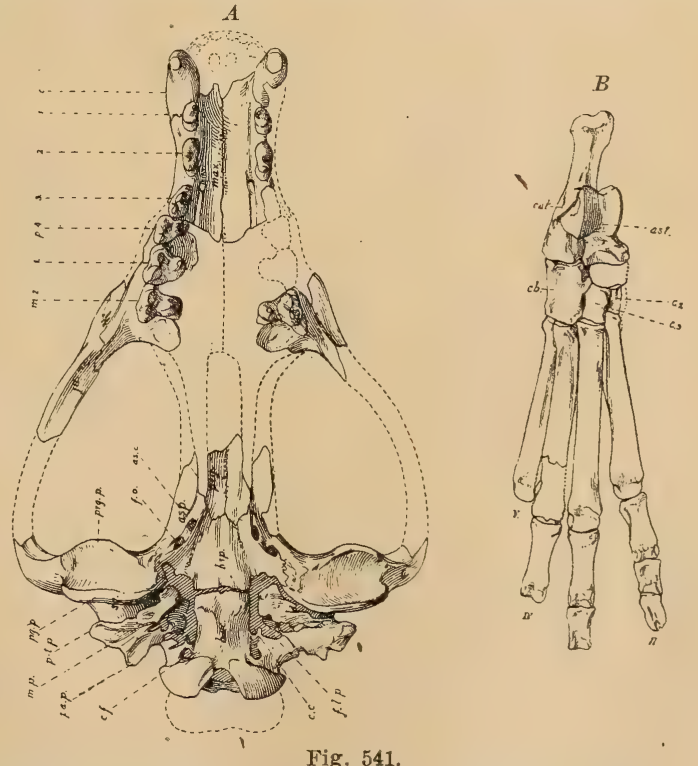

Fig. 541.

Mesonyx obtusidens Cope. Mitteleocän. Bridgerbed. Wyoming. $A$ Schädel von unten. $B$ Hinterfuß $1 / 3$ nat. Gr. (n. Matthew). 
verlängert, Hand und Fuß vierzehig. Astragalus mit tiefausgefurchter Trochlea. Bridgerbed. S. vorax. Marsh. sp.

Mesonyx Cope. (Fig. 540A, 541.) Schädel und Beine lang. Ohne $M^{3 .}$ Eocän. Bridger. M. obtusidens Cope.

\section{Tribus. Pseudocreodi.}

$M \frac{1}{2}$ oder $\frac{2}{3}$ als Reißzähne entwickelt. Krallen gespalten. Hand und Fuj: mesaxonisch. Fibula ain Calcaneum articulierend. Zygapophysen der Lendenwirbel zylindrisch oder eingerollt.

\section{Familie. Oxyaenidae Cope.}

$\frac{2-1}{2} M . \quad M^{1}$ und $M_{2}$ als Reißzähne ausgebildet, meist $M_{2}>M_{1}$. Schädel plump, mit breiter Basis Cranii. Unterkiefer massiv, mit kräftiger Symphyse. Extremitäten fünfzehig. Zehenstellung bei aquatilen Formen gespreizt, bei Landbewohnern plantigrad. Krallen stumpf, gespalten.

Osborn hielt die Gattung Palaeonictis für den Ahnen der Feliden, und Wortman vermutete in Patriofelis den Ahnen der Pinnipedia. Nach den Untersuchungen Mat thews kommt jedoch keiner von beiden Gattungen besondere stammesgeschichtliche Bedeutung zu. Der Schädel hat im Vergleich zum Körper ziemlich normale Dimensionen. Von den oberen $M$ ist der zweite klein und quergestellt und manchmal ganz verschwunden, $M^{1}$ besitzt außer den drei Hauptzacken einen schneidend entwickelten Metastyl. Die unteren $M$ bestehen aus einem hohen Trigonid und einem niedrigen Talonid, welches ebenso wie das Metaconid verschwinden kann.

\section{Unterfamilie. Limnocyoninae Wortman.}

Nur $P^{4}$ mit Innenhöcker. Untere $M$ tuberkulärsektorial. $\frac{2}{2} M$. Gebiß unreduziert. Lange Schnauze. Kleine bis mittelgroße Formen.

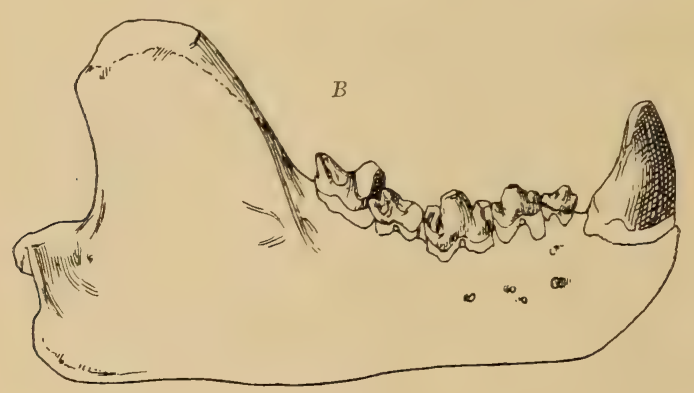

$A$

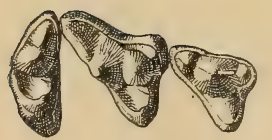

Fig. 542

A Limnocyon medius Wortman. Mittelmiocän. Bridgerbed. Wyoming. Obere $P^{4}$ bis $M^{2}$ nat. Gr. (nach Wortman.) $B$ Patriofelis ferox Marsh. Ebenda. Unterkiefer. $1 / 3$ nat. Gr. (nach Matthew.)

Limnocyon (Telmatocyon) Marsh. (Fig. 542 A). $J^{3}$ reduziert. Erster $P$ in beiden Kiefern zweiwurzelig, nur $P^{4}$ mit Innenhöcker; $M^{1}$ mit kräftigem Protocon. $M^{2}$ quergestellt. $M_{1}$ und $M_{2}$ mit dreispitzigem Trigonid und beckenförmigem Talonid. Schädel breit. Unterkiefer hoch und plump. Beine kurz, gebogen. Mitteleocän. Bridger.

Thinocyon Marsh. Beine lang und schlank. Größe von Hauskatze. Mitteleocän. Bridger.

Thereutherium Filhol. Mardergröße. Metaconid reduziert. Unterkiefer dick. Eocän. Phosphorite von Quercy. Th. thylacodes Filhol.

Oxyaenodon Wortman. $P$ dichtgedrängt und reduziert. $M$ wie bei Limnocyon. Unterkiefer mäßig hoch. Obereocän. Uintabed. 
Machairoides Matthew. Unterkiefersymphyse nach unten in einen Lappen ausgezogen. Mitteleocän. Bridgerbed.

\section{Unterfamilie. Oxyaeninae Wortman.}

$P^{3}$ und $P^{4}$ mit Innenhöcker. Friihzeitig spezialisierte Formen mit hurzer Schnauze, mit reduzierten $P$, häufig olme $M^{2}$ und $M_{2}$. Alle $P$ und $M$ schneidend ausgebildet.

Oxyaena Cope. $\frac{3.1 .4 .2}{2.1 .4 .2}$ Obere $P$ sämtlich mit Innenhöcker. $M^{1}$ mit kräftigem Protocon, $M^{2}$ quergestellt. Untere $M$ mit kleinem Talonid. Metaconid neben Protoconid stehend. Unterkiefer hoch, aber dünn. Beine mäßig lang. Untereocän. Wasatchbed. O. lupina Cope. In den Phosphoriten ron Quercy O. Galliae Filhol problematisch.

Patriofelis Leidy (Limnofelis, Oreocyon Marsh, Aelurotherinm Adams, Protopsalis Cope). (Fig. 542 B) $\frac{\text { ?.1.3.1. }}{3.1 .3 .2 .} P_{1}^{1}$ und $M^{2}$ fehlend. $M_{1}$ mit schwachem Talonid und kleinem Metaconid. $M_{2}$ groß, mit rudimentärem Talonid und Metaconid. Schnauze und Unterkiefer massiv. Beine kurz und plump. Zehen gespreizt. $M_{2}$ gleicht dem $M_{1}$, und $M^{1}$ dem $P^{4}$ von Felis. Eocän. Wasatchund Bridgerbed. P. ulta Leidy.

Palaeonictis Blv. 3.1.4.2. Nur. $P^{3}$ und $P^{4}$ mit Innenhöcker. $M^{1}$ mit scharf geschiedenem Paracon und Metacon, großem Protocon und Zwischenhöckern. $M^{2}$ rudimentär. Untere $M$ mit kräftigem Paraconid und Metaconid und beckenförmigem Talonid. $M_{2}>M_{1}$. Untereocän. Wasatchbed von Nordamerika und von Frankreich (Soissons). Wasatch.

Ambloctonus Cope. $\frac{1}{2} M$. Untere $M$ fast gleich groß. Untereocän.

\section{Familie. Hyaenodontidae Cope.}

$\frac{3-9}{3}$ M. $M \frac{2}{3}$ als Reißzalm entwickelt, vordere $M$ und $P^{4}$ ebenfalls als Scheren funktionierend, Schädel meist lang, seltener hurz und plump mit honkaver Stirn. Extremitäten meist zum Laufen adaptiert, mesaxonisch. Fibula am Calcaneum artikultierend. Krallen an der Spitze gespalten. Bulla tympanica mur ausnahmsweise vollkommen verknöchert.

Die Hyaenodontidae umfassen Formen von Fuchs- bis Wolfsgröße, nur wenige Arten erreichen allenfalls die Größe von Tigern. Bei HyaenodonArten kommt es zuweilen zur Verwachsung von Scaphoid und Lunatum, auch bekommt der Humerus häufig eine massive hohe Trochlea und ein Supratrochlearforamen und Pollex und Hallux können beträchtliche Reduktion erleiden. Der Schädel ist in der Regel gestreckt und schmal, bei Pterodon und manchen Hyaenodon-Arten hingegen kurz und plump. $M^{3}$ kann vollständig verschwinden. $M^{2}$ bildet mit $M_{3}$ zusammen eine Schere, doch funktionieren auch schon $M_{1}$ und $M_{2}$ mit $P^{4}$ und $M^{1}$ in ähnlicher Weise. Die ursprünglich trituberkulären oberen und die tuberkulärsektorialen unteren $M I$ können sich in schneidende Platten umbilden, wobei von den oberen $M$ fast nur Paracon und Metastyl und an den unteren nur Paraconid und Protoconid erhalten bleiben.

\section{Unterfamilie. Proviverrinae.}

${ }_{3}^{3}$ II. Obere MI trituberhulär, $M^{3}$ quergestellt, untere tuberkulürsehtorial, stets mit Metaconid versehen. Mrïßig scherenartige Ausbildung der Zühne. Körper schlank. Extremitüten fünfzehig. Zehen fast gleichlang. Krallen homprimiert.

Die Provicerrinae haben meist ungefähr die Größe von Fuchs und ein Viverrenähnliches Aussehen. 
Sinopa Leidy. (Stypolophus, Prototomus Cope.) $P$ lang und isoliert stehend. Außenhöcker der oberen $M$ voneinander getrennt, Talonid groß und beckenförmig. Zahlreiche Arten, zum Teil durch vollständige Skelette vertreten. Untereocän. Wasatchbed. S. hians Cope. Mitteleocän. Bridger. S. rapax Leidy, Grangeri Matthew. Angeblich auch im Untereocän von Belgien (Orsmael).

Tritemnodon Matthew. (Stypolophus Cope, Limnocyon Marsh.) Außenhöcker der oberen $M$ zusammengedrängt. Talonid klein. Mitteleocän Bridger.

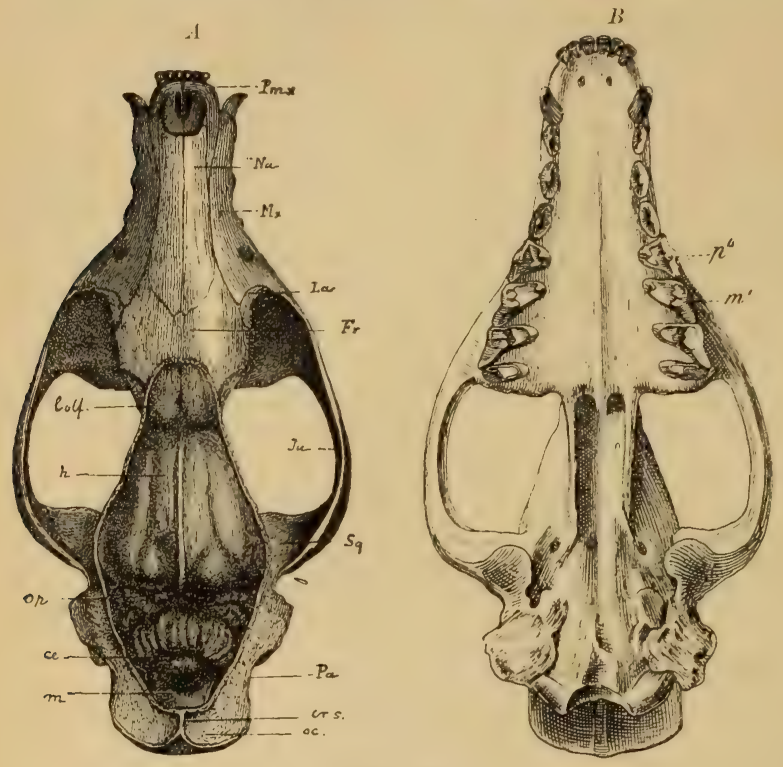

Fig. 543.

Proviverra (Cynohyuenodon) C'ayluxi Filhol. Phosphorit. Quercy. $A, B$ Schädel von oben und unten. $2 / 3$ nat. Gr. (Nach Gaudry und Filhol.) oc Supraoccipitale, $P a$ Scheitelbein, Fr Stirnbein, .Ju Jochbein, Sq Squamosum, La Tränenbein, Na Nasenbein, V $x$ Oberkiefer, P'mx Zwischenkiefer, crs Sagittalcrista, $m$ Medulla elongata, ce Kleinhirn, op Sehhügel, $h$ große Hemisphäre, lolf Riechlappen.

Galethylax Blainville. Eocän. Pariser ständig bekannt.

Quercytherium Filhol. $P$ stark verdickt. Phosphorite von Quercy.

\section{Unterfamilie Hyaenodontinae.}

$\frac{3-2}{3} M$, schneidend entwickelt, untere ohne Metaconid, mit nur kleinem oder ohne Talonid, obere meist mit verlängertem Metastyl, und reduziertem Paracon, zuweilen ohne Protocon, $P_{4}$ meist höher als $Y_{1}$. Körper plump. Beine meist zum Laufen adaptiert. Krallen dick.

Die Hyaenodontinen sind aus Proviverrinen entstanden, von welchen sie sich durch die schneidende Ausbildung der $M$ unterscheiden. In Europa erscheinen sie im jüngeren Eocän, in Nordamerika hingegen erst im Oligocän.

Pterodon Blv. (Hemipsalodon Cope). (Fig. 545.) $\frac{3}{3} M . M^{3}$ quergestellt, $U^{1}$ und $M^{2}$ mit dicht zusammengedrängten Außenhöckern und kräftigem Protocon. Untere $\boldsymbol{M}$ mit hohem dicken Protoconid, kräftigem Paraconid 
und rudimentärem Talonid, selten mit kleinem Metaconid. $P$ einfach, dick, $P_{1}$ und $J_{1}$ öfters fehlend. $C$ massiv. Schädel plump mit kurzer Schnauze. Obereocän. Pariser Gips, Débruges, Phosphorite von Quercy, Insel Wight $P$. dasyuroides Blv. Oligocän. White Riverbed von Kanada P. grandis Cope sp. und Oligocän von Ägypten $P$. africanus Andrews. Beide von Tigergröße.

Propterodon Martin. ${ }_{4}^{4} P$. Mitteleocän. Bohnerz von Egerkingen.

Pseudopterodon Douglass. Klein, unvollständig bekannt. Oligocän. Unt. White Riverbed.

Apterodon Fischer (Dasyurodon Andreae). Paraconid niedrig, Talonid groß, schneidend. Obere $M$ mit drei großen Haupthöckern und sehr schwachem Metastyl. Schädel und Schnauze lang. Extremitäten kurz, gebogen, zum Schwimmen adaptiert. Oligocän. Phosphorite von

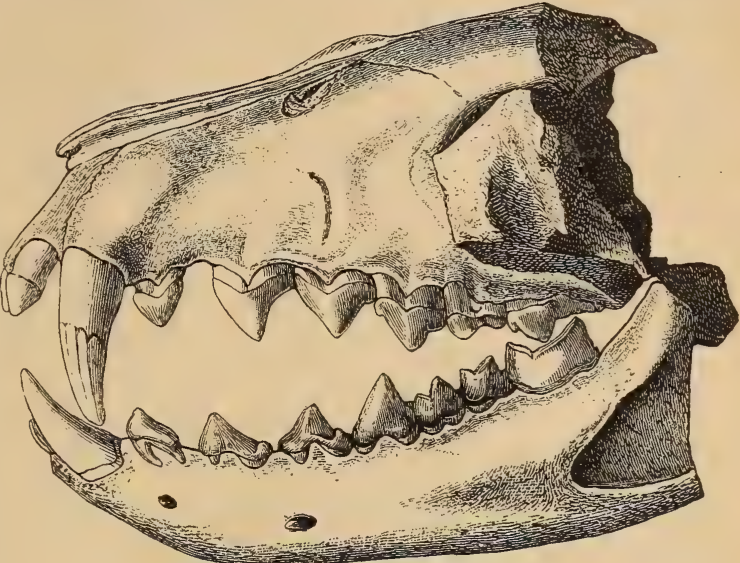

Fig. 544.

Hyaenodon leptorhynchus Laizer et Parieu. Ob. Eocän (Phosphorit.) Caylux. Vorderer Teil des Schädels nebst Unterkiefer. 1/2 nat. Gr. (Nach Filhol.) Quercy und Meeressand von

Flonheim. A. flonheimensis Andreae. Im Oligocän von Ägypten mehrere Arten A. macrognathus Andrews.

Hy cenodon Laizer et Parieu (Taxotherium Blv., Tulodon Gerv.). (Fig. 540B, 544.) Schädel und Extremitäten bald lang und schlank, bald kurz und plump.
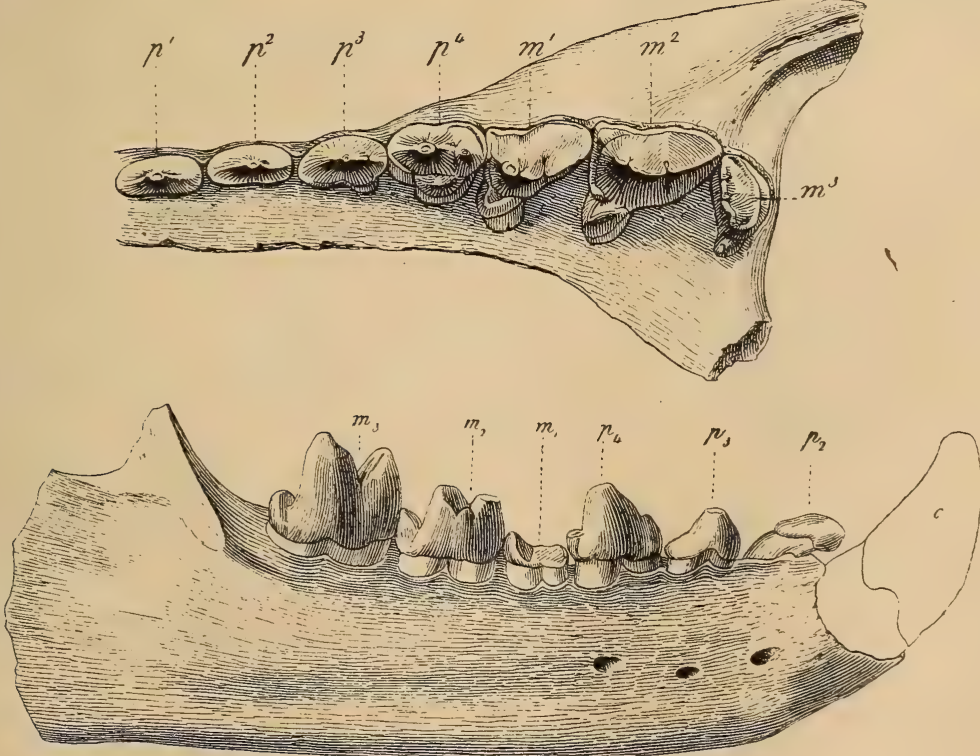

Fig. 545 .

Pterodon dasyuroides Gerv. Ob. Eocän (Phosphorit). Mouillac bei Caylux. A linke Oberkieferzähne von unten, nat. Gr. $B$ rechter Unterkiefer von außen, $2 / 3$ nat. Gr. 
$M^{3}$ fehlend; meist nur $\frac{2}{2} J . \quad M_{1}$ und $M_{2}$ mit kurzem Protoconid und rudimentärem Talonid, $M_{3}$ ohne dieses. Protoconid in eine lange Schneide verwandelt, ebenso der Metastyl an den oberen M. Paracon und Metacon mehr oder weniger fest verschmolzen, Protocon an $M^{1}$ rudimentär, an $M^{2}$ fehlend. Erste Zehe oft stark reduziert. Humerus mit kräftiger Trochlea. In Europa wohl schon im Bohnerz von Egerkingen, häufig im Obereocän, Phosphorite, Gips von Paris, Lignit von Débruge, Euzet les Bains (Gard) H. Requieni Gerv. Oligocän, Phosphorite von Quercy, zahlreiche Arten. Oligocän von Ronzon und Cournon. In Nordamerika zahlreiche Arten im Oligocän. "White Riverbed. H. horridus Leidy.

\section{Tribus. Eucreodi.}

$P^{4}$ und $M_{1}$ oder kein Zahn als Reijzahn entwickelt. Krallen komprimiert, nicht gespalten. Hand und Fuß fast paraxonisch, Fibula nicht am Calcaneum artikulierend, Zygapophysen der Lendenwirbel flach.

\section{Familie. Aretocyonidae Gervais.}

$\frac{3}{3}$ M. Ohne Reifizïhne, M niedrig, obere vielhöckerig, untere mit großen Talonid und reduziertem Paraconid. $P$ verkïmmert, einfach. Hand und Fuß fünfzehig, plantigrad. Centrale mit Scaphoid verwachsen.

Diese meist ziemlich großen Tiere zeigen vielfache Anklänge an die Ursiden, jedoch handelt es sich nur um eine frühzeitig erfolgte ähnliche

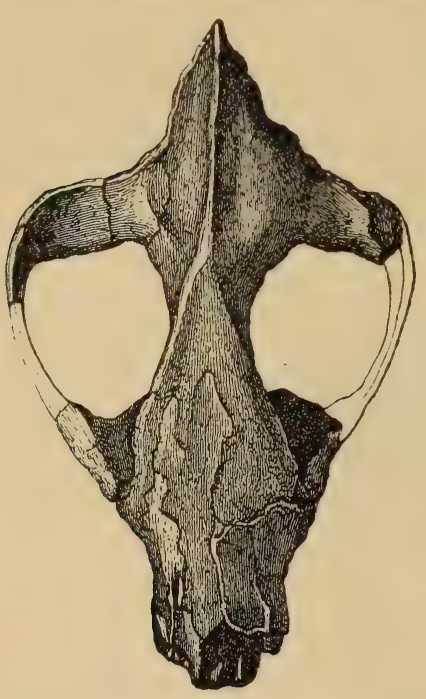

Fig. 546.

Arctocyon primaevus Blainv. Unterstes Eocän. La Fère bei Reims. Schädel $1 / 3$ nat. Gr. (Nach Gaudry.)
Spezialisierung von Creodontia. Im Untereocän von Reims und Nordamerika, hier Torrejon und Wasatchbed.
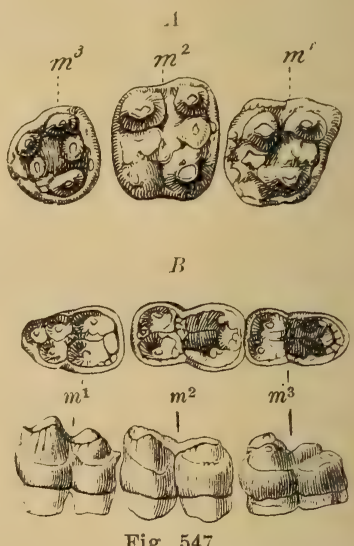

Arctocyon Gervaisi Lemoine. Unt. Eocän. Cernays bei Reims. A drei obere Molaren von unten (nat. Gr.). $B$ untere Molaren von oben und von der Seite $1 / 1$. (Nach Lemoine:)

Arctocyon Blv. (Fig. 546, 547.) Untereocän von Peims. Obere $M$ mit fünf großen und zahlreichen, kleinen Höckern.

Arctocyonoides Lemoine.

Claenodon Scott (Mioclaenus Cope). Obere $M$ wie bei vorigem, $P^{4}$ mit kräftigem Innenhöcker. Hand und Fuß Bärenähnlich, jedoch Astragalus mit langem Hals. Untereocän. Torrejon Neu-Mexiko. C. ferox, corrugatus Cope: 


\section{Familie. Miacidae. Cope.}

$P^{4}$ und $M_{1}$ als Reißzahn entwickelt, obere $M$ trituberkulär, untere tuberkulärsektorial mit stark reduziertem Trigonid. Hand und Fuß fünfzehig.

Die Miaciden sind kleine bis mittelgroße Raubtiere, welche im Gebiß teils den Viverriden teils den älteren Caniden und Ursiden ungemein nahestehen und auch zweifellos deren Ahnen darstellen. Sie unterscheiden sich nur durch das Fehlen einer knöchernen Bulla tympanica, durch die Trennung von Scaphoid, Centrale und Lunatum und durch den Besitz eines allerdings schon schwachen dritten Femurtrochanters. Dagegen zeigt das Gehin schon erhebliche Fortschritte gegenüber den anderen Creodontia. Bei genauerer Kenntnis des Skelettes dürften sich auch manche europäische Formen - wie eocäne 》Viverra《- und "Amphicyon«-Arten als Mia. ciden erweisen.

1. Unterfamilie. Viverravinae. Matthew.

$\frac{2}{2} M$. Innenzacken des. $P^{4}$ und Hinterzacken von $P_{4}$ groß. Zehen dicht aneinander gedrängt, digitigrad. Humerus mit niedriger Deltoidcrista und großem Tuberculum majus. Femur mit vorspringendem dritten Trochanter. Astragalus

Viverravus Marsh. (Didymictis Cope). Zähne komprimiert. $M_{1}$ mit kurzem grubigem Talonid. Obere $M$ ohne Z Zwischenhöcker, $\boldsymbol{M}^{1}$ mit kleinem Hypocon. Mitteleocän, Bridger. $V$. dawkinsianus Cope, minulus Wortman. Vielleicht auch im Obereocän von Quercy. »Viverra« Filhol, Schlosser. Angeblich im Landénien von Erquelinnes. Belgien.

Didymictis Cope. (Fi-
A

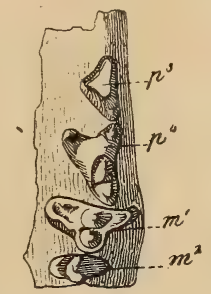
mit schmalem Caput und etwas ausgefurchter Trochlea. Fibula am Calcaneum artikulierend. Schädel gestreckt.

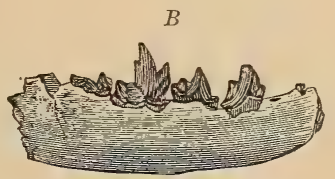

Fig. 548.

Didymictis Haydenianus Cope. Unteres Eocän. Puerco. NeuMexiko. Linker Oberkiefer mit zwei $M$ u. zwei $P$ von unten. $B$ Unterkiefer. (Nach Cope.) gur 548.) Zähne massiver, $M^{1}$ ohne Hypocon. Untereocän. Torrejonbed. D. haydenianus Cope. Wasatch und Wind Riverbed. D. protenus Cope.

2. Unterfamilie. Miacinae. Matthew.

$\frac{3}{3}$ M. Innenzacken des $P^{4}$ klein oder fehlend. Zehenstellung gespreizt, plantigrad. Humerus mit hoher Deltoidcrista und schwachem Tuberculum majus. Femur mit niedrigem, langgestrecktem dritten Trochanter. Astragalus mit breitem Caput und flacher Trochlea. Fibula vom Calcaneum getrennt. Schädel von mäßiger Länge.

Bären.

Miacis und Uintacyon haben Beziehungen zu den Hunden und

Miacis Cope. $P$ und $M_{1}$ mäßig bis groß, die beiden letzten $M$ klein. $M_{1}$ mit grubigem Talonid. $M^{1}$ meist mit kleinem Hypocon. $M$. parvivorus Cope. Wasatchbed. M. (Lycarion) Hargeri Wortm. M. (Harpalodon) sylvestris Marsh. Bridgerbed. M. (Prodaphaenus) uintensis Osborn. Uintabed.

Uintacy on Leidy. $P$ und $M_{1}$ klein, der letztere mit schneidendem Talonid. $M^{1}$ ohne Hypocon, hintere $M$ groß. Wasatchbed. U. massetericus Cope. Bridgerbed. U. vorax Leidy.

U. (Miocyon) (Prodaphaenus W. und M.) mit reduziertem $P$ und großen $\mathbb{M}$. Obereocän. Uinta. U. Scotti W. und M.

Vassacyon Matthew. $M$ mit grubigem Talonid, $P$ klein. Unterkiefer hoch. Untereocän. Wasatch. V. promicrodon W. und M. 
Die drei folgenden Gattungen sind nach Matthew Verwandte der Cercoleptiden. Reißzähne wenig differenziert. Alle $M$ einander sehr ähnlich.

Oodectes Wortman. Alle unteren $M$ mit wohlentwickeltem hohem Trigonid und schneidendem Talonid. Obere $M$ mit Protoconulus, ohne Hypocon. $P$ kurz und hoch. Bridgerbed. O. herpestoides Wortm.

Vulpavus Marsh. $\frac{4-3}{4-3} P$. Untere $M$ mit niedrigem, dreispitzigem Trigonid und breitem Talonid. $P$ massiv. Obere $M$ mit $Z$ wischenhöckern und dickem inneren Basalwuist. Wind Riverbed. $V$. canavus Cope. Bridgerbed, V. palustris Marsh. V. (Phlaodectes) ovatus Matthew.

Palaearctony $x$ Matthew. $P$ reduziert. $M$ niedrig, flach, obere groß, oblong. Bridgerbed. P. Meadi Matthew.

\section{Unterordnung. Fissipedia (Carnivora vera). R a ub tier e ${ }^{1}$ )}

Digitigrade oder plantigrade Fleischfresser, teilueise omnivor, mit grofiem gefurchtem Gehirn und vollständigem Gebiß. In der Regel J. C kräftig, höher als die übrigen Zähne. $P$ schneidend. $P^{4}$ und $M_{1}$ als Reifzahn entwickelt. Die oberen $M$ und die unteren $M_{2}$ und $M_{3}$ höckerig, znweilen verkümmert. Zehen getrennt. Extremitïten fünfzehig, selten Pollex und Hallux reduziert. Scaphoid
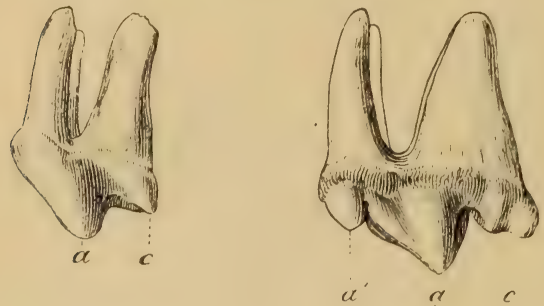

$a$

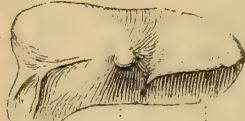

$a$

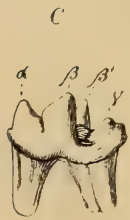

Fig. 549

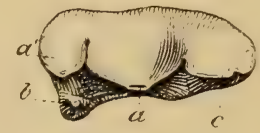

l)

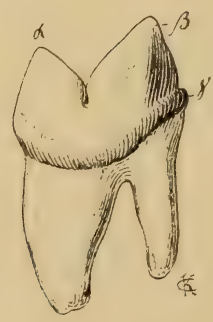
$A$ oberer Reißzahn vom Hund, $B$ vom Löwen, von
der Seite und von unten. $C$ unterer Reißzahn von Herpestes, $D$ vom Löwen. mit Iunatum und Centrale ver schmolzen. Endphalangen komprimiert, spitz, gekrümmt, zuveilen vetraktil.

Die echten Raubtiere oder Fissipedia stehen in ihrem Habitus und im Schädel- und Skelettbau den Creodontia am nächsten und unterscheiden sich von den Miaciden eigentlich nur durch die Verwachsung des Lunatum mit dem Scaphoid, durch die vollständige Verknöcherung der Bulla tympanica und die höhere Entwicklung des Gehirns. Die stark gefurchten Großhirnhemisphären bedecken zum großen Teil auch das Kleinhirn und die Riechlappen. Das Gebiß zeichnet sich durch starke Entwicklung der $C$ und die scherenartige Ausbildung des oberen $P^{4}$ und des unteren $M_{1}$ aus, die hier, wie bei den Miaciden, als »Reißzähne« (Figur 549) funktionieren. Die oberen $M$ sowie die unteren $M_{2}$ und $M_{3}$ sind höckerig ausgebildet, die ersteren trituberkulär, die letzteren tuberkulärsektorial, jedoch ist bei ihnen im Gegensatz zu $M_{1}$, welcher sich in der Regel durch kräftige

1) Cope E. D., Amer. Naturalist 1880 p. 833, 1883 p. 235. - Filhol H., Archiv. Museum d'hist. nat. Lyon. Tome III 1883. - Flower W. H., Proceed. zool. Soc. London 1869. - Gaillard $C l$., Archiv. Museum d'hist. nat. Lyon. Tome VII. 1899. 
Entwicklung des Protoconid und Paraconid auszeichnet, das Protoconid sehr niedrig, und das Paraconid mehr oder weniger verkümmert. Die oberen $M$ haben außer Paracon, Metacon und Protocon auch häufig Zwischenhöcker und einen Metastyl, auch kann manchmal ein Hypocon auftreten, allein in den meisten Fällen ist der eine oder andere dieser Bestandteile unterdrückt. Auch nimmt die Größe der $M$ vom ersten bis zum letzten in beiden Kiefern meist sehr rasch ab und von den oberen verschwindet sehr häufig $M^{3}$, öfters auch $M^{2}$, und ebenso fehlt von den unteren sehr oft $M_{3}$. Bei den Feliden geht fast stets $M_{2}$ und manchmal sogar $M^{1}$ verloren, während der untere $M_{1}$ sich in eine zweiteilige Schneide verwandelt. Bei omnivorer Lebensweise wird die Oberfläche der übrigbleibenden $M$ oder auch der obere $P^{4}$ durch Hinzutreten von Sekundärhöckern vergrößert. Der obere Reißzahn unterscheidet sich von $P^{3}$ durch den Besitz einer langen Schneide hinter dem Hauptzacken, auch ist er in den meisten Fällen mit einem Innenhöcker und einem Basalhöcker am Vorderrande versehen.

Im Milchgebiß (Fig. 550) gleicht $D_{4}$ im wesentlichen dem $M_{1}$, der untere Reißzahn, $D_{3}$ dem $P_{4}$, auch im Oberkiefer hat $D^{4}$ im ganzen die

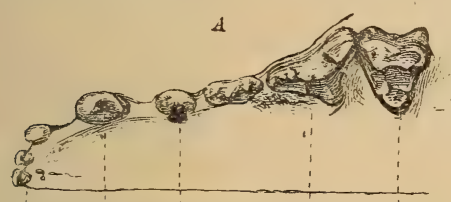
Zusammensetzung von $M^{1}$ und $D^{3}$ die von $P^{4}$, während $D^{2}$ sich $\operatorname{dem} P^{3}$ nähert,
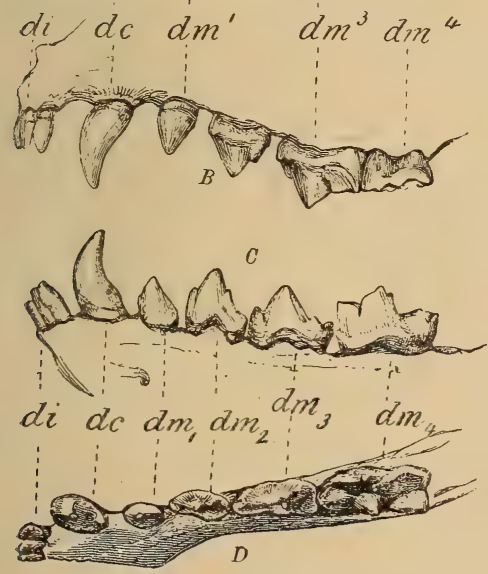

Fig. 550 .

Milchgebiß von Viverra civetta Lin. (Nach Mivart.) $A, B$ Oberkiefer von unten und von der Seite. $C, D$ Unterkiefer von der Seite und von oben.

$A$

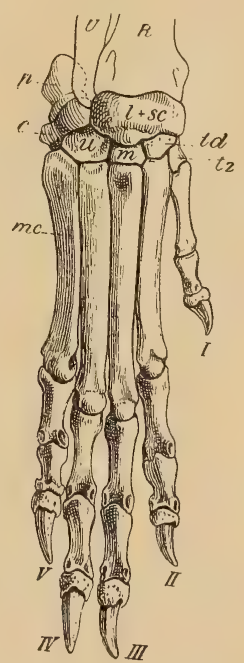

$B$

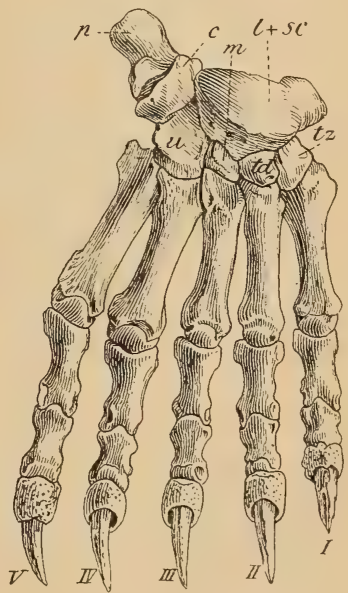

Fig. 551.

Vorderfuß $A$ vom Hund, $B$ vom Bären: $R$ Radius, $U$ Ulna, $l+s c$ Scapho-lunare, $c$ Cuneiforme (Triquetrum), $p$ Pisiforme, $u$ Unciforme, $m$ Magnum, td Trapezoid, $t z$ Trapezium, mc Metacarpalia, $I-V$ erster bis fünfter Finger.

jedoch sind die $D$ durchwegs zierlicher als ihre Ersatzzähne und der obere $D^{4}$ besitzt in der Regel keinen inneren Basalwulst, der untere $D_{4}$ hat ein verhältnismäßig großes Talonid, und an $D^{3}$ steht der Innenzacken weiter zurück als an $P^{4}$. An allen $D$ divergieren überdies die Wurzeln viel mehr als an den $P$.

- Lydekker R., Siwalik and Narbada Carnivora. Palaeontologia Indica. Ser. X vol. II. 1884. - Mivart G., Proceed. zool. Soc. London 1882. 1885. - Winge H., Jordfundne og nu levendé Rovdyr (Carnivora) fra Lagoa Santa. E. Museo Lundii. Kjobenhavn. 1895. - Wortman J. L. and Matthew C. W., Bull. Amer. Mus. Nat. Hist. New York 1899, p. 103. 
Der Brustgürtel enthält zuweilen eine rudimentäre Clavicula. Der Humerus besitzt öfters ein Foramen entepicondyloideum. Radius und Ulna bleiben getrennt. Im Carpus sind Scaphoid, Centrale und Lunatum verschmolzen (Fig. 551). Meist sind fünf Zehen vorhanden, wovon der Daumen oft viel kürzer ist als die übrigen. Die spitzen, komprimierten Krallen können bei den Katzen und Viverren über die zweiten Phalangen zurückgebogen werden. Dem Femur fehlt ein dritter Trochanter, und die Fibula hat ein Gelenk für das Calcaneum. Die Tarsalia sind dicht aneinander gepreßt, bleiben aber sämtlich frei. Der Astragalus ist unten konvex, selten gerade abgestutzt und oben mit meist tief ausgefurchter Trochlea versehen.

Die echten Raubtiere werden in die sieben Familien der Canidae, Ursidae, Procyonidae, Mustelidae, Viverridae, Hyaenidae und Felidae eingeteilt.

\section{Familie. Canidae. $\mathrm{H}$ und e. $\left.{ }^{1}\right)$}

$\frac{3.1 .4 .3-2}{3.1 .4 .3(4)-2 .} \quad P^{4}$ mit mäßigem Innenhöcker, kräftigem Hauptzacken und langer Schneide, $P^{3}$ und $P_{4}$, meist auch $P_{3}$ mit Nebenzacken. Obere $M$ trituberkulär, breiter als lang, öfters mit Zwischenhöckern. $M_{1}$ mit hohem Trigonid, mäßsig großem Metaconid und grubigem, selten schneidendem Talonid, $M_{2}$ viel nied. riger und kleiner als $M_{1}$. Paroccipitalfortsatz vorragend, an Bulla stoßend. Extremitäten digitigrad, anfangs fünfzehig, später Pollex und Hallux reduziert. Krallen nicht retraktil. Schwanz lang. Penis mit Knochen.

Die Caniden sind gegenwärtig über die ganze Erde verbreitet und stehen in ihrem Habitus und im Gebiß den Viverren am nächsten, obwohl sie schon im Creodontenstadium als Miaciden von ihnen getrennt waren. Sie beginnen im Obereocän von Europa, sind im Oligocän und Untermiocän hier ziemlich selten - nur durch Amphicyoninae vertreten - und werden erst wieder im Pliocän und Pleistocän häufig. Die Entwicklung während der mittleren Tertiärzeit ist in Nordamerika vor sich gegangen, von wo aus sie sich sowohl nach Eurasien als auch im Pleistocän nach Südamerika verbreitet haben.

\section{Unterfamilie. Cynodictinae.}

$\frac{2}{3}$ M. $P$ schlunk mit Nebenzacken. Obere $M$ viel breiter als lang, meist mit Zwischenhöckern. $M_{1}$ mit hohem Trigonid und mäßigem, grubigem Talonid. Humerus mit Entepicondylarforamen, Extremitüten fünfzehig. Metapodien mit halbkugelförmiger distaler Gelenkfäche. Astragalus distal konvex.

Im Skelett und Zahnbau gleichen die ältesten Cynodictinen, abgesehen von dem Besitz von $M \frac{2}{3}$, eher Viverren als Hunden.

Procynodictis Wortman. Obere $M$ ohne Zwischenhöcker. Obereocän. Uintabed.

Protemnocyon Hatcher. $C$ komprimiert, $P$ mit Nebenzacken. Obere $M$ mit Protoconulus. $\dot{M}^{3}$ reduziert. Untere $M$ mit schneidendem Talonid. Oligocän. White River.

1) Hatcher J. B., Oligocene Canidae. Memoirs Carnegie Museum. Vol. I 1902. - Huxley Th., Dental and cranial characters of the Canidae. Proceed. Zool. Soc. London 1880. - Merriam J. C., Pliocene and quaternary Canidae. University of California Publ. 1903. - Peterson O. A., Descr. of new Carnivores from the Miocene. Mem. Carnegie Mus. Pittsburgh. IV 1910. - Scott W. B., Notes on the Canidae of the White River Oligocene. Transact. Amer. Philos. Soc. Philadelph. Vol. XIX. 1898. - Studer Th., Die prähist. Hunde. Abhandl. Schweiz. paläont. Ges. XXVIII. 1901. - Woldrich J., Caniden aus dem Diluvium. Denkschr. Wien. Akad. math. naturw. Kl. 1878. Bd. 89. - Wortman J. L. and Matthew C. W., Bull. Am. Mus. Nat. Hist. New York 1899. 
Temnocyon Cope. Untermiocän. John Daybed. Oregon. T. altigenis Cope. Vorläufer von Cyon.

Mesocyon Scott (Hypotemnodon Eyermann). Untere $M$ mit schneidendem Talonid. Ebenda. M. coryphaeus Cope sp.

Cynodictis Bravard und Pomel. (Fig. 552.) Obere $M$ sehr breit, dreieckig, mit zwei Zwischenhöckern, untere mit grubigem Talonid. $P^{4}$ lang.

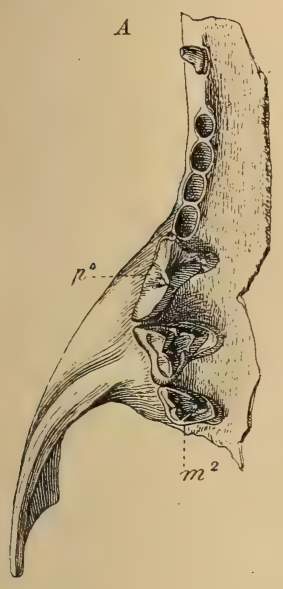
Obereocän. Pariser Gips, Débruge, Phosphorite von Quercy. C. lacustris Gervais, intermedius Filh. Galecynus Owen (Cynodictis Wortman). Obere $M$ gerundet dreieckig. $P^{4}$ kurz. Oligocän. White River. G. paterculus Matthew sp. gregarius Cope.

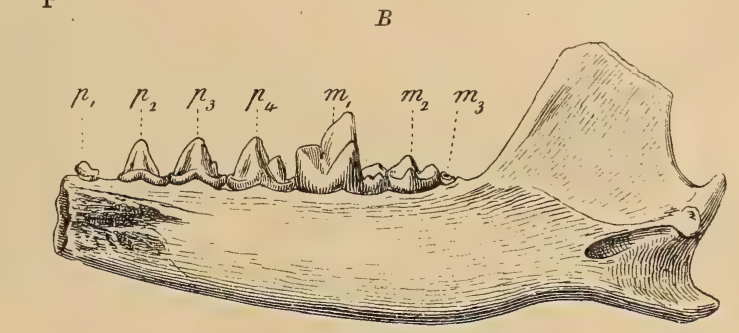

Fig. 552 .

Cynodictis lacustris Gerv. Oberes Eocän (Phosphorite). Quercy. $A$ rechtes Oberkieferfragment. $B$ rechter Unterkiefer von innen (nat. Gr.).

Untermiocän. John Daybed. G. oregonensis Merriam sp. Obermiocän. Europa. G. oeningensis v. Meyer?

Nothocyon Wortman (Galecynus Cope). Obere $M$ groß. $P^{4}$ klein. Untere $\boldsymbol{M}$ mit großem Hypoconid. Untermiocän. John Day. N. geismarianus Cope sp. Vorläufer der südamerikanischen lebenden Caniden.

Cynodesmus Scott. $M$ ähnlich denen von Wolf. ' Extremitäten fünfzehig. Hallux verkürzt. Miocän. Montana. C. thooides Scott. Süd-Dakota. C. Thomsoni Matthew.

Philothrax Merriam. Mit nur 3 P. Untermiocän. John Day. Oregon.

\section{Unterfamilie. Amphicyoninae.}

$\frac{3-2}{3-2} M . P^{4} \quad k u r z$, plump, mit kleinem, ziemlich weit vorne stehendem, öfters nach der Mitte verschobenem Innenhöcker, die übrigen $P$ in der Regel klein und einfach gebaut. $\mathbf{M}^{1}$ gerundet drei- oder viereckig, mit starkem inneren und meist auch äußerem Basalband, mit zwei konischen Außenhöckern und einem, seltener zwei Innenhöckern; im ersteren Falle mit Zwischenhöckern versehen. $M^{2}$ und $M^{3}$ oval. Untere $M$ mit kleinem Metaconid und grubigem oder schneidendem Talonid. $M^{3}$ und $M_{3}$ öfters fehlend. Humerus mit Foramen entepicondyloideum. Hand und Fuß fünfzehig, mit verhältnismäßig kurzen Metapodien. Krallen etwas retraktil. Schwanz lang.

Bei den späteren Formen, welche hauptsächlich aus dem Obermiocän und Pliocän von Nordamerika stammen, tritt Verkürzung des'Schädels ein, die mit dem Verlust von $M^{3}$ und Verkürzung von $M_{2}$ und $M_{3}$ und häufig auch mit Reduktion der Zahl der $P$ verbunden ist, wofür jedoch $P^{4} \mathrm{kom}$ plizierter wird, und $M_{2}$ bei Verlust des $M_{3}$ ein langes Talonid bekommt.

Amphicyon Lartet. (Fig. 553.) $\frac{3}{3} M$. $M^{3}$ stets klein. $M^{1}$ und $M^{2}$ trituberkulär, untere $M$ schlank, mit mehr oder weniger schneidendem Talonid. Oligocän. Phosphorite von Quercy. A. ambiguus Filh. Untermiocän. 
Europa A. lemanensis Pomel. Obermiocän A. major Blv. Pliocän. Siwalikhügel A. palaeindicus Lydekker.

Daphaenus (Daphaenodon Peterson). $\frac{3}{3}$ M. Sehr ähnlich Amphicyon lemanensis. Durch mehrere vollständige Skelette vertreten. Oligocän White River. D. felinus Scott, vetus Leidy. Untermiocän. D. superbus Peterson. gerus Cope sp.

Paradaphaenus Matthew. Untermiocän. John Daybed. P. cuspi-

Pseudamphicyon Schlosser. $P_{4}$ und $M_{1}$ mit hohem Hauptzacken. Obere $M$ mit schwachem Basalband. $\frac{2}{3} M$. Metapodien sehr kurz. Eocäne und oligocäne Bohnerze. P. lupinus Schlosser.

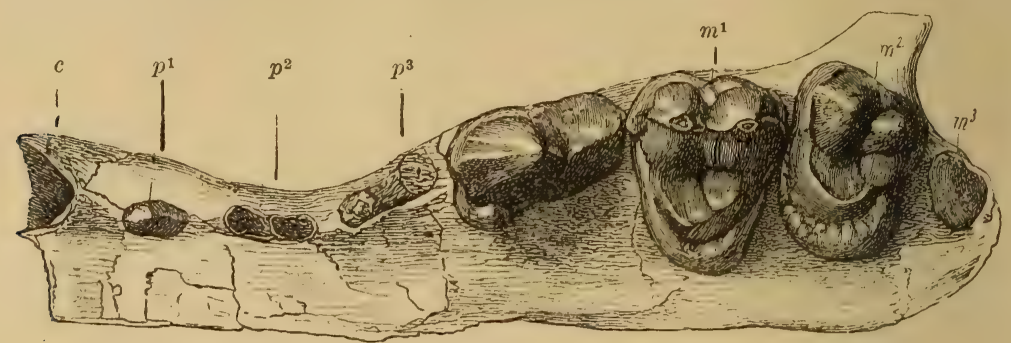

Fig. 553.

Amphicyon giganteus Laürill. Miocän. Sansan. Gers. Linker Oberkiefer von unten. 3/5 nat. Gr. (Nach Gaudry.)

Pseudocyon Lartet. $\frac{3}{3} M$. Talonid verkürzt, Protocon der oberen $M$ schwach. Basalband kräftig entwickelt. Miocän Tuchorschitz P. bohemicus Schlosser. Sansan (Gers). P. sansaniensis Lartet.

Pseudarctos Schlosser. $P$ und $M_{1}$ klein, $M_{2}$ und $M_{3}$ groß und flach. Obermiocän. Tutzing. P. bavaricus Schl.

Simocyon Wagner. Schnauze kurz, vordere $P$ stark reduziert. $\frac{2}{2} M$. $M_{2}$ mit langem Talonid. Unterpliocän. Pikermi, Eppelsheim.

Borophagus Cope (Dinocyon Matthew). $\frac{2}{3} \boldsymbol{M}$. Obere $M$ sehr breit, $P$ schwach. Schädel kurz und plump. Miocän. Montana und Texas. B. Gid-
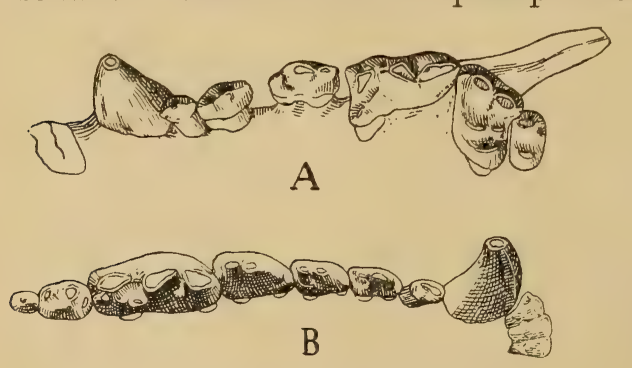

Fig. 554 .

Aelurodon wheelerianus Cope. Miocän. Süd-Dakota. $A$ obere, $B$ untere Zahnreihe $1 / 2$ nat. Gr. (nach Matthew.) leyi Matthew. Nebraska. »Amphicyon americanus Matthew von unsicherer Stellung.

Ischyrocyon Matthew. ${ }_{4}^{4} P$. Obermiocän. Loup. Fork. Süd-Dakota.

Aelurodon Leidy. (Figur 554.) $\frac{4}{4} P . \frac{2}{3} M . P$ mit Ausnahme des letzten klein, aber mit Nebenzacken. $P^{4}$ mit großem Innenhöcker und starkem Zacken vor dem Hauptzacken. $M_{1}$ ziemlich lang. Obermiocän Nebraska, Kansas. Ae. saevus Leidy, wheelerianus Cope.

Hyaenognathus Merriam.

${ }_{3}^{4}$ P. $\frac{2}{3}$ M. $P_{4}$ in beiden Kiefern plump und groß, hintere $M$ und vordere $P$ sehr klein, $J^{3}$ fast ebensogroß wie $C$, die unteren $J$ nebeneinander stehend. Pliocän. Kalifornien. H. pachyodon Merriam. Hyaenide?

Enhydrocyon Cope (Hyaenocyon Cope). Schädel stark verkürzt. $\frac{2}{3} P$. $\frac{2}{2} M$. $\quad P^{4}$ ohne Vorderhöcker. $M \frac{2}{2}$ sehr klein. $M_{1}$ mit schneidendem Talonid, ohne Metaconid. Untermiocän. John Day. E. stenocephalus Cope. Montana. E. crassidens Matthew. 
Fissipedia. Cynodontinae. Caninae.

\section{Unterfamilie. Cynodontinae.}

$\frac{2-1}{3-2} M . \quad P^{4}$ mit großem, nach rückwärts verschobenem Innenhöcker, die übrigen $P$ klein und einfach. Obere $M$ mit je zwei konischen Außenhöckern, großem Protocon und Metaconulus, stets ohne Protoconulus und mit mäßigem inneren Basalband. $M^{1}$ nicht viel kürzer als breit, dreieckig, $M^{2}$ elliptisch. $M_{1}$ mit schwachem Metaconid und meist grubigem, großem Talonid.

Diese Unterfamilie beginnt mit kleinen Formen, welche aber im Pliocän die Größe von Bären erreichen. Sie umfaßt zwei Stammesreihen, von welchen die eine ein Canis ähnliches Gebiß bewahrt und im Pliocän erlischt - Cephalogale - Dinocyon, während die andere - Cynodon unter Vergrößerung der $M$ sich zu den Ursiden entwickelt. Bei der ersten Gruppe findet Reduktion der $M$ und $P$ und Verdickung der bleibenden Zähne statt. Die Cynodontinae scheinen auf Europa beschränkt zu sein.

Cephalogale Jourdan. $\frac{2}{3} M$. $M^{1}$ gerundet, dreickig, $M^{2}$ schräg oval. $P$ klein. Untere $M$ mit großem Trigonid und kurzem, schneidendem Hypoconid. Lange, schlanke Metapodien. Oligocän. Phosphorite von Quercy, Untermiocän, St. Gérand le Puy.

Dinocyon Jourdan. Zum Teil schon von Bärengröße. Obermiocän Sansan (Gers), Steiermark. D. göriachensis Toula. La Grive St. Alban. D. Thenardi Jourdan. Im Unterpliocän Frohnstetten, Eppelsheim?

Hemicyon Lartet. $P^{4}$ mit weit zurückstehendem Innenhöcker. $M$ wie bei Cephalogale. Zehen digitigrad. Obermiocän. Sansan.

Cynodon Aymard. (Figur 555.) $P$ klein, mit Ausnahme des mit großem Innenhöcker versehenen $P^{4}$. Obere $M$ wenig breiter als lang. Metaconulus fast ebenso

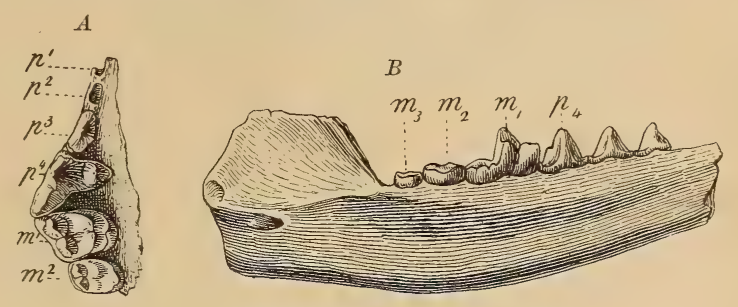

Fig. 555.

Cynodon leptorhynchus Filhol sp. Phosphorite. Mouillac. Quercy. $A$ rechter Oberkiefer von unten. $B$ linker Unterkiefer von innen. (nat. Gr.)

stark wie Protocon. Talonid der unteren $M$ ziemlich groß, grubig. Hand und Fuß mit gespreizter Zehenstellung. Oligocän. Phosphorite von Quercy. C. leptorhynchus Filh. sp. Ronzon. Ulm. C. velaunus Aymard.

Paracynodon Schlosser. Schmelz stark gerunzelt. Oligocän. Ulm. $P$. vulpinus Schlosser.

Pachycynodon Schlosser. Unterkiefer sehr hoch. $P$ klein. $P^{4}$ mit sehr großem, weit zurückstehendem Innenzacken. Obere $M$ oblong, untere $M$ mit sehr großem grubigem Talonid. Oligocän. Bohnerze von Schwaben und Phosphorite von Quercy. $P$. crassirostris Filhol sp.

\section{Unterfamilie. Caninae.}

$\frac{2}{3-2}$ M. $P$ schlank, hintere mit Nebenzacken. Untere $M$ mit grubigem oder schneidendem Talonid, $M_{1}$ mit schwachem Metaconid. Obere $M$ mit starkem inneren Basalband. Extremitäten vierzehig, mit rudimentärem Hallux und Pollex. Humerus ohne Entepicondylarforamen. Metapodien mit zylindrischen distalen Gelenkflächen. Astragalus distal ahgestutzt.

$\dot{C}$ anis Linn. Talonid schneidend mit rudimentärem Hypoconid. Die ältesten fossilen Vertreter der Gattung Canis sind: C. (Tephrocyon) temerarius Leidy im Obermiocän von Nordamerika, Cautleyi Bose im Pliocän der Sivalik, vielleicht auch in China, C. etruscus Major im Oberpliocän von Toskana. Im Pleistocän von Europa C. lupus Linn, in Nordamerika C. latrans Say, 
indianensis Leidy, occidentalis Rich etc. Als Canis Mikii, intermedius und hercynicus wurden Reste von angeblichen Wildhunden aus dem europäischen Pleistocän beschrieben. In Australien wurde der Dingo fossil nachgewiesen. Ächte Haushunde - C. familiaris - erscheinen erst in der jüngeren Steinzeit in den Pfahlbauten, C. f. palustris und der große Inostranzewi, in der Bronzezeit C. f. matris optimae und Leineri. Nach Studer ist die einheitliche Abstammung der zahlreichen lebenden Rassen sehr wahrscheinlich. Sie sind aus einer oder mehreren pleistocänen, wolfähnlichen wilden Hundearten hervorgegangen und später durch Züchtung und zum Teil auch Kreuzung mit Wölfen und Schakalen in der mannigfachsten Weise umgebildet worden. Die südlichen Hunderassen sollen aus einer Dingo-ähnlichen Form entstanden sein.

Vulpes Brisson. Talon der unteren $M$ grubig. $C$ und $M$ schlank. $V$. vulgaris Linn sp. fossil im Pleistocän von Europa. V. Donnezani Deperet im Mittelpliocän von Roussillon, V. borbonicus Brav. und megamastoides Pomel im Pliocän der Auvergne. V. sinensis Schlosser im Pliocän von China und V. curvipalatus Bose, in den indischen Siwalik. Der älteste Vertreter der Gattung Vulpes ist vielleicht Canis vafer Leidy im Obermiocän von Nordamerika.

Leucocyon lagopus Pallas. Eisfuchs, häufig im europäischen Pleistocän zusammen mit Ren und Lemming.

Cyon Blanford, meist mit nur $\frac{2}{2} M$; untere $M$ mit schneidendem Talonid. Lebend in Asien, fossil im europäischen Pleistocän. siliens.

Icticyon und Palaeocyon Lund. Fossil in Knochenhöhlen Bra-

Otocy on $\frac{3}{4} M$. Lebend in Südafrika.

\section{Familie. Ursidae. ${ }^{1}$ )}

3.1. 4-1.2. $C$ dick und gro $\beta, P$ im Verhältnis zu den $M$ stets sehr klein, $P_{2}$ und $P_{3}$ oft, seltener $P_{1}$ fellend. $P_{\frac{4}{4}}^{4}$ kurz, der obere mit zwei stumpfen Außenhöckern und einem weit nach hinten verschobenen Innenhöcker. Obere $M$ mehr oder weniger deutlich vierhöckerig und viel länger als breit. $M_{1}$ mit niedrigem Trigonid, Talonid an $M_{1}$ und $M_{2}$ groß und beckenförmig. $M_{3}$ mit rundlicher Krone. Extremitüten fünfzehig, plantigrad, fünfte Zehe stürker und länger als die übrigen. Schwanz kurz, Penisknochen groß. Schüdel gestreckt. Bulla tympanica flach. Processus paroccipitalis und mastoideus kräftig entwickelt.

$\mathrm{Zu}$ den Bären gehören große, meist omnivore Raubtiere, welche sich durch ihre großen quadratischen oder länglich vierseitigen, vielhöckerigen $M$ und den Mangel von eigentlichen Reißzähnen auszeichnen. Ihr Skelett ist dem der Amphicyoninen ähnlich, aber plumper und gedrungener und die plantigraden Extremitäten sind zum Greifen und Klettern geeignet. Sie bewohnen gegenwärtig Europa, Asien, Nordafrika und Nord- und Südamerika. Die fossilen Formen verteilen sich auf das nämliche Verbreitungsgebiet, jedoch erscheinen sie in Amerika erst im Pliocän oder sogar erst im Pleistocän. Thre ursprüngliche Heimat ist wahrscheinlich Europa, wo sie sich aus Cynodontinen entwickelt haben, welche ihrerseits von Miaciden abstammen.

Hyaenarctos Falc. und Cautley. (Fig. 556.) Vordere $P$ klein, hinfällig, obere $M$ vierhöckerig, quadratisch, gleich groß. Im Pliocän von Montpellier, Alcoy, Pikermi und in den Siwalik. H. sivalensis, punjabiensis Falc. Der letztere auch in Maragha. Eine Art auch noch im Pleistocän von China.

1) Schlosser M., Die Bären des europäischen Tertiärs. Palaeontogr. Bd. XLVI. 1899 und: Parailurus und Ursus aus den Ligniten ron Baroth. Mitteil. Jahrb. d. k. ungar. geolog. Anstalt.' Budapest 1899. 
Ursavus Schlosser. $P$ klein. $P^{4}$ mit großem Innenhöcker, obere $M$ vierhöckerig, untere $M$ mit schwachen Runzeln. Nicht größer als Wolf. Obermiocän von Steiermark, Schlesien U. brevirhinus Hofmann sp., La Grive St. Alban U. primaevus Gaillard sp. und in pliocänen schwäbischen Bohnerzen.

Ursus Lin. Obere $M$ viel länger als $P^{4}$ und wie die unteren mit vielen Runzeln bedeckt. Vordere $P$ sehr klein, öfters fehlend. Die ältesten Arten der Gattung Ursus finden sich in den Siwalik (U. Theobaldi Lyd.) und ịm Pliocän von China. Im Pliocän von Siebenbürgen U. Boeckhi Schlosser, im Pliocän von Toskana U. etruscus Cuv., in Roussillon und der Auvergne $U$. arvernensis Croiz.. Der Höhlenbär (U. spelaeus Blumb.) ist das häufigste Raubtier im europäischen Pleistocän. Viele Höhlen haben mehrere hundert Individuen in allen Altersstadien geliefert. Er unterscheidet sich vom braunen Bären durch seine stattlichere Größe, die viel
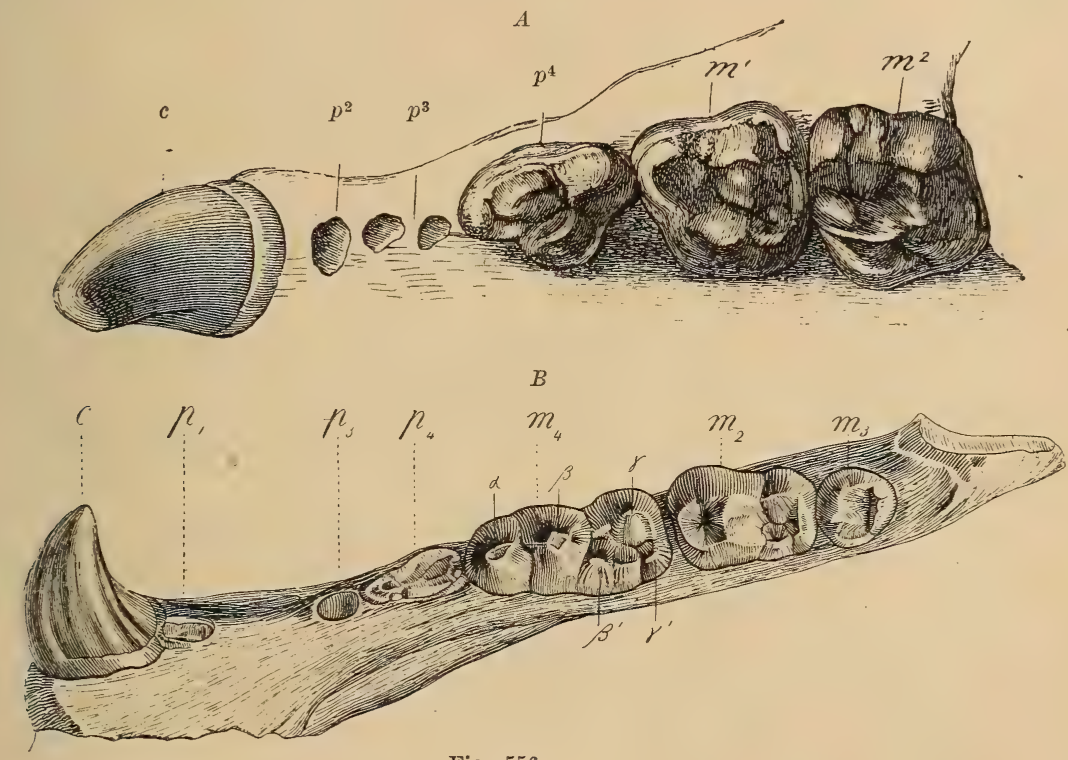

Fig. 556 .

A. Hydenarctos Sivalensis Falc. Unt. Pliocän. Sivalik, Ostindien. Linker Oberkiefer von unten. $3 / 5$ nat Gr. (Nach Gaudry.)

B Hyaenarctos Punjabiensis Lyd. Rechter Unterkieferast. $3 / 5$ nat. Gr. (Nach Lydekker.)

plumperen Knochen, die gewölbte Stirn und das Fehlen von $P^{1}$. Sein Vorläufer war $U$. Deningeri Reichenau im älteren Pleistocän. U. priscus Cuv. ebenfalls im europäischen Pleistocän, steht dem Grizzlybären nahe. Im Pleistocän von Nordamerika $U$. americanus Pallas und amplidens Leidy.

Arctodus Leidy (Arctotherium Bravard). Kiefer stark verkürzt, $P$ dicht stehend. Pleistocän von Kalifornien, Süd-Karolina A. pristinus Leidy. Pennsylvanien, Mexiko A. simus Cope sp. Südamerika A. bonariensis Gervais sp.

\section{Familie. Procyonidae (Subursi Blainville).}

3.1. 4-3.2. $\quad P^{4}$ und $M_{1}$ nicht als typische Reißzähne entwickelt. Obere $M$ and $P^{4}$ gerundet, viereckig, trituberkulär oder quadrituberkulär. Untere $M$ mit stumpfzackigem Trigonid und zweihöckerigem Talonid. Schädel kurz und breit. Extremitäten fünfzehig, plantigrad. 
Die Procyoniden bewohnen in der Gegenwart Nord- und Südamerika, mit Ausnahme der auf den Himalaya beschränkten Gattung Ailurus. Sie haben sich aus Miaciden entwickelt.

Procyon Storr. Waschbär. Lebend und im Pleistocän von Nordund Südamerika.

Bassariscus Coues. Lebend und im Pleistocän und Pliocän von Nordamerika. B. antiquus Matthew.

Nasua Storr. Lebend und fossil im Pleistocän von Südamerika.

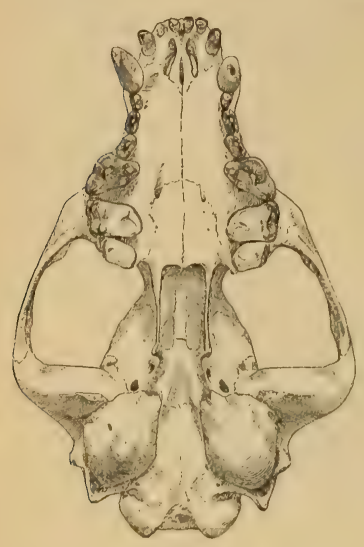

Fig. 557.

Phlaocyon leucosteus Matthew Miocän. Colorado. Schädel ron unten. $1 / 2$ nat. Gr. (Nach Matthew.)

Cyonasua, Pachynasua Ameghino in der Paranastufe und Amphinasua Moreno in der araukanischen Stufe - Pliocän - von Argentinien.

Phlaocyon Wortm. und Matthew. (Figur 557.) $\frac{4}{4} P . \frac{2}{3} M$. Schädel und Skelett Procyon-ähnlich. $P^{4}$ mit zwei Innenhöckern. Große Bullae osseae. Untermiocän von Colorado. $P$. leucostens Wortm. und Matthew.

Leptarctus Leidy. 3.1.3.2. $P$ mit Talonid. Miocän Loup. Fork. Süd-Dakota.

Parailurus Schlosser. Sehr komplizierte $M$, aber einfachere $P$ als bei der lebenden Gattung Ailurus. Pliocän - Red Crag - von England und Lignite von Baroth, Siebenbürgen.

Cynarctus Matthew. $3 M$ im Unterkiefer. Auch $M_{2}$ mit Protoconid und $M_{1}$ mit Zacken an Außenseite des Protoconid. Von Matthe w zu den Amphicyoninen gestellt. Obermiocïn, Loup Fork, Colorado. C. saxatilis Matthew.

4. Familie. Mustelidae. Marder.

$\frac{3.1 .4 .2-1 .}{3} P^{4}$ mit langer Schneide hinter dem Hauptzacken und mit kräftigem Innenzacken. $M_{1}$ mit wohlentwickeltem, grubigem oder schneidendem Talonid, meist auch mit kleinem Metaconid. $M^{1}$ querverbreitert, öfters gro $\beta$ und viereckig, in der Regel mit sehr starkem Basalband. $M^{2}$, wenn vorhanden, sehr klein, $M_{2}$ ebenfalls stark reduziert, aber öfters zweiwurzelig. Bulla ohne Septum, gewölbt, meist klein, getrennt vom Processus paroccipitalis. Ohne Alisphenoidkanal. Körper gestreckt, Fiiße meist fünfzehig, plantigrad oder digitigrad.

Die Musteliden sind kleine bis mittelgroße, schlanke, bewegliche Räuber, die gegenwärtig. mit Ausnahme von Australien über die ganze Erde verbreitet sind, hauptsächlich aber die nördliche Hemisphäre bewohnen. Die fossilen haben die nämliche Verbreitung und erscheinen zuerst im Oligocän von Europa und Nordamerika. Auf Grund der Schädelbasis werden sie zu den Arctoidea gestellt. Die ältesten Formen haben große gewölbte Bullae und $\frac{2}{2-3} M$ und sind gegen die ältesten Viverren nicht scharf abzugrenzen. Sie gehen wohl auf Viverravinen zurück.

\section{Unterfamilie. Putoriinae.}

Anfangs mit $\frac{2}{2}$, später $\frac{1}{2} M$, ausgezeichnet durch Reduktion der $P \frac{4}{4}$, des $M^{2}$ und des Metaconid an $M_{1}$ sowie durch das kleine Talonid von $M_{1}$.

Palaeoprionodon Filhol. $\frac{2}{2} M$. Obere $M$ trituberkulär. $M_{2}$ klein, zweiwurzelig, $M_{1}$ mit Metaconid und grubigem kleinen Talonid. Oligocän. Phosphorite von Quercy.

Stenoplesictis Filhol. (Fig. 558.) Oligocän. Phosphorite von Quercy. 
Bunaelurus Cope. (Fig. 559.) Oligocän. White River. Colorado. B. lagophagus Cope. Schädel gut bekannt.

Parictis Scott. Untermiocän. John Daybed.

Haplogale Schlosser. $\frac{1}{2} M$. $M_{1}$ mit sehr kurzem Talonid und kleinem Metaconid. $M_{2}$ einwurzelig. Oligocän, Phosphorite, bis Obermiocän.

Proputorius Filhol. Obermiocän, Sansan.

Stenogale Schlosser. $M_{1}$ mit Metaconid, $M_{2}$ schneidend, einwurzelig. Oligocän bis Obermiocän.

Pseudictis'Schlosser. $\dot{M}_{2}$ zweiwurzelig. Obermiocän.

Palaeogale v. Meyer. $M_{1}$ ohne Metaconid, $M_{2}$ zweiwurzelig. Oligocän bis Obermiocän.

Putorius Cuv. Wiesel. $M_{1}$ ohne Metaconid, $M_{2}$ einwurzelig. Pliocän der Auvergne. Lebend und im Pleistocän von Europa, besonders häufig $P$. vulgaris zusammen mit Lemming. In Nordamerika im Obermiocän, Loup fork P. nambianus Cope.

\section{Paroligobunis Peter-} son. 4 P. 2 M. Metaconid klein. Talonid schneidend. Untermiocän. Nebraska. P. simplicidens Peterson.

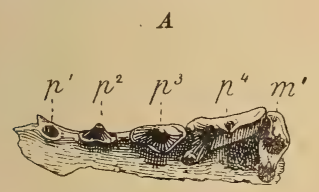

$B$

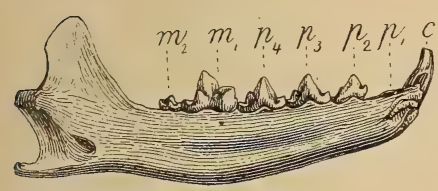

Fig. 558 .

Stenoplesictis Cayluxi Filhol. Phosphorite. Quercy. A Linker Oberkiefer von unten, $B$ Linker Unterkie ${ }^{\text {er }}$ von innen. (Nat. Gr.)

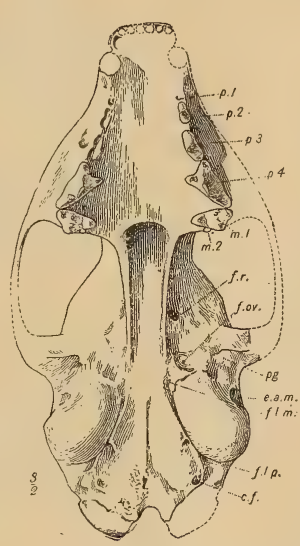

Fig. 559.

Bunaelurus lagophagus

Cope. Oligocän. Whito Riverbed. Colorado.

Schädel von unten, nat Gr. (nach Matthew.)

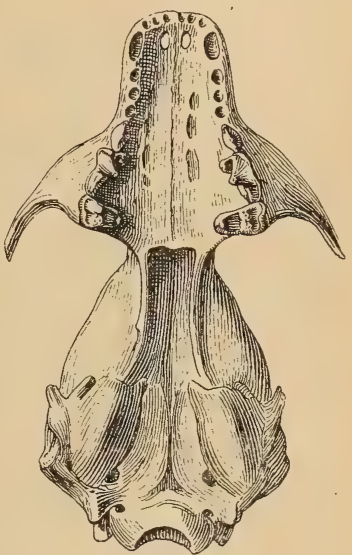

Fig. 560 .

Plesictis lemanensis Pomel. Unt. Miocän. St. Gérandle-Puy. Allier. A Schädel von unten. $3 / 4$ nat. Gr. (Nach Filhol.)

A elurocyon Peterson, $\frac{3}{4} P$. Megalictis Matthew, $\frac{3}{3} P$, beide groß, mit verkürzter Schnauze. $M_{1}$ ohne Metaconid, $M^{2}$ winzig. Miocän. Süd-Dakota. M. ferox Matthew.

Gulo Storr. Vielfraß. $\frac{4.1 .}{4.2} P$ und $M$ dick, $M^{1}$ zweihöckerig, $M_{1}$ ohne Metaconid. Gegenwärtig zirkumpolar. Fossil im Pleistocän von Europa und Nordamerika.

\section{Unterfamilie. Martinae.}

$M_{1}$ stets mit Innenzacken und grubigem Talonid. $M^{1}$ klein, $P^{4}$ mit sehr kleinem Innenhöcker.

Plesictis Pomel. (Fig. 560.) $\frac{2}{2} M$. $M^{1}$ trituberkulär. $M_{2}$ zweiwurzelig. $M^{2}$ klein oder fehlend. Oligocän, Phosphorite, und Untermiocän von Allier, Ulm, Mainz. Obermiocän, Steiermark, La Grive St. Alban.

Mustel a Linn. $\frac{1}{2} M . M_{2}$ einwurzelig. Obermiocän. Sansan, La Grive St. Alban, Steiermark. Pliocän. Pikermi und Siwalik. Pleistocän Europa. In Nordamerika, Miocän von Colorado $M$. ogygia Matthew. Pliocän $M$. minor Douglass.

Galictis Bell. Lebend in Südamerika. Fossil im Pleistocän von Brasilien und Maryland. 
Oligobunis Cope. $\frac{4-3}{4} P . \frac{2-1}{2} M$. Dachsgröße. Untermiocän. John Day bed 0 . crassivultis Cope. Dakota O. lepidus Matthew.

\section{Unterfamilie. Lutrinae.}

Mittelgroße aquatile Formen. $M_{1}$ mit Metaconid und schneidendem Talonid. $P^{4}$ mit breitem Innenhöcker.

Plesiocyon Schlosser: $\frac{2}{3} M$. Oligocän. Phosphorite von Quercy.

A mphictis Pomel $\frac{2}{2} \boldsymbol{M}$. $\boldsymbol{M}_{2}$ mit langem Talonid. Ebenda u. Untermiocän.

Potamotherium Geoffroy (Lutrictis Pomel, Stephanodon v. Meyer). (Fig. 561.) $\frac{4.2 .}{4.2 .} P^{4}$ mit verbreitertem Innenhöcker. $M^{1}$ querverlängert trituberkulär. $M^{2}$ sehr klein, $M_{1}$ mit großem Talonid. Bullae osseae flach. Skelett stärker spezialisiert als bei Lutra. Metapodien und Zehen abgeplattet. Untermiocän. Dep. Allier, Ulm, Mainz. Im Miocän von Nordamerika $P$. lycopotamicum Cope, Pliocän lacota Matthew. Wohl generisch verschieden.

Lutra Erxleben Otter. $\frac{1}{2} M$, gedrungener als bei voriger Gattung. Lebend auf der nördlichen Hemisphäre. Fossil im Miocän, Pliocän und

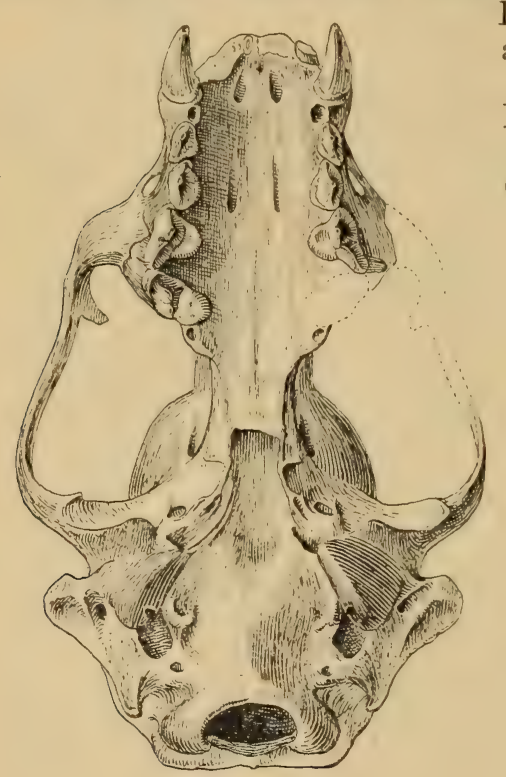

Fig. 561 .

Potamotherium Valetoni Geoffroy St. Hilaire. Unt. Miocän. St. Gérandle-Puy. Schädel von unten $2 / 3$ nat. Gr. Pleistocän von Europa, Asien und Nordamerika.

Brachypsalis Cope. $M_{2}$ sehr lang. Pliocän, Nebraska.

Enhydriodon Falconer. Unterpliocän, Monte Bamboli und Pliocän Siwalik.

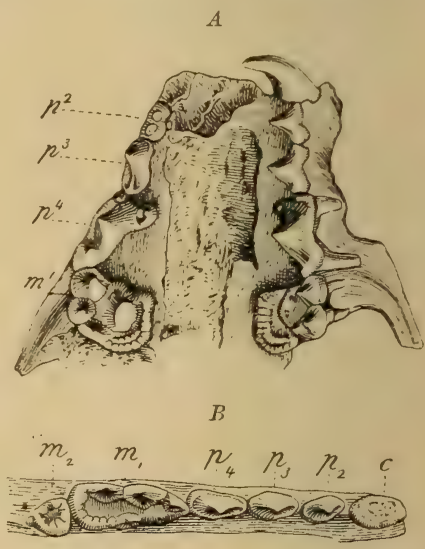

Fig. 562.

Promeles palaeattica Weithofer sp.

Unt Pliocän. Pikermi bei Athen. $A$ Gaumen von unten, $B$ Unterkiefer von oben, nat. Gr. (Nach W e ith of er.)

\section{Unterfamilie. Melinae.}

$\frac{1}{2} M . \quad M_{1}$ mit großem grubigem Talonid und meist mit Metaconid. $M^{1}$ stark vergrößert und kompliziert. Vordere $P$ stark reduziert.

Trochictis v. Meyer. $\mathrm{M}_{1}$ mit kurzem Talonid. Obermiocän. Europa.

Trochotherium Fraas. $M$ abgeplattet. Obermiocän. Steinheim.

Promeles Zittel. (Fig. 562.) $\frac{3.1 .}{3.2 .} \cdot P^{4}$ gestreckt. $M^{1}$ trituberkulär, viereckig, mit starkem Basalband, $M_{1}$ mit langem, vielböckerigem Talonid. Unterpliocän. Pikermi.

Meles Storr. Dachs. $P^{4}$ kurz. Lebend in Europa und Asien. Fossil im Unterpliocän von Maragha und China und im Pleistocän von Europa. 
Taxidea Waterh. Lebend und im Pleistocän von Nordamerika.

Mellivora Storr. Lebend in Südasien und Südostafrika. Fossil im Pliocän der Siwalik.

St. Alban.

Trocharion Major. $M_{2}$ zweiwurzelig. Obermiocän. La Grive

Promephitis Gaudry. $P$ bis auf $\frac{2}{2}$ reduziert. Unterpliocän. Pikermi.

Mephitis Cuv. Lebend und fossil im Pleistocän von Nordamerika. Thiosmus Illiger in Südamerika.

Brachyprotoma Brown. $\frac{2}{3} J$. Pleistocän von Nordamerika.

\section{Familie. Viverridae. Zibetkatzen.}

3.1. 4.2. $P^{4}$ gestreckt mit Vorderzacken vor dem Hauptzacken und kräftigem, weit vorne stehendem Innenhöcker. Obere $M$ trituberkulär. $M_{1}$ mit hohem, dreizackigem Trigonid und beckenförmigem, zackig begrenztem Talonid. $M \frac{2}{2} \ddot{a} h n l i c h ~ M \frac{1}{1}$. Schädel gestreckt, niedrig, mit ziemlich langer Schnauze. Bulla ossea groß, durch ein Septum vom Tympanicum geschieden. Extremitäten kurz, schlank, plantigrad oder digitigrad, fünf-, selten vierzehig. Schwanz lang.

Die Viverren sind meist kleine schlanke, schnellfüßige Raubtiere, welche jetzt ausschließlich Asien, Afrika und Südeuropa be-

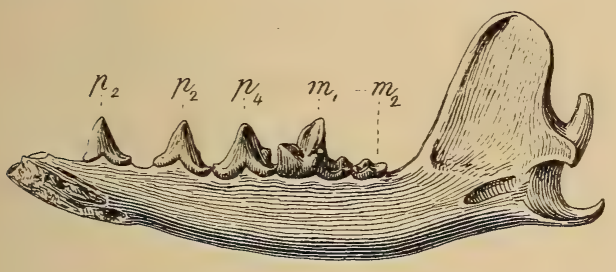

Fig. 563.

Viverra simplicidens Schloss. Phosphorite. Quercy. Rechter Unterkiefer von innen, nat. Gr.

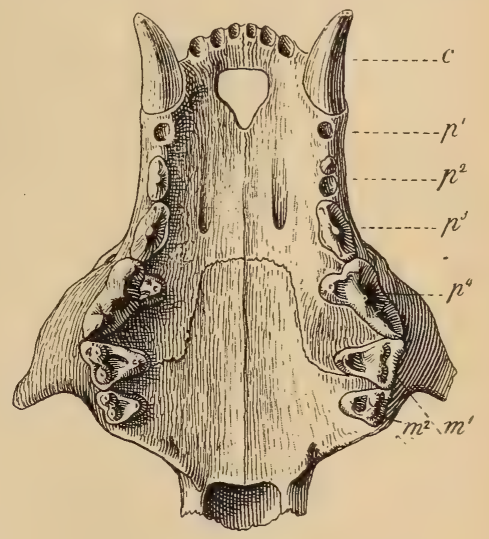

Fig. 564 .

Herpestes lemanensis Pomel (Viverra antiqua Blainv.). Unt. Miocän. Tretaux. - Allier. Gaumen von unten, nat. Gr.

wohnen und auch fossil im europäischen Tertiär und im Pliocän und Pleistocän von Südasien vertreten sind. Sie stammen von den Viverravinen des nordamerikanischen Eocän ab. Im Gebiß und Skelett weisen sie noch viele primitive Merkmale auf und zeigen vielfach Anklänge an die ältesten Caniden-Cynodictinae und die ältesten Musteliden-Palaeoprionodon.

Viverra Linn. (Fig. 563) und Herpestes Illiger (Fig. 564) leben jetzt in Südasien, Südeuropa und Nordafrika. Fossile Formen - „Viverra —

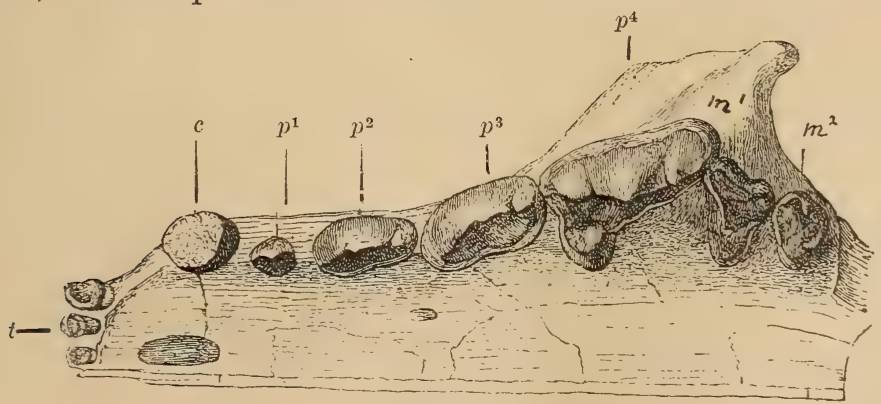

Fig. 565 .

Ictitherium robustum Nordm. sp. Unt. Pliocän. Pikermi bei Athen. Linker Oberkiefer von unten. Nat. Gr. (Nach Gaudry.) 
mit kleinem Talonid und kleinem $M_{2}$ im Eocän von Quercy und England. Auch die 》Viverra-« und »Herpestes«-Arten des europäischen Untermiocän weichen noch von den echten ab. Erst im Obermiocän - Progenetta incerta Lartet - und im Pliocän von Südfrankreich, Roussillon - Viverra Pepratxi Depéret - und in den Siwalikschichten von Ostindien treten typische Viverra-Arten auf.

Ictitherium Wagner (Thalassictis Nordmann, Palhyaena Gervais). (Fig. 565.) Schädel lang, schmal. $M^{1}$ und $M^{2}$ klein im Verhältnis zu $P^{4}$. Unterpliocän. Pikermi, Samos, Maragha, Lébéron, Bessarabien, China und Ostindien.

\section{Familie. Hyaenidae. Hyänen.}

$\frac{3.1 .4-3.1 .}{3.1 .4-3.1-2 .} P^{4}$ langgestreckt, kräftig, vor der Hauptspitze ein Vorderzacken und dahinter eine lange Schneide. Vordere $P$ klein, hintere und $C$ sehr massiv, kegelförmig. $M^{1}$ klein, quer rerlängert, von $P^{4}$ verdeckt. $M_{1}$ mit zwei langen Schneiden und schwachem Talonid, selten mit Metaconid. Untere J stets neleneinanderstehend. Schädel kurz und dick. Bulla ossea ohne Septum. Hinterbeine etwas kürzer als Vorderbeine. Hand und Fuß digitigrad. Hand meist, Fußs stets vierzehig. Metacarpale II stark über III übergreifend, Penisknochen schwach.

Das Gebiß der Hyänen zeichnet sich durch Reduktion des $\boldsymbol{M}^{1}$ und des $M_{2}$ und durch Reduktion des Talonid und Metaconid des $\boldsymbol{M}_{1}$ aus, wofür jedoch sein Paraconid und Protoconid zu kräftigen Schneiden umgestaltet

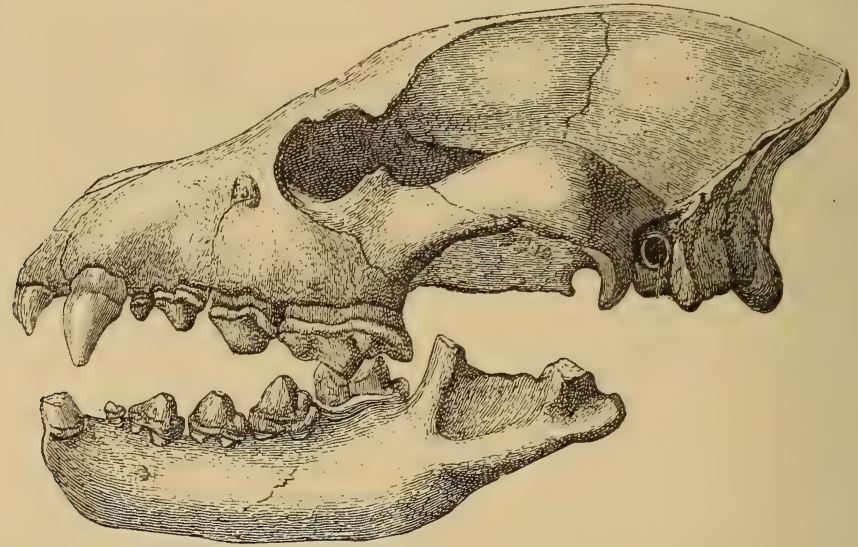

Fig. 566 .

Hyaena eximia Roth und Wagn. Unt. Pliocän. Pikermi bei Athen. 1/3 nat. Gr. (Nach Ga udry.)

werden, und die $P$ mit Ausnahme des vordersten sich in dicke Kegel umwandeln, wodurch das Gebiß zum Zermalmen von Knochen vorzüglich geeignet wird.

Die Hyaeniden werden gewöhnlich von den Viverren abgeleitet, wobei Ictitherium das Zwischenglied bilden soll. Sie bewohnen in der Gegenwart Afrika und Westasien, fossil treten sie zuerst im Pliocän von Europa und Asien auf. Es darf nicht verschwiegen werden, daß gewisse Caniden des nordamerikanischen Obermiocän, Aelurodon, Hyaenognathus, im Gebiß auffallende Ähnlichkeit mit den Hyänen aufweisen.

Lycyaena Hensel (Agnotherium, Agnocyon Kaup.) und Hyaenictis Gaudry aus dem Unterpliocän von Pikermi, Eppelsheim, Baltavar unterscheiden sich von Hyaena durch die schlankeren Zähne und den Besitz eines kleinen $\boldsymbol{M}_{2}$.

Hy a e n a Linn. (Fig. 566.) Zuerst im Unterpliocän von Pikermi, Samos, Maragha, Baltavar, Mont Lébéron $H$. eximia Roth u. Wagn. Im Pliocän 
der Siwalik Colvini, macrostoma Lydekker, felina, sivalensis Bose; in China $H$. gigantea Schlosser. Im Oberpliocän der Auvergne und von Val d'Arno H. arvernensis - auch in Roussillon und im Pleistocän von Mosbach - Perrieri Croiz. Job. und brevirostris Aym. Im älteren Pleistocän von Süd-Europa H. striata, der arvernensis ähnlich, im jüngeren europäischen Pleistocän Hyaena crocuta var. spelaea Goldf., der Perrieri ähnlich, auch in den indischen Karnulhöhlen. Im Pleistocän von China H. sinensis Owen.

\section{Familie. Felidae. Katzen. ${ }^{1}$ )}

$\frac{3.1 .3-2.1 .}{3.1 .3-2.1 .(2)} . C$ kräftig, am Vorder. und Hinterrand meist zugeschärft. $P^{4}$ verlängert, schneidend, mit Innenhöcker und drei Außenzacken. $M_{1}$ mit zwei konvergierenden, aus Paraconid und Protoconid entstandenen Schneiden und rudimentärem Talonid, selten auch mit rudimentärem Metaconid. $M^{1}$ und $M_{2}$ stets klein. $Z a h l$ der $P$ stets reduziert, die bleibenden $P$ mit Nebenzacken versehen. Bulla tympanica hochgewölbt, durch ein Septum geteilt, ohne verlängerten äußeren Gehörgang. Schnauze kurz. Cranium gewölbt, Extremitäten lang und schlank, digitigrad. Hromerus mit Foramen entepicondyloideum. Hand mit fünf, Fuß in der Regel mit vier Zehen, Krallen retraktil. Penisknochen klein.

Die Feliden sind gegenwärtig über die ganze Erdoberfläche mit Ausnahme von Australien verbreitet; fossil finden sie sich in denselben Gebieten, jedoch erscheinen sie zuerst in Europa und fast gleichzeitig auch in Nordamerika.

Die Katzen besitzen das reduzierteste aber zugleich spezialisierteste, zum Zerschneiden von Fleisch geeignetste Gebiß. Auch das Skelett vereinigt die zierlichste Form mit der größten Stärke. Von den übrigen Raubtieren sind sie scharf geschieden und selbst ihre ältesten Vertreter geben uns keine befriedigende Auskunft über ihre Abstammung, da sie schon alle typischen Merkmale besitzen. Selbst wenn die miocäne Gattung Proailurus, welche Filhol wegen der Ähnlichkeit mit der lebenden Gattung Cryptoprocta von Madagaskar für den Ahnen der Feliden hält, wirklich zu dieser Familie gehören sollte, so kann sie höchstens der Stammvater der echten Katzen, aber nicht auch der Machairodontinen sein, weil diese bereits im Oligocän oder sogar im Obereocän beginnen. Matthew leitet sowohl den Stamm der Machairodontinen als auch den der Felinen von Dinictis ab.

\section{Unterfamilie. Machairodontinae.}

Einkerbung von $P^{4}$ und $M_{1}$ seicht. Innenzacken von $P^{4}$ schwach. Obere $C$ allmählich größer, untere $C$ kleiner werdend. $P^{3}$ klein, $P_{3}$ rudimentär oder fehlend. Occiput hoch, schmal, Mastoidfortsatz vorspringend und größer werdend. Extremitäten massiv, Zehen gespreizt, Hallux und Pollex kräftig.

Eusmilus Gervais. 2.1.1.1. $M_{1}$ ohne Talonid und Metaconid. Symphysenlappen weit herabhängend. Phosphorite von Quercy. E. bidentatus Filhol. Oberoligocän. Dakota. E. dacotensis Hatcher.

Hoplophoneus Cope. (Pogonodon Merriam.) $\frac{3.1 .3-2.1 .}{3-2.1 .3-2.1 .} \quad M_{1}$ mit Metaconid. $\quad P \frac{2}{2}$ und $P \frac{3}{3}$.klein, $P_{2}$ meist fehlend. Oberer $C$ schlank. Bulla unvollständig verknöchert. Oligocän. White River. H. occidentalis Leidy.

Machairodus Kaup. ${ }_{3.1 .2 .1 .1 .}^{3} P^{4}$ meist mit vier Außenspitzen. $M_{1}$ ohne Metaconid und meist ohne Talonid. $P \frac{3}{3}$ rudimentär. $C$ lang, am Hinterrand gezähnelt, Symphysenlappen groß. Bullae vollständig verknöchert. Obermiocän. Sansan, Steinheim M. palmidens Blv. La Grive

1) Fabrini E., I Machairodus di Valdarno. Boll. Comitato geolog. Roma 1890. - Matthew W. D., The Phylogeny of the Felidae. Bull. Amer. Mus. Nat. Hist. New York 1910. 
St. Alban M. Jourdani Filhol. Unterpliocän von Pikermi, Eppelsheim, Samos (Ägypten) M. ap̉̆anistus Kaup, Maragha M. orientalis Macquenem. China $M$. horribilis Schlosser. Siwalik M. sivalensis Lyd. Im europäischen Mittel- und Oberpliocän $M$. cultridens Cuv. und im europäischen Pleistocän $M$. latidens Owen.

Smilodon Lund (Trucifelis Leidy, Dinobastis Cope, Smilodontopsis Brown). $\frac{3.2 .2 .1 .}{3-2.1 .2-1.1 .} P^{4}$ meist nur mit drei Außenzacken, $M_{1}$ ohne Talonid und Metaconid. $P^{3}$ klein, $P_{3}$ meist fehlend. Hallux kräftig. Nur in Amerika. Pleistocän von Nordamerika $S$. gracilis Cope, floridanus Leidy. Südamerika S. neogaeus Lund.

\section{Unterfamilie. Felinae.}

Einkerbung an $P^{4}$ und $M_{1}$ tief. $P^{4}$ mit kräftigem Innenzacken. Oberer $C$ allmählich kleiner, unterer $C$ allmählich größer werdend. $P^{3}$ gro $\beta, P_{3}$ und ${ }_{4}$ fast gleich stark. Mastoidfortsatz reduziert, Unterkieferkronfortsatz vergrößert. Extremitäten verlängert, digitigrad, Hallux reduziert.

Aelurictis Trouessart (Aelurogale Filhol). $\frac{3}{3} P, \frac{1}{2} M . \quad M_{2}$ schwach. $M_{1}$ ohne Metaconid, mit kräftigem Talonid, Metapodien lang, Symphyse mit Außenkante. Obereocän? Phosphorite von Quercy. A. intermedia, minor Filhol.

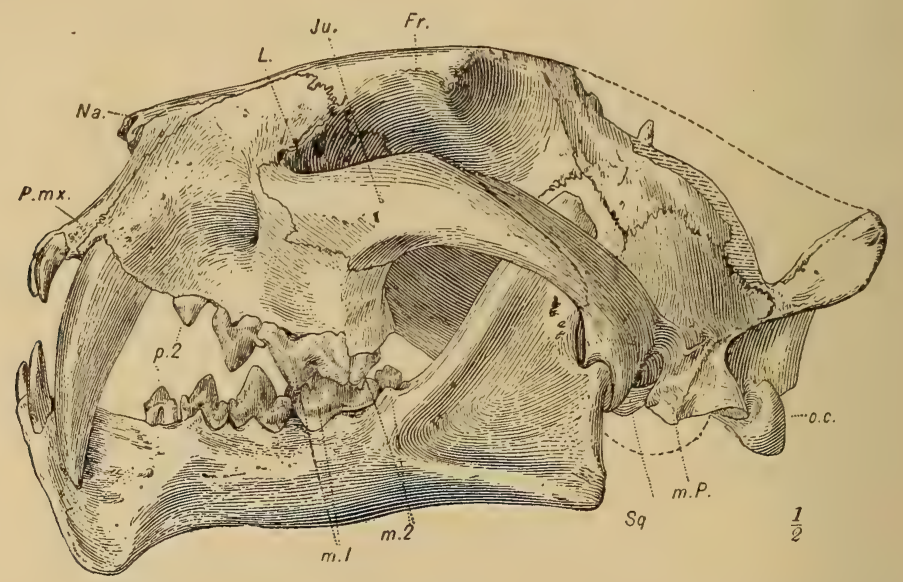

Fig. 567

Dinictis felina Leidy. Oligocän. White Riverbed. Schädel u. Unterkiefer. ${ }^{1} / 2$ nat. Gr. (nach Mat the w.)

Dinictis Leidy (Daptophilus Cope). (Fig. 567.) $\frac{3}{3} P, \frac{1}{2} M$, öfters mit 4 unteren $P$ und zuweilen mit $M^{2}$. $M_{1}$ mit Talonid und Metaconid. $C$ lang, Hinterseite schwach gekerbt. Unterkiefersymphyse mit herabhängendem Lappen. Carotidforamen getrennt vom Foramen lacerum posterius. Bulla unvollständig verknöchert. Hallux funktionierend. Metapodien kurz. Oligocän, White Riverbed, Nordamerika D. felina Leidy, squalidens Cope. Untermiocän, John Day, Oregon D. cyclops Cope.

Nimravus Cope (Archaelurus, Pogonodon Cope), $\frac{4-3}{3-2} P, \frac{1}{1-2} M$, sehr ähnlich Aelurictis. $M_{1}$ ohne Metaconid, $C$ mäßig entwickelt. Symphyse ohne Lappen. Untermiocän, John Day, Oregon N. debilis, platycopis, gomphodus Cope. Süd-Dakota sectator Matthew.

Pseudaelurus Gervais. (Fig. 568.) $\frac{3}{3-2} P, \frac{1}{1} M . M_{1}$ ohne Metaconid, mit kleinem Talonid, $C$ normal. Symphyse ohne Lappen. Obermiocän. Sansan P. quadridentatus Blv. La Grive St. Alban P. Lorteti Gaillard. 
Felis Lin. $\frac{2-3}{2} P, \frac{1}{1} M . \quad P^{4}$ mit drei Außenzacken. $M_{1}$ ohne Meta. conid und Talonid. $M^{1}$ rudimentär, Condylar- und Carotidforamen mit F. lacerum posterius verbunden. Mastoidfortsatz klein, dicht an die knöcherne Bulla gerückt. Symphyse ohne Lappen und ohne Kante. Lebend in der Alten Welt und Amerika, fossil im Obermiocän. Sansan $F$. media, pygmaea Gerv., Steiermark turnauenis Toula. La Grive St. Alban F. Zitteli Gaillard. Unterpliocän. Pikermi $F$. attica Wagn. Eppelsheim $F$. antediluviana Kaup. Pliocän von Roussillon und Maragha F. brevirostris Croiz. In Toskana und Auvergne $F$. pardinensis, arvernensis Croiz. Im Pleistocän Europas Felis leo (L. spelaea Goldf.), pardus, lymx etc. In Nordamerika (F. atrox Leidy), Südamerika ( $F$. onca Lin) und Ostindien.

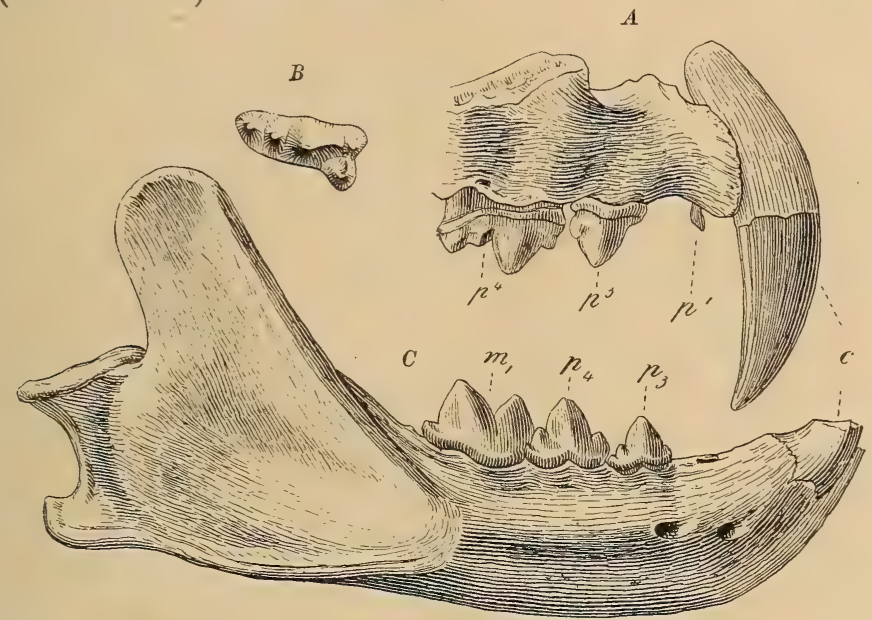

Fig. 568 .

Pseudaelurus quadrideniatus Blv. (Felis hyaenoides Lartet). Miocän. Sansan. Gers. A rechtes Oberkieferfragment, $B$ oberer Reißzahn von unten, $C$ rechter Unterkiefer von außen. $2 / 3$ nat. Gr. (Nach Filhol.)

\section{Unterordnung. Pinnipedia. Flossenfüßer. ${ }^{1}$ )}

Marine Fleischfresser mit kurzen Flossenfüßen, großem, stark gefurchtem Gehirn und vollständigem Gebiß mit gleichartig ausgebildeten $P$ und $M$, entweder konisch oder aus hoher Hauptspitze und vorderer und hinterer Nebenspitze bestehend. Die zwei hinteren $M$ meist fehlend. $J$ an Zahl hüufig reduziert, konisch, $C$ ziemlich kräftig. Extremitäten fünfzehig. Scaphoid mit Lunatum und Centrale verwachsen. Sämtliche Zehen durch Schwimmhaut verbunden.

Die Pinnipedia schließen sich im anatomischen Bau und in der Entwicklungsgeschichte ziemlich eng an die übrigen Carnivoren an, die Abweichung im Körperhabitus und in der Gestalt der Extremitäten sowie die Spezialisierung des Gebisses, bestehend teils in Reduktion der Zahl, teils in Vereinfachung der Zähne, öfters aber auch in Komplikation der $P$, beruht auf der Anpassung an das Wasserleben. Sie bewohnen die kälteren Regionen beider Hemisphären. Fossile Reste sind stets sehr selten und beginnen erst im Miocän. Über die Herkunft der Pinnipedia gibt uns weder die Ontogenie noch auch die Paläontologie eine befriedigende Aus-

1) Beneden van P. J., Descr. des oss. foss. des environs d'Anvers. Ann. Musée d'hist. nat. de Belgique T. I. 1877. - Toula F., Phoca vindobonensis. Beitr. z. Paläont. Österr.-Ungarns. 1897. 


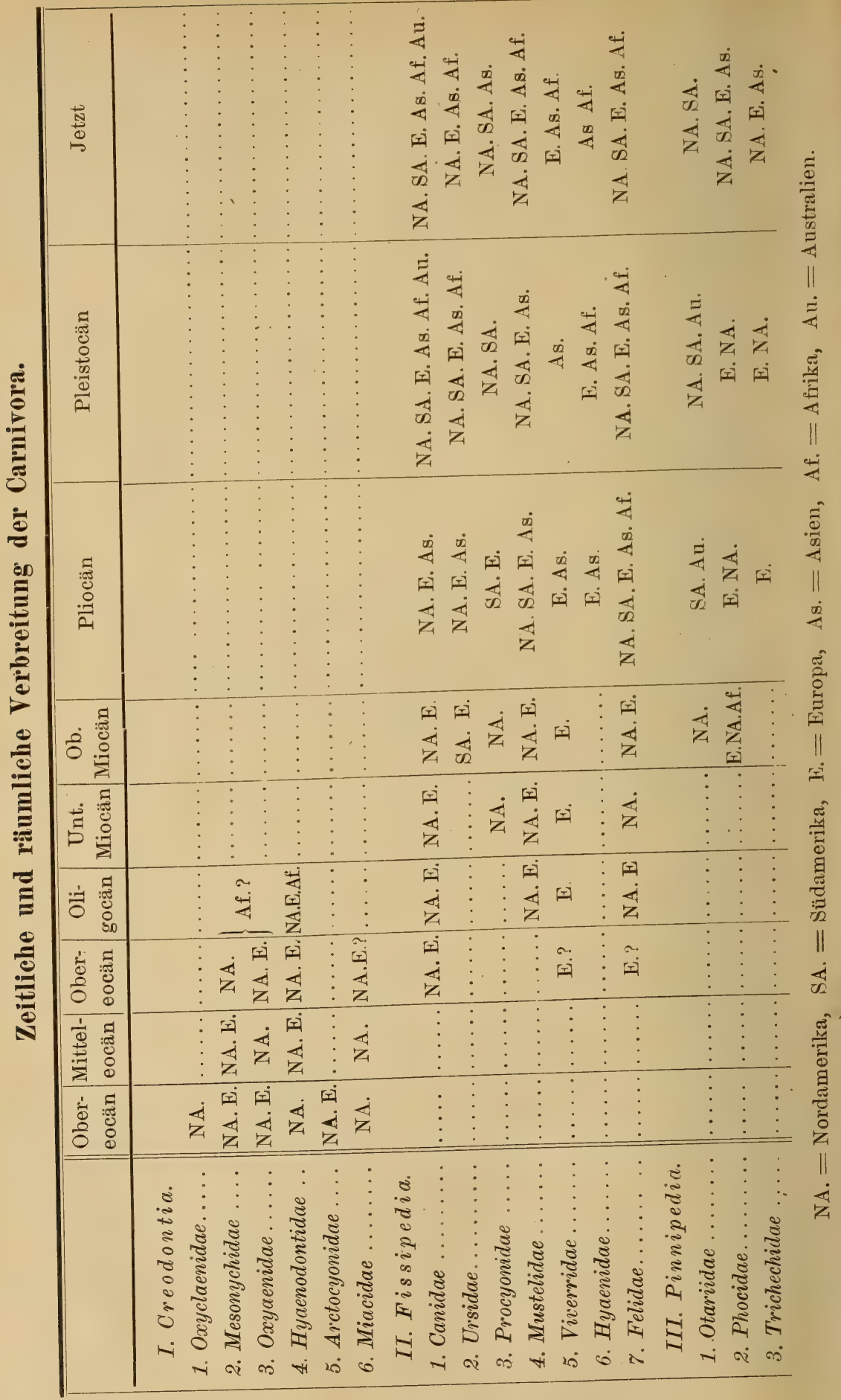


Die Waltiere bilden eine durch Lebensweise und fischähnliche Gestalt von allen übrigen Säugetieren abweichende Ordnung.

Den Körper umgibt eine dicke, glatte $\mathrm{Haut}$, unter welcher sich eine die Wärme schlecht leitende, dicke Fettschicht befindet. Haare fehlen im erwachsenen Zustand entweder gänzlich oder sind bei einigen Gattungen auf wenige Gesichtsborsten reduziert.

Die Skelettknochen der Cetaceen und namentlich die Wirbel zeichnen sich durch schwammige, grobmaschige Struktur aus und sind meist stark mit Fett imprägniert. Die Epiphysen bleiben nicht nur an den. Wirbeln, sondern auch an den marklosen Extremitätenknochen lange getrennt. Die vorderen und hinteren Flächen der
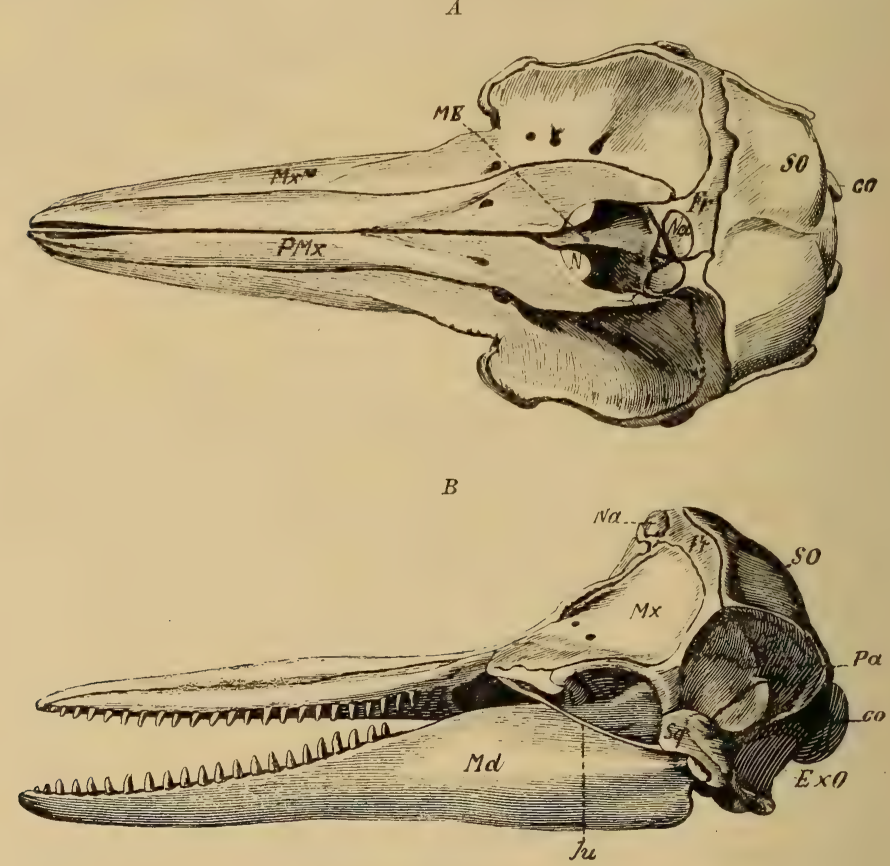

Fig. 570 .

Tursiops (Delphinus) tursio Fabr. sp. Atlantischer Ozean. A Schädel von oben, $B$ von der Seite (nach Cuvier), 1/6 nat. Gr. Pmx Zwischenkiefer, $M x$ Oberkiefer, $M E$ Mesethmoideum, Na Nasenbein, $N$ Nasenlöcher, Fr Stirnbein, Pa Scheitelbein, Ju Jochbogen, Sq Schuppenbein, So oberes Hinterhauptsbein, co Condylus, Exo Exoccipitale, Md Unterkiefer.

Wirbelkörper sind eben und durch dicke Knorpelscheiben verbunden; die Halswirbel zwar vollzählig vorhanden, jedoch häufig außerordentlich verkürzt, scheibenförmig und zuweilen alle oder einige miteinander verschmolzen. Hinter den 7 meist stark verkürzten Halswirbeln folgen 9-16 Rücken-, 3-24 Lenden- und 18-30 Schwanzwirbel. Ein Sacrum fehlt. Die oberen Bögen und verknöcherten Epiphysen der Rumpfwirbel bleiben lange vom Zentrum getrennt und verschmelzen erst im Alter vollständig mit demselben, die Zygapophysen verkümmern mehr oder weniger. Die Diapophysen dagegen sind namentlich in der Lendenregion lang und kräftig. Die Rippen der Cetaceen unterscheiden sich von denen der übrigen Säugetiere 
durch ihre lockere Verbindung mit der Wirbelsäule und mit dem Brustbein. Das Brustbein selbst besteht bei den Bartenwalen aus einer einfachen, breiten, schildförmigen, am Vorderrand häufig ausgeschnittenen Knochenplatte, bei den Zahnwalen liegen 2-5 Knochenstücke hintereinander.

Der Schädel (Fig. 570) erleidet höchst auffällige, wahrscheinlich durch die Lebensweise verursachte Umbildungen und besteht aus leichten, grobzelligen und dünnen Knochen. Die Gehirnhöhle zeichnet sich durch ungewöhnliche Höhe, ansehnliche Breite, aber sehr geringe Länge aus, und da sie sich nach oben verengt, so erhält das Gehirn die Form eines abgestutzten Kegels mit allseitig gerundetem Umriß. Die sehr stark gewundenen Hemisphären des Großhirns bedecken das Kleinhirn fast vollständig. Die Riechlappen fehlen gänzlich oder sind nur ganz schwach angedeutet, die Nasenhöhlen haben keine Muscheln und können nicht als Riechorgane, sondern lediglich zum Atmen verwendet werden. Mit Ausnahme von Zeuglodon stoßen die Scheitelbeine nicht in einer Sagittalnaht zusammen und berühren sich in der Mittelebene überhaupt nur bei den Bartenwalen. Aber auch bei diesen legt sich die ungemein große Hinterhauptsschuppe (Os supraoccipitale) über die Scheitelbeine und über das zwischengeschobene Interparietale und bildet den größeren Teil des Schädeldaches. Durch die Verkürzung und seitliche Abdrängung der Scheitelbeine stoßen das Supraoccipitale und Interparietale bei den Zahnwalen und den meisten Bartenwalen direkt mit dem ungemein kurzen Stirnbein zusammen, das sich nach außen jederseits in große, die Augenhöhlen überdachende Knochenplatten erweitert. Die hohe, schräg nach hinten abfallende Hinterhauptsfläche wird fast ganz vom Supraoccipitale gebildet. Das tief gelegene Schläfenbein (Squamosum $S q$ ) sendet einen starken Fortsatz nach vorne und oben, welcher sich mit dem hinteren Seitenflügel des Stirnbeins verbindet und dem bei den Zahnwalen dünnen, stabförmigen, bei den Bartenwalen ziemlich kräftigen, die länglichen Augenhöhlen unten begrenzenden Jochbein $(J u)$ als Stütze dient.

Die stark verlängerte, meist niedergedrückte und verschmälerte Schnauze besteht aus den häufig asymmetrischen Z wischenkiefern, den Oberkiefern, dem Vomer und Mesethmoid. Die Zwischenkiefer legen sich vorne entweder dicht aneinander an oder lassen eine nach oben offene Furche zwischen sich frei, die sich nach hinten erweitert. An ihrem hinteren Ende, also unmittelbar vor den Stirnbeinen, befinden sich die fast senkrecht nach oben, oder schräg nach vorne gerichteten Nasenlöcher, aus denen Wasserdampf ausgeatmet wird (Spritzlöcher). Die äußeren Nasenlöcher sind bei den Bartenwalen von kurzen, aber wohl ausgebildeten, bei den Zeuglodonten von sehr langen $\mathrm{N}$ as enbeinen $(\mathrm{Na})$ überdacht, während bei den Zahnwal€n eine starke Verkümmerung der Nasenbeine stattfindet, so daß sie häufig nur durch kleine Knochenhöcker angedeutet sind. Die Embryone zeigen noch primitive Verhältnisse. Das Zurückweichen der Nasenlöcher bewirkt Streckung der Ober- und Zwischenkiefer bis hinter die Orbita und Verkürzung der Stirn-, Scheitel- und Nasenbeine, welche hierbei auch meist auf die Seite rücken. Die Hirnhöhle wird nach vorne durch eine steil abfallende, breite und hohe Knochenplatte (Mesethmoideum) 
abgeschlossen. Bei allen lebenden Cetaceen sind die Zwischenkiefer ihrer ganzen Länge nach seitlich von den Oberkiefern $(M x)$ umschlossen und werden nur am vorderen Rand der Schnauzenspitze frei; bei den fossilen Zeuglodontiden und bei den Squalodontiden ragen die $Z$ wischenkiefer vorne über die Oberkiefer heraus und sind am Unterrand mit Zähnen besetzt. Tränenbeine existieren nur bei einigen Bartenwalen und bei den Physeteriden.

Die Unterseite der Schnauze wird vorherrschend aus den horizontalen Ästen der Oberkiefer gebildet, doch nimmt häufig auch noch der Vomer, als eine schmale, zwischen den Oberkiefern gelegene Medianleiste an der Zusammensetzung des Gaumendaches teil. An die Oberkiefer legen sich hinten die Gaumenbeine als kurze, bandförmige Knochen an und werden hinten von den stark entwickelten, in der Mitte vereinigten Flügelbeinen begrenzt, welche den harten

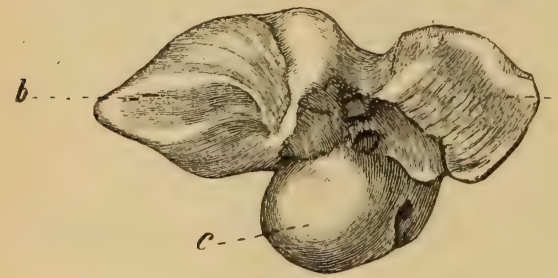

Fig. 571.

Linkes Perioticum von Globicephalus uncidens aus dem Crag von Oxford, von der dem Tympanicum zugewendeten Seite gesehen. $c$ halbkugeliger Teil, $a$ hinterer, $b$ vorderer Fortsatz. Gaumen verlängern und die seitlichen Wände der Choanen bilden.

\section{$a$}

Besonderes Interesse beanspruchen die $\mathbf{z}$ wischen dem Schuppenbein und Exoccipitale gelegenen Ohrknochen (Fig. 571) (Perioticum und Tympanicum). Sie zeichnen sich durch ungewöhnliche Dicke und dichte Struktur aus, sind nur lose mit den Schädelknochen verbunden und fallen darum beim Fossilisationsprozeß leicht heraus. Isolierte Felsenbeine oder Paukenbeine (Cetolithen) finden sich fast überall, wo Überreste von fossilen Cetaceen vorkommen, und auch aus der Tiefe des Ozeans wurden Gehörknochen von Walen herausgeholt.

Die Bezahnung der Cetaceen besteht meist aus gleichartigen, konischen, einwurzeligen Zähnen, die zuweilen in sehr großer Zahl (bis 60 in jedem Kiefer) vorhanden sind. Nur bei Zeuglodonten und Squalodonten unterscheiden sich die hinteren zwei- oder dreiwurzeligen Seitenzähne durch zusammengedrückte Krone von den einwurzeligen Vorderzähnen. Bei den Bartenwalen fehlen Zähne vollständig. Beim Narwal entwickelt sich beim Männchen im rechten Oberkiefer ein mächtiger, nach vorne gerichteter Stoßzahn. Ein Zahnwechsel findet niemals statt, wenn auch bei manchen Zahnwalen Ersatzzähne in der Anlage vorhanden sind, die aber nie zum Durcbbruch kommen. Aus dem ursprünglich heterodonten Gebiß entwickelt sich ein homodontes Gebiß. Homodontie und Reduktion der Zähne beginnt an der Spitze des Rostrum. Zuerst verschwinden die Zähne des Unterkiefers, später auch die des Oberkiefers, wobei jedoch die frühere Anwesenheit von Zähnen noch durch eine Rinne angedeutet bleibt.

Entsprechend der auf das Wasser beschränkten Lebensweise haben sich die Extremitäten der Cetaceen in eigentümlicher. Weise umgestaltet und erinnern in ihrem Habitus weit mehr an die Flossen ausgestorbener Meersaurier als an die Gehfüße der Säugetiere. Dem Schultergürtel fehlt ein Schlüsselbein, sowie ein diskretes Coracoid. Die Scapula zeichnet sich durch ungewöhnlich breite, flache und ver- 
hältnismäßig kurze Gestalt aus. Der Humerus ist kurz, stämmig, am proximalen Ende mit halbkugeligem Gelenkkopf, am distalen mit zwei flachen, in stumpfem Winkel zusammenstoßenden Gelenkfasetten versehen, an welche sich die seitlich zusammengedrückten, weder am Humerus - außer bei Zeuglodon - noch aneinander beweglichen Vorderarmknochen anlegen. Mit Ausnahme einiger Bartenwale, bei denen sonderbarerweise nicht der erste, sondern der dritte Finger durch Schwund in Verfall kommt, haben die Cetaceen fünf Finger. Dieselben sind nicht gelenkig, sondern durch Knorpel und Bindegewebe verbunden und vollständig von einer gemeinsamen Haut umhüllt. Sie bestehen aus länglichen, abgeplatteten, an den Enden gerade abgestutzten, in der Mitte etwas eingeschnürten Phalangen, deren Zahl im 2. und 3. Finger auf 9-15 steigen kann. Die hinteren Extremitäten und das Becken sind entweder total verkümmert oder zu winzigen, äußerlich nicht sichtbaren und im Fleisch steckenden Rudimenten des Ischiums herabgesunken.,

Als eigentliches Bewegungsorgan dient bei den Cetaceen statt der Extremitäten eine große horizontale Schwanzflosse, die nicht durch Knochen, sondern durch dichtes Fasergewebe gestützt wird. Polygonale Kalkplatten an der Rücken- und Brustflosse gewisser Wale werden von $\mathrm{Kückenthal}$ und Abel als Rudimente eines Hautpanzers gedeutet, der aber sicher nicht den ganzen Rumpf bekleidet hat.

Trotz aller durch Anpassung an ähnliche Existenzbedingungen verursachter äußerer Übereinstimmung der Cetaceen mit Fischen und Meersauriern erweist sich das Skelett doch in jeder Hinsicht nach dem Grundplan der Säugetiere gebaut und läßt nicht die geringste Beziehung zu jenem der Fische oder Reptilien erkennen. Die Cetaceen stammen nicht von wasserbewohnenden Reptilien, sondern wahrscheinlich von fleischfressenden placentalen Landsäugetieren mit normalem heterodonten Gebiß, $\frac{3.1 .4 .3}{3.1 .4 .3}$, ab, erreichen nicht selten riesige Größe und leben teils im offenen Ozean, teils in der Nähe der Küsten.

Fossile C e ta c e en beginnen im Eocän mit der bald erlöschenden Gattung Zeuglodon, gewinnen aber erst im Miocän und Pliocän eine größere Verbreitung und einen größeren Formenreichtum.

\section{Unterordnung. Archeoceti. Flower.}

Äußere Nasenlöcher nach vorne und oben geöffnet, auf der Oberseite der Schnauze gelegen. Nasenbeine kurz. Oberkiefer nicht über das Stirnbein geschoben. Zühne in Zwischenkiefer, Ober- und Unterkiefer, die vorderen einwurzelig, die hinteren zweiwurzelig, im Oberkiefer zum Teil dreiwurzelig.

\section{Familie. Zeuglodontidae. $\stackrel{1}{)}$}

Kopf verlängert, Hirnhöhle klein; Schläfengrube weit ausgedehnt, Sagittalcrista wohlausgebildet. Scheitelbeine verlängert, schmal, am Schädeldach teilnehmend;

1) Fraas E., Neue Zeuglodonten aus dem Mitteleocän von Mokattam. Geol. paläont. Abh. von Koken. Bd. X 1904. - Lucas F. A., Notes on the Osteology of Zeuglodon. Amer. Naturalist. 1895. - Müller Joh., Über die fossilen Reste der Zeuglodonten von N. Amerika. Berlin 1894. - Stromer v. C., Zeuglodontenreste aus dem Mitteleocän des Fayum. Beitr. Paläont. Österr.-Ung. u. des Orients. Bd. 15. 1903 und Die Archaeoceti des ägypt. Eocäns. Ibidem Bd. XXI 1908. 
Stirnbeine breit, kurz, die Orbita überdachend. Jochbogen stabförmig. Schnauze lang, zusammengedrückt, Nasenbeine lang und schmal. Unterkiefer lang, niedrig, ohne feste Symphyse. Zähne differenziert - $\frac{3.1 .4 .3-2}{3.1 .4 .3}-$ vollständiges Milchgebiß. Vordere Zühne $J_{1}-P_{2}$ (inkl.) isoliert, hintere dicht geschlossen. $J, C$ und meist auch $P_{1}$ gleichartig konisch, einwurzelig, hintere Zühne zweiwurzelig, $P_{2}$ bis $P_{4}$ meist
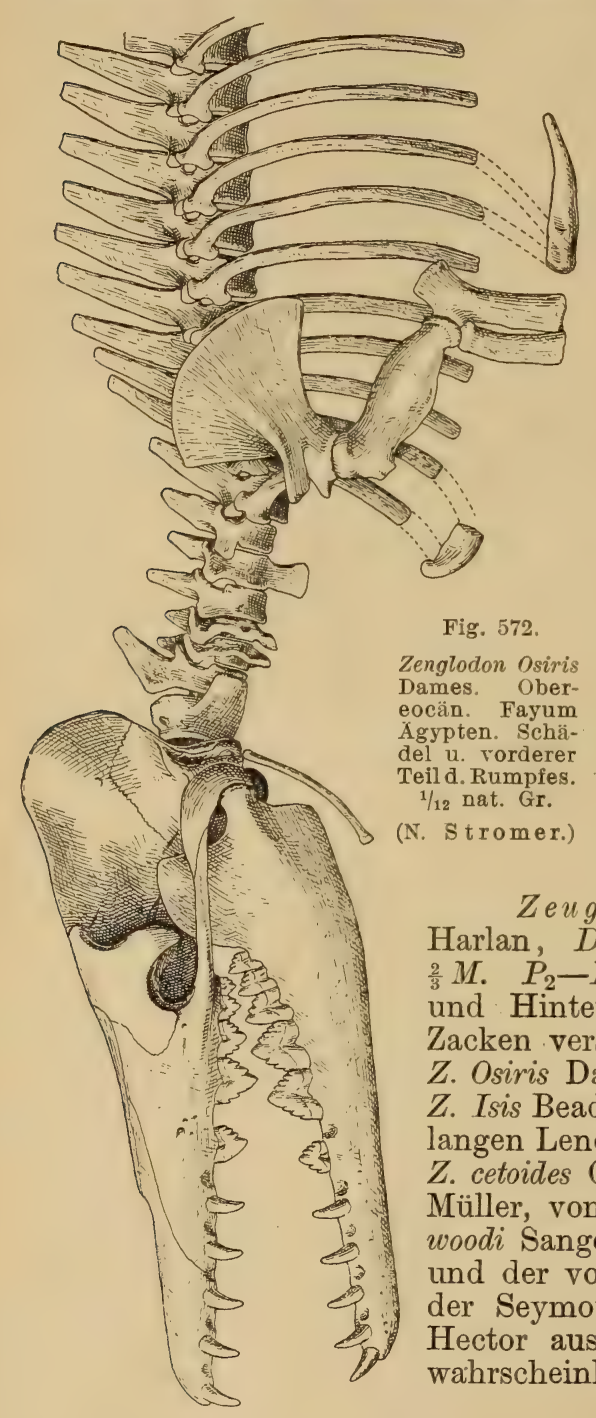
Zenglodon Osiris Dames. Obereocän. Fayum Agypten. Schädel u. vorderer Teil d. Rumpfes. $1 / 12$ nat. Gr.

(N. Stromer.) am Vorder- und Hinterrande, $M$ nur am Hinterrande mit Zacken versehen, die beiden letzten oberen $P$, selten auch die oberen $M$ dreiwurzelig. Halswirbel kurz, nicht verschmolzen. Mindestens 12 Rückenwirbel, der letzte, sowie die Lendenwirbel oft stark verlängert. Schwanzwirbelkurz. Rippen zweiköpfig. Scapula breit, mit Acromion und Coracoidfortsatz und rudimentärer Spina versehen. Humerus kurz, mit kräftiger Deltoidcristaund wohlentwickelter Trochlea. Radius vor der Ulna stehend, mit zwei distalen Gelenkflächen. Becken schwach. Brustbein mehrgliedrig. Vielleicht Hautpanzer vorhanden.

Protocetus Fraas. $\frac{3}{3}$ M. Die beiden letzten $P$ nur mit einem HinFig. 572. terzacken, $M$ auch mit Vorderzacken. $C-P_{2}$ undeutlich zweiwurzelig, $P^{3}$ b.s $M^{3}$ mit je drei Wurzeln. Wirbel klein, raubtierähnlich. Mitteleocän. Mokattam P. atavus Fraas.

Eocetus (Mesocetus) Fraas. Mit großen, gestreckten Lendenwirbeln. E. Schweinfurthi Fraas. Ebenda.

Zeuglodon Owen. (Fig. 572.) Basilosaurus Harlan, Dorudon Gibbes, Pontobasileus Leidy. $\frac{2}{3} M$. $P_{2}-P_{4}$ mit mehreren Zacken an Vorderund Hinterrand, $M$ nur am Hinterrand mit Zacken versehen. Im Obereocän von Ägypten. $Z$. Osiris Dames und Zitteli Stromer mit kurzen, Z. Isis Beadnell (Prozeuglodon atrox Andrews) mit langen Lendenwirbeln. Im Eocän von Alabama $Z$. cetoides Owen, serratus Gibbes, brachyspondylus Müller, von England Z. Wanklyni Seeley. Z. Harwoodi Sanger aus dem Eocän von Südaustralien und der von Wiman beschriebene Zeuglodon von der Seymour-Insel, sowie Kekenodon omata Hector aus dem Miocän von Neuseeland sind wahrscheinlich Squalodontiden.

\section{Unterordnung. Odontoceti. Z ahnwale.}

Äußere Nasenlöcher zu einem einfachen Spritzloch vereinigt, weit hinten gelegen und nach oben gerichtet. Nasenbeine verkïmmert. Oberkiefer hinten ausgebreitet, das Stirnbein teilweise bedeckend. Zähne zahlreich, zuweilen auf ein Paar reduziert. Vordere Rippen zweiköpfig. Brustbein aus zwei oder mehr Stïcken bestehend. 


\section{Familie. Squalodontidae. $\left.{ }^{1}\right)$}

Zwischenkiefer, Ober- und Unterkiefer bezahnt. Die vorderen Zühne konisch, einwurzelig, die Backenzähne zwei- bis dreiwurzelig, komprimiert, am Vorder-und Hinterrand gezackt. Scheitelbeine an der Bildung des Schädeldaches teilnehmend. entwickelt.

Die Squalodontiden haben sich wahrscheinlich aus Zeuglodontiden

IIicrozeuglodon Lydekker. Eocän? vom Kaukasus. Nur Zähne und Humerus bekannt. M. cancasicus Lyd.

Neosqualodon Dal Piaz. Mit zahlreichen, vielfach gezackten Backenzähnen. Mittelmiocän Sizilien. N. Assenzae F. Major sp.

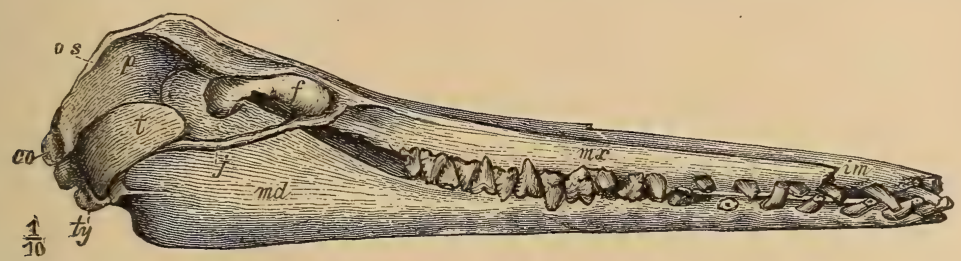

Fig.' 573 .

Squalodon Bariensis Jourdan sp. Miocän. 1/10 nat. Gr. Schädel restauriert aus Bari im Drôme-Dep. (nach Döderlein). co Hinterhauptsgelenk, os Occipitale superius, $f$ Stirnbein, $j$ Jochbein, $t$ Temporale, ty Tympanicum, $t m$ Zwischenkiefer, $m x$ Oberkiefer, $m d$ Unterkiefer.

Squalodon Grat. (Pachyodon, Arionius Meyer, Phocodon Ag. Rhizoprion Jourdan, Delphinodon Leidy.) (Fig. 573.) $\frac{3.1 .9-8.3 .}{3.1 .8 .3-2 .}$ Die letzten 7--8 Zähne zweiwurzelig. Im Miocän, Pliocän von Europa und Nordamerika zahlreiche Arten. Auch schon im Oligocän von Bünde, Westfalen (Phoca ambigua Münster). tinien.

Prosqualodon Lydekker. 5 Zähne zweiwurzelig. Miocän von Argen-

\section{Familie. Physeteridae Flower.}

Schädel stark asymmetrisch. Zwvischenkiefer und Oberkiefer bei den späteren Formen zahnlos, Unterkiefer mit einer wechselnden Zahl von einwurzeligen, konischen Zühnen. Schädelknochen hinter den Nasenlöchern steil ansteigend, und einen vorragenden, zuweilen ïberhängenden Querkamm bildend. Orbita klein. Tränenbeine groß. Unterkiefersymphyse anfangs lang, später kurz. Vordere Rippen zweiköpfig. Lebend und fossil im Miocän, Pliocän und Pleistocän von Europa, Nordamerika und Australien.

\section{Unterfamilie. Physeterinae.}

Halswirbel mit Ausnahme des Atlas verschmolzen. Zühne fast gleich groß, anfangs mit Schmelz.

Scaldicetus du Bus. (Balaenodon, Eucetus, Homoeocetus, Eudelphis, Palaeodelphis du Bus, Hoplocetus, Physodon Gerr.) Miocän und Pliocän von Europa, Nordamerika und Patagonien. 3 obere J. 19 Zähne im Ober-, 24 im Unterkiefer.

Thalassocetus, Prophyseter Abel, Belgien. Placoziphius vion Bened. Belgien, Italien. Physeterula von Bened. Im Miocän von Europa. Physeter, Kogia lebend, ohne obere Zähne.

$\left.{ }^{1}\right)$ Beneden van P. J., Mem. Acad. Roy. de Belgique. 1853 t. XXXV u. 1867 t. XXXVII. - Grateloup, Actes de la Soc. Linn. de Bordeaux 1840. t. II. - Jourdan, Rhizoprion Bariense. Ann. sc. nat. 1867. 4 ser. t. XVI. - Lortet L., Archives du Mus. d'hist. nat. Lyon. 1887. t. IV. - Paquier V., Mém. soc. géol. fr. Paléont. IV. 1894. - Piaz G. dal, Neosqualodon. Mém. soc. paléont. suisse Bd. 31. 1904. Zittel K. A., Palaeontographica. 1877. Bd. XXIV. 


\section{Unterfamilie. Ziphiinae.}

Von den Zähnen des Unterkiefers ein oder zwei Paar vergrößert. Atlas stets mit Axis verwachsen, die übrigen Halswirbel frei.

Palaeoziphius Abel. (Champsodelphis du Bus, Acrodelphis Abel partim.) Unterkiefer mit 14 Alveolen, 1. und 7. Zahn vergrößert und Mioziphius Abel(Placoziphius Gerv.). Die zwei vorderen Zähne vergrößert. Beide im Miocän von Belgien, Cetorhynchus Gerv. (Champsodelphis Gerv., Cyrto. delphis Abel) auch in Frankreich.

Choneziphius Duvernoy, Mesoplodon Flower (Dioplodon Gerv., Belemnoziphius Huxley). Miocän und Pliocän von Europa und Süd-Carolina und lebend. Ziphius Cuv. Berardius Duvernoy und Hyperoodon Lacep. Lebend.

\section{Familie. Eurhinodelphidae Abel.}

Rostrum stark verlïngert, schmal, mit sehr langem Zwischenkiefer. Schädel schwach konvex oder mit Querkamm. Oberkiefer und Unterkiefer mit vielen einwurzeligen Zähnen. Oberkiefer unterhalb der Orbita verdickt, Stirnbein oft vom Supraoccipitale bedeckt. Alle Halswirbel frei. Vordere Rippen zweiköpfig.

Eurhinodelphis du Bus (Priscodelphinus du Bus). Häufigster aller Wale im Miocän von Belgien. Auch in Nordamerika.

\section{Familie. Acrodelphidae Abel.}

Rostrum ursprünglich lang, später verkürzt. Oberkiefer öfters bis an das Vorderende des Rostrums reichend. Zühne polyodont, heterodont, einwurzelig. Schläfengrube unbedeckt, Cranium sehr wenig gewölbt, Supraorbitale viereckig. Halswirbel frei. Rumpf-, Lenden- und Schwanzwirbel lang. Vordere Rippen zweiköpfig.

\section{Unterfamilie. Argyrocetinae.}

Schädel flach. Stirnbeine ausgedehnt auf dem Gipfel des Craniums. Rostrum sehr lang. Zühne ungemein zahlreich, die vorderen spitz, die hinteren konisch.

Cyrtodelphis Abel (Champsodelphis Gerv.). Im europäischen Miocän sehr häufig. C. sulcatus Gerv.

Argyrocetus, Pontivaga und Ischyrorhynchus Ameghino und Saurodelphis Burmeister. Im Miocän und Pliocän von Argentinien.

\section{Unterfamilie. Acrodelphinae.}

Schädel flach, Stirnbeine schmal, Rostrum lang, Zähne mit kleinen Höckerchen. Acrodelphis Abel (Champsodelphis Brandt, Gerv., Phocaenopsis du Bus, Delphinodon Cope.) Im europäischen Miocän sehr verbreitet.

Von Heterodelphis leiondontus Papp fand sich im Miocän (Leita. kalk) des Soproner Comitats Ungarn ein fast vollständiges Skelett.

Priscodelphinus Leidy. Rhabdosteus, Lophocetus, Zarhachis, Ixacanthus Cope. Miocän von Nordamerika.

Die Unterfamilien der Iniinae und Beluginae sind fossil nicht bekannt. Die erstere enthält die langschnauzigen Gattungen Platanista, Inia, Pontistes und Pontoporia, welche nur $1 \frac{\mathrm{I}}{2}-2 \mathrm{~m}$ lang werden und die Mündungen großer Flüsse bewohnen, die letztere die kurzschnauzigen Gattungen Beluga und Monodon.

\section{Familie. Delphinidae. Flower.}

Schnauze kurz, Zwischenkiefer zahnlos, vom Oberkiefer umschlossen. Oberund Unterkiefer mit einer wechselnden Zahl konischer einwurzeliger Zähne. Unter. 
kiefersymphyse kurz. Orbita mäßig. Vordere Halswirbel verschmolzen. Vordere Rippen zweiköpfig.

Die Delphine bilden jetzt die formenreichste Familie der Odontoceten. Ihre zahlreichen Gattungen sind in allen Meeren verbreitet und bewohnen zum Teil auch die Mündungen großer Flüsse. Fossile Reste kommen in spärlicher Zahl im Miocän, Pliocän und Pleistocän von Europa und Amerika vor und werden teils als Delphinus Lin., Steno Gray, Tursiops Gervais (Fig. 570), Orca Gray, Pseudorca Reinh. und Globicephalus Lesson bestimmt, teils werden sie als besondere Gattungen beschrieben. Aus dem Miocän von Belgien Protophocaena Abel, aus der Krim Palaeophocaena Abel, aus Kroatien - Radoboj - Delphinopsis Freyeri Joh. Müller mit Panzer - zu den Phocaeninen gehörig, aus dem Miocän von Belgien Pithanodelphis Abel, ein Delphinine.

\section{Unterordnung. Mystacoceti. Bartenwale.}

Schädel symmetrisch. Nasenbeine kurz, die zwei Spritzlöcher etwas überdachend. Funktionierende Zähne fehlen, Oberkiefer mit Barten besetzt, hinten stark nach der Seite verbreitert, aber nicht über das Stirnbein geschoben. Trünenbeine klein. Unterkieferäste nicht in einer Symphyse zusammenstoßend, nach außen konvex. Meist alle Rippen einköpfig. Sternum kurz, breit, aus einem Stück bestehend und nur mit dem vordersten Rippenpaar verbunden.

Die Bartenwale erweisen sich durch die Verkümmerung des Gebisses und den Ersatz der Zähne durch Barten als die fremdartigste und spezialisierteste Gruppe der Cetaceen, allein der Umstand, daß bei Embryonen noch winzige, hinfällige, im Fleisch verborgene Zähnchen vorkommen, zeigt, daß auch sie von bezahnten Tieren abstammen. Im Schädelbau, namentlich in der Entwicklung der Nasenbeine, Stirnbeine und Scheitelbeine bleiben die Bartenwale auf einer primitiveren Stufe' stehen als die Zahnwale.

\section{Familie. Balaenopteridae. Furchenwale.}

Kopf kürzer als der vierte Teil der Körperlänge. Auf der Bauchseite meist zahlreiche Furchen. Rückenflosse vorhanden; Brustflosse vierfingerig, schmal und ziemlich lang. Barten kurz und breit. Halswirbel frei, mit mäßig verlängertem Centrum. Tympanicum länglich, stark angeschwollen, allseitig gerundet. Lebend und fossil im Miocän und Pliocän.

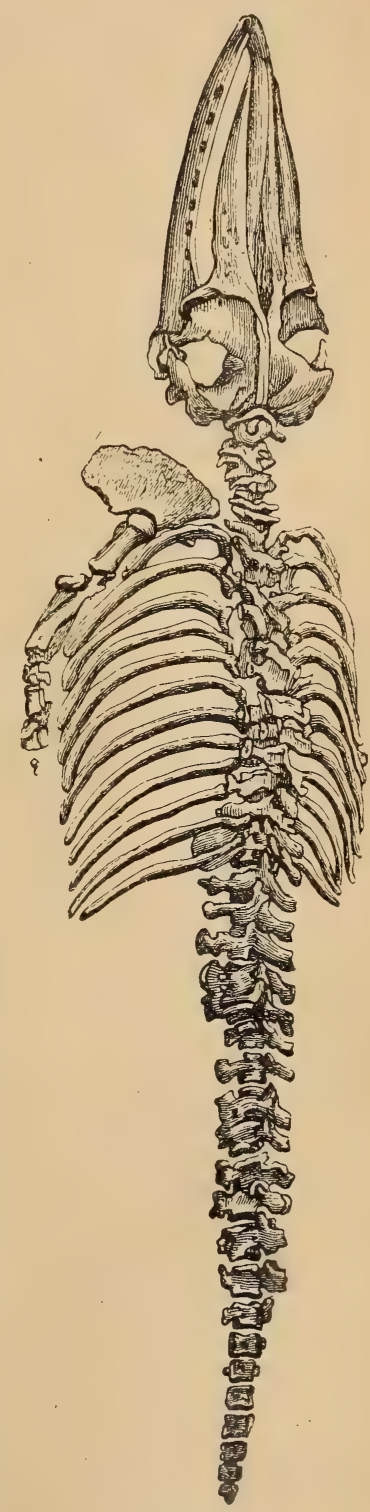

Fig. 574.

Plesiocetus Cuvieri Desm. Pliocän. Monte Pugnasco bei Piacenza. 1/46 nat. Gr. (Nach Cuvier).

Plesiocetus.v. Bened. (Fig. 574.) Im Miocän von Frankreich und Süddeutschland. Vollständige Skelette von 6 m Länge im Pliocän von Oberitalien. 


\section{Familie. Balaenidae. Glattwale.}

Schädel sehr groß, mindestens $1 / 4$ der Körperlänge einnehmend, Haut der Bauchseite glatt. Rückenflosse fehlt. Brustflossen breit und abgestutzt. Barten sehr lang und schmal. Unterkiefer schmal, stark gebogen, innen abgeplattet, mit kugeligem Gelenkkopf. Alle oder die nieisten Halswirbel verschmolzen; Lendenund Schwanzwirbel kurz. Tympanicum fast vierseitig, winklig, wenig angeschwollen. Brustflossen kurz, fünffingerig.

Die Glattwale sind gegenwärtig auf die polaren Gebiete der beiden Hemisphären beschränkt. Fossile Formen der Gattung Balaena Lin. finden sich spärlich in den jüngsten Tertiärablagerungen und im Pleistocän von Europa.

Cet otherium Brandt (Aulocetus v. Bened.). Miocän. Heterocetus, Herpetocetus, Mesocetus v. Bened. Balaenoptera Lacep. Megaptera Gray im Pliocän von Belgien und England. Von Mesocetus ein vollständiges Skelett in Ungarn (Soproner Comit). Im Miocän von Nordamerika Siphonocetus, Cetotherium und Mesoteras.

\section{Ordnung. Edentata. (Bruta Lin.) $)^{1}$ )}

Gebiß in der Regel nur aus prismatischen, schmelzlosen Backenzähnen bestehend, zuweilen vollständig fehlend. Endphalangen als lange, spitze, seitlich zusammengedrückte Krallen, selten hufartig entwickelt. Haut mit Haaren oder Hornschuppen oder Knochenschildern bedeckt.

Die Edentaten nehmen unter den placentalen Säugetieren eine ganz isolierte Stellung ein und wurden schon von $\mathrm{Cuvier}$ den Ungulaten und Unguiculaten als gleichwertige Gruppe gegenübergestellt. Das meist monophyodonte, aus prismatischen Zähnen bestehende Gebiß, in dem Eckzähne und Schneidezähne fast immer fehlen, der Mangel an Schmelz bei allen rezenten Formen, die schwankende Zahl der Rücken- und Schwanzwirbel bei vielen Gattungen, die Verbindung des Sitzbeins mit dem Sacrum, die Vermischung der Harn- und Geschlechtswege bei den Weibchen, und die Entwicklung eines knöchernen Hautskelettes bei den Gürteltieren bilden die auffallendsten Merkmale der in ihrer äußeren Erscheinung überaus verschiedenartigen Edentaten.

Über ihre Herkunft wissen wir nur, daß Nomarthra in Europa schon im Eocän oder Oligocän auftreten, und daß etwa gleichzeitig mit ihnen auch schon in Südamerika Gürteltiere gelebt haben, die aber freilich im Eocän in Nordamerika bereits früher erscheinen und möglicherweise auch in Europa im Eocän existiert haben. Ob die Ganodonta des nordamerikanischen Untereocäns die Ahnen der Gravigrada darstellen, ist etwas zweifelhaft, obschon ihr zeitliches Auf-

1) Ameghino Flor., Contribucion al conocimiento de los Mamiferos fosiles de la Rep. Argentina. Actas del Acad. nac. de cienc. en Cordoba 1889. - Les Edentés foss. de France et d'Allemagne. Anal. Mus. Nac. de Buenos Aires. Tomo XIII. 1905. - Burmeister H., Anal. del Mus. publ. de Buenos Aires. Entrega. I-XII. Cope E. D., The Edentata of North America. Amer. Naturalist 1889. - Filhol $H$., Annales scienc. nat. Zoologie et Paléontologie. T. XVI. 1894. - Lydekker R., Paleontologia Argentina III. Anal. Museo de la Plata 1894. - Owen Rich., Description of the skeleton of an extinct gigantic Sloth (Mylodon robustus). London. Phil. Trans. 1851-59. - On Glyptodon. 1838. - Reinhardt J., Vetensk. selsk. skin. Kjøbenharn 5. Raekke XI. XII. - Scott W. B., Reports of the Princeton University Exped. to Patagonia. Vol. V. Palaeontology. 1903. 1904. 
treten sich mit dieser Annahme sehr gut vereinbaren ließe, denn in Südamerika treffen wir echte Gravigrada erst im Untermiocän, in den Pyrotherium-Schichten.

Die Wirbelsäule enthält wohl differenzierte Hals-, Rücken-, Lenden-, Sacral- und Schwanzwirbel. In der Regel sind 7, selten 9 Halsmirbel vorhanden, wovon die hinteren zuweilen verschmelzen. Die Zahl der Rückenwirbel schwankt zwischen 12 und 24, die der Lendenwirbel zwischen 3 und 9. Bei den Glyptodontia verschmelzen sämtliche Dorsalwirbel nebst ihren Dornfortsätzen zu einer unbeweglichen Röhre und in gleicher Weise auch die Lendenwirbel mit dem Sacrum; auch die hinteren Schwanzwirbel bilden durch Ankylose der Centra ein unbewegliches Knochenstück.

Der Schädel ist bald stark verlängert, bald kurz, abgestutzt. Meist bleibt das Schädeldach eben, und nur bei den Gravigraden bilden die Parietalia zuweilen eine schwache Crista. Die Zwischenkiefer sind bei allen Edentaten schwach entwickelt und nehmen an der seitlichen Begrenzung der nach vorne gerichteten, meist großen Nasenlöcher keinen Anteil. Der Jochbogen ist entweder vollständig oder unterbrochen, zuweilen sogar rudimentär. Bei den Gravigraden, Tardigraden und Glyptodontia zeichnet er sich durch einen langen, nach unten, und einen etwas schwächeren, schräg nach oben und hinten gerichteten Fortsatz aus.

Fast alle Edentaten sind monophyodont; da jedoch bei den Gattungen Tatusia und Orycteropus Milchzähne dem definitiven Gebiß vorausgehen, so darf wohl angenommen werden, daß die Edentaten von diphyodonten Ahnen abstammen. Die Backenzähne sind oben und unten gleichartig oder doch nur wenig voneinander verschieden; ihre Zahl schwankt zwischen 4 und 10, wird zuweilen aber auch größer. Sie bestehen aus Dentin und einem Überzug von Zement. Die Dentinsubstanz des Zahnes ist in der Regel aus Schichten von verschiedener Härte und Struktur zusammengesetzt, die äußere, härteste Schicht lediglich von feinen Dentinkanälchen durchzogen; sie umgibt einen zentralen Vasodentinkern, in welchem zahlreiche gröbere Kanäle verlaufen. Die Backenzähne sämtlicher Edentaten haben prismatische Form und erreichen oft ansehnliche Höhe; sie sind wurzellos, unten offen und wachsen beständig in dem Maße weiter, als ihre Krone durch Gebrauch erniedrigt wird. Letztere ist meist eben, seltener schief abgekaut, oder es können sich auf der Krone auch einfache, abgedachte Querjoche bilden. Nicht selten besitzen alle oder ein Teil der Zähne auf der Außen- oder Innenseite oder auch innen und außen vertikale Furchen, welche eine Einschnürung des Zahnes bedingen und denselben zuweilen in zwei oder drei durch schmale Brücken verbundene Pfeiler zerlegen.

Die Extremitäten sind bald gleichmäßig ausgebildet, oder die hinteren kürzer und stämmiger als die vorderen. Die hohe mediane Spina des Schulterblattes endigt in einem sehr langen, überhängenden Acromion, das bei den Gravigraden sogar mit dem meist ungewöhnlich starken Processus coracoideus verwächst. Neben und in einiger Entfernung vom Hinterrand verläuft zuweilen eine zweite schwächere Crista. Eine Clavicula besitzen nur die Gravigrada und einige Gürteltiere. 
Der Humerus ist gedrungen und fast stets mit einem Foramen entepicondyloideum und einer sehr kräftigen Deltoidcrista versehen. Radius und Ulna bleiben getrennt. Der Carpus besitzt nur bei Manis ein Centrale und besteht meist aus sieben getrennten Carpalknöchelchen und einem Pisiforme. Nicht selten tritt eine Verschmelzung von Magnum und Trapezoid, oder von Scaphoideum und Lunare ein, oder das Trapezium verwächst mit dem Scaphoideum oder dem ersten Metacarpale. Von den Metacarpalia kommen bald alle, bald nur vier, sehr selten nur drei zur Entwicklung. Sie sind von verschiedener Länge und stützen sich auf 5-3 Phalangen, wovon die letzten als schmale, lange, zusammengedrückte, meist zugespitzte Klauen entwickelt sind.

Das Becken ist bei den Faultieren und Gravigraden nach vorne weit geöffnet, bei allen übrigen Edentaten verlängert und schmal. Mit Ausnahme von Orycteropus befestigen sich die ungemein stark entwickelten Sitzbeine am hinteren Teil des Sacrums. Die Schambeine sind schlank und dünn, die Symphyse kurz, das Foramen obturatorium groß. Tibia und Fibula sind bald getrennt, bald an ihren Enden verschmolzen.

Tarsus und Hinterfuß zeigen bei den Erdferkeln, den Ameisenfressern und Gürteltieren den normalsten Bau und sind meist fünfzehig; bei den übrigen verkümmern häufig die inneren oder äußeren Metatarsalia. Das Calcaneum hat einen verlängerten, rauhen Stiel, der Astragalus eine gewölbte Gelenkfläche für die Tibia und auf der Außenseite eine Grube für den konischen Fortsatz der Fibula. Die ersten und zweiten Phalangen sind kurz, zuweilen miteinander oder mit einem Metatarsale verschmolzen; die Endphalangen bald krallenförmig, bald (Glyptodontia) breit, hufartig und mit Nägeln bedeckt.

Die Gehirnhöhle der Edentaten hat höchstens mäßige Größe, das Gehirn differiert bei den verschiedenen Familien beträchtlich, indem das Großhirn glatt oder gefurcht und das Corpus callosum klein oder groß sein kann.

Bei den altweltlichen Formen erinnert die Beschaffenheit der Geschlechtsorgane an Huftiere. Die Hoden liegen in der Leistengegend, der Penis ist äußerlich, der Uterus zweihörnig, die Vagina ungeteilt und die Placenta diffus oder breit zonenförmig. Bei den amerikanischen Edentaten liegen die Hoden in der Bauchhöhle zwischen Mastdarm und Blase, der Penis ist klein, der Uterus einfach kugelig und die Placenta domförmig.

Die ersteren werden als $\mathrm{N}$ omarthra den amerikanischen Xenarthra gegenübergestellt.

\section{Unterordnung. Nomarthra. Gill.}

Die altweltlichen Edentaten zeichnen sich durch die einfache Gelenkung der hinteren Rücken und den Lendenwirbel aus. Die Familie der Orycteropodidae (Erdferkel) ist im Unterpliocän von Samos und Pikermi durch eine fossile Art, Orycteropus Gaudryi Forsyth Major, vertreten und durch einen Humerus - Palaeorycteropus Quercy $i$ Filhol in den Phosphoriten von Quercy. Von hier stammen auch der Schädel von Lepto- 
manis Edwardsi und Humerus, Femur und Tibia von Necromanis Quercyi Filhol. Eine teils an Orycteropus, teils an Manis erinnernde Form - $L$ Lutra franconica Quenstedt aus der miocänen Spaltausfüllung von Solnhofen wird von Ameghino Teutomanis und Galliaetatus benannt. Ein ganz ähnlicher Knochen, Metacarpale, auch im Miocän von Mont Ceindre bei Lyon. Immerhin zeigen diese dürftigen Reste, daß die scheinbar so weit entfernt stehenden Familien der Orycteropidae und Manidae einerseits und der Dasypodidae anderseits höchst wahrscheinlich doch gemeinsamen Ursprungs sind.

\section{Unterordnung. Xenarthra. Gill.}

Die Xenarthra, ausgezeichnet durch den Besitz ${ }_{\text {von }}$ mehreren akzessorischen Gelenken an den hinteren Rücken- und den Lendenwirbeln enthalten die »Unterordnungen" der Anicanodonta ohne oder höchstens mit Spuren eines Hautpanzers und der Hicanodonta Ameghino mit einem aus Knochen- und Hornplatten bestehenden Panzer.

\section{Tribus. Anicanodonta. Ameghino.}

Von den hierhergehörigen Familien sind die der Myrmecophagidae und Bradypodidae fossil nur durch spärliche Reste im Pleistocän von Südamerika vertreten. Um so zahlreicher sind dafür die der ausgestorbenen Familie der Gravigrada im Tertiär von Patagonien und im Pleistocän ron Südamerika. In Nordamerika ist sie auf Oberpliocän und Pleistocän beschränkt. Sie dürfte wohl aus den Ganodonta des älteren Eocän von Nordamerika hervorgegangen sein.

\section{Familie. Ganodonta. Wortman.}

$Z$ ahl der $J$ stets reduziert, $C$ gro $\beta, P$ und $M$ meist bewurzelt und mehr oder weniger vollständig mit Schmelz versehen. Wirbelgelenke ziemlich einfach. Untereocän von Nordamerika. Puerco bis Wind Riverbed.

Schädel und die massiven Extremitäten haben große Ähnlichkeit mit denen von Gravigrada. Auch das primitive Gebiß kann sich sehr gut in das der Gravigraden umgewandelt haben. Die geringe Schwierigkeit dieser Ableitung, welche darin besteht, daß diese Familie schon im älteren Tertiär von Patagonien auftritt, wird sehr leicht überwunden, wenn man annimmt, daß nur die Gattungen aus dem Torrejonbed für die südamerikanischen Formen stammesgeschichtliche Bedeutung haben, während die aus Wasatchund Bridgerbed ohne Hinterlassung von Nachkommen erloschen sind. Die Ganodonta haben wahrscheinlich gemeinsamen Ursprung mit den bei den Insectivoren angeführten Tillodontidae.

Der Humerus ist plump und mit kräftiger Deltoidcrista und Foramen entepicondyloideum versehen, die dicke Ulna besitzt ein hohes Olecranon. Die Form und Art der Gelenkung der Carpalia, Metacarpalien und Phalangen gleicht fast schon vollkommen der der Gravigrada, namentlich Mylodon, ebenso das flache Ilium. Nur der Astragalus unterscheidet sich durch seine primitive Form - langer Hals - wesentlich von dem der Gravigrada. Dagegen spricht das allmähliche Auftreten von akzessorischen Wirbelgelenken sehr für nahe Verwandtschaft. 


\section{Unterfamilie. Conoryctinae.}

2. ? 1. 4-3. 3. Schädel lang, niedrig und mit Scheitelkamm versehen. Unterkiefer gestreckt, Gelenkkopf nicht viel höher stehend als die Zahnreihe. J klein,

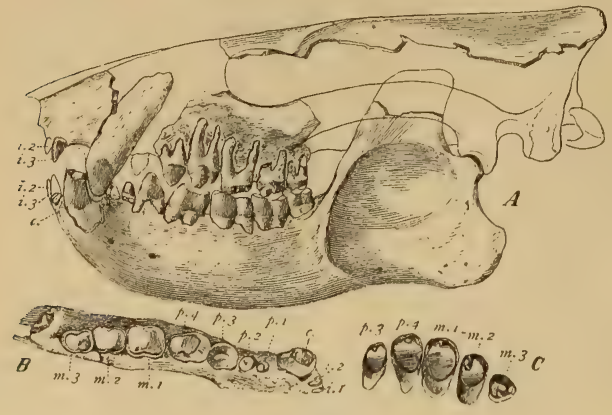

Fig. 575 .

Conoryctes comma Cope. Unterstes Eocän. Torrejonbed. Neu-Mexico. A Schädel und Unterkiefer, $B$ untere Zahnreihe, $C$ obere Backenzähne. 1/3 nat. Gr. (Nach Wortman.)

1. ? 1.4.3. Schädel und Unterkiefer kur\%. Kiefergelenk viel höher gelegen als die Zahnreihe. $C$ groß, mit sehr langer Wurzel oder mit persistierender Pulpa. $P_{3}$ und $P_{4}$ quergestellt. Wirbel mit Nebengelenken.

Hemiganus Cope. 2. 1. 4. 3. Obere $C$ allseitig, untere nur an Vorderseite mit Schmelz bedeckt. $P$ und $M$ bewurzelt. Unterstes Eocän. Puerco.

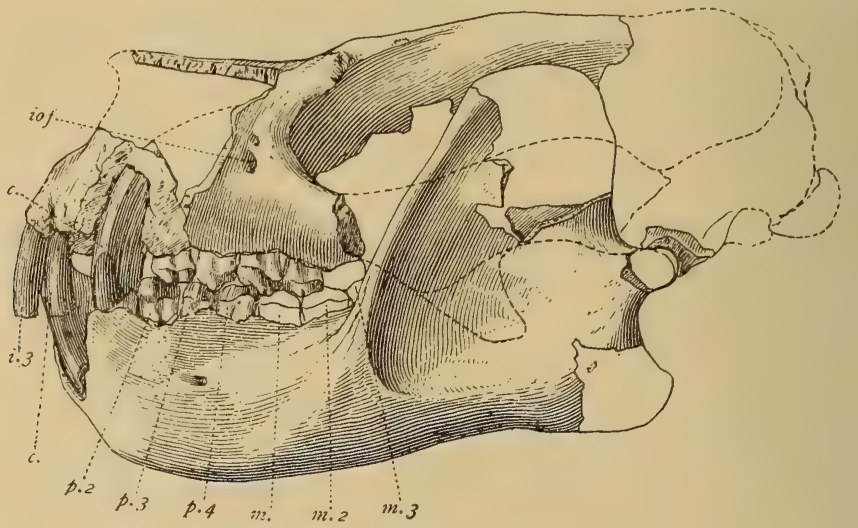

Fig. 576 .

Psittacotherium multifragum Cope. Unterstes Eocän Torrejonbed. Neu-Mexico. Schädel und Unterkiefer. 1/3 nat. Gr. (Nach Wortman.)

Psittacotherium Cope. (Fig. 576.) Obere und untere $C$ nur an Vorderseite mit Schmelz überzogen, bewurzelt. Wurzel an den $P$ und $M$ verschmolzen. $\frac{3}{3} P$. Untereocän. Torrejon. Von $P$. multifragum Cope ist das Skelett ziemlich vollständig bekannt. Der Schädel sieht dem von Megalony $x$ ähnlich.

Calamodon Cope (Dryptodon Marsh). 1.1.4.3.. C mit persistierender Pulpa, Nagezahn-ähnlich. $P$ und $M$ bewurzelt, $M$ aus vier jochartig gruppierten Höckern bestehend. Untereocän Wasatchbed. Wyoming, wohl auch im Fort Unionbed von Montana. In den mitteleocänen Bohnerzen von Egerkingen ein isolierter Zahn. C. europaeus Rütimeyer. 
Stylonodon Marsh. Alle $P$ und $M$ hypselodont ohne Wurzeln, nur mit Schmelzbändern versehen. Mitteleocän. Bridgerbed von Wyoming. St. mirus Marsh.

\section{Familie. Gravigrada. Ries en faultiere.}

Ausgestorbene, zum Teil große und plumpe Pflanzenfresser mit länglich zylindrischem Schädel. Jochbogen sehr stark, mit abwärts gerichtetem Fortsatz. $\frac{0.5-4 .}{0.4-3 .}$ Zühne zylindrisch. Schwanz ungemein dick und lang. Beine plump, mäsig lang. Hand als Greiforgan entwickelt, Hinterfuß plantigrad. Astragalus fach, höchstens mit kurzem Hals, distal abgestutzt.

$\mathrm{Zu}$ den Gravigraden gehören die plumpsten und unbehilflichsten Vertreter der Edentaten, welche sich von den heutigen Faultieren durch den längeren Schädel, den stärkeren Jochbogen und den langen ungemein kräftigen, als Stütze dienenden Schwanz, durch die kürzeren plumperen Extremitäten und häufig auch durch beträchtlichere Größe unterscheiden. Sie finden sich im Tertiär und Pleistocän von Südamerika und im Pliocän und Pleistocän von Nordamerika.

Die älteste Form ist die ganz mangelhafte bekannte Gattung Protobradys Ameghino aus den Notostylopsschichten von Patagonien. Im Miocän von Santa Cruz sind dagegen schon alle drei Unterfamilien Megatheriinae (Planops), Megalonychinae und Mylodontinae vertreten, unter welchen sich die Repräsentanten der Megalonychinae durch einen großen Artenreichtum auszeichnen. Diese älteren Formen sind fast insgesamt viel kleiner als ihre pleistocänen Verwandten. Hautossifikationen konnten bei keiner nachgewiesen werden. Die Zahnzahl ist stets $\frac{5}{4}$, und der erste Zahn in beiden Kiefern immer $C$-artig entwickelt. Der Schädel zeichnet sich durch eine lange Schnauze und ein geräumiges Cranium aus. Rumpf und Scapula sind jenen von Bradypodiden (Choloepus) ähnlicher als denen der pleistocänen Gravigraden. Die Extremitätenknochen sind noch durchgehends schlanker und der Humerus besitzt stets ein Foramen entepicondyloideum. Verwachsung von Carpalien, Tarsalien oder Phalangen kommt nicht vor. Das mittlere Metapodium ist zwar schon viel kürzer und dicker als die übrigen, aber die beiden äußeren sind noch viel weniger spezialisiert als bei den späteren Gravigraden, weil die Außenseite des Fußes noch nicht auf dem Boden aufliegt. Im Skelett nähern sich die miocänen Gravigraden noch vielfach den Bradypodiden und den Myrmecophagiden.

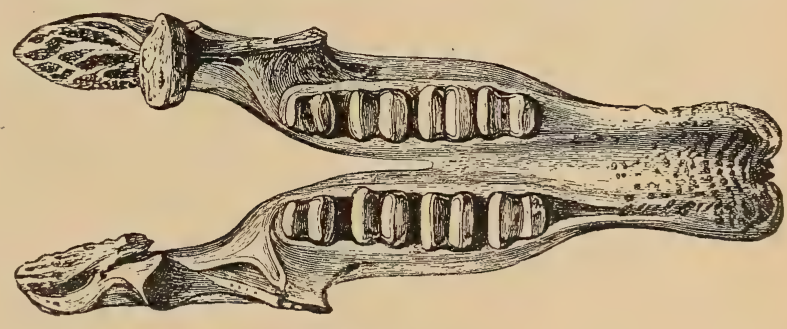

Fig. 577

Megatherium americanum Blumb. Pampasformation (PTeistocän). Argentinien. Unterkiefer, obere Ansicht. 1/8 nat. Gr. (Nach Owen.)

\section{Unterfamilie. Megatheriinae.}

Backenzähne prismatisch, vierkantig, in geschlossener Reihe, der letzte etwas kleiner als die übrigen. Hinterast des Alveolarkanals auf der Innenseite des Unterkiefers mündend.

Megatherium Cuv. (Fig. 577.) Das erste vollständige Skelett wurde schon 1789 in Argentinien ausgegraben und nach Madrid geschickt. Neben $M$. americanum Blumb. (= giganteum Pander) finden sich noch andere Arten im Pleistocän von Argentinien, Brasilien, Chile, Ecuador, Zentralamerika und den südlichen vereinigten Staaten. 
Nothroitherium Lydekker (Coelodon Lund) erheblich kleiner als Megàtherium. Pleistocän. Brasilien.

Neoracanthus, Essonodontherium Ameghino. Pleistocän von Argentinien.

Zamicrus, Promegatherium und Interodon Ameghino, im Pliocän von Argentinien.

Als Vorläufer der Megatherien betrachtet Scott die Planopsinen (Prepotheriiden Ameghino) aus dem Obermiocän von Santa Cruz in Patagonien mit den Gattungen Planops und Prepotherium Amegh., die letztere Gattung auch schon in den Colpodonschichten.

Es sind die größten Gravigraden aus dem Miocän von Santa Cruz. Mit den Megatheriiden haben sie bereits gemein den massiven Schwanz, die Verlängerung von Ischium und Pubis, den kurzen breiten Astragalus und das lange Sustentaculum des Calcaneums, dagegen bilden die Kauflächen noch keine Joche.

\section{Unterfamilie. Megalonychinae.}

Backenzähne prismatisch, vierseitig bis quer elliptisch, der vorderste von den übrigen weit abstehend und C ähnlich. Letzter Zahn klein. Alveolarkanal vor der Basis des aufsteigenden Astes oder auf der Außenseite, selten auf der Innenseite mündend.

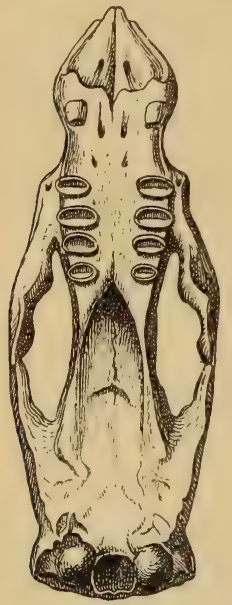

Fig. 578.

Hyperleptus garzonianus Amegh. Obermiocän. Santa Cruz. Patagonien. 1/3 nat. Gr. (Nach A meghino.)

Megalony $x$ Jefferson (Fig. 579) im Pleistocän von Nordamerika (Megalonyx Bed.) daselbst auch in Höhlen. Auch im Pliocän (Blancobed.) von Texas. M. leptostoma Cope.

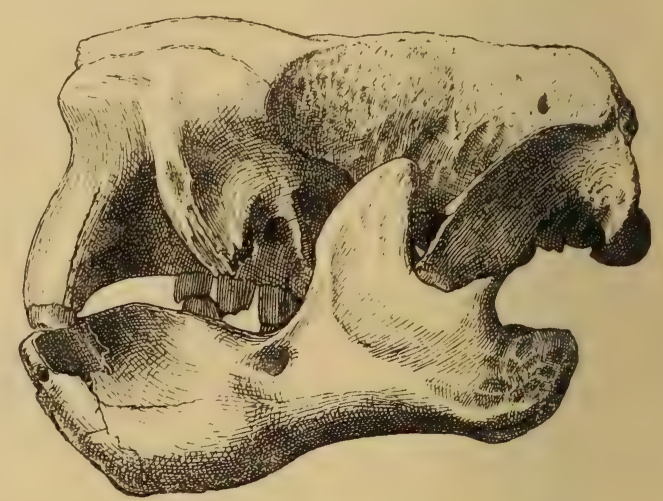

Fig. 579 .

Megalonyx Jeffersoni Leidy. Pleistocän. Kentucky. Schädel nebst Unterkiefer ca. $1 / 6$ nat. Gr. (Nach L eidy.)

Ameghino und Scott beschreiben aus dem Miocän von Santacruz in Patagonien eine Anzahl kleiner Gattungen - Hapalops, Eucholoeops, Hyperleptus (Fig. 578). Schismotherium, Megalonychotherium, Analcimorphus und Pelecyodon, unter welchen die Gattung Hapalops; (Geronops, Parahapalops Ameghino) bei weitem die häufigste und artenreichste und auch sehr vollständig bekannt ist. Alle diese Gattungen haben noch einen dritten Femurtrochanter. Noch ältere Reste sind die von Proplatyarthus Amegh. aus den Astraponotusvon Hapalops aus den Pyrotherium- und von Hapaloides und Proschismotherium aus den Colopodon-Schichten von Patagonien.

\section{Unterfamilie. Mylodontinae.}

Backenzähne prismatisch, von elliptisch dreieckiger Form. Letzter unterer Zahn größer als die übrigen und zweilappig. Hinterer Ast des Alveolarkianals außen mündend. 
Mylodon Owen. (Fig. 580.) $\frac{5}{4}$, mit breiter abgestutzter Schnauze und rudimentärem Zwischenkiefer. Jochbogen unterbrochen mit stark entwickeltem unteren Fortsatz. Vorderfuß fünf-, Hinterfuß vierzehig. Haut mit vielen Ossifikationen. Im Pleistocän von Argentinien $M$. robustus Owen. In Nordamerika, Oberpliocän, Blancobed von Texas, im Pleistocän M. Harlani Owen. Auch in Höhlen.

Paramylodon Brown. $\frac{4}{4} . \quad M_{3}$ dreiteilig. Pleistocän Nebraska.

Lestodon Gerv. Kiefer vorne verbreitert. Pleistocän Argentinien.

Pseudolestodon Ameghino. Altpleistocän. Tarija Tal. Bolivien.
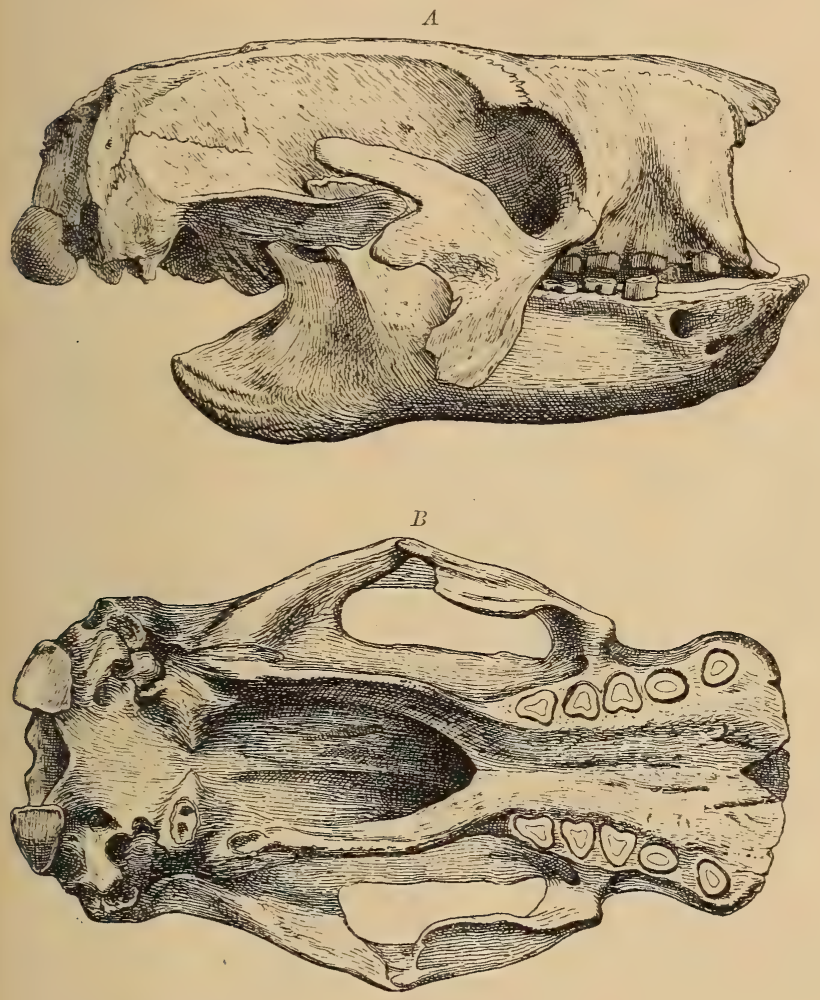

Fig. 580

Mylodon robustus Owen. Pampasformation. Buenos Aires. A Schädel nebst Unterkiefer von der Seite. $B$ Schädel von unten. $C$ linker Vorderfuß. ( $R$ Radius, $U$ Ulna, $s$ Scaphoideum, $l$ Lunare, $c$ Cuneiforme, $p$ Pisiforme, $t d$ Trapezoid, $m$ Magnum $u$ Unciforme, $I-V$ erster bis fünfter Finger.) $D$ linker Hinterfuß. (ca Calcaneum, $a$ Astragalus, $n$ Naviculare, $c b$ Cuboideum, $c$ " $c^{\prime \prime}$ Cuneiformia II und III. II-V zweite bis fünfte Zehe.) Alle Figuren $1 / 6$ nat. Gr. (Nach Owen.)
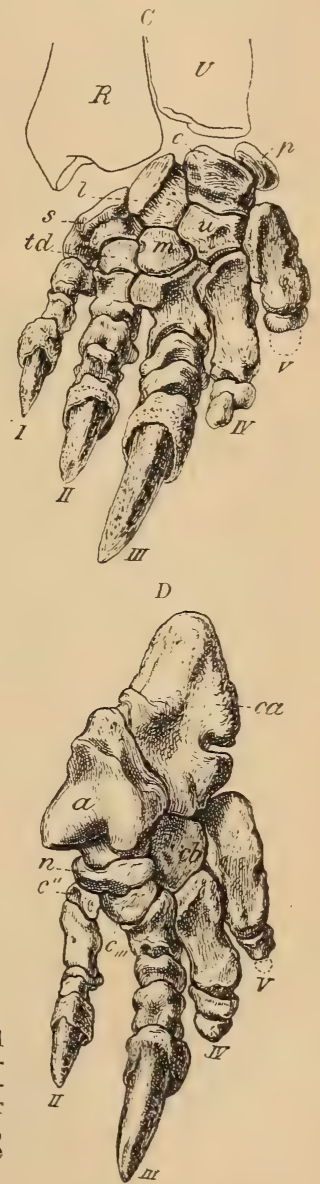

Scelidotherium Owen. Schädel lang, niedrig. Schnauze verlängert. Vorne vier, hinten drei Zehen. Pleistocän Südamerika.

Sphenotherus Amegh. (Platyonyx Lund). Pleistocän Südamerika.

Glossotherium Owen (Neomylodon Ameghino). Zwischenkiefer die Nasenöffnung vorne abschließend. G. Listai Amegh. sp. (Grypotherium domesticum Roth) war sicher noch ein Zeitgenosse der Menschen. In der Höhle Eberhardt am Meerbusen von Ultima Esperanza in Patagonien fanden sich zahlreiche Reste, darunter auch Fellstücke mit Knochenkernen.

Im Miocän von Santa Cruz in Patagonien sind die Mylodontinen nur spärlich vertreten durch kleine Formen Nematherium (Ammotherium, Limodon) und Analcitherium Ameghino, von welchen sich die letztere 
Gattung enger an Scelidotherium anschließt. Im Schädelbau haben sie noch große Ähnlichkeit mit den gleichaltrigen Megalonychinen. Im älteren Tertiär von Patagonien (Pyrotherium·Schichten), die ungenügend bekannten Gattungen Octodontherium und Orophodon Ameghino.

\section{Tribus. Hicanodonta, Ameghino. (Loricata. Gürteltiere.)}

Rumpf, Kopf und Schwanz von einem aus knöchernen Platten zusammengesetzten Panzer bedeckt. Mehr als 5 (meist 8-10) Backenzähne in jeder Kieferhälfte. Unterenden von Tibia und Fibula fest verwachsen. Radius, Ulna, Carpalia, Tarsalia und Metapodien stets frei. Hand und Fuß meist fünfzehig. Astragalus mit vertiefter, breiter Trochlea, ziemlich langem Hals und konvexer Gelenkfläche. Lebend und fossil in Süd- und Zentralamerika und in den südlichen Vereinigten Staaten von Nordamerika,

\section{Familie. Glyptodontidae.}

Ausgestorbene, zum Teil sehr große Gürteltiere mit dickem, unbeweglichem, aus polygonalen, durch Sutur verbundenen Knochenplatten bestehendem Panzer. Schädel kurz, hoch, vorne abgestutzt; Jochbogen mit abwürts gerichtetem Fortsatz. Backenzähne $\frac{8}{8}$, länglich-prismatisch, meist durch zwei tiefe Quereinschnürungen in drei Pfeiler geteilt. Gehirn sehr klein. Sümtliche Rückenwirlel zu einer Röhre verwachsen und die Lendenwirbel mit dem Sacrum verschmolzen. Hand und Fuß fünfzehig mit hufühnlichen Rlauen.

Die Glyptodonten begleiten im Tertiär und’'Pleistocän von Amerika überall die Gravigraden und stellen einen ausgestorbenen, eigentümlich spezialisierten Seitenzweig der Gürteltiere dar. Ihr auffallendstes Merkmal

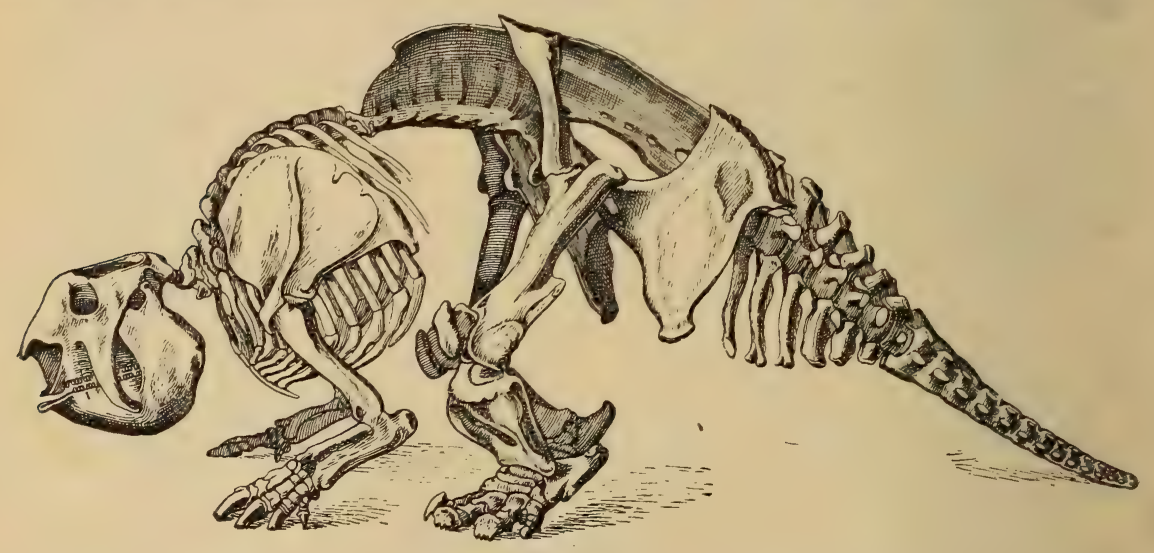

Fig. 581 .

Panochthus tuberculatus Owen sp. Restauriertes Skelett ohne Panzer. Pampasformation. Argentinien. $1 / 22$ nat, Gr. (Nach Burmeister.)

beruht in der Zusammensetzung des ungemein dicken, halbkugeligen oder länglich ovalen, unbeweglichen $R \ddot{u} \mathrm{ckenpanzers}$ aus sechs-, fünf- oder vierseitigen, verschiedenartig verzierten Knochenplatten, die durch Sutur fest miteinander verbunden sind. Bei den älteren Formen sind sie noch in Querreihen angeordnet, die auch noch eine gewisse Beweglichkeit besitzen.

Die W ir b els äu le enthält 7 Hals-, 12 Rücken-, 7 -9 Lenden-, 7-8 Sacralund 20-24 Schwanzwirbel. Von den Halswirbeln hat der Atlas mäßige Größe und bleibt stets frei; der Epistropheus verschmilzt mit den 3 oder $\mathbf{5}$ 
folgenden sehr kurzen Wirbeln; der letzte Halswirbel ist immer von den vorhergehenden getrennt, kann aber mit den Rückenwirbeln verwachsen. Die Centra und kurzen Dornfortsätze der letzteren sind sämtlich oder teilweise fest miteinander verschmolzen und bilden eine unbewegliche Röhre, deren Gliederung nur durch die Querfortsätze und seitlichen Nervenlöcher angedeutet wird. Diese dorsale Röhre artikuliert mit einem hinteren, ebenfalls unbeweglichen Teil der Wirbelsäule, welche aus den innig verschmolzenen Lenden- und Sacralwirbeln besteht und sich durch einen hohen, aus der Verwachsung der Dornfortsätze gebildeten Kamm auszeichnet. Die 7 vorderen Schwanzwirbel sind beweglich miteinander verbunden und mit starken Hämapophysen versehen. An dem sehr kurzen, hohen Schädel verschwinden die Suturen frühzeitig, der Gaumen ist von zahlreichen Öffnungen durchbohrt, die Jochbogen mit starkem, nach abwärts gerichtetem Fortsatz und der Unterkiefer mit ungewöhnlich hohem aufsteigenden Ast versehen. Von den Extremitäten sind die hinteren länger und plumper als die vorderen. Die Hüftbeine stehen fast rechtwinklig zur Körperachse, die Sitzbeine sind gewaltig verbreitert und mit der Wirbelsäule verwachsen.

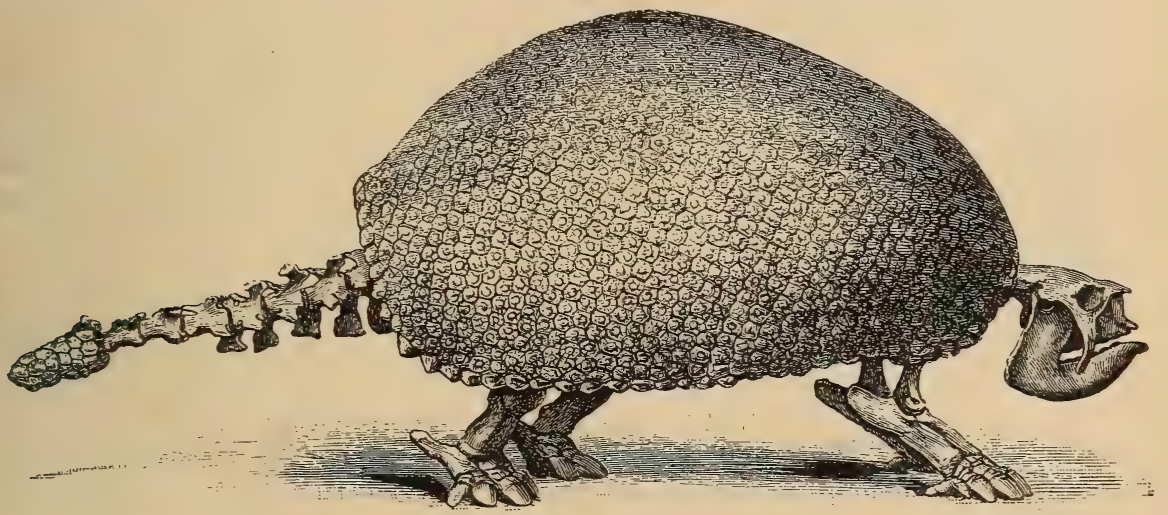

Fig. 252

Glyptodon reticulatus Owen (= Schistopleurum typus Nodot). Pampasformation. Rio Salado, Argentinien. Restauriertes Skelett mit Panzer im Pariser Museum (nach Ga a dry). 1/26 nat. Gr.

Glyptodon Owen. (Fig. 582, 583.) Schwanz kurz zugespitzt, von zahlreichen, aus konischen oder stacheligen Platten zusammengesetzten Querringen umgeben. Die Platten des Rückenpanzers außen rosettenartig verziert. In der Pampasformation von Argentinien und Uruguay. Selten im Pleistocän von Florida, Neu-Mexiko. Die Höhe von Gl. reticulatus Owen beträgt $1,2 \mathrm{~m}$, die Länge $2 \mathrm{~m}$.

Hoplophorus Lund. (Fig. 585.) Schwanz lang, allseitig mit ovalen oder rundlichen Platten bedeckt, deren Zwischenräume durch kleinere, polygonale Platten ausgefüllt sind. Pleistocän. Argentinien und Brasilien.

Panochthus Burm. (Fig. 581, 584.) Panzerplatten vier- oder fünfseitig, außen mit zahlreichen Höckerchen bedeckt. Schwanz vorne mit beweglichen Querringen, hinten von einer langen, gekörnelten Röhre umgeben, worin größere ovale oder rundliche, radial gestreifte Platten eingebettet sind. Pleistocän. Argentinien. Sämtliche Arten sehr groß.

Eleutherocercus Koken. Pleistocän.

Doedicurus Amegh. Panzerplatten außen mit Grübchen verziert. Schwanzröhre am Ende kolbig verdickt. Pampasformation. Argentinien.

Neuryurus, Lomaphorus, Sclerocalyptus Amegh. Pliocän. Argentinien. 
Glyptotherium Osborn. Pliocän. Blancobed von Texas.

Im Miocän von Santa Cruz in Patagonien sind die Glyptodontia durch die Gattungen Propalaeohoplophorus, Cochlops, Encynepeltus, Asterostemma und Metopotoxus Ameghino vertreten. Sie sind sämtlich viel kleiner als die der
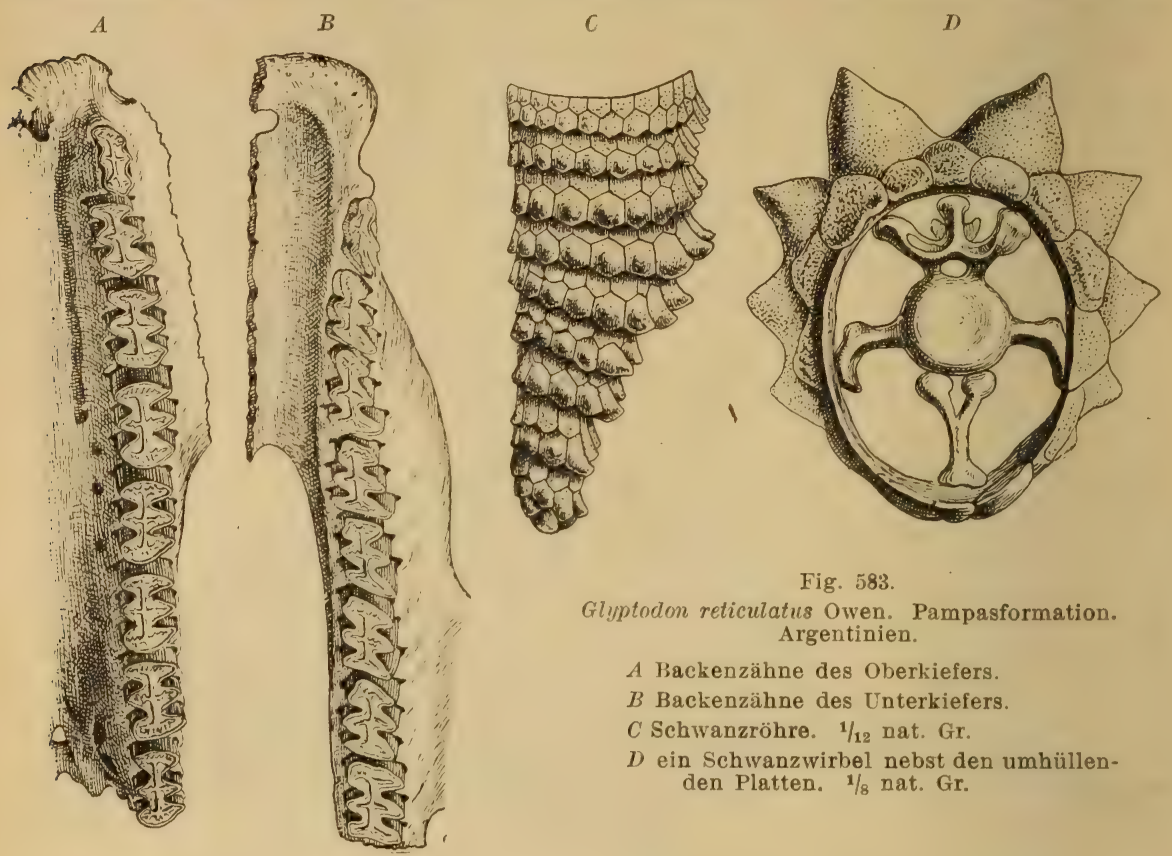

Fig. 583.

Glyptodon reticulatus Owen. Pampasformation. Argentinien.

$A$ Backenzähne des Oberkiefers.

$B$ Backenzähne des Unterkiefers.

$C$ Schwanzröhre. 1/12 nat. Gr.

$D$ ein Schwanzwirbel nebst den umhüllenden Platten. 1/8 nat. Gr.

Pampasformation und unterscheiden sich durch den niedrigeren Unterkiefer, die längere Schnauze, durch den einfachen Bau des vordersten Zahnes und durch die schlankeren Beine.

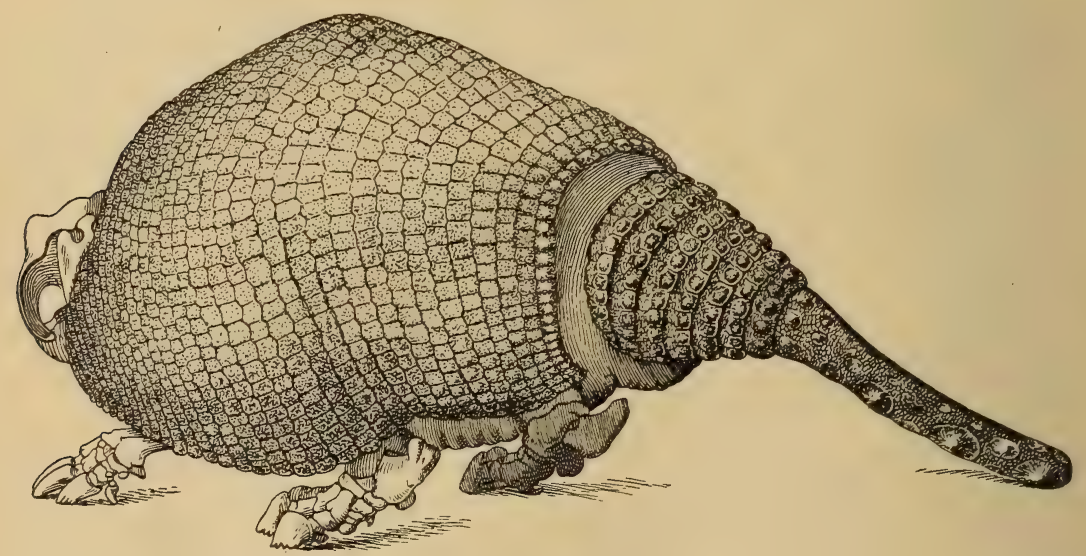

Fig. 584 .

Panochthus tuberculatus Owen sp. Pampasformation. Prov. Buenos-Aires. Panzer restauriert. $1 / 20$ nat. Gr. (Nach Burme ister.)

Von Propalaeohoplophorus, mit Glyptodon nahe verwandt, kennt man das Skelett ziemlich vollständig. Atlas frei, Epistropheus mit 3 bis 4 Hals- 
wirbeln verwachsen, 6. frei, 7. mit 1. und 2. Rückenwirbel fest verbunden. 3 . bis 5. frei, die 6 übrigen Rückenwirbel mit einem Lendenwirbel, die folgenden 5 oder 6 Lendenwirbel verwachsen. Sacrum aus $7-8$ Wirbeln gebildet. Nur 12 oder 13 Schwanzwirbel. Auch bereits in den etwas älteren Colpodonschichten.

Metopotoxus ist der Vorfahre von Panochthus.

In den Pyrotheriumschich. ten von Patagonien Palaeopeltis und Glyptatelus Ameghino.

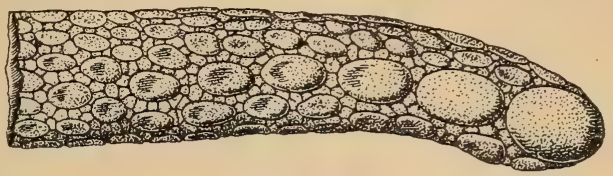

Fig. 585 .

Hoplophorus Heusseri Amegh. Pampasformation. Argentinien. Schwanzröhre von der Seite. $1 / 6$ nat Gr. (Nach A megh ino.)

\section{Familie. Dasypodidae. Gürteltiere.}

Hautpanzer entweder ganz aus beveglichen Querreihen von Knochenplatten oder aus einem unbeweglichen Schulter-und Beckenpanzer und dazwischen liegenden beweglichen Querringen bestehend. Schädel lang, niedrig mit verschmälerter Schnauze. Jochbogen ohne abwärts gerichteten Fortsatz. Zähne $\left(\frac{8-9}{9-10}\right)$ prismatisch, häufig heterodont. Alle Rücken- und Lendenwirbel frei. Extremitäten fünfzehig.

Die Dasypodidœ unterscheiden sich von den Glyptodontiden durch ihre primitivere Organisation - beweglicher Panzer, langgestreckter Schädel, einfachere Zähne, Fehlen von Randplatten und freie Wirbel. In der Größe bleiben sie mit Ausnahme von Chlamydotherium beträchtlich hinter den Glyptodontiden zurück.

Die Gürteltiere bewohnen das tropische und gemäßigte Südamerika, nur die Gattung Tatusia verbreitet sich von Zentralamerika bis nach Mexiko und Texas. Fossile Dasypodiden sind mit Sicherheit nur in Südamerika nachgewiesen. Das von Filhol aus den Phosphoriten von Quercy beschriebene Panzerfragment Necrodasypus Galliae, mit welchem Ameghino auch den Schädel von Necromanis Edwardsi Filhol vereinigt, wird von anderen als das der eocänen Gattung Placosaurus gedeutet. Die reduzierte Bezahnung 1. 1. 2. von Metachiromys Wortman aus dem Bridgereocän von Wyoming läßt sich schwer mit der Annahme

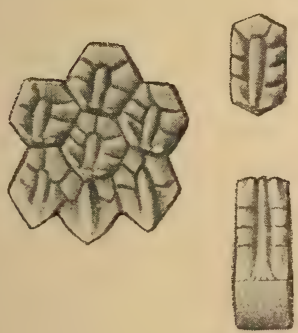

Fig. 586.

Prozaëdius proximus Amegh. Fiocän. Santa Cruz, Panzerplatten. Nat. Gr. Osborns vereinbaren, wonach diese Reste einem panzerlosen Dasypodiden angehören sollen.

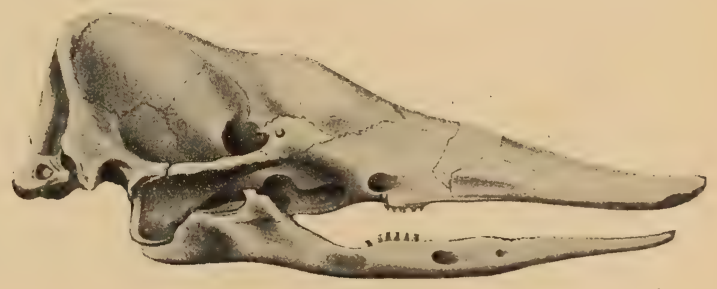

Fig. 587.

Stegotherium tesselatum Amegh. Miocän. Santa Crǔ. Schädel $1 / 2$ nat. Gr. (Nach Scott.)

Die Dasypoda aus dem Pleistocän von Südamerika, Pampasformation von Argentinien und aus brasilianischen Knochenhöhlen, gehören zumeist noch lebenden Gattungen - Tatusia, Dasypus, Tolypeutes, Xenurus etc. an. Chlamydotherium Ameghino zeichnet sich durch seine gewaltige Größe aus, auch schon im Pliocän zusammen mit Proeuphractus und Eutatus Amegh.

Sehr vollständige Reste beschreibt Scott aus dem Miocän von Santa Cruz in Patagonien. Sie verteilen sich auf die Gattungen Proëutatus, Prozaëdius (Fig. 586), Stenotatus Amegh., Pareutatus Scott und Stegotherium und 
Peltephilus Amegh., von welchen die beiden letzteren besonderes Interesse verdienen. Stegotherium (Fig. 587) leitet durch seine langgestreckte Schnauze

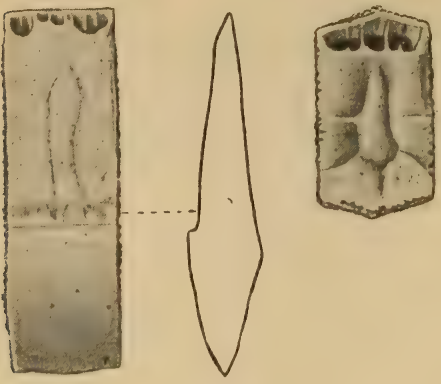

Fig. 588

Meteutatus lagenaeformis Amegh.

Untermiocän. Pyrotherium - Schichten. Patagonien.

Panzerplatten nat. Größe. und die stark reduzierten, auf den hintersten Kieferteil beschränkten Zähne zu den Myrmecophagiden hinüber. Pel. tephilus hat eine kurze, breite Schnauze und ein ausgedehntes, aber nur aus einer mäßigen Anzahl von Platten bestehendes Kopfschild, an welchem zwei Platten als Hörner entwickelt sind. Die nämlichen Gattungen treten auch in den Colpodon. Schichten auf, während die PyrotheriumSchichten auch noch einige Gattungen enthalten, welche solchen aus den eocänen Notostylops-Schichten sehr nahe stehen. Auf den ältesten Dasypodiden-Resten ba. sieren die Gattungen Prostegotherium. T'taëtus, Meteutatıs (Fig. 588), Machlydotherium etc. Amegh.

\section{Ordnung. Rodentia. (Glires) Nag er. ${ }^{1}$ )}

Extremitäten mitKrallen, selten mithufartigen Nägeln. Gebiß mit $\frac{1}{1} J$, selten mit $\frac{2}{1} J$. $J$ sehr lang, mit persistierender Pulpa, meist nur vorne und außen mit Schmelz versehen und mit zugeschärfter meißelförmiger Kaufläche. Backenzähne ${ }_{2-6}^{6}$, durch weites Diastema von den $J$ getrennt, brachyodont, bunodont, lophodont oder prismatisch. Gelenkkopf des Unterkiefers in einer Rinne eingefügt und vorwärts und rückwärts beweglich.

Die Nager bilden eine einheitliche, gegen die übrigen Placentalier scharf abgegrenzte, vielleicht aus primitiven Insectivoren hervorgegangene Ordnung, welche namentlich im Gebiß hochgradige Spezialisierung aufweist. Es sind meist kleine Pflanzenfresser, welche sich unterirdische Wohnungen graben, zuweilen aber auch zum Klettern und zum Schwimmen befähigt sind. Gebiß und Skelett sind durch die Art der Ernährung und Lebensweise stark beeinflußt.

Der Schädel (Fig. 589) ist meist niedrig, die Schnauze lang und das Hinterhaupt fällt steil nach unten ab. Die glatten Großhirnhemisphären lassen das Kleinhirn und die Riechlappen frei, die Nasenhöhle ist geräumig und mit Ethmoidalconchen ausgefüllt. Die Nasenlöcher öffnen sich stets nach vorne. Die $Z_{\text {wischenkiefer reichen bis }}$ zu den Stirnbeinen. Der Processus paroccipitalis hat häufig ansehn-

1) Brandt J. F., Mém. Acad. impér. St. Petersbourg 1835. VI. Ser. T. III p. 77 bis 336. - Cope E. D., The extinct R odentia of North America. Amer. Natur. 1883. p. 43, 165, 370. - Major Forsyth C. J., Nagerüberreste aus Bohnerzen Süddeutschlands u. d. Schweiz. Paläontogr. 1873. Bd. XXII. - On Fossil and Recent La g o mor pha. Trans. Linn. Soc. London 1899. - Matthew W. D., Bulletin Amer. Mus. Nat. Hist. New York 1902. Art. XXII. 1910. Art. VI. - Nehring A., Beitr. z. Kenntnis d. Diluvialfauna (Nager). Zeitschr. für ges. Naturw. 18i6. XLVII u. XLVIII. - Schlosser M., Nager d. europ. Tertiärs. Palaeontogr. 1884. Bd. XXXI. Scott W. B., Report of the Princeton Expeditions to Patagonia 1905. Vol. V. Part. III. - Tuilberg T., System der Nagetiere. Nova Acta Soc. Scienc. Upsala 1899. Winge $H$., Jordfundne og nu levende Gnavere (Rodentia) fra Brasilien. E Museo Lundii. Kjøbenhavn 1888. 
liche Länge. Die Augenhöhlen sind hinten offen. Der kräftige Processus zygomaticus des Oberkiefers ist vom Infraorbitalforamen durchbohrt, das häufig einen so weiten Kanal bildet, daß nicht nur der Nervus facialis sondern auch der vordere Ast des Massetermuskels darin Platz findet. Bei den Hystricoidea und Anomaluroidea übertrifft die Weite dieses Kanals nicht selten die Weite der Augenhöhle. Der Jochbogen ist immer wohl entwickelt und das Tränenbein hat eine ziemliche Ausdehnung. Die vorderen Gaumenlöcher haben ansehnliche Größe. Der Unterkiefer besitzt außen häufig eine vorspringende Leiste zur Anheftung des Massetermuskels. Der gewölbte Gelenkkopf ist länger als breit und ziemlich hochgelegen.

Im Schultergürtel ist häufig die Clavicula vorhanden. Die beiden Unterarmknochen sind zuweilen rotationsfähig. Der Carpus enthält nicht selten ein Centrale. Scaphoid und Lunatum verschmelzen häufig miteinander. Von den 5 Fingern verkümmert oft der erste. Die spitzen Endphalangen sind mit Krallen versehen.

Im $\mathrm{B}$ e c k e n gürtel zeichnet sich das Hüftbein durch schlanke, dreikantige Gestalt aus, Schambein und Sitzbein sind groß und die beiden Schambeine werden durch eine lange Symphyse verbunden. Das Femur trägt öfters einen dritten Trochanter. Fibula und Tibia verwachsen nicht selten mit ihren Unterenden, dagegen bleiben alle Tarsalia frei. Die Zehenzahl ist häufig fünf, selten drei, aber im letzteren Falle kann

Verschmelzung der dreí Metatarsalia er-

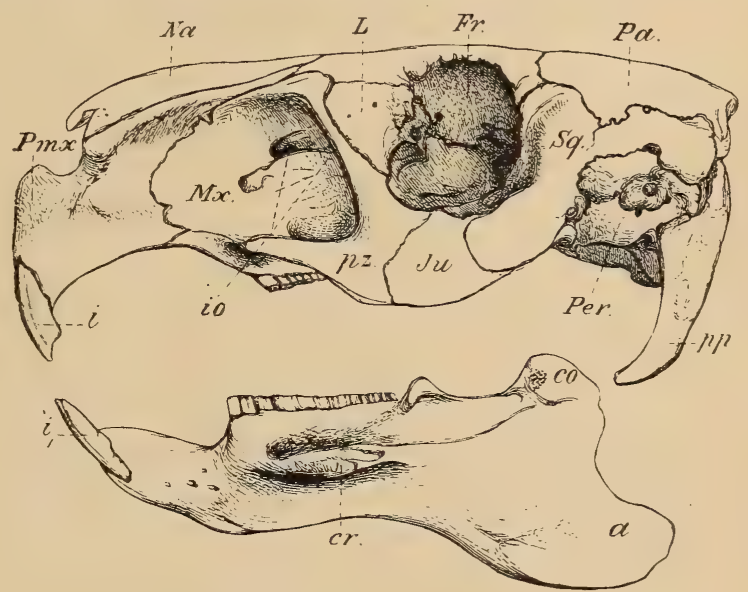

Fig. 589

Hydrochoerus capybara Erxl. Süd-Amerika. Schädel und Unter kiefer, $1 / 2$ nat. Gr. (Nach Flowe r.) $P m x \mathrm{Z}$ wischenkiefer, $M x$ Oberkiefer, $N a$ Nasenbein, $L$ Tränenbein, $F r$ Stirnbein, $P a$ Scheitelbein, $S q$ Schläfenbein, Ju Jochbein, Per Perioticum; $i$ oberer, $i_{1}$ unterer Schneidezahn, io Infraorbitalkanal, $p z$ Processus zygomaticus des Oberkiefers, $p p$ Processus paroccipitalis, co Condylus, a Angulus, cr Massetercrista des Unterkiefers. folgen.

Im Gegensatz zu dem primitiven Bau des Schädels und des Skelettes erscheint das Gebiß sogar schon bei den ältesten Nagern hochgradig spezialisiert. Die Zahnformel schwankt zwischen $\frac{2.0 .3 .3 .}{1.0 .3 .2 .}$ und $\frac{1.0 .2 \text {. }}{1.0 .2 .}$ Die Caninen sind gänzlich verschwunden und die Backenzähne trennt eine weite Lücke von den Incisiven, von welchen in der Regel auch nur je einer in jedem Kiefer und zwar der ursprüngliche $J_{2}$ vorhanden ist. Nur bei den Duplicidentata steht hinter dem großen $J^{2}$ noch ein kleiner $J^{3}$. Die $J$, hier wegen ihrer Funktion Nagezähne genannt, wachsen in dem gleichen Maße weiter, als ihre Krone durch Abkauung abgenutzt wird. Die Backenzähne sind niemals vollzählig vorhanden, die $P$ können ganz fehlen und von 
den $M$ der letzte verkümmern. Abgesehen vom vordersten $P$ haben alle Backenzähne übereinstimmenden Bau. Sie sind bald kurz, brachyodont und bewurzelt, bald hoch, hypselodont, prismatisch und unten offen und selbst im Alter wurzellos. Die ersteren haben bunodonte oder lophodonte Kronen, die letzteren bestehen aus Prismen oder Zylindern, die auf ihrer Kaufläche häufig Schmelzinseln - die Überreste früherer Quertäler - tragen oder aus komprimierten Lamellen. Ursprünglich bestanden die oberen Backenzähne aus drei oder vier und die unteren aus vier Höckern und dem kammartigen Vorder- und Hinterrand. Dann erfolgte Verbindung der benachbarten Höcker, welche sich zugleich zu Kämmen umgestalteten. Da die Schmelzdecke an den erhabenen Stellen der Krone stets durch die Abkauung entfernt wird, so unterbleibt hier die Schmelzbildung nicht selten sogar beim frischen Zahn. Die Vertiefungen des Zahnes liefern die Schrnelzfalten und Schmelzinseln, welche wegen ihrer oft nur geringen Tiefe bei der Abkauung teilweise oder ganz verschwinden.

Der Zahnwechsel beschränkt sich bei den Nagern in der Regel auf die $P$, die $J$ werden nur bei den Duplicidentata gewechselt. Bei den Nagern mit vier Backenzähnen sind die drei letzten die $M$, der vorderste ein $P$, der aber öfters keinen Vorläufer mehr besitzt. In den meisten Fällen geht ihm jedoch ein Milchzahn, $D$, voraus, welcher bei den geologisch älteren Nagern meist viel komplizierter ist und auch länger funktioniert als bei den jüngeren, wo er sogar wie bei den Caviinae schon beim Fötus gewechselt wird. An Embryonen von Sciurus hat A d loff Anlagen von drei $J$ und dem $C$ beobachtet.

Die Nager sind gegenwärtig die formenreichste Ordnung der Säugetiere. Man zählt mehr als 900 lebende Arten, von denen ein großer Teil Südamerika bewohnt. Nordamerika und Eurasien haben viele Gattungen miteinander gemein. In Afrika finden sich neben einer Anzahl eigentümlicher Typen auch Vertreter europäischer und asiatischer Familien und Gattungen.

Trotz ihrer Kleinheit und Zerbrechlichkeit ist die Zahl der fossilen Nagerreste nicht unbeträchtlich. In Europa kennt man ziemlich viele Arten und Gattungen aus dem Obereocän und Oligocän, namentlich aus den Phosphoriten von Quercy und aus miocänen Ablagerungen im Dep. Allier, von Mainz und Ulm, sowie von Sansan (Dép. Gers), La Grive St. Alban (Isère), von Steinheim und aus dern Ries bei Nördlingen. In Nordamerika sind Nagerreste etwas seltener und fast nur im Bridger-Eocän, im White River Oligocän, im John Day und Loupfork-Miocän vertreten, dagegen hat Südamerika namentlich im Santacruzeno von Patagonien und im jüngeren Tertiär und im Pleistocän von Argentinien eine reiche Nagerfauna aufzuweisen. Reich an Nagerresten sind auch manche pleistocänen Höhlenablagerungen in Europa sowie in Nord- und Südamerika.

Die Systematik der Nager bietet erhebliche Schwier gkeiten, denn so gut auch die beiden Unterordnungen der Duplicidenitata und Simplicidentata gegeneinander abgegrenzt sind, so schwierig ist die Einreihung gewisser Formen in die bisher üblichen drei Hauptgruppen der Sciuromorpha, Myomorpha und Hystricomorpha. Die Aufstellung einer vierten Abteilung, der Protogomorpha, ist nur ein Notbehelf, 
durch welchen ebenso wie durch die von Tullberg vorgenommene Gliederung in die beiden Tribus der Sciurognathi und Hystricognathi der Zusammenhang zwischen vielen fossilen Formen und ihren lebenden Verwandten verschleiert wird. Am zweckmäßigsten erscheint die von Weber gegebene Systematik, die auch hier mit Ergänzungen beibehalten wird.

\section{Unterordnung. Simplicidentata.}

Stets nur $\frac{1}{1}$ sehr lainge J. $\frac{2}{1}$ meist $\frac{1}{1} P$, öfters $\frac{0}{0} P$. Schmelz der $J$ fast stets gelb gefärbt und auf die Vorderseite beschränkt. Obere Zahnreihen nüher beisammenstehend als die unteren. Gelenkgrube für den Unterkiefer schmal. Scaphoid und Lunatum meist verwachsen. Fibula nicht am Calcaneum artikulierend.

\section{Familie. Aplodontoidea. Gill.}

$\frac{2}{1} P . \quad \frac{3}{3} M$. Schädeldach eben. Masseter nicht durch das in der Regel enge Infraorbitalforamen gehend. Ohne Postorbitalfortsatz. Tibia und Fibula frei.

\section{Unterfamilie. Aplodontiinae. Thomas.}

Backenzähne in de Regel brachyodont. An Stelle der Höcker unregelmäßig verlaufende Kämme.

Sciurodon Schlosser. Phosphorite von Quercy. Oregon.

Meniscomys Cope (Allomys Marsh). Untermiocän. John Day bed.

Mylagaulodon Sinclair. Untermiocän. Montana. amerika.

Haplodon Rafin. hypselodont. Lebend und im Pleistocän von Nord-

\section{Unterfamilie. Ischyromyinae. Alston.}

Backenzähne brachyodont. Eocän und Oligocän von Nordamerika.

Ischyromys Leidy. (Fig. 590.) Beide Höckerpaare der oberen $\boldsymbol{M}$ opponiert an den unteren alternierend. Oligocän. White Riverbed.

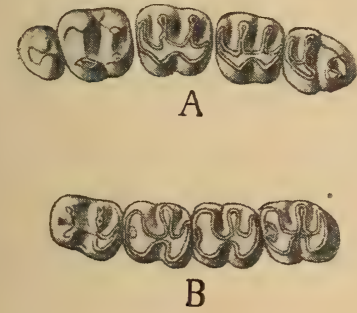

Fig. 590 .

Ischyromys typus Leidy. Oligocän. White Riverbed. $A$ obere, $B$ untere Zahnreihe,
$3 / 1$ nat. Gr.

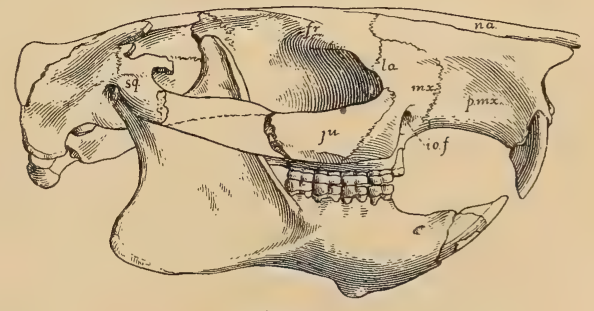

Fig. 591.

Paramys delicatus Leidy. Mitteleocän. Bridgerbed Wyoming. Schädel und Unterkiefer. 1/2 nat. Gr. (Nach Matthew.)

Mysops Leidy (Tillomys Marsh). Eocän. Bridgerbed.

Titanotheriomys Matthew. Oligocän. White Riverbed.

Paramys Leidy (Pseudotomus Cope). (Fig. 591.) Obere $M$ trituberkulär, zweites Höckerpaar der unteren $M$ den Hinterrand des Zahnes bildend, denen von Sciurus ähnlich. Zahlreiche Arten im Eocän von Nordamerika.

Plesiarctomys Bravard. Eocän. Debruge.

Sciuravus Marsh. Obere $M$ vierhöckerig. Eocän von Nordamerika. 


\section{Familie. Sciuroidea.}

$\frac{2}{1} P . \frac{3}{3} M$. Schädel gewölbt. Infraorbitallianal eng. Vorderer Ast des Masseter an der Vorderseite des Jochbogens angeheftet. Postorbitalfortsatz vorhanden. Tibia und Fibula frei.

\section{Unterfamilie. Sciurinae.}

Backenzïline brachyodont, bunodont oder lophodont. Letztes Höckerpaar den Hinterrand der unteren Backenzühne bildend. Obere $M$ und $P^{4}$ trituberkilüi:

Die Sciuriden gehen auf Paramys zurück und sind fast über die ganze Erde verbreitet.

Plesiospermophilus Filhol. Phosphorite von Quercy.

Spermophilus Cuvier. Ziesel. Lebend auf der nördlichen Hemisphäre Fossil im Pleistocän.

Prosciurus Matthew. White River Oligocän und John Day Miocän. Übergang von Paramys zu Sciurus.

Arctomys Gmelin. Murmeltier. Fossil im europäischen Pleistocän.

Cynomys Rafinesque. Nordamerika. Fossil vom Obermiocän an.

Sciurus Linn. Eichhörnchen. Fossil in Europa und Nordamerika im Miocän und Pleistocän.

Tamias Illiger. Lebend und im Pleistocän von Nordamerika.

Sciuvopterus Cuvier. Flughörnchen. Lebend in Asien und im Norden von Europa und Nordamerika.

Pter.omys Cuvier lophodont. Lebend in Südasien.

\section{Familie. Castoroidea.}

$\frac{1}{1} P . \frac{3-2}{3-2} M$. Schädeldach eben, meist ohne Postorbitalfortsatz. Infraorbitalforamen eng. Backenzähne schmelzfaltig, ohne Höcker, mehr oder weniger hypselodont.

\section{Unterfamilie. Castorinae. Biber.}

Schädel niedrig. $\frac{3}{j^{\prime}} M$. Backienzähne mehr oder weniger hypselodont. Obere meist mit drei Außen- and einer Innenfalte, untere mit drei Innen- und einer

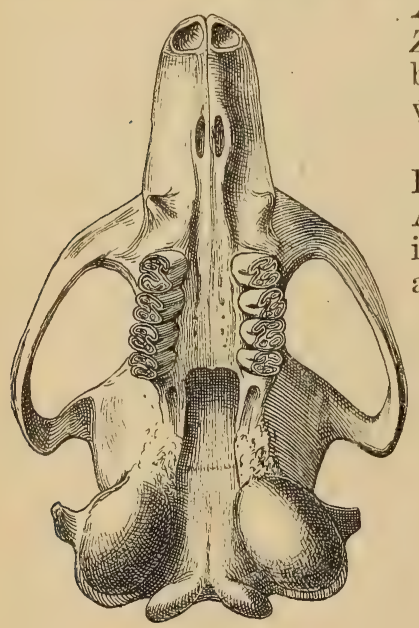

Fig. 592.

Sieneofiber Eseri H. ). Meyer (=St. Viciacensis Gervais). Unt. Miocän. St. Gérand-le-Puy. Allier. Schädel von unten. $3 / 4$ nat. Gr. (Nach Filh ol.) Aussenfalte. Falten senkrecht oder quergestellt zur Zahnreihe. Tibia und Fibula distal verwachsen. Lebend in Europa und Nordamerika, hier auch fossil ýom Oligocän an, in Europa erst vomMiocän an.

Steneofiber Geoffroy (Chalicomys, Chelodus Kaup, Palaeocastor Leidy) (Fig. 592). Zahlreiche Arten im Untermiocän von Nordamerika, häufig im europäischen Miocän, selten im Pliocän. Die amerikanischen Arten haben einen breiteren Schädel.

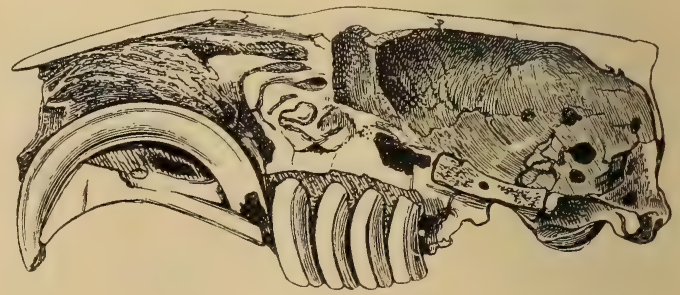

Fig. 593.

Vertikallängsschnitt durch einen Biberschädel (Castor fiber Lin.), um die Einpflanzung des Schneidezahns und der Backenzähne zu zeigen. (Nach Flower.) 
Castor Lin. Biber. (Fig. 593). Zähne stark hypselodont. Lebend in Europa und Nordamerika. Fossil in Europa im Pliocïn und Pleistocïn, in Nordamerika im Pleistocän.

Trogontherium Fischer. Älteres Pleistocän von Europa.

Castoroides Forster. Von Bärengröße. Pleistocïn von Nordamerika. Amblyrhiza Cope. Pleistocän der Insel Antigua.

Euhapsis Matthew und Eucastor Leidy (Sigmogomphins Merriam), Miocän von Nordamerika und Dipoides Jäger, im Pliocän von Europa, China und im Miocän von Nordamerika. Zeichnen sich durch geringe Faltenzahl aus.

Eutypomys Matthew hat zwei obere $P$. Backenzähne mit vielen kleinen Schmelzinseln. Oligocän White Riverbed.

\section{Unterfamilie. Mylagaulinae.}

Schädel stark verbreitert mit Postorbitalfortsatz. $\frac{3}{3}$ Backenzähne hoch, mit zahlreichen, parallel zum Kiefer gerichteten Schmelzinseln. Extremitäten plump, zum Graben geeignet. Tibia und Fibula frei. Im Miocän und Unterpliocän von Nordamerika. Nach Riggs Nachkommen von Meniscomys.

Mylagaulus Cope, Mesogaulus Riggs, Ceratogaulus Matthew, Epi. gaulus Gidley.

\section{Familie. Geomyoidea.}

$\frac{1}{1}$ P. $\frac{3}{3} M$. Schädel meist mit engem Infraorbitalforamen, olne Postorbitalfortsatz, mit großen Bullae osseae. Backenzähne meist hypselodont mit einer den Zahn halbievenden Falte. Tibia mit Fibula verwachsen. Nur in Nordamerika.

1.- Unterfamilie. Protoptychinae.

Infraorbitalkanal weit. Zähne bewurzelt.

Protoptychus Scott. Obereocän Uintabed.

2. Unterfamilie. Geomyinae.

Infraorbitalforamen eng. Backenzähne wurzellos, mit Außen- und Imnenfalte oder nur mit einer Querfalte.

Entoptychus und Pleurolicus Cope. Untermiocän Nordamerika.

Geomys Raf. Mit nur je $\frac{2}{2}$ M. Miocän und lebend in Nordamerika. amerika.

Thomomys Wied. Miocän, Pliocän, Pleistocän und lebend in Nord-

\section{Familie. Anomaluroidea.}

$\frac{1}{1}$ P. $\frac{3}{3} M$ Backenzähne brachyodont, bunodont oder lophodont. Infraorbitalforamen weit. Tibia und Fibula frei. Die lebenden, auf Afrika beschränkten Familien der Anomahurinae und Pedetinae sind fossil nicht bekannt. . Die hier angeschlossenen fossilen Formen haben vielleicht nur zufällige Ähnlichkeit mit den Anomalurinen.

\section{Unterfamilie. Pseudosciurinae.}

Backenzähne bunodont. Höcker paarig gruppiert. $D$ kleiner als $P$.

Sciuroides F. Major. Höckerpaare aller Backenzähne jochartig miteinander verbunden. Obere $M$ mit undeutlichen Zwischenhöckern. Eocän und Oligocän. Schweizer und Schwäbische Bohnerze und Phosphorite von Quercy. 
Pseudosciurus Hensel. (Fig. 594.) Höcker isoliert. Obere $M$ mit deutlichen Zwischenhöckern. Bohnerze von Württemberg.
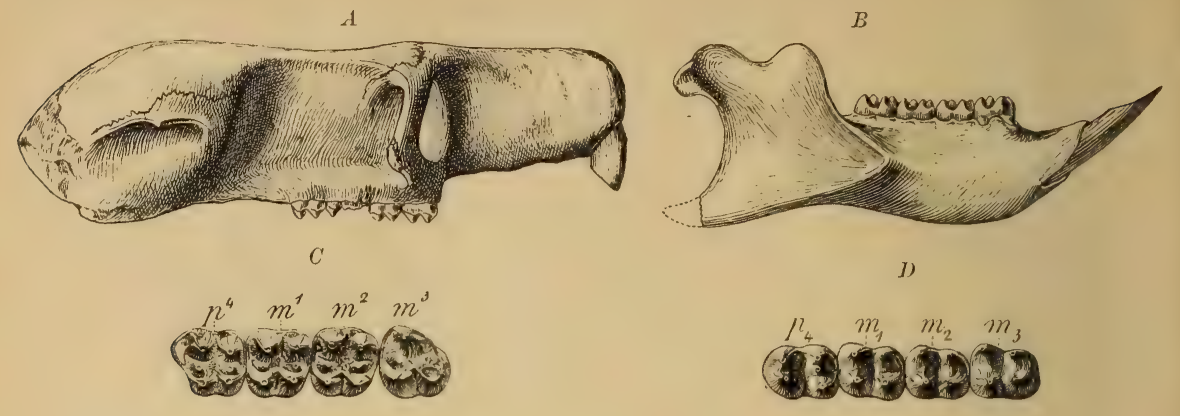

Fig. 594

Pseudosciurus suevicus Hensel. Oligocän (Bohnerz). Eselsberg bei Vlm. A Schädel, $B$ Unterkiefer von aussen, nat. Gr., $C$ obere, $D$ untere Backzähne vergr.

\section{Unterfamilie. Theridomyinae.}

Backenzähne lophodont. Höcker nur bei den ältesten Arten kenntlich, später Kaufläche eben, mit 3 bis 4 Außenfalten und einer Innenfalte an den oberen und 3 bis 4 Innenfalten und einer oder \% Außenfalten an den unteren Zähnen. D meist komplizierter als $P$. Tibia und Fibula frei. Im Eocän, Oligocän und Untermiocän von Europa.

- Diese Familie hat mit der vorigen den Ursprung gemein und ist der Anfang gewisser Hystricoidea - Capromyinae, Erethizontinae, Octodontinae, Chinchillinae und Echinomyinae -

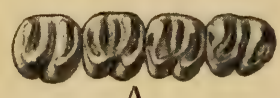

A
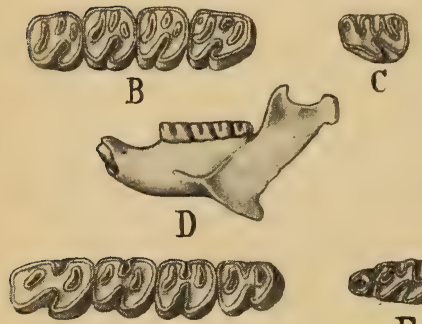

E

Fig. 595

A Theridomys Vaillanti Gerv. Obereocän. Débruge. Obere $P$ und $M$. $4 / 1$ nat. Gr.

$B$ Theridomys gregarius Schlosser. Oligocän. Phosphorite von Quercy. Obere $P$ und $M$.

$C$ oberer Milchzahn. $4 / 1$ nat. Gr.

$D$. Unterkiefer nat. Gr.

$E$ untere $P$ und $M$.

$F$ unterer Milchzahn. $4 / 1$ nat. Gr.

Theridomys Jourdan. (Fig. 595.) $P$ stets größer als $M$. Eocän. Débruge, Vaucluse. Schwäbische und Schweizer Bohnerze. Oligocän. Phosphorite und Ronzon.

Trechomys Lartet. $P$ meist viel kleiner als $M$. $D$ einfach. Eocän. Paris. Phosphorite von Quercy.

Phiomys Osborn. Mittlerer Querkamm kurz. Oligocän. Ägypten.

Protechimys Schlosser. Falten schräg. Backenzähne durch Vereinigung von Außenund Innenfalte gespalten. Zahnkronen etwas erhöht. Phosphorite von Quercy.

Archaeomys Laiz. et Parieu. Ähnlich. Zahnkronen ziemlich hoch. Oligocän. Dép. Allier.

Rhodanomys Depéret. Untermiocän von Savoien und Ulm.

? Cylindrodon Douglass. White River. Oligocän. Nordamerika.

6. Familie. Myoxoidea. Siebenschläf er. $\frac{1-0}{1-0} P . \frac{3}{3} M$. Backenzähne stets brachyodont mit parallelen oder konvergie. renden Schmelzleisten. Infraorbitalkanal weit und hoch gelegen. Tibia und Fibula verwachsen. Lebend im paläarktischen und äthiopischen Gebiet. 
Von den mit vier Backenzähnen versehenen Gattungen haben fast alle schon im europäischen Tertiär Vertreter.

Myoxus Schreber. (Fig. 596 A.) Vielleicht schon im Eocän (Phosphorite, Pariser Gips?), sicher im Miocän.

Eliomys Wagner. (Fig. 596 B.) Im Miocän und Muscardinus Wagner. Fossil im Pleistocän.

Leithia Adams. Pleistocän von Malta.

7. Familie. Dipodoidea. Springmäuse.

$\frac{1}{1}, \frac{1}{0}$ oder $\frac{0}{0} P \frac{3}{3} M$. Backenzähne brachyodont, meist bewurzelt, mit alternierenden Höckern. Infraorbitalkanal weit, gerundet. Fibula und Tibia verschmolzen. Hinterextremität verlängert, Metatarsalia öfters verschmolzen.

Die Springmäuse bewohnen gegenwärtig die Wüsten und Steppen der nördlichen Hemisphäre. Die fossilen Überreste gehören lebenden Gattungen und Ärten an und sind nur aus dem europäischen Pleistocän bekannt.

Die Zapodinae haben fünf freie Metatarsalia. Sminthus Keys. Auch fossil in Europa.

Bei den Dipodinae sind die drei mittleren Metatarsalia stark verlängert und miteinander der ganzen Länge nach verwachșen.

Alactaga Cuvier. Dreizehiger Hinterfuß. Pleistocän von Europa.

Dipus Gmelin. Fünfzehiger Hinterfuß.

Sciuromys Schlosser. $\frac{1}{1} P \frac{3}{3} M$. Zähne ähnlich wie bei Alactaga. Phosphorite von Quercy. Systematische Stellung unsicher.

\section{Familie. Myoidea. (Myomorpha.)}

(? $\frac{1}{1}$ P) $\frac{3-2}{3-2}$ M. Infraorbitalloch weit. Jochbogen kilein. Backenzähne brachyodont, bunodont oder lophodont oder prismatisch. Erster $M$ in der Regel größer und komplizierter als $M_{2}$ und $M_{3}$. Unterkiefer mit hohem Kronfortsatz. Eckfortsatz am Unterrand der Alveole entspringend. Fibula mit der Tibia verwachsen.

Die Myoidea haben fast immer nur geringe Körpergröße und sind jetzt über die ganze Erde verbreitet.

\section{Unterfamilie. Eomyinae.}

$\frac{1}{1} P \frac{3}{3} M$. Backenzähne brachyodont, mit je zwei opponierten Höckerpaaren, erhabenem Vorder- und Hinterrand und Kamm in Mitte des Zahnes. Oligocän von Europa und Nordamerika.

Diese durchwegs sehr kleinen Nager werden von Winge zu den $D i$. poidea und von Scott zu den Geomyidae gestellt. Die Zusammensetzung. der Zähne wie bei Cricetodon macht es wahrscheinlich, daß sie wenigstens teilweise als primitive Murinae zu betrachten sind.

Eomys Schlosser. Phosphorite von Quercy.

Gymnoptychus Leidy. Oligocän. White Riverbed.

2. Unterfamilie. Cricetinae. Hamster.

$\frac{3}{3}$ Backenzähne, bunodont, bewurzelt, mit vier paarig angeordneten Höckern. $M_{1}$ mit 5 oder 6 Höckern.

Die Cricetinae bewohnen die nördliche Halbkugel. 
Cricetodon Lartet. (Fig. 597.) $M_{1}$ fünfhöckerig. Eocän. Bohnerze. Oligocän. Phosphorite, Ronzon. Unter- und Obermiocän von Europa.

Eumys Leidy. Oligocän. White Riverbed.

Cricetus Pallas. $M_{1}$ sechshöckerig. Lebend und fossil im Pleistocän. Europa. Pliocän von Roussillon.

\section{Unterfamilie. Hesperomyinae.} amerika.

$\frac{3}{3}$ M. Im Zahnbau ähnlich den Cricetinen. Lebend in Nord- und Süd-

Hesperomys Waterhouse. (Fig. 598.) Lebend im Pliocän und Pleistocän von Südamerika.

Neotoma Say. Lebend und im Pleistocän von Nordamerika.

Paciculus Cope und Peromyscus Gloger. Im

A $m^{3} m^{2} m^{\prime}$

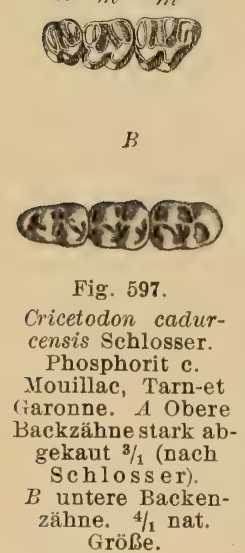

Untermiocän von Oregon.

Habrothrix, Oxymycterus, Colomys etc. Lebend und im Pleistocän von Sï̈damerika.

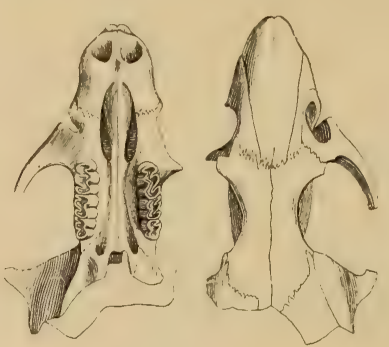

Fig. 598.

Hesperomys molitor Winge. Höhle von Escrivania. Brasilien. Schädel von unten und oben in nat. Gr. (Nach W inge.)
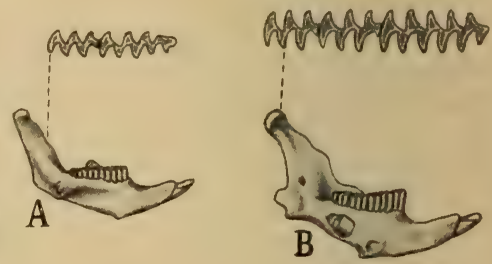

Fig. 599.

A Arvicola arvalis Blasius.

$B$ Cuniculus torquatus Pallas sp. Pleistocän. Velburg. Unterkiefer von innen und untere Molaren von oben vergr.

4. Unterfamilie. Murinae. Ratten und Mäuse.

$\frac{3}{3}$ Backenzähne brachyodont bewurzelt, obere mit 3, untere mit 2 Höckerreihen. Die Murinen sind altweltlich, haben sich jedoch über die ganze Erde verbreitet. Fossile Reste finden sich spärlich im europäischen Plio. cän und Pleistocän. Auch aus Asien und Australien kennt man fossile Reste; sie gehören den Gattungen $M u s$, Gerbillus und Nesokia an.

Mus Linne. Zuerst fossil im Pliocän von Roussillon, A comys Geoffroy. Fossil im Unterpliocän von Pikermi. Im Miocän von La Grive St. Alban ein Nesomyine - Anomalomys Gaillard.

\section{Unterfamilie. Arvicolinae. Wühlmäuse.}

$\frac{3}{3}$ Backenzähne prismatisch, aus zwei Längsreihen von 3 bis 6 kantigen mehr oder weniger deutlichen Prismen bestehend. Die Wühlmäuse bewohnen Europa und die nördlichen Teile von Asien und Nordamerika.

A rvicola Lacepède (Hypudaeus Illiger) (Fig. 599A). $J$ hinter dem letzten $\boldsymbol{M}$ endend. Zahlreiche rezente Arten im Pleistocän von Europa.

Cuniculus Wagner (Halsbandlemming). (Fig. 599 B). J unter dem letzten $M$ endend. Lebend im nördlichen Europa. Fossil im Pleistocän.

Myodes Pallas (Lemmus Linck) (Fig. 599). Vorkommen wie bei vorigen. 
Microtus Schrank und Fiber Cuvier. Lebend und im Pleistocän ron Nordamerika. Anaptogonia, Sycium Cope. Pleistocän von Nordamerika. Mimomys F. Major. Zähne bewurzelt, ziemlich hoch. Pliocän von Norwich. Ruscinomys Depéret. Pliocän von Roussillon. Lophiomys Depéret ebenda, von unsicherer Stellung.

\section{Unterfamilie. Spalacinae.}

Schädel und Zahnbau den Dipodinen ähnlich.

Siphneus Brants. Lebend und fossil im nördlichen Asien. Rhizomys Gray. Lebend in Asien, fossil im Pliocän der Siwalik.

Spalax Güldst. Fossil im Pliocän und Pleistocän von Ungarn.

\section{Familie. Hystricoidea. (Hystricomorpha.)}

Processus angularis von der Seitenwand der Alveole des Unterkiefers ansgehend. Kronfortsatz niedrig, Kiefer mur vor- und riickwärts berieglich. Schädel flach, ohne Postorbitalfortsatz mit sehr weitem Infraorbitalkanal. 1.0.1.3. 1.0. Backen. zähne schmelzfaltig, meist prismatisch-hypselodont, selten brachyodont. Fibula frei.

Die Hystricoidea erscheinen zuerst als Hystricinae, Theridomyinae und Issiodoromyinae in Europa. Die Hystricinae verbreiten sich später über die östliche Halbkugel, die beiden anderen Unter-Familien wandern nach Südamerika aus und entwickeln sich dort zu Erethizontinae, Capromyinae, Chinchillinae, Octodontinae und Caviinae. Die Ctenodactylinae und Bathyerginae sind auf Afrika beschränkt und bis jetzt nicht fossil vertreten. Vielleicht Nachkommen von Cylindrodon.

1. Unterfamilie. Hystricinae. Altweltliche Stachelschweine. und Inseln.

Backenzähne beuurzelt, mäßig hypselodont. Kaufläche mit Schmelzfalten

Hystrix Lin. Fossil in Europa vom Oligocän bis in das Pleistocän. Im Pliocän und Pleistocän auch in Indien. Eine große verwandte Gattung schon im Eocän von Quercy »Hystrix« Lamandini Filhol.

2. Unterfamilie. Erethizontinae. Neuweltliche Stachelschweine.

Backenzähne brachyodont. Nachkommen von Trechomys ?

Eosteiromys Amegh. Colpodon-Schichten von Patagonien; Steiromys Ameghino im Miocän von Santa Cruz. Brasiliens.

Coendu Lacép. Lebend in Südamerika. Fossil in Knochenhöhlen

Erethizon Em. Lebend und im Pleistocän von Nordamerika.

Sciamys und Acaremys Amegh. im Miocän von Santa Cruz und Protacaremys Amegh. in den Colpodonschichten von Patagonien sind kleinere Formen.

\section{Unterfamilie. Capromyinae.} domys?

Zähne biberähnlich. Meist mittelgroße Formen. Nachkommen von Theri-

Myocastor Herr. (Myopotamus Geoffr.). Lebend Südamerika. Fossil vom Pliocän.

Morenia, Discolomys etc. Ameghino. Pliocän von Argentinien.

Neoreomys Ameghino, im Santacruzeno von Patagonien. Hier auch die Gattungen Scleromys und Lomomys Ameghino. 


\section{Unterfamilie. Octodontinae.}

Die Gruppe der Ctenodontinae beginnt im Pliocän von Argentinien - Dicoelophorus, Plataeomys Ameghino. Ctenomys Blv. erst im Pleistocän von Südamerika. Die Gruppe der Loncherinae hat schon Vertreter im älteren Miocän von Patagonien - Colpodon-Schichten aufzuweisen - Protadelphomys, Prospaniomys. Im Miocän von Santa Cruz Stichomys, Adelphomys, Spaniomys etc. Ameghino. Loncheres Illiger, Echinomys, Mesomys Desm. fossil in brasilianischen Höhlen.

\section{Unterfamilie. Chinchillinae.}

Meist nur eine, quer über die ganze Kauflüche verlaufende Falte. Diese Familie geht wohl auf die europäische Gattung Archaeomys zurück.
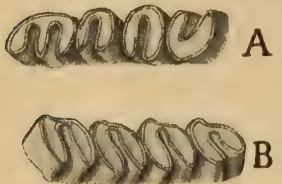

Fig. 600 .

Perimys incurvatus Ameghino. Miocän. Colpodon-Schichten. Patagonien. $A$ obere, $B$ untere Backenzähne nat. Gr.

Prolagostomus, Pliolagostomus Ameghino

A in Santacruzeno. Vorläufer von Lagostomus Brooks, fossil vom Pliocän an und lebend.

Perimys Ameghino. (Fig. 600.) Colpodon-Schichten und Santacruzeno von Patagonien.

Scotaeumys, Sphodromys Ameghino.

Megamys Laurillard. Der größte fossile Nager. Pliocän und Pleistocän von Argentinien.

\section{Unterfamilie. Caviinae.}

Backenzähne aus zwei, selten mehrkantigen Prismen bestehend.

Cephalomys Ameghino. Pyrotherium-Schichten von Patagonien.

Eocardia, Procardia, Schistomys, Phanomys Ameghino im SantaCruzeno. Vorläufer von Cavia.

Cavia, Pallas. Dolichotis Desmarest, Kerodon Cuv. lebend und im Pleistocïn von Südamerika. Für die pliocänen Vorläufer hat Ameghino zahlreiche Gattungen aufgestellt - Cardiodon, Anchimys etc.

$H_{i j} d r o c h o e r u s$ Brisson. (Fig. 589.) Der größte lebende Nager. Fossil im Pleistocän von Süd- und Nordamerika.

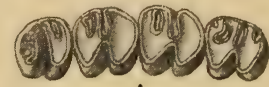

A

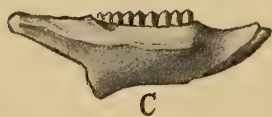

C

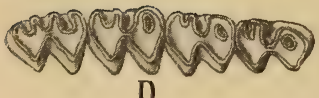

Fig. 601.

Nesokerodon Quercyi Schlosser. Oligocän. Phosphorite von Quercy. $A$ obere $P$ und $M, B$ oberer Milehzahn $4 / 1$ nat. Gr. $C$ Unterkiefer nat. Gr. $D$ untere $P$ und $M$. $E$ unterer Milchzahn $4 / 1$ nat. Gr.
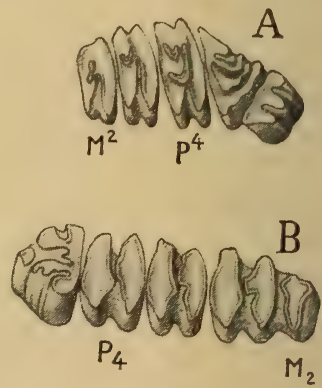

Fig. 602

Prolagus oeningensis König. Obermiocän. La Grive St. Alban. $A$ obere, $B$ untere Backenzähne $3 / 1$ nat. Gr. (Nach Forsyth M a jor.)

\section{Unterfamilie. Issiodoromyinae.}

Diese auf das europäische Oligocän beschränkte Familie vermittelt im Zahn- und Kieferbau den Úbergang von den Theridomyinae zu den Caviinae. $D$ kompliziert und funktionierend, $P$ und $M$ bewurzelt. 
Nesokerodon Schlosser. (Fig. 601.) Zähne frisch noch mit Außenund Innenfalten und mit Schmelzinseln. Phosphorite von Quercy.

Issiodoromys Croïzet, Oligocän. Dép. Allier.

\section{Unterordnung. Duplicidentata. (Lagomorpha).}

$\frac{2}{I} J$, allseitig von Schmelz umgeben, zweiter oberer $J-J^{3}-$ klein und hinter den vorderen $-J^{2}-$ gestellt. $P \frac{3}{2} . M \frac{3-2}{3-2}$. Backenzähne hypselodont, wurzellos, aus je zwei, selten drei kantigen Prismen bestehend. Abstand der beiden oberen Zahnreihen größer als der beiden unteren. Gelenkgrube für den Unterkiefer breit. Carpalia frei. Fibula mit Calcaneum articulierend.

Diese meist Lagomorpha genannte Gruppe unterscheidet sich von den übrigen Nagern durch den Besitz von zwei oberen Incisiven. Auch sind diese Zähne allseitig mit Schmelz bekleidet, der jedoch hinten und an den Seiten dünner ist als vorne. Der größere der beiden oberen $J$ ist mit einer Längsfurche versehen. Die Backenzähne sind wurzellos, unten offen, und die oberen im Querschnitt merklich breiter als lang. Sie bestehen aus Pfeilern, die von vorne nach hinten zusammengedrückt erscheinen und durch Zement miteinander verkittet sind. Die Einbuchtungen zwischen den Pfeilern haben an den unteren Zähnen gleiche Tiefe, an den oberen sind die an der Außenseite viel seichter als die an der Innenseite. Der vorderste obere $P$ und der letzte untere $M$ bestehen manchmal nur aus je einem Pfeiler, zuweilen hat der letzte untere $M$ jedoch drei Pfeiler. Der vorderste untere und die beiden vordersten oberen $P$ zeigen häufig einen von den $M$ stark abweichenden Bau. Manchmal kann man auf der Krone noch Schmelzinseln und Kämme unterscheiden, als Andeutung des ursprünglich bunodonten und lophodonten Zahnbaus. Den $P$ gehen niedrige, bewurzelte $D$ voraus, welche ausfallen, sobald der letzte $M$ in Funktion tritt. Im Milchgebiß sind oben drei $J D$ vorhanden.

\section{Familie. Leporidae. H a s en.}

$\frac{3}{2} P . \frac{3}{3} M . P^{2}$ stiftförmig, die übrigen $P$ den $M$ gleichend. Schädel seitlich zusammengedrïckt, Clavicula unvollständig. Hinterbeine und Ohren lang, Schwanz kurz. Oregon.

Palaeolagus Leidy. Oligocän White River, Untermiocän John Day.

Panolax Cope. Miocän Nordamerika.

Lepus Linn. In Nordamerika vom John Day Miocän bis in die Gegenwart, in Europa und Asien vom Unterpliocän bis in die Gegenwart.

\section{Familie. Ochotonidae (Lagomyidae). Pfeifhasen.}

$\frac{3-2}{2} P \frac{2-3}{2-3} M . \quad$ Nur $P_{4}=M$. Schädel niedergedrückt. Clavicula vollständig. Hinterbeine und Ohren kurz. Schwanz fehlt.

In Europa vom Oberoligocän bis in die Gegenwart. Lebend im östlichen Teil von Europa, in den Gebirgen Asiens und Nordamerikas - hier auch fossil.

Prolagus Pomel (Myolagus Hensel) (Fig. 602). 3.2. Miocän bis Pleistocän von Europa.

Titanomys v. Meyer $\frac{3 .}{2 .} \frac{2}{2-3}$. Ober-Oligocän und Miocän. T. visenoviensis v. Meyer, Fontannesi Depéret.

Lagopsis Schlosser. $\frac{3.2}{2.3 .}$ Miocän.

Ochotona Linck (Lagomys Cuv.). Lebend auf der nördlichen Hemisphäre, fossil im Pliocän und Pleistocän von Europa. 


\section{Zeitliche Verbreitung der Nager.}

Die ältesten Nager sind bis jetzt die aus dem Eocän von Nordamerika - Wasatch und Bridgerbed - und zwar sind es Paramyinae und Ischyromyinae. $\mathrm{Zu}$ ihnen gesellt sich im Obereocän, Uintabed, der Vorläufer der noch jetzt lebenden aber stets auf Nordamerika beschränkten Geomyinae - Protoptychus. Die Paramyinae werden in Nordamerika zu Sciurinae und Haplodontinae, von welchen wenigstens die ersteren sichi bald auch über Europa verbreiten. Die Ischyromyinae erlöschen im White-River-Oligocän, wo auch bereits Leporidae, Castorinae und Cricetinae erscheinen. Die Castorinae entsenden frühzeitig auch Repräsentanten nach Europa, während die letztgenannte Familie offenbar altweltlichen Ursprungs ist und die Leporidae erst im Pliocän über Asien nach Europa gelangen. Die gegenwärtige Nagerfauna Nordamerikas ist im wesentlichen die nämliche wie die von Eurasien. Zu den Nachkommen der schon im Tertiär einheimischen Familien gesellten sich im Pleistocän die aus Europa stammenden Arvicolinae und Ochotonidae und die aus Südamerika eingewanderten Erethizontinae.

In Europa entfalten die Nager schon im Eocän und noch mehr im älteren Oligocän einen nicht unbeträchtlichen Formenreichtum. Außer den von Nordamerika gekommenen Sciurinae finden wir die Pseudosciurinae, die mit ihnen ursprünglich verwandten Theridomyinae, ferner Hystricinae und Myoxinae, sowie Cricetinae, welch letztere Familie im Oligocän Vertreter nach Nordamerika ausschickt, aus welchen die Hesperomyinae entstehen, wofür dann Castorinae in Europa einwandern. Fast schon etwas früher treffen wir in Europa Ochotonidae, deren Herkunft bis jetzt freilich noch in Dunkel gehüllt ist. Alle genannten Familien erhalten sich hier mit Ausnahme der bald erlöschenden Pseudosciurinae und der Theridomyinae während des ganzen Tertiärs und ergreifen zum Teil auch Besitz von Asien und Afrika. Die im allgemeinen ziemlich spärlich vertetenen Cricetinae. entwickeln sich in Europa zu Murinae und Arvicolinae von welchen die ersteren sich allmählich über die ganze Erde verbreiten, während die letzteren hauptsächlich die nördlichen Teile von Nordamerika und Eurasien besiedeln. Hervorragende stammesgeschichtliche Bedeutung kommt den Theridomyinae zu. Vom Untermiocän an verschwinden sie zwar sämtlich aus Europa, sie erreichen aber bald darauf in Südamerika ihre Blüteperiode, denn sie erweisen sich nicht nur als die Stammeltern der Erethizontinae und Capromyinae, sondern auch der Octodontinae und Chinchillinae und durch die ebenfalls aus Theridomyinae entstandenen Issiodoromyinae sogar als die Ahnen der Caviinae. In Patagonien erscheint zuerst in den Pyrotheriumschichten ein Caviine, in den Colpodonschichten treten auch Erethizontinae und Octodontinae auf, und im Obermiocän von Santa Cruz entwickeln sich aus ihnen zahlreiche Gattungen und Arten, so daß diese Nagerfauna an Mannigfaltigkeit nur wenig zurücksteht hinter jener, welche wir in Südamerika im jüngsten Tertiär, im Pleistocän und in der Gegenwart antreffen. Die heutige Nagerfauna Südamerikas unferscheidet sich von jener des Santacruzeno eigentlich bloß durch die Anwesenheit von Leporidae und Hesperomyinae. Im Gegensatz zu den Hystricoidea, 
welche nur aus Europa gekommen sein können, sind diese beiden Familien von Nordamerika her eingewandert, wofür aber Erethizontince von Südamerika nach Nordamerika vordrangen.

\section{Ordnung. Ungulata. Huftier e. $\left.{ }^{1}\right)$}

Die Huftiere zeichnen sich dadurch aus, daß ihr Gebiß für pflanzliche, selten gemischte Kost eingerichtet ist und die Extremitäten ausschließlich zur Bewegung auf dem Boden dienen. Die Zehenendglieder sind daher meist breit, abgeplattet, seltener kantig oder gekrümmt und mit hornigen Hufen umgeben.

Der primitive Huftierfuß war nach Cope fünfzehig, plantigrad, dem der Raubtiere ähnlich, die ganze Extremität kurz und gedrungen. Die Entwicklung von Hand und Fuß vollzog sich in verschiedenen Etappen und zwar:

1. durch Umwandlung des plantigraden Fußes mittels steilerer Stellung der Metapodien in den semiplantigraden Fuß, wobei die Endphalangen und die hinten durch ein Muskelpolster gestützten und verstärkten Metapodien den Körper tragen. Aus dem semiplantigraden Fuß entwickelt sich einerseits der unguligrade $F u ß$, in welchem die Metapodien sich ganz vom Boden entfernen und fast senkrecht aufrichten, so daß nur die Endphalangen die Körperlast tragen, und anderseits der bei den Huftieren ziemlich seltene digitigrade Fuß Cameliden - bei dem zwar die Metapodien sich frei erheben, die durch ein Muskelpolster verstärkten Phalangen aber sämtlich noch auf dem Boden ruhen,

2. durch Streckung der Metapodien,

3. durch Ausdehnung und Verstärkung einzelner Metapodien und Zehen auf Kosten der benachbarten, womit gleichzeitig Reduktion oder Schwund der seitlichen Metapodien und manchmal auch von Carpalien und Tarsalien verbunden ist,

4. durch seitliche Verschiebung und festere Verkeilung der ursprünglich in parallele Reihen - serial angeordneten Carpalien, Tarsalien und Metapodien,

5. durch Verschmelzung von ursprünglich getrennten Carpalien, Tarsalien und Metapodien.

Neben dem Bau der Extremitäten liefert das Gebiß die besten Anhaltspunkte für die Systematik der Huftiere. Die primitiven Ungulaten hatten ein vollständiges Gebiß mit $\frac{3.1 .4 .3 .}{3.1 .4 .3 .}$, in welchem die Zähne, mit Ausnahme etwa der vorderen $P$, dicht aneinander schlossen. Durch Verlängerung der Kiefer bildeten sich größere Lücken zwischen den $C$ und den $J$ sowie zwischen den $P$. Die Schneidezähne sind stets einwurzelig und ursprünglich wie bei den Fleischfressern konisch,

1) Cope E. D., The Classification of the Ungulate Mammalia. Proceed. Amer. Philos. Soc. 1882 . - Gregory $W$. $K$., The Orders of Mammals. Bull. Amer. Mus. Nat. Hist. New York 1910. - Kowalevsky W., Monographie der Gattung Anthracotherium. Palaeontographica 1874. XXII. - Osborn H. F., Evolution of Mammalian Molar Teeth. New York 1907. - The evolution of the Ungulate foot. Trans. Amer. Philos. Soc. 1889 XVI. - Rütimeyer L., Beiträge zur vergleichenden Odonto. graphie der Huftiere. Verh. d. naturf. Ges. Basel 1863. - Schlosser M., Beiträge zur Stammesgeschichte der Huftiere. Morpholog. Jahrb. 1886. XII. 
werden aber durch Differenzierung meißel- oder schaufelförmig, zuweilen sogar stoßzahnartig. Ihre Zahl kann Reduktion erfahren, ja es kann sogar vollständiger Verlust der $J$, wenigstens der oberen, stattfinden. Die Eckzähne, welche ursprünglich den $C$ der Fleischfresser ähnlich waren, werden entweder zu kantigen Hauern, oder sie verkümmern oder es gehen zwar die oberen vollständig verloren, die unteren hingegen nehmen die Gestalt und Funktion eines vierten $J$ an - Ruminantia«. Die oberen Molaren bleiben nur selten auf der trituberkulären Stufe stehen und besitzen auch hier schon zwei Zwischenhöcker. Aus dem hinteren - Metaconulus - oder auch aus einem Basalhöcker entwickelt sich ein zweiter großer Innenhöcker - Hypocon. Verbinden sich die Höcker untereinander durch Joche oder Halbmonde, so werden die ursprünglich bunodonten Zähne lophodont oder selenodont. Weitere Differenzierungen ergeben sich aus der Verstärkung der Basis durch Basalwülstchen oder Pfeiler, durch Fältelung des Schmelzes, durch Entwicklung von Zement etc. Die unteren Molaren lassen sich insgesamt vom Tuberkulär-sektorialZahn ableiten, aus einem Zahn mit hohem dreispitzigem Trigonid und einem niedrigen, wohl ebenfalls dreispitzigen Talonid. Durch Verlust der Vorderspitze - Paraconid - und Erhöhung und Vergrößerung des Talonids entstehen vierhöckerige Zähne, die sich von den oberen hauptsächlich durch geringere Breite unterscheiden und wie jene lophodont oder selenodont werden können. Der letzte untere $\dot{M}$ besitzt häufig einen unpaaren großen Hinterhöcker oder ein bogenförmiges Joch. Die Prämolaren bleiben bei allen primitiven Ungulaten einfacher als die Molaren. Homoedontie wird nur bei vorgeschritteneren Formen erreicht. Reduktion der Backenzähne beginnt stets beim vordersten $P$ und erstreckt sich höchstens auf zwei oder drei $P$.

Ursprünglich waren die Backenzähne der Huftiere niedrig brachyodont - und die unteren zwei-, die oberen dreiwurzelig. Durch Teilung der beiden Wurzeln der unteren und der breiten Innenwurzel der oberen $M$ entstehen vierwurzelige Zähne. Häufig erfolgt bei reinen Pflanzenfressern Erhöhung der Zahnkrone und schließlich werden ihre Backenzähne hypselodont oder sogar prismatische Säulenzähne, die lange Zeit von unten in dem Maße nachwachsen, als sie oben durch Abkauung erniedrigt werden, und erst im späten Alter Wurzeln ansetzen.

Das Milchgebiß besteht normal aus Schneide-, Eck- und Backenzähnen. Die $J D$ und $C D$ unterscheiden sich nur durch ihre Schwachheit von den $J$ und $C$, dagegen bieten die $P D$ mancherlei charakteristische und systematisch wichtige Eigentümlichkeiten. Ihre normale Zahl 4 kann auf 3 herabsinken, aber umgekehrt auch unverändert bleiben bei Anwesenheit von nur $3 P$. Der hinterste $D$ hat stets die Zusammensetzung eines $M$, im Unterkiefer der Artiodactylen besitzt $D_{4}$ sogar ein drittes allerdings kleines Höckerpaar, während bei den Perissodactylen der untere $D_{3}$ öfters etwas komplizierter ist als die $M$.

Neben dem Gebiß und den Extremitäten liefert auch der Schädel wichtige systematische Anhaltspunkte. Bei den primitivsten Huftieren ist die Hirnhöhle sehr klein, die Hemisphären des Großhirns sind schwach gewunden und lassen das Kleinhirn unbedeckt. Bei den 
vorgeschritteneren Formen nimmt der Umfang des Großhirns und die Zahl seiner Windungen beträchtlich zu. Der Schädel selbst läßt bei den ältesten Vertretern der einzelnen Huftiergruppen kaum wesentliche Unterschiede erkennen. Er ist niedrig, hat ein flaches Dach und auf dem schmalen Cranium einen kräftigen Scheitelkamm, bei fortschreitender Entwicklung treten jedoch mancherlei Spezialisierungen ein. So können sich die Stirnbeine mit Lufthöhlen füllen oder es sprossen aus ihnen Geweihe oder Stirnzapfen hervor - Artiodactyla. Die in der Regel horizontale Schädelachse erleidet in diesem Falle größere oder geringere Knickung. Auch die Größe und Ausbildung der Nasenbeine und der Augenhöhle verleihen dem Schädel ein charakteristisches Aussehen, das zuweilen noch durch knöcherne Auswüchse auf der Nase verstärkt wird.

Die Huftiere sind gegenwärtig in allen Weltteilen mit Ausnahme von Australien verbreitet. Im Tertiär spielten sie eine kaum minder wichtige Rolle als jetzt.

Als echte Huftiere können nur jene bezeichnet werden, welche von bunodonten Formen abstammen oder doch wenigstens von solchen, welche normale $C$ besaßen und außerdem starke Spezialisierungen der Extremitäten aufweisen. In dieser Fassung gliedern sie sich in 5 Unterordnungen: Condylarthra, Litopterna, Perissodactyla, Artiodactyla und Amblypoda. Bei den letzten ist allerdings der Zusammenhang mit bunodonten Formen etwas zweifelhaft.

\section{Unterordnung. Condylarthra. Cope. ${ }^{1}$ )}

Ausgestorbene plantigrade Huftiere mit fünfzehigen Extremitäten. Astragalus mit verlängertem Hals und konvexer distaler Gelenkflüche, meist mit Foramen. Carpalia in geradlinige Reihen angeordnet. Gebiß vollständig. $\frac{3.1 .4 .3 .}{3.1 .4 .3 .}$ M bunodont. Humerus mit Foramen entepicondyloideum. Femur mit drittem Trochanter.

Die Condylarthren sind mit Ausnahme von einigen spärlichen Resten aus dem ältesten europäischen Eocän auf das älteste Tertiär des westlichen Nordamerika - Puerco-, Torrejon- und Wasatchbed - beschränkt und erweisen sich als die primitivsten Huftiere, aus welchen teils die Perissodactylen, teils die Artiodactylen und vielleicht auch die südamerikanischen Lit o p tern a hervorgegangen sind. Sie teilen im Schädelund Skelettbau sowie im Gebiß mancherlei Merkmale mit den Creodontia und haben wohl mit ihnen einen gemeinsamen Ursprung.

Der niedrige langgestreckte $\mathrm{Schädel}$ ist wenig differenziert und vereinigt Merkmale der Creodontia und der ursprünglichen Paar- und Unpaarhufer. Die Orbita ist hinten weit geöffnet, die Profillinie des Schädels fast horizontal, das Cranium mit einer Sagittalcrista versehen, das Gehirn klein und das Kleinhirn hinter den glatten Hemisphären des Großhirns gelegen. Der Processus postglenoideus ist wohl entwickelt, das Gebiß vollständig. Die $J$ und $C$ stimmen mit jenen der Creodontia und der primitiven Paar- und Unpaarhufer überein. Die $P$ sind viel einfacher als die brachyodonten, mehrwurzeligen, trituberkulären oder vierhöckerigen $M$.

1) Cope E. D., The Condylarthra. Amer. Naturalist 1884 p. 790. 892. Trans. Amer. Philos. Soc. 1888 p. 298. - Matthew W. D., Bull. Amer. Museum Nat. Hist. New York 1897 p. 293. - Osborn H. F. and Earle, Ibidem 1895 p. 47. - Osborn H. $F$., Ibidem 1898 p. 159. 
Der Zahnwechsel ist vollständig, $D_{4}$ gleicht dem $M_{1}$. Die oberen $M$ haben zwei Außen-, meist einen Innen- und zwei Zwischenhöcker, die unteren $M$ vier Haupthöcker und ein oder zwei Nebenhöcker.

Die plantigraden oder semidigitigraden Extremitäten haben vorne und hinten fünf Zehen, wovon die drei inneren stärker entwickelt sind als die beiden äußeren. Ein Schlüsselbein fehlt, der Humerus besitzt wohl immer ein Foramen entepicondyloideum und das Femur einen dritten Trochanter. Radius und Ulna sowie Tibia und Fibula bleiben getrennt. Die Fibula endet wie bei den Carnivoren frei. Die Carpalia sind beinahe serial angeordnet, auch dürfte öfters noch ein Centrale vorhanden sein. Der Tarsus stimmt im wesentlichen mit dem der Creodontia überein. Die gewölbte Endfläche des Astragalus greift tief in das Naviculare ein und berührt nur seitlich das hohe Cuboid. Die Trochlea besitzt häufig ein Foramen für den Flexor digitorum. Die Endphalangen sind distal abgeplattet, oder wie bei den Creodontia zugespitzt.

Im äußeren Habitus waren die Condylarthra omnivoren Raubtieren ähnlicher als Huftieren. Die Beschaffenheit von Hand und Fuß gestattete keine sehr rasche Bewegung. Das Gebiß läßt auf gemischte Kost schließen. Die größten Formen erreichten meist die Dimensionen eines Wolfs, die kleinsten die eines Fuchses oder Marders.

\section{Familie. Mioclaenidae. Osb. und Earle.}

Obere $M$ gerundet, dreieckig, breiter als lang, ohne zweiten Innenhöcker, untere $M$ vierhöckerig, höchstens mit kleinem unpaaren Vorderhöcker. $P$ einfach. $P^{3}$ und $P^{4}$ mit Innenhöcker. Skelett nicht bekannt.

Untereocän, Puerco und Torrejonbed von Neu-Mexiko. Sämtliche Arten kaum von Fuchsgröße.

Die Halbmondform der Außenhöcker der unteren $M$ spricht für Verwandtschaft mit den Paarhufern. Matthew stellt die Mioclaeniden als

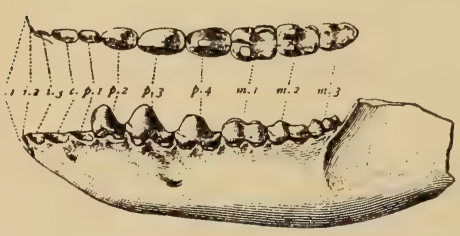

Fig. 603 .

Mioclaenus lemuroides Matthew. Unterstes Eocän. Torrejonbed. Neu-Mexico. Unterkiefer und obere Zahnreihe. $P^{3}-M^{3}$ nat. Gr. (nach Matthew.) höckerig. O. (Anisonchus) agapetillus Cope sp.

? Coryphagus Douglass. Fort Unionbed. Montana.

2. Familie. Periptychidae. Cope.

Obere $M$ trituberkulär oder quadrituberkulär. Obere und untere $P$ sehr groß, meist einspitzig oder mit niedriger Innenspitze. Tibiale Gelenkfäche des breiten kurzen Astragalus gewölbt, in der Mitte vertieft. Naviculare seitlich mit Calcaneum und Cuboid verbunden.

Im Untereocän, Puerco und Torrejonbed von Neu-Mexiko. Nach Matthew schließen sich die Periptychiden im Extremitätenbau an die Amblypoden an. Die $M$ unterscheiden sich jedoch wesentlich durch ihre Bunodontie. 
Periptychus Cope. Mit stark differenzierten großen $P$ und quadratischen oberen $M$. Etwa Größe von Schaf. P. rhabdodon Cope.

Ectoconus Cope. Ebenfalls groß mit vielhöckerigen $M$.

Haploconus, Hemithlaeus, Anisonchus (Zetodon) Cope. Conacodon Matthew. Alle klein, obere $M$ viel breiter als lang, ohne Hypocon.

\section{Familie. Phenacodontidae. Cope.}

Obere $M$ viereckig, breiter als lang mit je zwei Außen-, zwei Zwischenund zwei Innenhöckern. Untere $M$ meist mit sechs Höckern. Vordere $P$ einfach, $P_{3}$ mit Nebenspitzen. $P^{4}$ trituberkulär mit Nebenspitzen, $P_{4}$ fast wie $M$, nur schmäler. Astragalus mit ausgefurchter Trochlea. Fibula nur mit Astragalus, Naviculare mit Calcaneum und Cuboid artikulierend. Schwanz lang.

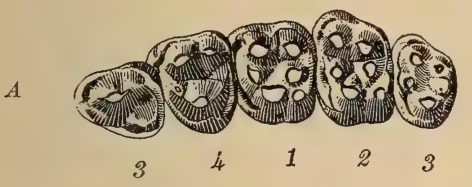

$B$

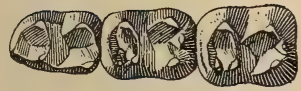

d4

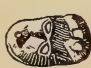

$p_{4}$

Fig. 604 .

Tetraclaenodon puercensis Cope sp. $A$ obere Backenzähne, $B$ untere Backenzähne $\left(D_{4} M_{1} \cdot 2, P_{4}\right)$ nat. Gr. (Nach Osborn.) $C$ Hinterfuß $1 / 2$ nat. Gr. (Nach Matthew.)

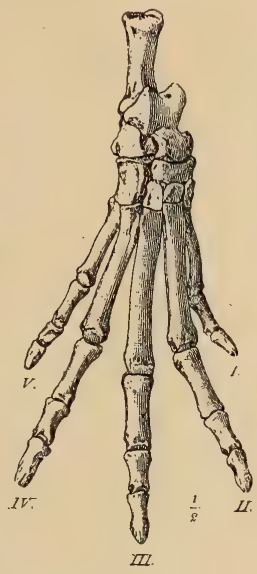

Die Phenacodontiden unterscheiden sich von den Periptychiden durch die kleineren $P$, durch den höheren, fester gefügtenTarsus und durch den längeren Astragalushals. $P_{1}$ und $P_{2}$

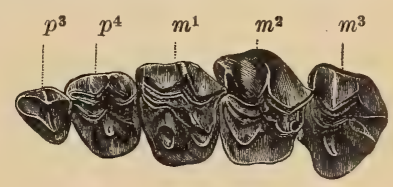

Fig. 605 .

Meniscotherium terrae-rubrae Cope. Unt. Eocän (WasatchStufe). Neu-Mexico. Die drei oberen Molaren u. zwei letzten Prämolaren in nat. Gr. (Nach Cope.)

einfach, $P_{3}$ mit Nebenspitze, $P_{4} M$-artig, aber schmäler. $P^{4}$ trituberkulär.

Phenacodus Cope. Von zwei Arten dieser Gattung kennt man das ganze Skelett. Die größere, $P$. primaevus Cope, hatte beinahe die Größe von Tapir, die kleinere, Wortmani Cope, die einer Dogge. Untereocän Wasatchbed.

Tetraclaenodon Scott (Protogonia Cope, Euprotogonia Matthew). (Fig. 604.) M Hyracotheriumähnlich, $P$ sehr einfach. Zierliche Extremitäten. Untereocän. Torrejonbed. Neu-Mexiko und Montana.

Protogonodon Scott (Mioclaenus pentacus Cope) sehr groß, mit fünfhöckerigen $M$. Ist vielleicht der Vorläufer gewisser Artiodactylen (Achaenodon). Untereocän. Puercobed. Neu-Mexiko.

\section{Familie. Meniscotheriidae.}

$Z$ Zahnreihe fest geschlossen. Obere $M$ mit $W$-förmiger Außenwand, zwei gebogenen Zwischenhöckern und zwei ungleichen konischen Innenhöckern. Hintere $P$ trituberkulär. Untere $M$ und $P_{4}$ mit zwei $V$-förmigen Außenmonden, $P_{1-3}$ einspitzig. Astragalus stark verlängert und mit konvexem Naviculargelenk. Schwanz lang.

Die Meniscotheriiden sind die Ahnen der Chalicotheriiden.

Meniscotherium Cope. (Fig. 605.) (Hyracops Marsh?) aus dem unteren Eocän, Wasatchbed von Neu-Mexiko.

\section{Familie. Pleuraspidotheriidae. Lemoine.}

Gebiß vollständig, $J, C$ und $P$ konisch. Vor und hinter $P_{2}$ ein kurzes Diastema. Obere $M$ mit zwei V-förmigen Innen- und zwei konischen Außenhöcker" 
und einem kleinen vorderen Zwischenhöcker. $P^{4}=M^{1}$. 'P mit einfachem Innenhöcker. Untere $M, P_{3}$ und $P_{4}$ mit vierpaarig opponierten konischen Höckern und einem unpaaren Vorderhöcker. Endphalangen der fünfzehigen Extremitäten schmal, distal, jederseits etwas verbreitert. Astragalus mit breiter Rolle und kurzem Hals.

Pleuraspidotherium Lemoine aus dem untersten Eocän von Reims hat möglicherweise phylogenetische Bedeutung für europäische Perissodactylen.

\section{Unterordnung. Litopterna. Ameghino. $\left.{ }^{1}\right)$}

Ausgestorbene, digitigrade Huftiere mit serial angeordneten Carpalien und Tarsalien, Hand und Fuß fünf-(?), drei- oder einzehig. Astragalus mit ausgefurchter Trochlea und konvexer distaler Gelenkfläche. Calcaneum mit Fibula artikulierend. Gebiß vollständig oder J reduziert. Zühne hüufig in geschlossener Reihe. Backenzähne bunolophodont, selenolophodont, meist brachyodont. Humerus ohne Foramen entepicondyloideum. Endphalangen breit abgeplattet.

Die Litopterna sind eine auf Südamerika beschränkte Unterordnung der Huftiere, welche sich aus eingewanderten bunodonten nordamerikanischen Condylarthren entwickelt und dabei eine ähnliche Zahnform und Reduktion der Seitenzehen erlangt haben wie manche Perissodactylen.

Die Reduktion erstreckt sich teils nur auf die erste und fünfte Zehe, teils auch auf die zweite und vierte, welche hierbei entweder bloß dünner oder kürzer werden, oder auch bis auf kurze Stummel verschwinden können. Die Zähne werden nur ausnahmsweise hypselodont, bei den brachyodont bleibenden äußert sich der Fortschritt in der Teilung der Wurzeln, so daß jeder Zahn im Unterkiefer mit vier Wurzeln versehen ist. Mit den Notoungulaten haben sie zwar die Kürze des Metalophs der oberen $M$ gemein, sie unterscheiden sich aber von ihnen, abgesehen von der Brachyodontie, schon dadurch, daß Trigonid und Talonid der unteren $M$ gleiche Größe besitzen. Die oberen $M$ bestehen aus zwei Außenhöckern, welche ein mit Para- und Mesostyl versehenes Ectoloph bilden, einem großen Protocon und zwei Zwischenhöckern und einem kleinen Hypocon. Der Protocon verbindet sich mit dem Protoconulus zu einem schrägen Protoloph, dagegen entsteht das kurze Metaloph aus dem Hypocon und aus dem erhabenen Hinterrand des Zahnes. Der Metaconulus vereinigt sich eher mit dem Protocon als mit dem Hypocon. Die unteren $M$ bestehen aus zwei gleichgroßen Halbmonden, der für die Notoungulata so charakteristische Innenhöcker seitlich vom zweiten Halbmond tritt nur bei den Macraucheniidae auf. Die $P$ sind einfacher als die $M$ und werden nach vorne zu dem $C$ ähnlich. Von den $J$ kann der letzte verschwinden, und der zweite größer werden als $J_{1}$. Alle Zähne sind meist brachyodont und schließen ziemlich dicht aneinander. Die einzelnen Knochen haben vielfache Ähnlichkeit mit jenen von Perissodactylen.

1) Ameghino Flor., Contrib. al conocim. de los Mammiferos fosiles de la Rep. Argent. Actas Ac. nac. Cordoba 1889. VI. - Sur les Ongulés fossiles de l'Argent. Revista del Jard. zoolog. Buenos Aires 1894. - Énumérat synopt. des mammifères foss. éocènes de Patagonie. Buenos Aires 1894. - Mammifères crétacés de l'Argentine. Bol. Instit. géograf. Argent. Buenos Aires. t. XVIII. 1897. - Rech. de morphologie sur les molaires supér. des Ongulés. Anal. Mus. Nac. Buenos Aires. t. IX. 1904. - Burmeister Herm., Anal. Mus. Publ. Buenos Aires 1864. t. I. Nova Acta Acad. Leop. Carol. 1885. XLVII. - Cope E. D., The Litopterna. Amer. Naturalist. 1889. XXV. - Gaudry C., Fossiles de Patagonie. Mém. Soc. géol. France. Paléont. t. XIII. 1904. Annal. de Paléont. 1906. - Lydekker R., Palaeontologia Argentina. Anal. Museo de la Plata. 1893. 


\section{Familie. Bunolitopternidae.}

Obere $M$ aus je zwei mehr oder weniger isolierten Außenhöckern, zwei Zwischenhöckern und zwei ungleich großen Innenhöckern bestehend, öfters auch mit einer Anzahl von Nebenhöckern versehen. Untere $M$ mit je zwei konischen Innenund zwei V-förmigen Außenhöckern. $P$ viel einfacher als die $M$.

Von den Condylarthren - Phenacodontiden - unterscheidet sich diese Familie hauptsächlich durch die Kleinheit $\operatorname{der} C$ und das Fehlen von Zahnlücken. Die Extremitäten waren möglicherweise noch fünfzehig.

Von den zahlreichen Gattungen, welche Ameghin o vorwiegend auf isolierte $M$ begründet hat, führen Lambdaconus, Oroacrodon etc. zu

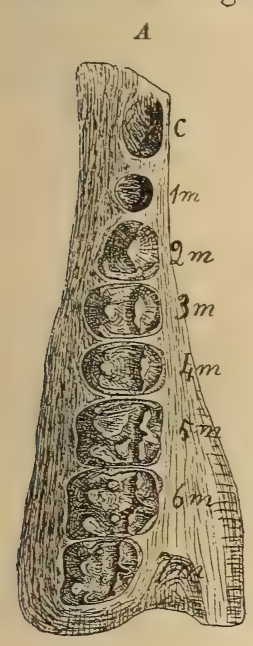
den Macraucheniiden, Notoprogonia, Lonchoconus, Proectocion etc. zu den Proterotheriiden, während andere Ricardolydekkeria, Josepholeidya, Argyro$l a m b d a$ etc. gänzlich erloschen sind. Nur von Didolodus (Fig. 606) ist die Zahnreihe ziemlich vollständig bekannt.

Alle Gattungen stammen aus dem Eocän - No. tostylops - Schichten - und Oligocän - Astraponotus-

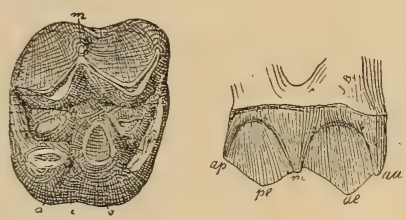

Fig. 607.

Frotheosodon coniferus Ameghino. Untermiocän. Pyrotherium-Schichten. Oberer Molar. Nat. Größe. (Nach Ameghino.)
$B$

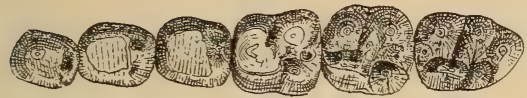

Fig. 606.

Didolodus crassicuspis Ameghino. Obereocän. Notostylops Schichten. Patagonien. A obere, $B$ untere Backenzähne nat. Gr. (Nach Amegh ino.)
Schichten - von Patagonien.
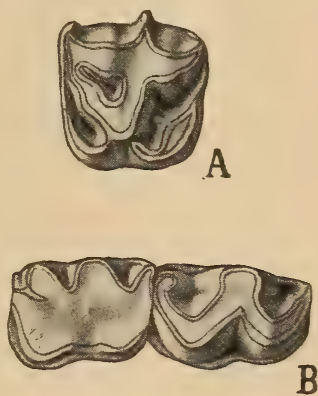

Fig. 608 .

Cramauchenia insolita Ameghino. Miocän. Colpodon-Schichten. $A$ linker oberer $M, B$ rechter unterer $P_{4}$ und $M_{1}$. Nat. Gr.

\section{Familie. Macraucheniidae. Gervais.}

Schädel langgestreckt, schmal, mit kleinem Cranium und weit zurïckliegender aufwärts gerichteter Nasenöffnung. Nasenbeine klein oder verkïmmert. $\frac{3.1 .4 .3 .}{3.1 .4 .3}$. Alle Zähne in geschlossener Reihe und allmählich ineinander übergehend. Mlophodont. Untere $M$ aus zwei Halbmonden und einem Innenhöcker bestehend, obere mit $W$.förmigem Ectoloph, großem Protocon, der mit Protoloph und Metaloph verbunden ist, und einem kleinen Hypocon. Vorder- und Hinterfuß dreizehig. Femur mit drittem Trochanter. Fibula am Calcaneum articulierend. Leitkiele nur auf der Hinterseite der Metapodien gut entwickelt.

Die Macraucheniiden beginnen im Eocän von Patagonien mit buno. donten-brachyodonten und erlöschen im Pleistocän von Argentinien mit selenolophodonten-hypselodonten Formen. Sie erreichen sehr ansehnliche Größe und zeichnen sich durch hohe, digitigrade Extremitäten, langen Hals und langgestreckten Schädel mit weit zurückliegenden Nasenlöchern aus. Die Zähne erinnern etwas an Anoplotherium. Vorder- und Hinterrand bilden einen hohen Kragen an der Innenseite der oberen $M$ und $P$. Die Lebensweise scheint aquatil gewesen zu sein.

Coniopternium, Protheosodon Ameghino. (Fig. 607.) Untermiocän. Pyrotherium-Schichten. Cramauchenia Amegh. (Fig. 608) und Theosodon 
Amegh. Miocän von Santa Cruz. Alle brachyodont. Orbita hinten offen, Nasenbeine kurz, frei vorragend. Vorder- und Hinterfuß dreizehig.

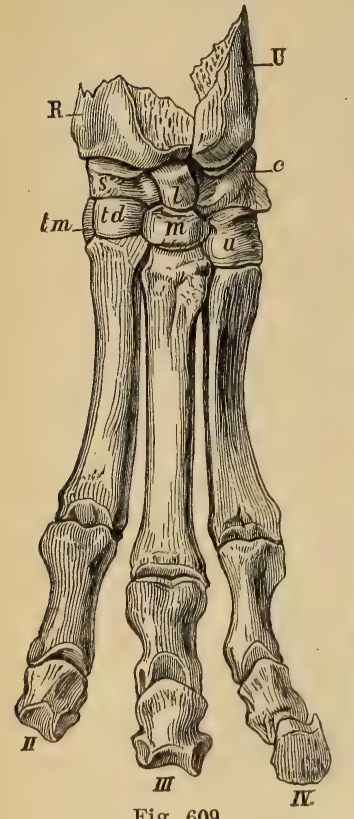

Fig. 609 .

Macrauchenia patachonica Owen. A Vorderfuß (nach Gervais).

Oxyodontherium, Scalabinitherium Amegh. Pliocän. Argentinien. Zähne mäßig hypselodont.

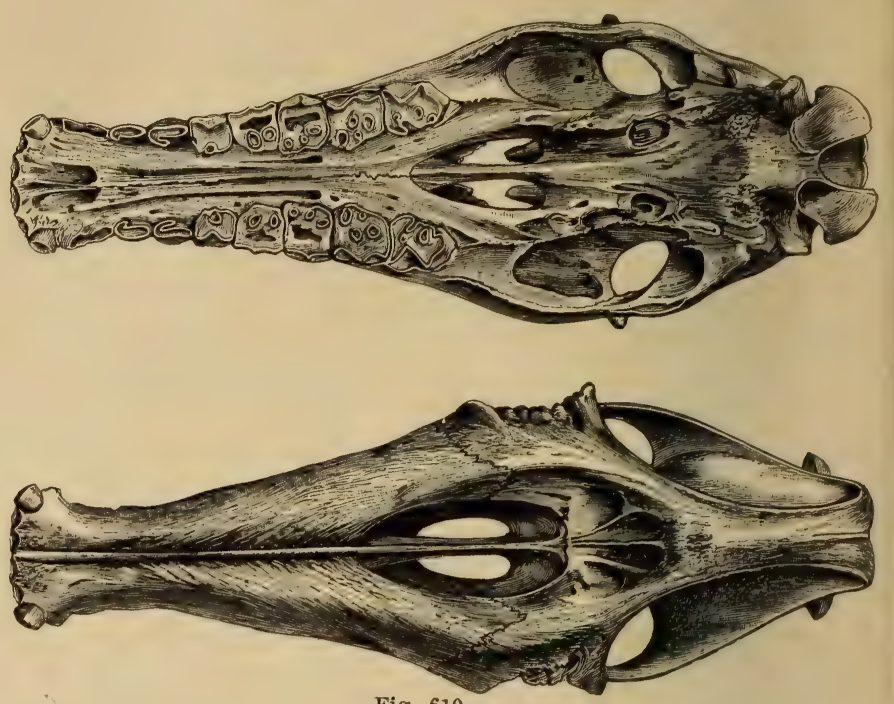

Fig. 610 .

Macrauchenia patachonica Owen. Pleistocän (Pampas-Stufe) von Buenos Aires. Argentinien. Schädel von unten und oben, $1 / 6$ nat. Gr. (nach Bravard).

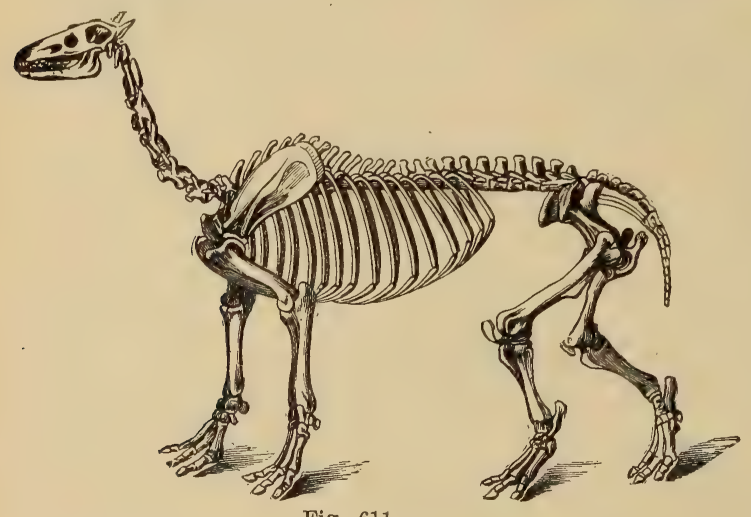

Macrauchenia Owen (Opisthorhinus Brav.) (Figuren $609,610,611$.) Nasenbein rudimentär, großes Nasenloch inmitten des Schädels gelegen. Orbita hinten geschlossen. Pleistocän.

\section{Familie.}

\section{Proterotheriidae.}

Ameghino.

Schädel mäßig lang mit verschmälerter Schnauze. $N a$ senbeine lang, Orbita hinten geschlossen. $\frac{1.0 .4 .3 .}{2.1 .4 .3 .}$. Alle

Iracrauchenia patachonica Owen. Restauriertes Skelett. (Nach Burmeis ter.) Zähne brachyodont. Im Oberkiefer kurze Zahnlücke. Obere $M$ mit $W$-förmigem
Ectoloph, zwei ungleich großen Innen- und ein oder zwei Zwischenhöckern. Die beiden letzten $P$ öfters $M$ ähnlich. Untere $M$ und $P_{2_{-4}}$ aus zwei Halbmonden bestehend und vierwurzelig. $J_{2}$ vergrößert, $C$ klein. Extremitäten drei- oder einzehig, nur die dritte kräftig entwickelt. Leitkiel über die ganze distale Fläche der Metapodien verlaufend.

Epitherium Ameghino. Zweite und vierte Zehe kurz und dünn. Älteres Pleistocän. Monte Hermoso. Argentinien. Eoauchenia Amegh. Ebenda. Zahnkronen hoch. 


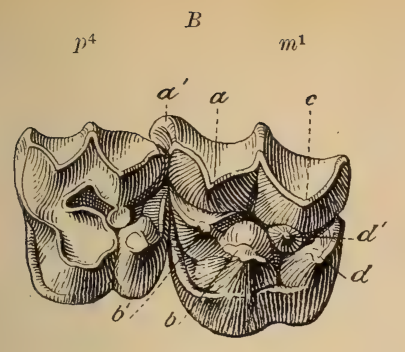

C
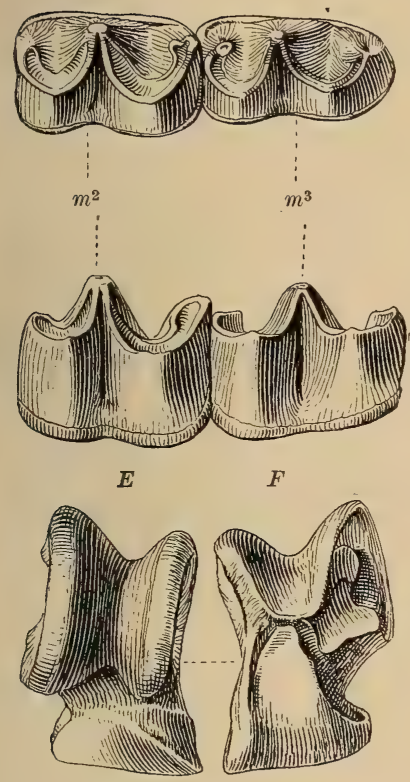

Diadiaphorus

(Figur 612) und Protero therium Ameghino. Miocän und Pliocän. Dreizehig. An dem Innenende der Halbmonde der unteren $M$ bei letzterer Gattung isolierte Pfeiler.

Brachytherium Ameghino. Pliocän von Argentinien. Licaphrium Ameghino Tetramerorhinus Ameghino. Miocän von Patagonien.

Thoatherium Ameg. hino. (Fig. 613.) Ebenda. Mit nur einer Zehe.

Eoproterotherium, Deutero therium Ameghino. Untermiocän. PyrotheriumSchichten von Patagonien.

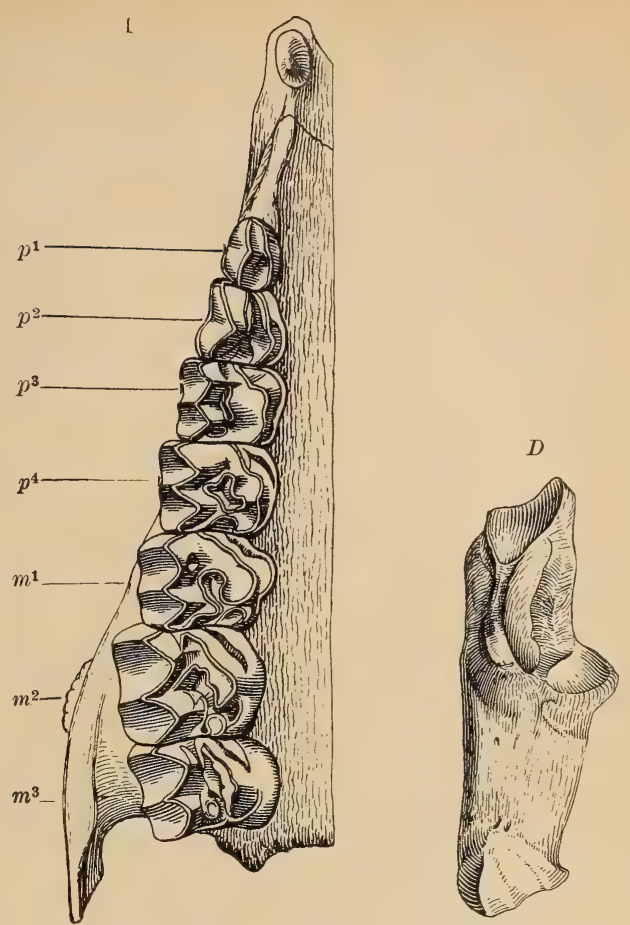

Fig. 612.

Diadiaphorus majusculus Ameghino. Obermiocän. Santa Cruz Patagonien. A linker Oberkiefer $3 / 4$ nat. Gr. (Nach A meghino.) $B$ oberer $M^{\mathbf{1}} \cdot 2$. $C$ unterer $M_{2}$ und $M_{3}$ nat. Gr. $D$ Calcaneum, $E F$ Astragalus $2 / 3$ nat. Gr.

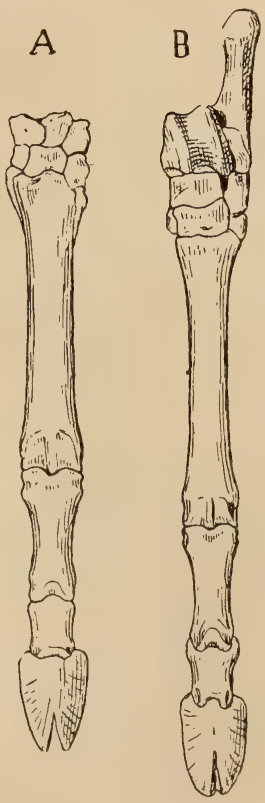

Fig. 613

Thoatherium crepidatum Ameg. hino. Obermiocän. Santa Cruz. Patagonien.

$A$ Vorderfuß, $B$ Hinterfuß.

$1 / 2$ nat. Gr. C Th. minusculum Ameghino. Unterkiefer.

$2 / 3$ nat. Gr. (Nach Ameghino.) 


\section{Familie. Adiantidae. Ameghino.}

Adiantus, Proadiantus Ameghino. Miocän von Patagonien. Nur Unterkiefer bekannt mit geschlossener Zahnreihe, 3.1.4. 3., $J$ und $C$ meißelförmig, $M$ ziemlich hoch aus zwei Monden und Innenpfeilern bestehend. Systematische Stellung unsicher.

\section{Unterordnung. Perissodactyla. ${ }^{1}$ ) Owen. Unpaarzeher (Mesaxonia Marsh).}

Unguligrad, mit vorwiegend entwickelter Mittelzehe, Hinterfuß meist dreizehig, Vorderfuß drei- oder vierzehig, zuweilen an beiden Füßen nur eine Zehe. Astragalus mit tief ausgefurchter Gelenkrolle, distal abgestutzt. Hand- und Fußwurzelknochen alternierend, Gebiß meist vollstïndig. Backenzähne lophodont, selten bunodont. Femur mit drittem Trochanter. Fibula nicht am Calcaneum articulierend.

Die Perissodactylen sind heutzutage nur mehr durch die drei Gattungen Tapirus, Rhinoceros und Equus vertreten, während sie im Tertiär einen großen Formenreichtum aufzuweisen haben. Sie sind ausgezeichnet durch die kräftige Entwicklung der dritten oder Mittelzehe an Vorder- und Hinterfuß, welche bei den spezialisiertesten Formen, den Equiden, ganz allein die Körperlast trägt und auch bei den übrigen stets die Hauptachse der Extremitäten enthält.

Der Schädel gewinnt durch das Úberwiegen der Gesichtsknochen über die Gehirnkapsel verlängerte Form. Das Hinterhaupt fällt steil ab, die Condyli sind quer konvex, die großen Schläfengruben von einer Crista temporalis überdacht. Die Nasenbeine ragen frei über die seitlich offenen, weit zurückreichenden Nasenlöcher vor, welche unten von den Zwischenkiefern und öfters auch vom Oberkiefer begrenzt werden. Zuweilen (Rhinoceros) tragen die Nasenbeine auf rauhen, polsterartigen Flächen Hörner, oder es können sich auf ihnen knöcherne Protuberanzen erheben (Titanotheriidae). Die Augenhöhlen sind in der Regel weit offen und nur bei den jüngeren Equiden ringsum knöchern begrenzt.

Das definitive GebiB der Perissodactylen besteht in seiner typischen Entwicklung aus je $\frac{3.1 .4 .3 .}{3.1 .4 .3}$. Diese Zahnformel gilt fast für alle eocänen Gattungen. Die Modernisierung des Gebisses veranlaßt bei jüngeren und vorgeschritteneren Formen eine Reduktion, zuweilen sogar vollständige Verkümmerung der $J$, der oberen und selbst der unteren $C$ und der vordersten $P$. Die Backenzähne sind bei den primitiveren Formen brachyodont, bei einzelnen vorgeschritteneren prismatisch. Die älteren Perissodactylen haben vorwiegend heterodonte, die jüngeren homöodonte Backenzähne. Die ursprünglich praktisch vierhöckerige, aber doch mit Nebenhöckern versehene Krone bleibt selten rein bunodont, meist sind die Höcker durch Joche verbunden (lophodont). Durch Vorsprünge an der Außenseite - Parastyl, Mesostyl, Metastyl-, an der Innenseite der Außenwand - Crista und an den Querjochen - Crochet und Antecrochet - der oberen Backenzähne wird die Zahnkrone häufig verstärkt und bei vorgeschritteneren Formen bekommt der Schmelz öfters auch eine Zementhülle.

Im Milchgebiß stimmen die $J D$ und $C D$ mit denen des definitiven Gebisses überein, die $D$ gleichen nur bei den homoeodonten Formen ihren Ersatzzähnen, bei den heterodonten besitzen nur die zwei hinteren Milch.

$\left.{ }^{1}\right)$ Cope E. D., The Perissodactyla. Amer. Naturalist. 1887 p. 985 . - Osborn $H$. $F$., Mammalia of the Uintaformation. The Perissodactyla. Trans. Amer. Philos. Soc. 1889 XVI. pag. 505. - Osborn H. F., and Wortman J. L, Perissodactyla of the lower Miocene. Bull. Amer. Mus. Nat. Hist. New York 1895, p. 343. - Owen R., Quart. Journ. geol. Soc. London 1847. IV. p. 103. - Stehlin H. G., Die Säugetiere des schweiz. Eocäns. Abh, schweiz, paläont. Ges. 1903. 1904. 1906. 
zähne die Gestalt von Molaren und der vorderste zeichnet sich in der Regel durch einfachere, $P$ ähnliche Form aus.

Die Wirbelsäule besteht aus 7 Hals·, 22 Rücken- und Lendenwirbeln, 5-6 Sacral- und mindestens 13 Schwanzwirbeln. Ein Schlüsselbein fehlt. Humerus kurz, gedrungen, ohne Foramen entepicondyloideum. Fossa olecrani niemals durchbohrt. Radius und Ulna bald gleichmäßig entwickelt, getrennt, bald distal verschmolzen.

Verwachsungen von Carpalia finden nicht statt, wohl aber werden die Carpalia durch seitliche Verschiebung der distalen Reihe und durch Streckung nach rückwärts fester ineinander verkeilt. Das Scaphoideum ruht nicht bloß auf dem Trapezoid wie bei den Condylarthra, sondern auch teilweise auf dem Magnum, das Lunare stützt sich auf Magnum und Unciforme, und nur das Cuneiforme wird bloß von einem Carpale, dem Unciforme getragen. Das Centrale ist nicht mehr vorhanden. Bei den Formen mit drei annähernd gleich langen Zehen ist der Carpus hoch, bei den jüngeren Equiden rit ungemein starker Mittelzehe verbreitert sich das Magnum und schiebt Trapezoid und Unciforme nach der Seite, wobei das Trapezium ganz aus dem Carpus verdrängt wird und zuletzt vollständig verschwindet. Die Zahl der Metacarpalia ist im Maximum vier, meist drei, beim Pferd nur eins. Ein Daumen fehlt stets, der fünfte Finger ist, wenn überhaupt vorhanden, kürzer als die übrigen.

Die Metacarpalia greifen mit ihren schwach konkaven proximalen Gelenken etwas zwischen die Carpalia herein und alternieren mit ihnen. Die Länge der Metapodien ist sehr verschieden. Verlängerung von Metapodien bedeutet in der Regel einen Fortschritt und ist meist mit Reduktion der Seitenzehen verbunden. Wird die ganze Körperlast auf die Mittelzehe verlagert, so bildet sich am distalen konvexen Gelenk von Metacarpale III (und Metatarsale III) ein zugeschärfter Leitkiel aus, welcher eine seitliche Verschiebung der Zehe verhindert. Bei den älteren drei- oder vierzehigen Perissodactylen sind die Leitkiele auf die Hinterseite der distalen Gelenkfläche beschränkt. Die dreieckigen, unten abgeplatteten Endphalangen sind von Hufen umgeben.

Der Oberschenkel zeichnet sich durch einen vorspringenden, öfters sehr stark entwickelten dritten Trochanter aus. Tibia und Fibula sind bei den Formen mit wenig überwiegender Mittelzehe vollständig entwickelt und getrennt, bei den jüngeren Equiden verkümmert die Fibula zu einem kurzen proximalen Griffelbein.

Von den Tarsalknochen hat das Calcaneum (Fig. 614A) einen verlängerten, am Ende rauhen Stiel (tuber calcis) und ein nach innen vorspringendes Sustentaculum mit drei Fasetten für den Astragalus

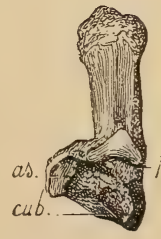

Fig. 614. Palaeotherium. Calcaneum.

as, $p^{\prime}$ Fasetten für den Astragalus, $c u b \mathrm{Fa}$ sette.für das Cuboideum.

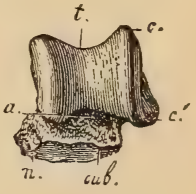

Fig. 615 Palaeotherium. Astragalus. $t$ Trochlea, $n, c u b$ Fasetten für das Naviculare und Cuboideum, $c^{\prime}$ Berührungsfläche mit dem Calcaneum, a Grube zur Aufnahme des unteren Endes der Tibia.

(Fig. $615 \mathrm{~B}$ ). Dieser letztere hat oben und vorne eine tiefausgefurchte Rolle für die Tibia, innen und hinten drei Gelenkflächen für das Calcaneum und an dem abgestutzten oder höchstens schwach gewölbten distalen Ende eine große Fasette für das Naviculare $(n)$ und eine kleine für das Cuboideum $(c u b)$. Zwischen der proximalen und der distalen Tarsusreihe liegt, ausschließlich vom Astragalus bedeckt, das von den drei Cuneiformia getragene Naviculare. Das Cuboideum ist hoch, trägt das Calcaneum, artikuliert aber auch stets mit dem Astragalus. Alle Tarsalia bleiben getrennt, nur bei den vorgeschritteneren Equiden kommen Verwachsungen von Cuneiformia vor. Die Reduktion der Seitenzehen ist am Hinterfuß vollständiger 
und konstanter als am Vorderfuß. Der Hinterfuß ist somit entweder dreizehig oder, bei den jüngeren Equiden, einzehig. Die meist ebenen proximalen Gelenkflächen der Metatarsalia greifen nicht in die untere Tarsusreihe ein.

Die Perissodactylen lassen sich in fünf Familien, Tapiridae, Rhinoceridae, Equidae, Titanotheriidae und Chalicotheriidae einteilen, von denen die vier ersten auf eine gemeinsame Stammform zurückgehen, welche der Condylarthengattung Tetraclaenodon vermutlich sehr ähnlich war, während die Chalicotheriidae ungezwungen von der Condylarthrengattung Meniscotherium abgeleitet werden können.

\section{Familie. Tapiridae. ${ }^{1}$ )}

Nasenbeine kurz, frei vorragend. $\frac{3.1 .4-3.3 .}{3-2.1 .4-3.3 .} J$ meißelförmig, C konisch. Backenzähne brachyodont. $P$ anfangs einfacher als $M$, bei den späteren Formen gleich $M$. Obere $M$ mit zwei untereinander verbundenen Außenhöckern und zwei geraden Querjochen, welche die Außenhïgel mit den beiden Innenhügeln verbinden. Parastyl kräftig. Untere $M$ mit zwei rechtwinklig oder schief zur Längsachse gerichteten Querjochen. Vorderfuß meist mit vier, Hinterfuß mit drei Zehen.

Die Tapiriden enthalten kleine, mittelgroße und ausnahmsweise auch große Formen. Die einzige noch existierende Gattung lebt in Südasien und

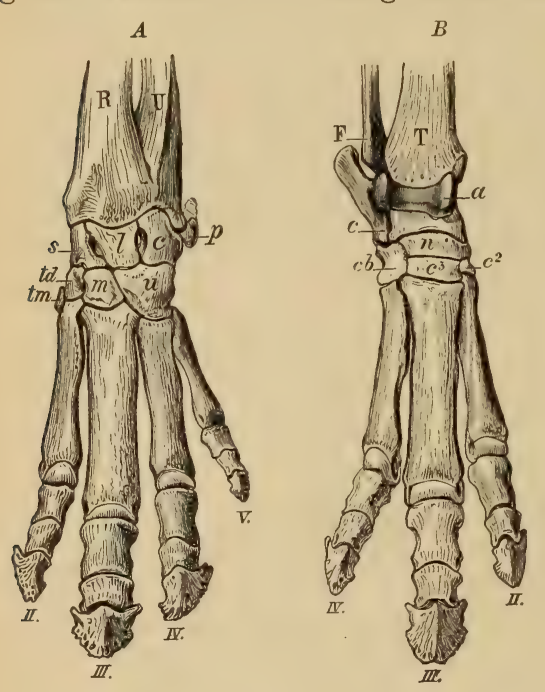

Fig. 616 .

Tapirus americanus Lin. A linker Vorderfuß $B$ rechter Hinterfuß. $1 / 5$ nat. Gr. im tropischen Amerika. Fossile Tapiriden beginnen im Untereocän von Europa und Nordamerika und reichen in Europa bis in das Pliocän. Im Pleistocän haben sie sich in ihre jetzigen Wohnsitze zurückgezogen, sind aber auch noch fossil in China und Nordamerika vertreten. Ihre nächsten Beziehungen haben sie zu den Rhinoceriden.

Fast alle Tapiriden besitzen ein vollständiges Gebiß. Die $C$ sind meist durch ein Diastema von den stets brachyodonten Backenzähnen getrennt. Das in der Regel gut entwickelte Cingulum bildet an der Vorderaußenecke der oberen $M$ und oft auch der $P$ einen Pfeiler (Parastyl). Die Querjoche, welche die Außenhöcker mit den Innenhöckern verbinden, verlaufen fast geradlinig (ortholophodont). Im Unterkiefer sind die vorderen Schenkel der ursprünglich V-förmigen Joche fast ganz verwischt, so daß in der Regel nur die hinteren Schenkel einfache Querjoche bilden. Bei allen alttertiären Gattungen unterscheiden sich die $P$ durch einfacheren, im Oberkiefer häufig noch trituberkulären Bau von den $M$, beim lebenden Tapir haben die $P$,

1) Déperet Ch., Études sur les Lophiodon. Archiv. Mus. Lyon. 1903. - Filhol H., Études sur les vertébrés fossiles d'Issel. Mém. Soc. géol. de France. 1888. - Gaudry $A$, La dentition des ancêtres des Tapirs. Bull. soc. géol. France 1897. Hatcher J. B., Recent and fossil Tapirs. Amer. Journal of Science 1896. - Maack G., Unters. über Lophiodon von Heidenheim. Jahresber. naturhist. Ver. Augsburg 1865 . - Meyer v. H., Fossile Reste des Genus Tapir. Palaeontogr. 1867. Bd. XV. Osborn H. F. uud Wortman J. L., Bull. Amer. Mus. Nat. Hist. New York. 1892. Wortman J. L. and Earle, Ibidem 1893. 
mit Ausnahme des vordersten, das Aussehen von echten $M$ erhalten. Im Oberkiefer sind meistens 4 , im Unterkiefer 3 bis $4 P$ vorhanden, welchen die $M$ ähnlichen $D$ vorausgehen. Im Unterkiefer tritt häufig Verlust des vordersten $P$ ein, während der Oberkiefer meist die volle Zahl (4) behält. Nur die Gattung Lophiodon besitzt trotz ihres hohen geologischen Alters oben und unten nur $3 P$. Der Schädel der Tapiriden ist in der Regel gestreckt, die Schnauze verschmälert, die Gehirnhöhle mäßig groß, die Orbita sind hinten nicht knöchern umgrenzt, die Nasenbeine frei vorragend, bei den älteren Formen sehr lang und groß, bei Tapir kurz und dreieckig, Raum für einen kurzen Rüssel lassend. Nasenöffnung groß und weit zurück. reichend. Postglenoid und Paroccipitalfortsätze wohl entwickelt. Die Extremitäten (Fig. 616) haben mäßige Länge, sie sind schlanker als bei den meisten Rhinoceriden aber plumper als bei den meisten Equiden. Ulna und Radius sind getrennt und nahezu gleich stark. Im Carpus ruht das Scaphoid auf Trapezoid und Magnum, und das Lunatum zum größten Teil auf dem Unciforme. Das Magnum trägt die Hauptlast und wird von Metacarpale II und III gestützt. Der Vorderfuß ist vier-, der Hinterfuß dreizehig. Das Femur hat einen mäßig entwickelten dritten Trochanter, die Fibula ist stets vollständig. Der Astragalus besitzt eine tief ausgefurchte Trochlea und distal eine große abgestutzte Gelenkfläche für das Naviculare und eine kleine für das Cuboid. Der Bau von Carpus und Tarsus hat bei den Tapiriden während des ganzen Tertiärs keine nennenswerten Veränderungen erfahren.

\section{Unterfamilie. Lophiodontinae.}

Obere und untere $M$ mit zwei schiefen Querjochen. Sämtliche $P$ oder doch die vordersten einfacher als die M. Metacon der oberen M konkav. Nur fossil im Eocän von Europa und Nordamerika.

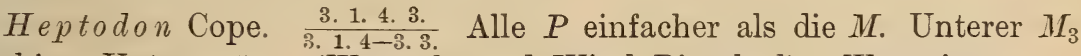
dreijochig. Untereocän. (Wasatch- und Wind Riverbed). Wyoming.

$H$. ventorum. calciculus Cope.

Helaletes Marsh (Dilophodon, Desmatotherium Scott). $\frac{4}{3} P, P^{3}$ und $P^{4}$ mit Nachjoch. Nitteleocän, Bridgerbed und Obereocän, Uintabed.

Chasmotherium Rütimeyer. $\frac{4}{4} P$, davon die beiden letzten $M$ ähnlich. Unterer $M_{3}$ nur mit zwei Jochen. Mitteleocän von Frankreich und Schweizer Bohnerze.

Lophiodon Cuv. (Tapirotherium Blv.) (Figur 617). $\frac{3}{3} P$, sämtlich einfacher als die $M$. Unterer $\boldsymbol{M}_{3}$ dreijochig. Schädel niedrig, lang, mit hohem Scheitelkamm. Hinterhaupt überhängend. Nasenbeine bis oberhalb $J^{1}$ reichend. Hand vierzehig. $M_{c} V$

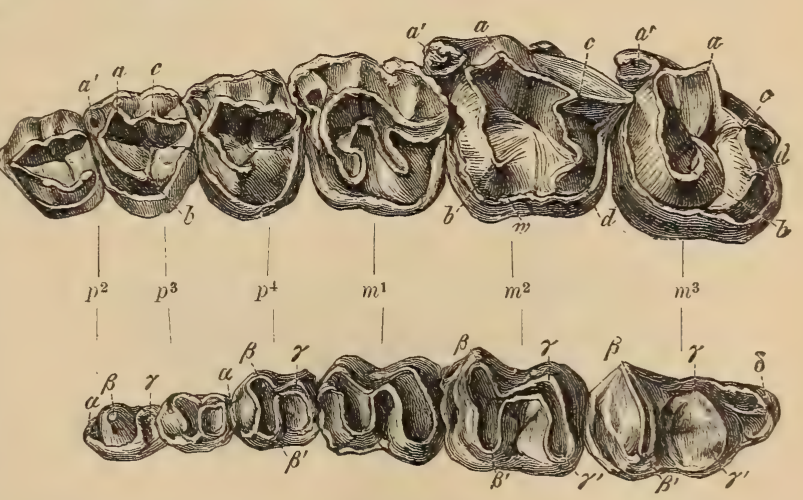

Fig. 617.

Lophiodon isselense Cuv. Mittel-Eocän. Issel bei Castelnaudary Aude. Zahnreihe des linken Oberkiefers und Unterkiefers, $1 / 8$ nat. Gr. (Nach Filhol.)

kurz. Zahlreiche Arten

im europäischen Eocän, in der Größe zwischen Schwein - L. occitanicum Gerv. - und Rhinoceros - L. rhinocerodes Rüt. - schwankend.

Lophiodochoerus Lemoine. Untereocän von Reims. 


\section{Unterfamilie. Tapirinae.}

Untere $M$ mit zwei rechtwinklig zur Längsachse stehenden Querjochen. Zweiter Außenhöcker der oberen $M$ in der Regel konisch. $P$ bei den älteren Formen einfacher, bei den jüngeren $M$ ähnlich.

Fossil im Eocän bis Pleistocän von Nordamerika, in Europa von Oligocän bis Pliocän, in Asien und Südamerika erst im Pleistocän.

Systemodon Cope. $P_{4}$ in beiden Kiefern nahe an $C$. Außenhöcker der Qberen $M$ fast gleich stark. Querjoche mit deutlichen Zwischenhöckern. $P^{1}$ klein, einspitzig, die übrigen $P$ dreihöckerig. Unterer $\boldsymbol{M}_{3}$ dreijochig. Im unteren Eocän (Wasatchbed) von Wyoming und Neu-Mexiko. S. semihians Cope.

Isectolophus Scott und Osborn. Obereocän. Bridger und Uintabed.

A

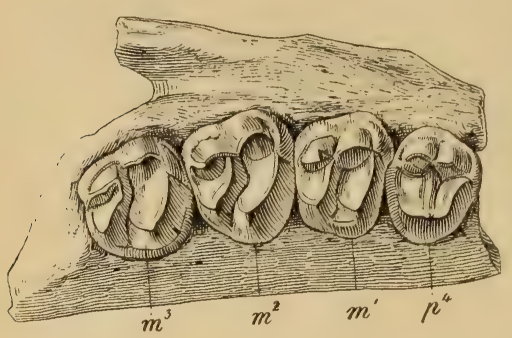

$\boldsymbol{B}$

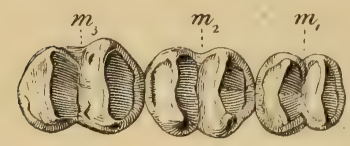

Fig. 618

Protapirus priscus Filhol. Quercy. Aletzter oberer $P$ und drei $M . B$ die drei hinteren $M$ des Unterkiefers in nat. Gr. (Nach Fil ho ol.)

Protapirus Filhol (Fig. 618). Oberer $P^{4}$ mit zwei äußeren Höckern und einem zweispitzigen Innenhöcker und zwei konvergierenden Jochen. Unterer $M_{3}$ zweijochig. Oligocän. Phosphorite von Quercy und Bohnerz von Ulm. P. priscus Filhol. Die amerikanischen Arten P.robustus Sinclair (Untermiocän von Oregon), obliquidens und simplex Wortman (Oligocän White Riverbed) sind wohl generisch verschieden - Nachjoch der unteren $M$ aus zwei fast isolierten Höckern bestehend.

Colodon Marsh. Ohne unteren $J_{1}$ und unteren $P_{1}$. Obere $P_{2}$ bis $P_{4}$ mit Nachjoch. Paracon der oberen $M$ konkav. Unterer $M_{3}$ zweijochig. Metapodium III viel kräftiger als die übrigen. Oligocän. White Riverbed.

Tapiravus Marsh. Miocän von New Jersey und Pliocän der Rocky Mountains, sehr unvollständig bekannt.

Palaeotapirus Gaudry (Paratapirus Depéret) (Fig. 619). $P^{1}$ dreieckig und undeutlich dreiböckerig, $P^{2}$ mit kurzem Vor- und langem Nachjoch. $P^{3}$ und $P^{4}$ oblong, mit gleichlangen Querjochen. $M$ trapezoidal im Umriß. Parastyl an den oberen $P$ schwach, an den $M$ kräftig entwickelt.

A

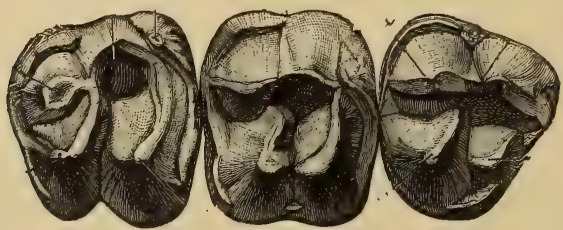

Fig. 619.
$B$

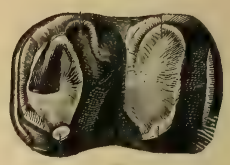

Palaeotapirus helveticus Meyer. Unt. Miocän. Eselsberg bei Ulm. $A P^{2}, P^{4}$ und $M^{1}$ des Oberkiefers. $B$ Ein Unterkiefer-Molar (nat. Gr.).

Untermiocän Ulm, Mainz, Brüx und Schweiz, Dep. Allier und Savoyen. $P$. helveticus Meyer sp.

Tapirus Linné (Elasmognathus Gill). Obere $P$ mit Ausnahme von $P^{1} M$ ähnlich aber oblong und mit schwächerem Parastyl. Unterer $P^{2}$ 
verlängert, Schädel mit sehr kurzen, vorne zugespitzten und zuweilen durch eine Wand gestützten Nasenbeinen. Lebend in Süd- und Zentralamerika und in Südindien. Fossil in Europa im Obermiocän T. Telleri Hofmann in Steiermark, im Unterpliocän T. priscus Kaup Eppelsheim, Mittelpliocän, T. hungaricus Meyer Steiermark und Ungarn, Oberpliocän, $T$. arvernensis Croiz. und Job. Auvergne. Im Pleistocän von Südchina lebte der riesige $T$. sinensis Owen. Im Pleistocän von Nordamerika T. Haysii. Leidy, in dem von Südamerika (Tarija) T. tarijensis Ameghino.

\section{Familie. Rhinoceridae. ${ }^{1}$ )}

Nasenbeine frei vorragend, häufig mit einem rauhen Polster für ein oder zwei Hörner. Nasenlöcher weit zurïckreichend. $\frac{3-0.1-0.4-2.3 .}{3-0.1-0.4-2.3 .} J$ und C öfters fehlend. $P$ den $M$ mehr oder weniger ähnlich, bei den älteren Formen einfacher. Obere $M$ mit dicker Aussenwand, Ectoloph, und zwei schiefen, schwach gebogenen und mit dem Ectoloph innig verbundenen Querjochen. Untere $\boldsymbol{M}$ mit zwei fast rechtwinklig geknickten Jochen, wovon sich das Nachjoch - Metalophid - mit seinem vorderen Schenkel an das Vorjoch anschließt. $M_{3}$ ohne drittes Joch. Vorderfuß mit drei oder vier, Hinterfuß mit drei Zehen.

$\mathrm{Zu}$ den Rhinoceridae gehören vorwiegend große, kurzhalsige, plumpe, kurzbeinige und kurzgeschwänzte Grasfresser, welche noch jetzt in sumpfigen Niederungen des tropischen Indien, der Sundainseln und in Zentralafrika leben, fossil im oberen Eocän von Europa und Nordamerika beginnen und im Oligocän, Miocän und Pliocän einen großen Formenreichtum entfalten. Im Miocän erscheinen sie auch in Nordafrika und bald darauf auch in Asien. In Europa haben sie ihre letzten Vertreter im Pleistocän. Sie zeichnen sich teilweise durch den Besitz starker Hörner aus, die als echte Hautgebilde aus innig verwachsenen Haarbüscheln entstehen und auf rauhen Protuberanzen dem Nasenbein, zuweilen auch dem Stirnbein aufsitzen. Sind zwei Hörner vorhanden, so stehen sie meistens hintereinander.

Das Gebiß ist nur bei den älteren Formen vollständig, bei den jüngeren verkümmern zuerst die $C$ und dann allmählich auch die $J$. Bei den älteren Formen sind alle oder doch die zwei vorderen $P$ einfacher gebaut als die $M$; bei allen jüngeren Rhinoceriden zeigen die $P$ und $M$ mit Ausnahme des vor-

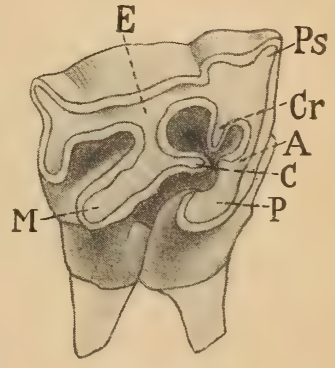

Fig. 620 .

Oberer Molar von Rhinoceros. $1 / 2$ nat. Gr. $E$ Ectoloph. $P$ Protoloph. $M$ Metaloph. Ps Parastyl. Cr Crista, $A$ Antecrochet. $C$ Crochet. dersten $P$ im wesentlichen gleiche Zusammensetzung. In das von den Querjochen der oberen $M$ (Fig. 620) begrenzte Quertal ragen häufig Vorsprünge, Sporne, vom Vorjoch, Protoloph, Antecrochet A, von der Außenwand, Ectoloph Crista $C r$, und vom Nachjoch, Metaloph Crochet $C$ nach Osborns Bezeichnungsweise herein, die sich auch be-

1) Abel O., Uber die paläogenen Rhinocerotiden Europas. Abhandl. k. k. geolog. Reichsanst. XX. 1910. - Brandt J. F., Mem. Acad. imp. Sc. St. Petersb. 1864 VIII. 1877 XXIV. 1878. XXVI. - Cope $E$. D., On the American Rhinoceroses Amer. Naturalist 1879. - Douglass Earl, Annals of the Carnegie-Museum. Vol. IV. 1908. - Duvernoy G. L., Nouv. études sur les Rhinoceros fossiles. Arch. du Museum Paris 1853. - Flower $W . H$., On cranial and dental characters of the existing: species of Rhinoceroses. Proceed. zool. Soc. 1876. - Hatcher J. B., New fossil Vertebrates. Ann. Carnegie Mus. 1901. - Meyer H. v., Die diluvialen Rhinozerosarten. Palaeontogr. 1864. - Osborn H. F., Memoirs Amer. Mus. Nat. Hist. NewYork 1898. - Bull. Amer. Mus. New York 1900 und 1904. - Pavlow M., Études sur l'histoire des Ongulés III. Rhinoceridae et Tapiridae VI. Les Rhinocéridae de la Russie. Bull. Soc. imp. Nat. Moscou 1892. - Roman F., Le Cadurcotherium. Arch. 
rühren und dann inselartige Räume umschließen können. An der Vorderaußenecke der oberen $P$ und $M$ befindet sich der Parastyl. Der letzte untere $M$ besitzt nie ein drittes Joch.

Der Schädel ist niedrig, langgestreckt, das Hinterhaupt durch einen scharfen Occipitalkamm begrenzt, die Orbiten sind hinten offen und die Schläfengruben sehr groß. Die frei vorragenden Nasenbeine sind bei den hornlosen Formen schmal, bei den behornten stark und breit und werden zuweilen durch ein verknöchertes Mesethmoid gestützt. Die Nasenlöcher können bis zum ersten $M$ reichen. Postglenoid und Mastoidfortsatz stehen zuweilen dicht beisammen.

Die Extremitäten sind meist kurz und plump, Radius und Ulna kräftig, ähnlich wie bei den Tapiriden und wie bei ihnen vollständig getrennt. Auch der Carpus ist, wenigstens bei den älteren Formen, dem der Tapiriden ähnlich. Von den Metacarpalien ist $M c$ III kräftiger als $M c I I$ und $I V . M c V$ ist, wenn überhaupt vorhanden, kurz. Der Oberschenkel zeichnet sich durch den Besitz eines großen, in Mitte der Diaphyse gelegenen dritten Trochanters aus. Tarsus und Metatarsus sind bei den primitiveren Formen etwas verlängert und schmal, bei den jüngeren kurz und breit.

1. Unterfamilie. Hyracodontidae. Cope.

Schädel kurz mit Sagittalcrista und seitlich sichtbarem Perioticum. Nasenbeine vorragend, hornlos. $\frac{3.1 .4 .3 .}{3.1 .4 .3 .} \quad C$ schwach und dicht an die meißelartigen $J$ stoßend, von den Backenzähnen durch ein Diastema getrennt. $P$ und $M$ entweder
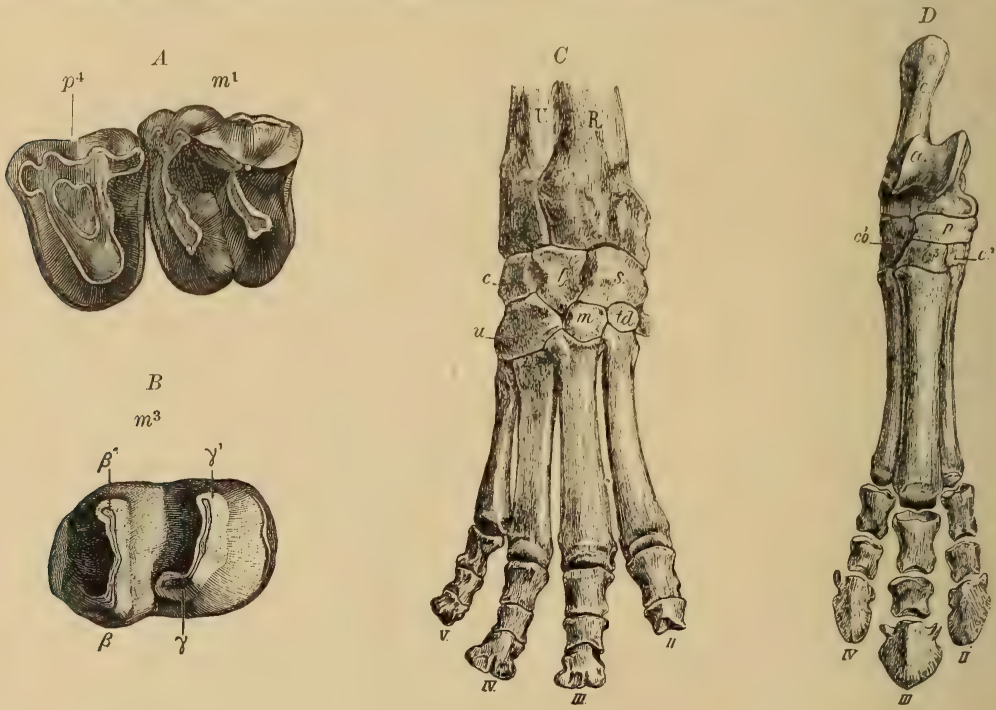

Fig. 621.

Hyrachyus eximius Leidy. Eocän (Bridger-Stufe). Wyoming. A Letzter oberer Prämolar und erster oberer Molar. B letzter unterer Backzahn (nat. Gr.). $C$ Vorderfuß (nach einem Gipsabguß). $D$ Hinterfuß (ca. $1 / 5$ nat. Gr.). (Nach Cope.)

heterodont oder nahezu homoeodont. Die oberen $M$ aus Außenwand und zwei schiefen Querjochen, die unteren aus zwei geknickten Halbmonden bestehend. Hals lang, Extremitäten lang und schlank. Vorderfuß vier-bis dreizehig, Hinterfuß dreizehig.

Mus. Hist. nat. Lyon. 1908. - Les Rhinocéridés de l'Oligocene d'Europe, Ibid. 1911. - Scott W. B., Osteologie von Hyracodon. Festschr. f. Gegenbaur 1896. - Toula Fr., Das Nashorn von Hundsheim. Abhandl. k. k. Reichsanstalt 1902. 1906. Weber M., Uber tertiäre Rhinocerotiden der Insel Samos. Bull. Soc. imp. Nat. Moscou 1904. 1905. 
Diese zierlichen, hochbeinigen, schlanken, langhalsigen Tiere erinnern eher an ältere Equiden als an Rhinoceriden, obwohl Schädel und Backenzähne im ganzen mit den letzteren übereinstimmen. Im Skelett stehen sie den Tapiriden nahe. Sie bilden einen gänzlich erloschenen Seitenzweig der Rhinoceriden, der auf Obereocän und Oligocän von Nordamerika beschränkt ist.

Hyrachyus Leidy (Fig. 621) (Colonoceras Marsh?) $P$ einfacher als $M$, die oberen $P$ dreihöckerig. Vorderfuß vierzehig, Hinterfuß dreizehig. Obereocän (Bridgerbed). Wyoming.

Triplopus Cope. Vorderfuß dreizehig. Obereocän (Bridger- und Uintabed).

Hyracodon Leidy (Fig. 622). Die drei hinteren $P$ Martig. Vorderfuß dreizehig. Oligocän White Riverbed.

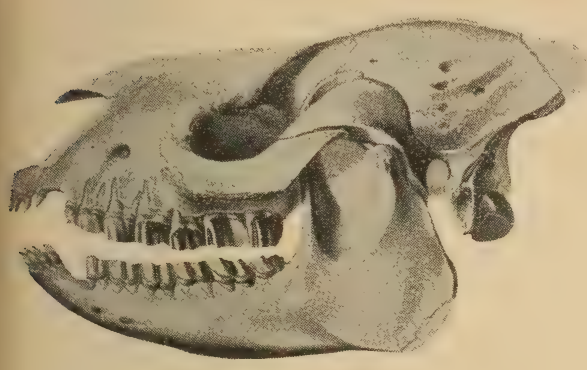

Fig. 622 .

Hyracodon nebrascensis Leidy. Oligocän. White Riverbed. Nebraska Schädel. $1 / 6$ nat. Gr. (Nach Scott.)

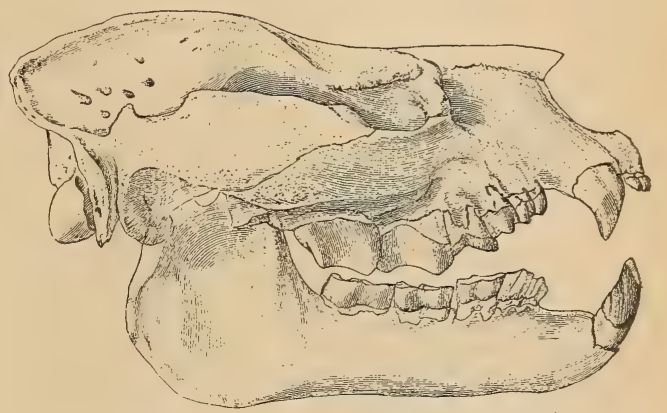

Fig. 623.

Metamynodon planifrons Osborn. Oligocän. White Riverbed. $1 / 10$ nat. Gr. (Nach O sborn.)

2. Unterfamilie. Amynodontinae. Scott and Osb.

Schädel vor der Orbita tief ausgehöhlt, Vorderrand der Schnauze breit. Nasenbeine sehr kurz, hornlos. C oben und unten viel stärker als die J, hauerartig. $M$ ähnlich wie bei Rhinoceros. Obere $M$ ohne Sporne. $P$ viel kleiner und einfacher als die $M$. Vorderfuß vier- und Hinterfnß dreizehig.

Von einer Gattung dieser plumpen Tiere (Metamynodon) ist das Skelett vollständig bekannt. Der Schädel gleicht eher dem eines Bären als eines Rhinoceriden. In Nordamerika im Obereocän und Oligocän, in Europa im Oligocän.

Amynodon Marsh (Orthocynodon Scott et Osb.) $\frac{3-2.1 .4 .3 .}{2-1.1 .4 .3 .} \quad M$ nicht komprimiert. Obersocän. Uintabed.

Metamynodon Scott u. Osb. (Fig. 623). 2.1.3.3. Zahnkronen sehr hoch, stark komprimiert. Oligocän. White Riverbed. Dakota.

Cadurcotherium Gervais $\frac{2.1 .3 .3 .}{1.1 .2 .3 .} M$ seitlich stark komprimiert. Oligocän Phosphorite von Quercy und Gips von Isle-sur-Sorgues.

\section{Unterfamilie. Rhinocerinae.}

Schädel langgestreckt, hinten ansteigend, ohne Sagittalcrista, aber mit Supraoccipitalkamm. Perioticum nicht an der Außenseite des Schädels hervortretend. Nasenbeine lang, vorspringend, nicht selten mit Hornpolster. $\frac{3-0.1-0.4-3.3 .}{3-0.0 .4-3.3 .}$ Obere $C$ fast immer, untere stets fehlend, $J$ frïhzeitig teilweise und später zuweilen ganz reduziert oder oberer $J^{1}$ und unterer $J_{2}$ stark spezialisiert. Obere Backenzähne mit Außenwand und zwei schiefen Querjochen, häufig mit Antecrochet, Crista und Crochet oder nur mit einem oder zwei dieser Sporne versehen. Obere und untere $P$ häufig den $M$ gleich. Hals kurz, Extremitäten plump. Vorderfuß vier-bis dreizehig, Hinterfuß dreizehig. 
Sämtliche Angehörige dieser Unterfamilie wurden von $\mathrm{Cuvier}$ in der einzigen Gattung Rhinoceros vereinigt, die jetzt in eine Anzahl von Subgenera zerlegt wird. Die fossilen Formen bilden zum Teil sehr vollstindig geschlossene Formenreihen.

Prohyracodon Koch. Extremitäten schlank. Obere $M$ ohne Sporne. Mitteleocän. Siebenbürgen

Trigonias Lucas. $\frac{3.1 .4 .3}{3.0 .4 .3}$ Oberer $J_{1}$ und unterer $J_{2}$ viel größer als die übrigen, $P$ viel einfacher als $M$. Nasenbeine und $Z$ wischenkiefer lang. Vorderfuß vierzehig. Oligocän White Riverbed. T. Osborni Lucas.

Leptaceratherium Osborn $\frac{2.1 .4 .3 .}{2 \cdot 0.3 .3 .}$ Vorderfuß dreizehig. Ehenda $L$. trigonodum Osborn.

Meniatherium Abel. Oligocïn. Krain. $P$ und $M$ einfach, klein.

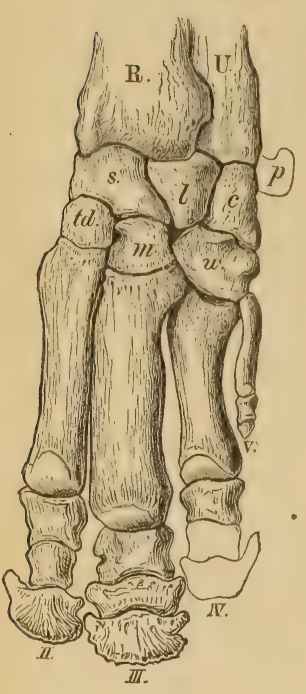

Fig. 624 .

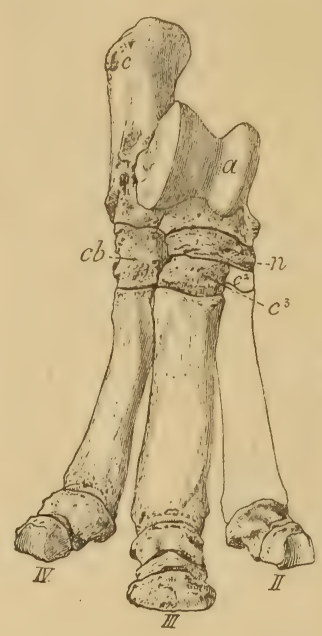

Fig. 625 Epiaceratherium Abel. Oli. gocän. Monte Bolca. $P^{4}$ dreieckig.

Ronzotherium Aymard. $P$ einfach. Nur Unterkiefer bekannt. Oligocän Ronzon. $R$. velaunum Aymard.

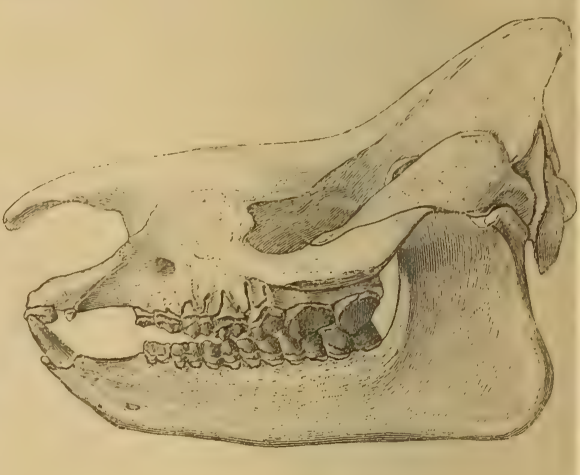

Fig. 626.

Aceratherium tridactylum Osborn. Oligocän. Oberes White Riverbed. Nebraska Schädel $1 / 9$ nat. Gr. (Nach Osborn.)

Praeaceratherium Abel. (Eggysodon Roman?) Obere $\boldsymbol{M}$ ohne Crochet und Antecrochet. $P$ mit parallelen, ungleich langen Jochen und gerundeter Innenseite. Oligocän Phosphorite, schwäbische Bohnerze, Meeresmolasse von Alzei, $P$. minus Filh. sp. E. Osborni Schl. mit oberem $C$.

Protaceratherium Abel. Obere $M$ mit Crochet und Antecrochet, $P$ vierseitig mit konvergierenden Jochen. Oligocän. Phosphorite von Quercy, Stampien und Braunkohlen von Böhmen und Piemont. P. cadibonense Roger sp., minutum Cuv. sp.

A c e r a th erium Kaup (Caenopus Cope) (Fig. 624-627). $\frac{2-1.0 .4 .3 .}{2-1.0 .4 .3 .3 .}$ Dolichocephal, Nasenbeine schmal, hornlos. Oberer $J^{1}$ komprimiert, $\vec{J}_{1}$ hinfällig, $J_{2}$ lang, eckzahnähnlich mit dreikantiger Schneide. $P$ stets einfacher als die $M$. Obere $P$ und $M$ anfangs nur mit Antecrochet. Vorderfuß dreizehig, zuweilen mit kurzem, dünnen, vierten Finger (Fig. 624). Oligocän. White Riverbed von Nordamerika. A. occidentale Leidy, tridactylum, platycephalum, Osborn, mite Cope, Miocän, Colorado persistens Osborn. Untermiocän Europa A. lemanense Pomel, Mittelmiocän platyodon Mermier, Obermiocän tetra. 
dactylum Lartet, Unterpliocän, incisivum Kaup. Im Unterpliocän von Samos A. samium, Schlosseri Weber, im Pliocän der indischen Siwalik und in China A. Blanfordi Lydekker, von Maragha A. Persiae Pohlig.

Diceratherium Marsh. $\frac{1.0 .4 \cdot 3 .}{2.0 .4-3.3 .}$ Kleine Tiere, dolichocephal. Nasenbeine mit zwei kleinen, seitlichen Hornpolstern. $P$ fast stets $M$ ähnlich. In Europa im Oligocän D. Zitteli Schlosser, im Mittelmiocän D. Douvillei Osborn, im Obermiocän D. steinheimensis Jaeger. In Nordamerika im Oligocän D. proavitum Hatcher, im Untermiocän (John Daybed) D. armatum, namum Marsh, D. Cooki, niobrarense Peterson.

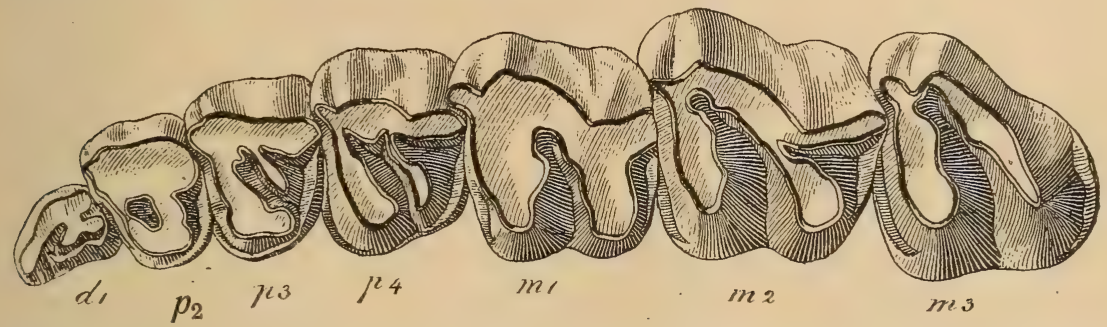

Fig. 627. Aceratherium platycephalum Osborn. Oligocän. White Riverbed. Obere Backenzähne. $1 / 2$ nat. Gr. (Nach Osborn.)

Brachypotherium Roger. $\frac{1.0 .4 .3 .}{1.0 .3 .3 .}$ Brachycephal, brachyodont. $J^{1}$ und. $J_{2}$ sehr kräftig. Obere $P$ und $M$ nur mit Antecrochet. $P$ einfacher als $M$. Schädel hornlos, Extremitäten kurz und plump. In Europa im Mittelmiocän $B$. aurelianense Nouel, im Obermiocän B. brachypus Lart., im Unterpliocän B. Goldfussi Kaup. In Ostindien B. perimense Lydekker.

Teleoceras Hatcher (Fig. 629) $\frac{1.0 .4 .3 .3 .}{1.0 .3-2.3 .}$ Brachycephal mit kleinem Horn an der Nasenspitze und Aphelops, Peraceras (Cope) ebenso, jedoch ohne Horn. Backenzähne bei beiden mehr oder weniger hypselodont. Extremitäten überaus kurz und plump, so daß der Habitus des Tieres eher einem Hippopotamus als einem Rhinoceros gleicht. Im Miocän A. megalodus Cope, im Unterpliocän Teleoceras fossiger Cope. Stammvater dieser nordamerikanischen Gattungen ist wohl Brachypotherium. Ceratorhinus Gray, Dihoplus Brandt (Fig. 628), mäßig do-

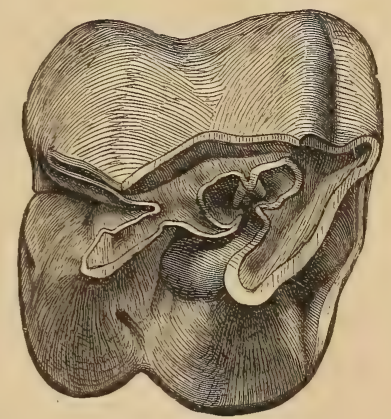

Fig. 628 .

Rhinoceros (Ceratorhinus) Schleiermacheri Kaup. Unterpliocän Eppelsheim. Oberer Nolar. $2 / 3$ nat. Gr.

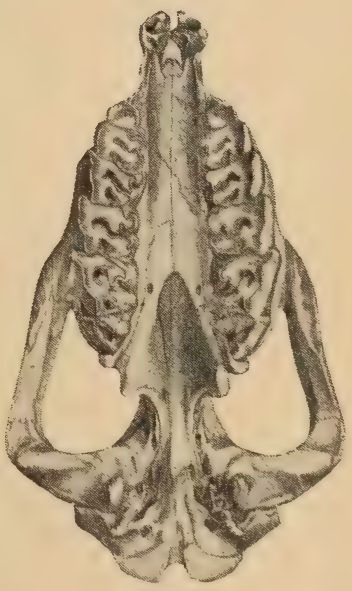

Fig. 629 .

Teleoceras fossiger Cope. Obermiocän. Kansas. Schädel ron unten." 1/10 nat. Gr. (Nach

lichocephal. $\frac{2-0.0 .4 .3 \text {. }}{1-0.0 .3 .3}$. Oberer $J^{1}$ und unterer $J_{2}$ ähnlich wie bei Aceratherium, zuweilen noch ein oberer $J^{2}$ vorhanden. $P$ häufig $M$ ähnlich und wie diese mit Crochet, Crista und Antecrochet. Alle $P$ und $M$ brachrodont. Nasenbeine lang, mit Hornpolster, ein zweites zuweilen auf den Stirnbeinen. Die jüngeren Arten verlieren die $J$, dagegen entwickelt sich ein knöchernes Nasenseptum. Im Untermiocän C. tagicis Roman. Im Obermiocän C. san- 
saniensis und simorrensis Lartet, im Unterpliocïn C. Schleiermacheri Kaup. Im Pleistocän von Niederösterreich C. hundsheimensis Toula. Lebend C. sumatrensis. Rhinoceros s. str. Gray (Zalabis Cope) $\frac{1.0 .4 \text {. 3. }}{1.0 .3 .3 .}$ Backenzähne häufig hochkronig. Schädel mit nur einem Horn. Occiput vorwärts geneigt. Processus postglenoideus und posttympanicus unten verwachsen. Lebend in Südindien ( $R$. sondaicus Horsf.) Fossil in den Siwalikschichten, Rh. palaeindicus und sivalensis Falc., und im Pleistocän von Ostindien und Borneo.

Diceros Gray (Atelodus Pomel) (Fig. 630). 0.0.4.3. Occiput nach hinten geneigt. Processus postglenoideus und posttympanicus unten frei.

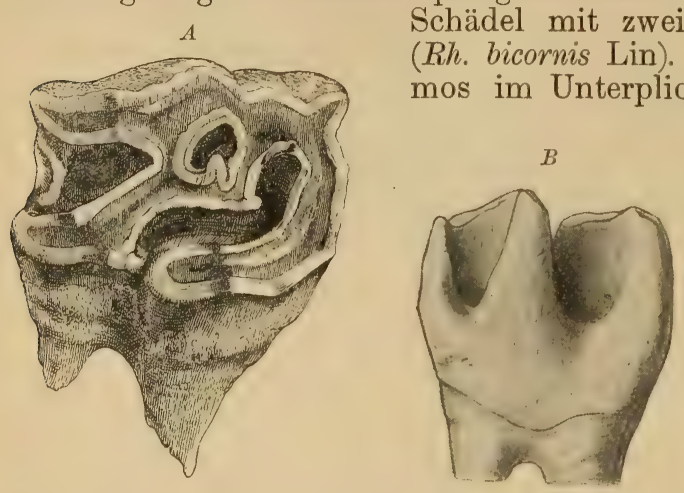

Fig. 630 .

Rhinoceros (Coelodonta) antiquitatis Blumb. A Oberer Molar. Pleistocän. Kent's Höble bei Torquay. $2 / 3$ nat. Gr. (Nach Owen.) $B$ unterer Molar von innen. $1 / 2$ nat. Gr.

Hörnern. Lebend in Afrika Fossil in Europa und auf Saän $R h$. pachygnathus Wagn., in Persien (Maragha) Rh. Morgani Mecquenem, im Mittelpliocän Rh. leptorhinus Cuv., (Rh. megarhinus Christol), im Pleistocän von Ostindien $R h$. deccanensis Lyd. und von China Rh sinensis Owen. Zweifelhaft ist die Stellung von $R h$. platyrhinus Lyd. aus den Siwalikschichten und von $R h$. $H a$. bereri Schlosser von China. Coelodonta Bronn. 0. 0. 4. 3. Nasenbeine groß, durch eine knöcherne Scheidewand gestützt. Occiput nach

hinten geneigt. Je ein Horn auf Nase und Stirne. Im Oberpliocän und im ältesten Pleistocän von Europa $R h$. etruscus Falconer, im Pleistocän von Europa und Nordasien Rh. Mercki Jäger (in China durch Rh. simplicidens Koken ersetzt) und Rh. antiquitatis Blumb. (Rh. tichorhinus Fisch.) In Sibirien hat man zwischen dem Jenisei und der Lena Leichen von Rh. Mercki und antiquitatis im gefrorenen Boden gefunden, die noch mit Wollhaar bekleidet waren. Die Vertiefungen der Backenzähne enthielten noch Futterreste (Coniferennadeln und Weidenblätter). Rh. Mercki, der Nachkomme von etruscus, erlosch bereits vor Ende des Pleistocäns, und erst nach ihm wird $R h$. antiquitatis häufig, der wahrscheinlich von Rh. platyrhinus abstammt. $R h$. etruscus geht vermutlich auf Schleiermacheri zurück.

\section{Unterfamilie. Elasmotheriinae.}

Schädel langgestreckt, mit zugespitzter Schnauze und großer halblugeliger Protuberanz auf dem Stirnbein: Nasenbeine schmal, nur an der Spitze mit einer kleinen Rauhigkeit versehen. $\frac{0.0 .2 .3 .}{0.0 .2 .3 .}$ Ohne $J$ und C. Backenzähne prismatisch, wurżellos. Obere $M$ aus Außenwand und zwei schiefen Jochen, untere $M$ aus zwei eckigen Halbmonden bestehend. Schmelz stark gekräuselt. P einfacher und kleiner als M. Skelett plump. Vorder- und Hinterfuß dreizehig.

Elasmotherium Fischer. Die einzige Art (E. sibiricum Fischer) im älteren Pleistocän von Südrußland und Sibirien, sehr selten auch im Rheintal.

\section{Familie. Equidae.1)}

Nasenbeine frei vorragend, vorne zugespitzt, hornlos. Gebiß $\frac{3.1 .4-3.3 .}{3.1 .4-3.3 .}$ $J$ meißelförmig, $C$ stets kräftiger als die $J ; P$ bei den geologisch älteren Formen

1) Burmeister $H$., Die fossilen Pferde der Pampasformation. Buenos Aires 1875. Suppl. 1889. - Cope E. D., Proceed- Amer. Philos. Soc. 1889. XXVI. - 
einfacher, bei den jüngeren gleich $M$. Obere $M$ aus zwei in der Regel zu einer. Außenwand verbundenen Außenhöckern, zwei Innenhöckern und meist zuei konischen oder leistenartig verlängerten oder halbmondförmig gebogenen Innenhöckern bestehend. Zwischen- und Innenhöcker meist jochartig verbunden. Untere II bei den primitivsten Formen praktisch vierhöckerig, in der Regel aber aus zwei $V$-oder halbmondförmigen, nach imnen geöffneten Jochen zusammengesetzt. Vorderfuß vier-oder dreioder einzehig, Hinterfuß drei- oder einzehig.

Die Equiden bilden die formenreichste, in ihren Endgliedern am meisten spezialisierte Familie der Perissodactylen. Sie beginnen im älteren Eocän und gipfeln in der jetzt noch lebenden Gattung Equus. Wie groß nun auch der Unterschied zwischen einem Pferd und den kleinen vierzehigen eocänen Anfangsformen sein mag, so sind doch die einzelnen Gattungen der Equidenreihe morphologisch aufs engste miteinander verbunden. Die Unterfamilien der Hyracotheriinae, Anchitheriinae und Equinae weichen bloß durch graduelle Unterschiede voneinander ab und stellen lediglich zeitlich getrennte Entwicklungsstufen dar. Nur die bald erlöschende Unterfamilie der Palaeotheriinae nimmt eine gesonderte Stellung ein.

Der Schädel ist langgestreckt, niedrig, die Stirne breit, das Gehirn groß und stark gefaltet. Die hornlosen zugespitzten Nasenbeine ragen frei über die zuweilen weit zurückreichende Nasenöffnung vor, welche unten vom Ober- und Zwischenkiefer begrenzt wird. Die Orbiten sind bei den älteren Gattungen groß, hinten offen, bei den jüngeren kleiner und ringsum knöchern begrenzt. Lacrimalia ausgedehnt. Processus postglenoidalis und paroccipitalis wohl entwickelt.

Sämtliche Equiden besitzen oben und unten jederseits drei $J$, einen $C$ und sieben oder sechs Backenzähne. Das Diastema zwischen den $C$ und $P$ vergrößert sich bei den jüngeren Formen infolge von Verlängerung der Gesichtsknochen. Die anfänglich kurzen, brachyodonten Zähne werden prismatisch, hypselodont, und die anfangs einfacheren $P$ bekommen den Bau der $\boldsymbol{M}$. Die oberen $M$ besitzen vier Haupthügel, zwei äußere und zwei innere von V-förmiger Gestalt und in der Regel kleine Zwischenhöcker. Bei den älteren Formen sind die Außenhügel von den Innenhügeln getrennt und nur die letzteren mit den $\mathrm{Zwischenhügeln} \mathrm{durch} \mathrm{schwache} \mathrm{Leisten}$ verbunden. Bei weiterer Entwicklung vereinigen sich nicht nur die Außenhöcker zu einer W-förmigen Außenwand, sondern auch die Innen- und Zwischenhügel zu schrägen Jochen. Die Außenwand besitzt drei Vorsprünge, am Vorderaußeneck, Parastyl, in der Mitte, Mesostyl, und am Hinteraußeneck Metastyl. Von den oberen $P$ ist der vorderste klein und einfach. Er fehlt niemals bei den eocänen Formen, bei den jüngsten verschwindet er in der Regel vollständig. Die hinteren $P$ sind bei den älteren Formen trituberkulär, bei den späteren werden sie nacheinander, vom hintersten beginnend, den $\Psi$ gleich. Die $P$ des Unterkiefers eilen in der Molarisierung denen des Oberkiefers etwas voraus. Bei Hyracotherium stehen die vier konischen Höcker einander paarweise oder alternierend gegenüber und bleiben ent-

Depéret Ch., Revion des Hyracotheridés européens. Bull. soc. géol. de France 1901. - Douglass E., Annals of the Carnegie Mus. Vol. IV 1908. - Gidley F. W., Bull. Amer. Mus. Nat. Hist. New York 1901. 1903. - Granger W, Bull. Amer. Mus. Nat. Hist. New York 1906. - Huxley Th., Adress delivered at the anniv. meet. of the geol. Soc. Quart. journ. 1870. - Kowalewsky W., Sur l'Anchitherium et sur l'hist. palaeont. des Chevarux. Mem. de l'Acad. St. Petersb. 1873. - Major C. Forsyth, Beitr. zur Geschichte der Pferde, insbesonders Italiens. Abh. Schweiz. pal. Ges. IV. 1877. VII. 1880. - Marsh O. C., Amer. Journ. Sc. 1879. XVII. 1892 XI. III. - Matthew W. D., Suppl. to Amer. Museum Journal. New York 1903. Mattherc W. D. and Gidley J. W., Bull. Amer. Mus. Nat. Hist. New York 1906. Nehring A., Fossile Pferde aus deutsch. Dilluvialabl. Berlin 1884. - Scott W. B., On the Osteology of Mesohippus. Journ. of Morphology 1891. V. 3. - Wortman J. L., Bull. Amer. Mus. Nat. Hist. New York 1896. 
weder isoliert oder sind nur durch undeutliche Querjoche verbunden. Bei allen jüngeren Equiden sind die Backenzähne lophodont und zwar die unteren selenolophodont. Den $P$ gehen drei oder vier $D$ voraus, von denen schon bei den ältesten Formen der hinterste stets und der vorletzte nahezu die Zusammensetzung eines Molaren besitzt. Der Komplikation der $P$ eilt die Molarisierung der $D$ immer um einen Zahn voraus, jedoch werden sie niemals hypselodont wie die $P$ und $M$.

Die Extremitäten sind bei den ältesten Formen gedrungen, bei den jüngeren schlank und lang. Die Knöchelchen der beiden Carpalreihen alternieren miteinander. Das ursprünglich kleine Os magnum verbreitert
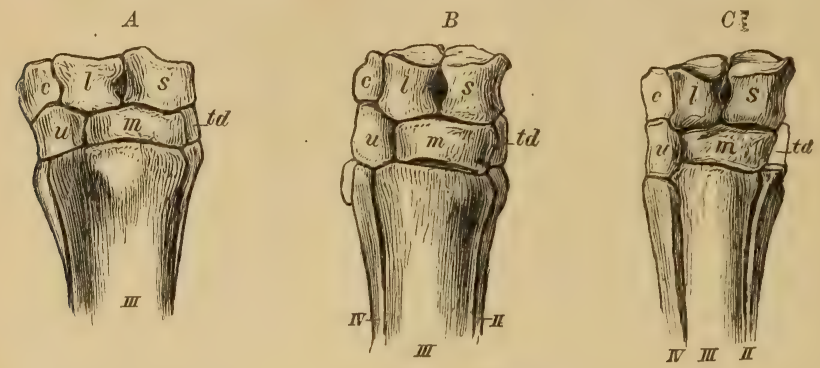

$D$

Fig. 631 .

Carpus und Metacarpus von A Equus, B Hipparion, C Anchitherium, $D$ Palaentherium. $c$ Cuneiforme, $l$ Lunare, $s$ Scaphoideum, $u$ Unciforme, $m$ Magnum, $t d$ Trapezoid, $I I$-V Metacarpalia $I I, I I I, I V$ und $V$.
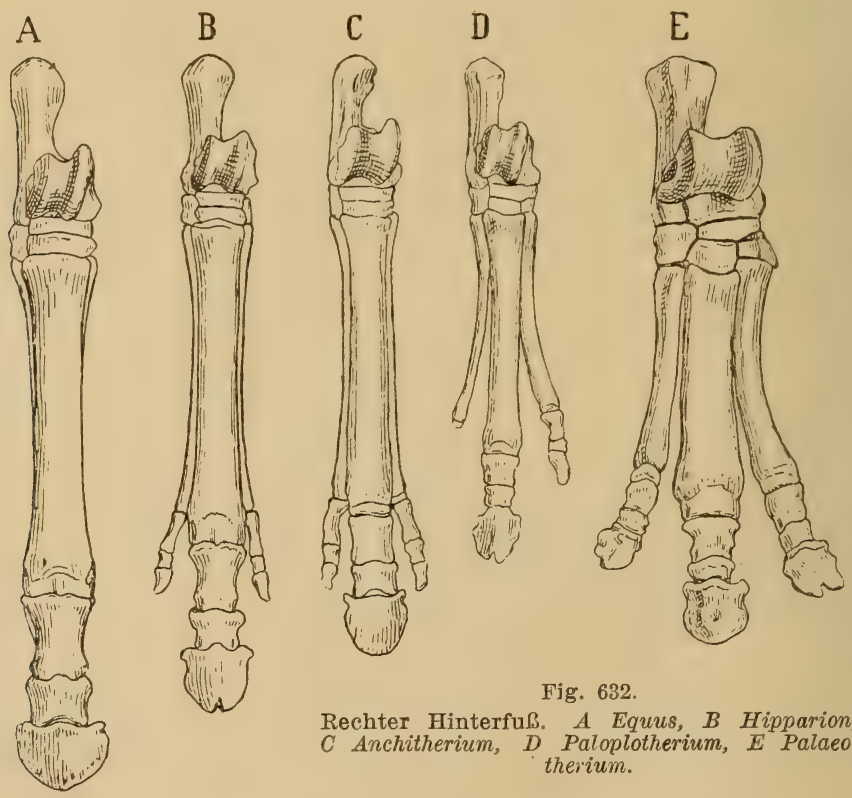

Fig. 632 .

Rechter Hinterfuß. A Equus, B Hipparion, $C$ Anchitherium, D Paloplotherium, E Palaeotherium.

sich bei den jüngeren Formen, drängt das Trapezoid nach innen und stützt gleichmäßig das Lunare und Scaphoideum. Die primitivsten Gattungen haben vier Metacarpalia. Bei Anchitherium gewinnt das Mc III infolge der Ausdehnung des Magnum ein starkes Übergewicht über die seitlichen Metapodien, deren Zehen jedoch den Boden noch berühren. Bei Hipparion (Fig. 631) und Protohippus nimmt der Metacarpus an Länge zu, die seit- 
lichen Metacarpalia II und IV sind dünn, aber fast ebenso lang wie $M c$ III, jedoch berühren ihre Zehen nicht mehr den Boden. $M c \mathrm{~V}$ ist nur als winziger Stummel angedeutet. Bei Equus, Hippidium und Pliohippus endlich wandeln sich die seitlichen Metacarpalia in dünne, nach unten zugespitzte Griffelbeine um, die kaum halb so lang sind wie Mc III. Metacarpale III allein besitzt drei kräftige Zehenglieder, von welchen das letzte von einem großen Huf umgeben ist. $M c \mathrm{~V}$ verschwindet vollständig.

Eine ähnliche Umbildung erleiden Tarsus und Hinterfuß (Fig. 632), so daß auch hier als Schlußresultat ein einzehiger Fuß mit zwei schwachen seitlichen Griffelbeinen entsteht. Die Leitkiele am distalen Ende der Metapodien sind anfangs auf die Hinterseite beschränkt, werden dann immer stärker und teilen bei den jüngsten Gattungen das ganze Gelenk in zwei gleiche Teile.

Die Equiden zerfallen in die vier Unterfamilien der Hyracotheriinae, der Palaeotheriinae, der Anchitheriinae und der Equinae, welche jedoch zum Teil nur Entwicklungsstadien verschiedener Formenreihen darstellen.

\section{Unterfamilie. Hyracotheriinae.}

Orbita hinten offen. $\frac{3.1 .4 .(-3) 3 .}{3.1 .4 .(-3) 3 .}$ Backenzähne sehr niedrig, mit starkem Basalband. $P$ meist einfacher als $M$. Obere $M$ mit vier Haupt- und zwei kleineren Zwischenhöckern, untere $M$ mit vier Höckern. Höcker entweder konisch, oder im Oberkiefer jochartig verbunden und die äußeren im Unterkiefer V-förmig. Radius und Ulna getrennt, gleich stark. Vorderfuß fast stets mit vier, Hinterfuß mit drei Zehen. Eocän von Nordamerika und Europa.

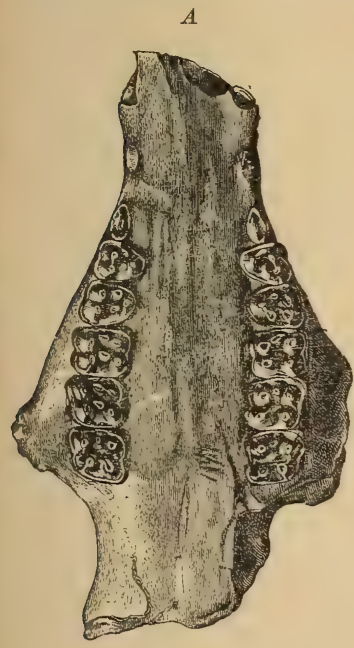

Fig. 633 .

Hyracotherium leporinum Owen. Unt. Eocän (London.clay). Herne Bay. Insel Wight. A Schädelfragment von unten. $B$ zweiter oberer, $C$ erster unterer Molar $2 / 1$ nat. Gr. (Nach Owen.)
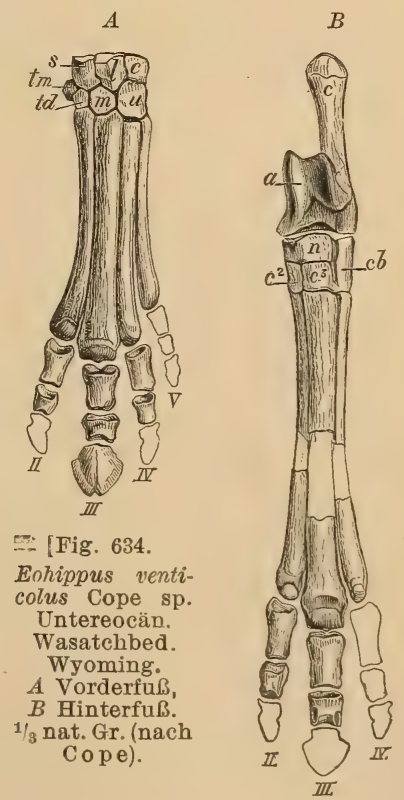

Die Hyracotheriien haben zum Teil noch bunodontes Gebiß. Die konischen Außenhöcker bleiben anfangs noch isoliert, verbinden sich aber bald zu einer mit Parastyl und Mesostyl versehenen Außenwand und bilden dann mit den Zwischen- und Innenhöckern schräge Joche. Die Joche der Unterkieferzähne werden V-förmig. Die $P$ sind fast stets einfacher als die $M I$. Die Hyracotheriinen lassen sich von der fünfzehigen Condylarthrengattung 
Tetraclaenodon. (Euprotogonia) ableiten, welche somit den Ausgangspunkt der Equiden darstellt. Sie hat jedoch nur für die nordamerikanischen Formen phylogenetische Bedeutung, weil nur sie mit einem für jene charakteristischen Hypostyl, dem Höcker inmitte des Hinterrandes der oberen $M$, versehen sind. Auch sind nur von ihnen die Extremitäten bekannt, weshalb auch die Zugehörigkeit der europäischen Gattungen wenigstens von Pachynolophus, Lophiotherium, Anchilophus und Propalaeotherium zu den Hyracotheriinen nur provisorisch sein kann. Die letzte der vier Gattungen gehört wohl schon zu den Palaeotheriinen, Anchilophus vielleicht zu den Anchitheriinen. Paloplotherium hingegen wird wegen der Einfachheit der $P$ zu den Hyracotheriinen gestellt, obwohl der Vorderfuß nur dreizehig ist.

Hyracotherium Owen (Pliolophus Owen). (Fig. 633.) Alle $P$ einfacher als die $M$. Höcker der $M$ und $P$ höchstens zu undeutlichen Jochen
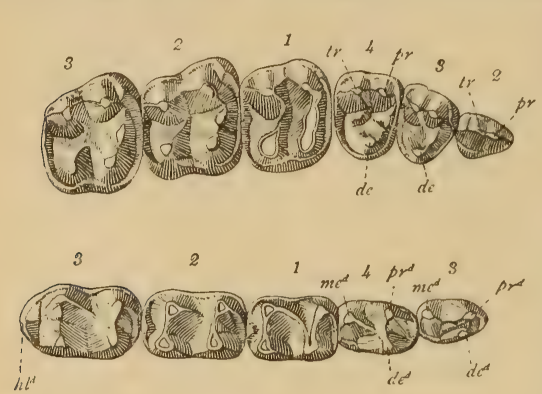

Fig. 635.

Eohippus tapirinus Cope. Untereocän. Wasatchbed. Wyoming. $A$ obere, $B$ untere Backenzähne. Nat. Gr. (nach Wortman.) verbunden. Unterer $M_{3}$ mit unpaarem Hinterhöcker. Untereocän. England. H. leporinum Owen.

Propachynolophus Depéret. $M$ weniger bunodont als bei Hyracotherium. Untereocän Reims. Erquellines (Belgien). P. Maldani, Gaudryi Lemoine sp.

Eohippus Marsh (Orotherium, Hyracotherium Cope, Protorohippus Wortman). (Fig. 634, 635.) $M$ deutlich lophodont. Obere $P$ einfacher als $M$. Extremitäten schlank, ziemlich lang, digitigrad. Metacarpale $\mathrm{V}$ viel kürzer als Mc II. Untereocän Wasatch und Wind Riverbed. Nordamerika. Eohippus venticolus, index etc. Cope.

Pachynolophus Pomel. Obere $M$ mit zwei pyramidalen Außenhöckern, mit schwachem Parastyl und Mesostyl und zwei nahezu konischen Innenhöckern nebst zwei Zwischenhöckern. $P_{4}$ in beiden Kiefern fast $M$-artig. Untere $M$ mit zwei eckigen Außenmonden, deren Enden hohe Spitzen bilden. Im Mitteleocän von Frankreich, Belgien und in Schweizer Bohnerzen. P. Prevosti Gervais.

Orohippus Marsh (Oligotomus, Helotherium, Hyracotherium Cope) wie Pachynolophus, jedoch obere $M$ mit Hypostyl. $P_{4}$ mehr oder weniger $M$-artig. Mitteleocän. Bridgerbed. O. pumilus Marsh, osbornianus Cope.

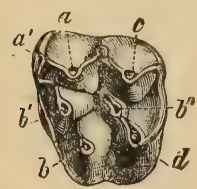

Fig. 636.

Lophiotherium cervulum Gervais. Obereocän. Pbosphorite von Quercy. Oberer Molar. $3 / 2$ nat. Gr.

Epihipp us Marsh, ähnlich Orohippus, $P$ aneinanderschließend, $P_{3}$ und $P_{4} M$-artig. Vorderfuß vierzehig. Obereocän. Uintabed. E. gracilis Marsh.

Lophiotherium Gerv. (Pachynolophus Pictet, Tapinodon v. Meyer (Fig. 636), die beiden hinteren $P$ M-artig. Höcker und Halbmonde dick. Obereocän. Frankreich, Schweiz. L. cervulum Gervais.

Propalaeotherium Gervais. Obere $M$ ähnlich wie bei Pachynolophus, aber meist größer. $P^{4}$ trituberkulär, auch unterer $P_{4}$ etwas einfacher als $M$. Am vorderen Halbmond der unteren $M$ ist der vordere Schenkel etwas verkümmert. Innenhügel plump, vorderer zweispitzig. Mittel-

eocän von Frankreich. $P$. argentonicum und isselanum Gervais, die letztere Art auch in den Schweizer Bohnerzen, hier auch das kleine P. parvulum Laurillard.

Anchilophus Gervais. Die beiden letzten $P M$-artig. Obere $M$ viel breiter als lang. Erster Innenhöcker der unteren $P$ und $M$ dick, zweispitzig. Obereocän Frankreich, Schweizer Bohnerze und Phosphorite von Quercy. 
Paloplotherium Owen (Plagiolophus Pomel). (Fig. 637.) Schädel pferdeähnlich. $\frac{3}{3} P$, alle einfacher als die $M$, die oberen $P$ dreihöckerig. Obere $M$ etwas länger als breit. Innenenden der Halbmonde an den unteren $P$ und $M$ als hohe Spitzen entwickelt. Backenzähne häufig mit Zement versehen und relativ hochkronig. Carpalia schmal und hoch. Extremitäten dreizehig, schlank, seitliche Metapodien sehr dünn. Häufig im europäischen Obereocän. $P$. annectens Owen, minus Cuv. etc. Selten im Oligocän. Ronzon $P$. ovinum Aymard und in schwäbischen Bohnerzen.
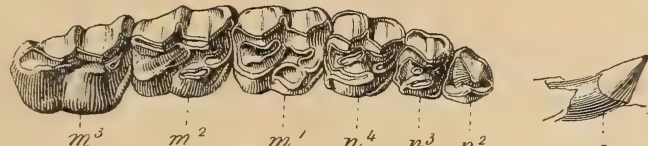

$B$

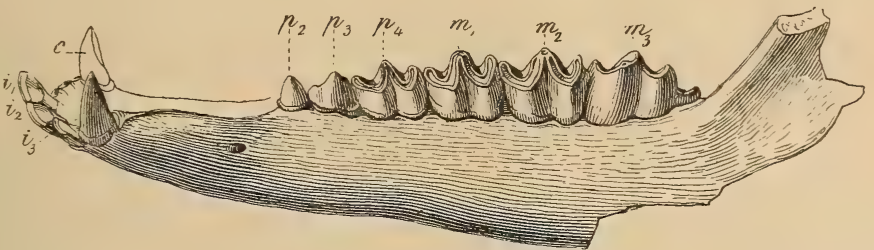

Fig. 637.

Paloplotherium minus Cuv. Ob. Eocän (Lignit). Débruge bei Apt. A Oberkieferzähne, $B$ Unterkieferzähne. $2 / 3$ nat. Gr.

2. Unterfamilie.

\section{Palaeotheriinae.}

\section{Orbitahinten weit} offen. $P$ meistens $M$ artig. Obere $M$ mit Wförmiger Außenwand und zweischrägenQuer- Palaentherium crassum jochen. Parastyl und Cuv. Erster unterer Mesostyl schwach entwickelt. Die zusammenstoßenden Innenenden der beiden Halbmonde der unteren $M$ bilden eine einfache Spitze. $M_{3}$ mit drittem Halbmond. Extremitäten relativ kurz und dick. Vorder- und Hinterfuß dreizehig. Seitenzehen nur wenig schwächer als die Mittelzehe. Nur im Eocän und Unteroligocän von Europa.

Palaeotherium Cuvier. (Fig. 638, 639.) Zahl der $P$ oben stets vier, unten meist drei. Extremitäten und Schädel tapirähnlich.

Die Körpergröße dieser artenreichen Gattung wechselt zwischen der von Schwein (P. curtum Cuv.) und der von Rhinoceros ( $P$. magnum Cuv.), die meisten Arten haben die Dimensionen eines Tapirs ( $P$. medium Cuv., Mühlbergi Stehlin), an welchen auch der Schädel und die einzelnen Knochen am ehesten erinnern.

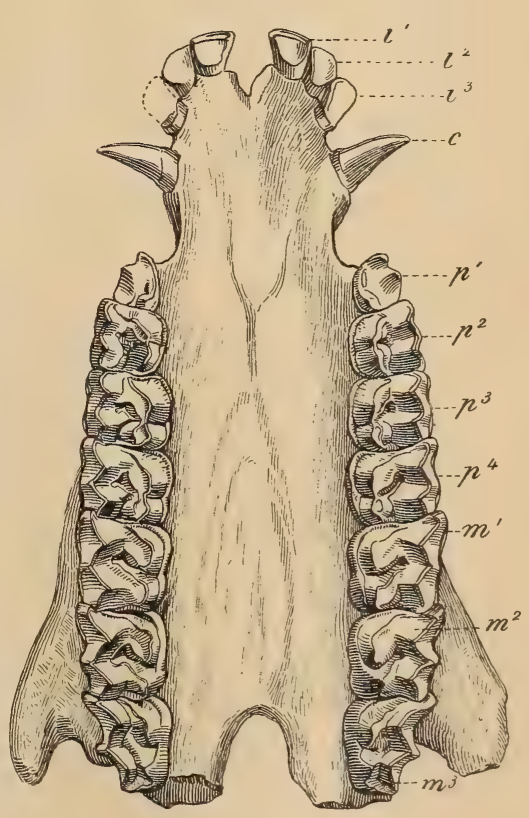

Fig. 639 .

Palaeotherium crassum Cuv. Lignit. Débruge bei Apt. Vaucluse. Unterseite des Schädels mit sämtlichen Zähnen. $1 / 2$ nat. Gr. 
Die Molarisierung der $P$ erfolgt hier sehr rasch, jedoch hat eine der ältesten Arten (P. Rütimeyeri Stehlin) sogar noch einen sehr einfachen $P^{4}$. Im Pariser Gips finden sich ganze Skelette, in den Ligniten von Débruge (Vaucluse) verdrückte Knochen und Schädel.

\section{Unterfamilie. Anchitheriinae.}

Orbita hinten offen, zuweilen vollständig knöchern begrenzt. Backenzälne brachyodont. Obere $M$ mit $W$-förmiger Außsenwand und zwei schrägen Querjochen. Parastyl, Mesostyl und Hypostyl wohl entwickelt. Innenenden der Halbmonde deutliche Kegel bildend. Dritter Halbmond des unteren $M_{3}$ stets rudimentür. Radius und Ulna anfangs getrennt. Extremitäten hoch und schlank, dreizehig. Seitenzehen den Boden beriihrend, aber dünner als die Mittelzehe.

Im Oligocän und Untermiocän von Nordamerika, im Mittel- und Obermiocän von Europa und im Unterpliocän von China.

Me so hippus Marsh (Fig. 640, 641). J meißelförmig, ohne Marke. P mit Ausnahme von $P_{1} M$-artig. Zwischenhöcker der oberen $M$ und Hypostyl kräftig entwickelt. Mittlerer Innenhöcker der unteren $M$ undeutlich zweispitzig. Vorderfuß mit griffelartigem Metacarpale V. Oligocän (White Riverbed) von Dakota M. Bairdii Leidy von Schafgröße. Im Untermiocän von Oregon M. equiceps Cope.

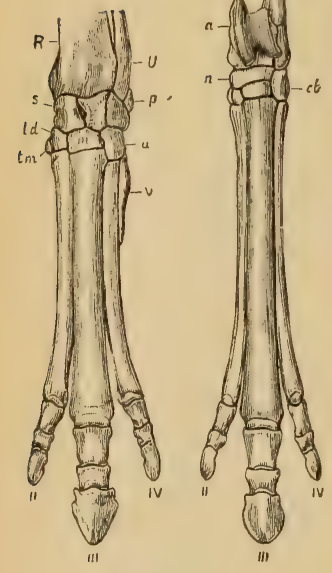

Fig. 640 .

Mesohippus celer Marsh. Unt. Miocän. Dakota. A Vorderfuß, $B$ Hinterfuß, $1 / 3$ nat. $G r$. restauriert (nach Marsh.)

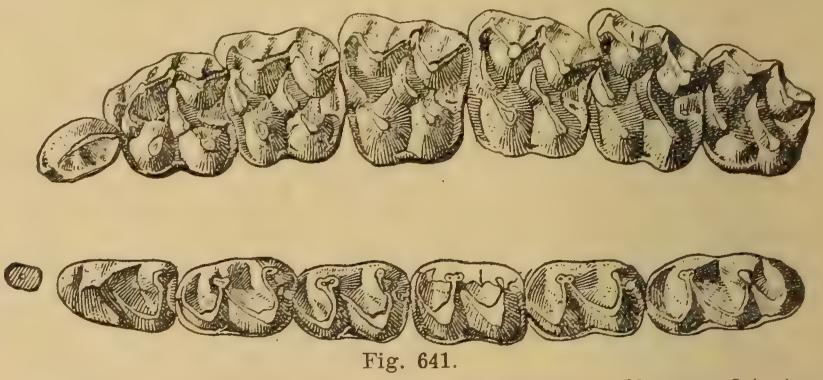

Mesohippus Bairdi Leidy sp. Unt. Miocän. Dakota. Obere und untere Backenzahnreihe, nat. Gr. (Nach Osborn.)

$A$

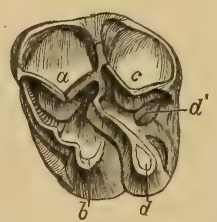

$B$

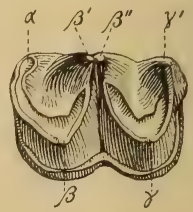

Fig. 642 .

Anchitherium aurelianense Cuv. sp. Miocän. Georgensgmünd. Bayern. $A$ oberer, $B$ unterer Molar $1 / 1$.

Anchitherium v. Meyer (Miohippus Marsh ?). (Fig. 642.) $P$ mit Ausnahme der kleinen $P_{1} M$-artig. Zwischenhöcker der oberen $M$ schmal, jochartig mit den Innenhöckern verbunden. Innenhöcker der unteren $M$ zweispitzig. $J$ mit undeutlicher Marke. Ulna nach unten dünner werdend und distal am Radius angewachsen. Scaphoid und Lunatum unten abgestutzt, beide auf dem breiten niedrigen Magnum ruhend. Unciforme schmal. Metacarpale II und IV viel dünner als Mc III, aber fast ebenso lang und mit drei Zehengliedern. Fibula schwach, griffelartig, mit der Tibia verwachsen. Hinterfuß dreizehig, seitliche Metatarsalia schwach. Die einzige europäische Art, A. aurelianense Cuv. sp. (Palaeotherium hippoides Blv.) 
charakterisiert das Obermiocän von Frankreich, Deutschland und Österreich. In China noch im Unterpliocän $A$. Zitteli Schlosser. In Nordamerika schon im Untermiocän $A$. praestans Cope sp., A. Condoni Leidy. Miocän. Archaeohippus Cope.

Altippus Douglass. $P$ und $M$ schon etwas erhöht. $P^{2}$ gestreckt. Metapodien sehr lang. Mittelmiocän. A. taxus Douglass. Hyp o hippus Leidy. Zähne ähnlich Anchitherium, jedoch etwas höher. Seitenzehen lang. Mittelmiocän. H. equinus Scott sp., affinis Leidy.
Parahippus (Anchippus) Leidy. (Fig. 643.) Obere $J$ mit

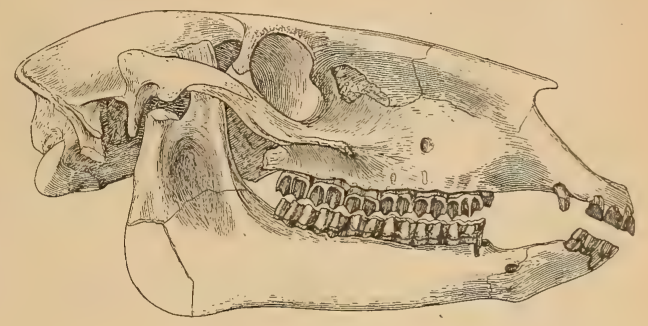

Fig. 643.

Parahippus nebrascensis Peterson. Miocän. Nebraska. Schädel $1 / 4$ nat. Gr. (nach Peters on.) Marken. Zähne mäßig erhöht. Orbita hinten geschlossen. Seitennzehen verkürzt. Mittelmiocän. P. (Desmatippus) crenidens Scott sp., nebrascensis Peterson.

\section{Unterfamilie. Equinae.}

Orbita hinten vollständig geschlossen. Backenzähne hypselodont, meist. mit reichlichem Zement. $P_{1}$ sehr klein, öfters fehlend, die übrigen $P$ M-artig. Obere $M$ mit verlängerten Zwischenhöckern, welche zu je zweien eine Marke bilden. Erster Innenhöcker groß, einem Basalpfeiler ähnlich, zweiter klein. Untere $M$ mit großem als Doppelschleife entwickelten Innenpfeiler an der Vereinigung der beiden Halbmonde. J meißelförmig mit einer durch Einstïlpung des Schmelzes entstandenen Marke. Radius und Ulna verwachsen, letztere in der distalen Hälfte sehr dünn. Vorder- und Hinterfuß drei- oder einzehig, die seitlichen Metapodien dïnn, entweder mit drei kurzen Phalangen versehen oder zu distal zugespitzten Griffelbeinen verkümmert. Leitkiel des dritten Metapodiums über die ganze distale Gelenkfläche reichend.

Fossil in Nordamerika yom Obermiocän bis in das Pleistocän, in Europa, Asien und Nordafrika vom Unterpliocän bis in die Gegenwart, in Südamerika nur im Pleistocän.

Merychippus Leidy. (Figur 644.) $P$ und $M$ mäßig hypselodont, mit viel Zement, Schmelzfältelung der oberen $M$ gering. $D$ brachyodont. Seitenzehen stark verkürzt. Mittel. miocän von Nordamerika. $M$. sejunctus Cope. Obermiocän. $M$. insignis Leidy.

Protohippus Leidy. (Fi. gur $645 D$.) Vorderer Innenhöcker.
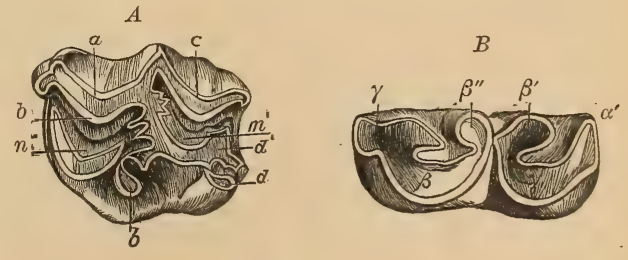

Fig. 644 .

Merychippus mirabilis Leidy. $A$ ob. Milchmolar, $B$ unt. Molar. 1/1. (Nach Leidy.)

Protocon der oberen $M$ mit dem ersten Zwischenhöcker verbunden. Fältelung des Schmelzes der oberen $M$ gering. $M$ mäßig hypselodont. Vorderund Hinterfuß dreizehig. Seitenzehen kurz. Obermiocän von Nordamerika. P. perditus, placidus, mirabilis Leidy. Pliocän. P. Cumminsi Cope.

Pliohippus Marsh. Wie vorige Gattung. Seitenzehen zuweilen ohne Phalangen. Pliocän Texas. P. simplicidens Cope.

Hipparion Christol (Hippotherium Hensel). (Fig. 645B). J mit Marke, $C$ bei beiden Geschlechtern vorhanden. Backenzähne hypselodont, aber niedriger als beim Pferd. $P^{1}$ klein, hinfällig, $P^{2}$ dreieckig, länger als die 
im Querschnitt quadratischen $P$ und $M$. Protocon der oberen $P$ und $M$ einen isolierten, im Querschnitt ovalen oder kreisrunden Pfeiler bildend. Schmelz an den Marken stark gefältelt. Innenenden der Halbmonde der unteren $P$ und $M$ als aneinanderstoßende langgestreckte Schleifen entwickelt. Zement der $P$ und $M$ sehr dick, an den $D$ dünn. Untere $D$ mit Außenpfeiler. Schädel etwas niedriger als beim Pferd. Vor dem Tränenbein eine lange, unten von der Crista maxillaris begrenzte Grube. Extremitäten dreizehig. Seitenzehen dünn, die Endphalange weit vom Boden abstehend. Körpergröße etwa zwischen der von Esel und Zebra. Hipparion lebte in Rudeln und die im Unterpliocän von Europa allenthalben verbreiteten und überaus häufigen Überreste von $H$. gracile Kaup (mediterraneum Hensel) gehören zu den wertvollsten Leitfossilien. Außer Europa kommt diese Art auch auf Samos, bei Troja und bei Maragha sowie in Ägypten und in Algier vor. In China ist sie vertreten durch $H$. Richthofeni Koken, in den indischen Siwalikhügeln durch $H$. antilopinum Falc. und Theobaldi Lyd. In Südrußland und auf Samos existiert neben ihr auch das kleine $H$. minus Pavlow. Im Mittelpliocän von Roussillon $H$. crassum Gervais.
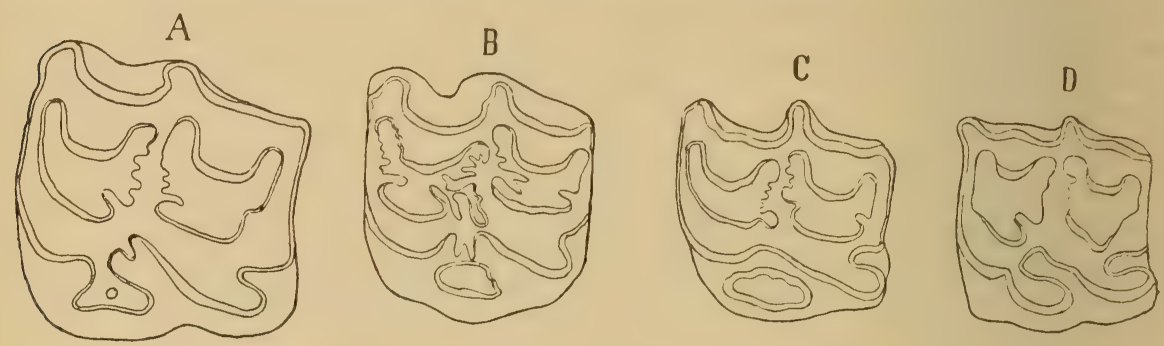

Fig. 645 .

Oberer Molar von A Equus Stenonis Cocchi, B Hipparion gracile Kaup, $C$ Neohipparion dolichops Matthew, D Protohippus sp.

Neohipparion Gidley. (Fig. 645 C). Gebiß ähnlich Hipparion, jedoch Schmelzfältelung schwächer, und Protocon der oberen $P$ und $M$ elliptisch wie bei Equus. Seitenzehen etwas stärker reduziert. Nur in Nordamerika. Obermiocän. Pliocän. N. occidentale, gratum Leidy, niobrarense Gidley.

Hippidium Owen (Rhinippus Burmeister). Backenzähne ohne Fältelung, sehr ähnlich denen von Protohippus, sehr niedrig und die oberen stark gekrümmt. Beide Innenhöcker der oberen $P$ und $M$ fast gleichgroß. Nasenbeine ungemein lang, Nasenausschnitt erst oberhalb $M^{3}$ endend. Metapodien kürzer und gedrungener als bei Equus. Seitenzehen nur als Griffelbeine entwickelt. Unteres Pleistocän. Südamerika.

Onohippidium Moreno wie Hippidium, jedoch mit langer tiefer Grube vor dem Tränenbein. Pleistocän. Südamerika.

Equus Lin. (Fig. 645A). J mit Marke. Backenzähne stark hypselodont. $P^{1}$ klein, stiftförmig. Schmelzfältelung viel schwächer als bei Hipparion. Erster Innenhöcker viel größer als der zweite und langelliptisch, jedoch ebenfalls mit dem entsprechenden Zwischenhöcker verbunden. Zementbelag dick. Vorderfuß ohne Trapezium und ohne Rudiment von $M c$ VDie seitlichen Metapodien als kurze, unten zugespitzte Griffelbeine endend. Zuweilen finden sich jedoch Individuen, bei welchen, wie bei Hipparion, sie $\mathrm{zu}$ vollständigen Seitenzehen ausgebildet sind. Solche Fälle dürfen nicht verwechselt werden mit Mißbildungen, wie das Marsh getan hat, denn es handelt sich bei den letzteren nur um Verdoppelungen der Mittelzehe, was aus der Anwesenheit eines zweiten Os magnum hervorgeht.

Die Gattung Equus tritt zuerst in Ostindien im Pliocän auf, in China anscheinend sogar zusammen mit Hipparion. In Europa ist die älteste Art 
E. Stenonis Cocchi im Oberpliocän und Altpleistocän, hierauf folgt $E$. süssenbornensis Wüst und zuletzt E. caballus Lin. im Pleistocän von Europa, Nordasien und Nordafrika. Im indischen Pleistocän $E$. namadicus Falc. Fossile Reste von Dschiggetai (E. hemionus) und Esel ( $\boldsymbol{E}$. asinus) sind selten, solche von Zebra kennt man aus Diamantseifen von Südafrika. In Nordamerika ist die Gattung Equus im älteren Pleistocän durch E. intermedius Gidley, complicatus und crenidens Cope, im jüngeren durch $E$ Scotti Gidley, fraternus Leidy etc. vertreten. Die südamerikanische Pampasformation enthält ebenfalls Reste von Equus, E. curvidens Owen, Andium Wagner. Noch vor der historischen Zeit erlosch die Gattung Equus in ganz Amerika. Alle heutigen Pferderassen sind Zähmungsprodukte von altweltlichen Wildpferden.

Über die Abstammung des Pferdes und der übrigen Equiden-Gattungen sind verschiedene Hypothesen aufgestellt worden. Schon Cuvier hatte auf die Verwandtschaft von Palaeotherium und Equus hingewiesen. Huxley bezeichnete Equus, Hipparion, Anchitherium und Paloplotherium (Plagiolophus) als Entwicklungsstufen einer genealogischen Reihe. Durch Kowalewsky wurde eingehend die allmäliche Umformung des Equidenfußes und -Gebisses geschildert, so daß der Stammbaum des Pferdes mit den genannten Etappen gesichert erschien. Die Entdeckung zahlreicher Gattungen in Nordamerika ermöglichte es jedoch, daß Marsh eine weit vollständigere Reihe von Entwickelungsstufen aus nordamerikanischen Formen zusammenstellen und Nordamerika als wirkliche Heimat der Pferde bezeichnen konnte.

Nach dem jetzigen Stand unserer Kenntnis ist der Stammbaum der Equiden etwa:

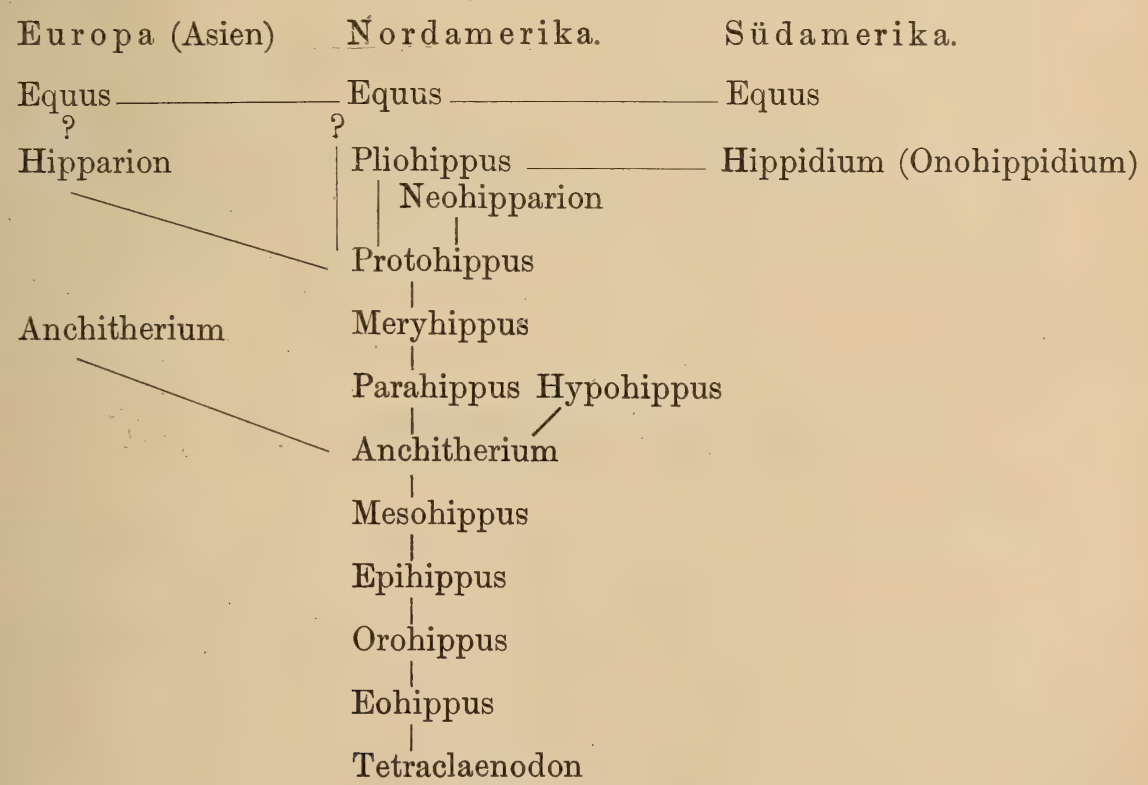

Die europäischen Gattungen Palaeotherium, Paloplotherium, Propalaeotherium, Anchilophus, Lophiotherium und Pachynolophus sind für die Stammesgeschichte der Pferde ohne Bedeutung. Sie treten fast gleichzeitig miteinander auf und haben auch zum Teil die gleiche Lebensdauer. Ihr gemeinsamer Ahne ist etwa in einem Hyracotherium der Fauna von Reims $\mathrm{zu}$ suchen. 


\section{Familie. Titanotheriidae. ${ }^{1}$ )}

Nasenbeine frei vorragend, glatt oder mit zwei Knochenfortsätzen versehen. Orbita hinten offen. $\begin{aligned} & 3-0.1 .4 .3 . \\ & 3-0.1 .4-3.3\end{aligned}$ bei den jüngeren Formen klein, hinfällig, bei den älteren sehr kräftig. Zwischen $C$ und $P$ ein sehr kurzes Diastema. Bei den älteren Formen alle $P$ einfacher als die $M$, bei den jüngeren $P_{3}$ und $P_{4}$ $M$ ähnlich. Obere $M$ mit $W$-förmiger Außenwand und zwei niedrigen konischen Innenhöckern, untere $M$ aus je zwei V-förmigen Halbmonden bestehend. $M_{3}$ mit drittem Halbmond. Vorderfuß vier-, Hinterfuß dreizehig. Hufe mäßsig breit.

Diese völlig erloschene und fast ganz auf das Eocän und Oligocän von Nordamerika beschränkte Familie besteht aus meist sehr großen, plumpen Huftieren, welche in ihrer äußeren Erscheinung teils an Tapir, teils an Rhinoceros erinnern und zuletzt Elefantengröße erreichten. Sie lebten, wie ihr Gebiß vermuten läßt, von saftigen Pflanzen. Die Kronen der Backenzähne sind sehr niedrig. Die oberen $M$ haben zwei Außenhöcker, welche zusammen eine $W$-förmige Außenwand mit Para-, Meso- und Metastyl bilden. Die beiden konischen Innenhöcker stehen meist ganz isoliert; der vordere ist immer größer als der hintere. Die $C$ sind klein, konisch und etwas gebogen und von den $P$ nur durch eine kurze Lücke getrennt. Die kleinen $J$ sind bei den eocänen Formen vollzählig, bei den oligocänen hinfällig. Die hinteren $P$ unterscheiden sich von den $M$ nur durch ihre geringere Größe, die oberen auch durch das Fehlen des zweiten Innenhöckers, die vorderen $P$ sind etwas einfacher. Im Unterkiefer bestehen alle $M$ und $P$ mit Ausnahme des vordersten aus je zwei $V$-förmigen Halbmonden. Der Schädel ist lang und niedrig, das Gehirn klein. Bei den jüngeren
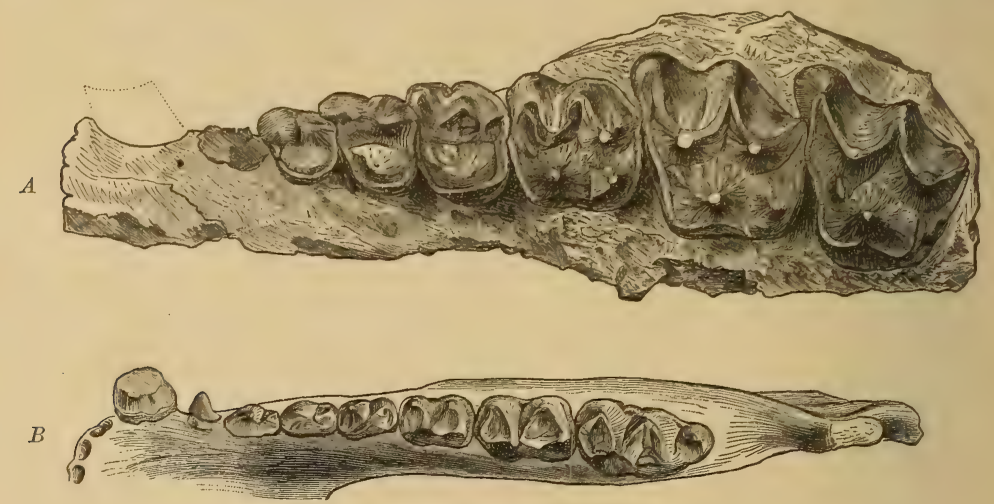

Fig. 646 .

Palaeosyopes major Leidy. Mittel Eocän (Bridgerbed). Green River. Wyoming. A Backenzähne des Oberkiefers, $B$ Unterkiefer.

Formen erheben sich am hinteren Rand der Nasenbeine zwei stumpfkonische Knochenzapfen, die beim Männchen viel größer werden als bei den Weibchen. Die Extremitäten sind denen von Tapir ähnlich, der Carpus breit. Die Carpalia der beiden Reihen stehen alternierend und sind wenig seitlich verschoben. Der Vorderfuß besitzt vier funktionierende, der Hinterfuß nur drei Zehen. Das Calcaneum artikuliert mit der Fibula. Die Endphalangen sind distal abgestumpft und etwas verbreitert.

1) Earle C. H., A Memoir upon the Genus Palaeosyops. Journ. Acad. nat. Sc. Philad. 1892 Vol. IX. - Hatcher J. B., Cranial elements of Titanotherium. Annals Carnegie Mus. 1901. - Amer. Naturalist 1895 p. 1084. - Marsh O. C., Amer. Journ. Sc. 1876 XI. 1889 XXXVII. 1890 XXXIX. - Osborn H. F., Bull. Am. Mus. Nat. Hist. New York 1902, 1908. 
In dieser Familie lassen sich verschiedene sehr vollständig geschlossene Formenreihen feststellen.

\section{Unterfamilie. Palaeosyopinae.}

Sämtliche $P$ einfacher als die M. Drei, selten zwei konische $J$ in jedem Kiefer. $C$ relativ groß. Obere $M$ mit deutlichem $Z$ wischenhöcker. Im Eocän von Nordamerika und von Europa.

Lambdotherium Cope schlankbeinig. Verbindet die Titanotheriiden mit den übrigen Perissodactylen. Untereocän Wyoming.

Palaeosyops Leidy (Limnohyus Marsh). (Fig. 646.) $\frac{3.1 .4 .3 .}{3.1 .4 .3 .}$ C groß, zugespitzt. Obere $P$ dreihöckerig. Vorderfuß vier-, Hinterfuß dreizehig. Häufig im Eocän von Nordamerika.

Limnohyops Marsh. Schädel breit.

Manteoceras Osborn.

Mesatirhinus und Mesorhinus Osborn mit schmalem Schädel. Mittelund Obereocän.

Dolichorhinus Osborn mit gestrecktem Schädel und langer Schnauze. Obereocän.

Telmatherium Marsh (Fig. 647) lange Nasenbeine mit knöchernen Protuberanzen. Obereocän. Uintabed.

Diplacodon Marsh Nasenbeine kurz, öfters mit zwei knöchernen Auswüchsen. Extremitäten plump. Obereocän. Uintabed.
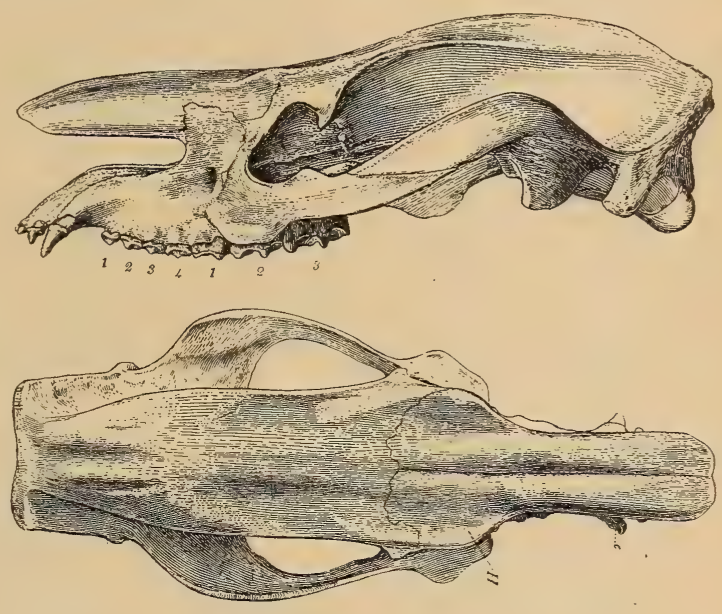

Fig. 647 .

Telmatherium cornutum Osborn. Obereocän. Uintabed. Schädel von der Seite und von oben. 1/8 nat. Gr. (nach Osborn.)

Brachydiastematherium Boeckh und Maty. Mitteleocän Siebenbürgen. Nur Unterkiefer bekannt.

\section{Unterfamilie. Titanotheriinae.}

Ein oder mehrere $P$ den $M$ ähnlich. $J$ mehr oder weniger reduziert. $C$ relativ klein. Im Oligocän von Nordamerika. Einige Zähne auch in Europa gefunden.

$\frac{2-0.1 .4 .3}{2-0.1 \text {. } 4)^{3.3}}$ in geschlossener Reihe, im Milchgebiß $\frac{2.1 .4}{2.1 .4 .} J$ klein, in verschiedener Zahl vorhanden, zuweilen ganz fehlend. $C$ konisch, im allgemeinen klein. $P$ kleiner als $M$, aber ähnlich. An der Grenze der Stirnund Nasenbeine ein paar stumpfe Knochenzapfen, welche bei den jüngsten Gliedern der einzelnen Stammesreihe riesige Dimensionen erreichen.

Von diesen gewaltigen Tieren, welche dem Elefanten nur wenig an Größe nachstanden, hat man zahlreiche Schädel und viele vollständige Skelette im unteren Oligocän, in der unteren Abteilung des White Riverbed von Dakota, Nebraska und Colorado gefunden, welche sich angeblich auf eine große Anzahl von Arten und Gattungen verteilen, deren genauere $\mathrm{Ab}$. grenzung jedoch schon durch sexuelle und Altersdifferenzen erschwert wird. Die Extremitätenknochen sind lang und kräftiger, aber doch etwas schlanker als bei Rhinoceros. 
Protitanotherium Osborn, riesige Form. Nur Unterkiefer bekannt. Obereocän Uintabed.

Titanotherium Leidy (Palaeotherium, Menodus Pomel, Brontotherium, Menops Marsh). (Fig. 649.) Oligocän von Diplacodon stammend.

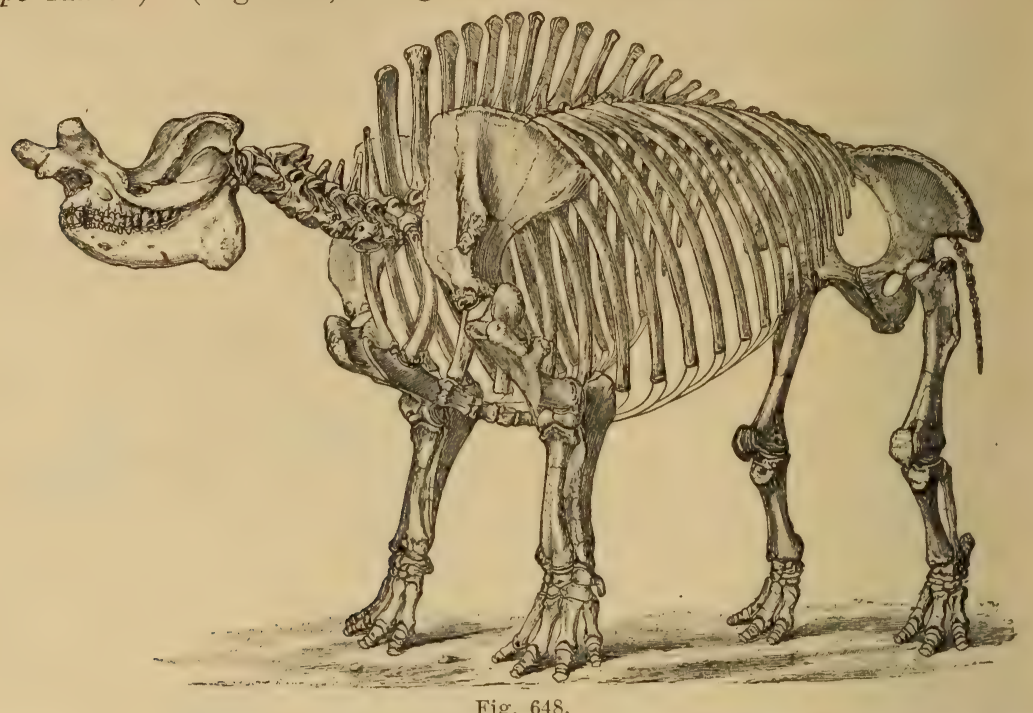

Restauriertes Skelett von Titanotherium. (Brontops) robustum Marsh. Oligociin. Dakota. ca. 1/40 nat. Gr. (Nach Marsh.)
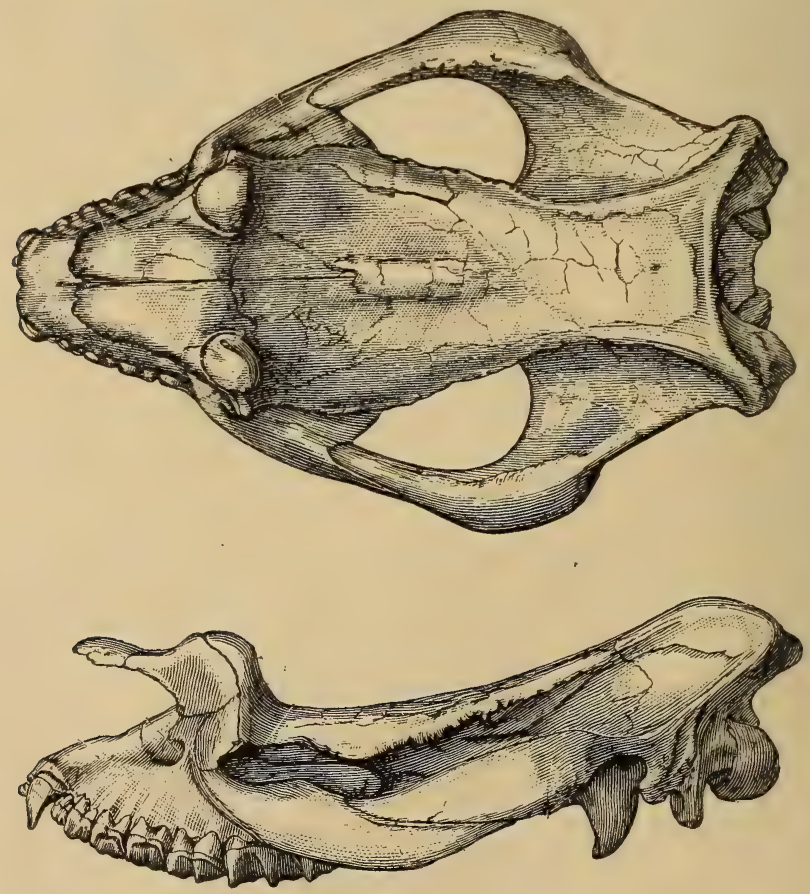

Fig. 649 .

Titanotherium (Brontops) dispar Marsh. Oligocän. Dakota. Schädel von der Seite und von oben, $1 / 8$ nat. Gr. (Nach Marsh.) 

gehend.

Megacerops Leidy (Brontops Marsh) Fig. 648, von Palaeosyops aus-

Allops (Diploclonus) Marsh. Symborodon Cope. Brontotherium (Titanops) Marsh. Mit riesigen Hörnern auf den Nasenbeinen. Ohne $J$.

Als Menodus rumelicus hat Toula einige Zähne aus Rumänien beschrieben.

\section{Familie. Chalicotheriidae. ${ }^{1}$ )}

Vorder- und Hinterfuß dreizehig, semidigitigrad Endphalangen gespalten, krallenförmig. Astragalus niedrig, Femur mit schwachem dritten Trochanter. Nasenbeine lang, frei vorragend. Orbita hinten nicht umgrenzt. $\frac{3-0.0 .3 .3 .}{3-0.1-0.3^{3} .3 .} \mathrm{J}$ und $C$ schwach oder fehlend. $P$ einfacher als die $M$; obere $P$ mit nur einem Außen- und einem Innenhöcker. Obere $M$ mit $W$-förmiger Außenwand und zwei ungleich großen Innenhöckern. Untere $M$, auch $M_{3}$, nur aus zwei $\vee$ förmigen $H a l b$ monden gebildet, deren Enden sich als Spitzen erheben. Im Tertiär von Europa, Nordamerika, im Pliocän von Ostindien und im Pleistocän von China.

Die Chalicotheriiden wurden früher in die Ordnung der Ancylopoda eingereiht, welche außerdem auch die Homalodontotheriidae umfaßte, welche jedoch ganz auf Südamerika beschränkt sind, mit jenen bloß die krallen-

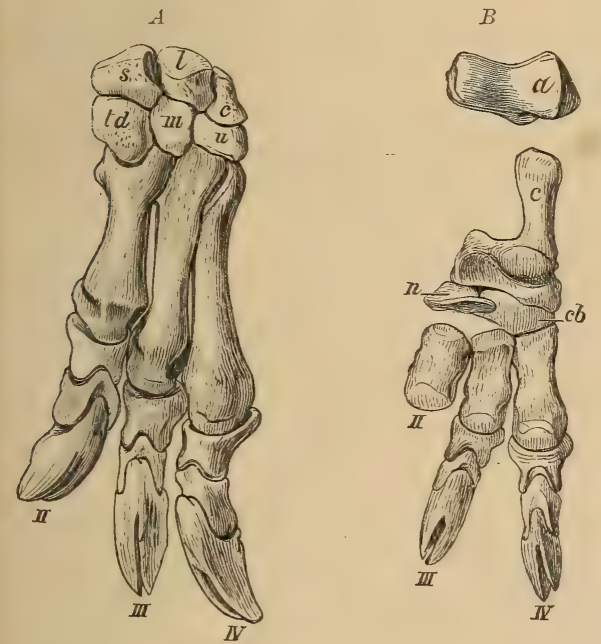

Fig. 650 .

Macrotherium giganteum Gervais. Miocän. Sansan. Gers. A Vorderfuß, $B$ Hinterfuß, $1 / 8$ nat. Gr. $a$ Astragalus, $c$ Calcaneum, $n$ Naviculare, $c b$ Cuboideum. (Nach Gervais.)

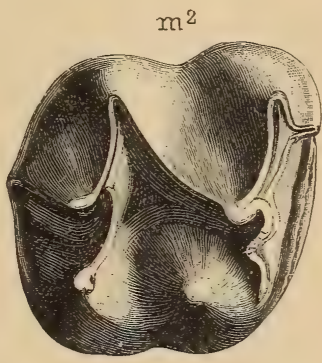

$B$ $\mathrm{m}^{3}$

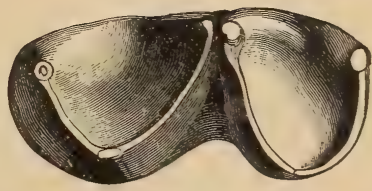

Pig. 651

Chaticotherium Goldfussi Kaup. Unt. Pliocän. Eppelsheim bei Worms. $A$ zweiter oberer Molar. $B$ letzter unterer Molar. $2 / 3$ nat. Gr.

artige Beschaffenheit der Endphalangen gemein haben und im folgenden als Subordnung der Entelonychia besprochen werden. Die Chalicotheriiden hingegen sind, wie das schon aus der Gestalt des Astragalus hervorgeht, unzweifelhaft Perissodactylen, unter welchen ihnen die Titanotheriiden im Zahnbau ungemein nahe stehen. Der Carpus stimmt in der alternierenden Anordnung der einzelnen Knöchelchen mit dem der Perissodactylen überein. Der Tarsus weist Merkmale von Perissodactylen und Condylarthren auf.

1) Depéret Ch., Archiv. Mus. d'hist. nat. Lyon V. 1892. - Filhol H., Mammifères de Sansan. Ann. sc. géol. XXI 1891. - Peterson O. B., American Naturalist
1907. 
Die Körperlast ruht niemals auf der Mittelzehe, sondern auf den äußeren Zehen. Die spitzen Endphalangen können, wie bei den Edentaten, weit zurückgebogen werden. In Europa erscheinen die Chalicotheriiden im Oli gocän und dauern bis ins Unterpliocïn, in Asien sogar bis in das Pleistocän. In Nordamerika sind sie auf Untermiocän und Mittelmiocän beschränkt. Sie sind die Nachkommen der Meniscotheriidae.

Schizotherium (Limognitherium) Gervais, basiert auf Fußknochen, zu welchen die von Gaudry als Chalicotherium modicum beschriebenen Zähne gehören. Oligocän. Phosphorite von Quercy.

Macrotherium Lartet (Anisodon Lartet) (Fig. 650). 3.1.3.3. Zwischen $C$ und $P$ eine Lücke. Vorderbeine länger als Hinterbeine. Endphalangen mäßig gekrümmt. Untermiocän von Ulm (Chalicotherium Wetzleri Kowalewsky) und Obermiocän von Frankreich und Deutschland. Bei Sansan (Gers) fand sich ein vollständiges Skelett, bei La Grive St. Alban (Isère) ein Schädel von $M$. grande Lartet.

Chalicotherium Kaup (Ancylotherium Gaudry). (Fig. 651.) Wie 1/ncrotherium, aber weder obere noch untere $J$ vorhanden. Untere $C$ sehr klein. Unterpliocän. Pikermi, Samos, Eppelsheim, Baltavar, Maragha, Ostindien. Pleistocän von China.

Moropus Marsh. Vorderfuß mit rudimentärem Metacarpale V. Obere $M$ gestreckter als bei Chalicotherium. Untermiocän, Chalicotherium bilobatum Cope - Moropus elatus Marsh -, bis Mittelmiocän von Nordamerika.

\section{Unterordnung. Artiodactyla. Owen. Paarhufer. $\left.{ }^{1}\right)$}

(Paraxonia Marsh.)

Unguligrade oder digitigrade Huftiere mit paarigen Zehen, uovon die beiden mittleren gleichmüßig entwickelt und stärker sind als die öfters stark reduzierten oder verkümmerten seitlichen. Astragalus mit ausgefurchter Trochlea und distaler Gelenkrolle. Hand- und Fußuurzelknochen alternierend. Gebiß vollständig, oder $J$ und C namentlich im Oberkiefer fehlend. Backenzühne bunodont, bunoselenodont oder selenodont. Femur olne dritten Trochanter. Fibula mit Calcaneum artikulierend.

Im Gegensatz zu den im Niedergang begriffenen Perissodactylen bilden die Artiodactylen gegenwärtig die formenreichste, lebenskräftigste und verbreitetste Gruppe unter den Huftieren. Sie kulminieren in den bunodonten Schweinen und den selenodonten Wiederkäuern, die zwar in auffallender Weise voneinander abweichen, aber gleichwohl gemeinsamen Ursprung besitzen. Das entscheidende Merkmal der Artiodactylen beruht in der paarigen Anzahl der Zehen und der Metapodien. Die beiden mittleren (III u. IV), sind stets gleichmäßig entwickelt, die seitlichen schwächer oder ganz verkümmert und die erste Zehe oder der Daumen nur bei einigen wenigen ausgestorbenen Formen (Oreodontidae, Anthracotheriidae) überhaupt vorhanden. Die Körperlast wird von den beiden Mittelzehen getragen, zwischen denen auch die Extremitätenachse verläuft. kurzbeinig.

Die Artiodactylen sind teils schlank und hochbeinig, teils plump und

Der Schädel erinnert bei den primitiveren Formen an Raubtiere und Unpaarhufer, bei den vorgeschritteneren Typen gewinnt er durch Verlängerung

1) Cope E. D., The Artiodactyla. American Naturalist. 1888-89. Vol. XXII XXIII. - Kowalewsky W., Palaeontographica XXII 1873-74. - Stehlin J. H. G., Abh. schweiz. paläont. Gesellsch. XXIII 1906. XXV 1908. XXVII 1910. 
der Gesichtsknochen, durch die Entwickelung von Luftzellen in der Stirnregion, von Stirnzapfen oder Geweihen ein sehr mannigfaltiges Aussehen. Die Tränenbeine nehmen einen relativ großen Raum auf der Schädeloberfläche ein und weisen bei den Wiederkäuern oft ziemlich tiefe Gruben (Tränengruben) zur Aufnahme von Talgdrüsen auf. Die Stirnbeine nehmen stets an der Bedeckung des Gehirns teil und gewinnen zuweilen sehr große Ausdehnung. Bei den Wiederkäuern tragen sie paarige Geweihe oder knöcherne von Hornscheiden umgehene Stirnzapfen. Der Unterkiefer ist bei ihnen lang, schlank und niedrig mit gerade aufsteigendem Kronfortsatz.

Das Gebiß besteht ursprünglich aus 44 Zähnen, die bei den primitivsten Formen eine geschlossene Reihe bilden. Durch Verlängerung der Kiefer oder durch Verkümmerung der vordersten $P$, zuweilen auch der oberen $C$, entstehen Lücken zwischen den Vorderzähnen und den Backenzähnen, die bei den Wiederkäuern am größten sind, weil hier der untere C dicht an die $J$ heranrückt und auch die Gestalt und Funktion eines $J$ erlangt. Reduktion und Verlust der $J$ und $C$ beginnt im Oberkiefer, jedoch sind Spuren der oberen $J$ selbst noch beim Embryo vom Schaf erhalten.

Die Backenzähne sind bei den primitiveren und älteren Formen brachyodont, bei den Wiederkäuern nicht selten prismatisch und häufig mit Zement versehen. Die Krone der unteren $M$ war wohl ursprünglich sechshöckerig, aber von diesen sechs Höckern ist der unpaare Vorderhöcker, Paraconid, und der unpaare Hinterhöcker, Mesoconid, schon sehr frühzeitig verschwunden oder zu einer Basalwarze zusammengeschrumpft und an den oberen $M$ verschmilzt der vordere Zwischenhöcker, Protoconulus, schon sehr bald mit dem benachbarten Innenhöcker, Protocon. Von Mitte des Tertiärs an bestehen die $\Psi$ nur mehr aus je zwei paar opponierten Höckern. Der zweite Zwischenhöcker, Metaconulus, der oberen $M$ ist in den meisten Fällen $\mathrm{zu}$ dem zweiten Innenhöcker geworden, ein wirklicher Hypocon ist nur ausnahmsweise vorhanden und dann immer aus dem Basalband hervorgegangen. Sind die Höcker konisch, so ist das Gebiß bunodont, nehmen sie Vförmige oder halbmondförmige Gestalt an, so wird das Gebiß bunoselenodont oder selenodont. Bei selenodonten oberen $M$ stoßen die Außenhöcker mit ihrer Basis aneinander und entwickeln an der Vereinigungsstelle eine mit vorspringender Vertikalfalte, Mesostyl, versehene Außenwand. Die Innenhöcker sind entweder konisch oder $\vee$ förmig oder sie umschließen, wenn sie als Halbmonde ausgebildet sind, gebogene Marken. Die unteren $M$ unterscheiden sich von den oberen durch ihre geringere Breite. Ihre vier Höcker sind bei den bunodonten Formen konisch und meist deutlich getrennt, jedoch waren auch bei ihnen, wie das bei den selenodonten Formen stets der Fall ist, die Außenhöcker ursprünglich $\bigvee$ förmig. Die Innenhöcker sind bei dieser letzteren Gruppe mehr oder weniger komprimiert und bilden zusammen eine Innenwand. Der letzte untere $M$ hat fast stets einen fünften Höcker oder Halbmond. Völlige Übereinstimmung zwischen $P$ und $M$ kommt bei Artiodactylen fast niemals vor, jedoch können bei Endgliedern mancher Formenreihen die $P_{4}$ in beiden Kiefern den $D$ oder den $M$ ähnlich und die vorderen $P$ ziemlich kompliziert werden. Im ganzen ist das Gebiß der Artiodactylen typisch heterodont und der Bau der $P$ viel einfacher als der der $M$. Auch werden die $P$ im Gegensatz zu den $M$ niemals prismatisch.

Im Milchgebiß weichen die $J D$ und $C D$ nur wenig von ihren Nachfolgern, den $J$ und $C$ ab, dagegen bieten die $D$ größere Mannigfaltigkeit als bei den Unpaarhufern. Der letzte obere $D$ hat die Zusammensetzung eines echten $Y$, der letzte untere $D$ trägt im Gegensatz zu den unteren $M$ drei Paare Höcker oder Halbmonde, ist aber vorne viel schmäler als die $M$. Der obere $D^{3}$ gleicht in seiner hinteren Partie einem halben $M$. vorne setzen sich noch drei Höcker oder Halbmonde an. Die übrigen $D$ sind 
etwas komplizierter als die $P$, aber ihnen doch sehr viel ähnlicher als den $M$.

Das Schulterblatt hat schmale dreieckige Form. Schlüsselbeine fehlen. Der Humerus ist bei den primitiveren Formen lïnger, bei den spezialisierteren aber kürzer als der Radius. Ulna und Radius bleiben entweder getrennt, oder die mittlere Partie der Ulna wird sehr dünn und der distale Teil verschmilat mit dem Radius. Der Carpus enthält dieselben Elemente wie bei den Perissodactylen und zeigt die nümliche seitliche Verschiebung der distalen Reihe, so daß Magnum und Unciforme stets je zwei Carpalia der proximalen Reihe stützen. Bei vorgeschritteneren selenodonten Formen erfolgt Verschmelzung von Magnum und Trapezoid und öfters Verlust des Trapeziums.

Fünf Metacarpalia sind bis jetzt nur bei Oreodontiden und Anthracotheriiden beobachtet worden, doch ist Metacarpale I auch hier klein und stummelartig und trïgt nur bei den Oreodon kurze Phalangen. Die vier übrigen $M I_{c}$ bleiben bei den primitiveren Formen aller Linien und bei den Hippopotamiden und allen Suiden getrennt. Bei den Wiederkäuern verkümmern die seitlichen Metacarpalia und die dazu gehörigen Zehen stecken entweder als kurze Afterklauen frei in der Haut, oder sie gehen vollstïndig verloren. Sind die seitlichen Metapodien griffelartig oder ganz verschwunden, so zeigen die mittleren Neigung, zu verschmelzen. Der so entstehende "Canon « hat jedoch stets zwei Markhöhlen, das distale Ende bleibt gespalten und ist mit zwei Gelenkflïchen versehen. Die Verwachsungsstelle wird äußerlich auf der Vorderseite des Canon durch eine Furche an. gedeutet. Die Lünge der Metapodien bedingt die Lauffähigkeit, sie sind daher bei den Wiederkäuern schlank und lang, bei den Suiden und Hippopotamiden kurz und dick.

Stets übertreffen die zwei gleichgroßen mittleren Metacarpalien (III u. $I V$ ) die beiden seitlichen (II u. V) an Stärke und Länge und zwar um so beträchtlicher, je mehr die Extremitäten zum Laufen und Springen dienen. Die distalen Gelenkköpfe der vorderen und hinteren Metapodien tragen Leitkiele, die namentlich bei den vorgeschritteneren Formen sehr gut entwickelt sind, indem sie sich auch über die ganze Vorderseite erstrecken.

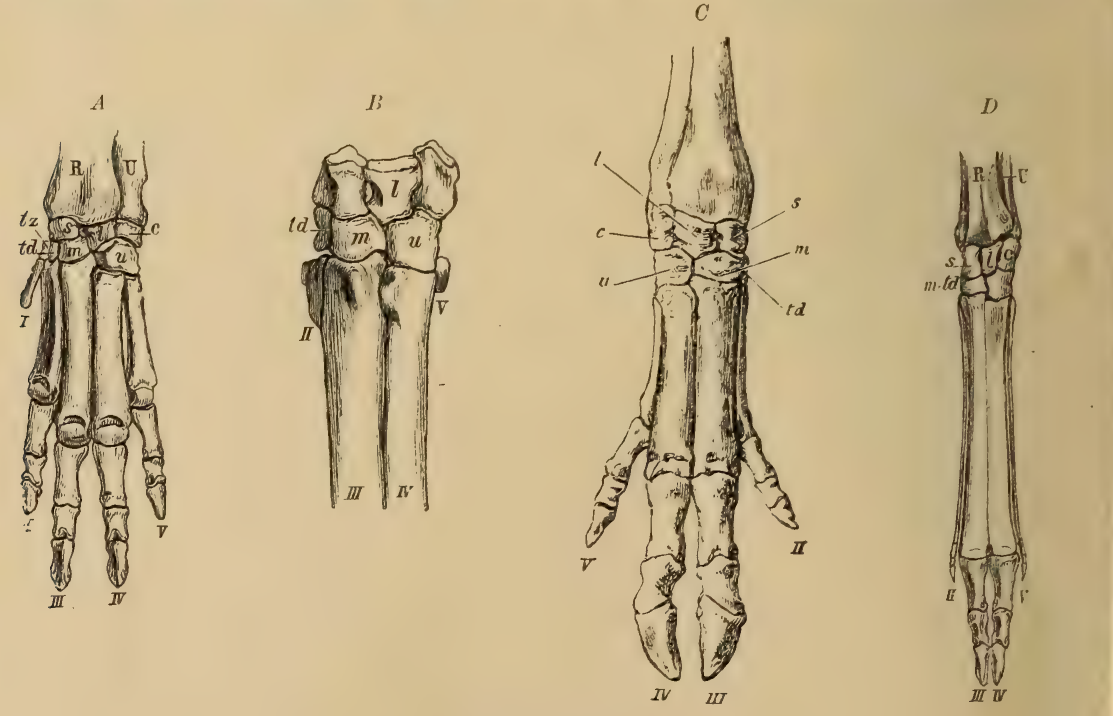

Fig. 652 .

Vorderfuß $A$ von Oreodon, $B$ von Xiphodon mit inadaptiver Reduktion, $C$ von $S u \varepsilon$, $D$ von Tragulus mit adaptiver Reduktion. 
Im ursprünglichen Artiodactylenvorderfuß artikulierte $M c I$ mit dem Trapezium, Mc II mit Trapezium, Trapezoid und Magnum, Mc III mit Magnum und Unciforme und $M c I V$ und $V$ mit dem Unciforme. Diese Anordnung kann festgehalten werden bei Reduktion der Seitenzehen, es behauptet bei dieser von Kowalewsky als sinadaptive Reduktion " (Fig. $652 A B$ ) bezeichneten Umbildung jedes Metacarpale hartnäckig seìnen Platz unter den dazugehörigen Handwurzelknochen, namentlich gilt dies von dem Mc II. Bei der »adaptiven Reduktion « (Fig. 652 CD) rücken die beiden mittleren Metacarpalia fast in gleiche Höhe, ihre proximalen Gelenkflächen breiten sich aus, drängen die seitlichen Metapodien nach außen und hinten und bemächtigen sich ihrer Ansatzstellen am Carpus. Mc II wird von der Verbindung mit dem Magnum ausgeschlossen und artikuliert nur mehr mit dem Trapezium und einem Teil des Trapezoids. Der Fuß erlangt hiedurch größere Festigkeit und Schnelligkeit. Alle noch jetzt existierenden Artiodactylen mit reduzierten Extremitäten gehören in die sadaptive« Reihe.

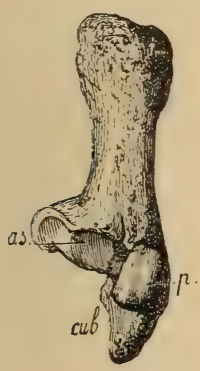

Fig. 653

Calcaneum von Anoplotherium commune von vorne. as Gelenkfläche für den Astragalus, $p \mathrm{Ge}$ lenkfläche für die Fibula, $c u b$ für das Cuboideum, $1 / 3$ nat. Gr. (Nach Gaudry.)
A

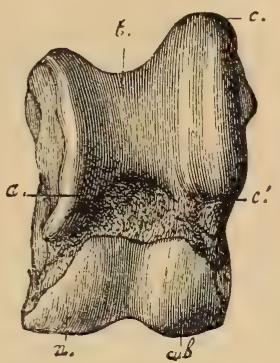

Fig. 654

Astragalus (Sprungbein) von Helladotherium Duvernoyi. $A$ von vorne und $B$ von hinten. $1 / 3$ nat. Gr. (Nach $G$ a u dry.) $t$ tibiale Gelenkfläche (Trochlea), $n$ naviculare Gelenkfläche, $c u b$ cuboidale Gelenkfiäche, cal hintere Calcaneumfasette, $c$, $c^{\prime}$ seitliche Fasette für das Calcaneum, ex freier Innenrand des Astragalus.

Das Becken ist gestreckt, das Hüftbein schmal. Dem Femur fehlt der dritte Trochanter. Tibia und Fibula sind bei den primitiveren Formen getrennt, und die letztere ist wohl entwickelt. Bei den vorgeschrittenen verkümmert die Fibula zu einem griffelartigen Knochen, von dem zuletzt nur ein kurzes, distales Stück erhalten bleibt. Das Calcaneum (Fig. 653) hat an seiner Vorderseite eine gewölbte Gelenkfläche für die Fibula. Am Astragalus (Fig. 654) ist die obere und vordere Gelenkrolle für die Tibia tief ausgehöhlt, sein distales, dem Naviculare und Cuboid aufruhendes Ende ist nicht abgestutzt wie bei den Perissodactylen, sondern bildet ebenfalls eine konvexe Gelenkrolle, welche auf der Hinterseite in eine große gewölbte Fläche (cal) übergeht. Bei den primitiveren vierzehigen Formen mit gut ausgebildeten Seitenzehen bleiben alle Tarsusknochen getrennt. Bei den Traguliden und den Wiederkäuern verschmelzen Naviculare und Cuboid, ebenso verwachsen Unciforme $I I I$ und $I I$ und zuweilen sogar alle Tarsalia mit Ausnahme von Cuneiforme $I$.

Auch am Hinterfuß verkümmern oft die seitlichen Metapodien und Zehen. $\boldsymbol{M} t I$ ist, wenn überhaupt anwesend, nur als Stummel vorhanden. Bei Anoplotheriiden und bei Dicotyles wird der Hinterfuß durch einseitige Verkümmerung einer Seitenzehe dreizehig. Auch die zwei mittleren Metatarsalia können zu einem Canon verwachsen und zwar sogar schon früher als die Metacarpalien (Hyaemoschus, Gelocus, Dicotyles). Bei der inadaptiven Ausbildung der Extremitäten bewahren die einzelnen Metatarsalia 
ihren Platz unter den entsprechenden Tarsalien. Bei der adaptiven Reduktion werden die seitlichen Metatarsalia von den sich ausbreitenden mittleren nach außen und hinten verdrängt. Die Zehen beider Extremitäten sind gleichartig gebaut, die Endphalangen dreieckig - nur bei den Anoplotheriiden und bei Agriochocerus krallenartig - und von Hufen umgeben.

Für das phylogenetische Verständnis der Extremitätenumbildung bei den Artiodactylen ist es von großem Interesse, daß selbst bei den vorgeschrit. tensten Paarhufern' (Cavicornia) die im späteren Alter verschmolzenen Knochen bei Embryonen getrennt angelegt sind und somit den geologisch älteren Formen entsprechen. Die scheinbar so weit auseinander liegenden Entwickelungsstadien des plumpen, kurzen, vierzehigen Hippopotamusfußes und der schlanken, langgestreckten, zweihufigen Wiederkäuerextremitäten werden somit gewissermaßen in kurzer Folge auch in der Ontogenie der höchststehenden Paarhufer durcheilt.

Nach dem Gebiß zerfallen die Artiodactylen in drei Hauptgruppen:
A. Bunodontia.
B. Bunoselenodontia.
C. Selenodontia.
1. Suidae
2. Elotheriidae
3. Leptochoeridae
4. Hippopotamidae

5. Anthracotheriidae
6. Anoplotheriidae
\%. Dichobunidae

8. Xiphodontidae

9. Caenotheriidae

10. Oreodontidae

11. Camelidae

12. Tragulidae

13. Hypertragulidae

14. Cervicornia

15. Antilocapridae

16. Cavicornia.

\section{A. Bunodontia.}

\section{Familie. Suidae. Schweine. ${ }^{1}$ )}

$\frac{3-2.1 .+-3.3 .}{3.1 .+-3.3 .}$ brachyodont und bunodont. Obere und untere .M mit vier stumpf konischen Höckern und hï̈fig mit vielen warzenartigen Nebenhöckerchen. Alteste Formen mit einem Zwischenhöcker - Metaconulus - in der Vorderhälfte der oberen .1. P einfacher als . I. C stark vorragend. Carpalia und Tarsalia nicht verschmolzen. Untere Hülfte des Astragalus gegen die obere etwas seitlich verschoben. Extremitïten vierzehig, der Hinterfuß zuweilen dreizehig. Metapodien getrennt. Seitenzehen dünner und kürzer als die Mittelzehen.

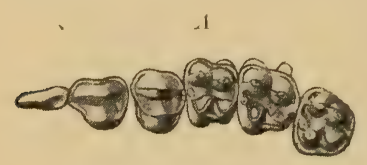

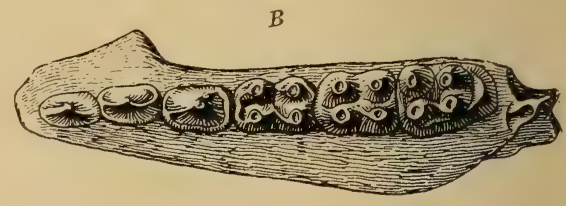

Fig. 655 .

A Cebochoerus Rütimeyeri Stehlin. Mitteleocäne Bohnerze von Egerkingen, Schweiz Obere Backenzähne nat. Gr. (nach Stehlin.) B Cebochoerus minor Gervais. Obereocän. Phosphorite von Quercy. Unterkiefer nat. Gr. (Nach Gaudry.)

Die Suiden stehen den Anthracotheriiden wenigstens anfangs ziemlich nahe. Beide dürften auf eine gemeinsame Stammform zurückgehen. In der Gegenwart bewohnen Suiden alle Kontinente mit Ausnahme von Australien. Ächte Suiden beginnen in Europa im Mitteleocän, in Nordamerika im Oligocän. Die Hauptentwicklung der Schweine fällt in die Zeit vom Miocän bis in die Gegenwart.

1) Stehlin H. G., Geschichte des Suidengebisses. Abhandl. schweizer. paläont. Gesellsch. 1899. 1900. 
Cebochoerus Gervais (Dichobune Rütimeyer, Acotherulum Gervais). (Fig. 655.) Oberer $C$ vertikal, dolchförmig, unterer $C$ als vierter $J$ und der zweiwurzelige untere $P_{1}$ als $C$ entwickelt, obere $M$ fast quadratisch, mit fünf Höckern, davon drei in der vorderen Hälfte. Unterkiefer hinten sehr hoch, mit gerundetem Eckfortsatz. Mitteleocän. Bohnerz von Egerkingen C. Rütimeyeri Stehlin. Obereocän. Mormont C. helveticus Pictet. St. Hippolyte de Caton, Phosphorite von Quercy C. minor Gerv. Débruge C. saturninus Gervais sp.

Choeromorus Pictet (Leptacotherulum Filhol). Obere $M$ etwas breiter als lang. Unterer $C$ und $P_{1}$ normal ausgebildet. $P_{4}$ mit Innenhöcker. Außenhöcker der unteren $M$ V-förmig. Stammvater der echten Schweine. Obereocän. Mormont. Ch. helveticus Pictet.

Eohyus Marsh. Eocän. Wyoming, durchaus problematisch.

Choeropotamus Cuvier. Oberer $C$ dolchförmig, $P^{1}$ vergrößert, unterer $C J$-ähnlich, $P_{1} C$-artig. $M$ mit vier Haupt- und vielen Nebenhöckern, obere auch mit Mesostyl. Unterer $P_{4}$ ohne Innenhöcker. Unterkiefer niedrig, hinten weit ausgezogen. Obereocän. Frankreich und England. Ch. parisiensis Blv.

Palaeochoerus Pomel. (Fig. 656.) Zahnreihe fast noch geschlossen. $C$ nicht viel stärker als $J$ und $P$. Obere und untere $M$ mit vier konischen Höckern und Basalband, unterer $M_{3}$ mit fünf Höckern. Untermiocän Europa. $P$. Meisneri Meyer, typus Pomel. Mittel miocän. P.aurelianensis Stehlin Propalae. ochoerus Stehlin. Oligocän. Phosphorite von Quercy.

Choerotherium Depéret (Colobus Fraas). Klein, sehr einfache $P$ und $M$. Obermiocän. Steinheim, Sansan, Schlesien etc.

Xenochoerus Zdarsky. Sehr komplizierte, $M$-ähnliche $P$. Obermiocän. Steiermark.

Hy o therium Meyer. (Figur 657.) Ähnlich Palaeochoerus, jedoch größer. Oberer $C$ zweiwurze-

A

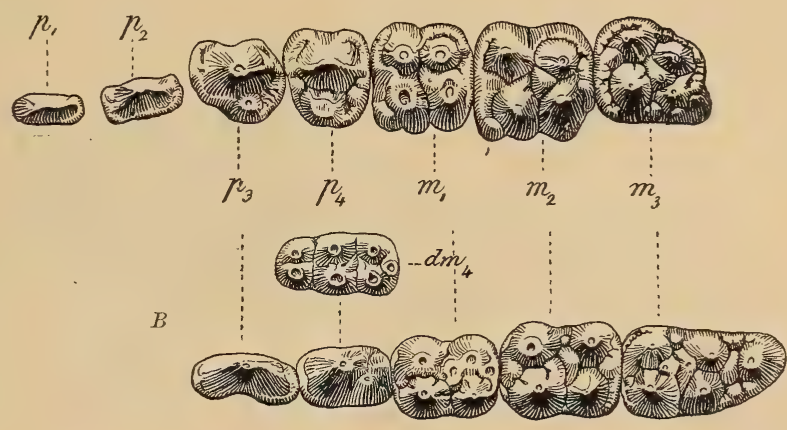

Fig. 656.

Palaeochoerus Meisneri v. Meyer. Intermiocän. Ulm. $A$ obere, $B$ untere Backenzähne, nat. Gr.

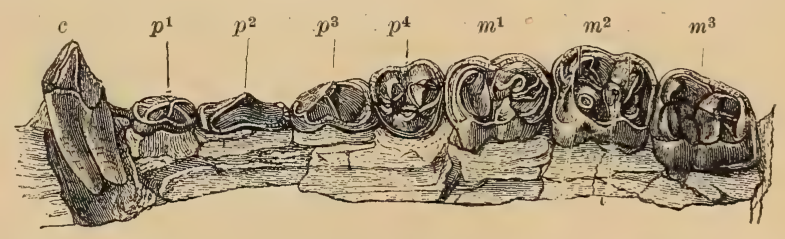

Fig. 655 .

Hyotherium Sömmeringi v. Meyer. Obermiocän. Eibiswald. Steiermark Oberkiefer. $1 / 2$ nat. Gr. (nach Peters.)

lig. Höcker der $M$ kantig. Im europäischen Mittel- und Obermiocän weit verbreitet. H. Sömmeringi Meyer. Unterpliocän Indien. H. perimense Lydekker.

Perchoerus Leidy. $\frac{4}{4} P$. Oligocän (White Riverbed) und Chaenohyus, Bothrolabis Cope, Desmathyus Matthew. Untermiocän (John Day). und Thinohyn Marsh im Obermiocän von Nebraska mit nur drei unteren $P$ sind die palaeochoerusähnlichen Vorläufer von:

Dicotyles Cuvier. $\frac{2.1 .3 .3 .}{3.1 .3 .3 .}$ Oberer $C$ dreikantig, vertikal, hintere $P$ wie die $M$ mit zwei Höckerpaaren und Nebenwarzen. Metatarsale III 
und IV proximal verschmolzen. IIt $\mathrm{V}$ zu einem kurzen Stummel reduziert. Lebend und im Pleistocän von ganz Amerika.

Platygonus Le Conte. Vor den drei $P$ langes Diastema. Hücker der $I I$ zu Jochen verbunden. Seitenzehen fast ganz reduziert. Obermiocïn bis Pleistocän von Nordamerika. Mylolyus Leidy. $J$. Höcker konisch. Metacarpale II und V noch mit Zehengliedern. Pleistocïn Nordamerika.

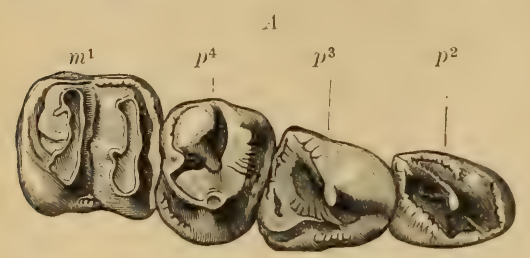

Fig. $65 \mathrm{~s}$

Listriodon splendens v. Meyer. Miocän (SarmatischeStufe.) Nußdorf bei Wien. A Prämolaren und erster Molar des Oberkielers. $B$ zweiter Molar des Unterkiefers. $3 / 4$ nat. Gr.

\section{B}

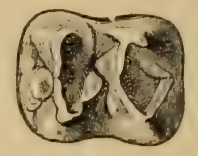

(Fig. 658.) $\frac{3}{3} P$. Obere $J$ mit breiten Kronen, untere horizontal, meißelförmig. Oberer (' dick und kurz, dreikantig und aufwärts gekrümmt. Untere $C$ lang, dreikantig, bogenförmig. $P^{4}$ dreihöckerig, die übrigen kurz und dick. II mit zwei Querjochen. Mittel- und Obermiocän von Europa $L$. splendens Meyer und in den indischen Siwalikschichten.

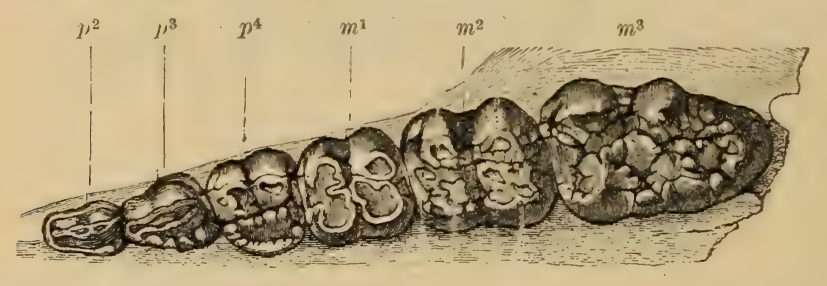

Fig. 659 .

Sus erymanthius Roth und Wagner. Unterpliocän. Pikermi bei Athen Backenzähne des Oberkiefers, $1 / 2$ nat. Gr. (Nach Gaudry.) thew Prosthe nops Matsehr lang, Oben nur 2 $J, 1 C, 3$ P. Obermiocän und Pliocän von Nebraska.

Doliochoerus Filhol. Höcker jochartig angeordnet. Oligocän. Phosphorite von Quercy.

Listriodon Meyer.
horizontal, meißel-
gekrummt. Untere
übrigen kurz und
Hippohyus Falconer. Molarhöcker mit zahlreichen Falten. Siwalik. Ostindien.

Sus Lin. Figur 659.) $J$ und $C$ wie bei Listriodon, $M$ mit vier stumpfen, niedrigen Haupthöckern und zahlreichen Nebenhöckern. $M^{3}$ mit langem Talon. Lebend in Europa, Asien und Nordafrika. Fossil im Unterpliocän von Montebamboli - S. choeroides Pomel - im Unterpliocän von Eppelsheim, Pikermi etc. S. antiquus Kaup, erymanthius Roth. Mehrere Arten in China und in den Siwalik. Im Oberpliocän von Toskana S. Strozzii Meneghini und im Pleistocän von Europa S. scrofa Linn.

\section{Familie. Elotheriidac. $\left.{ }^{1}\right)$}

3.1.4-3.3 5 Schädel mit schmalem kleinem Cranium und langer Schnauze. $J, C$ und $P^{\prime}$ krïftig entwickelt. $J$ und $C$ konisch. $P$ höher als die $I I$ und mit Ausnahme von $P^{4}$ einspitzig. Hypocon der oberen fïnfhöckerigen $M$ aus dem Basalband entstanden. Vordere Hälfte der unteren $M$ höher als die hintere. Extremitäten vier- oder zweizehig.

Die Elotheriidae unterscheiden sich von den Suiden hauptsächlich durch die primitive Ausbildung der $J, C$ und $P$, sowie dadurch, daß der zweite Innenhöcker der oberen $M$ nicht aus dem Metaconulus, sondern aus einer Basalwarze entstanden ist.

1) Peterson O. A., A Revision of the Entelodontidae. Memoirs of the Carnegie Museum 1909. - Scott W. B., The Osteology of Elotherium. Transact. Amer. Phil. Soc. 1898. 
Achaenodon Cope (Parahyus Marsh?). Schädel bärenähnlich, $\frac{3}{3} P$. Obereocän. Uintabed. Wyoming. A. insolens Cope;

Protelotherium Osborn. Jochbogen ohne Fortsatz, breite Stirn. Nur drei obere $P$ vorhanden, obere $I I$ fünfhöckerig. Extremitäten vierzehig. Obereocän. Uintabed $P$. vintense Osborn.

Elo the ri in Pomel (Entelodon Aymard, Archaeotheriun Leidy). (Fig. 660.) Obere 1 L fünfhöckerig, mit $Z$ wischenhöcker in der Vorderhälfte, alle mit starkem Basalband. Unterer $I_{3}$ ohne Hinterhöcker. Jochbogen mit nach unten gerichtetem Fortsatz. Unterkiefer mit Protuberanzen am Unterrand. Extremitäten zweizehig. 13 Brust- und 6 Lendenwirbel. Oligocän von Ronzon (Hte. Loire), Lobsann im Elsaß, Phosphorite von Quercy (E. magnum Aymard) und im Oligocän (White River) E. Mortoni Leidy, Untermiocïn (John Day) von Nordamerika E. (Boochoerus, Daeodon) humerosus Cope.

Dinohyus Peterson, ähnlich Elotherium. Miocän. Nebraska.

\section{Familie. Leptochoeridae. Leidy.}

Obere II viel kürzer als breit, trituberkulür mit Zwischenhöckern, untere II vierhöckerig. Vorderhälfte viel höher als die Hinterhülfte. P gestreckt, die unteren sehr kompliziert. Metapodien dünn.

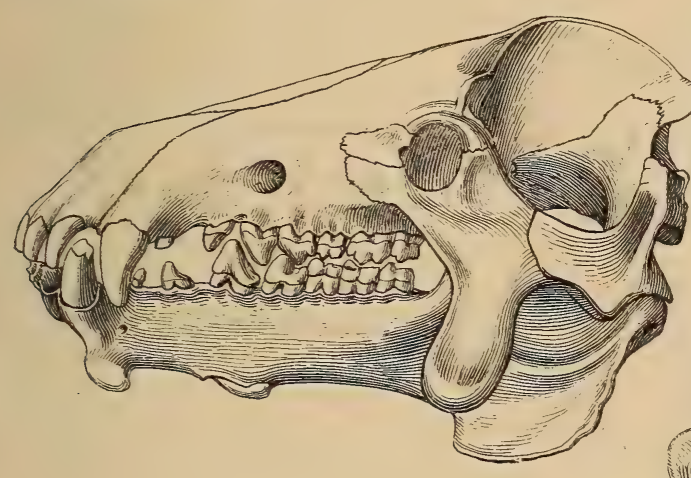

Fig. 660 .

Elotherium crassum. Oligocän (White Riverbed.) Dakota. Schädel von der Seite u. von oben, $1 / 8$ nat. Gr. (Nach Marsh.)

Kleine Formen von nicht ganz sicherer systematischer Stellung und auf das Oligocän von Nordamerika beschränkt.

Leptochoerus Leidy. (Laopithecus Marsh, Menotherium, Stibanus Cope, Oligocän (White Riverbed).

\section{Familie. Hippopotamidae. Flußpferde.}

$\frac{3-2.1 .4 .3 .}{3-1.1 .4 .3 .}$ Obere und untere $M$ mit vier stumpfen gefalteten Höckern, bei der Abkauning eine kleeblattartige Figu bildend. $P$ einfach. Obere $C$ sehr dich, kurz, vorne abgekaut. Untere $C$ gewaltig groß. dreikantig, bogenförmig, hinten mit Abkaungsfläche. Untere $J$ zylindrisch, sehr lang, wurzellos, nach vorne gerichtet. Alle Carpalia, Tarsalia und Metapodien getrennt. Füße vierzehig, seitliche Zehen nicht viel schwächer und kürzer als die mittleren. Endphalangen mit nagelartigen Hufen. 
Die einzige noch jetzt lebende Gattung dieser Familie ist auf das tropische Afrika beschränkt. Fossil findet sie sich im Pliocïn und Pleistocän von Asien, Europa und Afrika.

Hippopotamus Lin. wird je nach der Zahl der $J$ in die Subgenera Hexaprotodon und Tetraprotodon Falconer zerlegt. Im Pliocïn von Ostindien $H$. sivalensis Falconer, im Mittelpliociin von Ägypten und Algier $H$. hipponensis Gaudry, im Oberpliocän von Val d'Arno H. major und Pentlandi Falconer im europäischen Altpleistocän dem lebenden amphibius nahestehend. Im Altpleistocïn von Trinil (Java) sivajavanicus Dubois. Aus Algier beschreibt Pomel mehrere Arten. Zwergformen sind aus Höhlen auf Malta, Cypern und Kreta bekannt, sowie aus sehr jungen Ablagerungen von Madagaskar, $H$. madagascariensis Grandidier.

\section{B. Bunoselenodontia.}

\section{Familie. Anthracotheriidae. ${ }^{1}$ )}

Ausgestorbene Paarhufer mit vollständigem Gebiß. 3.1. .. 3. Olsere M mit vier Haupthöckern und einem Zwischenhöcker in der vorderen Hälfte, untere M mit je zwei konischen Innen- und hallmondförmigen Außenhöckern. P meist kurz,

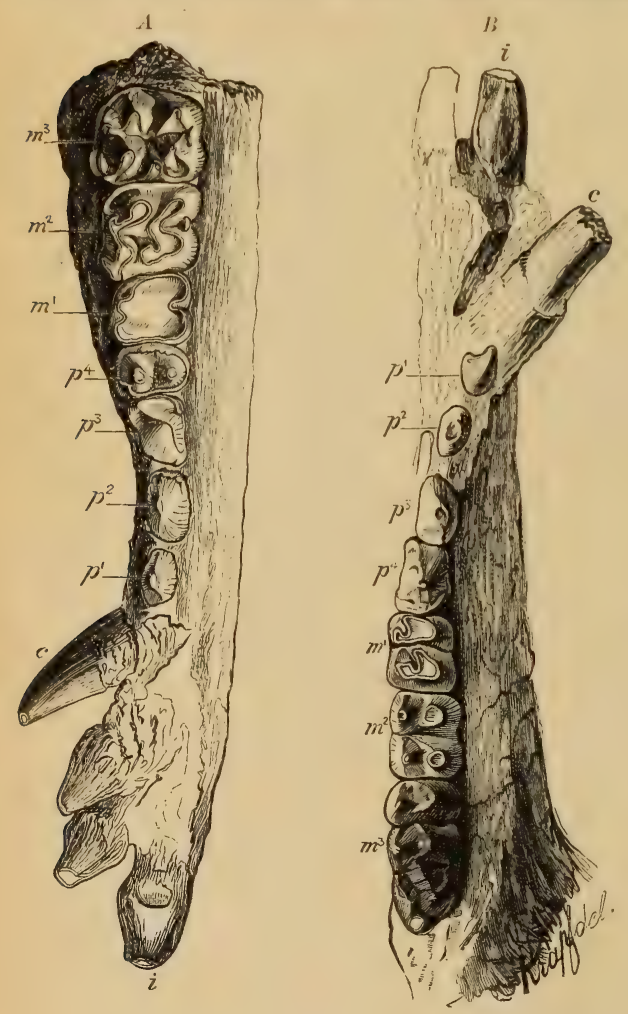

Fig. 661

Anthracotherium magnum Cuv. Oligocän. La Rochette bei Lausanne. $A$ Oberkiefer, $B$ Unterkiefer. $1 / 3$ nat. Gr. die drei vorderen einspitzig, meist durch ein Diastema vom C getrennt. Carpatia, Tarsalia und Metapodien nicht verwachsen. Füße vierzehig, die Seitenzehen meist dïnner und kürzer als die mittleren. Untere Astragalustrochlea nicht gegen die obere verschoben.

Die Anthracotheriiden bilden eine primitive Gruppe der Paarhufer, welche vorzugsweise in Europa, spërlicher in Nordamerika, Nordafrika und Ostindien verbreitet war. Die ältesten Überreste finden sich im Eocän (Bohnerze, Phosphorite), das Hauptlager für Anthracotherien ist das Oligocän. Die jüngsten Formen erlöschen im Miocän.

Anthracotherium Cuv. (Fig. 661.) Obere $M$ breiter als lang, mit vier $\bigvee$-förmigen oder konischen Höckern und einem vorderen sichelförmigen Metaconulus. Untere $M$ vierhöckerig, $M_{3}$ mit drittem Halbmond. $J$ oben und unten schaufelförmig, C sehr kräftig entwickelt. Diastema klein. Häufig imOligocän von Europa,namentlich in kohleführenden Ablagerungen, selten im Miocän? von Ostindien. Die Arten variieren in der Größe zwischen Rhinoceros (A. magnum

1) Filhol $H$., Mammifères fossiles de Ronzon. Ann. sc. géol. 1882. XII. Kowalewsky $W$., On the Osteology of the Hyopotamidae. Philos. Trans. 1873. Monographie der Gattung Anthracotherium. Palaeontographica 1873. XXII. - Scott W. B., Structure and Relationship of Ancodus. Journ. Acad. Nat. Sc. Philad. 1895. 
Cuv., A. alsaticum Cuv.) und Schwein (A. minus Cuv. valdense Kow.). Auch im Oligocän (White Riverbed) von Nordamerika kommen Anthracotherium und ähnliche Formen vor - Heptacodon, Octacodon Marsh.

Brachyodus Gervais. Backenzahnreihe geschlossen. Obere $M$ quadratisch. Oberoligocän B. porcinus Gerv., und Mittelmiocän von Europa B. onoideus Gerv. und Untermiocän von Ägypten B. africanus Andrews.

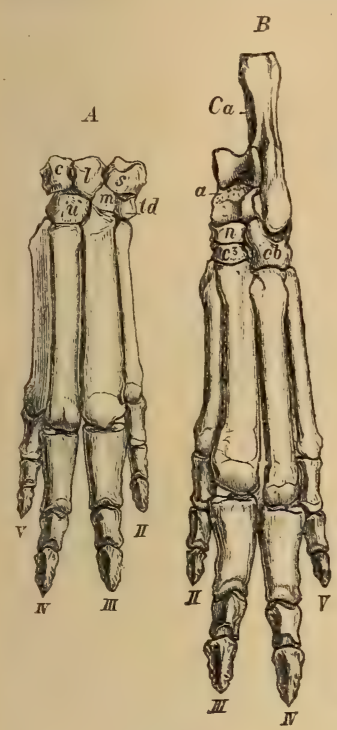

Fig. 662 .

Ancodus (Hyopotamus) velaunus Cuv. sp. Oligocän. Ronzon bei Le Puy. A Vor. derfuß, $B$ Hinterfuß.

$1 / 5$ nat. Gr. (Nach Kow a lewsky.)
Ancodus Pomel (Hyopotamus Owen, Bothriodon Aymard). (Fig. 662, 663.) Schädel länger und niedriger als bei Anthracotherium. $C$ schwächer und durch langes Diastema vom ersten $P$ getrennt. Hügel der oberen $M$ ausgezeichnet $V$-förmig, die Innenhöcker der unteren $M$ spitz konisch. Oligocän, be-
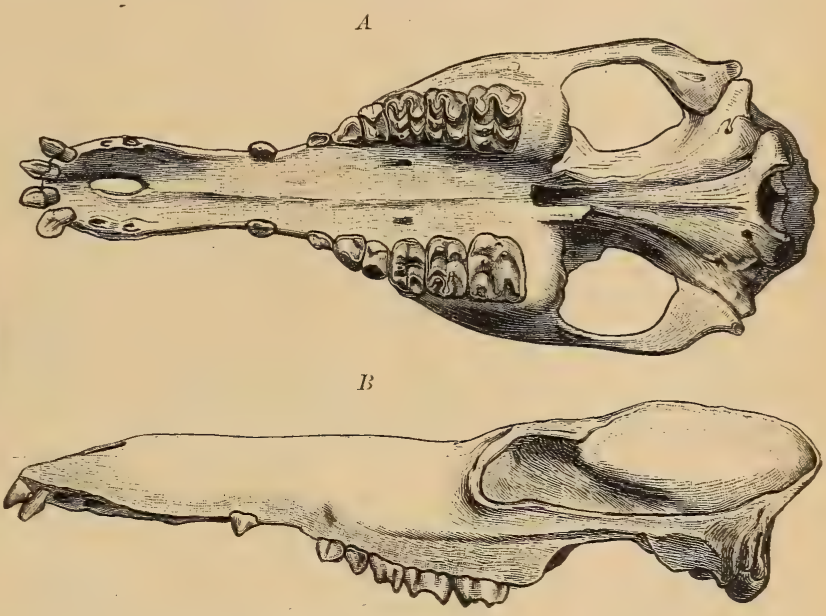

Fig. 663 .

Ancodus (Hyopotamus) velaunus Cuv. sp. Oligocän. Ronzon bei Le Puy. Schädel von oben und unten, $1 / 4$ nat. Gr. (Nach Filhol.)

sonders häufig in Ronzon (Hte. Loire). A. velaunus Cuv., bovinus Owen. Im Oligocän von Ägypten A. Gorringei Andrews, in dem von Nordamerika A. americanus Leidy. Die nordamerikanischen Formen unterscheiden sich durch die kürzere Schnauze und durch den Besitz eines großen Daumens.

Elomeryx Marsh. Arretotherium Douglass. Oligocän. Montana. Obere $M$ mit nur vier $V$-förmigen Höckern. Vordere $P$ schwach.

Merycopotamus Falcon. und Cautley. Obere $M$ mit nur vier $\vee$-förmigen Hügeln. Untere Siwalikschichten von Ostindien. M. nanus Lydekker.

Rhagatherium Pictet (Hyopotamus Rütimeyer). Obere $M$ mit fünf spitzen Höckern und mit Mesostyl. $P^{4} M$-artig, unterer $P_{4}$ und die übrigen $P$ sehr kompliziert und gestreckt. Zahnlïcke vor $P_{2}$. Eocäne Bohnerze. $R$. valdense Pictet von Mormont, frohnstettense Kow. von Sigmaringen.

Haplobunodon Depéret (Dichodon, Acotherulum. Rütimeyer, Anthracotherium Lydekker). $M$ wie beim vorigen, $P$ einfach, $P_{1} C$ artig, weit von $P_{2}$ abstehend. Unterkiefer niedrig. Eocän. Bohnerze der Schweiz. H. Muilleri Rütimeyer und solodurense Stehlin von Egerkingen.

Thaumastognathus Filh. Phosphörite von Quercy. Lophiobunodon Depéret. Obereocän.

\section{Familie. Anoplotheriidae.}

3. 1. 4. 3. Zahnreihe meist vollständig geschlossen. J1 öfters vergröjsert, vertikal und voneinander getrennt. Alle $J, C$ und $P$ meist allmählich ineinander über- 
gehend, die vorderen Pverlängert und schneident. If bumselenodont. Obere II im Cimriß trapezoidal, mit vier $V$ förmigen Höckern und konischem Protocon. Untere II mit V-förmigen Außenhöckern und zwei oder drei konischen Innenhöckern, im letzteren Falle zwei in der Vorderhälfte jedes. $W$. Hand mit vier bis zwei, Hinterfuß wit vier bis drei Zehen. Bei Anwesenheit von vier Zehen mittleve Metapodien kurz und plump, Seitenzehen diunn, bei nur drei Zehen, die zweite kurz und dick und seitlich abstehend. Carpalia und Tarsalia fiei, Endphalangen Frallenïlnalich. Schwanz sehr lang.

Der Schïdel hat, abgesehen von der.Kürze und Breite der Schnauze, einige Ähnlichkeit mit dem von c'amelus. Durch die Läinge des Schwanzes und die mit krallenähnlichen Endphalangen versehenen Extremitiiten gleichen die Anoplotherien eher Carnivoren als Huftieren. Sie sind auf das Eocän und ïltere Oligocän von Europa beschränkt.

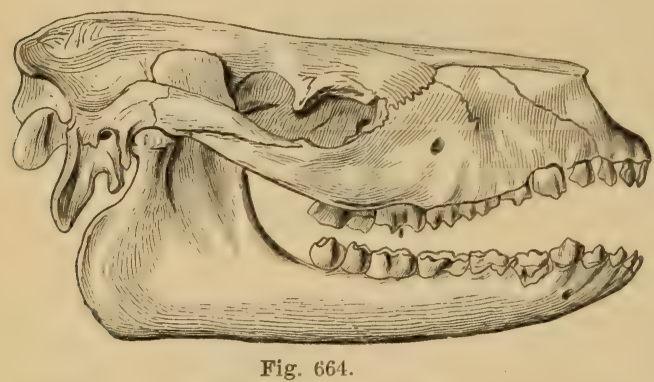

Anoplotherium commune Cuv. Ob. Eocän (Gips). Montmartre bei Paris. Schädel $1 / 5$ nat. Gr. (Nach Blainville.)

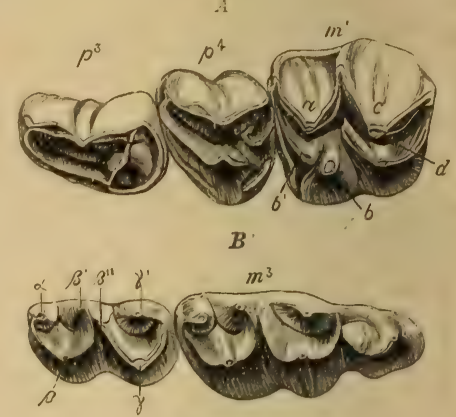

Fig. 665 .

Anoplotherium latipes Gerv. sp. Ob. Eocän (Phosphorite) Escamps. Quercy. A die zwei hinteren $P$ und der vordertse $M$ des Oberkiefers. $B$ die zwei letzten $M$ des Unterkiefers (nat. Gr.).

Anoplotherium Cuv. (Eurytherium Gervais). (Fig. 664, 665.) Außenwand der oberen II IV-förmig, Zwischenhügel nur in der vorderen Hälfte klein, vorderer Innenhöcker konisch, hinterer $V$-förmig. Untere $I I$ mit zwei Halbmonden auf Außenseite und drei spitzen Höckern auf Innenseite, davon zwei in der Vorderhälfte des Zahnes. $('$ in beiden Kiefern $P$ ähnlich. Die Anoplotherien waren kurzbeinige, gedrungene, mit langem krüftigen Schwanz versehene Huftiere von Tapir-Größe, die wahrscheinlich den Schwanz als Schwimmorgan benutzten. Ihre drei Zehen waren wohl durch Schwimmhaut verbunden. Im Obereocän von Paris A. commune Cuv. Hand mit nur zwei Zehen. Débruge bei Apt A. (Eurytherium) latipes Gervais. Hand dreizehig.

Diplobun e Rütimeyer (Hyracodontherium Filhol). (Fig. 667.) Sehr ähnlich Anoplotherium, jedoch kleiner. Oberer erster $J$ vergrößert. Die
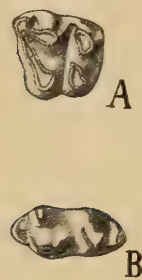

Fig. 666 .

Orthaspidotherium. Int. Eocän von Reims. $A$ oberer Molar, $B$ unterer $M_{3} 2 / 1$ nat. Gr. oberen $M$ sind relativ breit, und an den unteren $M$ stehen die beiden vorderen Innenhöcker ganz dicht beisammen. Extremitäten dreizehig. Wangenfläche ohne Grube. Im Oligocän, Bohnerz von Ulm und Pappenheim und in den Phosphoriten von Quercy. D. Quercyi Filhol, D. bavaricum Fraas. Im Eocän D. secundarium Cuv. sp.

Dacrytherium Filhol (Plesidacrytherium Filhol). Wangenfläche mit tiefer Infraorbitalgrube. Vorderer Innenhöcker der unteren $M$ schwach entwickelt. $P$ relativ einfach. Zwei wohlentwickelte, aber dünne Seitenzehen. Mittelund Obereocän. Phosphorite. Schweizer Bohnerze.

Leptotheridium Stehlin (Rhagatherium, Caenotherium Pictet, Hyopotamus Rütimeyer). Klein. Eocän. Schweiz. Bohnerze. 
Catodontherium Depéret. Wange mit seichter Vertiefung. Schnauze schmal. $P$ gestreckt. $P^{4}$ einfach. Vorderster Innenhöcker der unteren II sehr schwach. Eocän. Schweizer Bohnerze C. fallax Stehlin. Robiac C. robiacense Depéret.

Mix to therium Filhol (Adrotherium Filhol, Hyopotamus Rütimeyer). $P^{4}$ fast $W$-artig. $\quad C$ fast normal entwickelt. Schnauze kurz, Unterkiefer sehr hoch, Schädel mit kleinem Cranium und weit abstehenden Jochbogen. Eocän. Phosphorite.

Orthaspidotherium Lemoine (Figur 666). Untereocän. Reims. Sehr klein.
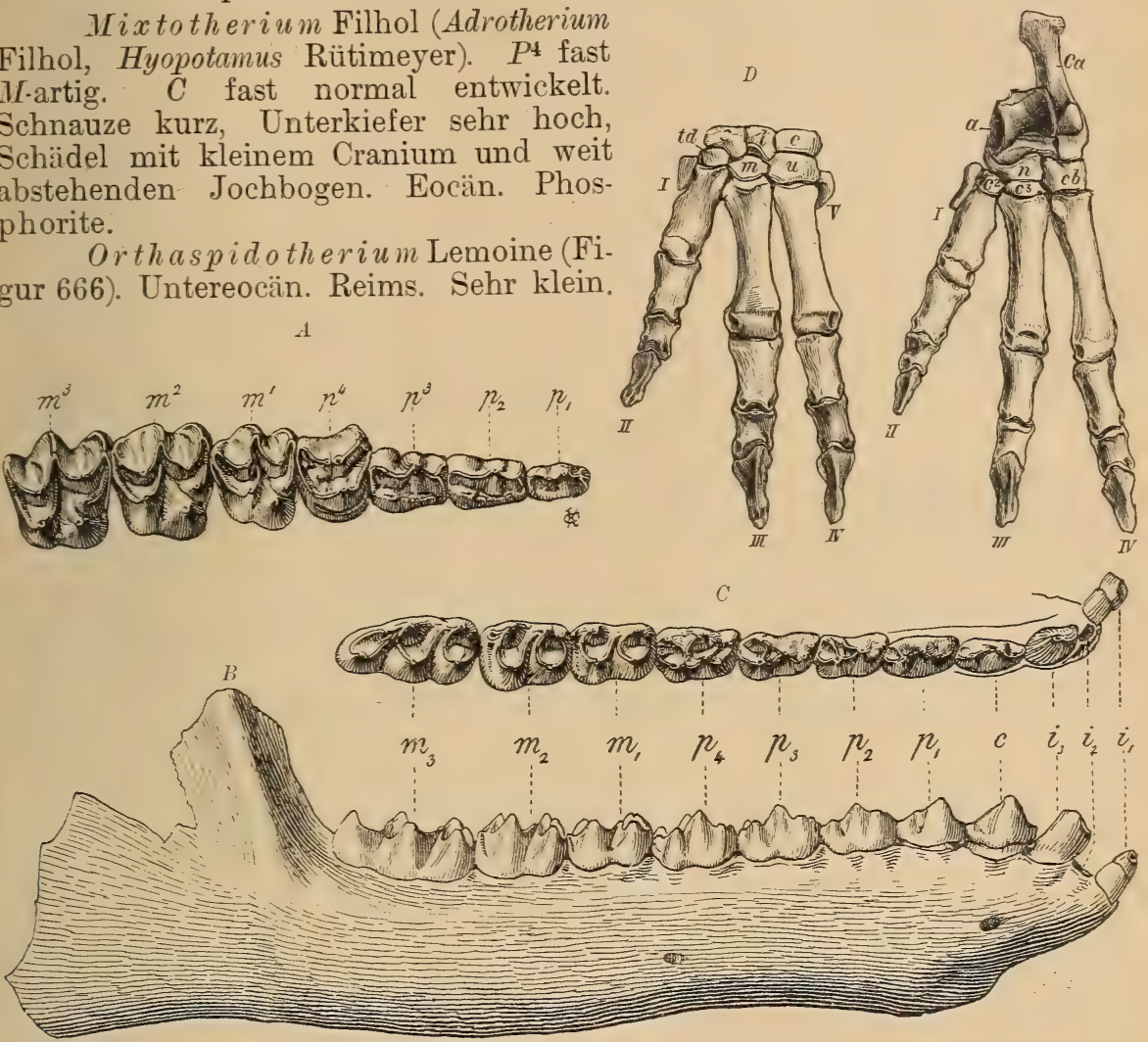

Fig. 667.

Diptobune Quercyi Filhol. Bohnerz. Eselsberg bei Ulm. A Backenzähne und Prämolaren des Oberkiefers. $B$ rechter Unterkiefer von der Seite. $C$ Unterkieferzähne von oben $(2 / 3$ nat. Gr.) $D$ Vorderfuß, $E$ Hinterful's ( $1 / 4$ nat. Gr.).

\section{Familie. Dichobunidae.}

Ausgestorbene, kleine Paarhufer mit vollständigem Gebijs $\frac{3.1 .4 .3 .}{3.1 .4 .3 .}$ Obere $M$ mit drei Höckern in der hinteren Hälfte, die Innenhöcker $V$-förmig, die ïbrigen meist konisch. Tntere $M$ mit konischen Innen. und V-förmigen Ausienhöckern. Torderer Innenhöcker meist doppelt. Vorderhälfte der unteren II etuas höher als die hintere. Extremitäten vierzehig. Seitenzehen dïn. Schüdel Tragulusähntich.

Durch den Besitz von drei Höckern in der Hinterhälfte der oberen II unterscheidet sich diese Familie von allen übrigen Paarhufern, obwohl sie im übrigen viele Ähnlichkeit mit primitiven Suiden, Anthracotheriiden und Traguliden aufweist. Die Dichobuniden beginnen in Europa schon im ïltesten Eocän, sterben aber im Oligocïn aus. In Amerika sind sie auf das Obereocän beschränkt.

Dichobune Cuvier (Fig. 668). (Microchoerus Wood, Hyopotamus Rütimeyer. Obere Zahnreihe geschlossen. Obere II mit Mesostyl. Alle Höcker 
mehr oder wenig konisch. $P$ einfach. Obereocïn, Bohnerze, Pariser Gips bis Oligocän. D. leporina Cuv. Bohnerze.

Hyperdichobune Stehlin. Oberer $P^{4}$ kompliziert. Eocïn. Schweizer

Mouill "citherium Filhol (Necrolemu;, Hyopsodus Rütimeyer). Ohne Zwischenhöcker in Vorderhälfte der oberen M. Untere $P$ gestreckt. Eocïn. M. Cartieri Rütimeyer sp.

Meniscodon Rütimeyer (Phenacodus, Protogonia Rütimeyer). Mittelgroße Tiere. ()bere $I I$ ohne Mesostyl, mit großem Parastyl. Mitteleocïn.

A

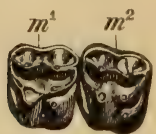

B

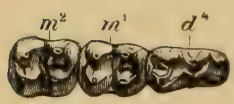

Fig. 668 .

Dichobune leporina Cuv phorite. Escamps. Quercs 1 zwei Molaren des Oberkiefers, B) letzter Milchzahn und die zwei vorderen Molaren des Unterkiefers. (Nat. Gr.)

Bohnerz von Egerkingen. M. europaeus Rütimeyer sp.

Metriotherium Filhol (Deilotherium, Spaniotherium Filhol). Groß. Phosphorite von Quercy.

Protorticholune Stehlin. Untereocïn von Epernay.

Homacodon Marsh. Obere $M$ sechshöckerig, untere $M$ vierhöckerig, dichobuneähnlich und $\mathrm{HelO}$ hyus Marsh. Obere $M$ mit fünf Höckern, untere $M$ mit zwei Innenhöckern in der Vorderhälfte. Mitteleocän. Bridgerbed. Wyoming.

Sarcolemur Cope. Sehr spitze Höcker an den unteren $M$. Ebendaselbst.

Trignnolestes Cope. Obere II dreihöckerig (?). Untereocän, Wasatchbed von Wyoming. T. (Pantolestes) brachystomus Cope.

\section{Selenodontia.}

\section{Familie. Xiphodontidae.}

Zahnreike geschlossen. $\frac{3.1 .4 .3 .}{3.1 .4 .3}$ Backenzähne selenodont. Obere M mit vier oder fünf Halbmonden, der Zuischenhiigel in der vorderen Hälfte. Lntere $M$ mit zuei komprimierten Innenhöckern und zuei äuseren Halbmonden. Vordere P gestreckt, unterer $P_{4}$, seltener auch der obere $P^{4}$ sehr kompliziert. Lnterer $P_{1}$ als

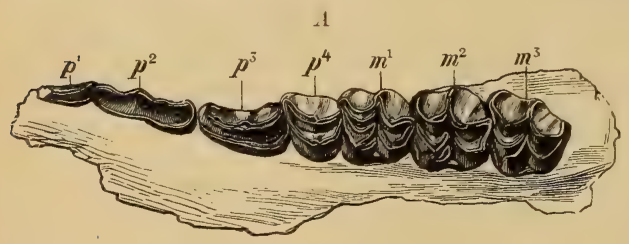

$\boldsymbol{B}$

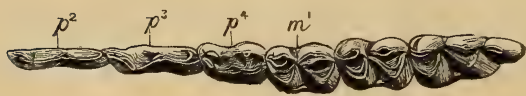

Fig. 669.

Xiphodon gracile Cuv. Ob. Eocän. Débruge bei Apt. Vaucluse. $A$ Backenzähne des Oberkiefers, $B$ des Unterkiefers. $3 / 4$ nat. Gr.

Amphimeryx Pomel (Hyaegulus Pomel, Xiphodontherium Filhol). Außenhöcker der fünfhöckerigen oberen $M$ halbmondförmig. Zahnlücke zwischen den unteren $P_{2}$ und $P_{3}$. Unterkieferrand ohne Einbuchtung. Eocän. Bohnerze der Schweiz, Pariser Gips, Débruge, Phosphorite von Quercy. Oligocän. Ronzon. $P$ ineinander übergehend. Extremi. tïten lang, schlank, zweizehig. Seitliche Metapodien zu kurzen. proximalen Stummeln reduziert, mittlere getrennt.

Im europäischen Obereocän. Phosphorite von Quercy, Bohnerze, Débruge bei Apt.

Die Xiphodontiden sind schlanke, hochbeinige, an Hirsche erinnernde Selenodonten, die aber sehr bald vollständig erlöschen.

Xiphodon Cuv. (Fig. 669.) Obere $M$ mit fünt Halbmonden. $P^{4}$ einfach. Cuboid und Naviculare getrennt. Eocän. $X$. gracile

Cuv., castrense Kowalewsky. Eckzahn ausgebildet, oder $J, C$ und 
Pseudamphimeryx Stehlin (Caenotherium Pictet, Mioclaenus, Plesiomeryx Rütimeyer). Ohne Zahnlücke zwischen $P_{2}$ und $P_{3}$. Unterkieferrand eingebuchtet. Schweizer Bohnerze. Phosphorite von Quercy.

Eine oder beide Gattungen besitzen fadenartige seitliche Metapodien. Cuboid und Naviculare verschmolzen.

Dichodon Owen. Obere $M$ mit vier Halbmonden. Ecken der Außenmonde der oberen und der Innenhöcker der unteren $M$ weit vorspringend. Letzter $P$ in beiden Kiefern sehr kompliziert, der obere $P^{4} M$-artig, $P_{4}$ $D_{4}$ ähnlich. Obereocän. England. D. cuspidatus Owen. Bohnerz von Sigmaringen $D$. frohnstettensis Fraas.

Haplomeryx Schlosser. $P$ mäßig kompliziert. Obere $M$ anfangs mit fünf, später mit vier Halbmonden. Eocän. Phosphorite, Schweizer Bohnerze.

Tapirulus Gervais. Obere $M$ fünfhöckerig, ohne Mesostyl. Höcker der oberen und Innenhöcker und Monde der unteren $M$ paarweise zu Jochen verbunden. Zahnreihe geschlossen. $P$ mit Ausnahme von $P_{4}$ trikonodont. Phosphorite. Schweizer und Ulmer Bohnerze. Systematische Stellung unsicher, vielleicht eine Suide.

\section{Familie. Caenotheriidae.}

Zahnreihe fast vollständig geschlossen, in der Regel $\frac{31.4 .3 .}{3.1 . t . \ddot{3} .}$ Obere $M$ aus fünf halbmondförmigen Höckern bestehend, der Protocon in die Hinterhälfte der Krone verschoben. Untere $M$ mit zuei äußeren Halbmonden und zwei konischen Innenhöckern, von denen der zweite nach voruärts gerïckt ist. $P$ ziemlich einfach, oberer $C$ klein, unterer als -vierter $J$, und $P_{1}$ als Eckzahn entwickelt. Extremitäten vierzehig, die Seitenzehen kürzer und dünner als die Mittelzehen. Cuboid und Naviculare getrennt. Obereocän bis Untermiocän. Europa.

Die Überreste dieser zierlichen, kaum Hasengröße erreichenden Tiere, die offenbar in Rudeln lebten, finden sich besonders häufig in den Phosphoriten von Quercy und im Untermiocän der Auvergne und des Mainzer Beckens.
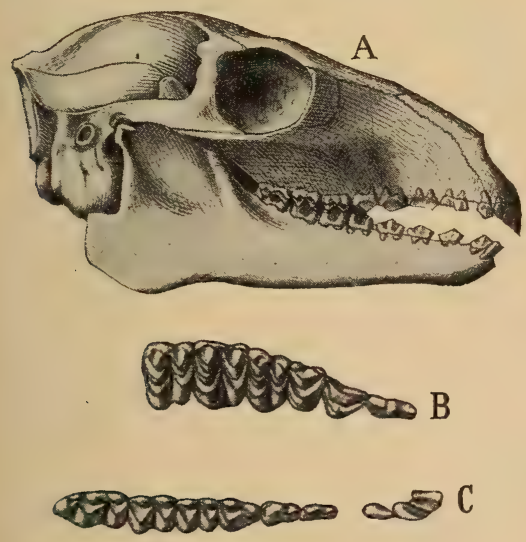

Fig. 670 .

Caenotherium elongatum Filhol. Oligocän. Phosphorite von Quercy. $A$ Schädel $2 / 3$ nat. Gr. $B$ obere $P^{2}$ bis $M^{3}, C$ untere Zahnreihe. $J_{2}$ bis $M_{3}$.

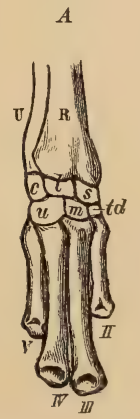

Fig. 671.

Caenotherium sp. Oligocän. Phosphorite. Quercy. A Vorderfuß, $B$ Hinterfuß. $4 / 5$ nat. Gr. (Nach Schlosser.) (Die nicht schattierten Carpalia und Tarsalia sind ergänzt.)

Oxacron Filhol (? Hyaegulus Pomel). Protocon der oberen $M$ fast in der Mitte des Zahnes gelegen. $\frac{3}{3} P$. Obereocän. Phosphorite, Débruge, Mormont. Ca enotherium Bravard (Microtherium Meyer). (Fig. 670, 771.) Unterkiefer und Extremitäten relativ plump. Oligocän und Untermiocän.

Plesiomery $x$ Filhol. Extremitäten und Unterkiefer schlank. Ebenda. 


\section{Familie. Oreodontidae. Leidy, ${ }^{1}$}

Gebiß meist vollständig. $\frac{3.1 .4 .3 .}{3.1 .4 .3 .}$ in geschlossener Reihe, manchnal mit Diastema. Backenzühne selenodont. Obere $M$ mit vier, selten mit fünf Halbmonden. $P$ in der Regel einspitzig, seitlich komprimiert, ziemlich hurz. $P_{4} z u$ weilen M-artig. Unterer $P_{1}$ stets als Eckzahn, $C$ als vierter Incisiv fungierend. Ulna, Radius, Carpalia, Tarsalia und Metapodien getrent. Extremitäten vierzehig, Seitenzehen dïnner und etwas kürzer als die Iittelzehen. Zuweilen noch ein Daumen vorhanden.

Die Oreodontiden sind vollkommen ausgestorben und bis jetzt nur aus dem Obereocän, Oligocän und Miocän von Nordamerika bekannt. Sie haben vermutlich mit den Cameliden die Stammform gemein.

\section{Unterfamilie. Agriochoerinae.}

(B)ere.M mit tief ausyefurchten Aujienhöck̉ern. Humevus mit nied.iger Trochlea. Endphalangen kiallenartig. Schwanz lang. Augenhöhle nicht geschlossen.
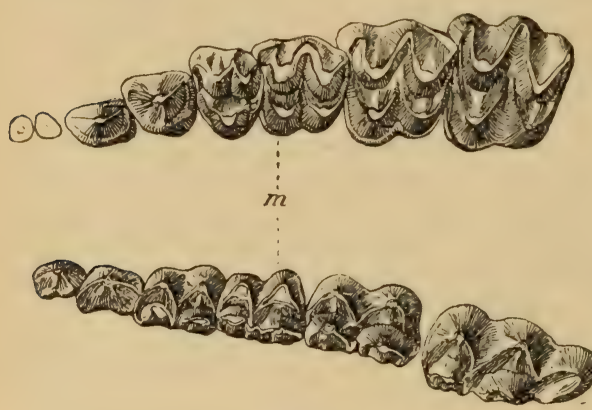

Fig. 672 .

Agriochoerus latifrons Leidy. Oligocän. White Riverbed. Nebraska. Obere und untere Backenzahnreihe. $3 / 4$ nat. Gr. (Nach Scott.) bed. A. major Leidy.

Die Agriochoerinen haben äußerlich mehr Ähnlichkeit mit Carnivoren als mit Huftieren und gleichen hierin auffallend den Anoplotheriiden, von denen sie sich je doch durch den Besitz von zwei Seitenzehen unterscheiden.

Protagriochoerus Scott. t $P$. Obere $M$ mit fünf Höckern. $P_{4}$ in beiden Kiefern einfach. Obereocän. Uintabed.

Agriochoerus Leidy (Artionyx Osborn, Merycopater, Coloreodon Cope, Agriomeryx Marsh). (Fig. 672.) Ohne obere $J . \quad \frac{4}{3} P . \quad P_{4}$ in beiden Kiefern kompliziert. Obere $M$ mit bed.

\section{Unterfamilie. Oreodontinae.}

Obere II mit W-förmiger Außenuand. Humerus mit hoher Trochlea. Endphalangen hufartig. Schwanz kurz. Augenhöhle meist geschlossen.

Die älteren Oreodontiden haben sowohl in ihrem Habitus als auch in der Größe Ähnlichkeit mit den amerikanischen Schweinen, Dicotyles, die jüngeren erlangen zum Teil durch Verdickung und weites Ausbiegen der Jochbogen eine gewisse Ähnlichkeit mit Hippopotamus.

Protoreodon Scott und Osborn (Hyomeryx, Eomeryx Marsh). Zahnreihe geschlossen. Obere $M$ mit Zwischenhöcker, Protoconulus, in der Vorderhälfte. Orbita hinten offen. Obereocän Uintabed. P. parrus Scott.

Limnenetes und Bathygenys Douglass. Ähnlich, jedoch $M$ ohne Zwischenhöcker. Unterstes White Riverbed.

1) Cope E., Proceed. Amer. Philos. Soc. Philad. 1884 XXI. - Matthew W. B., Mem. Amer. Mus. Nat. Hist. New York. Vol. I. Part. VU 1901. - Scott W. B., Beitr. zur Kenntnis der Oreodontidae. Morph. Jahrb. 1890. XVI. On the Osteology of Agriochoerus. Proc. Am. Phil. Soc. Philad. 1894. - Wortman J. L., Bull. Amer. Mus. Nat. Hist. New York 1895. 
Oreodon Leidy. (Fig. 673, 674.) Zahnreihe geschlossen. Obere $M$ aus vier Halbmonden bestehend. Orbita hinten geschlossen. Tränengruben groß. Schnauze kurz. Hand mit kurzem Daumen. Sehr häufig im Oligocän. White Riverbed von Nordamerika O. Culbertsoni, gracilis Leidy. Eporeodon Leidy (Eucrotaphus Leidy). Schädel gestreckt. Ohne Daumen. Untermiocän. John Daybed. Nordamerika. $E$. major Leidy.

Mesoreodon Scott. Zahnkronen ziem. lich hoch. Mittelmiocän. Deep Riverbed.

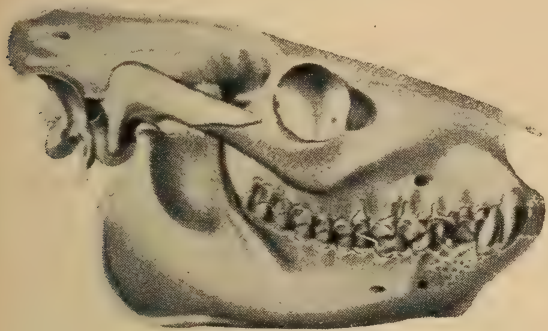

Fig. 673

Oreodon Culbertsoni Leidy. Oligocän. White Riverbed. Nebraska. Schädel und Unterkiefer $1 / 3$ nat. Gr. (nach Scott.)

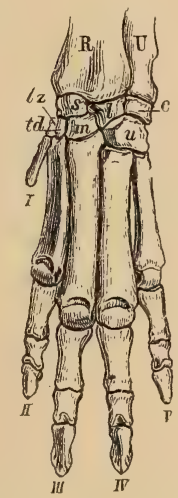

Fig. 674 Oreodon Culbertsoni Leidy. A Vorderfuß, $B$ Hinterfuß $1 / 3$ nat. Gr. (nach Scott.)
$B$

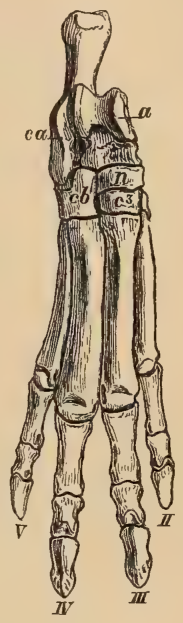

Merycochoerus Leidy. Cranium hoch. Schädel kürzer als bei Oreodon. Jochbogen stärker und weiter vorragend. Schnauze lang. Prämolarreihe kurz. Skelett größer und plumper. Mittelmiocän. M. proprius Leidy.

Promery cochoerus Douglass. (Fig. 675.)Schä. del und Prämolarreihe lang. Jochbogen hinten verdickt. Untermiocän. John Daybed.

Phenacocoelus Peterson. Mittelmiocän.

Merychyus Leidy. (Ticholeptus Cope). Schnauze verkürzt, mit Lücke zwischen Tränenund Stirnbein und Oberkiefer. Zähne ziemlich hochkronig. Seitenzehen stark reduziert. Mittel- und Obermiocän und Pliocän.

Leptauche-
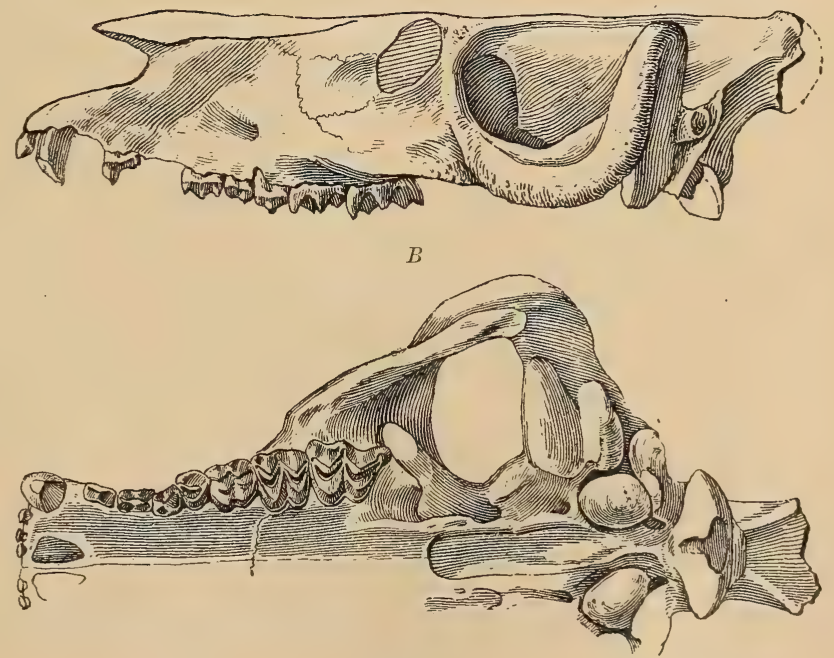

Fig. 675 .

A Promerycochoerus macrostegus Cope. Schädel von der Seite. $1 / 4$ nat. Gr. $B$ Promerycochoerus superbus Leidy. Schädel von unten. Unt. Miocän. John-Daybed. Oregon. 1/4 nat. Gr. (Nach Cope.) niaLeidy. Schnauze verkürzt, Jochbogen hoch. Nur zwei untere $J$ vorhanden. Zahnkronen ziemlich hoch. Oberstes Oligocän (White Riverbed) und Untermiocän. 
Cyclopidius Cope (Pithecistes Cope). Schädel flach. Mehrere Lücken im kurzen Gesichtsschädel, Jochbogen weit vorragend. Mittelmiocïn. Deep Riverbed.

\section{Familie. Camelidae. Tylopoda Illig. $\left.{ }^{1}\right)$}

Gelis. mehr oder weniger vollstündig $\frac{3-1.1 .+-2.3}{3} \frac{1 .+-1.3 .}{3}$ Bachenzähne selenordont, vom (' und häufig auch vom vordersten P duich Diastema getremnt. Obere M stets länger als breit. P häufig reduziert, der vorderste in beiden Kiefern O ïhnlich. Halswirbel olme Arterientianal. Carpalia und Tarsalia fiei, mit Ausinahme von Cuneiforme II und III. Extremititen vier-oder zweizehig. Seitenzehen bei den spüteren Formen günzlich verschumden. Mittlere Metapodien stets ohne vordere Leitkiele, bei den späteren Formen verschmolzen. Magen mit drei Abteilungen.

Von den zwei lebenden Gattungen bewohnt die eine - Camelus Nordafrika und Asien, die andere - Auchenia — das westliche Südamerika. Die Familie stammt aus Nordamerika, wo sie vom Obereocän bis zum Pleistocän vertreten war. Im Pliocän gelangte sie nach Asien und von da nach Nordafrika. Die fossilen nordamerikanischen Formen bilden eine geschlossene Stammesreihe und führen auf indifferente, vierzehige eocäne Urformen mit getrennten Metapodien und vollständigem Gebiß zurück.

Der Schädel trägt weder Geweihe noch Hörner, seine langgestreckte Form, die schräg abfallende Schnauze mit den kurzen, aber hohen Zwischenkiefern, die stark vorspringenden, geschlossenen Augenhöhlen und die geringe Neigung der Gesichtsachse gegen die kraniale Achse verleihen ihm eine gewisse Ähnlichkeit mit dem Pferdeschädel. Das Gebiß unterscheidet sich von dem der Wiederkäuer durch die gestreckteren oberen $M$ und durch die Anwesenheit von einem oberen $C$ und mindestens einem oberen $J$. Die $I^{\prime}$ können starke Reduktion erfahren.

Trotz der früh eintretenden Verschmelzung der Metapodien bleiben die Carpalia und Tarsalia frei mit Ausnahme von den miteinander verwachsenen Cuneiforme II und III. Das Trapezium kommt bei den jüngeren Formen in Wegfall. An den distalen Gelenken fehlen Leitkiele. Die fossilen Cameliden bilden in bezug auf Gebiß. und Skelettentwicklung eine ausgezeichnete, eng geschlossene Reihe, deren ältere Glieder sich mit Embryonen der lebenden Gattungen Camelus und Auchenia vergleichen lassen.

\section{Unterfamilie. Leptotragnlinae. Cope.}

Gebifi vollständig, oline Zahnlïcke. $\frac{3.1 .4 .3 .}{3.1 . t .3 .}$ Urachyodont, C gröjser als J. $P$ mit Ausnahme von $P_{4}$ schneidend. Obere iI aus vier Halbmonden besteliend. Metapodien nicht veruachsen, Hand vierfingerig, Fuß zweizehig mit proximalen Griffelbeinen. Radius und Ulna erst im Alter fest verbunden. Schädeldach eben. Schnauze kurz.

$B$ unomeryx Wortman. Obere $M$ mit fünf $\bigvee$-förmigen Höckern. $\frac{4}{3} P$, Molaren an Homacodon erinnernd, aber echt selenodont. Wohl eher verwandt mit Protocerces als mit den Cameliden. Obereocän. Uintabed $B$. elegans Wortman.

Leptotragulus Scott und Osborn (Parameryx Marsh). Uinta- bis Titanotheriumbed. Unvollständig bekannt, ebenso Oromery $x$ Marsh.

Protylopus Wortman. Schnauze kurz. Orbita hinten nicht geschlossen. Obereocän. Uintabed. P. Petersoni Wortman.

Eotylopus Matthew. Oligocän. Titanotheriumbed.

1) Cope E. D., The Phylogeny of the Camelidae. Amer. Naturalist 1886 . Matthew C. W., Mem. An. Mus. New York I. 1901. - Scott W. B., On the Phylogeny of Poebrotherium. Journ. of Morphology. 1891. V. und The selenodont Artiodactyls of the Uinta Eocene. Transact. Wagners free Institut Philad. 1899.

Wortman J. L., The Extinct Camelidae of North America. Bull. Amer. Mus. Nat. Hist. New York. 1898. 
2. Unterfamilie. Poëbrotheriinae. Cope.

Gebij: vollständig, meist mit $\frac{3.1 .4 .3}{3.1 .4 .3}$ Zwischenkiefer und Symphyse verlängert. Orbita hinten nicht vollständig geschlossen. Metapodien getrennt. Hand und Fuß zweizehig, digitigrad. Endphalangen hufartig. Seitenzehen nur durch proximale Stuminel angedeutet. Ulna und Radius verwachsen. Oligocän und Untermiocän von Nordamerika.

Pö̈brotherium Leidy (Fig. 676). Mit kleinem unteren C. Größe von Reh. Oligocän (White Riverbed). P. Wilsoni Leidy.

Paratylopus Douglass (Gomphotherium Cope). (Fig. 677.) Unterer $C$ groß. Orbita fast geschlossen. Gesicht verkürzt. Von Wildschafgröße. Untermiocän, John Day- und Oligocän, Protocerasbed.

Oxydactylus Douglass. Protomeryx Leidy. Mittelmiocän.

A

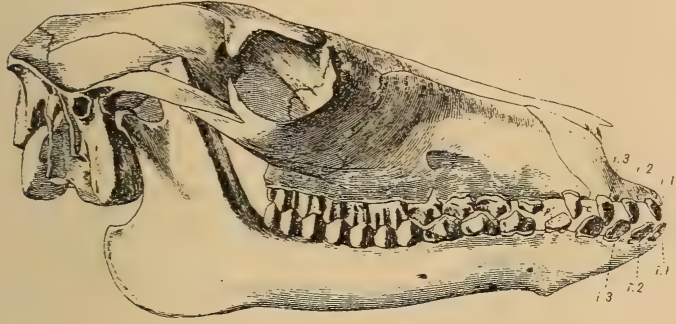

Fig. 676.

Poëbrotherium Wilsoni Leidy. Oligocän. White Riverbed Nebraska. A Schädel und Unterkiefer $2 / 5$ nat. Gr. B Vorderfuß. C Hinterfuß $1 / 3$ nat. Gr. (nach Wortman.)

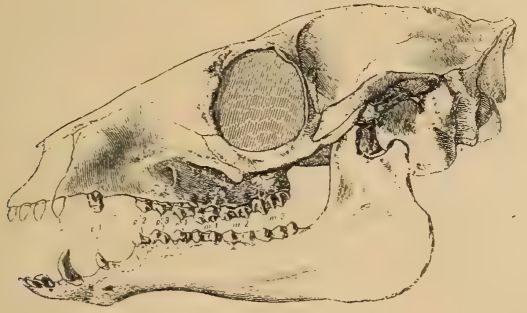

Fig. 677

Paratylopus Sternbergi Cope sp. Untermiocän. John Daybed. Oregon. Schädel und Unterkiefer. $1 / 4$ nat. Gr. (Nach Wortman.)

3. Unterfamilie. Protolabinae. Cope.

Gebiß vollstündig. Orbita vollständig geschlossen. Extremitüten zweizehig, semidigitigrad. Hauptmetapodien meist zu einem Canon veruachsen. Ulna und Radius verwachsen.

Im Miocän von Nordamerika. Lama- bis Kamelgröße.

Protolabis Cope. $\frac{\text { 3.1.4.3. }}{3.1 .4 .3 .} P_{1}$ zuweilen fehlend. Metapodien nicht verschmolzen. Obermiocän. Colorado. miocän

Stenomylus Peterson. $M$ langgestreckt und hochkronig. MittelPliocän.

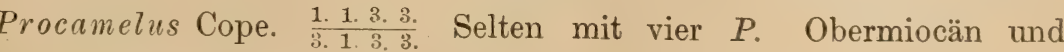


Plianchenia Cope. Ohne $P_{2}$. Obermiocän und Pliocän von Texas und Nebraska.

Alticamelus Matthew. Ohne obere $J^{1}$ und $J^{2}$, jedoch mit $4 I^{\prime}$. Hals, Metapodien, Femur und Tibia ungewöhnlich lang. Obermiocän von Colorado und Pliocän von Nebraska.

\section{Unterfamilie. Camelinae. Cope.}

Gebiß mehr oder weniger rerhuziert. Ulna mit Radius vernachsen. Extre. mitäten zweizehig. Alle drei Zehenglieder dem Boden aufliegend. Metapodien verschmolzen.

Im Pliocän und Pleistocän von Nord-und Südamerika und im Unterpliocän von Indien und China. Lebend in Asien, Nordafrika und Südamerika.

Camelus Lin. (Merycotherium Bojanus). 1. 1. 3.:. Im Milchgebiß noch drei obere Schneidezähne. $J_{3}$-ähnlich. Zahnlücke vor und hinter $C$ und hinter dem vordersten $P$. Untere $J$ schaufelartig, $C$ kräftig. $P^{3}$ und $P^{4}$ aus Außenwand und innerem Halbmond bestehend. $M$ ziemlich hoch. Lebend in Nordafrika und Asien. Fossil im Unterpliocän von Indien C. siralensis Falc. Cautl. und China und im Pleistocän von Sibirien und Südrußland, C. sibiricıs Boj. sp., von Rumänien C. alıtensis Stefanescu, von Algier (. Thomasi Pomel und von Nordamerika C. americanus Wortman.

Protauchenia Branco, Palaeolama Gervais, Hemiauchenia, Stilauchenia, Lamaops Ameghino im Pleistocän von Südamerika. anıerika.

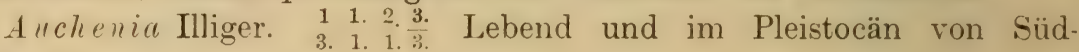

Camelops Leidy, Holomeniscus und Eschatius Cope stehen A॥chenia nahe, sind aber nur unvollständig bekannt. Pliocän? und Pleistocän von Oregon, Kalifornien und Mexiko.

\section{Familie. Tragulidae. Zwerghirsche. ${ }^{1}$ )}

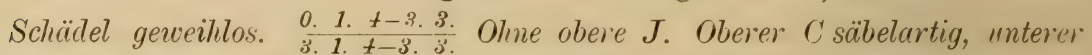
als vierter Incisiv ansgebildet. Zahnlücke ziemlich weit. II selenodont, mit nur viev. Höckern, die oberen allseitig vom Basalband umgeben. P verlängert, seitlich komprimiert und mit Ausnahme von $P^{4}$ schneidend. Carpalia und Tarsalia teilueise verschmolzen. Mittlere Metapodien viel stärker als die vollstïndig erhaltenen seitlichen, getrennt oder zn einem Canon verwachsen. Reduktion der Seitenzehen adaptiv. Magen mit drei Abteilungen.

Die Traguliden erreichen höchstens die Dimensionen vom Reh. Sie beginnen im Oligocän von Europa und gehen wohl auf Dirhobune ähnliche Formen zurück. Im Miocän sind sie bereits überaus selten und nur durch Dorcatherium vertreten, aus welchem sich die jetzt in Westafrika lebende Gattung Hyaemoschus entwickelt hat. Dagegen ist der Vorfahre der jetzt in Südindien und auf den Sundainseln verbreiteten Gattung Tragulus bis jetzt noch nicht ermittelt.

Der hornlose Schädel, die freibleibende Ulna, die unvollständige Verschmelzung der Hauptmetapodien, die Persistenz der seitlichen Metapodien, die bei den Gelocinen freilich in der Mitte aufgelöst werden, und die gestreckten einfacheren und schneidenden $P$ verleihen den Traguliden ein ursprünglicheres Gepräge gegenüber den Cervicornia und den Cavicornia, von welchen sich die beiden lebenden Gattungen auch durch die diffuse Placenta und den dreiteiligen Magen unterscheiden. Hingegen fehlen auch

1) Kowalewsky W., Gelocus. Palaeontogr. Bd. XXIV. 187. - Milne Edwards A. Annals scienc. nat. Zoologie 5. Ser. II 1864. 
bei ihnen schon die oberen $J$, und die $I$ haben große Ähnlichkeit mit jenen der Cericicornia, welche auch sicher auf gewisse Traguliden - Gelocinen - zurückgehen, denn sie sind mit diesen durch die geweihlosen Gattungen Amphitragulus und Dremotherium innig verbunden. Auch für die Cavicornia mit hirsch- und rinderähnlicher Bezahnung ist die Abstammung von den Gelocinen sehr wahrscheinlich.

\section{Unterfamilie. Tragulinae.}

Hinterhaupt groß und schmal. Bullue mit zelligem Geviebe erfiullt. . P einfach. langgestreckt, mit Ausnahme von $P^{4}$. Untere $I I$ meist mit schräger, von der Spitze des ersten Innen- und öfters anch des ersten Außenhöckers nach hinten verlaufenden Leiste. Obere II mit starkem Cingulum. Seitliche Metapodien vorne und hinten vollständig. Cuboid und Nariculare. später auch die Cuneiformia zu einem Knochen verschmolzen.

Fossil im Oligocän, Miocän und Unterpliocän von Europa und im Pliocän und Pleistocän von Südasien. Lebend in Südostasien und Westafrika. Die oligocänen Gattungen haben keine Nachkommen hinterlassen.

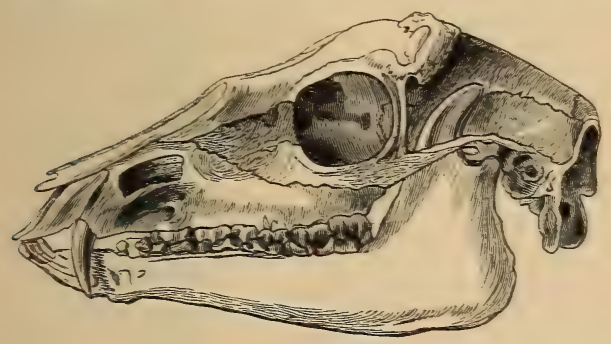

Fig. 67s.

Dorcatherium Naui Kaup. Unt. Pliocän. Eppelsheim bei Worms. Schädel, 1/3 nat. Gr. (Nach Kaup.)
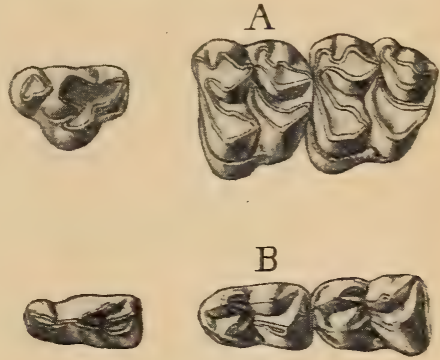

Fig. 679 .

Dorcatherium crassum Lartet $\mathrm{sp}$. Obermiocän. Günzburg. $A$ obere $P^{3}, M^{3}, M^{3}$ $B$ unterer $P_{3}, M_{1}, M_{\mathbf{2}}$.

Cryptomery $x$ Schlosser. $\frac{3}{4} P$. Untere $M$ mit Leiste am ersten Innenhöcker. Oligocän? Phosphorite von Quercy.

Lophiomeryx Pomel. Obere II vierhöckerig, untere ohne Leiste, mit konischem ersten Innenhöcker. Metapodien getrennt. Oligocän. Cournon, Frankfurt a. M., Phosphorite von Quercy.

Dorcatherim Kaup. (Fig. 678, 679.) $\frac{3}{4} P$, obere $M$ vierhöckerig, untere II mit Leiste am ersten Innen- und Außenhöcker. Oberer $C$ dolchartig. Vordere Metapodien getrennt, hintere verschmolzen. Seitenzehen sehr dünn. Obermiocän von Europa. D. guntianum Meyer, crassum Lart sp. Unterpliocän. D. Naui Kaup. Pliocän von Indien. 'D. majus Lyd.

Hyaemoschus Gray. $\frac{3}{3} P$. Lebend in Westafrika.

Tragulus Brisson. (Fig. 652 D.) Kleiner. Mittlere Metapodien im Alter fest verwachsen. Pliocän und Pleistocän von Südindien $T$. sicalensis Lyd. Lebend T. meminna Gray.

\section{Unterfamilie. Gelocinae.}

Tntere .II ohne Leisten am ersten Innen- und am ersten Aujienhöchier. Wittlere Metapodien mehr oder weniger fest zu einem Canon verwachsen. seitliche dïnn und in der Mitte aufgelöst. Cuboid und Nariculare miteinander verschmolzen. Oligocän von Europa.

Unter den Gelocinen haben wir sowohl die Ahnen der Hirsche, als auch die Stammeltern der Cavicornier mit hirsch- oder rinderähnlichen Backenzähnen zu suchen. 
Gelocus Aymard. (Fig. 680.) Obere $1 /$ niedrig, mit vier Höckern. Innenhöcker der unteren $I$ massiv. $P$ einfach, langgestreckt. Kleiner unterer $P_{1}$ vorhanden. Im Oligocän von Ronzon, Ulm, Böhmen und Phosphorite von Quercy.
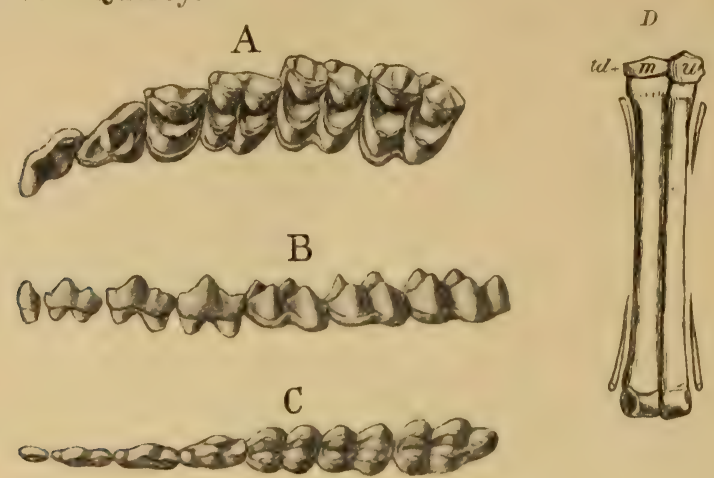

Fig. 680 .

Gelocus communis Avmard Oligocän. Ronzon (Haute Loire) $A$ obere Backenzähne, $B$ untere $P$ und $M$ von außen. $C$ von oben. $D$ Vorderfuß, $E$ Hinterfuß $1 / 2$ nat. Gr. (n. K ow alew sky.)

Paragelocus Schlosser. Obere $M$ mit fünf Höckern und Pseudagelocus Schlosser mit komplizierten unterem $P_{4}$. Oligocän. Bohnerze von Ulm.

Bachitherium Filhol. $\frac{3}{8} P$, unterer $P_{4}$ kompli-, ziert und Prodremotherium Filhol. (Fig. 681, 682.) $\frac{3}{3} P$, einfach gebaut. Oligocän. Phosphorite von Quercy.

\section{Familie. Hypertragulidae. $\left.{ }^{1}\right)$}

Schädel anfangs ohne knöcherne Auswüchse, später mit Geweih versehen, das stets von Haut bedeckt bleibt, mit Ethmoidalliicken, meist mit grofien Bullae osseae und mit vorspringender, hinten ge.

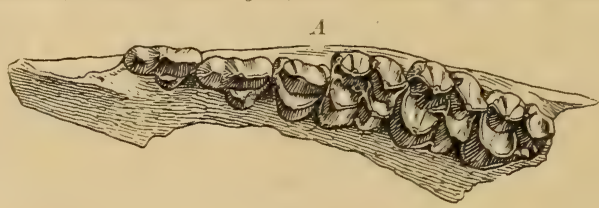

B

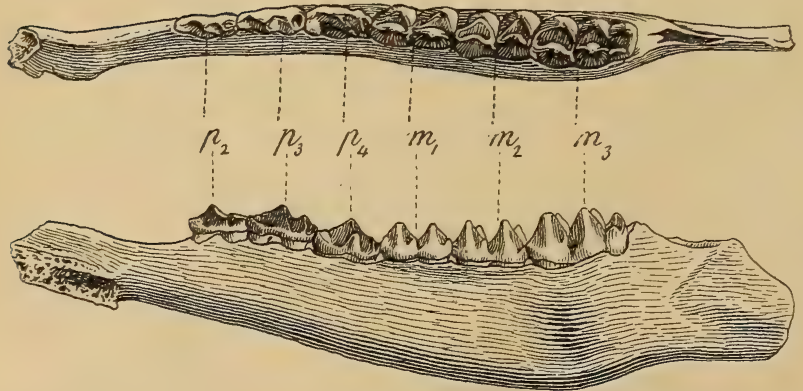

Fig. 681

Prodremotherium elongatum Filhol. Oligocän (Phosphorite). Quercy. $A$ Oberkiefer von unt., $B$ Unterkiefer von oben $\mathrm{u}$, von innen. $3 / 4$ nat. Gr. schlossener Orbita. Un terkiefer lang und schlank. Ohne obere $J$; oberer $C$ meist klein, unterer $C$ als $J$ ent. wickelt. $M$ brachyo. dont, selenodont, untere M ohne Falte auf Hin. terseite des ersten Außenmondes. Obere

1) Matthew W. $D$., Revision of the Hypertragulidae. Bull. Amer. Mus. Nat. Hist. New York 1902 und Osteology of Blastomeryx. Ibid. 1908. Scott W. B., White River Selenodonts. Transact. Wagners free Instit. of Science. Philad. 1899. 
II vierhöckerig. F ziemlich einfach. Vorderextremität vierzehig, mittlere Metacarpalien niemals zu einem Canon verwachsen. Seitenzehen wohl entwickelt. Hinterextremität zweizehig. Mittlere Metatarsalien zu einem Canon verschmolzen. Seitenzehen rudimentär. Cuboid und Naviculare verwachsen.

Die Hypertraguliden sind auf Nordamerika beschränkt. Sie treten hier zuerst im Oligocän (White Riverbed) auf und erreichen im Miocän ihre höchste Entwicklung in der Gattung Blastomeryx, welche nach Matthew den Vorfahren der südamerikanischen Hirschgattung Mazama darstellt.

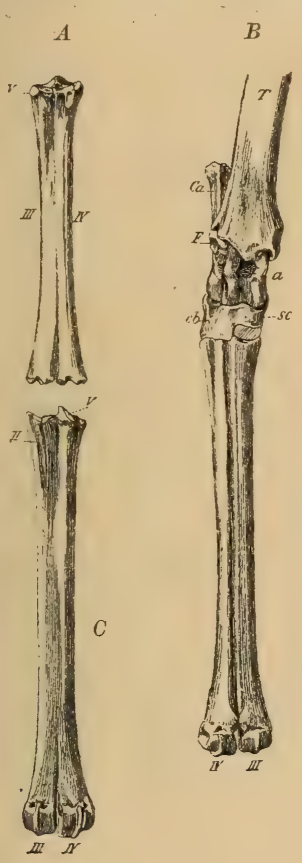

Fig. 682 .

Prodremotherium elongatum Filhol. Oligocän (Phosphorite). Quercy. A Metacarpus von hinten. $B$ Tibia, Tarsus und Metatarsus von vorne. $C$ Metatarsus von hinten. ( $T$ Tibia, $F$ Rudiment der Fibula, Ca Calcaneum, $a$ Astragalus, $c b+s c$ Cubo-scaphoideum.)
A

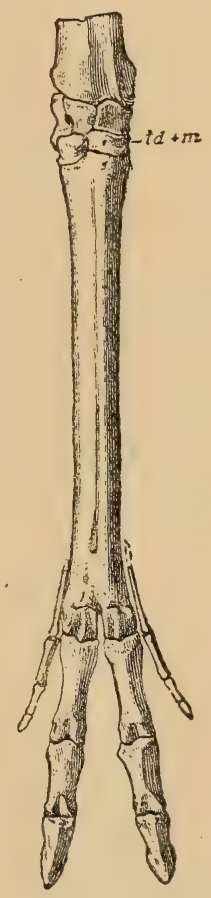

Fig. 683 .

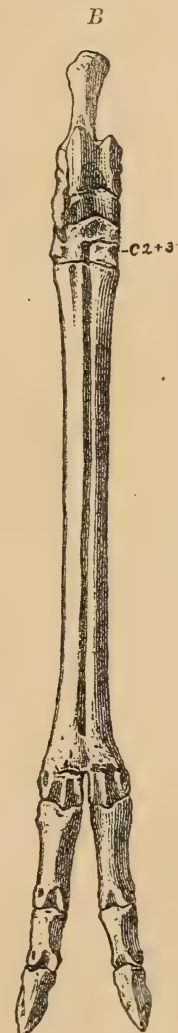

Blastomeryx gemmifer Cope. Unt. Pliocän (Loup Fork-Stufe). Nebraska. $A$ teleometacarpaler Vorderfuß,

$B$ Hinterfuß, $2 / 5$ nat. Gr. (Nach Scott.)

Die Hypertraguliden wurden früher mit den Traguliden vereinigt, von welchen sie sich jedoch durch das Fehlen der Falte an der Innenseite des Metaconids und des ersten Außenmondes der unteren $M$ unterscheiden.

Leptomery $x$ Leidy. Ohne $P^{1}$, unterer $P_{1}$ klein. Radius und Ulna frei. Oligocän. White Riverbed. L. Evansi Leidy. Untermiocän von Montana. Ist der Vorfahre von Blastomeryx.

Hypertragulus Cope. Oberer $C$ und unterer $P_{1}$ groß, die folgenden $P$ kurz. Radius und Ulna verwachsen. Oligocän und Untermiocän (John Daybed von Oregon). H. calcaratus Cope.

Allomeryx Merriam und Sinclair. Untermiocän. Oregon.

Blastomery $x$ Cope. $\frac{34-. .310 . .}{3.1 .4-3.3 .}$ Schädel geweihlos, oberer $C$ lang, $M$ brachyodont, untere ohne Palaeomeryxfalte. $P$ einfach. Oberer $P^{2}$ und 
$P^{3}$ mit kleinem Innenhöcker, untere $P$ mit unverästelten Kulissen an der Innenseite. Radius und Ulna getrennt. Vorderfuß vierzehig, mittlere Metapodien getrennt, Hinterfuß zweizehig mit proximalen Resten der Seitenzehen. Untermiocän. B. Olcotti, primus Natthew. Bl. gemmifer Cope (Fig. 683. mit kurzem Gablergeweih und rudimentären Seitenzehen ist jünger und auch generisch verschieden.

\section{Familie. Cervicornia. Geweihträger.}

Schädel der. Mämnchen in der Regel mit Geweih oder knöchernen Fortsützen

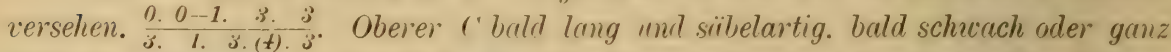
fehlend, unterer als vierter $J$ fungierend. Langes Diastema hinter den C: Backenzähne selenodont, brachyodont. Obere P' kurz, mit änfierem nnd innerem Halbmond. Carpalia - Magnum und Trapezoid - "nd Tarsalia - Cuboir und Nariculare teilueise verschmolzen. Hanptmetapodien stets z" einem r'anon reviachsen. Seit. liche Metapodien dium. meist mur als proximale orler distale Reste erhalten, mit kurzen Afterzehen.

Das Skelett der ('ervicmmia zeichnet sich wie das der Traguliden durch spröde Knochensubstanz mit reichlichen Osteoblasten und durch die dünnen Schädelknochen aus.

Der Schädel ist lang gestreckt, und seine faziale Achse ist nicht gegen die kraniale Achse geknickt wie bei den meisten Caricornia. Die gewölbte Hirnkapsel wird oben vorzugsweise von den Scheitelbeinen und nur zun geringeren Teil von den Stirnbeinen gebildet, seitlich gewinnen die Schuppen der Schläfenbeine ansehnliche Ausdehnung. Die ungewöhnlich großen Tränenbeine sind außen mit Vertiefungen, den Tränengruben, versehen. Zwischen Tränenbein, Nasenbein, Stirnbein und Oberkiefer ist sehr häufig eine »Ethmoidallücke vorhanden, die zu einem von dünnen Knochenlamellen und Lufthöhlen erfüllten Raume führt. Die seitlich vorstehenden Orbiten sind hinten geschlossen. Das Geweih hat nur geringen systematischen Wert, denn es fehlt den weiblichen Individuen außer beim Renntier immer und bei den ältesten fossilen Formen auch den Männchen. Auch bönnen ähnliche Gewreihformen bei Hirscharten vorkommen, die nicht näher mitander verwandt sind. Auf die Gesamtbildung des Schädels übt es einen viel geringeren Einfluß aus als die knöchernen Stirnzapfen der Cavicornia. Bei den Giraffen und Protoceratinen bleiben die Knochenfortsätze auf den Stirnbeinen dauernd von Haut bedeckt. Meist aber wird sie nach und nach abgerieben, "gefegt «, und die Gewreihe ragen dann frei vor. Die basalen Knochenzapfen, welche die eigentlichen nach der Brunstzeit abwerfbaren Geweihe tragen, heißen Rosenstock, der knotige Wulst an der Basis des Geweihes Rose. Bei den mit mehrfach gegabeltem Geweih versehenen Formen beginnt es mit einem einzigen Sprossen, Spießer, der sich im zweiten Jahre in zwei Äste gabelt. In den folgenden Jahren kommt jedesmal ein neuer Sproß zu den bereits vorhandenen hinzu. In ähnlicher Weise verläuft auch die phylogenetische Entricklung. Die ältesten, untermiocänen Formen besitzen überhaupt kein Geweih, bei mittel- und obermiocänen Formen besteht es lediglich aus einer oder zwei Sprossen, ebenso bei Dicrocerus, doch wird es hier schon bei einer Art abgeworfen. Im Pliocän beginnen Hirsche mit kurzem Rosenstock, langer Stange und zwei bis drei

1) Brook V., Classification of the Cervidae. Proceed, zool, Soc. London 1878. - Darkins Boyd, British Pleistocene Cerridae. Palaeont. Soc. London 1887. Mattheu W. D., Osteology of Blastomeryx and Phylogeny of Am. Cervidae. Bull. Am. Mus. Nat. Hist. New York 1908. - Pohlig H., Die Cerriden des thüring. Diluvialtravertins. Palaeontogr. Bd. 39. 1892. - Rütimeyer L., Beitr. zu einer natürl. Geschichte der Hirsche. Abh. Schweiz, palaeont. Ges. 1880-83. Bd. VII, VIII, X. 
Nebensprossen. Erst im Oberpliocän und Pleistocän entfalten die Geweihe jene Üppigkeit, Größe und reiche Verzweigung, wie sie beim Edelhirsch, Renntier, Elch und in höchster Potenz beim Riesenhirsch beobachtet werden.

Im Ge biß (Fig. 684) fehlen die oberen $J$ stets und die oberen $C$ sind bei den jüngsten Formen meist nur bei den Männchen vorhanden. Der untere $C$ hat die Form und Funktion eines $J$. Die Backenzähne sind brachyodont und die oberen drei-, die unteren zweiwurzelig. Die Krone ist mit dickem, runzeligem Schmelz bedeckt und in der Regel mit einem Basalpfeiler versehen, der sich an den oberen $I I$ auf der Innen-, an den unteren $M$ auf der Außenseite befindet. Die Außenseite der oberen $M$ trägt stets zwei Vertikalfalten - Parastyl und Mesostyl. Zwischen jedem Außenhöcker und dem benachbarten inneren Halbmond befindet sich die Marke, in welche meist vom inneren Halbmond aus ein spornartiger Fortsatz hineinragt. Die oberen $P$ sind kurz und stellen scheinbar halbe Molaren dar. Die unteren $M$ sind niedrig, typisch selenodont. Die ziemlich kurzen unteren $P$ bestehen aus einem kürzeren hinteren und einem längeren vorderen Abschnitt und tragen auf ihrer Innenseite vertikale Vorsprünge, Kulissen. Die ältesten fossilen Formen besaßen zum Teil noch vier $P$, bei den übrigen sind immer nur drei $P$ vorhanden.
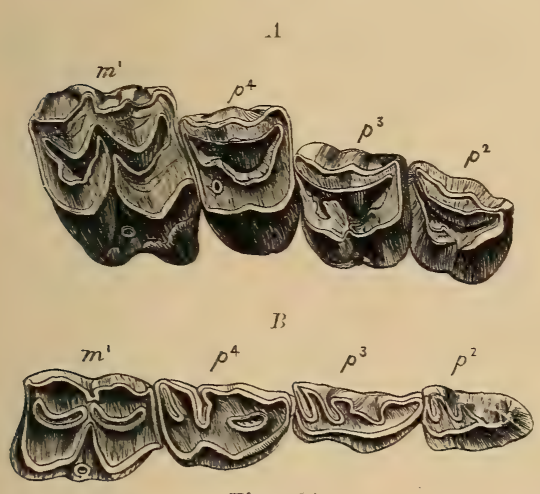

Fig. 684 .

Cervus (Polycladus) dicranius léest. Ob. Pliocän. Val d Arno. Toskana. A die drei $P$ und der erste $U$ des Oberkiefers. $B$ desgleichen vom Unterkiefer. Nat. Gr.

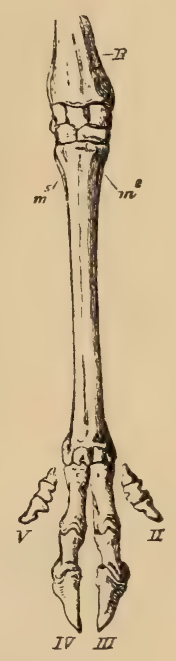

Fig 685 .

Plesiometacarpaler Vorderfuß von Cervus elaphus Lin., 1/7 nat. Gr. (Nach Flower.) $m^{5}$ und $m^{2}$ proximale Stücke der seitlichen Metacarpalia, $I I-V$ zweite bis fünte Zehe.

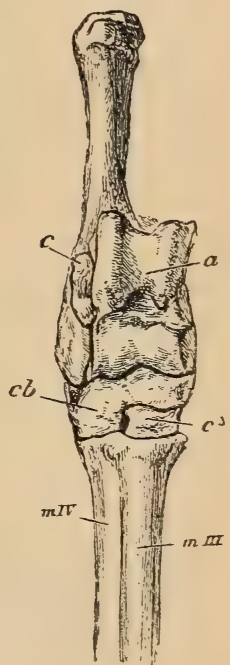

Fig. 686 .

Hinterfuß vom Hirseh (Cervus elaphus), 1/3 nat. Gr. (Nach Flower.) c Calcaneum. a Astragalus, $e b+b c$ Cuboscaphoideum, $c^{2}$ cuneiforme, $m I \mathrm{I}^{\mathrm{T}}$ und $m I I I$ Mretatarsalia.

Von den Carpalien verwachsen Magnum und Trapezoid miteinander, die mittleren Metapodien verschmelzen frühzeitig zu einem Canon, die seitlichen (II und V) sind meist unvollständig, indem bald nur die proximalen (Plesiometacarpi) (Fig. 685), bald nur die distalen Teile (Teleometacarpi) (Fig. 683) als griffelartige Rudimente zur Entwicklung kommen. Kurze Afterzehen sowohl an der Vorder-als an der Hinterextremität besitzen alle echten Hirsche, dagegen fehlen sie den Giraffen. Im Tarsus verwachsen stets Cuboid und Naviculare und ebenso Cuneiforme II und III, dagegen bleibt das kleine Cuneiforme I stets frei. Von den äußeren Metatarsalia sind nur die proximalen Enden ausgebildet, aber auch häufig mit dem Canon verwachsen.

Die Cervicornia bewohnen gegenwärtig ganz Asien, Europa und Amerika und in der Form von Giraffen auch das zentrale und südliche Afrika. In der alten Welt sind die plesiometacarpischen Formen, in der neuen die teleometacarpischen vorherrschend. Die echten Hirsche beginnen im unteren 
Miocän von Europa. Im oberen Miociin und Pliocän haben sie auch Vertreter in Nordamerika, im Pliocïn auch in Asien. Den Höhepunkt ihrer Entwicklung erreichen sie im Pleistocän und in der Jetztzeit.

1. Unterfamilie. Moschinae. Moschushirsche.

Schürtel geveihlos, obere C lang, sübelartig. $\frac{3}{3} P$. Distale Rudimente der seitlichen Metapodien mit langen dreigliederigen Afterzehen.

Dei beiden lebenden Gattungen (Moschus, Hydropotes) bewohnen die zentralasiatischen Hochländer. Fossile Reste von Moschus werden aus den Siwalikschichten von Indien erwähnt.

\section{Unterfamilie. Cervulinae. Muntjakhirsche.}

Schüdel geweihlos, oder. Männchen mit kurzem, weist nu. dichotom gegabeltem orler wenig sprossigem Geweih, das unf einem hohen Rosenstock sitzt und bei den ïlteren Formen nicht abgeworfen wnde. Obere Clang, sïbelartig, hinten schneidend. II alls vier .Monlen hestehend. Untere. II mit Leiste hinter dem ersten Aujenmond. P' wenig verlüngert, intere mit Kulissen. Vorderfußs meist plesiometacarpisch, selten telemetacarpisch.

Lebend in Südostasien. Fossil in Europa vom Miocän an.

Amphitragulıs Pomel. Schädel geweihlos, ohne Tränengrube und Ethmoidallücke. $M$ niedrig, die unteren mit Palaeomeryxleiste. $4 P \mathrm{im}$ Unterkiefer. Häufig mit distalen Resten der seitlichen Metapodien nebst Phalangen. Im Untermiocän. Auvergne, Ulm, Mainz, Pyrimont (Savoyen). A. elegans, lemanensis, gracilis Pomel. Hasen- bis Rehgröße.

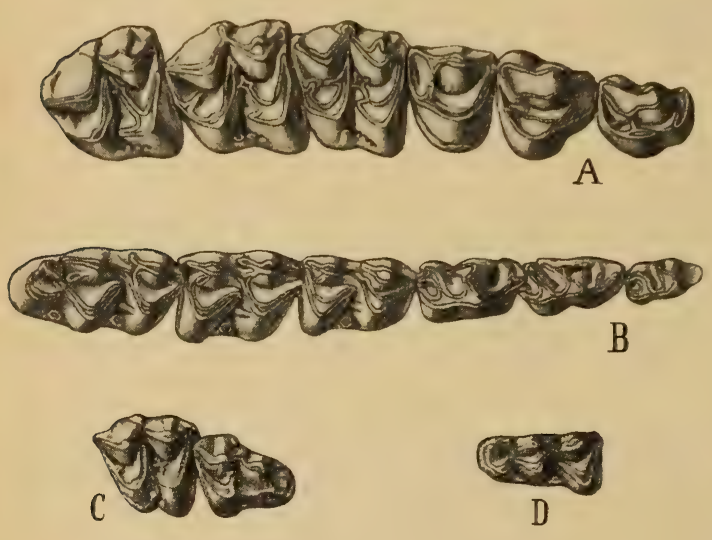

Fig. 687 .

Dicrocerus furcıtus Hensel sp. Obermiocän. Steinheim Württem. berg. $A$ obere, $B$ untere Backenzähne, $C$ obere Milchzähne $\left(D^{3}\right.$ und $\left.D^{4}\right), D$ unterer $D_{4}$ nat. Gr.

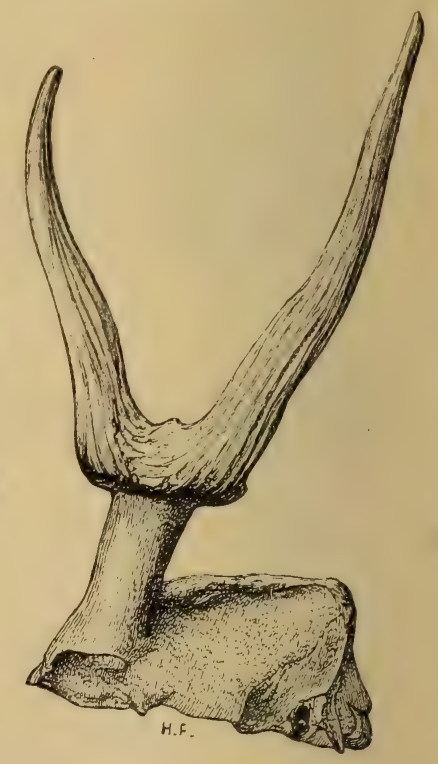

Fig. 688 .

Dicrocerus elegans lartet. :Obermiocän. Sansan. Gers. Geweih, $1 / 3$ nat. Gr. (nach Gaudry.)

Dremotherium Geoffroy. Nur drei untere $P$. Molarhöcker plump. Seitliche Metapodien nur durch proximale Griffel angedeutet, sonst wie vorige Gattung. Untermiocän. Auvergne, Ulm, Mainz. D. Feignouxi Pomel.

Micromeryx Lartet. Klein, mit relativ hohen $M$. Obermiocän. Sansan, Steinheim, La Grive St. Alban. 
Pal a e om ery $x$ v. Meyer. Schädel geweihlos, $M$ mit runzeligem Schmelz. Untere $M$ mit Leiste an Außenseite des vorderen Halbmondes. Meist große Formen. Mittelmiocän. Böhmen annectens Schlosser. Obermiocän P. Bojani, eminens v. Meyer.

Im Pliocän (?) von Nebraska kommen große Palaeomeryx ähnliche Formen vor, welche durch die schwache Ausbildung der Falte an den unteren $M$ und die Komplikation des unteren $P_{4}$ scheinbar den Übergang zu den Camelopardaliden vermitteln.

Dicrocerus Lartet (Procervulus Gaudry) (Fig. 687, 688). Wie vorige Gattung, jedoch Schädel mit zweisprossigem, selten dreisprossigem Geweih. Obermiocän. Schlesien, Steinheim etc. D. furcatus Hensel, Geweih ohne Rose, wohl persistierend. Sansan, Steiermark, bayerische Hochebene. D.elegans Lartet, Geweih mit Rose und wechselnd.

Lagomeryx Roger. Ähnlich, aber klein. Mit Spießer- oder kurzem verästeltem Geweih. Mittelmiocän Solnhofen, L. simplicicornis Schlosser. Obermiocän, Steiermark, Südbayern L. Meyeri Hofmann.

Cervavus Schlosser. Obere $C$ ziemlich kräftig, untere $M$ noch mit Spuren der Palaeomeryxfalte. Geweih dichotom. Größe von Reh. Unterpliocän von China. C. Oweni Koken sp.

Cervulus Blainv. Lebend in Südasien und fossil im Pleistocän von Indien und Java.

\section{Unterfamilie. Cervinae.}

Geweih mit kurzem Rosenstock, mehrfach gegabelt, periodisch wechselnd und abgesehen von Ren, nur bei den Männchen vorhanden. Obere $C$ schwach oder fehlend. Backenzähne brachyodont. Vorderfuß plesiometacarpal bei den altweltlichen

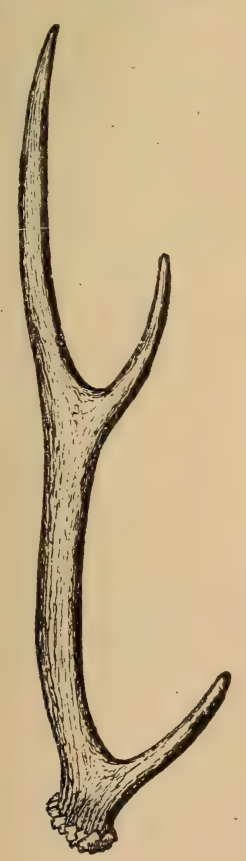

Fig. 689.

Cervus (Axis) pardinensis Croizet und Jobert. Oberpliocän. Auvergne. Geweih. 1/8 nat. Gr. (Nach Ga udry.) Hirschen (mit Ausnahme von Elentier, Ren und Reh), teleometacarpal bei den neuveltlichen (mit Ausnahme von Cervus canadensis). Lebend auf der nördlichen $\mathrm{He}$ misphäre und in Südamerika. Fossil vom Pliocän an in Europa und Asien, in Amerika erst im Pleistocän.
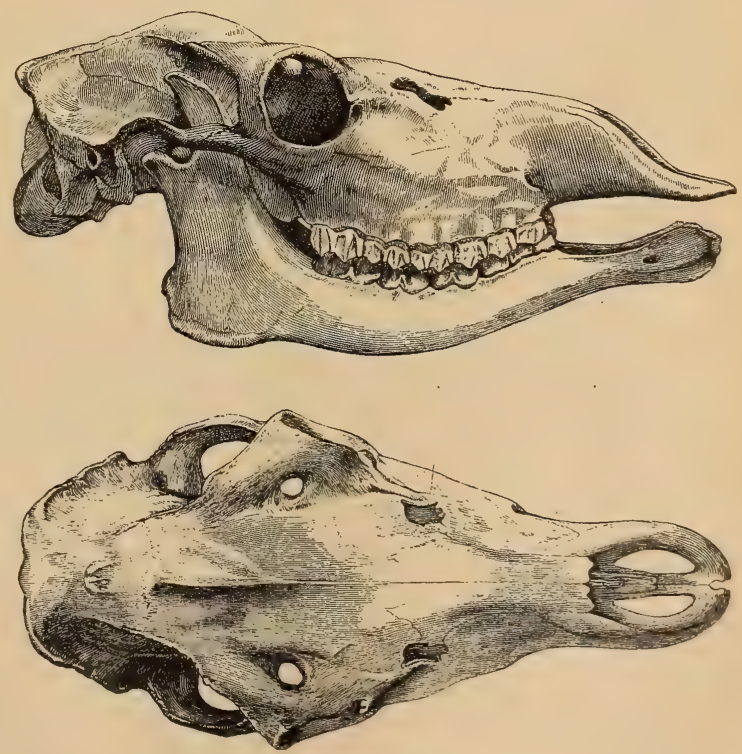

Fig. 690 .

Cervus (Megaceros) hibernicus Owen. Torf von Irland. Weiblicher Schädel. $1 / 7$ nat. Gr. (nach O we n.) 
Der Gattungsname Cervus sollte nur mehr für nicht näher bestimm. bare Hirschreste Anwendung finden, die besser erhaltenen fossilen lassen sich meist ziemlich ungezwungen unter die folgenden Subgenera verteilen.

Capreolus Ham. Smith. Geweih aufrecht, dreisprossig. Im Unterpliocän von Cucuron, Baltavar C. Matheroni Gerv., im Mittelpliocän C. australis de Serres, ruscinensis Depéret, im Oberpliocän der Auvergne (.. cusanus Croiz. et Job. Im Pleistocän C. capreolus Linn.

Furcifer, Blastoceras Gray, Mazama Rafinesque. Lebend und fossil in Südamerika. Odocoileus. Pleistocän und Gegenwart in Nordamerika.

Axis Ham. Smith. (Fig. 689.) Geweih schlank mit drei bis vier zylindrischen Nebensprossen. Plesiometacarpal. Pliocän der Auvergne (C. borbonicns, pardinensis Croiz et Job.), im Crag von England. Lebend und im Pleistocïn von Indien. Im Pleistocän von Trinil auf Java A. Iydekkeri Martin.

Rus a Ham. Smith. Asien. Fossil im Pleistocän von China. C. Aristotelis Cuv.

Elaphus Gervais. Geweih vielsprossig, im Querschnitt gerundet. Pliociin ('. Perrieri, arvernensis, issindorensis Croiz. et Job., Pleistociin von Europa C. elaphns und canadensis, auch in Nordasien und Nordamerika. Ähnliche Zähne schon im Unterpliocïn von China.

Polycladıs Gerv. (Fig. 684). Geweih vielsprossig, Sprossen distal abgeplattet. Pliocïn Europa C. ramosus Croiz. Job., Sedgwicki Falcon. Dama Ham. Smith. (Megaceros Owen). (Fig. 690.) Geweih anfangs zylindrisch, distal abgeplattet, später schaufelartig. Lebend C. dama Lin. Südeuropa und Kleinasien. Fossil im Pliocïn und Pleistociin von Europa C. Browni Dawkins. Die größte Art ist der Riesenhirsch Megaceros euryceros Aldrov. im ïlteren Pleistocïn. In Torfmooren von Irland finden sich ganze Skelette von Megaceros libernicus Owen. Weibchen geweihlos.

Cervalces Scott. Plèistocïn von Nordamerika.

Alces Ham. Smith. (Elentier). Lebend und im Pleistocïn von Europa, Nordasien und Nordamerika. Im europäischen L'nterpleistocän A. latifrons Dawkins.

Rangifer Ham. Smith. Beide Geschlechter mit starkem, gegabeltem Geweih, Sprossen abgeplattet. Das Renntier (C: tarandus Lin.) bewohnt die Polarländer der nördlichen Hemisphäre. Im Pleistocän in ganz Mitteleuropa verbreitet, besonders häufig als Begleiter des Magdalénien-Menschen. In pliocänen Bohnerzen finden sich Rangifer-ähnliche Zähne. Im Pliocän von Piemont C. pliotarandoides de Alessandrini.

\section{Unterfamilie. Protoceratinae. Marsh. ${ }^{1}$ )}

$\frac{3-0.1 .4 .3 .}{3 .}$ 1.4. Backenzühne brachyodont, mit runzeligem Schmelz. Obere und untere $C$ bei beiden Geschlechtern vorhanden. Schüdel lang und flach, ohne Bulla, bei den später en Formen mit paarigen knöchernen Auswüchsen. Carpalia getrennt. Vorderfuß mit zwei starken mittleren und zwei schwëcheren seitlichen Metapodien. Hinterfuß anfangs mit vier freien Metatarsalia, später mit unvollständig verschmolzenem Canon und proximalen Seitengriffeln. Alle Tarsalia frei.

Die Protoceratinen sind auf Nordamerika beschränkt, aber wahrscheinlich die Ahnen der Sivatheriinae.

Camelomeryx Scott mit $\frac{2}{3} J$ und Leptoreodon Wortman mit $\frac{3}{3} J$. Beide mit großem oberen $C$. Unterer $C$ als vierter $J$ und unterer $P_{1}$ als $C$ entwickelt. Hinter $P_{1}$ in beiden Kiefern ein langes Diastema. Schädel

1) Marsh O. C., Amer. Journ. of Science 1891 p. 81 - Osborn H. F. and Wortman J, L.. Bull. Amer. Mus. nat. hist. 1892 p. 351. - Scott W. B., Journal of Morphology. Boston 1895 p. 301. 
ohne Protuberanzen. Hand und Fuß vierzehig, mittlere Metapodien nicht verwachsen. Systematische Stellung unsicher. Obereocän. Uintabed.

Heteromeryx Matthew. Orbita hinten geschlossen. Vorderfuß vierzehig, Hinterfuß zweizehig. Oligocän. Unteres White Riverbed.

Protoceras Marsh. (Fig. 691.) $\frac{3}{3} J$. Schädel beim Männchen mit knöchernen Zapfen auf Stirn- und Scheitelbeinen, und vertikalen Knochen-

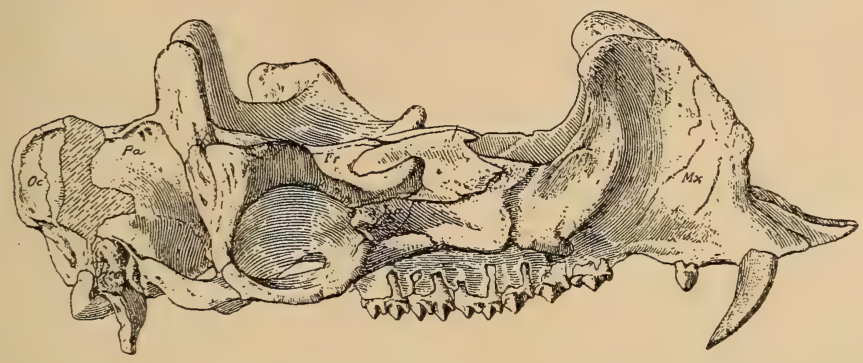

Fig. 691 .

Protoceras celer Marsh. Oligocän. Oberstes White Riverbed. Nebraska. 2/5 nat. Gr. (nach Osborn.)

platten auf Oberkiefer und Stirnbeinen, Weibchen nur mit schwachen Auswüchsen auf Scheitelbeinen. Vorderfuß vierzehig, Seitenmetacarpalia dünn, Hinterfuß zweizehig mit unvollständig verschmolzenem Canon und proximalen Resten der seitlichen Metatarsalia. Oberes Oligocän (White Riverbed).

Calops Marsh, Schädel ohne Hornzapfen. Ebendaselbst. beinen.

Syndyoceras Barbour, je ein einfaches Hornpaar auf Nasen- und Stirn-

\section{Unterfamilie. Giraffinae.}

Große hochbeinige Tiere mit langgestrecktem, entweder glattem oder mit kurzen paarigen, einfachen Stirnzapfen versehenem Schädel ohne Trünengrube, mit kleinen ringsum geschlossenen Orbita. Schädelknochen pneumatisch. Obere C fehlen, untere zweilappig. Backenzähne niedrig, gedrungen, hirschartig. Seitliche Metapodien und Afterzehen vollständig verkïmmert.

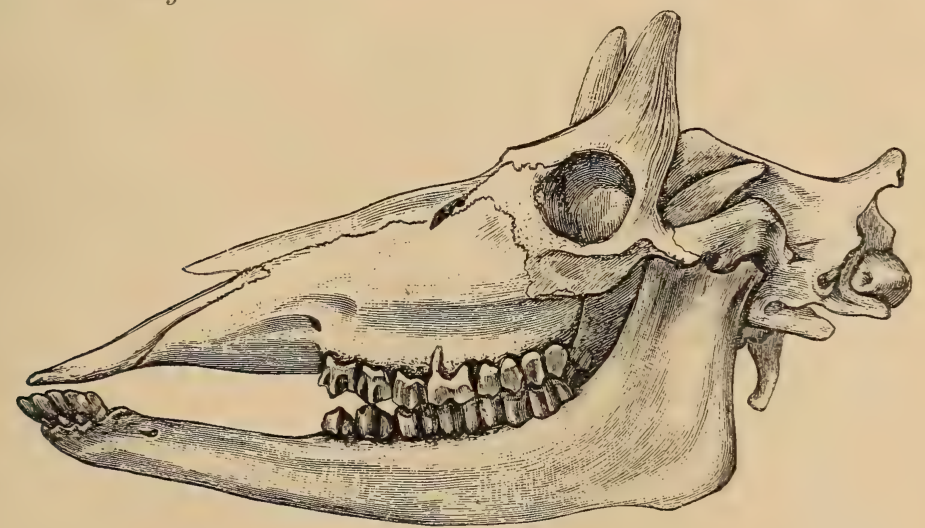

Fig. 692 .

Samotherium Boissierri Forsyth Major. Unt. Pliocän. Samos. Schädel verkleinert. (Nach Ly dekker.)

Lebend in Zentralafrika, fossil im Unterpliocän von Südeuropa, Persien, Indien und China.

Helladotherium Gaudry. Schädel ohne Stirnzapfen. Untere $P$ und $M$ ziemlich hoch. Hals mäßig lang. Hinterfuß und Vorderfuß fast 
gleich lang. Unterpliocän von Pikermi und Maragha. Ein ähnlicher Schädel aus den Siwalik gehört wohl zu Hydaspitherium grande.

Palaeotragus Gaudry. Klein. Schädel niedrig, mit weit vorne stehenden Hörnern. Zähne plump. Unterpliocän Pikermi. P. Roueni Gaudry.

Alcicephalus Rodler. Samotherium Forsyth Major. (Fig. 692.) Männlicher Schädel mit zwei stumpfen Knochenzapfen über den Orbita. Zähne plump. Hals kürzer als bei Giraffe. Unterpliocän von Samos, Persien und China.

Camelopardalis Schreber. Auf der Grenze von Stirn- und Scheitelbein ein Paar kurze Knochenzapfen und auf den Nasenbeinen eine Protuberanz. $P$ sehr kompliziert, it ziemlich schlank. Hals lang. Vorderbeine länger als Hinterbeine. Unterpliocän von Pikermi, Samos, Maragha, Siwalik, China und lebend.

Okapia R. Lancaster. Lebend Zentralafrika.

\section{Unterfamilie. Sivatheriinae.}

Große Wiederkïner mit stark ansgedehnten Stirnbeinen und pneumatischem Schüdeldach. Vor der Occipitrlkante, anf den hinteren Außsenecken der Stirnbeine zuei mächtige, öfter's anf gemeinsamer. Basis steltende, abgeplattete, schwach ver. ästelte, unten mit Hohlrïnmen verschene Knochenzapfen. Zunveilen auch ein Parr. konischer Knochenzupfen anf dem vorderen Teil der Stirnbeine. Backenzähne massiv und brachyodont.

Lydekker und Forsyth Major schließen die Sivatheriinen an die Giraffen an, während Murie und Rütimeyer Antilopencharaktere erkennen wollen. Das Gehörn erinnert an das Schaufelgeweih von Alces.

Sämtliche besser bekannte Vertreter dieser Gruppe (Sivatherium, Bramutherium Falconer und Hydaspitherium megacephalum Lydekker stammen aus den indischen Siwalikschichten. Im Unterpliocän von China kommen Zähne von Sivatheriinen vor, und aus Sanden von Adrianopel hat Abel einen Sivatherium-ähnlichen Hornzapfen beschrieben.

\section{Familie. Antilocapridae. ${ }^{1}$ )}

Schädel antilopenähnlich mit weit ausgedehnten Scheitelbeinen. Stirnbeine anf den supraorbitalen Teil des Schädeldaches beschränkt, mit gegabelten Knochenzapfen, welche von einer jührlich erneuerten Hornscheide umgeben sind. Lacrimale grof?. mit Grube, an Ethmoidallücke stoßend. Backenzüline hypselodont. Meist ohm obere Eckzähne und Schneidezrïne. Außenseite des oberen $M_{\ddot{z}}$ nrch rückwärts verlängert. $\frac{3}{3}$ sehr kurze $P$.

Auf Nordamerika beschränkt.

Hypisodus Cope. (Fig. 693.) Kaninchengröße. Schädel ohne Stirnzapfen. $\frac{3}{3}$ J. Hand und Fuß ohne Canon, mit vollständigen seitlichen Metapodien. Oligocän, White Riverbed.

Merycodus (Cosoryx) Leidy. (Fig. 694.) Schädel mit zwei- oder dreisprossigem, aufrechtstehendem und mit einem Rosenstock versehenen Geweih. Vorder- und Hinterfuß mit Canon und mit Afterzehen. Mittelmiocän bis Pliocän von Colorado und Kansas M. Osborni Matthew, furcatus Leidy.

Capromeryx Matthew. Nur Unterkiefer bekannt mit hypselodonten $M$ und reduzierten $P$. Pleistocän Nebraska.

Antilocapra Ord. Lebend und fossil. Nordamerika.

1) Matthen W. D., Hypisodus Bull. Amer. Mus. Nat. Hist. 1902. - Merycodus. Ibidem 1904. 


\section{Familie. Cavicornia. Hohlhörner. ${ }^{1}$ )}

Schädel beider Geschlechter, seltener nur der Männchen mit knöchernen, von

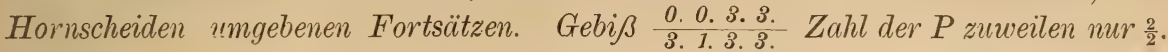

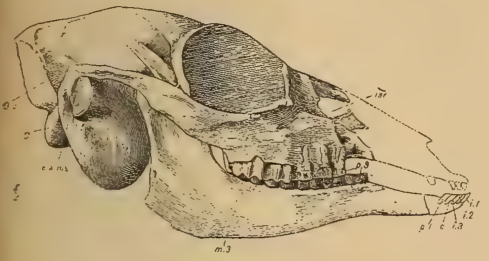

Fig. 693 .

Hypisodus minimus Cope. Oligocän. White Riverbed, Colorado. Schädel mit Unterkiefer. $3 / 4$ nat. Gr.

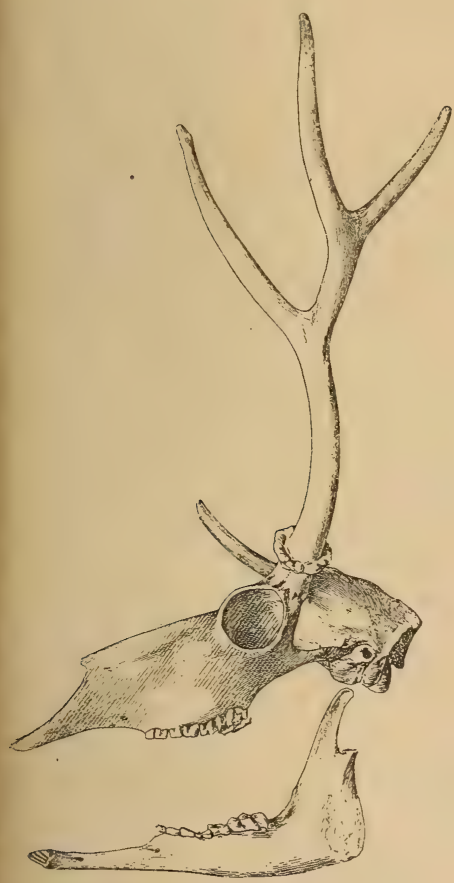

Fig. 694 .

Nerycodus Ösborni Matthew. Obermiocän. Colorado. Schädel $1 / 4$ nat. Gr. (nach Matthew.)
Backenzähne selenodont und brachyodont oder hypselodont. Carpus und Tarsus wie bei den Cervicornia. Hauptmetapodien zu einem Canon verschmolzen, mit scharfen distalen Leitkielen. Seitliche Metapodien niemals vollständig, häufig ganz verkïmmert. Afterzehen öfters vorhanden.

Die Cavicornier sind in mancher Hinsicht vorgeschrittener und spezialisierter als die Cervicornier. Die horizontal gestellte

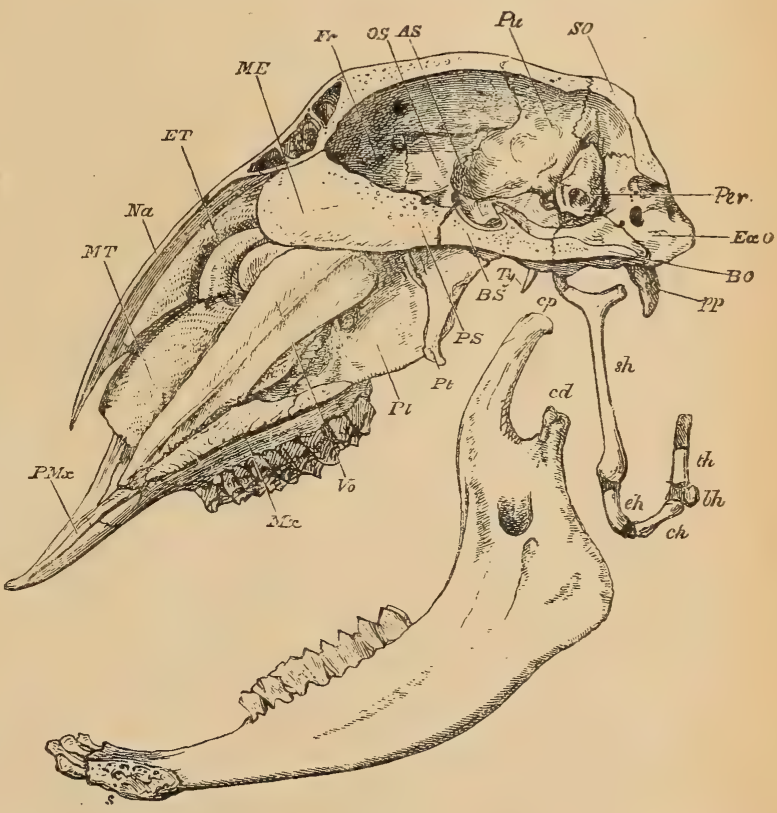

Fig. 695 .

Schädel eines hornlosen Schafes, in der Mittelebene vertikal durchschnitten, $1 / 3$ nat. Gr. (Nach Flower.) $P M x$ Zwischenkiefer, $N a$ Nasenbein, $M T$ Conchae des maxillaren, ET des ethmoidalen Riechrohres, ME Mesethmoideum, Vo Vomer, $P l$ Gaumenbein, Pt Flügelbein, PS Präsphenoid, Fr Stirnbein mit Lufthöhlen, OS Orbitosphenoid, AS Alisphenoid, BS Basisphenoid, $P a$ Scheitelbein, Per Felsenbein (Perioticum), Ty Griffelfortsatz des Tympanicum, SO Supraoccipitale, ExO Exoccipitale, BO Basioccipitale, $p p$ Processus paroccipitalis, $c p$ Kronfortsatz, $c d$ Condylus, $s$ Symphyse des Unterkiefers. $s h$, $e h, c h, b h$, th verschiedene Abschnitte des Zungenbeins.

kraniale Achse bildet mit der Gesichtsachse einen stumpfen Winkel. (Fig. 695.) Die Stirnbeine zeigen eine ungewöhnliche Ausdehnung. Die Frontalzone nimmt hinter den Orbiten den größten Teil des Schädeldaches ein und

1) Rütimeyer L., Die Rinder der Tertiärepoche. Abh. schweiz. paläont. Ges 1877-78. - Rodler und Weithofer, Die Wiederkäuer der Fauna von Maragha. Denkschr. k. k. Akad. Wiss. Wien 1890. - Schlosser M., Versuch einer Odontographie der Antilopen. Abh. II Cl. k, bavr. Akad. d. Wiss. XXU. Bd. 1903. - Die fossilen Cavicornier der Insel Samos. Beitr. Paläont. Öst.-Ung. Bd. XVII. 1904. 
drängt die stark verkürzten Scheitelbeine nach hinten, bei den extremsten Formen verlagern sich letztere sogar ganz auf die Hinterhauptstliiche. Mit der Ausdehnung der Stirnbeine ist häufig eine bedeutende Erweiterung der Sinus frontales verbunden, die Diploe wird durch Lufthöhlen ersetzt und die Stirn wird pneumatisch. Die verschiedenen Antilopen zeigen alle Stadien dieser Ausbildung der Frontalzone, z. B. bei gewissen Gazellen haben die Stirnbeine noch wie bei den Hirschen eine Knochendiploe, bei anderen treten schon kleinere oder größere Lufträume auf. In der hinteren Stirnregion über oder hinter den mehr oder weniger vorragenden geschlossenen Orbiten erheben sich - zuweilen nur beim Männchen - die knöchernen, bald massiven, bald pneumatischen Hornzapfen, deren hohle Basis mit den Lufträumen im Stirnbein kommuniziert. Bei den primitiveren Formen stehen die Zapfen aufrecht oder schräg nach hinten gerichtet zwischen den Augenhöhlen, bei den extremsten - Bos - rücken sie weit nach hinten und außen in die Hinterecken des Schïdels und richten sich fast rechtwinklig und horizontal nach außen. Nasenbeine, Oberkiefer und Trünenbeine sind meist stark entwickelt, die Jochbogen dagegen dünn und kurz. Tränengruben und Ethmoidallücken finden sich häufig bei Antilopen, niemals bei den Rindern, Schafen und Ziegen.

Das Gebiß ist unvollstïndig und ohne obere $J$ und $C$. Der untere $C$ hat sich in einen vierten $J$ verwandelt. Von den $\frac{3}{3} P$ kann zuweilen der vorderste verschwinden. Die selenodonten Molaren blieben bei den primitiveren Formen - gewisse Antilopen - brachyodont, bei den vorgeschritteneren sind sie dagegen hypselodont und nicht selten sogar prismatisch. Der Schmelz ist bald glatt, bald runzelig, akzessorische Pfeilerchen fehlen entweder oder sie werden (Bovinen) sogar ungewöhnlich stark. An den oberen $M$ besteht die durch Vertikalfalten verstärkte Außenwand aus zwei sichelförmig gebogenen Blättern, die halbmondförmigen Innenhügel bilden meist geschlossene Marken. Die unteren $M$ unterscheiden sich, abgesehen von ihrer Schmalheit dadurch, daß ihre Innenseite den Bau der Außenseite und ihre Außenseite den Bau der Innenseite der oberen $M$ imitiert. Basalpfeiler finden sich nicht selten an der Außenseite der unteren und an der Innenseite der oberen $M$. Die kurzen oberen $P$ bestehen aus einem äußeren und einem inneren Halbmond, die unteren aus einem nach innen etwas konkaven, nach vorne und hinten abfallenden Kamm, dessen Innenseite kulissenartige Vorsprünge trägt, deren Zahl am letzten $P$ am größten ist. Die $J$ und $C$ sind als horizontal gestellte Schaufeln ausgebildet, von denen die innerste die breiteste ist.

Das Skelett unterscheidet sich nicht wesentlich von dem der Cervicornier, jedoch erreicht die Reduktion der Seitenzehen einen höheren Grad als bei diesen. Die Hauptmetapodien verschmelzen schon frühzeitig zu einem vorne ausgefurchten Canon. Von den seitlichen Metapodien bleiben manchmal noch Griffel erhalten. Afterzehen sind häufig vorhanden. Carpus und Tarsus sowie Uterus und Placenta verhalten sich wie bei den Cervicornia.

Die Cavicornia sind die jüngste und formenreichste Gruppe von allen Huftieren. Sie haben erst in der Gegenwart den Höhepunkt ihrer Entwicklung erreicht und zeigen durch ihre Umbildungsfähigkeit bei der Züchtung, daß ihnen noch eine gewisse Plastizität und Jugendlichkeit innewohnt. Der Schauplatz, auf welchem sich die Cavicornier entwickelt und ausgebreitet haben, ist in der Hauptsache die Alte Welt, jedoch hat auch Nordamerika einen gewissen Anteil an ihrer Stammesgeschichte. Heute erscheint Afrika als ihr Verbreitungszentrum, in Wirklichkeit wurde es aber erst ziemlich spät von Asien und Europa her besiedelt.

Die bisherige Einteilung der Cavicornia in Antilopen, Ovinen und Bovinen wird der Stammesgeschichte nicht gerecht, es empfiehlt sich 
vielmehr, die unnatürliche, umfangreiche Gruppe der Antil.opinen nach dem Zahnbau in zwei Abteilungen zu zerlegen und diese mit den Ovinen, bzw. den Bovinen zu vereinigen, so daß sich zwei große Familien ergeben, die Aegodontia mit schon frühzeitig hypselodont werdenden Molaren, von denen auch die oberen bedeutend länger als breit sind und die Boodontia, mit mehr oder weniger hirschähnlichen Molaren, von denen die oberen fast quadratischen Umriß besitzen.

Die ältesten fossilen echten Cavicornier finden sich im Miocän von Europa. Sie gehen auf hirschähnliche Formen, vielleicht auf Dremotherium zurück und sind ihrerseits die Stammeltern aller Boodontia, welche vom Pliocän an einen großen Formenreichtum entfalten, aber erst im Pleistocän einen Vertreter auch in Nordamerika aufzuweisen haben. Hier sind jedoch aus Antilocapriden, etwa aus der oligocänen Gattung Hypisodus, die Aegodontia entstanden, welche dann im Pliocän in Asien mit zahlreichen Boodontia zusammentrafen. Von Asien aus verbreiten sie sich mit diesen über Afrika und entsenden auch schon bald, hauptsächlich aber erst im Pleistocän Repräsentanten nach Europa. Eine Anzahl von ihnen scheint jedoch in Nordamerika einen selbständigen Entwicklungsgang genommen $\mathrm{zu}$ haben, wenigstens die Moschusochsen.

\section{Unterfamilie. Aegodontia.}

Schädel fast stets gewölbt, häufig mit Tränengruben oder Ethmoidallücken oder auch mit beiden, oder mit einem Spalt neben den Nasenbeinen. Scheitelbeine ausgedehnt, Schüdelachse meist geknickt, Lufthöhlen in der Regel auf die Basis der dicht an den Orbiten beginnenden Hornzapfen beschränkt. Hörner selten gerade und zylindrisch, meist seitlich komprimiert und rïckwärts gebogen, selten spiralig oder auswärts gedreht. M fast immer hypselodont, selten mit Basalpfeiler, und nur ausnahmsweise mit schwachen Vertikalrippen an den Außen-resp. Innenhöckern. $P$ und $M$ stets mit glattem Schmelz.

Die Aegodontia umfassen die Neotraginen, Gazellinen (Antilopinen Sclaters), die Rupicaprinen, Ovicaprinen und die Ovibo. vinen. Die beiden ersteren unterscheiden sich von den übrigen Antilopen im weitesten Sinne sehr wesentlich in ihrem Zahnbau, dagegen schließen sie sich hierin den Ovicaprinen so enge an, daß ihr gemeinsamer Ursprung überaus wahrscheinlich wird, und zwar kommen als ihre Ahnen die nordamerikanischen Antilocapriden in Betracht, unter welchen die Gattung Hypisodus bereits im Oligocän einen hohen Grad von Hypselodontie erreicht hat.

Für die Verwandtschaft der Ovicaprinen mit den Gazellinen spricht auch der Umstand, daß sie noch lange Griffelbeine besitzen, die bei den ersteren - Capra - allerdings auf Metacarpale V beschränkt sind, während bei den Boodontia wie bei den plesiometacarpischen Hirschen Verkürzung oder völliger Verlust dieser Rudimente eintritt. Bei den Gazellinen findet öfters Verlust des vordersten $P$ statt.

\section{Gruppe. Neotraginae.}

Schädel wenig gewölbt, ohne Ethmoidallücken, mit Tränengmiben, Hörner zylindrisch nach rïckwärts geneigt. Spitze vorwärts gedreht. M brachyodont. in Afrika.

Neotragus, Oreotragus, Raphiceros,.Madoqua und Ourebia nur lebend

\section{Gruppe. Gazellinae.}

Schädel höchstens mäßig gewölbt, meist flach, mit Tränengruben und Ethmoidallücken, Hörner zylindrisch oder seitlich komprimiert, rückwärts gebogen, nur selten spiralig, niemals gekielt. Zühne in der Regel stark hypselodont. 
Lithocranius Kohl, lebend in Afrika und

A n til ope Ogilby im Pleistocän und lebend in Indien, beide brachyodont.

Gazella Blv. (Fig. 696.) Hornzapfen steil aufgerichtet oder rückwärts gebogen, meist zylindrisch, selten komprimiert. Unterpliocän von Pikermi, Cucuron, Baltarar, Maragha G. Urevicornis Wagn. deperdita Gervais, Samos und Maragha G. Gaudryi Schloss. Mehrere Arten im Pliocän von China. Im Oberpliocän der Auvergne G. borbonica Bravard, der Bresse G. burgundica Depéret, und von England G. anglica Newtąn. Lebend in Asien und Afrika, fossil in Algier.

Saiga Gray (Colus Wagner). (Fig. 697.) Stirnzapfen kurz, steil aufgerichtet. Im Pleistocän von Mitteleuropa und lebend in den Steppen des östlichen Europas und des westlichen Asiens.

Pantholops Hodgson. Im Pliocän von Tibet. P. hundesiensis Lyd. Lebend in Asien.
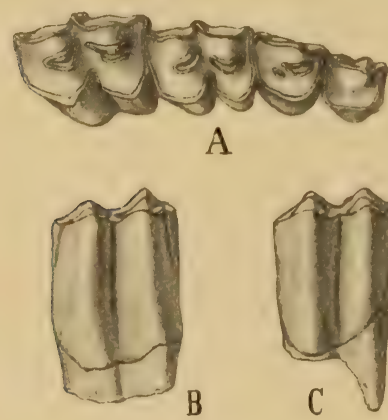

Fig. 696.

Gazella dorcadoides Schlosser. Unterpliocän. China. A obere Backenzähne. $P^{3}$ bis $M^{2}, B$ oberer $M$ von innen, $C$ unterer $M_{2}$ von außen. Nat. Gr.

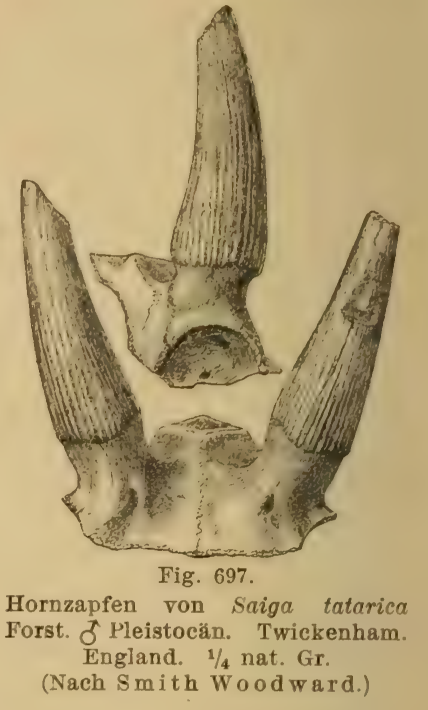

(Nach Smith Woodward.)

\section{Gruppe. Rupicaprinae.}

Schädel mit oder ohne Tränengruben und mit spaltförmiger Ethmoidallücke. Hornzapfen zylindrisch, aufrecht oder rückwärts geneigt. Zühne schwach hy. pselodont. Mitteleuropa.

Rupicapra Ham. Smith. Gemse, selten fossil im Pleistocän von

Nemorrhaedus Ham. Smith. Nur lebend in Asien.

\section{Gruppe. Ovicaprinae.}

Schädel stark geuölbt, Schädelachse geknickt, Hornzapfen meist hohl, gekielt, einfach gebogen oder spiralig. Tränengruben und Ethmoidalliicken höchstens schwach entwickelt. Zähne meist stark hypselodont und seitlich komprimiert.

Oioceros Gaillard (Antidorcas Roth, Helicophora Lydekker?) mit kleiner Tränengrube und Ethmoidallücke. Hornzapfen spiralig, gekielt. Zähne schwach hypselodont. Unterpliocän. Pikermi O. Rothi Gaudry sp., Maragha O. Atropatenes R. u. W., Samos O. proaries Schlosser.

Ovis Linné. (Fig. 695.) Mit Tränengrube, ohne Ethmoidallücke, Stirnbeinnähte nach vorwärts konvergierend. Scheitelnähte geradlinig. Stirnzapfen dreikantig, vorne breit, spiralig. Selten im europäischen Pleistocän O. Savinii Newton, O. argalioides Nehring. 
Capra Linné. Ohne Tränengrube, mit spaltförmiger Ethmoidallücke. Stirnbeinnähte geradlinig. Scheitelbeinnähte nach vorne konvergierend. Hörner komprimiert, rückwärts gebogen. Im Pliocän von Ostindien C. sivalensis, perimensis Lydekker. Im Pleistocän Europas C. pyrenaica Schimp., Ibex cebennarum Gervais, fossilis Nehring.

Haploceros Ham. Smith (Oreamnus Rafin). Lebend und pleistocän in Nordamerika, in Höhlen von Kalifornien.

Bucapra Rütimeyer. Großer Schädel aus dem Pliocän der Siwalik. B. Daviesi Rüt.

Pseudobos Schlosser. Zähne von Rindergröße, hypselodont. $M$ stark komprimiert, $P$ reduziert. Unterpliocän von China und von Maragha.

\section{Gruppe. Ovibovinae.}

Schüdel kaum gewölbt. Basis der Hömer meist stark verdickt, Hornspitzen auswärts gerichtet. Zähne mäßig hypselodont, M stark komprimiert.

Ovibos Blainv. (Symbos Osgood). Basis der hinter den Augen gelegenen Hornzapfen stark angeschwollen, aus schwammiger Knochensubstanz bestehend. Metapodien plump. O. moschatus Blv., der Moschusochse, bewohnt heutzutage nur die nördlichsten Teile von Nordamerika. Im Pleistocän war er nicht nur in Nordamerika, sondern auch in Europa weit verbreitet.

Euceratherium Sinclair. Schädel rinderähnlich. Scheitelbeine auf die fast vertikal stehende Hinterhauptsfläche verdrängt. Hörner komprimiert, weit hinter den Orbiten stehend, mit auswärts und vorwärts gedrehten Spitzen. Zähne mäßig hypselodont. Metapodien kurz und plump. Pleistocän, Höhlen von Kalifornien. E. collinum Sinclair und Furlong.

Preptoceras Furlong. Ähnlich, jedoch Hornzapfen mit rundem Querschnitt. Ebendaselbst.

\section{Unterfamilie. Boodontia.}

Schädeldach gerade oder gewölbt, mit oder ohne Tränengrube und Ethmoidalliicken, selten mit beiden. Scheitelbeine meist ausgedehnt. Schädelachse mehr oder weniger stark geknickt. Lufthöhlen in der Basis der Hornzapfen oder einen großen Teil der Schädelknochen erfüllend. Hornzapfen bald nahe an den Augenhiöhlen beginnend, bald mehr oder weniger weit nach hinten verschoben, in der Regel von rundem Querschnitt, zuweilen auch gekielt. M brachyodont, selten hypselodont, hüufig mit Basalpfeilern und mit Vertikalrippen an den Außenhöckern der oberen und an den Innenhöckern der unteren $M$. Schmelz rauh, öfters mit starkem Zementbelag.

Die Boodontia beginnen mit Formen, deren Zähne jenen der Hirsche noch sehr ähnlich sind. Die Tragelaphinen und Cephalophinen verharren noch jetzt in diesem Zustande, dagegen werden die Bubalidinen, Hippotraginen und Cervicaprinen im Zahnbau den Bovinen sehr ähnlich. Die Pseudotraginen nehmen bezüglich der Höhe ihrer $M$ eine Mittelstellung ein. Reduktion von $P$ findet nur sehr selten statt. Der anfangs gerade Schädel erleidet Veränderung teils durch Knickung der Schädelachse, teils durch Verlagerung der Hörner, wobei die Scheitelbeine immer mehr nach rückwärts und auf die Seiten verdrängt werden, so daß sie kaum mehr an der Bildung des Schädeldaches teilnehmen oder ganz verkümmern. Die Unterschiede zwischen den bisher als "Antilopen « bezeichneten Bubalidinen, Hippotraginen und Cervicaprinen gegenüber den Bovinen bestehen, abgesehen von der Beschaffenheit der Hörner nur darin, daß diese Formen immer bloß einen Teil der für die Bovinen charakteristischen Spezialisierungen erreichen, nämlich entweder nur deren Zahnbau oder nur deren Schädelbau. Von Seitenzehen finden sich meist nur proximale Rudimente, die bei den Bovinen auch vollständig fehlen. 
Die Boodontir sind ein altweltlicher Stamm, welcher sich wohl schon im Untermiocän von geweihlosen Cervicorniern abgezweigt hat und im europäischen Obermiocïn durch mehrere indifferente, als „Antilope“ cristratı. clarata und Martiniana beschriebene Formen mit hirschähnlichem Gebiß und durch die mäßig hypselodonte Gattung Protragocerus vertreten ist. Ihre Organisation gestattet die Ableitung fast aller späteren Formen.

\section{Gruppe. Cephalophinae.}

Schädel uenig gewölbt, Schädelachse nicht geknickt, große Tränengruben, olıne Eth,moidallïcken, Hörner kurz, zylindrisch, nach rïckwärts geneigt, M brachyodont, ohne Basalpfeiler.

Protetraceros Schlosser. Unterpliocïn von China. P. Gaudryi Schl.

Tetraceros Leach. Pliocän bis Gegenwart in Indien. Algier.

Cephalophus S. Smith. Lebend in Afrika, fossil im Pleistocän von

Boselaphus Blv. (Portax S. Smith). Pliocïn, Pleistocïn und lebend in Indien, von Rütimeyer zu den Cephalophinen, von den meisten anderen Autoren dagegen zu den Tragelaphinen gestellt, bildet wohl eine besondere Gruppe und steht der Urform der Pinder sehr nahe.

Duboisia Stremme, Sehr ähnlich, Altpleistocän von Java.

Paraboselaphus Schlosser. Zïhne aus den schwäbischen Bohnerzen und aus dem Unterpliocän von China.

\section{Gruppe. Pseudotraginae Schlosser.}

Schädel mïfsig oder stark genölbt, mit großer Tränengrube, ohne Ethnoidallïcken. Hömer gerade oder gebogen, Spitzen stets nach rïckwärts geneigt, mit elliptischem oder mndem Querschnitt. Backenzähne brachyodont oder schuach hypselodont, zuweilen mit Basalpfeilem. Mittelmiocän bis Unterpliocän.

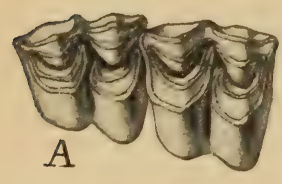

Fig. 698 .

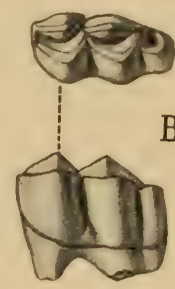

Eocerus (Antilope) cristatus Biedermann sp. Obermiocän. Leoben. Steiermark. $A$ obere $M^{2}$ und $U^{3}$ von unten, $B$ unterer $Y_{3}$ von oben und außen (nat. Gr.)

Diese Gruppe umfaßt die ältesten Cavicornier, die aber nur zum Teil Nachkommen hinterlassen haben. Die unterpliocänen Gattungen dürften vollständig erloschen sein.

Eocerus Schlosser. (Figur 698.) Größe von Schaf. Hörner gerade, stark nach hinten geneigt, mit rundlichem oder elliptischem Querschnitt. Zähne brachyodont, Cerviden-ähnlich. Obermiocän von Sansan, Steiermark, Süddeutschland $A n$ tilope Martiniana, sansaniensis, clavata Lartet, cristata Biedermann, "Cervus" lunatus und haplodon Meyer.

Pseudotragus Schlosser. Schädel ähnlich Capra. Zähne brachyodont. Unterpliocän von Samos P. capricornis Schlosser.

Pachytragus Schlosser. Hörner nur wenig gebogen, von gerundet polygonalem Querschnitt. Zähne schwach hypselodont. Unterpliocän. Samos $P$. crassicornis Schlosser.

Protoryx Major. Schädel lang und schmal. Hornspitzen rückwärts gebogen. Hornquerschnitt elliptisch. Zähne mäßig hypselodont. Unterpliocän von Samos, Maragha und Pikermi, vielleicht auch bei Odessa $P$. Carolinae Major.

Protragocerus Depéret. Hörner gerade, kurz, von gerundet dreieckigem Querschnitt. Zähne fast brachyodont. Obermiocän. La Grive St. Alban (Isère) $P$. Chantrei Depéret. 
Tragocerus Gaudry. Schädel lang, schmal. Hörner stark komprimiert, wenig gebogen, an Vorderseite gekielt. $M$ fast brachyodont. Unterpliocän von Pikermi, Cucuron, Baltavar etc. T. amaltheus Wagn. sp., eine Tarietät auch in Maragha und auf Samos. Unterpliocän von China T. gregarius Schlosser.

Neotragocerus Matthew. Hornzapfen kurz, gerade mit ovalem Querschnitt. Zähne brachyodont. Pliocän Nebraska. N. improvisus Matthew.

\section{Gruppe. Bubalidinae.}

Schädel lang und schmal, mit oder olne Tränengrube, ohne Ethmoidallïcken, Hörner ueit nach hinten gerïcht, meist von rundlichem Querschnitt, mehr oder weniger gedreht. Zähne meist hypselodont, ohne Basalpfeiler.

Bubalis Cuvier (Alcelaphus Blv.). Lebend in Mittel- und Südafrika, fossil im Pleistocän von Algier.

Damaliscus Sclater. Hörner lang, Scheitelbeine kurz. Lebend und fossil in Afrika. Fossil Unterpliocän der indischen Siwalik D. palceindicus Lyd.

Prodamaliscus

Schlosser. Scheitelbeine lang, Hörner stark rückwärts geneigt. Zähne mäßig hypselodont. Unterpliocän von Samos $P$. gracilidens Schlosser.

Connochaetes Lichtenst. Schädel und Hörner rinderähnlich. Lebend Südafrika. Pleistocän von Algier. In den schwäbischen Bohnerzen kommen Zähne vor - Antilope Jägeri Rütimeyer -, 'welche denen vom Gnu nicht unähnlich sind.

Criotherium Major (Crmiatherium Rodler). (Figur 699.) Scheitelbeine fast auf die Hinterhauptsfäche

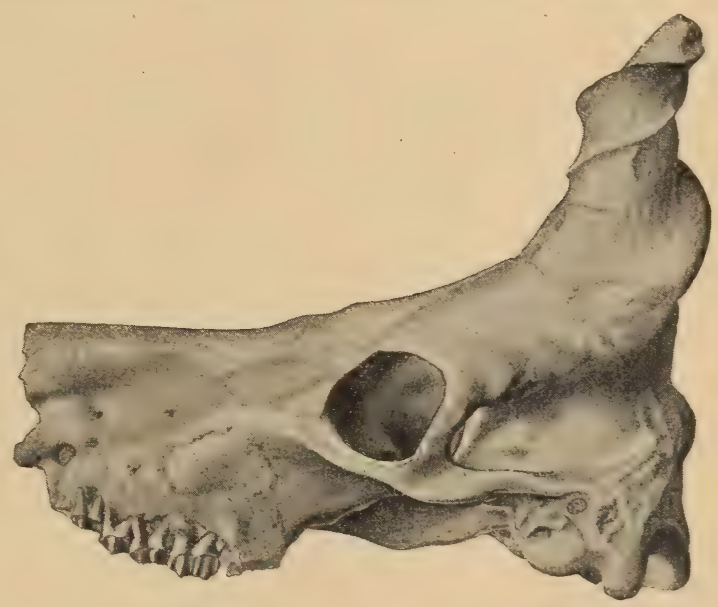

Fig. 699 .

Criotherium argalioides Forsyth Major. Unterpliocän. Samos. Schädel. $1 / 4$. nat. Gr. verdrängt. Cranium mit zahlreichen Lufthöhlen, Hörner weit nach hinten verschoben, kurz, spiralig und gekielt. Zähne fast brachyodont. Unterpliocän von Samos und Maragha C. argalioides Major.

\section{Gruppe. Hippotraginae.}

Schüdelachse geknickt. Schüdel lang, mit Ethmoidallïcken, ohne Tränengruben. Hörner lang, dicht an den Orbita gebogen oder gerade, von mundlichem Querschnitt. Zähne teils hypselodont und mit starken, teils brachyodont und mit schwachen Basalpfeilern.

Hippotragus Sundew. Hörner gebogen. Zähne hypselodont mit starken Basalpfeilern. Pliocän von Indien H. palaeindicus Lydekker. Pleistocän von Algier, lebend in Afrika.

Oryx Blv. Hörner lang, gerade, rückwärts geneigt. Lebend in Afrika

Pala eoryx Gaudry. Groß. Hörner rund, mäßig lang, wenig gekrümmt, wenig nach rückwärts geneigt. Zähne brachyodont. 'Unterpliocän von Pikermi und Maragha P. Pallasi Wagn., Samos Majori, Stiitzeli Schlosser, 
Majori auch bei Odessa. Oberpliocän Meneghinii Rütimeyer, P. Loodon und Cordieri Gervais.

Tragoreas Schlosser. Klein. Hörner stark rückwärts geneigt. Unterpliocän von Samos. T. oryxoides Schlosser. Afrika.

Addax Rafinesque. Leierförmige, spiralige, lange Hörner. Lebend in

Plesiaddax Schlosser. Mäßig hypselodonte, Addax ähnliche Zähne. Unterpliocän von China. P. Depereti Schlosser.

\section{Gruppe. Cervicaprinae.}

Schädel schwach gewölbt, mit Ethmoidallicken, ohne Tränengruben, Hörner wenig geneigt, leierförmig. Zähne bovinen ähnlich.

Cobus A. Smith. Zweifelhafte Arten aus dem Pliocän der Siwalik. Pleistocän von Algier, lebend in Afrika.

Cervicapra lebend in Afrika. Pleistocän von Algier.

Pelea nur lebend in Afrika.

\section{Gruppe. Tragelaphinae.}

Schüdel wenig gewölbt, mit Ethmoidallücken, bei den fossilen meist auch mit Tränengruben. Hörner lang, leierförmig, gekielt und spiralig, meist von rundem Querschnitt. Zähne stets brachyodont, bei den fossilen mit schwachen Basalpfeilern.

Tragelaphus Blainv., Strepsiceros Ham. Smith, Taurotragus Sclater, Oreas Desmarest. Lebend in Afrika. Von Strepsiceros und Oreas je eine Art im Pliocän der Siwalik (St. Falconeri Lyd., O. latidens Lyd.). Strepsicerosähnliche Zähne auch im Unterpliocän von China. Strepsiceros kudu fossil im Pleistocän von Algier.

Palaeoreas Gaudry. Hörner mit zwei Kielen. Unterpliocän von Pikermi und Maragha P. Lindermayeri Wagner sp., eine Art auch im Unterpliocän von China. Im Pliocän der Auvergne „Antilope" torticornis Aymard, vielleicht identisch mit P. Montis Caroli Major aus Val d'Arno.

Protragelaphus Dames. Hörner mit nur einem Kiel. Unterpliocïn von Pikermi - P. Skouzesi Dames - und Samos und Maragha.

Prostrepsiceros Major. Hörner mit zwei Kielen und dreieckigem Querschnitt. Unterpliocän von Maragha. "Tragelaphus" Houtum-Schindleri Rodler.

Illingoceras Merriam. Hörner spiralig, gerade und gekielt. Vielleicht ein Antilccaprine. Pliocän? West-Nevada. I. Alexandrae Merriam. Helicophora Major. Hörner mit nur einem Kiel und einwärts gedrehten Spitzen. Unterpliocän von Pikermi.

\section{Gruppe. Bovinae. ${ }^{1}$ )}

Hornzapfen hohl, kräftig, zylindrissch oder dreikantig, meist rechtuinklig nach außen gerichtet, ziemlich weit hinter den Orbita und an die Kante des Schädels geriickt. Stirnbeine groß, bis zum Occiput reichend. Scheitelbeine sehr kurz. $M$ prismatisch, oft mit starken Basalpfeilern und mit ziemlich dicker Zementschicht.

Bei den Rindern haben die Merkmale der Cavicornier ihre höchste Ausbildung erlangt. Die mit Lufträumen erfüllten Stirnbeine gewinnen die größte Ausdehnung und bilden fast die ganze Bedachung des Gehirns.

1) Dürst, U., Notes sur quelques Bovidés préhistoriques. L'Anthropologie. Paris 1900. - Rütimeyer, Versuch einer natürlichen Geschichte des Rindes. Neue Denkschrift. Schweiz. Ges. f. Naturw. 1866. 67. Bd. XXU. XXIII. - Turner, On the genera and subdivisions of the Bovidae. Proc. Zool. Soc. London 1849. 
Dagegen werden die Scheitelbeine zuweilen ganz auf die Hinterhauptsfläche gedrängt und die Hörner rücken weit nach hinten und außen. Tränengruben und Ethmoidallücken fehlen, Tränenbeine und Nasenbeine haben ansehnliche Länge.

Fossil erscheinen die Rinder zuerst im Pliocän der indischen Siwalik, später auch in Europa, jedoch werden sie erst im Pleistocän häufiger und gelangen auch nach Nordamerika.

Rütimeyer unterscheidet fünf Typen:

\section{A. Bubalus. Büffel.}

Stirnzone stark gewölbt. Scheitelbeine noch etwas auf der Oberseite des Schädeldaches liegend. Hornzapfen abgeplattet, meist dreikantig, zuerst nach hinten, dann nach aussen gerichtet, nahe an der Mittellinie des Schädels beginnend. M mit ungemein kräftigen, oft gefältelten Basalpfeilern.

Die Büffel verbinden in osteologischer Hinsicht die Rinder mit der Gattung Boselaphus (Portax).

Im Tertiär von Ostindien die erloschenen Gattungen Probubalus Rütimeyer (Hemibos, Peribos Falconer) und Amphibos Falconer. Ebendaselbst und im Pleistocän, sowie in dem von Java Buffelus Blumb. Im Pleistocän von Europa und Indien Bubalus Rütimeyer.

\section{B. Leptobos.}

Schädel niedrig, lang. Hörner dicht hinter den Orbiten, weit außen entspringend, nicht sehr kräftig, fast zylindrisch, nach hinten gerichtet. Scheitelbeine relativ groß, noch auf der Oberseite des Schädels gelegen.

Leptobos Rütimeyer. Im Pliocän, L. Falconeri Rütimeyer, und Pleistocän von Ostindien. Nach F. Major gehört auch Bos etruscus Falconer aus dem Oberpliocän von Val d'Arno, der Auvergne und von Spanien zu Leptobos.

\section{Bibos.}

Stirnbeine hinten quer verbreitert. Stirn groß und flach. Scheitelzone auf das Hinterhaupt gedrängt. Hörner mehr oder weniger abgeplattet, nahe dem Hinterhaupt beginnend, in der Jugend nach hinten, im Alter seitwärts gerichtet. Java.

Bibos Hodgson. Lebend und fossil in Indien und im Pleistocän von

\section{Bison.}

Schädel niedrig, Stirn flach, übercaus breit, relativ kurz. Hörner nahe den weit vorspringenden Orbiten beginnend, zylindrisch, nach außen und oben gerichtet. Scheitelbeine kurz und breit, stets noch auf der Oberseite des Schädeldaches. Gesichtsteil kurz. Nasenbeine kurz, hinten breit.

Die Gattung Bison erscheint zuerst im Oberpliocän von Indien (B. sivalensis Falconer). Spuren hiervon auch im Pliocän von Nordamerika. Im Pleistocän von Europa und Nordasien B. priscus v. Mey., im Pleistocän von Nordamerika $B$. antiquus Leidy und latifrons Harlan. Der fossile europäische B. priscus, Wisent, steht den amerikanischen Bisonten näher als dem B. europaeus.

E. Taurus. Ochsen.

Stirnbein enorm ausgedehnt, das ganze Schädeldach bildend, die kurzen Scheitelbeine ganz auf das Hinterhaupt gedrängt. Hörner zylindrisch, an den hinteren Außenecken des Schädels sitzend. 
In den Taurina hat der Schädelbau der Bovinen seinen Kulminationspunkt erreicht bezüglich der Ausbreitung der Stirnbeine und der Reduktion der Scheitelbeine.

Die einzige Gattung Bos erscheint zuerst in - jedenfalls jüngeren Siwalikschichten von Indien B. planifrons, acutifrons Lydekker. Im Pleistocän von Indien B. namadicus Falc., im Pleistocïn von Europa, Asien und - Nordafrika B. primigenius Bojanus und als Ur noch bis in die Bronzezeit. Er stammt nach Dürst von planifrons ab, während acutifrons und namadicus sich an die Bibovina und die Zebu anschließen. In Europa ist er gezïhmt worden und der Ahne der Primigenius- oder Trochoceros-Rasse, aus der wahrscheinlich auch die Frontosus Rasse hervorgegangen ist. Dagegen wurde die Brachyceros-Rasse - Brachyceros palustris - Torfkuh der Pfahlbauten, wohl aus Asien oder Nordafrika eingeführt.

\section{Unterordnung. Amblypoda. ${ }^{1}$ ) Cope.}

Ausgestorbene, meist grofie plantigrade Huftiere mit kurzen, fünfzehigen Fïßen und breiten, von Hufen umgebenen Endphalangen. Zweite Reihe des Carpus mit der ersten alternierend. Astragalus sehr breit und niedrig, mit Tibia und mit Fibula artikulierend, die tibiale Gelenkfläche schwach gewölbt oder eben, nicht ausgehöhlt. Gebiß meist vollständig. Backenzähne brachyodont und lophodont. Gehirn sehr klein.

$\mathrm{Zu}$ den Amblypoden gehören die größten Landsäugetiere der Eocänzeit. Ihre Extremitäten und Zähne und ihr ganzer Knochenbau zeigen neben primitiven Merkmalen auch sehr weitgehende Spezialisierungen, die sich zum Teil bei Perissodactylen, zum Teil auch bei Artiodactylen, zum Teil aber bei den Proboscidiern und Astrapotheria wieder finden.

Sie beginnen in der Puerco-Stufe (Unterstes Eocän) mit verhältnismäßig kleinen und schlanken Formen (Pantolambda), die durch trituberkuläre obere Molaren und semidigitigrade Extremitäten ihr primitives Gepräge verraten; in der Wasatchstufe und in den gleichaltrigen alteocänen $\mathrm{Ab}$. lagerungen Europas dominieren die plumpen und großen Coryphodonten mit einem vollständigen Gebiß, in welchem die Molaren bereits lophodonten Bau erlangt haben. Stärker differenziert sind die auf Nordamerika beschränkten mitteleocänen riesigen Dinoceratidae. Hier verkümmern die oberen $J$; die oberen $C$ ragen als mächtige Hauer über den Unterkiefer vor, während die unteren Eckzähne winzig klein werden und den Schneidezähnen gleichen. Die Backenzähne werden ausgezeichnet lophodont und die $P$ den $M$ ähnlich.

Die Extremitäten sind stämmig, mäßig hoch, vorne und hinten fünfzehig. Die Carpalia bilden schwach alternierende Reihen; zuweilen ist ein Os centrale vorhanden. Im Hinterfuß zeigen die Tarsalia eine starke, seitliche Verschiebung. Der niedrige, ungemein breite Astragalus bedeckt nicht nur das Naviculare, sondern im Gegensatz zu den Proboscidiern auch einen großen Teil des Cuboideums. Das Naviculare ruht auf den drei Cuneiformia. Dem Astragalus fehlt sowohl ein abgesetzter Kopf, als auch eine eigentliche Trochlea, indem die schwach gewölbte tibiale Gelenkfläche keine Ausfurchung besitzt, weshalb nur eine sehr unvollkommene Beugung des Fußgelenkes ermöglicht wird. Ein Flexor-

$\left.{ }^{1}\right)$ Cope E. D., The Amblypoda. Amer. Naturalist 1884-85. - Earle Ch., Revision of the species of Coryphodon. Bull. Amer. Mus, nat. hist. N. Y. 1892. - Hébert Ed., Ann. sc. nat. Zoologie 1856, p. 87. - Marsh O. C., Amer. Journ. Sc. Arts. 1877-81. - Dinocerata, A monograph of the extinct order of gigantic mammalia. U. S. Geol. Survey 1884. - Osborn H. F., Complete skeleton of Coryphodon. und Evolution of the Amblypoda. Bull. Amer. Mus. nat. bist. 1898. 
foramen, sowie eine Fasette am Hinterrand des Astragalus für ein sogenanntes Tibiale (Sesamoid) sind wie bei den Condylarthra vorhanden. Das Calcaneum und die kurzen, plumpen Metatarsalia erinnern an den Proboscidierfuß. Am Femur ist ein dritter Trochanter bei den ältesten Formen vorhanden, fehlt aber bei den Dinoceratiden. Die Fibula artikuliert bei diesen nur mit dem Astragalus.

Die Amblypoden besitzen unter allen Huftieren die kleinste Gehirnhöhle. Das Großhirn ist nahezu glatt und bedeckt weder die Riechlappen noch das Cerebellum.

Osborn leitet die Amblypoda von den Gattungen Protolambda, Ectoconodon und Synconodon aus der Laramiekreide ab, die jedoch nur auf isolierte trituberkuläre resp. tuberkulärsektoriale Molaren begründet sind. Auch vereinigt er die bunodonten Periptychidae mit den Pantolambdidae in eine Unterordnung, die Taligrada.

\section{Familie. Pantolambdidae (Taligrada). Cope.}

Schädel raubtierähnlich, mit hoher Sagittalcrista. $\frac{3.1 .4 .3 .}{3.1 .4 .3 .} J$ und $C$ normal entwickelt. Obere $P$ aus einem äußeren und einem inneren eckigen Halbmond bestehend, obere $M$ mit $\vee$-förmigem $P a$ racon, Metacon und Protocon nebst zwei Zwischenhöckern. Untere $M$ mit hohem $\vee$-förmigem Trigonid und einem niedrigen, ebenfalls V-förmigem Talonid, das an den $P$ sehr klein bleibt. Humerus mit Foramen entepicondyloi. Ideum, Femur mit drittem Trochanter. Astragaus flach mit schwach gewölbter Gelenkfläche für die Tibia und mit Foramen. Carpus mit freiem Centrale. Schwanz lang.

Pantolambda Cope. (Fig. 700, 701.) Unterstes Eocän. Torrejonbed von Neumexiko. P. bathmodon, cavirictus Cope.

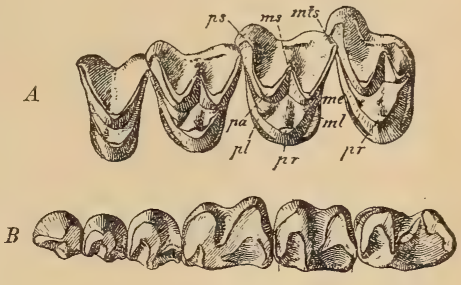

Fig. 700.

Pantolambda cavirictus Cope. Unterstes Eocän. Torrejonbed. Neumexiko. $A$ Obere $P^{4}$ bis $M^{3}$. $B$ Untere Backenzähne. $2 / 3$ nat. Gr. (nach Osborn.)
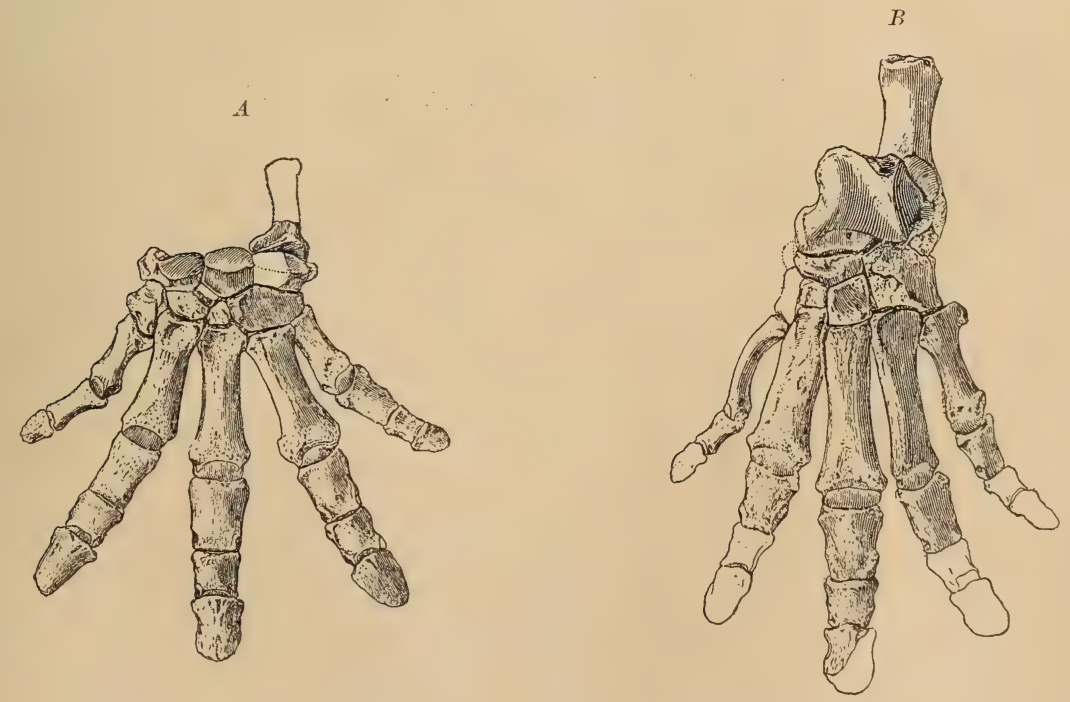

Fig. 701.

Pantolambda bathmodon Cope. Unterstes Eocän. Torrejonbed. Neumexiko. $A$ Vorderfuß. $B$ Hinterfuß. $1 / 2$ nat. Gr. (nach Osborn.) 


\section{Familie. Coryphodontidae. Owen.}

Schädel länglich, mit breiter, schräg abfallender Stirn. Gebiß vollständig. Obere $M$ mit Vorjoch und zwei durch ein V.förmiges Joch verbundenen Aujsenhöckern nebst einem oder zwei ungleich starken Innenhöckern, von denen Joche nach den Außenhöckern verlaufen. Untere $M$ mit zwei $V$-förmigen, nach innen geöffneten Jochen, wovon der vordere Schenkel mehr oder weniger verkümmert. $P$ einfacher als M. Schneidezähne konisch, obere und untere Eckzähne spitz, stark vorragend. Rumpf im Verhältnis zum Schädel sehr klein. Humerus ohne

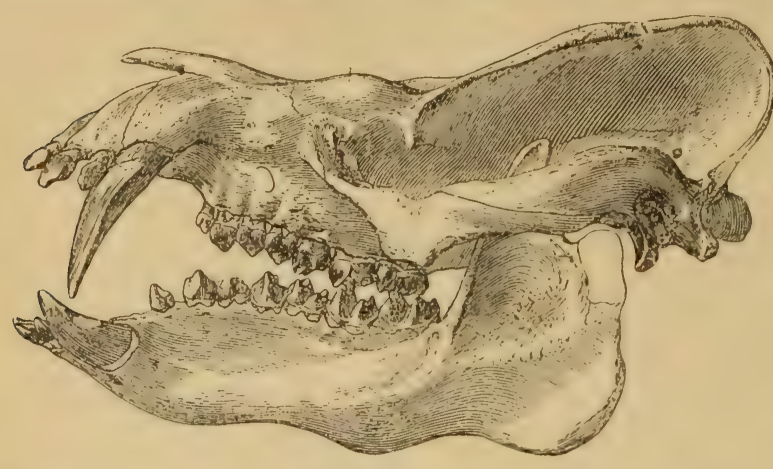

Fig. 702 .

Coryphodon testis Cope. Untereocän. Wasatchbed. Wyoming. Schädel und Unterkiefer. 1/6 nat. Gr. (nach Osborn.)

Foramen entepicondyloideum. Femur mit drittem Trochanter. Astragalus sehr niedrig, ohne Kopf, mit schwach gewölbten Ge. lenkflächen für Tibia und für Fibula.

Die Coryphodontiden waren plumpe, vorne digitigrade, hinten plantigrade Tiere von ansehnlicher Größe. Ihr Gebiß spricht für omnivore Nahrung, der Bau des Hand- und Fußgelenkes für langsame und ungeschickte Bewegung. Dem Schädel fehlen die sonderbaren Stirnzapfen der Dinoceraten, dagegen dienten die mächtigen, spitzen Eckzähne als gefährliche Waffen. Im Habitus hatte Coryphodon mehr Ähnlichkeit mit Bär als mit einem wirklichen Huftier.

Von den Gattungen Cory.

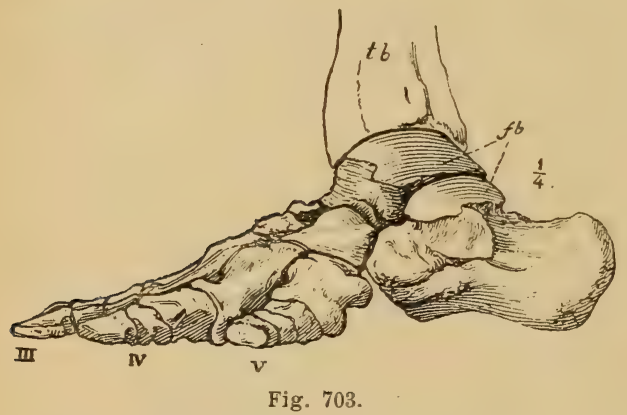

Coryphodon anax Cope. Unt. Eocän. Wasatch: Wyoming. Linker Hinterfuß. 1/4 nat. Gr. (nach Osborn.) ( $t b$ Tibia, Fb Gelenkfasetten des Astragalus und Calcaneums für die Fibula, $I I I-V$ dritte bis fünfte Zehe.) phodon Owen (Bathyopsis, Bathmodon, Metalophodon Cope) (Figur 702-704), Ectacodon und Manteodon Cope ist nur die erste genauer bekannt und in den Wasatch und Wind River Beds von Wyoming und NeuMexiko durch mehr als ein Dutzend Arten vertreten, unter welchen sich mehrere Entwicklungsreihen erkennen lassen. Manche Arten kommen teils im Schädelbau, teils in der Ausbildung der $C$ oder der $J$ den Dinoceratiden schon sehr nahe. In Europa finden sich C.eocaenus Owen und C. Oweni Hébert in Nordfrankreich, Belgien und England.

\section{Familie. Dinoceratidae. Marsh.}

Schädel mit je einem Paar vorragender Knochenfortsätze auf Scheitelbein,

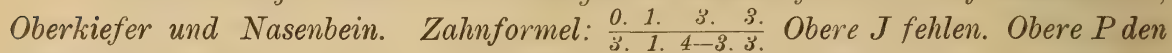
$M$ ähnlich, wie diese mit zwei nach innen konvergierenden Jochen, untere $M$ mit zwei schrägen Querjochen. Oberer $C$ gewaltig groß, weit über die untere Zahnreihe vorragend. Untere $J$ und $C$ klein. Unterkiefercondyli nach hinten gerichtet und nur wenig höher als die Zahnreihe. Femur ohne dritten Trochanter. Häufig im oberen Eocän (Bridger Beds) von Wyoming. 
Die Dinoceraten gehören zu den gewaltigsten und sonderbarsten Landsäugetieren. Die größten Arten von Loxolophodon (Tinoceras) erreichten eine Rückenhöhe von $2 \mathrm{~m}$ und eine Länge von nahezu $4 \mathrm{~m}$, standen also dem Elefanten an Größe beinahe gleich; andere kleinere Formen übertrafen Flußpferd und Rhinozeros nur wenig an Höhe.
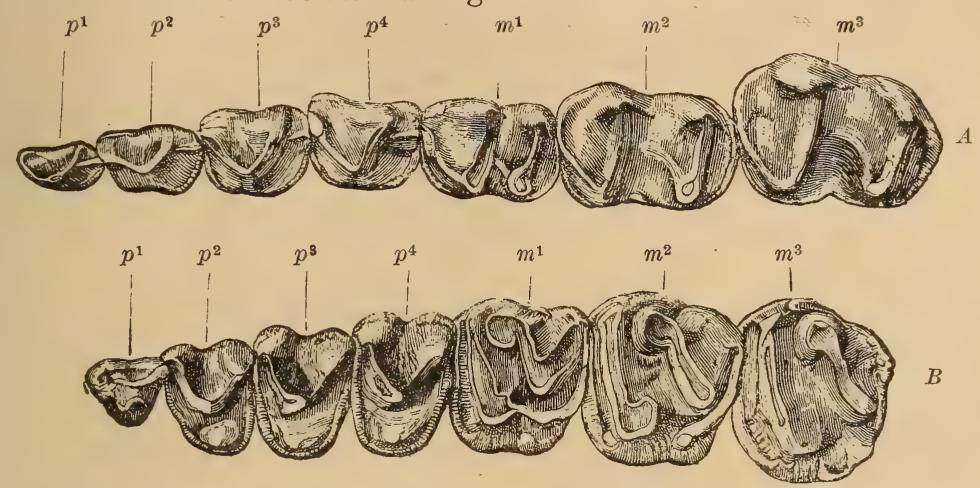

Fig. 704. Coryphodon hamatus Marsh. Unt. Eocän. Wyoming. Backenzähne des linken Oberkiefers $(A)$ und des linken Unterkiefers $(B)$. 1/2 nat. Gr. (Nach Marsh.)
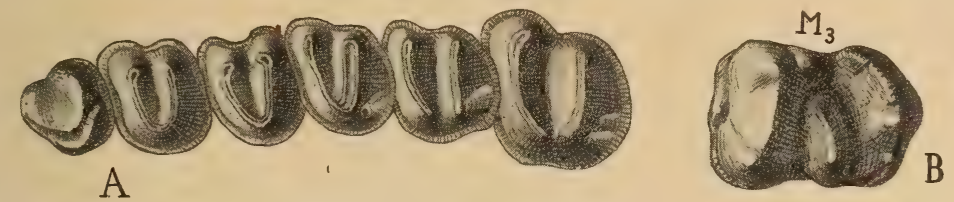

Fig. 705. Uintatherium mirabile Marsh. Mitteleocän. Bridgerbed. Wyoming. A obere Backenzähne. $3 / 1$ nat. Gr. $B$ linker unterer $M_{3}, 1 / 2$ nat. Gr.

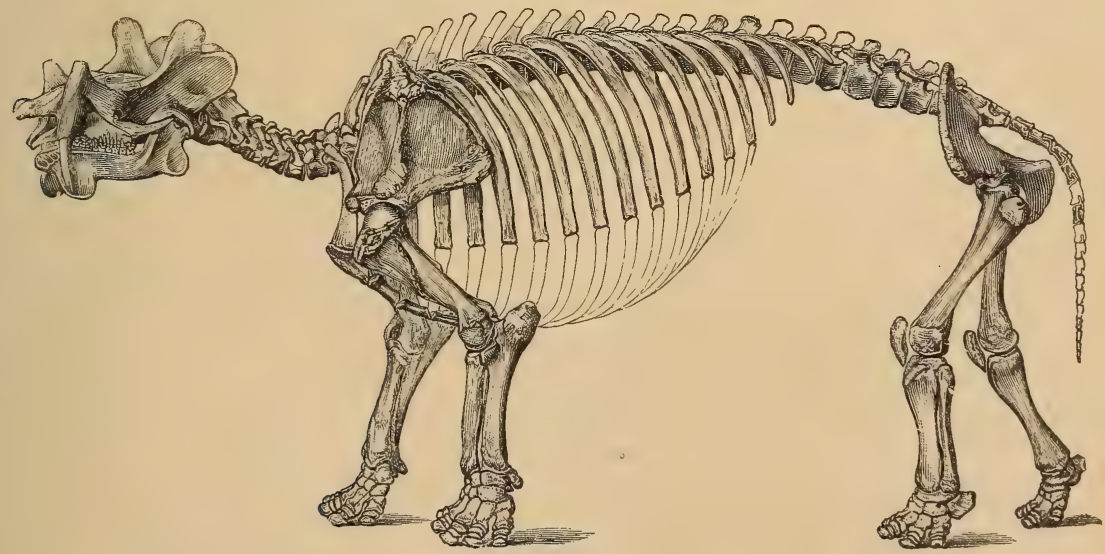

Fig. 706 .

Uintatherium mirabile Marsh sp. Restauriertes Skelett. 1/13 nat. Gr. (Nach Marsh.)

Uintatherium Leidy (Dinoceras Marsh, Octotomus Cope) (Fig. 705, 706). Die Protuberanzen auf den Nasenbeinen klein, vertikal, die porösen Knochenkämme auf den Scheitelbeinen hoch, über den Condylen des Unterkiefers. Dem mächtigen oberen Eckzahn entspricht am Unterkiefer ein nach unten vorspringender, breit gerundeter Fortsatz. Die oberen und unteren $M$ und $P$ besitzen zwei nach innen konvergierende Querjoche. Das Gehirn ist winzig klein. Becken und Extremitäten weisen infolge gleicher Funktion große Übereinstimmung mit den Proboscidiern auf. Die Hinter- 
beine sind etwas länger als die Vorderbeine. Die Füße fünfzehig. Mehrere Arten im Eocän von Wyoming.

Loxolophodon Cope (Tinoceras Marsh). Ähnliche, aber Nasenprotuberanzen stärker, schief nach vorne gerichtet, die Scheitelkämme hinter die Condyli reichend.

\section{Zeitliche Verbreitung der Ungulata.}

\begin{tabular}{|c|c|c|c|c|c|c|c|c|c|c|c|c|c|c|}
\hline & & & & 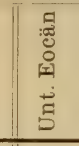 & 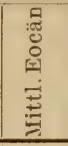 & 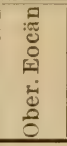 & 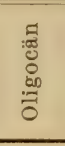 & 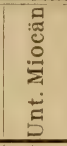 & 苂: & 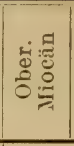 & 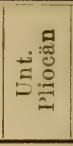 & 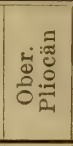 & 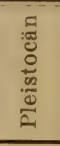 & 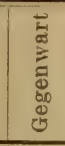 \\
\hline \multicolumn{15}{|l|}{ Condylarthra } \\
\hline \multicolumn{15}{|c|}{ Mioclaenidae. . . . - } \\
\hline \\
\hline & & & & - & \multicolumn{10}{|c|}{$\begin{array}{l}\text { Phenacodontidae. . . } \\
\text { Meniscotheriidae }\end{array}$} \\
\hline \multicolumn{13}{|c|}{$\begin{array}{l}\text { Meniscotheriudae } \\
\text { Pleuraspidotheriidae }\end{array}$} & & \\
\hline \multirow{2}{*}{\multicolumn{15}{|c|}{ Litopterna }} \\
\hline \multicolumn{14}{|l|}{ Bunolitopternidae } & \\
\hline \multicolumn{15}{|l|}{ Macraucheniidae. } \\
\hline \multicolumn{15}{|c|}{ Proterotheriidae . . . . } \\
\hline \multicolumn{15}{|c|}{ Adiantidae. . . . } \\
\hline \multirow{2}{*}{\multicolumn{15}{|c|}{$\begin{array}{l}\text { Perissodactyla. } \\
\text { Tapiridae . }\end{array}$}} \\
\hline & & & & & & & & & & & & & & \\
\hline \multicolumn{15}{|c|}{ Rhinoceridae . . . } \\
\hline \multicolumn{15}{|c|}{ Equidae . . . . . } \\
\hline \multicolumn{15}{|c|}{$\begin{array}{l}\text { Titanotheriidae . . . } \\
\text { Chalicotheriidae }\end{array}$} \\
\hline \multicolumn{15}{|c|}{ Chalicotheriidae . . . . } \\
\hline \multicolumn{15}{|c|}{ Artiodactyla } \\
\hline \multicolumn{15}{|l|}{ Suidae . . . . } \\
\hline \multicolumn{15}{|c|}{ Elotheriidae. . . . . . } \\
\hline \multicolumn{15}{|c|}{ Leptochoeridae . . . . } \\
\hline \multicolumn{15}{|l|}{ Hippopotamidae. } \\
\hline \multicolumn{15}{|l|}{ Anthracotheriidae } \\
\hline \multicolumn{15}{|l|}{ Anoplotheriidae. } \\
\hline \multicolumn{15}{|l|}{ Dichobunidae. . } \\
\hline Xiphodontidae. . & 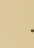 & 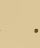 & . & & & & & & & & & & & \\
\hline Caenotheriidae. . & · & - . & . & & $\cdots$ & & & & & & & & & \\
\hline Oreodontidae. . & . & . & . & & & & & & & & & & & \\
\hline Camelidae. . & . & . . & . & & & & & & & & & & & \\
\hline Tragulidae. . & . & . . & .. & & & & & & & & & & & \\
\hline Hypertragulidae. & . & & - . & & & & & & & & & & & \\
\hline Cervicornia. . & 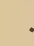 & 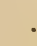 & .. & & & & & & & & & & & \\
\hline Antilocapridae. . & . & . & . & & & & & & & & & & & \\
\hline Cavicornia. . . & . & . & $\therefore$ & & & & & & & & & & & \\
\hline $\begin{array}{c}\text { A mblypoda } \\
\text { Pantolambdidae. }\end{array}$ & & & & & & & & & & & & & & \\
\hline Coryphodontidae. & 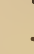 & & . & & & & & & & & & & & \\
\hline Dinoceratidae. . & . & . & .. & & & & & & & & & & & \\
\hline 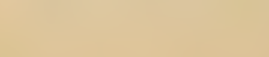 & & & & & & & & & & & & & & \\
\hline
\end{tabular}




\section{Ordnung. Notoungulata. Santjago Roth ${ }^{1}$ )}

A usgestorbene, a uf Südamerika beschränkte, plantigrade bis semidigitigrade, fünf-bisdreizehige Pflanzenfresser mit flachem, niedrigem Schädel, breiter Stirne und breitem Hinterhaupt. Jochbogen kräftig, hinten bis zur. Supra. occipitalcrista verlängert, Nasalia breit, Nasenöffnung in der Regel endständig. Orbita groß, nur unvollständig von den Schläfengruben getrennt, Mastoidregion meist stark ausgedehnt. Unterkiefer hoch und massiv, meist mit fester Symphyse. Gebiß in der Regel vollständig, meist ohne Zahn. lücken, häufig die vordersten $J$ vergrößert, die übrigen $J$ sowie $C, P$ und $M$ allmählich ineinander übergehend. Zähne brachyodont bis hypselod ont, prismatisch. Obere $M$ mit A u Benwand - Ectoloph, langem schrägen Vorjoch - Protoloph und kurzem geraden Nachjoch - Metaloph. Untere $M$ aus zwei ungleich großen Halbmonden und zwei Innenpfeilern bestehend. Carpalia alternierend, frei, Centrale fehlend. Astragalus mit schmaler, öfters ausgefurchter Trochlea und konvexem Naviculargelenk. Fibula stets am Calcaneum arti. kulierend. Endphalangen als stumpfe, kleine Krallen oder als Hufe oder als kräftige, gespaltene Klauen entwickelt.

Die Notoungulata vereinigen in ihrem äußeren Habitus viele Merkmale der Hyracoidea mit solchen der Nager. Die Ähnlichkeit äußert sich namentlich in der Breite und Ebenheit des Schädeldaches, in der kräftigen Ausbildung der Jochbogen, in der Breite des Hinterhaupts, in der Lage und Größe der Orbiten, in der Höhe der Unterkiefer und in der Vergrößerung der vordersten $J$. Auch die einzelnen Knochen sind jenen der Hyraciden und mancher Nager nicht unähnlich. Bei näherer Betrachtung ergeben sich jedoch fundamentale Unterschiede. So sind die $J$ im Gegensatz zu denen der Nager nicht seitlich, sondern von vorne nach hinten komprimiert und die Zahnzahl erleidet nur geringe Reduktion. Von den Hyracoiden unterscheiden sich die Notoungulata durch die alternierende Anordnung der Carpalia, durch die Artikulation der Fibula mit dem Calcaneum, durch die einfache seitliche Gelenkung des Malleolus der Tibia am Astragalus, und vor allem ist das Gebiß der Hyracoidea ursprünglich bundont, und die später entstehenden beiden Joche der oberen $M$, sowie die beiden Halbmonde der unteren $M$ sind stets gleichgroß, während bei den Notoungulaten der Metaloph der oberen und der vordere Halbmond der unteren $M$ stets viel kleiner ist als der Protoloph und der hintere Halbmond.

1) Ameghino Flor., Contrib. al conocimiento de los Mamiferos de la Republica Argentina. Buenos-Aires 1889. - Mamifères crétacés de l'Argentine. Bolet. del Instit. geografico argentino. T. XVIII 1897. - Rech. de Morphologie phylogénétique sur les Molaires supérieurs des Ongulés. Anal. Mus. Nac. Buenos Aires T. IX 1904. - Notices sur des Ongulés nouveaux de terrains crétacés de Patagonie. Bol. Acad. Nat.' de Cienc. de Cordoba. 1901. 1902. - Burmeister H., Description phys. de la Republica Argentina. 1879. t. III. - Gaudry A., Dentition de quelques Mammifères. Mém. Soc. géol. de France. Paléont. 1906. - Fossiles de Patagonie. Annal. de Paléontologie 1906. 1908. - Gregory W. K., The Orders of Mammals. Bull. Amer. Mus. Nat. Hist. New-York 1910. XXVII. - Lydekker R., Paleontologia Argentina II. Anal. Mus. de la Plata. Fol. 1893. - Roth Santjago, Los Ungulados sudamericanos. Anal. Mus. de la Plata. Paleontologia 1903. - Scott W. B., Classificat. of the Noto. ungulata. Science. Vol. XXI 1905. 
Den Molaren der Notoungulata (Fig. 707) liegt ein trituberkulärer bzw. tuberkulärsektorialer Bauplan zugrunde. An den oberen $M$ verbinden sich die beiden Außenhöcker sehr innig zu einer Außenwand Ectoloph, der vordere Innenhöcker - Protocon, wird zu einem langen schrägen Protoloph und der Hypocon zu einem kurzen geraden Metaloph. Sehr häufig bilden sich an diesen $M$ auch Crista- oder Crochet-ähnliche Sporne und am Vorderrand entwickelt sich ein Parastyl, so daß die Zähne eine gewisse Ähnlichkeit mit den oberen $M$ von Rhinoceros erlangen. Am Hinterrand kann sich aus einem besonderen Pfeiler noch ein weiteres Joch entwickeln. Bei den primitiveren Formen sind die $M$ bedeutend breiter als lang. Die unteren $M$ bestehen aus je zwei äußeren Halbmonden, von denen der vordere viel kürzer ist als der hintere, und aus zwei mehr oder weniger

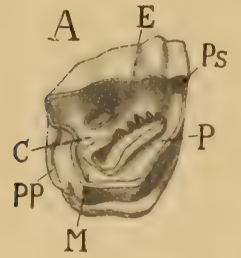

M

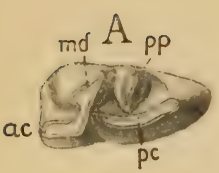

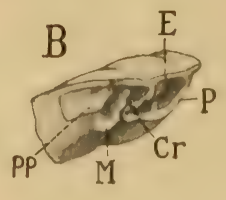

1
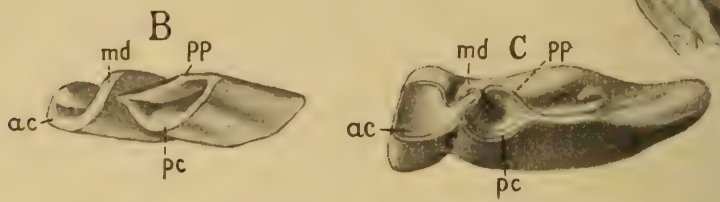

D

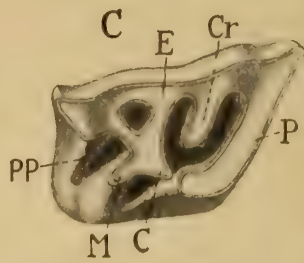

M C

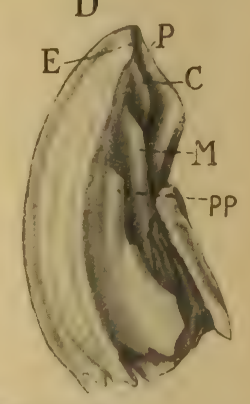

Fig. 707 .

Obere und untere Molaren von Notoungulaten von oben.

Obere: A Pleurostylodon, B Protypotherium, 2/1 nat. Gr., C Rhynchippus, D Rhynchippus. M ${ }^{3}$ von hinten. Untere: A Pleurostylodon. B Protypotherium, $\%$ nat. Gr. C Morphippus.

$E$ Ectoloph, $P$ Protoloph, $M$ Metaloph, $P \&$ Parastyl, $C r$ Crista, $C$ Crochet, $P P$ hinterer Pfeiler, $a c$ vorderer Halbmond, $p c$ hinterer Halbmond, $m d$ Metaconid, $p p$ hinterer Pfeiler.

komprimierten Innenhöckern gebildet wird, von welchen sich der vordere mit dem Hinterende des ersten Halbmondes innig verbindet, während der hintere dem zweiten Halbmond gegenüberliegt und häufig gänzlich isoliert bleibt. Mit den $M$ der Litopterna haben diese $M$ zwar die ursprüngliche Anlage gemein, aber es geht ihnen kein eigentliches Bunodontenstadium voraus.

Die $J, C$ und $P$ gehen ihrer Zusammensetzung nach ganz allmählich in die $M$ über, öfters kommt es zur Vergrößerung von einem oder zwei Incisivenpaaren, manchmal verschwinden auch ein oder zwei $J$ sowie $C$, oder es werden die $C$ zu echten hauerähnlichen Eckzähnen, womit zuweilen Verlust von 1 bis $3 P$ verbunden ist. Die Zähne sind anfangs brachyodont, später werden sie hypselodont und bewurzelt und zuletzt prismatisch wurzellos, jedoch bleiben auch in diesem Falle die $P$ erheblich niedriger als die $M$.

Als wesentlichstes Merkmal der Notoungulata bezeichnet Santjago Roth die Verbreiterung und Auftreibung der Mastoidregion 
und die Verbindung dieses oft mit blasigem Knochengewebe erfüllten Hohlraums mit der Bulla tympanica. Wennschon diese Organisation bereits bei den ältesten Formen zu beobachten ist, so bestehen doch hinsichtlich des Grades dieser Auftreibung erhebliche Unterschiede, weshalb auch kaum ein zwingender Grund vorliegt, die Astrapotherioidea wegen des Fehlens dieses Merkmals von den Notoungulata auszuschließen.

Die Extremitätenknochen zeigen je nach den Körperdimensionen große Verschiedenheit und weitgehende Spezialisierungen. Im allgemeinen lassen sie sich jedoch eher mit denen von Fleischfressern und Nagern, als mit solchen von echten Huftieren vergleichen. Bei kleinen Formen sind die langen Röhrenknochen schlank, ihr Humerus besitzt ein Entepicondylarforamen und das Femur einen dritten Trochanter. Die Ulna ist sehr kräftig entwickelt und nicht mit dem Radius verwachsen. Beide stehen häufig gekreuzt. Die Carpalia sind sämtlich frei und alternierend angeordnet. Der Astragalus hat stets ein konvexes, meist sogar halbkugelförmiges und langgestieltes Naviculargelenk, und die meist frei bleibende Fibula artikuliert stets mit dem Calcaneum. Die Zahl der Metapodien schwankt zwischen fünf und drei, die Leitkiele ihrer distalen Gelenkfläche sind immer auf die Hinterseite beschränkt. Die Zehenendglieder sind bald krallenartig, aber vorne etwas abgeplattet, bald wirkliche breite Hufe, bald gebogene, tief gespaltene, plumpe Klauen.

Die Notoungulata zerfallen in vier Unterordnungen: Typotheria, Toxodontia, Entelonychia und Astrapotherioidea.

\section{Unterordnung. Typotheria. Zitt. $\left.{ }^{1}\right)$}

Ausgestorbene plantigrade oder digitigrade Pfanzenfresser mit meist vierzehigen Vorder- und Hinterfïßen. Gebiß in der Regel vollständig, die inneren oberen $J$ vergrößert, die äußeren $J$ und die $C$ öfters reduziert, oder alle Zühne ineinander übergehend und in dicht geschlossener Reihe. Backenzähne oben lophodont, unten selenolophodont, anfangs brachyodont bewurzelt, später hypselodont prismatisch und wurzellos. Clavicula öfters vorhanden. Carpalia alternierend, Centrale fehlend. Humerus mit Foramen entepicondyloideum. Femur mit drittem Trochanter. Astragalus mit halbkugelförmigem Kopf. Fibula am Calcaneum artikulierend.

Die Typotheria sind auf das Tertiär und Pleistocän von Südamerika beschränkt. Sie stehen den Toxodontia sehr nahe, und sehen äußerlich manchen Nagern und den Hyracoideen sehr ähnlich, jedoch beruht dies nur auf Konvergenz und nicht auf wirklicher Verwandtschaft.

Der Schädel erinnert durch seine langgestreckte Form und die geradlinige Quernaht zwischen den Stirn- und Scheitelbeinen an Nager. Die nach vorne gerichtete Nasenöffnung wird seitlich durch die hohen Zwischenkiefer und oben durch die langen bis zur Schnauzenspitze reichenden Nasenbeine begrenzt. Die Scheitelbeine haben einen schwachen Sagittalkamm. Die hinten sehr kräftigen Jochbogen liegen sehr hoch und die weiten Orbiten sind hinten öfters von einem Processus postorbitalis des Stirnbeines begrenzt. Das Foramen infraorbitale steht vor dem Jochbogen. Das breite

1) Gervais P., Remarques sur le Typotherium. Zool. et Paléont. générales. I. 1867-69. - Sinclair W. J., Report of the Princeton Univers. Exped. to Patagonia. Vol. VI. Part. I. 1909.

Zittel, Grundzüge der Paläontologie II. 
Hinterhaupt ist mit Supraoccipitalcrista und mit langem Paroccipitalfortsatz versehen. Die Ausdehnung und Auftreibung der Squamoso-mastoidregion erreicht bei den Typotheria den höchsten Grad unter allen Notoungulata, Pachyrucos, ist aber keineswegs bei allen gleich stark ausgeprïgt. Diese bald hohle, bald mit blasigem Knochengewebe erfüllte Kapsel steht mit der Bulla tympanica in Verbindung und umschließt den weiten, nach aufwärts gerichteten äußeren Gehörgang. Das Gaumendach ragt oft weit hinter die letzten $M$ hinaus. Das hohe Unterkiefer bildet eine feste Symphyse und hat mit dem von Hyrax die Breite des aufsteigenden Astes und die Kürze des Kronfortsatzes gemein.

Das Gebiß ist in der Regel vollstïndig mit $\frac{31.4 .3}{3.1 .1 .3}$ in geschlossener Reihe, manchmal entsteht durch Verkümmerung der äußeren $J$, der $C$ und von einigen $P$ ein weites Diastema. Bei den älteren Formen sind alle Zähne brachyodont, später nur die Milchzähne. Die unteren $J$ zeigen häufig in der Mitte einen tiefen Einschnitt. Die oberen $J^{1}$ und die unteren $J_{1}$ und $J_{2}$ werden größer und lïnger und Nagezahn.ähnlich, jedoch sind sie in der Richtung von vorne nach hinten, anstatt seitlich komprimiert. Die folgenden $J, C$ und $P$ gehen entweder ganz allmählich in die $I I$ über, oder die $J$ und $C$ werden $z u$ schwachen Stiften oder fehlen sogar vollständig. Die $P$ sind meist einfacher als die $M$, da ihre hintere Hälfte kleiner bleibt als die vordere. Die oberen $P$ und $I I$ sind bei prismatischer Ausbildung nach innen, die unteren nach außen gekrümmt. Im Oberkiefer bestehen die $M$ aus einem Ectoloph, der mit einer vorspringenden Leiste versehen ist, einem schrägen Protoloph, einem etwas kürzeren Metaloph und einer Crista nebst einem hinteren Pfeiler. Im Unterkiefer haben sie

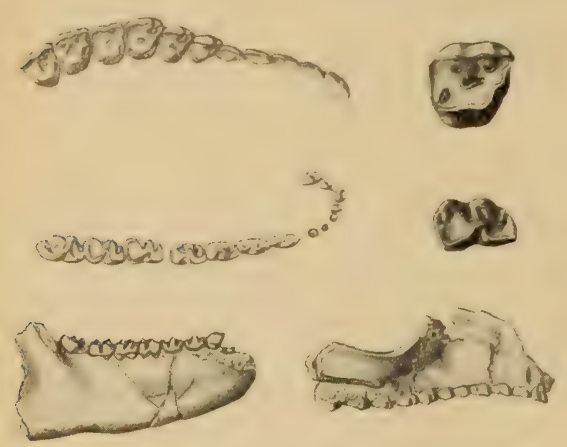

Fig. 708 .

Adpithecus secans Amegh. Obereocän. Notostylops-Schichten Patagonien. Obere und untere Zahnreihe, nat. Gr. Oberer und unterer $M$, $2 / 1$ nat. Gr. Unterkiefer, Oberkiefer, $2 / 3$ nat. Gr.
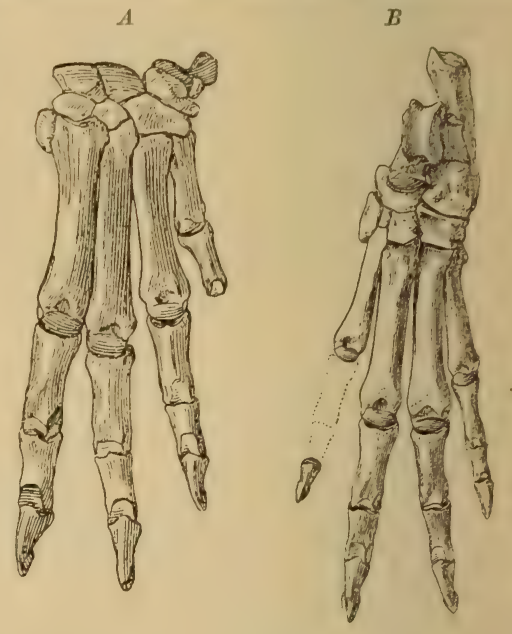

Fig. 709 .

Protypotherium australe Ameghino. Obermiocän. Santa Cruz. $A$ Vorderfuß, $3 / 4$ nat. Gr. $B$ Hinterfuß, $1 / 2$ nat. Gr. (nach Sinclair.)

zwei Außenmonde und zwei stark komprimierte Innenpfeiler, welche sich bald zu einer Innenwand vereinigen. Der untere $M_{3}$ ist stets viel größer als $\lambda I_{2}$. Von den $M$ der Toxodontia unterscheiden sich die der Typotheria dadurch, daß ihre vordere und hintere Partie fast gleich groß ist, und die Vertiefungen bei der Abkauung sehr rasch verschwinden, die oberen überdies durch die beträchtliche Streckung ihrer Kaufläche und den Besitz von sekundären Spornen. Die Zähne sind öfters mit einer dünnen Zementschicht versehen.

Die Zahl der Rückenwirbel ist 15, die der Lendenwirbel 7 und der Sacralwirbel 5, wenigstens bei den Typotherien aus dem Miocän von Santa- 
Cruz. Der Schwanz dürfte meist sehr lang gewesen sein. Das Schulterblatt ist mit einem Acromial- und einem Coracoidfortsatz versehen, und daran schließt sich wohl öfter eine gut entwickelte Clavicula. Der Humerus hat ein Entepicondylarforamen. Ulna und Radius sind frei und etwas gebogen. Der Carpus besitzt stets alternierende Anordnung. Das Centrale ist mit dem Scaphoid verwachsen. Die Zahl der Metacarpalia ist vier, der Daumen ist ganz verschwunden und der fünfte Finger etwas verkürzt, bei Typotherium hingegen ist der 2. bis 5. von fast gleicher Länge und der 1 . zwar kurz, aber noch mit Phalangen versehen. Die Zehenendglieder sind zugespitzt, aber an der Unterseite in eine dreieckige Platte ausgezogen oder hufähnlich und an der Spitze gespalten.

Das Femur trägt einen mäßig vorspringenden dritten Trochanter. Tibia und Fibula sind bald frei, bald an dem oberen und unteren Ende verwachsen. Das Calcaneum hat einen langen, dicken Tuber, eine breite konvexe Gelenkfläche für die Fibula und eine große Fläche für das Cuboid,
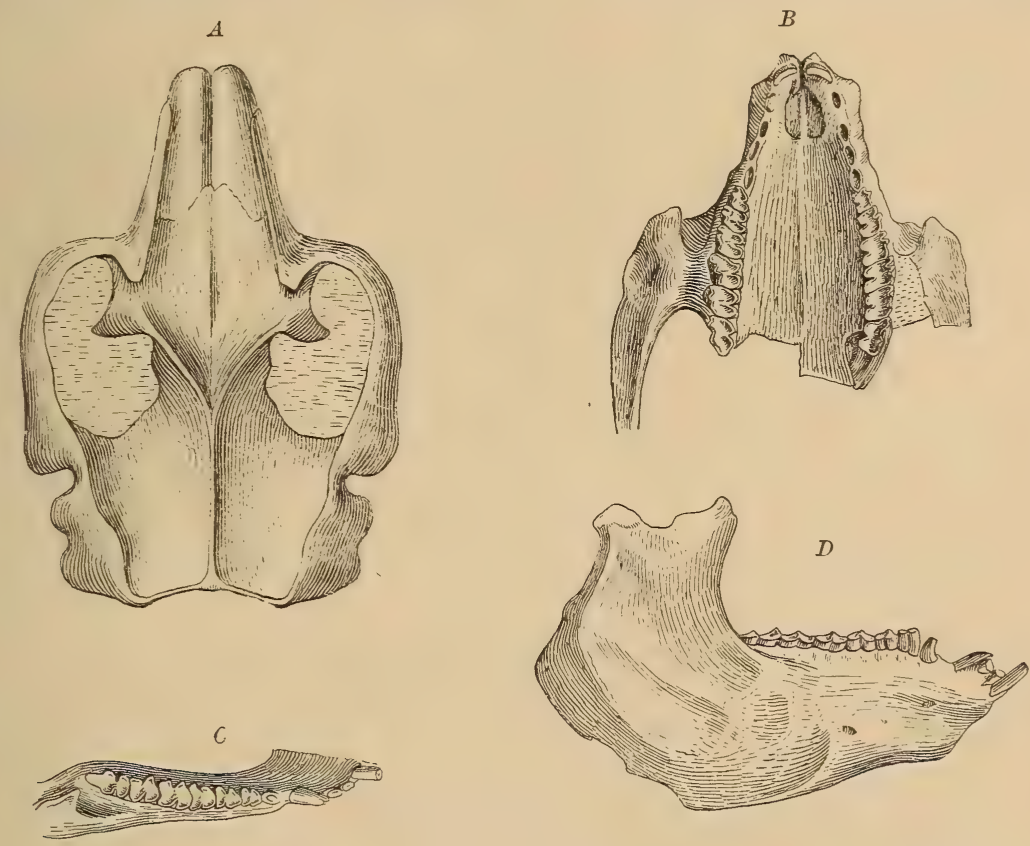

Fig. 710.

Interatherium robustum Ameghino. Obermiocän. Santa Cruz. Patagonien. A Schädel von oben, $B$ Gaumen von unten, $C$ Unterkiefer von oben, $D$ von außen, nat. Gr.

dagegen ragt das Sustentaculum nur ganz wenig vor. Der Astragalus zeichnet sich durch die schmale, nicht sehr tiefe Trochlea und das wohlgerundete, gestielte Caput aus. Von den vier Metatarsalien sind die seit. lichen öfters etwas schwächer. Im allgemeinen zeigt das Skelett den ursprünglichen Typus der Fleischfresser nebst zahlreichen, den Nagern eigentümlichen Spezialisierungen.

\section{Familie. Notopithecidae. Ameghino.}

$\frac{3.1 .4 .3}{3.1 .4 .3}$ in geschlossener Reihe, brachyodont, beuvrzelt. J, C und $P$ allmählich ineinander übergehend. $J^{1}$ bis $P^{1}$ schneidend, untere $J$ und $C$ meißelförmig, $P^{2}$ bis $P^{4}$ dreieckig, $M^{1}$ bis $M^{2}$, rhombisch, $M^{3}$ gerundet dreieckig - mit Außenwand, zwei ungleichen, an der Innenseite verbundenen Querjochen und hin- 
terem Basalwulst, nebst Spornen im Zentrum. Untere II mit zwei äußeren Halbmonden und zuei Innenhöckern, davon der erste mit dem ersten Halbmond verbunden, der zweite frei. Unterkiefer ziemlich schwach.

Diese auf das Eocïn - Notostylopsschichten - und Oligocän von Patagonien beschränkten Tiere von Kaninchengröße sind die Vorläufer der beiden folgenden Familien.

Notopithecus, Adpithecus (Fig. 708), Transpithecus, Infrapithecus etc. Amegh. Notostylops Schichten? Guilelmoscottia Amegh. Astraponotus Schichten.

\section{Familie. Interatheriidae. Ameghino.}

3.1.4.3.
$3.1 .4 .3^{3}$$J_{1}$ bewurzelt, alle ïbrigen prismatisch. $P_{3}$ und $P_{4}$ einfach gebaut. Obere M mit Imenfurche. Mastoid mit blasigem Gewebe erfüllt, Malare weit hinter dem Maxillare beginnend. Unterkiefer hoch. Jochbogen mit nach unten gerichtetem Fortsatz. Tibia und Fibula frei. Seitenzehen reduziert.

Protypotherium (Patriarchus) Ameghino. (Fig. 709). Jochbogenfortsatz schwach, Zähne gleichmäßig ineinander übergehend. Miocän von Santa Cruz. P. australe, attenuatum Amegh.

Interatherium (Ieochilus) Ameghino. (Fig. 710). Seitliche $J$ und $C$ reduziert. Jochbogen mit kräftigem Fortsatz. Humerus mit undeutlichem Foramen. Miocän von Santa Cruz. J. robustum, extensum Amegh.

Cochilius Amegh. Miocän. Colpodon-Schichten. Schichten.

Plagiarthrus Amegh. Zähne im Alter bewurzelt. Pyrotherium-

\section{Familie. Hegetotheriidae. Ameghino.}

$J_{1}$ in beiden Kiefern vergrößert. $P_{3}$ und $P_{4}$ M-artig. Obere $M$ innen konvex, außen glatt. Mastoid hohl, Malare an das Maxillare stoßend. Tibia und Fibula verwachsen. Seitenzehen ungleich reduziert.

Hegetotherium (Selatherium) Ameghino. 3.1.4.3. hintere $J$ und $C$ etwas reduziert. Endphalangen abgeplattet. Miocän. Colpodon-Schichten und Santacruzeno. $H$. mirabile Amegh. Schwanz lang. Fuchsgröße.

Archaeopilus, Prohegetotherium Amegh. Unt. Miocän. Pyrotherium-Schichten.

Prosotherium Amegh. 1.0.4.3. Pyrotherium-Schichten.

Eohegetotheriuu Amegh. Zähne noch bewurzelt. Oligocän. Astraponotus-Schichten.

Pachyrucos Amegh. (Paedotherium Burmeister) $\frac{1.0 .3 .3 .}{2.0 .3 .3 .}$ Mastoidregion ungewöhnlich stark aufgetrieben. Endphalangen hufartig. Schwanz kurz. Miocän. Santa Cruz. P. Moyani Amegh. Kaninchengröße. Schon in den Colpodon-Schichten. Auch im Pliocän und im Pleistocän. Monte Hermoso. $P$. typicus Amegh.

Eopachyrucos, Pseudopachyrucos Amegh. Astraponotus-Schichten. Propachyrucos Am. Pyrotherium-Schichten.

Argyrohyrax Amegh. 3.1.4.3. Die hinteren $J, C$ und $P^{1}$ und $P^{2}$ ineinander übergehend. $P^{3}$ und $P^{4} M$-artig. Pyrotherium-Schichten.

\section{Familie. Typotheriidae. Amegh.}

1.0.2.3. J1 breit, gekrümmt, an der Basis offen, an Vorderseite mit Schmelz versehen, unterer $J_{2}$ klein. Hinter den $J$ ein langes Diastema. Obere $P$ mit zwei, $M$ mit drei Jochen. Vorderpartie der unteren $M$ viel kürzer als die hintere. Alle Backenzähne prismatisch und teilweise mit Zement versehen. Carpalia alternierend. Hand mit dïnnem Daumen. Fibula nicht mit dem Calcaneum artikutierend. 
Typotherium Bravard (Fig. 711) erreicht fast die Größe eines Schweins. Älteres Pleistocän von Argentinien.

Trachytypotherium Ameghino. Pliocän.

Eutrachytherus und Proëdrium Amegh. mit $\frac{3.1 .4 .3}{2.1 .4 .3}$ aus den Pyro-

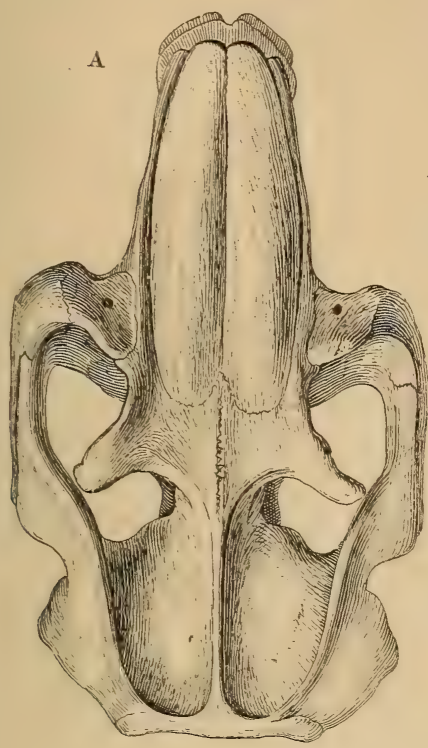
therium-Schichten von Patagonien von unsicherer Stellung.

An die Typotheria reihen sich am besten an die Archaeopithecidae und Acoelodidae Ameghino, beide brachyodont aus dem Eocän, Notostylops-Schichten, und die Archaeohyracidae mit prismatischen Zähnen aus dem Untermiocän, Pyrotherium-Schichten, von Patagonien. Die Archaoepitheciden sind wohl die Vorfahren der Archaeohyraciden und die Acoelodiden vielleicht Verwandte der Notohip. piden. Mit Primaten oder Hyracidae haben sie natürlich nichts zu schaffen. Extremitätenknochen nicht mit Sicherheit bekannt.

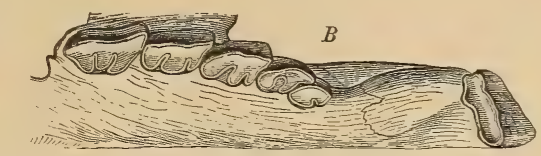

Fig. 711 .

Typotherium cristatum Serres. Pampas-Formation. Buenos-Aires, Argentinien. A Schädel von oben. $B$ Oberkiefer und Zwischenkiefer von unten. 1/4 nat. Gr. (Nach Gervais.)

5. Familie. Archaeopithecidae (Henricosborniidae, Pantostylopidae) Ameghino.

$P$ einfacher als $M$. Obere $P$ und $M^{3}$ dreieckig, $M^{1}$ und $M^{2}$ oblong, viel breiter als lang. Aiißemwand mit Parastyl, häufig anch mit Mesostyl und Metastyl. Protoloph schräg und länger als der gerade Metaloph. Beide Joche öfters an der Innenseite miteinander verbunden. Zuweilen Cristae und Crochet vorhanden.
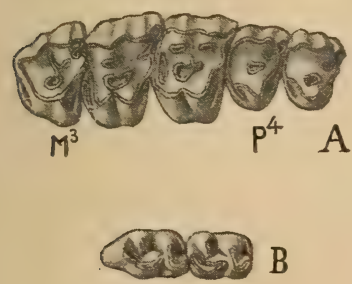

Fig. 712.

Oldfieldthomasia sp. Obereocän Notostylopssch. Patagonien. $A$ Obere Backenzähne, $B$ untere $\mathrm{M}_{2}$ und $Y_{3}$ nat. Gr. Hinterer Halbmond der unteren $P$ kleiner, an den $M$ größer als der vordere. $P$ mit nur einem Innen. höcker - an der Vereinigung der beiden Halbmonde $M$ mit zweitem Innenhöcker in der Nähe des Hinterendes des zweiten Mondes. Alle Zühne brachyodont. Unterkiefer (Selenoconus Ameghino) ziemlich niedrig. Kaninchengröße.

Nur im Eocän, Notostylops-Schichten, von Patagonien. Henricosbornia, Othnielmarshia, Archaeopithecus, Pantostylops etc. Ameghino.

Die Acoelodidae unterscheiden sich von den Archaeopitheciden im wesentlichen nur durch ihre beträchtlicheren Dimensionen - etwa Fuchs. größe - und durch den mehr schräg trapezoidalen Umriß der oberen $M$. Acoelodus, Oldfieldthomasia (Fig. 712), Eohyrax, Acoelohyrax etc. Amegh. Eocän. Notostylops-Schichten von Patagonien. 


\section{Familie. Archaeohyracidae. Ameghino.}

Schädel dem von Hegetotherium ähnlich, jedoch mit schwächerem Jochbogen

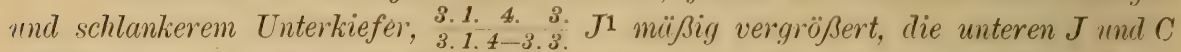
stiftförmig, die unteren $P$ M- ̈̈hnlich. Oben alle Zähne ineinander ïbergehend, II von schrïg dreieckig gemuletem Umriß und wie die $P$ mit Parastyl versehen. Alle Zähne prismatisch. $M_{3}$ mit großem dritten Lobus.

Wohl die Vorläufer von Typotherium. Untermiocïn-Pyrotheriumschichten und Oligocïn-Astraponotus-Schichten. Archaeoliyrax. Ameghino.

\section{Unterordnung. Toxodontia. Owen. ${ }^{1}$ )}

Ausgestorbene, digitigrade oder semiplantigrade Pflanzenfresser mit dreizeligen Extremitïten. Gebiß3 meist vollstündig. (' stets schwach, öfters fehlend. Bachienzähne gekrïmmt, lophodont. Clavicula fehlt. Carpalir alternierend. Astragalıs mit mäßig gewölbtem, schwach ausgefurchtem Tilialgelenk, distal abgestutzt, mur mit dem Naviculare artihulierend. Calcunenm plump, mit großer Gelenhflüche fiir die Fibula. Humerus oline Foramen entepicondyloideum.

Die Toxodontia sind große bis mittelgroße, auf Südamerika beschränkte Pflanzenfresser, welche im Oligocïn? von Patagonien beginnen und im Pleistocän von Argentinien und Brasilien aussterben.

Der Schädel ist mäßig hoch, das Dach häufig von der frei vorragenden Nasenspitze bis zum Hinterhaupt fast eben, die Schnauze verschmälert und ziemlich lang. Die Stirnbeine sind groß, die Scheitelbeine bilden einen schwachen Sagittalkamm. Das hohe breite Hinterhaupt fällt senkrecht ab, die Squamosomastoidregion ist nicht sehr stark aufgetrieben, und der äußere Gehörgang mündet schräg aufwärts. Die Condylen ragen ziemlich weit vor. Die Jochbogen sind ungemein hoch, aber nicht sehr dick, unter den nach hinten offenen Orbiten abwärts gebogen und zum größeren Teil aus dem Fortsatz des Squamosum gebildet. Zwischenkiefer verlängert und hoch, Tränenbein klein. Das gewölbte Gaumendach ragt über die letzten $M$ hinaus, so daß die inneren Choanen weit nach hinten rücken. Die vorderen Gaumenlöcher liegen ganz in den Zwischenkiefern. Unterkiefer mit sehr starker Symphyse, breitem Kronfortsatz und hochgelegenem, querem Condylus. Das Gebiß ist häufig vollständig und hochspezialisiert und bildet öfters eine ganz oder nahezu geschlossene Reihe. Die $J$ sind bald schaufelförmig, ganz oder fast allseitig von Schmelz umgeben und sämtlich oder zum Teil bewurzelt, bald stark verlängert, nagezahnähnlich, unten offen und nur vorne und hinten oder bloß auf der Vorderseite mit Schmelz bedeckt. Von den oberen $J$ ist in der Regel $J^{2}$, von den unteren $J_{3}$ kräftiger entwickelt. Oben gehen alle Zähne von $J^{3}$ an, unten von $C$ an allmählich ineinander über. Von den vier $P$ können die beiden vorderen verkümmern, die hinteren werden $M$-ähnlich. Die oberen $M$ haben schief vierseitigen oder dreiseitigen Querschnitt und meist einen Parastyl. Sie bestehen aus einer Außenwand und zwei ungleichen Jochen, zwischen welchen sich ein tiefes Quertal befindet, in welches eine oder zwei Cristae hineinragen. Am Hinterrand bildet sich oft noch ein weiteres Joch. Durch Abkauung verbinden sich alle Erhabenheiten der Kaufläche, und die Ver-

1) Burmeister H., Anales del Museo de Buenos Aires I 1867 und III. - Cope E. D., On Toxodon. Proceed. Amer. Philos. Soc. 1881. - Lydekker R., Anales del Museo de la Plata. Paleontologia Argentina 1890. - Owen $R$., (Toxodon) in the Zoology of H. M. S. Beagle 1840. - Descript. of some sp. of Nesodon. Philos. Trans. 1853. - Roth Santjago, Catalogo de los Mamiferos fosiles on el Museo de la Plata. Orden Toxodontia 1898. 
tiefungen werden zu Inseln, die später auch zum Teil oder vollständig verschwinden. Bei den primitiveren Formen sind die Kronen ganz von Schmelz umgeben, bei den spezialisierteren werden die Backenzähne prismatisch, die Wurzeln verschwinden und der Schmelz beschränkt sich auf die Außenund Vorderseite oder auf die Außen- und Innenseite. Öfters tritt eine Zementschicht auf, die den Zahn ganz oder teilweise umhüllt. Die unteren Backenzähne bestehen aus einem kurzen vorderen und einem viel längeren, gestreckten hinteren Halbmond und zwei Innenpfeilern, von denen der vordere mit dem Hinterende des ersten, und der zweite mit seiner Basis mit dem Vorderende des zweiten Halbmondes verschmilzt. Durch die Ab. kauung der Erhabenheiten der Innenseite kommt eine Art von Innenwand zustande. Die ursprünglichen Vertiefungen werden auch hier zu Schmelzinseln. Die oberen $J$ und $M$ sind stark nach innen gekrümmt, die unteren nach vorwärts geneigt, $M_{3}$ ist in beiden Kiefern verlängert. Die hinteren Milchzähne gleichen im wesentlichen den $M$, haben jedoch immer kurze, getrennte Wurzeln.

Das Skelett der Toxodontia ist im wesentlichen dem der Typotheria ähnlich und vereinigt viele primitive Merkmale mit hochgradigen Spezialisierungen. Die große Scapula ist ähnlich der von Rhinoceros, nur mit einem rudimentären Acromion versehen, was auch die Abwesenheit einer Clavicula bedingt. Der kurze kräftige Oberarm hat eine niedrige einfache Trochlea, aber kein Foramen entepicondyloideum. Die stämmige Ulna mit langem, starkem Olecranon und der kurze, etwas schwächere Radius stehen gekreuzt; sie sind aber sonst denen von Rhinoceros nicht unähnlich, was auch für die Beckenknochen gilt. Die Carpalia sind alternierend angeordnet, die Metacarpalia kurz und gedrungen. Das kurze Femur besitzt einen schwachen dritten Trochanter, sein erster Trochanter ragt weit nach außen vor. Die kräftige Fibula kann mit der Tibia verwachsen. Die erstere artikuliert innig mit dem plumpen Calcaneum (Fig. $714 B$ ). Der Astragalus (Fig. $714 B$ ) hat eine schwach gewölbte und mäßig vertiefte Trochlea und an dem kurzen einwärts gedrehten Hals eine schwach konvexe Gelenkfläche für das Naviculare. Die kurzen, plumpen Metatarsalia sind wie die Metacarpalia nur auf ihrer Rückseite mit schwachen, stumpfen Leitkielen versehen, die Zehenglieder bilden abgeplattete Hufe. Hand und Fuß haben nur je drei Metapodien.

\section{Familie. Notohippidae. Ameghino.}

3.1.4.3. Alle Zähne in geschlossener Reihe, hypselodont, im Alter bewurzelt and von $J_{1}$ bis $M_{3}$ fast unmerklich ineinander übergehend, oder die unteren $J$ und $C$ meißel- und die oberen schaufelförmig gestaltet, niemals vergrößert. Schödeldach eben, Nasenöffnung endständig. Astragalus mit ziemlich langem Hals.

Die Spezialisierung der $J$ und $C$ ist hier noch nicht so weit vorgeschritten wie bei den Nesodontiden. Die $P$ und $M$ sind noch auf allen Seiten mit Schmelz versehen. Der Hinterrand der oberen $M$ bildet ein drittes Joch. Die Auftreibung des Mastoid ist hier noch sehr gering.

Notohippus Amegh. Miocän von Patagonien.

Rhynchippus Amegh. (Fig. 707 D.) $J$ und $C$ meißelförmig.

Morphippus Amegh. (Fig. 707 C.) $J$ und $C$ schaufelförmig, den $J$ von Equus ähnlich.

Coresodon Amegh. Alle. im Untermiocän, Pyrotheriumsschichten.

Argyrohippus Amegh. Zähne mit dickem Zement, Stylhippus, Perhippidium Amegh. Miocän. Colpodonschichten. Schichten.

Eomorphippus und Interhippus Ameghino Oligocän. Astraponotus. 


\section{Familie. Nesodontidae.}

3.1.4.3. Zühne meist in geschlossener Reihe. $J^{1}$ und $J^{2}$ vergrößert, $J^{1}$ meißelförmig, nur vorne mit Schmelz bedeckt, $J^{2}$ dreikantig, hinten schmelzlos, $J^{3}$ $C$ und $P^{1}$ klein, allmählich den übrigen $P$ ähnlich werdend und durch kurze Lücken voneinander getrennt. Untere $J$ meißelförmig, $J_{3}$ vergrößert. Obere $P$ und $M$. nach hinten an Größe zunehmend, prismatisch, nur an der Außen-und Vorderseite mit Sclimelz bedeckt, stark nach innen gekrümmt, Innenenden der beiden Querjoche bei der Abkauung miteinander verschmelzend und eine inselartige Marke um. schließend. Untere $M$ nur außen und innen mit Schmelz versehen und stark komprimiert. Zähne nur teilweise und erst im Alter Wurzeln ansetzend.

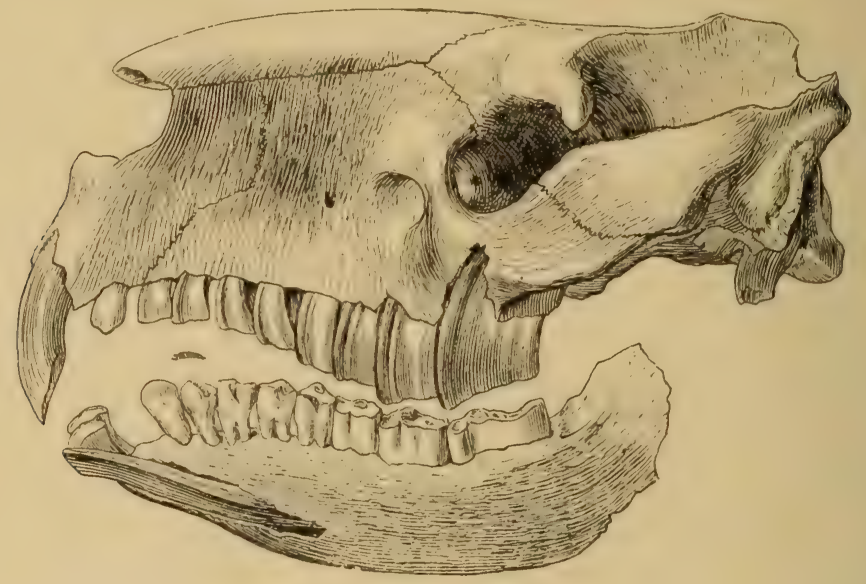

Fig. 713.

Nesodon imbricatus Owen. Obermiocän. Santa Cruz. Patagonien. Schädel mit Unterkiefer von der Seite ( $1 / 6$ nat. Gr.)

Nesodon Owen (Fig. 713, 714) (Gronotherium, Phobereotherium Ameghino) von mehr als Tapirgröße, ist eines der häufigsten Säugetiere im Miocän von

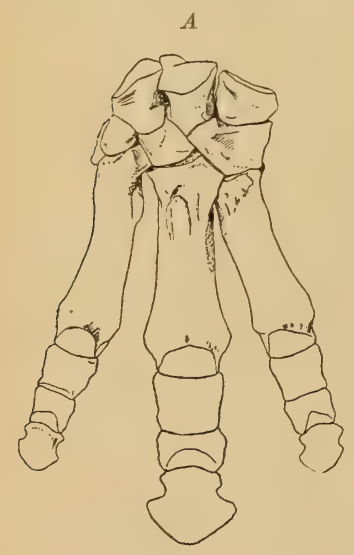

Fig. 714 .

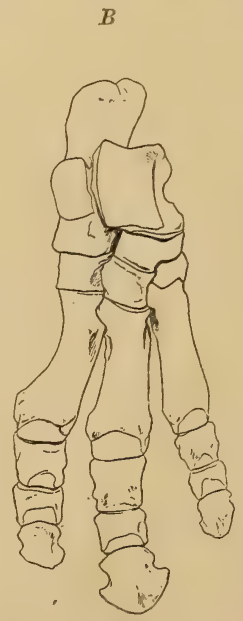

Nesodon imbricatus Owen. Obermiocän. Santa Cruz. Patagonien. $A$ Vorderfuß $1 / 5$ nat. Gr. $B$ Hinterfuß (1/5 nat. Gr. nach Sinclair.)
Santa Cruz. Patagonien. N. imbricatus Ow.

Stenostephanus Amegh. Unvollständig bekannt. Miocän und Pliocän.

Trigodon Ameghino. Pleistocän von Monte Hermoso.

Adinotherium Ameghino. (Fig. 715). Oberer $J^{3}, C$ und $P^{1}$ sehr klein. Miocän, Colpodonschichten und Santacruzeno. A. (Nesodon) ovinum Owen.

Pronesodon, Proadinotherium Amegh. Miocän, Pyrotherium und Colpodonschichten von Patagonien.

Acrotherium Ameghino. ähnlich Adinotherium, Miocän Santa Cruz. 


\section{Familie. Toxodontidae. Ameghino.}

Backenzähne stark komprimiert, schmäler und durch Verschmelzung von Vorsprïngen an der Innenseite auch einfacher als bei den Nesodontiden. Obere $M$ scheinbar nur aus Ectoloph und Protoloph bestehend. Zahnreihe durch Verkümmerung von $C$ und $P$ öfters mit Diastema. Alle Zähne prismatisch, wurzellos; allseitig mit Schmelz bedeckt, der jedoch durch schmelzlose Streifen unterbrochen ist. Astragalus mit flacher Trochlea.

$B$

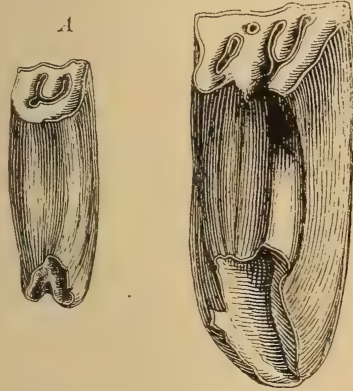

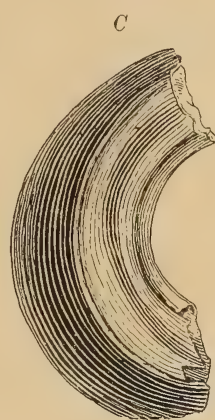

Fig. 715
$D$

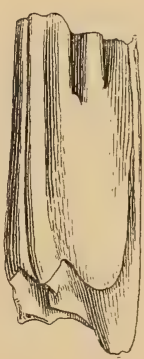

$E$

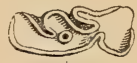

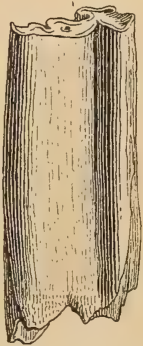

Adinotherium sp. Obermiocän von Santa Cruz. Patagonien. $A$ Ob. Prämolar von innen. $B$ Ob. Molar von innen, $C$ von hinten. D Unt. Backenzahn von innen, $E$ von außen und oben. $2 / 3$ nat. Gr.

Toxodontherium Amegh. (Haplodontherium, Trigodon Amegh.) 3.1.3.3 Obere $P$ und $M$ noch ziemlich breit.

Xotodon Amegh. $\frac{2.1 .4 .3}{3.1 .4 .3}$ Beide im Pliocän und Pleistocän von Argentinien.

Toxodon Owen. $\frac{2 \cdot 0.3 \cdot 3}{3 \cdot 1.4 .3}$ Größter aller Toxodontier, übertrifft in seinen Dimensionen die gewaltigsten Rhinoceroten. Nasenbeine kurz, Nasenlöcher ziemlich weit zurückgerückt. Pliocän und Pleistocän (Pampasformation) von Argentinien. T. platensis Owen.

3. Unterordnung. Entelonychia Ameghino ${ }^{1}$ ) (Ancylopoda, Tillodontia Amegh.).

Ausgestorbene, plantigrade oder semidigitigrade Pfanzenfresser mit vollständigem, selten reduziertem Gebiß. J, $C$ und $P$ entweder ineinander übergehend, oder oben und unten je ein $J$ kräftiger entwickelt. $C$-manchmal eckzahnartig. $P$ und $M$ lophodont, brachyodont bis hypselodont, stets mit Wurzeln versehen. $P$ einfacher als die $M$. Obere $M$ fast immer breiter als lang, aus Ectoloph und zwei ungleichen Querjochen bestehend, und stets mit Crochet, oft auch mit Crista versehen. Untere $M$ mit einem sehr kurzen vorderen und einem langgestreckten hinteren Halbmond und zwei Innenhöckern, von denen der erste stark in die Quere gezogen ist. Carpalia alternierend. Calcaneum lang, mit kleiner, meist schrägstehender Gelenkfläche für die Fibula. Astragalus mit Foramen oberhalb der

1) Ameghino Flor., Énumération synopt. des mammifères fossiles de Patagonie. Buenos-Aires 1894 p. 55. - Sur les ongulés fossiles del' Argentine, Revista de Jardin zoologico Buenos-Ayres 1894. - Notices préliminaires sur des Ongulés des terrains crétacés. Boletin Acad. nacional de cienc. de Cordoba. 1901. - Flower W., Homalodontotherium. Philos. Trans. 1874. 
flachen, am Oberrand tief ausgeschnittenen tibialen Gelenkff̈̈che. Endphalangen öfters als plumpe, gebogene Krallen oder als breite Hufe entwickelt, stets an der Spitze gespalten. Hand und Fuß fünfzehig.

Die Entelonychia sind mittelgroße bis große Pflanzenfresser und auf das Tertiär von Patagonien beschränkt. Mit den Co peschen »A n cylo poden«, jetzt Chalicotheriidae, haben sie zum Teil Form und Zurückziehbarkeit der Endphalangen gemein - Homalodontotherium, Asmodeus -, dagegen spricht die Bezahnung mit aller Entschiedenheit für eine nahe Verwandtschaft mit den Toxodontia, von welchen sie sich durch den Besitz von bewurzelten, allseitig von Schmelz umgebenen, niemals prismatisch werdenden Zähnen unterscheiden. Auch sind die oberen immer fast mindestens ebenso breit als lang und mit Crochet versehen, das allerdings durch die Verschmelzung mit den Spornen an der Innenseite des Ectolophs sehr bald undeutlich wird. Die unteren $M$ sind ebenfalls massiver als bei den Toxodontia. Auch besitzen die $M$ meist ein Basalband, das an den oberen auf der Vorder-, Hinter- und oft auch an der Außen- und Innenseite, an den unteren an der Außenseite entwickelt ist, bei den Toxodontia hingegen stets fehlt.

Der Schädel ist nur von Notostylops, Leontinia und Homalodontotherium bekannt und im wesentlichen wie bei Nesodon gebaut, jedoch ist meist die Nase viel tiefer ausgeschnitten und bei Homalodontotherium die Mastoidregion viel weniger aufgetrieben, und Notostylops hat eine viel kürzere und spitzere Schnauze. Vom Skelett kennt man, abgesehen von Calcaneum und Astragalus, nur Humerus, Ulna und Tibia, sowie Hand und Fuß von Homalodontotherium. Der Humerus hat eine kräftige Deltoidcrista und eine Andeutung des Foramen entepicondyloideum und seine distale Partie ist stark verbreitert. Ulna und Tibia sind sehr plump, die letztere auch sehr kurz. Hand und Fuß haben je fünf Metapodien, die Metacarpalia sind auffallend schlank, die Metatarsalia kurz und dick.

\section{Familie. Notostylopidae. Amegilino.}

$\frac{3.1-0.4 .3}{1.1-0.4-3_{3}^{3} .3^{.}} . J_{1}$ in beiden Kiefern vergrößert. $J^{2}$ bis $J^{3}$ und $C$ reduziert, untere $J_{2}, J_{3}$ und $C$ meist fehlend. $P$ den $M$ ähnlich, jedoch die oberen mit nur einem Innenhöcker. Obere $M$ viel breiter als lang, ohne Crista, mit Crochet. Hinterer Innenhöcker der unteren $M$ sehr schwach. Alle Zähne brachyodont. Schnauze kurz und zugespitzt. Hinterhaupt breit mit aufgetriebenem Mastoid.

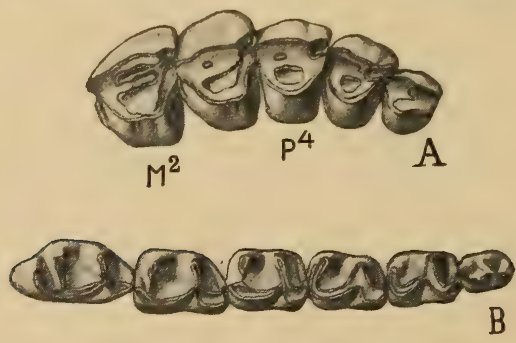

Fig. 716.

A Entelostylops triplicatus Ameghino. Obereocän Patagonien. Obere Backenzähne, nat. Gr.

$B$ Untere Backenzähne, nat. Gr.

C Notostylops murinus Ameghino. Schädel von unten, $1 / 3$ nat. Gr. (nach A meghino.)

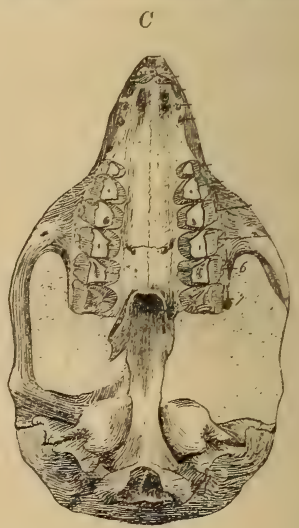

Diese frühzeitig spezialisierte Familie hat keine Nachkommen hinterlassen. Sie erlischt schon am Ende des Eocän. 
Notostylops Amegh. (Fig. 716) mit $\frac{3.1 .3 .4}{3.0 .3 .4}$, Catastylops Amegh. mit 4 oberen, Pliostylops mit 4 unteren $P$, Homalostylops Amegh. mit vollständigem Gebiß, Eostylops, Entelostylops etc. Amegh. Eocän. Notostylopsschichten von Patagonien.

\section{Familie. Isotemnidae. Amegh.}

3.1.4.3 Zähne in geschlossener Reihe und ineinander übergehend, nur oberer $C$ manchmal vergrößert. Backenzähne mäßig hypselodont; obere $P$ und $M$ mit mehreren Spornen, Cristae, an der Innenseite des Ectoloph und mit Crochet am Metaloph. Untere $P$ und $M$ mit sehr kräftigem, komprimiertem Höcker am Innenende des vorderen Halbmondes.

Isotemnus Ameghino. C klein, obere $P$ dreieckig, $M$ oblong. Eocän. Notostylopsschichten von Patagonien.

Pleurostylodon Amegh. (Fig. 717), Tychostylops, Plexotemnus, Dialophus Amegh. etc. Eocän etc.

Eochalicotherium Amegh. Dicke untere $M$. Ebenda.

Timerostephanus Amegh. Oligocän, Astraponotus- und Untermiocän, Pyrotheriumschichten.

Pleurocoelodon, Lophocoelus Ameghino. Untermiocän. PyrotheriumSchichten.
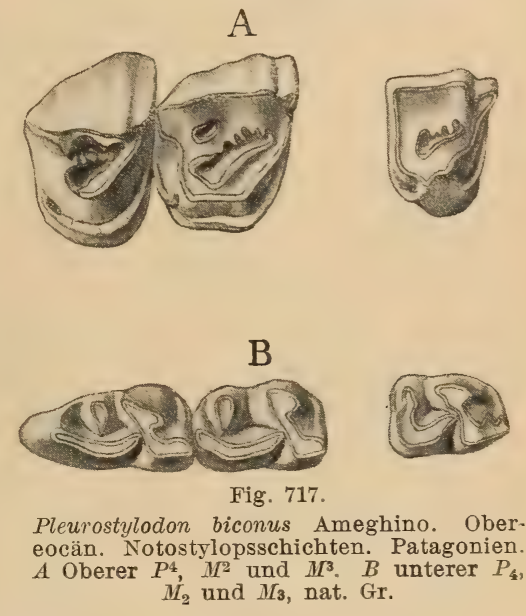

\section{Familie. Leontiniidae. Ameghino.}

$\frac{3.1-0.4 .3}{3.1-3,4.3 .}$. Oberer $J^{2}$ und unterer $J_{3}$ vergrößert, $C$ klein, manchmal fehlend, die $P$ und $M$ ineinander übergehend, die oberen $M$ etwas länger als breit, ohne Parastyl. Joche an der Innenseite innig verschmolzen. Schädel plump, mit breitem Hinterhaupt, mit massiven, weitabstehenden Jochbogen und tief ausgeschnittener Nasenöffnung zwischen den verdickten Zwischenkiefern und den etwas aufwärts gerichteten Nasenbeinen. Endphalangen als breite Hufe entwickelt, Astragalus und Calcaneum plump, Nesodon ähnlich (nach Gaudry).

Leontinia Amegh. mit C, Ancylocoelus Amegh. ohne C, Henricofilholia Amegh. Untermiocän. Pyrotheriumschichten.

Colpodon Burm. Miocän. Colpodonschichten.

Carolodarwinia, Stenogenium Amegh. Oligocän, Astraponotusschichten und Untermiocän.

\section{Familie. Homalodontotheriidae. Lydekker. (A n c ylopoda Zittel, partim).}

3.1.4.3. 3.1.4.3. C in beiden Kiefern vergrößsert, alle übrigen Zähne ineinander ïbergehend und dicht aneinandergeschlossen, brachyodont. Obere $M$ breiter als lang, ohne Sporne an der Innenseite des Ectoloph, aber mit äußerem und innerem, untere $M$ mit äußerem Basalband. Schädel mit kleinem, am Mastoid schwach auf. getriebenem Cranium, kurzen, weit zurückstehenden Nasenbeinen und kräftigen Jochbogen. Hand mit fünf schlanken Metacarpalien und zurückziehbaren, an der Spitze gespaltenen Krallen. Hinterfuß mit füinf kurzen Metatarsalien, langem Calcaneum und distal gerundetem Astragalus. 
Homalodontotherium Huxley. (Fig. 718, 719.) Obere $M$ gerundet trapezoidal. Humerus massiv, mit breitem Unterende und langer Deltoidcrista. Tibia kurz und dick. Miocän. Santa Cruz, Patagonien.

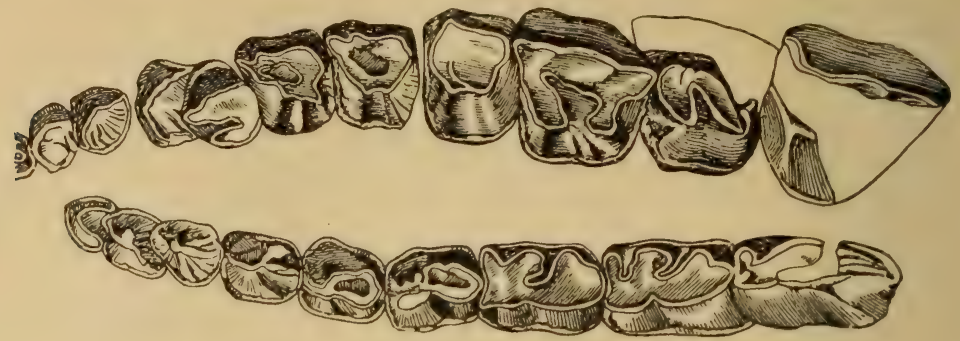

Fig. 718.

Iomaloclontotherium Cunninghami Flower. Miocï. Rio Gallegas. Patagonien. Obere und untere Backenzähne. 2/5 nat. Gr. (Nach Flower.)

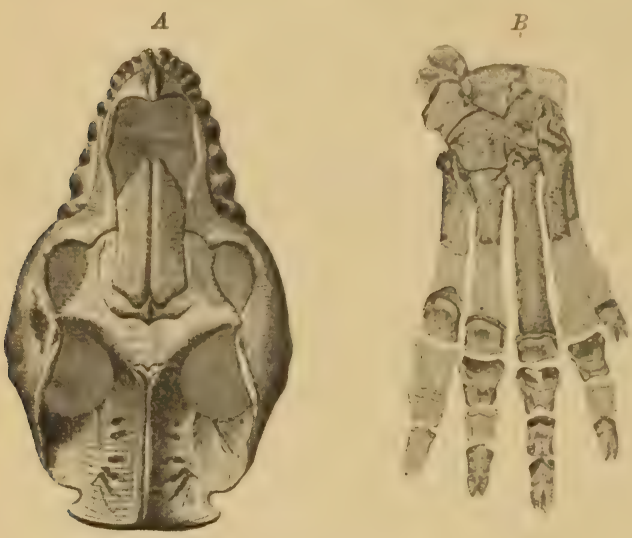

Fig. 719

Homalodontotherium Segoviae Ameghino. Obermiocän. Santa Cruz. $A$ Schädel von oben, $1 / 9$ nat. Gr. $B$ Vorderfuß, 1/3 nat. Gr. (nach A meghino.)

Thomashuxleya Ameghino. Obere $\boldsymbol{M}$ gerundet, sehr breit. Eocän. Notostylopsschichten von Patagonien.

Proasmodeus Amegh. Oligocän. Astraponotusschichten. Asmodeus Ameghino. Obere $M$ quadratisch. Untermiocän Pyrotheriumschichten.

Diorotherium, Prochalicotherium Amegh. Untermiocän.Pyrotheriumschichten.

\section{Unterordnung.}

Astrapotherioidea. Amegh. ${ }^{1}$ ) (Amblypoda Amegh.)

Mittelgroße bis große Pflanzenfresser mit brachyodontem Gebiß, mit meißelförmigen $J$ und hauerartig entwickelten $C . P$, zuweilen auch $J$ teilweise atrophiert, $P$ kleiner als die $M$. Obere $M$ in der Regel länger als breit, mit Parastyl und oft auch mit Crista am Ectoloph, mit gebogenem Protoloph und kurzem Metaloph. Untere $M$ mit zwei ungleich langen Halbmonden und zwei Innenhöckern, von denen der erstere mit dem Hinterende des ersten Halbmondes innig verbunden ist und der zweite später mit dem Vorderende des zweiten Halbmondes verschmilzt. Astragalus mit flachem Tibialgelenk.

Die Astrapotherioidea schließen sich eng an die Entelonychia an. Sie unterscheiden sich von ihnen hauptsächlich durch die hauerartige Ausbil. dung der $C$ und meist auch durch die mehr an Phinoceroten erinnernde

1) Ameghino Flor., Sur les Ongulés fossiles del'Argentine. Revista del Jardin zoologico. Buenos-Aires 1894. - Notices préliminaires sur des On gulés nouveaux des terrains crétacés. Bol. Acad. nacion. de cienc. de Cordoba. T. XVI. 1901. - Gaudry A., Mémoires de la Soc. géolog. de France. Paléont. Tome XII. 1904. Annales de Paléontologie. 1906. - Lydekker R., Anales del Museo de la Plata. Palaeontologia. II 1892. 
Form der $M$. Auch findet keine Auftreibung der Squamosomastoidregion statt, wenigstens nicht bei Astrapotherium. Die Trigonostylopiden stehen den Entelonychia am nächsten und weichen von ihnen nur ab in der Form der $J$ und $C$, in der hochgradigen Brachyodontie und dem einfachen Bau ihrer $M$. Der anfangs noch gewölbte Astragalus wird mit der Zunahme der Körpergröße ganz flach und büßt seine Beweglichkeit fast vollkommen ein.

\section{Familie. Trigonostylopidae. Ameghino.}

2.1. 4. 3. J klein, $C$ kräftig entwickelt. Vor und hinter dem kegelförmigen $P^{1}$ eiue lange Zahnlïcke. Obere $P$ und $M$ im Umriß gerundet vier- oder dreieckig, sehr einfach, nur mit Parastyl, Ectoloph, Protoloph und Andeutung eines Metalophs. Untere $P$ und $M$ aus kurzem, schrägem Querjoch und einem Halb. mond bestehend, mit dessen Hinterende sich der kleine Innenhöcker verbindet. Astragalus mit ziemlich langem Hals.

Die Trigonostylopidae haben unter allen Säugetieren des südamerikanischen Tertiärs die einfachsten und niedrigsten Jochzähne. Nachkommen dieser Familie sind nicht bekannt. Sie erlischt bereits im Oligocän.

Trigonostylops (Figur 720), Pleurystylops Ameghino. Obere $M$ dreieckig. Eocän. Notostylopsschichten.

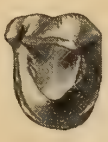

A
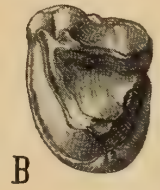

Fig. 720 .

Trigonostylops Wortmani Ameghino. Obereocän. Patagonien. A Oberer $P^{4}, B$ oberer $M, C$ unterer $M_{3}$, nat. Gr.

Pseudostylops, Edvardocopeia Ameghino. Obere $M$ viereckig. Oligocän. Astraponotusschichten.

\section{Familie. Albertogaudryidae. Ameghino.}

3. 2 1. 4. 3. Obere $M$ breiter als lang, rundlich viereckig, mit kurzem Protoloph und einem isolierten Innenhöcker. Untere $P$ und $M$ aus zwei Halbmonden und einem isolierten Innenhöcker bestehend. $J$ schwach, oberer $C$ dreikantig. $P$ einfacher als $M$. Astragalus mit kurzem Hals.

Diese Vorläufer der folgenden Familie hatten etwa Tapirgröße und gehörten zu den größten von allen Säugetieren des südamerikanischen Focän.

Albertogaudrya, Rütimeyeria Ameghino. Obere $M$ von gerundetem Umriß. Eocän. Notostylopsschichten. schichten.

Scabellia Ameghino. Obere $\boldsymbol{M}$ vierseitig. Eocän. Notostylops-

\section{Familie. Astrapotheriidae. Ameghino.}

3.1.3-2.3. J klein, besonders die oberen, spatelförmig, zweilappig. $C$ als kräftige, dreikantige Hauer ausgebildet, die mit ihren Spitzen aneinander schleifen. $P$ einfacher und kleiner als die $M$ und wenig zahlreich. Obere $M$ länger als breit, aus geradem Ectoloph, schrägem Protoloph und kurzem, geradem Metaloph bestehend und mit Parastyl und Crista versehen. $M^{3}$ ohne Metaloph. Untere $M$ aus zwei gestreckten Halbmonden und einem bald mit dem Vorderende des zweiten Mondes verschmelzenden Innenhöcker bestehend. Hand fünfzehig. Astragalus flach mit sehr kurzem Hals.

Diese großen, im Zahnbau an Rhinoceroten, namentlich an Metamynodon, erinnernden Huftiere besitzen einen verhältnismäßig kurzen Schädel mit breiter Stirn, breitem Gaumen und schmalem Cranium, ohne die für die Notoungulaten charakteristische Auftreibung der Squamosomastoidregion. 
Der Humerus hat eine weit herabreichende Deltoidcrista und eine niedrige einfache Trochlea, aber kein Foramen entepicondyloideum. Die Ulna ist kräftig, das Femur von vorne nach hinten komprimiert und mit einem lamellenartigen dritten Trochanter versehen und nicht viel länger als die ziemlich schlanke, nicht mit der Fibula verwachsene Tibia. Das Calcaneum ist kurz und dick. Der abgeplattete breite Astragalus artiukliert sehr innig mit Fibula und mit Cuboid und sieht dem der Amblypoden sehr ähnlich. Hand und Fuß sind fünfzehig, die Metapodien kurz und dick. Die Endphalangen waren vermutlich kurze breite Hufe. Im Milchgebiß sind noch $\frac{4}{3} D$ vorhanden.

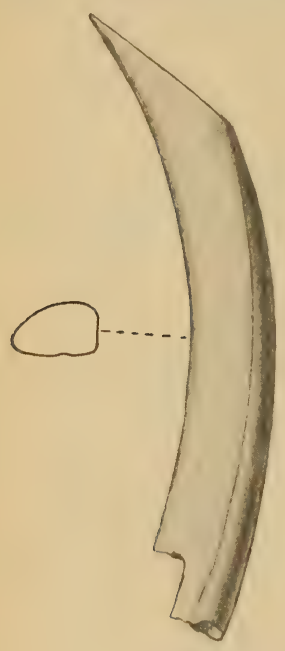

A

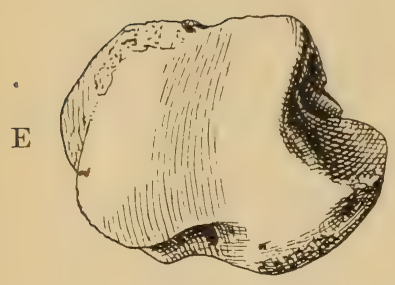

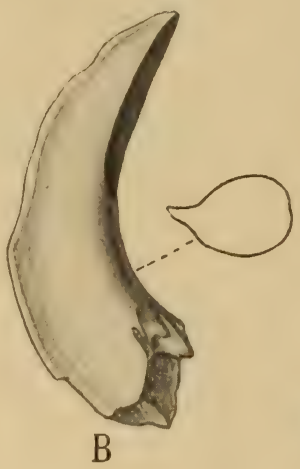
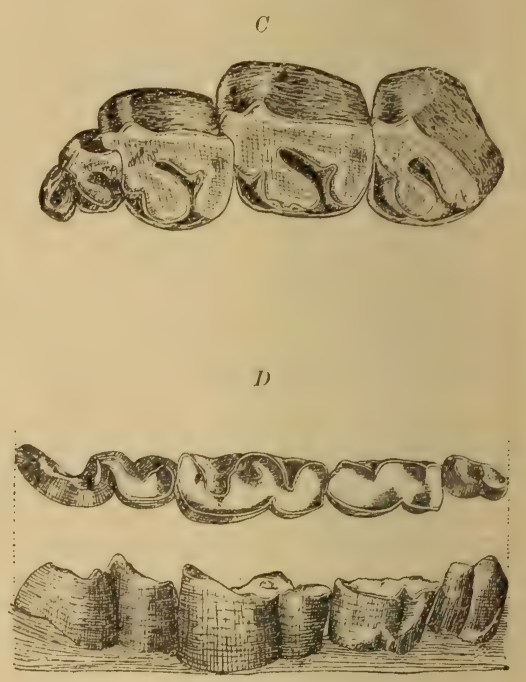

Fjg. 721 .

Astrapotherium magnum Ameghino. Obermiocän. Santa Cruz. $A$ oberer, $B$ unterer Eckzahn, $1 / 4$ nat. Gr., $C$ obere $P^{3}$ bis $M^{3}$, $D$ untere $P_{4}$ bis $\mathrm{M}_{3}, 1 / 3$ nat. Gr. (nach A meghino), $E$ Astragalus, $1 / 3$ nat. Gr

Astrapotherium Burm. (Fig. $721 A$ bis $E$ ), (Mesembriotherium Moreno, Listriotherium, Xylotherium Mercerat). $\frac{2}{1} P$. Nur von dieser Gattung sind auch Schädel und Extremitäten bekannt. Miocän. Patagonien.

Astrapothericulus Ameghino. Miocän.

Parastrapotherium Ameghino. $\frac{3}{2}$ P. Liarthrus Ameghino. Untermiocän. Pyrotheriumschichten.

Astrapo no tus Amegh. Angeblich mit noch vollständigem Gebiß. Oligocän. Proplanodus Ameghino. Eocän. Notostylopsschichten.

\section{Unterordnung. Pyrotheria. ${ }^{1}$ )}

Schädel kurz und nach vorne gezogen. Gebiß reduziert. 1. ? 0. 3. 3. Untere J lang und dick, vorwärts gerichtet. Backenzähne mit je zwei parallelen Jochen. Extremitätenknochen plump. Zehenzahl vermutlich fünf an Hand und Fuß.

1) Ameghino Flor., Mammifères crétacés de l'Argentine. Boletin del Inst. géografico Argentino 1897. - Linea filogenética de los Proboscideos. Anales del Museo Nacional Buenos-Aires 1902. - Gaudry A., Fossiles de Patagonie. Annales de Paléont. Paris 1909. 
Die Pyrotheria sind auf das ältere Tertiär von Patagonien beschränkt und gehören zu den größten aller südamerikanischen Huftiere. Sie treten zuerst in den Notostylopsschichten auf und erlöschen, nachdem sie in den Pyrotherium-Schichten den Höhepunkt ihrer Entwicklung erreicht haben.

Der Schädel kann nur kurz gewesen sein, weil die Backenzähne schon in der Nähe der stoßzahnartigen $J$ beginnen. Die Orbita liegt beim erwachsenen Tier oberhalb $P^{4}$. Im definitiven Gebiß fehlen obere $J . P^{2}$ ist dreieckig und besteht aus zwei Außen- und zwei kleinen Innenhöckern, $P_{3}$ hat einen Vorderhöcker und ein Querjoch. Alle übrigen $P$ den $M$ gleich und wie diese mit zwei parallelen Querjochen und Basalband, das an den oberen $M$ außen und vorne, an den unteren innen und hinten verdickt ist. Unterkiefer mit breitem aufsteigenden Ast und schwachem Coronoidfortsatz.

Scapula mit kräftigem Coracoidfortsatz. Oberarm und Oberschenkel viel länger als Unterarm und Unterschenkel. Humerus von vorne nach hinten stark komprimiert, ohne Foramen entepicondyloideum, aber beiderseits mit weit hinaufragenden Epicondylarcristae und mit starker, außen gelegener Deltoidcrista. Nach Gaudry spricht diese Organisation für grabende Tätigkeit verbunden mit großer Beweglichkeit der Finger. Radius kurz, mit der Ulna verwachsen. Olecranon hoch. Ileum auf lange Strecken am Sacrum befestigt. Femur nur mit erstem Trochanter, aber mit hochstehendem Caput. Tibia und Femur stehen senkrecht übereinander. Fibula oben und unten mit der Tibia verwachsen.Astragalus abgeplattet, mit ebenem Tibialgelenk dicht neben den Gelenkflächen fürNaviculare und Calcaneum. Naviculare ganz unter dem Astragalus gelegen, daher wahrscheinlich vertikale Zehenstellung.

Sowohl die Zähne als auch die Extremitätenknochen sind denen der Proboscidier, na-
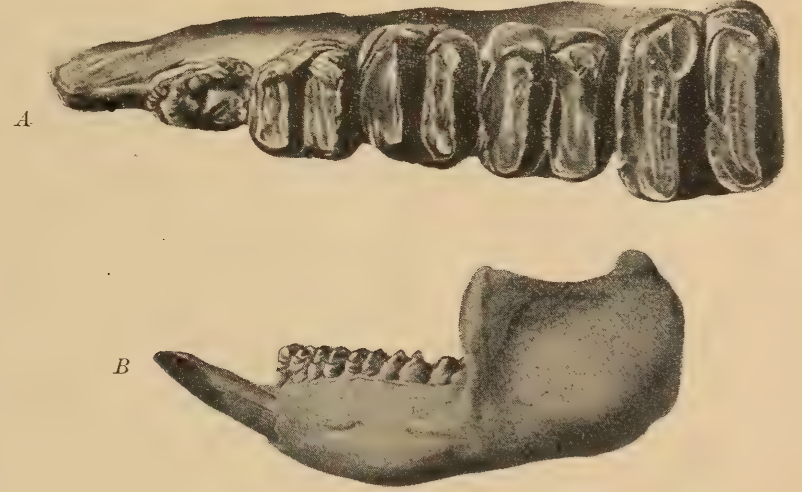

Fig. 722 .

Pyrotherium Romeroi Ameghino. Untermiocän. Patagonien. A obere Backenzähne von unten, $1 / 4$ nat. Gr., $B$ Unterkiefer, $1 / 12$ nat. Gr. (Nach Gaudry.)

\section{mentlich Dinotherium}

ähnlich, weshalb auch Ameghino die Proboscidier von Pyrotherium ableitet. Im Zahnbau besteht auch große Ähnlichkeit mit Diprotodon. Es kann jedoch weder von einer Verwandtschaft mit diesem Marsupialier noch mit den Proboscidiern die Rede sein. Die Herkunft der Pyrotheria ist vorläufig vollständig unbekannt.

Pyrotherium Ameghino. 1. ? 0.3.3. (Fig. 722) Joche der gerundet vierseitigen Backenzähne senkrecht zur Zahnreihe, an den unteren $M$ nach rückwärts, an den oberen nach vorwärts konvex. Untermiocän von Chubut. Patagonien. P. Romeror Ameghino.

Propyrotherium Ameghino. Kleiner. Oligocän. Astraponotusschichten. P. saxaeum Ameghino.

Carolozittelia Ameghino. Unterer $J$ mit langer Wurzel. Obere $M$ kreisrund mit zwei schräg nach rückwärts verlaufenden Jochen. Untere $M$ oval, mit zwei zur Zahnreihe fast senkrechten Querjochen. $M_{3}$ mit drittem Joch. Tapirgröße. Obereocän von Patagonien. Notostylopsschichten.

Ricardowenia und Archaeolophus Ameghino. Ganz problematisch. 


\section{Ordnung. Subungulata.}

Meist große plantigrade oder digitigrade oder dem Wasserleben angepaßte Pflanzenfresser mit ursprünglich vollständigem, brachyodont-bunodontem Gebiß. Ein Incisivenpaar frühzeitig vergrößert, häufig zu Stoßzähnen umgewandelt, die übrigen $J$ und $C$ reduziert oder ganz fehlend oder in ein. ander übergehend. $M$ anfangs praktisch quadrituberkulär, die oberen mindestens ebensolang wie breit. $P$ bald den $M$ ähnlich. Carpusund Tarsus schwach alternierend oder serial, Centrale Carpiöfters vorhanden. Extremitäten mannigfach spezialisiert, bei Wasserbewohnern die hintere vollkommen reduziert. Schädel anfangs lang gestreckt und niedrig, mit breitem Hinterhaupt. Uterus bicornis, Placentazonal, meist deziduat.

Wegen der hochgradigen Spezialisierungen, welche alle Skelettelemente der hierher gestellten Unterordnungen erfahren haben, ist eine präzisere Diagnose nicht möglich. Sie treten sämtlich fast gleichzeitig in Ägypten auf und zwar mit Formen, welche einen niedrigen Schädel mit breitem Hinterhaupt, wohl entwickeltem Scheitelkamm und schmalem Cranium besitzen, und meist Vergrößerung eines Incisivenpaares, verbunden mit Reduktion der übrigen $J$ und $C$ aufweisen. Die $M$ sind bunodont, brachyodont und praktisch quadrituberkulär. Ihre Höcker verbinden sich paarweise zu Jochen, die im Unterkiefer öfters halbmondförmig werden. Die $P$ werden zieḿlich bald $M$-ähnlich und die $J, C$ und $P$ gehen, wenn keine Vergrößerung eines vorderen Incisivenpaares erfolgt, allmählich ineinander über. Auch die Beschaffenheit der Schädelbasis scheint bei allen ziemlich ähnlich gewesen zu sein.

Die Extremitäten zeigen allerdings schon bei den ältesten Vertretern der Subungulata sehr verschiedene Spezialisierung. Die ältesten Hyracoidea haben, abgesehen von dem bunodonten Gebiß, bereits alle wesentlichen Merkmale der lebenden Formen, dagegen nähert sich Moeritherium, der primitivste Proboscidier, den Sirenen nicht bloß im Zahnbau, sondern auch in der Gestalt gewisser Knochen wie Humerus, Scapula und Pelvis, so daß die gemeinsame Stammform beider nicht mehr allzuweit zurückliegen dürfte, und die Embrithopoda zeigen trotz ihrer stark abweichenden Bezahnung im Extremitätenbau so viele Anklänge an die Proboscidier, daß an einer, wenn auch entfernten Verwandtschaft kaum zu zweifeln ist.

Daß die Abzweigung der vier Unterordnungen aus einer gemeinsamen bunodonten Stammform schon lange vor dem Obereocän erfolgt sein muß, sehen wir unter anderem auch daraus, daß bei keiner mehr das primitive Merkmal der Anwesenheit eines Entepicondylarforamen am Humerus vorhanden ist. Verwandtschaftliche Beziehungen zu den Notoungulata dürften vollkommen ausgeschlossen sein, denn das Gebiß dieser südamerikanischen Typen ist anscheinend direkt aus einem sekodonten hervorgegangen, während dem der Subungulata unzweifelhaft ein bunodontes zugrunde liegt, weshalb wir vielleicht doch eine Anknüpfung an ein Condylarthrenstadium erwarten dürfen. 
1. Unterordnung. Embrithopoda. Andrews.

Riesige Pflanzenfresser mit lophodonten $M$. Vorderextremität ähnlich der der Proboscidier, Hinterextremität Amblypoden-ähnlich. Obereocän und Oligocän von Ägypten.

Familie. Arsinoitheriidae. Andrews.

Riesige Huftiere mit einem Paar großer knöcherner Hornzapfen auf den Nasen- und zwei schwachen Hörnern auf den Stirnbeinen. Kurze, hohe Schnauze mit vorne abgeschlossener Nasenöffnung. Hinterhaupt nach vorne geneigt, mit dickem Supraoccipitalwulst. Orbita hinten offen. Gebiß vollständig. $\frac{3.1 .4 .3 .}{3.1 .4 .3 .}$ $J, C$ und $P$ allmählich ineinander übergehend und dicht aneinanderschließend.

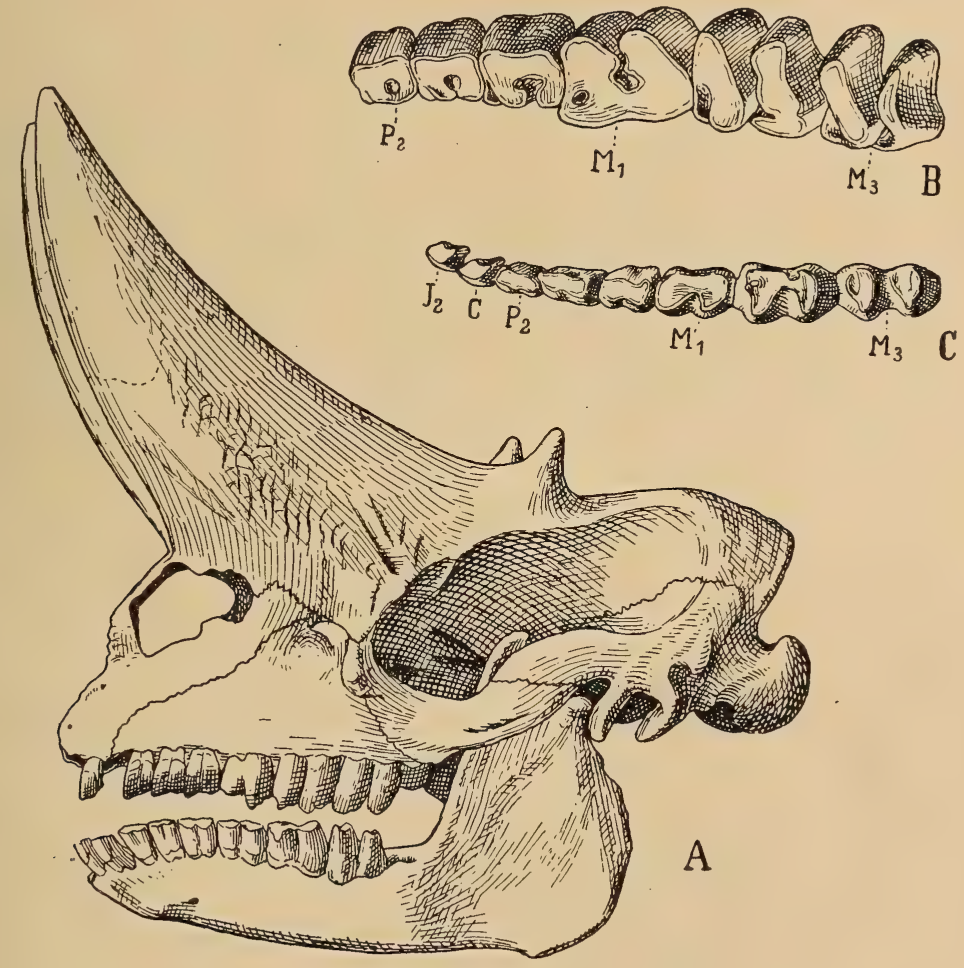

Fig. 723 .

Arsinoitherium Zitteli Beadnell. Oligocän. Fayum. Ägypten. A Schädel 1/9 nat. Gr. $B$ obere, $C$ untere Zahnreihe $2 / 9$ nat. Gr. (nach Andrews.)

$P$ einfacher als die $M$. Obere und untere $M$ aus je zwei $V$-artigen Kämmen gebildet, deren vorderer Schenkel verkümmert ist. Humerus und Femur lang und massiv. Tibia und Fibula kurz, Ulna viel dicker als Radius. Astragalus flach mit schwach gewölbter Trochlea und mit Gelenkfläche für das Cuboid. Vorderund Hinterfuß sehr kurz, fünfzehig.

Die Arsinoitheria sind auf das Oligocän von Ägypten beschränkt. Der Schädel hat ungefähr die Größe und auch in seiner Form eine gewisse Ähnlichkeit mit dem von Rhinoceros, allein die Nasenöffnung wird hier im Alter vorne durch eine Knochenspange abgeschlossen. Die 
hohen, auf den Nasenbeinen sitzenden vorderen Hornzapfen erinnern etwas an jene der Titanotheriiden. Der aufsteigende Ast des Unterkiefers ist sehr hoch und schmal. Die Zähne stehen dicht aneinander und gehen vom vordersten meißelförmigen $J$ bis zum $P_{4}$ ganz allmählich ineinander über. Die oberen $P$ haben eine gerade Außenwand und ein schräges Querjoch, die unteren bestehen aus zwei stark zusammengedrückten Halbmonden. Sie sind insgesamt sehr kurz und weichen hierin stark von den $M$ ab. Die $M$ bestehen aus je zwei $\bigvee$-förmigen Halbmonden, deren vorderer Schenkel bis auf eine scharfe Kante verkümmert, während der hintere ein breites hohes, etwas schräg nach rückwärts gerichtetes Joch bildet. Bei vorgeschrittener Abkauung kommt es scheinbar zur Bildung einer Innenwand. Die unteren $M$ erinnern etwas an jene von Coryphodon, die oberen an die von Uintatherium. Von den Milchzähnen gleichen die beiden letzten vollkommen den $M$.

Die Extremitätenknochen sind ungemein plump, die Scapula ist breiter als hoch, der Humerus besitzt eine mächtige Deltoidcrista, aber kein Entepicondylarforamen. Die Ulna ist viel dicker als der Radius und mit einem riesigen Olecranon versehen. Sie ruht halb auf dem Lunatum. Das Becken zeichnet sich durch die ganz ungewöhnliche Vergrößerung des Ilium aus. Das von vorne nach hinten komprimierte Femur hat nur einen, den großen Trochanter. Die Knochen der Vorderextremität lassen sich am ehesten mit jenen von Uintatherium, die der Hinterextremität mit jenen von Elephas vergleichen. Mit Elephas stimmt auch die Form und Anordnung der Carpalia, Tarsalia und Metapodien fast vollkommen überein, nur der Astragalus unterscheidet sich durch die Anwesenheit einer Gelenkfläche für das Cuboid. Mit den Proboscidiern besteht jedenfalls eine Verwandtschaft.

Die einzige bekannte Gattung ist Arsinoitherium Andrews (Fig. 723). Oligocän von Ägypten. A. Zitteli Beadnell.

\section{Unterordnung. Hyracoidea. Klippschliefer. $\left.{ }^{1}\right)$}

$\frac{3-1.1-0.4 .3 .}{3-2.1-0.4 .3 .} . J^{1}$ lang, vertikal gestellt, nagezahnähnlich, untere $J_{1}$ und $J_{2}$ meißelförmig. $\boldsymbol{P}$ mehr oder weniger $\mathbf{M}$-ähnlich. $\mathbf{M}$ bunodont bis lophodont, vierwurzelig. Jochbogenunterrand mit besonderer Gelenkflüche für den Unter. kiefer. Aufsteigender Unterkieferast stark verbreitert, mit schwachem Coronoidfortsatz und einem Foramen hinter $M_{3}$. Humerus ohne Entepicondylarforamen. Extremitäten plantigrad oder semidigitigrad. Vorderfuß vierzehig, Hinterfuß drei zehig. Carpus serial mit freiem Centrale. Astragalus distal abgestutzt, mit aus gefurchter Trochlea und tiefer, grubiger Gelenkfäche für den Malleolus tibiae.

Die Hyracoidea waren bis vor kurzem nur durch die kleine Formen enthaltende Gattung Hyrax repräsentiert, welche ursprünglich wegen der Beschaffenheit ihrer $J$ und der äußeren Schädelform zu den Nagern gerechnet wurde. Cuvier wies auf die Ähnlichkeit der Zähne und der Extremitäten mit jenen von Rhinozeros hin und Co pe errichtete für Hyrax wegen der serialen Anordnung der Carpalia die Ordnung der Taxeopoda.

Die Hyracoidea zerfallen in die Familien der Hyracidae und der Saghatheriidae.

1) Adloff $P$., Zahnsystem von Hyrax. Zeitschr. f. Morph. und Anthrop. 1902. - Andrews C. W., Catalogue 1906. - Geolog. Magazine 1908. - Brandt J. $F$., Untersuch. über die Klippschliefer (Hyrax). Mem. Acad. impér. St. Petersbourg 1869. 6 sér. XIV. - Major, Forsyth E. J., Pliohyrax graecus from Samos. Geological Magazine 1899. - Schlosser M., Säugetiere aus dem Oligocän von Ägypten. Beitr. Paläont. Öst.-Ungarns und des Orients. 1911. 


\section{Familie. Hyracidae.}

1.0.4.3. $P$ den $M$ gleich, wie diese brachyodont und lophodont. Obere $M$ mit Wförmiger Außenwand und zwei schrägen Querjochen. Untere $M$ aus zwei Halbmonden bestehend. Schädeldach eben, Schnauze kurz.

Die Hyraciden bewohnen das südliche und östliche Afrika, Arabien und Syrien. Fossile Arten sind nicht bekannt. Von den Saghatheriiden unterscheiden sie sich, abgesehen von ihrer Kleinheit, durch das ebene Schädeldach, die weit vorne liegenden, hinten meist geschlossenen Orbita, durch die Anwesenheit von zwei Temporalcristae an Stelle einer Sagittalcrista und durch die Verkürzung der Schnauze, womit Verlust $\operatorname{der} C$, von $J^{2}$ und $J^{3}$ und von $J_{3}$ verbunden war. Das Milchgebiß enthält noch 2.1.4. heit von $J_{3}, J^{2}$ und $\operatorname{der} C$ angedeutet wird. Die Extremitäten sind plantigrad, die Endphalangen distal abgeplattet und

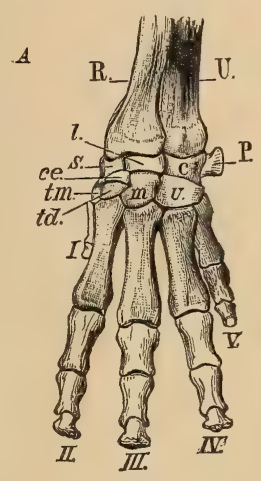

Fig. 724.

Procavia (Dendrohyrax) arborea Smith sp. Cap der guten Hoffnung. $A$ Vorderfuß, $B$ Hinterfub (nat. Gr.).

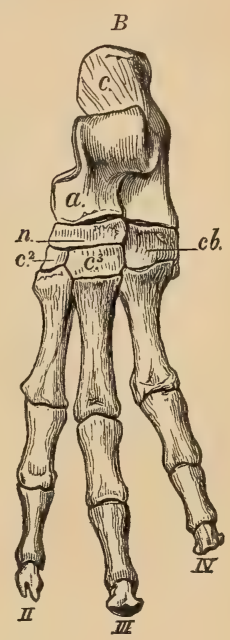
mit Nägeln versehen.

Die Backenzähne der Gattung Procavia Storr (Hyrax Herm., Heterohyrax und Dendrohyrax Gray) (Fig. 724) erinnern teils an Rhinoceros, teils an Paloplotherium oder Anchilophus.

\section{Familie. Saghatheriidae. Andrews.}

3.1.4.3. $J^{1}$ groß, dreikantig, untere $J_{1}$ und $J_{2}$ meißelartig, mit zwei Einkerbungen am Oberrand. Oberer $C P$-artig, unterer $C$ und $J_{3}$, sowie $J^{2}$ und $J^{3}$ knopfförmig oder Partig und meist durch Lücken voneinander und von den vordersten $J$ und den $C$ getrennt. $P$ in der Regel einfacher als die $M$, jedoch die oberen meist vierhöckerig oder mit einem vollständigen vorderen und einem kurzen hinteren Querjoch. Obere $\boldsymbol{M}$ mit $\mathbf{W}$ förmiger, Parastyl und Mesostyl tragender Außenwand und zwei schrägen, aus je einem kleinen Zwischenhöcker und einem niedrigen Innenhöcker gebildeten Querjochen. Untere $M$ mit zwei mehr oder weniger deutlichen äußeren Halbmonden und zwei Innenhöckern. $M_{3}$ stets mit drittem Halbmond. Schnauze meist lang und schmal, Cranium gewölbt, mit Sagittalcrista verstehen. Orbita weit hinten gelegen, unvollständig geschlossen. Unterkiefer hoch, mit weitem Kanal unterhalb der Zahnreihe, der unter $M_{3}$ ausmündet. Seitenzehen kürzer und dünner als die Mittelzehe. Carpus serial, hoch und schmal. Distales Astragalusgelenk schwach konvex.

Die Saghatheriiden erscheinen zuerst im Oligocän von Ägypten und entfalten sofort einen ungewöhnlichen Formenreichtum. Ihre Körpergröße schwankt $z$ wischen der von Fuchs und der von Tapir. Im Zahnbau bestehen alle möglichen Übergänge zwischen bunodonten, schweinsartigen - Geniohyus - und lophodonten, Paloplotherium-artigen M-Saghatherium. Die oberen $M$ von Geniohyus und Bunohyrax haben Ahnlichkeit mit jenen von Anthracotheriiden, die von Megalohyrax mit jenen von Palaeotherium. In Ägypten erlöschen die Saghatheriiden sehr bald, nur die Gattung Saghatherium hat in der unterpliocänen Gattung Pliohyrax einen Nachkommen.

Geniohyus Andrews. $P$ einfach, untere $M$ Sus-artig, obere Brachyodusähnlich. G. mirus Andr. 
Bunohyrax Schlosser. P kompliziert, obere gerundet dreieckig. Untere $M$ mit echten Halbmonden.

Mixohyrax Schlosser (Fig. 725). Obere $P$ viereckig. $M$ lophodont. M. niloticus. Schl.

Pachyhyrax Schlosser. Sporne an den Jochen der oberen $\boldsymbol{M}$.

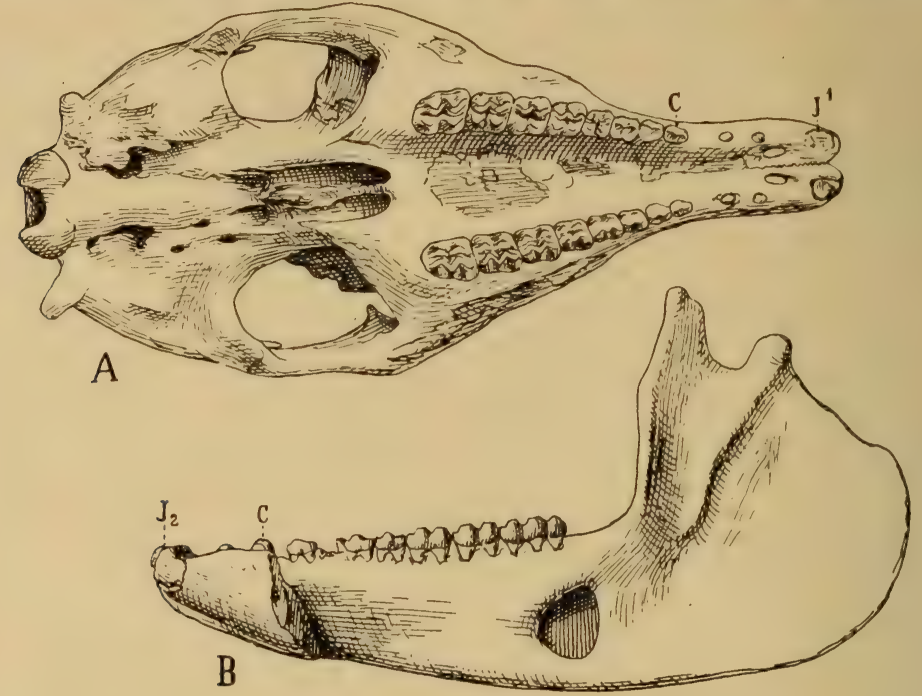

Fig. 725 .

Mixohyrax niloticus Schlosser. Oligocän. Fayum. Agypten. $B$ Schädel von unten, $B$ Unterkiefer von innen, $1 / 4$ nat. Gr.

Saghatherium Andrews, höchstens Schafgröße. Obere $P$ viel einfacher als $M$, obere $M$ lophodont, untere lophoselenodont. Zahnlücke sehr kurz. S. antiquum Andr.

Megalohyrax Andrews. Größter aller Saghatheriiden. $P$ fast sämtlich gleich M. M. eocaznus Andr.

Pliohyrax Osborn (Leptodon Gaudry). Unterkiefer ohne Zahnlücke. $J_{3}$, beide $C$ sowie $J^{2}$ und $J^{3} P$ ähnlich. Unterpliocän von Pikermi und Samos. P. graecus Gaudry sp.

\section{Unterordnung. Proboscidea. $\left.{ }^{1}\right)$ R üsseltiere.}

Große fünfzehige, meist hochbeinige, semidigitigrade Pflanzenfresser mit Rüssel. Schädel groß, meist mit grobzelligen Luftkammern in der Diploë.

1) Adams A. Leith, Fossil British Elephants. Palaeont. Soc. 1877. - Andrews $E$. W., Cataloge 1906 und Evolution of the Proboscidea. Philos. Trans. Ser. B 1903 - Bach F., Mastodon aus Steiermark. Beitr. z. Paläont. Ost.-Ungarns. Bd. XXIII 1910. - Cope E. D., The Proboscidea. Amer. Naturalist 1889. - Depéret Ch., Archiv. du Musée de Lyon. t. IV 1887 p. 190. - Falconer and Cautley, Fauna antiqua sivalensis 1846 und Palaeont. Mem. ed. by Murchison. 1863. Vol. I pag. 43. Kaup J. J., Ossements foss. de mammifères. 1832-35 Cah. I. IV und Akten der Urwelt. 1841 Heft IV und Beitr. z. Kenntnis urweltl. Säuget. $1857 \mathrm{Heft}$ III. Lartet Ed., Bull. Soc. géol. de Fr. 1859. - Lortet et Chantre, Arch. Mus. de Lyon. t. I 1872. t. II 1879. - Lydekker R., Catal. British Mus. t. V. 1886. - Meyer H. v., Mastodon. Palaeontogr. 1867 Bd. XVII. - Pohlig. H., Nova Acta Acad. Carol. Leopold. 1888-91. - Sismonda E., Osteographia di Mastodonte. Mem. Acad. Torino. XII. 1851. - Vacek M., Österr. Mastodonten. Abh. k. k. geol. Reichsanst. 1877. Bd. VII. - Weithofer $K$. A., Proboscidier des Arnotales. Beitr. Paläont. Óst.Ung. Bd. VIII 1890. 
Anfangs ein paar obere und untere $J$ vergrößert, später nur $\frac{1}{1-0} J$ vorhanden, $C$ nur bei der primitivsten Gattung anwesend. Backenzähne erst bunolophodont, . dann lophodont und zuletzt aus vielen schmalen Querlamellen bestehend. Femur fast immer ohne dritten Trochanter. Carpalia serial angeordnet. Astragalus breit mit schwach gewölbter Trochlea. Calcaneum mit Fibula artikulierend.

Die Herkunft der Proboscidier war bisher in völliges Dunkel gehüllt, doch vermutete schon Blainville verwandtschaftliche Beziehungen $\mathrm{zu}$ den Sirenia, was jetzt durch die Funde im Oligocän von Ägypten bestätigt wurde, denn die ältesten Formen haben unter anderem auch die hohe Zahnzahl und den Bau des Schädels und der Backenzähne mit den Sirenen gemein.

Das Gebiß der Proboscidier enthält außer bei Moeritherium nur Incisiven und Backenzähne und selbst hier ist schon ein Paar $J$ vergrößert. Bald vierschwinden die übrigen $J$ vollständig, die bleibenden werden $\mathrm{zu}$ riesigen gekrümmten Stoßzähnen, auch das bei den älteren Mastodon-Arten noch vorhandene untere Incisivenpaar geht verloren. Die Stoßzähne bestehen aus dichtem elastischem Elfenbein, welches im Querschnitt bogenförmige, vom Zentrum nach der Peripherie gerichtete Linien zeigt, die in zweierlei Richtung verlaufen und sich $W$-förmig, wie die Guillochierung eines Uhrgehäuses schneiden. Namentlich der hintere Teil der Stoßzähne wird häufig mit einer dünnen Schmelzschicht überzogen. Die Zähne liegen in tiefen Alveolen der Zwischenkiefer und haben eine große offene Pulpa.

Die Backenzähne der lebenden Elefanten unterscheiden sich durch ihre gewaltige Größe, durch die hohe Zahl der stark komprimierten Querjoche und durch die starke Entwicklung von Zement in den Quertälern von allen Huftierzähnen, stehen jedoch durch Übergänge mit den bunolophodonten Zähnen von Moeritherium in Verbindung, welche aus je zwei Paar jochartig verbundener Höcker und einem kleinen Talon gebildet sind. Bei Palaeomastodon nimmt die Zahl der Joche zu, die Zahl der Unterkieferzähne hingegen um einen ab. Bei Mastodon erfolgt immer weitergehende Reduktion der gleichzeitig fungierenden Zähne, wofür jedoch die Zahl der Joche allmählich größer wird. Noch bedeutender ist die Zahl der Querjoche bei Stegodon - 6 bis 12 -, dessen Quertäler auch schon mit Zement ausgefüllt sind. Bei Elephas steigt die Jochzahl bei jedem neuauftretenden Zahn und beträgt zuletzt bis zu 27. Die von Moeritherium bis Stegodon noch brachyodonten Zähne werden bei Elephas hypselodont. Die Joche werden zu Platten, die mittels Zement aneinander gekittet sind, das auch anfangs die Oberseite der Krone überzieht. Durch die Abkauung entsteht aus diesen selasmodonten « Zähnen eine ebene Fläche, in welcher breitere Querstreifen von Zement mit dünnen Lamellen von Schmelz und Dentin miteinander wechseln und so eine zur Zerkleinerung der pflanzlichen Nahrung trefflich geeignete. Reibfläche erzeugen. Bei Dinotherium haben sich je zwei benachbarte Höcker in schmale, scharfe Joche umgewandelt, ähnlich wie bei Tapir. Auch unter den Mastodon-Arten gibt es solche »tapiroide « Formen.

Die Zahl der $M$ beträgt je drei in einem Kiefer. Vor ihnen stehen ursprünglich drei $P$. Dann geht die Zahl der $P$ auf zwei zurück. Sie sind viel einfacher gebaut als die $M$ und ersetzen die drei $D$. Bei Elephas, Stegodon und den meisten Mastodon fehlen P. Alle Backenzähne stehen anfangs in horizontalen Reihen und die $P$ treten von unten an die Stelle der $D$. Von Mastodon an sind nie mehr als drei Zähne gleichzeitig in Funktion, später nur zwei und zuletzt nur einer. Sie entwickeln sich dann in großen Zeitintervallen und rücken, indem sie einen Bogen beschreiben, nach vorne, wobei sie den vorhergehenden Zahn allmählich ausschieben. Dieser Zahnwechsel dauert so lange das Tier lebt, und die Backenzähne werden bis auf unscheinbare Kronenreste abgerieben. Die Abkauung beginnt am vordersten Teil des Zahnes. 
Der Schädel (Fig. 726) erfährt von Moeritherium bis Elephas folgende Veränderungen. Die allmähliche Entwicklung des Rüssels und der Stoßzähne verursacht Verkürzung der Zwischenkiefer und Aufwärtsrücken der Nasenlöcher und diese Vorgänge wieder Wölbung des Schädels, die Bildung von Luftzellen und Verbreiterung des Hinterhauptes. Die Oberkiefer werden höher und die Jochbogen schwächer. Dagegen verlängert sich zuerst der

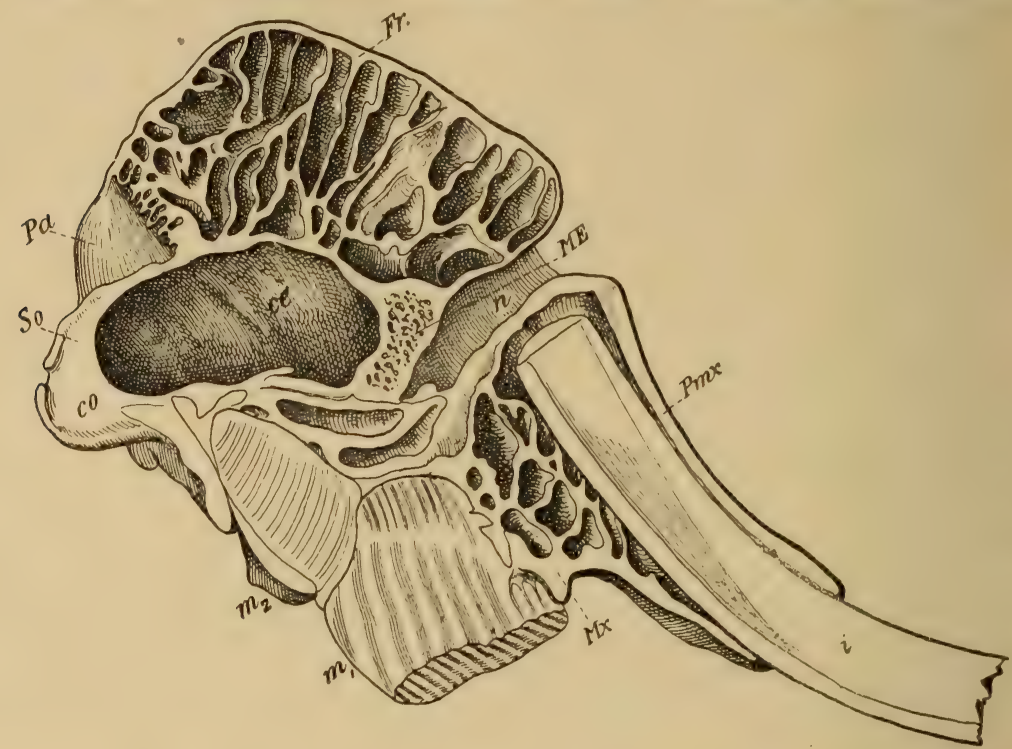

Fig. 726.

Schädel von Elephas indicus (vertikaler Längsschnitt). So Supraoccipitale, co Hinterhauptscondylus, $P a$ Scheitelbein, $F r$ Stirnbein, $M x$ Oberkiefer, $P m x$ Zwischenkiefer, $M E$ Mesethmoideum, ce Hirnhöhle, $n$ Nasenhöhle, $i$ Schneidezahn, $m^{1} m^{2}$ erster und zweiter Backenzahn.

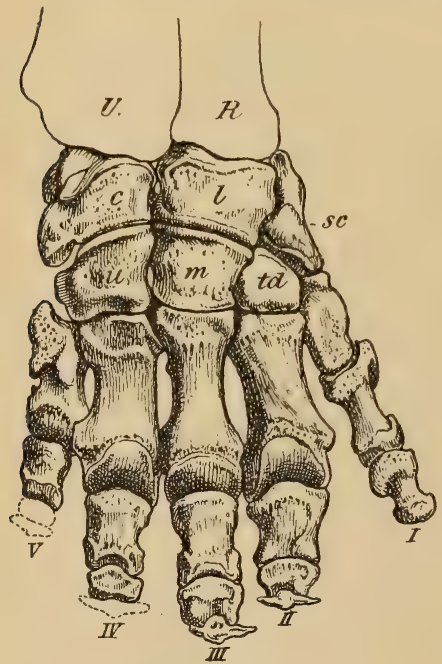

Fig. $727 \mathrm{~A}$.

Vorderfuß von Elephas indicus Lin. ( $U$ Ulna, $R$ Radius, sc Scaphoideum, $i$ Lunare, $c$ Cuneiforme [Triquetrum], $u$ Unciforme, $m$ Magnum, $t d$ Trapezoid).

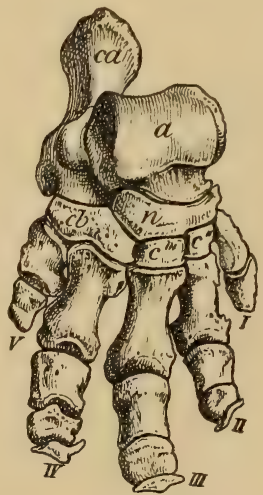

Fig. $727 B$.

Rechter Hinterfuß von Elephas indicus. (ca Calcaneum, a Astragalus, $n$ Naviculare $c b$ Cuboideum, $c I I I$, $c I I$ Cuneiforme tertium und secundum, $I-V$ erste bis fünfte Zehe.
Symphysenteil der Unterkiefer, um sich dann später nach Verlust der unteren Stoßzähne wieder zu verkürzen. Der aufsteigende Ast wird höher, aber dafür schwächer und das Kiefergelenk rückt immer höher hinauf. Die Extremitäten der Proboscidier (Fig. 727) sind hoch und stämmig, die langen Knochen ohne Markhöhlen. Ein Schlüsselbein fehlt. Die Ulna ist namentlich distal viel dicker als der Radius. Die Carpalia sind mehr oder weniger serial angeordnet. 
Der Elefant besitzt in der Jugend ein Centrale. Die seitlichen Metacarpalia (I und V) sind kürzer und schwächer als die mittleren. Der ganze Fuß steckt in einer gemeinsamen Hülle, aus welcher die einzelnen, von hufartigen Nägeln bedeckten Zehen nur wenig vorragen. Am Femur fehlt meist ein dritter Trochanter. Tibia und Fibula sind getrennt, die letztere distal verdickt. Sie ruht auf Astragalus und Calcaneum. Der Astragalus hat eine mäßig gewölbte Trochlea und artikuliert distal nur mit dem Naviculare.

Die Proboscidier sind heutzutage auf die tropischen Teile von Afrika und Asien beschränkt. Sie beginnen im Eocän von Ägypten, verbreiten sich im Miocän über die nördliche Halbkugel und erreichen erst im Pleistocän auch Südamerika. Als Leitfossilien sind ihre Backenzähne wegen der vielfachen Übergänge zwischen den zeitlich aufeinander folgenden Arten und wegen der bedeutenden Größenschwankungen bei ein und derselben Art nur mit Vorsicht verwendkar.

\section{Familie. Moeritheriidae.}

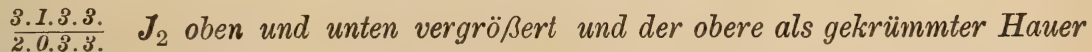
entwickelt. $J_{1}^{1}$ und $J^{3}$ sowie $C$ klein. $P$ einfacher als die $M$, wie diese brachyodont. Obere $P$ trituberkulär, untere $P$ aus zwei vorderen und einem hinteren Höcker bestehend. $M$ mit je zwei Höckerpaaren und einem Talon. Vorderpartie der unteren $P$ und $M$ höher als die hintere. Schädel niedrig, fast eben, mit langem schmalem Cranium und massiven, vorspringenden Jochbogen.
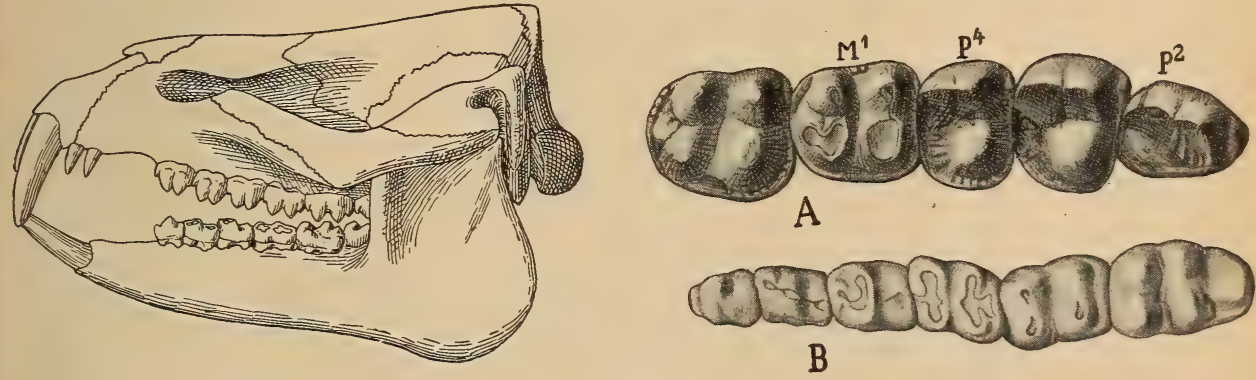

Fig. 728.

Moeritherium Lyonsi Andrews. Obereocän. Fayum. Ägypten. Schädel. 1/9 nat. Gr. B untere Backenzähne, 1/3 nat. Gr. (nach Andrews), A Moeritherium. Oligocän. Fayum. Obere Backenzähne. $(1 / 2$ nat. Gr.)

Die Moeritheriiden treten zuerst im Obereocän von Ägypten auf und erlöschen daselbst im Oligocän. Sie vermitteln im Schädelbau und in der Zahl und Beschaffenheit der Zähne den Übergang von den Sirenen zu den Proboscidiern und zeigen aufs deutlichste, daß beide einen gemeinsamen Ursprung besitzen.

Moeritherium Andrews (Fig. 728). Untere $J$ meißelförmig, nach vorne gerichtet, obere $J$ und $C$ fast vertikal gestellt. $J_{2}$ in beiden Kiefern vergrößert, der obere als gekrümmter, massiver Hauer entwickelt. Die übrigen $J$ und $C$ relativ klein. $J$ und $C$ allseitig mit Schmelz bedeckt. Obere $P$ mit zwei Außen- und einem Innenhöcker. $P^{2}$ dreieckig. $M$ in beiden Kiefern aus je zwei Außen- und Innenhöckern bestehend, die sich paarweise $\mathrm{zu}$ Querjochen verbinden. Die unteren $M$ mit kräftigem, die oberen mit schwachem Talon. Untere $P$ mit unpaarem Vorderhöcker, vordere Hälfte höher als die hintere. Nasenöffnung weit vorne stehend, mit kurzem Rüssel versehen, Schädeldach fast vollkommen eben, Orbita weit vorne gelegen. Nasenbeine kurz. Stirn- und Scheitelbeine lang, Cranium schmal und niedrig, mit Sagittalcrista versehen. Hinterhaupt vertikal, Jochbogen 
vorne und hinten massiv, weit vorspringend und hinten nahe am Occiput endend. Obereocän M. Lyonsi Andr. Oligocän M. Andrewsi Schlosser.

Die Extremitätenknochen sind schlank. Das Femur hat einen dritten Trochanter und der Astragalus einen relativ langen Hals. Das Sacrum verjüngt sich unmerklich nach hinten, was auf einen langen Schwanz schließen läßt, und das Ilium zeichnet sich durch seine Länge und Schmalheit aus. Es gleicht fast dem von Creodontiern.

Moeritherium hatte etwa die Größe von Tapir.

\section{Familie. Barytheriidae. Andrews.}

2.?.3.3. Unterer $J$ gro $\beta$, vorwärts geneigt, durch eine lange Lücke von $P_{2}$ getrennt. $P^{2}$ dreieckig, $P^{3}$ und $P_{4}$ mit einem dicken Querjoch, die unteren $P$ gleich den $M$ aus zwei fast geraden Querjochen bestehend. $M_{3}$ mit einem dritten Joch. Untere $M$ vierwurzelig. Joche der oberen $M$ nach hinten etwas konkav. Unterkiefer massiv, mit breitem aufsteigendem Ast.

Barytherium Andrews. Die systematische Stellung dieser nur unvollständig bekannten Gattung ist ziemlich unsicher. Ihr Zahn- und Kieferbau - massiv, mit breitem aufsteigendem Ast - und die gewaltige Körpergröße erinnert an Dinotherium. Der distal stark verbreiterte Humerus ist mit einer außerordentlich starken Deltoidcrista versehen, und der stämmige Radius artikuliert gleichmäßig mit Lunatum und Scaphoid. Obereocän von Ägypten. B. grave, Andrews.

\section{Familie. Dinotheriidae.}

$\frac{0.0 .2 .3}{1.0 .2 .3}$. Unterkiefersymphyse nach unten gebogen, mit einem Paar rïckwärts gekrümmter Stoßzähne. $M_{1}$ in beiden Kiefern mit drei, die übrigen mit zwei einfachen, zugeschärften, durch breite Täler getrennten Querjochen. Ohne Zement. Alle Zähne in einer Ebene, Zahnwechsel normal.
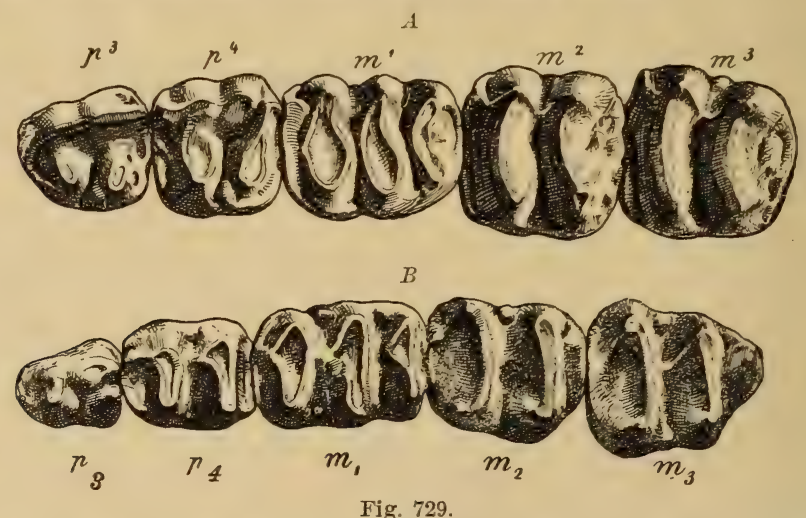

Dinotherium bavaricum Meyer. Ob. Miocän. Breitenbronn b. Augsburg. A Backenzähne des Oberkiefers, $B$ Backenzähne des Unterkiefers. ca. 1/4 nat. Gr.

Dinotherium Kaup (Fig. 729) hat einen nur mäßig hohen Schädel mit langen Zwischenkiefern und breiten Stirnbeinen. Unterkiefersymphyse vorn mit breiter Furche, stark abwärts gekrümmt. Die gewaltigen, nach unten gerichteten und nach hinten gebogenen $J$ sind in tiefe Alveolen eingefügt. $M_{1}$ in beiden Kiefern mit drei, die übrigen mit zwei Querjochen, die an den oberen nach vorne konvex, an den unteren nach vorne etwas konkav verlaufen. Obere $M$ fast quadratisch, dreiwurzelig, untere länger als breit. $M_{3}$ mit starkem Talon. Skelett ähnlich dem von Mastodon. Dinotherium übertrifft an Größe die meisten Elefantenarten. 
Im Obermiocän von Europa D. bavaricum Meyer (levius Jourdan). Im Unterpliocän von Europa und auf Samos (?) D. giganteum Kaup. In Ostindien $D$. sindiense Lydekker.

\section{Familie. Elephantidae.}

Obere $J$ als große gerade oder gekrümmte Stoßzähne ausgebildet. Untere $J$ schwächer und gerade, meist fehlend. $M$ groß, aus mehr als zwei Querjochen zusammengesetzt. Quertäler öfters mit Zement ausgefüllt. $P$ einfacher als $M$, häufig fehlend. Zahnwechsel anfangs normal, später durch Ausschieben der vorderen Zähne von hinten erfolgend. Oligocän bis Gegenwart.

Palaeomastodon (Phiomia) Andrews (Fig. 730) $\frac{\text { 3.3.0.1 }}{1.0 .2 .3}$. Backenzähne in gerader Reihe, gleichzeitig funktionierend. Obere $J$ relativ kurz, seitlich komprimiert, säbelförmig. Untere $J$ als lange Schaufeln entwickelt. Alle $J$ auf der Außenseite mit Schmelz versehen und mit persistierender Pulpa. $P^{2}$ und $P_{3}$ einhöckerig mit Talon, $P^{3}$ mit großem Außen- und kleinem Innenhöcker. $P^{4}$ oben und unten mit vier paarig angeordneten Höckern. $M$ wie bei Mastodon, mit je drei aus zwei Höckern bestehenden Querjochen. $M_{3}$ meist mit Talon. Unterkiefersymphyse verlängert. Nasenöffnung hoch und weit zurückgeschoben. Schädel ziemlich hoch und kurz, Scheitelbeine gewölbt, mit Sagittalcrista versehen. Oligocän von Ägypten. P. Beadnelli Andr. besaß einen mäßig
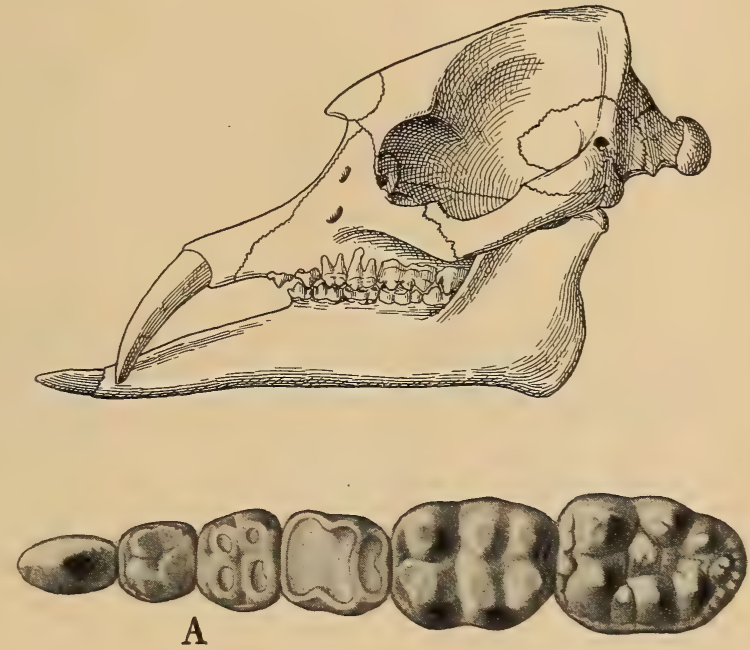

A

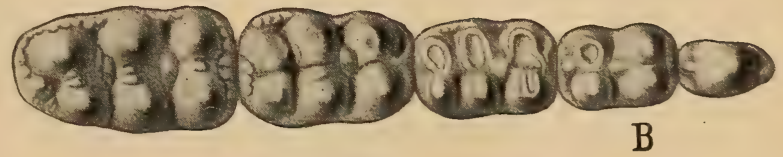

Fig. 730 . langen Rüssel.

Mastodon Cuvier. (Fig. 731-733.) Schädel ähnlich dem von Elephas, jedoch Stirne bei den älteren Arten weniger hoch ansteigend, Oberkiefer niedriger, Unterkiefersymphyse anfangs verlängert. Skelett plumper. $\frac{1}{1-0.0 .3-0.3}$. Obere $J$ meist gerade, seltener gebogen, bei den älteren Arten außen mit breitem Schmelzband. Untere $J$ kürzer, bei den späteren Arten fehlend. Backenzähne oblong, mit drei, vier, seltener fünf bis sechs hohen, entweder einfachen (Zygolophodon, tapiroid) oder in zitzenförmige Höcker aufgelösten Querjochen (Bunolophodon), die durch tiefe, zuweilen mit etwas Zement versehene Täler getrennt sind, in welchen häufig Sekundärhöcker auftreten. Jedes Joch und somit auch die ganze Krone wird durch einen medianen 
Spalt in zwei Hälften zerlegt. Die Krone der oberen Zähne ist innen stärker abgekaut als außen. Die etwas schmäleren unteren Zähne verhalten sich umgekehrt. Auch sind ihre Wurzeln einfach, die der oberen hingegen geteilt. Der letzte $M$ hat häufig ein Joch mehr als der vorletzte.

Das Milchgebiß besteht aus $\frac{1.0 .3}{1-0.0 .3}$. Die zwei hinteren $D$ werden bei den älteren Arten von unten her durch zwei $P$ ersetzt, bei den späteren werden die $D$ wie bei Elephas von vorne nach hinten ausgeschoben. Nach der Zahl der Joche unterscheidet man zwei Untergattungen: Trilop hodon mit $D \frac{1-2.2 .3}{1-2.2 .3}\left(P \frac{2.2}{2.2}\right), M_{3.3 .4}^{3.3 .4}$ und Tetralophodon mit $D \frac{2.3 .4}{2.3 .4}\left(P \frac{22}{2.2}\right) M_{4.4 .5}^{4.4 .5}$ Jedoch kann die Zahl der Joche individuell um eins zunehmen.

Im Mittel- und Obermiocän von Europa M. (Tril.) angustidens Cuv. (auch in Nordafrika) und turicensis Schinz (tapiroid) sehr häufig, der erstere in Ostindien durch $M$. palaeindicus vertreten. Im Unterpliocän von Europa M. (Tetral.) longirostris Kaup, von Pikermi, Samos, Persien M. Pentelici Gaudry (tapiroid) - in Ostindien. $M$. (Tril.) Falconeri Lyd., Pandionis Falc. (auch in China), M. (Tetral.) sivalensis Cautl., perimensis Lyd. (auch in China),

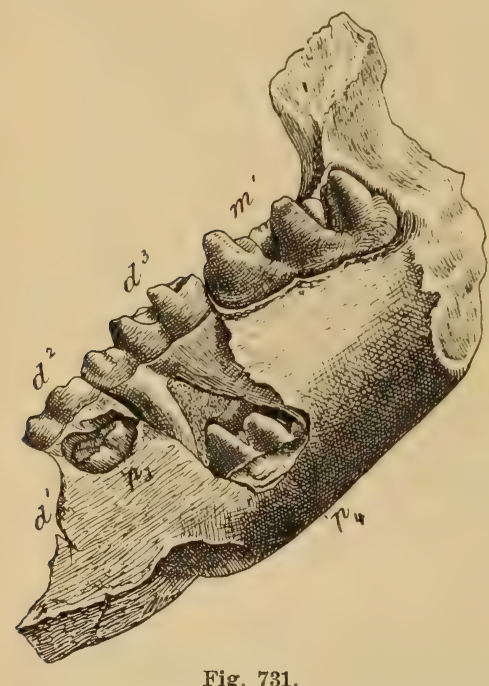

Fig. 731.

Mastodon angustidens Cuv. Miocän. Simorre. Gers. Rechter Unterkieferast von innen im Zahnwechsel, $d^{1} d^{2} d^{3}$ Milchbackenzähne, $p_{3}$ $p_{4}$ Ersatzprämolaren, $m^{1}$ erster Molar. $1 / 4$ nat. Gr. (Nach Lartet.)
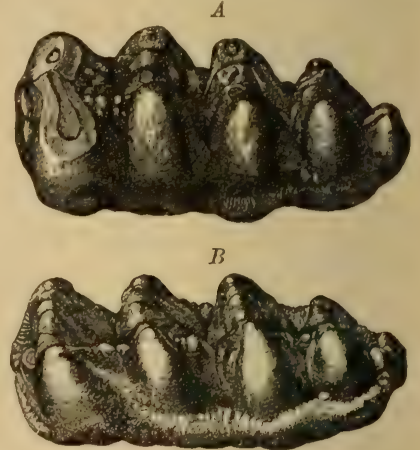

Fig. 732 .

A Mastodon angustidens Cuv. Miocän. II-enDodon. Letzter unterer Backenzahn. $1 / 4$ nat. Gr. $B$ Mastodon turicensis Cuv. Miocän. Simorre. Gers. Letzter unterer Backzahn. 1/s nat. Gr. (Nach Gaudry.)

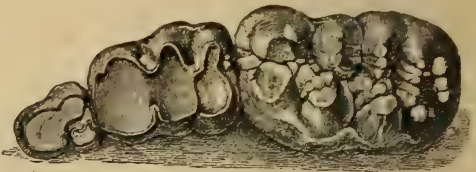

Fìg. 733 .

Mastodon (Tetralophodon) longirostris Kaup. Unt. Pliocän. Eppelsheim. Die drei oberen Milchbackenzähne. 1/3 nat. Gr. (Nach Ka up.)

Cautleyi Lyd., latidens Clift. in ganz Ostasien. Im Obermiocän von Nordamerika M. (Tril.) proavus und breviceps Cope, im Unterpliocän M. (Tril.) productus, euhypodon, campester, serridens Cope, floridanus Leidy, im Unterund Mittelpliocän von Europa M. (Tril.) Borsoni Hays (tapiroid), im Oberpliocän in Europa M. (Tetral.) arvernensis Croiz. und Job, in Nordamerika M. (Tril.) Shepardi, tropicus Cope und M. (Tetral.) mirificus Leidy. - Die Gattung Mastodon existiert in Amerika auch noch im Pleistocän, sie wird hier im Schädel- und Kieferbau ganz Elephas ähnlich und es fungieren nie mehr als zwei Zähne gleichzeitig. In Nordamerika M. (Tril.) americanus Cuv. öfters in vollständigen Skeletten erhalten, in Süd- und Zentralamerika $M$. (Tetral.) Humboldti Cuv., im westlichen Südamerika $M$. Andium Cuv. und M. bolivianus Phil. Mastodon findet sich auch in den Diamantseifen von Südafrika. 
Subungulata. Proboscidea. Elephantidae.

Stegodon Falconer (Fig. 734, 735). Übergangsform von Mastodon zu Elephas, mit dem ersteren durch $M$. latidens verbunden. Ohne untere $J$. Obere $J$ lang, ohne Schmelzband. $M$ mit 6-12 niedrigen, dachförmigen, etwas konvexen und meist vielwarzigen Jochen. Täler teilweise mit Zement ausgefüllt. $M_{1}$ und $M_{2}$ mit gleicher Jochzahl. Obere $M$ mit etwas weniger Jochen als die unteren. Mittelund Oberpliocän von Süd-und Ostasien. St. insignis Falc., bombifrons Falc. Im Pleistocän des Narbadatales St. Ganesa Falc., von Java St. Airawana Martin.:

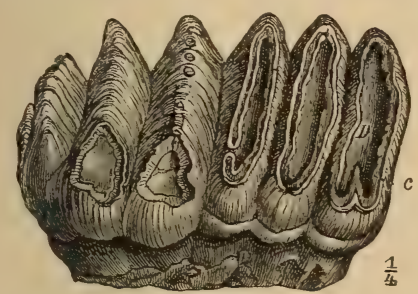

Fig. 734.

Stegodon Clifti Falcon. u. Cautley. Pliocän (oder Pleistocän) von Birma. Erster oberer Molar. $1 / 4$ nat. Gr. $D$ Dentin, $c$ Zement. (Nach Clift.)

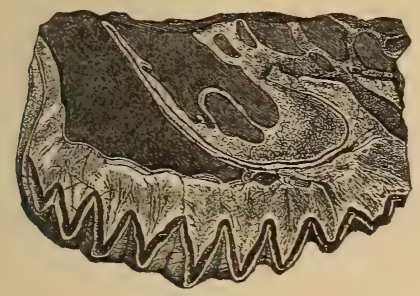

Fig. 735 .

Stegodou insignis Falcon. Siwalik. OstIndien. Oberer Molar, der Länge nach durchgeschnitten. $1 / 6$ nat. Gr. (Nach Falconer.)
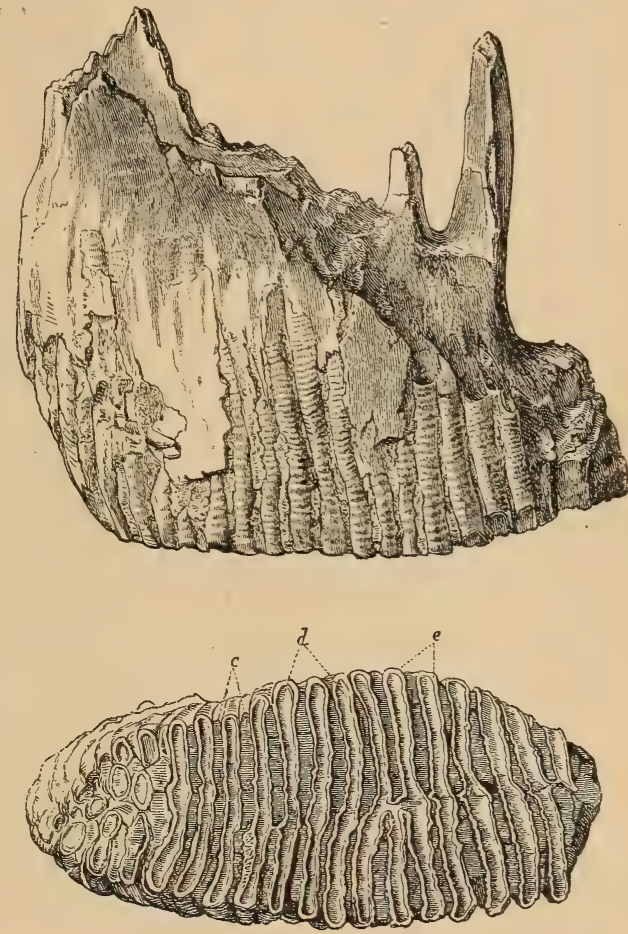

Fig. 736 .

Elephas primigenius Blumb. Diluvium. Essex. Oberer Backenzahn von der Seite und von unten. 1/5 nat. Gr. (Nach Owen.) $e$ Schmelz, $d$ Dentin, $c$ Zement.

Elephas Lin. (Fig. 736). $\frac{1.0 .3}{0.0 .3}$, seltener $\frac{1.0 .2 .3}{0.0 .2 .3} . J$ ohne Schmelzband. $M$ aus 5-27 hohen, komprimierten, am Oberrand gekerbten Querjochen bestehend. Täler ganz mit Zement ausgefüllt. Durch Abkauung entsteht eine ebene Fläche. Beim indischen Elefanten fällt $D_{2}$ im zweiten, $D_{3}$ im 5 . und $D_{4}$ im 9. Lebensjahr aus. $M_{1}$ tritt erst im 15. Jahre in Funktion. Meist nur ein Zahn in jedem Kiefer im Gebrauch.

Die Zahl der Querjoche vermehrt sich bei jedem neu auftretenden Zahn, so daß »isomere« Zwischenzähne mit gleicher Jochzahl hier nicht vorkommen, während sie bei Mastodon häufig sind. Die Jochzahlen sind bei den wichtigsten Arten folgende:

\begin{tabular}{|c|c|c|c|c|c|c|c|}
\hline \multirow{3}{*}{ Elephas } & \multirow{3}{*}{$\begin{array}{l}\text { africanus } \\
\text { u. planifrons }\end{array}$} & \multirow{3}{*}{$\begin{array}{l}D_{2} \\
\frac{3}{3}\end{array}$} & \multirow{2}{*}{$\begin{array}{c}D_{3} \\
6 \\
\end{array}$} & \multirow{2}{*}{$\begin{array}{c}D_{4} \\
7\end{array}$} & \multirow{2}{*}{$\begin{array}{c}M_{1} \\
7\end{array}$} & \multirow{2}{*}{$\begin{array}{c}M_{2} \\
8\end{array}$} & \multirow{2}{*}{$\begin{array}{r}M_{3} \\
10 \\
\end{array}$} \\
\hline & & & & & & & \\
\hline & & & & $\overline{7}$ & 7 & $\overline{8-9}$ & $\overline{11}$ \\
\hline \multirow[b]{2}{*}{$\nexists$} & \multirow{2}{*}{ meridionalis } & 3 & $5-6$ & $7-8$ & $8-9$ & $8-11$ & $10-14$ \\
\hline & & $\overline{3}$ & $\overline{5-6}$ & $\overline{7-8}$ & $\overline{8-9}$ & $\overline{9-11}$ & $\overline{11-14}$ \\
\hline \multirow{2}{*}{ 》) } & \multirow{2}{*}{ antiquus } & 3 & $5-7$ & $8-11$ & $9-12$ & $12-13$ & $15-20$ \\
\hline & & $\overline{3}$ & $\overline{5-8}$ & $\overline{9-11}$ & $\overline{10-12}$ & $\overline{12-13}$ & $\overline{16-21}$ \\
\hline
\end{tabular}




\begin{tabular}{|c|c|c|c|c|c|c|c|}
\hline & & $D_{2}$ & $D_{3}$ & $D_{4}$ & $M_{1}$ & $M_{2}$ & $M_{8}$ \\
\hline Elephas & indicus & $\frac{4}{4}$ & $\frac{8}{8}$ & $\frac{12}{12}$ & $\frac{12-14}{12-14}$ & $\frac{16-18}{16-18}$ & $\frac{24}{24-27}$ \\
\hline 》 & primigenius & $\frac{4}{4}$ & $\frac{6-9}{6-9}$ & $\frac{9-12}{9-12}$ & $\frac{9-15}{9-15}$ & $\frac{14-16}{14-16}$ & $\frac{18-27}{18-27}$ \\
\hline
\end{tabular}

Falconer teilt die Gattung Elephas in zwei Subgenera: Loxodon mit niedrigen, breiten, wenig zahlreichen Jochen, die bei der Abkauung rhombische Figuren bilden, und Euelephas mit hohen, schmalen, zahlreichen Jochen, die vollkommen parallel verlaufen. Die Zähne zerfallen leicht in die einzelnen lamellenartigen Joche. Fossile Elefanten erscheinen zuerst im Pliocän von Ostindien, E. (Lox.) planifrons und (Euelephas) hysudricus Falc. Im Oberpliocän von Europa Euelephas meridionalis Nesti, das größte aller bekannten Landsäugetiere, in Italien mit ihm vielleicht schon zusammen der sonst für das ältere europäische Pleistocän charakteristische Euel.antiquus Falc. Zwergrassen von diesem sind $E$. mnaidriensis Leith Ad. und melitensis Falc. auf den Mittelmeerinseln. E. namadicus Falc. vertritt den antiquus im älteren Pleistocän von Ost- und Südasien. Auf Java $E$. hysudrindicus Dubois. Im Pleistocän des südlichen Nordamerika $E$. imperator Leidy, des mittleren $E$. Columbi Falc., und im nördlichen der auch in Europa und Nordasien so verbreitete $E$. primigenius Blumb., das Mammut. Es ist charakteristisch für das jüngste Pleistocän. In Sibirien finden sich im gefrorenen Boden ganze Leichen mit Fleisch und wolligem Haar. Im europäischen Altpleistocän außer antiquus auch $\boldsymbol{E}$. trogontherii Pohlig.

\section{Unterordnung. Sirenia Seekühe.1)}

Dickhäutige, nackte, kurzhalsige, meist monophyodonte Pflanzenfresser. Nasenlöcher nach vorne gerichtet. Vorderfuß flossenartig. Hinterfuß frühzeitig reduziert. Schwanzflosse horizontal. Zwei Zitzen an der Brust.

Die Sirenen bewohnen den Unterlauf größerer Flüsse und Meeresküsten. Ihr zylindrischer, mit horizontaler Schwanzflosse versehener Körper, dessen Vorderfüße zu beweglichen Flossen umgestaltet sind, während die Hinterfüße höchstens durch Rudimente von Pelvis und Femur angedeutet werden, erinnert zwar an Cetaceen, die einzelnen Knochen haben jedoch viele Ähnlichkeit mit denen von primitiven Proboscidiern. Sie besitzen eine ungemein dichte Struktur, namentlich die Rippen und Wirbel zeichnen sich durch elfenbeinähnliche Beschaffenheit und bedeutende Schwere aus. Die langen Extremitätenknochen haben keine Markhöhlen. Auch die Schädelknochen sind zum Teil sehr dicht.

Die sehr kurzen Körper der Halswirbel bleiben in der Regel getrennt, die der Rückenwirbel haben annähernd dreieckigen Querschnitt und unten einen Kiel. Dornfortsätze und Zygapophysen sind wohl entwickelt. Die Zahl der Lendenwirbel ist 2-3, die der Sacralwirbel 1-2.

1) Abel O., Die Sirenen der mediterranen Tertiärbildungen Österreichs. Abhandl. k. u. k. geol. Reichsanst. 1904 . Bd. XIX. - Andrews W. C., Catalogue of the Tertiary Vertebrata of the Fayum 1906. - Capellini Giov., Mem. Accad. Sc. di Bologna 1872. 3 ser. t. I und 1886. 4 ser. t. VII. - Cope E. D., American. Naturalist. 1890. - Depéret Ch., Sitz.-Ber. Akad. Wien. 1895. p. 395. - Dollo L., Sur les Siréniens de Boom. Bull. Soc. Belge de Géol. 1889. - Kaup J., Beitr. zur Kenntnis d. urweltl. Säugetiere (Halitherium). 1855 Heft II u. V. - Lepsius $R$, Halitherium Schinzi. Die fossile Sirene des Mainzer Beckens. Darmstadt 1882. - Yoshiwara $S$. und Iwasaki J., Journ. of University Tokyo. t. XVI. 1902. 
Der Schädel (Fig. 738) zeichnet sich durch starke Jochbogen, große Schläfenbeine und eigentümlich gestaltetes Perioticum und Tympanicum aus. Scheitel- und Stirnbeine bilden das Schädeldach. Die Nasenbeine sind verkümmert und die Nasenlöcher weit nach hinten gerückt. Die plumpen Unterkiefer besitzen einen hohen aufsteigenden Ast.

Das Gebiß besteht fast nur aus lophodonten oder bunodonten Backenzähnen, welche etwas an die von Tapir resp. von Schwein erinnern. Ihre Zahl schwankt zwischen 4 und 10. Bei den Halicoriden werden die $D$ anfangs durch $P$ ersetzt, später unterbleibt der Zahnwechsel. Dagegen bilden sich bei den Manatiden hinten immer neue Zähne, so daß gleichzeitig in einem Kiefer '7-11 Zähne funktionieren. $C$ fehlen meistens, dagegen sind die $J$, namentlich die oberen, öfters sehr kräftig.

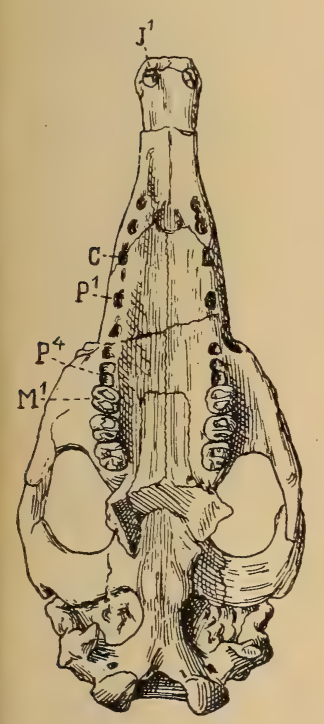

Fig. 737.

Protosiren Fraasi Abel. Obereocän. Fayum. Ägypten. Schädel von unten. $1 / 6$ nat. Gr. (Nach Andrews.)
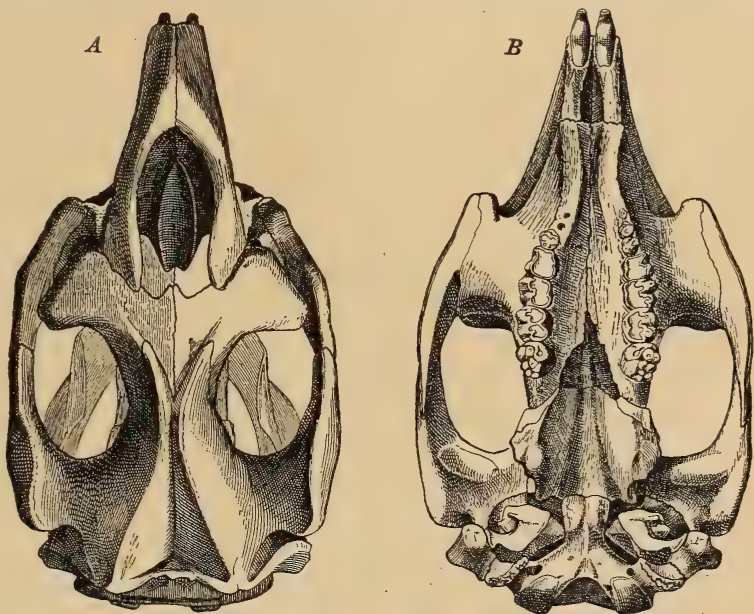

Fig. 738. Halitherium Schinzi. Kaup. Oligocän. Flonheim b. Alzey. Rheinhessen. A Schädel von oben. $B$ von unten. $1 / 6$ nat. Gr. (Nach Lepsius.)

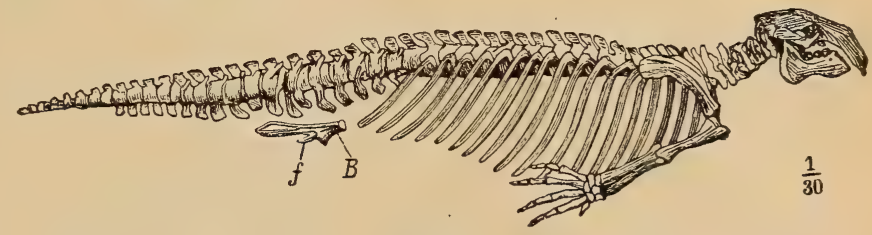

Fig. 739. Skelett von Halitherium Schinzi. Kaup. Restauriert nach Lepsius. $1 / 30$ nat. Gr. $B$ Becken, $f$ Oberschenkel.

Die Knochen der Vorderextremität sind gelenkig verbunden und beweglich. Schlüsselbeine fehlen, die Scapula ist sichelförmig, Radius und Ulna haben gleiche Stärke und Länge. Die proximale Carpusreihe besteht ursprünglich aus drei, die distale aus vier Knöchelchen, die zum Teil miteinander verwachsen. Die fünf Finger haben schlanke Metacarpalien und die normale Phalangenzahl. Das Becken besteht in der Halitherium Halicore-Reihe aus einem langen dicken Ilium und aus einem kurzen breiten Ischium. Bei Eotherium befindet sich zwischen Pubis und Ischium noch ein weites Foramen obturatorium. Bei den Manatidae wird das Ilium reduziert. Das rudimentäre, in der Haut verborgene Femur ist bei den späteren Formen nur durch Ligament mit dem Becken verbunden. Becken und Schädel sowie das Gebiß der ältesten Sirenen gleichen fast ganz jenen von Moeritherium, wodurch die schon von Blainville vermutete Verwandtschaft mit den Proboscidea vollkommen sichergestellt wird. Die Sirenen sind 
Vertebrata. Mammalia.

also dem Wasserleben angepaßte Huftiere. Die beiden lebenden Gattungen Manatus und Halicore bewohnen die Küsten von Afrika, Ostasien, Zentral- und Südamerika. Fossile Sirenen erscheinen zuerst im Mitteleocän, Eotherium, aus welchem sich die Manatiden und Halicoriden entwickelt haben. Die Gattungen Halitherium, Metaxytherium und Felsinotherium bilden eine genetische Reihe, welcher auch Halicore und Rhytina nahestehen.

\section{A. Manatidae.}

Prorastomus Owen. Gebiß vollständig. 3.1.4.3. $J$ im Querschnitt rund, oberer $C$ groß. Obere $M$ mit zwei rechtwinklig zur Längsachse stehenden Querjochen. Eocän. Jamaica. P. sirenoides Owen.

Manatus Rondel. (Ribodon Ameghino.) $J$ und $C$ rudimentär. Oben und unten je 8-10 Backenzähne; die oberen dreiwurzelig mit zwei Quer. jochen und Basalband, die unteren schmäler, zweijochig, mit Talonid. Beim Embryo Anlagen von $3 J, 1 \mathrm{C}$. Lebend an der Ostküste von Amerika. Fossil im Pliocän von Süd-Carolina und Argentinien.

Manatherium Hartlaub mit Manatus verwandt. Oligocän Belgien.

\section{B. Halicoridae.}

Eotherium Owen. $\frac{3.1 .4 .3}{3.1 .4 .3}$. Alle $J$ ziemlich groß. Eocän. Mokattam. Schichten. Ägypten.

Eosiren Andrews. $\frac{3.1 .4 .3}{3.1 .4 .3} . J_{1}$ groß, $J^{2}$ und $J^{3}$ später verschwindend. Schnauze überhängend. Obereocän von Ägypten.

Protosiren Abel. (Fig. 737.) Obereocän Ägypten.

Halitherium Kaup. (Fig. 738 u. 739.) Zwischenkiefer nach abwärts gekrümmt mit je einem langen $J$. Scheitelbeine lang, schmal, Stirnbeine kurz. Nasenbeine kurz, schildförmig, hinter der großen Nasenöffnung gelegen. $J$ mit Ausnahme des großen oberen $J^{1}$ sowie $C$ frühzeitig ausfallend. Backenzähne, $\frac{4}{4} P \frac{3}{3} M$, bunodont mit warzigen Querjochen. $P$ klein, einspitzig und einwurzelig, bald ausfallend. Im Eocän des Vicentin $H$. veronense de Zigno, im Oligocän von Deutschland und Frankreich H. Schinzi Kaup, im Miocän H. Christoli Fitzinger.

Metaxytherium Christol, ähnlich Halitherium, $M$ komplizierter und stärker reduziert. Miocän M. Cuvieri Christ., Krahuletzi Depéret. Pliocän $M$. Serresi Gervais.

Felsinotherium Capellini. $\frac{1.0 .2}{0.0 .2} \frac{3}{3}$. Statt der $P$ mit peristirenden $D$, welche den bunodonten $M$ ähnlich sind. Zwischenkiefer- und Unterkiefer. symphyse plump, nach unten gebogen. Pliocän Italien. F. For estii Cap.

Halianassa Meyer. $1 J 2 D 3 M$ Miocän. $H$. Studeri Mey.

Miosiren Dollo. $1 J 2 D 3 M$. Rhytiodus Lartet $1 J 1 D 3 M$. Prohalicore Flot. Miocän.

Halicore Illiger. $\frac{2-3}{2-3} D \frac{3}{3} M$. Obere $J$ groß. $P$ klein, einwurzelig, stiftförmig. Lebend. Afrika.

Rhytina Illiger. Ohne Backenzähne, dafür eine hornige Kauplatte in der Mundhöhle. Rh. Stelleri Cuv., ausgerottet am Ende des 18. Jahrhunderts.

Desmostylus Marsh. $\frac{1.0 .2 .22}{2.0 .2 .2}$. Schädel schmal und niedrig, Schnauze gestreckt, nicht abwärts gebogen. $J$ stoßzahnartig, mäßig lang, vorwärts gerichtet, $P$ klein, zweiwurzelig, $M$ groß, zweiwurzelig, aus zahlreichen, mit- 
einander verwachsenen, in Reihen geordneten Zylindern bestehend. Marines Miocän von Japan und Kalifornien. Osborn hält dieses Tier für einen Proboscidier.

\section{Zeitliche Verbreitung der Notoungulata und Subungulata.}

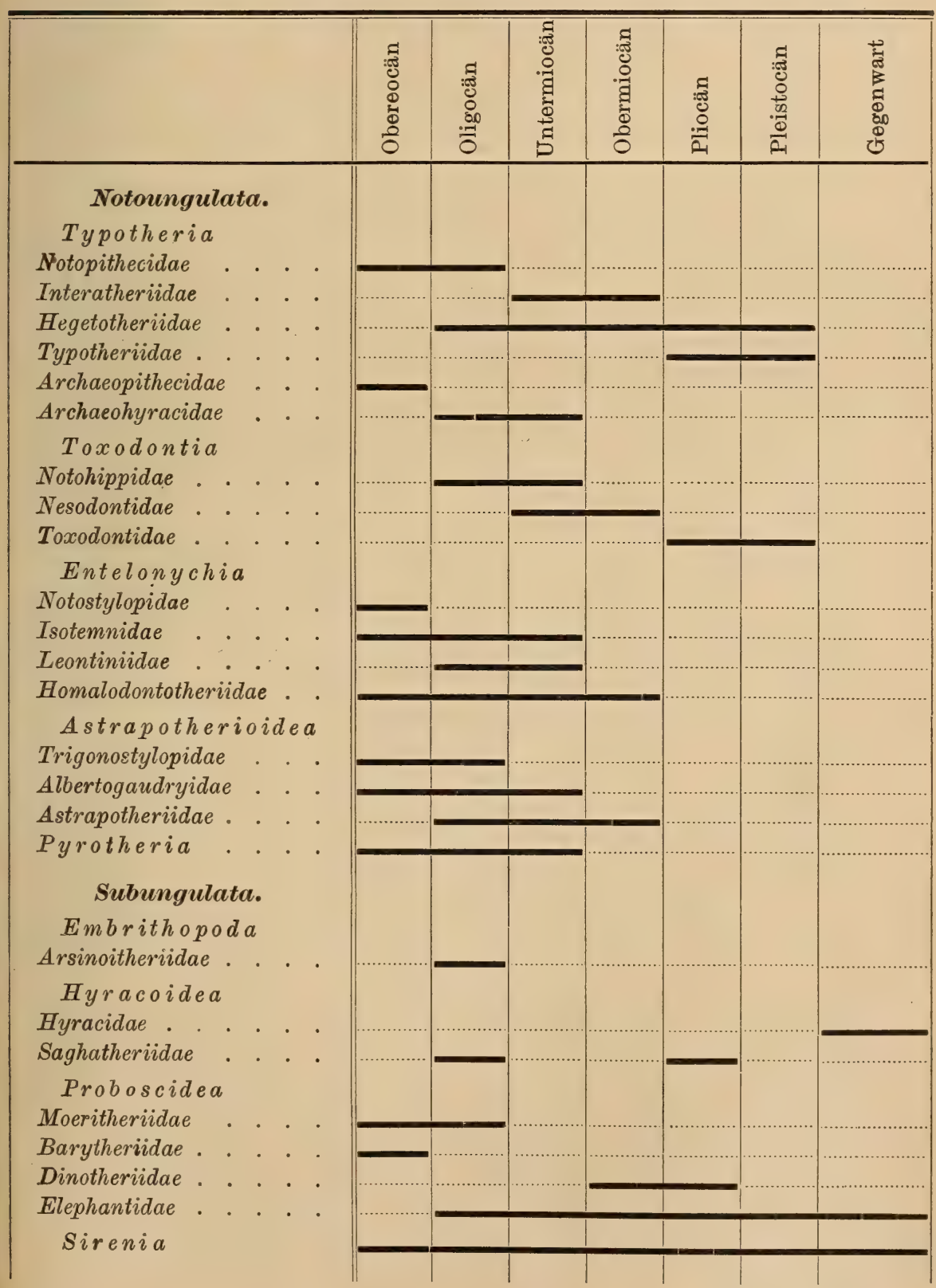




\section{Ordnung. Primates. Herrentiere.}

Linné hat unter dem Namen Primates den Menschen, die Affen, Lemuren, Fledermäuse und Edentaten zusammengefaßt. Abgesehen von den beiden letzten, bilden diese Gruppen eine in anatomischer Hinsicht wohl umgrenzte Ordnung, deren älteste Glieder freilich auch viele Anklänge an Insektivoren oder an Creodontier aufweisen. Die Primaten wurden bisher meist eingeteilt in die drei Unterordnungen der Prosimiae, Simicue und Bimana. Die Unterscheidung der beiden letzteren Unterordnungen ist jedoch in der Natur nicht begründet. Es empfiehlt sich daher, die von Wortman vorgenommene Zweiteilung in die Lemuroidea und die Anthropoidea anzunehmen.

\section{Unterordnung Lemuroidea. (Prosimiae, Halbaffen. $)^{1}$ )}

Plantigrade, meist fünzehige, frugivore oder omnivore Klettertiere mit opponierbarer erster Zehe. Finger und Zehen entweder sämtlich mit Nägeln oder teilweise mit Krallen versehen. Gebiß mehr oder weniger vollständig. Obere M quadri- oder trituberkulär, untere quadri- oder quinquetuberkulär. $P$ einfacher als M. Schnauze meist verlängert, Orbita in der Regel etwas seitlich gestellt, hinten knöchern umgrenzt, aber nicht immer durch eine Wand von den Temporalgruben getrennt. Lacrimale und Lacrimalgrube fast immer außerhalb der Augenhöhle gelegen. Gehirn schwach gefurcht. Kleinhirn nicht vom Großhirn bedeckt. Zitzen brust- oder bauchständig.

Die Halbaffen bewohnen gegenwärtig vorzugsweise Madagaskar, zum Teil auch Afrika und Südasien, früher lebten sie in Nordamerika und Mitteleuropa. Von den Anthropoidea unterscheiden sie sich durch das kleinere, wenig gefurchte Gehirn, durch das freie Kleinhirn, durch den unvollständigen hinteren Abschluß der Augenhöhle, durch das außerhalb der Augenhöhle gelegene Lacrimale, durch die manchmal bekrallten Zehen, durch die großen, stets opponierbaren Pollex und Hallux, durch behaartes Gesicht, zweihörnigen Uterus und zum Teil abdominale Zitzen. Die Placenta ist diffus und adeciduat.

Das Skelett der Halbaffen ist in vielfacher Hinsicht primitiver als das der Affen und erinnert an Insektivoren, Creodontia und Carnivoren. Die Hinterextremitäten sind manchmal stark verlängert, sogar Astragalus und Calcaneum. Der Humerus hat fast stets ein Entepicondylarforamen, das Femur einen dritten Trochanter. In Carpus treten nie Verschmelzungen ein, dagegen ist oft noch ein freies Centrale vorhanden. Das Gebiß ist bald geschlossen, bald hat es ein Diastema. Auch Verlust oder Spezialisierung

1) Brown Al., On some points in the Phylogeny of the Primates. Proc. Acad. Natur. Scienc. Philadelphia 1901. - Cope E. D., The Lemuroidea and the Insectivora of the Eocene of N. America. American Naturalist 1885. - Filhol H., Ann. scienc. géol. t. V. t. VIII. t. XIV. t. XVII. - Gervais P., Zoologie et Paléontologie générales. Tome II. 1876. - Leche $W$., Untersuchungen über das Zahnsystem lebender und fossiler Halbaffen. Festschrift für Gegenbaur, Leipzig 1896. - Os. born H. F., American Eocene Primates. Bull. Amer. Mus. Nat. Hist. New York 1902. - Schlosser M., Die Affen, Lemuren, Chiropteren etc. des europäischen Tertiärs. Beiträg. zur Paläont. Öst.-Ung. 1887. VI. - Beitrag zur Osteologie von Necrolemur und zur Stammesgeschichte der Primaten. Neues Jahrb. für Mineral. 1908. Festband. - Winge Herluf, Jordfundne og nu levende Aber (Primates) fra Lagoa Santa, Brasilien. E. Museo Lundii. Kopenhagen 1895. - Wortman J. L, Studies of Eocene Mammalia in the Marsh Collection. Part. II Primates. Americ. Journ. of Science. 1903. 1904. 
von $J, C$ und $P$ kann vorkommen. Die oberen $M$ sind entweder trituberkulär oder quadrituberkulär. Ihr Protocon ist oft noch $\bigvee$-förmig und durch seine beiden divergierenden Schenkel mit den Außenhöckern verbunden. Der Hypocon bleibt immer kleiner als der Protocon, auch kann er ganz fehlen. Ein Basalband ist fast immer vorhanden und öfters als Innenwall entwickelt. Die älteren Formen besitzen meistens ein oder zwei Zwischenhöcker. Die unteren $M$ bestehen aus einem zweihöckerigen Talonid und einem ursprünglich höheren, oft noch dreihöckerigen Trigonid, jedoch verschwindet nicht allzuselten der unpaare Vorderhöcker, Paraconid, auch bleibt er öfter nur am ersten Molar erhalten. Die in der Vierzahl vorhandenen Höcker stehen opponiert oder alternierend und sind dann meistens durch rechtwinklige oder schräge Joche verbunden. Die $\boldsymbol{P}$ sind stets einfacher als die $M$. Ihre Zahl beträgt ursprünglich vier, kann aber stark reduziert werden. Bei den lebenden Lemuren ist sie in der Regel drei, und der vorderste des Unterkiefers nimmt hier fast stets die Form eines $C$ an, während der wirkliche $C$ sich in einen dritten $J$ verwandelt. Der erstere macht sich aber dadurch als $P$ kenntlich, daß er hinter dem oberen $C$ stehen bleibt. Bei den ältesten Formen sind alle $J$ und $C$ normal entwickelt und mehr oder weniger vertikal gestellt. Die $J$ sind meißel- oder schaufelförmig und in der Zweizahl vorhanden.

Das Milchgebiß enthält individuell noch zuweilen einen dritten $J D-$ die $C$ haben die Form eines echten Eckzahnes. Die Reduktion von $J$ und $P$ tritt auch schon bei manchen geologisch alten Gattungen auf. Bei den jüngeren Halbaffen werden die oberen $J$ sehr klein, die unteren $J$ und der untere $C$ hingegen zu horizontal gestellten Pfriemen.

Co p e nannte einen Teil der eocänen Formen Mesodonta, einen anderen Teil stellte er zu den Prosimiae, Filhol nannte alle europäischen Pachylemuridae. Wortman erkannte die Beziehungen eines Teils der nordamerikanischen Formen zu den echten Affen. Er wählte daher für sie die Bezeichnung Palaeopithecini. Schlosser stellte für die Formen mit normalem Gebiß die Familie der Pseudolemuridae auf. Diese letzteren umfassen jetzt nach der Ausscheidung der zu den Insektivoren gestellten Hyopsodontidae nur mehr die Adapidae. Die Mixodectini mit ihren spezialisierten und in der Zahl stark reduzierten $J$ schließen sich zwar im Bau ihrer $M$ enge an die Primaten an, allein für die Ermittlung der wirklichen systematischen Stellung der einzelnen, hierher gerechneten Gattungen bedarf es noch weiterer Untersuchungen. Ein Teil, wenn nicht alle, gehört sicher zu den Insektivoren, bei welchen sie hier ausgeführt wurden.

Die Prosimiae oder Lemuroidea gliedern sich freilich am naturgemäßesten in die drei Abteilungen der Pseudolemuroidini, der Palaeopithecini und der Neolemuroidini, allein es dürfte hier genügen, die erste Gruppe nur als Familie der Adapidae anzuführen, die zweite zerfällt in die Anaptomor. phidae und die lebenden Tarsiidae und die dritte in die Familien der Lemuridae, Archaeolemuridae und Chiromyidae.

\section{Familie. Adapidae.}

2.1.4.3. Zahnreihe meist geschlossen. J oben und unten meißel- oder schaufelförmig, mehr oder weniger vertikal gestellt. $C$ als echter Eckzahn entwickelt, stets größer als die $J . P$ einfacher als $M$, jedoch $P_{4}$ öfters beträchtlich kompliziert. Untere $M$ aus vier oder noch fünf, meist alternierenden und unter einander verbundenen Höckern bestehend. $M_{3}$ mit kräftigem Talonid. Obere $M$ trituberkulär, mit kleinem Hypocon und mit ein oder zwei Zwischenhöckern. Außenhöcker mehr oder weniger konisch. Obere $P$ und $M$ allseitig von einem äußeren Basalband umgeben, untere in der Regel nur mit einem äußeren Basalband versehen. Schnauze und Unterkiefer ziemlich lang. Letztere öfters eine feste Symphyse bildend. 


\section{Fossil im Eocän von Nordamerika und Europa.}

Der nur von Adapis und Pronycticebus bekannte Schädel hat ein niedriges, aber breites Cranium, das bei Adapis mit einem hohen Sagittalkamm versehen ist. Hinter den ziemlich großen, hauptsächlich nach vorwärts sehenden und hinten durch eine breite Knochenspange abgegrenzten Augenhöhlen schnürt sich der Schädel stark ein. Die Schnauze ist ziemlich lang und schmal. Das Lacrimale befindet sich innerhalb der Augenhöhle, das Tympanicum liegt als freier Ring innerhalb der vom Petrosum gebildeten großen Bulla wie bei den madagascarischen Lemuren. Der Carotidkanal ist sehr eng. Das Gehirn zeigt einen sehr primitiven Bau. Die Unterkiefer bilden bei den späteren Formen in der Regel eine feste Symphyse. Der Schädel hat im ganzen ziemlich große Ähnlichkeit mit dem der Lemuriden. Dagegen unterscheidet sich der vordere Teil des Gebisses durch die normale Ausbildung der $J$ und $C$ sehr wesentlich von dem der Lemuriden. Es gleicht hierin fast ganz dem der echten Affen. Von den $P$ bleiben die drei vordersten sehr klein, und selbst $P_{2}$ hat wohl immer nur eine Wurzel. Dagegen erreicht der obere $P^{4}$ meistens den Trituberkulärtypus, und der untere $P_{4}$ kann fast ganz $M$-ähnlich werden. Die oberen $M$ lassen den Trituberkulärtypus noch deutlich erkennen, obwohl sie einen Hypocon besitzen. Von Zwischenhöckern sind meistens zwei, seltener nur einer vorhanden. Auch die vier- oder fünfhöckerigen unteren $M$ haben keine besonders charakteristische Form; sie erinnern teils an solche von primitiven Huftieren, teils an solche von Lemuren, jedoch ist die hintere Hälfte selten niedriger als die vordere. Die bis jetzt bekannten Skelettknochen besitzen am meisten Ähnlichkeit mit jenen der Lemuren. Der Humerus hat eine lange Deltoidcrista und ein wohlentwickeltes Entepicondylarforamen. Das Olecranon der dünnen Ulna ist kurz, die proximale Fasette des schlanken Radius kreisrund.
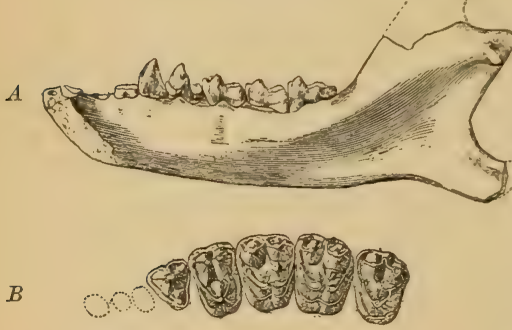

Fig. 740 .

A Pelycodus frugivorus Cope. Untereocän. Wasatchbed. Unterkiefer von innen. Nat. Gr. B Notharctus sp. Obere Backenzähne. $2 / 1$ nat. Gr. (nach Osborn.) Die Länge des.Femurs ist anscheinend ziemlich verschieden. Calcaneum und Astragalus sind echt primatenartig, ebenso die Metapodien und Zehenglieder.

Pelycodus Cope (Prototomus, Tomitherium Cope). (Fig. 740.) Obere $M$ undeutlich dreieckig, mit zwei pyramidenförmigen Außenhöckern, einem kräftigen $V$-förmigen vorderen und einem kleineren hinteren Innenhöcker und zwei Zwischenhöckern. Außenwand ohne Mittelpfeiler, $\boldsymbol{M}_{3}$ reduziert. Untere $\boldsymbol{M}$ mit $z$ wei Paar opponierten stumpfen Höckern und einem unpaaren Vorderhöcker, Paraconid. $M_{3}$ mit großem Talonid, Vorderhälfte höher als Hinterhälfte. Unterkiefer niemals verwachsen. Astragalus mit fast flachem Tibialgelenk. Endphalangen krallenartig. Im Eocän von Wyoming. P. tutus, frugivorus Cope. Wasatchbed. P. nunienus Cope Wind Riverbed.

Cryptopithecus Schlosser. Unterkiefer ohne feste Symphyse. $P_{4}$ kurz, aber $M$-artig. $M$ mit zwei hohen Vorderhöckern und niedrigem dreihöckerigem Talonid. $M_{3}$ kleiner als $M_{2}$. Obereocän. Bohnerz von Frohnstetten. C. sideroolithicus Schlosser.

Pronycticebus Grandidier. Vermutlich der Schädel von Cryptopi. thecus. $P^{1}$ und $P^{2}$ sehr klein, $P^{3}$ und $P^{4}$ zweihöckerig. $M$ dreihöckerig mit kleinem Innenhöcker, denen von Pelycodus sehr ähnlich. Eocän. Phosphorite von Quercy. P. Gaudryi Grandidier. 
Notharctus Leidy (Tomitherium Cope, Thinolestes, Limnotherium, Telmatolestes Marsh; Hipposyus Leidy) $J, C$ und $P_{1}$ und $P_{2}$ klein, durch kurze Lücken voneinander getrennt. $P^{3} \mathrm{kräftig}$, mit Innenhöcker. $P^{4}$ dreihöckerig, obere $M$ vierseitig, außen mit Mittelpfeiler. Hypocon kräftig entwickelt. Untere $P$ mit Ausnahme von $P_{4}$ einfach aber dick und einwurzelig. Höcker der $M$ schneidend entwickelt. Vorderhälfte kaum höher als Hinterhälfte. $M_{3}$ mit großem Talonid. Unterkiefer mit fester Symphyse. Femur lang, ohne dritten Trochanter. Mitteleocän, Bridgerbed von Wyoming N. tenebrosus, formosus Leidy, rostratus Cope. Diese aus Pelycodus entstandene Gattung ist vielleicht der Stammvater von:

Adapis Cuvier (Palaeolemur Filhol, Aphelotherium, Leptadapis Gervais). (Fig. 741.) Zahnreihe geschlossen, höchstens Lücke hinter $C$. Obere $J$

A

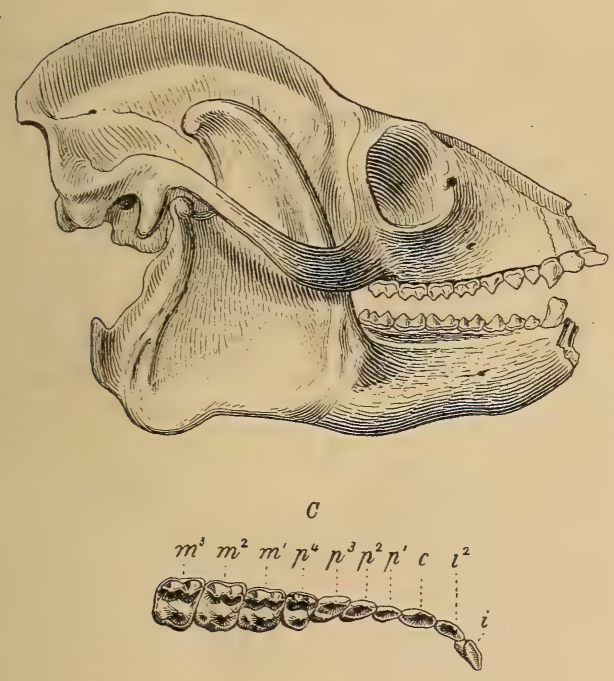

$D$

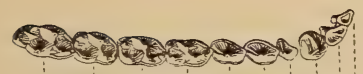

$\dot{m}_{3} m_{2} \dot{m}_{1} \dot{n}_{4} \dot{n}_{3} \dot{p}_{2} \dot{n}_{1}<\dot{i}_{2} i$,
B

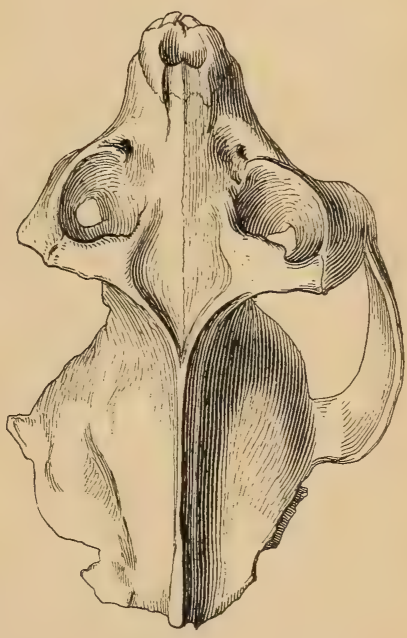

E

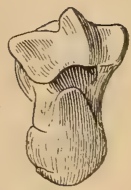

Fig. 741.

Adapis parisiensis Cuv. var. min. Phosphorite. Quercy. A Schädel mit Unterkiefer von der Seite, $B$ von oben, $C$ obere, $D$ untere Zahnreihe. $2 / 3$ nat. Gr. $E$ Astragalus von vorne und hinten, nat. Gr.

schaufel-, untere meißelförmig, oberer $C$ klein, unterer aufrecht, kräftig mit abgestutzter Spitze. $P_{1-3}$ in beiden Kiefern einfach, obere mit innerem Basalband, $P^{4}$ dreihöckerig. Obere $M$ fast quadratisch, mit zwei pyramidenförmigen Außenhöckern, einem großen $\bigvee$-förmigen Protocon und schwachem Hypocon und vorne mit einem kleinen Zwischenhöcker. $P_{4}$ und die unteren $M$ mit zwei Paar alternierenden, komprimierten, jochartig verbundenen Höckern. Schädel hinter den Augenhöhlen stark eingeschnürt mit breitem niedrigen Cranium und hohem Scheitelkamm. Schnauze lang, Unterkiefer mit fester Symphyse und hohem aufsteigenden Ast. Femur mit drittem Trochanter, nicht viel länger als Humerus. A dapis ist wahrscheinlich der Ahne der ausgestorbenen Gattung Megaladapis, vielleicht auch der von Lemur. Im Obereocän. Gips von Montmartre, Phosphorite von Quercy. 
A. parisiensis Cuv. Phosphorite von Quercy und Mergel von St. Hippolyte de Caton (Gard). A. magnus Filh.

Caenopithecus Rütimeyer. Nur obere $M$ bekannt, wahrscheinlich identisch mit Adapis. C. lemuroides Rütimeyer, im Bohnerz von Egerkingen.

\section{Familie. Anaptomorphidae. Cope.}

$\frac{3-2.1 .3-2.3 .}{2-1.1 .4-2.3 .} \quad J$ und $C$ normal, aber letztere klein. $P$ in beiden Kiefern klein und einfach, untere kurz und dick, obere meist mit Innenhöckern. Obere $M$ drei- oder vierhöckerig, meist mit Zwischenhöckern, untere M mit zwei Paar niedrigen, meist dicken und deutlich alternierenden Höckern. Unpaarer Vorderhöcker an den hinteren $M$ häufig reduziert. Unterkiefer niedrig, ohne feste Symphyse. Schädel meist brachycephal. Lacrimale und Lacrimalgrube ganz oder größtenteils vor der weiten, hinten durch eine Knochenspange abgegrenzten Augenhöhle. Extremitäten zuweilen spezialisiert.

Wortman vereinigt die Anaptomorphiden mit den Tarsiiden in der Gruppe der Palaeopithecini, die er auch schon zu den echten Affen, den Anthropoidea stellt. Im Eocän von Europa und Nordamerika.

Anaptomorphus Cope (Microsyops Leidy). (Fig. 742.) Zahnformel 2?1. 3. 3. den kurzen, aber breiten, zweihöckerigen $P$ getrennt. $M$ trituberkulär, viel breiter als lang. Innenhöcker $V$-förmig. Untere $P$ hoch mit innerem Basalband, untere $M$ mit schmaler kurzer Trigonid- und breiterer Talonidhälfte, aus zwei Paar alternierender Höcker und einem undeutlichen Vorderhöcker, Paraconid, bestehend. Schädel kurz, mit geräumigem Cranium und

B
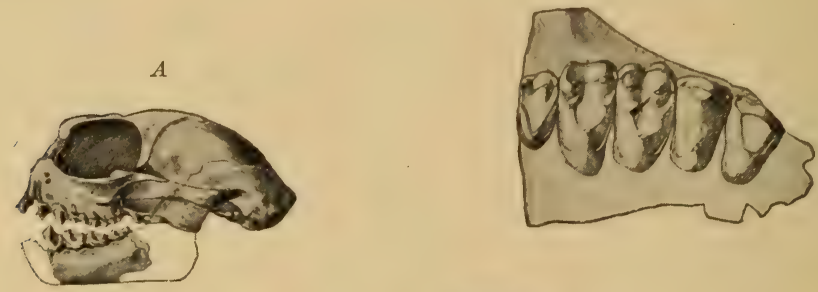

Fig. 742.

Anaptomorphus homunculus Cope. Untereocän. Wasatchbed. $A$ Schädel, nat. Gr., $B$ obere $P^{3}$ bis $M^{3}, C$ Unterkiefer von oben, $3 / 1$ nat. Gr. (nach O s b orn.)

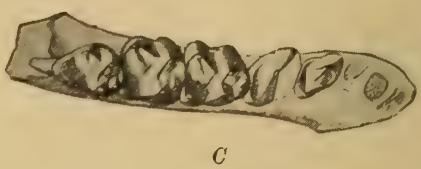

weit abstehenden Jochbogen, Augenhöhlen hinten durch den Postorbitalfortsatz des Stirnbeins geschlossen. Im Eocän von Nordamerika. Wasatchbed. A. homunculus Cope. Bridgerbed A. aemulus Cope. Uintabed A. uintensis Osborn.

Anaptomorphus sowie die folgenden nordamerikanischen Gattungen sind wahrscheinlich der Ausgangspunkt aller Anthropoidea, zum mindesten aber die Ahnen der Simiiden.

Omomys Leidy (Palaeacodon, Hemiacodon, Euryacodon Marsh). Gebiß mit sehr breiten, ovalen, trituberkulären oberen $M$ und mit unpaarem Vorderhöcker an den unteren $M$. Mitteleocän. Bridgerbed von Wyoming. O. Carteri Leidy.

Hemiacodon Marsh. Obere $M$ viereckig, stark in die Breite gezogen, mit drei konischen Höckern und mit kräftigen Zwischenhöckern. Vorder- 
hälfte der unteren $M$ dreispitzig und bedeutend höher als die hintere. BridgerEocän. H. gracilis Marsh.

Washakius Leidy. Nur acht Zähne im Unterkiefer. Vorderhälfte der unteren $M$ mit viertem Höcker. $M_{3}$ mit vierhöckerigem Talonid. Nur ein $J$ im Unterkiefer vorhanden. Obere $M$ mit drei großen vierkantigen Höckern, mit zwei Zwischenhöckern und mit Hypocon. Mitteleocän. Bridgerbed $W$. insignis Leidy.

Trogolemur Matthew. Nur Unterkiefer bekannt. Drei einfache, dicke P. $M$ fünfhöckerig. Kronen aller Zähne stark vorwärts geneigt. Eocän. Bridgerbasin. T. insignis Matthew.

Necrolemur Filhol (Fig. 743). $\frac{\text { (3) 2.1. 3.3. }}{1.1 .(4) 3.3 .}$ Zahnreihe geschlossen. Obere $M$ vierhöckerig mit zwei pyramidenförmigen Außen-, zwei $\bigvee$-förmigen Innen- und zwei kleinen Zwischenhöckern. $M^{3}$ reduziert. $P_{4}$ in beiden Kiefern verdickt. Nur $M_{1}$ mit wohlentwickeltem Paraconid. $M_{3}$ mit starkem Talonid. Der vorderste untere $P$ und ein oberer $J$ gehen später
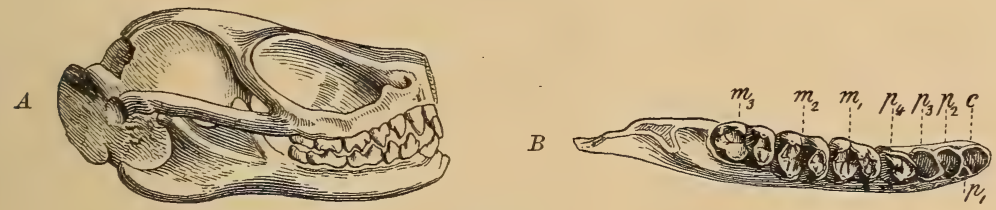

Fig. 743.

Necrolemur antiquus Filhol. Phosphorite. Quercy. A Schädel von der Seite, nat. Gr. (Nach Filh o1.) $B$ Unterkiefer von oben. $2 / 1$ nat. Gr.

verloren. Schädel niedrig, Cranium breit. Fibula mit dem unteren Drittel der schlanken Tibia verwachsen. Calcaneum und Astragalus gestreckt wie bei der lebenden Gattung Tarsius. Obereocän. Phosphorite von Quercy und Bohnerze von Mauremont. N. antiquus, Edwardsi Filhol, Zitteli Schlosser.

Microchoerus Wood. Nur Oberkiefer bekannt. Zähne ähnlich Necrolemur. Obereocän von Hordwell. England. M. erinaceus Woodw.

\section{Familie. Tarsiidae.}

2. 1.3. 3. Jklein, $C$ mäßig groß, untere $P$ einfach, aber dick, obere $P$ zweihöckerig. Untere $M$ fünfhöckerig, obere $M$ trituberkulär. Gesicht kurz, Cranium geräumig. Hinterextremität stark verlängert, namentlich Astragalus und Calcaneum.

Die ungemein primitive Form der $P$ und $M$, welche mit jenen der Primaten aus dem Oligocän von Ägypten sehr große Ähnlichkeit haben, und die scheibenförmige deciduate Placenta, welche Tarsius mit den echten Affen gemein hat, machen es sehr wahrscheinlich, daß Tarsius auf die nämliche Urform zurückgeht wie die Anthropoidea. Anderseits steht er in der Zahl und Zusammensetzung der Zähne den nordamerikanischen Anaptomorphiden sehr nahe.

\section{Familie. Lemuridae. ${ }^{1}$ )}

2. 1. 3. 3. Obere $J$ klein, im Alter oft verschwindend, $C$ dolchartig, $P$ klein, nur $P^{4}$ mit Innenhöcker. $M$ dreihöckerig. Untere $J$ und $C$ stiftförmig, horizon-

1) Grandidier G., Les Lemuriens disparus. Nouvelles Archives du Museum Paris 1905. - Forsyth Major C. J., Summary of the present knowledge of extinct Primates from Madagascar. Geolog. Magazine 1900. 
tal gestellt, vorderster unterer $P$ in einen kleinen Eckzahn umgewandelt. Untere $M$ aus alternierenden, durch Joche verbundenen Höckern bestehend. Extremitäten unspezialisiert. Femur nur wenig länger als der Humerus. Letzterer mit Ente. picondylarforamen, ersteres mit drittem Trochanter versehen.

Alle lebenden und fossilen Gattungen sind auf Madagaskar beschränkt. Die letzteren finden sich in Torfmooren bei Ambolisatra, Antisirabé, Belo und in Höhlen bei Andrahomana und stammen aus der jüngsten Vergangenheit. Die größten haben die Dimensionen von Mensch.

Lemur Linné. Kleine Formen, lebend. L. insignis Grandidier fossil, ungefähr Paviangröße.

Megaladapis Major (Thaumastolemur Filhol, Peloriadapis Grandidier, Palaeolemur, Mesoadapis Lorenz v. Liburnau). $\frac{0.1 .3 .3}{2.1 .3 .3}$. $J$ kräftiger als bei Lemur, obere $M$ gerundet dreieckig, untere $M$ und Schädel Adapis. ähnlich. Unterkiefer mit fester Symphyse, Humerus ähnlich dem der Anthropoidea, aber mit Entepicondylarforamen. Femur von vorne nach hinten abgeplattet. M. madagascariensis Major, Edwardsi Grandidier. Wahrscheinlich die Nachkommen der europäischen Gattung Adapis.

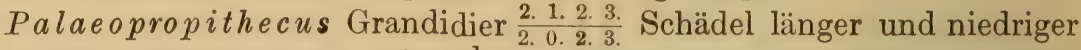
und feste Symphyse, sonst wie bei der lebenden Gattung Propithecus, jedoch viel größer.

5. Familie. Archaeolemuridae. Grandidier.

2. 1. 3. 3. Obere $J$ und $P$ kurz und dick. $M$ in beiden Kiefern quadratisch, mit je zwei Paar opponierten Höckern. Cranium groß, ohne Sagittalkamm, Augen vorvärts gerichtet.

Schädel- und Backenzähne erinnern an Cercopitheciden, namentlich an Colobus.

Nur fossil in Höhlen und Torfmooren von Madagaskar.

Archaeolemur Filhol (Lophiolemur Filhol, Nesopithecus, Globilemur Forsyth Major, Protoindris Lorenz v. Liburnau). A. Majori Grandidier.

Bradylemur Grandidier. B. ingens Gr.

Hadropithecus Lorenz v. Liburnau. Höcker der $P$ und $M$ durch Joche verbunden. $H$. stenognathus L. v. Liburnau.

\section{Familie. Chiromyidae.}

Diese nur durch die auf Madagaskar lebende Gattung Chiromys vertretene Familie zeichnet sich durch kurzen, hochgewölbten Schädel, durch das stark reduzierte Gebiß mit $\frac{2.1 .2 .3 .}{2.0 .2 .3 .}-$, im Milchgebiß $\frac{2.1 .3}{2.1 .3 .}-$, die nagezahnähnlichen vorderen $J$ und die stark verlängerten Finger aus.

Wortman stellt hierher einen Unterkiefer mit nur einem $J$ und zwei winzigen Zähnchen sowie Humerus und Tibia aus dem Bridgerbed von Wyoming und begründet hierauf die Gattung Metachiromys. Osborn hält sie jedoch für einen Dasypus ähnlichen Edentaten. Die von Wortman hierher gerechneten Microsyopiden gehören eher zu den Insektivoren, jedoch sind genetische Beziehungen zu Chiromys nicht ganz ausgeschlossen.

\section{Unterordnung. Anthropoidea. Mivart. ${ }^{1}$}

Plantigrade, mit der ganzen Sohle oder dem äußeren Fußrand auftretende Land-oder Klettertiere, mit opponierbarem Daumen und meist auch opponierbarer

1) Ameghino $\mathrm{Fl}$., Les formations sédimentaires de Patagonie. Anal. Museo de Buenos-Aires 1906. - Beyrich C., Über Semnopithecus pentelicus. Abh. Berlin. 
großer Zehe. Sämtliche Endphalangen (außer bei den Hapaliden) abgeplattet und mit Nägeln bedeckt. Gebiß vollständig, mit nur zwei Paar Schneidezähnen. Öfters kurzes Diastema. Backenzähne bunodont, $P$ in der Regel zweihöckerig, untere $M$ vier- oder fünfhöckerig, obere $M$ vier- oder dreihöckerig. Orbita nach vorne gerichtet, hinten durch eine knöcherne Scheidewand von den Schläfengruben getrennt. Foramen lacrimale innerhalb der Augenhöhlen gelegen. Gehirn groß, stark ge. furcht. Zwei Zitzen an der Brust.

Die Affen bewohnen heutzutage vorwiegend die heißen Regionen von Afrika, Asien und Amerika, nur eine Art lebt bei Gibraltar. Die ersten fossilen Affen treten im Oligocän von Ägypten auf, im Mittelmiocän erscheinen sie auch in Europa und etwas später in Südamerika, im Pliocän auch in Asien. Aus dem Pleistocän kennt man einzelne Arten sowohl aus Europa als auch aus Nordafrika und Südasien. Auch Südamerika besitzt im Miocän und Pleistocän Vertreter der noch jetzt dort lebenden Formen.

Die niedrigsten und kleinsten Formen schließen sich noch etwas an gewisse Halbaffen an, die hochstehenden und größten werden in ihrem Körperbau ganz menschenähnlich.

Der Schädel hat ein sehr geräumiges Cranium. Die tiefgefurchten Hemisphären des Großhirns bedecken das Kleinhirn fast vollständig. Die großen rundlichen Augenhöhlen sind nach vorwärts gerichtet und hinten durch eine vom Jugale ausgehende knöcherne Scheidewand von der Schläfengrube getrennt. Lacrimale und Foramen lacrimale liegen innerhalb der Orbiten. Die nur selten etwas längeren Gesichtsknochen steigen steil nach hinten an. Die Nasenbeine sind kurz, die Nasenlöcher nach vorne gerichtet und seitlich und unten von den Zwischenkiefern begrenzt. Die Stirnbeine verschmelzen miteinander und die nur selten mit einem Scheitelkamm versehenen Scheitelbeine vereinigen sich in der Sagittalnaht. Auch die Orbitalcrista ist meistens nur schwach entwickelt. Der aufsteigende Ast der eine feste Symphyse bildenden Unterkiefer ist in der Regel hoch und breit. Das Kinn steigt senkrecht oder schräg nach vorne zu an. Das Gebiß weist nur oben vor, unten hinter dem, namentlich bei den Männchen, meist kräftigen konischen $C$ eine kurze Iü̈cke auf. Die beiden $J$ sind oben und unten meißelförmig ausgebildet. Die $P$ bestehen in beiden Kiefern aus einem spitzen Außenhöcker und in der Regel aus einem niedrigen Innenhöcker. Der erste untere $P$ ist häufig in seiner Vorderpartie verstärkt, weil sie dem oberen Eckzahn als Antagonist dient. Die Zahl der $P$ beträgt bei den neuweltlichen Affen und bei den Parapitheciden $\frac{3}{3}$, bei den altweltlichen $\frac{2}{2}$. Die oberen $M$ besitzen bei den letzteren vier rechtwinklig oder schief gegenüberstehende, stumpf-konische oder kantige Höcker, von denen der zweite innere häufig schwächer ist als der vordere, bei den ersteren kann er auch vollständig fehlen. Die unteren $M$ haben zwei opponierte oder alternierende Höckerpaare. In letzterem Falle und fast immer am $M_{3}$ kommt ein weiterer Höcker am Hinterrand hinzu.

Akad. 1860. - Branco $W$., Die menschenähnlichen Zähne aus den Bohnerzen der schwäbischen Alb. Jahresh. Ver. f. vaterl. Naturkunde in Württemberg 1898. Dubois $E$., Über drei ausgestorbene Menschenaffen. N. Jahrb. für Miner. 1897. I. - Gaudry A., Le Dryopithèque. Mém. Soc. géol. France. Paléontol. 1890. I. Harlé Ed., Une machoire de Dryopithèque. Bull. Soc. géol. France 1898. - Nouvelles pièces de Dryopithèque. Ibid. 1899. - Lydekker, Palaeontologia Indica. Ser. X, Vol IV Siwalik Mammalia Suppl. L 1886. - Ristori G., Scimmie fossile italiane. Boll. comitato geol. ital. 1890. - Schlosser M., Beitr. z. Kenntnis der Säugetiere aus den süddeutsch. Bohnerzen. Geol. u. paläont. Abhandl. Jena 1902. - Die neueste Literatur über die ausgestorbenen Anthropomorphen. Zool. Anzeig. 1900. Die menschenähnlichen Zähne aus dem Bohnerz der schwäbischen Alb. Zool. Anz. 1901. - Wagner A., Abhandl. k. bayr. Ak. II. Cl. Bd. III 1. Abt. Bd. VII 2. Abt. Bd. VIII 1. Abt. 
Die Zahl der Wirbel ist 7 Hals-, 11-14 Rücken-, 4-7 Lenden- und meist 5 Sacralwirbel. Die Zahl der Schwanzwirbel ist sehr verschieden. Die Form der einzelnen Wirbel gleicht im wesentlichen den menschlichen Wirbeln. Die Länge des Schwanzes und das Längenverhältnis von Vorder- und Hinterextremität variiert außerordentlich. Bei den lebenden Simiiden fehlt der Schwanz, und ihre Vorderextremität ist beträchtlich länger als die Hinterextremität. Der Humerus hat öfters ein Entepicondylarforamen. Radius und Ulna sind getrennt, kräftig und umeinander drehbar. Der mit dem Vorderarm artikulierende Hinterrand des breiten kurzen Carpus verläuft konvex. Die Carpalien bleiben sämtlich frei. Ein Centrale ist häufig vorhanden. Das Trapezium hat eine sattelförmige, nach außen und unten gerichtete Gelenkfläche für den opponierbaren Daumen, der übrigens zuweilen bloß aus einem kurzen Metacarpalstummel besteht. Die Phalangen sind auf der Rückenseite konvex, auf der Unterseite flach. Die letztere ist schmal abgeplattet und kaum gekrümmt. Dem schlanken Femur fehlt ein dritter Trochanter, Tibia und Fibula sind kräftig und nur oben und unten miteinander verbunden. Astragalus mit konvexer, nicht gefurchter Tibialfasette und einer seitlichen Artikulation für die Fibula. Calcaneum mit langem Tuber, unten gerade abgestutzt. Der kurze Hallux ist fast immer opponierbar, so daß der Hinterfuß als Hand funktionieren kann.

Die Anthropoidea gliedern sich in die Familien der Hapalidae, der Cebidae, der Cynopithecidae, der Simiidae und der Hominidae, denen jedoch eine weitere hinzuzufügen sein dürfte, die Parapithecidae. Die beiden ersteren Familien sind auf Amerika, die übrigen mit Ausnahme der Hominidae auf die Alte Welt beschränkt.

\section{Familie. Hapalidae. Krallenaffen.}

2. 1.3. 2. Die beiden oberen $M$ trituberkulär, mit $\bigvee$-förmigem Innenhöcker. Obere $P$ breit, mit spitzem Außen- und Innenhöcker. Untere $M$ vierhöckerig, hinteres Höckerpaar niedriger als das vordere. C stark vorspringend. Schädel rundlich. Augenhöhle relativ klein. Alle Finger und Zehen mit Ausnahme des Hallux mit Krallen versehen. Schwanz länger als der übrige Körper.

Von den beiden im tropischen Südamerika lebenden Gattungen Hapale Illig. und Midas Geoffroy ist nur die erste durch eine in brasilianischen Knochenhöhlen vorkommende Art - Hapale penicillata Geoffroy - auch fossil vertreten.

\section{Familie. Cebidae.}

2. 1. 3. 3. Obere und untere $M$ vierhöckerig, $P$ zweihöckerig. Alle Zehen mit Nägeln. Schwanz lang.

Lebend in Süd- und Zentralamerika, fossil im Pleistocän von Brasilien und im Tertiär von Patagonien.

Mycetes seniculus L., Callithrix personata Geoffr. und Cebus fatuellus L. auch fossil in brasilianischen Knochenhöhlen, daselbst auch der ausgestorbene Eriodes protopithecus Winge (Protopithecus brasiliensis Lund.)

Homunculus Ameghino (Ecphantodon Mercerat). $C$ wenig vorragend und wie die einwurzeligen, kleinen $P$ mit Basalband, das an der Innenseite mit kleinen Höckerchen versehen ist. $M$ gerundet viereckig mit fünf schwachen, bogenförmig miteinander verbundenen Höckern. Vorderhälfte der $M$ höher als die Hinterhälfte. Unterkiefer hoch, fast parallel gestellt, eine feste Symphyse bildend. Obermiocän von Santa Cruz. Patagonien. H. patagonicus Ameghino.

Anthropops und Eudiastatus Ameghino. Nur Unterkiefersymphyse bekannt. Pitheculus Ameghino nur Unterkieferfragment. Alle drei aus dem Obermiocän von Santa Cruz. 
Clenialites und Pitheculites Ameghino aus den Colpodonschichten von Patagonien sind überhaupt keine Primaten.

\section{Familie. Parapithecidae. Schlosser.}

2.?1.3.3. J klein, $C$ (?) nur wenig größer als $J$ und ebenfalls etwas vorwärts geneigt, $P$ mit Ausnahme von $P_{4}$ einfach, ohne Innenhöcker. $M$ aus je zwei Paar dicken Höckern und einem kleinen Hinterhöcker bestehend. Vordere Hälfte der M etwas höher als die hintere. Höcker an $M_{1}$ und $M_{3}$ alternierend, an $M_{2}$ oppo. niert. Unterkiefer niedrig, stark divergierend, mit schräg ansteigendem hinteren Ast, ohne feste Symphyse.

Zahnzahl, Form der Zähne und Beschaffenheit der Kiefer und Körpergröße vermitteln vollständig den Übergang von den Anaptomorphiden und Tarsiiden zu den Simiiden, namentlich $\mathrm{zu}$ Pliopithecus. Zweifelhaft ist dagegen die Verwandtschaft mit den Cynopitheciden. Direkte Vorläufer der Cebiden können die Parapitheciden nicht sein wegen der Einzahl der unteren $J$.

Parapithecus Schlosser. (Figur 744.) Oligocän des Fayum Ägypten P. Fraasi.

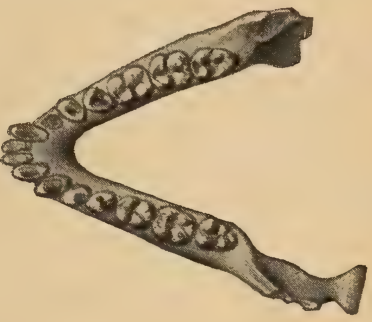

Fig. 744.

Parapithccus Fraasi Schlosser. Oligocän. Fayum. Ägypten. Unterkiefer nat. Gr. da M. Markgrafi Schl.

\section{Familie. Cynopithecidae. Hundsaffen.}

$\frac{2.1 .2 .3 .}{2.1 .2 .3 .} M$ oben und unten vierhöckerig, Höcker paarig opponiert. Außenhöcker von den Innenhöckern bald durch eine Längsfurche getrennt, bald durch Querjoche verbunden. $M_{3}$ mit drittem Lobus. $P_{2}$ zweihöckerig, unterer $P_{3}$ vergrößert. Schnauze vorspringend, häufig verlängert. Extremitäten plantigrad. Arme und Beine fast gleich lang. Schwanz meist lang.

Die lebenden Cynopitheciden zerfallen in die altweltlichen Paviane, Makak, Meerkatzen, Stummel- und Schlankaffen. Sie gehen fast immer auf allen Vieren, treten mit der ganzen Sohle auf und haben meist einen langen Schwanz, sowie Backentaschen und Gesäßschwielen. Die in Europa, Asien und Afrika fossil vorkommenden Formen schließen sich ziemlich enge an lebende Gattungen an.

Oreopithecus Gervais. Eckzähne oben und unten schwach. Obere $M$ gleich groß, mit zwei Paar opponierten, durch eine mediane Längsfurche getrennten, konischen Höckern und starkem Basalband. Die oberen $P$ mit hoher Außen- und kräftiger Innenspitze: Untere $M$ schmäler als die oberen mit zwei Höckerpaaren und unpaarem Hinterhöcker, der an $M_{3}$ sehr groß ist. Unterpliocän. Monte Bamboli, Toscana. O. Bambolii Gerv.

Cynocephalus Lacépède. Pavian. Lebend in Afrika und Arabien. Fossil in den Siwalikschichten von Ostindien C. (Semnopithecus) subhima. layanus Mey. sp. C. Falconeri Lyd. und in pleistocänen Knochenhöhlen von Madras.

Semnopithecus Cuv. Lebend in Südostasien. Fossil im Pliocän von Montpellier und von Casino in Toskana S. monspessulanus Gerv., in den Siwalikschichten von Indien S. palaeindicus Lyd., im Pleistocän von Madras S. entellus Düf.

Mesopithecus Wagner. Schädel und Gebiß wie bei Semnopithecus, Skelett plumper, Macacus ähnlicher. $C$ beim Männchen viel stärker als 
beim Weibchen. Schwanz lang. M. Pentelici Wagner aus dem Unterpliocän von Pikermi bei Athen, Baltavàr (Ungarn) und Maragha (Persien) ist der häufigste und am vollständigsten bekannte fossile Affe.

Dolichopithecus Depéret. Ähnlich Semnopithecus, jedoch Schnauze länger und Extremitäten kürzer und plumper. Im Pliocän von Perpignan D. ruscinensis Dep.

Zeitliche und räumliche Verbreitung der Primaten.

\begin{tabular}{|c|c|c|c|c|c|}
\hline & Afrika & Europa & Asien & Nordamerika & Suidamerika \\
\hline $\begin{array}{c}\text { Jetzt- } \\
\text { zeit }\end{array}$ & $\begin{array}{l}\text { Schimpanse } \\
\text { Gorilla } \\
\text { Cynopithecidae } \\
\text { Lemuridae } \\
\text { Chiromyidae } \\
\text { Galaginae }\end{array}$ & Macacus & $\begin{array}{l}\text { Simia } \\
\text { Hylobates } \\
\text { Cynopithecidae } \\
\text { Lorisinae } \\
\text { Tarsiidae } \\
\quad \text { ? }\end{array}$ & & $\begin{array}{l}\text { Cebidae } \\
\text { Hapalidae }\end{array}$ \\
\hline $\begin{array}{l}\text { Plei- } \\
\text { stocän }\end{array}$ & $\begin{array}{l}\text { Macacus } \\
\text { Cynocephalus } \\
\text { Megaladapis } \\
\text { Lemur } \\
\text { Palaeopropithecus } \\
\text { Archaeolemur } \\
\text { Bradylemur } \\
\text { Hadropithecus }\end{array}$ & Macacus & $\begin{array}{l}\text { Pithecanthropus } \\
\text { Semnopithecus } \\
\text { Cynocephalus }\end{array}$ & & $\begin{array}{l}\text { Cebus } \\
\text { Mycetes } \\
\text { Eriodes } \\
\text { Callithrix } \\
\text { Hapale }\end{array}$ \\
\hline $\begin{array}{l}\text { Plio- } \\
\text { cän }\end{array}$ & & $\begin{array}{l}\text { Anthropodus } \\
\text { Dryopithecus } \\
\text { Dolichopithecus } \\
\text { Macacus } \\
\text { Semnopithecus } \\
\text { Mesopithecus } \\
\text { Oreopithecus }\end{array}$ & $\begin{array}{l}\text { Palaeopithecus } \\
\text { Macacus } \\
\text { Semnopithecus } \\
\text { Cynocephalus }\end{array}$ & & \\
\hline $\begin{array}{l}\text { Mio- } \\
\text { cän }\end{array}$ & & $\begin{array}{l}\text { ? Dryopithecus } \\
\text { Pliopithecus }\end{array}$ & - & & $\begin{array}{l}\text { Homunculus } \\
\text { Anthropops? } \\
\text { Eudiastatus ? } \\
\text { Pitheculus? }\end{array}$ \\
\hline $\begin{array}{c}\text { Oli- } \\
\text { gocän }\end{array}$ & $\begin{array}{l}\text { Propliopithecus } \\
\text { Parapithecus } \\
\text { Moeripithecus }\end{array}$ & - & & & \\
\hline Eocän & & $\begin{array}{l}\text { Adapis } \\
\text { Caenopithecus } \\
\text { Cryptopithecus } \\
\text { Pronycticebus } \\
\text { Necrolemur } \\
\text { Microchoerus }\end{array}$ & & $\begin{array}{l}\text { Notharctus } \\
\text { Pelycodus } \\
\text { Anaptomorphus } \\
\text { Omomys } \\
\text { Washakius } \\
\text { Trogolemur }\end{array}$ & \\
\hline
\end{tabular}

Macacus Lacépéde (Inuus Geoffroy, Aulaxinuus Cocchi). Obere $M$ niedrig, vierseitig mit zwei Paar konischen oder kantigen, bald durch eine Längsfurche getrennten, bald durch Joche verbundenen Höckern. $P$ mit Außen- und Innenhöcker. Untere $M$ wie die oberen, nur schmäler. $C$ beim Männchen sehr kräftig. M. (Inuus) ecaudatus Geoffr. ist der einzige in Europa (Gibraltar) lebende Affe. Die übrigen Arten sind weit verbreitet im südlichen und östlichen Asien und bewohnen zum Teil Gebirge - 
Tibet, Himalaya, Japan. - Im Pliocän von Montpellier M. priscus Gerv., im Pliocän des Val d' Arno M. (Aulaxinuus) florentinus Cocchi. In den Siwalikschichten von Ostindien $M$. sivalensis Lyd. und im Pleistocän von Java, II. (Inuus) nemestrinus var. saradana Deninger. Aber auch im europäischen Pleistocän haben sich Überreste von Macacus gefunden. Im Heppenloch bei Kirchheim in Württemberg $M$. (Inuus) suevicus Hedinger, in einer Höhle bei Montsaunès (Haute Garonne) fand Harlé einen Unterkiefer zusammen mit Resten von Hyaena striata - M. tolosanus Harlé, und kürzlich fand Forsyth Major zahlreiche Kiefer bei Cap Faro auf Sardinien. Aus dem Pleistocän von Algerien stammt Macacus trarensis Pomel.

\section{Familie. Simiidae. Menschenaffen.}

$\frac{2.1 .2 .3 .}{2.1 .2 .3 .}$ Obere und untere $M$ vierhöckerig, Innen- und Außenhöcker miteinander alternierend. An den unteren $M$ in der Regel ein dritter Außenhöcker oder ein Höcker am Hinterrand vorhanden. An den oberen $M$ Außenhöcker mit dem ersten Innenhöcker mehr oder weniger innig verbunden, zweiter Innenhöcker kleiner als der erste. $P$ kürzer als lang, zweihöckerig. Schädel mit Sagittalund Supratemporalkamm oder mit Supratemporalwülsten. Vordere Extremität länger als die hintere. Gang meist aufrecht. Ohne Schwanz und ohne Gesäßschwielen (abgesehen von Hylobates).

Die Simiiden stehen dem Menschen im Skelettbau und in der Beschaffenheit des Gehirns am nächsten. Auch besitzen sie die Fähigkeit aufrecht zu gehen, wobei sie freilich nicht mit der Sohle, sondern mit dem äußeren Rand des Fußes auftreten.

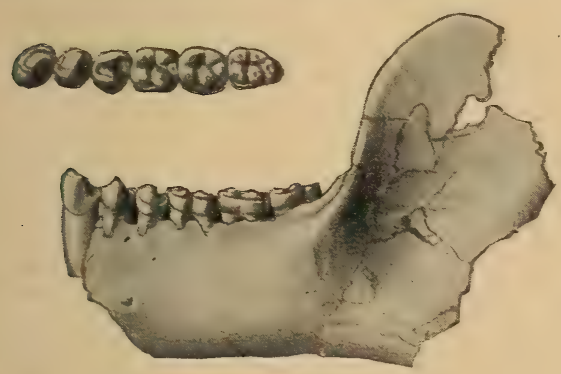

Fig. 745 .

Propliopithecus Haeckeli Schlosser. Oligocän.

Fayum. Ágypten. Unterkiefer. und untere $C$ bis $M_{3}$ von oben, nat. Gr.
Auch das Gebiß nähert sich dem des Menschen, es unterscheidet sich hauptsächlich durch die etwas größere Länge der $M$ und die stärkere Entwicklung der Eckzähne, die mit der Ausbildung eines Scheitel- und Hinterhauptkammes oder doch von Schläfenwülsten verbunden ist.

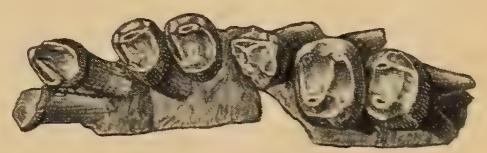

Fig. 746.

Pliopithecus antiquus Gervais. Obermiocän. Göriach in Steiermark. Oberkiefer, nat. Gr.

Propliopithecus Schlosser. (Fig. 745). $J$ und $C$ klein und aufrecht, $P$ einfach, nur der hintere mit Innenhöcker, $M$ niedrig mit kleinem Höcker am Hinterrand. Unterkiefer hoch, parallel gestellt, mit hohem, breitem aufsteigenden Ast. Sicher der Ahne der folgenden Gattung und wohl auch aller Simiiden und Hominiden. Oligocän des Fayum, Ägypten. P. Fraasi Schl.

Pliopithecus Gervais (Protopithecus Lartet) (Fig. 746). J schmal, ziemlich lang, $C$ individuell sehr kräftig. Vorderer unterer $P$ einspitzig, untere $M$ mit zwei Paar stumpfen Höckern und einem unpaaren Hinterhöcker. Obere und untere $M$, abgesehen von dem starken Basalband, denen von Hylobates sehr ähnlich. Im Miocän von Sansan (Gers.), La Grive S. Alban (Isère), des Orléanais und von Oppeln in Schlesien, ferner im bayrischschwäbischen Dinotheriumsand, und in den Braunkohlen von Elgg (Schweiz) und Göriach (Steiermark). $P$. antiquus ( $P$. platyodon Biederm.) Blainv. sp. Größe wie vom lebenden Gibbon, jedoch Unterkiefer viel höher. 
Palaeopithecus Lydekker. Nur Oberkiefer bekannt. P relativ klein und breit. $M$ vierhöckerig, glatt, menschenähnlich. Schimpansengröße. Pliocän der Siwalik von Jobi im Pundschab. P sivalensis Lyd.

Dryopithecus Lartet (Paedopithex, Pohlig, Pliohylobates Dubois) Unterkieferäste hoch, fast noch parallel gestellt, mit schwachen, vorwärts geneigten $J$, starkem $C$, großem einspitzigen $P_{3}$ und langem zweihöckerigem, mit Talon versehenen $P_{4}$. An Stelle des fünften Höckers des $M_{1}$ und $M_{2}$, an $M_{3}$ ein Doppelhöcker. Obere $M$ mit zwei großen Außen- und zwei ungleichen Innenhöckern, von denen der vordere, größere, mit beiden Außenhöckern verbunden ist. Schmelz aller $M$ stark gerunzelt. Humerus - von St. Gaudens - schlank, viel kürzer als das gerade, dünne Femur - von Eppelsheim. Dryopithecus hatte die Dimensionen des Schimpanse und ist auch wohl dessen Stammvater sowie von Orang Utang und Gorilla. Im Miocän von St. Gaudens (Haute Garonne) D. Fontani Lartet, im Unterpliocän von Eppelsheim und in Bohnerzen von Schwaben D. rhenanus Pohlig sp.

Dryopithecus Darwini und Gryphopithecus Suessi Abel, aus dem Miocän von Neudorf im Wiener Becken sind durchaus problematisch.

Anthropodus Schlosser. Nur unterer $M_{3}$ bekannt, viel länger als breit, mit vier niedrigen Höckern und großem Talonid. Runzelung mäßig. Unterpliocän, Bohnerz von Salmendingen. A. Brancoi Schl. Verwandtschaft mit Pithecanthropus und Homo nicht ausgeschlossen.

\section{Familie. Hominidae.}

Aufrechter Gang. Hand mit opponierbarem Daumen. Füße plantigrad, große Zehe nicht opponierbar. $\frac{2.1 .2 .3}{2.1 .2 .3 .}$ in geschlossener Reihe, halbkreisförmig angeordnet. C schwach, nicht höher als die J. Schädel ohne Scheitelkamm und ohne Schläfenwülste. Augenhöhle hinten durch eine Wand abgeschlossen. Gehirn gro $\beta$ mit zahlreichen Windungen.

Pithecanthropus Dubois. Schädeldach schmal, wenig gewölbt, mit postorbitaler Einschnürung. Ohne Sagittalcrista und ohne Schläfenwülste, $M^{3}$ stark reduziert, ohne deutliche Höcker mit vielen Runzeln. Femur lang. schlank, für aufrechten Gang geeignet. Unterpleistocän von Trinil in Java. $P$. erectus Dubois. ${ }^{1}$ )

Man kennt zwar nur das Schädeldach, einen Zahn und das Femur von Pithecanthropus, allein gerade diese Stücke sind am geeignetsten, uns ein Bild von seiner Organisation zu geben. Weil der Schädel trotz seiner Größe weder Scheitelkamm noch Schläfenwülste besitzt, so kann es nicht dem geringsten Zweifel unterliegen, daß die Eckzähne nicht größer gewesen sein können als die $J$. Auch kann der untere $P_{3}$ nicht spezialisiert gewesen sein wie bei den eigentlichen Menschen-Affen. Es kann sich daher nur um einen Vertreter der Hominiden handeln. Auch die Form des $M^{3}$ kann höchstens beim Menschen, aber niemals bei einem Menschen-Affen vorkommen, und selbst das Femur läßt sich nur dem menschlichen an die Seite stellen. Während manche Anthropologen in Pithecanthropus einen riesigen Hylobates erblicken wollten, betonen Turner, Topinard, Manouvrier und andere die große Ähnlichkeit mit dem Menschen. Auch Schwalbe findet im Schädelbau weitgehende Unterschiede gegenüber dem der Menschen-Affen. Es ist überhaupt ziemlich wahrscheinlich, daß wir es nur mit einer alten Spezies des Genus Homo zu tun haben.

1) Dubois $E$., Pithecanthropus erectus, eine menschenähnliche Ubergangsform aus Java. Batavia 1894. - Schwalbe G., Studien über Pithecanthropus. Zeitschrift für Morph. u. Anthr. 1899. 
Homo L. ${ }^{1}$ ) Der Mensch wurde schon von Linné zu den Primaten gestellt, denen er sich in körperlicher Hinsicht auch aufs engste anschließt. Die rundliche gewölbte Form der sehr geräumigen Schädelkapsel, das Überwiegen des Gehirnschädels über das Gesicht und die fehlende Sagittalcrista unterscheiden zwar den Kopf des Menschen von dem aller Simiiden, dafür stehen aber manche Cebiden in dieser Hinsicht sehr nahe. Auch das Gehirn unterscheidet sich nur in der relativen Größe von dem der Affen. Es hat sonst den nämlichen Bauplan. Die frühzeitige Verschmelzung der Zwischenkiefer mit dem Oberkiefer sowie das Fehlen von Zahnlücken sind unerhebliche Merkmale. Das steil abfallende orthognathe Gesicht, die damit in Zusammenhang stehende, fast vertikale Unterkiefersymphyse mit dem etwas vorspringenden Kinn, die Hufeisenform der Unterkiefer und der hierdurch geschaffene breite Raum für die Zunge unterscheiden den Menschen von den Simiiden, allein die ältesten bekannten Menschenschädel zeigen bereits einen gewissen Grad von Prognathismus, das Kinn ist wenig oder gar nicht entwickelt, die Wölbung und Kapazität des Schädels wird geringer, die Supraorbitalwülste werden größer, so daß sich die Unterschiede gegenüber den Affen immer mehr verwischen. Das Gebiß stimmt in Zahl und Form der Zähne mit dem der Simiiden überein, jedoch sind die $C$ schwächer und schließen dicht an ihre Nachbarn an, und die Höcker der Molaren sind stumpfer und breiter als bei den Affen. Obere und untere Molaren bestehen aus je vier Höckern, zu welchen jedoch im Unterkiefer in der Regel noch ein fünfter kommt, wie bei den Simiiden, während im Oberkiefer der kleine zweite Innenhöcker verschwinden kann. Bei den Negritos und den Negern erscheint zuweilen wie beim Orang Utang ein vierter Molar, während bei den zivilisierten Rassen der letzte Molar (Weisheitszahn) nicht selten ausbleibt.

Der aufrechte Gang des Menschen wird bedingt durch die doppelte $S$-förmige Krümmung der Wirbelsäule, die beträchtliche Länge und Muskulatur der Beine und die Breite der Schulter. Dagegen ist die relative Kürze der Arme viel eher ein primitives Merkmal als eine Folge des aufrechten Ganges. Die menschliche Hand übertrifft an Beweglichkeit, namentlich des Daumens, bei weitem die der Affen. Die Fußsoble liegt horizontal, Metatarsus und Tarsus bilden ein Gewölbe und die große Zehe dient nicht mehr als Greiforgan, sondern nur als Stütze des Körpers.

Unsere Kenntnis des prähistorischen Menschen hat in den letzten Dezennien ungeheure Fortschritte gemacht. Aus fast ganz Europa und den benachbarten Teilen von Asien sowie aus Nordafrika sind erstaunliche Mengen von Erzeugnissen menschlicher Kultur aus der Eisen- und Bronzeund aus der jüngeren Steinzeit zum Vorschein gekommen, nicht minder auch Überreste der Tiere, welche der Mensch gezüchtet oder gejagt hatte, und selbst zahlreiche mehr oder weniger vollständige menschliche Skelette

1) Birkner $F$., Die ältesten menschlichen Knochenreste. Beiträge zur Anthr. und Urgeschichte Bay. Bd. XVIII. 1909. - Boule M., Les Grottes de Grimaldi. L'Anthrop. 1906. - Observat. sur un silex taillée et sur la Chronologie de M. Penck. L'Anthrop. 1908. - Gorjanovic Kramberger, Der diluviale Mensch von Krapina. Wiesbaden 1906. - Klaatsch $H$, Die neuesten Ergebnisse der Paläontologie d. Mensch. Zeitschr. f. Ethnol. 1909. - Lehmann-Nitsche, Nouvelles recherches sur la format. Pampéenne et l'homme fossile de la Rep. Argentine. Revista del Museo de la Plata XIV 1907. - Obermaier H., Les restes humaines quaternaires L'Anthr. 1905, 1906. - Les formationes glaciaires des Alpes. L'Anthr. 1909. - Die Steingeräte des franz. Altpaläolithikums. Mitteil. prähist. Komm. kaiserl. Akad. Wien 1908. - Schoetensack, Der Unterkiefer des Homo heidelbergensis Leipzig 1908. - Schwalbe G., Der Neandertalschädel. Bonner Jahrbuch 1901. Zur Frage der Abstammung d. Menschen. Zeitschr. f. Morph. u. Anthr. 1906. Verneau R., Les fossiles aux Baoussé Roussé. Un nouveau type humain. L'Anthr. 1902. - Les Grottes de Grimaldi L'Anthr. 1906. 
hat die Forschung zutage gefördert. Für den Paläontologen bieten jedoch diese Funde kein weiteres Interesse, denn die Zeit, zu welcher diese Menschen lebten, war hinsichtlich des Klimas, der Pflanzen- und Tierwelt und der geologischen Verhältnisse von der Gegenwart nicht mehr verschieden. Diese Menschenreste und die damalige Kultur fallen daher ganz in das Gebiet der Anthropologie und Archäologie. Uns interessieren nur jene Überreste des Menschen und seiner Kultur, welche noch dem eigentlichen Pleistocän angehören, also den Perioden der mehrmaligen Vergletscherungen, der Zwischeneiszeiten und der unmittelbar auf die letzte Vergletscherung folgenden Postglazialzeit. Der damalige "paläolithische" Mensch besaß noch keine Haustiere, er kannte noch keinen Feldbau, die Kunst der Töpferei
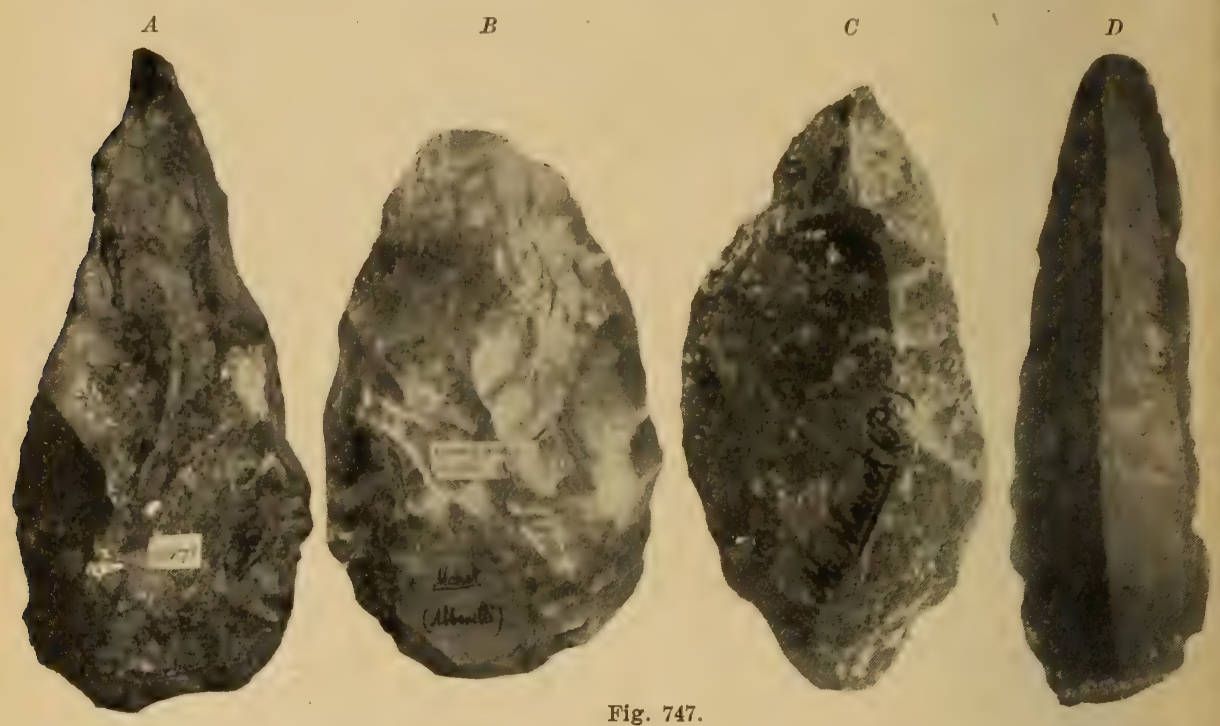

Paläolithische Steinwerkzeuge. $A$ Chelléen, $1 / 3$ nat. Gr. $B$ Acheuléen, $2 / 3$ nat. Gr. $C$ Mousterien, nat. Gr. $D$ Magdalénien, nat. Gr.

und die Bearbeitung von Metallen war ihm noch gänzlich fremd, ja selbst die Anfertigung von polierten, den „neolithischen“, Steingeräten hatte er noch nicht erlernt, er war vielmehr darauf beschränkt, durch Schlag, Absprengen und Nacharbeiten der Ränder seine Steinwerkzeuge zweckdienlich zu gestalten. Die Form dieser Steinwerkzeuge und die Art ihrer Herstellung bietet nun ein Mittel für die Bestimmung der Zeit, in welcher der Mensch sich ihrer bediente. Man benennt diese verschiedenen Perioden nach den Fundorten, die zuerst die charakteristischesten Objekte geliefert haben und unterscheidet so von den jüngsten bis zu den ältesten Magdalénien, Solutréen, Aurignacien, Moustérien, Acheuléen und Chelléen (Fig. 747).

Im letzten Abschnitt des »Paläolithicums , dem Magdalénien, hatte der Mensch zwar nur kleine Feuersteingeräte, die Mehrzahl seiner Waffen und Gebrauchsgegenstände verfertigte er aus Knochen und Geweihen von Renntier, aber er versah sie nicht selten mit Ornamenten, die zum Teil zwar nur in Linien bestehen, zum Teil aber auch Tiere, namentlich Ren, Pferd (Fig. 748) und Mammut, in durchaus künstlerischer Ausführung darstellen. Selbst die Wände vieler von ihm bewohnter Höhlen in Südfrankreich und Spanien hat er mit farbigen Abbildungen solcher Tiere geschmückt (Fig. 749), unter 
welchen besonders Bison sehr häufig vertreten ist. ${ }^{1}$ ) Auch der Vorgänger dieses Menschen der »Renntierzeit«, der Mensch des Solutréen, war bereits ein Künstler, jedoch hinterließ er keine Gravierungen auf Knochen, oder Stein, oder farbige Bilder, sondern Schnitzereien in Stein, Knochen und Elfenbein, welche vorwiegend menschliche Figuren darstellen. Man kennt solche aus Frankreich, Mähren und Niederösterreich. Die auch in Ungarn und Süddeutschland gefundenen, lorbeerblattähnlichen Steingeräte des Solutréen bilden einen schroffen Gegensatz zu den roh bearbeiteten Kratzern und Schabern des Moustérien, zu welchen jedoch die Steinwerkzeuge des Aurignacien den Übergang vermitteln. Das in ganz Mitteleuropa verbreitete

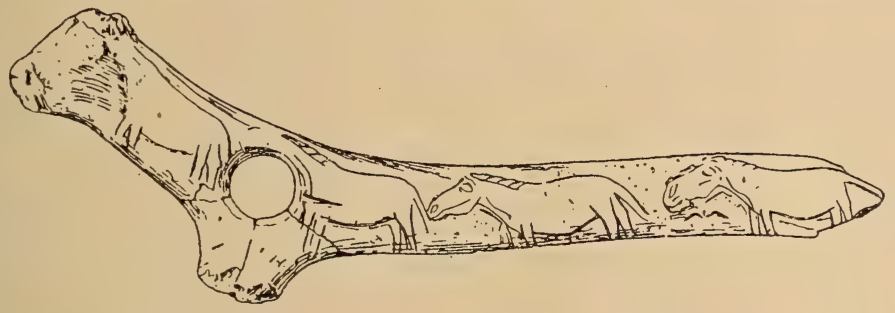

Fig. 748.

„Kommandostab" aus Renntiergeweih mit Gravierung. Magdalénien.

und in Frankreich besonders häufige Moustérien fällt wahrscheinlich teils in die letzte Eiszeit, teils in die ihr vorhergehende zweite - die kalte Phase des letzten Interglazials. Diese Industrie ist vergesellschaftet mit Rhinoceros tichorhinus und Elephas primigenius in Krapina jedoch mit Rhinoceros Mercki, in Taubach auch mit Elephas antiquus. Freilich kommen in Taubach keine ganz typischen Moustérien-Werkzeuge vor, dagegen kann in Krapina über die Gleichzeitigkeit der zahlreichen Reste des Menschen und des Rhinoceros Mercki mit typischem Moustérien kein Zweifel bestehen. Wo jedoch sonst diese beiden, ein warmes Klima anzeigenden Säugetierarten zusammen mit Steinwerkzeugen vorkommen. sind es immer solche des Chelléen, charakterisiert durch die großen Faustkeile, deren Ränder nicht sorgfältig nachretuschiert wurden. Zwischen Chel-

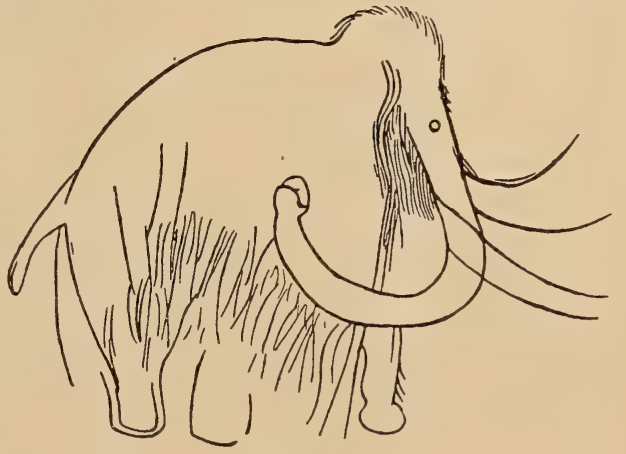

Fig. 749 .

Bild eines Mammut aus der Höhle von Combarelles. léen und Moustérien vermitteln die Steinwerkzeuge des Acheuléen zeitlich und auch in ihrer Bearbeitung den Übergang. Das Klima hat sich während des Acheuléen verschlechtert.

Mit dem Chelléen enden die sicher vom Menschen hergestellten Steinwerkzeuge. Man kennt zwar aus noch älterem Pleistocän und sogar aus dem Tertiär bis in das Oligocän die sog. Eolithe, deren Schlagspuren und Absplisse dem Menschen oder doch seinem Vorgänger zugeschrieben werden. Auch sollen sie ihre Form nicht einer wirklichen Bearbeitung, sondern nur

1) Nach den neuesten Untersuchungen Obermaiers fällt die einfache Umrißzeichnung in das Aurignacien, die Anfertigung schattierter und modellierter Bilder in das Solutréen und die polychrome Darstellung in das Magdalénien. 
der Benutzung von seiten des Menschen verdanken. Allein solche Eolithe können auch auf rein natürlichem Wege entstehen, bei dem Transport von Feuersteinen in wirbelndem Wasser und in Brandungswellen und sind daher kein Beweis für die einstige Anwesenheit des Menschen. Vor allem spricht gegen die Deutung der Eolithe als Gebrauchsgegenstand des Menschen der Umstand, daß sie bereits im Oligocän den nämlichen Charakter haben wie im Pleistocän, also keinerlei Fortschritt zeigen. Es müßtè daher der Mensch schon im Oligocän fertig entwickelt gewesen sein und somit auch schon seine jetzige Körpergröße erreicht haben, eine Annahme, welche mit unseren Erfahrungen über die Entwicklung der Säugetierstämme gänzlich unvereinbar ist.

Entsprechend den zahlreichen Funden von Geräten des paläolithischen Menschen hat auch die Zahl seiner körperlichen Reliquien in der letzten Zeit einen so gewaltigen Zuwachs erfahren, daß wir jetzt nur mehr jene Reste zu berücksichtigen haben, deren geologisches Alter vollkommen sicher gestellt ist. Die jüngsten paläolithischen Menschenreste sind jene aus dem Magdalénien. Sie gehören der Cro-Magnon-Rasse an, welche sich im Schädel- und Kieferbau schon enge an die lebenden Europäer anschließt. Skelette der Cro-Magnon-Rasse kennt man aus mehreren Höhlen in der Dordogne, aus einer Höhle bei Roussillon und aus einer Höhle bei Mentone. Außerdem werden zu dieser Rasse gestellt die Schädel von Brünn, von Brüx, von Podblaba, von Egisheim im Elsaß, von Engis in Belgien und von Tillbury und Galley Hill in England, jedoch sollen einige von ihnen, namentlich der von Tillbury, schon den Übergang zu der Neandertalrasse, dem Homo primigenius bilden, welche für das Moustérien charakteristisch ist. Diese Rasse zeichnet sich durch geringere Schädelkapazität, durch die geringe Wölbung der Stirn, durch die schwache Aufrichtung der Hinterhauptsfläche, durch die vorspringenden Supraorbitalwülste und durch das Fehlen eines vorspringenden Kinnes aus, welche Merkmale Kla ats ch auch bei den lebenden Australiern beobachtet hat. Man sollte daher konsequenterweise auch für diesen lebenden Typus eine besondere Spezies errichten. Außer Schädeln kannte man bisher auch schon Extremitätenknochen vom Neandertal im Rheinland und von Spy in Belgien. Sie unterscheiden sich durch ihre Plumpheit und Krümmung, durch die gleichmäßigere Rundung des Diaphysenquerschnittes, durch die Rückwärtsverlängerung der Femurcondyli und durch ihre Platyknemie von den Schenkelknochen des lebenden Menschen. Erst vor kurzem wurden Skelette dieser Menschenrasse auch bei Le Moustier in der Dordogne und bei La Chapelle aux Saints (Corrèze) gefunden, dagegen scheint der Schädel des neuentdeckten Skeletts von Montferrand de Périgord in der Dordogne dem von Galley Hill ähnlicher zu sein. Die Grimaldi-Grotte bei Mentone enthielt Skelette, welche nach Verneau negroide Merkmale zur Schau tragen, nämlich stark vorstehende Kiefer und Backenknochen und flache Nase. Sie waren vergesellschaftet mit Resten von Rhinoceros Mercki, Hippopotamus und Elephas antiquus und mit Steinwerkzeugen des Moustériens. Auch in Krapina in Kroatien fanden sich zahlreiche Menschenreste zusammen mit Rhinoceros Mercki und mit Industrie des Moustériens. Schwalbe stellt auch den Menschen von Krapina zu seinem Homo primigenius, er unterscheidet sich aber von dem echten Neandertalmenschen durch die starke Runzelung des Schmelzes und den auffallend hohen Wurzelhals seiner Backenzähne. Aus der Zeit des Acheuléen und Chelléen sind bis jetzt keine menschlichen Reste gefunden worden, abgesehen etwa von den erwähnten Skeletten von Mentone, welche wenigstens $\mathrm{Boule}$ in die Zeit des Chelléen zu versetzen geneigt ist. Um so größeres Interesse verdient daher der in Mauer bei Heidelberg gefundene Unterkiefer des Homo heidelbergensis, denn er stammt aus den ältesten bekannten außeralpinen Pleistocänschichten. Schon seine Begleitfauna, welche zum Teil aus Arten der pliocänen Val d'Arno-Fauna besteht, würde die 
Aufstellung einer besonderen Spezies vollständig rechtfertigen. Der Unterkiefer gleicht vollkommen dem der Anthropomorphen, die Zähne sind jedoch echte Menschenzähne. Durch die Reduktion seines letzten Molaren schließt sich Homo heidelbergensis enge an Pithecanthropus an. Ein genetischer Zusammenhang zwischen diesem und der Gattung Homo ist überaus wahrscheinlich, zum mindesten gehen beide auf eine gemeinsame Stammform zurück.

In Nordamerika fehlt es zwar keineswegs an Überresten des prähistorischen Menschen, allein ihr geologisches Alter ist nur in den seltensten Fällen näher zu ermitteln und dürfte höchstens bei einigen wenigen Funden in die letzte Interglazialzeit fallen, wie etwa bei dem Menschen von Lansing in Kansas. Somatische Unterschiede gegenüber dem jetzigen Menschen scheinen nicht $\mathrm{zu}$ bestehen. Die ältesten Steinwerkzeuge sollen nach Wilson dem Chelléentypus angehören. Sie stammen von der atlantischen Küste, von Ohio und vom Mississippi. Den Calaveras-Schädel hält Wils on für echt fossil, Sinclair hingegen ist der Ansicht, daß er erst später in die dortigen goldführenden Sande gekommen sein dürfte. Menschenknochen in Gesellschaft von ausgestorbenen Tieren wurden an verschiedenen Orten gefunden, bei Trenton zusammen mit Mammut, Mastodon und Ovibos, bei Natchez am Mississippi zusammen mit Mylodon, Megalonyx und Mastodon. Auch Steinwerkzeuge hat man im Missouri neben einem Mastodon-Skelett und in Kansas neben Bisonresten beobachtet. Dagegen sind alle Menschen. reste, welche in Höhlen zusammen mit ausgestorbenen Tieren gesammelt wurden, anscheinend jünger als diese Tiere.

Mindestens ebenso gering wie das Alter des prähistorischen Menschen in Nordamerika ist auch das der menschlichen Überreste aus Südamerika. Der scheinbar älteste, von hier bekannte menschliche Knochen ist ein Atlas aus den unteren Pampasschichten von Monte Hermoso. Aus den mittleren stammt der Schädel von Baradero in Argentinien. Der oberen Pampasformation gehören die Menschenknochen von Carcarañâ, Frias und Saladero, von Fontezuelas, vom Ufer des Samborombón, von Arrecifes, Chocoré und von La Tigra an. In Knochenhöhlen Brasiliens hatte schon Lund Menschenschädel zusammen mit Überresten von lebenden und ausgestorbenen Säugetieren gefunden, aber weder diese, noch auch die vorher erwähnten, von Lehmann-Nitsche genau studierten Menschenreste aus Argentinien zeigen Unterschiede gegenüber den jetzigen südamerikanischen Indianern. Die Gleichzeitigkeit von Mensch und ausgestorbenen Säugetieren, z. B. Riesenedentaten, scheint in Südamerika noch in die jüngste Vergangenheit zu fallen, wie die Funde in der Höhle von Ultima Esperanza in Patagonien beweisen, wo ein Mylodon - ähnliches Tier anscheinend sogar in Gefangenschaft gehalten wurde, von welchem hier auch noch Fellstücke und Kotballen erhalten geblieben sind.

Was den paläolithischen Menschen Afrikas betrifft, so scheint seine Existenz in Ägypten, vielleicht auch in Algerien ziemlich sicher gestellt zu sein, obschon über körperliche Überreste bisher nichts berichtet wurde und seine Anwesenheit bloß durch bearbeitete Feuersteine bewiesen ist. Im Kapland wurden vor kurzem Menschenreste in Zinkminen gefunden, deren Alter indessen kaum sehr weit zurückdatieren dürfte, denn die mit ihnen aufgesammelten Säugetierknochen gehören noch lebenden Arten an.

Asien wird voraussichtlich noch manche interessante Funde der paläolithischen Menschen liefern. Bis jetzt kennt man freilich erst aus Höhlen in Syrien Stationen des jungpaläolithischen Menschen, dagegen hat man auf Java in den Kendengschichten, welche bei Trinil auch die Reste des Pithecanthropus enthielten, einen Menschenzahn gefunden, welchem unzweifelhaft ein altpleistocänes Alter zukommt. In Birma wollte man auf Grund von wirklich geschlagenen Feuersteinen die Existenz des pliocänen 
Menschen bereits zusammen mit Hipparion nachgewiesen haben, allein genauere Untersuchungen ergaben, daß diese Silex nur auf der Oberfläche vorkommen. Gleichwohl dürfte Asien noch eine reiche Ausbeute an Werkzeugen und körperlichen Resten der ältesten Menschen in Aussicht stellen, denn nur Asien und Europa können als Urheimat des Menschen ernstlich in Betracht kommen.

\section{Chronologische Übersicht.}

\begin{tabular}{|c|c|c|c|c|c|}
\hline \multicolumn{3}{|c|}{ Geologische Gliederung } & \multicolumn{3}{|c|}{ Archäologische Gliederung } \\
\hline Penck und & Obermaier & Boule & Penck & Boule & Obermaier \\
\hline \multirow[t]{2}{*}{ Nacheiszeit } & letzte Phase & \multirow[t]{2}{*}{ Nacheiszeit } & \multirow[t]{2}{*}{ Magdalénien } & Magdalénien & $\left\{\begin{array}{l}\text { Magdalénien } \\
\text { Solutréen } \\
\text { Aurignacien }\end{array}\right.$ \\
\hline & erste Phase & & & Solutréen & \multirow{2}{*}{ Moustérien } \\
\hline \multicolumn{2}{|c|}{ IV. Würmeiszeit } & III. Eiszeit & Solutréen & Moustérien & \\
\hline $\begin{array}{l}\text { 3. Zwischen- } \\
\text { Eiszeit }\end{array}$ & $\left\{\begin{array}{l}\text { Kalte Phase } \\
\text { WarmePhase }\end{array}\right.$ & $\begin{array}{l}\text { 2. Zwischen- } \\
\text { Eiszeit }\end{array}$ & \multirow[t]{2}{*}{ Moustérien } & Chelléen & $\left\{\begin{array}{l}\text { Moustérien } \\
\text { ältester Typus } \\
\text { Acheuléen } \\
\text { Chelléen }\end{array}\right.$ \\
\hline III. Rißeiszeit & & II. Eiszeit & & & \\
\hline \multirow{2}{*}{$\begin{array}{l}\text { 2. Zwischen- } \\
\text { Eiszeit }\end{array}$} & $\left\{\begin{array}{l}\text { Gemäßigte } \\
\text { Phase }\end{array}\right.$ & \multirow{2}{*}{$\begin{array}{l}\text { 1. Zwischen- } \\
\text { Eiszeit }\end{array}$} & Acheuléen & & \\
\hline & $\overline{\text { WarmePhase }}$ & & Chelléen & & \\
\hline \multicolumn{2}{|c|}{ II. Mindeleiszeit } & \multirow{3}{*}{ I. Eiszeit } & & & \\
\hline 1. Zwischene & eiszeit & & & & \\
\hline I. Günzeiszei & & & & & \\
\hline
\end{tabular}




\section{Rückblick auf die geologische Entwicklung, Herkunft und Verbreitung der Säugetiere. $\left.{ }^{1}\right)$}

Bisher sind uns keine Säugetierreste bekannt, welche in vortriadischen Ablagerungen gefunden worden wären. Auch in der Trias sind Säugetiere noch überaus spärlich, aber immerhin repräsentieren sie doch schon zwei wesentlich verschiedene Typen, nämlich die Allotheria und die teils an Insektivoren, teils an polyprotodonte Beuteltiere erinnernden Dromatheriidae. Die ersteren verteilen sich auf die Gattungen Microlestes und Triglyphus aus dem rhätischen Bonebed von Württemberg und auf die Gattung Theriodesmus aus den Karrooschichten von Südafrika. Sie zeigen uns wenigstens, daß die im Eocän erlöschenden Allotheria schon damals sehr weit verbreitet waren. Die zweite Gruppe ist vertreten durch die Kieferchen der Gattungen Microconodon und Dromatherium aus der oberen Trias von Nordcarolina, und vor einigen Jahren wurde aus der Trias des Kaplandes ein winziges Kieferchen als Karoomys beschrieben, dessen Säugetiernatur jedoch mehr als zweifelhaft ist.

Wesentlich zahlreicher sind die Reste von Säugetieren aus dem Jura, denn sowohl die Allotheria als auch die polyprotodonten Marsupialia entfalten hier bereits einen nicht unbeträchtlichen Formenreichtum. In Europa sind zwar zu den längst bekannten Fundplätzen, dem Großoolith von Stonesfield und dem »Dirtbed « des Purbeck von England keine neuen hinzugekommen, dafür lieferte aber das Atlantosaurusbed von Wyoming und Colorado eine Anzahl von Säugetieren, die mit den aus England bekannten Formen teils nahe verwandt sind, teils sogar den nämlichen Gattungen angehören. Die Allotheria haben in England Vertreter in der Gattung Plagiaulax, in Nordamerika in den Gattungen Allodon und Ctenacodon. Die übrigen Säugetiere des Jura besitzen ein sekodontes Gebiß und wurden von $\mathrm{O}$ wen wegen

1) Ameghino Fl., Les formations sédimentaires de Patagonie. Anal. del Museo de Buenos Aires T. XV. 1906. - Lydekker R., Die geographische Verbreitung und geologische Entwicklung der Säugetiere. Jena 1897. - Marsh O. C., Introduction and Succession of Life in America. Amer. Assoc. for advancement of Science Nashville 1877. - Matthew W. D., Classification of the Fresh Water Tertiary of the West. Bull. Amer. Mus. Nat. Hist. New-York 1899. - Cenozoie Mammal Horizons of Western North America. Bull. U. S. Geolog Survey Nr. 361. 1909. Osborn H. F., The Rise of the Mammalia in North America. Amer. Assoc for advancement of Science. Madison 1893. - Correlations between Tertiary Mammal Horizons of Europe and America. Annals New York. Acad. of Science. Vol. XIII. 1900. - Stehlin H. G., Die Säugetiere des schweizerischen Eocäns. Abhandl. d. schweizer. paläont. Gesellsch. 1903-1910 und Mammifères éocènes et oligocènes du bassin de Paris. Bull. soc. géol. de France. 1909. 
ihrer Ähnlichkeit mit der lebenden Gattung Myrmecolius zu den polyprotodonten Beuteltieren gestellt. Osborn zeigte später, daß manche von diesen Formen im Zahn- und Kieferbau gewissen Insektivoren recht ähnlich sind, und daß bei einer Gattung, Peramus, sogar die Zahnformel mit jener der ursprünglichen Placentalier vollkommen übereinstimmt. Andere Formen hingegen, die Triconodontidae erweisen sich schon durch die Gestalt des Unterkiefereckfortsatzes als unzweifel. hafte Marsupialia. Bei der Unvollständigkeit des vorhandenen Materiales dürfte es sich empfehlen, auch die übrigen sekodonten Formen vorläufig nicht weiter in Familien und Ordnungen zu zerlegen und sie insgesamt den Marsupialia anzureihen.

In der Kreide kamen Säugetierreste erst im Jahre 1882 zum Vorschein. Die ersten Funde aus der Wealdonstufe Englands bestanden in Zähnchen der schon aus dem Jura bekannten Gattung Plagiaulax. Bald darauf entdeckte Cope in den Laramieschichten von Dakota einen Zahn von Meniscoëssus und kurz nachher glückte es Hatcher, in Wyoming und Colorado eine ziemliche Anzahl meist isolierter Zähne zu sammeln, auf welche Marsh eine Menge Gattungen und Arten begründete, die freilich durch Osborn eine gewaltige Reduktion erlitten haben. Durch diese Funde wurden zwar unsere Kenntnisse der fossilen Säugetiere nicht so bereichert, wie man gehofft hatte, denn die Mehrzahl dieser Zähne gehört den Allotheria an - Ptilodus, Meniscoëssus - aber nichtsdestoweniger verdienen sie doch insofern Interesse, als sie für diese Gruppe die Kluft zwischen Jura und Tertiär überbrücken. Unter den etwas weniger häufigen trituberkulären und tuberkulärsektorialen Formen glaubt Osborn sogar einige als Creodontier, Pediomys, und andere, Protolambda, als den Vorläufer von Pantolambda, mithin von Amblypoden ansprechen zu dürfen. Wäre das Material etwas zahlreicher und vollständiger, so ließen sich wahrscheinlich viel bessere phylogenetische Schlüsse ziehen.

\section{Eocän.}

Der Beginn der Tertiärzeit bedeutet einen entscheidenden Wendepunkt in der Entwicklung der Säugetiere, denn es treten jetzt schon mehrere Ordnungen von unzweifelhaften Placentaliern auf, während đie Allotheria allmählich erlöschen. Die ältesten Säugetierreste des europäischen Tertiär stammen aus der Gegend von Reims. Lemoine unterscheidet hier zwei zeitlich aufeinanderfolgende Faunen, die des Cernaysien und die des Agéien. Die erstere enthält noch Vertreter der Allotheria, Neoplagiaulax, Creodontia-Arctocyon, Dissacus, Hyaenodictis, die zweifelhaften Insectivoren Plesiadapis, Protoadapis, Adapisorex, einen Condylarthren - Pleuraspidotherium - und das auf Anoplotherium weisende Orthaspidotherium. Die Fauna des Agéien werden wir besser im folgenden besprechen. Freilich bedürfen diese beiden Faunen wegen der höchst sonderbaren, von Lemoine gegebenen Abbildungen dringend einer Neubearbeitung. Viel reicher sind nun die dem Cernaysien ungefähr gleichalterigen Faunen des Puercobed von Neumexiko und des etwas jüngeren Torrejonbed von Neumexiko und Montana. Die erstere enthält noch mehrere Allotheria, darunter die wichtigen Gattungen Neoplagiaulax und Polymastodon, Creodontia - 
Triisodon, Oxyclaenidae, Condylarthra - Mioclaenus, Oxyacodon, Protogono. don, Periptychidae und Taeniodontia, in der letzteren finden wir die letzten Allotheria und die Creodontia werden mannigfaltiger. Sie sind vertreten durch Arctocyonidae, Mesonychidae, Oxyclaenidae, Triisodontidae und die den echten Raubtieren schon sehr nahe stehenden Miacidae. Die Condylarthren sind durch zahlreiche Mioclaenidae, die ersten Phenacodontidae und Periptychidae, die Taeniodontia durch Conoryctes und die Insectivoren allenfalls durch die Mixodectidae repräsentiert. Zugleich erscheint der erste Amblypode Pantolambda.

Für die Systematik ergeben sich freilich nicht selten erhebliche Schwierigkeiten, denn die Organisation ist bei vielen dieser Formen sehr primitiv, das Gebiß enthält fast immer raubtierähnliche Incisiven, Caninen und Prämolaren, die Molaren sind bunodont oder sekodont, die unteren mehr oder weniger tuberkulärsektorial und die oberen trituberkulär, die Extremitätenknochen haben fast immer eine sehr indifferente Gestalt, der Humerus ist mit einem Entepicondylarforamen und das Femur oft mit einem dritten Trochanter versehen, und die kräftige Fibula stößt nicht an das Calcaneum. Hand und Fuß sind fünfzehig und, soweit bekannt, mehr oder weniger plantigrad, und die Endphalangen sind weder als echte Hufe noch auch als echte Krallen entwickelt. Es darf uns daher nicht wundernehmen, daß so viele Arten schon wiederholt ihren Platz nicht nur innerhalb der Gattungen, sondern sogar innerhalb der Ordnungen gewechselt haben, und daß selbst die Grenzen von Familien und Ordnungen öfters Verschiebungen erfahren haben.

Nichtsdestoweniger ist dies doch ein schwerwiegender Beweis für die Richtigkeit der Deszendenztheorie, denn die so einförmige Organisation der ältesten Placentalier gestattet eben keinen anderen Schluß, als daß alle oder doch die meisten Ordnungen der höheren Säugetiere auf eine oder doch auf nur wenige Stammformen zurückgehen. Die Fauna von Reims und die des Puerco- und Torrejonbed werden jetzt meist als Basaleocän bezeichnet.

Das Untereocän umfaßt in Europa das Sparnacien und YprésienLondonton, Teredinensande von Epernay, Landénien von Erquelinnes und Orsmael in Belgien und den plastischen Ton und Lignit des Pariser Beckens, in Nordamerika das Wasatchbed von Wyoming und Neumexiko und das etwas jüngere Wind Riverbed von Wyoming und Colorado. In Europa scheinen die Beziehungen zu der älteren Fauna des Cernaysien noch ziemlich innig zu sein, wenigstens enthält das Agéien und das Landénien noch Plesiadapis, Protoadapis, Dissacus, Didymictis, jedoch treten jetzt auch schon echte Nager - Plesiarctomys -, vorgeschrittenere Creodontia - Protoproviverra, Palaeonictis, Pachyaena und echte Perissodactylen - Hyracotherium, Propachynolophus, Pachynolophus, Chasmotherium und Lophiodon, ein Artiodactyle Protodichobune, und angeblich ein Condylarthre - Phenacodus? sowie die Amblypodengattung Coryphodon auf, welche im Wasatchund Wind Riverbed den Höhepunkt ihrer Entwicklung erreicht. Während in Europa nur die Paar- und Unpaarhufer, die Nager und gewisse Creodonten ein neues Element in der Zusammensetzung der Säugetierwelt darstellen, scheint in Nordamerika die Kluft zwischen der Fauna des Basal- und der des Untereocän etwas beträchtlicher zu 
sein. Es erscheinen dort echte Primaten - Anaptomorphidae, Pelycodus, Notharctus, zahlreiche, zum großen Teil den Primaten nahestehende Insectivoren - Mixodectidae - und die artenreichen Hyopsodontidae, zum Teil durch ihre Größe von den eigentlichen Insektenfressern abweichend - Esthonyx, Palaeosinopa, teils ihnen sehr ähnlich - Palaeictops, ferner die ersten Nager - Paramys, fast alle Familien der späteren Creodontia - Palaeonictidae, Oxyaenidae, Hyaenodontidae und Mesonychidae und die Miacidae entfalten einen nicht unansehnlichen Formenreichtum. Neue Erscheinungen sind endlich die Meniscotheriidae, ferner die zahlreichen Perissodactylen - Heptodon, Systemodon, Eohippus und Lambdotherium, gewisse Artiodactylen Trigonolestes, Parahyus, dagegen schließen sich die Taeniodontia Calamodon, Stylinodon, von den Amblypoden Coryphodon und von den Condylarthren die Phenacadontidae doch ziemlich eng an Formen des Torrejon an, auch ist der Unterschied zwischen den älteren Mesonychiden, Arctocyoniden und Miaciden und ihren untereocänen Vertretern doch nicht so groß, daß man jeden genetischen Zusammenhang zwischen diesen Faunen bestreiten müßte.

Während in Nordamerika schon die Faunen des Untereocän eine stattliche Anzahl von Arten, Gattungen und Familien aufzuweisen haben, tritt in Europa erst im Mitteleocän eine formenreichere Tierwelt auf. Die wichtigsten Fundplätze sind hier Argenton (Indre), der Pariser Grobkalk, La Livinière, Cesseras und Issel in Südfrankreich, Bracklesham in England, Buchsweiler im Elsaß und die Bohnerze von Lissieu, Chamblon und Egerkingen. Die Bohnerzfaunen galten bis vor kurzem vielfach als eine Mischung von Säugetierzähnen aus den verschiedensten Stufen des Tertiärs, da ja auch wirklich von ein und derselben Lokalität die verschiedensten Tierreste durcheinandergemengt vorlagen. Allein dies beruhte darauf, daß nur aus. nahmsweise Sachverständige die Aufsammlungen überwacht und die Reste nach ihrem Erhaltungszustand und ihrer Herkunft aus den einzelnen Spalten geschieden hatten. Genauere Sichtung des Materials ermöglichte sowohl für die süddeutschen als auch für die Schweizer Bohnerze eine sehr exakte Unterscheidung der verschiedenen Faunen, so daß wir wohl behaupten dürfen, daß in einer Spalte auch immer nur gleichalterige Reste eingeschlossen sind.

In der Fauna des europäischen Mitteleocän spielen die Perissodactylen entschieden die wichtigste Rolle. Die tapirähnlichen sind vertreten durch Chasmotherium und Lophiodon, die pferdeähnlichen durch Palaeotherium, Propalaeotherium, Paloplotherium, Lophiotherium, Anchilophus und Pachynolophus. Dagegen haben die Artiodactylen anfangs nur ganz wenige Repräsentanten, im unteren Lutetien nur in den Dichobunidae - Dichobune, Meniscodon und Anoplotheriidae - Catodontherium, Dacrytherium, sowie in der etwas rätselhaften Gattung Tapirulus. Erst im oberen Lutetien erscheinen Suidae - Cebochoerus und Choeromorus, Anthracotheriidae - Haplobunodon, Lophiobunodon, Rhagatherium, von Anoplotheriidae Mixtotherium und das kleine Leptotheridium und die ersten Xiphodontidae - Pseudamphimeryx, Dichodon und Haplomeryx: Nager, Creodontia und Primaten fehlen zwar gewiß nicht, allein sie sind hauptsächlich auf die Schweizer Bohnerze beschränkt und von Stehlin noch nicht näher untersucht worden. Um so genauer kennen wir 
jetzt die nordamerikanischen Vertreter dieser Ordnungen. Von Primaten finden sich im Bridgerbed Notharctidae und Anaptomorphidae, von Insectivoren Pantolestidae, Hyopsodontidae, Mixodectidae und die riesigen Tillotheriidae - Tillotherium - sowie verschiedene, den Talpiden, Centetiden und Leptictiden nahestehende kleine Formen. Von den Carnivoren entfalten die Miacidae - Viverravus, Miacis, Vulpavus, Oodectes ihren größten Artenreichtum. Die Oxyaenidae - Patriofelis, Limnocyon, Thinocyon sind ebenfalls gut vertreten, die Mesonychidae erlangen eine ähnliche Spezialisierung der Extremitäten wie sie jetzt die Hunde besitzen und die primitiven Hyaenodontidae - Sinopa sind schon etwas formenreicher als im Wasatchbed. Das nämliche gilt auch von den Nagern, Paramys und Sciuravus, denen sich jetzt auch noch einige neue Gattungen beigesellen. Wie in Europa werden auch in Nordamerika die Perissodactylen noch formenreicher als im Untereocän, die Artenzahl der Tapiriden, Helaletes, Isectolophus und der Equiden - Orohippus - bleibt zwar ziemlich konstant, aber dafür werden die Titanotheriidae um so formenreicher - Palaeosyops, Limnohyops, Telmatherium. Die Artiodactylen sind bloß durch Dichobunidae vertreten, die jedoch hier einen größeren Formenreichtum Homacodon, Sarcolemur, Helohyus - aufweisen als im Wasatchbed. Die Condylarthren sind jetzt vollständig verschwunden, die Amblypoden erreichen ihre höchste Blüte in den riesigen abenteuerlichen Dinoceratidae. Die Taeniodontia haben nur mehr einen einzigen Repräsentanten in der Gattung Stylinodon, die sich aber durch ihre hypselodonten Zähne gegenüber den früheren Formen als ein höchst vorgeschrittener Typus erweist. Besondere Erwähnung verdient die fast zahnlose Gattung Metachiromys, welche Osborn für einen noch panzerlosen Verwandten der Gürteltiere hält.

Im Obereocän - Bartonien und Ludien in Europa, oberstes Bridgerbed von Wyoming und Uintabed von Utah in Amerika nimmt der Formenreichtum der Säugetierfauna in Europa eher noch zu, dagegen verarmt sie in Nordamerika in auffallender Weise. Das Bartonien ist entwickelt in Südfrankreich, Minervois, Robiac und Castres, als Sables moyens im Pariser Becken und als Sande von Headonhill und Bracklesham in England. Auch gehört dem Alter nach hierher die Bohnerzfauna von Mormont und sogar schon ein Teil der Phosphorite von Quercy. Die Ludienfaunen stammen aus dem Pariser Gips, aus den Ligniten von Débruge (Vaucluse), aus den Mergeln von St. Hippolyte de Caton (Gard), von Lamandine (Tarn et Garonne) und aus dem Bembridgekalk von England. Auch enthalten die Bohnerze von Mormont und Obergösgen und die Phosphorite von Quercy zahlreiche charakteristische Arten des Ludien. Der Gesamthabitus der Faunen des europäischen Obereocäns weicht nur wenig von dem des Mitteleocäns ab. Die Perissodactylen machen sich auch jetzt noch als das vorherrschende Element geltend. Lophiodon hat zwar im Bartonien den Höhepunkt seiner Entwicklung erreicht, und Chasmotherium tritt daselbst zum letzten Male auf, ebenso Propalaeotherium und Pachynolophus, dafür gedeihen um so besser die Gattungen Palaeo- therium, Paloplotherium sowie die freilich artenarmen Gattungen Lophiotherium und Anchilophus. Die Artiodactylen werden jetzt allmählich zahlreicher. Von Suidue erscheint jetzt neben dem schon früher vor- 
handenen Cebochoerus auch Choeropotamus, die schon bisher vertretenen Anthracotheriidae - Haplohunodon, Rhagatherium - setzen sich fort, ebenso die Anoplotheriidae - Mixtotherium, Catodontherium, Dacrytherium und Leptotheridium, aber jetzt auch vergesellschaftet mit Anoplotherium und Diplobune, desgleichen die Xiphodontidae, Dichodon, -- Pseudamphimeryx, Haplomeryx vermehrt durch Xiphodon und Amphimeryx. Die Dichobunidae sowie Tapirulus erfahren zwar keine weitere Bereicherung, dafür erscheint jedoch eine neue Familie, die Caenotheriidae mit der Gattung Oxacron. Die Raubtiere, von welchen im Mitteleocän nur Hyaenodontidae - Sinopa, Proviverra und Propterodon und allenfalls auch Miacidae und Amplicyonidae in Europa existierten, zeigen eine bedeutend größere Mannigfaltigkeit, denn es gliedern sich die Hyaenodontidae in mehrere Gattungen - Hyaenodon, Pterodon, Quercytherium, Cynohyaenodon, von Miacidae "Viverra" liegen jetzt auch vollstăndigere Reste vor, es erscheint ein kleiner Oxyaenide - Thereutherium, sowie zahlreiche Arten der Gattungen Cynodictis, des primitivsten Caniden mit viverrenähnlichem Skelett. Von Nagern beginnen anscheinend Sciuroides und Plesiarctomys, vielleicht auch Theridomyidae und Cricetodon schon im Lutetien und werden im Obereocän etwas artenreicher. Ebenso dürften sich auch die Primaten - Adapis, Cryptopithecus, Microchoerus und Necrolemur verhalten. Im Ludien gibt es auch bereits echte Didelpliyidae, im Lutetien vermutlich sogar schon Talpa ähnliche Insectivoren und Chiropteren. In Nordamerika bilden die obereocänen Faunen durch ihre Formenarmut einen starken Kontrast gegenüber der Bridgerfauna. Die tiefere Abteilung des Obereocän enthält noch einen Primaten - Notharctus, einige Oxyaenidae, Mesonychidae, von Nagern Paramys, von Perissodactylen Hyrachyus, Amynodon, Heptodon, Dolichorhinus und Telmatherium, von Artiodactylen Achaeriodon und den ersten Cameliden Leptotragulus. Besonders charakteristisch für diese Fauna ist die Anwesenheit des letzten Dinoceratiden, Eobasileus. In der etwas jüngeren Uintafauna finden wir die letzten Miacidae, Oxyaenidae, Mesonychidae, den ersten Caniden Procynodictis, und die letzten Hyopsodontidae. $\mathrm{Zu}$ der jetzt allmählich erlöschenden Gattung Paramys kommt ein neuer Nagertypus, wohl ein Geomyide, Protoptychus. Die Perissodactylen sind etwas formenreicher als in der vorausgehenden Fauna, denn zu den schon vorhandenen Amynodontinen und Palaeosyopinen - Diplacodon, Telmatherium, Manteoceras gesellt sich auch ein Tapirine Isectolophus und vor allem die in stammesgeschichtlicher Beziehung so überaus wichtige Equidengattung Epihippus, während der Hyracodontine Hyrachyus durch den zierlicheren Triplopus ersetzt wird. Auch die Artiodactylen bekommen hier einen nicht ganz unansehnlichen Zuwachs, denn für die erloschene Gattung Achaenodon treten jetzt die ersten Oreodontiden - Protoreodon und Protagriochoerus auf, die Cameliden werden zahlreicher - Leptotragulus, Protylopus, Camelomeryx, auch erscheint die Gattung Bunomeryx, die wohl den Vorläufer von Protoceras darstellt.

Das genauere Studium dieser Faunen der nördlichen Hemisphäre hat nun freilich die Vermutung, daß zwischen Nordamerika und Europa während des ganzen Eocäns ein lebhafter Formenaustausch stattgefunden hätte, keineswegs bestätigt, denn die Zahl der beiden Kontinenten gemeinsamen Gattungen ist verschwindend gering, 
wohl aber hat sich aus diesen Untersuchungen eine stattliche Menge vikariierender Formen ergeben, die noch dazu auf beiden Kontinenten die gleiche oder doch sehr ähnliche fortschreitende Entwicklung zeigen und die Aufstellung einer Menge ungemein vollständiger genetischer Reihen gestatten. Dabei zeigt sich aber in der Regel nicht, wie man erwarten sollte, eine nach oben immer mehr zunehmende Verzweigung und Abstammung aus einer einzigen Urform, sondern meistens treten von einer Gattung schon gleichzeitig mehrere Arten auf und diese bilden dann unabhängig voneinander Parallelreihen. Die sorgfältigen Untersuchungen der europäischen Perissodactylen und Artiodactylen, welche wir Stehlin verdanken, lieferten uns eine große Anzahl solcher genetischer Reihen, die sich manchmal sogar vom Untereocän bis in das Oligocän erstrecken. Es seien hier nur erwähnt die Reihen innerhalb der Gattungen Choeropotamus, Cebochoerus, Choeromorus, Rhagatherium, Diplobune, Pseudaphimeryx, Dichodon, Anchilophus, Palaeotherium, Paloplotherium und Lophiodon. Das Studium der Creodontier, Nager und Primaten wird uns in nicht zu ferner Zeit eine willkommene Ergänzung bringen. Ähnliche Entwicklungsreihen haben Osborn, Wortman und Matthew aus dem nordamerikanischen Material gewonnen und zwar erstrecken sie sich hier auch auf Primaten, Creodontier, Nager, Ganodonta, Ambly. poda und nicht bloß auf Perissodactylen und Artiodactylen. Was uns an diesen Reihen besonders in Erstaunen setzt, ist der Umstand, daß wenigstens in Europa nur ausnahmsweise die Entstehung von neuen Gattungen aus geologisch älteren $\mathrm{zu}$ beobachten ist, was sich kaum anders erklären läßt als durch wiederholte Einwanderung aus einem uns vorläufig unbekannten Entwicklungszentrum, das bald in Asien, bald in einem arktischen Kontinent, bald im nordöstlichen Teil von Nordamerika gesucht wird, eine Frage, welche freilich erst zukünftige Entdeckungen beantworten können. Die Fortschritte innerhalb der einzelnen Reihen äußern sich vorwiegend in Zunahme der Körpergröße, bei den Perissodactylen und manchmal auch bei Artiodactylen in Komplikation der Prämolaren, in Spezialisierung gewisser Incisiven und der Caninen, bei den Ganodonten kommt es sogar schon zur Bildung hypselodonter wurzelloser Zähne, dagegen erfahren bei den Creodontia die anfangs trituberkulären bzw. tuberkulär-sektorialen Molaren Spezialisierung, meist in der Weise, daß an den oberen ein langes schneidendes Metastyl entsteht und dafür der Protocon Reduktion erleidet, während an den unteren häufig das Metaconid verschwindet und das Talonid beträchtlich reduziert wird; auch können sich Protoconid und Paraconid in lange Schneiden umwandeln. Zuweilen erfolgt auch Verringerung der Molarenzahl und bei den Stamme formen der ächten Carnivoren eine gewisse Reduktion der hinteren Molaren. Was die Extremitäten betrifft, so sind sie zwar bei den europäischen Säugern nur ausnahmsweise bekannt, aber das vorhandene Material zeigt uns doch, daß sowohl bei den Paar- als bei den Unpaarhufern die Reduktion der Seitenzehen schon frühzeitig begonnen hat, wobei bei den ersteren die dritte und vierte, bei den letzteren nur die dritte die Hauptfunktion übernommen hat, obgleich nicht selten die Hand noch vier und der Fuß noch drei Zehen besitzt. Auch bei Creodontiern erfolgt zuweilen Verlust der ersten Zehe. 
Im Eocän erscheinen auch die ersten Meeressäugetiere. Die Wale sind zwar bloß durch die Familie der Zeuglodontidae vertreten, aber sie haben schon eine ziemlich weite Verbreitung, im südlichen Teil von Nordamerika, in Europa, Ägypten und auf Neu-Seeland, und ebenso finden wir Sirenia in Westindien, Europa und in Ägypten. Die ersteren gehen höchstwahrscheinlich auf Creodontier zurück, die letzteren haben mit den Proboscidiern die Stammform gemein. Beide haben sich jedenfalls aus landbewohnenden Placentalia entwickelt.

Das Oligocån zeigt in Nordamerika eine viel schärfere faunistische Gliederung und zugleich auch einen viel beträchtlicheren Formenreichtum als in Europa. Die White River-Schichten von Nebraska, Dakota, Montana, Colorado und Wyoming lassen sich leicht in drei Horizonte gliedern. Der tiefste, das auch in Kanada vorhandene Titanotheriumbed, ist charakterisiert durch die riesigen Titanotheriidae, die größten aller Unpaarhufer und durch Clirysocliloridae-ähnliche Insectivoren, der mittlere durch die Häufigkeit der Oreodontidae und den Reichtum an Insectivoren und Didelphyiden und der oberste durch die Gattungen Leptauchenia und Protoceras, dagegen sind hier die Hyaenodontiden, welche zusammen mit Elotherium, Anthracotherium, Ancollus und dem Suiden Perchoerus ein europäisches Faunenelement repräsentieren, und von den Insektivoren die Leptictidae bereits vollständig erloschen. Allen Abteilungen des White-River-Oligocän sind gemeinsam Caniden - Amphicyoninae und Cynodictinae - Musteliden, primitive Feliden - Dinictis, Hoplophoneus - , zahlreiche Nager besonders Castoridae, Ischyromyinae und Leporidae, von Perissodactylen die Vorläufer der Pferde - Mesohippus -, Tapiriden und Rhinoceriden. Jedoch ist von den ersteren Colodon und von den letzteren Hyracodon und Metamynodon auf die älteren Schichten beschränkt, Protapirus erscheint erst etwas später, Aceratherium hingegen geht durch das ganze Oligocän. $\mathrm{Zu}$ den schon im Uintabed vorhandenen Cameliden und Oreodontiden, welche hier als Poëbrotherium, Agriochoerus, Oreodon und Leptauchenia schon erhebliche Fortschritte in ihrer Organisation aufzuweisen haben, gesellen sich jetzt von Selenodonten auch die kleinen Hypertragulidae, sowie zuletzt Protoceras, von Bunoselenodonten Anthracotherium, Ancodus und von Bunodonten Elotherium, die Leptochoeriden und ein echter Suide - Perchoerus.

In Europa ist das Oligocän vorwiegend charakterisiert durch das Auftreten der Gattung Anthracotherium und die Anwesenheit zahlreicher primitiver Aceratherium-ähnlicher Rhinoceriden. Eine zeitlich wohlumgrenzte und auch ziemlich formenreiche Fauna kennen wir aus Ronzon, Haute Loire. Es fehlt zwar an dieser Lokalität die Gattung Anthracotherium, allein sie hat sicher schon gleichzeitig mit den für Ronzon so charakteristischen Ancodus gelebt, wie die Funde bei Hampstead auf der Insel Whigt beweisen. Mit den Mergeln von Ronzon sind auch gleichzeitig die Bohnerze von Vehringen und Ulm, der Kalk von Brie, die Sande von Fontainebleau, ein großer Teil der Phosphorite von Quercy, Braunkohlen von Dalmatien, von Oberitalien - Monte Bolca, Monteviale - und von Böhmen und die Asphaltschichten von Lobsann im Elsaß. Besonderes Interesse verdient die Lokalität Calaf bei Barcelona, weil hier noch Diplobune zusammen 
mit Ancodus vorkommt. Aus dem Eocän reichen außer Diplobune auch noch Paloplotherium und angeblich auch Palaeotherium in das Oligocän hinauf, ron kleineren Artiodactylen Amphimeryx, Caenotherium und Plesiomeryx, ferner Metriotherium, Dichobune. Tapirulus, von Carnivoren Hyaenodon, Amphicyoninae, Cynodontinae - die vermutlichen Vorläufer der Bären - von Nagern Theridomys, Sciuroides und Pseudosciurus somie Insectivoren - Erinaceinen - und Beutelratten, so daß, wenn man auf diese Formen das Hauptgewicht legen will, man wirklich ron einer verarmten Eocänfauna sprechen könnte. Allein diesem allmählichen Erlöschen älterer Elemente, namentlich der eocänen Perissodactylentypen, steht denn doch ein nicht unbeträchtlicher Zuwachs an neuen Formen gegenüber, es erscheinen Rhinoceriden - darunter Cadurcotherium --, Protapirus, Chaticotherium, Vorläufer der Hirsche - Gelocus, Bachitherium, Prodremotherium -, und der Suiden - Palaeochoerus, Dotiochoerus - , ferner die Gattungen Anthracotherium, Ancodus und Elotherium und von Raubtieren kleine Hyaenodon, zahlreiche Musteliden Palaeoprionodon, Stenogale, Stenoplesictis, Plesictis, sowie Vorläufer von Bären - Cynodon, Pachycynodon und Cephalogale. Auch die zahlreichen Insectivoren, Chiropteren und der überwiegende Teil der Nager aus den Phosphoriten - die meisten Theridomys, sowie Protechimys, Nesokerodon, Cricetodon, Eomys - gehören wohl erst dem Unteroligocän an.

Die nächstjüngere Fauna - Stampien - aus den Mergeln ron Cournon, Peublanc, Gergovia, in der Auvergne, St. Henri bei Marseille und Briatexte (Tarn) bilden zwar die Fortsetzung der Fauna ron Ronzon, was sich aus der Anwesenheit der letzten Hyaenodon und der vorgeschrittenen Organisation der Nager - Archaeomys, Issiodo. romys - ersehen läßt, allein sie ist unvergleichlich ärmer an Arten. Die wichtigsten Formen sind ein großes Anthracotherium mit fast unreduzierten Seitenzehen, Lophiomeryx - auch in den Cyrenenmergeln des Mainzer Beckens - , auch treten Dremotherium und Amphitragucus sowie die ersten Ochotoniden - Titanomys - auf. Daneben erhalten sich noch Caenotherium und Plesiomeryx, auch fehlen wohl ebensowenig Palaeochoerus, Rhinoceriden und Tapire. Die jüngste Oligocänfauna ist die von La Milloque, Gannat, welcher auch die Tierreste aus den Braunkohlen von Cadibona, Rochette und von Rott angehören. Sie hat nur wenig Arten geliefert, unter welchen jedoch dem echten Anthracotherium magnum und den kleinen Microbunodon wegen ihrer Häufigkeit besondere Bedeutung zukommt. Ein großer Teil des europäischen Oligocän ist jedoch marin entwickelt und alsdann ausgezeichnet durch die Häufigkeit der Überreste von Sirenen - Halitherium -, während Cetaceen sehr selten und nur durch Squalodontidae vertreten sind, neben welchen aber auch vereinzelt Reste von Landtieren Apterodon, Anthracotherium und primitiven Rhinoceriden vorkommen.

Das Miocän beginnt in Nordamerika mit dem John Daybed von Oregon, welches sich besonders durch den Reichtum an Nagern und durch die Anwesenheit ron Diceratherium und Promerycochoenus auszeichnet. Aus dem White-River-Oligocän reichen noch herauf von Perissodactylen Aceratherium, Protapirus und Mesohippus, von Artiodactylen Elotherium, Perchoerus, Agriochoerus, Paratylopus und Hypertragulus, als neu gesellen sich aber zu den ersteren Diceratherizm, 
Miohippus und der Chalicotheriide Moropus, zu den letzteren Eporeodon und Promerycochoerus. Die zahlreichen Carnivoren verteilen sich auf die Gattungen Nothocyon, Mesocyon, Temnocyon, Enhydrocyon, Nimravus, Pogonodon und Hoplophoneus, die Nager auf die Gattungen Prosciurus, Steneofiber, Entoptychus, Pleurolicus, Meniscomys, Mylagaulodon, Paciculus, Peromyscus und Lepus. Die etwas jüngeren Faunen der HarrisonSchichten von Montana, der Rosebud-Schichten von Süd-Dakota, der Monroe Creek-Schichten von Nebraska etc. sind im ganzen ziemlich arm an Arten und Gattungen, als charakteristische und zugleich als neue Typen verdienen Interesse die Carnivoren-Gattungen Phlaocyon, Cynodesmus, Oligobunis, Megalictis und Aelurocyon, die Perissodactylen Parahippus, Anchitherium, Miohippus und die Artiodactylen Dinohyus, Desmathyus, Mesoreodon, Merycochoerus, Merychyus, Leptauchenia, Stenomylus, Protomeryx, Oxydactylus und namentlich die Gattung Blastomeryx, ein Hypertragulide. Auch die nächstfolgende Fauna des Deap-River und Flint Creek von Montana, des Pawnee Creek von Colorado und die Mascall-Schichten von Oregon bieten keineswegs eine solche Mannigfaltigkeit wie die des nordamerikanischen Oligocän. Sie enthalten im wesentlichen nur Nachkommen von früheren Caniden Rhinoceriden, Equiden, Oreodontiden, Cameliden und Suiden, jedoch haben sie sich fast sämtlich so stark verändert, daß die Aufstellung zahlreicher neuer Gattungen notwendig erschien. Von Caniden werden genannt Tephrocyon, Cynarctus, Amphicyon, Canis, von Feliden Pseudaehurus, von Rhinoceriden Caenopus, Aphelops, Teleoceras, von Equiden Merychippus, Hypohippus, Parahippus, von Suiden ein Dicotyline - Hesperhys -, von Oreodontiden Merycochoerus, Promerycochoerus, Mesoreodon, Merychyus und Cyclopidius und von Cameliden Miolatis, Procamelus, Protolabis und Alticamelus. Die Nager sind fast nur durch Mylagaulus-ähnliche Formen repräsentiert. Was jedoch diesen jüngeren Faunen besondere Wichtigkeit verleiht, ist das erstmalige Erscheinen der Proboscidier - Trilophodon - in Nordamerika. Einen fremdartigen Charakter gewinnen sie auch durch das Auftreten von ebenfalls an europäische Verhältnisse gemahnenden Rhinoceriden Aphelops und Teleoceras, von Palaeomerycinae und von Musteliden - Potamotherium und Mustela. Dagegen sind Blastomeryx und Merycodus sicher Autochthonen.

Während die Zusammensetzung der eben besprochenen Fauna entschieden eine Einwanderung altweltlicher Elemente bedingt, ist die nächstjüngere offenbar das Produkt einer ruhigen Weiterentwicklung der vorhandenen Typen wohl ohne fremde Beimischung. Leider steht auch sie an Mannigfaltigkeit ziemlich weit zurück hinter den älteren nordamerikanischen Tiergesellschaften, was jedoch teilweise durch einen nicht unbeträchtlichen Individuenreichtum ausgeglichen wird. Die etwas ältere Arikaree-Stufe hat anscheinend eine weitere Verbreitung - Nebraska (Niobrara), Süd-Dakota, Montana, Neu-Mexiko und Texas - als die jüngere Olagalla-Stufe in Kansas und Nebraska, die allerdings auch in Florida und Oregon durch spärliche Überreste angedeutet wird. Zeitlich schalten sich beide Stufen zwischen das europäische Obermiocän und Unterpliocän ein, wie überhaupt eine strikte Parallelisierung der nordamerikanischen und europäischen Fauna kaum gerechtfertigt erscheint, da es sich eher um ein zeitliches 
Alternieren handelt. Die Caniden sind vertreten durch Aelurodon, Amphicyon, Dinocyon, Canis, Ischyrocyon, die Musteliden durch Mustela, Putorius, Potamotherium, Lutra, Brachypsalis, die Feliden durch Machairodus und Pseudaelurus, die Proboscidier durch mehrere wohlcharakterisierte Arten von Trilophodon, die Rhinoceriden durch die letzten aber sehr häufigen Teleoceras, Peraceras und Aphelops. Sehr groß ist die Zahl der aus diesen Schichten beschriebenen Arten der Equiden, Protohippus und Neohipparion, neben welchen sich aber auch primitivere Formen Hypohippus, Parahippus und Merychippus erhalten haben. Von Artiodactylen finden sich Suiden - Platygonus, Prosthenops, von Cameliden Procamelus, Protolabis und Pliauchenia. Die Oreodontiden erlöschen allmählich mit den Gattungen Promerycochoerus und Merychynu, wofür jedoch Palaeomeryx-ähnliche Hirsche sowie Blastomeryx und der Antilocapride Merycodus ziemlich häufig werden. Die Nager endlich haben Repräsentanten in den Gattungen Sciurus, Palaearctomys, Dipoides, Sigmogomphins, Mylagaulus, Epigaulus, Geomys, Hesperomys, Panolax und Lepus.

Als untere Grenze des europäischen Miocän eignen sich am besten die durch das Vorkommen von Helix rugulosa charakterisierten Süßwasserablagerungen von Ulm und Mainz, welchen auch der Indusienkalk von St. Gérand le Puy, die Asphalte von PyrimontChallonges, Savoien, und die Braunkohlen von Brüx im Alter gleichstehen. Von oligocänen Typen erhalten sich noch das hier besonders zahlreiche Caenotherium und Palaeochoerus, von Carnivoren Palaeogale, Plesictis, Stenogale, Amphictis und Cephalogale, auch finden sich die letzten Beutelratten. Die Perissodactylen - Chalicotherium, Paratapirus, Aceratherium und Diceratherium sind nur vorgeschrittenere Entwicklungsstadien der schon bisher vorhandenen Typen. Das nämliche gilt auch von den Cerviden, Amphitragulus und Dremotherium. Eine hervorragende Rolle spielen Amphicyon, Potamotherium und Herpestes unter den Carnivoren, und Steneofiber, Plesiospermophilus, Myoxus, Cricetodon und Titanomys unter den Nagern. Ihre Abstammung von bisher in Europa vorhandenen Typen erscheint, wenigstens für einen Teil dieser Gattungen, einigermaßen zweifelhaft. Die Insectivoren und Fleder. mäuse schließen sich sehr enge an lebende Formen an und gehören zum Teil sogar lebenden Gattungen an. Die Anthracotheriiden sind jetzt durch einen neuen Typus - Brachyodus - vertreten.

Nach dieser Periode ergriff das Meer wieder Besitz von einem großen Teil des mitteleuropäischen Festlandes, weshalb auch Reste von Landsäugetieren im Mittelmiocän ziemlich selten und nur an nichtüberfluteten Orten in größerer Menge erhalten geblieben sind, wie bei Tuchorschitz in Böhmen und auf dem Juraplateau von Solnhofen. Sie gehören einer Fauna an, welche im wesentlichen mit der des Obermiocän übereinstimmt, aber mit jener des Untermiocän noch die Gattungen Brachyodus, Palaeochoerus, Amphicyon, Cephalogale, und Plesictis gemein hat. Die Caenotherien sind nahezu, die Beutelratten vollständig verschwunden. Von den Hirschen - Palaeomery $x$ - zeichnen sich die kleineren schon durch den Besitz eines Geweihes aus, die Rhinoceriden erweisen sich zum Teil - Aceratherium, Diceratherium als direkte Nachkommen von bereits vorhandenen Typen, daneben tritt jedoch eine neue Form Brachypotherium auf. Das wichtigste 
Ereignis ist jedoch das erstmalige Erscheinen von Proboscidiern, der Gattung Mastodon. In den Sanden des Orléanais kommt auch bereits Dinotherium sowie Anchitherium und sogar schon ein Anthropoide Pliopithecus vor. Das marine Miocän enthält im Gegensatz zum Oligocän nicht nur Sirenen - neben Metaxytherium auch noch Halitherium - und Squalodontidae, sondern auch zahlreiche modernere Zahnwale, darunter Physodon, Acrodelphis, Cyrtodelphis und Delphinus und sogar schon einen Bartenwal Plesiocetus. Auch erscheinen jetzt Robben - Phoca.

Während die Faunen des Oligocäns und Eocäns und selbst noch des Untermiocäns im ganzen doch immer nur auf eine verhältnismäßig geringe Anzahl von Fundplätzen beschränkt sind, erstreckt sich die Fauna des Obermiocån fast über ganz Mitteleuropa, sie findet sich aber auch bei Lissabon, Madrid und Südrußland. Es dürfte genügen, von den zahllosen Fundstellen nur..Sansan (Gers), La Grive St. Alban (Isère), Steinheim, Georgensgmünd, Öningen, die bayerisch-schwäbische Hochebene, die Braunkohlen von Steiermark und den Landschneckenkalk von Oppeln in Schlesien zu nennen. Aus dem Untermiocän erhalten sich fast unverändert die Amphicyoninen, Viverriden, Musteliden, jedoch erscheinen jetzt auch Vorläufer von Meles - Trochictis, echte Bären Ursavus und vor allem zahlreiche Feliden, sowohl Machairodus als auch echte Felis. Die Nager, Chiropteren und Insectivoren sind im wesentlichen die Nachkommen der schon im Untermiocän vorhandenen Gattungen, neu ist nur die fast allenthalben vertretene Gattung Galerix. Bei den Paarhufern läßt sich trotz des Formenreichtums ein nur geringer neuer Zugang konstatieren, nämlich primitive Antilopen mit hirschähnlicher Bezahnung und Hyaemoschus, gewissermaßen als Ersatz für die erloschenen Caenotheriiden und für Brachyodus, dagegen scheinen die zahlreichen und in der Größo verschiedenen Palaeomeryx-Arten, von denen die kleinen und mittelgroßen jetzt auch mit Geweihen versehen sind, nur weitere Entwicklungsstadien der verschiedenen untermiocänen AmphitragulusArten zu sein. Ein direkter genetischer Zusammenhang mit früheren Formen besteht nicht minder auch bei den Suiden, denn Hyotherium und die zum ersten Male vorhandene Gattung Sus sind die Nachkommen von Palaeochoerus, und Listriodon der von Doliochoerus. Unter den Perissodactylen lassen sich Chalicotherium, die Tapire und Acerctherium ungezwungen von untermiocänen Formen ableiten, und Brachypotherium und Ceratorhinus haben wenigstens Vorläufer im Mittelmiocän, wo auch schon, wie wir gesehen haben, Anchitherium zum ersten Male nachweisbar ist. Im Mittelmiocän muß also eine beschränkte Einwanderung stattgefunden haben und zwar aus einem uns vorläufig nicht näher bekannten Gebiet, das aber jedenfalls auch mit Nordamerika in Verbindung war. Diesem Gebiet verdankte Europa die Einwanderung der ebengenannten Perissodactylen und wohl auch der Feliden und der Gattung Galerix, dagegen können die gleichzeitig mit auftretenden Proboscidier, Mastodon und Dinotherium, sowie die Affen - Pliopithecus - nur aus Afrika gekommen sein.

Hat schon die obermiocäne Säugetierfauna eine weite Verbreitung in Europa, so gilt dies in noch höherem Grade von jener des Unter- 
pliocäns, der pontischen Stufe. In Süddeutschland hat sie freilich, abgesehen von Eppelsheim bei Worms und gewissen Bohnerzen der Schwäbischen Alb, keine Tierreste hinterlassen, auch in Frankreich sind solche nur von Cucuron und Mont Lebéron (Vaucluse) und aus der Gegend von Lyon bekannt, dagegen ist sie auf der hispanischen Halbinsel wahrscheinlich sehr verbreitet -- man kennt sie sowohl aus der Gegend von Lissabon als auch von Concud in der Provinz Teruel und im östlichen Europa finden sich Überreste dieser Fauna vom Wiener Becken an bis in das südliche Rußland und fehlen auch nicht in Rumänien. Besonders reich entwickelt war jedoch diese Tierwelt in Griechenland - Pikermi - im westlichen Teil von Kleinasien - Samos - und im westlichen Persien - Maragha - allein je weiter östlich die Fundorte liegen, desto mehr treten neue, der europäischen Fauna fremde Elemente auf, namentlich unter den Wiederkäuern. Während in Europa die Antilopen nur eine ziemlich geringe Rolle spielen und dafür die Hirsche besser vertreten sind, verschwinden diese letzteren im Osten fast vollständig, dagegen entfalten hier die Antilopen einen um so größeren Formenreichtum. In Mitteleuropa ist die Unterpliocänfauna, abgesehen von der Anwesenheit der Gattung Hipparion, an Stelle der erloschenen Gattung Anchitherium, streng genommen nur die Fortsetzung der obermiocänen Säugetierwelt, denn die Carnivoren, die Perissodactylen - Brachypotherium, Aceratherium, Tapirus, Chalicotherium - die Proboscidier Mastodon und Dinotherium sind nur wenig veränderte Nachkommen der obermiocänen Arten. Das nämliche gilt auch unter den Paarhufern für die Suiden, Hirsche, Dorcatherium und die wenigen Antilopen, und selbst die Primaten Dryopithecus und Anthropodus sind wohl aus Pliopithecus hervorgegangen. Die Nagerfauna ist recht ärmlich, weil fast alle Ablagerungen aus dieser Periode von Hochfluten oder aus geröllführenden Flüssen abgesetzt wurden und daher alle kleinen Knochen zugrunde gingen; sie besteht vorwiegend aus Castor, Lepus und Dipoides. Die beiden letzteren Gattungen sind von Osten über Asien aus Nordamerika gekommen, offenbar zugleich mit Feliden und Hipparion. Auch Hyaena ist wohl von Osten her eingewandert. Diese wenigen neuen Faunenelemente des westlichen Europa bilden einen scharfen Gegensatz zu der Menge neuer Typen, welchen wir im südöstlichen Europa und in Westasien begegnen. Die Unterpliocänfauna von Pikermi enthält einen von den europäischen verschiedenen Rhinoceriden, Atelodus pachygnathus, auf Samos und in Maragha noch weitere, an chinesische und indische Typen erinnernde Aceratherien, auch erscheint hier ganz unerwartet ein großer Hyracoide - Pliohyrax -, besonders charakteristisch sind ferner die im Westen ganz fehlenden Giraffen Camelopardalis, Helladotherium, Samotherium, Palaeotragus etc., ferner Palaeoryx, Protoryx, Protragelaphus und andere Antilopen, während bis Mittel- und Westeuropa von solchen nur Palaeoreas, Tragocerus und Gazella vorgedrungen sind. Auch die Hyänen sowie Ictitherium und Mesopithecus stellen entschieden östliche Typen dar. Die Fauna der ebenerwähnten Lokalitäten Samos und Maragha führt uns naturgemäß zur Besprechung der Fauna der indischen Siwalik und von China. In den Siwalik gehört zwar der größte Teil der fossilen Tierreste dem Unterpliocän an, aber es ist doch auch eine ältere 
Fauna europäischen Ursprungs wenigstens angedeutet durch Antlıracotherium, Merycopotamus und durch eine primitive Mastodon-Art. Auch Dinotherium und Listriodon gehören vielleicht in diese ältere Fauna. Die Pliocänfauna zeichnet sich aus durch das Vorkommen von mehreren Primaten, Palaeopithecus, Simia, Macacus und Cynocephalus. Die Raubtiere sind vertreten durch Canis, Amplicinon, Hyctenarctos, Ursus, Mellivora, Enhydriodon, Viverra, Machaerodus und verhältnismäßig viele Arten von Hyaena und Felis. Die Gattung Mastodon ist ebenfalls ziemlich artenreich, unter den Rhinoceroten finden sich neben europäischen Typen auch einige neve, die für lebende und wohl auch für Rlinno. ceros tichorlinus stammesgeschichtliche Bedeutung haben. Zugleich mit Hipparion tritt hier wie in China scheinbar auch schon Equus auf. Die zahlreichen Suiden haben schon sehr modernes Gepräge. Neben vielen Hirschen finden wir Giraffen und die abenteuerlichen Sivatheriinae und eine Menge Antilopen, welche zum Teil wie Strepsiceros, Hippotragus, Alcelaplus heutzutage in Afrika leben, wie ja auch die Gattung Hippopotrmus zum erstenmal in der Sivalikfauna auftritt. Nicht minder wichtig ist das Vorkommen von Camelus, von Capra, und von Bubalus und anderen Boviden, die aber vielleicht doch schon der jüngeren, im ganzen südlichen Asien so weit verbreiteten Stegodonfauna angehören. Die in China teils in roten Tonen, teils in rötlichen Sandsteinen eingeschlossenen Tierreste verteilen sich in der Hauptsache auf die nämlichen Gattungen, die wir eben als die Fauna der Siwalik kennen gelernt haben oder doch auf sehr nahestehende, ja einige Arten sind sogar vollkommen identisch mit indischen, jedoch gibt es hier auch einige Formen - Anctittierium und Cervavus, welche augenscheinlich nur die Nachkommen von europäischen Miocäntypen darstellen. Über China erfolgte offenbar auch am Ende des Miocäns die Einwanderung nordamerikanischer Faunenelemente, welche teils wie die Leporiden, Dipoides, Hipparion sowie Canis und Vulpes, vielleicht auch Hyaena, bis nach Europa gelangten, teils sich vorerst nur über Asien verbreiteten, Camelus, aegodonte-Antilopen und wohl auch der Sivatheriinae, der Nachkommen von Protoceras. Als Gegengabe erhielt Nordamerika die Aphelops-artigen Rhinoceriden, Palceomeryxähnliche Cerviden und vor allem die Gattung Mastodon und von Raubtieren Dinocyon und vielleicht auch schon Ursus.

Eine eigentümliche Stellung nimmt die Fauna von Monte Bamboli und Casteani in Toskana ein, denn sie enthält den ersten europäischen Cynopithecinen Oreopithecus. Von den hier vorkommenden Carnivoren ist Hyaenarctos primitiver als der von Pikermi, die Mustela ist einem Marder von Pikermi und Enhydriodon einer Art aus den Siwalik sehr ähnlich, die Antilopen lassen sich am ehesten mit solchen von Pikermi vergleichen und der Suide findet sich auch in Eppelsheim; dieser Fauna dürfte also doch am ehesten ein unterpliocänes Alter zukommen. Dagegen schließt sich die von Casino trotz ihrer Armut schon eher an die von Roussillon und Montpellier an, obwohl ihr die Anwesenheit von Hippopotamus fast ein etwas jüngeres Gepräge verleiht. Gegenüber der unterpliocänen Tierwelt erscheint die mittelpliocäne ziemlich dürftig. Eine nicht unbeträchtliche Anzahl wichtiger Arten, wie Machairodus crenatidens, Hyaena arvernensis, Ursus arvernonsis, Mastodon arvernensis, Tapirus arvernensis und Gazella borbonica 
sowie Lagomys corsicanus hat sie mit der oberpliocänen gemein, dagegen verleiht ihr die Anwesenheit von Hipparion, Mastodon Borsoni und allenfalls auch von Rhinoceros leptorhinus und einer Viverra einen altertümlicheren Charakter, auch die zahlreichen Hirsche sind noch etwas primitiver. Von den Antilopen leitet Palaeoryx boodon einigermaßen zu den Rindern hinüber. Während die Nager und die Feliden trotz ihrer nicht geringen Mannigfaltigkeit kein besonderes Interesse beanspruchen können, verdient das Vorkommen von mehreren Cynopithecinen Dolichopithecus, Semnopithecus und Macacus um so mehr Beachtung. Ungefähr gleichzeitig mit dieser Landfauna lebten zahlreiche Meeressäugetiere, vorwiegend Zahnwale. daneben auch einige Phociden und Sirenen - Felsinotherium, deren Überreste, namentlich bei Antwerpen, Montpellier, in Piemont und bei Siena in reichlicher Menge zum Vorschein gekommen sind.

Die oberpliocäne Säugetierfauna der Auvergne war schon frühzeitig Gegenstand eingehender Untersuchung, später wurden die wichtigsten der hier vorkommenden Arten auch im Arnotal in Toskana nachgewiesen, auch in England - Crag von Norwich - in Siebenbürgen und selbst bei Giurgewo in Rumänien fanden sich manche der charakteristischsten Formen. Während die meisten Hirsche und Antilopen, die Suiden, Tapir, Rhinoceros, Mastodon, die Nager und Raubtiere sich nur wenig von ihren mittelpliocänen Vorläufern unterscheiden und zum Teil sogar noch den nämlichen Arten angehören, erhält diese Fauna doch ein wesentlich jüngeres Gepräge durch das erstmalige Auftreten der Gattungen Elephas, Equus und Bos.

In Nordamerika ist unzweifelhaftes Pliocän nur von Texas und vielleicht auch von Nebraska bekannt. Die 》Blanco-Beds « enthalten große Caniden - Borophagus, Amphicyon, einen Musteliden Canimartes, einen Feliden - Felis hillanus - Edentata - Glyptotherium, Megalonyx und Mylodon, mehrere Proboscidia - Tritophodon, Dibelodon, Equiden - Pliohippus, Protohippus und Neohipparion, Suiden - Platygonus und Cameliden - Pliauchenia. Abgesehen von der Anwesenheit der aus Südamerika stammenden Edentata ist diese Fauna charakterisiert durch das vollständige Erlöschen der Oreodontiden und Rhinoceriden. Allenfalls dürfen auch noch die Schichten mit Elephas imperator von Texas und Mexiko in das Pliocän gestellt werden.

Das Pleistocän beginnt sowohl in Nordamerika als auch in Europa mit einer Fauna, die noch Arten eines warmen Klimas und sogar erloschene Gattungen enthält. In Nordamerika ist die Sheridanformation von Nebraska und das Rock Creek-Bed von Texas charakterisiert durch das erstmalige Erscheinen der Gattungen Equus, Antilocapra und Castoroides neben Elephas, Platygonus, Eschatius, Camelops, Felis, Canis, Lutra und Mylodon, während der Merycodus-ähnliche Capromeryx im Aussterben begriffen ist und die Nager, abgesehen von Castoroides, nur durch lebende Gattungen vertreten sind. In Europa finden wir die älteste pleistocäne Tiergesellschaft im Cromerforest-Bed von England und Holland, bei St. Prest und in Mauer bei Heidelberg, welch letztere Lokalität vor kurzem durch den Fund eines Menschenkiefers so große Berühmtheit erlangte. Neuere Untersuchungen der an diesen Orten gesammelten Tierreste haben den Nachweis erbracht, 
daß zwischen Pliocän und Pleistocän keineswegs eine so scharfe Grenze besteht, wie es bis dahin den Anschein hatte, denn wir treffen hier noch pliocäne Arten, nämlich Hippopotamus major, Equus Stenonis, Rhinoceros etruscus, Elephas meridionalis, Ursus arvernensis, Canis neschersensis, Lynx issiodorensis und Hyaena arvernensis, ja einige dieser Arten reichen sogar noch in die etwas jüngere Fauna von Mosbach bei Mainz hinauf, wo sich zu ihnen Capreolus caprea, Cerrus elaplus, Alces latifrons, Bison priscus, Sus scrofa und Castor fiber gesellen, welche dann mit Ausnahme von Ursus Deningeri und Alces latifrons in allen jüngeren Pleistocänablagerungen, die während eines wärmeren Klimas entstanden, wiederkehren, wie z. B. in Taubach, Krapina und in den Höhlen von Mentone. Neben ihnen kommt gelegentlich auch noch ein Inuus, Hippopotamus und Machairodus latidens sowie Hyaena striata vor. In Asien (China) lebten während des älteren Pleistocäns noch Hyaenarctos, Chalicotherium und ein riesiger Tapir neben Rlinoceros sinensis und plicidens, gewissermaßen die Stellvertreter des europäischen Mercki, ferner Elephas namadicus, Hyaena, Hirsch und Schwein. In das AltPleistocän fällt außer der Fauna des Narbadatales auch die durch das Vorkommen von Pithecanthropus so berühmt gewordene Fauna von Trinil auf Java mit Macacus, Merecyon, Feliopsis, Stegodon, Rhinoceros, Hippopotamus, Sus, Cervulus, Axis, Duboisia, mit Boselaphus verwandt, Buffelus und Bibos, welche insgesamt nur durch ausgestorbene Arten repräsentiert sind, was deutlich genug für das hohe Alter dieser Fauna spricht.

In Nordamerika scheint das eigentliche Mittelpleistocän charakterisiert zu sein durch das Verschwinden von Camelus, Arctotherium und von Elephas Columbi, an deren Stelle Mammut, Mastodon, Odocoileus, Haploceras, Bison, Alces, Ovibos, Rangifer, Cervus und Ursus treten, jedoch erhalten sich anfangs noch Machairodontinen, Megalonyx, Mylodon, Equus, Tapirus und Mylohyus. Eine Fauna aus dieser Periode scheint in der berühmten Port Kennedy-Höhle von Pennsylvanien enthalten zu sein, vielleicht auch in Mergeln von Westkansas. Auch in der Potter Creek-Höhle in Kalifornien und am Silver Lake in Oregon hat man noch Megalonyx und Nothrotherium sowie Equus und Elephas gefunden. Die Mehrzahl der Tierreste verteilt sich jedoch schon auf noch lebende Arten der Carnivoren, Nager, Hirsche, Bison, weben welchen allerdings Mastodon americanus zum erstenmal erscheint. Auch finden sich hier eigentümliche Ovibos-ähnliche, vollkommen ausgestorbene Formen - Preptoceras und Euceratherium. Die jüngsten Pleistocänfaunen Nordamerikas z. B., die aus einer Felsspalte in Arkansas bestehen, abgesehen von Equus, einem Machairodontinen und einem Moschusochsen, Symbos, nur mehr aus solchen Arten, welche noch heutzutage Nordamerika bewohnen.

Die Veränderungen in der Zusammensetzung der Tierwelt, das Aussterben oder doch Auswandern von wärmeliebenden Formen war in Nordamerika und in Europa vor allem bedingt durch die ausgedehnte Vergletscherung, allein in Nordamerika kennt man anscheinend außer der eben erwähnten Conard-Spalte in Arkansas keine Lokalität, wo eine größere Anzahl der nunmehr eingewanderten kälteliebenden oder doch der Kälte angepaßten Arten zum Vorschein gekommen wäre. In Europa hingegen spielt die Fauna 
der eigentlichen Eiszeit eine viel wichtigere Rolle als die präglaziale und interglaziale wärmeliebende Säugetierwelt. Fast in keiner Höhle von England, Belgien, Frankreich, Deutschland und Österreich-Ungarn wird man vergeblich nach Knochen und anderen Resten von Höhlenbär, Höhlenhyäne, Renntier, Rhinoceros antiquitatis und Mammut suchen, auch Höhlenlöwe, Vielfraß, Gemse und Steinbock sowie Saigaantilope und Moschusochse sind zuweilen mit ihnen vergesellschaftet. Die nämlichen Arten haben auch öfters im Löß, seltener in fluviatilen Ablagerungen Überreste hinterlassen. Ein nicht unwesentliches Element der jüngsten europäischen Pleistocänfauna sind ferner auch gewisse Nager - Cuniculus, Lemmus, Ochotona, Dipus, Alactaga, Bobak, welche heutzutage teils die arktischen Tundren, teils die Steppen Rußlands und des westlichen Asien bewohnen. Nach dem definitiven Zurückweichen der Gletscher zogen sie sich freilich in ihre heutigen Wohnsitze zurück. Auch Ren und Moschusochse wichen aus dem gemäßigten Teile Europas, während Löwe und Hyäne wohl nur durch den Menschen aus Europa verdrängt wurden. Um so rätselhafter erscheint uns dagegen das Aussterben von Mammut, Rhinoceros und Höhlenbär, denn es ist kaum anzunehmen, daß der Mensch allein sie ausgerottet hätte, wie das mit dem Riesenhirsch, mit Bison und Auerochs der Fall war.

Aus Afrika waren bis vor kurzem keine fossilen Säugetiere bekannt mit Ausnahme von jenen aus dem Pleistocän von Algier und einigen spärlichen Resten aus dem dortigen Tertiär. Nichtsdestoweniger spielte jedoch Afrika bei zoogeographischen Spekulationen eine hervorragende Rolle. Es sollte vor allem die Heimat aller pliocänen Säugetiere von Europa und Asien sein, auch soll es einen großen, afrikanisch-südamerikanischen Kontinent gegeben haben, und selbst die dann und wann im europäischen Eocän auftauchenden neuen Formen sollten unfehlbar aus Afrika stammen. Jetzt, wo wir Reste von Landsäugetieren sowohl aus dem Eocän und Oligocän, als auch aus dem Miocän und Pliocän von Ägypten kennen, stellt sich heraus, daß diese beiden jüngeren Faunen keine anderen Elemente enthalten als die gleichalterigen Tiergesellschaften von Europa und Asien, und daß mithin Afrika, wenigstens Nordafrika, auch damals schon faunistisch zu Eurasien gehörte. Im Eocän ist die Landsäugetierfauna nur auf zwei Gattungen, Moeritherium und Barytherium, beschränkt, die beide Subungulaten sind, und die Fauna des Oligocäns erweist sich als eine eigentümliche Mischung von einheimischen Formen, Subungulaten - Proboscidia, Palaeomastodon und Moeritherium - , Hyracoidea den zahlreichen Saghatheriidae - und Arsinoitheria einerseits und von Einwanderern aus Nordamerika und Europa anderseits. Aus Europa stammen Ancodus, Apterodon, Pterodon und ein nicht näher bestimmbarer großer Creodontier, die Nager Pliomys und Metaphiomys und wohl auch die Fledermaus, Provampyrus. Nachkommen alter nordamerikanischer Typen sind hingegen die Primaten - Parapithecus, Moeripithecus und Propliopithecus, wohl hervorgegangen aus Anaptomorphiden, der Insectivore Metolbodotes und wahrscheinlich auch Ptolemaia und Metasinopa. Es sind also nur die Subungulata ein wirklich afrikanisches Element und selbst diese könnten schließlich auch aus Condylarthren oder doch aus den primitivsten Placentaliern hervorgegangen sein und 
mithin praktisch auch nur Glieder der alten arktogäischen Fauna. Auf keinen Fall sind sie mit den südamerikanischen Notoungulata näher verwandt.

Die lebende und subfossile Säugetierwelt der Insel M a dag a sk a r stellt ein eigentümliches Gemisch von primitiven und modernen Typen dar. Die letzteren sind vor allem repräsentiert durch die Zwergform von Hippopotamus, der offenbar erst spät vom Kontinent her eingewandert ist, und Cryptoprocta ist wohl nur der Nachkomme eines miocänen europäischen Carnivoren. Dagegen lassen sich sowohl die noch lebenden als auch die ausgestorbenen, zum Teil riesigen Lemuriden nur von den Adapiden des europäischen Eocäns ableiten, und als Verwandte der Centetiden kommen nur gewisse Insectivoren des nordamerikanischen Oligocäns in Betracht, mit welchen sie auch geographisch durch die westafrikanische Gattung Potomogale und den auf Kuba lebenden Solenodon verbunden sind.

Aus den übrigen Teilen der südlichen $\mathrm{Halbkugel}$ waren von fossilen Säugern lange Zeit nur die Pampastiere und die Reste aus brasilianischen Höhlen sowie die ausgestorbenen Beuteltiere und die Monotremen Australiens bekannt. Nur allmählich erweiterten sich unsere Kenntnisse ein wenig durch Funde im Tertiär von Patagonien. Erst die umfassenden Aufsammlungen Ameghino's in diesem Gebiete gaben uns ein wirkliches Bild von der Mannigfaltigkeit der hier begrabenen Tierwelt, welche allerdings einen ganz fremdartigen Charakter aufweist. Statt der uns gewohnten Paar- und Unpaarhufer und der Proboscidier treffen wir hier Huftiere, die infolge des kurzen Schädels, der meist hohen Unterkiefer, des gewölbten Rückens, der niedergedrückten Vorderextremität, der tiefen Kopfstellung und der kurzen, meist dreizehigen und häufig mit stumpfen Krallen, nur selten mit Hufen versehenen Extremitäten eher das Aussehen von Nagetieren wie etwa von Capybara besitzen. Andere erinnern mehr an Hasen. Statt der Fledermäuse, Insectivoren und Raubtiere finden wir Beuteltiere, die zum Teil an die australischen Raubbeutler, zum Teil noch an die mesozoischen Allotheria erinnern. Ein wichtiges, Südamerika eigenes Element bilden auch die hier schon frühzeitig auftretenden Edentaten und selbst die etwas später erscheinenden Nager gehören Familien an, die noch heutzutage fast ausnahmslos auf Südamerika beschränkt sind. So fremdartig diese Tierwelt uns nun auch beim ersten Anblick erscheint, so ergeben sich bei näherer Betrachtung doch gewisse Anklänge an Formen der nördlichen Hemisphäre, denn ein Teil der Huftiere, die Litopterna, die in Gebiß und Extremitäten ein allerdings karikaturenhaftes Perissodactylengepräge zur Schau tragen, zeigt doch gewisse Beziehungen zu den Phenacodontiden, und selbst die so eigenartigen Typotheria, Toxodontia, Entelonychia und Astrapotherioidea beginnen mit Formen, deren Backenzähne sich allenfalls von jenen von Periptychiden - Haploconus, Anisonchus - ableiten lassen. Ebenfalls auf Typen des ältesten Eocäns von Nordamerika, auf die Ganodonta, gehen wohl auch die Gravigrada. zurück, und der älteste Vertreter der Gürteltiere war vielleicht auch ein Bewohner Nordamerikas, die Gattung Metachiromys, und was die oben erwähnten Beuteltiere betrifft, so stammen sie wahrscheinlich ebenfalls aus Nordamerika, und zwar teils von den 
A llotheria, teils von Didelphys-ähnlichen Typen des Laramie-Bed, der oberen Kreide. Die erst später auftretenden Nager haben allerdings einen anderen Ursprung. Ihre Vorfahren waren in Europa und Nordafrika beheimatet. Sie wanderten wahrscheinlich passiv, nämlich durch Raubvögel von Insel zu Insel verschleppt, und bedurften hierbei keiner soliden Landbrücke, es genügte hierfür vielmehr schon die Existenz einer Inselreihe zwischen Westafrika und Brasilien.

Die ältesten Schichten in Südamerika, aus welchen Säugetiere in nennenswerter Anzahl zum Vorschein kamen, sind die Notosty. lopsschichten von Casa mayor am Golf St. George in Patagonien, welchen etwa ein obereocänes Alter zukommt. Es sind hier mit Ausnahme der Nager schon fast alle Typen der fossilen südamerikanischen Säugetierwelt vertreten, aber erst durch kleine oder höchstens mittelgroße Formen mit durchwegs brachyodonten Backenzähnen, die Typo. theria durch die Notopithecidae und allenfalls auch durch die etwas ferner stehenden Archaeopithecidae und Acoelodidae, die Entelonychia durch Notostylopidae, Isotemnidae und Homalodontotheriidae - Thomashuxleya --, die Astrapotherioidea durch die Trigonostylopidae, Albertogaudryidae und die Litopterna durch die bunodonten Gattungen Didolodus und eine Anzahl anderer höchst mangelhaft bekannter Formen. Auch gibt es bereits Vertreter der so rätselhaften Pyrotheria, von denen namentlich Carolozittelia fast eine gewisse Verwandtschaft mit Pantolambda vermuten läßt. An die Allotheria erinnern die ebenfalls zu den Marsupialiern gehörigen Polydolopidae, die Raubbeutler haben schon einige Repräsentanten in Formen wie Procladosictis, Pharsaphorus sowie in den Didelphys-ähnlichen Gattungen Ideodidelphys, denen sich die eigentümlichen, bunodonten Caroloameghiinidae am besten anreihen lassen. Edentaten fehlen zwar keineswegs, allein die meisten der höchst problematischen Gattungen gehören schon in die nächste Nähe der lebenden Dasypodiden, und die einzige Gravigradengattung Protobradys ist nur sehr unvollständig bekannt.

Die nächstjüngere Säugetierfauna von Patagonien, die der oligocänen Astrap o notusschichten, läßt sich am besten als die Fortsetzung der Notostylopsfauna charakterisieren, sie ist aber zweifellos viel ärmer an Gattungen und Arten und bis jetzt nur sehr mangelhaft bekannt. Als neue Typen erscheinen eigentlich nur die Notohippidae, deren Zahnkronen erst eine ganz mäßige Höhe erlangt haben, Archaeohyracidae mit prismatischen Zähnen, Astrapotheriidae - Astraponotus - und von Edentaten die ersten Glyptodontia.

Die folgende Fauna, die der Pyrotheriumschichten südlich von Cabo Blanco, zeigt erhebliche Fortschritte gegenüber den beiden älteren und hat mit der am besten bekannten und formenreichsten Fauna Patagoniens, dem Santacruzeno, so viele Gattungen gemein, daß über ihr miocänes Alter nicht der leiseste $\mathrm{Z}$ weifel bestehen kann. Die rätselhaften, hier zum letzten Male vorkommenden Pyrotheria erreichen jetzt den Höhepunkt ihrer Entwicklung in der gewaltigen Gattung Pyrotherium. Die Typotheria und Toxodontia haben jetzt insgesamt schon prismatische Zähne. Die Notohippidae sind hier besonders zahlreich, auch erscheinen die ersten Nesodontidae, anscheinend sogar schon ein großer Nesodon, und Interatheriidae, Plagiarthrus. Von den Entelonychia sind zwar die Isotemnidae im Aussterben begriffen, dafür 
erreichen die Leontiniidae schon gewaltige Körpergröße - Leontinia, Ancylocoelus -, desgleichen die Astrapotheriidae und ebenso von den Homalodontothieriidae die Gattung Asmodeus. Die Litopterna sind jetzt schon als Protherotheriidae und Macraucheniidae spezialisiert, die letzteren aber nur durch ziemlich kleine brachyodonte Formen vertreten. Unter den Edentata bilden die Dasypoda die direkte Fortsetzung der Formen der Notostylopsschichten, die Glypiodontia und Gravigrada unterscheiden sich kaum mehr von den späteren, und ebensowenig ist dies. bei den Dasynuridae der Fall. Dagegen sind die Polydolopidae verschwunden und gewissermaßen durch die ersten Caenolestidae Palaeothentes, Parabderites und Halmariphus ersetzt. Als besonders wichtiges Moment muß die jetzt erfolgte erste Einwanderung von Nagern - Cephalomys und Eosteiromys - bezeichnet werden.

Zwischen diese Fauna und die des Santacruzeno schaltet sich zeitlich und morphologisch die Fauna der Colpodonschichten ein, die nach Tournouer am Coli Huapi-See besonders gut entwickelt sein soll. A meghino zitiert hieraus höchst zweifelhafte Primaten - Homunculites und Pitheculites -, von Nagern treten neue Typen auf, Acaremys, Spaniomys und Perimys, unter den Edentaten verdient Propalaeohoplophorus und unter den Notohippidae, die hier zum letzten Male vertreten sind, Argyrohippus wegen der dicken Schmelzbedeckung seiner Backenzähne besonderes Interesse. Die Entelonychia werden zwar schon formenärmer, dafür ist jedoch die wichtige hierher gehörige Gattung Colpodon um so häufiger. Typotheria, Litopterna und Astrapotheriidae sowie Dasyuridae bieten nichts, was besondere Erwähnung verdiente, dagegen darf der Umstand, daß die Nesodontidae jetzt schon typisch ausgeprägt erscheinen, nicht mit Stillschweigen übergangen werden. Zeitlich scheint diese Fauna der sonst marin ausgebildeten Patagonischen Stufe zu entsprechen.

Die nun folgende Fauna aus den Schichten von Santa Cruz ist die artenreichste und am besten studierte des ganzen südamerikanischen Tertiärs. A meghino nennt von hier mehrere Primaten, von denen allerdings nur die Gattung Homunculus wirklich zu dieser Ordnung gehören dürfte. Die Nesodontidae - Nesodon und Adinotherium - zeichnen sich durch besondere Häufigkeit aus, ebenso von den Typotheria die Gattungen Protypotherium, Interatherium und Hegetotherium, die kleinen Pachyrucos bleiben freilich hinter diesen an Individuenzahl weit zurück. Die Entelonychia. nur mehr durch Homalodontotherium vertreten, werden jetzt recht selten, auch die Astrapotheriidae sind dem Aussterben nahe, dagegen entfalten von den Litopterna die Proterotheriidae ihren höchsten Formenreichtum, während die Macraucheniidae sich nur durch beträchtliche Zunahme der Körpergröße von ihren Vorläufern unterscheiden. Ungemein zahlreich werden die Nager, sowohl die Caviinae, Chinchillinae als auch von den Octodontidae die Loncherinae und Canromyinae; dagegen zeigen von den Erethizontidae nur die Acaremyinae eine nennenswerte Bereicherung. Unter den Edentaten zeichnen sich die Megalonychinae durch besondere Häufigkeit aus, während die Megatheriinae erst langsam zunehmen. Das nämliche gilt auch von den Glyptodontia, während die Dasypoda ziemlich unverändert bleiben, sowohl in Hinsicht auf ihre Organisation als auch auf ihre Häufigkeit. Besondere Erwähnung ver- 
dient die Gattung Stegotherium, die wegen ihrer langen Schnauze und der reduzierten Zähne zu Myrmecophaga hinüberleiten dürfte, sowie die Anwesenheit eines Insectivoren Necrolestes, der etwas an die afrikanischen Chrysochloridae erinnert. Die Beuteltiere erreichen jetzt in Südamerika den Höhepunkt ihrer Entwicklung und zwar nicht nur die Dasyuridae, repräsentiert durch die stattlichen Borhyaena und Prothylacynus und die kleineren Cladosictis und Amphiproviverra, sondern auch die Caenolestidae - Palaeothentes, Abderites und Garzonia, von denen jedoch nur die letztere Gattung Nachkommen hinterlassen hat. Zu erwähnen wäre endlich noch die Anwesenheit eines Didelphyiden, Microbiotherium.

Pliocän. Die Faunen zwischen dem Obermiocän und dem Pleistocän stehen sowohl in bezug auf Mannigfaltigkeit als auch hinsichtlich ihrer Erforschung bedeutend hinter den früheren und den späteren zurück. Die Paranástufe ist marin ausgebildet und enthält daher von Säugetieren nur Cetacea, Pinnipedia und Sirenia, unter denen nur ein Zahnwal, Prosqualodon, größeres Interesse verdient. Die Landtierfauna ist charakterisiert durch das Seltenerwerden der Litopterna und Typotheria und das völlige Verschwinden von Dasyuridae, Palaeothentinae und Abderitinae, nur ein Caenolestide - Zygolestes und Didelphys werden aus dem Pliocän angegeben. Den Hauptbestandteil der Fauna bilden Toxodontinae, Macrauchaeniidae, Edentaten und Nagetiere. Auch unter den Nagern finden wir vielfach Formen, welche sich wie die Vertreter der eben genannten Gruppen von ihren Vorfahren durch bedeutende Zunahme der Körpergröße unterscheiden, so unter den Chinchillinen Megamys. Auch erscheinen bereits noch lebende Gattungen Myopotamus, Lagostomus und Hydrochoerus. Die Gravigrada und Glyptodontia sind teilweise schon durch Gattungen der Pampasformation repräsentiert, dagegen werden die Dasypoda ärmer an Zahl der Gattungen und Arten. Angeblich treten jetzt auch schon echte Carnivoren, Cyonasua, Arctotherium und ein Canide auf.

Eine wichtige und interessante Fauna ist die des Tarija-Tales in Bolivien. Sie hat jedenfalls ein wesentlich höheres Alter als jene der Pampasformation und enthält neben den bisherigen südamerikanischen Faunenelementen - Gravigrada, Glyptodontia, Dasypoda, Caviinae, Octodontinae und Capromyinae auch eine Menge Formen, die bis dahin ausschließlich Bewohner der nördlichen Hemisphäre oder doch von Nordamerika waren. Diese neu auftretenden Typen sind Mastodon, Tapir, Equiden - Hippidium -, Cerviden, Cameliden, Feliden -, Smilodon, Felis -, Bären, Arctotherium, und Hunde. Auch Musteliden, Mephitis, und Procyoniden, Leporiden und Hesperomyinen sowie Dicotyles sind am Ende des Tertiärs nach Südamerika gelangt und bilden dann im Pleistocän einen wesentlichen Bestandteil der südamerikanischen Säugetierfauna. Die ursprüngliche Fauna verarmt allmählich mit Ausnahme der schon länger einheimischen Nagertypen, jedoch erreichen die noch vorhandenen Toxodontia, Gravigrada, Glyptodontia und von den Litopterna die Macraucheniidae gewaltige Körperdimensionen und vielfach auch weitgehende Spezialisierung. In der älteren Pampasformation - Monte Hermoso - gibt es noch Typotheria - Pachyrucos und Typotherium, sowie Proterotheriidae Epitherium. Das Erlöschen dieser kleinen oder doch nur mäßig großen 
Formen dürfen wir unzweifelhaft auf die schädliche Konkurrenz der viel besser und zweckmäßiger organisierten Mastodonten und der Paarund Unpaarhufer sowie auf die Tätigkeit der eingewanderten Raubtiere zurückführen. Allmählich erlagen dieser Konkurrenz und den Nachstellungen der großen Feliden auch die Macrauchenien, Toxodonten und Riesenedentaten. Soferne der in Südamerika erst sehr spät auftretende Mensch an der Ausrottung dieser Tiere beteiligt war, kann es sich nur um die Vertilgung der allerletzten Überbleibsel der alteingesessenen Fauna handeln. Daß er wirklich noch Zeitgenosse wenigstens eines Gravigraden, des Glossotherium, war, geht aus den Funden in der Höhle Eberhard am Meerbusen von Ultima Esperanza mit Sicherheit hervor.

Während die bisher entdeckten Säugetierfaunen des südamerikanischen Tertiärs auf Patagonien beschränkt und ältere Pleistocänfaunen bis jetzt nur aus dem Tarija-Tal in Bolivien und vom Monte Hermoso bekannt sind, hat die des jüngeren Pleistocäns, die sogenannte Fauna der Pampasformation eine viel weitere Verbreitung. Die Hauptfundplätze sind zwar immer noch die nördlicheren Teile von Argentinien, allein auch aus Chile und Brasilien kennt man Überreste von Arten der Pampasformation, auch in den Höhlen von Minas Geraes in Brasilien sind vereinzelte Überreste von Riesenedentaten zum Vorschein gekommen, ebenso auch in den vulkanischen Tuffen von Ecuador, hier allerdings in verschwindend geringer Zahl gegenüber den Pferden und Auchenien.

Wir dürfen unsere Betrachtungen der fossilen Tierwelt der südlichen Hemisphäre nicht abschließen, ohne auch einen Blick auf Australien zu werfen, dessen Säugetierfauna den Faunen aller übrigen Kontinente so fremdartig gegenübersteht. Aus dem Tertiär kennt man hier allerdings nur die einzige Gattung Wynyardia, deren systematische Stellung wegen des Fehlens von Zähnen leider nicht näher ermittelt werden kann. Dafür sind uns aber im Pleistocän, namentlich aus Knochenhöhlen, Überreste von Monotremen und einer ziemlichen Anzahl Beuteltiere überliefert worden, die zum Teil riesige Körperdimensionen erreicht hatten. Sie stammen jedoch durchwegs von Formen, welche sich an noch lebende australische Gattungen mehr oder minder enge anschließen und zum Teil sogar noch lebenden Gattungen angehören. Man hielt die australischen Säugetiere in der Regel für Nachkommen von mesozoischen Formen, welche sich hier in ihrer Abgeschlossenheit ungestört in der mannigfaltigsten Weise differenzieren konnten. Jetzt aber seit der Entdeckung der nicht unbedeutenden Menge fossiler Polyprotodontia und Diprotodontia im Tertiär von Patagonien muß man sich eben doch die Fragen vorlegen, ob die australischen Typen nicht doch von diesen südamerikanischen Formen abstammen und wann sie etwa nach Australien gelangt sein könnten. Diese Fragen sind allerdings nicht leicht $\mathrm{zu}$ beantworten. Der Ableitung der australischen Dasyuriden von den patagonischen stehen zwar keine ernstlichen Hindernisse im Wege, dagegen erscheint es kaum statthaft, die Hypsiprymniden, Macropodiden, Phalangeriden sowie Phascolomys und Diprotodon auf die Ca enolestid en zurückzuführen, nur Thylacoleo könnte allenfalls von Abderites abstammen, denn bei 
den $\mathrm{C}$ aenolestiden haben die Molaren sehr ungleiche, bei den australischen Diprodontia aber gleiche Größe und zudem ist bei den ersteren der vorderste Molar nicht bloß der größte, sondern in der Regel auch stark differenziert. Anderseits ist es aber doch wieder sehr unwahrscheinlich, daß zwischen den australischen Diprotodontia und den Caenolestiden keine verwandtschaftlichen Beziehungen bestehen sollten, während dies doch offenbar der Fall ist bei den australischen und südamerikanischen Dasyuriden. Die Annahme eines gemeinsamen Ursprungs hat also doch eine gewisse Berechtigung. Soferne nun die Stammformen in Südamerika entstanden sind und sich von hier nach Australien verbreitet haben, kann diese Wanderung nur auf einer sehr unvollkommenen Landbrücke erfolgt sein, denn sonst wären auch Edentaten, Litopterna und Notoungulaten nach Australien gekommen. Es wäre jedoch auch nicht ausgeschlossen, daß Südamerika und Australien die Marsupialier aus einem uns vorläufig unbekannten Gebiet erhalten hätten. Jedenfalls wäre es verfehlt, die Frage nach der Herkunft der australischen Säugetiere jetzt schon definitiv beantworten zu wollen.

Wie wir gesehen haben, kommt der nördlichen Hemisphäre als Entstehungszentrum der Säugetiere eine ungleich größere Bedeutung zu als allen übrigen Teilen der Erdoberfläche. Selbst das während des Tertiärs so formenreiche Südamerika kann sich , bierin nicht im entferntesten messen, ja es ist nicht einmal ausgeschlossen, daß seine Tierwelt doch in Formen der nördlichen Hemisphäre wurzelt, obschon Verbindungen zwischen Nord- und Südamerika nur etwa bis in die Mitte des Eocäns und am Ende des Pliocäns bestanden haben. Afrika war nur während des Eocäns ein wirkliches Entstehungszentrum, aber nur für die Archaeoceti und für die Subungulaten, und selbst von diesen ist es keineswegs sicher, ob sie nicht doch aus Säugetieren der europäischen Kreide hervorgegangen sind. Vom Oligocän an gehört Afrika praktisch zu Europa. Was endlich Australien betrifft, so scheint seine Tierwelt erst ziemlich spät, sicher nicht vor dem Tertiär, eingewandert zu sein. Die Annahme eines antarktischen Kontinentes, welcher zugleich auch die Heimat gewisser Säugetiertypen, wie der Notoungulata und der Subungulata gewesen wäre, findet in der Geschichte der Säugetiere keine Stütze. 


\section{Register.}

A ale 127

Abderites 356 Abderitinae 356 Acanus 133

Acanthias 50

Acanthidium 50

Acanthobatis 67

Acanthoderma 142

Acanthodes 47

Acanthodi 46

Acanthodopsis 47

Acanthoessus 47

Acanthonemus 137

Acanthopholis 294

Acanthopleurus 142

Acanthopterygii 128

Acanthorhina 70

Acanthostoma 163

Acanthotidae 47

Acanthuridae 137

Acanthurus 137

Acaremys 431

Accipenser 95

Accipenseroidei 95

Accipitres 324

Acdestis 356

Acenthrophorus 106

Aceratherium 452

Achaenodon 475

Acheloma 169

Achelonia 250

Acherontemys 251

Achilemys 252

Achyrodon 360

Acichelys 250

Aciprion 210

Acoelodidae 517

Acoelodus 517

Acoelohyrax 517

Acomys 430

Acotherulum 473

Acrania 2

Acreodi 376

Acrocyon 362

Acrodelphidae 408

Acrodelphinae 408

Acrodelphis 408

Acrodobatis 50

Acrodus 54

Acrognathus 131

Acrolepis 98

Acronuridae 137

Acrosauridae 206

Acrosaurus 206

Acrotherium 520

Actaeosaurus 211

Actinobatis 66

Actinodon 168

Actinopterygii 89

Actiornis 323

Acyon 362

Adapidae 545

Adapis 547

Adapisorex 369

Adapisoricidae 369
Adapisoriculus 369

Addax 504

Adelphomys 432

Adiantidae 444

Adiantus 444

Adinotherium 520

Adlerfische 132

Adocus 256

Adpithecus 516

Adriosaurus 211

Adrotherium 479

Aechmodus 106

Aegodontia 499

Aelurictis 398

Aelurocyon 393

Aelurodon 388

Aelurogale 398

Aelurosauridae 197

Aelurosaurus 198

Aelurotherium 379

Aeolodon 269

Aepyornis 320

Aepyornithidae 320

Aepyosaurus 288

Aepyprymnus 357

Aeropoma 139

Aethalion 120

Aetholepis 107

Aëtobatis 68 .

Aetosauridae 260

Aetosaurus 260

Aeturaetus 324

Agama 210

Agamidae 210

Aganodus 44

Agassizia 114

Agathaumas 296

Agnocyon 396

Agnopterus 323

Agnotherium 396

Agomphus 256

Agriochoerinae 482

Agriochoerus 482

Agriomeryx 482

Agustylus 362

Aigialornis 325

Aigialosauridae 211

Aigialosaurus 211

Aistopodidae 165

Alactaga 429

Alamosemys 256

Alastor 374

Alauda 325

Albertogaudrya 525

Albertogaudryidae 525

Albertosaurus 281

Albula 121

Albulidae 121

Alcedines 324

Alcelaphus 503

Alces 494

Alcicephalus 496

Alepisauriden 125

Aletodus 72

Aletornis 322
Alexandrium 66

Algaosaurus 288

Allacodon 353

Alligator 272

Alligatorellus 270

Alligatorium 270

Allodon 353

Allolepidotus 116

Allomeryx 489

Allomys 425

Allopleuron 254

Allops 467

Allosaurus 282

Allotheria 351

Alopecias 52

Alopecodon 198

Alopiopsis 51

Alosa 120

Alpendohle 325

Alticamelus 486

Altippus 461

Ambloctonus 379

Amblotheriinae 360

Amblotherium 360

Amblyodon 163

Amblypeza 248

Amblypoda 506

Amblypristis 65

Amblypterus 98

Amblyrhiza 427

Amblyurus 106

Amia 117

Amiidae 116

Amioidei 113

Amiopsis 117

Ammosaurus 280

Ammotherium 417

Ampheristus 140

Amphibamus 163

Amphibia 143

Amphibos 505

Amphicentrum 101

Amphichelydia 247

Amphichelydidae 247

Amphicotylus 270

Amphictis 394

Amphicyon 387

Amphicyoninae 387

Amphidolops 354

Amphidophorus 111

Amphidozotherium 367

Amphilestes 359

Amphimeryx 480

Amphimorphae 323

Amphinasua 392

Amphioxiden

Amphipelargus 323

Amphiperatherium 363

Amphiplaga 132

Amphiproviverra 362

Amphisbaenia 210

Amphisbaenidae 210

Amphiserpentarius 324

Amphistium 137

Amphisyle 140
Amphitheriinae 360

Amphitherium 360

Amphitragulus 492

Amphitylus 360

Amyda 257

Amynodon 451

Amynodontinae 451

Amyzon 123

Anabas 141

Anacanthini 127

Anacanthus 67

Anacodon 380

Anaedopogon 121

Analcimorphus 416

Analcitherium 417

Anaptogonia 431

Anaptomorphidae 548

Anaptomorphus 548

Anarosaurus 233

Anas 323

Anaschisma 171

Anaspida 27

Anchilophus 458

Anchimys 432

Anchippodus 372

Anchippus 461

Anchisauridae 279

Anchisaurus 279

Anchitheriinae 460

Anchitherium 460

Ancistrodon 142

Ancodus 477

Ancylocoelus 523

Ancylopoda 523

Ancylostylus 121

Ancylotherium 468

Andrias Scheuchzeri 176

Andrias Tschudii 176

Anenchelum 136

Anguilla 127

Anguinidae 210

Anguisaurus 206

Anicanodonta 413

Anisacodon 370

Anisodon 468

Anisodoxis 169

Anisonchus 438

Anissolornis 324

Ankylosaurus 294

Anodontacanthus 44

Anogmius 124

Anomalapteryx 321

Anomalichthys 83

Anomalomys 430

Anomaluroidea 427

Anomodontia 198

Anomoeodus 105

Anomosaurus 194

Anoplosaurus 295

Anoplotheriidae 477

Anoplotherium 478

Anosteira 256

Anthodon 191

Anthracosaurus 171 
Anthracotheriidae 476 | Argyrosaurus 288 Anthracotherium 476 Anthropodus 556 Anthropoidea 550 Anthropops 552 Anthropornis 322 Antiarchi 35

Antidorcas 500

Antilocapra 496

Antilocapridae 496

Antilope 500

Antilopinen 499

Antliodus 61

Antrodemus 280, 282

Anura 177

Apateodus 131

Apatodon 295

Apatomerus 307

Apatornis 319

Apatosaurus 285

Apedodus 86

Aphaelepis 107

Aphanepygus 109

Aphaneramma 171

Aphelops 453

Aphelosaurus 204

Aphelotherium 547

Aphreidoderidae 132

Aplax 250

Aplodontinae 425

Aplodontoidea 425

Apodes 119, 127

Apogon 136

Apogonidae 136

Apostasis 137

Aprionodon 51

Apsopelix 135

Apternodus 366

Apterodon 381

Apteryges 321

Apteryx 321

Aquila 324

Archaelurus 398

Archaeobatis 61

Archaeobelus 194

Archaeornithes 316

Archaeocygnus 323

Archaeohippus 461

Archaeohyracidae 518

Archaeohyrax 518

Archaeolemur 550

Archaeolemuridae 550

Archaeolophus 527

Archaeomene 111

Archaeomys 428

Archaeophis 220

Archaeopilus 516

Archaeopithecidae 517

Archaeopithecus 517

Archaeopteryx 316

Archaeoteuthis 31, 135

Archaeotherium 475

Archaeotriton 176

Archaeotrogon 325

Archegosaurus 166

Archelon 254

Archeoceti 405

Arcogaster 132

Arctocephalus 401

Arctocyon 382

Arctoćyonidae 382

Arctocyonoides 382

Arctodus 391

Arctoidea 392

Arctomys 426

Arctotherium 391

Ardea 323

Ardeosaurus 206

Argillo chelys 254

Argillornis 323

Argyrocetinae 408

Argyrocetus 408

Argyrohippus 519

Argyrohyrax 516

Argyrolambda 441
Argyrosaurus 288
Arionius 407

Aristodesmus 190

Aristosuchus 280

Arius 123

Arius-Otolithen 124

Arretotherium 477

Arsinoitheriidae 529

Arsinoitherium 530

Arthrodira 78

Arthrodon 103

Artiodactyla 468

Artionyx 482

Arvicola 430

Arvicolinae 430

Ascondylacanthus - 72

Asineopidae 132

Asineops 132

Asio 325

Asmodeus 524

Aspideretes 257

Aspidodus 60

Aspidorhynchidae 111

Aspidorhynchus 111

Aspidosaurus 169

Aspius 123

Astephus 123

Asterodermus 66

Asterodon 107

Asterolepis 38

Asterosteidae 84

Asterostemma 420

Asterosteus 84

Asthenocormus 114

Asthenodon 361

Astrabodus 61

Astrape 66

Astraponotus 526

Astrapothericulus 526

Astrapotheriidae 525

Astrapotherioidea 524

Astrapotherium 526

Astrodon 288

Ateleaspis 34

Atelodus 454

Athecae 253

Atherina 135

Atheriniden 135

Atherstonia 100

Atlantochelys 255

Atlantosauridae 285

Atlantosaurus 287

Atoposauridae 270

Atoposaurus 270

Attakeopsis 111

Aublysodon 281

Auchenaspis 34

Auchenia 486

Aulacosteus 83

Aulaxacanthus 71

Aulaxinus 55

Aulocetus 410

Aulodus 68

Aulolepis 122

Aulostoma 140

Aulostomidae 140

Auxis 139

Aves 308

Axestemys 257

Axestus 257

Axis 494

Bachitherium 488

Baëna 248

Baeninae 247

Balaenidae 410

Balaenodon 407

Balaenoptera 410

Balaenopteridae 409

Baphetes 171
Arnognathus 198

Aspidichthys 83

Asteracanthus 56

Aulorhamphus 137
Baptanodon 228

Baptemys 256

Baptornis 318

Baptosaurus 217

Barbus 123

Barosaurus 287

Barsche 132

Bartenwale 409

Barytheriidae 536

Barytherium 536

Basilemys 256

Basilosaurus 406

Bassariscus 392

Bastard. Makrelen 137

Bathmodon 508

Bathrodon 370

Bathyerginae 431

Bathygenys 482

Bathygnathus 196

Bathyopsis 508

Batodon 363

Batrachosuchus 170

Bauria 198

Bdellodus 56

Belemnobatis 66

Belemnoziphius 408

Belenorhynchus 96

Belenostomus 96

Belodon 258

Belone 122

Belonorhynchidae 96

Belonorhynchinae 96

Belonorhynchus 97

Belonostomus 112

Beluga 408

Beluginae 408

Berardius 408

Beriophthalmus 96

Bernissartia 271

Berycidae 131

Berycopsis 138

Beryx 131

Bettongia 357

Beutelratten 362

Bibos 505

Bibovina 506

Bimana 545

Birkenia 27

Birkeniidae 27

Bison 505

Biziura 323

Blastoceras 494

Blastomervx 489

Blattwirbler 160

Blenniomoeus 110

Blind wühler 1.74

Blochiidae 140

Blochius 141

Boavus 220

Bolodon 352

Bolosaurus 192

Boodontia 501

Boremys 248

Borhyaena 362

Borophagus 388

Bos 506

Boselaphus 502

Bostrichthys 96

Bothremydidae 248

Bothremys 248

Bothriceps 170

Bothriodon 477

Bothriolepis 39

Bothriospondylus 287

Bothrolabis 473

Bottosaurus 272

Bovinae 504

Bovinen 499

Box 136

Brachauchenius 238

Brachibrachium 19

Brachiosaurus 285

Brachyacanthus 48

Brachyceros 506

Brachydectes 163

Brachydiastematherium 465

Brachydirus 82

Brachyichthys 110

Brachymylus 72

Brachyodus 477

Brachyops 170

Brachypotherium 453

Brachyprotoma 395

Brachypsalis 394

Brachyrhinodon 206

Brachyrhynchus 140

Brachyrophus 295

Brachysaurus 217

Brachytherium 443

Bradylemur 550

Bradypodidae 413

Bramatherium 496

Branchiosauridae 160

Branchiosaurus 160

Brevirostres 263

Brimosaurus 237

Brithopus 196

Brontops 467

Brontornis 323

Brontosaurus 285

Brontotherium 466

Brosmius 127

Bruta 410

Bubalidinae 503

Bubalis 503

Bubalus 505

Bubo 325

Bucapra 501

Buceros 324

Bucklandium 123

Büffel 505

Buffelus 505 
Camptosaurus 289

Campylognathus 304 Campyloprion 59

Canidae 386

Caninae 389

Canis 389

Canobius 98

Cantioscyllium 50

Capitodus 123

Capitosaurus 172

Capra 501

Capreolus 494

Caprimulgi 324

Capromeryx 496

Capromyinae 431

Captorhinus 192

Carangidae 137

Carangopsis 137

Caranx 137

Carcharias 51

Carchariidae 51

Carchariopsis 45

Carcharodon 53

Carcinodon 376

Cardiocephalus 169

Cardiodon 432

Caretta 254

Carettochelyidae 257

Carettochelys 256

Cariama 323

Carnivora 374

Caroloameghinia 363

Caroloameghiniidae 363

Carolodarwinia 523

Carolozittelia 527

Carsosaurus 211

Casea 196

Castor 427

Castorinae 426

Castoroidea 426

Castoroides 427

Castresia 257

Casuarius 320

Catapleura 251

Catastylops 523

Catodontherium 479

Catopsalis 354

Catopteridae 102

Catopterus 102

Caturidae 114

Caturus 114

Caulodon 288

Cavia 432

Cavicornia 497

Cavinae 432

Cayluxotherium 369

Cebidae 552

Cebochoerus 473

Cebus 552

Cecomorphae 322

Cenchrodus 108

Centetidae 366

Centracodon 368

Centrina 50

Centriscidae 140

Centrobatidae 66

Centrodus 87

Centrolepis 100

Centrophoroides 50

Centrophorus 49

Centropristis 133

Centrosaurus 296

Cephalaspidae 33

Cephalaspis 33

Cephalogale 389

Cephalomys 432

Cephalophinae 502

Cephalophus 502

Cephenoplosus 114

Ceramurus 111

Ceratodontidae 76

Ceratodus 77

Ceratogaulus 427

Ceratops 296
Ceratopsidae 295

Ceratopterinae 65

Ceratorhinus 453

Ceratosaurus 281

Cervalces 494

Cervavus 493

Cervicapra 504

Cervicaprinae 504

Cervicornia 490

Cervinae 493

Cervulinae 492

Cervulus 493

Cervus 494

Cestracion 56

Cestracionidae 56

Cetacea 401

Cetiosauridae 285

Cetiosaurus 285

Cetorhinus 53

Cetorhynchus 408

Cetotherium 410

Chaenohyus 473

Chaetodontidae 134

Chalcodus 61

Chalcosaurus 168

Chalicomys 426

Chalicotheriidae 467

Chalicotherium 468

Chamaeleo 210

Chamaeleontia 210

Chamaeleontidae 210

Chamops 210

Champsodelphis 408

Champsosauridae 204

Champsosaurus 204

Chanoides 121

Chanos 121

Characinidae 123

Characodus 86

Charadrius 322

Charithemys 248

Charitosomus 127

Chasmotherium $\mathbf{4 4 7}$

Chatossus 120

Chauna 323

Cheiracanthus 42

Cheirodopsis 101

Cheirodus 101

Cheirolepis 98

Chelodina 249

Chelodus 426

Chelone 254

Chelonemys 249

Chelonia 254

Chelonichthys 38

Chelonides 249

Cheloniidae 254

Cheloniidea 252

Chelotriton 176

Chelydosaurus 167

Chelydra 251

Chelydridae 251

Chelyidae 248

Chelyophorus 82

Chelyopsis 255

Chelyposaurus 201

Chelytherium 247

Chelyzoon 247

Chenomorphae 323

Chenopsis 323

Chenornis 323

Chersidae 252

Chilonix 192

Chiloscyllium 50

Chimaera 72

Chimaeracanthus 71

Chimaeridae 70

Chimaeropsis 70

Chinchillinae 432

Chirocentridae 122

Chirocentrites 122

Chirocentrus 122

Chiromyidae 550

Chiromys 550

Chiromystus 122
Chironectes 363

Chiroptera 373

Chirotherium 173

Chirotrichidae 134

Chirotrix 135

Chirox 353

Chisternon 248

Chitinodus 60

Chitracephalus 250

Chlamydoselache 49

Chlamydoselachidae 49

Chlamydotherium 421

Choeromorus 473

Choeropotamus 473

Choerotherium 473

Choloepus 415

Chomatodus 61

Chondrenchelys 44

Chondrostei 94

Chondrosteidae 94

Chond rosteosaurus 287

Chondrosteus 94, 287

Choneziphius 408

Chordata 3

Choristodera 204

Chriacus 376

Chromidae 134

Chrysemys 252

Chrysochioridae 366

Chrysophrys 136

Cimolestes 363

Cimoliasaurus 237

Cimolichthys 126

Cimolodon 354

Cimolomys 354

Cimolopteryx 325

Cinosternidae 256

Cinosternum 256

Cionodon 292

Cistudo 251

Citharus 128

Cladacanthus 59

Cladoclinus 355

Cladocyclus 122

Cladodontidae 44

Cladodus 45

Cladornis 322

Cladoselache 45

Cladosictis 362

Claenodon 382

Claorhynchus 293

Claosaurus 291

Clastes 113

Claudius 256

Cleithrolepis 100, 107

Clemmys 252

Clenialites 553

Clepsydropidae 194

Clepsydrops 194

Clepsysaurus 260

Clidastes 216

Climatius 48

Climaxodus 62

Cliorhizodus 196

Clupea 120

Clupeidae 120

Cnemiornis 323

Cobus 504

Coccoderma 89

Coccodus 105

Coccolepis 100

Coccosteidae 80

Coccosteus 8

Cochilius 516

Cochleosaurus 167

Cochliodontidae 59

Cochliodus 59

Cochlops 420

Coeciliae 174

Coelacanthidae 88

Coelacanthus 88

Coelocephalus 139

Coelodon 416

Coelodonta 454

Coelodus 104

Coelogaster 122

Coelolepidae 28

Coelolepis 29

Coelophysis 280

Coelosaurus 282

Coelosochus 270

Coeluridae 280

Coelurus 280

Coendu 431

Colii 324

Colobodus 107

Colodon 448

Colomys 430

Colonoceras 451

Coloreodon 482

Colpodon 523

Columba 324

Columbae 324

Colus 500

Colymboides 322

Colymbosaurus 236

Colymbus 322

Compsacanthus 72

Compsemys 248,256

Compsognathidae 282

Compsognathus 282

Conacodon 439

Conchiopsis 88

Conchiosaurus 233

Conchochelys 257

Conchodus 74

Conchopoma 75

Condylarthra 437

Coniopternium 441

Coniosaurus 211. 
Crotalus horridus 219 Cruschedula 322 Cryptobranchus 176 Cryptocleidus 236 Cryptocynodon 201 Cryptodira 250 Cryptomeryx 487 Cryptopithecus 5.46 Cryptoprocta 397 Cryptornis 325 Cryptosaurus 289 Crypturi 321

Ctenacanthus 53

Ctenacodon 353

Ctenerpeton 165

Ctenodactylinae 431

Ctenodontidae 75

Ctenodontinae 432

Ctenodus 75

Ctenomys 432

Ctenopetalus 63

Ctenopoma 140

Ctenoptychius 63

Ctenosaurus 195

Ctenothrissa 122

Ctenothrissidae 122

Cuculi 324

Cumnoria 289

Cuniculus 430

Curtodus 56

Cyamodus 240

Cybium 139

Cyclobatis 67

Cycloid- und Ctenoidschuppen 5

Cyclolepidoti 113

Cyclopidius 484

Cyclopoma 133

Cycloptychius 98

Cyclostomi 3

Cyclotosaurus 172

Cyclurus 117

Cyenorhamphus 306

Cygnus 323

Cylindrodon 428

Cymatosaurus 233

Cymbospondylus 228

Cynarctus 392

Cynocephalus 553

Cynocercus 255

Cynochampsa 198

Cynodesmus 387

Cynodictinae 386

Cynodictis 387

Cynodon 389

Cynodontia 198

Cynodontinae 389

Cynodontomys 370

Cynodontosuchus 271

Cynodraco 198,289

Cynognathus 198

Cynohyaenodon 380

Cynomys 426

Cynonycteris 374

Cynopithecidae 553

Cynosuchus 198

Cyon 390

Cyonasua 392

Cyphornis 324

Cyprinidae 122

Cyprinodontidae 122

Cyprinus 123

Cypselavus 325

Cypselus 325

Cyrtodelphis 408

Cyrtonodus 59

Cythaspis 32

Cyttidae 132

Cyttoides 132

Dacentrurus 294

Dacosaurus 269

Dacrytherium 478

Dactylodus 62

Dactylolepis 107
Dactylopogon 131

Dactylosaurus 234

Dama 494

Damaliscus 503

Danubiosaurus 294

Dapedius 106

Dapedoglossus 121

Daphaenodon 388

Daphaenus 388

Daptinus 128

Daptophilus 398

Dasyceps 168

Dasypodidae 421

Dasypus 421

Dasyuridae 361

Dasyurodon 381

Dasyurus 362

Datheosaurus 203

Dawsonia 162

Decastis 356

Degenfische 136

Deilotherium 480

Deinodon 281

Deinosuchus 272

Delphinidae 408

Delphinodon 407

Delphinognathus 198

Delphinopsis 409

Delphinornis 322

Delphinosaurus 228

Delphinus 409

Deltatherium 376

Deltodus 60

Deltoptychius 61

Dendrerpeton 163

Dendrodus 86

Dendrohyrax 531

Dendroptychius 86

Dentex 133

Dercetidae 125

Dercetis 125

Dermatemydidae 255

Dermatemys 256

Dermochelyidae 253

Dermochelys 253

Dermodactylus 307

Desmathyus 473

Desmatippus 461

Desmatochelydae 255

Desmatochelys 255

Desmatodon 192

Desmatotherium 447

Desmognathinae 176

Desmospondylus 190

Desmostylus 542

Deuterosauridae 196

Deuterosaurus 196

Deuterotherium 443

Devisia 251

Diacium 210

Diacodon 367

Diadectes 192

Diadectidae 192

Diademodon 198

Diadiaphorus 443

Dialophus 523

Diapsida 187

Diasparactus 192

Diastichus 123

Diatryma 323

Dicentrodus 45

Diceratherium 453

Diceratops 296

Diceratosaurus 164

Diceros 454

Dichelodus 61

Dichobune 479

Dichobunidae 479

Dichodon 481

Diclonius 291

Dicoelophorus 432

Dicotyles 473

Dicranozygoma 198

Dicrenodus 45

Dicrocerus 493
Dicrocynodon 361

Dictaea 62

Dictyocephalus 171

Dictyodus 139

Dictyopyge 102

Dicynodon 200

Dicynodontia 198

Dicynodontidae 201

Didelphia 350

Didelphops 363

Didelphyidae 362

Didelphys 363

Didolodus 441

Didus 324

Didymaspis 34

Didymictis 383

Didymodus 43

Dihoplus 453

Dilambdodonta 366

Dilophodon 447

Dimetrodon 194

Dimorphodon 304

Dimylidae 368

Dimylus 368

Dinichthys 82

Dinictis 398

Dinilysia 220

Dinobastis 398

Dinocephalia 198

Dinoceras 509

Dinoceratidae 508

Dinocyon 389

Dinodocus 288

Dinohyus 475

Dinopteryx 132

Dinornis 321

Dinornithidae 320

Dinosauria 273

Dinosaurus 196

Dinotheriidae 536

Din.otherium 536

Diodon 142

Diomeda 322

Diopecephalus 306

Diopeus 194

Dipodidae 429

Dioplodon 408

Diorotherium 524

Dipilus 356

Diplacanthidae 48

Diplacanthus 48

Diplacodon 465

Diplacodus 59

Diplaspis 32

Diplobune 478

Diplocaulidae 165

Diplocaulus 165

Diploclonus 467

Diplocynodon 272,361

Diplocynodontinae 361

Diplodocidae 288

Diplodocus 288

Diplodus 43

Diploglossus 210

Diplognathus 83

Diplolepis 114

Diplomystus 120

Diplopterus 87

Diplosaurus 270

Diplotomodon 283

Diplovertebron 17

Diplurus 89

Dipnoi 73

Dipodoidea 429

Dipoides 427

Dipriacanthus 73

Dipriodon 354

Dipristis 72

Diprotodon 358

Diprotodontia 355

Dipteridae 73

Dipterus 74

Dipus 429

Diracodon 294

Dirrhizodon 51

Discoglossus 178

Discolomys 431

Discosaurus 167

Dissacus 377

Dissorophus 169

Disticholepis 109

Distrophaeus 285

Ditaxiodus 115

Ditrochosaurus 240

Dittodus 44, 86

Docodon 361

Doedicurus 419

Dolichobrachium 194

Dolichopithecus 554

Dolichopterus 107, 323

Dolichorhinus 465

Dolichorhynchus 238

Dolichosauridae 211

Dolichosaurus 211

Dolichosoma 166

Dolichotis 432

Doliochoerus 474

Doliovertebra 234

Dollopterus 107

Domnina 367

Doratorhynchus 307

Dorcatherium 487

Dorcichthys 141

Dornhaie 49

Dorudon 406

Dorygnathus 304

Dorypterus 101

Dremotherium 492

Drepanacanthus 63

Drepanaspidae 29

Drepanaspis 30 
Eidechsen 207

Eifelosaurus 206

Eisvögel 324

Elaphis 220

Elaphrocnemus 323

Elaphus 494

Elasmobranchii 39

Elasmodectes 72

Elasmodus 72

Elasmognathus 72, 448

Elasmosaurus 238

Elasmotheriinae 454

Elasmotherium 454

Elcabrosaurus 194

Elentier 494

Elephantidae 537

Elephas 539

Eleutherocercus 419

Elginia 192

Eliomys 429

Elomeryx 477

Elonichthys 98

Elopidae 124

Elopopsis 125

Elops 124

Elornis 323

Elosaurus 288

Elotheriidae 474

Elotherium 475

Embaphias 237

Embassis 363

Embolomeri 171

Embolophorus 194

Embrithopoda 529

Empedias 192

Empo 126

Emydinae 251

Emydura 249

Emys 251

Enaliochelys 250

Enaliornis 318

Enaliosuchus 269

Enchelops 127

Enchelurus 125

Enchodontidae 125

Enchodus 126

Endothiodon 201

Endothiontidae 201

Engraulis 121

Enhydriodon 394

Enhydrocyon 388

Enneles 125

Enneodon 361

Enoplosus 133

Entelodon 475

Entelonychia 521

Entelostylops 523

Entenvögel 323

Entomacodon 368

Entomolestes 368

Entoptychus 427

Eoauchenia 442

Eocardia 432

Eocerus 502

Eocetus 406

Eochalicotherium 523

Eochelone 255

Eocottus 140

Eocynodon 139

Eodidelphys 363

Eohegetotherium 516

Eohippus 458

Eohyrax 517

Eohyus 473

Eomeryx 482

Eommanodon 355

Eomorphippus 519

Eomyinae 429

Eomyrus 127

Eomys 429

Eoneornis 323

Eopachyrucos 516

Eopristis 65

Eoproterotherium 443

Eosaurus 171
Eoserpeton 163

Eosiren 542

Eosphargis 254

Eospheniscus 322

Eosteiromys 431

Eostylops 523

Eosuchus 271

Eotherium 542

Eothynnus 139

Eotylopus 484

Epanorthus 356

Epanterias 288

Ephippus 134

Epiaceratherium 452

Epiceratodus 78

Epicordylus 168

Epigaulus 427

Epihippus 458

Episcoposaurus 260

Epitherium 442

Eplacentalia 349

Eporeodon 483

Equidae 454

Equinae 461

Equula 137

Equus 462

Erdferkel 412

Eremopezus 320

Erethizon 431

Erethizontinae 431

Eretmochelys 254

Eretmosaurus 236

Erinaceidae 369

Erinaceinae 369

Erinaceus 369

Eriodes 552

Erisichthe 130

Erismacanthus 73

Erismatopterus 132

Erpetosaurus 163

Erpetosuchus 171, 260

Erquelinnesia 251

Erycidae 220

Eryops 168

Erythrosuchus 260

Eschatius 486

Esocidae 122

Esoterodon 201

Esox 122

Essonodontherium 416

Essoprion 356

Esthonyx 372

Estonychinae 372

Eubaëna 248

Euboeicus 220

Eubrachiosaurus 198

Eucamarotus 287

Eucastor 427

Eucephalaspis 33

Euceratherium 501

Eucerosaurus 295

Eucetus 407

Euchirosaurus 168

Eucholoeops 416

Euclastes 251

Eucrania 3

Eucreodi 382

Eucrotaphus 483

Eucynepeltus 420

Eudactis 115

Eudelphis 407

Eudiastatus 552

Euelephas 540

Euglypta 171

Eugnathus 116

Euhaspis 427

Eukeraspis 34

Eulen 325

Eumylodus 72

Eumys 430

Euornithes 322

Eupelor 171

Eupleurodus 107

Euposaurus 210

Euprotogonia 439
Eupterornis 323

Eurapteryx 321

Eurhinodelphis 408

Eurosaurus 196

Euryacodon 548

Euryarthra 66

Eurycormus 116

Eurylepis 98

Eurynotus 100

Eurypholis 126

Eurysaurus 233

Eurysternum 250

Eurytherium 478

Eusemius 109

Euskelosaurus 279

Eusmilus 397

Eusthenopteron 87

Eusuchia 261

Eutatus 421

Eutelornis 323

Euthacanthus 48

Euthynotus 114

Eutrachytherus 517

Eutypomys 427

Exocoetoides 135

Fährten von Stegocephalen 173

Falco 324

Fayumia 123

Felidae 397

Felinae 398

Felis 399

Felsinotherium 542

Fiber 431

Ficrasfer 128

Filholornis 325

Fische 3

Fischlurche 176

Fischsaurier 220

Fissipedia 384

Fissodus 62

Fistularia 140

Flamingo 323

Fledermäuse 373

Fleischfresser 374

FlossenfüBer 399

Flugsaurier 298

Flußpferde 475

Flußschildkröten 256

Froschlurche 177

Fudica 323

Fuligula 323

Furchenwale 409

Furcifer 494

Gadidae 127

Gadus 127

Gafsachelys 251

Galechirus 198

Galecynus 387

Galeocerdo 51

Galerix 369

Galesauridae 197

Galesaurus 198

Galethylax 380

Galeus 51

Galictis 393

Galliaetatus 413

Gallinaceiden 321

Gallinae 324

Gallinuloides 324

Gallus 324

Gampsacanthus 59, 73

Ganodonta 413

Ganodus 71

Ganoidei 90

Ganoidschuppen 5

Ganolodus 86

Garzonia 355

Gastornis 323

Gastrodus 86

Gaudrya 167

Gavialidae 271

Gavialis 272

Gavialosuchus 271

Gazella 500

Gazellinae 499

Geikia 201

Gelocinae 487

Gelocus 488

Gemündenia 29

Gemündenidae 29

Geniohyus 531

Genyodectes 281

Genyornis 320

Geomyinae 427

Geomyoidea 427

Geomys 427

Geosaurus 196, 269

Gephyrostegus 163

Geranopterus 325

Gerbillus 430

Geronops 416

Gerres 133

Geweihträger 490

Giffonus 97

Gigantichthys 126

Gigantopterus 111

Gigantosaurus 287

Gillicus 129

Gingly mostoma 50

Giraffinae 495

Glattwale 410

Glires 422

Globicephalus 409

Globilemur 550

Globulodus 101

Glossochelys 251

Glossodus 63

Glossotherium 417

Glyphidodontidae 133 
Gypogeranus 324

Gypsornis 323 Gyracanthus 46 Gyrodus 102 Gyrolepis 100 Gyroptychius 87 Gyrosteus 95

Habrothrix 430

Hadrianus 252

Hadropithecus 550

Hadrorhynchus 363

Hadrosaurus 291

Hainosaurus 217

Halbaffen 544

Halcyornis 325

Halec 126

Halecomorphi 116

Halecopsis 121

Haliaetus 324

Halianassa 542

Halicore 542

Halicoridae 542

Halitherium 542

Hallopus 261

Halmarhiphus 355

Halmaselus 356

Halmaturus 357

Halodon 354

Halsbandlemming 430

Halticosaurus 283

Hamster 429

Hapale 552

Hapalidae 552

Hapalodectes 377

Hapalops 416

Haplacanthosaurus285

Haplacanthus 46,72

Haplobunodon 477

Haploceros 501

Haploconus 439

Haplodon 425

Haplodontherium 521

Haplogale 393

Haplomeryx 481

Haptodus 203

Hargeria 319

Harpacodus 63

Harpagolestes 377

Harpagornis 324

Harpalodon 383

Hasen 433

Hathlyacynus 362

Hatteria 201， 206

Hegetotheriidae 516

Hegetotherium 516

Helagris 220

Helaletes 447

Helemys 248

Heliarchon 176

Helichthys 100

Helicophora 504

Helicoprion 59

Heliobatis 67

Heliodus 74

Helladotherium 495

Helochelys 247

Helodermatidae 210

Helodus 60

Helopanoplia 257

Helotermatidae 210

Helotherium 458

Hemiacodon 548

Hemiauchenia 486

Hemibos 505

Hemicladodus 101

Hemictenodus 77

Hemicyclaspis 33

Hemicyon 389

Hemiganus 414

Hemilopas 108

Hemipristis 51

Hemipsalodon 380

Hemiptychodus 68

Hemirhynchus 136
Hemisaurida 130

Hemithlaeus 439

Hemithyrsites 137

Henricofilholia 523

Henricosbornia 517

Henricosborniidae 517

Heptacodon 477

Heptadiodon 142

Heptanchus 49

Heptanema 89

Heptodon 447

Herodii 323

Herpestes 395

Herpetocetus 410

Herpetotherium 363

Herrentiere 544

Hesperomyinae 430

Hesperomys 430

Hesperornis 318

Hesperornithes 318

Heteracanthus 72

Heterocerci 97

Heterocetus 410

Heteroclitotriton 176

Heterodelphis 408

Heterodontus 56

Heterohyrax 531

Heterolepidotus 116

Heteromeryx 495

Heteropython 220

Heterosteus 83

Heterostraci 28

Heterothrissops 114

Hexanchus 49

Hexaprotodon 476

Hicanodonta 418

Hierosaurus 294

Hipparion 461

Hippidium 462

Hippocampiden 141

Hippohyus 474

Hippopotamidae 475

Hippopotamus 476

Hipposyus 547

Hippotherium 461

Hippotraginae 503

Hippotragus 503

Hirundo 325

Histiocephalus 134,140

Histionotopterus 134

Histionotus 109

Histiophorus 140

Histiothrissa 121

Hohlhörner 497

Hulacanthodes 47

Holaspis 32

Holcodae 126

Holocentrum 132

Holocephali 69

Holodus 74, 75

Holomeniscus 486

Holonema 84

Holophagus 89

Holops 271

Holoptychiidae 85

Holoptychius 86

Holosaurus 217

Holosteus 131

Homacanthus 46, 72

Homacodon 480

Homaeosaurus 206

Homalodontheriidae

467,523

Homalodontotherium 524

Homalodus 61

Homalostylops 523

Hominidae 556

Homo 556

Homo diluvii tristis testis 176

Homoecetus 407

Homoeolepis 107

Homonotus 132

Homorophus 256
Homosteus 83

Homunculus 552

Hoplitosaurus 29

Hoplocetus 407

Hoplochelys 256

Hoplophoneus 397

Hoplophorus 419

Hoplopleuridae 125

Hoplopteryx 131

Hoplopygus 88

Hoplosaurus 295

Hoplosthetus 132

Howesia 205

Hühnervögel 324

Hülsenwirbler 162

Huftiere 435

Hunde 386

Hundsaffen 553

Hunosaurus 217

Hyaegulus 481

Hyaelobatrachus 176

Hyaelochelys 249

Hyaelosaurus 294

Hyaemoschus 487

Hyaena 396

Hyaenarctos 390

Hyänen 396

Hyaenictis 396

Hyaenidae 396

Hyaenocyon 388

Hyaenodictis 377

Hyaenodon 381

Hyaenodontidae 379

Hyaenodontinae 380

Hyaenognathus 388

Hyaenosuchus 198

Hybocladodus 45

Hybodontidae 53

Hybodus 53

Hydaspitherium 496

Hydraspis 249

Hydrochoerus 432

Hydropelta 249

Hydropesium 100

Hydropotes 492

Hydrornis 323

Hylaeochampsa 270

Hylerpeton 163

Hylobates 556

Hylonomidae 162

Hylonomus 162

Hyloplesion 162

Hyomeryx 482

Hyopotamus 477

Hyopsodontidae 369

Hyopsodus 480

Hyotherium 473

Hypamia 117

Hyperdichobune 480

Hyperleptus 416

Hyperodapedon 205

Hyperoodon 408

Hypertragulidae 488

Hypertragulus 489

Hypisodus 496

Hypnopous 192

Hypohippus 461

Hypolophites 68

Hypoprion 51

Hyporhina 210

Hyposaurus 270

Hypotemnodon 387

Hypselornis 320

Hypselosaurus 288

Hypsibaema 293

Hypsilophodon 289

Hypsilophontidae 289

Hypsiprymninae $\quad 357$

Hypsiprymnodon 357

Hypsiprymnopsis 352

Hypsirrhophus 283

Hypsocormus 114

Hypsodon 128

Hypudaeus 430

Hyrachyus 451

Hyracidae 531

Hyracodon 45

Hyracodontherium 478

Hyracodontidae 450

Hyracoidea 530

Hyracops 439

Hyracotheriinae 457

Hyracotherium 458

Hyrax 531

Hystricinae 431

Hystricognathi 425

Hystricoidea 428

Hystricomorpha 431

Hystrix 431

Jaccare 272

Janassa 62

Josepholeidya 441

Julis 134

Ibidopodia 323

Ibidopsis 323

Ibis 323

Ichthyodectes 129

Ichthyodectidae 128

Ichthyodorylithen 7,72

Ichthyoidea 176

Ichthyorhynchus 97

Ichthyornis 319

Ichthyosauria 220

Ichthyosaurus 228

Ichthyotomi 41

chthyotringa 130

Icochilus 516

Icticyon 390

Ictidosaurus 198

Ictidosuchus 198

Ictinocephalus 48 
Isurichthys 140

Isurus 140

Ixacanthus 408

Kadaliosaurus 203

Känguruh-Ratten 357

Kängurus 357

Kallistina 256

Karoomys 359

Karpfen 122

Katzen 397

Keiloskiosaurus 193

Keirognathus 200

Kekenodon 406

Keraterpeton 164

Kerodon 432

Kiemenlurche 176

Kistecephalus 201

Kletter-und Flugbeutler 357

Klippschliefer 530

Kloakentiere 349

Kogia 407

Krallenaffen 552

Krambergeria 133

Kranz- oder Schnittwirbler 166

Kriechtiere 179

Kuckucke 324

Kurtodon 361

Labidosaurus 190

Labrax 133

Labridae 133

Labrodon 134

Labrosauridae 280

Labrosaurus 280

Labrus 134

Labyrinthici 141

Labyrinthodon 173

Labyrinthodontidae171

Lacerta 210

Lacertidae 210

Lacertilia 207

Lacertilia vera 210

Lachse 121

Laelaps 282

Lagarodus 61

Lagomeryx 493

Lagomorpha 433

Lagomydae 433

Lagomys 433

Lagopsis 433

Lagopus 324

Lagostomus 432

Lamaops 486

Lambdaconus 441

Lambdodus 45

Lambdotherium 465

Lamna 52

Lamnidae 51

Lamnodus 86

Lamprosaurus 233

Lanarkia 29

Landschildkröten 252

Lanius 325

Laodon 361

Laopithecus 475

Laornis 323

Laosaurus 289

Lariosaurus 233

Larus 322

Lasanius 28

Lates 133

Latonia 178

Laurillardia 325

Lebias 122

Lecracanthus 73

Lederschild kröten 253

Legnonotus 109

Leiacanthus 54

Leidyosuchus 272

Leiodon 215

Leithia 429

Lembonax 255
Lemmus 430

Lemur 550

Lemuravus 370

Lemuridae 549

Lemuroidea 544

Leontinia 523

Leontiniidae 523

Lepidocothes 140

Lepidopides 136

Lepidopus 136

Lepidosauria 207

Lepidosaurus 108

Lepidosiren 77

Lepidosteidae 112

Lepidosteus 113

Lepidotus 108

Leporidae 433

Lepospondyli 162

Leptacanthus 71

Leptaceratherium 452

Leptacotherulum 473

Leptadapis 547

Leptarctus 392

Leptauchenia 483

Lepterpeton 165

Leptictidae 366

Leptictis 367

Leptobos 505

Leptocardii 2, 23

Leptochoeridae 475

Leptochoerus 475

Leptocladus 360

Leptocranius 268

Leptodon 532

Leptolepidae 119

Leptolepis 119

Leptomanis 412

Leptomeryx 489

Leptomylus 72

Leptophoca 401

Leptopilus 323

Leptoreodon 494

Leptorhamphus 272

Leptosomus 131

Leptotheridium 478

Leptotrachelus 125

Leptotragulinae 484

Leptotragulus 484

Lepus 433

Lestodon 417

Lestosaurus 217

Leuciscus 123

Leucocyon 390

Leucosarica 324

Liarthrus 526

Libys 89

Licaphrium 443

Lichia 137

Limnatornis 325

Limnenetes 482

Limnerpeton 163

Limnerpetontidae 162

Limnocyon 378

Limnocyoninae 378

Limnofelis 379

Limnohyops 465

Limnohyus 465

Limnophis 220

Limnosaurus 292

Limnotherium 370,547

Limodon 417

Limognitherium 468

Liodesmus 117

Liodon 217

Liognathus 81

Liopleurodon 237

Liotomus 353

Lipotyphla 365

Lippfische 133

Lisgodus 61

Lispocanthus 72

Lissoprion 59

Listriodon 474

Listriotherium 526

Lithocranius 500
Lithophis 220

Lithornis 324

Litopterna 440

Lobodon 401

Löffelstöre 96

Lomaphorus 419

Lomomys 431

Loncheres 432

Loncherinae 432

Lonchoconus 441

Lonchorhynchus 171

Loncosaurus 281

Longirostres 263

Lophacanthus 44

Lophidiochoerus 447

Lophiobunodon 477

Lophiodon 447

Lophiodontinae 447

Lophiolemur 550

Lophiomeryx 487

Lophiomys 431

Lophiotherium 458

Lophiurus 117

Lophius 134

Lophobranchii 141

Lophocetus 408

Lophocoelus 523

Lophodus 60

Loricata 418

Loxodon 540

Loxolophodon 510

Loxolophus 376

Loxomma 171

Lurche 143

Lurchschild kröten 247

Lutra 394

Lutrictis 394

Lutrinae 394

Lycarion 383

Lycoptera 120

Lycosaurus 198

Lycosuchus 198

Lycyaena 396

Lysorophus 218

Lystrosauridae 201

Lystrosaurus 200

Lytoloma 251

Iacacus 554

Macellodus 210

Macelognathus 295

Machaeracanthus 72

Machairacanthus 46

Machairodontinae 397

Machairodus 397

Machairoides 379

Machimosaurus 270

Machlydotherium 422

Machochelys 251

Macrauchenia 442

Macraucheniidae 441

Macrerpeton 171

Macrochires 324

Macrolemys 251

Macrolepis 132

Macromerosaurus 233

Macropetalichthys 83

Macropodinae 357

Macropoma 89

Macropus 357

Macrorhipis 111

Macrorhynchidae 269

Macrorhynchus 270

Macrosaurus 217

Macroscelididae 366

Macrosemiidae 109

Macrosemius 109

Macrotherium 468

Macruridae 127

Macrurosaurus 294

Madoqua 499

Makrelen 139

Mallotus 121

Mammalia 325

Manatherium 542

Manatidae 542

Manatus 542

Mancalla 322

Manidae 413

Manis 41

Manisaurus 237

Manteoceras 465

Manteodon 508

Marder 392

Marsipobranchii 23

Marsupialia 350

Martinae 393

Massospondylus 280

Masticura 66

Mastodon 537

Mastodonsaurus 172

Mauerschwalben 324

Maulwürfe 367

Mazama 494

Meeradler 67

Meerbrassen 135

Meerschildkröten

Megacerops 467

Megaceros 494

Megachiroptera 374

Megadactylus 280

Megaladapis 547

Megalapteryx 321

Megalichthys 87

Megalictis 393

Megalneusaurus 238

Megalobatrachus 176

Megalohyrax 532

Megalonychinae 416

Megalony chotherium 416

Megalonyx 416

Megalops 124 
Mesatirhinus 465

Mesaxonia 444

Mesembriotherium 526

Mesiteia 50

Mesoadapis 550

Mesocetus 406

Mesocyon 387

Mesodon 103

Mesodonta 545

Mesogaster 135

Mesogaulus 427

Mesogomphus 61

Mesohippus 460

Mesolepis 101

Mesoleptos 211

Mesomys 432

Mesonychidae 376

Mesonychinae 377

Mesnnyx 378

Mesopithecus 553

Mesoplodon 408

Mesopteryx 321

Mesoreodon 483

Mesorhinus 258, 465

Mesosauridae 240

Mesnsaurus 240

Mesosuchia 261

Mesoteras 410

Mesturus 103

Metachiromys 550

Metacordylodon 368

Metalophodon 508

Metamosaurus 196

Metamynodon 451

Metasinopa 380

Metatheria 350

Metaxytherium 542

Metepanorthus 356

Meteutatus 422

Metolbodotes 370

Metopacanthus 70

Metopias 172

Metoposaurus 172

Metopotoxus 421

Metriodromus 356

Metriorhynchidae 269

Metriorhynchus 269

Metriotherium 480

Miacidae 383

Miacinae 383

Miacis 383

Michrobrachis 163

Micrerpeton 162

Microbiotherium 363

Microbrachidae 162

Microbrachium 39

Microchiroptera 374

Microchoerus 549

Microclaenodon 377

Microcleidus 237

Microcoelia 131

Microcoelus 288

Microconodon 358

Microdon 102

Microgomphodon 198

Microlepidoti 113

Microleptosaurus 233

Microlestes 352

Micromeryx 492

Micropholis 170

Micropternodus 366

Microsauria 162

Microsauridae 162

Microsyopiden 550

Microsyops 370

Microtherium 481

Microtus 431

Microzeuglodon 407

Miksurnia 52

Milvus 324

Mimomys 431

Mioclaenidae 438

Mioclaenus 438, 481

Miocyon 383

Miohippus 460
Miolania 249

Miolanidae 249

Mioplosus 133

Miosiren 542

Mioziphius 408

Mixodectes 370

Mixodectidae 370

Mixohyrax 532

Mixosaurus 228

Mixtotherium 479

Mochlodon 289

Moeripithecus 553

Moeritheriidae 535

Moeritherium 535

Molche 176

Molgophis 166

Monachus 401

Monatherium 401

Monimostylica 183

Monocentris 132

Monoclonius 296

Monodon 408

Monopterus 122

Monotremata 349

Morenia 431

Morinosaurus 288

Moropus 468

Morosauridae 287

Morosaurus 287

Morphippus 519

Mosasauria 211

Mosasauridae 211

Mosasaurus 215

Moschinae 492

Moschus 492

Moschushirsche 492

Motacilla 325

Mouillacitherium 480

Müllerornis 320

Mugil 135

Mugiliden 135

Multituberculata 351

Muntjakhirsche 492

Muraenidae 127

Muraenosaurus 236

Murinae 430

Mus 430

Muscardinus 429

Musophagi 324

Mustela 393

Mustelidae 392

Mustelus 51

Mycetes 552

Mylagaulinae 427

Mylagaulodon 425

Mylagaulus 427

Myliobatinae 67

Myliobatis 67

Mylodon 417

Mylodonta 413

Mylodontinae 416

Mylognathus 72

Mylohyus 474

Mylorhina 68

Mylostoma 84

Myocastor 431

Myodes 430

Myogale 368

Myoidea 429

Myolagus 433

Myolestes 368

Myomorpha 429

Myopotamus 431

Myoxoidea 428

Myoxus 429

Myriacanthidae 70

Myriacanthus 70

Myriolepis 100

Myripritis 132

Myrmecobiidae 359

Myrmecobius 359

Myrmecophagidae 413

Myrmecophagiden 422

Myrus 127

Mysops 425
Mystacocoeti 409

Mystriosaurus 268

Mystriosuchus 258

Nager 422

Naiadochelys 248

Nannosaurus 289

Nannosuchus 270

Nanomys 354

Naomichelys 248

Naosaurus 195

Napodonictis 362

Narcine 66

Narcobates 66

Naseus 137

Nashornvögel 324

Nasua 392

Necrobyas 325

Necrodasypus 421

Necrogymnurus 369

Necrolemur 480,549

Necrolestes 366

Necrolestidae 366

Necromanis 413

Necromantis 374

Necrornis 325

Nectosaurus 207

Nectridae 163

Nemacanthus 72

Nemachilus 123

Nematherium 417

Nematognathi 123

Nematonotus 131

Nematopteryx 127

Nematoptychius 98

Nemorrhaedus 500

Neohipparion 462

Neolemuroidini 545

Neomylodon 417

Neoplagiaulax 417

Neoracanthus 416

Neoreomys 431

Neosodon 287

Neosqualodon 407

Neotoma 430

Neotraginae 499

Neotragocerus 503

Neotragus 499

Nephrotus 107

Neptunochelys 255

Nesodon 520

Nesodontidae 520

Nesokerodon 433

Nesokia 430

Nesomyine 430

Nesopithecus 550

Neurancylus 248

Neuryurus 419

Neusticosaurus 234

Neustosaurus 269

Nimravus 398

Nodosaurus 294

Nomarthra 412

Nostolepis 29

Notacanthiden 125

Notaeus 117

Notagogus 110

Notelops 125

Notharctus 547

Nothocyon 387

Nothodon 192

Nothosauridae 230

Nothosaurus 230

Nothotherium 358

Nothrotherium 416

Notidanidae 49

Notidanus 49

Notogoneus 127

Notohippidae 519

Notohippus 519

Notomorpha 256

Notopithecidae 515

Notopithecus 516

Notoprogonia 44

Notoryctes 359

Notoryctidae $35 \%$

Notostylopidae 522

Notostylops 523

Notosuchus 271

Notoungulata 511

Numenius 322

Nummopalatus 134

Nummulosaurus 171

Nuthetes 281

Nyctilestes 367

Nyctitherium 367

Nyctodactylus 307

Nyctosaurinae 307

Nyctosaurus 307

Nyrania 168

Nythosaurus 198

Ochlodus 44

Ochotona 433

Ochotonidae 433

Ochsen 505

Octacodon 477

Octodontherium 418

Octodontinae 428,432

Octotomus 509

Odocoileus 494

Odontacanthus 38

Odontaspis 52

Odonterpeton 163

Odonteus 133

Odontoceti 406

Odontolcae 317

Odontopteryx 324

Odontormae 318

Odontostomiden 125

Oenoscopus 111

Oestocephalus 163 
Orecyon 379

Oreodon 483

Oreodontidae 482

Oreodontinae 482

Oreopithecus 553

Oreotragus 499

Ornithischia 278

Ornithocephalus 306

Ornithocheiridae 306

Ornithocheirinae 306

Ornithocheiroidea 305

Ornithocheirus 307

Ornithodelphia 349

Ornithodesmus 307

Ornitholestes 283

Ornithomimus 283

Ornithopodidae 289

Ornithopsis 287

Ornithorhynchus 351

Ornithostoma 307

Ornithosuchus 261

Ornithotarsus 293

Ornithurae 317

Oroacrodon 441

Orodus 53

Orohippus 458

Oromeryx 484

Orophodon 418

Orophosaurus 237

Orotherium 458

Orthacanthus 44

Orthacodus 52

Orthagoriscis 142

Orthaspidotherium 479

Orthocnemus 323

Orthocosta 163

Orthocynodon 451

Orthodolops 354

Orthoganoidei 105

Orthognathus 86

Orthomerus 292

Orthopleurodus 60

Orthopoda 288

Orthopteryx 322

Orthopus 196

Orthybodus 53

Orycteropidae 413

Orycteropus 412

Oryx 503

Osmeroides 125

Osphromenus 141

Ostariophysi 119

Osteoglossidae 12

Osteolaemus 272

Osteolepidae 87

Osteolepis 87

Osteophorus 168

Osteopygis 251

Osteorhachis 116

O'steornis 323

Osteostraci 33

Ostinaspis 63

Ostracion 142

Otaria 401

Otariiden 401

Oterognathus 217

Othnielmarshia 517

Otocoelus 169

Otocyon 390

Otodus 52

Otolithen 128

Oudenodon 200

Ourebia 499

Ovibos 501

Ovibovinae 501

Ovicaprinae 500

Ovinen 499

Ovioceros 500

Ovis 500

Oxacron 481

Oxyacodon 438

Oxyaena 379

Oxyaenidae 378

Oxyaeninae 379

Oxyaenodon 378
Oxyclaenidae 376

Oxydactylus 485

Oxydaenus 376

Oxydontosaurus 272

Oxyglossus 178

Oxygnathus 100

Oxygomphius 363

Oxymycterus 430

Oxynotus 50

Oxyodon 194

Oxyodontherium 442

Oxyrhina 52

"aarhufer 468

Pachyaena 377

Pachycardii 3

Pachycormidae 113

Pachycormus 114

Pachycynodon 389

Pachygonia 173

Pachyhyrax 522

Pachylemuridae 545

Pachylepis 29

Pachymylus 72

Pachynasua 392

Pachynolophus 458

Pachyodon 407

Pachyosteus 82

Pachypleura 234

Pachypteryx 322

Pachyrhizodus 125

Pachyrhynchus 25

Pachyrucos 516

Pachysaurus 279

Pachytragus 502

Paciculus 430

Paedopithex 556

Paedotherium 516

Pagellus 136

Pagrus 136

Palaeacodon 370,548

Palaearctonyx 384

Palaeaspis 32

Palaedaphus 74

Palaeeudyptes 322

Palaeictops 367

Palaelodus 323

Palaeobalistum 105

Palaeobates 57

Palaeobatrachus 178

Palaeoborus 324

Palaeocastor 426

Palaeochoerus 473

Palaeocircus 324

Palaeocryptonyx 324

Palaeocyon 390

Palaeodelphis 407

Palaeoerinaceus 369

Palaeogale 393

Palaeogithalus 325

Palaeohatteria 203

Palaeohierax 324

Palaeolagus 433

Palaeolama 486

Palaeolemur 547, 550

Palaeolycus 126

Palaeomastodon 537

Palaeomedusa 250

Palaeomeryx 493

Palaeomylus 84

Palaeonictis 379

Palaeoniscidae 98

Palaeoniscus 98

Palaeonycteris 374

Palaeopeltis 421

Palaeoperdix 324

Palaeophis 220

Palaeophoca 401

Palaeophocaena 409

Palaeopithecini 545

Palaeopithecus 556

Palaeoprionodon 392

Palaeopropithecus 550

Palaeopython 220

Palaeoreas 504
Palaeorhinus 260

Palaeorhynchidae 136

Palaeorhynchus 136

Palaeornis 307

Palaeortyx 324

Palaeorycteropus 412

Palaeoryx 503

Palaeoscincus 294

Palaeoscyllium 50

Palaeosinopa 371

Palaeospheniscus 322

Palaeospinax 56

Palaeospiza 325

Palaeosyopinae 465

Palaeosyops 465

Palaeotapirus 448

Palaeoteuthis 31

Palaeothentes 356

Palaeothentinae 356

Palaeotheriinae 459

Palaeotherium 459

Palaeotragus 496

Palaeotringa 323

Palaeovaranus 210

Palaeoziphius 408

Palaepanorthus 356

Palamedea 323

Palapteryx 321

Paleryx 220

Paliguana 210

Palhyaena 396

Palimphyes 140

Paloplotherium 459

Palorchestes 357

Panochthus 419

Panolax 433

Pantholops 500

Pantolambda 507

Pantolambdidae 507

Pantolestes 371

Pantolestidae 371

Pantotheria 360

Pantotheriidae 360

Pantostylopidae 517

Pantostylops 517

Pantylus 192

Panzeriurche 147

Panzerwelse 123

Papageien 324

Pappichthys 117

Parabatrachus 87

Parabderites 356

Paraboselaphus 502

Paracestracion 56

Paracynodon 389

Paradaphaenus 388

Paradosuchus 198

Paragelocus 488

Parahapalops 416

Parahippus 461

Parahyus 475

Parailurus 392

Parameryx 484

Paramylodon 417

Paramys 425

Paraortyx 324

Parapithecidae 553

Parapithecus 553

Paraptenodytes 322

Parastrapotherium 526

Parasuchia 257

Parasuchus 260

Paratapirus 448

Paratylopus 485

Paraxonia 468

Pareiasauridae 189

Pareiasaurus 191

Parepanorthus 356

Pareutatus 421

Parexus 48

Parictis 393

Pariostegus 171

Pariotichidae 192

Pariotichus 192

Parioxys 168

Parligobunis 393

Partanosaurus 233

Passalacodon 370

Passalodon 72

Passeres 525

Pastinaca 67

Patagiosauria 298

Paterosauridae 217

Patriarchus 516

Patriofelis 379

Paucituberculata 355

Paurodon 361

Paurodontinae 361

Pedetinae 427

Pediomys 363

Pelagosaurus 268

Pelamycybium 139

Pelargopsis 323

Pelargorhynchus 125

Pelates 133

Pelecanus 324

Pelecyodon 416

Pelecyornis 323

Pelicorapis 135

Pelion 163

Pelobatochelys 250

Pelomedusa 248

Pelomedusidae 248

Peloneustes 237

Pelophilus 178

Peloriadapis 550

Pelorosaurus 287

Pelosaurus 162

Pelosuchus 198

Peltephilus 422

Peltochelys 251 
Pharsaphorus 362

Pharyngodophilus 134

Pharyngognathi 133

Phascolarctus 357

Phascolestes 360

Phascolomyidae 357

Phascolomys 358

Phascolonus 358

Phascolotherium 359

Phasianus 324

Phenacocoelus 483

Phenacodontidae 439

Phenacodus 439

Phenacops 367

Philothrax 387

Phiomia 537

Phiomys 428

Phlaocyon 392

Phlegethontia 166

Phlyctaenaspis 82

Phobereotherium 520

Phocaenopsis 408

Phoca 401

Phocasaurus 198

Phociden 401

Phocodon 407

Phoebodus 45

Phoenicopterus 323

Pholidogaster 168

Pholidophoridae 110

Pholidophorus 110

Pholidopleurus 111

Pholidosaurus 270

Pholidurus 96

Phorcys 64

Phororhacus 323

Phosphorosaurus 217

Phycis 127

Phylactocephalus 126

Phyllodus 133

Phyllolepidae 84

Phyllolepis 84

Phyllospondyli 160

Physeter 407

Physeteridae 407

Physeterinae 407

Physeterula 407

Physichthys 37

Physoclysti 118

Physodon 407

Physonemus 73

Physostomi 118

Phytosauridae 258

Phytosaurus 258

Picariae 324

Pichipilus 356

Pici 324

Picrocleidus 237

Picus 324

Pimelodus 123

Pinacodus 61

Pinguine 322

Pinnipedia 399

Piptomerus 237

Piratosaurus 237

Pisces 3

Pisodus 121

Pistosaurus 233

Pithanodelphis 409

Pithecanthropus 556

Pithecistes 484

Pitheculites 355, 553

Pitheculus 552

Placentalia 364

Placerias 191

Placochelys 240

Placodermi 26

Placodontidae 238

Placodus 239

Placoidschuppen 4

Placosaurus 210, 421

Placoziphius 407

Plagiarthrus 516

Plagiaulacidae 352

Plagiaulax 352
Plagiolophus 459

Plagiosternum 173

Planops 416

Plataeomys 432

Platanista 408

Platax 137

Platecarpus 217

Plateosauridae 279

Plateosaurus 279

Platinx 122

Platyacanthus 59

Platychelys 248

Platychoeropus 372

Platycosmus 138

Platygnathus 86

Platygonus 474

Platylaemus 134

Platynota 210

Platyonyx 417

Platyops 168

Platypeltis 257

Platypodosaurus 200

Platyrachis 210

Platyrhina 66

Platysiagum 100

Platysomidae 100

Platysomus 101

Platysternidae 256

Platysternum 256

Plectognathi 142

Plectrolepis 100

Plerodon 269

Plesiadapidae 370

Plesiadapis 370

Plesiaddax 504

Plesiarctomys 425

Plesictis 393

Plesidacrytherium 478

Plesiesthonyx 372

Plesiocathartes 324

Plesiocetus 409

Plesiochelydae 249

Plesiochelys 249

Plesiocyon 394

Plesiodimylus 368

Plesiodus 108

Plesiomeryx 481

Plesiosauridae 235

Plesiosaurus 235

Plesiospermophilus 426

Plesiosuchus 269

Plestiodon 210

Plethodidae 124

Plethodus 124

Pleuracanthidae 42

Pleuracanthus 43

Pleuraspidotheriidae 439

Pleuraspidotherium 440

Pleuristion 194

Pleurocoelodon 523

Pleurocoelus 287

Pleurodira 247

Pleurodus 60

Pleurolepis 107

Pleurolicus 427

Pleuronectes 128

Pleuronectidae 128

Pleuronura 160

Pleuropholis 111

Pleuroplax 60

Pleuroptyx 165

Pleurosaurus 206

Pleurosterninae 247

Pleurosternum 247

Pleurostylodon 523

Pleurystylops 525

Plexotemnus 523

Pliauchenia 486

Plicodus 50

Pliodolops 354

Pliohippus 461

Pliohylobates 556

Pliohyrax 532

Pliolagostomus 432
Pliolophus 458

Pliopithecus 555

Plioplatecarpus 217

Pliosaurus 237

Pliostylops 523

Plotus 324

Pnigeacanthus 59

Podiceps 322

Podocnemis 248

Pododus 101

Podopteryx 140

Poëbrotheriinae 485

Poëbrotherium 485

Poecilodus 60

Poecilospondylus 19

Pogonodon 397

Poikilopleuron 279

Polacanthus 294

Polacrodon 206

Poliosauridae 194

Poliosaurus 194

Polyacanthus 141

Polyacrodus 56

Polycladus 494

Polycotylus 238

Polydolopidae 354

Polydolops 35

Polymastodon 354

Polymastodontidae 354

Polyodon 96

Polyodontidae 96

Polyphractus 74

Polyplocodus 87

Polyprotodontia 358

Polypteridae 89

Polypterus 89

Polyptychodon 238

Polyrhizodus 62

Polysemia 176

Polythorax 248

Pomacanthus 134

Pomacentridae 133

Pomognathus 126

Pontistes 408

Pontivaga 408

Pontobasileus 406

Pontoleo 401

Pontoporia 408

Pontosaurus 211

Portax 505

Portheus 128

Porthochelys 255

Portis 142

Potamogalidae 366

Potamotherium 394

Praeaceratherium 452

Präanguilla 127

Praedentata 288

Prepotherium 416

Preptoceras 501

Priacodon 359

Priconodon 294

Primates 544

Priodontognathus 295

Prionolepis 126

Prionodon 51

Priscacara 133

Priscoldelphinus 73 , 408

Pristacanthus 72

Pristerodon 201

Pristerognathus 198

Pristicladodus 45

Pristidae 64

Pristigenys 132

Pristiophoridae 50

Pristiophorus 50

Pristiphoca 401

Pristipomatiden 136

Pristis 65

Pristisomus 107

Pristiurus 50

Pristodus 63

Proadiantus 444

Proadinotherium 520

Proailurus 397

Proantigonia 137

Proasmodeus 524

Probaëna 248

Proborhyaena 362

Proboscidea 532

Probubalus 505

Procamelus 485

Procardia 432

Procavia 531

Procladosictis 362

Procervulus 493

Prochalicotherium 524

Prochanos 121

Procolophon 193

Procolpochelys 255

Procynodictis 386

Procyon 392

Procyonidae 391

Prodamaliscus 503

Prodaphaenus 383

Prodicynodon 201

Prodremotherium 488

Proectocion 441

Proëdrium 517

Proeuphractus 421

Proeutatus 421

Proganochelynae 247

Proganochelys 247

Proganosauria 240

Proglires 370

Prognathodus 70

Prognathosaurus 217

Progymnodus 142

Prohalicore 542 
Prosimiae 544 Prosotherium 516 Prospaniomys 432 Prosqualodon 407 Prostegotherium 422 Prosthenops 474 Prostrepsiceros 504 Protacaremys 431 Protaceratherium 452 Protadelphomys 432 Protagocerus 502 Protagriochoerus 482 Protamia 117 Protapirus 448 Protauchenia 486 Protautoga 134 Protechimys 428 Protelotherium 475 Protemnocyon 386 Proteodidelphys 363 Proterix 369

Proterochersys 247 Proterosuchus 261 Proterotheriidae 442 Proterotherium 443 Protetraceros 502 Protheosodon 441 Prothylacinus 362 Protibis 323

Protitanotherium 466 Protoadapis 370 Protobalistum 142 Protobradys 415 Protoceras 495 Protoceratinae 494 Protocetus 406

Protochriacus 376 Protodichobune 480 Protodonta 358 Protogaleus 51 Protogomorpha 424 Protogonia 439 Protogonodon 439 Protohippus 461 Protoindris 550 Protolabinae 485 Protolabis 485 Protolambda 507 Protomeryx 485 Protophocaena 409 Protopithecus 555 Protoproviverra 362 Protopsalis 379 Protopterus 77 Protoptychinae 427 Protoptychus 427 . Protoreodon 482 Protorohippus 458 Protorosauridae 203 Protorosaurus 203 Protoryx 502 Protoselere 438 Protosiren 542 Protosorex 368 Protosphargis 254 Protosphyraena 130 Protosphyraenidae 129 Protostega 254 Protostegidae 254 Prototomus 546 Protragelaphus 504 Protragocerus 502 Protriton 160 Protylopus 484 Protypotherium 516 Provampyrus 374 Provipera 220 Proviverra 380 Proviverrinae 379 Prozaëdius 421 Prozeuglodon 406 Psammochelys 247 Psammodontidae 61 Psammodus 61

Psammosteus 30
Psephoderma 240 Psephodus 60 Psephophorus 254 Psephurus 96 Pseudaelurus 398 Pseudamphicy on 388 Pseudamphimeryx 481 Pseudarctos 388

Pseudictis 393

Pseudoberyx 121 Pseudoborhyaena 362 Pseudobos 501 Pseudocreodi 378 Pseudocyon 388

Pseudogaleus 51

Pseudogelocus 488 Pseudolemuridae 545 Pseudolestodon 417

Pseudolops 354

Pseudopachyrucos 516 Pseudopterodon 381

Pseudorca 409

Pseudorhina 64

Pseudorhinolophus 374

Pseudosciurinae 427

Pseudosciurus 428

Pseudosphaerodon 134 Pseudosphargis 254

Pseudostylops 525

Pseudosuchia 260 Pseudosyngnathus 141 Pseudothrissops 114 Pseudothryptus 124 Pseudothylacinus 362 Pseudotomus 425

Pseudotraginae 502

Pseudotragus 502

Pseudotrionyx 257

Psittaci 324

Psittacotherium 414

Psittacus 324

Ptenodracon 306

Pteranodon 307

Pteraspidae 30

Pteraspis 31

Pterichthys 37

Pterocles 324

Pterodactylidae 306

Pterodactyloidea 305

Pterodactylus 306

Pterodermata 303

Pterodon 380

Pteromys 426

Pteronodus 44

Pterosauria 298

Pterosphenus 220

Pterygocephalus 141

Pterygopterus 111

Ptilodus 353

Ptolemaia 371

Ptychacanthus 54

Ptychodonten 65

Ptychodontidae 69

Ptychodontinae 68

Ptychodus 68

Ptychogaster 252

Ptychognathus 200

Ptycholepis 116

Ptychosiagum 200

Ptychotrygon 67

Ptyctodontidae 83

Ptyctodus 83

Ptyonidae 163

Ptyonius 163

Ptyonodus 76

Puffinus 322

Puppigerus 254

Putoriinae 392

Putorius 393

Pycnodonti 102

Pycnodus 105

Pycnosterinx 134

Pygaeus 134

Pygopterus 98

Pyrhocorax 325
Pyrotheria 526

Pyrotherium 527

Pythoniden 220

Pythonomorpha 211

Quercytherium 380

Raben 325

Racken 324

Raja 66

Rajinae 66

Rallus 323

Rana 178

Rangifer 494

Raniceps 127

Raphiceros 499

Ratten und Mäuse 430

Raubbeutler 361

Raubtiere 384

Regnosaurus 295

Reiher 323

Reptilia 179

Rhabdoderma 88

Rhabdodon 293

Rhabdolepis 98

Rhabdosteus 408

Rhacheosaurus 269

Rhachitomi 166

Rhachitomus 168

Rhacolepis 125

Rhadinacanthus 48

Rhadinichthys 98

Rhagatherium 477

Rhamphocephalus 304

Rhamphodus 84

Rhamphognathus 135

Rhamphorhynchidae 304

Rhamphorhynchoidea 303

Rhamphorhynchus 305

Rhamphostoma 272

Rhamphosuchus 272

Rhamphosus 140

Rhea 320

Rheidae 320

Rhetechelys 251

Rhina 64

Rhineastus 123

Rhinellus 130

Rhineura 210

Rhinippus 462

Rhinobatinae 66

Rhinobatis 66

Rhinoceridae 449

Rhinocerinae 451

Rhinoceros 452. 454

Rhinochelys 248

Rhinognathus 52

Rhinolophus 374

Rhinoptera 68

Rhinorajidae 65

Rhinosaurus 217

Rhiptoglossa 210

Rhizodontidae 86

Rhizodopsis 86

Rhizodus 86

Rhizoprion 407

Rhodanomys 428

Rhodeus 123

Rhomaleosaurus 236

Rhombodus 67

Rhomboptychus 87

Rhombus 128

Rhophalodon 196

Rhymodus 61

Rhynchippus 519

Rhynchobatus 66

Rhynchocephalia 201

Rhynchodus 83

Rhynchoncodes 109

Rhynchorhinus 127

Rhynchosauridae 205

Rhynchosaurus 205

Rhynchosuchus 271

Rhynesuchus 173

Rhytidod on 259

Rhytidosteus 173

Rhytina 542

Rhytiodus 542

Ribodon 542

Ricardolydekkeria 441

Ricardowenia 527

Ricnodon 163

Riesenfaultiere $\mathbf{4 1 5}$

Rileya 260

Rochen 66

Rodentia 422

Ronzotherium 452

Rüsseltiere 532

Rütimeyeria 525

Rupicapra 500

Rupicaprinae 500

Rusa 494

Ruscinomys 431

Rutiodon 259

Sabursi 391

Saccobranchus 124

Sägefische 64

Säugetiere 325

Sagenodus 76

Saghatheriidae 531

Saghatherium 531

Saiga 500

Salamandrina 176

Salmo 121

Salmonidae 121

Saltopus 281

Samotherium 496

Sandalodus 60

Saniva 210

Sapheosaurus 206 
Scelidotherium 418 Schellfische 127 Schild kröten 241 Schismotherium 416 Schistomys 432 Schizotherium 468 Schlangen 218 Schlangenfische 128 Schmelzschupper 90 Schollen 128

Schuppenlurche 147 Schuppensaurier $20^{\circ}$ Schwalbe 325 Schwanzlurche 174

Schweine 472

Schwertfische 140 .

Schwimmvögel 322

Sciaenidae 132

Sciamys 431

Scincoidae 210

Scincosaurus 164

Sciuravus 425

Sciurinae 426

Sciurodon 425

Sciurognathi 425

Sciuroidea 426

Sciuroides 427

Sciuromorpha 424

Sciuromys 429

Sciuropterus 426

Sciurus 426

Sclerocalyptus 419

Sclerocephalus 168

Sclerodermidae 142

Scleromochlus 261

Scleromys 431

Sclerorhynchus 65

Sclerosaurus 190

Scoliodon 51

Scomber 139

Scomberodon 139

Scombresocidae 122

Scombresociden 133

Scombresox 122

Scombridae 139

Scombroclupea 120

Scopelidae 130

Scopeloides 131

Scorpaena 140

Scorpaenidae 140

Scorpaenoides 140

Scorpaenopterus 140

Scotaeumys 432

Scrobodus 108

Scylacosauridae 197

Scylacosaurus 198

Scylliidae 50

Scylliodus 50

Scyllium 50

Ssyllomus 255

Scymnosaurus 198

Scymnus 50

Scytalophis 220

Seekühe 540

Seeleya 163

Seelidotherium 417

Seepferdchen 141

Selache 53

Selachii 48

Selatherium 516

Selenacodon 354

Selenodontia 480

Sellosaurus 279

Semionotus 106

Semiophorus 137

Semnopithecus 553

Sericodon 268

Seriola 137

Serpentarius 324

Serranus 138

Serratodus 63

Serrolepis 107

Sesamodon 198

Seymouria 189

Shastasaurus 228
Sicarius 61

Siebenschläfer 428

Sigmogomphius 427

Siluridae 123

Simiae 545

Simiidae 555

Simocyon 388

Simoedosaurus 205

Simolestes 237

Simosaurus 233

Simplicidentata 425

Singvögel 325

Sinopa 380

Sipalocyon 362

Siphneus 431

Siphonocetus 410

Siphonostoma 141

Sirenia 540

Sirenoidea 77

Sironectes 217

Sitta 325

Sivatheriinae 496

Sivatherium 496

Smerdis 133

Smilodectes 370

Smilodon 398

Smilodontopsis 398

Sminthus 429

Socnopaea 123

Solea 128

Solenodon 126. 366

Solenognathus 140

Solenorhynchus 141

Solenostomiden 141

Sontiochelys 250

Sorex 368

Soricidae 368

Soricidens 123

Spalacinae 431

Spalacotherium 359

Spalax 431

Spanidon 125

Spaniomys 432

Sparagmites 167

Sparassodonta 362

Sparidae 135

Sparnodus 136

Spathiurus 111

Spathobatis 66

Spathodactylus 122

Spatula 323

Spatularia 96

Spechte 324

Spermophilus 426

Sphaerodontidae 107

Sphaerodus 108

Sphagebranchus 127

Sphargis 253

Sphenacanthus 53

Sphenacodon 196

Sphenocephalus 132

Sphenodon 201, 206

Sphenodontidae 206

Sphenodus 52

Sphenonchus 53,56

Sphenosaurus 168

Sphenospondy.lus 292

Sphenotherus 417

Sphodromys 432

Sphyraena 135

Sphyraeniden 135

Sphyraenodus 139

Sphyrna 51

Spinacidae 49

Spinacorhinus 70

Spinax 50

Spitzmäuse 368

Spondylosaurus 237

Springmäuse 429

Squalifera 64

Squalodon 407

Squalodontidae 407

Squaloraja 70

Squalorajidae 69

Squamata 207
Squatina 64

Squatinidae 64

Stachelschweine 431

Staganolepis- 258

Staurotypus 256

Stechrochen 66

Steganopodes 323

Stegocephali 147

Stegodon 539

Stegomus 260

Stegopelta 294

Stegops 165

Stegosauridae 293

Stegosaurus 293

Stegotherium 421

Steiromys 431

Stemmatodus 104

Stenarosaurus 237

Steneofiber 426

Steno 409

Stenogale 393

Stenogenium 523

Stenometopon 205

Stenomylus 485

Stenopelix 294

Stenoplesictis 392

Stenosaurus 268

Stenostephanus 520

Stenotatus 421

Stephanodon 394

Stephanospondylus 192

Stereocephalus 29

Stereorhachis 194

Stereospondyli 171

Stereosternum 240

Sternothaerus 248

Sterrholophus 296

Sthenurus 357

Stibarus 475

Stichacanthus 59,63

Stichomys 432

Stilauchenia 486

Stilotherium 355

Störe 95

Stomatidae 138

Stomatiden 126

Stratodontiden 125

Stratodus 125

Strauße 320

Streblodus 59

Strepsiceros 504

Strepsodus 86

Streptospondylus 282

Streptostylica 183

Strigogyps 325

Strinsia 127

Strix 325

Strobilodus 115

Strophodus 56

Struthiones 319

Struthionidae 320

Struthiosaurus 294

Sturmvögel 322

Stylacodon 361

Stylacodontidae 360

Stylemys 252

Stylhippus 519

Stylinodontinae 414

Stylodon 361

Stylodontidae 106

Stylodus 134

Stylognathus 363

Stylonodon 415

Stylorhynchus 97

Stypolophus 380

Subungulata 528

Suchodus 269

Suidae 472

Sula 324

Sumpfschildkröten 251

Sumpfvögel 322

Sus 474

Sycium 431

Syllaemus 135

Symborodon 467

Symbos 501

Symoliophis 219

Symphodus 134

Symphyrosaurus 288

Synapsida 187

Synconodon 507

Syndyoceras 495

Synechodus 56

Syngnathiden 141

Syngnathus 141

Syngonosaurus 295

Synoplotherium 377

Syntegmodus 124

Syodon 196

Systemodon 448

Taeniodus 60

Taeniolabis 354

Tagraubvögel 324

Taligrada 507

Talpa 367

Talpavus 367

Talpidae 367

Tamias 426

Tanaodus 62

Taniwhasaurus 217

Tanystrophaeus 281

Taoperdix 324

Taphaetus 324

Taphozous 374

Taphrosaurus 237

Taphrosphys 248

Tapinocephalus 198

Tapinopus 324

Tapiravus 448

Tapiridae 446 
Tetralophodon 538

Tetramerorhinus 443

Tetrao 324

Tetraprotodon 476

Tetrapterus 140

Tetrodon 142

Teutomanis 413

Thalassemydidae 250

Thalassemys 250

Thalassictis 396

Thalassocetus 407

Thalassochelys 254

Thalattosauria 206

Thalattosauridae 206

Thalattosaurus 207

Thalattosuchia 269

Tharrias 120

Tharsis 119

Thaumas 64

Thaumastognathus 477

Thaumastolemur 550

Thaumatosaurus 236

Thecodontosauridae 279

Thecodontosaurus 280

Thecophora 253

Thecospondylus 280

Thectodus 54

Thegornis 324

Thelodus 29

Thelolepis 29

Theosod on 441

Thereutherium 378

Theridomyinae 428

Theridomys 428

Theriodesmus 198

Theriodontia 196

Theriosuchus 270

Therocephalia 197

Theromora 188

Theromorpha 188

Theropleura 194

Theropoda 278

Thescelus 248

Thespesius 291

Theuthiidae 135

Thinocyon 378

Thinohyus 473

Thinolestes 547

Thinopus 173

Thinosaurus 210

Thiosmus 395

Thlattodus 115

Thoatherium 443

Tholodus 107

Thomashuxleya 524

Thomomys 427

Thoracopterus 111

Thoracosaurus 271

Thrinacodus 44

Thrissonotus 100

Thrissops 120

Thrissopteroides 125

Thryptodus 124

Thursius 87

Thyellina 50

Thyestes 34

Thylacinus 362

Thylacoleo 357

Thylacoleoninae 357

Thylacotherium 360

Thynnichthys 123

Thynnus 139

Ticholeptus 483

Tigrisuchus 198

Tillodontia 371,521

Tillodontidae 371

Tillomys 425

Tillotherinae 372

Tillotherium 372

Tinami 321
Tinamus 322

Tinca 123

Tinoceras 509

Tinodon 359

Titanichthys 83

Titanomys 433

Titanophis 220

Titanops 467

Titanosaurus 287

Titanosuchus 198

Titanotheridae 464

Titanotheriinae 465

Titanotheriomys 425

Titanotherium 466

Tolypeutes 421

Tomicosaurus 196

Tomistoma 271

Tomitherium 546

Tomodus 59

Tomognathidae 126

Tomognathus 126

Toretocnemus 228

Torfkuh 506

Torosaurus 296

Torpedininae 66

Torpedo 66

Totanus 322

Toxochelys 255

Toxodon 521

Toxodontherium 521

Toxodontia 518

Toxodontidae 521

Toxoprion 59

Toxotes 134

Trachemys 252

Trachiniden 134

Trachodon 291

Trachodontidae 291

Trachyacanthidae 59

Trachyaspis 256

Trachynotus 137

Trachytypotherium 517

Tragelaphinae 504

Tragelaphus 504

Tragocerus 503

Tragoreas 504

Tragulidae 486

Tragulinae 487

Tragulus 487

Transpithecus 516

Traquairia 47

Trechomys 428

Tremataspidae 35

Tremataspis 35

Trematops 169

Trematosaurus 171

Tretosternum 251

Triacanthodon 359

Triacranodus 43

Triaenaspis 125

Triaenodon 51

Triarchodon 198

Tribelesodon 306

Tribolod on 359

Tricentes 376

Triceratops 296

Trichechiden 401

Trichiurichthys 137

Trichiuridae 136

Trichogaster 141

Trichophanes 132

Tricleidus 237

Triconodon 359

Triconodontidae 359

Trigla 140

Triglidae 140

Triglochis 52

Trigloides 140

Triglyphus 352

Trigodon 520

Trigonias 452

Trigonodon 136
Trigonodus 60,64

Trigonolestes 480

Trigonorhina 66

Trigonostylopidae 525

Trigonostylops 525

Triisodon 377

Triisodontinae 377

Trilophodon 538

Trimerorhachis 169

Trimerostephanus 523

Trinacromerum 238

Tringa 322

Triodus 43

Trionychia 256

Trionychiidae 257

Trionyx 257

Triplopterus 87

Triplopus 451

Tripriodon 354

Tripterus 87

Trispondylus 196

Tristichopterus 87

Tristychius 54

Tritemnodon 380

Trituberculata 360

Tritylodon 352

Tritylodontidae 351

Trocharion 395

Trochictis 394

Trochoceros 506

Trochosuchus 198

Trochotherium 394

Trogolemur 549

Trogon 324

Trogontherium 427

Trogosus 372

Tropidemys 250

Trucifelis 398

Trygon 66

Trygoninae 66

Trygonobatus 66

Tuditanus 165

Tulodon 381

Tupajidae 366

Turdiden 325

Turdus 325

Turinia 29

Tursiops 409

Tychostylops 523

Tylopoda 484

Tylosaurus 217

Typotheria 513

Typotheriidae 516

Typotherium 517

Typothorax 260

Tyrannosaurus 281

Tyrsidium 166

Uestisaurus 294

Uintacyon 383

Uintatherium 509

Uintornis 325

Umberfische 132

Undina 89

Ungulata 435

Unpaarzeher 444

Uraeus 114

Urenchelys 127

Urfleischfresser 375

Urmiatherium 503

Urocordylus 163

Urodela 174

Urogymnus 67

Urolophus 67

Uronautes 237

Uronemus 75

Uropeltis 219

Urosphen 140

Ursavus 391

Ursidae 390

Ursus 391

Utaëtus 422

Varanidac 210

Varanosaurus 194

Varanus (Megalania) 211

Varanus monitor 208

Vassacyon 383

Vaticinodus 60

Vertebrata 1

Vespertiliavus 374

Vespertilio 374

Vesperugo 374

Viverra 395

Viverravinae 383

Viverravus 383

Viverridae 395

Vögel 308

Vollwirbler 171

Vomer 137

Vulpavus 38

Vulpes 390

Wale 401

Wardichthys 101

Washakius 549

Weichflosser 127

Weißfische 122

Weissia 168

Welse 123

Wirbeltiere 1

Wodnika 56

Wühlmäuse 430

Wynyardia 357

Xenacanthus 43

Xenarthra 413

Xenochelys 256

Xenochoerus 473

Xenopholis 105

Xenorhynchus 323

Xenotherium 366

Xenurus 421

Xestops 210

Xiphias 140

Xiphiidae 140

Xiphiorhynchus 140

Xiphodon 480

Xiphodontherium 480 


\title{
Grundzüge der Paläontologie (Paläozoologie)
}

von

\author{
KARL A. VON ZITTEL \\ neubearbeitet von \\ DR. FERDINAND BROILI \\ a. o. Professor an der Universität München
}

\section{Abteilung: INVERTEBRATA DRITTE}

\author{
vermehrte und verbesserte Auflage
}

590 Seiten gr. $8^{\circ}$ mit 1414 Abbildungen - Preis in Leinwand geb. M. 18.-

\section{INHALTS-ÜBERSICHT:}

\section{Einleitung}

Begriff u. Aufgabe derPaläontologie Systematik

\section{Stamm Protozoa (Urtiere) \\ 1. Klasse Rhizopoda}

\section{Stamm Coelenterata}

1. Unterstamm Porifera Klasse Spongiae

2. Unterstamm Cnidaria

1. Klasse Anthozoa (Pflanzentiere)

2. Klasse Hydrozoa

\section{Stamm Echinodermata}

(Stachelhäuter)

\section{A. Pelmatozoa}
1. Klasse Crinoidea (Seelilien)
2. Klasse Cystoidea
3. Klasse Blastoidea

B. Asterozoa
1. Klasse Ophiuroidea
2. Klasse Asteroidea

C. Echinozoa

1. Klasse Echinoidea (Seeigel)

2. Klasse Holothurioidea

IV. Stamm Vermes (Würmer)

V. Stamm Molluscoidea

1. Klasse Bryozoa

2. Klasse Brachiopoda

VI. Stamm Mollusca

1. Klasse Lamellibranchiata

2. Klasse Scaphopoda

3. Klasse Amphineura

4. Klasse Gastropoda

5. Klasse Cephalopoda

VII. Stamm Arthropoda (Gliedertiere)

1. Unterstamm Branchiata

1. Klasse Crustacea

2. Klasse Merostomata

2. Unterstamm Tracheata

1. Klasse Myriopoda

2. Klasse Arachnoidea 


\title{
Handbuch der Paläontologie
}

unter Mitwirkung von

\author{
W. PH. SCHIMPER und W. SCHENK
}

herausgegeben von

\section{KARL A. VON ZITTEL}

5 Bände gr. $8^{\circ} \quad$ Ermäßigter Gesamtpreis brosch. M. 65.-, geb. M.77.-

Einteilung des Werkes:

I. Abteilung: Paläozoologie (vier Bände)

1. Band: Protozoa, Coelenterata, Echinodermata, Mollusca, 772 Seiten mit 558 Abbildungen, $1876-1880$

2. Band: Mollusca und Arthropoda, 893 Seiten mit 1109 Abbildungen, 1881 - 1885

3. Band: Vertebrata (Pisces, Amphibia, Reptilia, Aves), 900 Seiten mit 719 Abbildungen, $1887-1890$

4. Band: Vertebrata (Mammalia), 799 Seiten mit 590 Abbildungen, 1892-1893

II. Abteilung: Paläophytologie (ein Band)

958 Seiten mit 429 Abbildungen, 1890

\section{Geschichte der \\ Geologie und Paläontologie}

bis Ende des 19. Jahrhunderts

von

$X I$ und 868 Seiten

KARL A.,VON ZITTEL

Dieses Werk bildet den 23. Band der „Geschichte der Wissenschaften in Deutschland", herausgegeben durch die historische Kommission bei der Kgl. Bayer. Akademie der Wissenschaften.

\section{INHALTS-UBBERSICHT}

Das geologische Wissen im Altertum - Anfänge der Versteinerungskunde und Geologie - Das heroische Zeitalter der Geologie von 1790-1820 Neuere Entwicklung der Geologie und Paläontologie - Kosmische Geologie Physiographische Geologie - Dynamische Geologie - Topographische Geologie - Formationslehre (Stratigraphie) - Gesteinskunde (Petrographie) Versteinerungskunde (Paläontologie) 







SMITHSONIAN INSTITUTION LIBRARIES

|| ||||||||||||||||||||||||||||||||||||||||||||||||||||||||||||||||||||

З 9088000477489 